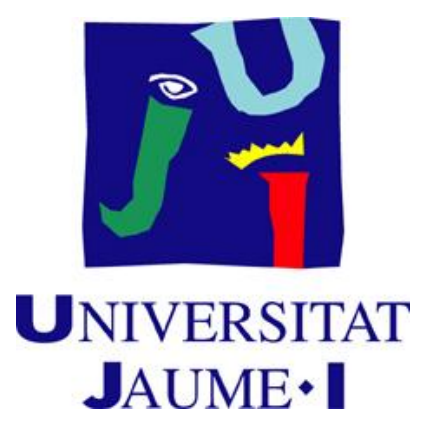

FACULTAD DE CIENCIAS HUMANAS Y SOCIALES. DEPARTAMENTO DE HISTORIA, GEOGRAFÍA Y ARTE

\title{
LA NEUTRALIZACIÓN DEL ADVERSARIO POLÍTICO. LA DEPORTACIÓN EN LA ESPAÑA DEL SIGLO XIX
}

TESIS DOCTORAL

Presentada por: JUAN LUIS BACHERO BACHERO

Dirigida por: JOSÉ ANTONIO PIQUERAS ARENAS 


\section{ÍNDICE}

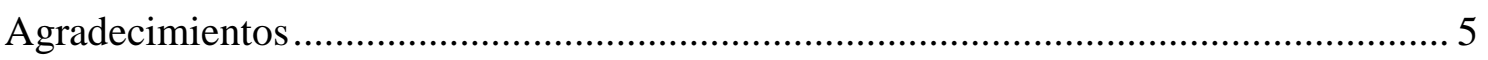

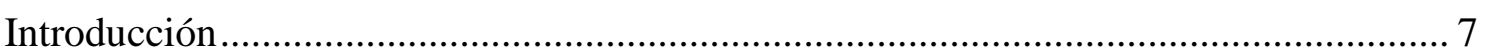

PRIMERA PARTE. CONTEXTUALIZACIÓN Y CONFIGURACIÓN DE LA PRÁCTICA DE LA DEPORTACIÓN

Capítulo 1. La deportación en la legislación española ...............................................25

1. El destierro en la legislación medieval y su uso real ................................................25

2. La evolución de la condena de destierro. Penas sustitutivas ....................................29

3. Destierros colectivos en la Edad Moderna. Judíos, moriscos, gitanos y jesuitas ...... 32

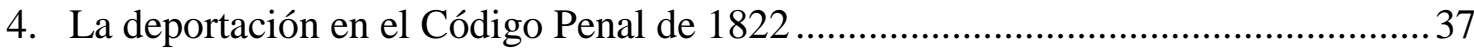

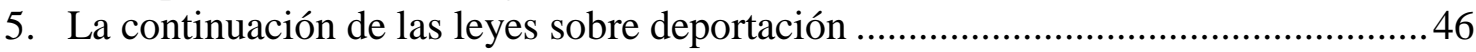

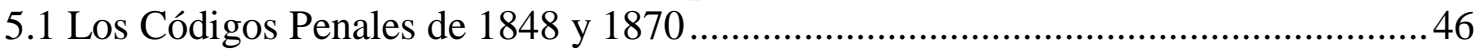

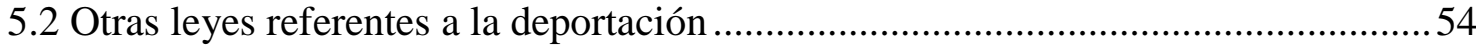

Capítulo 2. Los inicios de la deportación. El primer liberalismo............................59

1. La configuración de la deportación en la España peninsular ...................................59

1.1 Precedentes de la deportación en las postrimerías del Antiguo Régimen ................59

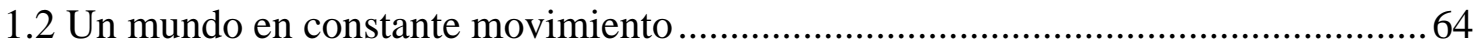

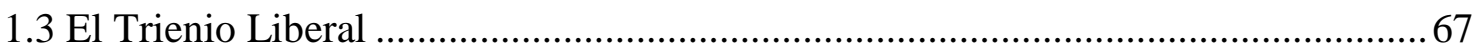

1.4 La represión en la Década Ominosa. Una vuelta atrás no integral...........................87

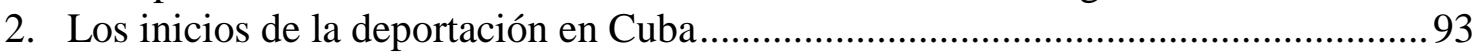

\section{SEGUNDA PARTE. LA DEPORTACIÓN EN LA ESPAÑA PENINSULAR}

\section{Capítulo 3. De los inicios de la Primera Guerra Carlista}

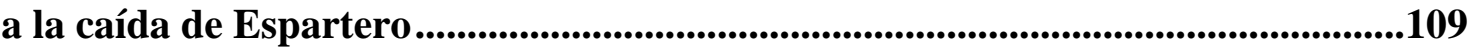

1. La Primera Guerra Carlista y el problema de los prisioneros. La deportación

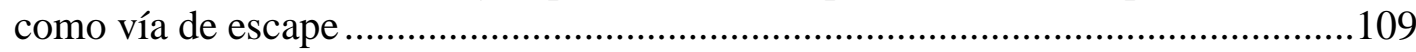

1.1 La primera represión sobre los sospechosos de carlismo .....................................109

1.2 Las deportaciones de combatientes a Cuba y Puerto Rico .....................................110

1.3 Otros casos y destinos diferenciados de deportación .............................................119

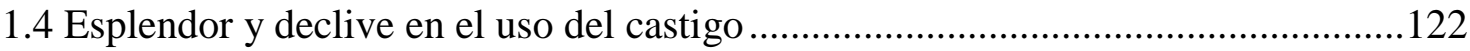

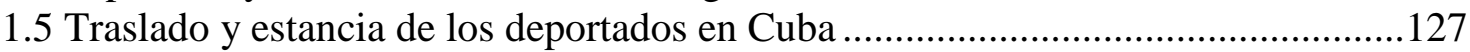

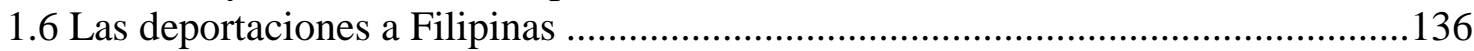

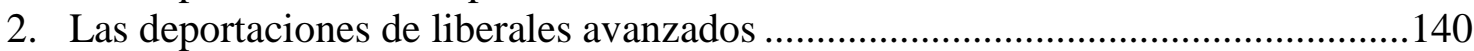

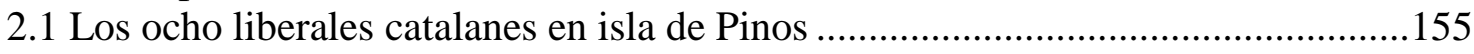

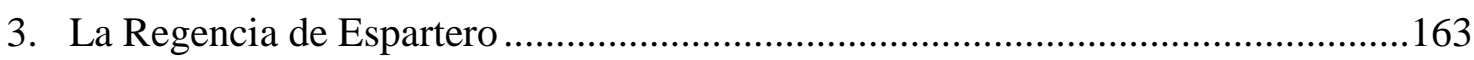




\section{Capítulo 4. La Década Moderada.}

La deportación en un periodo fuertemente represivo ...........................................167

1. La concepción moderada del poder y la primera represión.....................................167

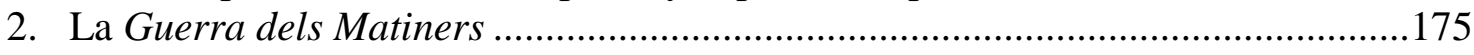

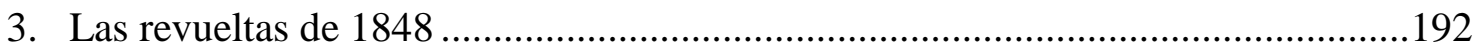

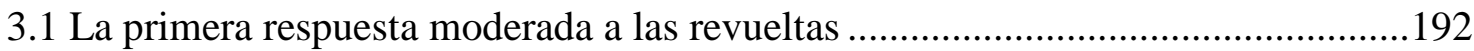

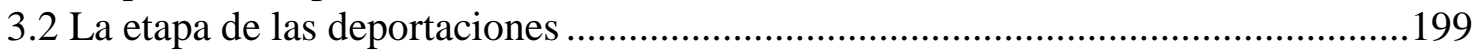

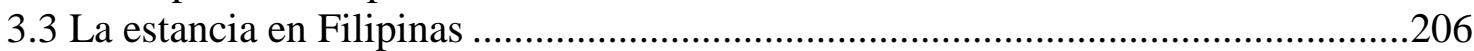

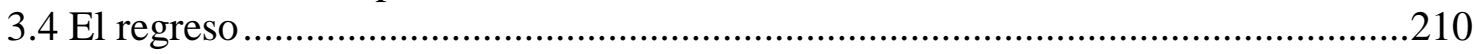

4. El fin de la Década Moderada .........................................................................2 215

Capítulo 5. Del Bienio Progresista a la Revolución Gloriosa ................................221

1. Hacia el reconocimiento de derechos de los represaliados..................................221

2. La oposición política al Bienio Progresista .......................................................226

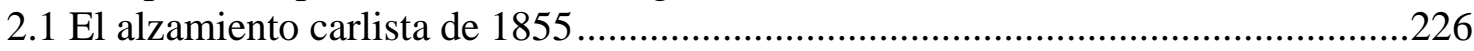

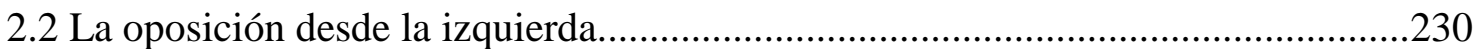

3. El Bienio Moderado y los sucesos de El Arahal ...............................................239

4. La deportación con finalidad colonizadora. Factores de cambio ............................2242

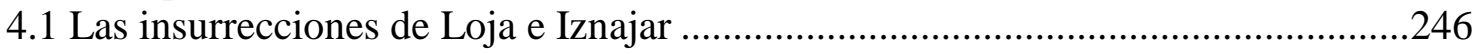

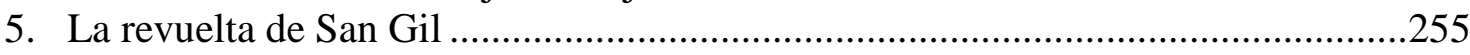

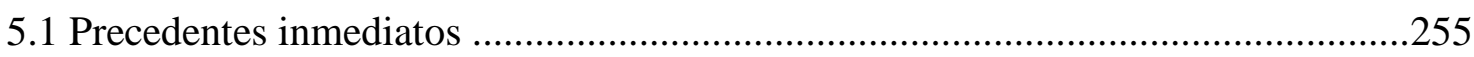

5.2 Detenciones y represión de civiles y militares. Los castigos impuestos .................256

5.3 Las deportaciones. Fernando Poo y otros destinos .................................................266

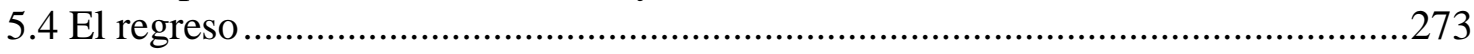

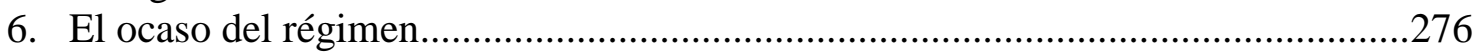

Capítulo 6. Del Sexenio Democrático al pronunciamiento de Villacampa.............283

1. Un régimen sustancialmente diferente. Las primeras deportaciones .....................283

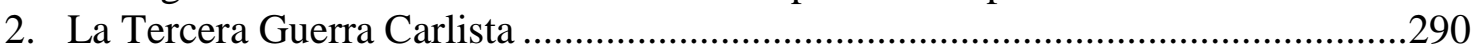

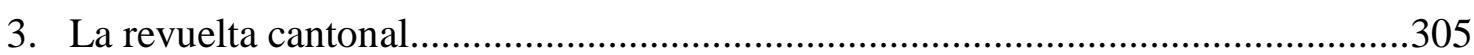

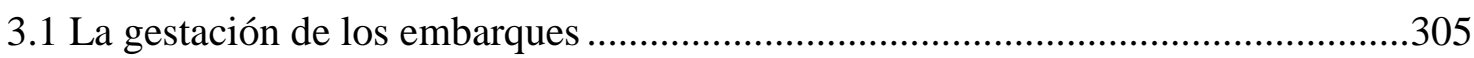

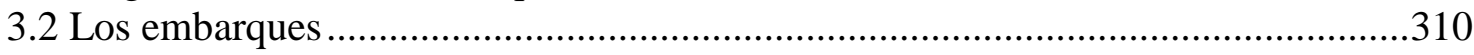

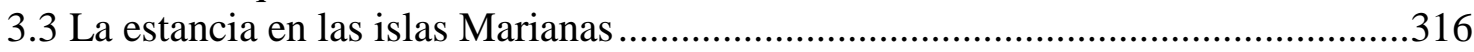

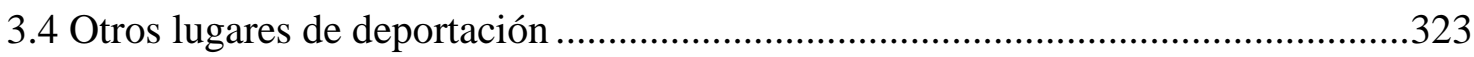

3.5 El cese en la situación de deportados: fugas, fallecimientos e indultos .................329

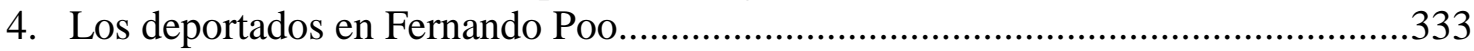

5. Los últimos usos de la deportación en la España peninsular del siglo XIX ............337

\section{TERCERA PARTE. LA DEPORTACIÓN EN CUBA}

\section{Capítulo 7. La capitanía general de Miguel Tacón}

y los años del "peligro negro" ...........................................................................................345

1. El mandato del Capitán general Miguel Tacón ......................................................345

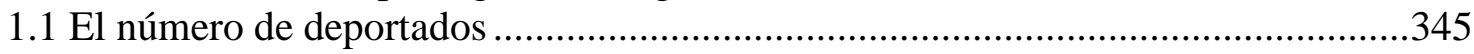

1.2 La llegada de Tacón y la primera represión ..........................................................349

1.3 La represión tras la exclusión de Cuba del alcance de la Constitución....................355

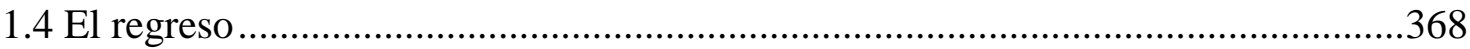

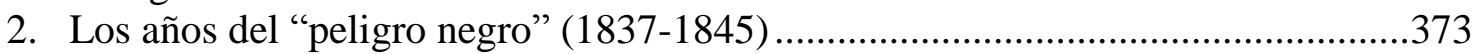




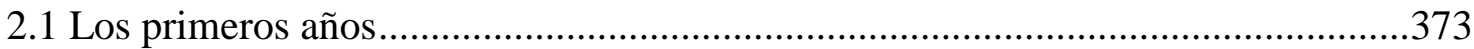

2.2 La respuesta a la conspiración de la Escalera.......................................................378

Capítulo 8. El movimiento anexionista y la Guerra de los Diez Años .....................389

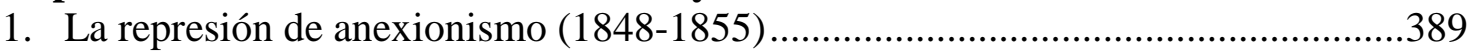

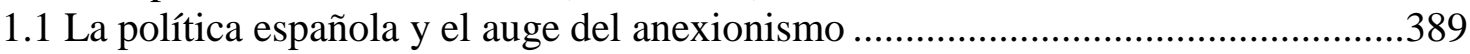

1.2 El mandato de José Gutiérrez de la Concha ............................................................395

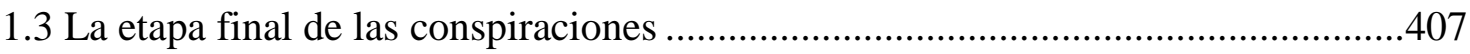

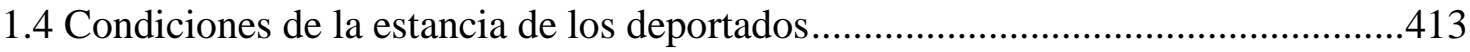

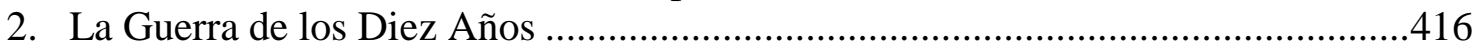

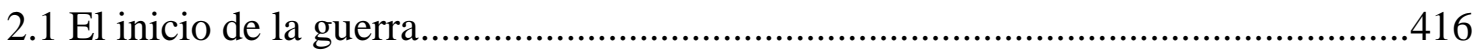

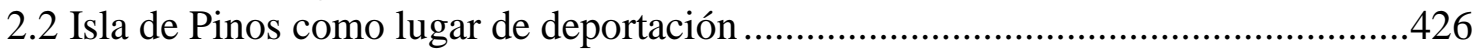

2.3 Las deportaciones como condena y como alzamiento de pena para infidentes......431

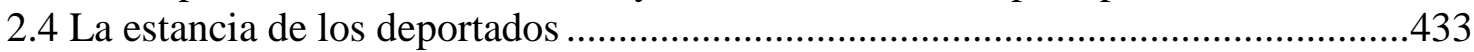

$2.5 \mathrm{El}$ fin de la guerra y el retorno de los relegados .................................................442

Capítulo 9. Una deportación cada vez más restrictiva. La Guerra Chiquita

y la Guerra de Independencia cubanas .......................................................................445

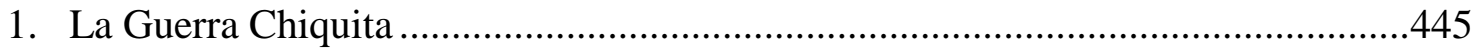

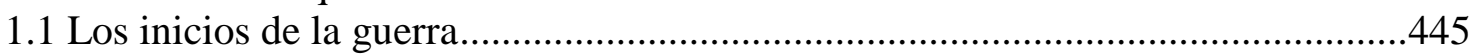

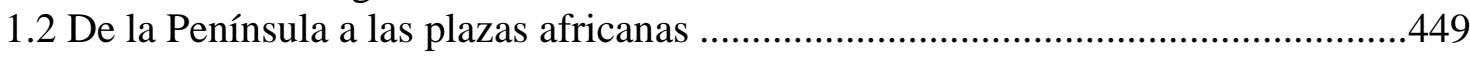

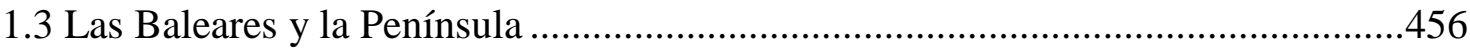

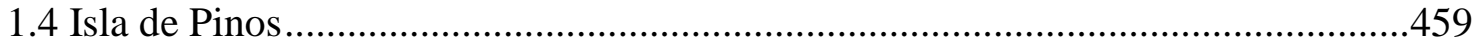

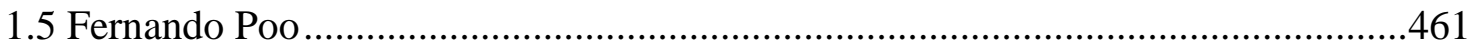

1.6 El regreso desde la Península y territorios adyacentes ..........................................466

1.7 El retorno desde Fernando Poo...............................................................................470

2. La Guerra de Independencia cubana ................................................................472

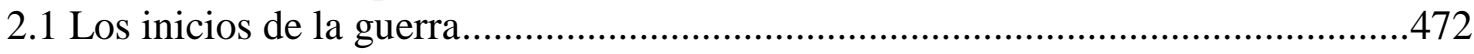

2.2 La sustitución de Martínez Campos por Weyler ....................................................478

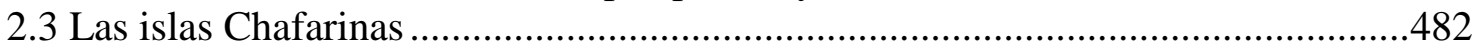

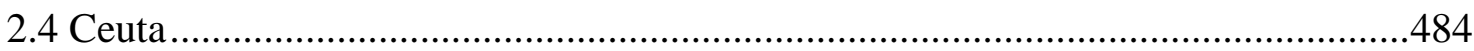

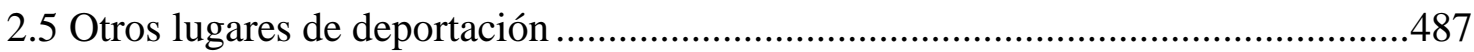

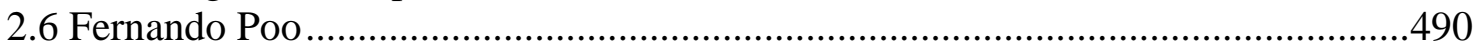

2.7 El Gobierno de Sagasta y el regreso de los deportados .......................................497

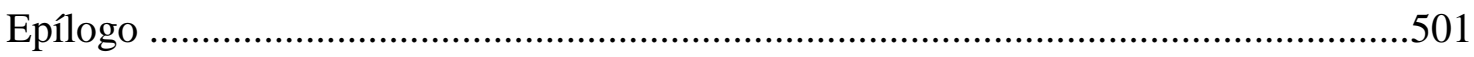

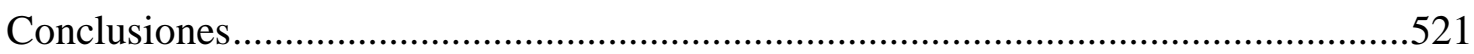

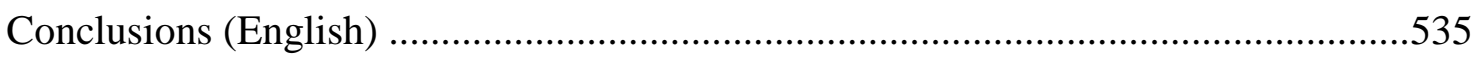

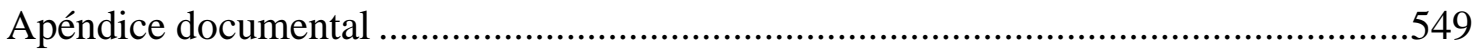

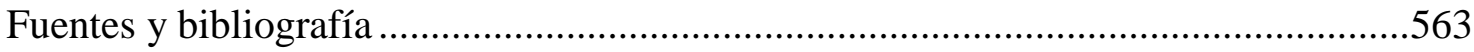

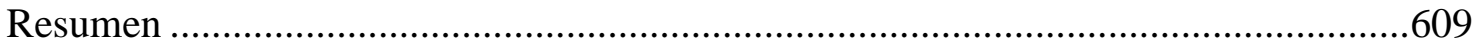

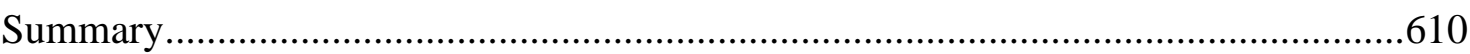




\section{ÍNDICE DE TABLAS Y GRÁFICOS}

Tabla 1. Destinados a las armas en los batallones de África (julio-agosto de 1848) 180

Tabla 2. Destinados al servicio a las armas en Ultramar (1848) 180

Tabla 3. Deportados a Filipinas (agosto-septiembre de 1848) .202

Tabla 4. Regreso de deportados tras la contrata gubernamental (1849-1850) 213

Tabla 5. Embarcados con destino a Fernando Poo (agosto-octubre de 1861) .250

Tabla 6. Deportaciones de prisioneros carlistas en 1873 .295

Tabla 7. Deportados a la Península desde agosto de 1869 hasta 10 de octubre de 1877 425

Gráfico 1. Distribución de los relegados fuera de Manila .209

Gráfico 2. Origen de los deportados por provincia de procedencia .315

Gráfico 3. Núcleos urbanos con mayor presencia de residentes deportados en el San Francisco de Borja

Gráfico 4. Distribución de los deportados del San Francisco de Borja por provincia de residencia.

Gráfico 5. Provincia de procedencia de los deportados a Pinos en 31 de julio de 1871

Gráfico 6. Apariencia racial de los deportados políticos en la Península y territorios adyacentes durante la Guerra Chiquita 


\section{AGRADECIMIENTOS}

La presente tesis doctoral ha sido realizada gracias a la ayuda del Ministerio de Educación para formación del profesorado universitario (AP2012-2505), consistente en una beca de dos años y un contrato de otros dos. También ha sido de gran importancia la participación en el proyecto de investigación del Ministerio de Economía y Competitividad "La sociedad creada por la plantación: lógicas confrontadas, consenso y disenso colonial (Cuba 1783-1898)" (HAR2012-36481) del Ministerio de Economía y Competitividad. Sin la financiación pública, el presente trabajo no hubiera sido posible o se hubiera producido en circunstancias de mayor precariedad.

Me gustaría resaltar la importancia del director de la misma, José Antonio Piqueras, con quien este trabajo tiene la mayor deuda. Sería injusto omitir que la idea de la que emana la tesis le pertenece. Idea en bruto y que ha ido tomando forma también gracias a él y sin la cual la tesis no hubiera sido posible. Quisiera agradecerle la lectura de los capítulos y las consiguientes correcciones, así como el señalamiento de las omisiones y consejos en toda la investigación. Por el vasto conocimiento que tiene de la historia de España y Cuba, es imposible que hubiera encontrado un director mejor.

También me gustaría agradecer la ayuda que me han prestado a las profesoras del departamento Imilcy Balboa Navarro y Amparo Sánchez Cobos. Siempre se han mostrado dispuestas a ayudarme en aspectos concretos de la investigación, lo que ha resultado en una mejora de la tesis. Quiero agradecer a mis compañeros de doctorado Delphine Sappez, Beatriz Joda, Paz Iver, Valeria Aguiar y Andrés Ortí la ayuda y colaboración que me han prestado siempre. En especial a Gwénaëlle Colez y Reinier Borrego con quienes tantas veces he debatido nuestros temas de investigación y muchas otras cosas más, y no siempre en la Universidad. Las tascas y las larguísimas comidas con el resto de compañeros del Máster de Estudios Contemporáneos e Investigación Avanzada son prueba de ello. Para ellos también mi gratitud: Pedro, Toni, Paula, Claudia, Giaco, Roger, Caroline, Esther y Edwin.

Uno de los incentivos de la tesis era que requería de la indagación en diversos lugares, en búsqueda de las fuentes. Esto me ha dado oportunidad de trabajar con otros profesionales de reconocido prestigio. Me agradaría en especial dar las gracias a las 
profesoras tutoras de las estancias de investigación, Consuelo Naranjo, del Instituto de Historia del Consejo Superior de Investigaciones Científicas en Madrid y María del Carmen Barcia, de la Casa de Altos Estudios Fernando Ortiz de la Universidad de La Habana. En Cuba, también estoy en deuda con Yolanda Díaz y Gerardo Cabrera, investigadores del Archivo Nacional de Cuba, quienes procuraron que mi estancia resultara provechosa laboral y personalmente.

Creo que es justo dedicar unas palabras al personal de los archivos y bibliotecas en los que he pasado largas horas de investigación. En especial, quisiera expresar mi reconocimiento a todo el personal de sala del Archivo Histórico Nacional. A Daniel Gozalbo del Archivo General de la Administración, por su conocimiento del archivo y sus consejos en la búsqueda de la documentación. Al capitán Agustín Pacheco, del Archivo General Militar de Madrid, por su inestimable ayuda, su orientación, asistencia, profesionalidad y enorme conocimiento de los fondos. En el Archivo Nacional de Cuba, me gustaría destacar la colaboración de Julito, toda una institución en el mismo. Su amabilidad, colaboración y dedicación al archivo y a los investigadores merece ser destacada.

Me gustaría agradecer a mis amigos que me han acompañado durante la realización de la tesis. Algunos de ellos se han interesado enormemente por mis avances y el resto me han obsequiado con su buena amistad. Sin Fauro, Ana D., Vicent, Edo, Marc, Marisa, Ximo, María, Cruz, Inés, Sergio, Pope, Nave, Antonio, Ana, Iván, Silvia, Jordi P., Estela y Jordi R., David y otros tantos, esto no hubiera sido lo mismo.

Finalmente, expresar la enorme suerte que tengo de tener a mi familia. Mi abuela María siempre me apoyo en todos mis proyectos, incluso cuando muchas veces no los entendía. Constante ha sido siempre el apoyo respaldo de mis padres, en especial de mi madre. A mí cuñada Rebeca. A mi hermano Pere, de quien aprendí ya hace muchos años lo más importante que se puede aprender en la vida, a ser uno mismo. A Mónica, por su paciencia, apoyo y cariño.

A mi hija Laia, que está empezando a descubrir el mundo. 


\section{INTRODUCCIÓN}

El ascenso al poder del liberalismo supuso la entronización de una cultura política basada en la limitación en la capacidad de participación en política. La distinción entre derechos según los grupos sociales fue una característica determinante del primer liberalismo que no dudó en imponer un sistema electoral ultrarrestrictivo con la intención de protegerse frente a aquellos que pretendían la vuelta al absolutismo y de los sectores que abogaban por una extensión de los derechos políticos a toda la población. ${ }^{1}$ La toma del poder por parte de una clase social inferior numéricamente implicaba dejar al margen a la mayoría de la gente.

En un contexto de triunfo del liberalismo e implantación del capitalismo en Europa, un regreso al pasado no hubiera sido sostenible a largo plazo. Pero en lo inmediato, dejar atrás el Antiguo Régimen significó desposeer a buena parte del campesinado de la seguridad alimentaria que su miserable modo de vida le garantizaba para ser arrojados a la proletarización forzada o la mendicidad. Era un grupo fuertemente influenciado por la Iglesia al que dejar al margen significaba asegurar no solo la realización de la revolución burguesa sino también el modo en que esta se hizo, que no fue otro que el de la adquisición de la propiedad de la tierra por parte de los adinerados, desposeyendo a los campesinos y a la Iglesia. Por otro lado, los grupos más avanzados, principalmente de carácter urbano, pretendieron la extensión de los derechos políticos y en ocasiones la incorporación de otros con un mayor contenido social, algo totalmente contrario a las pretensiones de los nuevos grupos dominantes.

Imposibilitaba la vía electoral, los perdedores y excluidos recurrieron a guerras, conspiraciones, motines, tumultos, insurrecciones y pronunciamientos, con el objetivo de acceder al poder o al menos influir en las decisiones gubernamentales. En muchas ocasiones, a la discriminación gubernativa se unía la miseria que en periodos de

\footnotetext{
${ }^{1}$ Alan S. Kahan, Liberalism in the Nineteenth Century Europe: The Political Culture of Limited Suffrage, Palgrave Macmillan, Basingtoke and New York, 2003; sobre el caso español ver María Sierra, Rafael Zurita y María Antonia Peña, "La representación política en el discurso del liberalismo español (1845-1874)". José Luis Ollero Valles, "De la liberación del presó encadenado al salto a las tinieblas: sobre representación y autenticidad en la cultura política del progresismo”. María Serena Piretti, “¿A quién representar, qué representar? Una mirada a través de la Europa del siglo XX”. Ayer, núm. 61, 2006, pp. 15-45, 105-137 y 189-211.
} 
recesión económica o de malas cosechas afectaba a las clases más populares. La propia actuación de la media y alta burguesía que restringía la participación en las tareas de gobierno y se negaba a otorgar derechos sociales incentivaba que ante la desesperación se produjeran actos vandálicos contra el poder. Para desactivarlos, el Estado creó una estructura basada en la utilización del ejército, la policía, la Guardia Civil y el entramado jurídico.

Ya en 1994 el profesor Aróstegui, refiriéndose al siglo XX, se alarmaba de la carencia de estudios sobre la represión política, "una de las formas más conspicuas y repetidas que ha adoptado en la España del siglo XX la violencia política", más allá de los que surgían sobre la ejecutada en la Guerra Civil y el primer franquismo con carácter más o menos local y que adolecían de una perspectiva explicativa general. ${ }^{2}$ En el siglo XIX la carencia es todavía mayor y la mayoría de los estudios van referidos a actos de las clases subalternas sobre el Estado o sus representaciones. Respecto al sometimiento estatal sobre las masas, las lagunas son mucho más alarmantes. Algunos estudios clásicos se han centrado en la evolución de las leyes para la represión. ${ }^{3}$ Con posterioridad han aparecido otros que la analizan en un periodo en concreto, con especial relevancia en la impuesta desde el absolutismo al liberalismo. ${ }^{4}$ En ocasiones, la violencia del Estado es tratada junto a la proveniente desde abajo hacia los enemigos en tiempos de guerra. ${ }^{5}$ Otras aportaciones se han centrado en las postrimerías del siglo XIX, por el gran interés que ha despertado la Restauración como periodo muy extenso

\footnotetext{
${ }^{2}$ Julio Aróstegui, “Introducción” a dossier Violencia y Política en España, Ayer, núm. 13, 1994, p. 15.

${ }^{3}$ Manuel Ballbé, Orden público y militarismo en la España constitucional (1812-1983), Alianza, Madrid, 1983; Alicia Fiestas Loza, Los delitos políticos (1840-1936), La Aurora, Salamanca, 1977.

${ }^{4}$ Por citar algunos, Jean-René Aymes, Los españoles en Francia (1808-1814). La deportación bajo el primer imperio, Siglo XXI, Madrid, 1987; Luis Lara López "La represión de los Afrancesados. Condenas sociales, jurídicas y políticas. El caso de Jaén (1812-1820)". Hispania Nova. Revista de Historia Contemporánea, núm. 3, 2003, pp. 39-50; Josep Fontana, "Represión política y violencia civil en 1823-1833. Propuestas para una interpretación" en Manuel González Portilla et al. Industrialización y nacionalismo. Análisis comparativos. Actas del I coloquio vasco-catalán de historia celebrado en Sitges: 20-22 de diciembre de 1822, Servicio de Publicaciones de la Universidad Autónoma de Barcelona-Bellaterra, 1985, pp. 313-327.

${ }^{5}$ Ramón Arnabat Mata, "Violencia política y guerra civil durante el Trienio Liberal en Cataluña (1820-1823)", y Lluís Ferran Toledano González, "A Dios rogando y con el mazo dando. Monopolio de la violencia y conflicto político en la última guerra civil en Cataluña (18721876), ambos en Vasconia. Cuadernos de Historia-Geografía, núm. 26, 1998, pp. 49-62 y 191208.
} 
de cierta estabilidad gubernativa, ${ }^{6}$ que no estuvo exento de conflictos sociales expresados generalmente en motines y ocupaciones de tierras por parte de los campesinos en tiempos de escasez. ${ }^{7}$ En este periodo comenzaron a manifestarse con todo su ímpetu las ideologías obreras, muchas veces de manera virulenta. ${ }^{8}$ Adolecíamos además de enfoques teóricos realizados en España, algo que también se va subsanando. ${ }^{9}$

Habitualmente, el periodo que transcurre desde el asentamiento del liberalismo hasta que el movimiento obrero adquirió fuerza permanece al margen de los estudios sobre represión gubernativa. La violencia emanada del Estado es mencionada como un elemento más de un hecho histórico, sin personalidad propia y que generalmente apenas ocupa algunas líneas o párrafos. Este hecho dificulta comprender la ferocidad que profesaban algunos sectores minoritarios del anarquismo, ya que el terrorismo hundía sus raíces en el largo historial de represalias que sufrieron, en muchas ocasiones únicamente por huelgas, manifestaciones pacíficas o la simple militancia. Por otra parte, centrarse únicamente en la vía legislativa nos oculta que el castigo no siempre discurrió por esa vía, ni tampoco por la de los tribunales especiales habilitados por la ley de 17 abril de 1821 o por el que con carácter permanente había en Cuba bajo el nombre de Comisión Militar. Las reales órdenes y decretos, bandos de los capitanes generales, las actuaciones arbitrarias de las autoridades militares y del Gobierno, en muchas ocasiones realizadas desde la improvisación, fueron los cauces habituales por los que se manifestó. La exclusión de derechos de la mayoría de la población facilitaba la arbitrariedad.

La escasez de estudios referentes a la acción del Estado sobre la disidencia política contrasta con el mejor conocimiento sobre la cárcel y el modo en que la sociedad burguesa trataba a la delincuencia "social". Probablemente por influencia teórica de Foucault, la readaptación del uso de la punición contra este grupo, principalmente a través de la cárcel, y la conceptualización del nuevo tipo de delincuente ha suscitado la atención de numerosos académicos, ${ }^{10}$ algo que en la

\footnotetext{
${ }^{6}$ Eduardo González Calleja, La razón de la fuerza. Orden público, subversión y violencia política en la España de la Restauración, CSIC, Madrid, 1998.

${ }^{7}$ Demetrio Castro Alfin, “Agitación y orden en la Restauración. ¿Fin del ciclo revolucionario?”, Historia Social, núm. 5, 1989, pp. 41 y ss.

${ }^{8}$ Ángel Herrerín López, Anarquía, dinamita y revolución social. Violencia y represión en la España de entre siglo (1868-1909), Catarata, Madrid, 2011.

${ }^{9}$ Eduardo González Calleja, La violencia en la política. Perspectivas teóricas sobre el empleo deliberado de la fuerza en los conflictos de poder, CSIC, Madrid, 2002.

${ }^{10}$ Por nombrar a algunos, desde el clásico de Justo Serna, Presos y pobres en España. La determinación social de la marginación, PPU, Barcelona, 1988, a nuevas aportaciones recientes Gutmaro Gómez Bravo, Crimen y castigo. Cárceles justicia y violencia en la España del siglo
} 
vertiente política lo ha sido principalmente en el caso de la prisión y otras formas de punición en la dictadura franquista. Lamentablemente esto no se ha producido en épocas anteriores ni se han incluido todas las formas de represalias.

El escarmiento por parte del Estado abarca diversas formas, principalmente se trataba de ejecuciones, prisiones, que generalmente son las más conocidas, y traslados forzados de domicilio. Estos últimos podían ser dentro del propio espacio geográfico o país, la metrópoli y Cuba para los habitantes de estos dos territorios, o a espacios ultramarinos. Nosotros nos hemos decantado por el estudio de las remisiones a territorios ultramarinos, pero sin desligarlas de los otros métodos a los que va unido, ya que en la mayoría de casos coexiste una combinación de estos, por lo que el análisis de las deportaciones solamente se entiende unido al del resto. Las relegaciones no pueden ir desligadas de su contexto para entender cómo se estructuró y cómo y porque se utilizó en ciertos casos, mientras que en otras ocasiones se optó por otras formas de sometimiento.

La relegación no había sido estudiada específicamente en su globalidad en España, algo de lo que alertaba Pere Gabriel que con datos parciales pero una gran intuición la circunscribía principalmente a la isla de Fernando Poo y a las Marianas, y en un espacio temporal anterior al triunfo de la Gloriosa. ${ }^{11}$ Esto nos hizo pensar, puesto que si se había aplicado a los cantonalistas, ${ }^{12}$ y en la década de 1860 era factible que hundiera sus raíces en tiempos precedentes. Otros estudios con diferente profundidad y pretensiones sobre periodos concretos reafirmaban esta idea. ${ }^{13}$ La deportación aparecía

XIX; Pedro Oliver, La pena de muerte en España, Síntesis, Madrid, 2008, y Cárcel y Sociedad represora. La criminalización del desorden en Navarra (siglos XVII-XIX), Tesis doctoral de la Universidad del País Vasco, Bilbao, 2001; Pedro Oliver y Jesús Carlos Urda, La prisión y las instituciones punitivas en la investigación histórica, Ediciones de la Universidad de Castilla-La Mancha, Cuenca, 2014.

${ }^{11}$ Pere Gabriel, "Más allá de los exilios políticos. Proscritos y deportados en el siglo XIX", en Santiago Castillo y Pedro Oliver (coords.), Las figuras del desorden. Heterodoxos, proscritos y marginados. Actas del V congreso de historia social de España (Ciudad Real, 10 y 11 de noviembre de 2005), Siglo XXI, Madrid, 2006, pp. 197-222.

${ }_{12}$ Julián Navarro Melenchón, Organización social y sistemas políticos durante la I República, Universidad de Murcia, Murcia, 2004; Belén Pozuelo Mascaraque, Presencia y acción españolas en las islas Marianas (1828-1899), Tesis doctoral de la Universidad Complutense de Madrid, Madrid, 1997.

${ }^{13}$ Jesús Raúl Navarro, "El exilio carlista" en Daniel Rivadulla, Jesús Raúl Navarro y María Teresa Berruezo, El exilio español en América en el siglo XIX, Mapfre, Madrid, 1992, pp. 157160; María Dolores Domingo Acebrón, "Los deportados de la Guerra de los Diez Años. Cuba (1868-1878)", Revista de Indias, vol. 51, núm. 191, 1991, pp. 154-155; María del Carmen Barcia, "Desterrados de la patria. Cuba 1869-1898", Revista de la Universidad de La Habana, núm. 258, 2003, pp. 31-35. 
como un elemento en muchos casos sin identidad propia, pero dado que la presencia de esta forma de castigo era patente y teniendo en cuenta la inestabilidad del periodo, era factible que hubiera sido utilizada con profusión. La información obtenida se ha completado con otras referencias de la época, que en ocasiones han sido muy útiles pero que generalmente proporcionaban datos incompletos o tendenciosos. La presente tesis, es heredera de todos estos estudios parciales a los que pretende completar, proporcionando un enfoque global y unas fuentes mucho más consistentes y ampliadas.

El desconocimiento de la deportación en España suponía un "agravio comparativo" en relación con la que se había producido en otros lugares. La más conocida es la británica a las Trece Colonias americanas, a Australia o Tasmania, ${ }^{14}$ pero también ha sido estudiada la portuguesa, ${ }^{15}$ y la francesa. ${ }^{16}$ Estos no fueron los únicos países que la practicaron, pero por la proximidad geográfica, cultural y su carácter de potencias con imperio ultramarino su aplicación podía asemejarse a la española. En todos los casos se trató del desembarazo de delincuentes en base a una estructura legal creada para favorecer la utilización de su fuerza de trabajo en aras de la colonización.

${ }^{14}$ A. Roger Ekirch, Bound for America: The Transportation of British Convicts to the Colonies, 1718-1775, Oxford University Press, Nueva York, 1987; Stephen Nicolas (ed.), Convict Workers: Reinterpreting the Australian Past, Cambridge University Press, Parramatta, 1988; Alan Brooke and David Brandon, Bound for Botany Bay: British Convict Workers to Australia, The National Archives, Kew, 2005; Robert Hugues, The Fatal Shore: A History of Transportation of Convicts to Australia, 1787-1868, Vintage Books, London, 2003; Alan Frost, Botany Bay, Black Inc., Collingwood, 2012; Alison Alexander, Tasmania's Convicts: How Felons built a Free Society, Allen and Unwin, Crows Nest, 2010.

${ }^{15}$ Timothy J. Coates, Convict Labour in the Portuguese Empire, Brill, Leiden, 2014.

${ }^{16}$ En Francia la deportación ha sido ampliamente estudiada. La deportación política entre la Revolución Francesa y el Segundo Imperio en Allyson Jaye Delnore, Political Convictions: French Deportation Projects in the Age of the Revolutions, 1791-1854, PhD Dissertation, University of Virginia, 2004; la deportación tanto política como de delincuentes en Louis-José Barbançon: Entre les chaînes et la terre. L'évolution de l'idée de déportation au XIX ${ }^{\circ}$ siècle en France, aux origines de la colonisation en Nouvelle-Calédonie. Thèse de doctorat d'histoire, Université de Versailles Saint-Quentin-en-Yvelines, 2000. Déportation et colonisation pénale en France (1789-1847). Introduction à la colonisation pénale en Nouvelle-Calédonie. Mémoire de maîtrise d'histoire, Université de Provence, 1991. Les Origines de la colonisation pénale en Nouvelle-Calédonie (1810-1863). Mémoire de D.E.A. d'histoire, Université française du Pacifique, 1992. L'Archipel des forçats: Histoire du bagne de Nouvelle-Calédonie, 1863-1931. La represión en la Revolución de 1848 en "Les transportés de 1848 (statistiques, analyse, commentaires)", Criminocorpus. Revue hypermédia. Historie de la justice, des crimes et des peines, 2008, [en Línea], https://criminocorpus.revues.org/148\#text; sobre los delincuentes reincidentes entre 1887 y 1953, Jean-Lucien Sánchez, La relégation des récidivistes en Guyane française. Les relégués au bagne colonial de Saint-Jean-du-Maroni, 1887-1953, Thèse de doctorat d'histoire, Ecole des Hautes Etudes en Sciences Sociales (EHESS), 2009; la deportación tanto por delitos políticos como comunes en Éric Fougere, Île-prison, bagne et déportation: les murs de la mer, éloigner et punir, L’Harmattan, París, 2002. 
Esto provocó que en el caso británico y portugués los represaliados políticos fueran incluidos dentro del procedimiento y destino habituales para los delincuentes comunes. En Francia, con sucesos tan importantes como la Comuna y la Revolución de París de 1848, las relegaciones políticas adquirieron mayor repercusión, pero el proceso siguió unas pautas regladas por el Código Penal y las leyes. En los tres países la medida es bien conocida, no sucede lo mismo en España donde no existía una estructuración penal de traslado de convictos a las colonias, lo que ha facilitado su ocultamiento. Únicamente en Ceuta se estableció el trabajo forzado de los mismos, pero la ciudad no puede considerarse una posesión y estuvo dirigida sobre los presos por delitos comunes.

La falta de estructura legal que la configurara como una práctica utilizada sistemáticamente y la improvisación facilitaron que pasara desapercibida. A esto no es ajeno la ausencia de una colonización efectiva constatable y perdurable. La contribución a la colonización no es desdeñable, pero esta no se produjo únicamente por esta vía lo que contribuyó a su ocultamiento. Aunque generalmente pasó inadvertida, cumplió un papel muy relevante para el poder como modo de represaliar a la disidencia mediante la prevención y castigo. Al contrario de lo que sucedió en los países comentados, en España la deportación era básicamente política por cuanto estos fueron los principales afectados. Incluso en el caso de que incluyera a otros grupos por su carácter social, lo fueron en tiempos de convulsiones como elemento preventivo para que su situación desesperada no derivase en apoyo a revueltas o insurrecciones. En estos casos hemos tratado a ambas como unidas ya que hemos considerado que no tenía sentido separarlas cuando ambas estaban motivadas por los mismos hechos y la separación, incluso entre las fuentes se da este caso, no era posible. Además, tampoco hubiera resultado coherente por cuanto fueron embarcados juntos y les sucedieron los mismos avatares en los puntos de destino.

El primer objetivo de la tesis ha sido hacer un estudio preciso sobre el número de afectados en cada periodo. En las ocasiones en que los datos que nos otorgaban las fuentes pudieran variar se ha indicado en el texto, pero en general el trabajo de indagación en los datos ha sido muy estricto. A partir de las cifras en cada caso concreto, se ha tratado de explicar el contexto que motivó la aplicación de las relegaciones.

Desde la instauración del liberalismo se fue imponiendo un modo de punición extrajudicial para los rivales políticos. La medida no es solo significativa por la cantidad 
de individuos a los que afectó durante todo el siglo, sino también como una herramienta útil para el poder a la que en tiempos de convulsiones recurría como modo de neutralización masiva de opositores a un costo más asequible que el asesinato.

Otra cuestión muy importante que pretendemos mostrar son los efectos de la práctica sobre los propios individuos. El desprecio del poder sobre ellos se muestra en los castigos que les infringió al margen de los tribunales, en la mayoría de los casos únicamente por su militancia o por no conocer el alcance real de su implicación. Conocer los avatares que tuvieron que soportar y la actuación gubernamental más allá de su traslado es imprescindible para contextualizar la magnitud de las represalias que no terminaron con la expedición a los puntos ultramarinos establecidos, en los que el amparo y la vigilancia continuaban.

El trabajo examina el papel esencial que la deportación como modo de represión política jugó en la España del siglo XIX. Para esto era necesario analizar detenidamente una serie de cuestiones. En que momentos se utilizó, que beneficios acarreaba para el poder, en que medida estaba institucionalizada, cuantos fueron los afectados, como se producían las aprehensiones y en qué condiciones eran embarcados y transportados. Otros problemas, no menos trascendentes, eran saber el modo en que continuaba la tutela de las autoridades sobre ellos en los puntos de destino, como se procuraba su manutención y la revocabilidad o permanencia en su condición.

El estudio de la relegación se inicia con la entronización del liberalismo, periodo en el que la Península y Cuba estaban inmersas en procesos muy diferentes. Hemos considerado finalizar el estudio en 1898 por las implicaciones que esto supone. La Antilla mayor consiguió su independencia y en la metrópoli el proceso de castigo mediante remisiones a los dominios perdió su sentido al perderse la propiedad de las posesiones más significativas. La irrupción del anarquismo como enemigo hizo replantearse al Gobierno su utilización: la práctica de la proscripción no desapareció, sufrió una transformación en la que fue perdiendo importancia el elemento ultramarino.

El siglo XIX se caracterizó por una permanente agitación. A las clases populares excluidas no les quedaba otra opción que la aceptación de su situación, la mendicidad o la delincuencia como elementos de rebeldía individual, o la oposición política a través del ultrarrealismo o el liberalismo más avanzado y popular que derivaría hacia 
postulados democráticos y republicanos. ${ }^{17}$ Otro tanto sucedía en Cuba, donde el grupo social que había liderado las independencias de América permaneció en la Antilla mayor leal a España, pero el precio que la metrópoli les hizo pagar por facilitar y amparar la producción de azúcar mediante esclavos fue el bloqueo al desarrollo de derechos de participación y sociales. En la posesión, además hemos de tener en cuenta los movimientos de los excluidos por cuestiones raciales, principalmente los libres de color que adquirieron cierta cultura y en ocasiones riqueza, y que buscaban un sitio en la sociedad.

La gran cantidad de insurrecciones, motines, guerras, conspiraciones y todo tipo de conflictos hicieron cuantiosas las deportaciones. El largo periodo estudiado, casi un siglo entero en dos países con una idiosincrasia muy diferente, hacía necesario acotar el tema para una correcta investigación. El tratamiento exhaustivo de ambos territorios ha requerido dejar al margen a las islas Filipinas. Frente a la relevancia económica de Cuba, el archipiélago era un territorio de menor importancia en la estructura del país y el independentismo se desarrolló más tardíamente. Aun así se produjeron relegaciones que aparecen en ocasiones en el texto por coincidir en Fernando Poo con los caribeños. Nuestra intención hubiera sido incluirla en el presente estudio pero este propósito se antojaba imposible, por lo que esperamos que forme parte de una futura investigación.

El marco cronológico iba irremediablemente unido a la aparición de la política. Para que esta eclosionara en 1808 era necesaria una difusión anterior de sus ideas, ${ }^{18}$ pero el poder, aletargado, fue incapaz de responder a este envite de una forma novedosa y recurrió a los castigos tradicionales. Fue el liberalismo el que vislumbró la potencialidad de la práctica, adaptada del antiguo destierro y la utilizó en beneficio propio contra los excluidos. Por esto, la tesis parte de 1808, año que encarna la ruptura con el Antiguo Régimen, y termina en 1898 que a su vez tiene una gran carga simbólica por representar el fin del poder colonial español.

\footnotetext{
${ }^{17}$ Alberto Gil Novales, "Las clases populares en la Revolución liberal española", en Manuel Ortiz Heras, David Ruiz González e Isidro Sánchez Sánchez (coords.), Movimientos sociales y Estado en la España contemporánea, Publicaciones de la Universidad de Castilla-La Mancha, Cuenca, 2001, p. 34.

${ }^{18}$ José Antonio Piqueras, Bicentenarios de libertad. La fragua de la política en España y las Américas, Península, Barcelona, 2010, pp. 13-30.
} 
El advenimiento de la política conllevó la aparición en escena de una serie de sujetos políticos. En la Península, el Trienio adquirió especial importancia como periodo en el que se institucionalizó una forma de reprimir caracterizada por la atribución de unas facultades excepcionales a los militares. La ley de 17 de abril de 1821 "extendía la jurisdicción militar al conocimiento de los delitos políticos cometidos por civiles". ${ }^{19}$ En Cuba, la real cédula de 28 de mayo de 1825 confirió al Capitán general poderes omnímodos. Ambas disposiciones, tomadas en periodos políticos diferentes, constituirían la base del sistema represivo posterior. Otorgaron impunidad a los represores y se utilizaron para castigar a la disidencia política: independentistas en Cuba y liberales avanzados y ultramontanos en la Península.

Los ultrarrealistas representaban un caso bastante lineal en cuanto al movimiento opositor, puesto que estaba conformado por los damnificados por la instauración del liberalismo político y económico: la baja nobleza cuya posición se resentía por el paso a una sociedad en la que el estatus venia determinado por el dinero; el clero, que vio disminuir su influencia y riqueza al ser sus tierras desamortizadas, y los campesinos, cuyas condiciones sufrieron un empeoramiento al perder en muchos casos las tierras que trabajaban y ser objeto de proletarización. Artesanos rurales y también urbanos, muchos de ellos de la industria domiciliaría, completaban las bases del carlismo. La pérdida de su miserable modo de vida para hallarse en la incertidumbre permanente de la búsqueda o el temor de pérdida del trabajo, hicieron que en los periodos iniciales en que se reprodujeron los cambios o en tiempos de crisis económica en que la escasez se aguzaba la inestabilidad se incrementaba y la oposición armada se recrudecía.

En los años en que no estalló una guerra generalizada, o las partidas que aparecían tenían poca importancia, el carlismo apenas es conocido, así sucede entre los años 1849 a 1855. En la década de 1860, el movimiento estuvo marcado por la proclamación del infante Carlos como pretendiente y por la creación del Reino de Italia y su posterior reconocimiento por Isabel II, que supuso los inicios de la convergencia entre neocatólicos y carlistas, realizada tras la caída de la reina. ${ }^{20}$

El resto de sujetos políticos pertenecientes a grupos excluidos fue cambiando con el devenir de los años. Los primeros liberales represaliados todavía pertenecían a grupos de notables. A las clases medias más radicalizadas de las sociedades secretas del

\footnotetext{
${ }^{19}$ Manuel Ballbé, Orden público y militarismo en la España constitucional, p. 74.

${ }^{20}$ Jordi Canal, El Carlismo, Alianza, Madrid, 2000, pp. 144-155
} 
liberalismo avanzado pertenecían los republicanos de mediados de la década de 1830 y principios de los $40 .{ }^{21}$ La categorización de este grupo todavía se observa en la represión diferenciada de que fueron objeto en el Bienio Progresista, respecto a los de menor categoría social. Un sector muy diferente al que representaba otra rama del republicanismo, de cariz más popular y mucho más sensible a demandas de democracia y justicia social y que con la caída del Bienio no dudó en alzarse en armas contra Narváez en Andalucía a finales de junio de $1857 .^{22}$

A partir de 1848, el socialismo, anteriormente con un marcado carácter utópico e intelectual, sufrió una evolución en donde adquirió un contenido ideológico mucho más delimitado. El bagaje teórico y las huelgas obreras en Barcelona durante el Bienio Progresista determinaron la evolución de parte del republicanismo que adquirió una naturaleza marcadamente obrera caracterizada por una resistencia a la proletarización, en un primer momento, y por ofrecer una salida a la miseria, una vez completado el proceso de proletarización, mediante la asociación y el cooperativismo. Otro grupo, representado por Pi y Margall tuvo un planteamiento menos social y se significó por su consideración del individuo como ser virtuoso. A su derecha, otra fracción se identificaba con la democracia liberal. ${ }^{23}$ Posteriormente, el sector socialmente más humilde dentro del republicanismo se sentiría atraído por el republicanismo federal y más tarde ante la ausencia de respuestas efectivas de este se desplazó hacia las ideologías obreras como el anarquismo y el socialismo de raíz marxista.

Los excluidos se reafirmaban por la posición que ocupaban frente a los grupos dominantes. Los partidos políticos eran agrupaciones de notables formadas por actores individuales que conformaban agrupaciones políticas con un carácter elitista. El carácter restringido del sufragio hizo innecesaria la creación de una estructura organizativa que emanara de la ciudadanía ya que esta había quedado excluida de la participación. Así, las bases del Partido Moderado estuvieron conformadas por miembros de la alta y media burguesía industrial, financiera y comercial; terratenientes; militares de alto rango; abogados; funcionarios y gente pertenecientes a otros sectores medios que se

\footnotetext{
${ }^{21}$ Demetrio Castro Alfin, "Orígenes y primeras etapas del republicanismo en España”, en Nigel Townson (ed.), El republicanismo en España (1830-1977), Alianza, Madrid, 1994, p. 49.

${ }^{22}$ Guy Thomson, El nacimiento de la política moderna en España. Democracia, asociación y revolución, 1854-1857, Comares, Albolote (Granada), 2014, pp. 87-90.

${ }^{23}$ Román Miguel González, La Pasión Revolucionaria. Culturas políticas republicanas en la España del siglo XIX, Centro de Estudios Constitucionales, Madrid, 2007, pp. 149-231.
} 
sintieron atraídos por el proyecto moderado basado en el mantenimiento arbitrario del orden público y el control de la revolución y de las clases populares. Los dirigentes conformaron un grupo de poderosos que ejercieron el poder ateniendo más a sus intereses como grupo, que a unos principios políticos determinados. ${ }^{24}$ El progresismo, heredero del liberalismo doceañista y del avanzado en el Trienio tenía mayor apoyo entre sectores sociales intermedios. Se erigían como teóricos defensores de la soberanía nacional, la limitación de poderes de la reina y la separación de poderes. ${ }^{25}$ Su acción de gobierno se caracterizó por una ampliación limitada del sistema para incluir a un sector que había quedado apartado y que pretendía una profundización del liberalismo, sin que ello supusiera incorporar a sectores más populares con reivindicaciones de carácter social.

A medio camino entre ambos se configuró la Unión Liberal, en la que confluyeron los sectores avanzados menos reaccionarios del moderantismo y los llamados resellados, la fracción más posibilista dentro del progresismo. Como partido que se autodenominaba centrista supieron atraerse a grupos sociales tanto elitistas como a miembros de la pequeña burguesía, profesionales liberales o comerciantes. ${ }^{26} \mathrm{La}$ extensión de los apoyos hacia la pequeña burguesía no debe confundirnos ya que los dirigentes formaban parte de un conglomerado mucho más elitista. Dentro de él cabria remarcar la importancia de su líder, el general Leopoldo O’Donnell, quien junto al general moderado Ramón María Narváez ocuparían la presidencia en la mayoría de los gobiernos que se sucedieron hasta la Gloriosa. La importancia del elemento militar en la política configuró una tolerancia muy escasa hacia cualquier tipo de disidencia y en especial hacia la de cariz político. Intransigencia que aumentaba a medida que esta emanaba de sectores cada vez más populares. El elemento castrense fue importante en la caída de Isabel II y condicionó la marcha del Sexenio. En la Restauración, las purgas, el cambio generacional y la política de atracción y beneficios llevada a cabo, facilitó la estabilización del sistema. ${ }^{27}$

\footnotetext{
${ }^{24}$ Francisco Cánovas Sánchez, El Partido Moderado, Centro de Estudios Constitucionales, Madrid, 1982, pp. 249-294.

${ }^{25}$ Jorge Vilches, Progreso y libertad. El Partido Progresista en la revolución liberal española, Alianza, Madrid, pp. 27-28.

${ }^{26}$ Francesc-Andreu Martínez Gallego, Conservar progresando. La Unión Liberal (1856-1868), Centro Francisco Tomás y Valiente UNED Alzira-Valencia/Fundación Instituto de Historia Social, Valencia, 2001, pp. 19-20.

${ }^{27}$ Daniel R. Headrick, Ejército y política en España (1866-1898), Tecnos, Madrid, 1981, pp. 62, 63, 75, 88-92 y 99.
} 
La relevancia del elemento militar fue incluso mayor en Cuba, en donde los capitanes generales ejercieron su mando dotados de facultades dictatoriales. En la colonia, los partidos que se formaron durante el Trienio: el liberal, formado tanto por peninsulares como criollos, el de los grandes hacendados y el independentista, ${ }^{28}$ conformarían la configuración inicial de los bloques políticos en Cuba, que los años y la respuesta de las autoridades españolas irían modificando. La lejanía cada vez mayor de las independencias americanas y la instauración del liberalismo en la metrópoli fortalecieron a este partido, que el Capitán general acabaría reprimiendo por tratar de extender el alcance de la Constitución a la colonia. La constatación de que Cuba quedaría al margen del liberalismo fortaleció al separatismo, cuyos movimientos armados entre 1848 a 1855 se manifestaron mediante insurrecciones y desembarcos anexionistas y a partir de 1868 a través de la guerra que buscaba la independencia.

Los grandes hacendados y la configuración de un partido español a partir de la capitanía general de Miguel Tacón conformaron la base sobre la que se sustentaría el sistema colonial. Algunos hacendados y miembros de las clases medias oscilaban entre el apoyo más o menos entusiasta a la metrópoli y la exploración de vías de adquisición de derechos políticos, eran los llamados reformistas. Incluso durante los años del anexionismo ante la debilidad de España ante la presión inglesa, los grandes hacendados estimularon la vía anexionista como modo de conservar sus intereses dentro de los Estados Unidos. Sin embargo, esta experiencia en la que tampoco se involucraron plenamente constituyó una excepción ya que el orden y la tranquilidad que pretendían para sus dotaciones les hacía ser reacios a cambios violentos. Con ellos, a pesar de salirse ocasionalmente del redil, la represión fue comedida.

Ante la Guerra de Independencia, sectores reformistas optaron por apoyar al Gobierno y posteriormente formarían el núcleo fundamental del autonomismo. ${ }^{29}$ Otra fracción derivó hacia el independentismo, conscientes de que la política española sobre la colonia difícilmente iba a cambiar considerablemente. En Cuba adquirieron mayor importancia las clases populares, sobre las que recaía el correspondiente desprecio social aplicado a los peninsulares, al que se sumaba el racial. Esto se manifestó desde la brutal represión de la Escalera hasta los presidios de ñáñigos en la Guerra de

\footnotetext{
${ }^{28}$ José Antonio Piqueras, "El mundo reducido a una isla. La unión cubana a la metrópoli en tiempos de tribulaciones", en José Antonio Piqueras (ed.), Las Antillas en la era de las luces y la revolución, Siglo XXI, Madrid, 2005, pp. 319-329.

${ }^{29}$ Inés Roldán de Montaud, La Restauración en Cuba. El fracaso de un proceso reformista, CSIC, Madrid, 2001, p. 129.
} 
Independencia y pasando por las deportaciones a isla de Pinos y Fernando Poo en las tres guerras independentistas.

La tesis ha sido dividida en tres bloques. En el primero, de carácter introductorio, analizamos los orígenes de la medida. En primer lugar nos centramos en la pena como evolución del destierro que se daba en el Antiguo Régimen. Aunque en España la deportación no fue impuesta por los tribunales ordinarios, los debates y la legislación penal que hubo en torno a la misma influyeron de un modo determinante en su ejecución real. También analizamos las primeras ocasiones en que se impuso, las motivaciones y el modo en que se empleó. De ahí derivó la contradicción entre un sistema que teóricamente impulsaba derechos pero que hizo frente a la exclusión que generaba por la vía de la represión. En el primer bloque hablamos de la Península y Cuba, como dos realidades en transición que todavía no se habían asentado, pero que ya configuraron respuestas diferentes en uno y otro caso. En el segundo y tercero, por las características diferenciadas de la realidad política, social y económica de ambos países, la diferenciación ha seguido este criterio.

Dentro del bloque específico para cada territorio, los diferentes capítulos siguen un orden cronológico. El Capítulo 3 va desde la muerte de Fernando VII a hasta la caída de Espartero. En el siguiente hablamos de la Década Moderada, un periodo especialmente convulso y con un Gobierno fuertemente autoritario, con el levantamiento de Solís, las revueltas de 1848 y la Guerra dels Matiners como hechos más destacados. El 5 comprende el Bienio Progresista y la etapa de la Unión Liberal. El 6 se extiende desde el Sexenio hasta la Villacampada. En cuanto a la Antilla mayor que conforma el siguiente bloque, esta estructurada en tres capítulos, el primero comprende desde la llegada de Tacón y la configuración de la posesión como colonia exenta de derechos políticos, hasta los años de revueltas de esclavos. En el 8 comprendemos el anexionismo y la Guerra de los Diez Años. Finalmente, la última sección comprende la Guerra Chiquita y la de Independencia, que finiquitó el dominio español sobre la isla.

Para la realización de la investigación se han consultado distintos fondos. En Madrid ha sido de vital trascendencia la documentación recogida en el Archivo 
Histórico Nacional, principalmente la referente al Ministerio de Ultramar, y en el Archivo General Militar de Madrid. También se han consultado fondos de la Real Academia de Historia. En Alcalá de Henares, el Archivo General de la Administración. El Archivo General de Indias y el Archivo Intermedio de la Región Militar Sur, de Sevilla, ampliaban la información de archivo en España. En Cuba se ha consultado principalmente el Archivo Nacional, pero también ha sido importante el fondo de Manuscritos de la Biblioteca Nacional José Martí y la sección de libros raros de la Universidad de La Habana. A través de los fondos del Archivo Nacional de Filipinas en el CSIC, se han consultado expedientes referentes a los deportados peninsulares en el archipiélago asiático y en las Marianas. La documentación referente a otras deportaciones se ha consultado a través del Archivo Municipal de la Ciudad de Barcelona y el Archivo Municipal Contemporáneo, de la propia ciudad condal.

Las fuentes primarias de archivo se completan con el Diario de Sesiones de las Cortes, las actas del Consejo de Ministros y la prensa. En particular, las publicaciones han sido de gran ayuda en la investigación y su consulta ha sido posible tanto a través de las páginas web de la Hemeroteca Digital de la Biblioteca Nacional y de la Biblioteca Virtual de Prensa Histórica, como físicamente en la hemeroteca de la Biblioteca Nacional de Madrid y de la Hemeroteca Municipal de Madrid. A través de la Hemeroteca Histórica de Cádiz se han consultado algunos periódicos de la ciudad. En Cuba se han analizado periódicos en la hemeroteca de la Biblioteca Nacional y en el Instituto de Literatura y Lingüística de La Habana.

Las fuentes empleadas son las que han permitido extraer los datos expuestos y cimentar el análisis de las mismas. A través de ellas la tesis aspira a hacer una contribución al estudio de la represión en España durante el siglo XIX. Esto, a través de mostrar la importancia de las relegaciones, que generalmente había pasado desapercibida y que tiene otras implicaciones además del control preventivo y castigo de los opositores. En este sentido, pretendemos complementar la investigación de otros historiadores, pero somos consciente que en un terreno bastante yermo. Esperamos haberlo conseguido con solvencia.

Para finalizar la introducción, habría que explicar que se entiende por deportación. Al hablar del término nos referimos a la acepción del siglo XIX, que 
continua en la actualidad, aunque la evolución social y política ha incorporado otras y ha hecho perder vigencia a esta. Entendemos por deportación el embarque forzado de uno o varios individuos con destino a un punto ultramarino perteneciente al mismo Estado, generalmente una colonia, en el que los sujetos permanecían con al menos cierto grado de libertad y en el que la tutela de las autoridades continuaba y la prohibición de salir se mantenía. Relegación se ha empleado como sinónimo puro, a la vez que otros vocablos se han empleado en ocasiones como sinónimos pero pueden tener significados distintos. Confinamiento se refiere a situar a alguien en un punto determinado del que no puede salir, lo que puede referirse tanto a un espacio presidiario, como a una deportación o un destierro. Destierro implica hacer salir a alguien de un lugar, lo que puede referirse a una deportación, pero en la mayoría de los casos se ha empleado como obligar a alguien a salir de un punto determinado teniendo como lugar de destino otro del mismo país, la isla de Cuba en el caso de los criollos y la España peninsular en el caso de los antillanos. 


\section{PRIMERA PARTE.}

\section{CONTEXTUALIZACIÓN Y CONFIGURACIÓN DE LA PRÁCTICA DE LA DEPORTACIÓN}




\section{CAPÍTULO 1. LA DEPORTACIÓN EN LA LEGISLACIÓN ESPAÑOLA}

\section{EL DESTIERRO EN LA LEGISLACIÓN MEDIEVAL Y SU USO REAL}

En el reino de Castilla, a partir de la promulgación del ordenamiento de Alcala en 1348 y especialmente de las Leyes de Toro de 1505 se estableció un sistema normativo en el que en primer lugar se aplicaría el propio Ordenamiento de Alcalá (y por extensión todo el Derecho real). En defecto de estas se aplicarían los fueros municipales, que serian los propios de cada municipio o el Fuero Juzgo o el Fuero Real, en caso de carecer de ellos. En tercer término se aplicarían las Partidas, unas normas con esencia de Derecho romano-canónico generalmente atribuidas a Alfonso X. El proceso criminal se caracterizaba por una falta absoluta de derechos para el reo y estaba encaminado a obtener su culpabilidad. ${ }^{1}$

El castigo del culpable se hacía con gran ostentación lo que derivaba de la propia finalidad de mantenimiento del orden social mediante el miedo de los súbditos. La nobleza como intermediaria entre el poder real y los vasallos tenía un trato diferenciado: un fuero especial, la inaplicabilidad de la tortura salvo contadas excepciones y su influencia y poder hacia que las penas contra ellos fueron generalmente blandas. Por el contrario, algunos delitos que perjudicaban al soberano como el contrabando de oro y plata o la falsificación de moneda eran duramente castigados. ${ }^{2}$

En la legislación de origen medieval encontramos la relegación a través de expresiones como echar de la tierra, echar del reino o desterrar, cuyos efectos han de considerarse una adecuación a las características propias de la época de lo que en el

\footnotetext{
${ }^{1}$ Francisco Tomás y Valiente, El derecho penal de la monarquía absoluta, (Siglos XVI-XVIIXVIII), Tecnos, Madrid, 1969, pp. 175-182 y 198-200. Álava, Guipúzcoa y Vizcaya, Navarra o la Corona de Aragón tenían fuentes diferentes pero en general un funcionamiento similar. En algunos casos introducían mejoras para el reo, así en el caso aragonés y catalán las sentencias debían ir motivadas. Sobre la normativa específica, ver José Manuel Pérez-Prendes MuñozArraco, Historia del derecho español, Servicio de Publicaciones. Facultad de Derecho. Universidad Complutense, Madrid, 2004, tomo II, pp. 1484-1486; María Paz Alonso Romero, El proceso penal en Castilla (Siglos XIII-XVIII), Ediciones Universidad de Salamanca, Salamanca, 1982, pp. 159-317. Las pruebas más importantes eran la autoconfesión del reo mediante la tortura y la prueba testifical que con dos testigos suponía la culpabilidad. El falso testimonio era frecuente ya que el acusador obtenía parte en las penas pecuniarias.

${ }^{2}$ Francisco Tomás y Valiente, El derecho penal de la monarquía absoluta, pp. 85-86 y 317-330.
} 
periodo contemporáneo denominamos deportación. Su contemplación en las Partidas tiene que ver con el influjo románico-canónico de las mismas, por lo que se incluía la relegación a una isla en un momento en que Castilla no disponía de territorios ultramarinos. Una acción que solía conllevar esta condena era no prestar ayuda al rey en acciones militares. ${ }^{3}$ Además se contempla en casos de herejía, incluida en ella la práctica de cualquier religión no católica, o de homicidio en el que concurrieran circunstancias atenuantes. Los matrimonios hechos en adulterio o parentesco solían terminar con expulsión. ${ }^{4}$ En delitos que merecían pena de muerte, los familiares podían otorgar el perdón al asesino a cambio de su destierro perpetuo. ${ }^{5}$ Pero en general, no existe un tipo de delitos a los que se le solía atribuir este castigo. La misma inconsistencia se detecta en otros ordenamientos como el aragonés, el catalán o el valenciano. ${ }^{6}$ En las Leyes de Indias se imponía para infracciones variadas. ${ }^{7}$ Sin

\footnotetext{
${ }^{3}$ Leyes VIII y IX, Titulo II, Libro IX, Fuero Juzgo en latín y en castellano, cotejado con los más antiguos y preciosos códices (en adelante Fuero Juzgo), Real Academia Española, Madrid, 1815.

${ }^{4}$ Ley II, Titulo XXVI, Partida VII. A los homicidios por imprudencia, Ley II, Titulo XV, Partida VII. Al padre o marido que encuentren a su hija casada o esposa en adulterio y maten a uno de los dos y es de rango igual o superior al fallecido. Ley XIV, Titulo XVII, Partida VII. Leyes VI, XIV y XVI, Titulo XVII, Partida VII; Leyes II y III, Titulo VIII, Partida VII. Las siete Partidas del rey don Alfonso el Sabio, cotejadas con varios códices antiguos, Imprenta Real, Madrid, 1807; Leyes I, II, III, IV, V y XII, Titulo III, Libro XII. Alguien que mate a un familiar y se refugie en una iglesia se le podría echar de la tierra en lugar de ejecutarlo, Fuero Juzgo, Ley XVIII, Título V, Libro VI. Al señor que mate a un siervo, Ley XII, Título V, Libro VI, Fuero Juzgo; Ley II, Título V, Libro III, Fuero Juzgo; Ley II, Titulo VII, Libro IV, Fuero Real (citado de Opúsculos Legales del rey don Alfonso el Sabio, Imprenta Real, Madrid, 1836, tomo II).

${ }^{5}$ Emilio Cabrera, "Crimen y castigo en Andalucía durante el siglo XV", Meridies. Revista de Historia Medieval, núm. 1, 1994, p. 31.

${ }^{6}$ Valgan como ejemplo: Libro III, De la facultad de las partes de entrar en la Cámara del Consejo sin armas. Fueros y observancias del Reino de Aragón, Diputación de Aragón, 1667, vol. I, que permite desterrar por algunos días de la ciudad o del reino a los que peleen en la Cámara del Consejo; Capítol XVI, (Constitucions de Cataluña), (Citado de Constitucions, capítols, $i$ actes de cort, Estampa de Rafel Figuerò, Barcelona, 1706), que destierra a las mujeres, personas mayores y niños gitanos. En estos ordenamientos la mayor importancia del derecho local y del consuetudinario hace todavía más difícil determinar su aplicación real; en el caso valenciano en el que la costumbre era menos relevante aparece con mayor frecuencia, Por ejemplo: Llei I, Rubrica V, Llibre 8, Furs de Valencia, (edición de Germà Colon i Arcadi García), 11 vols., Barcino, Barcelona, vol. 7, 1977. Contempla el exilio del Reino por un año, para los condenados por injurias que no paguen la multa estipulada.

${ }^{7}$ Ley 25, Titulo VI, Libro I, Recopilación compendiada de las Leyes de Indias, Adición al febrero, Imprenta de D. Ignacio Boix, Madrid, 1846. En casos de reincidencia de jurar el nombre de dios en vano; Ley 1, Titulo VI, Libro I. Entrometerse en los asuntos del patronato real; Leyes 6, 7 y 9, Titulo XVI Libro III. Los que obstaculicen la correspondencia entre la Península y las Indias.
} 
embargo, el carácter colonial y alejado del centro de poder político hacia recomendable una sujeción especial.

"Si a los virreyes pareciese que conviene al servicio de Dios nuestro señor y nuestro, desterrar de aquellos reinos, y remitir a estos a algunas personas, las hagan salir luego, habiendo procedido judicialmente, y nos remitan la causa fulminada, para que Nos veamos si tuvieron bastantes motivos para esta resolución".

Con este esta única ley se avalaba la utilización del traslado a la metrópoli para cualquier tipo de delito, lo que en comparación con los preceptos del Antiguo Régimen supone una simplicidad extraordinaria y una arbitrariedad incluso mayor derivada de la condición colonial de los territorios. En la legislación peninsular muchas actuaciones podían terminar con la imposición de la condena, pero la enorme cantidad de penas, la diferencia entre la aplicación según el estrato social de cada sujeto y la contradicción dentro de las propias leyes y de unas a otras hacen imposible establecer generalidades. Además, para un mismo delito las normas eran contradictoras.

Frente al anquilosamiento de una normativa totalmente anticuada dictada hacia varios cientos de años e inadecuada a las pretensiones del momento surgieron las Pragmáticas. Significaban la expresión del poder normativo del rey y se fueron dictando de manera acumulativa, lo que conllevó un gran crecimiento del derecho y una dificultad en su aplicación que se trató de solventar con recopilaciones periódicas. Su constante promulgación permitía una mayor adecuación a los deseos y las necesidades de la monarquía, en un momento en que se estaba produciendo un afianzamiento del poder real. La utilidad del destierro influía en su importancia creciente para conductas muy diversas en la nueva legislación que iba apareciendo. Geográficamente podía significar la expulsión desde tan solo la Corte hasta la expulsión de nuestros reinos. ${ }^{9}$

A pesar de lo expuesto, hemos de tener en cuenta que las sentencias no tenían por qué adecuarse a lo que la legislación establecía. En un estudio sobre los castigos

\footnotetext{
${ }^{8}$ Ley 61, Titulo III, Libro III, Recopilación de las Leyes de Indias, Ignacio Boix, Editor, Madrid, 1841, tomo II. Esta ley era de 1568, pero ya encontramos la misma atribución en 1531 dirigida a personalidades de relevancia, sin referencia a ningún tipo de juicio y estipulando que podía hacerse "sin muy gran causa", Ley 18, Titulo VIII, Libro VII.

${ }^{9}$ Ley XXXIII, Titulo VII, Libro I. La censura en la impresión de libros y otros documentos. Ley XXX, Titulo IV, Libro II. La prohibición de regalos a funcionarios de la corte por parte de otros menores. Ley V, Titulo XVIII, Libro VI. Prácticas contra el comercio real o la compra de oro en América por extranjeros. Ley II, Titulo XVIII, Libro IX. Fraude a la hora de pagar impuestos, Recopilación de las leyes de estos reinos (en adelante Nueva Recopilación), Catalina de Barrio y Angulo y Diego Díaz de la Carrera, Madrid, 1640.
} 
impuestos por la Real Chancillería de Valladolid entre los años 1475-1530, el destierro se impuso en el 37,16\% de las ocasiones. Poder librarse del delincuente sin la crueldad de su ejecución pública y posibilitar la utilización del reo para repoblar territorios de frontera o de reciente adquisición, en las minas de Almadén, las galeras reales o como soldados en campañas bélicas, ${ }^{10}$ determinaron su imposición en casos en que la normativa no la contemplaba.

La idea de la importancia real del destierro por encima de su plasmación legal es corroborada en otros estudios. En la Chancillería de Ciudad Real y Granada para el periodo de 1495-1510, se aplicó en un 36,4\% de las ocasiones. También se impuso en un $37,5 \%$ en los procesos por envenenamiento en el reino de Navarra en los siglos XVI y XVI, e incluso en un $49 \%$ de las veces por desórdenes públicos en la Edad Moderna en el mismo reino. En Vizcaya, también fue la pena más utilizada en los siglos XVI y XVII, pero perdió importancia en el XVIII a favor de otras como servicios en el ejército $\mathrm{y}$ trabajos forzados en presidios o arsenales. ${ }^{11}$ Para el caso gallego, el destierro en el siglo XVI correspondía al 30,3\% de los juzgados, en el XVII al 26,7\% y en el XVIII solamente al $9,1 \%$, lo que muestra su progresiva sustitución por otras penas consideradas más provechosas. Las condenas difícilmente superaban los seis años y en raras ocasiones alcanzaban los diez o lo eran a perpetuidad, siendo generalmente de

\footnotetext{
${ }^{10}$ Iñaki Bazán Díaz, "El destierro en el País Vasco (siglos XIV-XVI)" en Cesar González Mínguez, Iñaki Bazán Díaz e Iñaki Reguera (eds.), Marginación y exclusión social en el País Vasco, Servicio Editorial de la Universidad del País Vasco, Bilbao, 1999, pp. 25-53. En 278 procesos de la Real Chancillería de Valladolid el destierro se impuso en 68 ocasiones, seguido de penas corporales (28), económicas (27), devolución del honor (26), muerte (16), devolución de lo sustraído (11) y ejército y galeras (7); la pena de muerte a partir del reinado de los Reyes Católicos fue cada vez menos empleada, ya que se prefirió que los reos fueran utilizados en las empresas económicas y militares de la monarquía. Iñaki Bazán Díaz, "La pena de muerte en la Corona de Castilla en la Edad Media", Clío \& Crimen. Revista del Centro de Historia del Crimen de Durango, núm. 4, 2007, pp. 306-352.

${ }^{11}$ Juan Miguel Mendoza Garrido et al., "Delincuencia y justicia en la Chancillería de Ciudad Real y Granada (1495-1510)" Primera Parte. Estudio, Clío \& Crimen. Revista del Centro de Historia del Crimen de Durango, núm. 4, 2007, p. 457; Mikel Berraondo, "Maneras de matar. Violencia y envenenamiento en la Navarra de los siglos XVI y XVII", en Carlos Mata Induráin y Adrián J. Sáez (eds.), "Scripta manent». Actas del I congreso internacional jóvenes investigadores Siglo de Oro (JISO 2011), Servicio de Publicaciones de la Universidad de Navarra, Pamplona, 2012, pp. 54-56; Javier Ruiz Astiz, "Castigos impuestos a los causantes de desórdenes. La actitud de los tribunales reales de Navarra durante la Edad Moderna", Sancho el Sabio, núm. 34, 2011, pp. 28-29; Luis María Bernal Serna, Sociedad y violencia en Portugalete (1550-1833), Ayuntamiento de Portugalete, Portugalete, 2007, pp. 153 y 160-161. Establece que el trabajo en los presidios africanos y las galeras eran las penas más comunes.
} 
cuatro años o menores. Respecto al alcance geográfico, normalmente alcanzaba a la localidad aunque se podía llegar a determinar la expulsión del reino. ${ }^{12}$

También en América hemos encontrado noticias de su aplicación. Según Ramón Francisco Valdés hubo una aplicación frecuente de la medida al margen de las leyes de modo que el regente del reino pidió mesura en su uso a raíz de la muerte de unos desterrados de hambre en Barcelona, bajo la argumentación que para los ricos no era un castigo y para los pobres era "la miseria y la muerte". Además, se procedía a ellos sin

juicio y sin la remisión de la correspondiente causa. ${ }^{13}$ Para evitar la desautorización o desaprobación lo más sencillo era remitirlos a otros lugares del imperio. Desde México se enviaban delincuentes a Filipinas. ${ }^{14}$ Era muchísimo mejor remitirlos a otros lugares donde las autoridades metropolitanas ni se enteraran, por lo que este segundo destino podría ser más habitual.

\section{LA EVOLUCIÓN DE LA CONDENA DE DESTIERRO. PENAS SUSTITUTIVAS}

El descubrimiento de nuevas tierras en América ofrecía nuevas posibilidades para la aplicación de esta pena. Una ley de 1497 mandaba conmutar el destierro a alguna isla, así como trabajos agrícolas o en minas a favor de los reyes por el pase a La Española durante un tiempo de diez años en caso de que fuera perpetuo y la mitad del tiempo de la condena para el temporal, dedicándose a las tareas que el almirante les mandase o "labor de metales". Diez homicidas fueron deportados a la isla en virtud de esta disposición en el tercer viaje de Colón, entre ellos dos hombres y dos mujeres de

\footnotetext{
${ }^{12}$ Pedro Ortego Gil, "Los ámbitos temporal y de exclusión territorial del destierro en los siglos XVI-XVIII. La práctica judicial gallega", Boletín da Facultade de Direito de Coimbra, núm. 77, 2001, pp. 123-157. Las penas impuestas en más ocasiones son de cuatro años (113 veces), 2 años (96), 6 años (75) y un año (59); Iñaki Bazán Diez, Delincuencia y criminalidad en el País Vasco en la transición de la Edad Media a la Moderna, Servicio de Publicaciones del Gobierno Vasco, Vitoria-Gasteiz, 1995, pp. 587-588. La mayoría de las penas de destierro no superaban el año, siendo más suaves que en el caso gallego, aunque en ambos casos se trata de pocos años.

${ }^{13}$ Ramón Francisco Valdés, Diccionario de Legislación y jurisprudencia criminal, Imprenta Militar de D. Manuel Soler, La Habana, 1859, p. 214.

${ }^{14}$ Carlos de Sigüenza y Gondora, Infortunios de Alonso Ramírez, Maxtor, Valladolid, 2012, p. 37. Edición facsímil del original de 1690; Vicente Alemany, Andanzas del buscón don pablos por México y Filipinas, (Celsa Carmen García Valdés ed.) Universidad de Navarra, Pamplona, 1998, pp. 105-106.
} 
etnia gitana. ${ }^{15}$ Este tipo de relegación no tuvo demasiado éxito, principalmente por la gran afluencia de población libre y por la falta de mano de obra para las galeras reales.

Aun así en el siglo XVIII encontramos diversas leyes que pretendían el uso de la fuerza de trabajo de los reos en territorios ultramarinos. En Cuba, tras la toma por los ingleses el nuevo gobernador, el conde de Ricla, llegó con la orden expresa de reforzar las defensas, en las que junto a esclavos negros trabajarían presidiarios traídos principalmente desde México, la Península y desde otros puntos de América. ${ }^{16}$ Exceptuando casos concretos, como la necesidad de fortificación de La Habana, la exigencia de reclusos en la metrópoli haría que el traslado a América o Filipinas fuera puntual, no así la utilización de los propios presos de las colonias.

En el siglo XVI se afianzó el uso de las galeras, preexistente pero con una aplicación infrecuente. En 1530, 1534 y 1535, Carlos V ordenaba que los sentenciados a penas corporales, destierro perpetuo y otras semejantes fueran utilizados en estas por un tiempo mínimo de dos años. En 1552 se establecía que en los delitos en donde se podía substituir las sentencias por hurtos, robos, salteamientos y otros delitos semejantes por las galeras, se hiciera. En 1566 Felipe II lo ampliaba a vagabundos, ladrones, blasfemos, rufianes, testigos falsos, bígamos, y a los que se resistían a los justicias, ${ }^{17}$ lo que suponía una extensión en su aplicación incluso a gente sin conducta delictiva. Las disposiciones al respecto continuaron promulgándose, alcanzando a un número creciente de delitos, por lo que se convirtió en la pena más utilizada. Esto implicó un decrecimiento en la importancia del destierro en la Edad Moderna y su derivación hacia trabajos a favor del Estado, en lo que conformaba un aprovechamiento de la fuerza de trabajo de los reos mostrando que la utilidad no era un concepto nuevo de carácter capitalista.

De forma paralela se desarrollaba el trabajo forzado en Almadén, cuyas minas conocidas desde la antigüedad adquirieron una importancia creciente tras la introducción en América en 1554 de la amalgama de mercurio con la plata. ${ }^{18}$ Así, la producción minera de este pequeño municipio entroncó con la extracción de metales

${ }^{15}$ Ley I, Titulo XIV, Libro VIII, Nueva Recopilación; Juan Gil, "El rol del tercer viaje colombino", Historiografía y Biblioteca Americanista, vol. XXIX, núm.1, Sevilla, 1985, p. 102.

${ }^{16}$ Ruth Pike, Penal Servitude in early modern Spain, University of Wisconsin Press, Madison, 1983, pp. 134-147; Leyes XIII, XIV y XXIII, Titulo XL, Libro XII, Novísima Recopilación de las leyes de España (en adelante Novísima Recopilación), Madrid, 1805.

${ }^{17}$ Pragmática de 31 de enero de 1530; Ley IV, Titulo XXIV, Libro VIII. Ley VIII, Titulo XI, Libro VIII. Ley VI, Titulo XXIV, Libro VIII, Nueva Recopilación.

${ }^{18}$ Germán Bleiberg, El «informe secreto» de Mateo Alemán sobre el trabajo forzoso en las Minas de Almadén, Támesis Books Limited, London, 1985, p. 15. 
preciosos en las colonias americanas. En 1559, los arrendatarios solicitaron al Rey que les enviara penados a galeras como trabajadores. Más de 2.000 reos cumplirían allí su sentencia hasta 1799. Se ha constatado la presencia simultánea de unos 100 trabajadores, de los cuales aproximadamente la mitad serían presidiarios y el resto esclavos, aunque dicha cantidad fluctuaba en función de las necesidades de la armada real. El tiempo de punición oscilaba entre las mínimas de dos años y las máximas de diez, al igual que sucedía con las galeras, aunque la mayoría lo eran a las de dos, cuatro o seis años. Un 39\% moría antes de la terminación del castigo, un $8 \%$ se fugaba y solo un $49 \%$ era liberado tras cumplir la condena. La necesidad de mano de obra no decayó, y tras la derogación de las galeras, en 1803, el rey dispuso que los reos que las merecieren por delitos infames se destinasen ahora a las minas en el caso de ser robustos, mientras que los débiles y enfermos se enviasen a las penitenciarías de África. ${ }^{19}$

La concepción utilitarista de la penalidad determinó una evolución continua. En la década de 1780, el destierro se impuso en Castilla en 85 ocasiones, pero destacan sobremanera las sentencias de presidio africano (520 veces), servicios armados (270) y los trabajos en arsenales (162). A estas habría que sumar las de cárcel en la Península (52) y las galeras (93), castigo que estuvo suprimido entre 1748 y 1784 y que una vez reincorporada por necesidades militares del momento no conservó la importancia precedente. La cárcel implicaba trabajos forzados en la Península, África e incluso en América, en minas o construyendo caminos, puertos y otras infraestructuras. ${ }^{20}$ Las mujeres generalmente eran recluidas en cárceles específicas, también denominadas galeras y que compaginaban el fin represivo con el moralizador y correccional, objetivo que pretendían alcanzar a través de la disciplina y de la fe católica.

En tiempos de paz la utilización en el ejército perdía importancia. En 1802, entre los 1.939 presos juzgados por la Sala de Alcaldes en 1802 ninguno fue condenado a muerte. Las penas más repetidas fueron la de multa (566 ocasiones), el apercibimiento (531), el envío a hospicios (216), presidios (133), obras del Camino Imperial (119) y el destierro (67). A servicio a las armas, arsenales y reenvío a cuerpos militares fueron

\footnotetext{
${ }^{19}$ Julián Antonio Prior Cabanillas, La pena de minas. Los forzados de Almadén, 1649-1699, Universidad de Castilla-La Mancha. Gabinete del Rector, Ciudad Real, 2003, pp. 25-26, 28, 41, 44-45, 50-51 y 70-100; Pragmática de 4 de noviembre de 1749.

${ }^{20}$ José Miguel Palop Ramos, "Delitos y penas en la España del Siglo XVIII", en Estudis. Revista de Historia Moderna. Monográfico dedicado a conflictividad y represión en la sociedad moderna, núm. 22, 1996, pp. 90-103.
} 
sentenciados un total de 123 individuos. La suavización punitiva es clara en comparación con los siglos precedentes. La mutilación se sustituyó progresivamente por la marca y esta también vio declinar su importancia y cayó en desuso. ${ }^{21}$ Los jueces se aprovechaban del arbitrio judicial para imponer castigos menos severos, influenciados por el papel de la Ilustración en el pensamiento europeo del periodo y sus pretensiones humanizadoras.

La Novísima Recopilación de 1805 significó el punto culminante en la evolución que alcanzó el derecho penal del Antiguo Régimen, realizada por Lardizábal recogía buena parte de los preceptos de su antecesora y a la vez que añadía abundante legislación del siglo XVIII ya menos rigurosa. Era una recopilación del derecho del Antiguo Régimen, que contenía leyes contra judíos y moros, la herejía, la blasfemia, el adivinamiento y la hechicería. El destierro se mantenía principalmente por los preceptos antiguos, pero también se utilizaba en algunos recientes relacionados con lugares acotados para la caza del Rey. En la mayoría de los casos, los castigos se orientaban hacia un fin más utilitario, este es el caso de una norma de 1775 que conmutaba las penas impuestas a los vagos por el servicio a las armas y otra de 1771 que imponía la de arsenales a los delitos más graves a los que no se aplicaba la de muerte. ${ }^{22}$ Las reacciones a su publicación fueron diversas, pero en este momento ya no se debían tener en cuenta tan solo los errores que contenía la compilación, inherentes al propio sistema legal, sino que la creación del Código Penal francés en 1810 que superaba el sistema anterior, con el cual cada vez más personas se sentían identificadas por cuanto ofrecían mayores garantías jurídicas y se adaptaban mucho mejor a los tiempos imperantes.

\section{DESTIERROS COLECTIVOS EN LA EDAD MODERNA. JUDÍOS, MORISCOS, GITANOS Y JESUITAS}

Los actos delictivos eran realizados por sujetos concretos y sobre ellos se actuaba judicialmente. Sin embargo, había grupos sociales que por su mera configuración como tal eran vistos como una amenaza, por cuanto no compartían creencias religiosas, políticas o formas de vida. Su caso puede considerarse el de

\footnotetext{
${ }^{21}$ Francisco Tomás y Valiente, El derecho penal de la monarquía absoluta, pp. 367 y 385-387.

${ }^{22}$ Leyes III y XIII, Titulo X, Libro III. Ley VII, Titulo XXXI, Libro II y Ley VII, Titulo XL, Libro XII, Novísima Recopilación.
} 
disidentes pre-políticos. Dentro de estos grupos habría que citar a los judíos. La presión visigoda hizo que muchos colaboraran con los musulmanes, pero con la llegada de los benemérides y almohades la mayor parte emigraron a las zonas cristianas, en donde se les ofrecía tolerancia y seguridad, a pesar de las leyes discriminatorias. El número exacto de los que vivían en los territorios cristianos es imposible de saber, Ladero Quesada la establece entre 150.000 y 200.000 en 1275, número que Pérez aumenta hasta 250.000 hacia $1370 .^{23}$

El declive vino determinado por las epidemias, las guerras y el hambre propias del periodo, a lo que habría que añadir el antisemitismo. En el siglo XIV los asaltos a juderías fueron cada vez más frecuentes y con mayor violencia. En 1320 "pastorellos" franceses cruzaron los pirineos y atacaron juderías de Navarra y Aragón. En 1348 las juderías de diversas poblaciones catalanas fueron asaltadas, entre ellas la de Barcelona. En 1391 se produjeron asesinatos de judíos en diversas poblaciones andaluzas, Valencia, Cataluña, y Castilla, en las que algunos barrios fueron totalmente arrasados. Las causas de la expansión del antisemitismo fueron diversas, entre las que cabría destacar las predicaciones del bajo clero, el vacío de poder, el resentimiento acumulado, la situación de crisis económica y miseria, las riquezas de algunos judíos y su dedicación a la usura. Como modo de escapar de la violencia se iniciaron las conversiones masivas. ${ }^{24}$ Así llegamos a 1492 en que los Reyes Católicos promulgan la elección entre expulsión o conversión que tuvo como consecuencia la salida de entre 75.000 a $90.000 .^{25}$ Parece ser que apenas hubo conversiones, probablemente los dispuestos a hacerlo ya lo habrían hecho anteriormente y siempre existía el temor a la inquisición. Varios centenares regresaron a la Península para convertirse tras las penalidades que tuvieron que soportar en otros lugares.

${ }^{23}$ Miguel Ángel Ladero Quesada, "El número de judíos en la España de 1492. Los que se fueron", en Sefarditas. Conversos. La expulsión de 1492 y sus consecuencias, Ámbito, Valladolid, 1995, p. 172; Joseph Pérez, Historia de una tragedia. La expulsión de los judíos de España, Crítica, Barcelona, 2004, pp. 22-23; la mayoría vivían en el Reino de Castilla. También eran numerosos en el reino de Aragón. En Cataluña y Valencia hablamos de porcentajes bajos, aunque en Cataluña estaban concentración en unas pocas ciudades.

${ }^{24}$ Un análisis compilado de las causas en José Belmonte y Pilar Leseduarte Gil, El auge y expulsión de los judios. Auge y ocaso del judaísmo en Sefarad, Beta III Milenio, Bilbao, 2007, pp. 105-118.

Miguel Ángel Ladero Quesada, "El número de judíos en la España de 1492. Los que se fueron", p. 171; Carlos Carrete Parrondo lo rebaja a unos 70.000, "Comunidades judías castellano-leonesas", en Ana María López Álvarez y Ricardo Izquierdo Benito (coords.), Juderías y sinagogas de la Sefarad medieval, Universidad de Castilla-La Mancha, Cuenca, 2003, p. 379. 
Los musulmanes eran la minoría religiosa más importante, eran muy relevantes en Granada y constituían poblaciones significativas en Valencia y Aragón. En 1502 los Reyes Católicos ordenaron la conversión forzada en la Corona de Castilla, aunque la mayoría continuaron practicando el islam. En la Corona de Aragón la conversión impuesta se promulgó en 1525. La presión social se manifestaba en tumultos y conversiones forzadas como en las Germanías, unas 15.000, y el predicamento del bajo clero. La legislación real cada vez les castigaba más: prohibía sus vestiduras, que portasen armas, su lengua, la circuncisión, el desarrollo de ciertos oficios, la propiedad de esclavos, los desplazamientos de población, el sacrificio ritual de los animales para carne e imponiéndoles el impuesto de la farda. Esta coerción tuvo como consecuencia la huida de un buen número y el alzamiento de granadinos en diciembre de 1568, revuelta que fue sofocada en 1570 y que terminó con la expulsión de Granada de la práctica totalidad de los moriscos, unos 80.000 , que se reasentaron por la geografía peninsular. ${ }^{26}$

A partir de la Guerra de las Alpujarras asistimos a un aumento de las tensiones entre los dos grupos. Los moriscos eran vistos como inasimilables por la persistencia en su fe y sus tradiciones, a lo que se unía el miedo a un desembarco turco o norteafricano y la ayuda que pudieran prestarles. Pero seguramente la causa más importante sería la búsqueda de la unidad religiosa por parte de Felipe III. De este modo, comenzando por el reino de Valencia, en 1609 se produjo su progresiva expulsión que terminó en 1614 y que afecto a unas 300.000 personas, a las que habría que añadir entre 10.000 y 12.000 que murieron en las rebeliones de Valencia y durante el traslado a los puertos de embarque. Un numero difícil de establecer permaneció: ancianos, enfermos, ocultos, niños arrebatados a sus padres, hijos de matrimonios mixtos, mujeres casadas con cristianos viejos, religiosos de origen morisco y aquellos que contaban con certificación de buena conducta cristiana. Algunos regresaron posteriormente, pero en cualquier caso la asimilación estaba asegurada. ${ }^{27}$

Los gitanos fueron a su vez objeto de intentos de asimilación. Su suerte fue diferente a la de los judíos y moriscos pero su historia fue intrincada y no estuvo exenta de peticiones encaminadas a su expulsión definitiva. Las primeras noticias de su estancia en la Península son de 1425 , periodo en que causaron extrañeza pero fueron

\footnotetext{
${ }^{26}$ Antonio Domínguez Ortiz y Bernard Vincent, Historia de los moriscos. Vida y tragedia de una minoría, Revista de Occidente, Madrid, 1978, pp. 21-28 y 56.

${ }^{27}$ Mikel de Epalza, Los moriscos antes y después de la expulsión, Mapfre, Madrid, 1992, pp. 120-126 y 200; Luis F. Bernabé Pons, Los moriscos. Conflicto, expulsión y diáspora, Catarata, Madrid, 2009, pp.140-146.
} 
bien acogidos al creerse que fueron expulsados por los musulmanes de sus tierras a causa de su fe. Sin embargo, ya en 1499 los Reyes Católicos les exigieron que se sedentarizaran o que abandonaran el país en 60 días. ${ }^{28}$ Los gitanos deambulaban en grandes grupos y vivían de la venta ambulante y muchas mujeres de echar la buenaventura. Se les acusaba de mendigar y de dedicarse a hurtos y a pequeños timos y de no respetar la moral ni las normas civiles y religiosas. Por esto fueron objeto de numerosa legislación con el objetivo de asimilarles, o al menos posibilitar la utilización de su trabajo, aunque no faltaron voces que consideran la expulsión como la política más eficaz. ${ }^{29}$ La ley de los Reyes Católicos fue reformada en 1535 para que los comprendidos entre 20 y 50 años fueran condenados a 200 azotes y galeras durante seis años a los varones y destierro para las mujeres. Felipe II ordenó que se asentaran y Felipe IV les vedó que vagaran por el reino, les obligó a establecerse en lugares de mil vecinos, les vetó dedicarse la compraventa de ganado, vestir sus trajes típicos, hablar su lengua y utilizar el nombre de gitanos. Pocos años más tarde se les prohibió cualquier trabajo no agrícola. Estos preceptos cada vez más restrictivos muestran el fracaso en su aplicación. Como consecuencia de las mismas hubo gitanos que sirvieron en galeras, minas o arsenales de la marina. ${ }^{30}$

Fueron objeto de redadas colectivas como la de 1572 y 1573 con objeto de conseguir hombres para las galeras, que además de gitanos, afectó a ladrones, vagabundos, rufianes, ladrones y otros grupos marginales. Esta alcanzó a algunos que estaban establecidos sedentariamente y que fueron enrolados a cambio de un salario. En la gran detención de 1749 se encarceló a un número muy elevado de gitanos, aunque la

\footnotetext{
${ }^{28}$ Ley XII, Titulo XI, Libro VIII, Nueva Recopilación. Bajo pena de 100 azotes y destierro perpetuo la primera vez; de corte de orejas, sesenta días en cadena y destierro la segunda; y ser cautivos del que los tomare la tercera.

${ }^{29}$ Bernard Leblon, Los gitanos de España. El precio y el valor de la diferencia, Gedisa, Barcelona, 1993, pp. 11-28, 30-32, 50, 51 y 67; Antonio Gómez Alfaro, "La polémica sobre la deportación de los gitanos a las colonias de América", Cuadernos Hispanoamericanos, núm. 386, 1982, pp. 308-336. Esta opción de la deportación a América fue desestimada porque se pensó que en vez de extinguir el problema suponía simplemente trasladarlo de lugar.

${ }^{30}$ En las minas de Almadén fueron unos 40 entre 1646 y 1699. Julián Antonio Prior Cabanillas, La pena de minas, p. 49. Representaban un 2,9\% de los condenados a galeras entre 1586 y 1589; I.A.A. Thompson, "A Map of Crime in Sixteenth Century Spain", Economic History Review, núm. 21, 1976, pp. 244-267; María Helena Sánchez Ortega, "Los gitanos condenados como galeotes en la España de los Austrias" Espacio, Tiempo y Forma, Serie IV, Historia Moderna, tomo 18-19, 2005-2006, p. 92; Ley XII, Titulo XI, Libro VIII. Ley XIV, Titulo XI, Libro VIII. Ley XV, Titulo XI, Libro VIII. Ley XVI, Titulo XI, Libro VIII. Ley XVII, Titulo XI, Libro VIII, Nueva Recopilación.
} 
gran mayoría pronto fueron liberados. ${ }^{31}$ Las normas fueron incluso más duras en la Corona de Aragón de donde fueron formalmente expulsados, ${ }^{32}$ aunque este objetivo no se consiguió. La constatación de los continuos fracasos se expresa en 1783, año en que se les conminó a abandonar su lengua, trajes y forma de vida, a cambio de considerarles españoles con los mismos derechos que el resto. Esto implicaba fijar voluntariamente su residencia, posibilidad de trabajar en cualquier oficio, derecho a atención a sus enfermos y derecho a un juicio en condiciones iguales al resto de la población, entre otros. ${ }^{33}$

A finales del siglo XVIII asistimos a la expulsión de los jesuitas de España. La medida estuvo inmediatamente precedida por la portuguesa de 1759 bajo la acusación de instigar un atentado contra el rey, por la cual 1.100 miembros de la orden fueron desterrados y 250 quedaron presos. Poco después fueron expulsados de Francia, tras un escándalo financiero, declarando que su existencia era atentatoria contra la monarquía. ${ }^{34}$ Con estos precedentes, al producirse el Motín de Esquilache algunos aprovecharon para culpar a la compañía de Jesús. Las causas reales fueron variadas: el juramento de obediencia al papa y, en oposición a él, la difusión del regalismo por Europa, la política de los jesuitas en Paraguay, la leyenda negra antijesuítica que circulaba por Europa desde hace varios siglos, los precedentes en otros países y la rivalidad con otras confesiones religiosas. No podemos olvidar el factor económico ya que los bienes de la orden pasaron a manos de la Corona, que procedió a subastarlos.

Los jesuitas de la monarquía hispana tuvieron que abandonar los territorios. Esto englobaba a unos 5.000 según Egido-Isidoro. A Córcega o Italia llegaron 2.503 desde la Península, ya que el papado se negó a admitirlos. El modo de proceder a la expulsión dista mucho del que sufrieron otros colectivos, ya que estuvo mejor organizada, se les trató bien y se les asignó una pensión vitalicia. ${ }^{35}$ A continuación se produjo el

\footnotetext{
${ }^{31}$ Manuel Martínez Martínez, "Los gitanos en el reinado de Felipe II (1556-1598). El fracaso de una integración", Chronica Nova. Revista de Historia Moderna de la Universidad de Granada, núm. 30, 2003-2004, pp. 415-421; María Helena Sánchez Ortega, Documentación selecta sobre la situación de los gitanos españoles en el siglo XVIII, Editora Nacional, Madrid, 1977, p. 140. Establece una cifra entre 9.000 y 10.000 .

${ }^{32}$ Capítol XVI, Constitucions de Cataluña.

${ }^{33}$ Pragmática de 22 de septiembre de 1783.

${ }^{34}$ Jonathan Wright, Los jesuitas. Una historia de los «soldados de Dios», Debate, Barcelona, 2005, pp. 197-203.

${ }^{35}$ Teófanes Egido e Isidoro Pinedo, Las causas "gravísimas y secretas de la expulsión de los jesuitas por Carlos III, Fundación Universitaria Española, Madrid, 1994, p. 9; Pilar García Trobat, La expulsión de los Jesuitas. Una legislación urgente y su aplicación en el Reino de Valencia, Consell Valencià de Cultura, Valencia, 1992, p. 34; Colección general de las providencias hasta aquí tomadas por el Gobierno sobre el extrañamiento y ocupación de
} 
extrañamiento en otros estados, a la vez que aumentaba la presión sobre Roma para que disolviese la orden. Su extinción se produjo en 1773, pero fue posteriormente revocada en 1814, permitiendo así la vuelta de la Compañía de Jesús a tierras españolas.

Hubo además, en el Antiguo Régimen, desterrados por causas ligadas a los enfrentamientos bélicos que sacudieron al país. Durante el transcurso de la Guerra de Sucesión se produjeron expulsiones de austracistas en las zonas conquistadas por los borbónicos. Una vez finalizada muchos de ellos pudieron volver a sus casas, ${ }^{36}$ pero otro nutrido grupo tuvo menos suerte y fue confinado a diversos lugares de la Península o salieron hacia el extranjero ya fuera por voluntad propia o por decisión de las autoridades, que establecieron que todos los ciudadanos de otras provincias que se encontraban en Cataluña debían abandonar el país. En total se estima que fueron llegando a territorios austriacos en diversas oleadas entre 20.000 y 30.000 personas, ${ }^{37}$ muchos de los que finalmente retornarían.

\section{LA DEPORTACIÓN EL CÓDIGO PENAL DE 1822}

Desde los primeros compases de la revolución las autoridades se esforzaron en que el amplio deseo de libertad y de cambio y la efervescencia política que provocó no derivase en una situación potencialmente revolucionaria. En la Europa del periodo la instauración de la democracia y el consiguiente desafío al orden conservador establecido suponía una amenaza intolerable, un peligro con el cual el nuevo sistema tenía que lidiar y que supuso, entre otros factores, una disgregación del liberalismo entre dos tendencias, una avanzada y otra moderada. ${ }^{38}$ El Estado liberal representaba una ruptura con el Antiguo Régimen, cuyas bases fueron socavadas por las nuevas ideas que se expandían por Europa y que encarnaban los intereses de la burguesía. De este modo, se produjo en España un proceso paulatino de transformación de las estructuras preexistentes que terminaría con la entronización de unos nuevos principios, entre los

temporalidades de los regulares de la compañía de Jesús, Imprenta Real de la Gaceta, Madrid, 1767, pp. 10-11 y 48-49.

${ }^{36}$ Virginia León Sanz, "«Abandono de patria y hacienda». El exilio austracista valenciano", Revista de Historia Moderna, núm. 25, 2007, p. 241.

${ }^{37}$ Agustí Alcoberro, L'exili austriacista (1713-1747), Fundació Noguera, Barcelona, 2002, vol. I, pp. 46-54 y 56.

${ }^{38}$ Alberto Gil Novales, El Trienio liberal, Siglo XXI, Madrid, 1989, pp. 6-8. 
cuales podríamos citar como los más importantes la soberanía nacional, la división de poderes y el reconocimiento de derechos económicos del ciudadano.

En seguida comenzaron una serie de reformas que terminaron con la sustitución de un modelo de organización económica, social y política, por otro completamente diferente. En el plano del derecho estas transformaciones se producirán a través de la codificación. Era un proceso iniciado en Francia y que fue adoptado por los diversos países al reconocer su superioridad respecto al sistema legal precedente. En España, el Código Penal emanaba de la propia Constitución. La comisión encargada de su confección fue designada el 22 de agosto de 1820 y la promulgación definitiva por el rey se produjo el 9 de julio de 1822 . El procedimiento de creación fue muy rápido para una obra de tanta importancia, especialmente teniendo en cuenta que se dejó un tiempo para que diversas instituciones emitieran sus juicios y que en el Parlamento se debatieron todos y cada uno de los artículos en qué consistía. La celeridad era una muestra de la debilidad en que comenzaba a encontrarse el régimen con la sucesión de alzamientos realistas y de la vorágine reformadora del periodo. El resultado fue un cambio en la estructura que mantendría algunos de los elementos característicos del Antiguo Régimen como elemento que trataba de transigir con parte de las antiguas élites.

"El Código de 1822 es un código científico. La ciencia del derecho y la buena filosofía inspiran la mayor parte de sus disposiciones. Digno del siglo, mejoraba inmensamente la situación penal de la nación. Pero es a veces demasiado duro: transige demasiado con las antiguas preocupaciones españolas, muy vivas aún en aquella edad, (...). Hay en él algo del Fuero Juzgo y de las Partidas, envuelto con el carácter del Código de Napoleón". ${ }^{39}$

La influencia francesa es evidente en la idea de la necesidad de establecer una codificación penal, decrece en la estructura y es menor en la redacción concreta. ${ }^{40}$ Esta diferenciación no sorprende teniendo en cuenta que el Código francés de 1810 databa de la época napoleónica y en el caso del Trienio se pretendió darle un contenido más liberal. Pero también es cierto que desde la comisión se trató de minimizar este influjo

\footnotetext{
39 José Francisco Pacheco, "Introducción", a El Código Penal concordado y comentado, Imprenta de D. Santiago Saunaque, Madrid, 1848. Tomo I, p. 57.

${ }^{40}$ Isabel Ramos Vázquez y Juan B. Cañizares-Navarro, "La influencia francesa en la primera codificación española. El Código Penal francés de 1810 y el Código Penal español de 1822", en Aniceto Masferrer (ed.), La Codificación española. Una aproximación doctrinal $e$ historiográfica a sus influencias extranjeras, y a la francesa en particular, Thomson ReutersAranzadi, Cizur Menor (Navarra), 2014, pp. 259-260.
} 
para darle un mayor sentido de relación con la tradición castellano-española. Recurrir a la filosofía, de la que se habían nutrido ambos, ocultaba el influjo francés, pero la codificación en el país vecino era un hecho de magnitud colosal que necesariamente debía servir como modelo.

La brevedad del Trienio impidió una formulación más concreta de la relegación. Sin embargo, la aplicación de ésta, unida a la de otras figuras similares como el destierro tuvieron un papel muy importante en la configuración de la misma desde un punto de vista teórico. El proyecto de ley sobre la responsabilidad de los infractores de la Constitución de 1810, establecía en su artículo 18 a la deportación perpetua como castigo complementario para aquellos que aboliesen alguna facultad que por la Constitución residiera en las Cortes. Aunque según el texto parezca que realmente se trataba de una expulsión perpetua del país, introdujo la palabra y con ella la idea de traslado forzoso en la legislación liberal. En 1811, 1813 y 1814 se nombraron tres comisiones para la reforma de la normativa criminal, tarea que no finalizaron. En 1819 el propio Fernando VII manifestó su intención de formación de un Código Criminal. ${ }^{41}$ Sin embargo, no fue hasta la sublevación de Riego de 1820 y la consiguiente reinstauración de la Constitución de 1812, cuando este propósito llegó a buen término.

La idea de la deportación fue recogida de nuevo en el Código Penal en el que se estipuló para ciertos tipos de delitos políticos, aunque no para todos y tampoco exclusivamente para ellos. En España, las relegaciones se habían producido de una manera espontánea, desorganizada y caótica, pero con la codificación se ofrecían una serie de indicaciones que indicaban como debía ejecutarse. La consignación legal y la aplicación real en este periodo supusieron un fuerte espaldarazo a su posterior ejecución, entendiéndose así, cada vez más como una posibilidad de la que disponía el Estado, que reposaba en algún oscuro cajón y que podía ser sacada de él en cuanto las circunstancias lo requirieran.

La influencia del Código Penal francés y de la experiencia en dicho país es evidente. En este se recogía la deportación entendida como que el reo sería transportado a perpetuidad a un lugar establecido por el Gobierno fuera del territorio metropolitano y en caso de volver a él se le impondrían trabajos perpetuos. Además contemplaba el

\footnotetext{
${ }^{41}$ Antón Oneca, "Historia del Código Penal de 1822", Anuario de Derecho Penal y Ciencias Penales, Tomo 18. fasc./mes 2, 1965, pp. 266 y 267.
} 
destierro, entendido como el ser enviado fuera del imperio entre cinco y diez años. ${ }^{42}$ Ambas figuras estaban contempladas en la legislación española, si bien es cierto que en esta se contemplaban más formas limitativas de la libertad de residencia.

Calatrava afirmaba que se inspiró principalmente en las obras de Bentham, Becaria, Montesquieu, Filangieri y Bexon. El criminólogo Rafael Salillas repasó las discusiones en las Cortes y estableció que Bentham fue el autor más citado, seguido de Montesquieu, Beccaria, Filangieri y Lardizabal. ${ }^{43}$ Es evidente que realizar un Código de corte liberal suponía tener en cuenta lo expuesto por los pensadores más importantes. Sin embargo, tendríamos que tener en cuenta la dificultad que plantea la aplicación real de la teoría y el funcionamiento del parlamentarismo, en el que un orador puede adornar sus discursos recurriendo y citando a filósofos, especialmente en aspectos etéreos de garantía de derechos y pretensiones, pero sin intentar poner en funcionamiento sus ideas y en muchos casos sin conocerlas en profundidad. De hecho, el propio Bentham se mostró decepcionado con el resultado y fue muy crítico con él. El pensador Inglés se sentía ofendido porque no se le había encargado la redacción del mismo o al menos de una versión. Además criticaba la poca participación de los criollos y el excesivo peso de los juristas, que tenían otras prioridades que las de la felicidad del mayor numero. Consideraba que era demasiado duro y que fue hecho de manera demasiado apresurada por lo que pretendía que rigiera por un tiempo limitado. ${ }^{44}$

El Códice utilizaba profusamente la pena de muerte para numerosos delitos, incluyendo tratar de establecer una religión distinta a la católica, y en el que macabramente se estipulaban todos los pasos del ritual de la ejecución. El rigor generalizado aumentaba en las asonadas y motines, lo que ocasionó la oposición de los liberales más exaltados, ${ }^{45}$ en una prueba más de la fractura liberal.

De haberse seguido estrictamente la doctrina de los pensadores mencionados la legislación de la última pena hubiera sido otra, puesto que Bentham la desaprobaba y

\footnotetext{
${ }^{42}$ Arts. 7 y 17 y 32, Código Penal francés de 1810. No obstante, el desarrollo de las distintas modalidades de deportación y su evolución se produjo a través de leyes posteriores.

${ }^{43}$ Rafael Salillas, Evolución penitenciaria de España, Analecta, Pamplona, 1999, tomo II, pp. 259-261. Edición facsímil de la primera, 1918; Antón Oneca, "Historia del Código Penal de $1822 "$, pp. 267, 270-271 у 276.

${ }^{44}$ Cartas de Jeremías Bentham, al señor conde de Toreno, sobre el proyecto del Código Penal presentado a las Cortes, Imprenta de don Diego García y Campoy, Madrid, 1821; Bentham desacreditaba algunos detalles técnicos concretos, ver Rafael Salillas, Evolución penitenciaria de España, pp. 269-278.

${ }^{45}$ Manuel Torres Aguilar, Génesis parlamentaria del Código Penal de 1822, Sicania University Press, Messina, 2008, p. 258; Arts. 40 y 227. Código Penal de 1822.
} 
Montesquieu y Beccaria la justificaban solo en casos muy acotados. ${ }^{46}$ El castigo capital era un tema de vital importancia, lo que muestra como la filosofía y las buenas intenciones podían dejarse de lado en un régimen que se sentía débil y por tanto tenía que recurrir a castigos sobredimensionados y que quería mostrar a los realistas conservadores que el liberalismo restringido que planteaban no iba a terminar con el orden.

Bentham se mostraba contrario a la utilización del destierro, el extrañamiento y también a la deportación a la que atribuía diversas perversidades: no servía para el escarmiento; no era útil para la reinserción; no arrebataba a los delincuentes el poder de volver a delinquir; no reparaba el daño sufrido por las victimas; era perniciosa económicamente para el Estado; y podía agravarse conduciendo a la muerte del reo. Prefería la idea de casa de penitencia, que denominaba panóptico y que afirmaba que era superior. ${ }^{47}$ Las diferencias derivaban de las pretensiones de cada uno, establecer una ley justa en el caso del pensador y reprimir a los delincuentes y opositores en el caso de los legisladores, pero no olvidemos que Bentham era inglés y en aquel momento su país tampoco estaba haciendo caso a sus teorías y estaba implementando una relegación masiva a Australia motivada por el desembarazo y la utilidad al Estado. El país más avanzado del mundo y modelo para muchos liberales la estaba utilizando con profusión. En palabras de Calatrava al hacer la presentación del proyecto del Código.

"Dudo al principio la comisión sobre la pena de deportación (...) adoptada por varias
naciones cultas de Europa, y la experiencia ha mostrado su utilidad y saludables efectos;
pero entre nosotros parecía no traer ahora ventajas conocidas, ni ideas de conveniencia
publica. ¿Sería buena política deportar gentes criminales a las islas y colonias de

${ }^{46}$ Jeremías Bentham, Teoría de las penas y de las recompensas, Masson e hijo, París, 1826, Libro I, Capítulo III; Montesquieu solo la contemplaba en ciertos casos de quebranto en la seguridad de los bienes y homicidio o intento del mismo. Charles-Louis de Secondat, barón de la Brède y de Montesquieu, Del espíritu de las leyes, Tecnos, Madrid, 2007, Libro VI, Capítulos IX y XII, pp. 97-101; para Becaria solo debe ser impuesta cuando en tiempos turbulentos un ciudadano podía poner en peligro la seguridad de su país o realizar una revolución contra el Gobierno. Cesare Beccaria, De los delitos y las penas, (traducido por Juan Antonio de las Casas), Joaquín Ibarra, Impresor, Madrid, 1774, Capítulo XXVIII.

${ }^{47}$ Bentham, Teoría de las penas y de las recompensas, Libro II Capítulos VIII, XI y XII; ni Beccaria ni Montesquieu se refieren a la deportación, pero establecen algunos casos de destierro de la sociedad, para Beccaria aquellos que no aportan trabajo ni riqueza a la sociedad deberían ser desterrados y también en ciertos casos de culpabilidad de la que no se tiene una certeza absoluta. Beccaria, De los delitos y las penas, Capítulos XXI, XXIV y XXV; Montesquieu, Del espíritu de las Leyes, Libro XII, Capítulo IV, pp. 212-214. Solo contemplaba la expulsión de la ciudad y de la sociedad en ciertos casos de delitos contra las costumbres y el exilio en delitos contra la tranquilidad. 
Ultramar, en la situación en que hoy se hallan esos países? ¿Existe en ellos algún establecimiento en que se ocupe provechosamente a los deportados? Sin embargo, la comisión, deseando dar alguna mayor extensión a la escala de las penas, y llenar el gran vacío que a las veces existe entre unas y otras, admitió la deportación como término medio entre el destierro o extrañamiento perpetuo del Reino y la pena de trabajos violentos para siempre, cuyos extremos casi distan infinitivamente. La admitió para lo sucesivo, cuando el Gobierno, excitado por las Cortes, organizase en Ultramar establecimientos análogos a este importante objeto, y en que los deportados, sujetos a una rigurosa disciplina, pudiesen ser útiles a sí mismos y a la sociedad". ${ }^{4}$

Existían algunas dudas acerca de su aplicación. El Colegio de Abogados de Granada resaltaba en sus informes la falta de establecimientos adecuados, sin hacer un análisis de su conveniencia. ${ }^{49}$ Según Calatrava tan solo dos organismos opinaban al respecto: el Ateneo Español la impugnaba y el Colegio de Abogados de Madrid la aprobaba. Aseguraba que un alto funcionario que había estado en Manila y en Nueva España le aseveró que la creación de un establecimiento para deportados seria de gran utilidad al Estado, "en una de las islas del mar Pacífico, y me parece que citó las Marianas. Pero esto ya conocerán las Cortes que pende del Gobierno, a cuyo celo debe dejarse la ejecución". Tendría un carácter perpetuo y se irían dando derechos paulatinamente a los afectados para que no cayesen en la desesperación, tal y como se hacía en Botany Bay. ${ }^{50}$ La influencia de la practica británica esta clara, la intención de Calatrava no era otra que establecer el sistema que estos estaban empleado para repoblar con éxito Australia, pero reconociendo que no podía aplicarse por el momento. La situación de independencia real en las colonias americanas hacía que el contexto fuera del todo inadecuado.

La pena consistía en la propia remisión a una "isla o colonia remota", en la que se les daría algún trabajo público o en ciertos oficios para el desarrollo de la posesión. Las mujeres de los relegados podrán acompañarles libremente o en caso contrario pasarían a disponer de sus bienes. Calatrava contemplaba al menos dos establecimientos, uno en Ultramar para los peninsulares y otro en la parte europea del país para aquellos que delinquiesen en los dominios. ${ }^{51}$ En la mayoría de las aportaciones de los diputados no se observan discrepancias en el fondo, tan solo aclaración de matices u objeciones parciales.

\footnotetext{
${ }^{48}$ Diario de Sesiones de las Cortes (en adelante DSC), 1 de noviembre de 1821.

${ }^{49}$ DSC, 23 de noviembre de 1821.

${ }^{50} \mathrm{DSC}, 17$ de diciembre de 1821.

${ }^{51} D S C, 21$ y 26 de diciembre de 1821.
} 
Algunos diputados como Alejandro Dolarrea no se mostraban de acuerdo en su uso, por cuanto se oponían a la perpetuidad, a la muerte civil y a la confiscación de bienes que suponía para el reo. Resulta significativa la crítica dado el perfil del navarro, de carácter foralista y de tendencia conservadora. También el diputado guatemalteco Juan Esteban Milla, que poco después estamparía su firma en el acta de Independencia de las Provincias Unidas de Centroamérica, se mostró contrario a la propuesta aduciendo que al deportado "se le ataca la propiedad, la patria potestad, y se disuelven los lazos matrimoniales para los efectos civiles". El radical Romero Alpuente, incidía en la desigualdad entre ricos y pobres, ya que los primeros perderían mucho y los otros nada. No se oponía a su imposición, pero indicaba que no debía establecerse nada acerca de la disolución del matrimonio, de los bienes o de la patria potestad, y que la pérdida debía limitarse a los derechos de ciudadanía. Otras críticas iban encaminadas a la duración excesiva de la condena. ${ }^{52}$ Las mayores objeciones hacían referencia no a la imposición de la propia pena, sino a la muerte civil del sentenciado que acarreaba tal y como estaba planteada.

El diputado mexicano Pablo La Llave no se oponía pero indicaba que la separación de la patria produciría un gran sufrimiento. El diputado exaltado Antonio Puigblanch se oponía a la publicación y a la sanción del Código por imposibilidad de aplicación de algunos artículos, entre ellos el referente a las relegaciones. Joaquín Rey se mostraba partidario de la misma, pero diciendo que debía retrasarse su cumplimiento hasta que se crearan los establecimientos para su cumplimiento. ${ }^{53}$ Las críticas, contestadas por Calatrava de una forma muy arrogante, evidenciaban que las posiciones contrarias a la misma fueron más bien una muestra de la rivalidad política de los intervinientes. A causa de la celeridad con que se despachó y de la aprobación del bloque progubernamental, los debates no tuvieron la profundidad que un proyecto de tal magnitud merecía y que fue aprobado sin una oposición excesiva.

El Códice distinguía tres tipos de punición: corporal, no corporal y pecuniaria. Dentro del primer grupo encontramos las que restringían la libertad de residencia: "El reo condenado a deportación será conducido a una isla o posesión remota, de donde no podrá fugarse, y permanecerá en ella para siempre"; "El que sea condenado a destierro perpetuo o extrañamiento del territorio español, será conducido hasta ponerle fuera de

\footnotetext{
${ }^{52}$ DSC, 21 de diciembre de 1821.

${ }^{53}$ DSC, 30 de diciembre de 1821 y 13 de febrero de 1822 .
} 
él”; "El reo sentenciado a confinamiento en un pueblo o distrito determinado no podrá salir de este y de sus arrabales, y tendrá obligación de notificar a la autoridad local su habitación y modo de vivir"; y finalmente exponía que "El reo condenado a destierro perpetuo o temporal de un pueblo o distrito determinado, será conducido fuera de él". ${ }^{54}$ El Código no deja lugar a dudas en cuanto al significado de cada una de ellas.

Mayor confusión encontramos en cuanto a la aplicación a determinados tipos de delito. El confinamiento tan solo se contemplaba para aquellos sujetos a vigilancia de la autoridad que no depositaran fianza y a los que la ley les obligaba a que presentasen un fiador y no lo hicieren. El extrañamiento del reino se contemplaba para religiosos que denigrasen a los poderes gubernativos y para funcionarios públicos o religiosos que cuestionasen las facultades de la Iglesia y fueran reincidentes. ${ }^{55}$ No ocurría lo mismo con el destierro, que aparecía en delitos contra particulares como accesoria de la privación de libertad, y la deportación, cuya aparición a lo largo del articulado del texto era más habitual.

La manifestación en el Código de estas penas era en la mayoría de los casos aleatoria, por cuanto no iba orientada, en general, a reprimir un tipo de delito determinado. La relegación podía ser impuesta tanto por delitos políticos como alentar infructuosamente a potencias extranjeras a cometer hostilidades o guerra contra España; pretender o conseguir entregar informes sobre fortificaciones, puertos o arsenales a naciones extranjeras; cometer acciones contra naturales de otros países que provocasen la declaración de guerra; o a los funcionarios que de manera ilegal entregasen a un extranjero a su país de procedencia cuando este había sido castigado con la muerte. ${ }^{56}$ Junto a estos delitos contra la seguridad del Estado, otros como quemar intencionadamente propiedades públicas rústicas o mandos militares que después de ser cesados continuaran en el mando. En la mayoría de las ocasiones, se contemplaba para delitos comunes y los condenados a trabajos perpetuos, a los diez años también podían pasar a ser deportados. ${ }^{57}$ La intención de colonizar para Calatrava era clara, por esto fue

\footnotetext{
${ }^{54}$ Arts. 28, 50, 51, 72 y 73. Código Penal de 1822.

${ }^{55}$ Arts. 78, 79, 324 y 325. Código Penal de 1822.

${ }^{56}$ Arts. 251, 257, 258 y 271. Código Penal de 1822.

${ }^{57}$ Arts. 144, 345, 502, 615, 638, 671, 672, 693, 738, 753, 758 y 788. Código Penal de 1822. Esto es, homicidio, esterilizar a alguien con su consentimiento, pederastia que causa al niño o niña secuelas de por vida, o sin causárselas cuando se abuse de su posición educativa o de custodia, padres o cuidadores que abandonen a un niño menor de 7 años en un lugar de poco tránsito y que resulte en muerte del niño, ladrones reincidentes, quiebra fraudulenta realizada
} 
impuesta a una mezcla de gente de la que se quería desembarazar tanto por motivaciones políticas como por su perfil de delincuentes. Pero en general, tal y como pasaba en Australia, los motivos comunes fueron los más importantes. Dado el enredo a causa de la inexistencia de una escala gradual que agrupase a penas similares, encontramos que en delitos políticos y comunes en los que se estipulaba otra punición había excepciones en las que se contemplaba la relegación para ciertas actuaciones delictivas.

Finalmente, desoyendo las críticas en este sentido, la deportación provocaría la muerte civil del sentenciado en España, y a los diez años los afectados podrían recuperar algunos o todos sus derechos civiles, así como quedar habilitados para obtener empleos y cargos públicos. Respecto a las condiciones que el convicto tendría que soportar en el lugar de destino, el Código establecía que sería empleado en las tareas que se le encomienden, de acuerdo con los reglamentos, pero podría conservar aquello que llevase consigo y disponer de los frutos de su trabajo. Se ofrecía al cónyuge la posibilidad de acompañarle, en cuyo caso el matrimonio mantendría su validez. El que se fugase una vez sería castigado a realizar los trabajos más duros por un tiempo determinado y si delinquiera seria juzgado como reincidente. ${ }^{58}$

En cualquier caso el Códice tuvo una corta vida, puesto que con la invasión de los Cien Mil Hijos de San Luis su aplicación se suspendió, volviendo a estar vigentes la Novísima Recopilación, los Fueros Juzgo y Real y las Partidas. Su vigencia ha sido tradicionalmente motivo de distintas interpretaciones, aunque ahora se acepta que rigió por un breve tiempo. ${ }^{59}$ No fue hasta 1848 en que de nuevo volvió a estar vigente el nuevo Códice aprobado en ese año.

por "corredor, cambista, comisionado o factor" o incendios en lugares no habitados que causasen daños elevados.

${ }^{58}$ Arts. 50, 51, 53, 144 y 147. Código Penal de 1822.

${ }^{59}$ Emilio de Benito Fraile, "Nuevas aportaciones al estudio sobre la aplicación práctica del Código Penal de 1822", Foro, Nueva Época, núm. 8, 2008, pp. 41-68; José Luis Bermejo Cabrero, "Sobre la entrada en vigor del Código Penal de 1822", Anuario de Historia del Derecho Penal, núm. 66, 1996, pp. 967-972; José Ramón Casado Ruiz, "La aplicación del Código Penal de 1822", Anuario de Derecho Penal, núm. 32, 1979, pp. 333-344; Alicia Fiestas Loza, "Algo más sobre la vigencia del Código Penal de 1822", Revista de Historia del Derecho, núm. II-I, 1977, pp. 55-77. 


\section{LA CONTINUACIÓN DE LAS LEYES SOBRE LA DEPORTACION}

\subsection{Los Códigos Penales de 1848 y 1870.}

En 1830, 1831 y 1834 se produjeron diversos intentos de formulación de un Código Criminal que fracasaron. ${ }^{60}$ Las circunstancias políticas y la continuación del régimen absolutista dificultaban la creación de una codificación que se antojaría inconsistente en un momento en que se avecinaban grandes cambios y en el que había multitud de ultrarrealistas en espacios de poder que no estaban dispuestos a realizar concesiones. Con posterioridad, la Guerra Carlista y las divisiones dentro del liberalismo imposibilitaron la creación de uno nuevo. Únicamente tras la llegada de los moderados al poder se rescató la idea de una nueva codificación, de acuerdo con la Constitución de 1845, que preconizaba la soberanía compartida, un sufragio muy restringido y permitía amplias cotas de intervención gubernamental. En consecuencia, el Código de 1848 ha sido definido como "autoritario liberal", ya que proporcionaba los delitos a las penas, en general rebajándolos respecto a su precedente y a la vez que mantenía la dureza para delitos políticos. ${ }^{61}$ Lo que supone la plasmación en la esfera de la disidencia del proyecto moderado, cuyo autoritarismo no se circunscribía únicamente a la disidencia ya que abarcaba a la propia conducta social.

Con motivo de los sucesos del 1848 se produjeron cambios en el Códice, que castigaban más severamente actividades conspirativas como la rebelión y la sedición y contemplaba la proposición para delinquir. A las novedades habría que añadir las técnicas, lo que dio lugar a una nueva versión en 1850 con grandes cambios, introducidos unilateralmente por el Gobierno. ${ }^{62}$ Para Narváez y los moderados primaba el control y la represión de la oposición. El Código Penal moderado fue uno de los

\footnotetext{
${ }^{60}$ ver Juan Francisco Lasso Gaite, Crónica de la codificación española, Ministerio de JusticiaComisión General de Codificaciones, Madrid, 1970, Tomo 5 (Codificación penal), vol. 1, pp. $172-250$.

${ }^{61}$ Antón Oneca, Derecho penal, Akal, Los Berrocales del Jarama, 1986, pp. 75-76.

${ }^{62}$ María Dolores del Mar Sánchez González, La codificación penal en España. Los códigos de 1848 y 1850, Boletín Oficial del Estado-Centro de Estudios Políticos y Constitucionales, Madrid, 2004, pp. 287-298; en todo caso al referirnos al Código Penal de 1848 nos referimos a su versión renovada que fue la que rigió efectivamente. Existían diecinueve tipos de penas aflictivas y siete de correccionales. Las aflictivas comienzan por la de muerte y en cuarto lugar encontramos la relegación perpetua, en quinto el extrañamiento perpetuo, en séptimo la relegación temporal, en octavo el extrañamiento temporal, en undécimo el confinamiento mayor y en decimonoveno el confinamiento menor. Respecto a las penas correccionales, el destierro conforma la tercera pena más grave dentro de este grupo.
} 
medios teóricos mediante el cual se plasmó legislativamente su voluntad de permanencia en el poder en un sistema diseñado sobre la carencia de derechos para la práctica totalidad de la población.

El Códice de 1848 mantenía la presencia y el significado de todas las penas que restringían la libertad de residencia. Los únicos cambios fueron que la deportación pasó a denominarse relegación, algo que no afectó a sus características, y en el caso del confinamiento se distinguía entre mayor y menor, consistiendo el primero en el que se realizaría en un pueblo o distrito de las islas Baleares o Canarias. Sin embargo, a los que debieran ser trasladados a islas adyacentes, el Ejecutivo podía enrolarlos forzosamente en el ejército si fuesen solteros y no tuvieran medios de vida. El menor se realizaría en el lugar estipulado por la sentencia, que debería distar al menos diez leguas de donde se produjera el delito y de la residencia del reo. ${ }^{63}$ Se facilitaba el enrolamiento forzoso en el ejército, en consonancia con lo que se había realizado en la Guerra dels Matiners.

La relegación se establecía para los delitos de sedición no ejecutados, aquellos que sin alzarse contra el Gobierno lo realizasen "por astucia o por cualquier otro medio". ${ }^{64}$ Es decir, se avalaba una punición exclusivamente política de carácter tanto represivo como preventivo y de amplio alcance, en consonancia con la represión efectuada en las revueltas de 1848 en España. El extrañamiento se establecía en algunas actuaciones contrarias a la religión católica, siendo la mera práctica pública de otro credo motivo suficiente para que un individuo fuese expulsado. Tanto el confinamiento como el destierro afectaban a algunos delitos políticos menores y a sacerdotes que realizaran algún tipo de desorden público. ${ }^{65}$ Mantenía teóricamente la voluntad colonizadora expuesta por Calatrava en 1822, lo que significaba que se salvaguardaba la posibilidad de realizarla en el futuro, perseverando la inconsistencia en su imposibilidad a causa de un estado aletargado y carente de dinamismo y previsión. Eso sí, cambiando el perfil de los sujetos a los que debía imponerse. La experiencia reciente, la revolución de 1848 y el pavor que supuso entre las élites europeas determinaron que puesta la realización de la normativa punitiva en manos de un Gobierno autoritario en grado sumo, priorizara la disidencia y dejara de contemplarse para delitos comunes. Con esta variación dejaban de estar contemplados los asentamientos al estilo inglés. El sistema moderado estaba planificado para preservar el orden en momentos convulsos y por eso

\footnotetext{
${ }^{63}$ Arts. 107 y 108. Código Penal de 1848.

${ }^{64}$ Art. 172. Código Penal de 1848. Establece para estos delitos una pena de relegación perpetua.

${ }^{65}$ Arts. 128, 129, 130, 136 y 202. Código Penal de 1848
} 
sobrevivió y fue empleado por gabinetes posteriores, aunque una deportación a la inglesa probablemente hubiera limitado la inestabilidad social y política y posibilitaba su puesta en práctica real, algo que no se produciría yendo a remolque de las insurrecciones.

El Código de 1848 suplió algunas de las carencias de su predecesor. Estaba mejor estructurado y disponía de escalas graduales que agrupaban los delitos análogos, lo que significaba que las circunstancias agravantes o atenuantes producirían cambios dentro de la misma escala, con el resultado de una mayor conexión entre delitos similares. La relegación y el extrañamiento perpetuos llevaban aparejados la inhabilitación absoluta perpetua para cargos públicos y derechos políticos y la sujeción a la vigilancia de la autoridad de por vida. Si fueran temporales, la primera acabaría al cumplir la sentencia y la segunda habría de prorrogarse algún tiempo más. ${ }^{66}$

Respecto a las condiciones que deberían afrontar mientras estaban deportados, mejoraron respecto a las del Códice precedente puesto que podrán dedicarse libremente, a su profesión u oficio "dentro del radio a que se extiendan los límites del establecimiento penal", ${ }^{67}$ lo que suponía teóricamente evitar la posibilidad de los trabajos forzados o en favor del Estado. No contemplaba nada acerca de la posibilidad de que los familiares acompañen al reo, hecho que sería más lógico ahora que expresamente se indicaba que el reo podría vivir de su trabajo o de sus rentas.

Era un Código duro, muy influenciado en el de Brasil y que tuvo un gran influjo en otros países latinoamericanos. En él, los redactores optaron por abrazar el modelo austriaco y desechar el francés. ${ }^{68}$ Castigaba severamente los delitos políticos, religiosos e incluso los sociales como la huelga, muy en la línea de la visión gubernativa de los moderados. Se basaba en su predecesor pero estaba más madurado y disponía de mayores referentes internacionales, lo que le permitió ser superior técnicamente y eliminar buena parte de las reminiscencias de condenas antiguas. La caída del Gobierno moderado no le afectó ya que conjugaba perfectamente con la alternancia entre moderados y unionistas que se dio a partir de 1856. Solo a partir de 1868 , con el

\footnotetext{
${ }^{66}$ Arts. 24 y 57. Código Penal de 1848; la duración de las penas temporales de relegación y extrañamiento eran de doce años a veinte años, la de confinamiento mayor de siete a doce, el menor de cuatro a seis y el destierro de siete meses a tres años. Art 26. Código Penal de 1848. ${ }^{67}$ Art. 102. Código Penal de 1848.

${ }^{68}$ Bernardino Bravo Lira, "La Fortuna del Código Penal español de 1848", Anuario de Historia del Derecho Español, núm. 74, 2004, pp. 50-54.
} 
advenimiento de la Gloriosa y su intento de impulsar un liberalismo de base más amplia se realizaría una nueva codificación.

El nuevo Código Penal de 1870 no podía entenderse sin la Constitución de 1869, aunque su vida la superó rigiendo hasta 1928, cuando en 1876 fue aprobada una nueva Carta Magna. La Constitución de 1869 garantizaba derechos individuales: de reunión y asociación; libertad de imprenta y de cultos; soberanía nacional; sufragio universal y la separación entre ejecutivo y legislativo. El Códice era una reformulación del anterior para hacer posibles los derechos y libertades recogidas en la Carta Magna de 1869. Además, habría que citar la pretendida humanización que derivó en disminuir el tiempo de cumplimiento, las condenas a perpetuidad pasarían a ser de treinta años, salvo en situaciones excepcionales. ${ }^{69}$ También se introdujeron mejoras técnicas.

En los años precedentes al triunfo de la Gloriosa se ejecutó una fuerte represión contra los opositores, que se materializó en numerosos fusilamientos, deportaciones y encarcelamientos. La rebaja en la dureza en todos los delitos y en particular en los políticos era comprensible, ya que entre los revolucionarios muchos habían sido víctimas de las represalias y su objetivo era instaurar un cambio profundo. En general podemos hablar de una mejor salvaguarda de los derechos individuales: los bandos no podían imponer penas distintas a la normativa y la Ley de Orden Público en la que se establecían los mecanismos de excepción solo podía ser aplicada por disposición de las Cortes. Sin embargo, una vez impuesta las fuerzas de orden publico estaban dotadas de amplias potestades incluida la de detención preventiva, el destierro de hasta 250 kilómetros para personas consideradas peligrosas o sobre las que recaigan indicios razonables de participación en altercados de cariz política, la suspensión de publicaciones y los consejos de guerra, incluso para civiles alzados en armas. Aun así, se dejaba a la autoridad tanto civil como militar la facultad de declarar unilateralmente el estado de guerra. ${ }^{70}$ Pese a pretender una mayor protección de los derechos, la inestabilidad y la propia autoprotección diseñaron un régimen en el que la represión de

\footnotetext{
${ }^{69}$ Antón Oneca, "El Código Penal de 1870", Anuario de Derecho Penal y Ciencias Penales, tomo 23, fasc./mes 2, 1970, pp. 237-251.

70 Pedro Cruz Villalón, El estado de sitio y la Constitución, Centro de Estudios Constitucionales, Madrid, 1980, pp. 399-424; la Ley de Orden Público corroboraba lo estipulado en la Constitución de la Monarquía Española de 1869. Art. 31. Eduardo González Calleja, "La política de orden público en la Restauración", Espacio, Tiempo y Forma, Serie V, Historia Contemporánea, tomo 20, 2008, p. 102. De acuerdo a los artículos 12 y 13 de la Ley.
} 
los opositores tuvo un papel relevante. Al menos, en el caso de la deportación, su uso quedaba eliminado de la normativa legal que regulaba la vía excepcional.

Desaparecía la distinción entre confinamiento mayor y menor por la vía de eliminar el menor. Los tribunales habrían de tener en cuenta la profesión u oficio del reo a la hora de señalar el punto geográfico, para que este pudiera subsistir. Además para que el condenado a esta pena pudiera ser destinado al servicio militar se necesitaba su consentimiento. $^{71}$

La relegación se contemplaba por la vía jurisdiccional para los funcionarios que disolvieran manifestaciones o asociaciones pacíficas sin haberlo advertido dos veces y como resultado de ello causara la muerte de alguno. Además de este supuesto, todos los demás en que estaba prevista se situaban en la sección segunda del Título II, Capítulo I, denominada delitos contra las Cortes y sus individuos y contra el Consejo de Ministros, que contenía diversos tipos de delitos de nueva creación como adaptación a las circunstancias políticas surgidas tras el triunfo de la Revolución Gloriosa. Serían castigados con relegación temporal o perpetua los familiares del rey, ministros y funcionarios civiles o militares que cuando vacare la Corona impidieran al poder legislativo reunirse o nombrar rey o regente, o no obedecieran a la Regencia. Esta misma condena, con carácter temporal, se impondría a los miembros del gabinete ante diversos incumplimientos graves de la Constitución, ya fueran propios o de la figura del rey; los que invadieren el Congreso o el Senado estando estos reunidos; los que perteneciendo a una fuerza armada irrumpieran y realizaran peticiones a las Cortes; los que injuriasen a cualquiera de los cuerpos legisladores, hallándose estos reunidos o en comisión; y los que invadieren las reuniones o coartasen la libertad del Consejo de Ministros. El resto de infracciones, de menor gravedad, de esta sección estaban punidas con confinamiento o destierro, siguiendo la escala de gravedad de las mismas. ${ }^{72}$ La

\footnotetext{
${ }^{71}$ Art. 116. Código Penal de 1870; el significado del resto de las penas restrictivas de la libertad ambulatoria no varió, aunque el Código contemplaba ahora dos escalas graduales con ellas, Art. 92; la descripción de penas restrictivas de la libertad ambulatoria extraída de Julián González de Maya, Las penas restrictivas de la libertad ambulatoria en la codificación española, Tesis doctoral de la Universidad de Murcia, Murcia, 2011.

${ }^{72}$ Arts. 166, 166, 167, 170, 173, 178 y 234. Código Penal de 1870; actos como intentar penetrar en las Cortes para influenciarlas sin ser miembro de una fuerza armada; los que siendo parte de una fuerza armada presentaren peticiones a las Cortes; los que injuriasen no gravemente a las Cortes; los que injuriasen gravemente a los ministros o emplearen la fuerza para no permitirles asistir al Consejo de Ministros; así como los que realizaren otros actos tendentes a no permitir la libre expresión y voto de los parlamentarios y los duelos. El extrañamiento tan solo se utilizaría
} 
mayoría de los delitos que tenían como objeto alterar el normal funcionamiento de las instituciones se penaban generalmente con la cárcel o en los casos más graves con la muerte. $^{73}$

En todos los casos se trataba de obstaculizaciones del funcionamiento de las instituciones al más alto nivel y por tanto difícilmente ejecutable por las clases bajas. Se percibe un intento de suavización de los castigos, una mayor defensa de los derechos y también un cierto aroma a autoprotección, como pertenecientes a las clases medias y antiguos conspiradores. El objetivo quedaba configurado en los políticos, funcionarios y militares, que en caso de delitos de sedición no serian encarcelados ni ejecutados, sino que con la ley en la mano serían remitidos a un lugar lejano, en el que no estarían sujetos a trabajos de ningún tipo y podrían vivir de sus rentas. La diferencia con el Código precedente es importante, ya que la relegación pasaba a ser planteada para actos no ejecutados contra las altas instancia del Estado, a aquellos efectivamente realizados. También influyó en el cambio que se considerase la forma más eficaz de luchar contra ellos, ya que estas personas con un alto perfil social eran las que más fácilmente podían desestabilizar al sistema.

Las penas de deportación y extrañamiento temporales llevarían la de inhabilitación absoluta temporal en toda su extensión y la de confinamiento durante el tiempo de la condena. Esto implicaba la privación de todos los honores, empleos y cargos públicos, así como la imposibilidad de obtenerlos y del derecho a elegir y ser elegido. Por lo demás, las condiciones del relegado no variaban, pudiendo trabajar y obtener el fruto de su trabajo tal y como establecía el Códice precedente, aunque en esta ocasión no se establece que la vigilancia de la autoridad debía ser de por vida. ${ }^{74}$

Encontramos un precepto novedoso, "El funcionario público que deportare o extrañare del Reino a un ciudadano, a no ser en virtud de sentencia firme, será castigado con confinamiento y multa de 500 a 5.000 pesetas". ${ }^{75}$ Una muestra de que al menos teóricamente se trataba de proteger a los ciudadanos contra este atropello de sus

para eclesiásticos que utilizaran su cargo para atacar el sistema político. Arts. 144, 171, 172, 173, 174, 178, 437 y 441, Código Penal de 1870.

${ }^{73}$ Arts. 181-187, Código Penal de 1870.

${ }^{74}$ Arts. 33, 54 y 57. Código Penal de 1870. La diferencia es que en toda su extensión se refiere a que si el reo fuese indultado continuaría con la inhabilitación absoluta temporal, a no ser que fuera a su vez indultado de la pena accesoria.

${ }^{75}$ Art. 222, Código Penal de 1870. 
derechos habitual en los años precedentes. Era una declaración de intenciones en toda regla que las autoridades no secundaron en los momentos críticos.

La paz de Zanjón supuso la introducción paulatina de Cuba en la España liberal, lo que supuso que poco a poco las leyes peninsulares fueran llegando a la colonia. ${ }^{76} \mathrm{El}$ Código Penal, se extendió a Cuba y Puerto Rico mediante real decreto de 23 de mayo de 1879, con algunas modificaciones. En el caso de la relegación se estipuló que debía cumplirse fuera de dichas islas en los puntos que el Gobierno designase. No cambiaban las condiciones, puesto que también se estipulaba que podrían dedicarse a su profesión u oficio "dentro del radio a que se extienden los límites del establecimiento penal", siempre bajo la vigilancia de la autoridad. ${ }^{77}$

En la Antilla mayor, las deportaciones se hacían de manera administrativa y en caso de pretender un aval legal, este existía. En real cédula de 28 de mayo de 1825 se le confirió al Capitán general la facultad de gobernar el país con poderes omnímodos como si de una plaza sitiada se tratara, lo que en la práctica avalaba cualquier decisión para garantizar el orden público. Las reales órdenes de 16 de mayo y 12 de diciembre de 1847 y 5 de marzo de 1856 obstaculizaban el regreso de los reos que habían cumplido reclusión en la Península o plazas africanas, donde podían recabar los condenados por un tiempo superior a dos años. Otras disposiciones facultaban a la máxima autoridad colonial a realizar relegaciones, por real orden de 25 de mayo de 1847 quedaba autorizado a realizarlas gubernativamente, siempre que las motivase, no se excediera en sus facultades y remitiera las causas, en lo que supone una plasmación de las atribuciones contenidas en las Leyes de Indias utilizadas en el Antiguo Régimen. En 16 de octubre de ese mismo año se prohibía el regreso a la Antilla mayor de los trasladados por vía administrativa en la metrópoli siempre que no contaran con permiso para retornar. La facultad del Capitán general se ratificaba de nuevo mediante real decreto de 16 de noviembre de 1867, y en el caso concreto de reincidentes y gentes de mal vivir mediante reales órdenes de 20 de agosto de 1865 y 27 de abril de $1866 .^{78}$

\footnotetext{
${ }^{76}$ María Paz Alonso Romero, Cuba en la España liberal (1837-1898), Centro de Estudios Políticos y Constitucionales, Madrid, 2002, pp. 51-59.

${ }^{77}$ Art. 109, Código Penal de Cuba y Puerto Rico de 1879.

${ }^{78}$ Archivo Histórico Nacional (en adelante AHN), Ultramar, Leg. 4770, Exp. 46. Deportación de José María Gally; nota a oficio de Capitán general de Cuba a ministro de Ultramar, 14 de febrero de 1865, AHN, Ultramar, Leg. 4718, Exp. 5. Expediente sobre medidas tomadas contra individuos reincidentes; Archivo Nacional de Cuba (en adelante ANC), Asuntos Políticos, Leg. 227, Sig. 20. "Expediente formado a virtud de real orden de 20 de agosto 1865, autorizando al Gobernador Superior Civil, para extrañar de la isla a las personas de malos antecedentes".
} 
El caso de desobediencia a la Regencia para la familia del Rey, los ministros, las autoridades y demás funcionarios era el único en el que se contemplaba la pena, que variaría desde la temporal hasta la perpetua, desapareciendo el resto de casos contemplados en el Códice peninsular. Además de los funcionarios que disolviesen reuniones o manifestaciones sin haberlo avisado dos veces con resultado de muerte. ${ }^{79}$

El Código de 1870 se extendió a Filipinas mediante real decreto de 4 de septiembre de 1884. La adaptación también se hizo teniendo en cuenta las características del archipiélago, por lo que se estipuló que tanto la relegación perpetua como la temporal pudieran cumplirse en la Península o en Filipinas, sin especificar en este último caso si debía ser alguna isla diferente. ${ }^{80}$ Además desaparecía el otro supuesto en el que se contemplaba este castigo en el Código Penal antillano. Todos los preceptos relativos a las condiciones del cumplimiento, duración, castigos asociados y represalias por incumplimiento permanecían inamovibles.

En Cuba y Puerto Rico, el confinamiento se haría en "un pueblo o distrito situado en las islas inmediatas, en el cual permanecerán en completa libertad bajo la vigilancia de la autoridad", lo que la configuraba como una deportación cercana para casos de delitos contra las Cortes y contra el Consejo de Ministros de importancia menor: peticiones colectivas a cualquier cuerpo legislador formuladas por un colectivo de pertenecientes a una fuerza armada o individuales realizadas al margen de las leyes, en cuyos casos se extenderían a los que ejercieran el mando en la misma; a los que realizaran injurias, amenazas o intimidación a miembros de las Cortes; a los funcionarios que sin estar facultados por ley expulsasen del reino a una persona y los que disolviesen una reunión o manifestación sin avisar dos veces con resultado de lesiones graves o muerte; al practicante en público de algún culto no católico; a los religiosos que incitaran a altercados contra las autoridades o bienes públicos y a los duelistas que faltaran a su palabra de desistimiento de su propósito o en algunos casos en que causasen homicidio. ${ }^{81} \mathrm{El}$ confinamiento variaba en el Códice del territorio asiático, que estipulaba que los condenados serían llevados a un pueblo situado entre 30 y 300 kilómetros del lugar del delito, sin mencionar para nada el carácter insular del mismo. También se reducía el número de delitos en los que se imponía, quedando

\footnotetext{
${ }^{79}$ Art. 163. Código Penal de Cuba y Puerto Rico de 1879.

${ }^{80}$ Art. 110. Código Penal de Filipinas de 1884.

${ }^{81}$ Arts. 114, 164, 165, 211, 222, 228, 275, 438 y 440. Código Penal de Cuba y Puerto Rico de 1879.
} 
únicamente para los casos de las peticiones realizadas por miembros de la fuerza armada, la deportación realizada por un funcionario público y en determinados casos de duelos. $^{82}$

\subsection{Otras leyes referentes a la deportación}

La deportación estuvo presente en el Código Penal pero en ningún momento se aplicó. ${ }^{83}$ Aun así, su mera presencia en la normativa es muestra de que en el momento en que se legislaba se pensaba que podía ser útil. En este apartado hacemos un seguimiento de los preceptos encaminados a fomentar esta práctica, ya sea como un intento de adecuación a lo expuesto en el Códice o que aparecía en relación a intentos inconexos de fomentar esta práctica. Es una normativa que manifestaba y ratificaba la voluntad "colonizadora penal" pero que no se llevó a la práctica o lo hizo de manera residual. Hemos excluido la que aparecía puntualmente como modo de desembarazo de la disidencia política, porque se va explicando en los diferentes capítulos.

En las leyes, además se explicitaban algunos aspectos relativos a la forma en que se ejecutara la condena. Los lugares a los que serían enviados, las condiciones que afrontarían y los medios en que se realizarían los transportes son cuestiones suficientemente importantes que debían ser tenidas en cuenta y que serían desarrolladas en otros preceptos. Esta legislación trataba de regularla de un modo que iba en paralelo a la realidad de su desarrollo y manifestaba las pretensiones del poder en cada momento. Con la pérdida de la mayor parte de los dominios americanos, los esfuerzos se centraron en lo que a la regulación se refiere hacia Filipinas, las Marianas y Fernando Poo, aunque en la práctica estas se produjeron también en otros destinos dado que con la relegación las autoridades pretendían sofocar de manera expeditiva un problema surgido de improvisto, cosa que dificultaba su adecuada planificación.

A pesar de la llegada del liberalismo, el Estado pretendió guardarse la potestad de cambiar la residencia de individuos considerados peligrosos. Anteriormente al Código Penal de 1822, encontramos la ley de 17 de abril de 1821 que establecía el traslado a las islas adyacentes con pérdida de honores empleo y sueldo, a los que

\footnotetext{
${ }^{82}$ Arts. 114, 166, 167, 212, 424 y 426. Código Penal de Filipinas de 1884.

${ }^{83}$ Fernando Cadalso, La pena de deportación y la colonización por penados, Imprenta de José Góngora, Madrid, 1895, p. 16; Francisco Lastres, La colonización penitenciaria de las Marianas y Fernando Poo, Imprenta de Eduardo Martínez, Madrid, 1878, pp. 30-31.
} 
predicaran que la Constitución no debía guardarse y a los que propagasen ideas contrarias a la misma. ${ }^{84}$ Algunos preceptos en la Década Ominosa iban en la línea del Antiguo Régimen, previendo el envío de presos a cárceles de África, las Antillas y Asia para delitos de falsificación, lugares en que deberían hacer trabajos públicos. ${ }^{85}$ En tiempos de guerra, el Estado se asegura la práctica legal que justificaba la arbitrariedad represiva, en 1836 se estipuló que con la mera convicción moral de que alguien se tratase de un conspirador se le podría confinar en las islas adyacentes durante seis meses. $^{86}$

Al tercer día al que se le impusiera la relegación, el reo debería ser puesto a disposición de la autoridad gubernativa de la provincia que se ocuparía de ejecutar la sentencia. Los gobernadores provinciales darían parte tan pronto supieran que el deportado hubiera llegado a su punto de destino o el extrañado hubiera traspasado la frontera. ${ }^{87}$ Mediante real orden de 3 de septiembre de 1857 , realizada con motivo de haber remitido a unos opositores políticos peninsulares a las Marianas, se recomendaba crear un presidio en ellas. La oposición del gobernador de la posesión dejó en nada la pretensión y se impulsó la llegada de un número limitado de presos filipinos. ${ }^{88}$

El primer intento de organizar la colonización penal con peninsulares se estableció en 1860, durante el Parlamento Largo de O’Donnell, mediante real orden expedida por el Ministerio de Gracia y Justicia que declaraba que la relegación perpetua se cumpliría en las Marianas y la temporal en Mindoro. En la misma se facultaba al Capitán general para que cambiara los lugares en caso de estimarlo conveniente. ${ }^{89}$ Tan

\footnotetext{
${ }^{84}$ Arts. 3 y 7. Ley de 17 de abril de 1821, en Colección de los decretos y órdenes generales expedidos por las Cortes extraordinarias, de los años de 1820 y 1821, Imprenta Nacional, Madrid, 1821, tomo VII, pp. 37-51. Esta ley fue recuperada en 30 de agosto 1836 y rigió hasta la Ley de Orden Publico de 1867, aunque volvió de nuevo brevemente con la Gloriosa; la ley se incorporó en buena medida al Código Penal de 1822. Alicia Fiestas Loza, Los delitos políticos, pp. 87-88.

${ }^{85}$ Decreto de 3 de mayo de 1830 sobre delitos de fraude, en Decretos del rey nuestro señor don Fernando VII, Imprenta Real, Madrid, 1831, Tomo XV, pp. 136-194, ver arts. 23, 26, 78, 90 y 91.

${ }^{86}$ Real decreto de 22 de diciembre de 1836, en Decretos de S.M. la reina doña Isabel II, Imprenta Nacional, Madrid, 1837, tomo XXI, pp. 593-595, ver art. 6.

${ }^{87}$ Real decreto de 14 de diciembre de 1855, en Colección Legislativa de España (en adelante CLE), Imprenta Nacional, Madrid, 1855, Tomo LXVI, pp. 489-498, ver arts. 3 y 7.

${ }^{88}$ Felipe de la Corte Ruano, Memoria descriptiva e histórica de las islas Marianas, Imprenta Nacional, Madrid, 1875, pp. 188-194.

${ }^{89}$ Real orden de 5 de noviembre de 1860, en CLE, Imprenta del Ministerio de Gracia y Justicia, Madrid, 1860, tomo LXXXIV, pp. 341-342.
} 
solo un año después dos disposiciones dirigidas a los respectivos capitanes generales, ordenaban crear dos cárceles, una en Fernando Poo y otro en las Marianas. ${ }^{90}$

En 1869, ya en pleno Sexenio, esta intención se reafirmó. La ley establecía que debían crearse establecimientos en el golfo de Guinea o las Filipinas para los deportados. Allí se destinaría a los tenidos por incorregibles y a los condenados a muerte, en caso de abolirse esta pena. También se crearía una colonia penitenciara para menores de 21 años en San Fernando. El confinamiento mayor se cumpliría en los establecimientos de Baleares y Canarias, en Santoña o en los arsenales de la Carraca, el Ferrol y Cartagena, lo que lo asimilaba a la reclusión o a los trabajos en favor del Estado. Se establecía que los reos por delitos políticos irían a secciones diferentes dentro de los mismos para que no sufrieran privaciones y molestias añadidas. ${ }^{91}$

Tras la aprobación del Código Penal de 1870, en la propia ley se reconocía la situación ruinosa de las cárceles y la provisionalidad de algunas disposiciones que regulaban la deportación, a causa de la inexistencia de establecimientos adecuados. Por esto se establecía que los sentenciados a cadena, reclusión y relegación perpetua, fueran destinados a los presidios de Alhucemas, Ceuta, Chafarinas, Melilla y Peñón de la Gomera; y los sentenciados a cadena, reclusión y relegación temporales, la cumplían en los de Cartagena, Coruña, Palma de Mallorca, Santoña y Tarragona. Únicamente en el caso de los confinados serían llevados a pueblos de Canarias y Baleares. ${ }^{92}$ Por lo que en realidad, el castigo de deportación pasaba a ser de presidio.

Poco después se establecía que los presos políticos conformaran una brigada especial en cada cárcel, al margen de las demás, que estuvieran separados del resto de presos y situados en los mejores pabellones. ${ }^{93}$ En 1879 se legisló para que este tipo de reos fueran conducidos al presidio de Valladolid, en una sección independiente de todas las demás. Además establecía que las mujeres cualesquiera que fuera su condena fueran llevadas al correccional de Alcalá de Henares y los menores de 20 años al presidio de

\footnotetext{
${ }^{90}$ Reales órdenes de 20 de junio de 1861, en CLE, Imprenta del Ministerio de Gracia y Justicia, Madrid, 1861, tomo LXXXV, pp. 529-530.

${ }^{91}$ Ley de 21 de octubre de 1869, en CLE, Imprenta del Ministerio de Gracia y Justicia, Madrid, 1869, Tomo CII, pp. 661-666, bases 8, 9, 14 y 18.

92 Decreto de 5 de diciembre de 1870, en CLE, Imprenta del Ministerio de Gracia y Justicia, Madrid, 1871 , tomo CV, pp. 869-876, art 3, reglas $1^{\mathrm{a}}, 2^{\mathrm{a}}$ y $6^{\mathrm{a}}$.

${ }^{93}$ Decreto de 16 de julio de 1873, en CLE, Imprenta del Ministerio de Gracia y Justicia, Madrid, 1874, tomo CXI, pp. 59-60, art 6.
} 
hombres de la misma población. ${ }^{94}$ Por otra parte en estos primeros años de la Restauración, mediante la Ley de Secuestros. El Gobierno se aseguraba la capacidad de alterar el domicilio de los vagos y maleantes durante un año. ${ }^{95}$

La mala publicidad de la pena, manifestada en el resultado de las memorias en el concurso de la Real Academia de Ciencias Morales y Políticas, no frustró el desarrollo de una normativa inaplicada y que si bien incidía esporádicamente en una supuesta colonización penal no lo hacía de una manera planificada y estructurada. En real decreto de 29 de septiembre de 1881 se creó una comisión encargada de fundar presidios en Fernando Poo y demás posesiones ultramarinas y un establecimiento penitenciario en los dominios para los sentenciados a relegación. Tras un breve paréntesis, volvió a intentarse aunque esta vez por medios privados, otorgando en 1888 a Fernando Canga la concesión de una importante extensión en la isla de Paragua (Filipinas), para que tratara de establecer una población peninsular. Para ello se utilizaría el trabajo indígena y más tarde el de los reclusos peninsulares, llegando a utilizar hasta unos 250 presos nativos de ambos sexos. El proyecto se suspendió poco después. ${ }^{96}$

Un real decreto de 1889 pretendía crear en Mindoro (Filipinas) una colonia penitenciaria con 500 presos para los reos de cadena o reclusión perpetuas o temporales. Estaba destinada para hombres de 20 a 45 años y establecía que se sumasen mujeres del presidio de Alcalá de Henares. Esto indica la intención de que esta fuera permanente, atrayendo posteriormente a la inmigración libre. En la exposición de motivos se resaltaban estos dos hechos, unido a la voluntad de aprovechar la fuerza de trabajo de los condenados. Esta iniciativa tampoco prosperó. ${ }^{97}$ Todas estas leyes suponían una oposición flagrante de los contenidos del Código Penal, puesto que tras el de 1870 la relegación quedaba estipulada tan solo en delitos políticos, teniendo un contenido punitivo diferente al que se pretendía desarrollar en las disposiciones de rango inferior.

\footnotetext{
${ }^{94}$ Real decreto de 1 de septiembre de 1879, en CLE, Imprenta del Ministerio de Gracia y Justicia, Madrid, 1880, tomo CXXII, pp. 228-231, arts. 4 y 6. En este decreto se mantienen los presidios para la relegación temporal excepto el de Coruña que desaparece de la lista y es sustituido por el de Zaragoza.

${ }^{95}$ Ley de 8 de enero de 1877, en CLE, Imprenta del Ministerio de Gracia y Justicia, Madrid, 1877, tomo CXVIII, pp. 16-20, art. 7.

96 Pedro Dorado Montero, "Colonias penitenciarias" en Luis Moutón Ocampo et al., Enciclopedia jurídica española, Francisco Seix, Editor, Barcelona, 1910, tomo VII, p. 173.

${ }^{97}$ Real decreto de 26 de enero de 1889, en CLE, Imprenta del Ministerio de Gracia y Justicia, Madrid, 1889, tomo CXLII, pp. 66-73; Pedro Dorado Montero, "Colonias penitenciarias", p. 174; Julián Gómez de Maya, Las penas restrictivas de la libertad ambulatoria en la codificación española, p. 238.
} 
Sin embargo, la deportación no se impuso. La norma que habilitaba la cárcel para esta pena hubiera imposibilitado su aplicación, pero también la ausencia de lugares establecidos para ello. Hemos encontrado tres casos de aplicación del confinamiento mayor en 1860, contemplado únicamente para autoridades que no hubieran resistido a una rebelión o para los meros ejecutores de la misma. ${ }^{98}$ Esto, siempre que no existiera en la recopilación una confusión entre este castigo y alguno de los tipos de reclusión, o se aplicara para otros delitos, abre una posibilidad a una aplicación absolutamente puntual y marginal de la penalidad, que en cualquier caso seria insignificante en relación con la práctica habitual. En este caso seria realizada sobre las islas adyacentes, pero recordemos que también pudo terminar con el enrolamiento forzoso en el ejército a ciertos sujetos.

En 1896, La Ley de Represión del anarquismo atribuía a la jurisdicción militar los atentados terroristas y establecía que los que propagasen ideas ácratas o formasen parte de ciertas asociaciones podrán ser extrañados, y en caso de volver a la Península se les castigaría con relegación a una colonia lejana por un tiempo superior a tres años. ${ }^{99}$ Se contemplaba únicamente como último recurso en casos de expulsión del país.

En definitiva, no sorprende el fracaso más absoluto de la deportación por la vía legal. Con un Código Penal vulnerado y una gran desorganización y escasez de recursos. Todo unido a la celeridad con que se pretendía eliminar la presencia de elementos potencialmente peligrosos, configuraron a la relegación como un castigo extralegal, sin ningún tipo de base jurídica, y utilizado repetidamente durante todo el siglo XIX por vía administrativa. Estos hechos fueron muy nocivos por cuanto tuvieron como consecuencia establecer unas condiciones de vida muy difíciles para los reos y desvirtuaron la teórica buena intención en la aplicación de la misma, dándole el carácter esencial de neutralización de los adversarios políticos de manera expeditiva.

\footnotetext{
${ }^{98}$ Enrique Martínez Ruiz, La delincuencia contemporánea. Introducción a la delincuencia isabelina, Universidad de Granada, Granada, 1982, p. 192; Arts. 170 y 186. Código Penal de 1848.

${ }^{99}$ Ley de 2 de septiembre de 1896. Art. 4.
} 


\section{CAPÍTULO 2. LOS INICIOS DE LA DEPORTACIÓN. EL PRIMER LIBERALISMO}

\section{LA CONFIGURACIÓN DE LA DEPORTACIÓN EN LA ESPAÑA PENINSULAR}

\subsection{Precedentes de la deportación en las postrimerías del Antiguo Régimen}

Por mucho que Fernando VII se empeñara en anular la obra de Cádiz como si nunca hubiera existido, la realidad en 1814 era bien distinta. Tras la llegada de las ideas revolucionarias y la experiencia gaditana algo había cambiado en nuestro país. Al menos en las mentes de algunos que se empeñarían en sustituir el Antiguo Régimen por un nuevo sistema de corte liberal. Asistimos pues, en esta etapa, al nacimiento de la política en el sentido contemporáneo del término, lo que para unos significaba ni más ni menos que atentar contra el orden y las reglas y para otros implementar la razón en las tareas de gobierno. Esto daría lugar a un nuevo tipo de delitos, los políticos, a los que el Estado haría frente con los viejos métodos represivos, principalmente a través de penas de cárcel, destierro y muerte. ${ }^{1}$

En el Antiguo Régimen era común que la caída en desgracia ministros o altos funcionarios llevara aparejada algún tipo de destierro, ya sea de la capital o mediante el confinamiento en algún punto determinado. Algunas veces se producía a posesiones más alejadas, como le sucedió al exvalido Valenzuela durante el reinado de Carlos II, que permaneció diez años en Filipinas. Desterrados fueron los participantes en la conjura de El Escorial en 1807, como Escoiquiz, el Duque de San Carlos y el Duque del Infantado. Menos suerte tuvo Jovellanos, de procedencia más humilde, ya que tras ser recluido en la Cartuja de Jesús de Nazaret en el municipio mallorquín de Valldemosa acabó preso en el Castillo de Bellver en la mencionada isla.

Los presidios ultramarinos en América, Filipinas o Ceuta continuaban aplicándose, lo que según las necesidades de mano de obra podía exigir la realización de trabajos forzados. La mayoría de los implicados en la revuelta de San Blas, de carácter republicano, fueron enviados a cárceles de América, tras librarse de la pena de muerte a

\footnotetext{
${ }^{1}$ Sobre los cambios en la sociedad que llevan a España al camino de la política moderna ver José Antonio Piqueras, Bicentenarios de libertad.
} 
la que habían sido condenados gracias a la intervención del embajador de Francia. Juan Bautista Picornell, Manuel Cortes Campomanes, Sebastián Andrés y José Laz, fueron llevados a Venezuela en donde obtendrían un trato favorable de las autoridades coloniales, que les permitieron recibir visitas y relacionarse con jóvenes criollos, hasta que con la ayuda de estos últimos y connivencia de los mandatarios los tres primeros se fugaron. ${ }^{2}$ El viaje inverso hizo Servando Teresa de Mier, que fue desterrado de México a España a mediados de 1795 en donde estuvo preso y recluido en distintos conventos. ${ }^{3}$ Su caso no fue único, existiendo muchos otros, como el de Juan German Roscio y otros siete independentistas que habían sido apresados por las tropas realistas. Fueron remitidos a la Península en octubre de 1812, para ser encarcelados primero en Cádiz y posteriormente en Ceuta, donde estuvieron hasta que Roscio y algunos compañeros lograron escapar en 1815 y refugiarse en Gibraltar.

Al regreso del absolutismo, en 1814, se trató de nuevo de implantar el sistema represivo existente en el Antiguo Régimen, con alguna ligera atenuación de la legislación dentro de un marco de severidad. ${ }^{4}$ Los jefes políticos y los órganos judiciales pedían información a los ayuntamientos acerca del comportamiento de los vecinos durante la ocupación napoleónica, ${ }^{5}$ en lo que supuso unas represalias organizadas desde arriba que afectarían a distintos sectores sociales.

Personalidades de relevancia como el importante jurista Nicolás María Garelly, que participó en la Novísima Recopilación y que posteriormente tendría un papel esencial en el proyecto de Código Civil liberal, fueron castigadas. Garelly, que había sido preso varias veces por los franceses, fue transportado a Ibiza a mediados de $1814 \mathrm{y}$ permaneció allí dos años, en los que gozó de atenciones del gobernador militar de la plaza y del obispo y en los que se le permitió dar clases de derecho en el castillo. ${ }^{6} \mathrm{Se}$

\footnotetext{
${ }^{2}$ Caracciolo Parra Pérez, Historia de la Primera República de Venezuela, Biblioteca Ayacucho, Caracas, 1992, pp. 37-38, Antonio Elorza, La ideología liberal en la Ilustración española, Tecnos, Madrid, 1970, pp. 304-309.

${ }^{3}$ Ver Manuel Ortuño Martínez, Servando Teresa de Mier, Memorias de un fraile mexicano desterrado a Europa, Trama, Madrid, 2006, pp. 27-67.

${ }^{4}$ Cesar Herrero Herrero, La Justicia Penal Española en la crisis del Poder Absoluto, Ministerio de Justicia, Madrid, 1989, pp. 416-428.

${ }^{5}$ Gutmaro Gómez Bravo, Crimen y castigo, p. 49.

6 Nicomedes Pastor-Díaz y Francisco de Cárdenas, Galería de españoles celebres contemporáneos o biografías y retrasos de todos los personajes distinguidos de nuestros días en las ciencias, en la política, en las armas, en las letras y en las artes, Imprenta de Vicente de Lalana, Madrid, 1842, vol. II, pp. 17-25. Garelly fue prendido por orden de Bassencourt con los también miembros de la Junta de Valencia Agustín Aicart y Lorenzo Martínez, fueron llevados a Peñíscola primero y al Castillo de Bellver después. Al poco de regresar, Suchet volvió a
} 
llevó a cabo una práctica de destierros que se mantuvo hasta el ocaso del Antiguo Régimen y que manifestó una progresiva incapacidad para hacer frente a la creciente oposición. Se producían tal y como se había hecho con anterioridad, con una finalidad en la que primaba el castigo individualizado. Se trataba de actuar como si nada hubiera sucedido, lo que conducía irremediablemente a repetir la punición al margen de los cambios sociales. Como el Antiguo Régimen negaba categóricamente el más mínimo esbozo de participación política, no tenía sentido que el alejamiento fuera para dificultar la misma, por cuanto eso se daba por sentado. Del mismo modo, tal y como sucedía tradicionalmente, podían producirse en la Península o en alguna isla.

El problema que se planteaba desde esta conceptualización era el del alcance, ya que podía servir para delitos comunes, pero en el caso de los políticos comprendían a un elevado número, en consonancia con la expansión del liberalismo y la experiencia constitucional que se había producido. En 1814 la librería del impresor Miguel Domingo, fue asaltada y él llevado a Mallorca donde permaneció encarcelado ocho meses y posteriormente confinado cuatro años en Ibiza. ${ }^{7}$

La represión alcanzaría a los jefes políticos. En 1814, la mayoría de ellos fueron presos o desterrados, lo que muestra la focalización sobre un colectivo disidente. El de Mallorca, Ignacio Guillermo de Montis fue condenado a cuatro años de destierro de esa isla, de la corte y de los sitios reales, aunque podía redimir los dos últimos mediante el pago de mil pesos fuertes. Su crimen, haber escrito y difundido la Proclama a los Labradores y El Imparcial Libre o sea mi asistente y yo, en las que defendía el régimen constitucional y mostraba su opinión favorable a que el rey jurase la Carta Magna. Cayetano González y Vicente Seguí, empleados de su oficina, fueron condenados por colaboradores a fijar su residencia durante dos años en los que deberían presentarse a su obispo a fin de que éste vigilara su conducta. Montis se estableció en Mahón, lugar donde también lo hizo José María Gutiérrez de Terán, diputado por Nueva España, exvicepresidente y exsecretario de las Cortes. A Miguel de Victorica se le impuso residir fuera de Menorca durante dos años y al pago de las costas judiciales por enseñar

apresar a Garelly, que permaneció preso en Peñíscola unos meses muy duros, hasta que el comandante de la plaza le permitió residir en un domicilio particular; $D S C, 7$ de septiembre de 1820.

${ }^{7}$ Miguel de los Santos Oliver, Mallorca durante la primera revolución (1808-1814), 3 tomos, Luis Ripoll, Palma, 1982, tomo 3, pp. 650 y 676-680. La distinción en la fuente entre prisión y confinamiento, y en el caso de Garelly indican que no permanecería estrictamente recluido; Andreu Murillo, "La revolta menorquina de 1810. Aproximació al primer intent autonòmic de la Menorca contemporània", Randa, núm. 2, 1976, p. 99. 
ideas contra la soberanía absoluta del rey y por haber dado lecciones en la cátedra de Constitución, creada por orden de las Cortes. El juez de letras Juan Pablo Sandino, odiado por los frailes por un proceso que había seguido contra ellos, huyó a Tarragona donde fue preso y posteriormente confinado en Porreras. Agustín Argüelles que había sido forzado a ser soldado fijo en el regimiento de Ceuta, hasta que le fue conmutado por residencia en Alcudia, donde vivió desde 1815 a 1820 en una casa de la calle de los Carniceros. En la misma población se establecieron otros residentes forzados, y muchos más fueron condenados a la misma pena, a cárcel o a fuertes multas. ${ }^{8}$

Atendiendo a las causas conocidas en la comisión creada en 14 de septiembre de 1814, podemos afirmar que el destierro fue aplicado con suma frecuencia. Veamos la sentencia de Antonio Landaduce, a quien se le estipuló el "destierro de esta Corte, Sitios Reales y aquella villa veinte leguas en contorno". ${ }^{9}$ La circunscripción a los sitios reales y la posibilidad del cumplimiento parcial de la misma responden a una concepción antigua, que hasta ahora se había utilizado frente a otro tipo de delitos y que en esta ocasión se amplió a las causas políticas, de reciente aparición. Esto sucedió porque existía una voluntad real de no ser excesivamente duro con aquellos que habían tenido una participación de menor relevancia, lo que favoreció su aplicación al evitar la reclusión y los castigos físicos.

Por el contrario, con los más destacados liberales de las Cortes de Cádiz, así como otros que se habían significado en su defensa se siguió un procedimiento específico que terminó principalmente en presidios. Los exdiputados y ministros laicos fueron enviados a los de África. Los eclesiásticos fueron confinados en distintos conventos. Todos durante un periodo de entre seis y ocho años, perdiendo además sus sueldos y empleos y pagando las costas procesales. ${ }^{10}$ En las leyes existían figuras penales como la de traición, pero los diputados habían realizado la revolución en nombre del rey y en ausencia de este, por lo que estos preceptos no les eran aplicables. Por esto, tras un largo proceso que pasó por distintos magistrados y comisiones fue el propio rey quien mediante real orden dictó la sentencia. ${ }^{11}$ A la arbitrariedad de las condenas en el Antiguo Régimen se sumó la de ser castigados por motivaciones

\footnotetext{
${ }^{8}$ Ibídem.

${ }^{9}$ Causas sentenciadas por la Comisión nombrada por S.M., Imprenta Real, Madrid, s/a.

${ }^{10}$ Ignacio Lasa Iraola, "El primer proceso de los liberales (1814-1815)", Hispania. Revista Española de Historia, núm. 115, 1970, pp. 379-380.

${ }^{11}$ Ibídem, pp. 327-383.
} 
políticas, unos delitos que no existían en las leyes, y que por tanto les fueron impuestos por vía administrativa y no judicial.

La represión sufrió necesariamente un salto cualitativo ya que la extensión de la participación, si bien todavía era elitista, ya alcanzaba a círculos alejados del ejercicio del poder en el absolutismo. Contra algunos de estos, por arbitrariedad o por haber adquirido una importancia desmesurada para su "condición", se tomaron medidas. El fallo para Juan Rodríguez, llamado el cojo de Málaga, y el brigadier Juan Moscoso, consistió en la muerte, según Vayo, el primero por aplaudir los discursos favorables a la Constitución y por atribuírsele la música de una canción revolucionaria, y el segundo por permanecer callado mientras otros la vitoreaban. ${ }^{12}$

De los diputados, tan solo a Flórez Estrada y el Conde de Toreno, que ya se encontraban refugiados en Inglaterra, se les impuso la muerte, aunque ello no debe darnos la idea de una represión tibia, ya que incluso las principales potencias europeas protestaron contra la misma. ${ }^{13}$ Además, muchos de los liberales no fueron represaliados por el simple hecho de haber huido anticipándose a las fuerzas represivas. Las condenas a los prohombres de Cádiz, aunque duras, contrastaban con la facilidad con que se podía imponer la pena de vida al pueblo llano, mostrando que la pertenencia a un extracto social elevado continuaba siendo de gran ayuda para salir airoso de la represión en caso de que determinados hechos se considerasen de gravedad.

De igual modo, el destierro se continuó aplicando para aquellos realistas que caían en desgracia, este fue el caso del exministro José García de León y Pizarro, que pasó del Consejo de Estado a sufrir este castigo en Valencia en 1818. También Antonio Ranz Romanillos, quien fue nombrado Secretario de Hacienda en octubre de 1814 y fue desterrado en $1815 .{ }^{14}$ Sin embargo, recurriendo a lo establecido con anterioridad no se podían abarcar todos los supuestos que habían emergido en estos años convulsos.

La vuelta al absolutismo tuvo una serie de perjudicados. A los liberales, habría que añadir los antiguos jefes guerrilleros que no vieron reconocido su mérito en la

\footnotetext{
${ }^{12}$ Estanislao de Kostka Vayo, Historia de la vida y reinado de Fernando VII de España, 3 tomos, Imprenta de Repullés, Madrid, 1842, tomo II, pp. 23-56. A Juan Rodríguez se le perdonó la vida a los pies mismos de la horca.

${ }^{13}$ Ana Guerrero Latorre, "El reinado de Fernando VII, 1808-1814", en Alfredo Alvar Ezquerra, (dir.) Historia política, 1808-1874, Istmo, Madrid, 2004, pp. 78-79.

${ }^{14}$ José García de León y Pizarro, Memorias (1770-1835), Edición de Álvaro Alonso-Castrillo, Centro de Estudios Políticos y Constitucionales, Madrid, 1998, p. 316; Enric Sebastià y José Antonio Piqueras, Pervivencias feudales y revolución democrática, Alfons el Magnànim, Valencia, 1987, p. 55.
} 
guerra y que no fueron integrados en los regimientos, o a quienes se recompensó tan solo con mandos intermedios y a menudo en plazas militares alejadas y carentes de importancia. El ejército y la marina estaban descontentos por el abandono y la falta de recursos, por lo que muchos de sus miembros se desplazaron hacia el liberalismo, fomentando la lenta pero inexorable extensión de esta ideología. Esto, unido a la ruinosa coyuntura económica hizo la situación insostenible. ${ }^{15}$ Los sectores más activos se acercaron a la masonería que tendría un papel esencial en el triunfo en 1820 del pronunciamiento de Riego. En este momento pudo darse un salto hacia delante para transformar el régimen represivo, implementando una modalidad nueva de destierro, aquel focalizado sobre la disidencia. El cambio se haría con no pocos problemas.

\subsection{Un mundo en constante movimiento}

La deportación con finalidad colonizadora ya se había utilizado en el Antiguo Régimen por países como Portugal, Inglaterra, Rusia, Francia y Holanda. Sin embargo, en España esta práctica no había cuajado a causa de la afluencia de emigración voluntaria hacia América, el rechazo de penados para repoblar el continente y la preferencia de los brazos de los presos para las galeras o las minas de Almadén. En Inglaterra, la relegación se llevaba utilizando desde principios del siglo XVII, como modo de eliminar delincuentes y disidentes político-religiosos al tiempo que permitía colonizar los vastos territorios de las posesiones americanas y proporcionar mano de obra a los empresarios. Con la independencia de estas, la colonización se orientó hacia Australia. Con los años, también Francia se desprendería de sus delincuentes y de los opositores, a la vez que los utilizaba para tratar de poblar la Guyana en un primer término y Nueva Caledonia después. Influenciado esto por la práctica inglesa y por la gran cantidad de emigrados, expulsados, desterrados, presos y deportados a la Guyana y a Guadalupe que se había producido recientemente a causa del triunfo de la Revolución Francesa. ${ }^{16}$

En los países en que existía un sistema organizado de remisión a Ultramar para los delincuentes comunes, los contrincantes políticos pudieron ser incluidos en el

\footnotetext{
${ }^{15}$ Ver Josep Fontana, La quiebra de la monarquía absoluta. 1814-1820, Ariel, Barcelona, 1987 y Miguel Artola, Antiguo Régimen y revolución liberal, Ariel, Barcelona, 1978, pp. 185-216.

${ }^{16}$ Ver el breve resumen de la deportación en Europa, Pedro Dorado Montero, "Deportación", en Luis Moutón Ocampo et. al., Enciclopedia jurídica española, Francisco Seix, Editor, Barcelona, 1911, tomo, X, pp. 757-794.
} 
mismo procedimiento. En España, dada su inexistencia, la relegación emergió con acciones individuales con una finalidad específica de desembarazo. Estas actuaciones dispersas fueron institucionalizadas en el Trienio, periodo en que este castigo se intensificó y se regularizó su aplicación. Por esto, en el caso español, la deportación iba íntimamente ligada al liberalismo, que trataba de eliminar el problema de la oposición de un modo distinto al de los absolutistas que utilizaban la vieja penalidad para los nuevos delitos.

Transportar a determinados sujetos a un lugar donde no fueran peligrosos permitía erradicar o disminuir el riesgo, a la vez que se producía una menor conculcación de los derechos que esta ideología atribuía a las personas. Por contra, en el absolutismo no existían sino vasallos, hecho que facilitaba la dureza en la represión. A esto cabría añadir que en el Antiguo Régimen la gobernanza estaba circunscrita a unas élites muy minoritarias y con el liberalismo la participación se expandió hacia capas cada vez más amplias de la sociedad, por lo que los disidentes constituían un número mayor, disponían de una mayor capacidad de acción y estaban cada vez más coordinados con correligionarios de su misma ciudad y de otros puntos del país. Todo esto disminuía la eficacia de los destierros a territorios peninsulares, por lo que se hizo necesaria la superación de los viejos esquemas represivos y entre ellos la utilización de la relegación tuvo un papel muy importante, puesto que trataba de adecuar una punición antigua a la nueva situación política y social.

Para entender la evolución hay que ver los cambios que se produjeron en el periodo 1808-1814, en el cual el absolutismo sufrió su primera quiebra. En diciembre de 1809 fueron deportados desde Valencia a Ibiza, Vicente Bertrán de Lis, José Canga Argüelles y Pedro Cros, por orden del Capitán general de Valencia. Una vez en su destino los ubicaron en el castillo, donde les acomodaron, aunque poco después ya se les permitió transitar libremente por la isla y tan solo cinco meses más tarde llegó la orden de su vuelta a Valencia. ${ }^{17}$

En 1810 fueron llevados a Ibiza, Bruno Pomar, Jaime Martí, Vicente Santander, Bernardo Ferra, Miguel Ramón de Puigpunyent, Julián Abraham y Salvador Truyols, por un periodo de tiempo que iba desde los dos meses hasta la perpetuidad. Procedentes de Palma, habían participado en un motín que tuvo lugar el 12 de marzo de 1810. Martí

\footnotetext{
${ }^{17}$ Vicente Bertrán de Lis, Apuntes biográficos de don Vicente Bertrán de Lis o sea apéndice a los folletos titulados los gobiernos y los intereses materiales, Establecimiento Tipográfico Militar de Mateo y Torrubia, Madrid, 1852, pp. 67-74.
} 
y Santandreu, fueron pronto indultados puesto que ayudaron al gobernador a reprimir una revuelta de agricultores en Ibiza. El resto no tardó en salir, excepto Truyols que fue nuevamente condenado por "haber contraído un matrimonio clandestino". De alguna manera la práctica influenció a Ibiza y dos años más tarde pasó a ser punto de remisión, además de darle un contenido político. Desde allí, el Consejo Supremo de Regencia destinó a Formentera al anterior ayuntamiento, formado por Mariano Montero, Mariano Ramón Arabí, Pedro Palau y Juan Tur, como regidores del estado noble; Simón Planells y Bartolomé Ferrer, regidores del estado llano; Pedro Gutiérrez y José Arabí, diputados del común y al síndico Luis Herrera. La orden fue ejecutada el 6 de marzo de 1812 y en medio de fuertes tensiones fue revocada provisionalmente el 3 de octubre y el 14 de enero de 1813 manera definitiva. ${ }^{18}$

La extensión de la disensión política y social tuvo como consecuencia la progresiva utilización de los destierros que afectarían a un número cada vez mayor de individuos. Se trataba de acciones aisladas, que no respondían a una práctica oficial, sino que simplemente trataban de solucionar el problema de la permanencia de sujetos molestos con inmediatez. Conservaban elementos del Antiguo Régimen, como que la mayoría de alejamientos se producían a un entorno cercano. Los represaliados lo fueron por ser opositores, pero recordemos que el castigo también se empleaba para delitos comunes, por lo que podemos hablar de una pena ambivalente.

Eran tiempos inestables en que los traslados de domicilio eran muy habituales. Con la Revolución francesa muchos súbditos de este país se establecieron en España, principalmente en Cataluña. De manera que se les instó a regularizar su estancia bajo amenaza de destierro a las Baleares. La mayoría de los ciudadanos franceses posteriormente regresarían a su país, aunque hubo intentos infructuosos de limitar su presencia a Mallorca y a las Canarias para restringir la extensión de sus ideas. Esto podría ser considerado como el primer intento de reubicación en España por causas políticas, aunque no alcanzaría a ciudadanos españoles sino franceses. Durante la guerra con la República francesa 100 prisioneros de guerra franceses llegaron a Ibiza. En la Guerra de Independencia diversos obispos se refugiaron en las Baleares, entre ellos casi todos los catalanes. Varios miles de cautivos franceses fueron abandonados a su suerte en la isla de Cabrera en la Guerra de Independencia, falleciendo muchos de ellos. Otros

\footnotetext{
${ }^{18}$ Ibídem; Isidoro Macabich, Historia de Ibiza, Daedalus, Palma de Mallorca, 1966, vol. II, pp. 13-14 y 281-282. Parece claro, que en ambos casos los deportados tenían libertad de movimientos.
} 
puntos del archipiélago sirvieron de cárcel para los soldados franceses capturados, como Ibiza, que albergó a 324. ${ }^{19}$

Tras el fin de la guerra, según Aymes, unos 65.000 apresados españoles fueron llevados a Francia, país en el que había además 2.699 desertores de las tropas españolas. A estos habría que añadir un mínimo de entre 1.200 y 1.400 refugiados civiles, 820 mujeres de prisioneros y 1.515 rehenes civiles cogidos por los franceses. Además, unas 12.000 familias de afrancesados se establecieron en Francia huyendo de la represión. ${ }^{20}$ Al finalizar la guerra, las Cortes de Cádiz decretaron la confiscación de bienes de los afrancesados, lo que unido al miedo a las represalias significó el exilio de un buen número de ellos. Grupo al que después se unirían los liberales, a causa de la represión de Fernando VII tanto en 1814 como en 1823 y los absolutistas tras el advenimiento del Trienio. Dio comienzo un periodo de continuas guerras y eternos conflictos que tendrán como una de sus consecuencias el abandono del país de un gran número de sus ciudadanos.

Todos estos movimientos voluntarios y forzados de ciudadanos eran demasiado significativos para que fueran obviados. El absolutismo podía pretender volver a la situación anterior como si nada hubiera sucedido. Pero los liberales entendían mejor los cambios que estaban aconteciendo, de los que en parte eran impulsores, y trataban de adaptarse y sacar partido de ellos. Especialmente cuando junto a ellos siguieron produciéndose destierros individuales, ya fuera en el territorio peninsular o a las islas, constituyendo el antecedente inmediato de la deportación.

\subsection{El Trienio Liberal}

Después de una sucesión de tentativas frustradas, el primero de enero de 1820 se produjo el pronunciamiento del teniente coronel Riego. Tras un primer momento en que se desplazó con sus hombres por Andalucía en busca de apoyos, finalmente, la adhesión a la sublevación de un grupo de oficiales en La Coruña precipitó la extensión de una

\footnotetext{
${ }^{19}$ Enric Moreu-Rey, Els immigrants francesos a Barcelona, IEC, Barcelona, 1959, pp. 35-50; Jaime Carrera Pujal, Historia política de Cataluña en el siglo XIX, Bosch, Barcelona, 1957, tomo I, pp. 53-60; Isidoro Macabich, Historia de Ibiza. vol. II, pp. 199-202; Gaspar Feliu i Montfort, La clerencia catalana durant el Trienni, IEC, Barcelona, 1972, pp. 24-29; sobre los prisioneros franceses en Cabrera, ver Miguel de los Santos Oliver, Mallorca durante la primera revolución, tomo 2 .

${ }^{20}$ Jean-René Aymes. Los españoles en Francia, pp. 93-115; Miguel Artola, Los afrancesados, Alianza, Madrid, 2008, pp. 235-255.
} 
reacción favorable para que el rey aceptase la Constitución. El monarca no tuvo más remedio que ceder a la presión, de modo que el 9 de marzo se iniciaba el Trienio al nombrar el rey su primer Gobierno liberal. Se inició un proceso de gran efervescencia política en la que comenzaron a surgir en numerosas ciudades la Sociedades Patrióticas como expresión de la voluntad de extensión de la participación. ${ }^{21}$

En el plano normativo, inmediatamente comenzaron una serie de reformas importantes que sentarían las bases de lo que posteriormente seria el Estado. Se hicieron cambios importantes como la aplicación de la Carta Magna, Cortes elegidas mediante sufragio, desamortización de bienes de la Iglesia y comunales, abolición del régimen señorial, supresión de mayorazgos, reforma hacendística, desaparición de órdenes monacales, supresión de los jesuitas, libertad de imprenta o libertades económicas entre otras, si bien en muchas ocasiones los nuevos avances contenían usos antiguos que no se modificaron. En ocasiones las normas nuevas contenían remisiones a las Partidas o la Novísima Recopilación, pero especialmente nos referimos a la pervivencia de los usos arbitrarios en la represión, contenidos en la nueva normativa que se promulgaba.

Por lo que respecta al orden público, se seguiría el camino de reforzarlo en base al autoritarismo. El Código Penal mantenía la pena capital para un gran número de delitos, tanto políticos como comunes. Entre los primeros se englobaban preceptos contra la Constitución, el rey, las Cortes, la religión católica, traición o rebelión. ${ }^{22}$ La punición contemplada en el Códice, emanaba en buena medida de la Ley de Orden Público 17 de abril de 1821. El Decreto VI de la misma, sobre conspiradores contra la Carta Magna establecía la muerte para los que conspirasen contra la Constitución, el Gobierno, las Cortes, para reinstaurar el absolutismo o para instituir en España una religión distinta de la católica. También establecía la pérdida de "empleos, sueldos y honores" y el confinamiento a "islas adyacentes" de los que tratasen de convencer de que la máxima norma no debía aplicarse. La proscripción seria de uno a cuatro años en el caso de propagar "máximas o doctrinas que tengan una tendencia directa a destruir o trastocar la Constitución política de la monarquía". El decreto VII de 17 de abril de 1821, transfirió a los militares las competencias sobre el orden público, otorgándoles el poder jurisdiccional sobre este tipo de delitos con la excepción tan solo de algunos

\footnotetext{
${ }^{21}$ Alberto Gil Novales, Las Sociedades Patrióticas (1820-1823), 2 vols., Tecnos, Madrid, 1975, vol. I, pp. 17-19.

${ }^{22}$ Arts. 188, 189, 191, 204, 219-221, 224, 227, 250-253, 256, 262, 271 y 276. Código Penal de 1822.
} 
casos en que las detenciones se realizaran a instancias de la autoridad civil y los reos no opusieran resistencia al ser detenidos. La conjunción de ambos decretos configuraba un sistema que aunque regulado bajo la égida de la ley gozaba de una gran discrecionalidad amparado en la excepcionalidad. Ambas disposiciones fueron aprobadas con poca oposición, pese a que contaban con remisiones a la legislación del Antiguo Régimen y no se sabía con claridad contra quienes podría ser invocada. ${ }^{23}$

De esta manera, se configuró un sistema represivo nuevo alejado de la arbitrariedad del Antiguo Régimen, por cuanto establecía unos procedimientos claramente reglados. Sin embargo, otorgaba unas facultades discrecionales muy amplias a los capitanes generales, de quienes en última instancia se pretendía depender para garantizar la supervivencia del régimen. A este hecho no podía ser ajeno el estado de excitación del momento y ante todo la situación de guerra civil en que se encontraba el país, puesto que en el momento de su aprobación ya se habían levantado partidas realistas y el liberalismo no quería perder la baza de reprimirla duramente. En última instancia, lo que se pretendía era avalar jurídicamente posibles extralimitaciones de los militares en el uso de la represión, que en uso de las competencias atribuidas por la ley de manera expeditiva o a través de juicios sin las garantías suficientes, quedaban facultados para deportar a ciertas personas. No se pretendía implantar un sistema basado en la relegación, pero dejaba la puerta abierta a su utilización. Lo mismo que sucedió respecto al Código Penal, tal y como hemos visto en el capítulo precedente.

Por otro lado, el liberalismo se enfrentaba a grandes divisiones internas, que abatían todavía más al ya de por sí debilitado sistema. Los avanzados creían que las reformas eran poco profundas y pedían mayor determinación en la lucha contra los realistas. Los moderados se mostraban partidarios de la transacción con las antiguas élites y se postularon como defensores "del régimen monárquico representativo, incompatible con toda forma democrática". ${ }^{24}$ En consonancia con las intenciones de los sectores revolucionarios más conservadores y su mayor poder, las elecciones de 1820 dieron como resultado una victoria de los moderados. ${ }^{25}$

\footnotetext{
${ }^{23}$ Manuel Ballbé, Orden público y militarismo en la España Constitucional, pp. 61-85; para una mejor comprensión de la Ley de Orden Público, de 17 de abril de 1821 ver: Boletín de Jurisprudencia y Legislación, 1843, Imprenta de Viuda de Jordán e hijos, Madrid, 1842, tomo III, pp. 125-135, 167-180, 223-239, 285-297, 335-347 y 391-403.

${ }^{24}$ Antonio Elorza, La modernización política de España, Endymion, Madrid, 1990, p. 154.

${ }^{25}$ Alberto Gil Novales, El Trienio Liberal, pp. 14-18; las Cortes de 1820 estuvieron formadas principalmente por eclesiásticos (28\%), militares (17\%), abogados (15\%), funcionarios y cargos
} 
A pesar de la nula oposición que hubo al pronunciamiento de Riego, las conspiraciones ultramontanas comenzaron enseguida. ${ }^{26}$ No obstante, durante este año y el siguiente la actividad insurreccional fue débil hasta que se produciría un acrecentamiento sustancial en 1822. Este incremento paulatino tuvo que ver con el posicionamiento frente al régimen constitucional de una serie de grupos: la Iglesia, los campesinos y buena parte de las capas altas del ejército y de la nobleza se mantenían fieles al rey. Las conspiraciones en última instancia contaban con el apoyo del monarca, que desde el primer momento trató de reinstaurar su poder absoluto, aunque sin ejercer esta labor abiertamente.

La creciente oposición tendría como respuesta una mayor represión. En 1820 fueron cesados de sus cargos y expulsados de Ibiza los miembros de varios batallones y altos cargos por considerarse adversos al sistema liberal y a finales de 1822 fueron deportados a Barcelona tres personas tenidas por serviles, el secretario Vicente Gotarredona y Luis Herrera, que ya habían sido represaliados en 1813, y el dominico José Oliver. Actuaciones como estas se reproducían en otros lugares como un simple modo de desembarazarse o de castigar a aquellos tenidos por reaccionarios o que habían participado en actividades contrarrevolucionarias. Esto creaba problemas en los puntos receptores que no siempre se resignaban a aceptar a sujetos potencialmente problemáticos. En marzo de 1820 el ultrarrealista conde de España fue depuesto de su cargo de segundo cabo de comandante de la tropa en Cataluña y mediante real orden fue trasladado a Mallorca, donde no se le permitió desembarcar ni dirigirse a la isla de Cabrera y fue desviado a Mahón, donde fue encerrado en el Lazareto. ${ }^{27}$

(12\%) y magistrados e intelectuales (8\%). En las de 1822 se observa una tendencia modernizadora, todavía primaban los eclesiásticos pero su peso había bajado hasta el $18 \%$. El resto eran abogados (16,5\%), militares (15\%), funcionarios $(13,5 \%)$, hacendados $(9 \%) \mathrm{y}$ comerciantes/fabricantes (8\%). Quintí Casals Bergés, La representación parlamentaria en España durante el Primer Liberalismo (1810-1836), Edicions de la Universitat de LleidaServicio de Publicaciones de la Universidad de Cádiz, Lleida-Cádiz, 2014, pp. 135-136 y 149150.

${ }^{26}$ Ramón Arnabat Mata, "Violencia política y guerra civil durante el Trienio en Cataluña", p. 51; Manuel Gorostiza, Cataluña a fines de 1822, o sea rápida ojeada sobre el origen, progreso, proyectos y recursos de la facción liberticida en las cuatro provincias, Imprenta de Eusebio Álvarez, Madrid, 1822, pp. 9-11; Antoni Sánchez Carcelén, La revolució liberal a Lleida (18201823), Universitat de Lleida, Lleida, 2006, p. 133.

${ }^{27}$ Isidoro Macabich, Historia de Ibiza, vol. II, pp. 25-33; Teatro de la guerra. Cabrera, los montemolinistas y republicanos en Cataluña, Imprenta de D. R. González, Madrid, 1849, pp. 69-70 (biografías). 
La invasión austriaca de Nápoles en 1821 comportó la huida de un buen número de liberales napolitanos, muchos de los cuales eligieron España para establecerse. La indignación que produjo este hecho, unido a las informaciones dadas por los propios italianos caldeó enormemente el ambiente y se produjeron disturbios en diferentes lugares del país. En Barcelona, el 4 de abril, una Junta presidida por todas las autoridades fue interrumpida por paisanos armados y militares, a la cabeza de los cuales se encontraba el coronel de la Milicia Nacional, José Costa. Este presentó una lista con hombres que habían de ser detenidos y dijo que de lo contrario no sería capaz de mantener el orden. Los mandatarios la aprobaron e inmediatamente comenzaron a producirse las detenciones. Así, fueron capturados el obispo de Barcelona, Pablo Sitchar; el vicario general, Pedro José Avellá; el exinquisidor Llozer; el guardián de San Francisco, José Planas; los tenientes generales, barón de Eroles y Pedro Sarsfield; los mariscales de campo, Blas de Fournas y el barón de la Barre; el brigadier Campell y el hacendado Joaquín March. Al día siguiente los detenidos fueron embarcados con dirección a Mallorca, excepto el obispo que fue llevado a Aragón y el barón de la Barre que salió con destino a Flandes. Junto a los de Baleares salieron un tal Butibamba y el brigadier Andriani y Strauch, comandante del regimiento de Barbastro y hermano del obispo de Vic. ${ }^{28}$

La presión popular había conseguido que las autoridades, bien por garantizar el orden o por garantizar la vida de los tenidos por serviles, hubieran cedido a la presión. Los sucesos de Barcelona y la posterior ley de 17 de abril, que contemplaba la posibilidad de realizar deportaciones a Baleares y Canarias, muestran cómo su utilización formaba parte del bagaje político de los liberales, que entendían que podía ser una pena útil para luchar contra los contrarrevolucionarios. No obstante, los conservadores habían planificado las relegaciones como una atribución otorgada a los mandos castrenses y la actuación de las masas populares había alterado esta pretensión excediendo lo dispuesto legislativamente.

Sarsfield y Eroles fueron acogidos en Mallorca por miembros de la Casa Cortadellas, por intermediación de Manuel Lasala y Antoni Satorras, que se hacían

\footnotetext{
${ }^{28}$ Mateu Crespí, Diario de Memorias de Barcelona, Arxiu Històric de la Ciutat de Barcelona (en adelante AHCB), MS A-112 (1821), pp. 17-18. De los tres últimos nada indica Crespí, pero probablemente fueron presos con anterioridad; Miscelánea de Comercio, Política y Literatura, 10 de abril de 1821; Joaquín de March y Basols, remitió una petición al congreso para poner fin a su destierro y que se castigase a los culpables de la vulneración de sus derechos. DSC, 19 de mayo de 1821 .
} 
cargo de sus gastos. A mediados de 1821, Eroles, José Planas, Sarsfield y Strauch conspiraban, creyendo que las Baleares eran un buen sitio para ubicar las armas que debían recibir del extranjero y que allí tendrían ayuda entre la población. En otras ciudades como Cádiz, Sevilla, Málaga, Algeciras, Cartagena, Oviedo y Granada, se reprodujeron los actos violentos y atropellos similares. ${ }^{29}$ En Galicia fueron detenidas y llevadas a La Coruña alrededor de cien personas, y de ellas 42 fueron enviadas a Canarias el 8 de mayo de 1821 y el resto quedaron presas. La mayoría eran religiosos, aunque les acompañaban destacados absolutistas. Una vez en Canarias fueron a parar al Castillo de Paso Alto en Tenerife, en donde permanecieron "encerrados en cuartos estrechos". Este hecho causó un gran revuelo de manera que el Gobierno depuso al gobernador político José María Puente, quien se defendió aduciendo que se preparaba una conspiración y que los embarcó para defenderles de las iras de los que le incitaron a su detención y del pueblo. La decisión de prenderles fue tomada a instancias del Capitán general Espoz y Mina, la guarnición de La Coruña, la Milicia Nacional y la Tertulia Patriótica, en una decisión colegiada con las autoridades locales, provinciales y militares. ${ }^{30}$

El hecho de que permanecieran presos hace que no se pueda hablar de deportación, sino de presidio, al menos en un primer momento. Aun así, se trató de un envío forzoso de personas por ser opositores y fue discrecional, pues no existía juicio ni declaración condenatoria. A esto habría que añadir la remisión de las personas a Ultramar, es decir, a territorios españoles fuera de la Península, con el objeto de una mayor eficacia en la neutralización de los disidentes. Debe ser entendida como una manera de deshacerse de elementos peligrosos, de evitar disturbios, de garantizar la vida de los detenidos, de dificultar la liberación de los mismos o una combinación de todo ello. Pero en los casos estrictos de relegación, en la que los sujetos disponían de libertad

${ }^{29}$ Ramón Arnabat Mata, La revolució de 1820 i el Trienni Liberal a Catalunya, Eumo, Barcelona, 2001, pp. 212-213; Miguel Ferrer Flórez, "La regencia de Urgell y las Baleares", Bolletí de la Societat Arqueològica Lul-liana. Revista d'Estudis Històrics, núm. 59, 2003, pp. 133-156; Estanislao de Kostka Vayo, Historia de la vida y reinado de Fernando VII de España, tomo II, pp. 238-239. En esta obra se atribuye su autoría a los carbonarios, extendida a través de los fugitivos de Nápoles.

${ }^{30}$ El Universal, 16 de mayo de 1821; Colección Eclesiástica Española (en adelante CEE), 14 tomos, Imprenta de E. Aguado, Madrid, 1823-1824, tomo XIV, p. 136; Miscelánea de Comercio, Política y Literatura, 18 de julio de 1821; José María Puente, Manifiesto que hace a la nación don José María Puente, jefe superior político que fue en la provincia de Galicia, Imprenta del Imparcial, Madrid, 1821, pp. 3-14 y 75-85; Alberto Gil Novales, Las sociedades patrióticas, vol. I, pp. 177-178. Afirma que el bergantín Hermosa Rita ya se había utilizado en marzo de 1820 para ese mismo cometido. 
de movimientos, ya fuera total o limitada, el carácter remoto del destino revestiría una importancia capital pues dificultaba la fuga y la continuación de sus presuntas actividades conspiratorias mientras permanecían en libertad. De todas maneras, era una figura en formación y su aplicación era todavía confusa, pues no existía una voluntad clara de utilizarla emanada de las altas instancias gubernativas y la aplicación de estos traslados forzosos ha de enmarcarse en un contexto de grave deterioro del orden público.

La voluntad del Gobierno de impedir los excesos era difícil de conseguir por el incremento de partidas realistas, las amenazas desde el exterior y las peticiones de profundización de la revolución y de represión de absolutistas. Los avanzados incitaban a la rebeldía y participaban en motines, creyendo necesarias medidas más radicales. Tras las revueltas de principios de mayo, el Ejecutivo reubicó o destituyó a numerosos veinteañistas. También fueron detenidos por una supuesta conspiración el fraile mexicano Luis Gonzaga Oronoz y Francisco Brotons que fueron posteriormente liberados y Bessieres que fue condenado a muerte y a quien por la presión popular se expulsó a Francia. Gonzaga negó la existencia de esta conspiración y lo atribuía a maquinaciones de los doceañistas. ${ }^{31}$ En cualquier caso, todas estas disputas son la muestra de la tensión entre los que pretendían profundizar en la revolución, acusando a los gobernantes de transigir con los contrarrevolucionarios, y los que preferían una revolución más tranquila, más limitada y en la que participasen o al menos dieran su asentimiento de las antiguas élites políticas y económicas, lo que implicaba mantener, al menos momentáneamente, parte de la estructura del Antiguo Régimen.

El mayor peligro para la revolución lo constituían los realistas. La presencia de partidas se incrementó paulatinamente y en 1822 ya estaban diseminadas por buena parte del territorio, con mayor influencia en las áreas rurales del norte, especialmente en la zona norte de Cataluña, autentico epicentro de la insurrección. Las sublevaciones armadas se reprodujeron con mayor virulencia en la primavera de 1822, hasta que el 14 de agosto se formó la Regencia de Urgell, con base en la Seo de Urgell. La difícil orografía facilitaba las acciones de los alzados y la cercanía a la frontera proporcionaba los suministros. También disponían de apoyo social, puesto que los campesinos les apoyaron masivamente. Su cosmovisión fue atacada por los liberales que limitaban el

\footnotetext{
${ }^{31}$ Luis Gonzaga Oronoz, Manifiesto que Fr. Luis Gonzaga Oronoz hace a la España entera sobre la sonada conspiración para destituir las autoridades legítimamente constituidas, Imprenta Constitucional de Joaquín Jordi, Barcelona, 1821, pp. 14-17.
} 
poder del rey y de la Iglesia. Las reformas económicas no les incluyeron al no tener acceso a las tierras desamortizadas y sufrir la pérdida de buena parte de las comunes; la modificación en el sistema impositivo y en el régimen de rentas reemplazó los pagos en especie por los monetarios y provocó dificultad en el desembolso y en ocasiones aumentó de las rentas. El comercio con América se había perdido y a los precios a la baja se unieron a las malas cosechas y diversos brotes de fiebre amarilla, que acrecentaron la mala marcha de la economía. Las arengas de buena parte de los eclesiásticos, aprovechando la escasa formación de los campesinos, y las conspiraciones en ámbitos castrenses y nobiliarios absolutistas, fueron capaces de canalizar parte del descontento agrario hacia la vía insurreccional. ${ }^{32}$

La escalada bélica tuvo como consecuencia la declaración del estado de guerra, el 23 de julio, y la llegada de Espoz y Mina junto a nuevas tropas de refuerzo, En Barcelona no tardaron en distribuirse los manifiestos de la Regencia de Urgell, algunos de los cuales fueron incautados. El 5 de septiembre de 1822 por la noche, en cumplimiento de la orden dada por las autoridades municipales, el verdugo procedió a la quema pública de los mismos. Posteriormente miembros del ejército y milicianos detuvieron a decenas de personas acusándolas de serviles, para proceder posteriormente a su remisión a Mallorca. En total fueron 60, la mayoría eran eclesiásticos y militares, pero también había entre ellos siete funcionarios, dos colonos, un aristócrata y dos integrantes de la Milicia Nacional, además de otros tres en que no se especificaba. Otros diez fueron detenidos y puestos en libertad después de ser embarcados. Algunos de ellos, como Llozer, Blas de Fournas y José Avellá, ya habían sido enviados a la isla en abril de $1821 .^{33}$

Los moderados protestaron por estas actuaciones, al estimar que debilitaban al sistema. Además, exponían que algunos de los trasladados lo fueron realmente por motivos personales y ponían como ejemplos a liberales reconocidos como Narciso Rius, que fue alcalde constitucional de la ciudad, Antonio Puig y Luca, Pedro Bruguera, Ramón Llano y Chavarri y José Tárbené. Estos dos últimos, junto a Pablo Miranda, Matías Massanet y Andrés Rubiano elevaron una exposición a la Diputación

\footnotetext{
32 Jaime Torras Elías, Liberalismo y rebeldía campesina, 1820-1823, Ariel, Barcelona, 1976, passim

${ }^{33}$ Mateu Crespí, Diario de Memorias de Barcelona, AHCB, MS A-112 (1822), pp. 73-80. Había un total de 27 eclesiásticos y 18 militares.
} 
permanente del Congreso quejándose de su deportación a las Baleares, ${ }^{34}$ por lo que cabe pensar al recurrir a las altas instancias gubernamentales por la vulneración de sus derechos, compartirán esta ideología, siendo en la práctica incluidos entre los serviles algunos moderados.

Puig vivió en un domicilio particular en un pueblo del interior y permaneció libre, hasta que fue recuperado para el servicio activo. También el realista José Ignacio Pombo residió en un pueblo recóndito. Ambos estuvieron vigilados por las autoridades pero dispusieron de un grado relativamente alto de libertad. Es posible que los considerados serviles pudieran estar sometidos a un mayor control, aunque su estancia no diferiría ostensiblemente. ${ }^{35}$

En cualquier caso, la relegación fue breve. El 17 de septiembre una real orden permitió que los que quisieran volvieran a la Península, exceptuando, por motivos obvios a la ciudad de Barcelona. ${ }^{36}$ La división entre distintos grupos de liberales era patente, haciéndose fuertes cada uno de ellos en ámbitos determinados. Desde el pueblo llano y militares de baja graduación se produjeron acciones que superaron lo pretendido por las autoridades, partidarias del orden. Las acciones de los primeros, que desde la calle incitaba y ejecutaban deportaciones, fueron combatidos por las altas instancias gubernativas.

Hechos similares se reprodujeron casi inmediatamente en Cataluña. Un ciudadano llamado Pol de Quimbert había sido detenido y argumentó ser un espía, delatando la ayuda que los facciosos estaban recibiendo del clero. A partir de aquí comenzó una persecución contra los religiosos en numerosos puntos de Cataluña, con gran cantidad de encarcelamientos, clausuras de conventos y robos en los mismos. Esto provocó numerosas huidas para evitar represalias o para unirse a los realistas. Algunos fueron embarcados, a principios de noviembre de 1822 un grupo de 72 franciscanos de Barcelona fueron llevados a Cartagena. Únicamente a los que se secularizaron se les

\footnotetext{
${ }^{34}$ Ibídem, pp. 79-80; José Marquet y Roca, Memorias para la historia de la última guerra civil de España, Imprenta de Brusi, Barcelona, 1826, tomo II, p. 63-64; DSC, 29 de octubre de 1822, Actas secretas de la Diputación Permanente; el expediente no se resolvería, puesto que el 9 de mayo de 1823 la comisión de legislación decidía remitirlo al Gobierno para que lo instruyera correctamente. DSC, 9 de mayo de 1823. En este caso se refiere a la petición de Juan Miranda y Ramón del Llano. En la anterior sesión se refiere a Pablo Miranda, por lo que desconocemos si se trata de una confusión o había dos deportados, Juan y Pablo con el mismo apellido.

35 Antonio Buxéres, Elogio del difunto coronel don Antonio Puig y Luca, Imprenta de José Tauló, Barcelona, 1849, p. 7; Federico Suárez, Documentos del reinado de Fernando VII. Tomo VIII. Los agraviados de Cataluña, (4 vols.), EUNSA, Pamplona, 1972, vol. 3, pp. 226-227.

${ }^{36}$ Ramón Arnabat, La revolució de 1820 i el Trienni Liberal a Catalunya, p. 285.
} 
permitió quedarse, lo que disparó las peticiones que alcanzaron la cifra de 50 en los dos días siguiente al destierro a Algeciras. ${ }^{37}$ Los que se quedaron tuvieron que vivir en un entorno hostil.

Los levantamientos ultramontanos habían debilitado en extremo al Gobierno de Martínez de la Rosa. A raíz de una sublevación en Madrid sofocada por la Milicia Nacional los avanzados subieron al poder, formándose el 6 de agosto de 1822 un Ejecutivo encabezado por Evaristo San Miguel. Los veinteañistas fueron incapaces de reconducir la situación en otros aspectos, pero en el bélico el nombramiento de Espoz y Mina como jefe de los batallones del Norte resultó tremendamente eficaz para derrotar a los absolutistas, que fueron perdiendo terreno y en última instancia se vieron obligados a refugiarse en Francia. Esto no significó el fin de las partidas, que continuaban operativas en buena parte de la geografía de la Península, pero constató su incapacidad para derrotar por sí mismas al constitucionalismo. A partir de ahí las esperanzas de los realistas se depositaron en una intervención de las potencias europeas, quienes convencidas de que la revolución se radicalizaba acordaron la invasión del país. En este momento las tornas cambiaron, el ejército francés, mejor preparado, más numeroso y que contaba con la ayuda de las partidas, comenzó una lenta pero inexorable marcha a través del territorio español hasta conseguir dominarlo totalmente.

La llegada al poder de los avanzados significaría la entronización de una nueva manera de hacer política que pretendía romper de manera más contundente con el sistema anterior y que estaba más abierta a los cambios. Las relegaciones y destierros forzados realizados puntualmente en base a presiones del pueblo llano suponían desde el punto de vista de los mandatarios una práctica censurable ya que constituía una vulneración de derechos y un ataque a la legalidad. Pero al mismo tiempo resultaba tremendamente útil, por lo que lo más lógico era proceder a su codificación y que los traslados de domicilio se efectuaran de manera legal.

Esta pretensión se vería favorecida por la situación de guerra que amparaba la medida contra los rebeldes y exaltaba los ánimos por las muertes en los combates. Tras la muerte de varios milicianos y el asesinato de varias autoridades locales o militares en Aragón, el ayuntamiento de Zaragoza y el comandante de la tropa de la ciudad informaban al Gobierno del estado de excitación que se vivía en la ciudad y pedían una ley que permitiera la deportación "a las islas más proporcionadas a todos los que sean

\footnotetext{
${ }^{37}$ Gaspar Feliu i Montfort, La clerencia catalana durant el Trienni Liberal, pp. 172-175.
} 
cogidos con las armas en la mano o en actitud de obrar contra la Patria, por el mero hecho de ser aprehendidos in fraganti". 38

Apenas unas semanas más tarde, un decreto de 11 de noviembre de 1822 , aprobado mientras el Congreso de Verona se estaba realizando, estableció la forma de reprimir a los facciosos. Los cabecillas, militares, empleados públicos, cargos públicos, eclesiásticos, desertores de presidio o ejército y los que hubiesen participado directamente en la sedición serían juzgados de acuerdo a las leyes. Con el resto, que según se estableció en el decreto de 16 de mayo de 1821 habían de ser devueltos a sus casas, a partir de ese momento se establecieron diversas alternativas: los reincidentes, serían enviados a Ultramar bajo la disposición de los comandantes generales y vigilados por la autoridad durante diez años; los que sin ser reincidentes se hubieran unido voluntariamente a los facciosos serían destinados durante seis años al ejército colonial, a disposición de los capitanes generales, que en caso de estimarles inaptos para el servicio podrían emplearlos en otros menesteres. ${ }^{39}$ El precepto difería del tipo de deportaciones realizadas mediante petición "popular" de grupos de manifestantes contra sujetos por su militancia antiliberal. Pero en un contexto de guerra, la medida fue recogida por la legislación como modo de lucha en el conflicto político para ciertos casos concretos. La relegación se realizaba de manera encubierta camuflando a los afectados como reclutas, pero en la misma se excedía del simple uso en los batallones por cuanto se avalaba la utilización de los individuos en otras tareas. Promulgada en una situación prebélica y de enorme tensión, iba dirigida a regir los cauces por los que iba a discurrir la represión. Por esto, a medida que aumentaba la presión tanto desde dentro como de fuera de las fronteras su puesta en práctica era cuestión de tiempo.

Otra cosa era que forzada por las circunstancias su aplicación no se produjera en sentido estricto, sino ampliando lo expuesto en ella para dar cabida a aquellos que en principio habían quedado al margen de la mencionada disposición. La relegación pasó de estar contemplada en las leyes a utilizarse efectivamente. El 5 de enero de 1823 el

\footnotetext{
${ }^{38}$ DSC, 14 de octubre de 1822 . Se han respetado las mayúsculas y cursivas del original.

${ }^{39}$ Colección de los decretos y órdenes generales expedidos por las Cortes extraordinarias, que comprende desde el 3 de octubre de 1822 hasta 19 de febrero de 1823, Imprenta de don Tomás Albán y Cia., Madrid, 1823, pp. 23-24; Colección de los decretos y órdenes generales expedidos por las Cortes extraordinarias, que comprende desde el 25 de febrero hasta el 30 de junio del último año, Imprenta Nacional, Madrid, 1821, pp. 94-95; la única nota discordante fue la del diputado Ángel de Saavedra, duque de Rivas, que creía que en las colonias serían más perjudiciales que convenientes y que lo mejor era utilizarlos en trabajos públicos en la Península. DSC, 5 de noviembre de 1822.
} 
Ministerio de la Guerra hacia saber al comandante general de primer distrito militar que ciertos sargentos, cabos, soldados y tambores de dos regimientos de guardias de infantería que se encontraban en el depósito de Madrid, habían realizado sus actos "más bien de ignorancia que de malicia" y por tanto, dado que el rey era contrario a la multiplicación de procesos, habían decidido darles utilidad a la nación en el ejército de las Antillas mayor y menor, "distribuyéndolos en pequeñas porciones en cada uno de ellos". En 6 de febrero salieron de Madrid con "dirección a La Coruña cincuenta hombres de los 300 destinados a las islas de Cuba y Puerto Rico, debiendo seguirles en breve los demás”. El Ministerio de la Guerra exhortaba a la rápida salida de ambos grupos, pues en eso "se interesa la humanidad y aun la tranquilidad pública" y resultaba en un gran beneficio en la Antilla mayor, por cuanto aumentaba la población blanca de la colonia. ${ }^{40}$

En el caso de la tropa no se trataba de una deportación propiamente dicha, puesto que continuaban ejerciendo sus funciones en otro punto de España. Aun así, se trata de un precedente muy importante puesto que se superaba la espontaneidad emanada del pueblo y se facilitaba la asunción de esa práctica. La traslación no solo suponía reubicar a un sujeto determinado por entender su presencia perjudicial en un territorio determinado, sino que además ello podía resultar de utilidad para las pretensiones del Estado. Tras la reciente independencia de la mayoría del imperio americano, reforzar el ejército ultramarino con peninsulares era sumamente conveniente y los desplazamientos forzados facilitaban la asunción de este objetivo. En un momento de gran importación de esclavos africanos, la deportación de blancos podía servir para compensar el aumento poblacional de los primeros. A pesar de esto, no fue el factor principal como muestra el hecho de redistribuirlos por dos posesiones con presencia muy diferente de población negra.

Entre los remitidos a las Antillas había tanto miembros de la tropa como civiles. El 13 de enero, el Ministerio de la Guerra ordenaba al comandante general del séptimo distrito militar, el embarque desde Barcelona a Cádiz de 54 individuos, todos paisanos, que habían de ser llevados a la Antilla menor. De ellos 51 eran reincidentes, y por tanto

\footnotetext{
${ }^{40}$ Archivo General de Indias (en adelante AGI), Ultramar, 847, N.42. "Expediente sobre facciosos destinados a Cuba y Puerto Rico".
} 
destinados durante diez años, y los otros tres castigados por haberse unido voluntariamente a los facciosos, y sentenciados por ello durante seis años. ${ }^{41}$

El gran número de reincidentes muestra hasta qué punto la utilización de la relegación sirvió para dar salida a una situación insostenible. Los liberales chocaban en cuanto a la represión con sus principios y con la voluntad real, refractaria a condenas duras contra los partidarios de su reinado absoluto. Por otro lado, liberar a los combatientes era contraproducente por cuanto estos podían fácilmente reingresar en las filas de los combatientes realistas. La deportación se erigió así como un medio eficaz para combinar neutralización de los combatientes enemigos sin necesidad de recurrir a su muerte. Máxime cuando esta se realizaba a lugares tan lejanos y por un tiempo tan largo, lo que suponía en muchos casos resolver el problema de manera definitiva, ya que por rehacer su vida en esos territorios o por fallecer, jamás regresarían a la Península. Precisamente por esto se convirtió en política oficial

En las distintas jurisdicciones castrenses, las autoridades hacían listas con los sujetos que según las leyes habían de ser destinados a Ultramar. Desde Valencia, el 1 de marzo el comandante general del octavo distrito del ejército enviaba una lista a Madrid con ocho individuos unidos voluntariamente a los alzados. El día 7 de ese mismo mes se ordenó que fueran llevados a Cádiz para ser embarcados a Puerto Rico. El 17 de marzo se ordenaba al comandante general del noveno distrito militar que remitiera a siete facciosos. Sin embargo, el proceso discurría en medio de una gran desorganización, como muestra la carta de este último comandante que no sabía a donde había de conducirlos ni cuál sería su destino final. El 16 de abril se ordenaba un nuevo pase desde Valencia a Cádiz, para que pasasen a la Antilla menor siete facciosos. El 14 de abril, el jefe del tercer distrito recibía la orden de transportar desde Valladolid a La Coruña a otros siete facciosos, que habían de ser empleados durante seis años a los batallones de Cuba. ${ }^{42}$

Al margen de lo estipulado por el Gobierno, la guerra exaltaría de nuevo los ánimos produciéndose matanzas, prisiones y traslados forzosos de residencia entre los que incluiríamos distintas relegaciones, motivadas por la sed de venganza o por la

\footnotetext{
${ }^{41}$ AGI, Ultramar, 847, N.43. "Expediente sobre envío de facciosos a Puerto Rico".

${ }^{42}$ AGI, Ultramar, 847, N.45. "Expediente sobre facciosos destinados a Puerto Rico"; AGI, Ultramar, 847, N.46. "Expediente sobre el destino de facciosos del IX distrito militar"; AGI, Ultramar, 847, N.48. "Expediente de facciosos del IX distrito militar"; AGI, Ultramar, 847, N.47. "Expediente sobre embarque de facciosos para Puerto Rico"; AGI, Ultramar, 847, N.49. "Expediente sobre facciosos del III distrito militar".
} 
pretensión de neutralizar el riesgo que representaba la presencia de ultrarrealistas. La invasión comenzó el 7 de abril y se prolongaría hasta la capitulación de Barcelona, el 26 de octubre de 1823. En abril salieron de Tarragona dos expediciones, una a Málaga con ocho sacerdotes y un propietario, y la otra a Ceuta con cuatro religiosos y otros doce sujetos entre los que se encontraba el alcalde constitucional de 1821, varios abogados y el marqués Fivaller de Riudoms. El 16 de abril fue asesinado el obispo de Vic y posteriormente otras 24 personas fueron ajusticiadas en Manresa. El 23 de julio, numerosos presos de La Coruña, entre los cuales había algunos desterrados de otros lugares, fueron arrojados al mar. Estas acciones se combinaban con otras como la remisión de serviles desde Algeciras a Mallorca, traslado que falló al lograr estos apoderarse del barco. Desde Alicante zarparon 24 frailes con la orden de llevarlos a alguna isla y el patrón los llevó a Oropesa. También desde el norte de la Península se reproduciría esta práctica. El marqués de Valdespina fue encerrado en Bilbao y desde ahí pasó a Portugalete, hasta que finalmente fue embarcado con otros con dirección a Canarias. Por un temporal, el barco atracó en Cádiz en donde permaneció seis meses hasta el arribo del ejército francés. ${ }^{43}$

En cuanto a las deportaciones de manera desorganizada, la zona mediterránea suponía un lugar privilegiado puesto que reunía los elementos de efervescencia política con la cercanía de las Baleares, que facilitaban extraordinariamente su puesta en práctica. En el centro del país, sin acceso al mar, su uso era más complicado ya que estaba apartado de las zonas costeras más aptas para los transportes: Canarias estaba muy alejada y Ceuta y Melilla tenían un perímetro muy reducido. Desde Castellón salieron en abril de 1823 con destino a Ibiza un boticario, un cirujano, un sastre y seis eclesiásticos. Por esas mismas fechas llegaron a Ibiza algunas personalidades:

"el marqués de Paredes, gentil hombre de S.M.; el teniente coronel Sr. conde de Calderón, el brigadier de infantería D. Joaquín García, el coronel de artillería D. Tomás del Anillo y el de provinciales de Ciudad Real D. Cenón Hijito «por no haber querido tomar el mando en Valencia cuando el consejo de guerra contra el general Elio.»" ${ }^{44}$

En total fueron 110 los relegados que atracaron en Ibiza procedentes del País Valenciano durante 1823. El gran número de ultramontanos implicaba un peligro de

\footnotetext{
${ }^{43}$ Diario Constitucional, Político y Mercantil de Barcelona, 17 y 30 de abril de 1823; Estanislao de Kostka Vayo, Historia de la vida y reinado de Fernando VII de España, tomo III, pp. 119-122; Panorama español, crónica contemporánea, 4 tomos, Imprenta del Panorama Español, Madrid, 1842-1845, tomo I, pp. 56-57.

${ }^{44}$ Isidoro Macabich, Historia de Ibiza, vol. II, p. 283.
} 
insurrección latente. En los autos instruidos acerca de la fracasada intentona realista de 13 de septiembre se hace constar que se contaba con 56 de los confinados que se encontraban en las Atarazanas para que se unieran a los insurrectos. ${ }^{45}$

Las diferencias entre los propios liberales terminaban ocasionalmente con destierros y prisiones de algunos de estos. Francisco Villamor fue sentenciado en septiembre de 1821 a ser deportado durante ocho años en Santa María de Betancuria (Fuerteventura), acusado de conspiración republicana, así como a pérdida de empleos, honores y sueldos. Durante su estancia debía estar vigilado por las autoridades. En marzo de 1823, tras unos incidentes en Cádiz, Bartolomé Gutiérrez Acuña relegó a Palma a Leonardo Pérez. En el mismo año hizo lo propio con Francisco Díaz Morales. ${ }^{46}$

Las disensiones se acrecentaron a medida que el régimen se desmoronaba. El 23 de octubre de 1822 se produjo una renovación en la confederación de comuneros en la que salieron reforzados los más avanzados, aunque no pudieron imponerse con rotundidad. El 23 de febrero de 1823 se produjo la escisión de los comuneros, ${ }^{47}$ agrupándose los más radicales en torno a su órgano de expresión, El Zurriago. El Gobierno se había retirado a Sevilla, en donde permanecería hasta mediados de junio en que se trasladó a Cádiz. La situación bélica era desfavorable puesto que el ejército constitucional era incapaz de oponer una resistencia eficaz a las tropas invasoras, lo que se traducía en una situación política muy tensa.

El Ejecutivo informó al Congreso de que haciendo uso de la facultad que le otorgaba un decreto aprobado en julio había ordenado la detención y la remisión a las Islas Canarias del ultrarrealista Blas Ostolaza y de Nicolás Santiago Rotalde, Domingo de la Vega, Félix Mejía, Benito Morales, Leonardo Pérez, José Espinola, Ramón Ceruti, Ramón Sánchez y Bonifacio Castillo. También dictaminó la del periodista y comunero revolucionario José Moreno Guerra y José Aricochea, “donde quiera que se hallen”, con el mismo destino. Desconocemos cuantos fueron apresados, pero la especificación de que se hacía a dos de ellos de que no se sabía su paradero, parece indicar que el resto estarían presos o localizados. Así, Rotalde, Mejía, el resto del equipo del periódico El Zurriago, "con otros de su calaña", fueron presos y desterrados a Canarias. Rotalde culpabilizaba directamente a Miguel López Baños, cuya conducta censuraba

\footnotetext{
${ }^{45}$ Ibídem, pp. 33-35. Hubo algunas condenas por estos hechos, pero no se aplicaron.

${ }^{46}$ Alberto Gil Novales, Las sociedades patrióticas, vol. I, pp. 221-230 y vol. II, pp. 914 y 810811.

${ }^{47}$ Marta Ruiz Jiménez, El liberalismo exaltado. La confederación de comuneros españoles durante el Trienio Liberal. Fundamentos, Madrid, 2007, pp. 30-32.
} 
especialmente como represor de los comuneros. En una visión más conservadora, Aviraneta explicaba que "conspiraron en Cádiz el coronel Espinola, el médico Pérez, Ceruti y otros comuneros, para derribar al gabinete existente, fueron presos y deportados a las Canarias." De donde lograron escapar en un barco con dirección a los Estados Unidos, para posteriormente pasar a México. ${ }^{48}$

El envío contemplaba a otros de ideología absolutista como el caso del deán Ostolaza, uno de los firmantes del Manifiesto de los Persas. Ostolaza había sido llevado en el bergantín Jason a Cádiz a principios de abril, en donde permanecía preso. En julio fue ubicado en Santa Cruz de Tenerife y encerrado en el castillo de Paso Alto, lo que indica un trato distinto. Su periplo no terminó ahí, pues posteriormente pasó a El Hierro, La Palma y volvió a Tenerife. Finalmente, a finales de febrero de 1824 retornó a Cádiz. ${ }^{49}$

En Barcelona, el gran héroe Espoz y Mina también utilizó los embarques. En la noche del 9 de agosto, cuando la ciudad estaba rodeada por las tropas francesas, fueron detenidos diversos avanzados opuestos al pacto con los franceses: los alcaldes constitucionales Ramón M. Sala, Antoni Rodón y Francesc Raüll; el presbítero y director del diario El Indicador Catalán, Antonio Guillen Mazón; el procurador Miguel Comellas y el teniente coronel Juan Roth. En Cartagena fueron aprendidos por una goleta francesa. Desde Málaga, Riego ordenó embarcar a los generales Zayas, Abadía, Zarco del Valle y Plasencia. Junto a ellos tres religiosos y varios jefes políticos, entre los cuales el gobernador Aguilar. ${ }^{50}$ En una etapa de gran descontrol, los traslados de domicilio fueron utilizados para reprimir a los opositores y utilizada para dirimir los conflictos dentro del liberalismo. No obstante, dada la atomización del poder las intenciones de los líderes locales podían varias de manera importante. Resistir a toda costa y tratar de evitar que cierta gente de gran importancia se pasara al enemigo era una

${ }^{48}$ Diario Constitucional de Barcelona, 9 de octubre de 1823; DSC, sesión extraordinaria de 3 de agosto de 1823; Gaceta de Madrid, 18 de julio de 1823; Nicolás Santiago de Rotalde, La España vindicada o baraja de fulleros en la época de la revolución española, J. Ridway and E. Wilson, Londres, 1825, pp. 8 y 75; Eugenio de Aviraneta e Ibargoyen, Mis memorias intimas o apuntes para la historia de los últimos sucesos ocurridos en la emancipación de la Nueva España, 1825-1829, Moderna Librería Religiosa de J. L. Vallejo, México, 1906, pp. 62. Esta información se la dio Tiburcio Campe.

${ }^{49}$ Francisco Candel Crespo, La azarosa vida del Deán Ostolaza, Academia Alfonso X el Sabio, Murcia, 1981, pp. 143-144.

${ }^{50}$ Mateu Crespí, Diario de Memorias de Barcelona, AHCB, MS A-112 (1823) p. 55; El Restaurador, 3 de septiembre de 1823. La noticia no especifica cual era el destino de los embarcados, pero suponemos que irían hacia el territorio controlado por las fuerzas liberales, probablemente Cádiz. 
opción, sin embargo, en otros lugares este planteamiento iba en contra de los intereses de las autoridades que preferían la transacción.

Con la caída del Gobierno en Cádiz tan solo la ciudad de Barcelona resistía. El 23 de octubre, ante la constatación de que había conversaciones entre los jefes castrenses y los sitiadores, multitud de ciudadanos fueron a ver al general Roten a exigirle información acerca de las entrevistas y éste les dijo que era Mina quien negociaba. A continuación, los alborotadores se agolparon delante de la casa del general, quien les tranquilizó como pudo y les dijo que no había nada claro, desviándolos al ayuntamiento que tenía constancia de lo que se estaba tratando. Los mandatarios municipales les explicaron los puntos que les había ofrecido Moncey, pero apaciguaron a la multitud diciendo que nada estaba ratificado y consiguieron que se fueran a sus casas. Mina hizo arrestar el día 24 a algunos avanzados: el alcalde constitucional primero Vicente Cabanilles, el coronel José Costa, el coronel retirado Tadeo Aldea, el capitán de resguardo militar Jaime Canet, el comandante de la Milicia Nacional José Portell, D.N. Carrera, el interventor del resguardo militar Mariano Albo y cuatro cazadores. El día 25 fueron deportados a Mallorca, tan sólo un día antes de la capitulación de la ciudad. ${ }^{51}$

En Ibiza, los ánimos estaban excitados a causa de la situación en la Península. Los rumores de una invasión realista se sucedían. Por esto, ante el fin inminente de la situación y para evitar desmanes contra ultramontanos significados, el coronel D. Francisco Strauch y los padres Domingo Lladró y Miguel Ferrer, que se encontraban en el Castillo, fueron trasladados al término de la Mola en Formentera de manera temporal por órdenes del gobernador. Al coronel Strauch le informaba de que el arresto seria "tenido con las debidas consideraciones" y al alcalde de Formentera que le vigilara dentro de una discreta libertad "sin encierro alguno" y proporcionándoles "todo el ensanche, comodidad y auxilios posibles, sin permitir de modo alguno que alguien los insulte ni los atropelle". Con ellos marcharon un hijo de Strauch y un criado y fueron acompañados por el teniente coronel Mariano Tur, que les escoltó hasta el punto de embarque, que se realizó después de la puesta del sol. ${ }^{52}$

\footnotetext{
${ }^{51}$ Francisco Espoz y Mina, Memorias del general don Francisco Espoz y Mina, Imprenta de M. Rivadeneyra, Madrid, 1851, tomo III, pp. 450; Ramón Arnabat Mata, La revolució de 1820 i el Trienni Liberal a Catalunya, p. 337. Los rangos militares de algunos de los detenidos varían según los autores, yo he indicado la dada por Mina. Uno de los cazadores seria el capitán Narciso Puig, mencionado por Arnabat.

${ }^{52}$ Isidoro Macabich, Historia de Ibiza, vol. II, p. 283.
} 
La caída del Gobierno marcó el final de una etapa en la que España había sufrido enormes transformaciones económicas, sociales y políticas. Las autoridades, con el rey a la cabeza, intentarían que esta breve etapa fuera olvidada, pero la propia evolución social y económica haría que esto no fuera un final sino un gran paso en la enorme transformación que pocos años después sería reemprendida. Entre los múltiples cambios que se producirían incluiríamos las formas de represión de la disidencia, que el absolutismo castigaría con las formas tradicionales. Por el contrario, el liberalismo, sin renunciar a los ajusticiamientos y a las prisiones, ofrecía más variedad de matices readaptando la vieja pena del destierro a los nuevos tiempos mediante la utilización de la relegación.

\section{La represión sobre el clero realista}

En los inicios del Trienio la Iglesia tuvo una actitud entre opositora y expectante a los cambios. ${ }^{53}$ En un principio, la actitud contemporizadora de los moderados y su victoria en las urnas hicieron que la institución mantuviera una posición prudente. Sin embargo, a pesar del carácter conservador de la revolución cambiar la política respecto a la Iglesia iba en sintonía con lo pretendido por los liberales, para los que mitigar la influencia social de la institución y tender al secularismo formaban parte esencial de su programa. La venta de los bienes de las órdenes religiosas otorgaría unos beneficios fiscales al Estado, a la vez pondría en producción las tierras y generaría apoyo social entre los beneficiarios de la desamortización, que fueron en su mayor parte burgueses de las ciudades o en menor medida campesinos acomodados. ${ }^{54}$

Las leyes aplicadas provocaron un auténtico desacuerdo en la Iglesia que veía como su papel central en la sociedad española comenzaba a estar amenazado. Por tanto, se significaron en el combate al nuevo régimen y como consecuencia sufrirían una

\footnotetext{
${ }^{53}$ Antoni Sánchez Carcelén, "La repercusión del régimen constitucional en la Iglesia de Lleida durante el Trienio Liberal", Hispania Sacra, vol. 59, núm. 119, 2007, pp. 323-336. El obispo se opuso desde el primer momento; otros esperaron los acontecimientos, ver José Manuel Cuenca Toribio, "La Iglesia española en el Trienio Constitucional", Hispania Sacra, vol. 18, núm. 36, 1965, pp. 333-362.

${ }^{54}$ Manuel Gesteiro Araujo, "Desamortización y devolución de bienes durante el Trienio Liberal. Cuenca”, Espacio, Tiempo y Forma, Serie V, Historia Contemporánea, núm. 15, 2002, pp. 99100; Luis Barbastro Gil, El clero valenciano en el Trienio Liberal (1820-1823). Esplendor y ocaso del estamento eclesiástico, Instituto de Estudios Juan Gil-Albert, Alicante, 1985, pp. 209210.
} 
fuerte represión. La gran presencia de esta institución en Cataluña, así como el hecho de constituir un bastión absolutista, y la presencia de Mina, Roten y Milans como jefes militares hicieron que la represión fuera allí más relevante que en cualquier otro sitio. Según el obispo de Barcelona, solo en esa diócesis fueron asesinados 54 eclesiásticos; presos, robados y maltratados 105; deportados y robados 78; y obligados a fugarse $122{ }^{55}$ Respecto al propio obispo de Barcelona, en una asonada se pidió su remisión a las islas, aunque finalmente este hecho no se produjo. ${ }^{56}$ En el caso de las relegaciones, las cifras no han de ser tomadas por ciertas, puesto que la mayoría fueron desterrados. Pero aun así, nos proporcionan una idea de la magnitud de las represalias que sufrió esta institución por su mayoritaria y clara apuesta absolutista.

En el resto de Cataluña, en consonancia con la situación bélica se produjeron numerosos atropellos contra los religiosos, que tuvieron que soportar privaciones de destino, prisiones, expulsiones del país, amenazas, robos, saqueos, destierros y ejecuciones. La geografía también condicionaba, puesto que desde el interior alejar a los elementos hostiles podía hacerse más fácilmente hacia la frontera con Francia que hacia el mar. Por ello, varios sacerdotes de la diócesis de Lérida y el obispo de Solsona fueron confinados en la Cerdaña. El obispo de Lérida, sin embargo, fue llevado a Barcelona el 13 de febrero de 1823, cuando la invasión francesa aún no había comenzado, y allí fue protegido para que nada le sucediese. A mediados de abril fue embarcado junto con su familia en un navío en que iban otros legos y eclesiásticos. El obispo y su familia debían bajar en Tarragona, pero las autoridades se negaron a recibirlo y siguió su camino con el resto conformando un envío de 51 personas, entre los que se encontraban los trinitarios de Piera que habían sido presos el 22 de febrero de 1823. Ante la inconveniencia de liberarles continuaron su viaje en el Jason hacia Motril, acompañados durante el viaje por el presbítero y diputado Joaquín Lorenzo de Villanueva, con el objeto de protegerles. Una vez en su destino quisieron trasladarlos a Ceuta, pero finalmente fueron liberados. ${ }^{57}$

Según las explicaciones que da el propio prelado, su vida peligraba en Barcelona y las autoridades de la ciudad condal creyeron conveniente su salida para evitar

${ }^{55}$ CEE, tomo IX, pp. 291-292; Manuel Revuelta, Política religiosa de los liberales en el siglo XIX. Trienio Constitucional, CSIC, Madrid, 1973, p. 365.

${ }^{56}$ CEE, tomo IV, p. 291.

${ }^{57}$ Cayetano Barraquer y Roviralta, Los religiosos en Cataluña durante la primera mitad del siglo XIX, Francisco J. Altés y Alabart, Barcelona, 1915, tomo I, pp. 831-832; CEE, tomo XIV, pp. 144-152. 
altercados que pudieran acabar con la vida de estos ciudadanos y subvertir el orden público, sin embargo, el principal motivo seria la eliminación expeditiva de estos opositores. No obstante, la desorganización en esta práctica y su nula coordinación no hacían sino mermar su eficacia, ya que al remitir a los detenidos a otra ciudad se ponía en compromiso a los mandatarios de esa nueva localidad. En este caso concreto, desde Málaga ya se había expulsado a su obispo y este había ido a parar a Gibraltar, ${ }^{58}$ así que el envío del obispo ilerdense no hacía sino ponerles en un aprieto, tal y como ya había sucedido anteriormente en Tarragona.

En el País Valenciano, el arzobispo de Valencia, Veremundo Arias Teixeiro, fue expulsado de España en noviembre de 1820. Tres eclesiásticos realistas fueron asesinados y se reprodujeron otros atropellos. Encontramos algunos casos de traslado forzoso de individuos. En 1823, casi todos los padres capuchinos de Monovar fueron llevados a la prisión de Novelda y desde ahí a la isla de Tabarca. Los padres dominicos de Orihuela fueron apresados por el jefe político de Murcia y en Cartagena embarcados con dirección a Cádiz por orden del gobernador, el canónigo Joaquín Jimeno, nombrado a petición de los avanzados, y del que dicen que manifestó que no habría sosiego ni prosperidad hasta que todos los frailes fueran relegados a América o a Filipinas. Apuntaba una posibilidad que superaría la visión a corto plazo que tenían las deportaciones y destierros que se estaban produciendo. Desde Valencia, ante la aproximación de los realistas a la ciudad, el 9 de marzo de 1823 los miembros de la congregación de san Felipe Neri fueron encerrados en la ciudadela. Posteriormente fueron presas otras 48 personas, entre ellos 18 eran religiosos. Al día siguiente todos los detenidos fueron conducidos al Grao desde donde fueron deportados a Ibiza, lugar desde el que el día 16 zarparon en dirección a Alicante, donde no se les concedió permiso para atracar por lo que se dirigieron a Denia. ${ }^{59}$

Actos como estos se repitieron por buena parte del territorio español, especialmente en aquellos lugares en los que los más radicales habían conseguido hacerse con el poder. El obispo de Ceuta, Rafael Vélez, y otros tres sacerdotes habían sido expulsados, ofreciéndoles el ayuntamiento la posibilidad de marcharse a donde

\footnotetext{
${ }^{58}$ CEE, tomo XIV, pp. 144-152; Cayetano Barraquer y Roviralta, Los religiosos en Cataluña durante la primera mitad del siglo XIX, tomo I, pp. 831-832; CEE, tomo IX, pp. 8-9.

${ }^{59}$ CEE, pp. 105-129; sobre el pensamiento de los clérigos valencianos, incluyendo a los liberales como Joaquín Jimeno, ver Luis Barbastro Gil, Revolución liberal y reacción (18081833). Protagonismo ideológico del clero en la sociedad valenciana, Caja de Ahorros Provincial de Alicante, Alicante, 1987.
} 
quisiesen y en la forma que lo estimasen conveniente. En Motril ocho eclesiásticos fueron desterrados y otros dos en Granada, lugar de donde otros huyeron. En Gijón, cinco religiosos y varios seglares fueron desterrados a La Coruña. ${ }^{60}$ A ello habría que sumar a los que se exiliaron o escaparon a otras zonas por voluntad propia.

Los clérigos sufrieron principalmente confinamientos dentro de la Península y en las escasas ocasiones en que fueron deportados lo fueron por acciones aisladas que no formaban parte de la política gubernamental. La relegación durante el Trienio fue planificada para ser realizada con los combatientes, es decir, contra aquellos que en el transcurso de una guerra revisten mayor peligrosidad. Al fin de la misma se extendió hacia los opositores de una manera desordenada.

\subsection{La represión en la Década Ominosa. Una vuelta atrás no integral}

Con la vuelta al poder de Fernando VII se inició un proceso de retorno al pasado, tratando de eliminar la obra realizada en el Trienio. No significaba únicamente el cambio de un sistema por otro, sino que aquellos que habían tenido la osadía de desafiar la autoridad real iban a pagar por ello. Riego fue ejecutado públicamente en una ceremonia propia del Antiguo Régimen, vestido con una túnica blanca y una capucha verde fue llevado en un serón tirado por un burro, acompañado de una comitiva formada por realistas y clérigos, uno de los cuales hacía sonar una campaña. Los individuos que formaron la regencia de Sevilla huyeron ayudados por los generales franceses. Las intenciones de los gobernantes respecto a los derroteros por los que iba a caminar la represión presagiaban una enorme dureza. Tres elementos influirían en que no fuera todavía más brutal. Por un lado la huida de unos 20.000 liberales, anticipándose a la represión. ${ }^{61}$ Por otro, parte del entorno del rey así como sus aliados extranjeros trataban de mitigar la fiereza de la represión fernandina. Finalmente, cabría reseñar la propia ineficacia y desorganización de la estructura represiva. Debemos hablar de dos tipos de castigos, los realizados de manera estructurada desde arriba y los ejercidos por los cuadros menores de la administración e incluso por elementos del propio pueblo.

${ }^{60}$ CEE, tomo VI, pp. 248-251; en este caso el Gobierno emitió una real orden para que regresaran a su destino, pero ésta no se cumplió. DSC, 4 de mayo de $1822 ; C E E$, tomo XIV, pp. 131-159.

${ }^{61}$ Leopoldo de Alba Salcedo, La revolución española en el siglo XIX, Biblioteca Universal Económica, Madrid, 1869, pp. 36-39; Estanislao de Kostka Vayo, Historia de la vida y reinado de Fernando VII de España, tomo III, p. 429. 
En suelo francés se encontraban como prisioneros de guerra y diseminados por distintos departamentos gran cantidad de integrantes del derrotado ejército español. En enero de 1824 la cifra alcanzaba los 12.159 militares y 300 mujeres y niños. La entrada de los mismos es confusa y muchos lo hicieron voluntariamente huyendo de la represión. En mayo de 1824 se cerraron los campos y se incitó a sus ocupantes a regresar. La mayoría retornaron, pero un grupo significativo no lo hizo por miedo a las represalias. A ellos habría que añadir los que habiéndose significado durante el Trienio se exiliaron, la mayoría en Inglaterra. ${ }^{62}$

La represión se complementaba por aquella que ejercían las Juntas de Fe, que vendrían a sustituir a la Inquisición, y la realizada por los voluntarios realistas y otras sociedades secretas como El Ángel Exterminador. Las condenas a muerte mediante horca y garrote se multiplicaron y alcanzaron a numerosas personas por meras opiniones contrarias al rey o a favor del liberalismo. Algunas de ellas fueron posteriormente descuartizadas y sus miembros puestos a la vista a modo intimidatorio, en una práctica del Antiguo Régimen. En total 2.044 personas fueron asesinadas en Cataluña, la mayor parte de ellas por motivos políticos, y muchos más fueron llevados a presidios. ${ }^{63}$ En Navarra se produjeron multitud de reclusiones ya fuera por actos gubernativos o por grupos de exaltados. En Pamplona, según una lista oficial, eran 400 las personas que debían ser detenidas cuando la ciudad fuera tomada por los ultramontanos. A la par que desde la máxima autoridad en el reino, el conde de España, se impusieron multas y confiscaciones de bienes de liberales. A esto habría que añadir la represión extraoficial. $^{64}$

Otra forma de castigo fueron las purificaciones en la administración. Entre el 6 de julio y el 3 de noviembre de 1823 fueron destituidas 91 personas, de un total de 728 investigadas. En los años sucesivos prosiguieron, produciéndose 410 expulsiones en 1824, 427 en 1825 y 259 en 1826. Continuaron hasta 1833, aunque en esta segunda

\footnotetext{
${ }^{62}$ Rafael Sánchez Mantero, Liberales en el exilio. (La emigración política en Francia en la crisis de Antiguo Régimen), Rialp, Madrid, 1975, pp. 51-52, 19-29, y 64-72; respecto a la emigración liberal ver Vicente Llorens, Liberales y románticos, Castalia, Madrid, 2006.

${ }^{63}$ Josep Fontana, "Represión política y violencia civil en 1823-1833. Propuestas para una interpretación", pp. 313-327; una muestra de la actuación de las Juntas de Fe en Luis Alonso Tejada, Ocaso de la inquisición en los últimos años del reinado de Fernando VII. Juntas de Fe, Juntas Apostólicas, conspiraciones realistas, Zero, Vizcaya, 1969, pp. 145-190.

${ }^{64}$ Ramón del Rio Aldaz, Orígenes de la guerra carlista en Navarra (1820-1824), Gobierno de Navarra-Institución Príncipe de Viana, Pamplona, 1987, pp. 339-372.
} 
etapa los casos descendieron moderadamente, totalizando 1.015 en este periodo de seis años. A estas cifras habría que añadir las realizadas por la administración territorial. ${ }^{65}$

La deportación como modalidad de castigo que podía alcanzar a un número elevado de gente quedaba postergada, produciéndose algunos casos de relegación individualizada tal y como correspondía al sistema punitivo que se pretendía restablecer. Algunas de estas podían ejecutarse en las islas, por ejemplo, el que fuera estrecho colaborador de Mina, Juan Antonio Aldama, fue desterrado a Mallorca en 1823. Los intentos revolucionarios acababan con la mayoría de los alzados que fueron apresados y ejecutados sin piedad. Así ocurrió en las expediciones de Valdés e Iglesias en 1824, la de los hermanos Bazán en 1826, el intento de invasión desde Francia en 1830 y la de Torrijos en $1831 .{ }^{66}$ A pesar de pretender que nada había cambiado, algunas relegaciones se realizaron contra los liberales y no contra delincuentes comunes o por caer en desgracia algún personaje importante. La política había llegado para quedarse y esto lo reconocían, sin quererlo, quienes se empeñaban en reprimirla.

Desde círculos ultramontanos, las tímidas reformas, la creciente influencia de realistas moderados sobre el rey, así como el hecho de que la vuelta al Antiguo Régimen no fuera completa provocaron malestar e intentos conspiratorios. En la rebelión de Bessières de 1825, además del cabecilla fueron detenidos catorce oficiales, tres sargentos y cuatro soldados, de los cuales fueron ajusticiados el propio Bessières y siete de los oficiales, hecho que contrasta con las masivas ejecuciones en los casos de conspiraciones liberales. Aun así, las detenciones fueron numerosas y muchos de los reos castigados a confinamiento en conventos, destierros o prisiones, estas últimas tanto en la Península como en Ceuta. ${ }^{67}$

En los mismos parámetros podemos situar la represión resultante de la Guerra de los Agraviados que acaeció en Cataluña en 1827, producida también por elementos

65 Jean-Philippe Luis, L'utopie réactionnaire. Épuration et modernisation de l'Etat dans l'Espagne de la fin de l'Ancient Régime. (1823-1834), Casa de Velázquez, Madrid, 2002. pp. 65-68, 109-112, 123-125 y 138-140.

${ }^{66}$ Alberto Gil Novales, Diccionario biográfico de España (1808-1833), Mapfre, Madrid, 2010, tomo I, p. 107; ver Irene Castells, La utopía insurreccional del liberalismo. Torrijos y las conspiraciones liberales de la Década Ominosa, Crítica, Barcelona, 1989.

${ }^{67}$ Josep Fontana, De en medio del tiempo. La segunda restauración española, 1823-1834. Crítica, Barcelona, 2006, p. 192. Dos sargentos de realistas, que fueron criados personales de Bessières y encarcelados con él, estaban en el presidio de Ceuta en 1830, fecha en que solicitaron el indulto; Roberto Quirós Rosado, "El mariscal Jorge Bessières (1780-1825). Vida de un aventurero en la España de Fernando VII", Revista de Historia Militar, núm. 102, 2007, pp. $125-130$. 
ultramontanos y que tuvo escasa importancia en el resto del país. El movimiento que había movilizado a entre 10.000 y 30.000 personas según las fuentes, fue finiquitado en primera instancia con unos pocos fusilamientos, alrededor de 300 enviados a las penitenciarías de Ceuta y una veintena de religiosos trasladados a conventos de fuera de Cataluña. A pesar de rebelarse, al ser realistas se les trató con mayor magnanimidad. La connivencia o implicación en mayor o menor medida de altos cargos gubernativos o eclesiásticos con la insurrección parece clara y contribuyó a suavizar la represión. Por esto, aunque había voces como la de Calomarde que pedían la ejecución de los 300 apresados, personas del entorno del rey le convencieron de lo contrario. Otros pudieron escapar de la muerte por conexiones con las altas esferas del poder, así lo indica Dufort que menciona la intervención directa de la reina parar salvar las vidas del canónigo Corrons y de los padres Oris y Cundaro. ${ }^{68}$ Tanto en la revuelta de Bessières como en esta, fue el monarca mediante la promulgación de diversas disposiciones legislativas el que marcó los límites de la represión. ${ }^{69}$

Tras la insurrección, la conflictividad política en Cataluña continuaba y el Capitán general actuó según su criterio contra los implicados. El 24 de abril de 1828 fueron ejecutados en Figueras siete miembros de una partida. En septiembre de 1828 otros 11 individuos fueron condenados a distintas penas de presidio en Puerto Rico acusados por "cómplice en el levantamiento de una facción en el pueblo de Alfara", estar "comprendido entre los sublevados de dicho principado, "haber sido aprehendidos

\footnotetext{
${ }^{68}$ Ver Josep Fontana, De en medio del tiempo, pp. 226-227; Jaime Torras Elías, La guerra de los agraviados, Publicaciones de la Cátedra de Historia General de España, Barcelona, 1967, pp. 79-87; Federico Suárez, Documentos del reinado de Fernando VII. Tomo VIII. Los agraviados de Cataluña, vol. 2, pp. 347-352; hay discrepancias respecto quien convenció al rey. Según Opisso fue el conde de España, Gebhart dice que fue obra de los altos mando militares de Cataluña y Pirala establece que le convenció el entorno del rey ya en Valencia. Alfredo Opisso, Historia de España y de las repúblicas latino-americanas, Gallach, Barcelona, 1915, tomo XII, pp. 33-34. Víctor Gebhart, Historia general de España y de sus Indias, Imprenta de Luis Tasso, Barcelona, 1863, tomo VI, pp. 780-781. Antonio Pirala Historia de la guerra civil, y de los partidos liberal y carlista, segunda edición, refundida y aumentada con la historia de la Regencia de Espartero, 5 tomos, Imprenta de F. de P. Mellado y Cía. (tomo I), Imprenta del Crédito Comercial (II-VI), Imprenta de Dionisio Chaulié (III y IV) e Imprenta y Librería Universal (V), Madrid, 1868-1869, tomo I, pp. 50-51; Armand Dufort, Révélations d'un militaire français sur les agraviados d'Espagne, Levavaseur, París, 1829, p. 109.

${ }^{69}$ Sobre las mismas ver Juan Luis Bachero Bachero, "La represión en el absolutismo. Entre la ley y la arbitrariedad", en Marieta Cantos y Alberto Ramos (coords.), La represión absolutista y el exilio, Servicio de Publicaciones de la Universidad de Cádiz, Cádiz, 2014, pp. 79-80; las leyes realizadas contra los liberales en los inicios de la Década Ominosa en Mariano Peset Reig y José Luis Peset Reig, "Legislación contra liberales en los comienzos de la Década Absolutista (1823/1825)", Anuario de Historia del Derecho Español, núm. 37, 1967, pp. 437-485.
} 
con las armas en la mano y pertenecer a los rebeldes", o "haber hecho armas contra la tropa del rey y seguir en rebeldía", en lo que significaba una extensión de la represión a causa de los Agraviados. Los represaliados eran de origen modesto, con profesiones tales como labrador, tendero, sastre o pastor y pertenecían a distintas pequeñas poblaciones catalanas. Al menos algunos de ellos fueron utilizados para servir en el ejército colonial en las Antillas. ${ }^{70}$

Esta práctica, copiada de los liberales, significaba una reproducción de las deportaciones realizadas por estos y mostraba que tal y como sucedió en otros aspectos también en este, durante la Década Ominosa el régimen incorporó el uso de las relegaciones, en este caso para un grupo social de carácter rural y de afiliación ultra con los que se creyó que se podía sacar partido en las Antillas. No fue la tónica predominante puesto que solían discurrir por unos derroteros de mayor dureza e incluso de muerte, pero podía servir para excepciones como la que constituían estos individuos de convicciones realistas y humildes en su origen.

El 12 de marzo dos sujetos del campo de Gibraltar fueron condenados a presidio en la Antilla menor por hacer de correo para los rebeldes. En 16 de marzo tres más lo fueron por contrabandistas y conducir la correspondencia de los revolucionarios. El 26 de mayo otros tres acusados de tener inteligencia del desembarco en la bahía de Gibraltar. El mismo destino sufrieron algunos de los presuntos participantes en la expedición de Torrijos, apresados en circunstancias extrañas. Este es el caso de dos marineros que fueron detenidos uno en la playa de Torremolinos y el otro en las inmediaciones de esta ciudad y que fueron sancionados con dos años de reclusión en Puerto Rico acusados de pertenencia al grupo de Torrijos. La laxitud de la pena y el lugar donde fueron detenidos parece determinar que su implicación seria escasa o existiría poca certeza sobre ello. Al ser hombres de mar se les relacionaría con el traslado de los insurrectos, tal y como les ocurrió a cuatro marineros naturales de Mahón que fueron detenidos en las barcas que llevaron a los insurrectos a las costas a los que se les impusieron cuatro años en la misma cárcel. Al mismo destino durante ocho años, fue enviado un ciudadano apresado en Estepona el 7 de diciembre. Todos

\footnotetext{
${ }^{70}$ Josep Fontana, De en medio del tiempo, p. 242; AHN, Ultramar, Leg. 1078, Exp. 54. "Amnistía concedida presos por delitos políticos". Los 7 individuos procedían de distintas poblaciones catalanas. Con posterioridad fueron llevados a Cádiz e ingresaron en la prisión de Puerto Rico en enero de 1830.
} 
ellos fueron comprendidos en la amnistía de 29 de octubre de $1832 .{ }^{71}$ A la cárcel se le unía el alejamiento, que comenzaba a adquirir importancia para delitos políticos de poca relevancia.

A raíz de la sublevación de la isla de León en 1831 un grupo de 20 miembros del ejército que habían participado fueron trasladados a Canarias ese mismo año. En 1832 el capitán del regimiento de lanceros Francisco Illas fue destinado a Cuba, a petición de la máxima autoridad militar de Galicia. ${ }^{72}$ Del mismo modo que se había remitido a ultrarrealistas a la Antilla menor a partir de 1822, ahora eran los realistas lo que infringían el mismo castigo a sus opositores. Esto incluyó a reaccionarios que de un modo u otro continuaron con la sublevación de 1827 y a algunos cuyo grado de implicación en la intentona de Torrijos se consideró menor. A pesar de esto no podemos hablar de paridad, ya que los ultramontanos se habían sublevado contra el Gobierno y los miembros de la izquierda en su mayoría habían sido reprimidos por motivos puramente ideológicos.

Después de la revuelta de los agraviados, los reaccionarios comenzaron a atisbarse como enemigos reales. En el caso de los liberales, en cambio, la arbitrariedad era mucho mayor y el hecho de extralimitarse no suponía ningún problema para sus autores. Se llevó a cabo una represión despótica con penas emanadas de juicios sin ninguna garantía jurídica. Así sucedió con la llegada del conde de España como Capitán general de Cataluña, tras la Guerra de los Agraviados. Desde que se le otorgó la jefatura castrense de Cataluña ejecutó una gran represión sobre la izquierda, favorecido por la salida de los franceses de Barcelona a finales de 1827. En noviembre de 1828 fusiló a trece personas acusándolas de conspirar para restablecer la Constitución de 1820. A estos se sumarian once más en enero y nueve en julio de 1829. A las ejecuciones se sumarian prisiones en la ciudadela y en Ceuta, a donde fueron a parar 400 personas. Familiares de los represaliados y otros ciudadanos fueron desterrados de la ciudad, en número de unos 1.800. Otros acabarían presos o serían ejecutados, tal y como sucedería en Berga donde varios fueron encarcelados y dos de ellos ejecutados. En el resto del país la represión también se recrudecería a raíz de la expedición de 1830, el asesinato

\footnotetext{
${ }^{71}$ AHN, Ultramar, Leg. 1078, Exp. 54. “Amnistía concedida a presos por delitos políticos”. Los presos políticos en Puerto Rico fueron un total de 29.

72 AGI, Ultramar, 52, N.33. "Sobre el pago de gastos en el transporte de varios oficiales facciosos destinados al presidio de aquella capital" (Puerto Rico).
} 
del gobernador de Cádiz, el levantamiento de la Isla y el fracasado intento de Torrijos, alcanzando incluso a personas que nada tenían que ver con ellas. ${ }^{73}$

\section{LOS INICIOS DE LA DEPORTACIÓN EN CUBA}

Contrariamente a lo que sucedió en la Península, Cuba no sufrió un proceso de transformación basado en la introducción de una revolución liberal para desmontar el Antiguo Régimen e introducir unas estructuras adientes para el desarrollo del capitalismo. El cambio vino determinado por el enorme desarrollo alcanzado en la producción azucarera en la última década del siglo XVIII basada en la creciente aportación de mano de obra esclava, lo que produjo un auge espectacular en los negocios y una inflación también desmesurada. ${ }^{74}$

El crecimiento económico alcanzado sobre la base de una población esclava condicionó el posterior devenir político. Según la explicación de Arango y Parreño de la insurrección haitiana, "los esclavos han aspirado a la libertad civil por el ejemplo de sus amos". ${ }^{75}$ Por tanto, tratar de evitar que en la Antilla mayor sucediera lo mismo significaba que los criollos habían de quedar al margen de los derechos políticos para que los esclavos no pretendiesen emularlos. La isla debía continuar al margen de la Revolución Francesa y de sus ideas. La interpretación fue hecha en 1791 pero el espíritu de la misma perduró y en los momentos de apogeo del liberalismo en la Península los hacendados trataron de que la colonia permaneciera impermeable a dichos cambios. La esclavitud lo constriñó todo ya que lo esencial seria la pervivencia de este sistema económico. Esto no quiere decir que la sociedad cubana en su conjunto, ni siquiera

\footnotetext{
${ }^{73}$ Joaquín del Castillo y Mayoné, La ciudadela inquisitorial o las victimas inmoladas en aras del atroz despotismo del conde de España, Imprenta de Manuel Saurí, Barcelona, 1835, pp. 46100. A los enviados a presidio en Ceuta se les rapaba el pelo y después eran embarcados "bajo escotilla", sin ni siquiera permitírseles despedirse de sus familias; María José Vilar, Ceuta en el siglo XIX. A través de su cartografía histórica y fuentes inéditas. (1800-1912), Universidad de Murcia, Murcia, 2002, p. 80; Jacinto Viladarga y Cañellas, Efemérides berguedanas. Colección de todos los hechos acaecidos en Berga que han llegado a nuestra noticia desde los primitivos tiempos hasta nuestros días, Imprenta San José, Manresa, 1919, p. 211; Estanislao de Kostka Vayo, Historia de la vida y reinado de Fernando VII, tomo III, pp. 338-340, 348-350 y 354356.

${ }^{74}$ Manuel Moreno Fraginals, El ingenio. Complejo económico social cubano del azúcar, Critica, Barcelona, 2001, p. 81.

${ }^{75}$ Francisco Arango y Parreño, "Representación hecha a S.M. con motivo de la sublevación de esclavos en los dominios franceses de la isla de Santo Domingo", en Obras, Imprenta de Howson y Heinen, La Habana, 1888, tomo I, p. 48.
} 
todos los hacendados, estuvieran de acuerdo con la exclusión total de los derechos políticos. Pero en general, los tímidos intentos estuvieron supeditados al mantenimiento del orden. El temor a una revuelta de esclavos, mayor cuanto más se tenía que perder, les atenazó.

En el aspecto económico se introdujeron en el interior conocimientos azucareros provenientes de Francia e Inglaterra, a la par que se hizo un esfuerzo considerable por el desarrollo de otros propios, proceso en el que tuvieron una gran importancia las innovaciones técnicas. ${ }^{76}$ Para favorecer el desarrollo de la plantación se requería un robustecimiento del dominio en el interior y la creación de una red clientelar que incluyera a algunas de las personalidades más importantes de palacio con objeto de facilitar las medidas necesarias para el desarrollo legal de la producción azucarera diseñada por Parreño. ${ }^{77}$

El "pacto" mediante el cual Cuba proporcionaba rentas a la metrópoli a cambio de que esta no interfiriera en la estructura azucarera esclavista, se vio superado por la ocupación napoleónica de España en 1808. En ese momento, incentivados por el Capitán general, el marqués de Someruelos, un sector de la oligarquía habanera comandado por Arango pretendió establecer una Junta para reforzar la autoridad del Capitán general en estos tiempos convulsos. La élite criolla terminó por imponer sus pretensiones de contención de los cambios en los que la permanencia de la esclavitud fue el elemento esencial. En este sentido Arango se postulaba como el que mejor pretendía compaginar el criollismo con la españolidad. No fueron los peninsulares los que temían la libertad, sino los que antepusieron sus posesiones, y entre ellas los siervos, y la continuación de la economía basada en la plantación. El temor a revueltas de esclavos en caso de disensiones entre blancos, el refuerzo de los peninsulares y su predominancia en el ejército imposibilitaron cualquier cambio de relevancia. ${ }^{78} \mathrm{El}$

\footnotetext{
${ }^{76}$ María Dolores González Ripoll, Cuba, la isla de los ensayos. Cultura y sociedad (17901815), CSIC, Madrid, pp. 198-205.

${ }^{77}$ Ver José Antonio Piqueras, "Los amigos de Arango en la Corte de Carlos IV", en María Dolores González Ripoll e Izaskun Álvarez Artero (eds.), Francisco Arango y la invención de la Cuba azucarera, Ediciones Universidad, Salamanca, 2009, pp. 151-166; la influencia de los esclavistas se reafirmó tras el retorno del absolutismo, ver José Antonio Piqueras, Sociedad civil y poder en Cuba. Colonia y poscolonia, Siglo XXI, Madrid, 2005, pp. 77-80.

${ }_{78}$ José Antonio Piqueras, "Leales en época de insurrección. La élite criolla cubana entre 1810 y 1814", en Izaskun Álvarez y Julio Sánchez (coord.), Visiones y revisiones de la independencia americana. III Coloquio de historia de América, "La independencia de América", Ediciones Universidad, Salamanca, 2003, pp. 183-206.
} 
proceso ejemplifica la postura de la oligarquía criolla que ante cualquier temor a disensión cerraba filas con los más reaccionarios.

El resultado fue el refuerzo del poder de Someruelos que pretendió que la Antilla mayor quedara al margen del conflicto en Europa. Trató de proteger a los franceses, de los cuales unos 20.000 habían entrado en Cuba tras la revuelta de Haití. Únicamente cuando la animadversión hacia estos se incrementó y se produjeron disturbios decretó su salida. Otros huyeron voluntariamente por temor a represalias, pero finalmente muchos pudieron permanecer al obtener del Capitán general las consiguientes cartas de naturalización, de modo que finalmente un tercio se quedaron en el país. ${ }^{79}$ Mantener el orden era una prioridad y a pesar de mostrarse en contra no dudó en represaliar a los franceses para evitar los altercados. La situación de guerra difícilmente iba a dejarles al margen. El 18 de julio de 1810 fue detenido Manuel Rodríguez Alemán y Peña, de origen mexicano, con 33 pliegos destinados a las máximas autoridades coloniales del continente con la intención de que apoyaran al Gobierno de José I. El agente fue condenado a muerte y ejecutado el 30 del mismo mes. ${ }^{80} \mathrm{Su}$ sacrificio podía marcar una pauta de actuación contra la disidencia política, si bien es cierto que teniendo en cuenta la gravedad de los delitos que se le atribuían, su carácter ajeno a la sociedad criolla y las pruebas aplastantes que existían contra él difícilmente podía imponérsele otro castigo.

Muy diferente fue el caso de la conspiración de Román de la Luz, sobre la que hay una gran opacidad. Según el Capitán general, el levantamiento debía estallar el 7 de octubre de 1810 y debía contar con dos frentes, uno organizado en torno a la masonería y personalidades blancas de importante prestigio social y el otro en torno a un sector más popular de libres de color y esclavos. Lo cierto es que los 11 detenidos en un primer momento pertenecían todos al primer grupo. De estos solo fueron condenados tres ya que Joaquín Infante pudo huir utilizando redes masónicas: A Román De Luz se le impusieron diez años de presidio con prohibición de volver a América, a Luis Bassave ocho años de encierro y extrañamiento de Cuba y a Manuel Ramírez cuatro años de destierro. Los libertos de los batallones de pardos y morenos, Ramón Espinosa, Buenaventura Cervantes y Carlos Flores, debían sufrir diez años de prisión con grillete y expulsión perpetua de la isla; a dos esclavos se les impusieron ocho años de reclusión

\footnotetext{
${ }^{79}$ Olga Portuondo, "La inmigración negra en Saint Domingue en la Jurisdicción de Cuba (17981809), en Juan Manuel de la Serna (coord.), El Caribe en la encrucijada de su historia, 17801840, Universidad Nacional Autónoma de México, México, 1993, pp. 47-74.

${ }^{80}$ Jacobo de la Pezuela, Historia de la isla de Cuba, Carlos Bailly-Bailliere, Madrid, 1878, tomo III, pp. 410-415.
} 
con grillete, 200 azotes y fueron enviados a la Península donde realizarían trabajos perpetuamente para el rey. Otros tres fueron sentenciados a pago de costas, uno y tres meses de cárcel respectivamente. Desconocemos la raza y condición de los mismos, ${ }^{81}$ probablemente serían blancos ya que las penas fueron muy tenues.

Román de la Luz decía que había sido el que había descubierto la conjura, afirmación que también sostenía Bassave. ${ }^{82}$ En cuanto a de la Luz, esta afirmación es ratificada por el propio Someruelos que le acusaba de que la delación formaba parte del complot puesto que con el pretexto de saber dónde estaban los conspiradores, "pidió al Gobierno gente armada para salir, autorizado, a su frente, reunir después otros de su facción, considerados con el nombre de patriotas, y dispersar la rebelión”. De Bassave, a quien acusaba de borracho, argumentaba que pretendía insurreccionar a "los negros y mulatos y la hez del pueblo", por lo que sabiendo de la Luz de "las gestiones de Bassave, procurase acalorarlo contando con la fuerza que iba adquiriendo en el populacho, para arrancárselo en su oportunidad" y a Manuel Ramírez a quien se acusaba de conducta sospechosa y francmasón. ${ }^{83}$ Según las explicaciones del propio Capitán general, a Ramírez no se le conectaba directamente con la supuesta conspiración y no existía una colaboración clara entre Bassave y de la Luz, sino que es el segundo el que trataba de aprovecharse del primero que exaltaba al populacho por su cuenta. Unas explicaciones poco convincentes que hacen dudar seriamente de la presencia de una trama organizada, o al menos del conocimiento de Someruelos, más allá de una voluntad manifiesta de castigo de la masonería y de elementos liberales exaltados.

De la Luz, Bassave e Infante, junto a otros principales habían firmado una carta al Ayuntamiento en apoyo de las pretensiones de Arango favorables al libre comercio, ${ }^{84}$ por lo que de la Luz fue detenido junto a otros cuatro acusados de intrigar para alterar el "buen orden y el gobierno de esta isla". ${ }^{85}$ Además, tal y como señala Barcia, los conjurados formaban parte de las élites y tenían ideas racistas sobre el funcionamiento de la sociedad cubana, por lo que un alzamiento de negros atacaba a sus propios

\footnotetext{
${ }^{81}$ Levi Marrero, Cuba. Economía y sociedad, Playor, Madrid, 1992, vol. 15, pp. 15-16.

${ }^{82}$ María del Carmen Barcia, Cuba. Acciones populares en tiempos de la independencia americana, Ediciones Matanzas, Matanzas, 2011, p. 68.

${ }^{83}$ Carta de Capitán general de Cuba a ministro de Justicia, 6 de octubre de 1810. AGI, Ultramar, Leg. 113. "Sublevación y francmasonería en Cuba".

${ }^{84}$ Francisco J. Ponte Domínguez, La masonería en la Independencia de Cuba, Editorial Modas Magazine, La Habana, 1954, p. 17-18.

${ }^{85}$ George Hallam, Narrative of the voyage from Montego Bay in the island of Jamaica to England, C.J.G. \& F. Rivington, London, 1831, pp. 31 y 32. Traducido del original en inglés.
} 
intereses. ${ }^{86}$ La mayoría del esclavismo optó por el orden ante la inestabilidad que la creación de una Junta podía provocar, anteponiendo sus libertades económicas, pero los acusados formaban parte de la oligarquía esclavista que pretendían aprovecharse del vacío de poder para imponer sus intereses. Este sector más avanzado pretendía conjugar esclavitud con derechos políticos para los criollos blancos. La obtención de la independencia aseguraría disponer de un Estado con plena soberanía que no tendría que ceder ni negociar ante un poder lejano sujeto a un complejo entramado de relaciones con otros estados.

La implantación de la masonería en la Antilla mayor es un hecho y que se producían reuniones y charlas de carácter sedicioso también. ${ }^{87}$ Pero dado el carácter de esclavistas y su prevención frente a las personas de color, llevar adelante una insurrección interracial parece complicado. Probablemente la conspiración se encontraba en fases iniciales y también es muy posible que no hubiera pasado a concretarse en nada serio. A partir de aquí se abren dos posibles explicaciones. La primera es que la red entraría en enlace con otros grupos de color a través del esclavo de Infante, Laureano, uno de los dos siervos condenados, lo que finalmente produciría el temor de los mismos y de la Luz la delató pensando que su condición racial y social le salvaría de la represión. La segunda es que en ningún momento tuvieran intención de confabularse con gente de color y al conocer el hecho lo denunciaran como un hecho totalmente ajeno a sus propias reuniones. En cualquier caso, la explicación del Capitán general es bastante rocambolesca y suponía poner en alerta a los mandatarios, con lo que se perdía el efecto sorpresa, y volver contra las autoridades a sus propias tropas. De ser cierto, el plan constituía una osadía de proporciones gigantescas, demasiado para un grupo que aunque avanzado políticamente formaba parte de unas clases acomodadas.

Por tanto nos inclinamos a creer que si bien se hacían reuniones y se conspiraba de palabras entre la masonería, en este caso no hubo una intención real de alzamiento o se estaba en una fase muy incipiente. Someruelos, advertido de la presencia de los

\footnotetext{
${ }^{86}$ María del Carmen Barcia, Cuba. Acciones populares en tiempos de la independencia americana, p. 62.

${ }^{87}$ Sobre la masonería en Cuba en este periodo ver: Eduardo Torres-Cuevas, Historia de la masonería cubana, seis ensayos, Imagen contemporánea, La Habana, 2004, pp. 33-53; Manuel Hernández González, Liberalismo, masonería y cuestión nacional en Cuba, 1808-1823, Idea, Santa Cruz de Tenerife, 2012, pp. 68-69; José Manuel Castellano Gil, La Masonería española en Cuba, Centro de la Cultura Popular Canaria, Santa Cruz de Tenerife, 1996, pp. 47-49; Francisco Morales Padrón, Conspiraciones y masonería en Cuba (1810-1826), Anuario de Estudios Americanos, tomo 29, 1972, pp. 343-377.
} 
masones y de sus reuniones y temiendo alterados de esta índole, el día que se le presentó el exaltado de la Luz denunciando un complot lo utilizó como chivo expiatorio, bajo el razonamiento de que si sabía algo era que estaba implicado de algún modo. La oportunidad de reforzar su poder y enviar un mensaje a los criollos blancos, los realmente peligrosos, era demasiado buena para desaprovecharla y se incluirían a conocidos del delator o reconocidos liberales. La posibilidad de sacar de la isla a la gente demasiado avanzada políticamente también. Para ampliar el alcance del supuesto complot y darle la calificación de interracial había que reprimir a algunos pardos libres y esclavos, y así se hizo.

Más allá de simples contactos, la existencia de esta trama combinada creemos que es inexistente, o nimia en todo caso. La supuesta conjura tradicionalmente ha sido considerada como el primer intento independentista de sublevación y más bien podría definirse como la primera represión gubernamental por este motivo. A tenor de los hechos parece más una acción desafortunada que una maquinación real. La escasa punición sobre libres de color y esclavos, en un momento en que la afluencia de estos últimos estaba garantizada, refuerza la idea de núcleos avanzados políticamente sin que hubiera un peligro serio de alzamiento.

Joaquín Infante fue a Caracas y en junio de 1813 publicó el primer proyecto de Constitución cubana. Allí fue detenido y comprendido en la capitulación que le excluyó de sus responsabilidades en territorio continental. Pero dado que la causa por los sucesos de la Antilla mayor no podía sustanciarse se le remitió a Ceuta como recluso entre 1814 y 1816, escudándose en los sucesos de Caracas donde fue auditor de guerra y marina en Puerto Cabello y se le denominaba el segundo Robespierre. Con la amnistía de 8 de marzo de 1820 fue puesto en libertad y pasó a Cádiz, desde donde regreso a principios de 1822, residiendo mientras tanto en Algeciras, aunque teóricamente debía ser juzgado todavía por la causa de la conjura de $1810 .^{88}$

En cuanto a los libres, blancos y de color, en los presidios peninsulares pasaron nueve meses en Cádiz y posteriormente fueron incluidos en un real indulto y liberados, pasando a residir en la misma ciudad bajo la condición de deportados. Entre ellos estaba un tal Juan José González, a quien junto a los otros tres se le concedió el pasaporte a

\footnotetext{
${ }^{88}$ AGI, Ultramar, 847, N.40 y Ultramar, 339, N.136. Expedientes de Joaquín Infante; sobre la vida y pensamiento de Joaquín Infante ver Leida Fernández Prieto, "Una mirada sobre las independencias americanas. El ideario político de Joaquín Infante, de lo local a lo continental". Revista de Indias, vol. 75, núm. 264, 2015, pp. 555-570.
} 
mediados de $1812 .{ }^{89}$ El único al que no se dejó volver por el momento fue a Román de la Luz, a quien se le concedió el pasaporte en 19 de octubre de 1820. Que cuatro miembros del batallón de morenos de La Habana fueran autorizados a repatriarse, perteneciendo a una milicia armada, muestra la poca consistencia de los cargos. A quien realmente se temía era a de la Luz por su carácter liberal e importancia social.

Manuel Ramírez fue condenado a 4 años de destierro. Se le trasladó a Cádiz a finales de 1810 donde residió sin ningún tipo de ayuda hasta el advenimiento del liberalismo en 1820, a pesar de que en 13 de agosto de 1813 la sentencia declaró que no había lugar para el procedimiento y castigó a los asesores que cometieron el exceso al pago de los viajes de ida y vuelta. Con la llegada del Trienio se le dio ayuda pecuniaria y se le permitió retornar al ser amnistiado, pero entonces fue el mismo Ramírez el que pretendía aplazar el regreso, su mujer había fallecido y probablemente habría desarrollado en Cádiz un circulo de relaciones personales. ${ }^{90}$ En la época, residirían en Cádiz muchos otros americanos del continente, unos relegados por las autoridades y otros exiliados.

Diferente seria el trato con los considerados sediciosos de color. Ya en 1795 el pardo Nicolás Morales fue ajusticiado por pretender, con las armas si fuese necesario, la equiparación de los derechos de los libres de color con los de los blancos. ${ }^{91}$ En Cuba, el mayor peligro venia por la conjunción de esclavos y libres de color, o mejor dicho, por la ayuda que los segundos podían prestar a los primeros al dotar a los levantamientos de una mejor organización, planificación, connotaciones políticas y líderes con mayor prestigio social. Esto sucedió en la conspiración de Aponte, ${ }^{92}$ que fue cruelmente reprimida. En un contexto en que las Cortes debatían la esclavitud y la influencia de la todavía reciente insurrección de Haití. Además de José Antonio Aponte, el líder, fueron ejecutados cinco libres y seis esclavos y posteriormente la represión se expandiría a otras ciudades con ajusticiamientos en Puerto Príncipe y Bayamo. El resto fueron condenados en su mayoría a reclusión entre uno y diez años, que en el caso de los esclavos se complementaron con entre 100 y 200 azotes. Para los siervos, el abanico de

\footnotetext{
${ }^{89}$ AGI, Ultramar, 328, N. 44 y Ultramar, 339, N.132. Expedientes de Román de la Luz.

${ }^{90}$ AGI, Ultramar, 847, N.34. "Expediente de Manuel Ramírez de Soto".

${ }^{91}$ José Luciano Franco, Ensayos históricos, Editorial de Ciencias Sociales, La Habana, 1974, pp. 95-100.

${ }^{2}$ Sobre la conspiración de Aponte ver: Matt D. Childs, The 1812 Aponte Rebellion in Cuba and the Struggle against Atlantic Slavery, University of North Carolina Press, Chapel Hill, 2006; José Luciano Franco, La conspiración de Aponte, Consejo Nacional de Cultura-Publicaciones del Archivo Nacional, La Habana, 1963.
} 
castigos era más amplio ya que algunos fueron punidos con azotes sin prisión y otros con ramal y grillete por un tiempo de entre cuatro meses y dos años, realizando al mismo tiempo los trabajos más duros de las fincas de sus amos. Un esclavo fue destinado al arsenal de La Habana por dos años y una sierva a seis años de servicio en una casa de beneficencia, entre otras penas. ${ }^{93}$

Los presidios se cumplieron en Florida, San Juan de Ulúa, Omoa y Puerto Rico, tanto para los libres como para los esclavos, pero solo en el caso de estos últimos se introdujeron clausulas especiales como que no pudieran regresar a la colonia, o que antes de hacerlo pidieran permiso. El hecho de sacar a los esclavos fuera del país y en algunos casos impedírseles volver indica que la afluencia de bozales era constante y que el miedo estaba más focalizado contra ellos. Los libres de color no requirieron para la capitanía general de medidas especiales de alejamiento y una vez cumplidas las sentencias pudieron repatriarse. La planificación de la revuelta, el carácter de los conjurados, su dispersión geográfica y la conjunción de pardos libres y de color la hicieron especialmente peligrosa a ojos de las autoridades. El intento de liberación de los esclavos y las muertes causadas a algunos blancos posibilitaron un escarmiento brutal. Algo que no sucedió con los represaliados de 1810. La distinción entre la represión de los hechos de 1810 y 1812 es evidente y viene marcada por el perfil de unos y otros. Las pretensiones de cada complot y el hecho de que la de Aponte fue una conspiración real y la de 1810 es más que dudosa también influyeron en la política punitiva.

La vuelta del absolutismo fue bien recibida por los esclavistas en La Habana ya que garantizaba alejarse de pretensiones liberales que pudieran alcanzar a los esclavos. La Constitución de Cádiz no liberó a los esclavos, pero la institución quedaba mejor garantizada con la Corona en manos de un rey absoluto. Acuciado por la deuda en el erario público, desde la Península se tomaron una serie de medidas impulsadas por Arango y Parreño para mejorar la situación económica de la colonia.

\footnotetext{
${ }^{93}$ ANC, Asuntos Políticos, Leg. 12, Sig. 24. Aprobación de la sentencia contra Aponte y otros; ANC, Asuntos Políticos, Leg. 13, Sig. 38. Expediente sobre cobro de costas por la conspiración de Aponte; ANC, Asuntos Políticos, Leg. 12, Sig. 23. Causa contra José de la Cruz y Narciso Taboada; ANC, Asuntos Políticos, Leg. 12, Sig. 25. Octava pieza de la segunda conspiración de Aponte; ANC, Asuntos Políticos, Leg. 12, Sig. 27. Autos seguidos contra varios negros por conspiración; José Luciano Franco, "Las conspiraciones de 1810 y 1812", en José Luciano Franco (comp.), Las conspiraciones en Cuba de 1810 y 1812, Red Ediciones, Barcelona, 2016, pp. 24-26.
} 
La llegada del Trienio configuró en la isla tres partidos principales. El liberal avanzado, que incluía a la fracción del presbítero Tomás Gutiérrez de Piñeres y a grupos de criollos liberales. Frente a este sector se postularon los grandes hacendados, temerosos de que la extensión de los derechos pusiera en entredicho la esclavitud y de que la participación política y el sufragio pusieran en peligro el dominio que este sector ejercía en la isla. El tercer partido, de carácter independentista, permanecería oculto y su visibilidad fue mucho menor, por razones obvias. Los liberales se hicieron fuertes en La Habana y los criollos en provincias, desatándose una lucha entre ambos de la que salieron victoriosos los hacendados. Las algaradas protagonizadas por los exaltados y la necesidad del apoyo de los isleños hicieron que el Capitán general Nicolás Mahy se decantara por estos últimos, llevando a cabo algunas expulsiones a España de liberales destacados del ejército. Con la llegada de Francisco Dionisio Vives a la capitanía general, en 2 de mayo de 1823, comenzaron a implementarse una serie facultades que le otorgaban unos poderes omnímodos para luchar contra la disidencia política y mantener el orden público, entre ellas las de actuar contra la prensa exaltada. ${ }^{94}$ En real cédula de 28 de mayo de 1825 se le confirió la facultad de gobernar el país con poderes absolutos, como si de una plaza sitiada se tratara.

El poder del Capitán general en ningún momento se había puesto en duda, pero ahora se reforzaba. En Cuba todo fue más reglado y menos convulso a causa de la existencia de una única autoridad centralizada con facultades de castigo sobre una población menor, con una conciencia política menos desarrollada y que incluso en el caso de tenerla prefería abstraerse por el perjuicio que podía ocasionar a sus negocios. Esto determinó que en buena medida las convulsiones políticas tuvieran una menor impronta, lo que a su vez derivó en una represión de menor intensidad tanto cuantitativa como cualitativamente sobre los integrantes de la sociedad cubana.

El incremento en la autoridad se vio favorecido por la marcha de la guerra en América, claramente desfavorable para las armas españolas. En el plano interno, los excesos de los exaltados le aseguraron la lealtad de la élite económica cubana. Así, los independentistas en el continente y los liberales radicales peninsulares permitieron a España imponer con la ayuda de los criollos un régimen tiránico, que en última instancia serviría para controlarles también a ellos, ya que eran los que tenían la

\footnotetext{
${ }^{94}$ José Antonio Piqueras, "El mundo reducido a una isla", pp. 319-342; Justo Zaragoza, Las insurrecciones en Cuba. Apuntes para la historia política de esta isla en el presente siglo, 2 tomos, Imprenta de Manuel G. Hernández, Madrid, 1872-1873, tomo I, p. 192.
} 
suficiente fuerza para desestabilizar al país y encauzarlo hacia la autodeterminación. Sin embargo, Vives dotado de poderes omnímodos, por si fuera necesario, no los utilizó y el Trienio acabó sin ningún tipo de correctivo especial. La pretensión de que la colonia permaneciera al margen de la política sirvió para atemperar las represalias, ya que de lo que se trataba era de aparentar normalidad.

El descubrimiento de la conspiración de los Soles y Rayos, gracias a la infiltración de agentes en las sociedades masónicas, pudo influir en aplacar los castigos. Lo que se pretendía era que la punición sirviera de advertencia, sin ser excesiva, para que pudiera considerarse un aviso a la oposición política en general. Haciéndolo así magnificaba el verdadero alcance del complot reforzando la idea de la necesidad de un Gobierno fuerte. El perfil de la mayoría de los implicados, de los que una parte eran hijos de algunas de las familias criollas más importantes, lo desaconsejaba, a pesar de que también había un componente popular entre muchos de ellos. ${ }^{95}$ Vives tampoco decidió centrarse en las capas más bajas y optó por una represión centrada en los principales dirigentes.

Un total de 602 personas fueron encausadas. A la Península fueron deportados 14 hombres, entre los que se encontraba el máximo dirigente José Francisco Lemus, que fue enviado a Sevilla desde donde escaparía a Gibraltar. A otros 14 que se encontraban huidos se les impuso la misma pena y a un único individuo la de diez años de cárcel, por creerse que había participado en un asesinato. El resto, 67, fueron sentenciados con multas que iban entre los 500 y los 1.500 pesos. ${ }^{96}$ La mayoría de los condenados a relegación eran de La Habana y Matanzas, mostrándose claramente la focalización de la trama y la percepción de peligrosidad. Muchos evitaron las represalias por haberse

\footnotetext{
${ }^{95}$ Circulación de papel sedicioso sobre la independencia de Cuba, s/f. AGI, Ultramar, Leg. 113. "Sublevación y francmasonería en Cuba".

${ }^{96}$ ANC, Comisión Militar, Leg. 8, Exp. 2. El Legajo se refiere a la conspiración del Águila Negra, pero contiene también la sentencia por la de los Soles y Rayos. Los deportados fueron: de La Habana José Francisco Lemus, Ignacio Félix del Junco, Andrés Silveria, Rodrigo Martínez, Francisco Corral, Antonio Bión y el pardo José Joaquín Balmaseda; de Matanzas Manuel de Acosta, Miguel Madruga, Santiago Hueso, Juan García Niño y el pardo Francisco Herrera; de San Antonio y Guatao, José María González y de Hanabana Tomás de Sotolongo, Los condenados a deportación pero que se encontraban huidos eran: de La Habana Juan Jorge Peoli, Pedro Pascasio de Armas, Pedro de Rojas, Mariano Seguí y Antonio de Acosta; de Matanzas Manuel Madruga, presbítero Domingo Hernández, José Teurbe Tolón, José María de Heredia, Francisco García Medina y Luciano Ramos; de Guanajay Martin de Mieres; de Guatao y San Antonio, José María Miralla; y de Güira de Melena José María Delgado; los nombres de los apresados en Roque E. Garrido, Historia documentada de la Conspiración de los Soles y Rayos de Bolívar, Imprenta El Siglo, La Habana, 1929, tomo II, pp. 244-259.
} 
exiliado, pero en todo caso no se pretendió que estas fueran salvajes. Por la gran cantidad de afectados es posible que tuviera relación con la nula represión por los altercados del Trienio, por lo que parece muy probable que se les incluyera en los Soles y Rayos con ánimo de escarmentarles y que la causa sirviera para camuflar la extensión de la punición. El propio conocimiento de su inocencia y el hecho de que excepto dos, para validar la supuesta conexión entre ambos grupos raciales, todos fueran blancos determinaron que esa fuera suave.

La deportación constituyó una pena liviana en comparación con los delitos que se les imputaban y además fue poco impuesta en comparación con el número de apresados. Resulta significativo que a las condenas impuestas en la causa, suaves y perfectamente aceptables para los esclavistas, le sucediera la creación de la Comisión Militar. El mensaje era claro, la conspiración de los Soles y Rayos, a pesar de estar extendida por muchos puntos de la isla, se despachó de una manera tolerable como modo de cerrar una época protagonizada por los “excesos" políticos.

La Comisión Militar Ejecutiva y Permanente fue creada por Francisco Dionisio Vives en marzo de 1825 para que viera de las causas por delitos políticos, lo que auguraba un aumento en la severidad o al menos en la fiscalización por parte del poder de la disidencia política. La intención de aplicar una mayor dureza, dentro de las posibilidades del Estado, vino apoyada por un hecho externo. En 15 de junio de ese mismo año se produjo una revuelta de esclavos que se inició en Guamacaro y que alcanzó a 18 o 20 plantaciones y en la que fueron asesinados 16 blancos y cuatro o cinco resultaron heridos, produciéndose un gran temor entre la población de la zona muchos de los cuales buscaron refugio en Matanzas. ${ }^{97}$ Los castigos contra los sublevados fueron despiadados. La cercanía a la capital de la insurrección, en una zona de gran importancia económica y el número de fallecidos elevó el pavor de los blancos, lo que alteró el equilibrio entre capitanía general y criollos, facilitando la intención de las autoridades de constreñir derechos para asegurar el orden público.

El desembarco de diez individuos a principios de 1826 fue despachado con la ejecución de los dos aprehendidos. ${ }^{98}$ En noviembre de 1825 fueron condenados a muerte, estando prófugos, ocho peninsulares miembros del ejército por "haber querido

\footnotetext{
${ }^{97}$ Gloria García, Conspiraciones y revueltas. La actividad política de los negros en Cuba (1790-1845), Editorial Oriente, Santiago de Cuba, 2003, pp. 83-85.

${ }_{98}$ Adrián del Valle, Historia documentada de la gran conspiración del Águila Negra, Imprenta El Siglo, La Habana, 1930, pp. 94-95.
} 
restablecer el abolido y odioso sistema constitucional en Matanzas". ${ }^{99}$ El hecho de que escaparan y la consiguiente demostración de dureza sin realizar ejecuciones no nos ha de hacer olvidar que a los fugados de los Soles y Rayos se impusieron penas de cárcel, lo que supone un aumento en la dureza. Comenzaba una etapa de mayor despotismo.

En teoría, instaurar en la colonia el liberalismo no afectaba a la independencia de la isla y era reversible, por lo que el análisis ha de ir determinado en función del apoyo cubano a España. Proclamar el liberalismo podía suponer una complicación para la pervivencia de la esclavitud y era perentorio acabar con estas intentonas inmediatamente. Ser europeos no determinó un mejor trato, aunque en este caso se encontraban fugados. Probablemente no estaban en el perfil de los expedicionarios y de los esclavos, pero no dejaban de ser sujetos ajenos a la sociedad con los que era posible ejercer una mayor rigidez. En cambio, con los conspiradores de los Soles y Rayos pertenecientes a la élite autóctona y algunos de ellos personalidades importantes una punición despiadada no se contemplaba ya que hubiera podido socavar el apoyo de los hacendados a España. En la política seguida se aprecia claramente la debilidad de la metrópoli que no se sentía fuerte para retener la soberanía si se sustraía del apoyo de los esclavistas y percibía de una manera rotunda que este solo se daba por una estricta conveniencia de intereses. Las intentonas separatistas tuvieron que ser tratadas como hechos realizados por miembros "descarriados" del grupo social que les sustentaba y por tanto no pudieron se represaliados de una manera ejemplar.

Las deportaciones a España de los implicados de mayor relevancia era una declaración de intenciones. Las ejecuciones de criollos eran inasumibles para la alta sociedad local, contrariamente a lo que podía suceder a esclavos y exiliados. Sacarles de allí, en cambio, era asumible por cuanto permitía su neutralización y la purgación del grave delito cometido. Así, el pacto tácito entre esclavistas y Gobierno se trasladó a la organización de la represión, para unos suponía un castigo aceptable para otros la forma que mejor posibilitaba la neutralización de la disidencia con un costo político asumible. Para eliminar la posibilidad de reincidencia y hacer la más eficaz el destino empleado fue la Península, donde en teoría debían permanecer vigilados.

\footnotetext{
${ }^{99}$ Causas del fiscal Francisco Letamendi en el año 1832. Se trataba de Gaspar Rodríguez, Antonio Arias, Gabriel Rodríguez, Gregorio Rijas, Martin Benart, Rafael Bumanart, Javier Lozano y Francisco Panadero. ANC. Comisión Militar, Leg. 131, Exp. 2. "Relaciones de las causas que ha sentenciado la Comisión Militar del año 1826 a 1839".
} 
La punición se extendió a otros actos políticos ajenos a la conspiración: a Juan Calvet se le impusieron diez años de extrañamiento de la isla por pedir la independencia en un impreso; a José del Canto otros diez años de extrañamiento de los dominios españoles por haber continuado trabajando como administrador de correos después de la emancipación de Nueva España. ${ }^{100}$ En actos políticos de escasa relevancia sin conexión con confabulaciones sediciosas y sin importancia que se solucionaron con la salida del país pero sin remitirles a la metrópoli, en donde teóricamente su vigilancia era mayor.

En 1829 fue descubierto el último de los complots separatistas del periodo. La Gran Legión del Águila Negra se había constituido en 30 de mayo de 1823 en Veracruz y se extendió a La Habana en 1826 en donde intrigaron en redes masónicas, en espera del apoyo de México y Colombia. ${ }^{101}$ En la fecha del arresto la experiencia liberal del Trienio quedaba lejos y la capitanía general estaba más afianzada, lo que pudo conllevar una mayor dureza en la represión dentro de los límites marcados de eludir la inhumanidad. Seis hombres fueron condenados a muerte, pero todas evitaron el último castigo, uno por encontrarse huido y el resto porque Vives hábilmente suspendió su ejecución a la espera de la ratificación del monarca que finalmente se la conmutó por diez años de presidio en África. A tres se les impuso reclusión en África, uno durante diez años y el resto durante ocho, aunque uno de ellos se encontraba fugado y a otros siete la cárcel lo fue por entre seis y ocho años. Otras 5 personas fueron sentenciadas a penas menores, vigilancia, separación de empleo, compurgación con la prisión sufrida y seis meses de cárcel. ${ }^{102}$

La escalada en la severidad se amplió a Miguel Teurbe Tolón y otros 9 fugados implicados en la trama de los Soles y Rayos, a los que se incluyó en la causa del Águila Negra y se les impuso la pena de muerte y confiscación de bienes. ${ }^{103}$ Se trataba de una medida disuasoria para que no regresaran a la isla. Vives amplió el rigor siempre tratando de no realizar ejecuciones, pero resulta significativo el aumento en la dureza ya

\footnotetext{
${ }^{100}$ ANC, Comisión Militar, Leg. 5, Exp. 9. Causa contra Juan Calvet por un folleto; ANC, Comisión Militar, Leg. 6, Exp. 6. Causa contra Tomás y José del Canto por sospechosos de infidencia.

${ }^{101}$ Adrián del Valle, Historia documentada de la gran conspiración del Águila Negra, Imprenta El Siglo, La Habana, 1930, pp. 94-95.

${ }^{102}$ ANC, Comisión Militar, Leg. 7, Exp. 3. Leg. 8, Exp. 2, Leg. 8, Exp. 1 y Leg. 9, Exp. 3. Causas por la Conspiración del Águila Negra.

${ }^{103}$ Causa 35 de las que ha sentenciado este tribunal en los seis primeros meses de 1830. ANC. Comisión Militar, Leg. 131, Exp. 2. "Relaciones de las causas que ha sentenciado la Comisión Militar del año 1826 a 1839”.
} 
que la mayoría de las condenas impuestas fueron de presidio en vez de deportación. El traslado a la Península se dejó para casos excepcionales, siendo impuesto únicamente a Diego de Araoz, que tras huir al continente se presentó voluntariamente y no se le probaron las acusaciones, y a Manuel Rojo, del que se creía que era el máximo dirigente de la organización masónica pero contra el que no se encontraron pruebas concluyentes. Ambos se remitieron a los Capitanes generales de Andalucía y Extremadura respectivamente para que les señalase el punto en el que debían residir. Rojo, poco después solicitaría pasar a la Sevilla. La relegación ya no se utilizó contra los principales acusados, sino contra aquellos contra los que no cabía una sentencia rigurosa por falta de pruebas. Fue utilizada como una pena ambigua.

El incremento en la relevancia de la represión ocurrió, aunque tuvo una importancia mucho menor en comparación con la que se dio en la metrópoli, donde miles de personas fueron ejecutadas, encarceladas o desterradas. En Cuba, la necesidad de apoyo social determinó unos castigos menos rigurosos, lo que se extendió a los represaliados por el Águila Negra, sentenciados en la segunda mitad de 1830 y que fueron incluidos en el real decreto de indulto de 15 de octubre de 1832. La magnanimidad respecto a los criollos emanaba de nuevo con objeto de mantener su lealtad a la metrópoli. 


\section{SEGUNDA PARTE. \\ LA DEPORTACIÓN EN LA ESPAÑA PENINSULAR}




\section{CAPÍTULO 3. DE LOS INICIOS DE LA PRIMERA GUERRA CARLISTA A LA CAIDA DE ESPARTERO}

\section{LA PRIMERA GUERRA CARLISTA Y EL PROBLEMA DE LOS PRISIONEROS. LA DEPORTACIÓN COMO VÍA DE ESCAPE}

\subsection{La primera represión sobre sospechosos de carlismo}

Tras la revuelta de los agraviados el ultrarrealismo había permanecido a la espera, en vista de que el normal desarrollo de los acontecimientos terminaría con la Corona en manos de don Carlos. Sin embargo, Fernando VII tenía otros planes y tras la muerte de su tercera esposa se casó con María Cristina de Borbón, que quedó rápidamente embarazada. El rey alteró el orden de sucesión para que su descendencia ocupara el trono al margen de su sexo, lo que frustró las esperanzas de los realistas y de su propio hermano. El carácter sobrio de don Carlos retrasó el inicio de la guerra hasta la muerte del monarca. La proclamación de don Carlos como rey en Talavera de la Reina el 2 de octubre de 1833 marca el inicio de la guerra. Los pronunciamientos se sucedieron en distintos lugares de la geografía española, la mayoría de los cuales fueron desactivados mediante una política de numerosos fusilamientos y la promulgación de indultos para que los sublevados abandonaran a sus cabecillas.

Las primeras intentonas conspiratorias datan del periodo de 1831 a fin de 1833 , en que se estaba preparando la sucesión del trono excluyendo a don Carlos y concluyeron con destituciones de altos cargos políticos y militares y traslados forzados de domicilio. Tomás Blanco Cicerón, Francisco de Paula Fenech y José de Miró, fueron deportados a Baleares. El teniente Ignacio Alonso Cuevillas fue confinado en Sevilla por ser el cabecilla del alzamiento previsto en Zaragoza para marzo de 1833. ${ }^{1}$ Sospechosos de carlistas sufrieron encarcelamientos y confinamientos.

Las purgas en el ejército y altas instancias públicas se hicieron mediante una serie de destierros con un carácter elitista e individualizado. Miguel Otal, Luis Lesmes,

\footnotetext{
${ }^{1}$ Alfonso Bullón de Mendoza, La Primera Guerra Carlista, Actas, Madrid, 1992, pp. 20-37; Fastos españoles o efemérides de la Guerra Civil desde octubre de 1832, 2 tomos, Imprenta de D. Ignacio Boix, Madrid, 1839-1840, tomo I, pp. 140, 150, 254-255, 412 y 619-620; Pere Anguera, Déu, rei i fam. El primer carlisme a Catalunya, Publicacions de l'Abadia de Montserrat, Barcelona, 1995, pp. 243-244. Miró no regresó hasta 1845.
} 
el conde del Prado y Mariano Novoa fueron despojados de sus honores y sueldos y confinados en Ibiza, Tenerife, Menorca y Cartagena, respectivamente. Pedro Grimarest, Juan José Marco del Pont, el conde de Negri y Rafael Maroto, a las mismas privaciones y a confinamiento en San Sebastián, Peñíscola, Pamplona y Alicante, de donde no podían salir sin la autorización real. A Santiago Gómez de Negrete y a Vicente Frígola, de Barcelona, se les ordenó que "fijen sus residencias" en Ibiza y en Mallorca donde serían vigilados por las autoridades militares correspondientes. Gómez de Negrete y el también relegado Marcos Núñez Abreu vivían en la mayor de las Pitiusas compartiendo casa con un criado, hasta que a finales del mismo año huyeron. Miguel Otal desapareció en 1838 con otros tres deportados catalanes y con sus criados. En 13 de diciembre de 1833, el Gobierno trasladó a Sevilla a cuatro importantes legitimistas, por sospechosos de conspiración. El carácter ultramarino de algunos de estos destierros les confiere la consideración de deportaciones, pero hemos de tener en cuenta que fueron hechas desde un prisma tradicional al tener un carácter individualizado y ser los realistas de un extracto social elevado tratados mucho mejor que los liberales. En noviembre de 1833, el Capitán general de Cataluña embarcó hacia Mallorca al marqués de Paredes. Entre el 26 y el 27 de diciembre fueron detenidos 52 sospechosos, parte de los cuales fueron trasladados a las Baleares. ${ }^{2}$

\subsection{Las deportaciones de combatientes a Cuba y Puerto Rico}

La situación de España a principios de la década de 1830 era cuanto menos inestable. Contrariamente a lo que había sucedido en los países más avanzados de Europa, la estructura social no había cambiado en demasía. La industrialización era incipiente y posesión tradicional de la tierra apenas había sido modificada. Económicamente, el comerció se había resentido con la pérdida de las colonias americanas y en el interior era dificultoso por la precariedad de los medios de comunicación y sistemas de transporte. En contraste con esta aparente calma las fuerzas

\footnotetext{
${ }^{2}$ Fastos españoles o efemérides de la guerra civil desde octubre de 1832, tomo I, pp. 314, 416417 y 428; Isidoro Macabich, Historia de Ibiza, vol. II, p. 284; Actas del Consejo de Ministros, 10 tomos, Javier García Fernández (ed.), Ministerio de la Presidencia, Madrid, 1989-1996, tomo IX, p. 85. Se trataba de Juan Bautista de Erro desterrado a Cartagena, el teniente general Carlos Ulman y Cecilio Corpas a Barcelona, el arcediano José Morales a Alicante y José María Malvar a Valencia; Fastos españoles o efemérides de la guerra civil desde octubre de 1832, tomo II, pp. 244-245; Pere Anguera, Déu, rei i fam. El primer carlisme a Catalunya, p. 99.
} 
del cambio habían adquirido una fuerza considerable. ${ }^{3}$ El liberalismo se había expandido entre amplias capas populares, de modo que en 1823 tuvo que ser necesaria la invasión francesa para poder derribarlo. Entre los campesinos se había extendido la negación al pago de los diezmos y algunos aspiraban a la propiedad capitalista de la tierra, anhelo que compartían con parte de la aristocracia. La incipiente burguesía constituía un factor de cambio y el exilio formaba buena parte de la capa más preparada de la población. El agotamiento financiero y político y la posterior rebelión obligó a los partidarios de la reina a buscar el apoyo de los liberales.

La enfermedad del rey había configurado dos grupos dentro de la camarilla palaciega: los ultrarrealistas, adeptos a hermano del Rey, don Carlos, y los moderados, defensores de la regente y de los derechos de la infanta Isabel y partidarios de reformas tímidas de carácter administrativo, incluso sin llegar a la convocatoria de las Cortes. ${ }^{4} \mathrm{La}$ inoperancia de Francisco Cea Bermúdez en ejecutar una política de reformas le hizo perder apoyos y motivo su cese. Su nula respuesta a los alzamientos carlistas determinó que fueran los capitanes generales los que realizaran acciones por su cuenta para contener la revuelta, como controlar a los voluntarios realistas y desarmar a los paisanos. ${ }^{5}$

La acción de funcionarios y militares para suplir la escasa determinación gubernamental contra los insurrectos en los primeros compases de la guerra se trasladó a la deportación. El Capitán general de Extremadura, José Ramón Rodil, de trayectoria liberal, a instancias del gobernador de Badajoz envió al Gobierno un parte en que hacía constar la gran cantidad de combatientes presos y pedía su envío a "algunas de nuestras islas". El Ejecutivo nombró una Junta para proclamar una ley al respecto, que se materializó en la real orden de 21 de enero de 1834 que castigaba a los facciosos con grado de sargento o cabo a los regimientos de Ceuta, La Habana y a las compañías fijas de los presidios de África, y a los combatientes rasos a unidades de Cuba, Puerto Rico y Filipinas, todos durante un periodo de seis años. ${ }^{6}$ Los destierros más o menos individualizados difícilmente podrían mantenerse en un contexto de guerra civil, en el

\footnotetext{
${ }^{3}$ Carlos Marichal, La revolución liberal y los primeros partidos políticos en España, 18341844, Cátedra, Madrid, 1980, pp. 21-63.

${ }^{4}$ Pedro Pérez de la Blanca Sales, Martínez de la Rosa y sus tiempos, Ariel, Barcelona, 2005, p. 73.

5 Josep Fontana, Revolución liberal. Política y hacienda, 1833-1845, Instituto de Estudios Fiscales, Madrid, 2001, p. 17-29.

${ }^{6}$ Actas del Consejo de Ministros, tomo IX, sesión de 27 de diciembre de 1833; Gaceta de Madrid, 23 de enero de 1834.
} 
que la participación política a través de las armas no se limitaría a las élites sociales sino que alcanzaría a un importante número de hombres. Quedaban excluidos los cabecillas y los oficiales a los que se debía ejecutar.

Aunque pedida desde abajo, esta ley se promulgó pocos días después que Martínez de la Rosa accediera a la presidencia del Gobierno, por lo que contaría con su beneplácito. El nuevo presidente representaba una forma nueva de entender la política en el Ejecutivo, una versión moderada del liberalismo alejada de intentonas revolucionarias y transaccionista con los realistas no ultras, partidarios de la reina. La expresión de la misma fue el Estatuto Real y la promulgación de una serie de reformas atemperadas que contaron con el beneplácito de Inglaterra y Francia. ${ }^{7}$

La utilización de la deportación y su institucionalización fueron un aspecto más de los cambios que el liberalismo introdujo en España, por su propia ideología y por la situación bélica. Dejar presos a gran cantidad de carlistas podía provocar motines o intentos de liberación; el fusilamiento masivo era éticamente reprobable y había alzado voces en contra, especialmente en el plano internacional; los indultos podrían servir para que algunos se reincorporaran a la lucha en caso de mejorar las perspectivas de su causa. La real orden posibilitaba resolver el problema de los prisioneros con un coste humano más asequible, principalmente teniendo en cuenta su gran número, a la vez que permitía sacar provecho de su fuerza de trabajo. Además, permitía una distinción frente a los ultrarrealistas que usualmente fusilaban a los aprehendidos, lo que permitió a los isabelinos aparecer como "civilizados" frente a sus oponentes. En este sentido ha de entenderse la cesión a las presiones inglesas para la firma del Convenio Eliot sobre la preservación de la vida de los cautivos y los intercambios periódicos entre los de uno y otro bando. La brutalidad de las ejecuciones amparaba este acuerdo, pero en el momento de su firma la mayoría de los legitimistas apresados eran relegados.

Los lugares establecidos para las remisiones fueron las colonias ultramarinas. En el caso de Cuba se estipuló que se remitirían un máximo de 1.500 individuos y 500 serían destinados a Puerto Rico, mientras que Filipinas quedaría para casos muy concretos. Para proceder a la aplicación de la ley se crearon depósitos de prisioneros en La Coruña, Cádiz, Barcelona y Cartagena. En mayo de 1835, otra real orden confirmó a Puerto Rico y Cuba como lugares de envío, a la vez que facultaba a los capitanes

\footnotetext{
${ }^{7}$ Manuel Moreno Alonso, La forma del liberalismo en España. Los amigos españoles de Lord Holland, 1793-1840, Congreso de los Diputados, Madrid, 1997, p. 432.
} 
generales a ocuparles en otro tipo de trabajos fuera del ejército, siempre que fuera útil para el fomento de la isla. ${ }^{8}$ El castigo estaba presente en las mentes de las altas jerarquías políticas y militares que habían tomado nota de la experiencia y la habían incorporado como un medio útil de luchar contra los partidarios del pretendiente, siendo una prueba más de la transacción entre el realismo con el liberalismo de signo más moderado. Aun así, los capitanes generales y las autoridades menores tuvieron una gran capacidad de acción y sus medidas estuvieron a medio camino entre lo estipulado y la discrecionalidad.

Inmediatamente comenzaron los embarques, 101 salieron desde Cataluña a las Antillas el propio 21 de enero y al menos sesenta y tantos desde el País Vasco en los próximos meses. La ley permitió actuar rápidamente a los capitanes generales allá donde estimaban que la salida de los presos era perentoria por encontrase cerca de las zonas controladas por los rebeldes. La deportación se basaba en un desembarazo de los aprehendidos, según la máxima autoridad militar catalana: "para no volver jamás a la tierra que les vio nacer, ni al seno de sus familias". ${ }^{9}$ El carácter litoral de las zonas con mayor actividad insurrecta facilitaba la aplicación de esta medida, que tendió a ser menos utilizada en otras zonas de presencia carlista interiores, como Castilla-La Mancha, donde Narváez ejerció un escarmiento despiadado.

En Cataluña, tras la derrota de Mayals los embarques se intensificaron, alcanzando los 498, por 72 fusilados y 123 indultados durante 1834. Como bien puntualiza Santirso, la cifra real de fusilados sería superior a la reconocida por las autoridades y la prensa gubernamental, ${ }^{10}$ pero en cualquier caso la relegación se convirtió en el modo "oficial” de represión contra el carlismo, y como tal, adquiriría una importancia capital. Las ejecuciones legislativamente se reservaban para los jefes, lo que concordaba con el discurso oficial de considerarles culpables frente a los

\footnotetext{
8 "Acuerdo de las secciones reunidas de Guerra e Indias", 12 de noviembre de 1834. Oficio del Capitán general de Cuba a secretario de Estado y del despacho de la Guerra, en que dicta informe sobre real orden de 8 de agosto de 1834, s/f. Oficio del Capitán general de Puerto Rico a secretario de Estado y del despacho de la Guerra, 8 de noviembre de 1834. AGI, Ultramar, 52, N.33. "Sobre el pago de gastos en el transporte de varios oficiales facciosos destinados al presidio de aquella capital" (Puerto Rico).

${ }^{9}$ Pere Anguera, Déu, rei i fam. El primer carlisme a Catalunya, pp. 102 y 304; Actas del Consejo de Ministros, tomo IX, sesión de 22 de enero de 1834; Panorama Español, tomo II, p. 20.

${ }^{10}$ Teatro de la guerra, p. 70; Manuel Santirso, Revolución liberal y guerra civil en Cataluña (1833-1840). Tesis doctoral de la Universitat Autònoma de Barcelona, Barcelona, 1994, pp. 107-109.
} 
combatientes tenidos por ignorantes manipulados. Las deportaciones sirvieron para dar salida al fracaso de la insurrección en el principado, marcado por el apoyo en zonas de la Cataluña central que se habían empobrecido por el fracaso de la incipiente industrialización y del comercio agrícola. ${ }^{11}$ Los combatientes conformaban un grupo cercano al bandolerismo social, en el que las condiciones materiales de vida tuvieron una importancia mayor que el pleito sucesorio. Gente que había perdido su modo y su medio de vida o que lo conservaba en una situación muy precaria. Este era el perfil de los soldados legitimistas, que por encima de la ideología tenía en la pobreza a su elemento aglutinador.

En Cataluña, alrededor de un $20 \%$ de los apresados entre finales de 1833 y mediados de 1835 estaban catalogados como labradores que cultivaban la tierra de su propiedad o en diversas formas contractuales, y aproximadamente otros tantos eran peones, la mayoría agrícolas, o ejercían otras actividades como pastoreo, leñadores o carboneros. Un 17,9\% eran tejedores de la fallida industria rural y urbana, un 5,97\% militares y un $5,06 \%$ eclesiásticos. ${ }^{12}$ Respecto a los aragoneses del corregimiento de Alcañiz en 1835, el 36,4\% trabajaban en actividades agropecuarias, el $11 \%$ eran artesanos, el 8,4\% militares y el 3,9\% clérigos. Las diferencias entre catalanes y aragoneses no son significativas y marcan para los inicios de la guerra un perfil muy similar de combatiente. Los fugados a las partidas eran principalmente jóvenes sin bienes propios o con escasas pertenencias. ${ }^{13}$

Resulta irrefutable que la masa de excluidos formaban la columna vertebral de los alzados, especialmente en las primeras etapas de la contienda. Incluso para aquellos que tenían propiedades a quienes la pertenencia a la facción podía aportar ingresos extra o aligerar las cargas familiares de manutención. De ahí la desmovilización en los primeros momentos de la guerra en la etapa de recolección de las cosechas. Los excluidos por el devenir de la economía no formaban únicamente la parte esencial de la facción. La desamortización efectuada a partir de 1834 sobre bienes de los

\footnotetext{
${ }^{11}$ Josep Fontana, "Crisi camperola i revolta carlina", Recerques. Història, Economia i Cultura, núm. 10, 1980, p. 15; Antoni Pons Anguera, Libro de varias cosas sucedidas en esta villa y algunos parajes de Cataluña, Virgili \& Pagès, Lleida, 1988, pp. 130-131.

${ }^{12}$ Pere Anguera, Déu, rei i fam. El primer carlisme a Catalunya, pp. 227-234. Las listas fueron realizadas con los apresados entre finales de 1833 y mediados de 1835 . En estas no se diferenciaba entre ultrarrealistas armados y delincuentes comunes, pero es evidente que había un modus operandi similar y que la frontera entre ambos grupos era muy tenue.

${ }^{13}$ Pedro Rújula, Contrarrevolución. Realismo y carlismo en Aragón y el Maestrazgo, Prensas Universitarias de Zaragoza, Zaragoza, 1998, pp. 386-396.
} 
ayuntamientos y sobre tierras del clero regular culminó con las subastas de 1836 y 1837 en las que los campesinos pobres fueron excluidos del reparto, al no disponer del importe necesario para la compra. ${ }^{14}$ La revolución liberal no fue un proceso plenamente planificado y estructurado para la imposición de una sociedad capitalista burguesa. En las medidas adoptadas y el proceso seguido hubo mucho de intereses de clase, que en la cuestión de la tierra resultó en la adquisición de buena parte de la tierra vendida por miembros de la burguesía y de la antigua aristocracia. ${ }^{15}$

Muchos campesinos perdieron el acceso a los beneficios que las tierras municipales les ofrecían y se vieron imposibilitados de pagar las rentas establecidas por los nuevos propietarios. Este grupo de pobres por desposesión formaba los inicios del proletariado en España. ${ }^{16}$ Despojados de sus tierras, en caso de no obtener trabajo muchos no tuvieron otra alternativa que unirse a los facciosos, con quienes a falta de recursos al menos podían adquirirlos violentamente. Estos proletarizados forzosamente hubieran podido ser útiles para la burguesía en tiempos de paz ya que mantenían los sueldos bajos e incidían negativamente en las peticiones de mejoras laborales. En ese momento constituían un peligro indudable por haberse unido a los partidarios del Antiguo Régimen, careciendo de alternativa. Constituían un grupo cuya incorporación al sistema no era posible y al que perentorio neutralizar.

Gran número de combatientes fueron obligados a combatir coaccionados o a través de quintas, especialmente en los lugares que controlaban militarmente, otros por identificación con los ideales absolutistas que identificaban a la causa del pretendiente e incluso por espíritu aventurero o por percibir un sueldo. ${ }^{17}$ Estos grupos cuyo peso aumentaría con el devenir de la guerra formarían un conglomerado que aunque diferente tampoco era asimilable por el sistema ya que era factible que se reincorporaran de nuevo a la lucha. A pesar de no haber entrado en las guerrillas carlistas por necesidad, eran en su mayor parte campesinos y artesanos a los que se había dejado fuera de la

\footnotetext{
${ }^{14}$ Germán Rueda, La desamortización de Mendizábal y Espartero en España, Cátedra, Madrid, 1986, pp. 154-176.

${ }^{15}$ Pedro Ruiz Torres, "Modelos sociales del liberalismo español", en Ricardo Robledo, Irene Castells y María Cruz Romeo (eds.), Orígenes del liberalismo. Universidad, política, economía, Ediciones Universidad de Salamanca, Salamanca, 2003, pp. 180-183.

${ }^{16}$ Enric Sebastià, La revolución burguesa, la transición de la cuestión señorial a la cuestión social en el País Valenciano, 2 vols., Centro Tomás y Valiente UNED AlziraValencia/Fundación Instituto de Historia Social, Valencia, 2001, vol. II, pp. 18.

${ }^{17}$ Pere Anguera, “¿Por qué eran combatientes carlistas?”, Vasconia. Cuadernos de HistoriaGeografía, núm. 26, 1998, pp. 111-124.
} 
propiedad privada o habían salido perjudicados por la industrialización. En ambos casos, se trataba de excluidos de los beneficios de la revolución liberal. Gente sin recursos en un mundo en el que la posición social se basaba en la riqueza, personas prescindibles y sin derechos para el poder, con los que cabía perfectamente el extrañamiento y la explotación en las Antillas.

Desconocemos el número exacto de deportados a Cuba, aunque el Capitán general Miguel Tacón dice que incorporó a 2.917 en los distintos cuerpos del ejército. ${ }^{18}$ Por tanto, su número superaría ampliamente la cifra de 3.000, ya que los enrolados forzosamente, si bien fueron la mayoría no constituyen la totalidad y de ahí habría que descontar los fallecidos durante el traslado y los que fueron a Puerto Rico. Respecto a los embarques de los que conocemos su procedencia, se realizaron principalmente desde la costa mediterránea: 19 desde Barcelona, cuatro desde Tarragona, cinco desde Cartagena y siete desde Cádiz. En la cornisa atlántica, 11 salieron desde La Coruña y uno desde Santander. ${ }^{19}$ La concentración en Barcelona sobresalía en 1834 y a partir de ese año los puntos de embarque se diversificaron. La importancia de Cataluña da idea de que la mayoría de las remisiones las conformarían miembros de las partidas que operaban en este territorio y en la zona del Maestrazgo, lugares donde a pesar de haber una fuerte presencia insurrecta no se consiguieron zonas plenamente bajo su mando hasta fechas muy tardías. En contraposición, en el País Vasco y Navarra, cuya zona de dominio se consolidó desde los primeros compases de la guerra, los frentes eran más estables y las capturas menores. Desde allí, así como desde el norte de Castilla y Galicia los embarques se producirían en La Coruña. En el sur, los combatientes castellanomanchegos y andaluces serían transportados principalmente a través de Cartagena y Cádiz.

La mayoría de los combatientes carlistas eran muy jóvenes, 25,4 años de media entre 1833 y 1835 y 24,8 en el siguiente bienio, siendo el grupo más importante el que oscilaba entre 19 y 21 años. ${ }^{20}$ Elementos como la juventud predisponía a ciertos presos a sufrir este castigo por su mayor fortaleza física y su mayor bisoñez, que les hacía más fácilmente manipulables. Ante un exceso de mano de obra, la capacidad de los más mayores era menor. Aquellos pertenecientes a facciones que actuaban cerca de la costa

\footnotetext{
${ }^{18}$ Miguel Tacón, Relación del Gobierno superior y capitanía general de la isla de Cuba, Imprenta del Gobierno y Capitanía General, La Habana, 1838, p. 26.

${ }^{19}$ Jesús Raúl Navarro, "El exilio carlista”, pp. 157-160; Gaceta de Madrid, 3 de julio de 1834.

${ }^{20}$ Manuel Santirso, Revolución liberal y guerra civil en Cataluña, pp. 486-487.
} 
tenían más posibilidades de terminar en el Caribe, mientras que la extensión de los trabajos forzados a la Península facilitaba que los capturados en el interior pudieran ser obligados a trabajar en la metrópoli. El control de los cristinos de la mayoría del territorio permitía que muchos pudieran permanecer en España. El laboreo forzoso en la Península había comenzado con anterioridad. Tras la derrota de Mayals, unos 700 combatientes legitimistas cautivos habían sido llevados a Tarragona para trabajar en obras públicas o ser ubicados en los depósitos. También hay constancia de sentencias a conspiradores a trabajos en el canal de Castilla ya en 1834, lugar donde en agosto de 1836 había 2.000, aproximadamente la mitad por delitos políticos. ${ }^{21} \mathrm{La}$ inmensa mayoría, sino todos, lo serían por pertenecer a la facción. Al igual que sucedió con los confinados a Ultramar, la explotación de presos comunes y de guerra se fue estandarizando hasta llegar a constituir un método de grandes dimensiones de obras tanto de carácter civil como militar.

A Puerto Rico fueron a parar un grupo menor de individuos integrados en las expediciones regulares, en Agosto de 1835 el San Agustín llevó a 36, en Marzo de 1836 llegaron 20 en el Volador y otros 26 arribaron en el Amable Malagueño en abril de 1836. ${ }^{22}$ Además, entre los trasladados a esta isla encontramos algunos casos atípicos. En 11 de marzo de 1834 zarparon en el Soberano desde La Coruña el excoronel Juan Felipe Ibarrola y otros siete oficiales a los que se había conmutado la pena de muerte por la de presidio en dicho territorio. En noviembre de ese mismo año, estando la expedición de Gómez cerca de Málaga, cundió el rumor de que se dirigía a esa ciudad lo que propagó el pánico en la urbe que solo contaba con las fuerzas de la Milicia Nacional para defenderse. Muchos malagueños salieron por mar y 300 fueron embarcados rumbo a Puerto Rico por simpatías con los sublevados. ${ }^{23}$ En febrero de 1835, la goleta Isabel Ana fue interceptada con un cargamento de pólvora y plomo para los rebeldes. Al tratarse de un barco inglés y con la mayoría de la tripulación de esa nacionalidad, el Gobierno británico presionó a las autoridades españolas para que no se les aplicara la

\footnotetext{
${ }^{21}$ Teatro de la guerra, p. 65; La Revista Española, 7 de noviembre de 1834; El Español, 5 de agosto de 1836; la otra cara de la moneda fueron los campesinos obligados por los carlistas en trabajos de fortificación. Pere Pasqual i Domènech, "Carlisme i societat rural, la Guerra dels Set Anys a la conca d'Òdena", Recerques. Història, Economia i Cultura, núm. 10, 1980, pp. 79 y 89.

${ }^{22}$ Jesús Raúl Navarro, "El exilio español en América en el siglo XIX”, pp. 157-160

${ }^{23}$ AGI, Ultramar, 52, N.33 "Sobre el pago de gestos en el transporte de varios exoficiales facciosos destinados al presidio de aquella capital" (Puerto Rico); El Eco del Comercio, 1 de diciembre de 1836 .
} 
pena capital. Finalmente fueron remitidos en la goleta Primera Gallega que llegó a su destino en de abril de 1836. A su llegada permanecieron libres, lo que aprovecharon varios insurrectos, entre los que se encontraba Antonio Urbiztondo, para escapar a Santo Tomás. ${ }^{24}$ El caso de los apresados en la goleta Isabel Ana fue especial, ya que junto a los 26 oficiales y un paisano fueron llevadas tres mujeres y dos niñas, cosa que no sucedía con los combatientes que eran deportados sin sus familias. El coste del traslado ascendió a 4.370 pesos fuertes, que los interesados debían devolver. A raíz del precio elevado de los deportados respecto de la escolta, podíamos inferir algún trato de favor a tenor de que todos excepto uno eran militares. Aun así, no hubo distinciones en el envío, ya que todos incluso el paisano ocasionaron el mismo gasto.

En teoría, el Gobierno retribuía los pasajes que después se deducía de los salarios de aquellos destinados a trabajar o repercutía a los destinados al ejército. Los envíos habían de ser realizados en barcos de la marina, pero en ocasiones se contrataba a barcos privados, lo que incrementaba notablemente el riesgo de rebelión por parte de los deportados. ${ }^{25}$ La escasa escolta dio lugar a incidentes durante el traslado como en el caso del bergantín mercante Lancero durante su trayecto a Cuba. El barco salió de Barcelona y en Tarragona recogió a 150 cautivos carlistas con destino a la mayor de las Antillas, pero a pocas millas de Gibraltar los prisioneros se sublevaron y se apoderaron del barco, cuya tripulación estaba formada por tan solo dieciséis hombres y el capitán, y tomaron rumbo hacia dicha plaza.

Sobre los remitidos a Puerto Rico tenemos pocos datos. Rafael Novelle fue trasladado al presidio en 1837 cuando fue declarado inútil para el servicio militar que estaba prestando. En el mismo regimiento de infantería de Granada cumplía el servicio militar Manuel Suarez. Mateo Sáenz, posiblemente represaliado carlista, había sido autorizado a residir en Trujillo Bajo y a principios de 1838 residía en casa de la familia

${ }^{24}$ Antonio Pirala, Historia de la guerra civil, y de los partidos liberal y carlista, tomo I, pp. 463-464; Alejandro Anca Alamillo, La armada en la Primera Guerra Carlista, Fundación Alvargonzález, Gijón, 2011, pp. 171-174; Alexander Gallardo, Britain and the First Carlist War, Norwood Editions, Norwood, 1978, pp. 105-106; Teatro de la guerra, pp. 29-44 (biografías). Urbiztondo había escapado de ser condenado a muerte en 1821, por su participación en el levantamiento de Salvatierra, pero se las ingenió para hacer creer al tribunal que tenía 16 años, en lugar de los 18 que ya había cumplido, por lo que finalmente fue confinado a Oñate de donde no tardó en escapar. Tuvo un papel muy importante en el Convenio de Vergara; AHN, Ultramar, Leg. 1069, Exp. 2. "Intendencia para transporte de oficiales facciosos".

${ }^{25}$ AHN, Ultramar, Leg. 1069, Ex. 2. "Intendencia para transporte de oficiales facciosos"; $E l$ Eco del Comercio, 28 de julio de 1835; El Español, 3 de diciembre de 1835. Información de El Grito de Carteya. 
Quiñones. Juan Ballesteros obtuvo permiso para dormir fuera del presidio, licencia que le fue revocada en 1838 por lo tuvo que pernoctar en el mismo, tal y como hacía Mateo Sáenz. ${ }^{26}$ En Puerto Rico, probablemente por decisión del Capitán general, la relegación estuvo más vinculada al presidio donde residirían, lo que induce a pensar que estuvieron sujetos a un mayor control a pesar de gozar de libertad de movimientos durante el día.

\subsection{Otros casos y destinos diferenciados de deportación}

Los combatientes civiles y de procedencia rural embarcados después de pasar por los depósitos de prisioneros fueron el grupo más importante, pero no el único. Después de la derrota de Carnicer en Cortes de Arenoso, en octubre de 1834, unos 200 carlistas fallecieron y los prisioneros fueron llevados a Valencia. Los eclesiásticos fueron deportados a Ultramar y el resto dedicados a obras públicas. ${ }^{27}$ Los clérigos constituían un grupo con un perfil muy diferente al de los combatientes por lo que cobra sentido una distinción en el trato. La noticia no especifica a donde fueron, aunque lo más probable seria las Baleares como una deferencia por su estatus y su ascendencia sobre otras personas. El resto, menos peligrosos y más acostumbrados a trabajar duramente para sobrevivir, fueron empleados en la realización de trabajos a beneficio del Estado.

En ocasiones, las relegaciones fueron manifestaciones de la ira popular. En agosto de 1835 se produjeron revueltas en distintas ciudades que alcanzaron mayor grado en Barcelona, donde en 5 de agosto fue asesinado el general Bassa, y en Tarragona, donde fueron asesinados el teniente rey y el mayor de la plaza. En Valencia, los amotinados consiguieron forzar las puertas de la Torre de Quart y la Milicia Nacional fusiló a siete encarcelados, entre los que se encontraba el deán Ostolaza. Posteriormente se produjeron redadas contra los absolutistas de los que el 6 de agosto más de 100 fueron remitidos a Ceuta. Después otro grupo salió hacia Palma, compuesto principalmente de "curas, canónigos y militares de la clase de jefes". ${ }^{28} \mathrm{El}$ hecho de que

\footnotetext{
${ }^{26}$ Jesús Raúl Navarro. "El exilio español en América en el siglo XIX”, p. 166.

${ }^{27}$ Antonio Pirala, Historia de la guerra civil, y de los partidos liberal y carlista, tomo I, pp. 310-311; Dámaso Calbo y Rochina de Castro y Ramón Cabrera y Griñó, Historia de Cabrera y de la Guerra Civil en Aragón, Valencia y Murcia, Establecimiento Tipográfico de D. Vicente Castelló, Madrid, 1843, p. 61.

${ }^{28}$ Antonio Pírala, Historia de la guerra civil, y de los partidos liberal y carlista, tomo II, pp. 138-140; Vicente de la Fuente, Historia de las sociedades secretas antiguas y modernas en
} 
se tratara de una práctica perfectamente reglada, no excluía que en ocasiones se produjera de manera espontánea, debido a desmanes del pueblo contra otros que estaban en presidios por no constituir el perfil de los deportados a las Antillas.

El 4 de enero de 1836 se reprodujeron los incidentes en Barcelona por la publicación del falso rumor de que 33 prisioneros cristinos habían sido ejecutados, la reciente fuga de varios cautivos y la percepción de levedad del castigo de deportación al que fueron condenados varios carlistas. Muchos ultrarrealistas en la Ciudadela, Canalejas y las Atarazanas o heridos en el hospital militar fueron asesinados. Mina realizó embarques de liberales, pero también de algunos de los que eran tenidos por partidarios del pretendiente. ${ }^{29}$ Las noticias de los sucesos de Barcelona llegaron a Tarragona donde también hubo tumultos. Los exaltados no pudieron hacerse con el control de la ciudad por lo que se vieron abocados a negociar con las autoridades el transporte de unos 40 legitimistas a las Antillas. Las autoridades incumplieron este último precepto y los embarcados fueron rápidamente llevados a Ibiza. ${ }^{30}$

Con estas actuaciones se evitaban futuros altercados al mismo tiempo que se les protegía de la ira popular. La relegación sirvió para salvar la vida a algunos no combatientes. Los más radicales la consideraban liviana en contraposición a los fusilamientos que los alzados solían aplicar a los presos, dadas sus dificultades para el sostenimiento y guarda de los mismos. Fue una manera de eliminar el problema con la máxima celeridad y evitar cualquier tentación de violencia sobre los mismos. Al margen de actuaciones de parte de la ciudadanía también el Gobierno recurrió a los traslados a las islas adyacentes. En el caso de las colonias ultramarinas o a Ceuta estaba estipulado para los combatientes, pero en el transcurso de la guerra se produjeron situaciones que no se contemplaban bajo esta categoría. Sospechosos, propagandistas y figuras

España, 3 tomos, Imprenta de Soto Freire, Lugo, 1870-1871, tomo III, p. 794; Rafael Sánchez, Historia de don Carlos y de los principales sucesos de la guerra civil de España, Imprenta de Tomás Aguado y Cía., Madrid, 1844, tomo I, p. 238; entre los deportados enviados a Ceuta se encontraban Francisco Guijarro, Manuel María Ruiz y Pablo Ruiz, La Revista Española, 3 de octubre de 1835; Francisco Javier de Burgos, Anales del reinado de doña Isabel II, 6 tomos, Establecimiento Tipográfico de Mellado, Madrid, 1850-1851, tomo II, p. 212.

${ }^{29}$ Jaime Carrera Pujal, Historia política de Cataluña en el siglo XIX, Editorial Bosch, Barcelona, 1957, tomo III, p. 75; la cifra de ejecutados varia ostensiblemente según los autores. Desde los 53 de Melchor Ferrer, Domingo Tejeda y José F. Acedo, Historia del tradicionalismo español, Trajano, Sevilla, 1941, tomo IX, p. 137; a los 170 que da Javier de Burgos, Anales del reinado de Doña Isabel II, tomo III, p. 99-100.

${ }^{30}$ Javier de Burgos, Anales del reinado de Doña Isabel II, tomo III, p. 99-100. 
relevantes fueron llevados a las Baleares, que se convertiría en punto de residencia de muchos de estos carlistas de alta alcurnia.

Entre los deportados al archipiélago en los inicios de la guerra, el brigadier Ortaffá, el conde de Orgaz y el marqués de Trigona. En 1834 arribaron a Mallorca el capitán de infantería Esteban Portas, condenado a 12 años de confinamiento en Baleares por intervenir en el levantamiento de una partida, y el marqués de Sentmenat. En 1835, los mariscales de campo Pedro Méndez Vigo y Pedro Podio Valero, este último por desafecto al régimen, llegaron a las Baleares y Fray Rafael Vélez, obispo de Santiago, se instaló en Mahón. Junto a estos otros que se encontraban en las cárceles del territorio o habían abandonado la Península por temor. Durante 1835 se generalizaron las represalias sobre sectores civiles afines al pretendiente que eran desterrados a distintos puntos de España. Un grupo de religiosos asturianos fueron transportados a Canarias en marzo de 1836 por negarse a reconocer al nuevo obispo, alegando que era una decisión gubernamental. Todavía en 1839 se produjeron algunas llegadas. ${ }^{31}$

La mayoría de los que conocemos su destino fueron destinados a Ibiza. En este sentido hemos de tener en cuenta la labor recopiladora del padre Macabich para recoger los sucesos acaecidos en la Pitiusa mayor, por lo que es posible que hubiera grupos numerosos en Mallorca y Menorca. Aun así, la isla ofrecía las ventajas de estar más alejada y menos poblada y podía ofrecer recursos a los deportados con mayor facilidad que Formentera. Los remitidos allí no eran combatientes y lo fueron por actos de desobediencia testimoniales o se actuó con ellos preventivamente. La mayoría eran importantes: militares, de origen aristocrático o clérigos sobre quienes los trabajos forzados no se contemplaban. Además fueron llevados preferentemente por decisiones de las autoridades locales o condenados en juicio a esta pena.

En Ibiza estaban divididos en militares, eclesiásticos y paisanos. Los primeros no podían salir del recinto amurallado y el resto de la población, sin contar con permiso

\footnotetext{
${ }^{31}$ Alfonso Bullón de Mendoza, "La nobleza carlista", en María del Carmen Iglesias et al., Nobleza y sociedad en la España moderna, Fundación Cultural de la Nobleza Española-NobelFundación Central Hispano, 1997, vol. II, pp. 93-94; Successos de Barcelona. 1822-1835, Josep María Ollé Romeu (ed.), Universitat de Barcelona-Curial, Barcelona, 1981, p. 126; Isidoro Macabich, Historia de Ibiza, vol. II, pp. 286-288; Víctor Manuel Arbeloa, Clericalismo y anticlericalismo en España, (1767-1930), Encuentro, Madrid, 2009, p. 88; Fernando Garrido, Historia del último Borbón de España, Salvador Manero, Editor, Barcelona, 1868, tomo I, p. 220; Fernando García Villarrubia, Aproximación al carlismo andaluz en la guerra de los siete años, EASA, Madrid, 1979, pp. 160-161; Actas del Consejo de Ministros, tomo IX, sesiones de 26 de diciembre de 1835 y 14 de enero de 1836; El Católico, 6 de julio de 1844.
} 
explícito, y uno de cada grupo debía informar del resto de miembros. Los considerados más peligrosos estaban retenidos en el castillo. El riesgo no eran únicamente las fugas, a Carlos Ulmán, el gobernador le pidió que limitase sus paseos por miedo a que sufriera ataques. En 1839 hubo cierta efervescencia política en la isla, por lo que fueron recluidos temporalmente con objeto de protegerles. A excepción José María Gómez, el único caso conocido de no carlista ya que fue acusado de haber dado vivas a la república, al que se le ayudó con el rancho de los sargentos y se le debía dar socorro, desconocemos si al resto se le daría alguna ayuda. ${ }^{32}$ Lo cierto es que este constituyó un caso especial por tratarse del único liberal deportado y por estar en una situación de miseria extrema. La mayoría, al proceder de un estrato social elevado, no tendría problemas para mantenerse, aunque lo más probable es que el Estado no les dejara desvalidos. Además habríamos de tener en cuenta las redes sociales de apoyo, sobre todo articuladas alrededor de Iglesia.

\subsection{Esplendor y declive en el uso del castigo}

Una disposición de 20 de octubre de 1835 facultaba a los capitanes generales a imponer el estado de sitio sin necesidad de comunicarlo al Ejecutivo, hecho que de facto permitía a estos autoprotegerse ante cualquier vulneración de derechos que ejecutaran. Estos dictaban bandos con disposiciones particulares en las que reprimían a su conveniencia y que en ocasiones significa ampliar el uso de la deportación. El 1 de enero de 1836, el Gobierno aprobó la propuesta del General en Jefe del Ejército del Norte, para que los desertores del ejército cristino apresados en los batallones rebeldes fuesen llevados a Ceuta u otro destino semejante en vez de ser fusilados. ${ }^{33}$ El ritmo de embarques entre 1834 y 1836 se mantenía constante creciendo ligeramente, ${ }^{34}$ lo que suponía una gran afluencia. La relegación ganaba espacio como un método represivo entre políticos y militares. Para ambos era la mejor manera de desembarazo sin recurrir a ejecuciones, facilitándose la salida de multitud de presos de guerra.

\footnotetext{
${ }^{32}$ Isidoro Macabich, Historia de Ibiza. vol. II, pp. 286-288.

${ }^{33}$ Manuel Ballbé, Orden público y militarismo en la España constitucional, pp. 119-120; Actas del Consejo de Ministros, tomo IX, sesión de 1 de enero de 1836.

${ }^{34}$ Jesús Raúl Navarro, "El exilio español en América en el siglo XIX", pp. 157-160; Gaceta de Madrid, 3 de julio de 1834; aunque los datos están incompletos, de los 2.743 que conocemos el año de deportación 743 lo fueron en 1834, 830 en 1835, 1.043 en 1836 y 127 en 1837.
} 
En Cuba, el Capitán general no estaba de acuerdo con tener que alojar y proporcionar trabajo a tantos hombres, cuya presencia en la colonia podía resultar perjudicial por obedecer a razonamientos políticos. El 6 de octubre de 1835 una Junta compuesta por las máximas autoridades de la isla pedía al Gobierno que cesaran los envíos. Según exponían, el Castillo de la Cabaña, que ubicaba a 700 encarcelados mientras se construía la nueva cárcel, y el del Morro, donde se ubicaban 120 legitimistas y otros 430 presos, estaban llenos y no había otros lugares donde ubicarles. A los recientemente llegados los colocaron en el del Morro con grandes estrecheces desde donde serían diseminados por el territorio, lo que a juicio de las autoridades planteaba un problema por su gran número. El argumento principal era el orden público, ya que argüían que los conspiradores introducían en los cuarteles o desperdigaban por sus alrededores anónimos subversivos, unos favorables a la independencia y otros a Carlos V. Los carlistas, que según la exposición eran unos 1.500, estaban ocupados en obras públicas y debidamente vigilados, pero al ser peninsulares como sus guardias era inevitable que se familiarizaran con ellos y con sus ideas. La mala influencia que podían ejercer se extendía a los negros por lo que los propietarios no querían a ultrarrealistas en sus fincas y remitirles a lugares con escasa guarnición era contraproducente. ${ }^{35} \mathrm{El}$ bloqueo a su utilización para realizar tareas agrícolas con los esclavos se debía al miedo a que les insuflasen ideas antiesclavistas e independentistas. Los siervos debían saber que su posición era subordinada y trabajar junto a forzados blancos era envíales un mensaje erróneo.

El peligro de insurrección era real, si bien el éxito de la misma era dudoso. En Ibiza hubo un intento de sublevación en la noche del 3 al 4 de octubre de 1835 con el objetivo de proclamar a Carlos $\mathrm{V}$ y que contó con la participación de algunos confinados. Esta terminó con tres fusilados, varios condenados a penas de prisión y el presbítero Vicente Torres a seis años de servicio en los hospitales de la Antilla mayor. Sebastián Ramis, uno de los deportados en la Pitiusa mayor, fue trasladado a Formentera. En Cuba, a finales de 1835 el cabo primero Antonio Lobo pretendió realizar una rebelión y hubo otro intento en julio de 1838 que terminó con un fusilado, catorce remitidos a los presidios africanos y tres condenados a trabajar como los

\footnotetext{
${ }^{35}$ AHN, Ultramar, Leg. 4603, Exp. 35. "Inconvenientes de admitir en Cuba a gente sospechosa deportada de la Península".
} 
presidiarios en la Antilla mayor. ${ }^{36}$ A pesar de los riesgos que conllevaba, el peligro no era exclusivo de este castigo puesto que el hacinamiento en las prisiones también podría dar lugar a revueltas, tal y como sucedió en Ceuta, Melilla y Alhucemas.

Al margen de las exageraciones de las autoridades locales para que cesara la práctica, de ahí la mención al independentismo cosa bastante ilusoria por el perfil social e ideológico de los represaliados españoles, el número de unos 1.500 era real y constituía un grupo muy relevante. Las sucesivas quejas influyeron en la promulgación de la real decreto de 22 de diciembre de 1836, en el que se concedían poderes especiales al Ejecutivo para la lucha contra los conspiradores, incluido el de relegar a Baleares o Canarias por un tiempo máximo de seis meses a aquellos sobre los que recaiga la "convicción moral" de que conspiran contra el Estado. ${ }^{37}$ Este decreto tuvo una doble vertiente, por un lado contra los conspiradores liberales, pero por otro suponía admitir que Cuba estaba tan saturada de ultrarrealistas que podían constituir un problema de orden público. Se trataba de dar salida a los nuevos presos sin necesidad de trasladarles a las Antillas.

El destino a los regimientos planteaba el problema del excesivo número de combatientes carlistas armados, más peligroso si cabe cuando todavía había algunos jefes enviados a las Antillas en las guerra de 1823 y otros castigados al servicio a las armas por la sublevación de 1827. A finales de septiembre de 1836 llegaron 35 apresados en el bergantín goleta Amable Malagueño. El Capitán general, de acuerdo con lo estipulado por la Junta de Autoridades, retornó inmediatamente a los 21 que tenían peores antecedentes en la fragata mercante Juliana. Tacón, harto de que sus quejas fueran desatendidas procedió a actuar por su cuenta, devolviendo a aquellos que le suponían un estorbo mayor, tal y como se hacía desde los depósitos. Finalmente, el Gobierno resolvió que "se suspenda el confinamiento de personas de todas clases a las referidas provincias ultramarinas", 38 "y en su lugar se les destine a la Península a los

\footnotetext{
${ }^{36}$ Isidoro Macabich, Historia de Ibiza, vol. II, pp. 52-54: Jesús Raúl Navarro, "El exilio español en América en el siglo XIX”, pp. 148-149.

${ }^{37}$ Alicia Fiestas Loza, Los delitos políticos, pp. 139-140; Decretos de S.M. la reina doña Isabel II, dados en su real nombre por su augusta madre la reina gobernadora, y reales órdenes, resoluciones y reglamentos, Imprenta Nacional, Madrid, 1837, (CLE, tomo XXI), pp. 592-595, ver art. 6.

38 Informes de la sección de Guerra e Indias del Consejo Real, desde noviembre de 1834. AGI, Ultramar, 52, N.33. "Sobre el pago de gastos en el transporte de varios oficiales facciosos destinados al presidio de aquella capital" (Puerto Rico); AHN, Ultramar, Leg. 4603, Exp. 35. "Inconvenientes de admitir en Cuba a gente sospechosa deportada de la Península".
} 
trabajos públicos o a otra ocupación semejante". La real orden de 26 de octubre significaba el cese de la remisión de carlistas a las Antillas, pero no el de su explotación. La prohibición de envío de presos a Ultramar se extendió a los delincuentes comunes en 30 de junio de 1837, lo que causó congestión en los correccionales de la Península, planteándose incluso la utilización de los pontones para los presos de guerra. ${ }^{39}$

Esto significaba que en principio los embarques a las colonias de Ultramar iban a cesar, y así sucedió de manera temporal. Sin embargo, apenas unos meses más tarde, el 4 de abril de 1837, fue el propio Tacón el que pediría que se le enviara una nueva remesa de deportados expresando que:

"siendo urgente reemplazar hasta tres mil doscientas plazas de aquel ejército, por bajas naturales y por cumplidos que se van licenciando, y habiendo acreditado la experiencia que los prisioneros facciosos incorporados ya a los cuerpos de aquella guarnición hacen un buen servicio, y observan una excelente conducta, propone que para cubrir la mitad de dichas bajas se le envíen 1.890 prisioneros facciosos de 18 a 24 años de edad". ${ }^{40}$

El Ejecutivo, amparándose en que la suspensión se había producido a petición del Capitán general y en el buen servicio que desempeñaban los carlistas en el ejército, accedió a su petición y pretendió extenderla a Puerto Rico. En real orden de 25 de mayo se reglamentó que los enrolados fueran únicamente soldados presos en los depósitos, primando los que reunieran mejores cualidades y fueran más robustos y los presentados voluntariamente. Cada compañía de depósito del ejército entregaría a 100 prisioneros. Si en alguna no fuera posible, se habría de comunicar a la máxima autoridad de cada región militar para que diera solución al problema. ${ }^{41}$ El ejército y la política de grandes obras públicas habían absorbido el gran contingente de transportados hasta hacer necesario incrementarlo. El cambio producido en los puntos de remisión no se consumó y Cuba continuó siendo el destino de la mayoría. Desconocemos cuantos lo hicieron voluntariamente, pero teniendo en cuenta las circunstancias climáticas y de lejanía probablemente su número no sería demasiado importante.

Dada la ausencia de incidentes importantes protagonizados por los carlistas, Tacón consideró necesario continuar aprovechándose de su fuerza de trabajo y reforzar al mismo tiempo el ejército colonial. Tras la proclamación de la Constitución por parte

\footnotetext{
${ }^{39}$ Reales órdenes de 26 de octubre y de 30 de junio de 1836, en Colección legislativa de presidios y casas de corrección de mujeres, Imprenta Nacional, Madrid, 1861, tomo I, pp. 131132 y $145-146$.

${ }^{40}$ AHN, Ultramar, Leg. 4604, Exp. 18. Expediente promovido por la petición del Capitán general de Cuba para las bajas de aquel ejército con prisioneros facciosos de la Península.

${ }^{41}$ Ibídem.
} 
del general Lorenzo, el 13 de agosto de 1816, y la ola represiva desencadenada contra los liberales, reforzó los regimientos ante el temor a que hechos como estos se reprodujeran. La guerra civil no se trasladó a la Antilla mayor, donde la distinción era entre los partidarios del mantenimiento de la isla como posesión, representados por el Gobierno español y el Capitán general como su delegado, y los que pretendían la extensión de derechos a criollos y peninsulares.

A principios de noviembre de 1836 hubo una reasignación de la mayoría hacia el ejército, algunos incluso a petición propia. ${ }^{42}$ Con la intentona de Lorenzo, Tacón advirtió que el liberalismo había penetrado en el ejército y la mejor manera de desactivarlo era llenar los regimientos de combatientes carlistas, a la par que se trasladaba a la Península a un buen número de militares liberales. Desde un punto de vista personal, muchos habían perdido sus tierras por la desamortización o culpaban de su miseria a los cambios recientemente introducidos. Pese a su bajo perfil ideológico era indudable que tendían al ultraconservadurismo y a una postura favorable a la Iglesia y a la religión, por lo que ya no fueron vistos como un estorbo sino como una herramienta efectiva para reforzar el ejército y aumentar su poder sobre este. Con la intervención sobre esta institución se reforzaba el poder coercitivo del Estado, lo que suponía un mayor control sobre los liberales, criollos y población negra. El pase al ejército pudo ser aprovechado por otros que estaban trabajando en condiciones que consideraban menos ventajosas, pero resulta sintomático del cambio que significó incluso los propios relegados pudieron participar de algún modo su propia estancia.

En 1837, a raíz de la petición de Tacón se hicieron dos nuevos envíos a Cuba, ambos desde Cádiz y con fecha de llegada en septiembre y diciembre, transportando a 127 individuos. Los depósitos estarían llenos y la necesidad de nuevos soldados posibilitó descongestionarlos. La práctica a partir de esa fecha no se consolidó ya que no hemos encontrado deportaciones en 1838. Es probable que éstas no trascendieran al realizarse su traslado como reclutas dentro del ejército. Pero también es cierto que esta práctica tenía sus detractores. En abril de 1839, Van Halen y Cabrera firmaron el Convenio de Lécera. El acuerdo favorecía los intercambios de prisioneros y por eso el

\footnotetext{
${ }^{42}$ Archivo Nacional de Cuba, Junta de Fomento, Leg. 106, Núm. 4547. "Oficio de Tacón referente a los 12 prisioneros destinados en el pontón Cristina"; ANC, Junta de Fomento, Leg. 106, Núm. 4550, "Expediente relativo a seis deportados de los empleados en la limpia del puerto que solicitan pasar a ser soldados en el ejército de esta isla".
} 
general cristino consideró que era conveniente prohibirlas, porque además de impedir los canjes era muy costosa económicamente. ${ }^{43}$

\subsection{Traslado y estancia de los deportados en Cuba}

El sincretismo entre realismo y liberalismo moderado en la metrópoli no afectó al modo de Gobierno en Cuba. Los insulares participaron en las Cortes generales desde 1834 a 1836 y solo fueron excluidos a principios de 1837 cuando los progresistas decidieron que las posesiones debían regirse por leyes especiales. El motivo, la falsa idea de que conceder derechos políticos iba irremediablemente unido a la extensión del independentismo y a la dominación negra. En el fondo, los factores determinantes eran económicos pues los beneficios de ciertos grupos iban ligados al mantenimiento de la producción esclavista. Los hacendados querían mantener la esclavitud y con ello sus beneficios y el erario público dependía en gran medida de las remesas procedentes de Cuba para financiar la guerra. ${ }^{44}$ Fue durante el mandato de Tacón cuando se fueron configurando las bases de la relación colonial de la isla en el liberalismo español. No podemos considerar a este proceso ni lineal ni planificado meticulosamente. La improvisación y la disparidad de intereses entre el Ejecutivo y la capitanía general suscitaron conflictos entre ambas autoridades, tal y como sucedió en el caso de las deportaciones desde la Península.

Los cautivos eran mantenidos en los depósitos hasta que la máxima autoridad de cada región militar decidiera realizar los envíos, que se deberían realizar al haber un número suficientemente elevado para dejar espacio a los nuevos detenidos, lo que significaba transferir el problema de la tenencia de prisioneros a sus homólogos en las Antillas. Dadas las condiciones de los viajes en la época, la fácil transmisión de enfermedades, el tiempo del trayecto y el hacinamiento, no es de extrañar que se produjeran enfermedades. Según Tacón desde que el primero de junio hasta pasado el verano de 1834 habían muerto entre el 20 y 25\% de los remitidos a causa de la fiebre Amarilla y pedía que se suspendiesen las remisiones en verano. Su demanda no fue

\footnotetext{
${ }^{43}$ Jesús Raúl Navarro, "El exilio español en América en el siglo XIX", pp. 158-159. Un tercer posible envió recabaría en la isla en noviembre y saldría desde el mismo punto; Antonio Pirala, Historia de la guerra civil y de los partidos liberal y carlista, tomo V, pp. 293-294.

${ }^{44}$ José Antonio Piqueras, Sociedad civil y poder en Cuba, p. 83.
} 
aceptada por la falta de barcos y de dinero para habilitarlos a la vez, por lo que se le pedía que los ubicase en puntos saludables a su llegada. ${ }^{45}$

Las cifras argüidas pueden ser exageradas, dado que en ese momento era contrario a la práctica, pero es innegable se producirían fiebres o epidemias a bordo. A pesar de esto, desde Madrid se decidió continuar con los embarques mostrando que la vida de estos combatientes importaba más bien poco y que el objetivo principal de las relegaciones era el desembarazo. Legislativamente se configuró desde el primer momento el aprovechamiento de su fuerza de trabajo, pero en esos primeros momentos el éxito de una práctica tan masiva era más que dudoso. Las condiciones del viaje no mejorarían a causa de la gran cantidad de presos disponibles. En 1836 arribó la Carolina, cuyos confinados llegaron envueltos en sarna y prácticamente desnudos, y en el caso del Cristineta, del mismo año, cuatro de los 180 que transportaba fallecieron durante el viaje. ${ }^{46}$ Las condiciones de traslado, el tiempo de la travesía y el hacinamiento harían que las muertes no fueran infrecuentes. Aun así, las autoridades estipularon que la ración diaria de alimentos debía ser al menos igual a la ración de armada sin vino, que podía ser mejorada a voluntad del capitán del barco. ${ }^{47}$ Esto garantizaba abastecerles de los alimentos para su subsistencia, lo que suponía que la inmensa mayoría llegaran vivos a su destino. Todo lo demás fue descartado y en el caso de la vestimenta y el calzado no se les proveyó de ropas cuando muchos iban prácticamente desnudos o descalzos.

La real orden de mayo de 1835 dejó abierta la posibilidad de emplearles en la utilización de obras públicas o en cualquier otra que se dispusiese, en lo que suponía una adaptación a las circunstancias. Esto pudo deberse a dos motivos que no se excluían entre sí, que las carencias de individuos en el ejército fueran cubiertas, o se cubrirían fácilmente dado el gran número de envíos, y que se recelaba de armar a un número demasiado elevado de procedentes de la facción. Una de las excusas para pedir el cese de la práctica era el escaso número de militares de que disponía para custodiarles y mantener el orden público, que cifraba entre 5.000 y 6.000 hombres. Así, los primeros

\footnotetext{
${ }^{45}$ Oficio del Capitán general de Cuba a secretario de Estado y del consejo de la Guerra, s/f. AGI, Ultramar, 52, N.33. "Sobre el pago de gastos en el transporte de varios oficiales facciosos destinados al presidio de aquella capital" (Puerto Rico).

${ }^{46}$ Jesús Raúl Navarro, "El exilio español en América en el siglo XIX”, pp. 152-153 y 158-159.

${ }^{47}$ ANC, Reales Órdenes y Cédulas, Leg. 99, Exp. 115. En este caso los propietarios recibieron 44 pesos fuertes por cada relegado.
} 
remitidos se emplearon en el ejército, pero con posterioridad se posibilitaría la utilización en la realización de obras públicas. ${ }^{48}$

Tacón, en principio, consideró la presencia de miles de alzados en armas contra el Gobierno en la Península como un factor de inestabilidad. Su concepto de poder, muy militarista, giraba en torno al orden y la disciplina con unas atribuciones omnímodas para sí mismo y apoyándose en colaboradores de la metrópoli desplazando a los criollos. Además de reorganizar el negocio de la entrada de bozales para que los ingresos fueran recaudados en exclusiva por el Capitán general, mejorando los ingresos del Estado y los suyos propios, ${ }^{49}$ el otro eje esencial de su actuación fue el orden público, que trató de asegurar a toda costa. Reorganizó el cuerpo de policía exigiendo eficacia en la persecución del crimen, creó el cuerpo de serenos al que otorgó funciones policiales y construyó la nueva prisión. En 1836 instauró el Tribunal de Vagos y Picapleitos, mostrando que su idea de delincuencia excedía del de la criminalidad y abarcaba a los marginados. Las penas por robo y hurto se incrementaron. ${ }^{50}$ La extensión de la represión a aquellos que no querían o no podían trabajar constituía un salto cualitativo puesto que se trataba de individuos que no habían delinquido. La concepción de "delito" que rebosaba incluso la propia definición del mismo y la decisión de utilizarles en tareas de utilidad pública, determinó una gran disponibilidad de mano de obra forzada a su disposición. En este contexto, el laboreo de los carlistas no era necesario y suponía tener en Cuba a gente con un perfil similar al que se estaba represaliando en el interior.

De entre los llegados entre 1834 a 1836, 1.100 fueron destinados al ejército, 350 al depósito de prisioneros de la Nueva Cárcel y un centenar a las obras públicas. ${ }^{51}$ Pero los que estaban en la prisión también fueron utilizados en los trabajos forzados. ${ }^{52}$ Los empleados en el ejército lo serían en una primera etapa, puesto que una vez cubiertas las

\footnotetext{
${ }^{48}$ AGI, Ultramar, 52, N.33. "Sobre el pago de gastos en el transporte de varios oficiales facciosos destinados al presidio de aquella capital" (Puerto Rico)".

${ }^{49}$ Juan Pérez de la Riva, "Introducción" a Correspondencia reservada del Capitán general don Miguel Tacón, 1834-1836, Biblioteca Nacional José Martí, La Habana, 1963, p. 41.

${ }^{50}$ Yolanda Díaz Martínez, "Delincuencia, represión y castigo en La Habana bajo el Gobierno de Miguel Tacón", Cuadernos de Historia, núm. 40, 2014, pp. 15-17, 20-21.

${ }^{51}$ Jesús Raúl Navarro, "Ejército y Constitución en Cuba. Actitudes políticas en torno al año 1836" en Alberto Gil Novales (ed.), Ejército, pueblo y Constitución. Homenaje al general Rafael del Riego. Actas del coloquio internacional celebrado en la Facultad de Ciencias de la Información, Universidad Complutense de Madrid, los días 9, 10 y 11 de abril de 1984. Anejos de la Revista Trienio. Madrid, 1984, pp. 526-527.

${ }^{52}$ Miguel Tacón, Relación del Gobierno superior y capitanía general de la isla de Cuba, p. 17.
} 
plazas y dada la política de obras públicas emprendida serían reconvertidos hacia ellas. También es posible que realizaran faenas de fortificación y mejora de las instalaciones militares.

A través del envío del barco Especulación, que llegó el 4 de octubre de 1835 con 120 presos, podemos hacer una extensión de que sucedería con los demás. A su llegada fueron ubicados en el Castillo del Morro en donde había cautivos por causas comunes y ultrarrealistas, por hallarse el de la Cabaña en total saturación. Después fueron distribuidos rápidamente con otros peninsulares que se encontraban en los depósitos, amparándose en la gran cantidad de facciosos que había en La Habana:

"Ciento a la colonia Reina Amalia o isla de Pinos, para que se dediquen a los trabajos de sus nacientes establecimientos: cincuenta a la ciudad de Santiago de Cuba; para que se ocupen de trabajos de publica utilidad, y con los mismos fines, diez a la villa del Bayamo, diez a Matanzas, veinte a Trinidad, diez a Cienfiuegos, y ciento cuarenta dedicados al camino de hierro que se emprende desde esta ciudad al Rincón en las cercanías de la ciudad de Santiago de las Vegas, como también veinte y cuatro para la limpieza de esta Bahía con el buque de Vapor". 53

A raíz de estas palabras es fácil deducir la gran importancia de los relegados legitimistas en la política de obras públicas emprendida en Cuba durante el mandato del Capitán general. Junto a ellos trabajaban presidiarios, esclavos, cimarrones capturados, emancipados y vagos, que permitieron la construcción de numerosas obras: "Casas de beneficencia, hospitales, paseos, teatros, fuentes, muelles, plazas, calles, carreteras, caminos, cárceles y un sinfín de obras de pública utilidad". Había dos clases de edificaciones: las ejecutadas directamente por la administración a través de los forzados como el paseo de Tacón, la nueva cárcel, la fuente de Neptuno, el campo de Marte, la calzada de San Luis Gonzaga y la pavimentación de algunas calles, y las realizadas por contratistas privados de la camarilla palaciega. Dentro de éstas estaban los mercados del Cristo, María Cristina y del Vapor, la pescadería y el teatro de Tacón. Dada la configuración social de la Antilla mayor y la maximización del beneficio que ello suponía, es posible que este segundo grupo contara entre sus filas con trabajadores forzosos entre los que pudiera haber prisioneros de guerra. Otros fueron empleados como sirvientes en hospitales, e incluso 100 trabajaron frenéticamente durante una semana para la fiesta que los altos militares en el país organizaron en honor del Capitán general con motivo de recibir los títulos de vizconde del Bayamo y marques de la Unión

\footnotetext{
${ }^{53}$ AHN, Ultramar, Leg. 4603, Exp. 35. "Inconvenientes de admitir en Cuba a gente sospechosa deportada de la Península".
} 
de Cuba, en recompensa del Gobierno por su victoria sobre el general Manuel Lorenzo. ${ }^{54}$ Teniendo en cuenta la gran disponibilidad de mano de obra, las tareas ejecutadas serían tan amplias como la imaginación de los capataces.

La abundancia de mano de obra forzada determinó que su importancia se extendiera a otras poblaciones del interior del país. En isla de Pinos, en 1835 la colonización estaba en un estado incipiente, con una población de poco más de 480 habitantes y problemas de autoabastecimiento y de precios elevados en las importaciones de víveres. ${ }^{55}$ Los forzados fueron divididos en cinco brigadas de trabajo, a cargo de un cabo o soldado de confianza y estuvieron a disposición del comandante. Los deportados recibían remuneración, aunque inferior a la que disfrutaban los hombres libres y algunos de los legitimistas consiguieron puestos de capataces. ${ }^{56}$

En principio, los combatientes apresados debían ser retribuidos ya que la intención era que reintegraran a la marina el importe de su transporte. Creemos que esto no se produjo dadas las enormes dificultades administrativas que implicaba el descuento gradual de las escasas percepciones que recibían y al hecho de que en ninguno de los documentos justificativos de las retribuciones y gastos por alimentación de los relegados existe ninguna retención bajo este concepto. Como ejemplo, los que trabajaban en los pontones de servicio a limpieza del puerto cobraban una remuneración mensual de 3 pesos y 6 reales y eran socorridos diariamente con un real para la alimentación. ${ }^{57}$ Dado el elevado número de presos y su distribución en ocupaciones y

\footnotetext{
${ }^{54}$ Opúsculo que contiene el discurso que pronunció el Sr. Alejandro Oliván diputado de la provincia de Huesca en la sesión del 9 de diciembre y diferentes documentos concernientes al relevo y partida del Excelentísimo Señor don Miguel Tacón, Imprenta del Gobierno y Capitanía General, La Habana, 1838 p. 27; Juan Pérez de la Riva, "Introducción" a Correspondencia reservada del Capitán general Tacón con el Gobierno de Madrid, pp. 35-37, y 65-66; Jesús Raúl Navarro, "Carlistas castellano-manchegos sentenciados a Cuba durante la Primera Guerra Carlista”, en Campesinos y señores en los siglos XIV y XV. Castilla-La Mancha y América. Actas del I congreso de historia de Castilla-La Mancha, Talavera, 1988, tomo VI, p. 68.

${ }^{55}$ Antonio Nuñez Jiménez, Isla de Pinos. Piratas, colonizadores, rebeldes, Arte y Literatura, La Habana, 1976, pp. 389-400.

${ }^{56}$ José María Canalejas et al., Justificación de los deportados de Barcelona a Canarias y Pinos, y relación de las vicisitudes de los fugados hasta su arribo a Barcelona, Imprenta del Constitucional, Barcelona, 1839, pp. 14-17, 29 y 34-37 Según Canalejas, José María Isla, máxima autoridad de la colonia, tuvo una actitud favorable a los legitimistas; Jesús Raúl Navarro, "Ejército y Constitución en Cuba: actitudes políticas en torno al año 1836", p. 531.

${ }^{57}$ ANC, Junta de Fomento, Leg. 106, Núm. 4593. Relación de sueldos y socorro de soldados y destinados a los pontones; según Tacón, reorganizó la comida de presidiarios y prisioneros facciosos rebajando el precio de dos reales diarios a uno y medio, del cual tres cuartos eran en rancho, medio en pan y el otro cuarto se les entregaba para sus gastos personales. Además el panadero debió poner el $40 \%$ de lo que se le entregaba que iba destinado a un fondo para
} 
lugares muy distintos, estas condiciones no pueden ser generalizadas a todos, pero tampoco diferirían ostensiblemente. Con la mano de obra reducida a un salario muy inferior al de mercado, los costes totales de las obras promovidas por el Capitán general se vieron reducidos notablemente.

Para la construcción del ferrocarril, aparte del cuerpo técnico especializado, hicieron falta trabajadores que debían desarrollar las tareas más duras y peligrosas. Para esto se recurrió a contingentes especiales como trabajadores irlandeses y canarios, a los que se unirían los forzados. En 30 de junio de 1837 se cedieron 140 prisioneros de guerra, 87 emancipados, 145 esclavos y entre 200 a 250 cimarrones. Estos grupos no constituirían el elemento principal, teniendo en cuenta que los trabajadores requeridos eran aproximadamente 1.500. Un total de 927 habían llegado procedentes de Canarias, de los que a los dos años de su llegada el 16,8\% había muerto, el 9\% se había fugado y el 3,8\% habían sido declarados inútiles. Con posterioridad, los deportados peninsulares trabajando en el ferrocarril se redujeron a $30 .{ }^{58}$ Desconocemos las motivaciones que implicaban que unos debían permanecer en la realización de estos trabajos penosos, pero probablemente se trataría de un castigo.

La elevada accidentabilidad laboral sería posiblemente mayor en el caso de los trabajadores forzados y se incrementaría, dentro de estos, en los grupos de color. Las necesidades de mano de obra fueron constantes y los ulrarrealistas, emancipados, esclavos y cimarrones permitieron cumplimentarlas a un módico precio. No olvidemos que durante la realización de la infraestructura surgieron importantes problemas monetarios y a estos se les retribuía con un salario menor. En el caso de los legitimistas, sabemos que recibían un real diario de gratificación y causaban un gasto de un real en rancho y medio en pan. Condiciones mejores que las del resto de grupos de forzados no solo en el aspecto monetario y el rancho sino también en el trato recibido. ${ }^{59}$ En lo que

comprarles sombreros de paja, zapatos y una muda anual. Miguel Tacón, Relación del Gobierno superior y capitanía general de la isla de Cuba, pp. 17-18. Sin embargo, a nuestro juicio la argumentación de Tacón tiene dos carencias. La primera es englobar tanto a prisioneros comunes como a facciosos en el mismo grupo, cuando las condiciones de los carlistas eran mejores. La segunda son las dificultades inherentes a la gestión del fondo con el $40 \%$ por parte del panadero en unos trabajadores distribuidos en infinitud de ocupaciones diferentes. Si hubiera pretendido realizarse así, lo más lógico es que este dinero lo hubiera retenido el Estado.

${ }^{58}$ Eduardo L. Moyano Bazzani, La nueva frontera del azúcar. El ferrocarril y la economía cubana del siglo XIX, CSIC, Madrid, 1991, pp. 107-109; Oscar Zanetti y Alejandro García, Caminos para el azúcar, Editorial de Ciencias Sociales, La Habana, 1987, p. 37.

${ }^{59}$ ANC, Junta de Fomento, Leg. 130, Núm. 6376. Designación de 140 prisioneros para el ferrocarril; esto significaba un gasto de 13 pesos mensuales en el caso de los peninsulares que 
respecta a la alimentación, los carlistas en el ferrocarril eran los que generaban un gasto mayor, respecto a los utilizados en otros lugares.

La explotación que sufrieron todos estos grupos de trabajadores coaccionados contribuyó a aligerar los gastos de la construcción del ferrocarril. Sin embargo, teniendo en cuenta la elevada disponibilidad de otros grupos, la reducción en el número de los partidarios del pretendiente que trabajaron en el mismo es significativa. No tenía sentido que fueran los peninsulares blancos los que realizaran las tareas más duras y más peligrosas cuando había emancipados, esclavos y cimarrones que podían realizarlas, y cuya vida era mucho menos valiosa que la del incipiente lumpenproletariado español. Económicamente su laboreo era más costoso y entorpecía el negocio de cesión de esclavos y cimarrones para la realización de esta infraestructura, lo que conllevó su reducción en la construcción del ferrocarril.

Los relegados configuraron una especie de élite dentro de los trabajadores forzosos en la isla. Su condición racial y su procedencia les permitieron tener en general unas mejores condiciones. En el caso de las obras públicas, los cargos de capataces fueron privativos para ellos. ${ }^{60}$ Aun así, no por ser mejor su situación que la de los esclavos, emancipados, cimarrones y presos, podemos considerar idílica su situación. Enrolados en la facción principalmente a causa de su miseria o bajo coacción, fueron deportados en condiciones lamentables a miles de millas de distancia en un viaje que duraba varios meses, y posteriormente obligados a servir en el ejército o en la realización de obras públicas, en un clima tropical en el que no estaban acostumbrados. Además, en el caso de los trabajadores forzosos tuvieron que trabajar junto a negros y esclavos, lo que en la época era considerado indigno.

La planificación gubernamental al destinar a los prisioneros de guerra al servicio militar en las posesiones antillanas fue eficaz para sus intereses. Eran blancos y aunque se habían sublevado contra la reina, lo habían hecho principalmente por carecer de los recursos más elementales y como tal tenían un perfil ideológico muy básico. No eran liberales y carecían de la más mínima noción de independentismo: los mejores candidatos de entre los disponibles para ponerles un arma en la mano. El ejército colonial, permanentemente escaso de personal y de recursos, fue el gran beneficiado de

eran 9 en el caso de emancipados y esclavos y 1 real diario los cimarrones. Eduardo L. Moyano Bazzani, La nueva frontera del azúcar, pp. 103-107; ANC, Junta de Fomento, Leg. 131, núm. 6407. Expediente sobre la queja de trabajadores isleños contratados.

${ }^{60}$ Justo de Latorre, Una ojeada al manifiesto que publicó el Excmo. Sr. D. Miguel Tacón al dejar el mando de la isla de Cuba, Domingo Feros, Cádiz, 1838, p. 27. 
la guerra civil que desangraba a la metrópoli y a un coste reducido. La manutención diaria costaba a las arcas públicas 0,5 reales diarios, o sea un peso y medio al mes. A esta cifra habría que sumar artículos y vestuarios y el coste de transporte. La información no aclara cuanto se entregaba a los relegados para sus gastos, aunque atendiendo al resto de casos parece claro que se les otorgaría alguna pequeña cuantía. Aun así, su utilización en el ejército significaría una disminución importante en el gasto del ejército, ya que los fusileros, rango menor que podían alcanzar los soldados, percibían una remuneración mensual de 9 pesos, 2 reales y 28 ms mensuales. ${ }^{61}$

Con un número tan elevado de legitimistas era inevitable que se produjeran fugas. Desde Cuba huyó Fernando Fulgosio que se incorporó en el ejército del norte donde ascendió a Coronel hasta que murió en Béjar en 1838. A finales de ese mismo año resultó frustrado un intento de tomar un barco para regresar a sus casas. El principal instigador, un músico del regimiento de Galicia fue ejecutado mediante garrote vil y otros 17 fueron condenados a presidio. ${ }^{62}$ En Puerto Rico se produjeron bastantes fugas por lo que parece que se creó alguna red de huida. En 1835, consiguieron escapar cuatro deportados y un natural desde Ibiza. ${ }^{63}$

Acerca del retorno de las Antillas se plantea una enorme dificultad para saber si volvieron efectivamente, o si por el contrario se establecieron. Dado su enorme número es evidente que hubo casos de todo, pero hemos de tener en cuenta que había diversos elementos que actuaban a favor de que su situación se prolongara. Quedaron excluidos de la amnistía del Convenio de Vergara. Tampoco fueron incluidos en el indulto general de 30 de noviembre de 1840, en que se estipulaba que en Ultramar la amnistía quedaba vinculada a la oportunidad y a las modificaciones convenientes. ${ }^{64}$ El Ejecutivo pretendió continuar aprovechándose de ellos en Ultramar, por lo que bloqueo su regreso. Dado

\footnotetext{
${ }^{61}$ AHN, Ultramar, Leg. 1072, Exp. 35. "Extracto del presupuesto de guerra correspondiente al año de 1839, para dicha provincia" (La Habana).

${ }^{62}$ Melchor Ferrer, Domingo Tejera, José F. Acedo, Historia del tradicionalismo español, Editorial Católica Española, Sevilla, 1938, tomo XV, p. 235; AHN, Ultramar, Leg. 4610, Exp. 27. "Expediente sobre la fuga de seis deportados en la isla de Pinos", incluye otro referente al de 15 individuos más confinados por el capitán general de Cataluña a la isla de Pinos.

${ }^{63}$ Jesús Raúl Navarro, "El exilio español en América en el siglo XIX", pp. 183-186; el 3 de mayo de 1836 dos individuos llegaron a Saint Thomas en una balandra que zarpó desde Luquillo, Las fugas, según las autoridades se producían desde esa población o desde Fajardo. El hijo del duque del Infantado se fugó pagando 43 onzas a un balandro por llevarle a Saint Thomas desde Luquillo. Lo mismo hicieron un individuo llamado Juan José Córdoba y un coronel apellidado Padilla (o Guadilla) que habían sido llevados a Puerto Rico desde Cuba; Isidoro Macabich, Historia de Ibiza, vol. II, p. 286.

${ }^{64}$ Gaceta de Madrid, 1 de diciembre de 1840.
} 
que se les condenó por seis años, el final del servicio se produciría entre 1840 y 1844. Un largo tiempo en la isla en la cual podían haber iniciado una nueva vida.

A los incluidos en los regimientos seguramente se les asimilaría al resto de reclutas en cuanto a la vuelta a sus hogares, pero la permanente escasez de efectivos que afectaba al ejército ultramarino hizo que fuera habitual que los quintos no fueran licenciados cuando les tocaba. ${ }^{65}$ Los que estaban fuera del ejército deberían hacer frente al pasaje al que únicamente podrían acceder los que consiguieran empleo y asegurar su subsistencia, precisamente a aquellos a los que la repatriación le resultaba menos perentoria. El largo periodo de estancia actuaba como un freno puesto que permitía desarrollar redes afectivas en las que no pocos crearían allí su propia familia. La vinculación con compañeros y excompañeros que actuarían de sostén y podían proporcionar ocupación. Hemos de tener en cuenta que el perfil mayoritario de los alzados era el de individuos cuyo modo de vida se había derrumbado y por tanto sabían que de volver a sus casas les esperaba la miseria.

Paralelamente, a partir de 1835 se simplificaron los trámites para la emigración a las colonias americanas y en 1839 se reconoció el derecho de establecerse en ellas, lo que muestra el interés en la población en la composición de la población y significó el incremento en la inmigración peninsular. ${ }^{66}$ Ya a partir de la década de 1830 se observa un asentamiento de la emigración catalana vinculada al comercio. La misma procedencia mayoritaria de la afluencia voluntaria y forzosa pudo significar el establecimiento de relaciones entre ambos grupos y actuar los mercaderes como elementos que pudieran proporcionar trabajo a los carlistas y facilitar su asentamiento. La dispersión de los presos hacia la integración más fácil, ya que distribuidos por distintas poblaciones en contingentes no demasiado numerosos posibilitaba el trato con las autoridades e incrementaba las opciones de obtener colocación una vez terminado el castigo. Desperdigados hacia el interior, la lejanía con los puertos que hacían los viajes hacia la metrópoli aumentaba y su carácter de campesinos facilitaba su asentamiento.

Atendiendo a los censos de población, observamos que hubo un incremento de 107.240 personas de raza blanca en la Antilla mayor entre 1827 y 1841 , mientras que las licencias de embarque de peninsulares desde 1800 a 1835 fueron únicamente de

\footnotetext{
${ }^{65}$ Pedro José Guiteras, Historia de la isla de Cuba, Cultural, Habana, 1928, tomo III, p. 134; Antonio Pirala, Anales de la Guerra de Cuba, 3 tomos, Felipe González Rojas, Editor, Madrid, 1895-1898, tomo I, p. 34.

${ }^{66}$ Cesar Yáñez Gallardo, Saltar con red. La temprana emigración catalana a América, ca. 1830-1870, Alianza, Madrid, 1996, pp. 30-33 y 47-56.
} 
4.249. ${ }^{67}$ La mayoría de estos nuevos habitantes blancos eran emigrados de las antiguas colonias americanas. En cuanto a la población metropolitana, a pesar de la existencia de una emigración ilegal en 1846 era únicamente de 27.264 y la canaria de 19.759. De este modo, la unión de europeos y canarios representaba únicamente un $11 \%$ de la población blanca de la isla, en un momento en que la población de color ya era superior a la blanca, en 1841, 589.333 por 418.291. Estos datos muestran la debilidad en la importancia poblacional de los españoles, no solo frente a los de raza negra, sino también frente a los criollos americanos. Por esto, a pesar de la nula planificación, las relegaciones determinaron el reforzamiento del grupo español en un momento, el mandato de Tacón, en el que se configuró un partido español que desplazó a los criollos de muchos de los espacios de poder que hasta entonces ostentaban. Así, la nueva presencia de españoles armados no solo debe entenderse como dar ocupación a los desplazados forzosamente, sino como la demostración de quien tenía el poder en el territorio. El Capitán general, que en un primer momento se mostró reticente a su presencia así lo entendió y de ahí la petición de nuevos reclutas en 1837.

\subsection{Las deportaciones a Filipinas}

En Filipinas, las órdenes religiosas tenían un papel central en el proceso de colonización. La lucha entre liberalismo e Iglesia que se daba en la Península no se expandió al archipiélago a causa de la importancia de los clérigos en la administración de la colonia y el temor al influjo que tenían sobre la población. ${ }^{68}$ La relevancia de los religiosos y las enormes simpatías de estos hacia el carlismo explica que se dejara para casos muy concretos. Mientras que en Cuba los carlistas fueron utilizados en el ejército o en la realización de obras públicas, en Filipinas no sucedió lo mismo. Los envíos, realizados con gente con características determinadas dificultaba la apropiación del trabajo de los mismos. Así, mientras en el Caribe desembarazo iba ligado a utilidad, el archipiélago asiático fue una especie de Baleares por el perfil de los represaliados, con

\footnotetext{
${ }^{67}$ María Dolores Pérez Murillo, Aspectos demográficos y sociales de la isla de Cuba en la primera mitad del siglo XIX, Servicio de Publicaciones de la Universidad de Cádiz, Cádiz, 1988, p. 121.

${ }^{68}$ María Dolores Elizalde y Xavier Huetz de Lemps, "Un singular modelo colonizador. El papel de las órdenes religiosas en la administración española de Filipinas, siglos XVI al XIX", Illes $i$ Imperis, núm. 17, 2015, pp. 201-202.
} 
un mayor alejamiento y proscripción y que en determinados casos significaba que debían permanecer presos y no deportados.

Los primeros en llegar fueron el exgeneral Pedro Grimarest y el exalcalde de Madrid y exfiscal de la real audiencia de Granada Ramón Pedrosa, a quienes se condenó a relegación a las Marianas por sospechosos de actividades a favor del pretendiente Llegaron el 25 de febrero de 1836 acompañados de José Izquierdo Morales, capitán de voluntarios de Navarra y administrador de loterías, a quien se le conmutó la condena a muerte por conspiración, por la de presidio en Filipinas. ${ }^{69}$ El 5 de julio de ese mismo año arribaron otros cinco individuos: Mateo Jara, canónigo de la catedral de Coria; Manuel Tellería, exintendente de Asturias y Francisco Redondo por intento de conspiración. Los dos primeros fueron condenados a ocho años de presidio y el último a diez. Habían formado parte de la Junta carlista en Portugal y fueron detenidos por un grupo de liberales exiliados en ese país. Junto a ellos Miguel Brieva, condenado a diez años de presidio por pertenencia a la facción y Justo Amador, sentenciado por gritos sediciosos en la Corte a la misma pena. Otros diez llegaron entre septiembre de 1836 y agosto de 1837 condenados a distintas penas. ${ }^{70}$

Ninguno de los condenados a presidio en las Marianas fue llevado a dicho archipiélago. El motivo que daba el Capitán general, Pedro Antonio de Salazar, era la inconveniencia de esa medida por cuanto el gobernador no tenía medios para evitar la fuga en los muchos buques balleneros que atracaban allí, ni para impedir la propagación de sus ideas entre los indígenas. A esto habría que unir el coste del traslado que debería hacerse en barcos ajenos a la flota, puesto que esta no disponía de ningún barco "capaz de emprender la travesía desde Manila a las Marianas". ${ }^{71}$ Los obstáculos a que hacía referencia Salazar no eran insuperables y la dejación en la represión a los

\footnotetext{
${ }^{69}$ AHN, Ultramar, Leg. 5155, Exp. 6. "Medidas tomadas con los reos de la Junta carlista de Córdoba", Contiene relación de sujetos confinados a esas islas desde 1835, delitos y destinos en que cumplen sus condenas; El Eco del Comercio, 16 de mayo de 1835.

${ }^{70}$ AHN, Ultramar, Leg. 5155, Exp. 6. "Medidas tomadas con los reos de la Junta carlista de Córdoba", Contiene relación de sujetos confinados a esas islas desde 1835, delitos y destinos en que cumplen sus condenas; Galería militar contemporánea, colección de biografías y retratos de los generales que más han conseguido en los ejércitos liberal y carlista, durante la última guerra civil, Sociedad Tipográfica de Hortelano y Cia., Madrid, 1846, tomo II, p. 17; Fastos españoles o efemérides de la guerra civil desde octubre de 1832, tomo II, p. 100; La Revista Española, 8 de diciembre de 1833.

${ }^{71}$ AHN, Ultramar, Leg. 5155, Exp. 10. "Causa por correspondencia de contenido carlista".
} 
propagandistas ultrarrealistas vinculados a la parte mayoritaria del clero, ${ }^{72}$ indica que fue un intento de mantenerse al margen de la contienda peninsular, sin tomar partido por el Gobierno, probablemente por simpatías hacia la causa del pretendiente y como modo de adaptación a la sociedad manilense. La lejanía facilitaba la omisión de funciones en un territorio escasamente poblado por españoles en la que las disputas políticas se vivirían de un modo diferente por una mayor cohesión en torno a la cuestión racial. Por mucho que buena parte de la población tuviera simpatías carlistas, era difícil que se decidieran a tomar las armas.

El nuevo Capitán general, Andrés García Camba, arribó a la isla en 27 de agosto de 1837 y se encontró con que Pedrosa se hallaba alojado en el convento de San Juan de Dios, en la provincia de La Laguna, donde se hacían reuniones de legitimistas, vivía completamente libre y paseaba casi diariamente con el deán Pedro Morales. Jara había sido ubicado en la provincia de Pampanga, lugar en el que estaba libre y en el que intentaba minar la disciplina de los sargentos. Había un estado de indolencia por parte de las autoridades que toleraban cualquier manifestación favorable al pretendiente, lo que daba lugar a tertulias e intrigas. Los confinados vivían en plena libertad y eran visitados y obsequiados por la superioridad, aunque desconocemos si esto se extendió a aquellos que eran menos relevantes. Camba puso limitaciones a las condiciones de que gozaban para terminar con las reuniones y ubicó a Jara, Pedrosa y a Telleria en la fortaleza de Santiago en Manila, aunque sin restricciones en su comunicación, y Grimarest, que habitaba en la capital y era socorrido con 50 pesos fuertes mensuales, fue llevado a Santa Rosa en la provincia de la Laguna donde quedó libre a causa de su avanzada edad y de su salud. Respecto a los 3 individuos de la Junta carlista de Córdoba, basándose en el buen comportamiento que mostraron durante el viaje los alojó en Santa Cruz de Malabón, quedando al cuidado de los dominicos y bajo la vigilancia del gobernador de la provincia de Cavite. Posteriormente, recibió órdenes de remitirlos a presidio por lo que los ubicó en la fortaleza de San Felipe de Cavite. ${ }^{73}$ El resto estaban en las cárceles de Misamis, Calamianes, Capiz, Manila y Caraga. ${ }^{74}$

\footnotetext{
${ }^{72}$ José Montero y Vidal, Historia general de Filipinas desde el descubrimiento de dichas islas hasta nuestros días, Viuda e Hijos de Tello, Madrid, 1895, tomo III, pp. 6-18; El Eco del Comercio, 16 de mayo de 1835.

${ }^{73}$ Andrés García Camba, Los diez y seis meses de mando superior de Filipinas, Imprenta de D. Domingo Feros, Cádiz, 1839, pp. 19, 38 y 64 (libro) y 30 (documentos).

${ }^{74}$ AHN, Ultramar, Leg. 5155, Exp. 6. "Medidas tomadas con los reos de la Junta carlista de Córdoba", Contiene relación de sujetos confinados a esas islas desde 1835, delitos y destinos en
} 
Lo primero que cabría destacar acerca de los transportados es su escaso número. Todos fueron realizados por mandato expreso, ya fuera del Gobierno o de los tribunales. $\mathrm{Su}$ carácter particularizado lo fue en atención a unos delitos también excepcionales. Únicamente dos habían sido combatientes en las facciones, uno siendo menor, y del otro se decía que había pertenecido, por lo que se entiende que en ese momento ya estaba fuera de ella. El resto fueron condenados por supuestas conspiraciones, intentos de unirse a D. Carlos, realizar gritos subversivos y conformar una Junta carlista. Dado que la mayoría eran personalidades importantes y no se les podía sacar provecho, se tendía hacia una mayor neutralización de los relegados. Los presidios o condiciones restrictivas lo garantizaban con una mayor facilidad.

Los castigos que se les impusieron estaban perfectamente delimitados. La mayoría fueron condenados a presidio, cinco de ellos a las Marianas. Además hubo dos que debían pasar al Regimiento de Asia y uno al que se le dejó en libertad. A los condenados a la Micronesia se les impuso una punición añadida, aunque no había presidio allí. Esta intentona no tendría ninguna finalidad colonizadora puesto que cinco individuos en poco podían contribuir a esto. En el otro lado se encontraban los dos condenados a servir en el ejército, uno por huir a Portugal y el otro por haber pertenecido a la facción siendo menor de edad. La mayoría de los penados con presidio lo fueron por tribunales ordinarios, lo que dejaba el traslado a las Filipinas como un reducto aparente de legalidad dentro de una represión bastante arbitraria.

La suspensión de los envíos a las colonias se extendió a las Filipinas en donde las autoridades se mostraban contrarias a esta práctica, al considerarla perjudicial para la imagen de los españoles y no disponer de medios suficientes para hacer frente a posibles altercados. Esto incluía a hombres sujetos a causas por delitos comunes que cumplían sus penas en el archipiélago. En abril de 1839 se fugaron dos delincuentes de la prisión de Zamboanga, pero que en la realidad estaban libres y tan solo tenían que presentarse dos veces por semana. En Junio se escapó de la fortaleza de Cavite Juan Olaya Sánchez de la Junta cordobesa. Las causas de la huida fueron según el Capitán general un excesivo descuido o la facilidad para sobornar a los guardianes. ${ }^{75}$

que cumplen sus condenas; AHN, Ultramar, Leg. 5161, Exp. 1. "Permiso de residencia en Caraga al confinado J. Amador". Se le concedió en 1848 permiso para permanecer en Caraga durante un año a arreglar sus asuntos, ya que aunque había finalizado el cumplimiento de su condena no había solicitado su licencia absoluta con anterioridad.

75 AHN, Ultramar, Leg. 5155, Exp. 16. "Inconveniencia de confinar a Luis Marques en Filipinas"; AHN, Ultramar, Leg. 5155, Exp. 42. "Fugados del presidio de Zamboanga J. Rivet y 
Otro elemento a considerar seria las condiciones de la estancia. Justo Amador o los dos fugados del presidio de Zamboanga se encontraban libres cuando fueron condenados a presidio, uno de estos últimos a perpetuidad. El alejamiento y la procedencia facilitaban que habiendo pocos peninsulares tuvieran un trato de favor, especialmente en las provincias. Además había una gran desorganización ya que incluso no se conocían las causas de la fuga de Sánchez del Villar, lo que unido a la presencia de carlistas en la isla, pudo determinar que algunos de los que fueron castigados con presidio no se encontraran presos en sentido estricto, o que sus condiciones mejoraron con el tiempo. Respecto al regreso de los mismos poco conocemos, pero dado que Grimarest continuaba en Manila, donde murió en 1841 y que a Justo Amador no se le permitió volver hasta que finalizó el tiempo de su condena en 1848, lo más probable es que el tiempo de condena se cumpliría para todos.

\section{LAS DEPORTACIONES DE LIBERALES AVANZADOS}

Las deportaciones más numerosas durante los años treinta fueron las que afectaron a los carlistas, lo que resulta lógico a tenor de la guerra civil que vivía el país. La mayoría de las disposiciones contra la oposición política fueron dirigidas hacia este grupo, pero la propia legislación muestra el temor del nuevo presidente del Gobierno Martínez de la Rosa a aquellos que consideraban su presidencia como excesivamente conservadora y continuista. ${ }^{76} \mathrm{El}$ transaccionismo entre moderados con sectores realistas configuraría un liberalismo muy restringido que dejaría descontentos a los sectores más radicales cuyas reacciones se querían controlar. Antes del inicio de la guerra y durante los primeros momentos, el presidio en España o Ultramar se contempló para reprimir a los avanzados. El real decreto de 26 de abril de 1834 posibilitaba la cárcel para los que se alistasen de manera reincidente en sociedades secretas. El de 26 julio, motivado por los motines anticlericales, permitía la reclusión en Ultramar para los grupos que se dirijan a atacar algún convento, colegio o casa particular.

M. Mas"; AHN, Ultramar, Leg. 5155, Exp. 43. "Juan Olaya Sánchez fugado de la cárcel de Cavite"; AHN, Ultramar, Leg. 5155, Exp. 19. "Relación de confinados políticos en Filipinas amnistiados". Mateo Jara no se encontraba en una nueva lista por lo que habría fallecido o escaparía.

${ }^{76}$ Anna Maria Garcia Rovira, La revolució liberal a Espanya i les classes populars, Eumo, Vic, 1989, pp. 51-57. 
Los más progresistas comenzaron las sublevaciones para tratar de imponer un régimen estrictamente liberal. El 18 de enero de 1835 se produciría la ocupación de la casa de correos en Madrid, intentona que fracasó. Como consecuencia de esto, el teniente de regimiento Francisco José Cardero fue relegado a Mallorca, de donde no tardó en escapar con dirección a Barcelona, ciudad en la que Mina le nombró su ayudante. ${ }^{77}$ Este fue un caso individual, pero ante la creciente presión que venía por la izquierda, el Ejecutivo extendió hacia ella la neutralización de la disidencia política.

Durante el verano se produjeron revueltas protagonizadas por la izquierda en varias ciudades. Desde Valencia fueron transportados a Ceuta muchos sospechosos por carlismo en agosto de 1835, pero la situación continuaba siendo tensa. Las asonadas del mes anterior habían evolucionado hacia un conflicto entre el liberalismo conservador y el progresista, que la Junta constituida no pudo atemperar. A esto habría que sumar el temor a la represión gubernamental, las noticias de los pronunciamientos a favor de la Constitución en otras ciudades y especialmente el aumento de la actividad carlista. El 8 de septiembre la Junta pedía la destitución del ministerio a quien culpaba de los males del país y el día 14 se disolvió, siendo los miembros más populares los que intervinieron exigiendo la democratización de la milicia y represalias contra los ultrarrealistas. Ante la negativa, el día 17 por la mañana un grupo pidió al capitán de bomberos Pedro Fuster que intercediera con el Capitán general, conde de Almodóvar, para satisfacer sus exigencias. La situación se complicó y por la tarde, fue el propio Almodóvar quien se sintió amenazado y tuvo que huir. El día 20, la milicia tomó el control de la ciudad y comenzaron las detenciones a los que se llevó a la Ciudadela a la espera de su deportación. $^{78}$

Entre los destinados a Ceuta el librero y editor Mariano Cabrerizo, el médico Mariano Batllés, el teniente coronel Juan Antonio Escalante y otros tres de los que desconocemos su profesión. A Filipinas tenían que ir: José Fajarnés, abogado; Lorenzo Milans, hijo del general; Cándido Mesa, coronel retirado; Vicente Ferrandis, zapatero; Esteban Paluci, maestro de escuela; así como otros siete de los que desconocemos su dedicación. Uno debía ir a La Habana y dos quedarían en los presidios de Cartagena y

\footnotetext{
${ }^{77}$ Vicente de la Fuente, Historia de las sociedades secretas antiguas y modernas en España, tomo II, pp. 20-23; Javier de Burgos, Anales del reinado de doña Isabel II, tomo II, p. 347.

${ }^{78}$ Vicente Boix, Historia de la ciudad y reino de Valencia, Imprenta de D. Benito Montfort, Valencia, 1847, tomo III, pp. 311-323; Enric Sebastià, La revolución burguesa, vol. I, pp. 147155.
} 
Cádiz. ${ }^{79}$ De estos, solo Boggiero y Batllés habían tenido actividad en las Juntas anteriores al día 17. Para los sectores moderados el peligro no se circunscribía únicamente a los alborotadores miembros del pueblo llano. Los líderes progresistas lo eran en igual o mayor medida, por lo que hay primacía en este grupo social entre los castigados.

Cabrerizo fue embarcado con el resto en dirección a Ceuta el 21 de septiembre y llegaron el 6 de octubre, siendo encerrados en un cuartel para presidiarios en el Monte Hacho. El gobernador de Ceuta, José Villamil, tras hablar con dos miembros de la escolta, les trasladó esa misma tarde al pabellón de los oficiales. Gozaron de total libertad, además de ayuda y muestras de afecto de las autoridades de la plaza. El día 1 de noviembre Cabrerizo y Mariano Batllés fueron a Cartagena. Fortuna parecida tuvieron los que habían de ser enviados a los otros puntos, puesto que tras realizar una escala en Cádiz la milicia de esa ciudad consiguió convencer al gobernador general de que los dejara en libertad. ${ }^{80}$

La ciudad más agitada políticamente era la de Barcelona. En verano de 1835 se habían producido distintos tumultos. El primero, el 27 de julio, tomó cariz anticlerical pero en medio de la fuerte crisis derivaron hacia un mayor carácter político y social. ${ }^{81} \mathrm{El}$ general Bassa fue asesinado y el 5 de agosto se incendió la fábrica Bonaplata, en una actuación de las clases populares contra la proletarización. En el campo los excluidos se aproximaron hacia el absolutismo, pero en la ciudad lo hicieron hacia posiciones avanzadas dentro del liberalismo. En ambos casos se trató de la aproximación a la política a través de medios violentos de unos ciudadanos que estaban destinados a permanecer fuera, por lo que no se les extendieron los derechos políticos. En Barcelona, los exaltados auxiliaban a uno de los dos grupos que dentro del sistema optaban por el poder y por la imposición de sus políticas. Los más radicales políticamente y los marginados podían secundar a los progresistas, siempre que estos estuvieran fuera del

\footnotetext{
${ }^{79}$ La Revista Española, 26 de septiembre de 1835; El Eco del Comercio, 3 de noviembre de 1835. Una carta de un lector se queja de la arbitrariedad contra los detenidos en Valencia.

${ }^{80}$ Mario Cabrerizo, Historia de mis vicisitudes políticas desde 1820 a 1836, Imprenta de Mario Cabrerizo, Valencia, 1854, pp. 147-150. Expone que los deportados a Filipinas iban a ser catorce, por lo que seguramente contaría en este envío al que debería haberlo sido a La Habana $\mathrm{y}$ los dos que fueron destinados a los presidios.

${ }^{81}$ Anna Maria Garcia Rovira, "Liberalisme «no respectable» i poble menut urbà. Bullangues i revolució liberal (1832-1835)", Recerques. Història, Economia i Cultura, núm. 22, 1989, pp. 59-62.
} 
poder. Cuando ostentaran la autoridad suponían un grave peligro ya que sus acciones incontroladas podían dificultar el mantenimiento del orden público.

En septiembre de 1835 Mendizábal fue nombrado presidente del Gobierno y en octubre Espoz y Mina, que ya había realizado deportaciones durante el Trienio, fue nombrado Capitán general de Cataluña. Tras los sucesos del día 4 de enero de 1836, el día 5 se intentó infructuosamente proclamar la Constitución de 1812. Esa misma noche comenzaron las detenciones. Parece ingenuo pensar que dado el estado de excitación política en Barcelona y las actividades conspiratorias a través de las sociedades secretas presentes en la ciudad, ${ }^{82}$ no hubiera participación alguna de estas avivando las bullangas y que los actos violentos fueran simplemente obra de un populacho descarriado. La incitación a la rebelión era difícil de probar, aunque esto no supuso un obstáculo insalvable para las autoridades que reprimieron sin llevar a cabo ninguna investigación. Mina no pretendió aclarar demasiado los incidentes y utilizó los hechos para descabezar a los avanzados de la ciudad, incluyendo entre los mismos a muchos que ni siquiera habrían participado en los incidentes. Decenas de culpables de los asesinatos quedaron impunes.

Los apresados y relegados a Canarias fueron 19, la mayoría militares, abogados, comerciantes, hacendados y en menor medida algunos con distintos oficios. Aviraneta y Soler negaban toda responsabilidad en los acontecimientos del 4 y 5 de enero, e incluso el primero aseguraba que estaba en Barcelona enviado por el presidente del Gobierno, Juan Álvarez Mendizábal, para desenmascarar las intrigas de los carlistas y de los moderados y que se le ordenó que colaborara con Mina. Los dos acusaban principalmente a Feliu de la Peña, a Ramón Xaudaró, director de El Catalán y a quien consideraban espía de Mina, y a las autoridades de Barcelona que por inacción y contribución pasiva en los sucesos del día 4 y por incitar a que se produjera la proclamación de la Constitución del día $5 .^{83}$

\footnotetext{
82 Joaquín del Castillo y Mayoné, Las bullangas de Barcelona o sacudimientos de un pueblo oprimido por el despotismo ilustrado, Imprenta de A. Gaspar y Cía., Barcelona, 1837, pp. $37-$ 69; Antonio Pirala, Historia de la guerra civil y de los partidos liberal y carlista, tomo II, pp. 398-404; sobre las sociedades secretas en Barcelona ver, Anna Maria Garcia Rovira, "Sociedades secretas, facciones y partidos políticos durante la revolución liberal. La Barcelona revolucionaria (1835-1837)", Trienio. Ilustración y Liberalismo, núm. 32, 1998, pp. 68-102.

${ }^{83}$ Eugenio de Aviraneta e Ibargoyen y Tomás Bertrán Soler, Mina y los proscriptos, Imprenta de la Colonia, Argel, 1836, pp. 10-23 y 45-46. Los deportados eran Antonio Gironella, comerciante y comandante del $6^{\circ}$ batallón de la Guardia Nacional de Barcelona; José Montero, coronel de infantería; Eugenio de Aviraneta, comisario de guerra; Tomás Bertrán Soler, abogado y hacendado; Ignacio Bonifaci, peluquero; Ignacio Valart, cafetero y Guardia Nacional
} 
Según Aviraneta, la medida fue una actitud injustificada de Mina sobre inocentes, pero Ollé Romeu ha demostrado la participación de algunos: Gironella, capitaneando su batallón inició la proclamación de la Constitución; acerca de Montero se desconocía su intervención en los hechos del 5, pero de algún modo contribuyó en los del día 4; sobre Aviraneta y Bertrán Soler que de una u otra manera estaban involucrados. De Pons, que su posible intervención sería de manera individual. Sobre Raüll que su implicación no sería importante, pero que su faceta como periodista y escritor no gustaba a Álvarez y que ya fue deportado por Mina en 1823 por ser opositor político y sobre todo por criticar "la manera com el cap militar va recaptar diners abans de partir cap l'exili". En todo caso formarían parte de un plan más amplio de represión de los avanzados que incluiría purificaciones en la Guardia Nacional. ${ }^{84}$ La inclusión del muchacho tuvo como objetivo escarmentar a los grupos de adolescentes que tomaban partido en las bullangas. De hecho, el 1 de febrero de 1836 remitió a otros 15 jóvenes de entre 11 a 15 años a Ibiza bajo la etiqueta de "vagos malentretenidos, sin domicilio fijo, sospechosos fundamentalmente de rateros". ${ }^{85}$ La punición se centró sobre buena parte de los liberales progresistas influyentes de la ciudad, pero también tuvo un componente popular al alcanzar a algunos grupos que rozaban la marginalidad.

Mina se defendía diciendo que su decisión era ilegal, pero que de no haber hecho uso de ella les tendría que haber formado un consejo de guerra, que le hubiera obligado a realizar ejecuciones. ${ }^{86} \mathrm{El}$ castigo hubiera sido mayor para los participantes, pero esto no indica que hubieran tenido que ser ejecutados ya que los hechos del 4 no se investigaron y no había muertes que se les pudieran atribuir. Un castigo judicial

de caballería; Peregrín Negre, peluquero; Salvador Champané y Juan Rojas, sastres; Francisco de Paula González, abogado; José María Pons, capitán de migueletes; Francisco Raüll, alcalde primero, abogado y capitán de la Guardia Nacional; Agustín Gal, veterinario y teniente de la Guardia Nacional; Juan Nevot, cafetero; Domingo Vila, capitán de la Guardia Nacional; Francisco Padró, fabricante de fideos y Guardia Nacional de caballería; Agustín Salazar, oficial de la Diputación Provincial y teniente de la Guardia Nacional; Jaime Vidal, aprendiz de pintados y de catorce años de edad; y José Galindo, primer actor dramático y teniente de la Guardia Nacional.

${ }^{84}$ Josep María Ollé Romeu, Les bullangues de Barcelona durant la Primera Guerra Carlina (1835-1837), 2 vols., El Mèdol, Tarragona, 1993-1994, vol. I, pp. 318-326.

${ }^{85}$ Isidoro Macabich, Historia de Ibiza, vol. II, pp. 288-289; Manuel Santirso, Revolución liberal y guerra civil en Cataluña, p. 322; el gobernador militar de Ibiza los devolvió sugiriéndole que pudiera destinarlos a algo útil para la sociedad como "un depósito de tambores para el ejército". Lo insólito de esta situación se convirtió en autentico esperpento cuando el Consejo de Ministros otorgó en 14 de febrero de 1836 la facultad de deportar a Ibiza a "cuantos vagos y putas se hallaran en el Principado". Se avalaba de éste modo cualquier posible acción de Mina.

${ }^{86}$ Antonio Pirala, Historia de la guerra civil y de los partidos liberal y carlista, tomo II, p. 403. 
necesitaba la aportación de algún tipo de pruebas, mientras que la deportación podía emplearse sin necesidad de evidencias y con la ventaja de sacarles inmediatamente de Barcelona. La sustentación de un proceso penal, especialmente si se pedían penas muy severas, podría haber reproducido los incidentes en la ciudad por lo que amparándose en no realizar ejecuciones hizo lo que más convenía a sus intereses, que era desembarazarse de los elementos que consideraba más perjudiciales. La mayoría de represaliados eran liberales avanzados de la pequeña y media burguesía que incluso pudieron en algunos casos excitar a las masas, pero no parece que de su perfil se derivara la autoría de los asesinatos.

El 4 de febrero el comandante general de Canarias informó de la llegada del Artemisa. Pidió que la medida no se generalizara puesto que en el archipiélago ya había sujetos radicales y alertaba de que no disponía de medios para la "seguridad, vigilancia y manutención" de los recién llegados. El Consejo de Ministros ordenó que a los militares se les pagase el sueldo de excedentes, a los funcionarios el de cesantes y a los paisanos un socorro de acuerdo a su condición. Fueron distribuidos entre Santa Cruz de Tenerife y Las Palmas. ${ }^{87}$ El brigadier José Marrón era un viejo amigo de Aviraneta y de otros y les ayudó económicamente. Todos permanecieron libres y gozando de completa libertad y recibiendo ayuda de las autoridades y de los liberales de la isla. Aviraneta incluso se vanagloria de haber organizado en Canarias "la sociedad Isabelina". Finalmente Aviraneta y Bertrán Soler se fugaron en una goleta mercante catalana un par de meses después de su llegada, con dirección a Cádiz, donde reanudaron sus intrigas. ${ }^{88}$ La ayuda gubernamental y privada muestra el buen trato hacia estos a los que no se quería infringir sufrimiento añadido.

El Capitán general de Cataluña se opuso a su retorno, por lo que el 3 de junio el Consejo de Ministros permitió que pudieran repatriarse a condición de que establecieran su residencia en Madrid. Allí probablemente pensaron que estarían más vigilados y que

\footnotetext{
${ }^{87}$ Archivo General de la Administración (en adelante AGA), Presidencia del Gobierno, Caja 51/67. La posibilidad de regreso no se aplicó a los fugados Aviraneta y Bertrán Soler; El Español, 25 de marzo de 1836. En Tenerife estuvieron Gironella, Montero, Aviraneta, Bertrán, Galindo y Rojas y el resto en Las Palmas.

${ }^{88}$ Pedro Ortiz-Armengol, Aviraneta o la intriga, Espasa-Calpe, Madrid, 1994, pp. 398-402. En Cádiz contactó con Tiburcio Campe que fue quien le imprimió el Mina y los proscriptos, aunque le pusieron en el pie de imprenta Argel para despistar; el agradecimiento a las autoridades civiles y militares y a la población que les ayudo también lo manifiestan otros deportados, ver Antonio de Gironella, Manifiesto de don Antonio de Gironella, primer comandante del $6^{\circ}$ batallón de línea de la Guardia Nacional de Barcelona, Imprenta de Vicente Bonet, Santa Cruz de Tenerife, 1836, pp. 10-11.
} 
su evasión a Barcelona seria más dificultosa. El regreso no se produciría de manera inmediata para todos, ya que Raüll afirma que permaneció diez meses en Gran Canaria, ${ }^{89}$ por lo que no se produjo hasta después del Motín de la Granja. Aun así, la libertad de que gozaron y la ayuda gubernamental indican que no estaba en la intención del Ejecutivo sobrepasar la vulneración de derechos de los individuos más allá de lo que consideraban estrictamente necesario. Eran liberales considerados demasiado radicales o descarriados, pero correligionarios al fin y al cabo en un momento en que todavía no se había consumado definitivamente la ruptura y había un enemigo común alzado en armas.

La policía estuvo en casa de Xaudaró, Mata, Ferrer, Degollada y en otros domicilios. Degollada evitó la deportación huyendo de la policía y otros estuvieron encarcelados un breve tiempo. ${ }^{90}$ Peor suerte tuvieron Miguel Ferrer, teniente del batallón de la Blusa y catedrático de medicina, y Ramón Xaudaró, director de $E l$ Catalán. Según afirma Xaudaró, durante los disturbios acompañó a las autoridades, tratando de que no hubiera ningún derramamiento de sangre. Sea como fuere, recibió la orden de cesar la publicación del periódico y aunque pudo escapar momentáneamente por la delación de un amigo, el día 19 fue detenido. Después de negarse a colaborar con Mina, acompañado de Ramón Ferrer fue llevado en la corbeta Aurelia a La Habana, desde donde se les condujo al fuerte del Morro en el que permanecerían presos hasta el 25 del mismo mes, en que fueron embarcados de nuevo rumbo a La Coruña donde se les liberó y permanecieron bajo vigilancia de las autoridades. Xaudaró se estableció temporalmente en Madrid, donde fundaría un nuevo periódico. ${ }^{91}$ Aviraneta clamaba por

\footnotetext{
${ }^{89}$ AGA, Presidencia del Gobierno, Caja 51/67. La posibilidad de regreso no se aplicó a los fugados Aviraneta y Bertrán Soler.

90 Joaquín del Castillo y Mayoné, Las bullangas de Barcelona o sacudimientos de un pueblo oprimido por el despotismo ilustrado, pp. 65-67; Rafael Degollada, Memoria del abogado don Rafael Degollada, en defensa de su honor ultrajado, Imprenta Senés, Marsella, 1839, p. 8; Josep María Ollé Romeu, Les bullangues de Barcelona durant la Primera Guerra Carlina, vol. I, pp. 318-326; Mateu Crespí, Diario de memorias de Barcelona, AHCB, MS A-135 (1836), pp. 7-8.

${ }^{91}$ Ramón Xaudaró, Manifiesto de las injustas vejaciones sufridas por D. Ramón Xaudaró, redactor del periódico El Catalán que se publicaba en Barcelona, Imprenta de M. Calero, Madrid, 1836; Anna Maria Garcia Rovira, "Ramón Xaudaró, el «Marat barcelonés»", en Manuel Pérez Ledesma e Isabel Burdiel (eds.) Liberales eminentes, Marcial Pons, Madrid, 2008, p. 138. Expone García Rovira que pudo escapar por el aviso de su amigo José María Canalejas, quien fue su abogado en el juicio que lo llevó al cadalso. Canalejas sería uno de los ocho liberales deportados a isla de Pinos en 1837.
} 
un castigo contra los más avanzados que él y Mina los trasladó más lejos por considerarles todavía más perniciosos.

La extensión de la sublevación de 26 de julio de 1836 de Málaga por otras ciudades culminó con el pronunciamiento de la Milicia Nacional en Madrid, con el apoyo del ejército. La regente no tuvo más remedio que proclamar la vigencia de la Constitución de 1812 y nombrar jefe del Gobierno a José María Calatrava. En noviembre del mismo año, el Capitán general, Antonio Quiroga, embarcó sin formación de causa en el Joven Merced (a) Nacional a 23 implicados en la revuelta de Málaga, casi todos de la Milicia Nacional, con destino a Puerto Rico. Entre estos estaban los dos supuestos asesinos del gobernador de Málaga. Los relegados consiguieron adueñarse del barco y se dirigieron a Santo Tomás, donde las autoridades danesas les permitieron residir, y poco después fueron a Venezuela y otros países. Los altercados se reprodujeron en numerosas ciudades. A finales de agosto, 23 progresistas sorprendidos por los urbanos de Murcia acabaron en Mallorca. ${ }^{92}$ La utilización de las deportaciones iba íntimamente ligada a las luchas políticas, por esto cuando estas se extendían a otros puntos de la Península las autoridades solían responder del mismo modo, es decir, quitándose de en medio a los opositores.

Entre los represaliados observamos a muchos miembros de la Milicia Nacional, que impulsados por el ascenso al poder de los progresistas y la guerra, cobraron una importancia creciente que inquietó a los moderados. Poco antes del triunfo del motín de la Granja Quesada había intentado desarmarla, proceso que se vio abortado por la propia sublevación que al triunfar impulsó su ampliación. ${ }^{93}$ La extensión de la Milicia había posibilitado la incorporación de elementos avanzados, que al tener acceso a las armas suponían un peligro para los más conservadores. La lucha alrededor de la misma tuvo como consecuencia que fuera blanco de la represión de los moderados.

En Barcelona grupos de ciudadanos se concentraron el 15 de agosto en la plaza del Palacio pidiendo la proclamación de la Constitución. Mina se opuso pero tuvo que ceder a la presión popular. No obstante, siete u ocho liberales fueron llevados al bergantín goleta Isabel II, en donde permanecieron ocho días. Entre ellos se

\footnotetext{
${ }^{92}$ AHN, Ultramar, Leg. 5062, Exp. 31"Averiguación del paradero del Capitán del bergantín Merced"; Francisco Javier de Burgos, Anales del reinado de doña Isabel II, tomo II, p. 235; el medico Manuel de León fue a Puerto Rico, alegando no haber tomado parte en la sublevación. 93 Juan Sisinio Pérez Garzón, Milicia Nacional y revolución burguesa, CSIC-Instituto «Jerónimo Zurita», Madrid, 1978, pp. 407-415.
} 
encontraban Rafael Degollada, un habitual en estas lides, y Pedro Mata, ${ }^{94}$ por lo que cabe inducir que el resto de los candidatos a ser relegados lo formarían otros que como él estaban en el punto de mira de los conservadores y que con toda probabilidad habían sido represaliados en otras fechas. En esta ocasión, el triunfo de la revolución les permitió eludir su destino. Ya en los años 30 se observa como la composición social de la población catalana aumentará la exigencia de mantenimiento del orden a toda costa. La diferencia entre política moderada y progresista, adquiría aquí menores diferencias que en el resto del país, puesto que ambos grupos temían la conflictividad social auspiciada por la temprana proletarización.

Las deportaciones por estos sucesos se estaban produciendo fuera de la legalidad, por lo que el Gobierno se determinó a proporcionarles cobertura jurídica. El real decreto de 22 de diciembre de 1836 suponía una ruptura, ya que permitía extrañar en las islas adyacentes a los que se creía que eran conspiradores. La norma podía ser interpretada de manera que incluyera en ellas a liberales y por esto fue abiertamente criticada por muchos avanzados. La votación en el congreso arrojó un total de 103 votos a favor de su aprobación y 42 en contra, saliendo aprobada por una alianza entre los centristas y la derecha. Los debates en el Congreso y en la prensa acerca de esta represión contrastaban con las pocas noticias aparecidas y la nula defensa de la situación de los carlistas. $^{95}$

La fractura entre moderados y progresistas apareció con rotundidad debido a que encarnaban proyectos políticos diferentes. Ambos habían renunciado al utopismo de Constitución de Cádiz y al sufragio universal, pero los progresistas pretendían reformas

\footnotetext{
${ }^{94}$ Joaquín del Castillo y Mayoné, Las bullangas de Barcelona o sacudimientos de un pueblo oprimido por el despotismo ilustrado, pp. 78-81; Rafael Degollada, Memoria del abogado don Rafael Degollada, p. 12.

${ }^{95}$ DSC, 8 de diciembre de 1838, Carlos Marichal, La revolución liberal y los primeros partidos políticos en España, pp. 132-137. Los radicales en el Congreso, unos 30, tan solo consiguieron el apoyo de algunos centristas a título individual como el de Olózaga; entre las criticas destaca la del diputado Domingo María Vila que criticaba que las deportaciones ejecutadas principalmente en Barcelona podían socavar el apoyo al régimen. Aniceto del Álvaro se mostró contrario porque vulneraba la Constitución de 1812 y la división de poderes, aunque aceptaría una reforma parcial de la Constitución. Manuel Beltrán de Lis criticaba la inseguridad jurídica que produciría y manifestó que únicamente la aprobaría si especificara que solo se podía utilizar contra carlistas. Miguel Cabrera de Nevares se oponía porque era inútil, ya que durante los seis meses el conspirador podría ocultar su conducta. Ver DSC: 4, 6, 7 y 10 de diciembre de 1836; los familiares de los deportados liberales elevaron peticiones al Congreso, valga como ejemplo el $D S C$ de 16 de julio de 1838 .
} 
graduales, que tuvieran en cuenta a una amplia base de la sociedad. ${ }^{96}$ Las medidas planteadas por los conservadores eran muy tenues, su manera de entender la política les había llevado a la connivencia con los realistas, con quienes mantenían una comunión de intereses. Las diferencias se extendían a la economía donde los moderados defendieron un sistema beneficioso únicamente para una minoría muy restringida. Los progresistas, al menos teóricamente, ponían por delante el bien general.

La legislación acerca de la deportación y su uso constituyeron un elemento más de la fractura entre facciones liberales, configurándose un grupo que creía que las reformas eran excesivamente tímidas, que el carácter del Estado era excesivamente conservador y que la lucha contra la contrarrevolución no era lo suficientemente dura. Las leyes ya la contemplaban en el caso de los ultrarrealistas, aunque sin estipular el carácter preventivo. Esta disposición podía aplicarse a estos, pero como demuestran la votación y los debates se interpretó como el intento de dar cobertura legal a la práctica que se estaba produciendo contra los más progresistas. Aquellos que pretendían enarbolar los derechos de los ciudadanos como un bastión inviolable fueron vencidos por los que anteponían el orden, el suyo, basado en un afianzamiento de su poder económico y social. Esta fue una manifestación más de una lucha, no exenta de intereses y opiniones personales, pero que en líneas generales significaba una contraposición de intereses entre grupos sociales diferentes. La ley establecía unas directrices de espacio y de tiempo para las relegaciones, pero la llegada de los moderados al poder en septiembre de 1837 las dejó en papel mojado, excediendo las Baleares y Canarias como sitio y los seis meses como límite temporal.

El día 4 de mayo de 1837 se produjo en Barcelona una nueva Bullanga en que se pedía la caída del ayuntamiento, que no había sido renovado tras la proclamación de la Constitución, y la cesión por parte del Capitán general de las competencias que había asumido sin que le correspondieran. El intento no triunfó y muchos fueron detenidos, entre estos Ramón Xaudaró que fue condenado a muerte y ejecutado. ${ }^{97}$ Xaudaró era el

\footnotetext{
${ }^{96}$ María Cruz Romeo Mateo, "La cultura política del progresismo. Las utopías liberales, una herencia en discusión", Berceo, núm. 129, 2000, pp. 25-26.

${ }^{97}$ Joaquín del Castillo y Mayoné, Las bullangas de Barcelona o sacudimientos de un pueblo oprimido por el despotismo ilustrado, pp. 121-165; el abogado de Xaudaró fue su amigo José María Canalejas quien deportado en la isla de Pinos escribió Breve reseña de los sucesos de abril y mayo de 1837 en Reus y Barcelona, con relación al juicio y sentencia de don Ramón Xaudaró, Imprenta de Julio Barile, Marsella, 1839. En este libro hace un repaso del juicio y explica las irregularidades que en él sucedieron. En última instancia la sentencia a muerte fue un intento de los moderados de atemorizar a los sectores más progresistas.
} 
líder del republicanismo barcelonés y ya en 1832 había escrito un libro titulado Bases para una Constitución política o principios fundamentales de un sistema republicano. $\mathrm{Su}$ ideología era tenida por demasiado radical incluso entre los progresistas y los moderados temían la ascendencia que tenía entre las clases populares, por lo que pretendieron ejemplificar y neutralizarla con su ajusticiamiento.

Entre los detenidos había algunos acusados de simpatizar con el carlismo, pero casi todos eran liberales considerados demasiado avanzados. Entre estos había profesores, propietarios, comerciantes y gente con oficios. La mayoría fueron llevados a Mallorca en la goleta La Mahonesa. A su llegada fueron encerrados en el Castillo de Bellver hasta su indulto el 28 de junio de ese mismo año, ${ }^{98}$ en que el temor al carlismo inicio una política de acercamiento entre facciones liberales. En esta ocasión se optó por unas medidas diferentes, un fusilado a manera de escarmiento y el resto presos, lo que auguraba un crecimiento en su intensidad. Para sectores derechistas, el simple traslado a un lugar ultramarino era considerado una pena leve. En el incremento de la punición tuvo importancia la investidura de Ramón de Meer y Kindelán, barón de Meer, como Capitán general de Cataluña en marzo de ese mismo año. Se había caracterizado por su gran autoritarismo y con el ascenso de los moderados al poder adquiría mayor capacidad de acción. También tuvieron gran influencia el jefe político Cambronero y la élite económica barcelonesa muy temerosa de las clases populares desde el incendio de la fábrica Bonaplata. A partir de octubre se dispusieron a descabezar a los progresistas para consolidar su dominio sobre Barcelona. El pretexto fue el asesinato del antiguo alcalde el 8 de octubre, Mariano Vehils, a quien los avanzados culpaban de la represión. ${ }^{99}$

La ciudad estaba en un estado de enorme tensión, pero los derechistas se vieron lo suficientemente fuertes para amputar a los grupos dirigentes de la izquierda y comenzaron una campaña de detenciones que terminarían con la realización de nuevas deportaciones que incluirían a buena parte de los habituales en estas lides, aunque extendiéndola a otros que hasta el momento habían sido intocables como Canalejas o el

\footnotetext{
${ }^{98}$ Mateu Crespí, Diario de Memorias de Barcelona, AHCB, MS A-136 (1837), pp. 32 y 42. Entre los detenidos Joaquín del Castillo, Rafael Degollada, Tomás Bruguera, Ignacio Gali, Jaime Sansano, José Botmes, Clemente Roig Molé, José Oriol Ronquillo, Joaquín Ayerve y Pasetino (que no fue trasladado), José Santamaría y José Vila; Rafael Degollada, Memoria del abogado don Rafael Degollada, pp. 18-19 y 34. Eduardo Bonelli, casado con una española y con tres hijos, fue expulsado de Barcelona; El Eco del Comercio, 3 de julio de 1837.

${ }^{99}$ Panorama Español, tomo IV, pp. 42-43.
} 
alcalde constitucional de la ciudad, Joaquín Oliver, que fue deportado a Mallorca de donde era oriundo, por lo que pudo vivir en su propia casa y rodearse de familiares y amigos. Que un hombre con su prestigio y edad fuese represaliado muestra la inseguridad jurídica para los elementos más destacados del progresismo barcelonés. Juan Vilaregut fue detenido y tras pagar sus amigos la fianza fue desterrado en Sallent. Tanto en su caso como en el de Oliver debió pesar la influencia social y el poderío económico de ambos. Respecto a los represaliados había "un diputado de provincia, un alcalde constitucional, tres comandantes de milicia, varios oficiales de ella, algunos hacendados y propietarios y otros artesanos". ${ }^{100}$ Pertenecían pues a las clases medias, verdadero soporte social del liberalismo progresista. Sus vicisitudes se explican en el siguiente epígrafe.

La deportación era un medio más en el variopinto engranaje de la represión en el que destierros y encarcelamientos eran el medio más habitual. A raíz de los sucesos de octubre de 1837, muchos individuos fueron presos en las cárceles de la Ciudadela y Atarazanas, a los que en junio de 1839 ni siquiera se les había tomado declaración. Según Crespí 500 personas fueron desterradas a otros puntos de Cataluña o de la Península. ${ }^{101}$ La relegación fue utilizada contra aquellos que eran tenidos por más peligrosos y con cierta consideración social. Fue en el caso de los liberales una pena elitista por cuanto al "populacho" se podía represaliar de manera más indiscriminada privándoles incluso de la libertad.

Las detenciones y presidios se reprodujeron en otros lugares. En Cartagena, poco antes de lo sucedido en Barcelona, habían sido aprehendidos más de 60 ciudadanos. En Cádiz, el editor y director de El Defensor del Pueblo, Tiburcio Campe, fue embarcado con dirección a Puerto Rico a finales de 1837 a pesar de su enfermedad, pero no se le

\footnotetext{
${ }^{100}$ Josep María Ollé Romeu, Les bullangues de Barcelona durant la Primera Guerra Carlina, vol. II, p. 280-282; Juan Sotorra, Historia del ilustre español don Guillermo Oliver, Imprenta de Francisco Sánchez de los Baños, Barcelona, 1841, pp. 93-107. Cuando el barón de Meer fue cesado, Oliver volvió a Barcelona a petición de sus hijos, pero se encontraba en un estado de salud muy precario por lo que murió unos pocos días después de su regreso. Antonio Ribot, que ya había regresado de la isla de Pinos le dedicó una poesía en su funeral; Rafael Degollada, Memoria del abogado don Rafael Degollada, p. 26; Roser Solà i Montserrat, Joan Vilaregut $i$ Albafull, industrial $i$ progressista (Barcelona 1800-1854), Publicacions de l'Abadia de Montserrat, Barcelona, 2001, p. 64; DSC, 16 de diciembre de 1838; los deportados a Canarias y Cuba fueron Degollada y Bruguera, junto a José Baigés, Ignacio Brugades, José María Canalejas, Ramón Casas, Antonio Giberga, Joaquín Jaumar, Miguel María de Llorella, José Malla, Jaime Menta, Ramón Millá, Bartolomé Moncerdá, Cipriano Munné, Ramón Pons, Pedro Pujades, Antonio Ribot, José Vila y Ramón Vila Figueras.

${ }^{101}$ Mateu Crespí, Diario de memorias de Barcelona, AHCB, MS A-138 (1839), pp. 26-27.
} 
permitió apearse y fue remitido a Cuba, donde la máxima autoridad colonial, Joaquín de Ezpeleta, lo remitió a Galicia. Además fueron desterrados sus tres colaboradores en el periódico, en una operación con el objetivo de silenciar la publicación. También desde Cádiz salió para Cuba Juan Antonio Escalante, acusado de intentar sobornar al cabo Lorente para que pusiera las tropas a su disposición para una rebelión contra el gobernador. No podría regresar en diez años. ${ }^{102}$

En 1838 fueron llevados a la Antilla mayor por el Capitán general de Andalucía tres hombres por "haber salido tumultuariamente del cuartel del tercer batallón de la guardia nacional de Cádiz, tocando generala”. En 1839 llegaron también desde Andalucía, Francisco Hidalgo y José Llovet, por unos incidentes producidos en la iglesia de San Felipe de Cádiz al producirse el escrutinio de las elecciones. Todos permanecieron en La Habana y se les otorgó pensión alimenticia. Hidalgo se dedicó a la fabricación de velas de sebo y Llovet al comercio, consiguiendo una posición acomodada. Ambos solicitaron que se les levantara la prohibición de volver a la metrópoli, aunque según manifestaban su deseo era permanecer allí. ${ }^{103}$ Esto en un momento en que las deportaciones a las Antillas estaban prohibidas por ley y las decisiones fueron en todos los casos despóticas.

En Barcelona, el Capitán general ordenó la aprehensión de 15 individuos, acusándoles de haber sido los ejecutores del teniente de rey y del sargento mayor de Tarragona y del general Pedro Nolasco Bassa en Barcelona. Según sus palabras: "hay que sacar de aquí esta plaga de revolucionarios incorregibles y trasladarles a pasaje y distancia en que no les sea posible ejercer su pernicioso influjo", lo que resultaba contradictorio con sus gravísimas acusaciones. Respecto a los cargos se expresaban frases como "tuvo parte en los asesinatos", "hay sospechas de que tuvo parte" o "estuvo entre los amotinados". En el caso de Tarragona, únicamente se señalaba a Pablo Orri

${ }^{102}$ Alfonso Torres de Castilla, Historia de las persecuciones políticas y religiosas, ocurridas en Europa desde la Edad Media hasta nuestros días, Imprenta de Salvador Manero, Barcelona, 1866, tomo VI, p. 1070; DSC, 18 de enero y 9 de febrero de 1839; El Eco del Comercio, 8 de diciembre de 1838 y 10 de febrero de 1839; Tiburcio Campe, Al público. Acusación contra el conde de Clonard cometida en la persona de Tiburcio Campe, Imprenta de F. Orza, La Coruña, 1838 , pp. 27-31.

${ }^{103}$ AHN, Ultramar, Leg. 4613, Exp. 11. "Expediente sobre la asignación de seis reales diarios hecha a los confinados en La Habana por el Capitán general de Andalucía, D. Antonio Flores, D. Manuel Izquierdo y D. Antonio del Pozo, y sobre la observancia de los dispuesto en materia de confinamiento a Ultramar"; AHN, Ultramar, Leg. 4613, Exp. 23. "El Capitán general de Cuba da cuenta de haber declarado comprendidos en la amnistía decretada en 30 de noviembre de 1840 a D. Francisco Hidalgo y José Llovet, confinados a aquella isla por el Capitán general de Andalucía. 
como autor material "según noticias". En cuanto a los tres implicados en el caso de Nolasco en los que se especificaban los motivos, eran jactarse de haber sido su asesino. ${ }^{104}$ Las autoridades no tenían la certeza de quien había ejecutado estos actos, por lo que optaron por una represión amplia incluyendo a sujetos sobre los que no había ninguna seguridad de haber participado en los asesinatos, aunque si lo pudieron hacer en los altercados. En las relegaciones anteriores de carácter ideológico muchos de los nombres se repetían cosa que no sucede en esta ocasión, lo que significó una extensión hacia debajo de la práctica que alcanzó a capas sociales más populares.

Fueron enviados en el bergantín goleta Joven Casimiro que llegó a su destino el 13 de diciembre de 1838. El Capitán general, Joaquín Ezpeleta, informaba que si su presencia en Cataluña era perjudicial también lo era en Cuba, dados "los gérmenes de desorden que encierra esta isla y los peligros exteriores que la amagan”, y pedía que la prohibición de remisión de facciosos se extendiera a "anarquistas o criminales". Ezpeleta procedió a su inmediato embarque rumbo a Canarias, justificando la medida en la falta de seguridad en isla de Pinos. A su llegada, el 5 de marzo de 1839 fueron diseminados la mitad en el Hierro y la otra en La Gomera, sufriendo una proscripción acentuada. Se les permitió regresar a Barcelona en octubre de 1839. ${ }^{105}$ La aprobación y la puesta en conocimiento de la medida a los jefes políticos y capitanes generales peninsulares puede considerarse una directriz para que no se repitieran de nuevo.

Las bullangas desaparecieron a partir de octubre de 1837 y la situación política estaba más apaciguada. Aun así hubo un cambio en las destinaciones, con la ascensión de los moderados la mayoría se produjeron a la Antilla mayor. Las deportaciones de carlistas efectuadas durante toda la guerra ofrecieron un destino de mayor rigor, que se

${ }^{104}$ AHN, Ultramar, Leg. 4610, Exp. 27. "Expediente sobre la fuga de seis deportados en la isla de Pinos", incluye otro referente al de 15 individuos más confinados por el capitán general de Cataluña a la isla de Pinos.

${ }^{105}$ AHN, Ultramar, Leg. 4610, Exp. 27. "Expediente sobre la fuga de seis deportados en la isla de Pinos", incluye otro referente al de 15 individuos más confinados por el capitán general de Cataluña a la isla de Pinos. Los individuos en cuestión eran: José Bosch, José Casola, Juan Simó, Baudilio Elies, Serafín Aimat, Vicente Maimó, Tiburcio Soler y Pablo Orri de Tarragona. Juan Risso, José Maisnet y Alejandro Reinoso por el crimen de Barcelona. Jaime Casellas, Gaspar Torres, Pablo Torras y Francisco Vilaseca fueron detenidos con posterioridad y se hallaban en el cuartel general de Barcelona, por lo que estarían inculpados por este asesinato; Josep María Ollé Romeu, Les bullangues de Barcelona durant la Primera Guerra Carlina, vol. II, p. 281. En 1838 Ramón Alomá y Agustín Puigsech fueron encerrados en el Castillo de Cardona. Ignoramos si su causa tenía que ver con el asesinato de Vehils, al igual que ocurre con Jerónimo Casañas que fue deportado en estos años a Baleares. Mateo Roca fue desterrado a Valencia. 
aplicó a los liberales desde el momento en que las disputas entre los partidarios de la reina se acrecentaron. Estos conformaban un grupo social diferenciado del carlismo, cultos, preparados, de mejor posición social y económica y de ascendencia urbana. Por esto, y quizá también por ser defensores de la reina, sus relegaciones se plantearon desde su origen como un simple desembarazo desprovisto de utilidad. La percepción de su mayor peligrosidad ideológica determinó que las autoridades coloniales actuaran de manera diferente, no los pusieron a trabajar y trataron de deshacerse de estos lo más rápidamente posible, llevándoles a isla de Pinos, Canarias o devolviéndolos a la Península.

Los envíos a Ultramar y los destierros decayeron. Desde agosto de este mismo año hasta julio de 1840 se sucedieron una serie inestable de Ejecutivos moderados, pero hubo la intención del Gobierno central de congraciare con los elementos más progresistas, lo que en Barcelona se tradujo en la sustitución del barón de Meer por Jerónimo Valdés en julio de 1839. Se realizaron nuevas elecciones en el ayuntamiento y en las Cortes y se posibilitó el regreso de todos los extrañados.

Aun así, poco antes de la llegada Regencia de Espartero se produciría la breve deportación del escritor Wenceslao Ayguals de Izco y otros seis vinarocenses, por una pugna entre los moderados y el grupo de tendencia demócrata. El conflicto se dio por la presidencia de las elecciones que Ayguals no quería ceder a la diputación al corresponderle como alcalde de la población. El 17 de enero de 1840, dos días antes de las elecciones, el gobernador militar de Vinaroz declaró el estado de sitio y los trasladó a las Baleares en el bergantín Plutón. El 19 de enero llegaron a Palma, pero rápidamente se ordenó su retorno. Wenceslao Ayguals fue elegido diputado a Cortes en esas mismas elecciones. ${ }^{106} \mathrm{El}$ caso del grupo de Vinaroz no fue más que un pequeño incidente de escasa duración. Además, se enmarcaba en un contexto diferente. El conflicto electoral muestra que la división entre conservadores y progresistas continuaba, pero en general la situación política estaba más tranquila y no se manifestaba en la calle con algaradas.

\footnotetext{
${ }^{106}$ DSC, 25 de marzo de 1840. No se trató de un hecho aislado, puesto que en otros lugares se produjeron numerosas irregularidades incluyendo la declaración del estado de sitio. Sin embargo, la única deportación fue la que se produjo en Vinaroz; DSC 25 de abril de 1840; $E l$ Eco del Comercio, 1 de febrero de 1840; El Genio de la Libertad, 3 de febrero de 1840; los deportados fueron el escritor Wenceslao Ayguals de Izco, alcalde constitucional y comandante de la Milicia Nacional, entre otros cargos; Demetrio Ayguals de Izco, hermano del anterior y capitán de la Milicia Nacional; Joaquín Aguilar, presbítero; Agustín Jordán, subteniente de la milicia; Zacarías Millán y Agapito Esteban, practicantes de farmacia y cirugía; y Francisco Cols.
} 


\subsection{Los ocho liberales catalanes en isla de Pinos}

En la noche del 15 de octubre de 1837 los mozos de escuadra irrumpieron en sus hogares y fueron encerrados en la Ciudadela. Se les acusaba de ser los instigadores de todas las revueltas que había habido en Barcelona desde 1833 al 1837. Una acusación genérica y que escondía las ansias de los moderados por descabezar al progresismo barcelonés. A Antonio Giberga y a Joaquín Jaumar se les trató de relacionar con el asesinato de Vehils, ya que el primero había perdonado del pago para la obtención del pasaporte a su presunto asesino, Antonio Cariñes (a) Capa Cubero. Según Cambronero, ambos habían intervenido para tratar de sacar de Barcelona a Cariñes, acusación que Giberga desmentía aduciendo que desconocía esa circunstancia y que si había accedido era por su condición de pobre. Meer no pretendió realizar ningún tipo de procedimiento judicial y ni siquiera tomó declaración a los encausados. ${ }^{107}$

El día 21 fueron embarcados en el Guadalete, un barco que según declaraban estaba en pésimas condiciones. Durante el trayecto un temporal les obligó a parar en Almería donde pudieron enviar una carta a sus familiares, una exposición a la Reina y otra a las Cortes en las que se defendían de las acusaciones y pedían castigo para el Capitán general de Cataluña por sus actuaciones arbitrarias entre las que citaban desarmar la milicia, disolver la Diputación, encarcelar al director de El Constitucional, prohibir las armas y la represión desatada. El 10 de noviembre llegaron a Santa Cruz de Tenerife donde 11 abandonaron el barco y fueron llevados al Lazareto. El resto continuaron su viaje en dirección a Cuba, trayecto durante el cual la conducta del comandante continuó siendo autoritaria, alternando actos de cortesía con otros de naturaleza contraria. ${ }^{108}$

\footnotetext{
107 José María Canalejas et al., Justificación de los deportados de Barcelona a Canarias y Pinos, pp. 5-7; carta del gobernador civil de Barcelona, José María Cambronero, a su superior inculpando a Giberga, 20 de noviembre de 1837. AHCB, 5D96 S3:40; Albert Ghanime y David Cao, Antoni Giberga $i$ el liberalisme progressista a Barcelona durant la minoria d'edat d'Isabel II, Arxiu Històric de la Ciutat de Barcelona, 2013, pp. 40-41; carta de Giberga a su esposa, s/f. AHCB, 5D96 S1:1. Giberga fue comandante de un batallón de la Milicia Nacional y diputado provincial por Barcelona.

${ }^{108}$ Cartas de los deportados en isla de Pinos a la reina y las Cortes, 8 de noviembre de 1837. AHCB, 5D96 S2:33 y AHCB, 5D96 S2:35; Joaquín Jaumar, Manifiesto del ciudadano don Joaquín Jaumar, en vindicación de las calumnias que se le han prodigado, durante su deportación a la isla de Pinos, Imprenta de Julio Barile, Marsella, 1839. Jaumar fue alcalde tercero de la ciudad, durante el periodo de Guillermo Oliver como primer edil; José María Canalejas et al., Justificación de los deportados de Barcelona a Canarias y Pinos, pp. 7-10.
} 
La responsabilidad no era exclusiva de la máxima autoridad militar, pues este realizaba sus funciones ayudado por un buen número de colaboradores. Degollada, expresaba:

\begin{abstract}
"Los mismos hombres que me suscitaron la primera persecución fueron iniciados en el club franciscano: este club, purificado de todo elemento liberal, se vino a confundir, porque conspiraba al propio fin, en la sociedad de Jovellanos: y este club y esta sociedad, que tiene escrito mi nombre y el de todo buen liberal en sus índices inversos, han sido mis constantes perseguidores y me han hecho sentir su implacable odio cada vez que han dado con autoridades débiles como Álvarez, Parreño, Pastors y Luna, que han firmado, acaso sin leer, las listas de proscripción, o con autoridades afiliadas y eminentemente despóticas como Meer o Cambronero". 109
\end{abstract}

Canalejas extendió a media docena de moderados de sus desgracias. A las causas reales no eran ajenos los intereses particulares y las rivalidades personales. En el caso de José María Canalejas era un reconocido liberal en su vertiente más radical, con una amplia trayectoria política y en la Milicia Nacional. Había combatido contra los realistas en el Trienio, fue encarcelado por el conde de España, separado de sus funciones públicas y acabó exiliado hasta su regreso en 1834. Había ocupado distintos trabajos como funcionario por lo que su salida significaría una plaza vacante y además se le acusaba de haber avisado a Xaudaró sobre su inminente detención y presionar para la liberación del preso Ignacio Balar. En la misma dirección iban Jaumar y Giberga, quien culpaba al barón de Meer y muy especialmente a Cambronero y a los moderados tanto en la ciudad como en el Gobierno central. Giberga apuntaba su propia ideología como la causa de la deportación pero la relacionaba también con la reorganización en la Milicia que habían efectuado. ${ }^{110}$

Canalejas se ofreció con otros para proclamar la Constitución de 1812 en el verano de 1836 en Barcelona y se opuso a la represión efectuada por Vehils. En enero de 1837 formó parte de un grupo que intercedió para que no se produjeran deportaciones. Esto había llevado a una situación muy tensa, en la que el general Serrano, Vehils y otros le reprendieron por no haber tomado medidas contra los

\footnotetext{
${ }^{109}$ Rafael Degollada, Memoria del abogado don Rafael Degollada, passim. La cita en p. 31.

110 José María Canalejas, El ciudadano José María Canalejas, uno de los deportados a Pinos, conjura y provoca a sus perseguidores y detractores a que denuncien los delitos y faltas que hubiese cometido como particular y como empleado, Imprenta del Constitucional, Barcelona, 1839, pp. 3-12. Balart fue posteriormente uno de los deportados junto a Aviraneta; Joaquín Jaumar, Manifiesto del ciudadano don Joaquín Jaumar; Antoni Giberga, Vindicación del ciudadano Antonio Giberga, uno de los deportados a la isla de Pinos, de las imposturas con que se le deprimió por el general Meer y el jefe político Cambronero, con sus fautores. AHCB, 5D96 S2:39.
} 
bullangueros. Además, había sido el defensor de Ramón Xaudaró en el juicio que terminó con su ejecución, en el que efectuó acusaciones a ciertos hombres y sobre las motivaciones que había detrás de los cargos. En esos momentos fueron llevadas varias personas presas a Mallorca, aunque no Canalejas, hecho que podría ser atribuido a la cercanía del ajusticiamiento de Xaudaró. Con posterioridad solicitó un cargo y le fue concedida la plaza de segundo de la secretaria de la capitanía general. Respecto a los demás, Ribot y Fontseré bordeaba el republicanismo y más tarde el socialismo utópico. ${ }^{111}$ Políticamente, formaban parte de los grupos más avanzados de Barcelona.

El grupo de los que desembarcaron en Canarias fueron remitidos a la Gomera y al Hierro y se les comunicó que su estancia allí se prolongaría durante un año. Algunos pudieron pasar a Tenerife transcurrido ese tiempo, pero no se les permitió regresar a la Península. ${ }^{122}$ A los que se quiso imponer mayor castigo, probablemente en relación a su mayor radicalidad política y significancia, continuaron hacia La Habana a donde llegaron el 19 de diciembre. Eran Tomás Bruguera, José Baigés, Rafael Degollada, Antonio Giberga, Joaquín Jaumar, Cipriano Munné, Antonio Ribot y José María Canalejas. A su llegada fueron llevados a la prisión y separados del resto de presos. Tacón les visitó y les comunicó su próxima salida a isla de Pinos, ya que de permanecer en La Habana continuarían recluidos y aunque convino en lo ilegal de su deportación, adujo que las circunstancias imposibilitaban su retorno. Tacón concilió su libertad con lo más importante para él, que no tuvieran contacto con "los vagos que pululan en las grandes poblaciones", y se comprometió a hacerse cargo de su subsistencia. Tras 16 días más en la cárcel, periodo durante el cual pudieron recibir visitas y ayuda de habaneros a título individual, el 5 de enero fueron subidos a bordo en La Habana y el día 9 llegaron a Nueva Gerona. Degollada se quejaba del agravio comparativo que sufrían ya que cientos de carlistas gozaban de libertad en Cuba. ${ }^{113}$

111 José María Canalejas, El ciudadano José María Canalejas, pp. 3-12; Jordi Maluquer de Motes, El socialismo en España. 1833-1868. Crítica, Barcelona, 1977, pp. 14 y 121. En el caldeamiento del ambiente de la ciudad contribuyeron enormemente las acusaciones sensacionalistas reiteradas de El Vapor hacia los republicanos, que culminaron en las acusaciones de conspiración para proclamar la república.

${ }^{112}$ DSC, 28 de diciembre de 1838.

${ }^{113}$ Carta de Giberga a su esposa, 10 de noviembre de 1837. AHCB, 5D96 S1:4; José María Canalejas et al., Justificación de los deportados de Barcelona a Canarias y Pinos, pp. 10-14 y 30; AHN, Ultramar, Leg. 4610, Exp. 27. "Expediente sobre la fuga de seis deportados en la isla de Pinos", incluye otro referente al de 15 individuos más confinados por el capitán general de Cataluña a la isla de Pinos. La explicación sobre la opinión de Tacón la da su sucesor en el cargo, Joaquín de Ezpeleta, quien afirma se la dio su predecesor; Rafael Degollada, Memoria 
Degollada obviaba las duras condiciones de trabajo que la mayoría de estos estaban soportando, por lo que el trato otorgado a unos y a otros les benefició ya que no fueron explotados a beneficio del Estado. Esto vino determinado por su mayor percepción de peligrosidad en la colonia, los ultrarrealistas llegados a millares y habiéndose insurreccionado contra el Gobierno eran menos temidos que un grupo de liberales que podían ayudar a difundir ideas tenidas por perniciosas. La intención de Tacón y de los gobernantes españoles en general era que la pugna en la Península entre dos maneras opuestas de entender el país no se manifestará en la Antilla mayor. Era una posesión y como tal debía permanecer indemne a ideas de libertad y emancipación, lo que significaba permanecer incomunicada, volcada en sí misma y ajena al devenir de los tiempos. Respecto a los carlistas, su pertenencia mayoritaria a un estrato social bajo, acostumbrados a tareas duras y con un perfil mucho más próximo a la reacción a un mundo cambiante en el que salían perjudicados que a la oposición política, eran elementos que pese a que en un primer momento no fueron deseados fueron aprovechados para trabajar. Los ocho, pertenecientes a las clases medias, representaban un problema puesto que su escasa fuerza de trabajo era un beneficio infinitamente menor del peligro ideológico que suponían.

En esta ocasión las denuncias en el Congreso alcanzaron su cenit. Situaciones anteriores llevadas a cabo contra los liberales se habían criticado, pero en el caso de estas deportaciones se había producido un salto exponencial al cambiar las islas adyacentes por otra situada a miles de millas y que estaba casi virgen. Al mayor atropello habría que añadir que eran los moderados los que lo habían realizado, lo que permitía a los más radicales oponerse con mayor contundencia. En este sentido cabría destacar la defensa realizada por el catalán Antonio Viadera diciendo que con estas actuaciones la aplicación de la Constitución quedaba en suspenso en Cataluña. La oposición en el Parlamento no se circunscribió a los diputados. La esposa de José María Canalejas realizó una petición para que se permitiera regresar a su marido con cargo al Estado e incluso desde ciudadanos a título personal llegaron peticiones al Congreso para que se indultara a los relegados. ${ }^{114}$

En la isla de Pinos, el 1 de agosto de 1838 había un grupo de 75 migueletes catalanes que eran utilizados en trabajos públicos junto a 8 carlistas y 20 presos. Dado

del abogado don Rafael Degollada, p. 35; carta de Giberga a su esposa, 23 de diciembre de 1837. AHCB, 5D96 S1:5.

${ }^{114}$ DSC, 2 y 9 de junio y 15 y 28 de diciembre de 1838. 
que llegaron a la isla a principios de 1838 y no hablan de ultrarrealistas, la reasignación hacia el ejército iniciada en noviembre de 1836 ya les había comprendido. Esto significa que habían sido sustituidos en los trabajos forzados de la colonia por los migueletes, de quienes Giberga se quejaba de que comían lo mismo que los presidiarios y eran tratados como tales, obligados a trabajar en las obras públicas, maltratados y mandados por capataces legitimistas. Los deportados estaban destinados al trabajo en la colonia y en ocasiones a discreción del comandante, ayudaban a los particulares. ${ }^{115}$ Uno de los milicianos, Domingo Barba, se alistó voluntariamente sirviendo más de un año. Posteriormente, según su padre, se separó del cuerpo con el fin de ver a sus progenitores y se presentó en su ciudad, donde fue aprehendido. En 1836 el Capitán general de Cataluña dispuso que fuera castigado con servir en los cuerpos de Ultramar en Cuba y con ese objeto fue embarcado en el bergantín Amnistía, con otros desertores e indisciplinados. A su llegada, el 8 de septiembre de 1836, Tacón dispuso su pase a isla de Pinos, donde aún permanecería en enero de $1841 .^{116}$

Dado que hubo 100 carlistas en la colonia, los ocho que quedaron serían aquellos que lo hicieron voluntariamente por tener allí una buena posición. Al resto se les permitiría pasar a la Antilla mayor. Resulta paradójico que los insurrectos tuvieran mejores condiciones que los combatientes liberales, por mucho que algunos resultaran desertores o indisciplinados. Por el carácter opositor de los relatores, probablemente sus condiciones no serían tan negativas y sus palabras contenían alguna exageración. Los migueletes conformaron un grupo diferente a los ocho deportados, con los que compartían algunas similitudes como su pensamiento político más o menos desarrollado según los casos, lo que motivo que el Capitán general no quisiera retenerles. Sin embargo, había diferencias, el grupo de los ocho al que se castigó únicamente por su ideología eran de carácter urbano y pertenecían a las clases medias, por lo que fueron privados de trabajar cosa que no sucedió con los migueletes a los que se castigaba por sus faltas.

Los recién llegados fueron instalados en una cabaña y se dedicaron a la lectura, a paseos y a la escritura. El gobernador al enterarse de que Canalejas y Giberga tenían nociones de matemáticas les encargó regularizar las calles de Nueva Gerona y trazar

\footnotetext{
${ }^{115}$ Carta de Giberga a su esposa, 1 de agosto de 1838. AHCB 5D96 S1:18; José María Canalejas et al., Justificación de los deportados de Barcelona a Canarias y Pinos, pp. 14-17 y 34-35.

${ }^{116}$ AHN, Ultramar, Leg. 4612, Exp. 38. "Onofre Barba, vecino de Barcelona, pide la libertad de su hijo, confinado en el presidio de isla de Pinos".
} 
una zanja para desecar unas lagunas inmediatas a la población. Comían en casa de un tendero, lo que unido al tabaco y el lavado de ropa les costaba unos 20 duros al mes. ${ }^{117}$

Explicaba Canalejas a su esposa, respecto a la dieta que mantenían:

"nuestra vida consiste en un almuerzo a las 9 de la mañana, que se reduce a uno o dos huevos fritos para cada uno y algunas veces buñuelos de bacalao con harina, algún día también hay su sopa de pan; pan y vino. A las 5 de la tarde otra comida que consiste en olla con su sopa de fideos o arroz y después un principio de carne o de bacalao".

Un día cotidiano en su vida transcurría así:

"nos levantamos a las 7 de la mañana, poco más o menos, a excepción de Jaumar, que no se levanta hasta las 9, hasta cuya hora pasamos en conversación, después de almorzar, unos leemos, otros escriben, otros hablan, otros se van a dormir un rato, y de este modo llegamos a las 5 de la tarde, hora de comer. Acabada la comida salimos a dar un paseo hasta las 8 o $8 \frac{1}{1} 2$, a cuya hora nos retiramos y pasamos en conversación hasta las 10, que nos vamos a la cama hasta el otro día, y así se van sucediendo los días y nuestra monotonía no varía en nada, no visitamos ninguna casa y no más que dos o tres nos visitan a nosotros: figúrate como estaremos". 118

En 20 de enero elevaron una nueva carta a la reina y otra a las Cortes en las que relataban lo que les había sucedido, exigían su libertad y pedían daños y perjuicios. Tenían un buen trato con el gobernador de isla de Pinos, José María Isla, especialmente Canalejas y Giberga, quienes hacían sus paseos diarios con el mismo y que fueron invitados por la máxima autoridad del territorio en el día de su santo. Giberga informaba a su mujer que el 5 de marzo de 1838 llegaron dos nuevos deportados procedentes de Cádiz, un padre de 65 años y su hijo de 19. En mayo dejaron de comer en la tienda en la que comían ya que el dueño les dijo que perdía dinero con lo que le pagaban. Después pidieron un asistente al gobernador, que les concedió a un miguelete de Vic. ${ }^{119}$

Con la sustitución de Tacón por Ezpeleta remitieron infructuosamente un escrito a este ultimo solicitando que les dejara pasar a cualquier punto de la metrópoli o del extranjero. En otra carta le pidieron conocer cuando se les expediría pasaporte y que

\footnotetext{
117 José María Canalejas et al., Justificación de los deportados de Barcelona a Canarias y Pinos, pp. 14-17, 29, 31-32 y 34-37; Juan Martínez Villergas y José Ribot y Fontseré, Los políticos en camisa, historia de muchas historias, Imprenta del Siglo, Madrid, 1847, tomo III, pp. 300-302. Ribot decía que a causa del estado lastimoso de su hacienda comían lo que podían, pero aun así, al no realizar actividad laboral alguna, hemos de considerar que recibirían algún tipo de ayuda de las autoridades; carta de Giberga a su esposa, 10 de enero de 1838. AHCB, 5D96 S1:6.

${ }^{118}$ Carta de Giberga a su esposa, 1 de agosto de 1838. AHCB, 5D96 S1:18.

${ }^{119}$ Petición de los deportados en isla de Pinos a la reina, 20 de enero de 1838. AHCB 5D96 S2:37; cartas de Giberga a su esposa, 21 de enero, 5 de febrero, 5 de marzo y 23 de marzo de 1838. AHCB 5D96 S1:7. AHCB 5D96 S1:8. AHCB 5D96 S1:9 y AHCB 5D96 S1:10.
} 
hasta ese momento se les permitiera residir en La Habana, a lo que el nuevo Capitán general contestó que a más tardar a final de año se les dejaría abandonar la ínsula, pero que hasta ese momento debían continuar allí. Cerca de expirar el año impuesto pidieron a sus consortes que intercedieran por ellos para lograr el retorno. Sin embargo, sus expectativas quedaron frustradas cuando recibieron una real orden emitida en Barcelona en 20 de julio de 1838 que prolongaba de manera indefinida su estancia aduciendo "poderosas razones de política y conveniencia pública". Como respuesta decidieron elevar una nueva exposición a la reina, pero poca fe tendrían en su efecto puesto que a excepción de Bruguera y Baigés el resto huyeron en la noche del 12 al 13 de noviembre. Junto a la prolongación de su deportación se les endurecieron las condiciones. Fueron obligados a retirarse a las diez de la noche y a no alejarse más de un cuarto de hora, e incluso al sirviente se le prohibió salir de noche. La vigilancia se incrementó y temían que se les trasladara a lugares más inhóspitos en la posesión. ${ }^{120}$ Tema aparte es tratar de conocer el papel de los que se quedaron. Canalejas y el resto no especifican el motivo, pero dicen que en ningún caso esto es síntoma de discrepancias, ni de falta de patriotismo. Por esto lo más lógico es pensar que el riesgo les parecería demasiado elevado, o incluso en algún problema de salud, ya que Baigés murió poco después en la Isla.

El comandante de isla de Pinos escribía respecto a ambos: "diferían sobremanera en el comportamiento respecto al resto, pues en sus paseos, convites y concurrencias solían no acompañarlos y hasta en el mismo trato domestico se advirtió esa misma diferencia". Su actuación fue determinante para favorecer la fuga, puesto que la noche de la huida dejaron una nota para sus dos compañeros y que daba información errónea sobre su paradero. Ambos se presentaron al comandante para entregarle la carta, en la que sus compañeros explicaban que habían cogido un buque con dirección a la Península y se disculpaban por no haberse despedido. Esto, unido a que sus dos compañeros informaron de que se habían dejado objetos personales, llevó a la máxima autoridad del territorio a disponer que tres buques reconocieran el mar y las zonas

\footnotetext{
${ }^{120}$ Cartas de Giberga a su esposa, 10 de agosto y 27 de octubre de 1838. AHCB, 5D96 S1:19 y AHCB 5D96 S1:25; petición de los deportados en isla de Pinos a la Reina, 27 de octubre de 1838. AHCB, 5D96 S2:38; José María Canalejas et al. Justificación de los deportados de Barcelona a Canarias y Pinos, p. 30-34; Juan Martínez Villergas y José Ribot y Fontseré, Los políticos en camisa, tomo III, pp. 300-302. Ribot por contra no dice nada de ninguno de estos dos individuos, pero criticaba duramente a Jaumar a quien acusaba de comer en cantidades exageradas; también Giberga acusaba a Jaumar de ser muy egoísta y explicaba a su esposa algunas tiranteces en el grupo en la carta de 22 de agosto de 1838. AHCB, 5D96 S1:20.
} 
costeras, en la creencia de que habían salido apresuradamente hacia el mar o la metrópoli. ${ }^{121}$ Una maniobra de despiste bien preparada en la que por dos medios distintos se llegaba a la misma conclusión y que tuvo un papel importante en excluir a los dos de ningún tipo de responsabilidad por la escapada de sus compañeros.

En varios intentos fallidos de evasión no habían participado ni Bruguera, ni Baigés ni Jaumar. Una carta de la esposa de Giberga le informó de que Ramón de Meer podía pedir su remisión para abrirles causa por asesinato, lo que decidió a Jaumar a unirse a sus compañeros. En realidad se mantuvieron dieciséis días en el interior de la colonia con la ayuda de los isleños, que les proporcionaban alimentos. Pero decisiva fue la ayuda de uno que los ocultó en varios lugares y finalmente les condujo a un barco que les sacaría de isla de Pinos, permitiéndoles burlar la persecución del indignado José María Isla y el cerco que había tratado de establecer por mar. Fueron trasladados al norte de la Antilla mayor y cogieron un buque para pasar a Nueva Orleans, de ahí a El Havre y haciendo escala en París fueron a Marsella donde esperaron para regresar en Barcelona. Cuando entraron en la ciudad condal recibieron ayuda de sus amigos y las autoridades no hicieron nada para detenerles. ${ }^{122}$ Bruguera volvió con el relevo de Meer al frente de la capitanía general catalana.

Las esposas e hijos de los deportados dependerían del trabajo e ingresos del varón, de manera que si no disponían de recursos su situación se vería seriamente comprometida. Esto llevó a que en la representación que elevaron a S.M. pedían que se les permitiera el retorno a Barcelona, pero que en caso contrario se les dejara al menos residir en otra provincia de España e incluso en el extranjero a fin de poder trabajar. Entre los relegados a Canarias hubo uno cuya familia tuvo que recurrir a la limosna y los fugados de isla de Pinos contrajeron deudas debido al largo viaje que llevaron a cabo. Los parientes de algunos tuvieron que verse obligados a recibir ayuda económica de amigos o tuvieron que enajenar propiedades para poder costear la educación de sus hijos. Degollada afirmaba que había tenido que vender la mitad de sus propiedades y que su despacho de abogado, antes boyante, se encontraba hundido. El drama no se

\footnotetext{
${ }^{121}$ AHN, Ultramar, Leg. 4610, Exp. 27. "Expediente sobre la fuga de seis deportados en la isla de Pinos", incluye otro referente al de 15 individuos más confinados por el capitán general de Cataluña a la isla de Pinos.

${ }^{122}$ Carta de Giberga a su esposa, 15 de diciembre de 1838. AHCB, 5D96 S1:28; Antonio Ribot y Fontseré, Mi deportación. Trobas marítimas y americanas, Imprenta de Gaspar y Cía., Barcelona, 1839, pp. 45-75. Ribot no menciona quien era su benefactor, seguramente para evitarle problemas; José María Canalejas et al., Justificación de los deportados de Barcelona a Canarias y Pinos, pp. 17-22, 26-27, 30.
} 
circunscribió al ámbito económico, puesto que sus mujeres e hijos tuvieron que encontrarse con los que habían represaliado a sus maridos y padres. ${ }^{123}$

En el plano personal, las familias sufrirían por la angustia de no saber qué iba a suceder con los relegados y la separación obligada a la que fueron sometidos. Por las cartas de Giberga sabemos que su esposa soportó muy mal anímicamente la separación, mostrándose celosa en repetidas veces y acusando a su marido de ser el culpable de lo que le estaba sucediendo. Giberga trataba repetidamente de infringirle ánimos, recordándole continuamente lo mucho que la quería a ella y a sus ocho hijos. ${ }^{124}$ Desconocemos las circunstancias del resto, que podían ser muy diferentes, pero en cualquier caso todos sufrirían emocionalmente por su deportación.

\section{LA REGENCIA DE ESPARTERO}

El prestigio alcanzado por Espartero durante la guerra le había servido para forzar el exilio de María Cristina, que salió de España el 12 de octubre de 1840. Desde entonces gobernó el país, primero en calidad de presidente del Consejo de Ministros y después como regente. Detrás de su ascenso estaban las confrontaciones entre moderados y progresistas, especialmente virulentas en lo que respectaba a la organización de la administración local. La ayuda de los progresistas permitió a Espartero doblegar a María Cristina en el pulso que ambos mantenían. Sin embargo, el nuevo regente no sería un progresista en sentido estricto y durante su mandato no se desligó de su condición de militar. La oposición hacia su figura dentro del partido fue creciendo hasta el punto de quedarse con unos apoyos insuficientes y verse obligado a tomar el camino del exilio. ${ }^{125}$

\footnotetext{
123 José María Canalejas et al., Justificación de los deportados de Barcelona a Canarias y Pinos, pp. 22-23 y 26-27; Rafael Degollada, Memoria del abogado don Rafael Degollada, pp. 5-6; carta de Giberga a su esposa, 22 de agosto de 1838. AHCB 5D96 S1:20.

${ }^{124}$ Esto se observa en repetidas cartas, valga como ejemplo las de 10 de noviembre de 1837,1 de enero, 5 de febrero, 1 de septiembre, 10 y 27 de octubre y 4 de noviembre de 1838 y 22 de febrero de 1839. AHCB, 5D96 S1:4. AHCB, 5D96 S1:11. AHCB SD96 S1:8. AHCB, 5D96 S1:23. AHCB, 5D96 S1:24. AHCB, 5D96 S1:25. AHCB, 5D96 S1:26 y AHCB, 5D96 S1:31.

${ }^{125}$ Pedro Díaz Marín, "Espartero. El regente plebeyo", en Emilio La Parra López (coord.), La imagen del poder. Reyes y regentes en la España del siglo XIX, Síntesis, Madrid, 1998, pp. 177178.
} 
En octubre de 1841 se produjo una revuelta moderada contra Espartero. El día 1 se sublevó Leopoldo O’Donnell en Pamplona, el 4 del mismo mes Montes de Oca en Vitoria y el día 5 se extendió a Vizcaya y posteriormente a Guipúzcoa. El día 7 el general Urbiztondo proclamó como regente de España a María Cristina. La intentona no cuajó en el resto de lugares donde se intentó, pero los hechos más dramáticos sucedieron en Madrid. Allí, el 7 de octubre un grupo encabezado por el general León trató de apoderarse de la futura reina para llevarla al norte. El asalto fracasó y la represión se cernió sobre ellos. En Zaragoza fue ejecutado el general Borso y en Madrid, un consejo de guerra sentenció a muerte al general León, al brigadier Gregorio Quiroga, al teniente Manuel Boria, al coronel Dámaso Fulgosio y al subteniente José Gobernado. El brigadier de Infantería Fernando Norzagaray fue condenado a pérdida de empleo y honores y seis años de confinamiento en las Marianas; el conde de Requena a seis años de encierro en el Castillo del Morro de Puerto Rico; y al teniente coronel José Fulgosio a seis años en el Hacho, con pérdida de trabajo y honores incluida. Al teniente Luis Asensio y al subteniente Juan Mier se les conmutó la pena de muerte "en la inmediata extraordinaria, que deberán sufrir en las Marianas". El general Manuel de la Concha, el teniente Coronel Ramón Nouvillas y los comandantes Joaquín Rabanet y Francisco Lersundi, así como otros implicados evitaron la pena de muerte al estar prófugos. En Bilbao se produjeron varias condenas a muerte y de presidio. ${ }^{126}$ Del resto de los acusados, algunos fueron condenados a varias penas de prisión o sus causas fueron sobreseídas.

El fusilamiento de dos generales fue desaprobado por la alta jerarquía militar. Muchos de los implicados salieron del país, consolidándose en Francia un núcleo de conspiradores moderados. El envío a las Islas Marianas puede ser considerado teóricamente como deportación por la inexistencia de presidios, como lo muestran las reales órdenes de 3 de septiembre de 1857 que recomendaba la construcción del mismo y de 20 de junio de 1861 que lo ordenaba. Finalmente Norzagaray quedó en Manila donde permaneció en libertad, algo que se haría extensible al resto. El señalamiento de Marianas como destino tenía que ver con remarcar que se les pretendía castigar con

\footnotetext{
${ }^{126}$ Nemesio Fernández Cuesta et al. Causas formadas a consecuencia de la sedición militar que tuvo lugar en la noche del 7 de octubre de 1841, Compañía General de Impresores y Libreros, Madrid, 1841; Raquel Sánchez García, Alcalá Galiano y el liberalismo español, Centro de Estudios Políticos y Constitucionales, Madrid, 2005, p. 267.
} 
severidad, ya que hace referencia a un lugar alejado e inhóspito incluso de las Filipinas, en un intento de recalcar que se les pretendía aplicar una proscripción máxima.

La relegación no formaba parte de la política del regente, puesto que ante situaciones de revuelta optó por situaciones más expeditivas. A la sublevación de Barcelona de noviembre de 1842 motivada por el rumor de un tratado de libre comercio, respondió con el bombardeo de la ciudad. Una vez sofocada, la Comisión Militar condenó a 14 individuos a ser ajusticiados, de los cuales 13 serían fusilados, y a 84 a prisiones, la mayoría durante diez años. ${ }^{127}$ Es cierto que en las políticas gubernamentales tenían peso las opiniones personales de los dirigentes, pero con una gran influencia del contexto. En el caso de las recientes deportaciones de carlistas se utilizaron para dar salida a gran cantidad de cautivos. En el de los liberales, porque suponía en parte asumir la imposibilidad de eliminar el problema ya que durante el transcurso de la guerra una represión excesivamente dura podía haber exacerbado, todavía más, las diferencias entre los partidarios de la reina. En ambos casos supusieron una salida que permitió deshacerse de disidentes sin utilizar una excesiva severidad que en ocasiones pudo incluso suponer dejar impunes ciertos crímenes. Finalizada la situación excepcional, podía volverse a las medidas habituales, que incluían ajusticiamientos, prisiones, la suspensión de todos los diarios excepto el Diario de Barcelona, la prohibición de la asociación de tejedores y multas para satisfacer la construcción de la ciudadela y para indemnizar a los particulares que habían sufrido daños. Por todo esto, en caso de producirse algún caso de deportación seria aislado. ${ }^{128}$

\footnotetext{
${ }^{127}$ La Revolución y bombardeo de Barcelona en 1842. Escrita por un sargento primero, que era en aquella época, del batallón de artillería de la Milicia Nacional de esta ciudad, Imprenta de A. Albert, Barcelona, 1843, pp. 194-196; Manuel de Marliani, La regencia de D. Baldomero Espartero, conde de Luchana, duque de la Victoria y de Morella, y sucesos que la prepararon, Imprenta de Manuel Galiano, Madrid, 1870, p. 441.

${ }^{128}$ El primer comandante del primer batallón de la Milicia, José María Guerrero, fue condenado por un motín antiesparerista en Valencia a seis años de "confinamiento en la plaza de Mahón" aunque la información dice que fue él quien lo abortó. Desconocemos si seria preso o deportado por la ambiguiedad del término, pero al hablar de plaza y no de presidio parece que pudo ser efectivamente deportado. Los diputados pintados por sus hechos. Colección de estudios biográficos sobre los elegidos por el sufragio universal en las constituyentes de 1869, 3 tomos, R. Labajos y Cía., Editores, Madrid, 1869-1870, tomo II, pp. 430-432.
} 


\section{CAPÍTULO 4. LA DÉCADA MODERADA. LA DEPORTACIÓN EN UN PERIODO FUERTEMENTE REPRESIVO}

\section{LA CONCEPCIÓN MODERADA DEL PODER Y LA PRIMERA REPRESIÓN}

El Partido Moderado era un conglomerado de personalidades y fracciones de distinta procedencia, desde progresistas desencantados que se habían hecho conservadores a realistas y procedentes del carlismo, cuya ideología giraba en torno a conceptos como orden, monarquía, religión y síntesis entre lo antiguo y lo nuevo. De estos elementos cabría destacar la noción de orden público como elemento primordial y necesario para la aplicación del resto de su programa. En mayo de 1844 subiría al poder Ramón María Narváez, lo que marca el inicio de la Década Moderada. De carácter autoritario, violento e intuitivo, supo ascender vertiginosamente hasta convertirse en el referente del partido y el hombre más importante de su época. ${ }^{1}$

La violencia no fue patrimonio de los moderados. Espartero se había mostrado enormemente expeditivo en el castigo de las distintas sublevaciones que habían acontecido durante su Regencia. La gran diferencia consiste en que el general ayacucho actuaba en defensa de un régimen constitucional en el que las libertades estaban garantizadas y los derechos se iban adquiriendo. El moderantismo, por el contrario, instauró una gran limitación de derechos, sustentándose sobre una base social elitista y escasa, pero poderosa.

Con los moderados la represión cobró mayor intensidad y se institucionalizó, es decir, se convirtió en política de Estado. Su propia consolidación en el poder se hizo bajo estos parámetros con 214 opositores a los gobiernos de González Bravo y Narváez ejecutados entre 1 de diciembre de 1843 y 13 de diciembre de $1844 .^{2}$ Con el ascenso al poder de Narváez se acentuaron las medidas con objeto de instaurar el orden moderado, cuya pieza angular fue la Constitución de 1845. La Ley de Vagos, en la legislatura de 1844 a 1845 demostró que la disidencia excedería de la puramente política. La creación

\footnotetext{
${ }^{1}$ Manuel Salcedo Olid, Ramón María Narváez (1799-1868), Homo Legens, Madrid, 2012, pp. 9 y 251. Constituye la más completa y reciente biografía de Narváez, aunque a nuestro juicio se da una imagen demasiado idílica de su persona y de su trayectoria política.

${ }^{2}$ El Clamor Público, 17 de diciembre de 1844.
} 
de la Guardia Civil, a caballo entre las presidencias de González Bravo y Narváez, como cuerpo para el castigo político y de traslado de prisioneros. La supresión de la Milicia Nacional y las nuevas leyes de prensa, de ayuntamientos y electoral, que reducía el censo en aproximadamente una quinta parte, hasta el $0,8 \%$ de la población. ${ }^{3}$ Fueron medidas todas ellas pensadas específicamente para mantenerse en el poder y evitar el ascenso de los progresistas tanto por la vía insurreccional como parlamentaria.

El bloqueo al acceso al poder por vías pacíficas impulsó el encumbramiento de una práctica política basada en la conspiración. Tras la muerte de Fernando VII y la entronización de un liberalismo limitado que no llegaba a otorgar derechos a las clases más populares, estas comenzaron a actuar autónomamente a través de numerosas sociedades secretas y a sufrir un proceso de radicalización. ${ }^{4}$ Las "bullangas" en Barcelona de 1835 a 1837, la revuelta antiesparterista de finales de 1842 y la contestación armada tanto de militares como de paisanos a la entronización de los moderados, muestran que había un elemento popular conspirador contra el Ejecutivo, que no se correspondía con el del progresismo mayoritario. Su extracción social y sus reivindicaciones que excedían de la ampliación del liberalismo determinaban una mayor animadversión respecto a ellos.

Lo arbitrario de las represalias posibilitaba la ejecución de deportaciones individualizadas. A principios de 1844, Abdón Terradas fue desterrado a Sigüenza y se le prohibió volver a Cataluña bajo pena de muerte. José Soler y Matas, alcalde de Barcelona, y José Oriol Ronquillo, regidor del mismo ayuntamiento estuvieron implicados en la revolución de Barcelona iniciada en septiembre de 1843 que proclamó una Junta Central, negándose a reconocer a Narváez. El final convenido de dicho levantamiento y la experiencia personal del barón de Meer, investido de nuevo Capitán general de Cataluña, influyeron en su deportación a Mallorca de la que pronto salieron camino del exilio debido a las presiones de las autoridades. Posteriormente llegaron a la misma isla el catedrático y exdiputado Francisco Castañs y el administrador de rentas de Mataró, el primero de los cuales fue expelido a las pocas horas de su arribo hacia el extranjero, y el segundo llevado a Andratx. El general Grases recibió la orden del Capitán general, Miguel Tacón, de “fijar su residencia a Ciudadela de Menorca". A

\footnotetext{
${ }^{3}$ Francisco Cánovas Sánchez, El Partido Moderado, pp. 38-72 y 112-154; a lo que habría que añadir los mecanismos para alterar las elecciones, ver Manuel Santirso, Progreso y libertad, España en la Europa liberal (1830-1870), Ariel, Barcelona, 2008, pp. 34-35.

${ }^{4}$ Anna Maria Garcia Rovira, "Radicalismo liberal, republicanismo y revolución (1835-1837)", Ayer, núm. 29, 1998, p. 69.
} 
Mahón fue destinado de cuartel el brigadier Luna. En noviembre de 1844 fueron desterrados de la ciudad de Málaga treinta y tres liberales. ${ }^{5}$ También en noviembre, Prim fue condenado a seis años de prisión por conspiración y debía ser remitido a las Marianas, sentencia que por la intercesión de su madre a la reina no se le aplicó, con el beneplácito de Narváez. La alianza moderada con los progresistas contra Espartero fue puramente circunstancial y una vez eliminado el enemigo común, los moderados, cuyas bases sociales eran muchísimo más poderosas, no tardaron en imponerse.

Por el contrario, los partidarios y absolutistas que habían sufrido represalias, como el obispo Vélez, fueron rehabilitados. Norzagaray fue condecorado y se ordenó su regreso de las Marianas. En Asturias comenzaron a llegar a sus diócesis algunos de los religiosos que se negaron a reconocer al obispo nombrado en 1836, José Joaquín Pérez de Necochea. Las medidas tomadas por los progresistas, que atacaban los privilegios y bienes materiales de la Iglesia, reafirmaron la alineación de esta con el carlismo. Pero tras la derrota en la contienda bélica pocos en la alta jerarquía católica creían en la posibilidad de una vuelta al Antiguo Régimen, produciéndose como consecuencia un acercamiento al partido conservador. ${ }^{6}$ Estos pretendían el apoyo de la Iglesia, y esta creía que al menos podrían garantizar que no se tomaran nuevas medidas en contra de sus intereses, viéndolos como un mal menor frente a los progresistas. Desde el primer momento quedó claro qué grupos conformaban las bases sociales del moderantismo y los intereses de qué sectores de la población defenderían.

El líder republicano Víctor Pruneda, comandante de la Milicia Nacional y director del El Centinela de Aragón, fue detenido el 12 de febrero de 1844 acusado de ser el autor de un escrito que incluía un plan para una conspiración. Fue juzgado por cinco tribunales diferentes tanto civiles como militares y finalmente se le impuso la pena de destierro por cinco años a Canarias. Desde Cádiz partió en dirección a Santa Cruz de Tenerife el 2 de julio, arribando a su destino el día 7. Durante su estancia se dedicó a recopilar información sobre las islas. Probablemente permaneció toda su estancia en Santa Cruz, pero aun así realizó excursiones por Tenerife con objeto de desempeñar su investigación. Estos viajes le permitieron relacionarse con liberales de

\footnotetext{
5 Jaume Guillamet, Abdón Terradas. Primer dirigent republicà, periodista $i$ alcalde de Figueres, Institut d'Estudis Empordanesos, Figueres, 2000, pp. 113-114; El Eco del Comercio, 27 de diciembre de 1844. Francisco Castañs fue diputado por Gerona desde marzo de 1841 a enero de 1843, adscrito al progresismo templado de Olózaga; El Clamor Público, 21 de noviembre de 1844.

${ }^{6}$ El Genio de la Libertad, 8 de octubre de 1844; El Católico, 6 de julio de 1844.
} 
otras poblaciones, como de La Laguna, que le ayudaron tanto en su investigación como para su supervivencia. El 17 de octubre de 1846 fue promulgada una ley de amnistía por delitos políticos, pero el jefe político no le dejó partir hasta febrero del año siguiente, alegando que no había recibido instrucciones específicas sobre su persona. El 8 de febrero de 1837 levó anclas el Paibelot que le llevaría de regreso a la Península. Sus amigos y también trasladados, Cayetano Cardero, exjefe político de Badajoz, el general Pedro Ramírez y el coronel Pedro Tandon se encontraban bajo mando militar y por esto tuvieron que esperar algunos meses más para abandonar el territorio. ${ }^{7}$

Pruneda fue juzgado junto a Guillermo Masfarner, condenado a seis años de confinamiento como él, aunque no conocemos el destino. El otro juzgado, José Martínez, fue desterrado a diez leguas de Teruel, de Madrid y de los sitios reales. Además, la represión alcanzó a otros que fueron encarcelados y muchos otros optaron por exiliarse, así lo hicieron Narcís Monturiol, Abdón Terradas y el general Ametller. Lorenzo Rubio Caparrós fue desterrado de la provincia de Jaén durante un mes en febrero de 1844 y otros tres en 1845. En el mismo año, al abogado de ideas liberales Juan Andrés Bueno, se le obligó a fijar su residencia fuera de Llerena, donde hacía pocos días que se había establecido. ${ }^{8}$

La poca población de la isla de Tenerife en la época, 83.381 habitantes, según el propio Pruneda, ${ }^{9}$ y la libertad de movimientos de que disfrutaba, le facilitaban enormemente introducirse en los ambientes liberales y conocer personas desplazados forzosamente en la isla. Por esto, el hecho de que tan solo mencione a tres constata la poca utilización de la deportación en estos años. Es innegable que hubo otras remisiones individualizadas, como la de un pastor protestante a Canarias en 1844 y también la utilización de figuras similares, como la que le fue impuesta al brigadier Luis Raceti, quien en 1845 fue destinado de cuartel a Puerto Rico, donde estuvo más de dos años hasta su regreso en junio de 1847, pero no tuvieron nada que ver con las masivas relegaciones que afectaron a miles de carlistas en la primera de las guerras legitimistas.

El caso de Pruneda resultó enormemente engorroso. El proceso se dilató sobremanera y los conflictos de competencias, además de contribuir a su retraso

\footnotetext{
${ }^{7}$ Víctor Pruneda, Un viaje a las islas Canarias, Imprenta de Anselmo Zarzosa y Cia., Teruel, 1848, pp. 8-41 y 83-106.

${ }^{8}$ El Eco del Comercio, 23 de marzo de 1845; Jordi Maluquer de Montes, El socialismo en España, p. 285; Los diputados pintados por sus hechos, tomo I, pp. 255-257 y tomo II, pp. 279280.

${ }^{9}$ Víctor Pruneda, Un viaje a las islas Canarias, p. 68.
} 
mostraron la ineficacia de la estructura vengativa. Los moderados, si bien no tenían el más mínimo pudor de actuar al margen de la ley, tuvieron como un pilar de su actuación la institucionalización de la represión, de manera que esta resultara más eficaz, discurriera por los cauces marcados y evitara futuros problemas de sus actores por no actuar dentro de las leyes.

Conscientes de la importancia de la prensa, no escatimaron esfuerzos en relación a la misma. En junio de 1842 nació El Heraldo, que consiguió convertirse en el diario conservador más representativo del periodo. Por el contrario, la prensa de la oposición fue otro de los enemigos a batir. El real decreto de 9 de abril de 1844 que creaba los delitos de imprenta y el real decreto de 6 de julio de 1845, que aumentó los considerados en esta clasificación. ${ }^{10}$ La presión provocó que muchos periódicos fueran cerrados. Numerosos periodistas fueron desterrados, encarcelados u optaron por salir del país. Las penas impuestas por estas leyes eran pecuniarias, con el objetivo de ahogar económicamente al medio. Sin embargo, el Gobierno actuaba al margen de la ley cuando se le antojaba y podía recurrir a medios más expeditivos, como la cárcel, los destierros y las deportaciones. La especial animadversión de Narváez por la prensa opositora resultó en la detención de Fernando Corradi y Juan Pérez Calvo, redactores de El Clamor Público, a causa de un artículo satírico que publicó dicho periódico referente a una decisión tomada por el Consejo de Ministros. El 25 de mayo de 1845 ambos fueron apresados, pero Narváez no se sintió satisfecho y enseguida ordenó detener a José Gómez Cañero y a un tal Prats. Nada sabemos del segundo, pero Gómez Cañero logró evitar la acción de la policía y desde la clandestinidad continuó editando El Clamor Público. Los dos detenidos fueron llevados inmediatamente a Sevilla y desde ahí a Cádiz donde fueron encerrados en el Castillo de Santa Catalina con objeto de ser remitidos a Filipinas o a las Marianas. Las presiones del cuerpo diplomático, con el que Corradi tenía muy buena relación, salvaron a ambos de tan larga travesía y terminaron con su liberación tras dos meses presos. ${ }^{11}$

\footnotetext{
${ }^{10}$ Los delitos de prensa quedaban divididos en subversivos, sediciosos, obscenos e inmorales. Sobre estas leyes y otras leyes referentes a la prensa de los moderados, ver Alicia Fiestas Loza, Los delitos políticos, pp. 133-162.

${ }^{11}$ Manuel Ovilo y Otero, Historia de las Cortes de España, Imprenta de D. Baltasar González, Madrid, 1847, Tomo II, pp. 244-250; Francisco Pi y Margall y Francisco Pi y Arsuaga, Historia de España en el siglo XIX. Sucesos políticos, económicos, sociales y artísticos acaecidos durante el mismo, 8 tomos, Miguel Seguí, Editor, Barcelona, 1902, tomo III, pp. 581-584; El Clamor Público, 16 de enero y 27 de mayo de 1846; en las dos ediciones citadas de El Clamor Público dicen que iban a ser deportados a Marianas, Pi y Margall afirmaba que a Filipinas.
} 
En Málaga, en 28 de julio de 1845 el Capitán general ordenó la salida de la ciudad de 21 personas entre las que se encontraban distintas personalidades del Partido Progresista como "D. Luis y D. Antonio Bresca, D. Joaquín García Segovia, D. Francisco Rebul (diputado que fue a Cortes), D. Andrés Vilches, del comercio, los Castañeres, un tal Reyes, D. José Hernández y otros”. Joaquín García Segovia fue relegado a Ceuta, ${ }^{12}$ por lo que es posible que el resto sufrieran el mismo escarmiento. La proximidad de la plaza lo facilitaba.

Las sublevaciones se reproducían en diversas partes del territorio y aunque la mayoría revestían poca importancia, el Estado las contestaba con encarcelamientos, destierros y deportaciones, extendiendo los castigos sobre los progresistas más destacados. El 2 de abril de 1846 se produjo el levantamiento de Solís en Galicia. La conspiración fue planeada por los progresistas gallegos y en la misma adquirió un papel esencial el ejército, produciéndose pronunciamientos en distintos cuarteles de las principales ciudades gallegas a los que posteriormente se unieron civiles armados. Fracasada la revuelta, el día 23 del mismo mes Solís se entregaba, lo que dio inicio a la represión que acabó con su propio fusilamiento junto al de once oficiales. La pena para los máximos cabecillas fue muy dura, pero la participación había sido más amplia, comprendiendo a otros miembros de los regimientos, a integrantes del Partido Progresista y a grupos civiles entre los cuales intelectuales y provincianistas. ${ }^{13}$ Muchos lograron pasar a Portugal, pero otros fueron apresados bien por integrar las tropas que se rindieron o por ser aprehendidos con posterioridad ya que se requirieron a los ayuntamientos informes de lo sucedido durante la rebelión, lo que muestra la voluntad manifiesta de realizar unas represalias con voluntad de ser numerosas. ${ }^{14}$

El Capitán general de Galicia, José de la Concha, ordenó una distinción entre los presos. Algunos paisanos fueron desterrados hacia distintos puntos en la Península. Luis Pérez del Aya a Cádiz y Joaquín Sinian y un zapatero apellidado Pérez a distintos pueblos de la Alcarria. El progresista Francisco Huertas fue confinado en Guadalajara y Toledo, el presbítero Ignacio Oviedo, de Villafranca del Bierzo, tuvo que salir de la

\footnotetext{
${ }^{12}$ La Esperanza, 1 de agosto de 1845; Manuel Morales Muñoz, “ ¡La burguesía al poder! De la quiebra del Antiguo Régimen «la Gloriosa»", en Diego Caro Cancela (ed.), El primer liberalismo en Andalucía (1808-1868). Política, economía y sociabilidad, Universidad de Cádiz, Cádiz, 2005, p. 176.

13 Juan Do-Porto, Reseña histórica de los últimos acontecimientos políticos de Galicia, Imprenta de la viuda de Burgos, Madrid, 1846.

${ }^{14}$ Xosé R. Barreiro Fernández, El levantamiento de 1846 y el nacimiento del galleguismo, Pico Sacro, Santiago de Compostela, 1977, pp. 165-173.
} 
provincia de León y tres militares condenados a muerte a los que se conmutó la pena por diez años de presidio fueron a Ceuta. ${ }^{15}$ Estipuló la remisión a los regimientos de "La Habana y Puerto Rico" a todos los individuos de clase de tropa apresados. En un primer momento de la Concha tenía previsto que la medida afectara a unos 700 soldados y dejó en Santiago a "todos los sargentos, guardias civiles, carabineros y paisanos armados". Con posterioridad amplió la represión a estos grupos y con las nuevas remesas de soldados fueron remitidos a El Ferrol entre 1.800 y 2.000 presos, todos esperando para embarcar. $^{16}$

Se planteaba un castigo ejemplarizante que tenía como objetivo al ejército. La gran cantidad de soldados capitulados planteaba la incógnita de qué hacer con ellos. Dejarles libres era enviarles el mensaje de que la sublevación no era castigada y de permanecer en los regimientos constituían un peligro. Ejecutarles, aunque fuera de manera selectiva con el objetivo de atemorizar no era una opción factible por cuanto de la Concha les perdonó la vida antes de entregarse, lo que dificultaba la extensión a otros aprehendidos con posterioridad. Los fusilamientos se reservaron para los cabecillas, aun así, en caso de extenderse no solucionaban el problema de la multitud de presos a los que había que dar salida. La revuelta se utilizó para depurar y disciplinar de una manera muy severa el ejército. Uno de los barcos se insubordinó y pudo recabar en Portugal. La mayoría de los 286 transportados formaban parte de los batallones, pero había aproximadamente un $8,5 \%$ de civiles entre el total de deportados. Entre ellos algunas figuras del provincianismo gallego como Francisco Añón, Antonio Romero Ortiz y Antolín Faraldo. $^{17}$

\footnotetext{
${ }^{15}$ El Clamor Público, 18 de abril, 14 de junio y 11 de julio de 1846; El Eco del Comercio, 12 de julio de 1846.

${ }^{16}$ Oficio de Capitán general de Galicia a secretario de Estado y del despacho de la Guerra, 29 de abril de 1846. Oficio de Capitán general de Galicia a ministro de la Guerra, 8 de mayo de 1846. Oficios de Capitán general a gobernador de la plaza de El Ferrol, 5, 6 y 7 de mayo de 1846. Archivo General Militar de Madrid (en adelante AGMM), Ministerio de la Guerra, Sig. 5948.5 "Prisioneros capturados tras la rebelión militar en Galicia (1846)"; según Villacampa los embarcados al ejército ultramarino debían permanecer diez años y ser todos degradados y considerados soldados. Aun así, la documentación no lo específica y las decisiones acerca de la represión fueron tomadas por José de la Concha. Francisco Tettamancu, La Revolución gallega de 1846, Librería Regional de E. Carré, La Coruña, 1908, pp. 375-377.

${ }^{17}$ Camilo Fernández Cortizo, "Las «ocurrencias revolucionarias» de 1846 en Galicia. Exilio en Portugal y relaciones hispano-lusas", População e sociedade: relações Externas de Portugal, vol. 21, 2013, p. 19; El Clamor Público, 12 de julio de 1846; La Esperanza, 11 de julio de 1846; aplicando el mismo porcentaje de civiles a los 2.000 que debían ser enviados, podemos hablar perfectamente de una estimación de entre 150 a 200 deportados.
} 
La focalización de la punición en los regimientos y la inclusión de otros grupos armados muestra cual era el verdadero temor de los moderados. La política estricta merecía castigo pero por no constituir un peligro determinante podía ser menor. Levantarse en armas, y todavía más formando parte del ejército, era un acto intolerable que debía ser duramente punido. Este caso constituyó una excepción por cuanto se envió a la tropa colonial al mayor número de progresistas, cuando las remisiones masivas fueron efectuadas con carlistas. Se trataba de militares a los que se cambiaba de destino a uno peor. Pero en cualquier caso, dada la cantidad de presos y la pretendida disciplina militar, se pensó que esta fue la mejor de las opciones. La salida de la Península requería que fueran trasladados a algún punto. El temor a una insurrección en la isla, donde la composición social era muy diferente y podía ser interpretada como antiespañola, existía pero era poco probable. Algo muy alejado de las rivalidades políticas en el interior. Era además un peligro decreciente, a causa de la expansión de las enfermedades entre la tropa a causa del clima tropical. Aun así, a causa de la boda de la reina, en 17 de octubre se dictó una amnistía.

"Los expatriados podrán volver, en virtud de esta declaración, a entrar en el reino; los presos y sentenciados serán puestos en libertad desde luego y sin costas. Los recargos de servicio impuestos últimamente a la clase de tropa del ejército y armada, los declaro alzados". ${ }^{18}$

La norma contemplaba una amnistía completa por lo que podemos hablar de un trato de favor hacia los miembros de los batallones a los que una vez escarmentados se decidió reingresar a la disciplina militar peninsular, frente al sector social que representaban los ultramontanos. Los primeros años de la Década Moderada fueron de una represión muy fuerte, aunque esto no implicaba necesariamente la utilización de las remisiones a Ultramar, que no tuvieron demasiada importancia a excepción de este último caso causado por el elevado número de presos. Esto muestra que para situaciones de alteraciones del orden público con motivaciones políticas los métodos preferidos para efectuar su castigo eran otros. La utilización de la relegación cobraría especial importancia cuando los opositores a la dictadura moderada fueran capaces de articular acciones cuya importancia y percepción de riesgo para el Gobierno fuera mayor. Muy pronto, dos sucesos de ideología totalmente opuesta iban a discurrir por estos

\footnotetext{
${ }^{18}$ Real orden de 17 de octubre de 1846. CLE, Imprenta Nacional, Madrid, 1849, tomo XXXIX, pp. 39-41.
} 
derroteros: la Guerra dels Matiners y la llegada a España de la oleada revolucionaria de 1848.

\section{LA GUERRA DELS MATINERS}

La deportación a las colonias se había utilizado ampliamente en la Primera Guerra Carlista como modo de neutralizar a los prisioneros del ejército del pretendiente, lo que teóricamente facilitaba que una vez alzados de nuevo, en caso de adquirir un carácter masivo, pudiera ser empleada de otra vez. Tras la finalización de la primera contienda, partidas sueltas a menudo confundidas con el bandolerismo apolítico continuaban en los montes en ciertas zonas como el Maestrazgo o en otros puntos de la geografía peninsular en donde aparecían de manera dispersa. ${ }^{19}$ Los componentes de un grupo aprehendido en la provincia de Gerona y otro en Galicia a inicios de 1841 fueron fusilados. Acciones armadas y fusilamientos se sucedieron en Barcelona y Aragón relacionados con actividades conspirativas y también en la represión contra los grupos de trabucaires que operaban en Cataluña. En el Maestrazgo, casi todas las cuadrillas desaparecieron y sus líderes fueron fusilados en mayo de 1843. En 1844, en la campaña dirigida por el general Villalonga en el Maestrazgo, 78 fueron condenados a muerte, a los que posteriormente se les conmutó por presidio en Ultramar, y 29 fueron indultados. $^{20}$

El insuficiente poderío de los sublevados tuvo como consecuencia que la punición se ejerciera por los canales más habituales. Esto es, la combinación de ajusticiamientos, reclusión e indultos, que continuarían hasta que las acciones de los trabucaires adquirieran mayor ímpetu. La prolongación de la guerra determinó que la intención gubernamental fuera terminar de manera expeditiva con la insurrección. La limitada focalización territorial y numérica de los combatientes determinaba que las ejecuciones no fueran masivas y representaran unos números "tolerables" para el Estado.

\footnotetext{
${ }^{19}$ sobre los trabucaires ver Ferran Sánchez i Agustí, Carlins amb armes en temps de pau. Altres efemèrides d'interès (1840-1842), Pagès, Lleida, 1996.

${ }^{20}$ El Heraldo, 26 de junio de 1844; La Posdata, 29 de junio de 1844; El Boletín del Ejército, 1 de julio de 1844; Antonio Pirala, Historia contemporánea. Segunda parte de la guerra civil. Anales de la guerra civil hasta el fallecimiento de Alfonso XII, 6 tomos, Felipe González Rojas, Editor, Madrid, 1893-1895, tomo I, pp. 169-176, 198, 199 y 301-303.
} 
A finales de 1846 y principios de 1847 comenzaron a incrementarse el número de grupos y su presencia en Cataluña. Así, los encuentros y por ende, las aprensiones de montemolinistas, fueron cada vez más importantes. Tras una serie de escaramuzas dispersas entre las fuerzas gubernamentales y las carlistas, el coronel Vaxeras sorprendió a una partida el 24 de abril en Vasellas haciendo catorce prisioneros de los que 5 fueron fusilados. Acerca de los nueve restantes hay informaciones contradictorias, aunque lo más probable es que fueron enviados hacia los presidios ultramarinos. ${ }^{21}$

En mayo de ese mismo año los ultramontanos sufrieron la pérdida de sus dos cabecillas más importantes. Ros de Eroles, que se encontraba enfermo y fue muerto durante su aprensión, y Benet Tristany, que fue efectivamente detenido y fusilado en Solsona el 17 de mayo de 1847 junto con otros cabecillas y el cadáver de Ros de Eroles. De este modo, se volvía a consagrar parte del modo de proceder respecto a la primera de las contiendas legitimistas. Los cabecillas serían ejecutados sin piedad mientras que para el resto quedaba un abanico más amplio de posibilidades. Aun así, la mayoría eran castigados no por su presencia en la facción, sino por otro tipo de delitos en buena medida inherentes a la propia pertenencia a la misma, como el robo, que en muchos casos era necesario para subsistir. Por esto, la ejecución se consagró como la punición principal para la mayoría de estos, en una apuesta personal de Pavía por la severidad en las represalias. $^{22}$

Pavía estableció una represión todavía más dura que la utilizada en la guerra anterior, en la que en líneas generales se fusilaba únicamente a los cabecillas y oficiales, mientras que el resto fueron principalmente deportados y utilizados en el servicio de las armas en Ultramar o en trabajos públicos en la Península o las Antillas. Esto, realizado cuando se trataba de una confrontación de mucha menor intensidad era reflejo del carácter autoritario del Capitán general, pero a la vez tenía un significado político al desposeer a los combatientes de su carácter de disidentes y tratarles como a vulgares

\footnotetext{
${ }^{21}$ Josep María Ollé Romeu, Matiners, febrer, 1847 - 1848, febrer, PPU, Barcelona, 2007, p. 90. Dice que fueron enviados a presidio o a Ultramar; Manuel Pavía y Lacy, Memorias sobre la guerra de Cataluña, desde marzo de 1847 hasta septiembre del mismo año y desde noviembre de 1847 a septiembre de 1848, D. B. González, Madrid, 1851, p. 278. Hace una recopilación de las deportaciones desde su nombramiento, el 7 de marzo de 1847, como Capitán general de Cataluña y no menciona este caso; el único que dice que fueron deportados a Ultramar es E. Flávio, Historia de don Ramón Cabrera, Establecimiento Tipográfico de G. Estrada, Madrid, 1870, Tomo II, p. 344. Sin embargo, aún en el caso de que fuera realmente deportados constituiría un caso aislado y es indudable que la estructura general de la represión giró en torno al binomio ejecuciones y prisiones.

${ }^{22}$ Josep María Ollé Romeu, Matiners, febrer, 1847- 1848, pp. 71-242.
} 
criminales. Pavía creyó que únicamente con castigos sería capaz de controlar la conflagración, obviando las raíces de la misma: el descontento con la presión tributaria, la mala situación económica y la falta de medios de subsistencia, que incitaban a una política más conciliadora. Con la muerte de Tristany y Ros de Eroles volvió a reimplantar las quintas, siempre tan impopulares en Cataluña. El resultado fue el enquistamiento transitorio de la contienda.

Tras la reactivación de la lucha en verano de 1847, a finales de año de nuevo bajó en intensidad hasta reducirse a una mínima expresión. El Capitán general fue cesado el 1 de septiembre y sustituido por Manuel Gutiérrez de la Concha, que fue depuesto el 3 de noviembre, siendo nombrado su sucesor el propio Pavía. Su retorno a la capitanía trajo un nuevo plan de acción que combinaba diversos tipos de acciones para luchar contra los grupos alzados. Se consiguió el compromiso del Consejo de Andorra para expulsar a los carlistas en su territorio. Militarmente se aumentaron los efectivos, se mejoró la coordinación y se proclamó un somaten general que puso en una situación apurada a las partidas. El acoso al que estaban sometidos unido a los indultos a los que se acogieron gran número de los rebeldes redujo de manera importante el número de combatientes, favoreciendo el regreso a sus hogares. Estas medidas fueron acompañadas de una política de obras públicas para dar trabajo a los desempleados y la supresión de aduanas interiores en la Península para favorecer a la industria. ${ }^{23}$

La miseria y el desempleo se habían extendió entre los trabajadores afectados por la crisis económica, lo que otorga un trasfondo social innegable tanto a las revueltas de 1848 como a la Guerra dels Matiners. La réplica de las revoluciones europeas en Madrid fue tratada por la vía de las deportaciones de progresistas y pobres a Filipinas. Su espontaneidad, desorganización y escasa fuerza determinaron que se empleara únicamente la represión. En Cataluña, el enquistamiento de la contienda aconsejaba tratar con el trasfondo social del conflicto como modo de ayudar a desactivarlo.

El 15 de diciembre, Pavía publicó un bando por el que establecía que la pena de muerte fuera aplicada a los cabecillas y oficiales, a los que hubiesen cometido asesinato $\mathrm{u}$ otros actos delictivos relacionados con su actividad armada: robos, cobros de exacciones, incendios, secuestros o torturas. El castigo seria de diez años de cárcel para los procedentes de Francia, de las prisiones o del ejército. Los que no hubieran

\footnotetext{
${ }^{23}$ Manuel Pavía y Lacy, Memorias sobre la guerra de Cataluña, pp. 31-33; Robert Vallverdú, La Guerra dels Matiners a Catalunya (1846-1849). Una crisi econòmica i una revolta popular, Publicacions de l'Abadia de Montserrat, Barcelona, 2002, pp. 234-242.
} 
cometido ninguno de los delitos anteriores serían sancionados con el servicio militar en Ultramar, que sería de diez años para los capturados con las armas en la mano y seis para los desarmados. ${ }^{24}$ El Capitán general establecía una política represiva basada principalmente en los fusilamientos, ya que a la mayoría se les imputarían delitos asociados. Según esta disposición la relegación se aplicaría a un número reducido de combatientes, pero mediante una aplicación laxa de lo expuesto en la norma podía llegar a convertirse en una opción mayoritaria contra los apresados. En muchos casos, los delitos concretos para cada legitimista en particular serían difíciles de probar.

Inmediatamente después de la publicación del bando comenzaron los confinamientos. Resulta significativo que siendo el rechazo a las quintas en Cataluña una de las causas que explican la guerra, ${ }^{25}$ fuera precisamente esta el método seguido para ponerle fin por la vía de la remisión masiva a las colonias. En la línea marcada por el edicto, los miembros de este grupo serían empleados en el servicio a las armas. Pavía había aprendido de sus errores en el pasado y, sin renunciar a la brutalidad, dio a su política una mayor coherencia con el fin de acabar con la insurrección. Esto implicó sacar a la deportación del ostracismo y utilizarla como un método más de lucha contra la rebelión. Una posibilidad que se nos plantea es la inclusión de los presentados en estas expediciones. La coincidencia temporal entre varias derrotas carlistas con las presentaciones masivas a indulto hacen probable que algunos de los entregados, aquellos considerados más peligrosos, fueran incluidos en los envíos como modo cuasi definitivo de contener la amenaza que representaban.

A principios de 1848 tan solo restaban algunas partidas poco numerosas en el territorio catalán. Incomprensiblemente, el éxito alcanzado por Pavía no le granjeó el apoyo del Gobierno, que hizo caso omiso de las peticiones que el Capitán general consideraba imprescindibles para garantizar el fin completo de la contienda: continuar la política de obras públicas, realizar una compra de armas a los particulares y mantener al ejército en la zona. ${ }^{26}$ Esto provocó que a medida que el invierno se alejaba y espoleados por el triunfo de la revolución en Francia y su réplica en España, la insurrección fuera adquiriendo mayor intensidad y planificación. El 23 de junio de 1848 Ramón Cabrera entró en el país para hacerse cargo del mando supremo de las

\footnotetext{
${ }^{24}$ La Esperanza, 23 de diciembre de 1847; Manuel Pavía y Lacy, Memorias sobre la guerra de Cataluña, pp. 33-34 y 104-105.

${ }^{25}$ Carlos Seco Serrano, Historia del conservadurismo español. Una línea política integradora en el siglo XIX, Temas de Hoy, Madrid, 2000, p. 123.

${ }^{26}$ Robert Vallverdú, La Guerra dels Matiners a Catalunya, pp. 239-240.
} 
operaciones militares, suponiendo un revulsivo para las guerrillas. Su entrada supuso la unificación del mando y la consecución de una tropa más organizada y disciplinada, sin olvidar el efecto moral que produjo su presencia ya que su figura ya estaba muy mitificada durante su vida.

Ante esta situación Pavía no iba a quedarse sin actuar. El 17 de febrero de 1848 publicó un nuevo bando con la pretensión de requisar todas las armas de fuego existentes en Cataluña, otorgando únicamente permiso para su posesión a los que lo pidieran a los jefes civiles o políticos. A los que no las entregasen antes del primero de marzo se les amenazaba con ocho años de servicio a las armas en Ultramar, si fuesen aptos para el servicio, y en caso contrario se les conduciría a presidio. El 5 de marzo, previa concesión de la reina a su petición, ampliaba esta pena para los montemolinistas indultados de los que se temiera que iban a volver a reunirse con los trabucaires. A estos habría que añadir a los pobres, "dispuse que fueran recogidos todos aquellos individuos que no tuviesen padres ni hogar, o no contaran con ocupación conocida", para enviarlos con destino al ejército colonial. En 11 de junio afirmaba haber remitido a más de 400 personas. Pocos días antes había pasado una orden a más de doscientos pueblos del Principado con objeto de que se capturasen a "vagos y gentes de mal vivir", con destino a la cárcel y a los batallones de África y de las Antillas, junto con los combatientes que se le presentaran a indulto. El mismo castigo empleó para tratar de contrarrestar las posibles réplicas de la sublevación francesa en Barcelona, expeliendo a los menesterosos de la ciudad hacia sus pueblos naturales o con destino a los regimientos de Ultramar, ${ }^{27}$ en el caso de los más desarraigados. (Tablas 1 y 2).

Para esto dispuso el edificio llamado de la Virreina, situado en las afueras de la ciudad, donde eran conducidos los "vagos" que recogían los dependientes de seguridad pública. Allí se les tomaba una declaración indagatoria y se les seleccionaba para uno u otro destino. ${ }^{28}$ Esta acción poco tenía que ver con la rebelión carlista, pero muestra cómo se produjo un viraje en su modo de pensar y como consideraba a esta práctica fundamental para acabar con la disidencia de todo tipo. De hecho, el Capitán general no distinguía entre actuaciones para frenar la guerra y las sublevaciones de carácter progresista-democrático. Su intención pasaba en ambos casos por expulsar de una forma u otra a los más pobres de la sociedad. De este modo, la relegación dejó en un periodo

${ }^{27}$ El Español, 26 de febrero de 1848; Manuel Pavía y Lacy, Memorias sobre la guerra de Cataluña, pp. 53, 195, 202-203 y 215-219; El Popular, 12 de mayo de 1848.

${ }^{28}$ Manuel Pavía y Lacy, Memorias sobre la guerra de Cataluña, pp. 50-55. 
muy breve de tiempo de ser un modo de represión no utilizado a ser la piedra angular de la política de orden público de Pavía.

Tabla 1. Destinados a las armas en los batallones de cazadores de África (julio-agosto de 1848)

\begin{tabular}{llc}
\hline Nombre del barco & Fecha de Salida & $\begin{array}{l}\text { Número de individuos } \\
\text { según Pavía }\end{array}$ \\
\hline $\begin{array}{l}\text { Blasco de Garay (vapor de } \\
\text { guerra) }\end{array}$ & 4 de Julio de 1848 & 31 \\
$\begin{array}{l}\text { Lepanto (vapor de guerra) } \\
\text { Piedad (goleta mercante) }\end{array}$ & 17 de Julio de 1848 de Agosto de 1848 & 37 \\
Total de embarcados & & 47 \\
\hline
\end{tabular}

Fuente: Elaboración propia a partir de Manuel Pavía y Lacy Memorias sobre la guerra de Cataluña, pp. 276-277.

Tabla 2. Destinados al servicio a las armas a Ultramar (1848)

\begin{tabular}{llll}
\hline Fecha de embarque & Nombre de los buques & $\begin{array}{l}\text { Dirección de los } \\
\text { buques }\end{array}$ & $\begin{array}{l}\text { Número de } \\
\text { individuos } \\
\text { (Pavía) }\end{array}$ \\
\hline 4 de Enero de 1848 & Bergantín Tres de Mayo & Isla de Cuba & 49 \\
\hline 25 de Enero de 1848 & Vapor Blasco Garay & Cádiz & 93 \\
\hline 26 de Febrero de 1848 & Bergantín Triunfo & Isla de Cuba & 23 \\
\hline 18 de Abril de 1848 & Bergantín Nuevo Fígaro & Isla de Cuba & 90 \\
\hline de Junio de 1848 & Vapor Lepanto & Cádiz & 120 \\
\hline 25 de Junio de 1848 & Bergantín Jesusa & Isla de Cuba & 81 \\
\hline 16 de Julio de 1848 & Vapor Lepanto & Cádiz & 106 \\
\hline 10 de Septiembre de 1848 & Fragata Teresa Cubana & Isla de Cuba & 150 \\
\hline Total de embarcados & & & $\mathbf{7 1 2}$ \\
\hline
\end{tabular}

Fuente: Elaboración propia a partir de Manuel Pavía y Lacy Memorias sobre la guerra de Cataluña, p. 278.

Además había otros 218 que estaban en Cádiz esperando su envío, de los que 63 iban a zarpar inmediatamente y el resto se encontraba suspendido por distintas causas: por hallarse enfermos, 12; por disposición de la máxima autoridad militar catalana, 14; por no habérseles concretado su destino, 18; y por no haber llegado al depósito todavía, 111. ${ }^{29}$ De los pendientes de ser trasladados, algunos no lo serian, especialmente en el caso de los que no se habían incorporado o presentado. Otros serían posteriormente capturados o se presentarían a indulto, pero aun así, muchos conseguirían eludir su destino. Respecto a los embarcados, tres de las expediciones con un total de 319

${ }^{29}$ Ibídem, p. 278. 
personas fueron llevadas a Cádiz, esto supone que tal y como afirma Pavía fueron subidos a bordo en Barcelona, pero desconocemos si todos acabaron en las Antillas. Este sería el destino mayoritario, pero aun así, algunos podían haber ido a África o en su defecto a Canarias o Filipinas, donde estaban siendo deportados principalmente los progresistas. Otros permanecerían en Cádiz sin que su embarque definitivo se produjera.

Para conocer el perfil de los confinados hemos de acudir a las reclutas obligatorias. El Capitán general sabía que la llamada a quintas era contraproducente puesto que muchos de jóvenes preferían incorporarse a las facciones que operaban en las inmediaciones de sus casas. Sin embargo, el Gobierno presionaba para que las quintas se hicieran tal y como sucedía en el resto del país, aunque permitiendo una rebaja del 10\% del cupo y "dejando a los pueblos la libre elección de presentar los sustitutos con arreglo a lo mandado, o entregar cinco mil reales por cada quinto”. El Ejecutivo pretendía sacar un buen número de soldados para el ejército en la Península o Ultramar y una cantidad importante de dinero, a pesar de que este deseo era contraproducente sobre el terreno. Ante la falta de flexibilidad gubernamental, Pavía reaccionó haciendo levas falsas. Es decir, omitió las quintas y en su defecto envió a desempleados, pobres y vagabundos. ${ }^{30} \mathrm{~A}$ estos habría que añadir los sospechosos de colaboradores con las partidas, los presentados o los capturados desarmados, según los diferentes edictos publicados. Por esto, aunque la prensa los calificaba mayoritariamente como "facciosos", discernir el porcentaje de unos y otros no es posible por cuanto no está especificado, en determinados casos la diferencia entre ambos grupos no está claramente delimitada y además existía una voluntad explícita del Capitán general de englobarlos a todos bajo la etiqueta de carlistas.

El falseamiento de la realidad nos permite conocer hasta qué punto la guerra estuvo causada por la fuerte crisis económica y los combatientes eran gente desesperada sin recursos para subsistir. Las malas cosechas derivaron en un aumento de los precios y en la imposibilidad de abastecer a una población rural en aumento. La crisis industrial había provocado un incremento muy importante del desempleo, y con él, de gente que no podía adquirir los productos necesarios para su supervivencia. Un 30\% de los registrados como rebeldes en la demarcación de Gerona eran jornaleros y braceros, un

\footnotetext{
${ }^{30}$ Ibídem, pp. 202-206.
} 
$20 \%$ artesanos, un $17 \%$ trabajadores de la industria, un 6,5\% taperos y un $3 \%$ payeses. $^{31}$ Una caracterización como esta podía extenderse a todo el Principado, dando como resultado que la mayoría tenían un eminente carácter popular que los hacía especialmente sensibles a una situación económica nefasta. Ante su precaria situación, la máxima autoridad militar optó por quitarles de en medio preventivamente. Si el perfil medio de los insurreccionados era de alguien que carecía de medios de vida, Pavía relegó a aquellos que estaban en la pobreza y no habían tomado las armas, para asegurarse que de este modo no se unirían a los sublevados.

También desde Santander fue enviado en agosto de 1848 un contingente de 69 individuos con destino a los regimientos de Cuba. Se decía que eran soldados desertores o reincidentes, negando que se tratara de deportados por motivaciones políticas. ${ }^{32}$ Sin embargo, es posible que algunos fueran efectivamente legitimistas lo que supondría la extensión de la práctica, en un momento en que las partidas que operaban en el norte habían sido derrotadas.

El hecho de que Pavía había sentenciado al ejército ultramarino a más de 1.000 personas, empezando los confinamientos a principios de 1848 , muestra visiblemente que este modo de represaliar había sido utilizado en primer lugar contra los montemolinistas ampliándose después para la represión de los progresistas tras las revueltas de 1848, focalizadas principalmente en Madrid. Cuando el Gobierno decidió relegar masivamente a los liberales se ofreció la oportunidad de que los carlistas fueran incluidos en estas remesas a Filipinas o Canarias, ampliando el abanico de lugares utilizados como destino hasta la fecha: Cuba y Ceuta. Así, 57 trabucaires catalanes fueron embarcados en la fragata Nueva Zafiro que salió de Cádiz a principios de septiembre de ese mismo año en dirección al archipiélago asiático. Una vez en su destino el grupo de ultramontanos fue separado del resto de deportados, "A los facciosos que vinieron los han enviado a la provincia recientemente formada de Nueva Guipúzcoa. Van también algunas mujeres de esta capital para colonizar el país". ${ }^{33}$ No tenemos constancia de que fuera cierto que un grupo de féminas les acompañaba, pero

\footnotetext{
${ }^{31}$ Joan Camps i Giró, La Guerra dels Matiners y el catalanisme polític (1846-1849), Curial, Barcelona, 1978, pp. 31 y 33-40; Josep Clara, "Sobre la identitat dels matiners de les comarques del N.E. de Catalunya", Estudi General, núm. 1, vol. 1, 1981, pp. 179-185; Ramón Arnabat, "Els matiners al Penedès, una hipòtesi de treball”, Miscel-lània Penedesenca, núm. 88, 1993, pp. 414-415.

${ }^{32}$ La España, 6 de diciembre de 1848; El Espectador, 6 de diciembre de 1848.

${ }^{33}$ El Popular, 3 de septiembre de 1848; La España, 27 de abril de 1849.
} 
sí de que 50 fueron remitidos en el vapor Elcano hacia dicha provincia. ${ }^{34}$ Respecto a los otros siete es posible que evitaran este segundo destierro, pero también pudieron haber sido destinados a alguna otra provincia del sur.

Los trabucaires fueron llevados a una provincia recientemente pacificada y creada, en el extremo sur de Mindanao y muy alejada de la capital, y por tanto, del área efectivamente dominada por los españoles. Dado que en muchos puntos la presencia española se limitaba a lugares fortificados cuya población se limitaba a militares, religiosos y funcionaros, con ellos se trató de establecer una estructura que asegurase los recientes éxitos militares con el objetivo de conseguir la incorporación efectiva al dominio español de las islas de Joló y Mindanao. ${ }^{35}$ Los progresistas fueron liberados una vez en su destino y se les otorgó una ayuda por el Estado, como veremos más adelante. Los trabucaires recibirían algún tipo de apoyo del gubernamental, puesto que en caso contrario la pretendida colonización resultaría todavía más difícil. Los combatientes, acostumbrados a la guerra, al trabajo agrícola o artesanal y a las penurias de la vida en la montaña podían ser mucho más útiles en la repoblación de un territorio inhóspito que los progresistas, que mayoritariamente tenían una procedencia urbana. Esto incluiría la posibilidad de armarles para hacer frente a ataques de los naturales. Además, con los considerados ultramontanos las condiciones podían ser peores, ya que ni los oradores parlamentarios ni la prensa denunciaban su situación.

A esto habría que añadir la distinta percepción de peligrosidad. Los progresistas, con una ideología mejor formada y sus pretensiones de ampliación del liberalismo, representaban un peligro mayor para el moderantismo en los lugares de destino. El ultraconservadurismo o su defensa a ultranza de la religión católica podían ser compartidos en cierto modo por los moderados. La mayoría de los alzados eran personas con poca formación en general, característica que se extendía a la política. La defensa del rey, la religión y el orden social no dejaban de ser elementos abstractos. Muchos combatían obligados por la necesidad, para evitar las quintas, coaccionados por las partidas existentes en sus comarcas o influenciados por el clero. Otros por el afán de aventuras, la necesidad o por las ansias de botín. La mayoría no tenían unos objetivos claros de transformación política, especialmente en sus bases cuyo perfil ideológico era

\footnotetext{
${ }^{34}$ Oficio del Capitán general a intendencia de milicias, 15 de febrero de 1849. Philippines National Archives (en adelante PNA), Guerra, Leg. 136.

${ }^{35}$ Luis E. Togores "La última frontera. El establecimiento de la soberanía española en el país moro", en María Dolores Elizalde, Josep M. Fradera y Luis Alonso Álvarez (eds.), Imperios y naciones en el pacifico, CSIC, Madrid, 2001, vol. I, p. 687.
} 
más bajo. De este modo, se favorecía una distinción en el trato entre los distintos grupos opositores. Los prisioneros de guerra al ser destinados a los regimientos tendrían aseguradas sus necesidades básicas, pero lo mismo sucedió con los progresistas por vía de las ayudas establecidas. La diferencia estribaba en que los primeros, por su condición social, eran susceptibles de ser explotados en beneficio del Estado en sus lugares de relegación, algo que no sucedió con los liberales.

El Gobierno, descontento con los nulos avances de Pavía, le relevó del mando en 10 de septiembre siendo sustituido por Manuel Fernández de Córdova. El nuevo Capitán general, se mostraba favorable a que no se ejecutara a los matiners aprehendidos y que en vez de enviarlos a Ultramar lo fueran a Baleares, en donde participarían en actividades de fortificación. ${ }^{36}$ Lo efímero de su mandato hace difícil conocer hasta qué punto se produciría alguna variación en la práctica. Sin embargo, pese a verse desbordado y ser rápidamente sustituido, con él se empezaría una nueva política con objeto de atraerse a cabecillas de las partidas, sobornándoles mediante dinero y el reconocimiento de los grados militares obtenidos en el ejército carlista.

Fernández de Córdova fue destituido a finales de noviembre ante la imposibilidad de frenar el auge de las tropas montemolinistas, siendo sustituido por Manuel Gutiérrez de la Concha. Pocos días después, el 7 de diciembre, estaba cercano a salir de Barcelona el vapor de guerra Piles con 108 cautivos hechos en los últimos encuentros. El destino del barco era el presidio de la Carraca, en Cádiz, para después ser deportados a Ultramar. Una real orden de 25 de diciembre de 1848 establecía que todos los matiners apresados debían ser enviados a Puerto Rico para servir en la tropa. ${ }^{37} \mathrm{De}$ esta manera quedaba instituido cual sería el destino de los montemolinistas más allá de las actuaciones ordenadas por el Capitán general de Cataluña. El ejército colonial cubano por esas fechas se encontraría más que reforzado y se decidió que a partir de este momento los envíos se realizaran a la Antilla menor. Así, en enero de 1849 se remitió un nuevo envío de 112 prisioneros a Cádiz en el vapor de guerra Castilla, con destino a los batallones de Puerto Rico. ${ }^{38}$

Esta política de proseguir con las relegaciones como manera de arrasar la posibilidad de que las partidas continuaran reclutando hombres, implicaba el castigo de

\footnotetext{
${ }^{36}$ Antonio Pirala, Historia Contemporánea, tomo I, pp. 954-955.

${ }^{37}$ El Espectador, 12 de diciembre de 1848; Diario Constitucional de Palma, 11 de diciembre de 1848; Jesús Raúl Navarro, "El exilio carlista”, pp. 189-190.

${ }^{38}$ Oficio de ministro de la Guerra a Capitán general de Andalucía, 14 de enero de 1849. AHN, Ultramar, Leg. 6348, Exp. 12; El Clamor Público, 18 de enero de 1849.
} 
multitud de ciudadanos únicamente por el hecho de ser pobres o sospechosos. Algo cruel e injusto, pero que sin ninguna duda el Estado estaba dispuesto a asumir. No obstante, el propio desarrollo de la conflagración varió las características de la práctica. Desde el 1 de enero al 17 de abril de 1849, según los datos oficiales, habían sido capturados 1.360 soldados y 40 oficiales y 216 oficiales y 3.281 soldados se habían presentado a las autoridades. ${ }^{39}$ La política de soborno instaló la desconfianza entre las filas carlistas y el agotamiento tras un periodo tan largo de lucha y la constatación de la imposibilidad de vencer al Gobierno hicieron decaer la moral de los combatientes.

Ante esta situación de desmembramiento, el Ejecutivo respondió con confinamientos de la tropa rebelde cuya neutralización era para sus intereses perentoria. El 7 de marzo un nuevo envío de 210 matiners salió desde Barcelona en el Blasco de Garay para ser trasportados a las Antillas. ${ }^{40}$ La estrategia seguida en la primera y la segunda de las guerras legitimistas fue muy diferente. En la primera se utilizó desde el inicio y fue causa de la "menor" dureza en la represión. En los matiners, el procedimiento principal usado en los primeros momentos fueron los ajusticiamientos, pero con el tiempo se dieron cuenta de la mayor utilidad de la remisión de los prisioneros a las colonias, puesto que permitía neutralizarles sin necesidad de quitarles la vida a la vez que se sacaba provecho de su fuerza de trabajo. En las postrimerías de la contienda su utilidad se acrecentó por cuanto permitió dar una respuesta rauda al desmembramiento del ejército ultramontano.

El 14 de marzo, mediante un bando, Gutiérrez de la Concha daba un plazo de un mes a los partisanos para presentarse y poder ser amnistiados. Negaba el indulto a los que se presentasen sin armas y a los que se unieran a partir de esa fecha a las facciones. El resto sufrirían la pena de diez años de servicio militar en Ultramar, diez años de presidio con retención, o la muerte en casos de reincidencia, haber cometido asesinato, ser espías o incendiarios. Ampliaba la posibilidad de aplicar esta condena a los miembros de ayuntamientos que no comunicasen a los mandatarios listas con los vecinos que se encontraban en las partidas o a miembros de los ayuntamientos o

\footnotetext{
${ }^{39}$ Teatro de la guerra. p. 251 (biografías).

${ }^{40}$ El Popular, 13 de marzo de 1849. No fueron embarcados todos los carlistas existentes en el depósito, puesto que quedaron los sujetos a causes por delitos comunes.
} 
masoveros que no informasen inmediatamente de los movimientos de los montemolinistas. $^{41}$

La represalias sobre no combatientes ya se habían producido con anterioridad. En medio de una guerra cruenta era difícil distinguir entre colaboradores de los rebeldes y simples civiles pacíficos, lo que provocó unos castigos muy fuertes hacia la población. Especialmente cuando desde la alta jerarquía militar se pretendía la colaboración activa de ayuntamientos y ciudadanos, que en la mayor parte de los casos trataban simplemente de sobrevivir. Los destierros a otras partes del territorio español fueron corrientes y esto dio lugar a deportaciones individuales. El 31 de julio de 1847 partieron relegados, por orden del Capitán general de Cataluña, hacia la isla de Cabrera los miembros del consistorio de San Pedro de Riudevitlles por haber abandonado permanentemente el pueblo. El 10 de julio de 1848 dos miembros del consistorio de San Boi de Llobregat fueron remitidos a Mallorca por orden de la máxima autoridad militar del Principado, acusados de recaudar fondos para la guerrilla de Jaume Montserrat. Poco más sabemos acerca de su estancia allí, excepto que como ellos mismos expresaban estuvieron confinados en Palma y después regresaron a Barcelona donde "permanecieron arrestos". ${ }^{42}$ La distinción indica que las condiciones serían distintas en uno u otro lugar. Sin embargo, ambos casos pueden considerarse atípicos por los cargos que ocupaban y los delitos que se les imputaban. Es posible que se produjeran hechos similares a causa de la intransigencia de los capitanes generales que pretendían que cada uno de los pueblos catalanes participaran en su lucha contra el carlismo y que no dudaron en reprimir incluso a los familiares de los sublevados. El edicto tuvo una clara intencionalidad de amedrantar y precipitar de ese modo el fin rápido de la contienda. En cualquier caso, decretado en la fase final de la misma, tendría poco tiempo para su aplicación y su contribución seria escasa, por cuanto las partidas montemolinistas estaban ya en una fase avanzada de su inexorable derrumbamiento.

\footnotetext{
${ }^{41}$ El Clamor Público, 21 de marzo de 1849; Robert Vallverdú, La Guerra dels Matiners a Catalunya, pp. 309-315; El bando posibilitaba la deportación a América, el destierro y las prisiones a los miembros de los ayuntamientos y los masoveros.

${ }^{42}$ El Clamor Público, 6 y 7 de agosto de 1847. Información extraída de El Barcelonés; Mercè Renom "Introducció" en Ferran Balanza i González et al., Guerrilles al Baix Llobregat. Els "carrasquets" del segle XVIII, i els carlins i els republicans del segle XIX, Abadia de Montserrat, Barcelona, 1986, pp. 92 y 100. Se trataba del síndico Antonio Martí (a) Cachumbo y del regidor Josep Font. El confinamiento se les levantó hasta el 20 de septiembre de ese mismo año; Jaume Codina i Vilà, "Guerrilles i guerrillers a Sant Boi", en Ferran Balanza i González et al., Guerrilles al Baix Llobregat, pp. 185 y 188-189.
} 
Desde el comienzo del mandato de Fernández de Córdova hasta el 13 de marzo de 1848 fueron expedidos más de 1.800 indultos. Este fue el medio más empleado, lo que no garantizaba que los adscritos a él tuvieran impunidad total. Muchos fueron desterrados a otras partes de Cataluña o de la Península y tuvieron que soportar la presión social y de las autoridades. Igualmente, desde la llegada de Manuel Gutiérrez de la Concha hasta esa misma fecha fueron embarcados 577 prisioneros para las Antillas, existiendo más de 300 cautivos en distintos puntos del Principado, que debían ser trasladados a Barcelona. El 28 de abril fueron subidos a bordo del Lepanto desde la ciudad condal unos 200 con dirección hacia Cádiz, lugar desde donde zarparían hacia su destino. El 30 del mismo mes, 230 o 250 según el medio, salieron desde la misma ciudad con el mismo destino en el Blasco de Garay. El 19 de mayo, 150 más hicieron lo propio del depósito de la ciudadela de la capital catalana en el León. ${ }^{43}$ En total, entre 1.157 y 1.177 salieron durante el mandato de Manuel Gutiérrez de la Concha.

La relegación terminó utilizándose como medio masivo de expulsión de los presentados puesto que el gran número de combatientes dificultaría enormemente conocer cada caso individual. Mezclados con ellos los pobres, ya que en este periodo en el que se estaba desmoronando el ejército carlista se ordenó el embarque de todos los vagos. En una población como Valls hubo 12 mandados a Cádiz con el objeto de salir para Ultramar y uno a Filipinas. ${ }^{44}$ Haciendo extensible lo sucedido en esta ciudad al total de las poblaciones del Principado, vemos la importancia de esta práctica.

Las deportaciones no se aplicarían únicamente a los catalanes por mucho que la guerra estuviera concentrada en aquella región. Aprovechando la situación desde otros puntos, las autoridades trataron de deshacerse de los mismos grupos sociales. En Valencia, a finales de diciembre de 1848 fueron detenidos una veintena de personas acusadas de ser vagos o gentes de mal vivir y en Albacete una quincena con el mismo perfil fueron llevados a la misma ciudad. Se decía que ambos grupos iban a ser trasladados a Ultramar. También en Valencia, el 8 de marzo de 1849 entró una cuerda

\footnotetext{
${ }^{43}$ El Heraldo, 18 de abril de 1849. Información extraída de El Locomotor de Barcelona de 13 de abril; El Observador, 19 de abril y 4 de mayo de 1849; El Católico, 5 y 6 de mayo de 1849. Información recogida de El Barcelonés; El Heraldo, 6 de mayo de 1849; Diario Constitucional de Palma, 23 de mayo de 1849.

${ }^{44}$ Joan Papel i Tardía i Julio Luis Quilez Mata, La Història de Valls. Extractes de les "Anotaciones de la Historia de Valles por un vallense, anno MDCCCLXXXIV", Cossetania, Valls, 1999, p. 121.
} 
de presos en la que iba Arnau, el cuñado de Cabrera, que según un periódico local iban a ser llevados a Filipinas. ${ }^{45}$

Se observa que mientras los primeros envíos eran hacia América, poco a poco va apareciendo el archipiélago asiático como punto de destino. La utilización en el ejército perdía importancia una vez este estaba nutrido de reclutas. El precario estado de la colonización del territorio asiático hacía que allí podían ser empleados en el fomento de la población europea en el mismo. En este caso no serían empleados en el ejército, ya que la apertura del mismo a los nativos hacía que no fuera necesaria la afluencia constante de reclutas. Ocasionalmente hubo otros destinos alternativos. En Mallorca, cinco carlistas o cómplices se fugaron en 6 de marzo de ese mismo año. La noticia específica que su caso fue por un hecho excepcional, pero aun así, podría haber otros en su misma situación. ${ }^{46}$

Después de la derrota de Iturmendi en Solana, 19 partisanos fueron presos y fusilados. Pero el Capitán general del ejército del norte, Francisco Serrano, creyó que sería conveniente ofrecer un indulto de la pena de muerte para los que se presentasen en ese distrito. La reina aceptó y por real orden de 12 de febrero conmutaba la ejecución por servir en los regimientos de antillanos a los que se presentasen voluntariamente. Hostigados por las fuerzas gubernamentales y apenas sin medios muchos lograron pasar la frontera y otros, con su cabecilla Emeterio Iturmendi a la cabeza, se entregaron. Con objeto de partir hacia su destino, un grupo salió desde Pamplona a Valencia, y desde ahí a Cádiz, a donde arribaron el 3 de abril de 1849. Al menos nueve recabaron en Puerto Rico, por lo que parece lógico pensar que la mayoría irían a este destino, que por otra parte era el habitual en estas fechas. En total eran 57 matiners vasco-navarros entre los que se encontraban dos legitimistas franceses. Junto a estos quince republicanos de los valles de Roncal y Salazar que tras haberse alzado decidieron entregarse a causa de las adversas circunstancias y sufrieron el mismo destino que los matiners. ${ }^{47}$ La deportación sirvió para acallar definitivamente las armas en la zona vasco-navarra, puesto que dada la precaria situación salvar la vida fue considerado premio suficiente para muchos.

\footnotetext{
${ }^{45}$ El Observador, 7 de febrero de 1849; El Clamor Público, 11 de marzo de 1849. Información de $E l$ Cid de Valencia de 8 de marzo.

${ }^{46}$ El Popular, 15 de marzo de 1849.

${ }^{47}$ Javier Larráyoz Zarranz, "La Segunda Guerra Carlista en Navarra. 1848-1849”, Príncipe de Viana, núm. 52, 1956, pp. 181-185; El Católico, 12 de abril de 1849. Según este periódico eran de 70 matiners y 13 federales.
} 
Poco más tarde fueron detenidos y llevados a la Ciudadela de Pamplona otros catorce presos carlistas. Desde ahí fueron conducidos a San Sebastián, lugar del que salieron en el mes de marzo en el bergantín goleta Constancia con destino al ejército puertorriqueño. ${ }^{48} \mathrm{Al}$ igual que sucedió en el envió anterior, fueron relegados sin que hubiera distinción entre el tipo de pena aplicado a soldados y jefes. Esto resultaba de mayor utilidad por cuanto trataba de evitar ejecuciones innecesarias en una contienda ya prácticamente terminada. Además, facilitaba la presentación voluntaria por cuanto los combatientes rasos sabían que sus jefes no serían ejecutados, limitando las posibilidades de continuar la lucha por lealtad con sus superiores. En el caso de los oficiales facilitaba un mejor análisis de la situación y ponía en la balanza la posibilidad de una entrega voluntaria.

Las continuas remisiones de quintos unidas a las de legitimistas saturaron los batallones coloniales. Así, el 22 de junio de 1849 el intendente de Puerto Rico informaba de la llegada de 73 reclutas y de los 14 navarros apresados para los cuerpos peninsulares de la tropa. Al mismo tiempo, se quejaba de la saturación en que se encontraban los regimientos, hasta el punto de que los gastos de su manutención no se podían mantener con los ingresos. A causa de esto, el Capitán general hizo continuar un envío de 93 montemolinistas hasta La Habana y solicitaba el cese del envío tanto de "reclutas como de facciosos". ${ }^{49}$ La petición fue realizada en un momento óptimo ya que a mediados de mayo las actuaciones de las partidas eran testimoniales y la conflagración se dio oficialmente por terminada, con lo que las deportaciones perdieron su razón de ser.

Inmediatamente comenzaron a realizarse una serie de medidas con objeto de reincorporar a los ultrarrealistas a la vida cotidiana del país. A los cabecillas que lo pidieron se les incorporó al ejército isabelino. Los combatientes rasos o de rango menor, gracias a las sucesivas amnistías se reincorporaron a su vida anterior, principalmente a las tareas agrícolas en las pequeñas poblaciones o masías. De este modo, se producían sucesivos retornos de los exiliados principalmente en suelo francés y liberaciones de

\footnotetext{
${ }^{48}$ Oficio de ministro de la Guerra a Capitán general de Navarra y Vascongadas, 25 de marzo de 1849. AHN, Ultramar, Leg. 6348, Exp. 14; Javier Larráyoz Zarranz, "La Segunda Guerra Carlista en Navarra", pp. 181-184. Los deportados eran Fernando Ezcurra, Nolasco Ollobarren, Manuel Argonz, Jesús Antoñana, Pedro Antón, Jerónimo Díaz, Juan Miguel Berrenache, Esteban Astiz, Cesáreo Fernández, José Riezu, Victorio Azcárate, Joaquín Sarasa, Juan Astrain e Hilario Gaztambide.

49 AHN. Ultramar, Leg. 1069, Exp. 126. Aprobada la suspensión de reclutamiento de voluntarios y prisioneros facciosos.
} 
presos a los que en muchas ocasiones no se les permitió volver a sus hogares, obligándoles a residir temporalmente en lugares estipulados por las autoridades. ${ }^{50}$

Este hecho contrasta con la ausencia de medidas específicas para los numerosos deportados destinados a servir en Ultramar, puesto que no se estipuló nada respecto a ellos. Los moderados debieron considerar que su regreso resultaba contraproducente por cuanto habían sido utilizados para servir en el siempre escaso ejército colonial y que en la Península serían un estorbo, a causa de su condición social y del nunca extinto temor a nuevas revueltas. Esto determinó la continuación en su castigo cuando lo más justo hubiera sido que volvieran a sus hogares, máxime cuando muchos habían sido enviados por pobres y sin tener ninguna vinculación con el carlismo. La diferenciación entre progresistas y ultramontanos también se dio en cuanto a la repatriación. Los primeros pudieron regresar, al tener un perfil social diferente y haber sido represaliados políticamente el mantenimiento de su situación suponía un coste político para el Gobierno. Los matiners constituían una clase social muy baja y eran una población predominantemente rural. La prensa no denunciaba su situación y su permanencia en los puntos de relegación era útil para el Estado.

Los que tuvieron más fácil su vuelta a casa fueron los que todavía se encontraban en Cádiz. El 4 de julio, poco después del fin de la guerra, algunos ya fueron embarcados en el León con dirección a Cataluña. Los presos en el resto de cárceles debían ser amnistiados y en teoría regresarían pronto a sus casas. ${ }^{51}$ No sucedió lo mismo con los montemolinistas. En Puerto Rico, José Formen (o Tormen) Puche, carlista catalán destinado al servicio a las armas en Puerto Rico en 1848, fue indultado en 1849 , al año siguiente de su remisión. Se trata de un indulto individualizado y realizado para un ciudadano que iba a permanecer en Puerto Rico, ${ }^{52}$ elemento que pudo ser importante para que fuera objeto del perdón. No hemos encontrado ninguna disposición de indulto general tal y como solía suceder en estos casos, a excepción de los cautivos legitimistas remitidos a Ultramar.

En cuanto a la mayoría, había elementos que dificultaban que pudieran regresar a sus casas. Muchos habían sido quintos y se habían unido a las facciones para no realizar el servicio a las armas. Además, el castigo que se les impuso dificultaba que de

\footnotetext{
${ }^{50}$ La España, 7 de julio y 2 de agosto de 1849; El Católico, 28 y 29 de junio y 6 de julio de 1849.

${ }^{51}$ El Popular, 23 de junio de 1849; El Nacional, 31 de mayo de 1849.

${ }^{52}$ Estela Cifre de Loubriel, La formación del pueblo puertorriqueño. La contribución de los catalanes, baleáricos y valencianos. Instituto de Cultura Puertorriqueña, San Juan, 1975, p. 181.
} 
repente buena parte del ejército colonial resultara desmovilizado. El elevado número de deportaciones provocó que la tropa puertorriqueña excediera en más de 300 hombres los 14.000 establecidos reglamentariamente. Teniendo en cuenta esto y que las cajas para su mantenimiento no podían soportar el gasto que ocasionarían, el Capitán general decidió amnistiar en 4 de septiembre a 322 individuos prisioneros de las facciones, la mayoría catalanes, aunque también había aragoneses, navarros y del Maestrazgo. El Capitán general tenía dudas sobre si el real decreto de amnistía de 8 de junio les incluía, pero aun así les amnistió aplicándoles el artículo tercero que les obligaba a hacer un juramento de fidelidad. ${ }^{53}$ De este modo, indultó a los que sobrepasaban el número estipulado y por problemas presupuestarios, lo que muestra que mientras no se excediese ese número el resto permanecerían en su destino.

Dado que fueron enrolados como quintos, el regreso se produciría con el resto cuando finalizara el tiempo de servicio. Aun así, habríamos de tener en cuenta dos consideraciones al respecto. En primer lugar, el elevado índice de mortalidad en los regimientos coloniales. En Cuba, en la década de 1850 a 1859 fallecieron 14.779 soldados, en un ejército que mantenía un promedio de $18.051 .^{54} \mathrm{La}$ otra posibilidad es que una vez terminado el tiempo de servicio pasaran a instalarse en la Antilla mayor o menor ya como residentes. En el caso gallego, si bien en periodos precedentes, se ha constatado que fue "uno de los canales utilizados para la emigración de gran cantidad de hombres". ${ }^{55}$ Los matiners eran mayoritariamente de procedencia catalana, pero las condiciones de miseria que posibilitaron el levantamiento y las características de la represión extendida hasta el punto de convertirla en social, determinaban unas condiciones similares entre ambos grupos.

Las dificultades para volver se extenderían a Cuba. En agosto de 1849 un grupo de 40 que había sido llevado a Nueva Gerona en la isla de Pinos estaba reclamando poder volver a la Península. ${ }^{56}$ A pesar de que la mayoría de los combatientes iban destinados a los batallones, la relegación se concibió más como una manera de

\footnotetext{
${ }^{53}$ AGMM, Ministerio de la Guerra, Caja 5602, Carp. 18. Entre los indultados estaban 9 de los 14 del último grupo de carlistas navarros. Esteban Astiz, Juan Astrain, Nolasco Ollobarren, Cesáreo Fernández, Miguel Barreneche, Manuel Argonz, Hilario Gaztambice, Joaquín Sarasa y Pedro Antón.

${ }^{54}$ Manuel Moreno Fraginals y José J. Moreno Masó, Guerra, migración y muerte (El ejército español en Cuba como vía migratoria), Ediciones Júcar, Colombres, 1993, p. 64.

${ }^{55}$ Juan Francisco Martin Rebollo, "El aporte gallego al ejército antillano en el siglo XVIII", en I Jornadas presencia de España en América. Aportación gallega, Deimos, Madrid, 1989, p. 154.

${ }^{56}$ El Católico, 12 de octubre de 1849.
} 
desembarazo que podía terminar con los carlistas en puntos diversos y destinados en ocupaciones diversas. La remisión a Pinos podría tener una tendencia colonizadora, ya fuera a través de su mera estancia en este territorio o a través de la realización de obras públicas u otros trabajos. Por esto es probable que ante el gran número de deportados en las Antillas a algunos de ellos se les destinase a otras ocupaciones al margen del ejército, repitiendo lo ocurrido en la primera de las guerras legitimistas.

\section{LAS REVUELTAS DE 1848}

\subsection{La respuesta moderada a las revueltas}

En 1848 una oleada revolucionaria se expandió por buena parte de Europa, en lo que constituyó la manifestación de la imposibilidad de subsistencia del sistema emanado de la etapa de los Congresos. Los grupos tradicionalmente excluidos, pequeña y media burguesía, artesanos y proletarios, se unieron en una serie de manifestaciones, tumultos e insurrecciones, estimulados por la crisis económica y la eclosión de nuevas ideas. En la mayoría de países los gabinetes se vieron obligados a ceder en algunas demandas de los sublevados. En Italia y Alemania se produjeron movimientos endebles hacia la unidad nacional, pero el caso más paradigmático es el de Francia por ser el irradiador y aquel en que la revolución alcanzó una mayor radicalidad con la proclamación de la República y el reconocimiento del derecho al trabajo.

Las aspiraciones de los revolucionarios de París de conseguir una "república democrática y social" también fueron recogidas en España. Se trataba de unas ideas vagas, no claramente definidas, en las que república podía significar tanto gobierno sin rey como en favor del bienestar común. La petición de extensión de los derechos políticos y la inclusión de reivindicaciones sociales, como el derecho al trabajo, marcaron los puntos esenciales del movimiento. ${ }^{57}$ Políticamente, en España tuvo una influencia esencial en el Partido Progresista. La parte mayoritaria se decantó por el mantenimiento del orden y el resto fueron partidarios de la acción revolucionaria. Estas diferencias tuvieron como consecuencia la separación de la fracción minoritaria y la

\footnotetext{
${ }^{57}$ Clara E. Lida, "Los ecos de la república democrática y social en España. Trabajo y ciudadanía en 1848", Semata. Ciencias Sociais e Humanidades, vol. 12, 2000, pp. 323-338.
} 
creación del Partido Democrático. ${ }^{58}$ Desde un punto de vista social puso en primer plano los efectos del capitalismo sobre la población europea más vulnerable. A partir de entonces, la cuestión social se convirtió en uno de los puntos básicos en la administración para cualquier Gobierno. ${ }^{59}$

El carácter autoritario de los moderados y el conocimiento de lo sucedido en Francia y otros países hicieron que el Ejecutivo estuviera preparado. Como respuesta a los acontecimientos de febrero en el país vecino, mediante la ley de 13 de marzo de 1848 Narváez tomó poderes dictatoriales y el día 22 suspendía las Cortes. ${ }^{60}$ La "dictadura legal" de Narváez se explicaba en la prevención frente a las revueltas, no solo por los apuros en que pusieron a los sucesivos gabinetes europeos, sino por su propio significado. En palabras de Tocqueville, testigo de los sucesos de París.

"Vi la sociedad partida en dos: los que no poseían nada, unidos en una común codicia, y los que posean algo en una común angustia. Ya no había lazos ni simpatías entre aquellas dos grandes clases: por todas partes, la idea de una lucha inevitable y próxima (...). En París no pasaba día sin que los propietarios fuesen atacados o amenazados en su capital o en sus rentas". 61

El pánico de las clases altas se trasladó a España, donde los privilegiados creyeron que se había desencadenado un proceso que ponía en peligro la estabilidad social. Las relaciones entre el Ejecutivo de Luis Felipe de Orleans y los moderados españoles eran estrechas entre 1834 y 1848. El propio Narváez había estado exiliado en Francia durante la Regencia de Espartero y el doctrinarismo francés ejerció una gran influencia sobre el pensamiento de muchas de las personalidades del partido.

El blindaje gubernamental no consiguió amilanar a los conspiradores, entre los que encontramos a republicanos que maquinaban desde algunos puntos del litoral mediterráneo y estaban en conexión con los revolucionarios de París, y a los carlistas. En la revuelta madrileña del 26 de marzo participaron desde republicanos a progresistas

${ }^{58}$ Florencia Peyrou, "1848 et le Parti démocratique espagnol”, Mouvement Social, núm. 234, 2011, pp. 27 y $29-32$.

${ }_{59}$ Mike Rapport, 1848: Year of Revolution, Basic Books, New York, 2009, p. 407; las aportaciones más recientes respecto de las revoluciones de 1848 van dirigidas a constatar su influencia en América, ver Guy Thomson (ed.), The European Revolutions of 1848 and the Americas, Institute for the Study of the Americas, London, 2002; Timothy Masons, Distant revolutions, 1848 and the Challenge to American Exceptionalism, University of Virginia Press, Charlottesville, 2009.

${ }^{60}$ DSC, 22 de marzo de 1848. En una sesión de indiscutible brevedad, Narváez se limitó a leer el real decreto que dictaba la suspensión de las cortes.

${ }^{61}$ Alexis Tocqueville, Recuerdos de la Revolución de 1848, Trotta, Madrid, 1994, pp. 28, 88 y 115. El pensador francés a pesar de culpabilizar a la burguesía se alineó con esta por temor a ver amenazada la propiedad privada. 
avanzados. Por la tarde, grupos de paisanos armados tomaron algunas calles del centro de la ciudad, pero carentes de organización adecuada y del apoyo social necesario el resultado fue una estrepitosa derrota. Al día siguiente un consejo de guerra dictó algunas condenas a muerte que posteriormente fueron conmutadas por la inferior mediante decreto de 31 de mayo, aunque el Gobierno advirtió que en caso de reproducirse las insurrecciones actuaria con gran severidad. El 7 de mayo se produjo un nuevo alzamiento de mayor importancia ya que fueron miembros del ejército los que formaron la base del movimiento, aun así, fue dominado fácilmente. Las réplicas en otros puntos de la geografía peninsular terminaron de igual modo. ${ }^{62}$

Las acciones legislativas del Ejecutivo comenzaron inmediatamente después del primer intento de levantamiento. El 26 de marzo se suspendieron las garantías constitucionales, el 27 se declaró el estado de sitio en Madrid y se dieron facultades extraordinarias a los capitanes generales. Con todo bajo control, el día 30 una circular ordenaba abrir sumario contra los vagos, ${ }^{63}$ extendiendo a Madrid la política llevada a cabo en Barcelona por el Capitán general Manual Pavía.

De igual modo que en la Guerra dels Matiners (1846-1849), se optó por una represión no solo política sino también social, que se extendería a pobres, desempleados, vagabundos, presuntos delincuentes y demás marginados. Según Narváez, el tribunal que debía ser utilizado era el de la "opinión pública", ${ }^{64}$ lo que implicaba que la punición se ejecutaría al margen de la justicia ordinaria y de acuerdo a rumores y delaciones. El castigo no se planteó como una forma de correctivo de culpables, sino que lo que se pretendió fue amedrentar a ciertos grupos sociales. Esto determinó que no fueran excesivamente crueles, ya que al fin y al cabo el único "delito" de muchos era su pobreza. La respuesta gubernamental contrasta con los fusilamientos muy numerosos en los inicios del mandato del partido, lo que demuestra que en 1848 se sentían plenamente consolidados y en ningún momento sintieron su poder amenazado. En realidad, las intentonas no tuvieron posibilidades de victoria.

\footnotetext{
${ }^{62}$ AGA, Presidencia del Gobierno, Caja 51/3489, Exp. 743; Sonsoles Cabeza SánchezAlbornoz, Los sucesos de 1848 en España, Fundación Universitaria Española, Madrid, 1981. pp. 20-39, 77-97 y 207-210; Salvador Sánchez Pardo, La revolución de 1848 en España, Tesis doctoral de la Universidad Complutense de Madrid, Madrid, 1985, tomo II, p. 601.

${ }^{63}$ Sonsoles Cabeza Sánchez-Albornoz, Los sucesos de 1848 en España, p. 140; Gaceta de Madrid, 27 de marzo de 1848; El Clamor Público, 1 de abril de 1848.

${ }^{64}$ Biblioteca de la Real Academia de Historia, Archivo de Narváez, 9/8090, vol. 17/2.
} 
Antes del día 30 de marzo diversos generales habían sido trasladados "de cuartel" a Baleares, Canarias, Ceuta y otros puntos alejados de la capital. Muchos líderes del Partido Progresista, como Salustiano Olózaga o Patricio de la Escosura, fueron detenidos y otros desterrados dentro de la Península, como José Gálvez Cañero, o a Baleares, como el diputado por Cádiz Juan Pablo Muchada. Si bien es cierto que las represalias que soportaron estas personalidades importantes fueron en general más leves que las de otros muchos que no tenían su distinción y la posibilidad de eludirlos se incrementaba tal y como lo hacía el poder, el dinero, la respetabilidad o las influencias. Olózaga pudo huir durante su conducción a Cádiz y Patricio de la Escosura dentro del propio castillo de Santa Catalina. ${ }^{65}$ A pesar de ello, muchos otros prohombres de la sociedad terminarían en las Filipinas.

Los que tomaron parte en la insurrección formaban parte de un estrato social diferente: militares de baja graduación y miembros de las clases populares, a los que comenzaban a influenciar las ideas demócratas, republicanas y socialistas. ${ }^{66} \mathrm{La}$ extensión hacia abajo de la política y la inclusión de reivindicaciones sociales tuvieron como consecuencia la expansión en el mismo sentido de la corrección, diferenciándose de los destierros de liberales de la década precedente, cuando tuvieron un carácter muy selectivo y afectaron a individuos pertenecientes a las clases medias. Una vez que la burguesía hubo tomado el poder, tal y como sucedió en Francia, hubo un proceso acelerado de expulsión de la tierra de muchos pequeños productores que no tuvieron más remedio que proletarizarse o convertirse en jornaleros agrícolas. ${ }^{67}$ La revuelta de

\footnotetext{
${ }^{65}$ The Newspaper, 8 de abril de 1848; El Nacional, 8 de julio de 1848; Francisco Pi y Margall y Francisco Pi y Arsuaga, Historia de España en el siglo XIX, tomo III, p. 684-685 y 689.

${ }^{66}$ Sobre los inicios de estas ideas en España ver Florencia Peyrou, El republicanismo popular en España 1840-1843, Servicio de Publicaciones de la Universidad de Cádiz, Cádiz, 2002; Román Miguel González, La Pasión Revolucionaria; Anna Maria Garcia Rovira, "Republicanos en Cataluña. El nacimiento de la democracia (1832-1837)" y Genís Barnosell Jordà, "«Libertad, igualdad humanidad». La construcción de la democràcia en Cataluña (18391843)", ambos en Manuel Suarez Cortina (ed.), La redención del pueblo. La cultura progresista en la España liberal. Universidad de Cantabria, Santander, 2006; María Cruz Romeo Mateo, "Los mundos posibles del liberalismo progresista", en E. Laparra y G. Ramírez (eds.), El primer liberalismo. España y Europa desde una perspectiva comparada, Biblioteca Valenciana, Valencia, 2003; Antonio Eiras Roel, El Partido Demócrata español (1849-1868), Rialp, Madrid, 1961.

${ }^{67}$ Jordi Maluquer de Motes, El socialismo en España, pp. 46-49; este proceso fue más importante en el sur peninsular German Rueda, "El proceso de la desamortización de bienes de origen eclesiástico (1769-1964) en España. Cuantificación y consecuencias socioeconómicas", en Bernard Boidinier, Rosa Congost y Pablo F. Luna (eds.), De la Iglesia al Estado. Las desamortizaciones de bienes eclesiásticos en Francia, España y América Latina, Prensas Universitarias de Zaragoza, Zaragoza, 2009, pp. 200-203; Rafael Pérez del Álamo, Apuntes
} 
1848 hizo temer a los beneficiados que el proceso podía invertirse, de ahí que pusieran todo su empeño en evitar el triunfo de los revolucionarios.

El 31 de marzo comenzó el proceso de traslado de los presos en Madrid, cuyas cárceles se estaban colapsando por la gran cantidad de detenidos. La primera salida consistió en el envío de 11 sujetos de destacada militancia progresista con destino a Cádiz. El 9 de abril partió otra cuerda de prisioneros para Chafarinas, Ceuta, Melilla y Peñón de Vélez de la Gomera. La conducción se llevaría a cabo por la Guardia Civil, 4.000 de cuyos miembros fueron concentrados en la capital para asegurar el orden y con posterioridad para el transporte de los presos. ${ }^{68}$

Gracias al testimonio de Agustín Reverter, uno de los detenidos, podemos saber cómo se efectuaban las marchas. Tras dos días en la jefatura de policía fue internado en la cárcel de Corte. Una noche se les sacó al patio y fueron atados a sus compañeros y llevados a la de Saladero, desde donde partieron hacia Valdemoro. Allí se les unió otro grupo y juntos salieron, a veces a pie y a veces en carreta, con destino a Málaga para finalmente ser trasladados a Ceuta. Junto a los represaliados por vía administrativa, había otro grupo condenado por consejo de guerra que fue destinado a trabajos en el Peñón de Vélez de la Gomera y Chafarinas. Los castigados sin juicio permanecieron exentos de tareas en Ceuta y después en el citado peñón, fueron instalados fuera de los calabozos y gozando de libertad de movimientos. ${ }^{69}$ Las remisiones a las zonas costeras limítrofes son un primer paso para la realización de las expulsiones a Ultramar, pero en este momento no había un plan gubernamental estructurado más allá del simple desembarazo de los apresados.

Únicamente en el caso del grupo de 11 que salió inmediatamente de Madrid se contempló el confinamiento a Filipinas desde el primer momento. El día 11 de mayo fueron embarcados en el Ligero, dos hacia Tenerife y el resto continuaron en dirección a

sobre dos revoluciones Andaluzas, Zero, Madrid, 1971, pp. 76 y 60. Según el cabecilla de la insurrección de Loja las causas fueron el malestar de la gente del campo por el empobrecimiento causado por el proceso de desamortización que supuso concentración de la tierra en pocas manos, así como la explotación que sufrían colonos y braceros.

${ }^{68}$ AHN, Ultramar, Leg. 5161, Exp. 61. "Concesión de pensiones a deportados políticos"; $E l$ Clamor Público, 28 de abril de 1848; Wenceslao Ayguals de Izco, El palacio de los crímenes o el pueblo y sus opresores, Imprenta de Ayguals de Izco hermanos, Madrid, 1855, tomo I, pp. 177-178 y 187; José Sidro y Surga y Antonio de Quevedo Donis, La Guardia Civil. Historia de esta institución y de todas las que se han conocido en España con destino a la persecución de malhechores, Atlas, Madrid, 1858, pp. 591-592.

${ }^{69}$ Agustín Reverter, Carta que ha dirigido a sus amigos y enemigos el ciudadano Agustín Reverter, Imprenta de Antonio Puigrubí y Canals, Tarragona, 1855, pp. 9-12. 
Manila, a donde llegaron el 5 de diciembre. ${ }^{70}$ Este grupo, por su implicación efectiva en los levantamientos o por la fijación con ellos por sus ideas avanzadas o su relevancia, fue objeto desde el primer momento de una idea muy clara respecto a la pena que se les iba a imponer. Su caso podría también entenderse como una prueba por si en el futuro se consideraba necesario extender su utilización.

En Cataluña, los embarques de carlistas y pobres hacia las Antillas que se estaban ejecutando desde principios de año posibilitaban la inclusión de progresistas. El 10 de julio salió el vapor Lepanto con 58 individuos destinados al ejército en Ceuta y 106 al de Ultramar, entre los que había algunos liberales. ${ }^{71}$ El mismo día, siete progresistas sevillanos salieron en el Joven Emilio hacia La Habana. La cifra de relegados a las Antillas es la menos clara, García Ruiz asevera que fueron "algunas docenas", ${ }^{72}$ cantidad inconcreta pero que se adecua a la información de la que disponemos.

Encontramos deportaciones ordenadas por algunos capitanes generales, lo que añadía desorganización a la práctica. Tampoco había un perfil de castigado, más allá de la pertenencia al progresismo exaltado y tener cierta significación, o ser cazado por las autoridades estando al borde de la marginalidad social, características que podían ser compartidas por un gran número de los que por el momento no sufrieron este castigo. Aun así, en el caso de los represaliados desde el Gobierno central, la tendencia era la de alejarles de la capital sin incurrir en traslados a las colonias. La expansión a Madrid de unas insurrecciones con una indudable raíz popular, que tradicionalmente estaban localizadas en Barcelona, supone un elemento que explica la celeridad y el modo de proceder a la represión. Lo que se trataba era de "aislar" a la capital de las perturbaciones políticas. El carácter de guerra abierta que se estaba librando en Cataluña aconsejaba que no se abriera otro frente y que la capital quedara al margen de las turbulencias políticas.

Desde este punto de vista, un buen lugar era Ibiza, a donde fueron dos cuerdas desde Madrid con más de 200 presos, incluyendo a cinco mujeres deportadas y a otras

\footnotetext{
${ }^{70}$ El Clamor Público, 2 de marzo de 1849. Los transportados declararon que sufrieron un viaje penoso, siendo acomodados en el sollado donde ni siquiera podían erguirse, así como carecer de instrumentos de aseo personales, recursos y equipaje; Wenceslao Ayguals de Izco, El palacio de los crímenes o el pueblo y sus opresores, tomo I, pp. 177-178.

${ }^{71}$ El Popular, 21 de julio de 1848; El Clamor Público, 13 de julio de 1848.

${ }^{72}$ El Clamor Público, 20 de julio de 1848; Eugenio García Ruiz, Historias, A. Bacaycoa, Madrid, 1878, tomo II, p. 533.
} 
que habían ido voluntariamente siguiendo a sus maridos. Del total, tres provenían de Barcelona, nueve de Valencia, diez de Alicante y el resto de Madrid. La primera partió tras los sucesos del 7 de mayo. El segundo grupo lo hizo el 10 de junio comprendiendo a 144 individuos, los de mayor consideración social viajaron en carruajes y el resto a pie. Para escoltarles se destinaron 80 guardias civiles de infantería y 20 de caballería, lo que da buena muestra del celo de los mandatarios para evitar cualquier fuga de los apresados. Algunos quedaron presos en Valencia pues únicamente 109 pasaron a Ibiza en el Blasco de Garay, que zarpó de Valencia el 7 de julio. Los de mayor categoría social hicieron el trayecto en la cubierta del buque y al llegar a Ibiza fueron liberados inmediatamente. Los que pudieron mantenerse salieron el día siguiente y los demás fueron liberados en los próximos días con una ayuda de 12 reales diarios. ${ }^{73}$

De este modo, los más acaudalados buscaron alojamiento de mayor comodidad y el resto siempre podían hospedarse en la cárcel, sin que ello limitase la libertad de que disponían. Esto les permitió tener una estancia más digna dado que algunos pudieron trabajar para ganarse la vida y el resto estableció relaciones con los ibicencos que les ayudaron de manera decisiva. Los trasladados hacían vida normal, organizaban funciones teatrales en su tiempo libre y se relacionaban con los oriundos, surgiendo vínculos afectivos entre ambos grupos. ${ }^{74}$

Sin embargo, su permanencia en Ibiza a pesar de su integración con la población, su buen comportamiento y de no producirse conspiraciones, fue imposible. La primera fase de la represión, la que siguió a los conatos insurreccionales, iba a ser sustituida por una nueva caracterizada por la ejecución de un plan perfectamente estructurado que contemplaba relegaciones masivas. Este cambio se oficializó el 4 de agosto cuando el Gobierno decretó la remisión a Filipinas de los presos. ${ }^{75}$ Antes de su consumación, era necesario que los represaliados se reunieran en un punto determinado desde el que se producirían los embarques, este lugar fue Cádiz. El 29 de agosto arribaron a la ciudad andaluza 54 hombres procedentes de Valencia e Ibiza en el místico de guerra Águila. El 8 de septiembre hizo lo propio el León, con entre 126 y 128 de los

\footnotetext{
${ }^{73}$ Isidoro Macabich, Historia de Ibiza, vol. II, pp. 289-290; Wenceslao Ayguals de Izco, El palacio de los crímenes o el pueblo y sus opresores, tomo I, pp. 351-353, 375-421, 468-475 y 481-487.

${ }^{74}$ Francisco Robello, Refutación al libelo infamatorio que con el título de descripción de la Isla de Ibiza escribió D. Pedro López Villanueva, Ibiza, D. Manuel García, 1848, Capítulo XXXIII. (Citado por Isidoro Macabich, Historia de Ibiza, vol. II, pp. 292-294).

${ }^{75}$ Wenceslao Ayguals de Izco, El palacio de los crímenes o el pueblo y sus opresores, tomo I, pp. 435-436.
} 
que restaban en Ibiza. $^{76}$ Con los presos diseminados en la costa mediterránea y las posesiones africanas, podía comenzar la fase de las deportaciones.

\subsection{La etapa de las deportaciones}

En esta segunda fase, el objetivo del Gobierno era el debilitamiento extremo y la aniquilación del Partido Progresista, algo que siempre había estado en la mente de los moderados. Para ello se siguió una política planificada de relegaciones que implicaban la desaparición del territorio metropolitano de numerosos opositores y la neutralización de los que quedaban mediante el miedo. El carácter militarista de Narváez y sus ayudantes, se manifestó en actuaciones arbitrarias en cuestión de orden público. ${ }^{77}$ Que en una primera etapa esta se hubiera manifestado en prisiones, destierros y deportaciones al Ultramar cercano tenía dos causas fundamentales. La primera era la improvisación, pues la estructura de castigo ejecutada se fue formando mediante la praxis, no había un plan preconcebido sino que iban proponiendo medidas y leyes adaptándose a los sucesos. La segunda eran los hechos de junio en Francia, donde los trabajadores y las clases populares armadas se enfrentaron al Gobierno. Esto incrementó el rigor de las medidas del Ejecutivo.

A principios de 1848, Narváez se había reunido con progresistas destacados como Juan Álvarez Mendizábal para frenar la revolución, ofreciéndoles que desistieran de apoyar a los levantamientos a cambio de establecer un turnismo al estilo inglés. En ese momento, al margen del sector más izquierdista, la mayor parte del partido estaba dentro del sistema, acatando la Constitución de 1845 y la monarquía. Cuando estallaron los alzamientos, el Partido Progresista se posicionó con el Ejecutivo, ordenando a sus militantes en las provincias que actuaran en contra de los revolucionarios. ${ }^{78}$ Esto muestra el temor que tenían a ser perseguidos y quedar totalmente proscritos, pero también que no se identificaban con el componente popular de las revueltas y con las medidas tomadas en Francia. En última instancia lo que pretendían era una ampliación

\footnotetext{
${ }^{76}$ Oficio de dirección de seguridad pública a Capitán general de Andalucía, 29 de agosto de 1848. Archivo Intermedio Militar Sur (en adelante AIMS), $2^{a}$ división orgánica, Caja 1312, Carp. 7; Isidoro Macabich, Historia de Ibiza, vol. II, pp. 290-292; Wenceslao Ayguals de Izco, El palacio de los crímenes o el pueblo y sus opresores, tomo I, pp. 533-559. De Ibiza escaparon entre 22 y 25 confinados con ayuda de la población civil.

${ }^{77}$ Manuel Ballbé, Orden público y militarismo en la España constitucional, pp. 137-138.

${ }^{78}$ Fernando Fernández de Córdova, Mis memorias intimas, Sucesores de Rivadeneyra, Madrid, 1889, tomo III, p. 156; Jorge Vilches, Progreso y libertad, pp. 44-46.
} 
del liberalismo que incluyera a otros grupos sociales, pero dejando al margen a las capas más bajas de la sociedad y, por tanto, desconfiaban de una revolución liderada por las mismas.

Los moderados aprovecharon los fracasados movimientos para cargar contra el grupo opositor, incluso contra aquellos que les habían sido fieles como Olózaga y Gálvez Cañero que habían participado en la comisión en que el partido se posicionó contra los revolucionarios. Esto muestra que no tenían ninguna intención de ceder el poder y que una vez que habían utilizado a los progresistas para mitigar las posibilidades de éxito de la insurrección, aprovecharon para arremeter contra ellos. Sin embargo, para que la voluntad represiva derivara en transportaciones masivas era necesario que se produjera el convencimiento de que este castigo era el más adecuado para combatir a sus enemigos políticos. Llevarles a miles de millas de distancia significaba vaciar las cárceles y depósitos, al tiempo que permitía ganar tiempo a causa de la inmensa lejanía.

En la Europa de la época, la deportación se empleaba ampliamente. El caso más paradigmático es el británico, aunque allí tenía un cariz diferente ya que fue concebida como un modo de deshacerse de población a la que el sistema era incapaz de absorber. La elevada natalidad y la mecanización habían dejado a muchos sin trabajo y sin medios de vida, por lo que paralelamente a los traslados forzados a Australia hubo una gran emigración libre tanto a dicha isla como a América. Los relegados británicos eran principalmente ladrones de poca monta que habían tenido que recurrir a la delincuencia para subsistir. ${ }^{79}$ Su perfil por tanto era bastante diferenciado del caso español. Además, el Gobierno de Londres había dotado a la práctica de una organización y estructura jurídica que la configuraban como legal, algo que no se extendió a España.

En los años anteriores miles de polacos habían sido desterrados en Siberia y en 1847, 36 liberales portugueses fueron remitidos a Angola. ${ }^{80}$ En Francia, tras los sucesos de junio de 1848 empezó un debate sobre qué hacer con los detenidos y cómo sacarles el mejor provecho. La controversia pudo tener cierto influjo en la situación española pero esta marchaba autónomamente, como muestra el hecho de que los embarques se

\footnotetext{
${ }^{79}$ Alan Brooke and David Brandon, Bound for Botany Bay, p. 90.

${ }^{80}$ El Católico, 12 de febrero de 1847.
} 
produjeron antes en España, alcanzaron a un número superior de personas, ${ }^{81}$ y se produjeron a lugares mucho más lejanos. Esto a pesar de que la sublevación francesa proclamó la República y tuvo un carácter más social. En Francia, los trabajadores formaban un grupo mayor numéricamente hablando y con una ideología más desarrollada, aunque en nuestro país las doctrinas del socialismo ya se habían difundido, especialmente en Barcelona y Cádiz. En la ciudad condal se gestó un incipiente asociacionismo obrero, cuya expresión más importante fue la Asociación de Tejedores de Barcelona, con 3.000 asociados a mediados de 1840 y con conexiones con organizaciones análogas y sectores políticos demócratas. En Andalucía, desde finales de la década de 1830 se produjeron diversas huelgas sectoriales. ${ }^{82}$ Estos hechos, sin duda atemorizarían al Gobierno, que vio en las fracasadas revueltas una oportunidad para reprimir a estos grupos.

El hecho de que la Antilla mayor fuera la joya de la Corona no excluye acciones en otras colonias con el objetivo de fomentar su progreso económico. En la década de 1830 se dieron en Filipinas una serie de tímidas reformas hacendísticas, que se reforzaron en la década siguiente. Se hicieron expediciones de castigo a pueblos que mercadeaban al margen del monopolio tabaquero y para afianzar el dominio político. El comercio se liberalizó y se produjeron continuos esfuerzos de las autoridades para conseguir un tabaco de calidad que incrementó la producción y la contribución a las arcas de la metrópoli. ${ }^{83}$ En este sentido, la insurrección de 1848 ofreció una oportunidad, puesto que centenares de comerciantes, profesionales liberales y artesanos, una vez en el archipiélago asiático podían contribuir a la repoblación y mejora económica de la posesión, escasamente desarrollada. El hecho de que la militancia política de los confinados estuviera más asentada hacia inconveniente su traslado a Cuba, por el mayor peligro que significaba la expansión de ideas avanzadas en la isla a causa de su carácter esclavista y del peligro a una sublevación criolla. Decidido el Gobierno a deshacerse de los opositores de izquierda, el territorio asiático fue su mejor opción. Esto supuso la primera deportación masiva de opositores políticos a las

\footnotetext{
${ }^{81}$ Louis-José Barbançon, "Les transportés de 1848 (statistiques, analyse, commentaires)". Por delitós comunes fueron deportados 234 individuos y por políticos 225 , en tres casos no se expresa.

82 Jesús de Felipe Redondo, Trabajadores. Lenguaje y experiencia en la formación del movimiento obrero, Genueve, Oviedo, 2012, pp. 110-161; Clara E. Lida, Anarquismo y revolución en la España del siglo XIX, Siglo XXI, Madrid, 1973, pp. 31-38.

${ }^{83}$ Josep Maria Fradera, Filipinas, la colonia más peculiar. La hacienda pública en la definición de la política colonial, 1762-1868, CSIC, Madrid, 1999, pp. 169-179, 191-253 y 32.
} 
Filipinas, que hasta el momento tan solo había sido el destino de algunos casos individuales. (Tabla 3).

Tabla 3. Deportaciones a Filipinas (agosto-septiembre de 1848)

\begin{tabular}{lccc}
\hline Nombre del barco & Fecha de salida & Fecha de llegada & $\begin{array}{c}\text { Número de } \\
\text { afectados }\end{array}$ \\
\hline Nueva Zafiro & $28-8-1848$ & $30-1-1849$ & $145(57 \mathrm{de}$ \\
& & & ellos carlistas) \\
Manila & $2-9-1848$ & $21-1-1849$ & 99 \\
Colón & Total & $30-3-1849$ & 306 \\
\hline
\end{tabular}

Fuente: Elaboración propia a partir de: AHN, Ultramar, Leg. 5161, Exp. 41. "Partes de tranquilidad de Filipinas"; Oficio de encargado del depósito a Capitán general de Filipinas, 21 de enero de 1849. PNA, Guerra, Leg. 136; El Popular, 3 de septiembre de 1848; El Comercio, 3 de septiembre de 1848; El Nacional, 24 de septiembre de 1848; El Comercio, 23 de septiembre de 1848.

A efectos del traslado, los presos se diferenciaron en tres categorías atendiendo a su perfil social y económico dando como resultado que 46 fueron catalogados como “oficiales", 71 como "sargentos" y 376 como "soldados". Esta distinción no tenía nada que ver con el carácter militar de los relegados, de los que apenas había unos pocos, sino que se trataba de una clasificación puramente formal basada en el perfil social y económico de los represaliados, efectuada para diferenciar las condiciones en la remisión de unos y otros. ${ }^{84}$ A los "oficiales" se les dieron camarotes individuales, mientras que el resto de grupos ocuparon partes del sollado. El elevado número de los considerados de menor categoría muestra que la revuelta y su represión tuvieron un componente eminentemente popular, pero englobando también a miembros la baja y media burguesía.

El largo viaje a las Filipinas, de alrededor de cinco meses de duración, garantizaba librarse de los opositores durante un periodo de al menos un año y varios meses, que podía fácilmente ampliarse. Esto sin la realización de juicios molestos que necesitaban de la aportación de pruebas. A corto plazo, su militancia política quedaba

${ }^{84}$ Entre los catalogados como "oficiales" encontramos a catedráticos, empleados públicos, propietarios, cesantes de ministerios, relojeros, comerciantes, militares y médicos. En la de "sargentos", había empleados públicos de menor categoría, comerciantes, propietarios y labradores, así como fabricantes y oficios desde veterinarios y profesores de música a maestros carpinteros o albañiles. En la de "soldados", los trabajadores manuales por cuenta propia y ajena y algunos dependientes de comercio. Relación de presos en La Carraca procedentes de Ibiza y Valencia, agosto de 1848. Relación de presos que debe embarcarse en la Zafiro, 28 de agosto de 1848. AIMS, $2^{a}$ división orgánica, Caja 1312, Carp. 7. 
neutralizada sin necesidad de ejecuciones. El Gobierno se negó a hacerlas tras los sucesos del 26 de marzo, y alcanzaron a 14 personas tras los acontecimientos del 7 de mayo en Madrid, ${ }^{85}$ número excesivo, pero limitado si lo comparamos con lo que haría el propio Narváez en El Arahal en 1857 frente a una insurrección campesina con un contenido social mucho más acusado. En su destino, desprovistos de sus trabajos, de sus medios de subsistencia y de sus círculos sociales, su capacidad de influencia en la política española disminuía hasta la irrelevancia. A largo plazo, un número indeterminado no volverían a España, por establecerse en el territorio, por exiliarse a otros países o por fallecimiento. Los que regresaran, lo harían cuando se les permitiese, sabiendo que cualquier insubordinación seria castigada duramente.

Las aprehensiones se hicieron de manera bastante indiscriminada, por lo que incluyeron a muchos inocentes a los que era difícil separar de los efectivamente implicados. De ahí otra de las ventajas que ofrecía esta punición para el poder, la de ser ambigua, ya que al mismo tiempo que era dura permitía la libertad en su punto de residencia. Además encontramos en la represión un fuerte desprecio social, al haberse incrementado el desempleo y la miseria entre los trabajadores por la crisis económica de 1848. Según la mentalidad del Gobierno lo más probable es que muchos terminaran en la miseria, sino lo estaban ya. En Castilla la Vieja, León y Andalucía la reducción de los sueldos reales, aumento de impuestos e incremento del precio del trigo por la exportación provocaron motines en 1847. En 1848, la situación continuaba siendo precaria y el coste de la vida había aumentado respecto al año precedente. En Madrid se vivía una situación social de extrema gravedad. ${ }^{86}$

De este modo, el Ejecutivo actuó con celeridad tratando de evitar la conjugación de protesta social y política. Por esto, su confinamiento también sirvió para deshacerse de ciudadanos a los que la crisis había llevado a la marginalidad. El temor de los moderados se aprecia en su obra legislativa, la Ley de Vagos de 1845 y especialmente en el Código Penal de 1848, que consideraban delito a la vagancia. A causa de la revuelta de 1848 se asoció el mantenimiento del orden público al castigo de la

\footnotetext{
${ }^{85}$ Antonio Pirala, Historia Contemporánea, tomo I, p. 462.

${ }^{86}$ Javier Moreno Lázaro, Los hermanos de Rebeca. Motines y amotinados a mediados del siglo XIX en Castilla la Vieja y León, Región Editorial, Palencia, 2009, pp. 12-32; Antonio Elorza, "Estudio preliminar", en El Fourierismo en España, Ediciones de la Revista de Trabajo, Madrid, 1975, pp. 69-74; Antonio Fernández García, "Madrid en el tiempo de las revoluciones burguesas", en Alfredo Alvar Ezquerra (coord.), Visión histórica de Madrid (siglos XVI al XX), Real Sociedad Matritense de Amigos del País, Madrid, 1991, pp. 234-235.
} 
ociosidad. ${ }^{87}$ En esta medida subyacía el desprecio de hacia los marginados y el temor de que pudieran ser utilizados con fines políticos por sus adversarios.

Las condiciones del viaje fueron objeto de quejas por parte de los represaliados. Agustín Reverter, embarcado en el Nueva Zafiro, afirmaba que la comida era escasa y que habitualmente estaba compuesta por "caldos de carne salada y algunos días podrida". También nos informa del equipaje que se les proporcionó.

"Cuatro camisas de cotonía, dos blancas y dos de color; una blusa; dos pantalones; una chaqueta; dos pañuelos; todo de tela la más ordinaria; un par de zapatos de munición; una bolsita de badana, con un alfiletero de pino; que contenía media docena de agujas y alfileres: unas tijeras de hierro: dos madejitas de hilo podrido; un sombrero de palma, un capote mallorquín y un peine de madera. A la clase de oficiales nos dieron además un colchoncito ancho que no cabía uno, y blando como la piedra; un cabezalito de lo propio y una manta transparente". ${ }^{88}$

Después de transportar a alrededor de 550 personas en un periodo inferior a un mes, la isla de Ibiza y los presidios de la costa mediterránea, Cádiz y África se encontrarían descongestionados. Así, la represión volvió a tener una manifestación similar a la que tuvo anteriormente, incluyendo prisiones y envíos pormenorizados a las cárceles, en donde permanecían recluidos. El 7 de noviembre llegó a Cádiz el Isabel II procedente de Ibiza, Cartagena y Valencia, en donde había recogido a 68 progresistas y 47 procedentes de la facción. Cuando los castillos gaditanos estuvieron llenos un nuevo embarque los aligeró, el 19 de diciembre zarpó el místico Buen Mozo, recogiendo presos en la Carraca y en la cárcel de Cádiz con destino a Canarias, con un total de 93 presos políticos y diez comunes. ${ }^{89}$

El día 15 de diciembre se reabrieron las Cortes. Los moderados consideraban que la suspensión del Parlamento ya no era necesaria. Sin embargo, no tuvieron el más mínimo pudor para continuar con su política de mano de hierro. En fecha tan tardía como el 6 de enero de 1849 partió desde Cádiz el último envío a Filipinas en este periodo. Fue la fragata Maribeles la que trasladó a 181 presos, que arribaron a dicho archipiélago el 4 de junio. Se trataba de participantes en la sublevación republicana de Huesca de octubre. ${ }^{90}$ Lo que elevó la cifra de deportados en la posesión a 740 hombres.

\footnotetext{
${ }^{87}$ Gutmaro Gómez Bravo, Crimen y castigo, p. 115.

${ }^{88}$ Agustín Reverter, Carta que ha dirigido a sus amigos y enemigos el ciudadano Agustín Reverter, pp. 13 y 24.

${ }^{89}$ El Espectador, 14 de noviembre de 1848; El Nacional, 20 de diciembre de 1848.

90 AHN, Ultramar, Leg. 5161, Exp. 41. "Partes de tranquilidad de Filipinas"; El Clamor Público, 13 de enero de 1849; Demetrio Castro Alfin, "Orígenes y primeras etapas del republicanismo en España", p. 56.
} 
Con la reapertura de las Cortes, diputados progresistas como Gálvez Cañero clamaban contra el Ejecutivo por su política de relegaciones al margen de la justicia. También desde el Congreso, el ministro de la Gobernación, Luis Sartorius, humillaba una vez más a los transportados asegurando que eran en su mayoría "vagos, ladrones y asesinos", en un intento de menospreciar el contenido político y social de las insurrecciones. ${ }^{91}$ La prepotencia y menosprecio de Sartorius fue secundada por Donoso Cortés, quien el 4 de enero declaró en el hemiciclo: "Cuando la legalidad basta para salvar a la sociedad, la legalidad; cuando no basta, la dictadura". Exponía que dictadura era una palabra terrible, pero en circunstancias como las de entonces, se convertía en un Gobierno "bueno", "provechoso" y "racional”. Justificaba su razonamiento aludiendo a acciones de las administraciones de las antiguas Grecia y Roma, y de las actuales Francia e Inglaterra, y a una pretendida legitimación teológica ciertamente bastante torticera. ${ }^{92}$ Todo para tratar de justificar que podían reprimir a su gusto.

Cortés representaba al sector más integrista del Partido Moderado. El impacto de los sucesos de 1848 y el profundo miedo al socialismo decantaron rápidamente al pensador extremeño hacia posiciones ultras. ${ }^{93} \mathrm{El}$ refuerzo de las posiciones antiliberales del partido a causa de los sucesos revolucionaros pudieron haber provocado el temor de Narváez a verse desplazado y a diseñar de este modo una represión de amplio alcance. La severidad en los castigos le concedió la aprobación de los grupos sociales a los que representaban. De este modo, personificó en sí mismo la política moderada de garantizar el orden público lo que permitió cohesionar a sus bases sociales en torno a su figura y le ayudó a constituirse en la personalidad más emblemática del moderantismo.

Según el conde de San Luis, la cifra de represaliados fue de 1.514, de todas las provincias excepto de nueve, Madrid con 685, Zaragoza con 187 y Barcelona con 151 constituían las provincias con mayor número de afectados. De estos, proseguía Sartorius, 400 ya habían regresado a sus casas y solo una tercera parte, los más peligrosos, fueron enviados a Ultramar. ${ }^{94}$

El ministro manipulaba las cifras, ocultando de ese modo las causas reales y su alcance numérico. En esos momentos ya habían sido embarcados 559 hombres a Filipinas, al menos 106 a Canarias y varias docenas a las Antillas. Esto sin contar a los

\footnotetext{
${ }^{91}$ DSC, 30 de diciembre de 1848 .

${ }^{92}$ DSC, 4 de enero de 1849.

${ }^{93}$ Begoña Urigüen, Orígenes y evolución de la derecha española. El neo-catolicismo, CSIC, Madrid, 1986, pp. 57-60.

${ }^{94}$ DSC, 30 de diciembre de 1848 y 4 de enero de 1849.
} 
181 próximos a zarpar en la fragata Maribeles. El número de provincias con represaliados y el hecho de que en muchas no pasaran de la decena nos indican que en estos casos se trató de motivaciones puramente políticas, especialmente teniendo en cuenta que los movimientos no habían sido tan dispersos. El carácter elitista y la escasa militancia de los partidos facilitaban que con la relegación de unos pocos en cada demarcación los progresistas quedaran prácticamente desarticulados. En cambio, en las provincias con mayor número la represión política se combinaría con aquella que afectó a los excluidos, cuyo modo de vida había empeorado por la desamortización. ${ }^{95}$ En ambos casos se trató de deportaciones preventivas, ya que incluso cuando afectó a individuos que efectivamente participaron en las revueltas el objetivo fue evitar nuevos alzamientos y no el de castigar a los presuntos infractores de la ley, que deberían haber sido juzgados de acuerdo al Código Penal y no confinados arbitrariamente.

\subsection{La estancia en Filipinas}

La constitución de la noción del orden político moderado se asentaba sobre su supuesta moralidad como mantenedores del orden frente a los revoltosos "identificando el resultado de la revolución con la revolución misma", 96 augurando un desorden perpetuo en caso de que perdieran el mando. El hecho de presentarse como los "buenos" frente a los "revoltosos" determinó las condiciones de las prisiones y la remisión de los apresados. El discurso de los conservadores consistente en denigrar a los represaliados, mientras que ellos se presentaban como preservadores del orden, si bien resultaba enormemente inconsistente, podía ser aceptado por sectores conservadores. Bajo este esquema maniqueo era posible digerir la reclusión y el traslado de centenares de personas a Ultramar, e incluso que el trato que recibieran no fuera del todo favorable,

\footnotetext{
${ }^{95}$ El proceso de usurpación de tierras comunales y eclesiásticas ha sido ampliamente estudiado. En la provincia de Castellón José Antonio Piqueras, "El carlismo latente. Desposesión agraria y protesta campesina en Castellón (1843-1868)", Saitabi, núm. 44, 1994; en Valencia, Vicent Mir Montalt, Desposeer y custodiar. Transformación agraria y guardería rural en la provincia de Valencia, 1844-1874, Edicions Alfons el Magnànim, Valencia, 1997; en Navarra, Joseba de la Torre y José Miguel Lana Berasain, "El asalto a los bienes comunales. Cambió económico y conflictos sociales en Navarra, 1808-1836", Historia Social, núm. 37, 2002, pp. 75-95. En ocasiones, tres un largo periodo de litigios los campesinos pudieron conseguir la propiedad, Ángel Ramón del Valle Calzado, Desamortización eclesiástica en la provincia de Ciudad Real, 1836-1854, Universidad de Castilla-La Mancha, Cuenca, 1995, pp. 295-296.

${ }^{96}$ Raquel Sánchez García, "Reflexiones sobre la Revolución de 1848", en Ayeres en discusión. Temas claves de historia contemporánea hoy, IX congreso de la Asociación de Historia Contemporánea, Murcia, 17-19 de septiembre de 2008. p. 4.
} 
pero sin que esto supusiera realizarlas bajo unas condiciones percibidas como excesivamente crueles.

Con los envíos a Filipinas, el Gobierno trasladó el problema al Capitán general del archipiélago, Narciso Clavería, quien tuvo que ir improvisando sobre la política a emplear con estos sujetos. Esto demuestra el despreció de los moderados por los castigados, al desentenderse de su suerte. Sin embargo, unas condiciones de indigencia, mendicidad y muerte en cantidades importantes podían resultar contraproducentes tanto para el partido gobernante en la metrópoli como para los propios mandatarios coloniales, ya que había la creencia entre ellas de que el dominio español se basaba en parte en una supuesta autoridad moral sobre los nativos que hacía desaconsejable que los indígenas vieran como unos españoles ultrajaban a otros.

Al llegar a su destino, el Capitán general les hizo una alocución exponiéndoles que allí no habían diferencias políticas: “aquí no hay más que españoles desde el momento en que se pisa este suelo, y Vds. serán tratados por mí y por todos como compatriotas desgraciados, como españoles y caballeros". ${ }^{97}$ Políticamente, las posibles intervenciones de las potencias extranjeras, la guerra continua contra los piratas de Joló y Mindanao y las campañas intermitentes para afianzar el dominio sobre determinadas islas, generarían una sensación de inquietud entre los colonos españoles. A ello habría que unir el miedo a una rebelión independentista, con precedentes como el "Motín de Novales" de 1823 y la "Conspiración de los Palmeros" de 1829. En 1843 se sublevó el regimiento de Tayabas, cerca de Manila, en una revuelta conectada con la rebelión de carácter religioso de Pule entre 1840 y 1841 en la misma provincia.

La poca población española en el archipiélago, circunscrita básicamente a la capital y compuesta por unas 5.000 personas de las que únicamente 1.500 eran de origen europeo, ${ }^{98}$ recomendaba un buen trato a los relegados. La sociedad filipina les ayudó comprándoles ropas y alimentos. ${ }^{99} \mathrm{El}$ arribo de 740 hombres suponía un aumento casi del $50 \%$ respecto a la población peninsular anterior, lo que unido a su carácter de represaliados políticos, es decir individuos alejados de la delincuencia, hizo que la respuesta de los peninsulares fuera la de arroparles. Se ayudaba a sujetos pertenecientes

\footnotetext{
${ }^{97}$ Manuel Buzeta y Felipe Bravo, Diccionario geográfico-estadístico-histórico de las islas Filipinas, Imprenta de D. José C. de la Peña, Madrid, 1851, tomo II, pp. 266-267.

${ }^{98}$ Sinibaldo de Mas, Informe sobre el estado de las islas Filipinas en 1842, Imprenta de I. Sancha, Madrid, 1843, tomo I, "Estado de las islas en 1842. Población", p. 138.

${ }^{99}$ El Católico, 4 de julio de 1849. Información extraída de periódicos de Manila; La Nación, 20 de julio de 1849 .
} 
a la misma nación, pero esto tenía un factor interesado ya que reforzaba la propia posición como grupo minoritario frente al resto de poblaciones de los naturales. En un entorno percibido como hostil, el grupo dominante se cohesionó y creó lazos de unión y de solidaridad.

Las diferencias entre los grupos continuaron. Desde un punto de vista social a los catalogados en clase de "oficial" se les alojó en casas particulares y se les dejó en completa libertad, mientras que el resto fueron distribuidos entre los dos depósitos establecidos al efecto en Manila y en Cavite. ${ }^{100}$ En estos tuvieron libertad limitada, puesto que pudieron salir a ciertas horas. La estancia en los mismos fue puntual, mientras no fueran capaces de procurarse alojamiento y medios de subsistencia.

Una vez establecidos habría que cubrir sus necesidades básicas. En Canarias se asignaron pensiones a los confinados más pobres. Esto se hizo extensible a las Filipinas, donde la dificultad para absorber a una cantidad tan importante de población era mayor. Fueron los mandatarios coloniales los que les otorgaron las pensiones que en un principio oscilaron entre los 15 y los 30 pesos mensuales, pero con la llegada masiva tuvieron que ser reducidas a 20 pesos mensuales a los de clase de "oficial" y al resto ración de pan y arroz, lumbre para que pudieran cocinar y 82 reales mensuales. ${ }^{101}$ Las condiciones que habían soportado los relegados durante su aprehensión y traslado, estrechez y penuria pero no total desamparo, continuaron en Filipinas. Permanecieron libres, aunque sin disponer de libertad absoluta para establecerse donde quisieran. El tutelaje de las autoridades continuó, ya que incluso en la lejanía se temía su militancia política.

El Capitán general había tolerado la presencia de los del Ligero en Manila por ser un grupo poco numeroso, pero tras conocer las remisiones multitudinarias decidió repartirlos por provincias. ${ }^{102}$ Centenares de represaliados por disidencia política, ociosos y concentrados en un punto determinado podían representar un peligro potencial.

\footnotetext{
${ }^{100}$ Oficio de encargado del depósito a Capitán general de Filipinas, 21 de enero de 1849, PNA, Guerra, Leg. 136; Wenceslao Ayguals de Izco, El Palacio de los crímenes o el pueblo y sus opresores, tomo I, pp. 453 y 662-665; El Nacional, 29 de agosto de 1849.

${ }^{101}$ AHN, Ultramar, Leg. 5161, Exp. 61. "Concesión de pensiones a deportados políticos". Al intendente honorario Agustín Algarra se le asignaron 30 pesos, 15 al actor Alejandro Basora y 20 al resto, que eran oficiales del ejército, funcionarios relevantes, comerciantes o industriales; Wenceslao Ayguals de Izco, El Palacio de los crímenes o el pueblo y sus opresores, tomo I, p. 665; El Observador, 7 de abril de 1849.

102 Carta de Narciso Clavería a Narváez, 18 de enero de 1849. BRAH, Archivo de Narváez, 9/7831, II-C-b-3.
} 
Esparcidos por el territorio resultaban casi inofensivos. Además, su utilidad lejos de la capital era mayor, pues su presencia pudo ser aprovechada para extender la colonización fuera de Manila y estos eran los únicos blancos a los que se podía obligar a variar su lugar de residencia. A diferencia del caso británico, todo el proceso se fue improvisando, el asentamiento forzado en las posesiones no fue el objetivo primordial sino que lo que se pretendió fue hacer frente a la disidencia política y social. (Gráfico 1).

Gráfico 1. Distribución de los relegados fuera de Manila

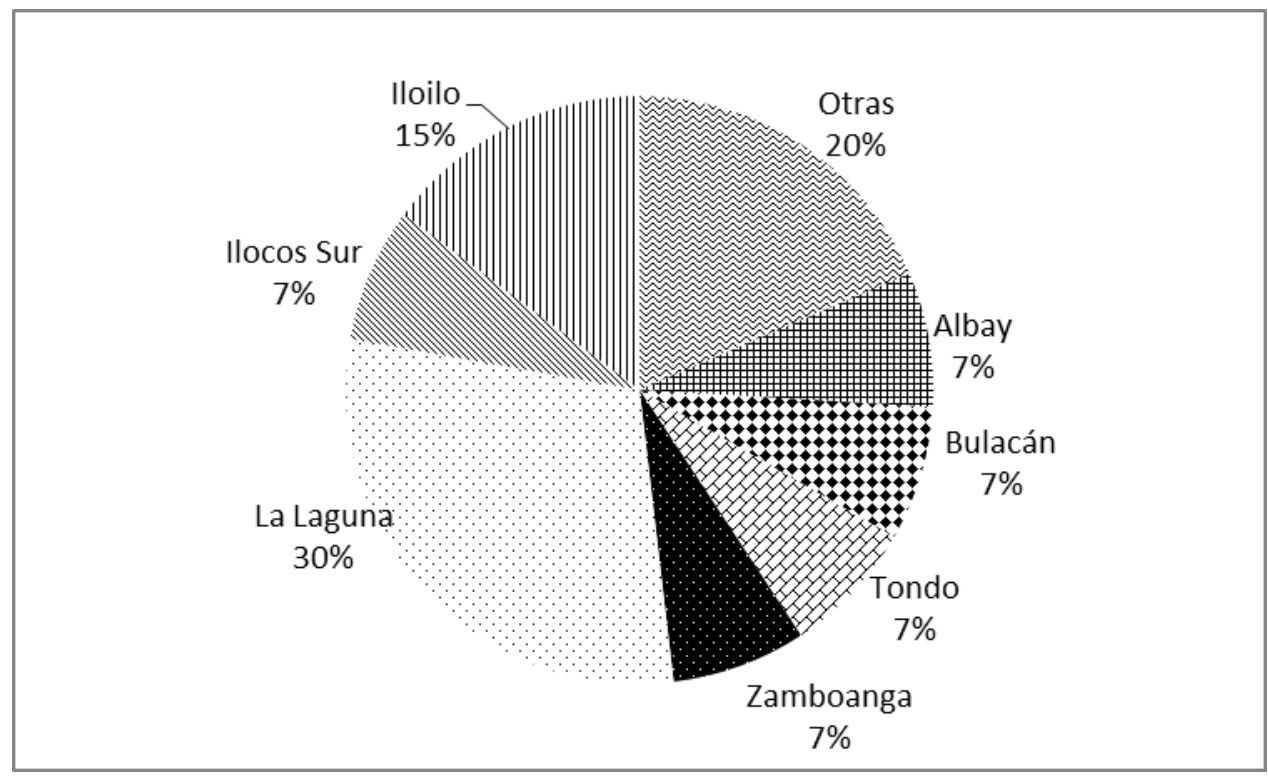

Fuente: Elaboración propia sobre los 27 de los que tenemos estos datos: PNA, Oficios, Leg. 4. Causa contra cinco individuos de Tauste; PNA, Guerra, Leg. 136. Relación de deportados a las Filipinas y punto para el que son llevados; PNA, Guerra, Leg. 136. Expedientes de cesación de ayudas a deportados; AHN, Ultramar, Leg. 5162, Exp. 70. "Permiso de residencia al deportado Bernardo Yubal"; AHN, Ultramar, Leg. 5163, Exp. 39. "Concesión de permiso de residencia a Tomás Bara"; AHN Ultramar, Leg. 5163, Exp. 40. "Concesión de permiso de residencia a José Cosculluela"; AHN, Ultramar, Leg. 5163, Exp. 45. "Concesión de permiso de residencia a Isidro Romanos García"; PNA, Consultas, Leg. 12. Relación de deportados que han obtenido permiso para permanecer en Filipinas; Agustín Reverter, Carta que ha dirigido a sus amigos y enemigos el ciudadano Agustín Reverter, p. 15.

Todos los que encontraron trabajo en Manila pudieron residir en la capital, por lo que sería el destino mayoritario de los confinados. Esta medida puede ser entendida como una presión al resto para que trataran por todos los medios de obtenerlo y dejar de ser una carga para las cuentas de la administración colonial. En cuanto al resto, la distribución fue bastante uniforme, abarcando a islas del centro del país, aunque predominantemente en Luzón, donde por su carácter urbano su utilidad era mayor, 
tratando de establecer puntos con población peninsular cercanos a Manila. Cuanto más al sur menor fue su presencia, exceptuando al grupo de trabucaires. Entre los afectados por el destierro interior había algunos clasificados como "oficiales", pero no olvidemos que estos disponían de más facilidad para relacionarse con la alta sociedad de Manila.

En cuanto a los oficios, conocemos los de una muestra bastante representativa, en total 75. De estos, once se dedicaban en Filipinas al comercio, uno en un establecimiento de carruajes de alquiler y otro regentaba una sombrerería. Antonio Canals y Llinas había iniciado un exitoso negocio de pavimentos de mosaicos de madera. Nueve trabajaban para diversos ciudadanos, lo que podría incluir tanto actividades comerciales como de servicio en general. Cuatro trabajaban como mayordomos y 11 en actividades relacionadas con la construcción civil o militar. Tres eran actores y otros tres trabajaban en el teatro de Binondo. Uno era periodista, dos practicantes de medicina y cirugía, un veterinario y un farmacéutico. En cuanto a los oficios manuales encontramos una amplia variedad: un ceramista, un panadero, un alfarero, dos herreros, un escribiente, un pintor, dos carpinteros, un peluquero y tres zapateros. Otros seis trabajaban en un establecimiento de carrocería y zapatería. Un individuo encontró trabajo como fogonero, uno como músico en el regimiento Luzón, uno inicio la carrera eclesiástica y tres se dedicaban a la agricultura, probablemente como colonos a causa de la gran cantidad de tierras disponibles. Otro trabajaba para la Compañía Hispano-filipina. ${ }^{103}$ Las profesiones que realizarían no serían en la mayoría de los casos muy distintas a las que realizarían en sus lugares de origen. Esto nos da una muestra bastante gráfica del sector social al que pertenecían los embarcados.

\subsection{El regreso}

Una vez que el Gobierno se sintió completamente afianzado, publicó el real decreto de 14 de enero de 1849 que cesaba los efectos de la ley de 13 de marzo del año anterior. A los presos se les concedía la libertad y a los deportados y exiliados se les

\footnotetext{
${ }^{103}$ PNA, Guerra, Leg. 136. Expedientes de cesación de ayudas a deportados; PNA, Consultas, Leg. 12. Relación de deportados que han obtenido permiso para permanecer en Filipinas. Desconocemos si los mayordomos lo eran en el ámbito doméstico o como capataces, al no especificarlo la documentación; AHN, Ultramar, Leg. 5163, Exp. 55. "Concesión de permiso de residencia en Manila a Felipe Ortega"; AHN, Ultramar, Leg. 5163, Exp. 50. "Concesión de permiso de residencia a D. Joaquín Oliu"; AHN, Ultramar, Leg. 5162, Exp. 2. "Concedido permiso de residencia al deportado Andrés Arbós".
} 
permitía volver. Los que se hallaban fuera del territorio metropolitano debían acudir a los cónsules para que les expidiera pasaporte. La ley fue publicada el 26 de abril en el Diario de Manila. Sin embargo, junto a la misma no llegaron las instrucciones de cómo y a cargo de quien se efectuaría el regreso, por lo que tuvieron que esperar varios meses hasta que la consulta elevada por el Capitán general tuviera respuesta. ${ }^{104}$

De este modo, en un principio únicamente pudieron volver aquellos que disponían del dinero necesario para comprar el pasaje, aunque también se ideó un sistema mediante el cual ciertos sujetos adelantaban el dinero a los relegados para posteriormente cobrarlo de la contrata de transporte. ${ }^{105}$ Con la necesidad del pago del billete, se facilitaba la repatriación de los de mayor categoría social y por tanto tenidos por menos bullangueros. Las trabas a la vuelta provocaron la denuncia sistemática de los progresistas, que desde la tribuna parlamentaria o la prensa presionaron al Ejecutivo para un pronto retorno de los confinados. Precisamente lo que trataba de evitar, ya que de este modo se ralentizaba el regreso de los represaliados. Un grupo de 40 consiguieron adquirir el billete por la vía del istmo de Suez. De estos, 33 arribaron a Marsella a finales de julio. La mayoría eran hombres de cierta posición, pero también encontramos a dos artesanos y a un barbero, ${ }^{106}$ mostrando como algunos individuos de las clases bajas pudieron acceder a la vuelta por la vía más rápida.

El real decreto de enero fue ampliado con el de 8 de junio de 1849, publicado en el Diario de Manila en 26 de agosto, que ofreció una amnistía total para los delitos políticos y contenía dos novedades importantes: los deportados tenían un mes para presentarse a las autoridades a partir de la fecha de publicación y se requería que los afectados prestasen juramento de fidelidad a la Reina y a la Constitución. ${ }^{107}$ Sin embargo, el problema principal continuaba siendo la obstinación en no pagar el coste de su repatriación, lo que dejaba la ley sin aplicación efectiva, exceptuando contadas ocasiones. Así, el retorno durante estos meses tuvo un carácter selectivo. El 31 de mayo

\footnotetext{
${ }^{104}$ Gaceta de Madrid, 15 de enero de 1849; Wenceslao Ayguals de Izco, El palacio de los crímenes o el pueblo y sus opresores, tomo I, pp. 680-682.

${ }^{105}$ PNA, Guerra, Leg. 134. Solicitudes del abono de pasajes para la Península de deportados de 1848.

${ }^{106}$ Wenceslao Ayguals de Izco, El palacio de los crímenes o el pueblo y sus opresores, tomo I, pp. 681-682; La Esperanza, 2 de agosto de 1849. Información de El Portafoglio Maltese.

107 Gaceta de Madrid, 9 de junio de 1849; Wenceslao Ayguals de Izco, El palacio de los crímenes o el pueblo y sus opresores, tomo I, p. 682.
} 
regresaron a Cádiz desde La Habana cuatro personas y el primero de agosto hizo lo propio otro grupo desde Cuba. ${ }^{108}$

En Filipinas, avanzaba muy lentamente. El 3 de octubre de 1849 partió la fragata inglesa Benlah con dos relegados. El 24 de noviembre hizo lo propio Enrique Labedan en la fragata inglesa Berenice. A principios de febrero llegó a Cádiz la fragata Maribeles con varios confinados. ${ }^{109}$ Todos zarparon con anterioridad a que se produjera la licitación gubernamental de los costes, adelantando el importe. No es de extrañar, por tanto, la cortesía que declaraban haber recibido durante el viaje, ya que al fin y al cabo se trataba de pasajeros.

El 3 de diciembre se realizó la subasta de los pasajes, para lo que se tuvo en cuenta la misma clasificación que para la ida, catalogándolos como "oficiales", "sargentos" y "soldados" a tenor del perfil social de los deportados. Cuarenta irían en calidad de "oficiales" por un precio unitario de 412 duros. Los otros seiscientos serían considerados como "clase de tropa", con un coste individual de 178,18 duros por los "sargentos" y 131,40 por los "soldados". La contrata la obtuvo Manuel Iturriaga, exgobernador de Antigua y comandante del ejército en activo, ${ }^{110}$ quien sacaría beneficio económico de la desgracia de centenares de personas y de la decisión del Gobierno de mercantilizar su retorno. El gabinete podía permitir su repatriación ya que representaban un peligro tolerable y la prolongación de su permanencia suponía un desgaste político incuestionable. Cerca de dos años después de los conatos insurreccionales en España, el miedo era mucho menor y el mantenimiento de su situación anómala era cada vez menos justificable. Una vez realizada la contrata, comenzaría la vuelta de la mayoría, organizada y pagada por el Ejecutivo. (Tabla 4).

Al estar licitado el transporte, el Gobierno trató de acelerar el proceso, pero el rápido desarrollo preconizado no se adaptó a la realidad y se prolongó durante varios meses. Todos los que embarcaron en navíos españoles fueron con destino a Cádiz, haciendo el mismo viaje de ida a la inversa. Junto a los relegados fueron repatriados buena cantidad de militares cuyo número en el archipiélago había aumentado precisamente por la presencia de los primeros. El Ejecutivo licitó el pasaje para 640, pero en esos momentos desconocía con certeza el número de los que iban a regresar.

\footnotetext{
${ }^{108}$ El Nacional, 31 de mayo de 1849; El Observador, 6 de agosto de 1849.

109 PNA, Guerra, Leg. 134. Solicitudes de deportados pidiendo el abono del pasaje a la Península; El Nacional, 31 de enero de 1850.

${ }^{110}$ La Época, 2 de marzo de 1850.
} 
Además, en la contrata se incluyó el pago a los avalistas de algunos que habían zarpado con anterioridad. Aun así, es posible que el retorno comprendiera otros barcos de los que no tenemos constancia.

Tabla 4. Regreso de deportados tras la contrata gubernamental, (1849-1850)

\begin{tabular}{lcc}
\hline Nombre del vapor & Fecha de salida & $\mathbf{N}^{\mathbf{0}}$ de deportados \\
\hline Amistad & $10-12-1849$ & 1 \\
Fragata inglesa (nombre & $17-12-1849$ & \\
desconocido) & $17-12-1849$ & 2 \\
Hispano Filipina & $23-12-1849$ & 229 \\
Churruca & $23-12-1849$ & 152 \\
Bella Bilbaína & $7-2-1850$ & 157 \\
Fortuna & $12-2-1850$ & 3 \\
Preciosa & $6-3-1850$ & 15 \\
Amable Carmita & $27-3-1850$ & 20 \\
Victoria & $9-8-1850$ & 3 \\
Bella Gallega & $9-8-1850$ & 1 \\
Gertrudis & & $\mathbf{5 8 7}$ \\
Total de afectados & & \\
\hline
\end{tabular}

Fuente: Elaboración propia a partir de: oficios del Capitán general a secretario de Estado y del despacho de la Gobernación del reino, 13 y 23 de febrero, 6 de marzo, 6 de abril y 13 de agosto de 1850. PNA, Consultas, Leg. 12; El Clamor Público, 2 de marzo de 1850; El Nacional, 28 de abril de 1850; La Época, 25 de mayo de 1850.

Un viaje de estas características resultaba peligroso: siete hombres fallecieron en el viaje de la fragata Churruca. También permanecieron en cuarentena las fragatas Preciosa y Fortuna, que llegaron a Cádiz el 21 de junio y el 1 de julio respectivamente, a las que las autoridades de Cádiz no permitieron desembarcar y fueron desviadas hacia el lazareto de Vigo. ${ }^{111}$ A causa del largo periodo de estancia, de la precariedad de sus condiciones y de la difícil aclimatación de los europeos al clima, durante el tiempo de residencia en el territorio se produjeron varias defunciones. Tenemos contabilizadas 21 , entre los que 14 que fallecieron durante el trayecto de Manila al depósito de Cavite, atacados por el cólera, cuatro que fallecieron durante el viaje del Colón, y ya en Filipinas, otros tres individuos. ${ }^{112}$

${ }^{111}$ El Clamor Público, 17 de abril de 1850. Información de El Progreso de Cádiz, de 13 de abril; La Esperanza, 15 y 22 de julio de 1850.

${ }^{112}$ AHN, Ultramar, Leg. 5162, Exp. 55. "Comunicado el fallecimiento de Manuel Galindo"; $E l$ Nacional, 29 de agosto de 1849; El Clamor Público, 31 de enero de 1850. 
Algunos habían decidido establecerse. Un mínimo de 43 solicitaron y consiguieron el correspondiente permiso para permanecer en el archipiélago. ${ }^{113}$ La larga estancia ocasionó que algunos se adaptasen a la vida en la colonia y decidieran afincarse por motivos económicos o familiares. La obtención de la residencia significaba renunciar a volver por cuenta del Estado, pero en este caso se requería buscar un fiador para hacerse cargo del regreso en el caso de que quisiesen volver a la Península y no dispusieran de medios para adquirir el pasaje. ${ }^{114}$ Para poder quedarse había que obtener el permiso de las autoridades. Se dio la aciaga paradoja de que personas que fueron detenidas, encarceladas y deportadas a miles de kilómetros de sus casas, una vez rehechas sus vidas allí tuvieran que pedir permiso para residir la posesión. El Gobierno accedió a las peticiones que hemos encontrado, aunque esto no quiere decir que todas tuvieran que ser aceptadas, puesto que en todos los casos se requirieron informes de su comportamiento.

Es posible que el número de los que permanecieran en Filipinas fuese mayor. El Capitán general informaba en 6 de junio de 1850 que en Nueva Guipúzcoa "se hacen bastantes adelantos en aquel nuevo establecimiento abriéndose tierras de labor y comunicaciones entre aquellos pueblos”. Esto implicaría que algunos permanecerían allí. ${ }^{115}$ Su pobreza en la Península y su carácter de campesinos pudo suponerles alguna mejora al obtener tierras para su asentamiento. Aun así, con el embarque de la mayoría, el impulso que podía haberse efectuado en la colonización quedó muy atenuado. Este modo de proceder imposibilitaba una repoblación a la británica, como la que se estaba efectuando en Australia.

El Ejecutivo fue menos condescendiente con los trasladados a Canarias. Al comprometerse en las Cortes a pagar la vuelta de todos los desterrados, varios barcos habían llevado a Cádiz a muchos de ellos, con la confianza de que el Estado se haría

${ }^{113}$ PNA, Guerra, Leg. 136. Expedientes de cesación de ayudas a deportados; PNA, Consultas, Leg. 12. Relación de deportados que han obtenido permiso para permanecer en Filipinas (excluidos los de Nueva Guipúzcoa); AHN Ultramar, Leg. 5163, Exp. 55. "Concesión de permiso de residencia en Manila a Felipe Ortega"; AHN Ultramar, Leg. 5163, Exp. 50. "Concesión de permiso de residencia a D. Joaquín Oliu"; AHN, Ultramar, Leg. 5162, Exp. 2. "Concedido permiso de residencia al deportado Andrés Arbós".

${ }^{114}$ Oficio del Capitán general a secretario de Estado y despacho de la Gobernación del reino, 17 de julio de 1850, PNA, Consultas, Leg. 12.

115 Oficio del Alcalde de Bislig al Capitán general, 23 de diciembre de 1851. PNA, Consultas, Leg. 12. De ellos al único que tenemos identificado es a Joaquín Oliu que se había dedicado a la agricultura, a la apertura del camino entre Bislig y Minao y a otros trabajos para el alcalde de Bislig. Solicitó quedarse en Filipinas y le fue concedido. 
cargo de su pasaje. Sin embargo, a fecha de mayo de 1850 esto todavía no había ocurrido. ${ }^{116} \mathrm{Al}$ desentenderse las autoridades del abono de sus pasajes tuvieron que recurrir a sus propios fondos o a la ayuda de familiares, amigos o correligionarios políticos. Dado que las relegaciones al territorio asiático suponían un atropello mucho mayor, la presiones fueron encaminadas hacia su denuncia, lo que dejó a los desplazados al archipiélago más cercano en un segundo plano. La desidia e indolencia del Gobierno explican que pagara el billete de 640 individuos desde Filipinas y se negara a hacer lo mismo con los transportados a Canarias, que suponían un coste muchísimo menor por la mayor cercanía y por ser un número más reducido.

Una vez que regresaron a la Península, se reincorporarían a sus quehaceres cotidianos, pero aun así se les había causado un enorme perjuicio, que no sería reparado hasta años después. Los moderados consideraban que haber acarreado con los gastos del retorno de la mayoría era suficiente y en ningún momento demostraron la más mínima intención de compensar a las víctimas por el daño tanto moral, laboral y económico que se les hubiera causado. No sería hasta el Bienio Progresista cuando mediante la Ley de 2 de agosto y el real decreto de 16 agosto, ambos de 1855, se establecieron los mecanismos de resarcimiento y compensación para los deportados y exiliados como consecuencia de la represión política de los moderados.

\section{EL FIN DE LA DÉCADA MODERADA}

Tras las enormes tensiones producidas por la sublevación carlista y las revueltas de 1848, se volvió en cuanto al uso de deportaciones a una situación similar a la que se dio en los primeros años de la Década Moderada, aunque las situaciones no eran equiparables. Los inicios de la década de 1840 fueron tiempos de enorme agitación política y castigo, mientras que en los primeros 50 la situación era muchísimo más calmada. El general Manuel Pavía y Lacy, antiguo Capitán general de Cataluña, fue destinado de cuartel a Madrid en septiembre de 1849 donde permaneció dedicado a sus asuntos personales y como senador destacó por su oposición a Narváez. En estas condiciones permaneció hasta que en 15 de julio de 1850 se le castigó con el traslado de cuartel a Canarias, que finalmente no cumplió porque se le permitió permanecer en

${ }^{116}$ El Clamor Público, 12 de mayo de 1850. 
Cádiz. El 22 de junio de 1850 fue relegado a Palma de Mallorca el destacado liberal Bernardo Baldrich. ${ }^{117}$ Con una situación política calmada no tenía sentido ejercerlas masivamente y se volvió en cuanto a su uso, a una utilización muy puntual.

El 10 de enero de 1851 Narváez presentó la dimisión como presidente del Gobierno, agotado por la falta de apoyos. Fue sustituido por Juan Bravo Murillo que subió al poder el 14 del mismo mes con un programa de reformas administrativas, hacendísticas y de obras públicas. Su mandato comenzó con un carácter tecnocrático que poco a poco fue convirtiéndose en más autoritario. El desdén por la política y el normal funcionamiento de las Cortes le valió finalmente la oposición de sus propios correligionarios. A Bravo Murillo, le sucedieron los ministerios de Federico Roncali y Francisco Lersundi, que apenas tuvieron trascendencia.

Mucho más importante fue el ascenso al poder de José Luis Sartorius el 18 de noviembre de 1853. Sartorius, había sido ministro de la Gobernación durante 1848 y por tanto coparticipe, junto con Narváez, de las deportaciones ejecutada entonces. Los retos a los que se enfrentaba para consolidar su ministerio eran enormes: un Partido Moderado dividido y enfrentado; una corrupción muy relevante, que a pesar de ser estructural, terminaría desgastándole; un incremento de los precios a finales de 1853, que se transformó en escasez al año siguiente; un aumento del desempleo y de la mendicidad y una situación social revuelta, con hitos como la huelga de tejedores en Barcelona entre el 22 de marzo y el 3 de abril de 1854. Esto produjo un acrecentamiento de las críticas en la prensa y de las actividades conspiratorias, que excedieron de la realizada por progresistas y demócratas hasta alcanzar a un grupo que había apoyado y formado parte del Gobierno del Partido Moderado. ${ }^{118}$ Las disensiones en el grupo conservador se manifestaron en un enfrentamiento en el Senado a raíz de la nueva Ley de Ferrocarriles, propuesta por Sartorius. Cuando fue derrotada, el presidente respondió suspendiendo las Cortes e imponiendo una férrea censura informativa. El intento de mantenerse a toda costa en su cargo, unido al momento de descomposición política en la que estaba inmerso el país, implicaba necesariamente la acentuación de la política represiva gubernamental.

\footnotetext{
${ }^{117}$ Biografía del Excmo. Señor Manuel Pavía y Lacy, marqués de Novaliches, Imprenta de Manuel Minuesa, Madrid, 1861, pp. 83-88; El Genio de la Libertad, 18 de mayo de 1851. En esta fecha su hermano se encontraba en Madrid haciendo gestiones para tratar de conseguir su regreso.

${ }^{118}$ ver Francisco Cánovas Sánchez, El Partido Moderado, pp. 495-513.
} 
Por votar contra Sartorius en la Ley de Ferrocarriles fueron cesados seis consejeros reales; dieciséis miembros del Tribunal de guerra y marina, entre ellos su presidente, el barón de Meer; Francisco María Marín, secretario de las reales órdenes de Carlos III e Isabel la Católica; Antonio Ros de Olano, director general del cuerpo de Sanidad Militar y José de la Concha, director general de caballería. El 17 de enero, fueron destinados a Canarias de cuartel los generales Manuel Gutiérrez de la Concha y Leopoldo O’Donnell y a Baleares José de la Concha y Facundo Infante. O’Donnell y José de la Concha pudieron huir y ocultarse en Madrid y en Francia respectivamente. Ambos serían posteriormente cesados de sus funciones, lo mismo que sucedería con Francisco Serrano y ya a finales de junio, con los generales Ros de Olano, Félix Messina y Domingo Dulce. El 21 de febrero Serrano fue destinado de cuartel a Arjona, Francisco Armero a León y Manzano a Cuenca y los tenientes generales Agustín Nogueras y Zabala a Valladolid y Bayona respectivamente. Las represalias no terminaron ahí, puesto que Evaristo San Miguel y Chacón, también fueron obligados a salir de Madrid. Otros militares importantes fueron trasladados de cuartel, desterrados o encarcelados, alcanzando las iras de Sartorius a otros políticos y periodistas, que serían presos, desterrados o deportados. ${ }^{119}$

El Ejecutivo, sabiendo que algo se tramaba realizó una represión con carácter preventivo, pero comedida, puesto que ahora los opositores pertenecían a idéntico estrato social y en ocasiones al mismo partido que el Gobierno. Esto imposibilitaba unos castigos generalizados, ya que por afectar a miembros de la élite podía socavar aún más los escasos apoyos con que contaba el presidente. También descartaba las relegaciones a lugares tan lejanos como las Filipinas, por lo que las relegaciones tuvieron como destino principal las islas Canarias y en mucha menor medida a Baleares, y además, hubo diversos casos de destierros. A los militares de alta graduación se les remitió a los mismos puntos pero de cuartel, es decir, fuera del empeño momentáneo del

\footnotetext{
119 José Ramón de Urquijo y Goitia, La revolución de 1854 en Madrid, CSIC, Madrid, 1984, pp. 54-55; El Balear, 9 de enero de 1855; Ramón de Santillán, Memorias (1815-1856), Studium Generale, Pamplona, 1960, vol. 2, pp. 227-228; Ángel Fernández de los Ríos, Estudio histórico de las luchas políticas en la España del siglo XIX, English y Gras, Madrid, 1880, tomo II, pp. 313-315; sobre la revolución de 1854 ver: Cristino Martos, La revolución de julio de 1854, Colegio de Sordomudos y Ciegos, Madrid, 1854; Ildefonso Bermejo, Alzamiento popular de 1854, que comprende desde la cuestión de ferrocarriles hasta la entrada del duque de la Victoria en Madrid y disposiciones posteriores. Establecimiento tipográfico de Mellado, Madrid, 1854. También Antonio Ribot y Fontseré, La revolución de julio en Madrid, Imprenta de Gaspar y Roig, Madrid, 1854.
} 
ejército pero con la subsistencia asegurada. Únicamente en el caso de los civiles podemos hablar de deportación aunque su importancia social determinó que fueran llevados al Ultramar cercano.

Los casos conocidos correspondían a presuntos conspiradores y opositores más destacados. Este grupo era el más conocido por su importancia social y porque resultaba el más peligroso para Sartorius. Aun así, la inestabilidad pudo ser aprovechada para embarcar a otros sujetos de menor importancia social, o relacionados con la delincuencia o la marginalidad. Esta idea viene determinada por un grupo de 35 mallorquines enviados a Canarias y que tras su regreso desde Santa Cruz de Tenerife a Barcelona manifestaron no tener dinero para alojarse, para comer, ni para el viaje de vuelta. En su petición de ayuda excluyeron cualquier referencia a las causas por las que fueron trasladados, incluso cuando ya se trataba de un Gobierno diferente. Además, los hosteleros de Barcelona, donde fueron alojados con cargo al ayuntamiento se quejaban de su comportamiento y de los objetos que habían sustraído. ${ }^{120}$ En cualquier caso, este grupo constituiría una excepción que nada tenía que ver con la creciente inestabilidad política que terminaría con la Década Moderada.

Manuel Gutiérrez de la Concha se instaló en el valle de la Orotava, dedicándose a la botánica. El 7 de marzo, llegaron a la misma isla en el vapor Duque de Riansares en calidad de deportados: Manuel Bermúdez de Castro, exministro de Hacienda; Manuel Rancés, director de El Diario Español; Dionisio L. Roberts, redactor del mismo periódico y León Valentín de Bustamante, redactor de Las Novedades. Todos ellos se alojaron en una fonda inglesa. Al mismo destino había sido llevado a finales de febrero el director de El Tribuno, Alejo Galilea y Vicente Barrantes, redactor de Las Novedades. La presión que tuvo que soportar la prensa durante 1854 fue muy fuerte, pero muchos periodistas se mantuvieron firmes, e incluso nombraron a principios de año una comisión para representarla. Estuvo compuesta por José Gálvez Cañero, redactor de El Clamor Público; Augusto Ulloa, redactor de El Tribuno; y Manuel Rancés, director de El Diario Español. El primero tuvo que ocultarse, el segundo término desterrado en Galicia y el tercero, acabaría en Canarias. ${ }^{121}$

\footnotetext{
${ }^{120}$ Arxiu Municipal Contemporani de Barcelona, A-183. Comissió de Governació, Exp. A2996. Sobre deportados de Baleares.

${ }^{121}$ El Clamor Público, 22 de enero, 26 de febrero, 18 de marzo y 15 de agosto de 1854; El Áncora, 26 de enero de 1854; La Época, 1 de abril y 2 de octubre de 1854; Los diputados pintados por sus hechos, tomo I, pp. 141-142.
} 
El otro eje contra el cual se actuó fueron los posibles conspiradores, grupo en el que se incluyeron a los que se habían manifestado contrarios al Ejecutivo, o sobre los que existieran sospechas. Este grupo estuvo formado principalmente por militares de alta graduación con los que se siguió una política de alejamiento. El coronel García Muñoz había sido detenido en Antequera, y desde allí trasladado preso a Málaga y posteriormente a Cádiz. Fue embarcado el 16 de marzo también con dirección a Canarias a la vuelta del Duque de Riansares. Junto a él debía haber salido el señor Laberon, pero consiguió huir estando en casa de Ramón de Boladeras. Por esto fue su anfitrión quien finalmente recabó en Mallorca y una vez allí, fue puesto en la cárcel. El progresista Facundo Infante salió de Barcelona el 24 de enero y arribó a Ibiza el 22 de febrero, adonde había sido destinado de cuartel. El conde de la Romera fue desterrado en La Coruña. El general Manzano, que en principio había sido confinado en Cuenca, terminó en Puerto Rico. El brigadier Vargas fue enviado a Canarias. ${ }^{122}$

El número de represaliados fue mayor, aunque la dificultad estriba en conocer cómo fueron efectivamente reprimidos. En la época circulaba una lista, pero tras rastrear los nombres vemos que está equivocada en algunos casos. Además, en el caso de las deportaciones ofrece problemas añadidos, puesto que algunos de los que cataloga como relegados fueron desterrados o destinados de cuartel. ${ }^{123}$ En cualquier caso, la lista abarcaba a poco más de cuarenta personas, a los que añadía a los oficiales del regimiento pronunciados en Zaragoza. La represión no cumplió el objetivo de paralizar el cambio que se produjo después de la adhesión de las masas urbanas progresistas y demócratas al pronunciamiento de Vicálvaro, superando las intenciones de este y consiguiendo el triunfo del bienio progresista.

Los confinados en Canarias fueron bien tratados por el Capitán general del territorio, Jaime Ortega. El 6 de julio de 1854, Manuel Gutiérrez de la Concha, Marqués del Duero, Manuel Rancés y otro de los deportados, se fugaron yendo a parar a Londres. A finales de julio ya habían regresado a Barcelona. Su huida, según Montes, se produjo con la connivencia del Capitán general, que les dejó marchar el mismo día que llegó una orden de traslado a Marianas. ${ }^{124}$

${ }^{122}$ El Balear, 28 de marzo de 1854; El Genio de la Libertad, 10 de julio de 1854; El Clamor Público, 29 de enero de 1854; La Época, 27 de junio y 31 de julio de 1854; Ildefonso Bermejo, Alzamiento popular de 1854, pp. 7-8 y 39-40.

${ }^{123}$ La Esperanza, 2 de agosto de 1854, información de La Nación, 29 de julio de 1854.

${ }^{124}$ El Balear, 30 de julio de 1854; Pedro Domingo Montes, Historia de la gloriosa revolución española en septiembre de 1868, Elizalde y Cía., Editores, Madrid, 1868, p. 472. Según Montes, 
Ortega dejo escapar a Manuel Gutiérrez de la Concha el mismo día que llegó una orden de deportación contra el a las Marianas. 


\section{CAPÍTULO 5. DEL BIENIO PROGRESISTA A LA REVOLUCIÓN GLORIOSA}

\section{HACIA EL RECONOCIMIENTO DE DERECHOS DE LOS REPRESALIADOS}

La represión moderada no pudo mantener un régimen en descomposición. A la situación económica y de carestía habría que añadir la política, con la oposición de antiguos miembros del partido aperturistas, progresistas y el pueblo que empezaba a estar fuertemente sensibilizado con las demandas de demócratas y republicanos de sufragio universal, soberanía popular y medidas de carácter social. La insurrección popular hizo caer al último gabinete de Fernández de Córdoba formado el 17 de julio de 1854. El día 19, la Corona nombró jefe del Gobierno a Espartero, como mal menor. Comenzaba el Bienio Progresista. El día 29, Espartero entró en la capital y formó un Ejecutivo con progresistas y puritanos, excluyendo a los demócratas. ${ }^{1}$

La deportación volvió a estar al orden del día, pero no mediante su utilización sino por su inclusión en el juego político. Al constituir una arbitrariedad gubernamental de gran calado fue utilizada para desacreditar a los moderados. Los generales O’Donnell, Dulce y Messina publicaron en diversos periódicos un manifiesto muy duro.

"Así, el principio social de la legalidad ha desaparecido entre nosotros, siendo la voluntad de los ministros ley única. Así la seguridad individual ha desaparecido, siendo deportados, sin forma de juicio, los ciudadanos más respetables; otros desterrados a países extranjeros, muchos obligados a ocultarse abandonando sus intereses y hogares. De este número son los generales, los senadores, los diputados que intentaron ejercitar el derecho de petición concedido por la ley fundamental a todos los ciudadanos; los escritores que osaron guardar silencio a tiempo que la esclavitud hacia vil el aplauso". ${ }^{2}$

O’Donnell y los suyos denunciaban las relegaciones más recientes que afectaron a personalidades importantes de su mismo grupo social. El ideario unionista, todavía en formación, se entreveía perfectamente en sus declaraciones. El nuevo Gobierno comenzó inmediatamente una rehabilitación rápida de los represaliados de alto estrato social. El día 26 de agosto los generales O’Donnell, Serrano, Ros de Olano, de la Concha, Messina y Dulce fueron rehabilitados en sus empleos, grados y

\footnotetext{
${ }^{1}$ Sobre el periodo inmediato al triunfo de la revolución, ver José Ramón de Urquijo y Goitia, $\mathrm{La}$ revolución de 1854 en Madrid, pp. 149-313.

${ }^{2}$ El Genio de la Libertad, 19 de julio de 1854; La Ilustración, 24 de julio de 1854.
} 
condecoraciones. Junto a ellos otros menos conocidos como el brigadier Vargas y el coronel Fructuoso García Muñoz, que habían sido remitidos a Canarias. ${ }^{3}$

Sin embargo, otros sectores habían participado en la revolución de 1854. En la revuelta de Madrid tuvieron un peso determinante las clases populares y dentro de ellas los obreros, mientras que los jefes de las barricadas: "En su mayoría pertenecían al grupo de profesionales liberales y pequeños propietarios". La expansión de la ideología democrática era un hecho, pero la crisis económica y el paro tuvieron un factor determinante en el malestar social de los trabajadores. Las protestas obreras se mantuvieron por la insuficiencia de la ocupación pública y la salida de la reina provocó la reacción de los demócratas que reanudaron la formación de barricadas, pero que finalmente se disolvieron pacíficamente. ${ }^{4}$

Desde un sector social intermedio se reivindicó una rehabilitación completa, el 20 de agosto fue convocada una reunión de los deportados y extrañados de 1848 y de otras épocas de la persecución moderada. ${ }^{5}$ El encuentro estuvo convocado por personalidades relevantes, algo que los conceptuados como vagos y delincuentes no hubieran podido realizar. Los congregados decidieron pedir algún tipo de resarcimiento por sus desventuras. En un ambiente de enorme cordialidad, el secretario se reunió con el duque de la Victoria el día 25, apenas unos pocos días tras la reunión, muestra de las intenciones gubernamentales de cooperar con la comisión y reparar el daño que habían sufrido las víctimas. ${ }^{6}$

Había en los inicios del régimen un consenso entre la prensa liberal y los políticos para condenar la represión de los conservadores. Los periódicos informaban de las relegaciones acaecidas, contaban las vivencias de los afectados y las censuraban. Los antiguos represaliados volvieron a sus ocupaciones y algunos ocuparon puestos importantes, como el general Manzano, nombrado gobernador político y militar del departamento occidental de Cuba. ${ }^{7}$ El regreso y adquisición de responsabilidades de muchos supuso una ampliación hacia abajo del sistema, al que beneficiaba para aumentar sus bases y para remarcar la diferencia entre sus predecesores. Sin embargo,

\footnotetext{
${ }^{3}$ La España, 2 de enero de 1855; El Clamor Público, 20 y 23 de agosto de 1854.

${ }^{4}$ Carmen García Monerris y Juan Sisinio Pérez Garzón, "Las barricadas de 1854. Análisis sociológico", Anales del Instituto de Estudios Madrileños, núm. 12, 1976, pp. 213-237.

${ }^{5}$ El Clamor Público, 15 de agosto de 1854.

${ }^{6}$ La Iberia, 16 y 22 de agosto de 1854 y 1 de marzo de 1855 . La iniciativa de los deportados en Madrid, se extendió a Málaga y más tarde a Sevilla.

${ }^{7}$ La Época, 28 de noviembre de 1854.
} 
cada vez era más evidente que un sector de los revolucionarios estaba quedando al margen. Las elecciones celebradas entre el 4 y el 6 de septiembre dieron la victoria a los progresistas, los demócratas obtuvieron 30 diputados.

El 12 de noviembre, Agustín Reverter y 28 ciudadanos madrileños más relegados a Filipinas en 1848, pedían al Congreso que se les indemnizara por daños y perjuicios. Algunos afectados o sus esposas lo extendieron al periodo desde el acceso al poder de los moderados. ${ }^{8}$ Las Cortes nombraron una comisión a principios de enero, compuesta principalmente por progresistas y con únicamente dos demócratas, y que el 27 del mismo mes ni siquiera se había reunido. ${ }^{9}$ La rehabilitación de los represaliados de la izquierda no era una prioridad, únicamente el empuje de una élite de entre estos hacía que los trabajos para el reconocimiento de los deportados avanzaran. La exclusión de los sectores más situados a la izquierda se trasladó al resarcimiento de las víctimas, lo que incluyó a los deportados "sociales".

El ultraconservador Cándido Nocedal clamaba en el Congreso contra el resarcimiento. Se oponía a que fuesen reconocidos como años de servicio en el ejército o la función pública aquellos no efectivamente realizados y opinaba que habían sido castigados por insurrección de acuerdo a la normativa. Según afirmaba, así se incentivaban las sublevaciones actuales como las de los obreros de Barcelona o los carlistas en Aragón. También se oponía a la indemnización en metálico y a las condecoraciones. ${ }^{10} \mathrm{Su}$ interpretación era muy sesgada, ya que muchos ni siquiera se alzaron y la legitimidad de los gabinetes era muy cuestionable por lo restrictivo del censo. Las leyes simplemente blindaron la arbitrariedad gubernamental por lo que no podía hablarse de cauces legales. Resarcir a los que habían sufrido deportaciones y habían sido cesados de sus puestos por su militancia era lógico, especialmente teniendo en cuenta el carácter fuertemente autoritario de la Década Moderada.

Para Fernando Madoz la norma era necesaria ya que los sentenciados por los tribunales fueron una minoría y había habido represión en lugares donde no hubo levantamientos. ${ }^{11}$ El 15 de julio fue aprobada la ley dotando una partida presupuestaria de 50.000 reales por año. Según la disposición se exigirían responsabilidades a los gobernantes culpables de estos hechos. Proclamaba el derecho a ser recompensados a

\footnotetext{
${ }^{8}$ El Clamor Público, 23 de noviembre de 1854; DSC, 5 de enero de 1855.

${ }^{9}$ DSC, 30 de diciembre de 1854, 26 de enero y 13 de julio de 1855. Únicamente García Ruiz y García López eran demócratas; La Época, 4 de enero de 1855.

${ }^{10}$ DSC, 12 de julio de 1855 .

${ }^{11}$ DSC, 13 de julio de 1855 .
} 
los que hubiesen permanecido desterrados, relegados o exiliados por un tiempo superior a dos meses, concediéndoles un ascenso en la carrera y estableciendo la preferencia de acceso a puestos públicos de acuerdo a su idoneidad, situación personal y sufrimientos soportados. A los empleados del Estado se les abonarían los salarios por el tiempo que no pudieron trabajar. Se facilitaba la concesión de honores y condecoraciones y establecía pensiones para los familiares, debiendo optar los parientes entre una de ambas. ${ }^{12}$ Los beneficios que establecía para los deportados eran importantes. Suponía el resarcimiento económico de aquellos que fueren empleados públicos y les daba facilidades para la obtención de empleos de funcionariado y establecía ayudas para los familiares. Se trataba de revertir el proceso mediante el cual los moderados habían apartado de las altas instancias militares y gubernativas a los opositores y en la medida de lo posible dar ventaja a sus propios correligionarios.

La ley fue complementada por el real decreto de 16 de agosto, que nombró una Junta calificadora y establecía los plazos y procedimientos para solicitar las prebendas. Los relegados debían pedir un certificado que acreditara el castigo que sufrieron a la secretaría de las Cortes en el término de cuatro meses, lo que muestra que se quería acabar rápidamente con este tema, incluyéndose únicamente a los represaliados por "causas políticas de afección a las instituciones liberales", 13 Los carlistas quedaban excluidos de cualquier tipo de ayuda. Esto es una manera de resarcir, pero también de promoción, los moderados habían copado el ascenso en el ejército y los progresistas y unionistas trataban de solucionar esta situación ascendiendo a los suyos.

La disposición comenzó a aplicarse inmediatamente con la obtención de varias plazas de funcionarios, otorgamiento de condecoraciones, ascensos de funcionarios y militares y pensiones a familiares. ${ }^{14}$ García Ruiz se mostraba descontento con el avance en los trabajos de la comisión de reconocimiento de las víctimas, que dependían de la cooperación de otros ministerios y otras autoridades. El gobernador civil de Cádiz decía

\footnotetext{
${ }^{12}$ CLE, Imprenta Nacional, Madrid, 1855, tomo LXV, pp. 594-596. Las pensiones eran entre cinco y ocho reales de vellón para los padres, viudas e hijos de los fallecidos que hubiesen sido represaliados más de seis meses. Para los progenitores la pensión seria perpetua, para la esposa mientras no varíe de estado y para los hijos hasta los 25 años, trabajasen o terminasen una carrera universitaria; también hubo compensaciones para los represaliados con anterioridad. En el caso del fusilamiento del teniente de carabineros Luis Molina en Alicante, en 1844, recayó en su hijo. La España, 12 de junio de 1855.

${ }^{13}$ CLE, tomo LXV, pp. 679-680.

${ }^{14}$ Valgan como ejemplos: La Época, 6 de octubre de 1855 y 22 de febrero de 1856; La España, 23 de noviembre de 1855 y 9 de febrero y 11 de junio de 1856; Gaceta de Madrid, 13 de junio de 1856; DSC, 23 de junio de 1856. Apéndice cuarto.
} 
que era imposible conocer el alcance de la represión porque con el traslado del archivo los expedientes se habían enmarañado o perdido. ${ }^{15}$ Los capitanes generales de Aragón y Cataluña también obstaculizaron su avance en algunos casos. En abril se negó la gran Cruz de Isabel la Católica a los diputados demócratas Manuel Fernández Poyán, Juan Román Patiño y José Antonio Aguilar. ${ }^{16}$ La puesta en marcha de una ley como esta era tremendamente dificultosa y no todos percibían el progreso de la misma como satisfactorio. Los obstáculos eran evidentes. Era posible atribuir este problema a una mala planificación o a la incompetencia de cargos políticos y funcionarios, pero también pudo deberse a maniobras dilatorias por parte de mandos militares o civiles de tendencia moderada o unionista.

El distanciamiento entre los sectores más izquierdistas y más conservadores del Parlamento se percibió claramente en esta cuestión. La derecha, el 7 de junio de 1856 aseguraba que el cumplimiento de la norma había sido el correcto y que los pendientes de reconocimiento eran muy pocos. García Ruiz expuso varios casos de militares a los que no se había concedido el ascenso, no se les había reincorporado en el ejército o no se le había abonado el salario correspondiente al tiempo que estuvieron cesados. El bloqueo en su caso contrastaba con una mejor aplicación a los civiles, en lo que supuso un intento de O’Donnell de limitar la promoción a los más avanzados y de los demócratas. El papel del instituto armado era demasiado relevante para llenarlo de opositores a costa de los afines. La sesión terminó con un voto de censura contra el ministro de la Guerra, que contó con únicamente 11 votos a favor por 147 en contra. ${ }^{17}$

Respecto al ejército es notorio que hubo un tapón para los miembros de las clases populares, que topaban con el corporativismo, y otro de carácter político que limitaba el ascenso de los progresistas, mientras que la vía de ascenso fue mucho más rápida para los afines a los proyectos puritano y moderado. ${ }^{18} \mathrm{El}$ bloqueo se extendería a civiles por tener una ideología demasiado exaltada. En ambos casos, el Gobierno

\footnotetext{
${ }^{15}$ DSC, 14 de abril de 1855.

${ }^{16}$ La Época, 31 de octubre de 1855; DSC, 11 de diciembre de 1855; El Balear, 2 de mayo de 1856. Extraído de La Discusión. Al mismo tiempo se le otorgó al señor Castellanos, que residía en Cuba.

${ }^{17}$ DSC, 7 de junio de 1856. En esta sesión explicaron los distintos ministros cuantos casos hay en su departamento. Según el ministro de la Guerra seis u ocho; un único caso en el de Gracia y Justicia y unos pocos en Gobernación. El de Hacienda y el de Fomento, argumentan que faltaban algunas colocaciones, que se harían en cuanto fuera posible; $D S C, 16$ de junio de 1856.

${ }^{18}$ José Antonio Piqueras y Enric Sebatià, Agiotistas, negreros y partisanos. Dialéctica social en vísperas de la Revolución Gloriosa, Alfons el Magnànim, Valencia, 1991, pp. 123-125; Daniel R. Headrick, Ejército y política en España, pp. 62, 63, 75, 88-92 y 99.
} 
percibía a los represaliados como gente potencialmente peligrosa. Además reinsertarlos dificultaba la futura promoción de afines. Esto planteaba la extensión a la esfera personal de cada uno, en que el reconocimiento social y los emolumentos que se derivaban de los empleos o ascensos estaban en peligro.

En el otro lado se situaron los progresistas, que teóricamente defendían los derechos individuales y cuyas denuncias por las deportaciones de 1848 tenían un contenido político evidente. Censuraban la injusticia de aquellos hechos, pero excluyeron completamente a los carlistas que habían sufrido el mismo destino en la Guerra dels Matiners ya que eran ultrarrealistas. La patrimonialización de la relegación dejaría fuera a buena parte de los que sufrieron este castigo durante la Década Moderada, aun cuando la mayoría se habían enrolado en las filas carlistas como modo de tratar de cubrir sus necesidades vitales o de defender su modo de vida. Lo que es incluso peor, muchos otros habían sido deportados junto a los legitimistas por pobres o desempleados. Además, los progresistas, cuando se vieron acosados por los extremos tuvieron la reacción de recurrir de nuevo a esta práctica, aunque no tan duramente como lo hicieron sus antecesores. Obviaban, de ese modo, la extensión hacia otros grupos de los derechos políticos que habían conseguido para ellos mismos.

\section{LA OPOSICIÓN POLÍTICA AL BIENIO PROGRESISTA}

\subsection{El alzamiento carlista de 1855}

El Ejecutivo, al mismo tiempo que pedía resarcimiento para las víctimas pasadas tuvo que hacer frente a la inestabilidad social y política. Los carlistas conspiraban desde el inicio del Bienio animados por la debilidad de la Corona. En marzo y abril de 1855 ya había distintas partidas en Guipúzcoa, Vizcaya y Álava, alzándose después una en Los Hierros y otra con más de cien hombres en Cihuega (Soria). En Aragón se planeaba un alzamiento de cierta consideración que fue abortado por las autoridades, que el 16 de mayo descubrieron un depósito de armas y detuvieron a más de 20 personas. El día 23, varios escuadrones de Zaragoza se insurreccionaron y salieron de la ciudad a las órdenes del capitán Corrales. Tuvieron gran importancia los sargentos del cuerpo disuelto de guardias de la Princesa, que al ser equiparados al resto de sargentos se 
sintieron degradados. El 24 se levantó otra partida en Acered, comandada por Marco de Bello. En Caspe y varias poblaciones del Maestrazgo aragonés algunos hombres se lanzaron al monte. A finales de mayo de 1855, aparecieron cuadrillas en Cataluña formadas por alzados en el interior y grupos que cruzaron la frontera francesa. ${ }^{19}$

En Aragón, las partidas llegaron a tener varios centenares de hombres armados. ${ }^{20}$ La dispersión geográfica, la planificación y el nada desdeñable número de alzados en armas resultaban extremadamente peligrosos, por lo que se trató de bloquear la expansión a otros territorios. En la provincia de Ciudad Real se llevó a cabo una labor preventiva por la que fueron detenidos y posteriormente liberados algunos supuestos partidarios del pretendiente por pequeños actos aislados de adhesión al carlismo, por denuncias falsas o por exceso de celo entre los mandatarios. ${ }^{21}$

La represión del movimiento aragonés en un primer momento se basó en los fusilamientos, un total de 7 en los primeros días. El 30 de mayo, el Gobierno ordenaba que se indultase a los facciosos que se presentasen antes del 3 de junio, exceptuando las causas por delitos comunes y los oficiales del ejército, cabecillas, oficiales, desertores, eclesiásticos o reincidentes en la facción. Posteriormente se estableció que los jefes y oficiales serían juzgados por consejo de guerra y el resto serían destinados ocho años a los regimientos de Ultramar. ${ }^{22}$ La pretensión de desmarcarse de los moderados hacia recomendable que las represalias discurrieran por cauces legales. Ejecutarlos mediante consejo de guerra, aun con la ausencia de garantías que ello implica, era políticamente mucho más acertado.

Perseguidos y acosados muchos carlistas se entregaron, entre los que había algunos cabecillas como el capitán Manuel García. Con la práctica destrucción del alzamiento, la magnanimidad facilitaba la desmovilización al rebajar la dureza en los castigos, por lo que se produjeron varios perdones de los capitanes generales en Aragón y Burgos que permitieron a los alzados regresar a sus casas. Esto supuso contradecir las

\footnotetext{
${ }^{19}$ Vicente Pinilla Navarro, Conflictividad social y revuelta política en Zaragoza (1854-1856), Diputación General de Aragón, Zaragoza, 1985, pp. 157-163; La Libertad, 22 de mayo de 1855; Francisco Pi y Margall y Francisco Pi y Adsuara, Historia de España en el siglo XIX, tomo IV, p. 132.

${ }^{20}$ Antonio Caridad Salvador, "El carlismo aragonés en armas. La revuelta de 1855", Cuadernos de Historia Contemporánea, vol. 36, 2014, pp. 165-188.

${ }^{21}$ Juan Antonio Inarejos Muñoz, La Revolución de 1854 en la España rural. El Bienio Progresista en Ciudad Real (1854-1856), Instituto de Estudios Manchegos, Ciudad Real, 2010, pp. 156-165.

${ }^{22}$ AGMM, Guerras Carlistas, Leg. 63-E, Carp. 27.
} 
órdenes del Ejecutivo que entendía el indulto solo de la pena de muerte y sin que supusiera la exención de responsabilidades. ${ }^{23}$ Las autoridades militares tuvieron gran habilidad para acabar con la rebelión manteniendo una actuación más flexible posibilitada por un mejor conocimiento de la situación y que resultó eficaz para contrarrestar la insurrección.

En Aragón, Espartero conmutó al dirigente carlista Marcelino Millán el castigo capital por deportación a las Marianas, alegando que había que ser generoso con los vencidos. Esto causó rechazo entre el pueblo bajo de Zaragoza por el trato desigual, ya que algunos soldados y sargentos habían sido fusilados. En las protestas tomó parte la Milicia Nacional, que nombró una comisión para negociar el asunto con el ayuntamiento. Los ánimos solo se calmaron cuando se decidió enviar un telegrama de protesta a Madrid. ${ }^{24}$ Lo sucedido a Millán debía aplicarse a los jefes, cabecillas, eclesiásticos y desertores, mientras que los paisanos podrían incorporarse a sus vidas cotidianas. Por el contrario, los capturados con armas serían pasados por las armas en el término de tres horas desde su detención. ${ }^{25}$ La imposición de condenas duras para los que continuaban la lucha y ofrecer una salida que permitiera salvar la vida a aquellos que habiendo sido jefes u oficiales del ejército se entregaran, abrió una salida para un grupo de hombres que habiéndose alzado eran constantemente hostigados y que no tenían otra alternativa que abandonar la lucha armada.

En el Maestrazgo, los alzados fueron desmovilizados tras prometérseles el indulto, pero el Capitán general Juan de Villalonga les ocultó o desconocía que el Gobierno pretendía que algunos fueran represaliados. Según una real orden de 11 de junio, "Los oficiales procedentes de las filas carlistas que después de incorporados en el ejército constitucional, han tomado parte en las facciones del bajo Aragón y del Maestrazgo, serán enviados por diez años las Islas Marianas." Habían de ser remitidos en consideración de penados y perdiendo su consideración de militares. El día 23, una nueva real orden concedía un amplio indulto para los sublevados, pero no abarcaba a

\footnotetext{
${ }^{23}$ AGMM, Guerras Carlistas, Leg. 63-E, Carp. 27.

${ }^{24}$ Vicente Pinilla Navarro, "La conflictividad social en Zaragoza durante el Bienio Progresista", Hispania. Revista Española de Historia, vol. 44, núm. 158, 1984, pp. 591-593. Los conflictos en Zaragoza terminaron con depuraciones importantes en la Milicia Nacional, pp. 597-598.

${ }^{25}$ Real orden de 17 de julio de 1855. AGMM, Guerras Carlistas, Leg. 63-E, Carp. 27; Vicente Pinilla Navarro, Conflictividad social y revuelta política en Zaragoza, pp. 163-171.
} 
aquellos que cobraban un sueldo del Estado. ${ }^{26}$ Así, por engaño o desconocimiento de Villalonga, los 12 que estaban en ese caso en Valencia tendría que salir pronto hacia sus destinos. Con estos la magnanimidad no se contemplaba, puesto que en el ejército no se toleraba la indisciplina y el miedo hacia ellos, por estar armados, tener experiencia y entrenamiento militar era mayor.

Al grupo de Valencia se añadieron Millán y José Pérez Martin, que llegó también desde Aragón. Embarcaron el 22 de febrero y 17 de junio a Filipinas en las fragatas mercantes Hispano Filipina y Guadalupe. Los de la Guadalupe llegaron tras 107 días de navegación, manifestando haber sido mal tratados por el capitán del barco. Todos fueron instalados en el hospital de San Juan de Dios hasta que pudieran ser remitidos. Dadas las condiciones de las Marianas lo más lógico es pensar que no embarcarían dado que las condiciones no eran las más adecuadas. En 1855 unos 200 niños y un anciano murieron por una epidemia y se produjeron varios terremotos. En 1856 se desató una epidemia de viruela que provocó que en el mes de septiembre murieran cada día entre 70 y 80 personas. ${ }^{27}$ Además, Aniceto Ibáñez del Carmen no menciona en su diario lo que hubiera sido una noticia tan relevante como esta. Las conexiones entre Manila y el archipiélago de la Micronesia tenían una periodicidad semestral lo que dificultaba la salida al tener tiempo para establecer relaciones la capital. A su permanencia contribuiría el hecho de observar un comportamiento correcto y la experiencia de lo sucedido con los presos y deportados durante la Primera Guerra Carlista.

Una vez que la mayoría de insurrectos se habían desmovilizado, la traslación a las Antillas cobró importancia como modo de desactivar a la facción de Los Hierros. El capitán de caballería José Perula de Laparra, que fue hecho prisionero, y Feliciano Villalobos, que se presentó a indulto, fueron condenados a servir ocho años en los regimientos de Cuba. El mismo castigo se le impuso a otro miembro que pudo huir a

\footnotetext{
26 "Relación de los oficiales carlistas que deben pasar a las islas Marianas a cumplir los diez años de destierro a que han sido condenados", AGMM, Guerras carlistas, Leg. 63-E, Carp. 27; El Clamor Público, 14 de junio de 1855; El Áncora, 7 de julio de 1855.

${ }^{27}$ La Esperanza, 27 de junio de 1855. Información recogida de El Esparterista; AGMM, Guerras Carlistas, Leg. 63-E, Carp. 27; El Clamor Público, 11 de septiembre de 1856; Marjorie G. Driver y Omaira Brunal Perry, Chronicle of the Mariana Islands by Aniceto Ibáñez del Carmen, Francisco Resano del Corazón de Jesús et al., University of Guam, Mangilao, 1998, pp. 132-138.
} 
Estados Unidos en $1856 .{ }^{28}$ La práctica se extendió a Barcelona, donde en un contexto de desmovilización por los escasos avances de los carlistas, la máxima autoridad militar se planteó la utilización de la relegación. En noviembre fueron llevados a Barcelona 40 carlistas, entre los que había un cura y dos mujeres. Los hombres iban a ser deportados a Ultramar. ${ }^{29}$

Los combatientes no fueron los únicos que sufrieron la represión. Según de la Fuente, hubo jesuitas deportados a Mallorca. Durante la sublevación fue detenido por orden del Capitán general el obispo de la Seo de Urgel, José Caixal, que acusado de complicidad con el carlismo fue remitido a Mallorca el 8 de julio en el Lepanto. El obispo de Osma, Vicente Horcos, fue confinado en Cádiz y posteriormente trasladado a Tenerife. También fueron desterrados o relegados los obispos de Barcelona y Palencia. ${ }^{30}$ Estas actuaciones contra prelados y otras personas influyentes dejaron una situación extraña. Dado el carácter de copríncipe de Andorra que ostenta el obispo urgelitano, se dio la extraña situación de que a pesar de ser ciudadano español, era mandatario de un estado extranjero. Un país demasiado pequeño e insignificante para paralizar el despotismo del general Zapatero.

\subsection{La oposición desde la izquierda}

En la izquierda se iba consolidando un movimiento obrero cuya adscripción social y demandas desbordaban al progresismo. La persistencia de la crisis económica y las expectativas en el cambio crearon las condiciones para las reivindicaciones proletarias. En marzo de 1854, una huelga en Barcelona terminó con multitud de presos y varios muertos. En julio de 1854 se produjo la quema de dos fábricas y de gran cantidad de selfactinas en Barcelona, acción respondida con el fusilamiento de tres saboteadores. El 15 de agosto se llegó a un acuerdo entre patrones y obreros, mediante el cual los primeros podían seguir utilizando estas máquinas a cambio de un aumento

\footnotetext{
${ }^{28}$ Barón de Artagán, Cruzados modernos, Imprenta y Litografia Fiol, Barcelona, 1910, p. 175; El Clamor Público, 5 de agosto de 1856.

${ }^{29}$ La España, 14 de noviembre de 1855.

${ }^{30}$ Vicente de la Fuente, Historia eclesiástica de España, Impresores y Libreros del Reino, Madrid, 1875, tomo 6, pp. 257-259; La Esperanza, 20 de julio de 1855; María Fe Núñez Muñoz y Franco Díaz de Cerio, El Bienio Progresista (1854-1856) y la ruptura de relaciones de Roma con España según los documentos vaticanos, Universidad de la Laguna, La Laguna, 1983, pp. 96 y 150-151; La Esperanza, 16 de febrero de 1856. La deportación del obispo de Urgel dio lugar a una movilización de eclesiásticos de su diócesis para proceder a su liberación.
} 
salarial. La conflictividad continuó con distintos incidentes y paros a finales de año. A principios de 1855 la situación volvió a tensarse en un contexto de creciente coordinación del movimiento obrero, lo que atemorizó a las élites que optaron por desactivarlo. ${ }^{31}$

En Cataluña, el Capitán general Juan Zapatero no fue ajeno al temor a los trabajadores y llevó a cabo una política autoritaria y contraria a los mismos. Una real orden de 19 de mayo de 1855 anulaba lo pactado en la negociación colectiva desde verano de 1854. El 6 de junio ejecutó a José Barceló, dirigente de la Asociación de Hiladores, por falsa participación en un crimen común. El 21 de junio prohibió el asociacionismo obrero, exceptuando las que tuvieran un objeto filantrópico o de socorros mutuos, que deberían estar supeditas a la autoridad local y a la militar. Como respuesta, el 2 de julio comenzó la huelga general: "En un día y a una hora concreta han cesado los trabajos en todas las fábricas de Cataluña, y cien mil hombres se han lanzado a la calle pidiendo pan y trabajo y gritando asociación o muerte". Demandaban una reducción de jornada y la formación de jurados mixtos para solucionar los conflictos laborales. ${ }^{32}$ Las peticiones resultaban inaceptables para unos patronos acostumbrados a imponer su criterio y que tenían el apoyo de la capitanía general. Pero incluso más relevante fue la constatación del peligro que significaba la unión de los obreros y la organización con que se planificó y ejecutó el paro y lo masivo que fue.

Las medidas drásticas de Zapatero estaban íntimamente relacionadas con la huelga, pero lejos de rectificar reafirmó su despotismo convencido de la necesidad de desactivar las reivindicaciones de los obreros. Para ello contaba el estado de guerra que había declarado el 30 de mayo para toda Cataluña. Así, aprovechaba la presencia de partidas carlistas para dirigir la represión del movimiento obrero, atribuyéndose las facultades de juzgarles mediante consejo de guerra según la ley de 17 de abril de $1821 .^{33}$

El 5 de julio publicó un bando en el que declaraba que los forasteros que no tuvieran cédula de vecindad o modo de vida conocido y aquellos que impidiesen el acceso a las fábricas serían destinados al ejército de Ultramar durante seis años, o sometidos a pena equivalente sino fuesen aptos. El 7 de julio, unos 70 obreros salieron de Barcelona en dirección a La Habana en la fragata Julia, para servir en el ejército

\footnotetext{
${ }^{31}$ Ver Manuel R. Alarcón Caracuel, El derecho de asociación obrera en España (1839-1900), Ediciones de la Revista de Trabajo, Madrid, 1975, pp. 92-110.

${ }^{32}$ La Corona de Aragón, 4 de julio de 1855.

${ }^{33}$ Josep Benet i Casimir Martí, Barcelona a mitjan del segle XIX, 2 vols., Curial, Barcelona, 1976, vol. 1, p. 758.
} 
colonial. Además de los trabajadores iban reclutas y carlistas, totalizando 492 hombres. Durante el trayecto hubo un conato de insurrección y 21 de los soldados fueron bajados a tierra y sometidos a causa por el tribunal competente. ${ }^{34}$

El día 5 una representación de los obreros fue a Madrid a reunirse con Espartero, pretendían obtener el derecho de asociación, la jornada de diez horas y jurados mixtos. El duque de la Victoria les recibió pero les instó a volver al trabajo. ${ }^{35}$ La actitud comedida y negociadora de los obreros contrastaba con la respuesta del Capitán general, que continuó con las detenciones a pesar del cese de la huelga. Los liberales, cuyo pensamiento y base social estaba enormemente alejada de los obreros, no supieron dar una respuesta inclusiva y optaron por unas represalias estrictas. Fue la manifestación de unos intereses de clase diferentes.

El 27 de julio zarpó el Lepanto con 150 obreros barceloneses en dirección a Cádiz, mientras que decenas quedaban en las prisiones. A principios de agosto, el Gobierno estableció que los deportados a los batallones ultramarinos fueran llevados a Cádiz, donde su expediente seria examinado de nuevo, siendo relegados únicamente los más culpables. El resto serían diseminados por distintas ciudades andaluzas, ${ }^{36}$ donde su peligrosidad disminuía ostensiblemente. Ignoramos el número de los englobados en uno y otro caso, pero es relevante que el Ejecutivo limitó la actuación de Zapatero casi desde sus inicios. Políticamente suponía una desautorización para Zapatero, pero en la práctica no fue cesado porque les resultaba útil. En Cataluña el Capitán general aseguraba el orden a la burguesía, lejos de la zona de peligro era conveniente mostrarse más magnánimo y no defraudar a los progresistas del resto del país.

Las detenciones formaron parte de un plan más amplio de purificación de los miembros más radicales de la Milicia Nacional, de extracción cada vez más popular, y de detenciones de los principales líderes obreros. ${ }^{37}$ La huelga manifestó la capacidad movilizadora del movimiento obrero que por primera vez se manifestaba en toda su extensión. Los progresistas lo temían y tenían ansias por descabezarlo, pero a la vez no querían sustraerse el apoyo de las clases más populares, que hasta el momento les habían permanecido mayoritariamente fieles. La desautorización de Zapatero fue más táctica que real, puramente con efectos propagandísticos. Los liberales, que

\footnotetext{
${ }^{34}$ La Época, 9 y 10 de julio de 1855; El Balear, 3 de agosto de 1855.

${ }_{35}$ Manuel Tuñón de Lara, El movimiento obrero en la historia de España, SARPE, Madrid, 1985, vol. I, pp. 121-122.

${ }^{36}$ La Época, 3 de agosto de 1855.

${ }^{37}$ La Época, 7 de agosto de 1855.
} 
constantemente clamaban contra las injusticias, no podían permitirse ejercer el despotismo sin caer en la contradicción más absoluta. Una punición brutal era contraproducente. Limitarla y focalizar las deportaciones únicamente a los cabecillas, permitía aparecer con mayor flexibilidad y neutralizaba al movimiento obrero con un menor coste político y causando un menor sufrimiento a los afectados. En esto tuvo gran relevancia la aplicación de los destierros, que tenían una eficacia similar. Al constituir el movimiento obrero una especificidad en las zonas industrializadas, distribuir a sus miembros por unas zonas agrícolas y sin producción mecanizada, suponía alejarles de las condiciones necesarias para la expansión de su propia ideología. Se les eliminó de Barcelona llevándoles a lugares donde su capacidad de actuación era casi nula.

La represión también se explicaba por las rivalidades entre los elementos más conservadores de la revolución con los más progresistas. O’Donnell había conseguido “colocar" a Zapatero en la capitanía general de Cataluña, lo que significaba el triunfo de la facción dura. Parte del Ejecutivo y del Parlamento eran partidarios de una línea de mayor despotismo. Este sector, comandado por el conde de Lucena, actuó tratando de imponer sus criterios en la medida de lo posible. Entre los progresistas también se temía a la oposición, el 29 de agosto de 1854 Espartero dictó un real decreto prohibiendo las reuniones políticas. El 12 de marzo de 1855, mediante real orden se pidió a los gobernadores que reprimieran duramente las alteraciones del orden público. La ley de 3 de junio de 1855 autorizaba al Gobierno a destinar a cualquier punto de la Península a cualquiera que se creyera que fuera a alterar el orden público y a suspender los periódicos que "excitan, auxilian o preparan la rebelión". 38 Fue la respuesta a cierta inestabilidad en Barcelona. La eclosión del movimiento obrero y la petición de inclusión en el sistema se solucionaron con una negativa rotunda y un incremento de las represalias. Los derechos que proclamaban los progresistas tuvieron un recorrido muy corto, ya que básicamente se trataba de la extensión a ellos mismos. Los castigos se ampliaron hasta abarcar también a los demócratas, a los que por el momento no se les relegaba. En julio, Abdón Terradas fue llevado a Medina Sidonia donde falleció y al abogado Juan Nogués, se le liberó con la condición de pasar a Francia a donde partió el

${ }^{38}$ CLE, tomo LXV, pp. 228-229; Manuel Ballbé, Orden público y militarismo en la España constitucional, pp. 171-179; CLE, tomo LXVI, pp. 491 y 492. Decía esta norma en su artículo séptimo que los gobernadores provinciales han de dar parte tan pronto sepan que el deportado haya llegado a Ultramar. 
1 de septiembre. ${ }^{39}$ Las veleidades despóticas de Zapatero no conocían de límites nacionales.

A principios de abril de 1856 hubo en Valencia motines contra las quintas que terminaron con el desarme de algunos batallones de la Milicia Nacional. ${ }^{40}$ A raíz de esto, Zapatero procedió a la detención de Ceferino Tresserra, Alberto Columbrí y Pablo Armengol a los que confinó en Granada, Almería y Mallorca respectivamente. A principios de mayo fue detenido en Barcelona el famoso republicano francés Armand Barbès, que fue desterrado a Sevilla. El 1 de julio fueron deportados a Palma de Mallorca Antonio Clavé y su hermano, el popular músico José Anselmo Clavé. Allí residían forzosamente otros catalanes como Planas, Pablo Armengol, Benito Seguí, y Francisco Flores. ${ }^{41}$ Estos ataques fueron una forma de reprimir a aquellos que desde posturas a la izquierda del Partido Progresista habían sido capaces de entender e incorporar a su programa las reivindicaciones obreras y exigían mayor democracia. Además de una punición por hechos concretos como huelgas o incidentes, hubo otra puramente ideológica en la que se englobó a los demócratas y a la mayoría de los obreros represaliados. Los sectores cultos de carácter izquierdista y alejados del movimiento obrero fueron desterrados o relegados al Ultramar cercano, las Baleares.

El movimiento obrero era el objetivo principal de los gobernantes liberales. En diciembre de 1855, los fabricantes comenzaron algunas acciones para debilitar al asociacionismo obrero: despidos y negativa a contratación de obreros sindicados e intentos de crear asociaciones controladas por los empresarios. Los obreros conminaron a los empresarios a que no contratasen a aquellos que no estaban afiliados por lo que las autoridades llevaron a cabo consejos de guerra contra líderes sindicales. Fue una

\footnotetext{
${ }^{39}$ Jaume Guillamet, Abdón Terradas, pp. 131-138; DSC, 22 de diciembre de 1855. Nogués pasó a Bourg-Madame, pueblo francés prácticamente pegado a su ciudad natal.

40 Joaquín Azagra Ros, El Bienio Progresista en Valencia. Análisis de una situación revolucionaria a mediados del siglo XIX, Publicaciones de la Universidad de Valencia, Valencia, 1978, pp. 233-243.

${ }^{41}$ Alberto Columbrí, Memorias de un presidiario político (1857), I. López, Editor, Barcelona, 1864, pp. 157-163; Josep Benet i Casimir Martí, Barcelona a mitjan del segle XIX, vol. 2, pp. 376-389. Establecen que los hermanos Clavé fueron a parar a Palma tras su paso por Mahón. Columbrí tan solo menciona que fueron a la Ciudadela y nada dice de la capital mallorquina; Ceferino Tresserra, Carta de un demócrata confinado, dirigida al Excmo. Sr. D. Juan Zapatero, Capitán general del ejército y principado de Cataluña, Benavides, Granada, 1856. Tresserra permaneció en la Ciudadela hasta el día 2 de mayo en que fue embarcado en El Balear y llevado a Granada; Ignacio Puig Pujadas, Vida d'heroi. Narcís Monturiol, L'Avenç, Barcelona, 1918, p. 92; José Anselmo Clavé estuvo cuatro meses en Mahón antes de escapar y regresar a Barcelona, donde el estado de su hija enferma había empeorado sustancialmente. Josep Maria Poblet, Josep Anselm i Clavé i la seva època (1824-1874), Dopesa, Barcelona, 1973, pp. 116-119.
} 
represión organizada hacia la vanguardia del movimiento obrero con prisiones, exilio y clandestinidad. ${ }^{42}$ Uno de ellos, Tomás Cerdá, fue deportado. Era director de la Sociedad de Hiladores, detenido a finales de marzo y a quien se le formó consejo de guerra por "haber amenazado de muerte a varios obreros no asociados, si no abandonaban las maquinas en que trabajaban”. El fiscal pedía diez años de presidio para Cerdá, pero la pena que se le impuso fue de cuatro años de confinamiento en Cuba. ${ }^{43}$

Arribó el 10 de julio de 1856 y permaneció libre en La Habana bajo la vigilancia de la policía. El Capitán general expresaba la inconveniencia de la remisión de individuos con ideas sediciosas que podían infiltrarse entre la población. Sus quejas surtieron efecto e inmediatamente recibió permiso para relegarlo a la isla de Pinos o devolverlo a la Península en caso de que su comportamiento lo exigiese. El 20 de septiembre se emitió una real orden mediante la que las deportaciones necesarias para mantener el orden público se realizarían a las Marianas, dada su menor importancia. Las razones eran que era prácticamente imposible que los relegados no manifestasen sus ideas en su vida cotidiana, que su carácter se tornaba más exasperante con el castigo sufrido, que el régimen gubernativo de los dominios hacía más peligrosa la llegada de ideas perniciosas, que allí no debían manifestarse las disensiones de la metrópoli y la participación de peninsulares en las independencias americanas y en las conspiraciones en Cuba. Les catalogan como "las heces de toda sociedad, gentes de mal vivir, malaventurados pescadores de rio revuelto, aventureros de condición levantisca" y ponían como ejemplo el traslado a Filipinas en 1848, que a su juicio, significaron el inicio del sentimiento de hostilidad a España. ${ }^{44}$

Una sucesión de prejuicios típicos de la época que contenían en el fondo alguna verdad. La presencia de sujetos con ideas radicales en un territorio colonial era perjudicial por cuanto su cuestionamiento del statu quo podía expandirse. Sin embargo, la estrategia estatal basada en la defensa de los beneficios económicos de la metrópoli y en la anulación de derechos políticos de los criollos, ya había logrado por sí sola la difusión del separatismo con varias conspiraciones y desembarcos armados de carácter anexionista. Tampoco es convincente que Cerdá fuese el director de la Sociedad de

\footnotetext{
${ }^{42}$ Josep Benet i Casimir Martí, Barcelona a mitjan del segle XIX, vol. 2, pp. 360-376.

${ }^{43}$ El Clamor Público, 26 de marzo y 10 de abril de 1856; Josep Benet i Casimir Martí, Barcelona a mitjan del segle XIX, vol. 2, pp. 363-366.

${ }^{44}$ AHN, Ultramar, Leg. 4646, Exp. 9. "Orden para que no se deporte ni confine a reos a las Antillas ni en Filipinas". El hecho de que no se nombrara a ninguno más indica que probablemente Cerdá sería el único.
} 
Hiladores y aquí se calificase a los deportados como populacho dirigido por gente con instrucción. Entre todas estas argumentaciones ninguna se preguntaba donde quedaban los derechos de los afectados.

Ya a mediados de 1855 el apoyo social a la revolución comenzaba a resquebrajarse. La elite burguesa, con buena parte de las reformas tolerables efectuadas, comenzó a tender el conservadurismo. La pequeña burguesía veía como muchas de las leyes que esperaba para poder participar activamente en política y ascender socialmente no se abordaban y los trabajadores urbanos no percibían cambios positivos en su situación. ${ }^{45}$ El partido iba perdiendo sostenes por ambos extremos. Durante junio y julio de 1856 tuvo lugar un gran incremento de la conflictividad social. En la meseta norte castellana se reprodujeron motines y destrucción de fábricas de harina y depósitos de grano, lo que motivó el fusilamiento de tres incendiarios en Valladolid. Comenzó la propagación de noticias alarmantes que se sumaron al creciente agotamiento gubernamental hasta desembocar en una crisis que arrastraría al gabinete progresista. Los más conservadores se sentían fuertes y con el apoyo del ejército y de la reina pudieron hacer frente sin problemas a la revuelta de la Milicia Nacional en Madrid y en otras ciudades como Sevilla, con centenares de encarcelados y donde más de cien personas fueran fusiladas. La caída de Espartero provocó en Barcelona un levantamiento popular de grandes dimensiones que Zapatero mandó reprimir duramente. Los choques entre la tropa y ciudadanos armados se prolongaron desde el 18 al 22 de julio, con la escalofriante cifra de 63 muertos en la fuerza pública y 403 entre los ciudadanos. ${ }^{46}$

El Capitán general actuó por su cuenta en un momento en que hubo una insurrección armada de cierta relevancia y desprovisto de las limitaciones al salvajismo que los progresistas representaban. Presentaba así su candidatura a continuar en su puesto. Previniendo que los altercados se extendieran a Barcelona, se preparó por anticipado. Un bando del 4 de julio extendiendo a los sublevados lo previsto contra los carlistas, es decir juicios mediante consejos de guerra y las penas de muerte y prisiones, lo que dejaba un estrecho margen para la deportación que solo se utilizaría en el caso de

\footnotetext{
${ }^{45}$ Joaquín Azagra Ros, El Bienio Progresista en Valencia, p. 208.

${ }^{46}$ Víctor Gordon Kiernan, La revolución de 1854 en España, Aguilar, Madrid, 1970, pp. 244 y 280; Ramón Aguirre, Relación de los sucesos de Barcelona en julio de 1856, Imprenta de M. Rivadeneyra, Madrid, 1856, p. 22; Josep Benet i Casimir Martí, Barcelona a mitjan del segle $X I X$, vol. 2, p. 499. A estas cifras, según Benet y Martí, habría que añadir los del barrio de Gracia y otras zonas circundantes a la capital catalana.
} 
obreros que abandonaran colectivamente su trabajo. El día 23 fueron ejecutados tres alzados, mientras que sus compañeros sentenciados a reclusión fueron obligados a presenciar la ejecución. El día 28 fueron ejecutados 16 individuos que formaban parte de un grupo de Gracia que capituló sin oponer resistencia en Sallent. El día 4 de agosto fue ejecutado Jaume Puig, al que se condenaba por haber participado en los asesinatos de los militares, pero que la opinión pública creía que era inocente. ${ }^{47}$

La represión continuaba implacable y generalizada a toda Cataluña, desde donde se llevaban los presos a las abarrotadas cárceles de Barcelona. La mayoría fueron castigados con presidio y solo algunos fueron relegados. Este fue el destino de la mayoría de los miembros de uno de los grupos más eficaces en el combate al ejército, el comandando por Vicenç Martí (a) Noi de la Barraqueta. Una vez derrotada la insurrección en Barcelona se dirigieron a Zaragoza donde obtuvieron el indulto del general Dulce, a condición de no instalarse en ninguna de las cuatro capitales catalanas. Unos 180 combatientes que regresaron a sus casas fueron aprehendidos por Zapatero que los embarcó en el Gaditano a la espera del consejo de guerra. Martí, los hermanos Clavé, Narcís Monturiol y Feliu fueron a Madrid, evitando de este modo su captura. ${ }^{48}$

Lo ocurrido en Barcelona contrastaba con la magnanimidad que se estaba llevando a cabo en Madrid impulsada por el Ejecutivo de O’Donnell, que decidió dejar libres a los sublevados una vez terminados los enfrentamientos y que incluyó en las instituciones a progresistas y moderados. ${ }^{49}$ En Cataluña Zapatero actuaba a sus anchas, probablemente sin seguir órdenes de Madrid, pero con el tácito beneplácito del conde de Lucena, que en ningún momento censuró sus actuaciones o trató de limitarlas. Incluso, el 5 de agosto de ese mismo año le ascendió a teniente general, todo un aval a su política por parte del presidente del Ejecutivo. Las contradicciones internas del progresismo y la conflictividad social habían determinado el ascenso del conde de Lucena, cuyo Gobierno no influyó en la marcha de las deportaciones realizadas desde Barcelona.

\footnotetext{
${ }^{47}$ Josep Benet i Casimir Martí, Barcelona a mitjan del segle XIX, vol. 2, pp. 437-438, 513-528 y 761. El jorobado al que todos le atribuían la culpabilidad era Llorenç Casas, condenado a diez años de presidio; Alberto Columbrí, Memorias de un presidiario político, pp. 166-180.

${ }^{48}$ Isidre Clopas i Batlle, "Els germans Martí, «El Noi» i «El Xic» de la Barraqueta, guerrillers del Baix Llobregat" en Ferran Balanza et al., Guerrilles al Baix Llobregat, pp. 713-714; La Iberia, 19 de agosto de 1856.

49 José Ramón de Urquijo y Goitia, "Las contradicciones políticas del Bienio Progresista", Hispania. Revista Española de Historia, vol. 57, núm. 198, 1997, p. 299.
} 
Avanzados y demócratas fueron relegados a Canarias o desterrados a finales de julio. Al archipiélago mencionado fueron llevados el exdiputado tarraconino Joaquín María Nin y el exalcalde de Barcelona Joaquín de Molins, por oponerse a la represión del Capitán general. Los miembros del último ayuntamiento de Barcelona, Pesquer, Miralles y Depares, fueron desterrados a distintos puntos de la Península. El consejo de guerra de los apresados en el Gaditano terminó con unas pocas sentencias de muerte, 48 condenados al presidido de Cartagena y las 187 restantes al servicio en el ejército de Ultramar, a donde partieron en la fragata Numa el 19 de agosto. A principios de agosto, 17 personas habían sido embarcadas en el Pájaro del Océano. Entre los que se encontraban Francisco Flores, el demócrata Josep Soler y los tarraconenses Rafael de Magriñá, Nemesio Elías, José Folch, Pedro Bové, el diputado en las Cortes de 1854 Juan Martell y Fructuoso Canonge, conocido por sus ideas democráticas. En Cádiz, Martell y Magriñá fueron liberados y Elías, Bové, y Folch fueron conducidos a Canarias. El resto, al parecer irían a La Habana de donde regresarían seis con la amnistía de 1857 con ocasión del nacimiento del príncipe de Asturias, y hubo algún caso de fallecimientos. También en La Habana murieron algunos del grupo del Noi de la Barraqueta. Los amnistiados llegaron a Barcelona en diciembre de ese año. ${ }^{50}$

El tradicional miedo a remitir a gente políticamente avanzada a Cuba no se concretó en este caso. El despotismo de Zapatero eligió lugares más lejanos para realizar las deportaciones, las Canarias y el Caribe, mostrando que con la caída del progresismo su capacidad de acción incluso aumentó. En Canarias fueron instalados en Santa Cruz de Tenerife, donde fueron ayudados por sus correligionarios y por sus familias y el Gobierno les pagó el viaje de retorno en noviembre de ese mismo año. Se aprecia una distinción entre el grupo de Canarias y el de las Antillas que vendría determinada por su pertenencia a estratos sociales diferentes y por las reivindicaciones que planteaban unos y otros. Las de los primeros, tenían un contenido predominantemente político y en las de los segundos primaba lo social. Los condenados a los regimientos coloniales pertenecían a las clases populares con alguna excepción

\footnotetext{
${ }^{50}$ Josep Benet y Casimir Martí, Barcelona a mitjan del segle XIX, vol. 2, pp. 529-533; Alberto Columbrí, Memorias de un presidiario político, pp. 176-178, 253-261. Entre los deportados en el Pájaro del Océano, Soler, de diecinueve años fue sometido a un simulacro de fusilamiento, que le trastocó fuertemente el carácter. Murió al poco de llegar a La Habana; La Discusión, 8 de noviembre de 1856. Información de periódicos de Canarias; La Época, 14 de agosto de 1856; El Clamor Público, 12 de agosto de 1856; La Discusión, 31 de diciembre de 1857; La Discusión, 14 de mayo de 1857 . Es posible que algunos permanecieran encarcelados varios meses para ser posteriormente deportados, tal y como le sucedió a Pedro Carreras.
} 
como la de Canonge, que era un pequeño empresario. Algunos habrían participado en los altercados, pero esto no importó demasiado a Zapatero que siempre optó por una represión ejemplarizante y arbitraria. Un destino más cercano y con mayor salubridad, un trabajo forzoso inexistente, una mayor posibilidad de recibir ayuda y un regreso más rápido marcaron las diferencias entre sectores distintos.

\section{EL BIENIO MODERADO Y LOS SUCESOS DE EL ARAHAL}

El 12 de octubre Narváez sustituyó a O’Donnell como presidente del Gobierno. Se entronizó una forma de pensar extremadamente autoritaria en cuanto al funcionamiento del Estado y a la resolución de conflictos sociales y políticos. Las primeras medidas fueron la limitación del papel de la prensa, la paralización de la desamortización, el reconocimiento del concordato de 1851, la suspensión las leyes de reconocimiento por la represión de 1848 y la anulación del abono de 11 años para los cesantes de $1843 .^{51}$ Esto significaba eliminar la preferencia que tenían los represaliados para la obtención de empleo, honores y ascensos. La prioridad de los moderados para ocupar y medrar en las ocupaciones públicas y en el ejército se reinstauraba. En Andalucía, los grupos conservadores comenzaron a excluir y perseguir a los opositores. "Demócratas y progresistas avanzados respondieron restableciendo sus redes clandestinas, ampliando sus actividades en el frente internacional y adaptando la estrategia de acción de «Mazzini» a la tradición española de la revolución liberal". ${ }^{52}$ Andalucía se convirtió en la región donde la contestación armada a moderados y unionistas fue mayor, lo que por los enormes desequilibrios en la distribución de la tierra se consideraba una cuestión de máxima relevancia.

El nuevo Gobierno publicó una disposición de amnistía, que aunque limitada permitió el retorno de algunos de los relegados por cuenta del erario público. El día 3 de noviembre habían llegado a Cádiz Nemesio Elías, Pedro Bové, Francisco Flores y José Folch, quienes estaban aguardando a que el Capitán general de Andalucía les expidiera el pasaporte para poder regresar a sus casas. De los tres desterrados que había en Cádiz, Martell permanecería en la ciudad, mientras que Nin iba a ser trasladado a Córdoba y

\footnotetext{
${ }^{51}$ Gaceta de Madrid, 9 de noviembre de 1856; La Época, 14 de octubre de 1856.

${ }^{52}$ Guy Thomson, El nacimiento de la política moderna en España, p. 65.
} 
Molins a Jerez de la Frontera. ${ }^{53}$ Narváez ni siquiera amnistió completamente a todos los que había en Canarias. Los de Cuba hubieron de esperar al año siguiente.

A la par que a unos se les eximia de permanecer deportados en el archipiélago canario y se les conmutaba dicha pena por la de destierro en la Península, continuaba una represión individualizada. Victoriano Sugrañes y Manuel Subirán fueron detenidos por orden del Capitán general de Cataluña a causa de las opiniones políticas expresadas en un café de Barcelona y fueron embarcados hacia las Islas Canarias. A principios de 1857, un grupo de turolenses en el que se encontraba Víctor Pruneda fueron confinados en Ciudad Real. Zapatero hizo prender a Alberto Columbrí en enero de 1857, quien fue encarcelado en Cartagena. ${ }^{54}$ El nuevo régimen, apenas sin oposición, decidió mantener una actitud prudente para fortalecer su implantación. Aun así, se produjeron relegaciones excepcionales por cuanto lo característico de esta etapa fue unos castigos de baja intensidad.

Conociendo la trayectoria de Narváez y de los moderados, esto iba a cambiar cuando se produjera alguna conspiración o insurrección. El 30 de junio salieron de Sevilla más de cien hombres mal armados a Utrera, y a continuación a otras poblaciones como El Arahal, donde se produjo el asalto al cuartel de la Guardia Civil y la quema de los archivos notariales, entre otros desórdenes y pillajes. El ejército no tuvo problemas para derrotar y apresar a los alzados, la mayoría de los cuales eran artesanos. Las represalias se manifestaron mediante numerosas ejecuciones, entre 98 y 100, a las que habría que sumar, los miembros aprehendidos de una partida levantada en La Carolina. La ciudad de Sevilla envió a representantes a Madrid para atajar los ajusticiamientos, cosa que lograron. Los intentos revolucionarios se reprodujeron en Málaga, Arenas y otros puntos de Andalucía. ${ }^{55}$ Una vez detenidos los ajusticiamientos, cabría preguntarse qué sucedió con aquellos que habían sido condenados a muerte por el consejo de guerra y pudieron eludirla.

\footnotetext{
${ }^{53}$ La Discusión, 8 de noviembre de 1856; La España, 9 de noviembre de 1856; La Época, 11 de diciembre de 1856.

${ }^{54}$ La Discusión, 8 de noviembre de 1856; La Discusión, 10 de noviembre de 1857. Pruneda explica sus dos destierros de ese año; La Discusión, 31 de diciembre de 1857. Sugrañas regreso a Barcelona en diciembre de 1857, proveniente de Francia; Alberto Columbrí, Memorias de un presidiario político, pp. 9-368.

${ }_{55}$ Antonio Pirala, Historia contemporánea, tomo I, pp. 724-727; Joaquín Guichot, Historia general de Andalucía desde los tiempos más remotos hasta 1870, Eduardo Perié, Sevilla, 1871, tomo VIII, pp. 79-82.
} 
La sublevación se había producido en varias ciudades y poblaciones andaluzas, pero tal y como solía suceder la represión se extendió hacia otros lugares. En el distrito militar de Granada, se produjeron algunos casos individuales de destierros. En Barcelona, a mediados de julio habían sido detenidas seis personas y otras seis habían conseguido huir. Los apresados fueron deportados a las Islas Baleares. José Lázaro, hacendado y progresista de Dos Hermanas, había salido preso hacia Sevilla. El 10 de julio, catorce turolenses fueron detenidos y ocho de ellos, posteriormente confinados gubernativamente a Tolosa. En este mismo mes, en Córdoba, Abelardo Abdé fue encarcelado y posteriormente desterrado a Badajoz por orden de la máxima autoridad militar. En septiembre, seis de los turolenses en Tolosa fueron liberados, quedando únicamente Víctor Pruneda y Enrique Pons en la ciudad guipuzcoana. En Madrid, varias cuerdas con ciudadanos presos fueron remitidas a un depósito que se había establecido en Leganés. ${ }^{56}$ Las represalias sobre individuos por su ideología aconsejaban envíos a un entorno cercano.

En Málaga se produjo una insurrección republicana de escasa importancia que provocó múltiples detenciones, alegando que eran vagos y gentes de mal vivir. El día 22 de octubre salieron 91 en dirección a Cádiz y al día siguiente otro grupo con otros 31 llegados de Málaga o los pueblos circundantes, para ser deportados a Canarias. El embarque a Canarias no se produjo, aunque un número indeterminado fueron a Ceuta. ${ }^{57}$

El grueso de la represión se había producido en Andalucía, donde según la prensa afín las relegaciones se habían suspendido y el nuevo ministerio Armero-Mon había decidido liberar a los deportados de Málaga y a los detenidos en Leganés, ${ }^{58}$ en lo que suponía una amnistía parcial. Un grupo de 26 republicanos levantados en La Carolina fueron embarcados a las Filipinas con destino a las Marianas. Las instrucciones eran que debían permanecer libres para contribuir a "adelantar la colonización de aquellas islas", contribuyendo a la agricultura y el comercio. A la vez se ordenaba crear un establecimiento penal para confinados políticos que no debieran pasar

\footnotetext{
${ }^{56}$ La Discusión, 29 de julio, 17 de septiembre y 10 y 29 de noviembre de 1857; DSC, 28 de enero de 1858.

${ }^{57}$ La Discusión, 20 y 29 de octubre de 1857; La Época, 5 de enero de 1858. Información de El Parlamento.

${ }^{58}$ La Época, 24 de noviembre de 1857.
} 
a los presidios peninsulares, africanos, filipinos o antillanos, y que se incrementara la frecuencia en las comunicaciones entre Manila y el archipiélago. ${ }^{59}$

Finalmente, fueron indultados estando todavía en Manila en 7 de diciembre. ${ }^{60} \mathrm{La}$ referencia explícita al poblamiento, unido las diferentes acciones para favorecerla indica la existencia de una voluntad en este sentido por parte del Gobierno. Probablemente se trataría de una excepción producida en un momento en el que muchos ya estaban regresando a sus casas. Aprovechando la multitud de apresados el Ejecutivo dispuso hacer una prueba sobre la viabilidad futura de esta práctica, que en último terminó no siguió adelante a causa de que se decidió que en ese momento era más ventajoso el perdón.

Los relegados de La Carolina, pasarían algún tiempo en Manila hasta su retorno definitivo, en diciembre de 1858. El resto, volverían a Málaga a principios de enero de ese mismo año, desde Cádiz o las posesiones africanas. ${ }^{61}$ Para ser vagos y delincuentes altamente perniciosos para la ciudad, su estancia fuera de la misma se prolongó durante un tiempo bastante escaso. Este discurso obedecía a un intento de hacer pasar a los detenidos como sujetos peligrosos. Se trataba de asimilar la disidencia política con la marginalidad social, tratando de denigrar a los detenidos, mostrándolos como personas levantiscas, sin cultura, educación, ni valores.

\section{LA DEPORTACIÓN CON FINALIDAD COLONIZADORA. FACTORES DE CAMBIO.}

El rápido desgaste de los moderados provocó que la reina llamara a O’Donnell. El conde de Lucena encabezaría el gabinete desde el 30 de junio de 1858 hasta su dimisión el 27 de febrero de 1863. Ésta etapa se caracterizó por una prosperidad económica, una relativa tranquilidad política y una forma de actuar que sin dejar de tener grandes similitudes con sus predecesores, permitía al menos un mayor pragmatismo en las labores de gobierno. La administración exterior unionista venia

\footnotetext{
${ }^{59}$ PNA, Guerra, Leg. 23. Expediente sobre los gastos de los deportados políticos destinados a las Islas Marianas, 1857 y 1858.

${ }^{60}$ PNA, Guerra, Leg. 23. Incidente relativo al pasaje de los deportados que deben volver en la fragata Luisita, s/f.

${ }^{61}$ La Iberia, 5 de enero y 14 de diciembre de 1858. Estuvieron confinados por providencia gubernativa en las posesiones africanas, lo más probable es que como deportados, aunque posiblemente estarían sujetos a algún tipo de retención o vigilancia.
} 
motivada por múltiples factores interconectados: el prestigio internacional y el fomento del nacionalismo interior tuvieron un papel importante, diseñándose una estrategia planificada de defensa de los intereses de la metrópoli. ${ }^{62}$ En esta política tuvieron una relevancia indudable las acciones de carácter económico. Se trataba básicamente de fortalecer y ampliar las áreas de influencia española y proporcionar mano de obra esclava o "libre", formada esta ultima por africanos, asiáticos y yucatecos cuyas condiciones laborales diferían poco de la esclavitud. ${ }^{63}$ Asentarse efectivamente en Fernando Poo y en la costa centroafricana permitía establecer bases desde las que podrían importarse trabajadores para las Antillas.

En los años anteriores, la deportación tuvo un componente básicamente de desembarazo de opositores y la elección de los lugares de destino se tomó aleatoriamente y sin planificación. La utilidad en los puntos de remisión se añadió con posterioridad como acciones tomadas improvisadamente y no en virtud de una estrategia de Estado. Con los unionistas, las intenciones de la relegación variaron ostensiblemente dándole una pretensión colonizadora que desviaba los envíos hacia los territorios nominalmente españoles pero sobre los que el dominio era en el mejor de los casos bastante laxo. Esto sucedía con numerosas islas Filipinas, algunas en el centro de África, y los archipiélagos de las Marianas y las Carolinas. Hacia algunos de estos lugares se desviarían los nuevos grupos, pero es evidente que no todos tenían el mismo interés.

Fernando Poo conjugaba tener un papel esencial para la trata y unos innegables intereses comerciales, ya que su ubicación en el centro del golfo de Guinea le confería un lugar estratégico para el comercio y se podían extraer ciertos productos agrícolas, como aceite de palma y ñames, y forestales. Repoblar esos departamentos era la mejor manera de que cumplieran con los objetivos que se había diseñado para ellos. Para conseguirlo, la deportación no era el único medio, ni tampoco el mejor, pero en ocasiones de revueltas sociales permitía deshacerse de determinados individuos en la metrópoli a la vez que se trataba de aprovecharse de ellos para repoblar estos territorios. Así, se utilizó como complementaria de otros métodos. Se pasó de una relegación

\footnotetext{
${ }^{62}$ Juan Antonio Inarejos, Intervenciones coloniales y nacionalismo español. La política exterior de la Unión Liberal y sus vínculos con la Francia de Napoleon III (1856-1868), Silex, Madrid, 2010, passim.

${ }^{63}$ Francesc A. Martínez Gallego, Conservar progresando, pp. 117-156.
} 
estrictamente represora a una donde esta era la característica esencial pero en la que se contemplaba la colonización ya en su origen.

Oportunidades de ponerlas en práctica no le faltarían, especialmente dado que O’Donnell aun sin la brutalidad de los moderados mantenía la animadversión hacia el movimiento obrero y la disidencia política y social. En agosto de 1858 se produjo una huelga en Sabadell para equiparar su sueldo al de otras poblaciones, una veintena de trabajadores fueron embarcados a las "colonias de Ultramar". La medida fue tomada por el Capitán general de Cataluña, Domingo Dulce, que ejercía tal y como era habitual un poder despótico en la región. ${ }^{64}$ Esta actitud contaba con la habitual aquiescencia del Gobierno y mostraba que en cuanto al reconocimiento de derechos de los trabajadores nada había cambiado. Cualquier intento de limitar el poder de los empresarios mediante la unidad de los obreros y medidas de presión como los paros, se perseguirían duramente. Las medidas se centraron contra los dirigentes sindicales. Desconocemos que sucedió con ellos, pero teniendo en cuenta los precedentes inmediatos lo más probable es que fueran relegados a las Antillas, previsiblemente para servir en el ejército. El poco tiempo transcurrido entre la llegada del primer gabinete del conde de Lucena y la huelga y la intervención de Dulce hizo que la respuesta fuera todavía continuista.

Una vez expuesta la relevancia de Fernando Poo y la continuación de la disidencia habría que ver la situación de la posesión. Tras la cesión de la soberanía a España por parte de Portugal, mediante el tratado de San Ildefonso, se realizó una primera expedición en 1778 para la toma de posesión que fracasó. Los intentos se retomaron a raíz de la frustrada venta a los ingleses en 1841. En 1842, el concurso anual de la Sociedad Económica Matritense versaba sobre la memoria que mejor propusiese medios de colonizar y hacer útiles Fernando Poo y Annobón. Las dos obras ganadoras fueron publicadas conjuntamente. ${ }^{65} \mathrm{El}$ interés de la Sociedad Económica Matritense, compuesta de los prohombres de la economía y la política, mostraba como desde los sectores influyentes del país se tomaba a Fernando Poo en consideración. Su influencia facilitaba la propagación a medios de decisión gubernativa y a otros sectores sociales a través de la prensa. La campaña para evitar la venta a Inglaterra consiguió visibilizarla y

\footnotetext{
${ }^{64}$ La Discusión, 29 de agosto de 1858; La Época, 30 de agosto de 1858.

${ }^{65}$ José de Móros y Morellón y Juan Miguel de los Ríos, Memorias sobre las islas africanas de Fernando Poo y Annobón, Compañía Tipográfica, Madrid, 1844, pp. 28-34 y 85-93; Adolfo de Guillemard, Opúsculo sobre la colonización de Fernando Poo y revista de los principales establecimientos de la costa occidental de África, Imprenta Nacional, Madrid, 1852, pp. 10-11.
} 
a partir de ahí los oscuros intereses de la trata consiguieron imponer la idea de que su explotación podía ser positiva tanto económica como políticamente. Era un punto estratégico para el comercio clandestino que no debía caer en poder de los ingleses. A raíz de la aprehensión de dos buques por los ingleses en 1856 y 1857, acusados de practicar la trata, los esclavistas presionaron y consiguieron que se planteara con hechos su ocupación efectiva. ${ }^{66}$

Con anterioridad se habían producido exploraciones. La primera, en diciembre de 1842, estaba comandada por Juan José Lerena, que entre otras misiones en la costa africana tuvo la de afianzar la soberanía española en el territorio. A su regreso, gracias a sus informes, una comisión estableció la potencialidad agrícola y piscícola de Fernando Poo y la definió como un punto importante para el comercio. En julio de 1845 zarpó otra al mando de Adolfo Guillemard, que completó la información y estableció un plan de acción. Guillemard escribió un Opúsculo sobre la colonización de Fernando Poo, en el que explicaba el viaje y sus razonamientos. El padre Usera, que había ido en la expedición de 1845, escribió en 1848 Memoria de la isla de Fernando Poo y en 1852 como respuesta a la obra de Guillemard sobre la que se mostró muy crítico. En un nuevo libro denominado Observaciones al llamado opúsculo sobre la colonización de Fernando Poo publicado por D. Adolfo de Guillemard de Aragón, abogaba por la intervención de la religión y el establecimiento de misiones y apuntaba la relevancia como reserva de obreros africanos que sustituyeran a los esclavos en las Antillas. ${ }^{67}$

El 23 de mayo de 1858 llegó a Fernando Poo el vapor de guerra Vasco Núñez de Balboa al mando del capitán Carlos Chacón y poco después arribaron otros tres barcos que completaban la expedición, con el objetivo de asentar el dominio español y preparar la posterior colonización. El 13 de diciembre, las Cortes aprobaron el estatuto orgánico de la posesión. Pronto, los miembros de la expedición comenzaron a sufrir las fiebres, por lo que se embarcó a 26 condenados en el presidio de marina de la Carraca para que trabajaran en los desmontes. Mientras tanto se preparaba la expedición que llevaría a 128 colonos, que arribaron en la Santa María el 10 de julio de 1859 y en la Ferrolana que atracaría poco después. Tras unos meses de estancia, azotados por las fiebres, casi

66 Jose Antonio Piqueras, La Revolución Democrática (1868-1874). Cuestión social, colonialismo y grupos de presión, Ministerio de Trabajo y Seguridad Social, Madrid, 1992, pp. 449-461.

${ }^{67}$ Mariano L. De Castro y Luisa de la Calle, Origen de la colonización española en Guinea Ecuatorial (1877-1860), Universidad de Valladolid, Valladolid, 1992, pp. 135-165; J. Usera, Memoria de la isla de Fernando Poo, Imprenta de Tomás Aguado, Madrid, 1848, p. 77. 
todos pidieron volver a la Península. El envío de pobladores se suspendió el 4 de septiembre y en diciembre, de la Gándara tuvo que aceptar la repatriación de la mayoría en lo que constituyó un estrepitoso fracaso: 17 murieron, dos desertaron, 92 regresaron y solo ocho se establecieron. En el mismo estado se encontraba la guarnición en 1861, de los 151 miembros, 22 habían muerto y 83 eran inútiles para el servicio. ${ }^{68}$

El 5 de mayo de 1860, el gobernador de Fernando Poo nombró una nueva comisión para la exploración de la isla. Dos reales órdenes de 20 de junio de 1861 establecían la próxima creación de dos penitenciarías, uno en las Marianas y otro en Fernando Poo. ${ }^{69}$ La normativa dejaba de nuevo abierta la puerta a un sistema penal al estilo británico, puesto que no tenía sentido conducirlos a lugares tan remotos para permanecer estrictamente recluidos. A pesar de la diferencia entre la ley y la aplicación real de la deportación, mostraba las intenciones respecto a la utilización de represaliados políticos. A partir de entonces y durante unos años la relegación quedaría enlazada con las pretensiones colonizadoras.

\subsection{Las insurrecciones de Loja e Iznájar}

El día 29 de junio de 1861 varios cientos de campesinos se concentraron en el cortijo de la Torre, entre Loja e Iznájar, para levantarse en armas. Un movimiento de tales dimensiones fue posible gracias a la expansión en los cinco años anteriores de la sociedad de los carbonarios en la ciudad. También tuvo un papel esencial la figura de Pérez del Álamo como elemento capaz de atraerse a los sectores populares atendiendo a

\footnotetext{
${ }^{68}$ Oficio de gobernador de Fernando Poo a ministro de Guerra y Ultramar, 24 de septiembre de 1861. AGA, África-Guinea, Caja 81/6946; Dolores García Cantús, Fernando Poo. Una aventura colonial española en el África occidental (1778-1900), Tesis doctoral de la Universidad de Valencia, Valencia, 2004, pp. 364-433; Mariano L. De Castro y Luisa de la Calle, Origen de la colonización española en Guinea Ecuatorial, pp. 219-220; la expedición de Chacón, en Joaquín J. Navarro, Apuntes sobre el estado de la costa occidental de África y principalmente de las posesiones en el golfo de Guinea, Imprenta Nacional, Madrid, 1859; Mary Kingsley, Cautiva en África, Mondadori, Barcelona, 2001, p. 57. Dice que 50 regresaron en el Patiño; otros 17 regresaron en el San Antonio; Agustín Miranda Junco, Leyes Coloniales. Legislación de los territorios españoles del golfo de Guinea, Sucesores de Rivadeneyra, Madrid, 1945, p. 30. Real orden de 14 de julio de 1859.

${ }^{69} \mathrm{La}$ comisión publicó sus experiencias como Informe de la comisión nombrada por el gobernador de Fernando Poo en 5 de mayo de 1860, Imprenta Nacional, Madrid, 1861; CLE, tomo LXXXV, pp. 529-530.
} 
la alfabetización, politización y ayuda a las reivindicaciones de los jornaleros. ${ }^{70}$ Los alzados entraron en Iznájar y posteriormente en Loja, donde se parapetaron y se les unieron varios centenares provenientes de distintas poblaciones. El 4 de julio, las tropas se apostaron enfrente de la ciudad y Pérez del Álamo y los suyos la abandonaron y se dispersaron.

La importancia de la sublevación, dirigida por gente preparada frente a otras insurrecciones anteriores de carácter más espontaneo, la configuraron como una gran manifestación de la fuerza de las clases populares en el sur de España. ${ }^{71}$ El día 4, el gobernador de Málaga recibió una orden del Ministerio de la Gobernación que consistía en que los alcaldes dieran parte de aquellos que se habían ausentado, para proceder a ser juzgados según la ley de 17 de abril de 1821. Las autoridades esperaron a que regresaran desprevenidos a sus casas para iniciar las detenciones. Solo en Málaga hubo 629 presos, sin contar los que había en Granada y Loja, lugar este último a donde las columnas del ejército que recorrían la zona enviaban sus aprehendidos. Los consejos de guerra arrojaron la cifra de 478 condenados a cadena y presidio que serían distribuidos así: a Fernando Poo, los 34 sentenciados a cadena perpetua; a Canarias, los 206 a cadena temporal; a Baleares, los 114 a presidio; y a Santoña, los 124 a prisión mayor. Más de 300 consiguieron escapar dirigiéndose a Gibraltar, Cerdeña, Inglaterra y a Rabat, Santa Cruz u otras poblaciones de la costa africana. Seis fueron ejecutados, uno por cada una de las poblaciones de mayor importancia en el levantamiento. ${ }^{72}$

Las represalias por los sucesos de 1861 afectaron a un gran número de individuos, en consonancia con la amplitud de la misma y su carácter social. Pero aun así se optó por que la mayoría fueran encarcelados. Entre los dirigentes se pretendía acabar con la monarquía, pero entre los campesinos los ideales democráticos y republicanos representaban un mayor acceso a la tierra, el fin de las quintas y los

\footnotetext{
${ }^{70}$ Guy Thomson, "La revolución de Loja en julio de 1861. La conspiración de los carbonarios y la democracia en la España moderna", en Alda Blanco y Guy Thomson (eds.), Visiones del liberalismo. Política identidad y cultura en la España del siglo XIX, Publicacions de la Universitat de Valencia, Valencia, 2008, pp. 159-193.

${ }^{71}$ Clara E. Lida, “QQué son las clases populares? Los modelos europeos frente al español en el siglo XIX”, Historia Social, núm. 27, 1997, pp. 3-23.

${ }^{72}$ Antonio Guerola, Memoria de mi administración en la provincia de Málaga, Fundación Sevillana de electricidad, Sevilla, 1995, vol. III, pp. 1109-1114. De ellos, más de 600 estuvieron recluidos al mismo tiempo; La Época, 13 de mayo de 1862; Antonio Pirala, Historia contemporánea, tomo I, p. 911; Ángel Aroca Lara, "Iznajar en el levantamiento de Pérez del Álamo”, en Juan Alonso Sánchez Martínez (coord.), Rafael Pérez del Álamo, 150 aniversario de la Revolución de Loja, Loja, 2011, pp. 11 y 22.
} 
consumos. ${ }^{73}$ Pérez del Álamo pretendía proclamar la república lo que implicaba necesariamente la expansión a otros puntos. Sin embargo, el Ejecutivo resto importancia al contenido político de la revuelta e incidía en el social, al considerar que iba contra la propiedad. ${ }^{74}$ Esto pudo tener que ver con tratar de atraerse a los terratenientes en rivalidad con los moderados y auguraba dureza en la represión.

La mayoría de los aprehendidos fueron civiles pero también hubo participación de un pequeño número de soldados, que fueron destinados a los cuerpos de Ultramar. ${ }^{75}$ Dada su diferente condición se les utilizó en el siempre escaso ejército colonial donde su adiestramiento militar podía ser mejor empleado. A un grupo de los civiles, se les reservaba otro cometido no menos "patriótico", participar en la repoblación de territorios nominalmente españoles pero con escasa implantación real.

Las sentencias impuestas por el consejo de guerra fueron mediatizadas por el Gobierno, que al disponer que 34 pasaran a un lugar en el que no había ningún presidio cambió las condiciones de cumplimiento de las penas. El Ejecutivo conocía perfectamente los estragos provocados por las fiebres entre pobladores y soldados y la precaria situación de Fernando Poo. Por esto, su envío debe ser considerado como intento de impulsar la colonización con un grupo de personas para ponerlas a disposición del gobernador. Eran individuos cuya vida poco importaba al poder y que constituirían el primer intento de colonización de la posesión con represaliados políticos. El carácter rural y la clase social facilitaban una represión dura. Además, teóricamente eran los más indicados a causa de sus conocimientos agrícolas y fueron remitidos en escaso número, en un intento de no saturar los escasos recursos del dominio.

La respuesta de O’Donnell fue diferente a la que Narváez había dado en 1857 a los sucesos de El Arahal. A esto pudo influir el carácter propio de cada uno de ellos y sus diversos intereses. Para el duque de Tetuán una punición desmesurada podía haberle granjeado opositores entre los sectores progresistas de su partido y debilitar a los unionistas en Loja. Además, la aplicación de la deportación le permitió "sustituir" la sentencia de muerte por otra muy rigurosa que permitía dar rienda suelta a las ambiciones imperiales de algunos, aunque fuera únicamente a título propagandístico.

\footnotetext{
73 Antonio Maria Calero, "Introducción", en Rafael Pérez del Álamo, Apuntes sobre dos revoluciones andaluzas, p. 18.

${ }^{74}$ La Época, 9 de julio de 1861.

${ }^{75}$ La Discusión, 8 de septiembre de 1861.
} 
Los esfuerzos de O’Donnell en Fernando Poo significaban la constatación de la importancia de los intereses de los esclavistas en su administración. Además de un interés económico del que carecían las Marianas, ofrecía la ventaja de estar más cercana y ser su transporte más económico.

Mediante real orden de 9 de agosto de 1861 se instaba su salida. Únicamente uno de los condenados a cadena perpetua permaneció en Málaga y eludió este castigo. ${ }^{76}$ No conocemos el motivo por el que no fue embarcado, probablemente por enfermedad o por disponer de contactos adecuados. No olvidemos que el simple paso del tiempo enfriaba las represalias gubernamentales. La prensa relata el embarque de los prisioneros en el Caridad:

"Nos escribe un amigo de Málaga, con fecha del 16, que aquella población se había afectado extraordinariamente con el espectáculo de los infelices sentenciados por el consejo de guerra, que con esposas y cadenas y escolta de infantería y de caballería, se habían conducido al embarcadero para ser transportados a Fernando Poo. Varios vecinos cerraron las puertas de sus casas para no presenciar tan desolador espectáculo, pues en pos de los presos iban muchos de sus familias y amigos, que esperaban en vano poderse despedir de ellos al tomar la falúa que les había de conducir al buque". ${ }^{77}$

El día 27 salieron el Vasco de Núñez de Balboa con 52 individuos para Palma de Mallorca y el Nuestra señora de Covadonga con 119 para Gran Canaria y 5 para Fernando Poo. Algunos de los barcos para Fernando Poo desembarcaron en Canarias a presos destinados allí. Los embarcados salieron de la ciudad con el traje del establecimiento penal y con los amplios sombreros de paja utilizados por la gente del campo. ${ }^{78}$ (Tabla 5).

El Gobierno no pretendió realizar deportaciones masivas, tal y como había ocurrido con anterioridad. Los trasladados al resto de lugares irían a las prisiones. Únicamente en Fernando Poo se pretendió poner en práctica las ideas materializadas en la ley de 20 de junio de 1861. Ante la llegada de la goleta Caridad, el 11 de septiembre, con el primer grupo de 13 confinados, el gobernador del territorio, José de la Gándara, informaba el estado lamentable del dominio motivado por el clima perjudicial y la carencia de recursos. Exponía que el hombre blanco no podía realizar esfuerzos

\footnotetext{
${ }^{76}$ La ley en Agustín Miranda Junco, Leyes Coloniales, p. 21; AGA, África-Guinea, Caja $81 / 6946$

${ }^{77}$ El Contemporáneo, 20 de agosto de 1861. Información de El Pueblo.

${ }^{78}$ La Esperanza, 28 de agosto de 1861; Antonio Guerola, Memoria de mi administración en la provincia de Málaga como gobernador de ella desde 6 de diciembre de 1857 hasta el 15 de febrero de 1863, vol. III, pp. 1109-1114. El gobernador de Málaga calificó el embarque de "triste espectáculo".
} 
corporales en la posesión, especialmente en la intemperie, sin ser atacado por las fiebres de las que solo se salía tras grandes cuidados y en las que se recaía fácilmente. La comida era escasa hasta el punto que la marina racionaba a su gente desde la Península y la infantería se avituallaba por medio de paquetes remitidos desde Londres. El alojamiento se reducía a un pontón para la estación naval y otro para los de la colonia. El cuartel que se construyó para la guarnición se utilizaba únicamente de día, por la gran cantidad de enfermos que hubo cuando estaba ocupado. El hospital, con plaza para 40 personas, se saturaba frecuentemente y tenía que habilitarse espacio en los pontones. ${ }^{79}$

Tabla 5. Embarcados con destino a Fernando Poo (agosto-octubre de 1861)

\begin{tabular}{llc}
\hline Nombre del barco & Fecha de salida & $\mathbf{N}^{\mathbf{0}}$ de sentenciados \\
\hline Goleta Caridad & 16 de agosto & 13 \\
Goleta Covadonga & 22 de agosto & 5 \\
Vapor Colón & 2 de septiembre & 6 \\
Vapor Liniers & 21 de septiembre & 4 \\
Vapor León & 24 de septiembre & $0^{*}$ \\
Vapor Vulcano & 9 de octubre & 5 \\
Total & & $\mathbf{3 3}$ \\
\hline
\end{tabular}

Fuente: AGA, África-Guinea, Caja 81/6946; La Discusión, 18 de agosto de 1861; La Esperanza, 28 de agosto de 1861; La España, 25 de septiembre de 1861; La Correspondencia de España, 24 de octubre de 1861; *El León recogió a los del Liniers y Colón que habían desembarcado en Canarias y los llevó a Fernando Poo.

En ese momento se estaba construyendo la iglesia con la ayuda de cinco o seis soldados albañiles y otros tantos carpinteros, todos en tan mal estado de salud que cada día la mitad no estaban en disposición de trabajar. Por esto comunicaba la imposibilidad de fundar un establecimiento disciplinario y manifestaba lo inconveniente de arribo de un número elevado de penados. Dado que los trece relegados eran hombres del campo solo podían ser empleados en "desmontes, movimientos de tierras, peonajes y trabajos a la intemperie", por los que caerían enfermos en menos de quince días. Pidió que en el caso de enviársele más tuviesen algún oficio. La escolta era escasa y en el caso de custodiarles hasta su lugar de ocupación se vería todavía más mermada al ser expuesta al exterior. Exponía que el cese de actividades estaba condicionado a la aprobación del Gobierno y que su postura era compartida por los médicos y el consejo de la colonia. ${ }^{80}$

\footnotetext{
${ }^{79}$ Oficio de gobernador de Fernando Poo a ministro de Guerra y Ultramar, 24 de septiembre de 1861. AGA, África-Guinea, Caja 81/6946.

${ }^{80}$ Ibídem.
} 
El gobernador los alojó en el Pontón Perla, donde recibían la ración ordinaria de la tropa sin vino y pedía que se le aumentasen las remesas de víveres teniéndoles en cuenta. Solicitaba aclaraciones sobre las tareas a realizar, las habilidades, organización y sueldo de los confinados, así como planos detallados de los presidios en la Península. El Ejecutivo, en real orden de 4 de diciembre de 1861 avalaba la ubicación en el Perla y que se les eximiese de laborar en las faenas del campo "únicas para las que son útiles". Aun así, remitió los planos para la construcción de la penitenciaría y le respondió que les remunerara con lo que estimara conveniente. ${ }^{81}$ La correspondencia muestra la improvisación gubernamental y un gran desconocimiento de la situación real de la colonia. Aun así, O’Donnell se desentendía de la suerte de los confinados y avalaba cualquier decisión que tomara el gobernador general. Decidió mantenerlos aunque su contribución al progreso de la misma era dudosa. La ayuda en la prosperidad del dominio formaba parte de un segundo escalón en las intenciones gubernamentales. El pilar fundamental, el castigo y consiguiente atemorización de la disidencia, podía seguir ejecutándose mediante su mera permanencia en Fernando Poo.

Lo sucedido a los de la Caridad se extendió al resto. Según el vizconde de San Javier, testimonio presencial, José de la Gándara se preocupó de que estuvieran lo mejor posible. El vizconde corroboraba lo referente a la estancia en el Perla habilitado como "presidio y alojamiento de los socialistas" y afirmaba que los deportados tenían derecho a "ración de armada y fresco diario, exceptuándose el vino que solo se suministraba a los enfermos". ${ }^{82}$ Así, todos los días se les permitió salir a tomar fresco lo que indica que de algún modo pudieron deambular por el barco o la isla. Esta idea se refuerza por la afirmación de "presidio y alojamiento", situaciones ciertamente contradictorias que pueden ser entendidas como que su hospedaje estuvo a medio camino entre ambas figuras, o que hubo individuos en diferentes condiciones.

En marzo de 1866 llegaron cuatro sargentos condenados a diez años de presidio con retención por participar en la sublevación de enero, el gobernador general expuso que no los ubicó en la prisión puesto que era inadecuada para los blancos y que todos ellos:

"sean custodiados a bordo del Pontón Perla, donde son socorridos con ración ordinaria de armada sin vino, y empleados en las faenas de a bordo, habiéndome servido de

\footnotetext{
${ }^{81}$ Oficio de gobernador de Fernando Poo a ministro de Guerra y Ultramar, 26 de septiembre de 1861. AGA, África-Guinea, Caja 81/6946; Agustín Miranda Junco, Leyes Coloniales, p. 33.

${ }^{82}$ José Muñoz y Gaviria (Vizconde de San Javier), Tres años en Fernando Poo. Viaje a África, Urbano Manini, Editor, Madrid, 1871, pp. 230-231.
} 
precedente para adoptar esta medida, el que en el año de 1861 se tomó la misma con los confinados procedentes de Loja". ${ }^{83}$

Según el vizconde de San Javier, a los de Loja no se les asignó ningún tipo de trabajo físico y únicamente ayudaron en dos ocasiones a los soldados y los krumanes del Gobierno en el traslado de unos cañones desde unos almacenes para colocarlos en el cuartel. Por su ayuda recibieron la misma gratificación que la tropa, incluyendo la asignación correspondiente de vino y aguardiente. ${ }^{84}$ La ayuda en ocasiones concretas no excluye la realización de ciertas tareas de colaboración en el barco en el que estaban alojados. En cualquier caso, queda descartada la consideración estricta de reclusos. No dispusieron de libertad completa de movimientos, pero dadas las circunstancias de la colonia sus condiciones no podían considerarse malas. Residían en el barco, que era el lugar más seguro y confortable y allí eran llevados los miembros de los regimientos que caían enfermos. La predisposición del gobernador hacia ellos fue positiva y lo más probable es que a causa de la escasa presencia de peninsulares después de un tiempo observando una conducta apropiada recibirían mayor libertad.

Mantenerlos en el pontón facilitaba la custodia, lo que minimizaba el riesgo de fuga. Para los trabajos físicos más duros se disponía de los krumanes y los europeos únicamente realizaban labores especializadas. Sin embargo, a pesar de ser campesinos hubieran podido ayudar a los militares albañiles y carpinteros de algún modo. La decisión de no emplearles fue una decisión personal del gobernador, que no consintió que los relegados sufrieran castigo innecesario, probablemente porque no quería cargar con la culpa de haber tenido que ver con su muerte. Para la tropa, en cambio, formaba parte de su obligación y de su esfuerzo podía avanzar el estado de la colonia.

La deportación a Fernando Poo en la época se asemejaba a una sentencia a muerte, por lo que la oposición política y mediática, entre la que cabe destacar a $L a$ Discusión, no iba a permanecer sin criticar esta actuación. Diversas iniciativas la denunciaron y trataron de que se les perdonara. Sagasta presentó un proyecto de ley en

\footnotetext{
${ }^{83}$ Oficio de Gobierno de Fernando Poo a ministro de Ultramar, 31 de marzo de 1866. AGA, África-Guinea, Caja 81/6941.

${ }^{84}$ Ibídem; José Muñoz y Gaviria (Vizconde de San Javier), Tres años en Fernando Poo, pp. 230-231. Muñoz se encontraba en la isla y por tanto en principio su versión podía ser más creíble, pero el libro fue escrito diez años más tarde y peca de exagerado en algunos de los datos que aporta como cuando afirma que los deportados eran 90 y que todos llegaron en el León. En cambio, según los apuntes de Guerola y toda la documentación oficial los 33 deportados están perfectamente localizados.
} 
mayo de 1862 para amnistiar a los represaliados por los sucesos de Loja, plan que fue refutado por 35 votos a favor frente a 142 en contra. ${ }^{85}$ El rechazo a la amnistía terminó planteando un problema sanitario de grandes dimensiones, cuando poco más tarde se propagó una epidemia. La enfermedad fue transmitida por un buque ingles conocido por el Pontón Blanco, desde donde se extendió a los barcos españoles. En el caso del Perla según los facultativos se vio favorecida por "la aglomeración de individuos acostados con falta de ventilación imprescindible en este clima más que en otro alguno y otras razones que no hay tiempo para estudiar convenientemente". El día 15 se produjo el primer fallecimiento, y otro feneció el día siguiente. Entre los días 21 y 25 de ese mismo mes murieron otros siete. La epidemia también se extendió a la fragata Caridad, que se encontraba en el puerto y al pontón Isabel. ${ }^{86}$

El 22 de junio, el comandante del pontón, instado por los profesionales sanitarios, pidió desalojar a los deportados, lo que planteaba el problema de que no había ningún sitio con las condiciones sanitarias y de seguridad adecuadas. De la Gándara dispuso que fueran trasladados a la montaña de Basilé, a una altura de unos 400 metros de altura, en donde se edificaría bajo la supervisión del comandante de ingenieros un campamento en el lugar más adecuado y con todas las comodidades posibles hasta que se construyera el edificio que les serviría de alojamiento definitivo. Bajo su supervisión quedarían "todos los carpinteros de la compañía de la guarnición y algunos de la estación si fueran precisos", para su construcción dispondría de todos los krumanes y los materiales que fuesen necesarios. ${ }^{87}$

Entre el día 27 de junio y el 5 de julio fallecieron cinco en el Perla y otros dos a finales de julio y principios de agosto. La epidemia también afectó a la tropa y provocó durante los dos meses en que duró la muerte de un total de 86 individuos: 53 en la

\footnotetext{
${ }^{85}$ Ver La Discusión: 1 de enero de 1862, 16 de enero de 1862 y 22 de febrero de 1862; DSC, 10 de mayo de 1862; el proyecto en DSC, 7 de mayo de 1862. Apéndice segundo.

${ }^{86}$ Luis Iglesias Pardo, Observaciones teórico-prácticas sobre las fiebres africanas de Fernando Poo precedida de una reseña histórico-geográfica de la isla, Taxonera, Ferrol, 1874, p. 12; oficio de Gobierno de Fernando Poo a ministro de Guerra y Marina, 28 de junio de 1862. AGA, África-Guinea, Caja 81/6946. Los fallecimientos fueron comunicados por José de la Gándara a ministro de Guerra y Ultramar mediante oficios de 20 y 28 de junio de 1862 . El día 15 falleció Salvador Fernández, el 16 Cristóbal Godoy. Entre los días 21 y 25 de ese mismo mes murieron Salvador de Llamas, José Velázquez, Francisco Sulivi (o Sulivis), José de Llamas, Manuel del Carpio López, Pedro Pablo Guillen y José Bueno. Todos ellos en el Perla.

${ }^{87}$ Oficio de Gobierno de Fernando Poo a ministro de la Guerra y Marina, 28 de junio de 1862. Incluye el "Expediente sobre la traslación del presidio de la colonia del pontón Perla a la montaña de Santa Isabel”, AGA, África-Guinea, Caja 81/6946.
} 
estación naval, 12 soldados de infantería y 21 extranjeros o vecinos. ${ }^{88}$ Se trató de una plaga que afectó a la colonia en su totalidad. En el campamento tenían la subsistencia asegurada ya que los krumanes del Gobierno les llevarían raciones. Debían ser custodiados por los soldados, aunque en las órdenes se especificaba que lo mejor era persuadirles de que la fuga era imposible y de que les llevaría a la muerte, ${ }^{89}$ en una clara muestra de que la vigilancia no sería del todo estricta. En un territorio en el que los barcos que llegaban eran muy escasos la huida se antojaba casi imposible. Además, habría que añadir las malas condiciones climáticas inhabilitaban la opción de escaparse para permanecer oculto. Lo más factible es que los relegados disfrutarían de libertad de movimientos en los alrededores del campamento, lo que se acrecentaría desde la fecha en que se conoció el indulto hasta su repatriación, periodo en el que deberían permanecer libres.

En la metrópoli, la situación de los allí transportados podía maquillarse de progreso de la civilización mientras todo transcurría sin problemas. ${ }^{90}$ A finales de agosto toda la prensa informaba de la epidemia de fiebre amarilla y de los fallecimientos. El Gobierno había llevado a unos individuos a miles de quilómetros y a un clima muy peligroso para los europeos camuflándolo de contribución al desarrollo de la posesión. Pero cuando estos comenzaron a morir tuvo que rectificar para limitar el daño político que podría sufrir. El 5 de septiembre aprobaba una ley que indultaba a todos los presos por los sucesos de Loja y el resto de poblaciones andaluzas en junio y julio de $1861 .{ }^{91}$ Esto supuso la aceptación de un nuevo fracaso en la repoblación de Fernando Poo, fiasco que en realidad se había producido desde el mismo momento de

\footnotetext{
${ }^{88}$ Oficios del Gobierno de Fernando Poo a ministro de la Guerra y Ultramar, 9 de julio, 5 de agosto y 25 de agosto de 1862. Caja 81/6946; "Estado demostrativo de las bajas causadas en esta colonia por la fiebre amarilla", 28 de noviembre de 1862. AGA, África-Guinea, Caja 81/6962. Los fallecidos fueron: el día 27 de junio Antonio Ramos, el 28 Manuel Marín, el 30 Francisco Pérez, el 2 de julio Juan Ruiz, el 5 Gregorio Carrillo, el 27 Francisco Camacho y el 2 de agosto Pedro Gálvez.

${ }^{89}$ Oficio de Gobierno de Fernando Poo a ministro de la Guerra y Marina, 28 de junio de 1862. Incluye el "Expediente sobre la traslación del presidio de la colonia del pontón Perla a la montaña de Santa Isabel". AGA, África-Guinea, Caja 81/6946; según La Época, 8 de septiembre de 1862, la información salió ese mismo día en el correo para Fernando Poo. Por lo que si el viaje dura aproximadamente un mes, se produce un intervalo de tiempo en el que se sabe que van a ser liberados y traídos a la Península.

${ }^{90}$ La Esperanza, 19 de abril de 1862.

${ }^{91}$ La ley en CLE, Imprenta del Ministerio de Gracia y Justicia, Madrid, 1862, tomo LXXXVIII, pp. 414-415.
} 
su llegada. La deportación y el trágico fin de casi la mitad de ellos contribuyeron a que el resto de represaliados saliera de las cárceles.

De este modo, a pesar de que la epidemia ya había pasado no restaba más que la vuelta de los relegados. El Estado se hizo cargo de los costes del regreso que se materializó en noviembre. El nuevo gobernador desde el 30 de junio, Pantaleón López, puso en libertad a todos excepto a José Aranda García, que había sido condenado por la Audiencia de Granada a catorce años por homicidio. Los otros 16, retornaron a sus poblaciones, dos estando muy enfermos. ${ }^{92}$ El Ejecutivo no renunció a la colonización del territorio, pero dado el nulo avance producido con peninsulares blancos decidieron cambiar de táctica. El 21 de marzo de 1862 se remitió desde La Habana un barco con 200 "emancipados" cubanos, que llegó a Santa Isabel el 1 de agosto.

\section{LA REVUELTA DE SAN GIL}

\subsection{Precedentes inmediatos}

En la propia revuelta de Loja se había puesto de manifiesto la disparidad de medidas contra civiles y militares, que dejaban la práctica de la deportación en exclusiva para los elementos civiles. Después de 1861, la oposición al régimen vino principalmente desde las filas castrenses. A partir de 1862 se dieron algunos casos de traslados de cuartel, ${ }^{93}$ como una estrategia de alejamiento de opositores. Esta política también fue utilizada por los moderados y abarcó al propio Prim, destinado de cuartel a Oviedo y a cuatro sargentos y un teniente del regimiento de Saboya que fueron llevados a Ultramar para continuar sus carreras castrenses allí, en agosto de $1864 .{ }^{94}$ El Gobierno, tenía una auténtica obsesión por blindar el sistema frente a la insurrección, conscientes que el apoyo del régimen era cada vez menor.

\footnotetext{
${ }^{92}$ Gaceta de Madrid, 5 de septiembre de 1862; Luis Iglesias Pardo, Observaciones teóricoprácticas sobre las fiebres africanas de Fernando Poo, p. 12; oficio de Gobierno de Fernando Poo a Gobierno civil de Cádiz, 28 de noviembre de 1862. AGA, África-Guinea, Caja 81/6946; El Contemporáneo, 25 de enero de 1863.

${ }_{93}$ El Contemporáneo, 16 de abril de 1863; El Clamor Público, 1 de agosto de 1862.

${ }^{94}$ Pere Anguera, El general Prim. Biografía de un conspirador, Edhasa, Barcelona, 2003; La Época, 10 de octubre de 1864; La Iberia, 26 de agosto de 1864; El Clamor Público, 14 de octubre de 1864.
} 
El mismo castigo se reprodujo en el pronunciamiento de Prim de 3 de enero de 1866 en Villarejo de Salvanés. Una vez finalizada la sublevación comenzó la represión que incluyó varios fusilamientos. Unos 30 fueron conducidos a Filipinas para cumplir el tiempo que les reste de servicio y cuatro a Fernando Poo condenados a diez años de presidio con retención. ${ }^{95}$ Allí fueron alojados en el Perla con la misma ración de armada y se les empleo en las tareas del barco. Una vez que Prim estaba en Portugal y el peligro había pasado. O’Donnell podía centrarse en la punición, ayudado en el estado de sitio que duró hasta el 18 de marzo y que le permitió actuar a sus anchas y hacer enmudecer a la prensa. Hechos como estos se reprodujeron con anterioridad a San Gil, mostrando que había una acción de corrección sostenida de baja intensidad. ${ }^{96}$ O’Donnell aferrado al poder pretendía por todos los medios atajar la caída de la reina y la suya propia.

A causa de este movimiento revolucionario, 449 militares huyeron a Portugal. El Ejecutivo portugués aun simpatizando con los liberales temía una revuelta en el interior, por lo que movilizó a 24.000 reservistas y deportó a muchos a las Azores: entre diez y 15 oficiales a la de San Miguel y 261 a Terceira. ${ }^{97}$ La presencia de disidentes políticos españoles en suelo portugués significaba para el Gobierno luso un doble problema: Internamente, podía ser considerada como una mala influencia. En cuanto a las relaciones con España, la desproporción de poderío entre ambos estados desaconsejaba acoger con excesiva benevolencia a los españoles, hecho que podría ser considerado hostil por los gobernantes españoles.

\subsection{Detenciones y represión de civiles y militares. Los castigos impuestos}

El temor del Ejecutivo y la represión desatada mostraban como el régimen se sentía débil. Políticamente, la Noche de San Daniel, en 10 de abril de 1865, supuso el distanciamiento de importantes sectores de la intelectualidad. El mito de Prim permitió a muchos sectores de las clases populares tener un referente que era asimilado a la libertad. La crisis económica había empobrecido a buena parte de las capas bajas de la

\footnotetext{
95 Oficio de Gobierno de Fernando Poo a ministro de la Guerra, 31 de marzo de 1866. AGA África-Guinea, Caja 81/6941. De los cuatro dos fallecieron por una epidemia de fiebre amarilla durante ese mismo año; La Iberia, 7 de febrero de 1866, cita información de El Eco del País.

${ }^{96}$ La Iberia, 30 de mayo de 1866; La Discusión, 16 de junio de 1866.

${ }^{97}$ Carlos Cordeiro y Susana Serpa, "«Mártires da liberdade». O exílio de revolucionários espanhóis nos Açores (1866-1868) na perspectiva da impresa local”, Pasado y Memoria. Revista de Historia Contemporánea, núm. 9, 2010, p. 178.
} 
sociedad que habían salido perjudicadas en la desamortización en casos de propiedad enfitéutica y bienes comunales. A ello habría que unir la cuestión de las reivindicaciones de los sargentos, que topaban con grandes dificultades de ascenso en el ejército. Todo esto configuró una amalgama de factores, que determinarían el triunfo de la Revolución Gloriosa. ${ }^{98}$

El conflicto se manifestó con toda su crudeza en la sublevación del cuartel de San Gil de 22 de junio de 1866. En esta ocasión se contó con la ayuda del elemento civil que montó barricadas y combatió a las tropas gubernamentales. Aun así, en la noche de ese mismo día los insurrectos fueron vencidos. Entre 1.500 y 2.000 personas fueron detenidas y sus causas vistas por los tribunales militares. Sesenta y seis fueron fusiladas hasta el 7 de julio. La mayoría sargentos, cabos o soldados, pero entre ellos hubo un antiguo coronel carlista y un civil. ${ }^{99}$

La rebelión causó entre 200 y 500 muertos, ${ }^{100}$ lo que obligaba a algún tipo de acción ejemplarizante y de demostración de fuerza. Al ejecutarse se produjo la sustitución de O’Donnell por Narváez, el 10 de julio. Hacer cargar a O’Donnell el coste político de los 66 fusilados no fue la única causa para su cese. Existía el convencimiento, corroborado por los hechos, de que el malestar social se incrementaría y que las intentonas serían cada vez más fuertes. Las actuaciones de O’Donnell, si bien habían sido enormemente duras se habían producido de manera reactiva. La nominación de Narváez supuso una declaración de intenciones de la reina, que quería salvar su trono a cualquier precio. La trayectoria del espadón de Loja, que unía a la experiencia de gobierno su absoluta falta de escrúpulos a la hora de reprimir con dureza cualquier intentona insurreccional, le situó como el más indicado para cumplir los designios regios.

Narváez suspendió las Cortes en 11 de julio y en Barcelona fueron fusilados dos oficiales por su participación en las sublevaciones. A los pocos periódicos a los que se permitía publicar se les prohibió exceder en sus noticias políticas lo aparecido en la Gaceta, amenazando con consejos de guerra a los que incumplieran esta medida. El 26 de julio suspendió las garantías constitucionales, haciendo uso de la ley de 8 de julio aprobada por su predecesor. El 30 de julio una real orden declaraba a la democracia

\footnotetext{
${ }^{98}$ Sobre la confluencia de factores que determinaron el éxito de la revolución de 1868, ver José Antonio Piqueras y Enric Sebastià, Agiotistas, negreros y partisanos.

${ }^{99}$ Antonio Pirala, Historia contemporánea, tomo II, pp. 94-95; Revista Hispano-Americana, 12 de julio de 1866; Eugenio García Ruiz, Historias, tomo II, p. 703.

${ }^{100}$ José Luis Comellas, Isabel II. Una reina y un reinado, Ariel, Barcelona, 1999, p. 307.
} 
“incompatible con las instituciones fundamentales de la nación”. El Ejecutivo prohibió permanentemente "todas las manifestaciones públicas de la democracia y de los partidos que con ella se confundan, y destruir bajo cualquier forma que adopten, ya clandestina, ya aparente, su organización y sus asociaciones". ${ }^{101}$ Se instituyó una represión puramente ideológica al margen de la participación en acciones armadas y conspiraciones. No hay duda de que con O'Donnell fue fuerte, pero con su sucesor se intensificó sobremanera y se amplió el espectro de afectados.

El 16 de julio, el Capitán general de Aragón comunicaba a su homónimo de Cataluña el envío de Juan Pablo Soler, presidente del Comité democrático de Zaragoza, y Santiago Duleg, vocal del mismo. ${ }^{102}$ Desbaratar las organizaciones implicaba reprimir a sus miembros y extenderla desde los militares apresados a los civiles sin participación en los alzamientos y por motivos estrictamente políticos. A la hora de las represalias, el autoritarismo de Juan Zapatero supuso adelantarse al curso normal de los hechos ya que todavía se estaba represaliando a los participantes en la revuelta. Su marcha a Aragón provocó que sobre los demócratas de esa región cayera una gran represión.

El caso de Soler resulta muy ilustrativo, importante demócrata zaragozano y de fuertes convicciones religiosas, había constituido un club republicano en la ciudad. Entre 1857 y 1860 fue editor del periódico clandestino El Tizón. Tras el exilio de Ruiz Pons cogió las riendas del Partido Democrático en Aragón, lo que le supuso varios problemas con la justicia. En 1863 fue desterrado durante 18 meses por un artículo publicado en La Discusión y El Pueblo. A causa de los sucesos de Aranjuez constituyó una Junta revolucionaria en Zaragoza y tras el fracaso de la insurrección se ocultó y fue condenado en rebeldía a 12 años de prisión. Después de siete meses prófugo le fue revocada la pena, pero tras regresar a su domicilio fue detenido inmediatamente y se le formó consejo de guerra del que salió absuelto. Aun así, Zapatero ordenó su deportación a Fernando Poo y fue llevado encadenado a Barcelona, desde donde fue conducido a Cádiz y encerrado en el Castillo de Santa Catalina, en espera del transporte. ${ }^{103}$

\footnotetext{
${ }^{101}$ Las leyes en $C L E$, Imprenta del Ministerio de Gracia y Justicia, Madrid, 1866, tomo XCVI, pp. 33, 142-143 y 176-181; Eugenio García Ruiz, Historias, tomo II, p. 706.

${ }_{102}$ Oficio de gobernador de Fernando Poo a ministro de Ultramar, 1 de septiembre de 1866. Telegrama del subsecretario de Ultramar al gobernador de Cádiz, 13 de agosto de 1866. AGA, África-Guinea, Caja, 81/6941.

${ }^{103}$ Emilio Castelar et al., Biografías de los diputados a Cortes de la Asamblea Constituyente de 1869, con los retratos de los mismos perfectamente litografiados por los principales artistas de esta capital, Imprenta de Tomás Alonso, Madrid, 1869, tomo I, pp. 731-732; Emilio Castelar et al., Anuario republicano federal, compendio de lo más útil e indispensable del saber humano en
} 
Con los militares se plantearon traslados masivos a otros puntos. A 130 se les impuso diez años de presidio con retención en Cuba y otros 40 a Puerto Rico. El 6 de agosto se iniciaron los preparativos y el día 31 del mismo mes llegaron 36 a Puerto Rico en la fragata Antonio López. La celeridad en los juicios y el embarque inmediato muestra como el asunto era prioritario para el Gobierno. ${ }^{104}$ El 5 de agosto se dispuso la salida de cuatro soldados para cumplir el tiempo de recluta en el ejército de Cuba. ${ }^{105} \mathrm{Su}$ destino fue distinto por no ser profesionales lo que les eximia de responsabilidad. Alejarles y aprovecharse de su fuerza de trabajo fue suficiente castigo.

Contra los civiles se habían planteado unas represalias puramente ideológicas por el mero hecho de su militancia favorable a la democracia. La remisión de individuos a los penales de Cádiz fue constante. Desde Alicante salió a mediados de agosto para dicha ciudad Miguel Estanga en la goleta Concordia para ser deportado a Fernando Poo, aunque finalmente fue liberado a condición de que no volviera a Aragón. En la misma ciudad se encontraba preso José Colomina, a quien el 16 de agosto se le conmutó la relegación a Fernando Poo por la de destierro del País Valenciano. También a mediados de agosto habían sido detenidos en Lérida los paisanos Pedro Pérez, vocal del comité democrático de aquella ciudad, y Rómulo Mascaró, abogado y secretario del comité progresista puro leridano. Ambos fueron conducidos a Barcelona, donde permanecerían hasta la llegada de once aragoneses, condenados también a conducción a Fernando Poo por "sus malos antecedentes". ${ }^{106}$ Para los civiles, desde el primer

filosofía, ciencias, literatura, arte y política. Con el calendario republicano para 1871, J. Castro y Cía., Editores, Madrid, 1870, p. 1504; oficio de Gobierno de Fernando Poo a ministro de Ultramar, 1 de septiembre de 1866. AGA, África-Guinea, Caja 81/6941.

${ }^{104}$ Oficio de Ministerio de la Guerra al de Ultramar, 6 de agosto de 1866, adjunta relación de los mismos. Oficio de Ministerio de Ultramar al de Marina, 7 agosto de 1866. AGA, África-Guinea, Caja, 81/6941. Los nombres de los que llegaron a Puerto Rico son los represaliados en real orden de 18 de julio que correspondían a los extinguidos regimientos de artillería quinto y sexto a pie; La Iberia, 7 de octubre de 1868. Una vez en Cuba, algunos fueron trasladados a isla de Pinos.

${ }^{105}$ Oficio de Ministerio de la guerra a Capitán general de Castilla la Nueva, 5 de agosto de 1866. Incluye la relación de los mismos. Oficio de Ministerio de Ultramar a gobernador de la provincia de Cádiz, 8 de agosto de 1866. AGA, África-Guinea, Caja, 81/6941.

${ }^{106}$ Oficio de Ministerio de la Guerra al de Ultramar, en que le informa de lo ordenado al Capitán general de Andalucía, 17 de agosto de 1866. Oficio de Ministerio de la Guerra al de Ultramar, en que le informa de lo ordenado al Capitán general de Valencia, 16 de agosto de 1866. Oficio de Ministerio de la Guerra al de Ultramar, en que le informa de lo ordenado al Capitán general de Cataluña, 19 de agosto de 1866. Oficio de Ministerio de la Guerra a Ministerio de Ultramar, 27 de agosto de 1866, adjunta relación de los once aragoneses que eran: Pascual Lambea, Sebastián Rodríguez Tomás Monaj, Dionisio Mareo, Joaquín Barón, Pascual Rojas, Orbez Galindo, José Cuello, Francisco Marrare, Rudesindo Alegre y Antonio Marín, todos de Huesca 
momento se estableció la relegación a Fernando Poo o las Marianas. La idea del desembarazo y posterior aprovechamiento de los represaliados para fomentar la colonización, había arraigado.

Una vez en Cádiz, a los civiles se les encerraba en las prisiones para que más adelante se produjera el envío a los lugares a los que estaban destinados. Esto facilitaba el enfriamiento de la represión y la sustitución por otro punto. Dado que entre los afectados había un sector democrático, culto y en ocasiones adinerado y otro formado por marginados, desempleados y delincuentes, el primer grupo tendría más mecanismos para sortear la relegación a Fernando Poo. Este pudo ser el caso de Colomina, que creó una fábrica de abanicos en 1840 y en 1872 era el segundo mayor contribuyente industrial de la provincia de Valencia. De ideas demócratas y republicano federales, en el Sexenio acabó acatando la monarquía de Amadeo de Saboya. Se aproximó a los radicales y fue elegido senador y alcalde de Valencia, además de formar parte de la Junta del Centro Hispano-Ultramarino de Valencia y su portavoz en Madrid. ${ }^{107} \mathrm{Su}$ caso resulta paradigmático del de una nueva élite económica de ideas avanzadas cuyo progreso estaba siendo bloqueado por el moderantismo. Esto tiene diversas implicaciones en un momento en que liberalismo económico y político iban ligados. Las pretensiones eran superar el estancamiento en que se encontraba el Estado, profundizar la revolución burguesa y ampliar la democracia, en un proyecto que incluía un relevo generacional. En su caso, que no fue el único, cuando alcanzaron el poder y la influencia se hicieron más conservadores.

El único caso de embarque inmediato de civiles fue el de Mariano y Dionisio Artiga y José Monforte, condenados a deportación en Marianas pero que permanecieron en Filipinas. Se produjo aprovechando el envío de once militares sentenciados a presidio en el mismo archipiélago. En cumplimiento de la orden dada fueron

excepto los dos últimos. Finalmente los once aragoneses fueron deportados a Canarias y los dos catalanes a Fernando Poo, Oficio de Ministerio de la Guerra a Ministerio de Ultramar, en que comunica que ha informado al Capitán general de Cataluña de que 124 individuos condenados a deportación a Fernando Poo han de pasar a Canarias, incluye relación, 7 de febrero, Relación de los individuos deportados a Fernando Poo y puestos en libertad por real orden de 8 de noviembre de 1867, 29 de enero de 1868. AGA, África-Guinea, Caja, 81/6941.

107 Javier Paniagua y José Antonio Piqueras (dirs.), Diccionario biográfico de políticos valencianos, 1810- 2006, Diputación de Valencia-Institució Alfons el Magnànim-Centro Francisco Tomás y Valiente. UNED Alzira-Valencia/Fundación de Instituto de Historia Social, Valencia, 2006, p. 179. 
embarcados en la fragata Emigrante, que zarpó en la segunda quincena de agosto. ${ }^{108} \mathrm{La}$ diferencia entre el destino de unos y otros era clara. Los miembros de la tropa eran remitidos a Filipinas, Cuba y Puerto Rico principalmente. Es decir, a territorios en mayor o menor medida colonizados. La celeridad en la salida muestra la mayor percepción de peligrosidad para el poder. En principio iban a la cárcel, lo que no excluía la utilización en el ejército ultramarino ya que hubo casos en que se les conmutó la reclusión por servir en los regimientos. ${ }^{109}$

En Aragón, 56 individuos de diversas poblaciones de la provincia de Huesca habían sido detenidos por disposición del gobernador civil "por sus malos antecedentes y conducta". El Gobierno autorizó la deportación a Fernando Poo, tal y como solicitó el Capitán general. ${ }^{110}$ La cantidad de municipios de procedencia de los detenidos, implica que se trataba de una redada general contra los demócratas de esa región, muchos de los que serían dirigentes. También es posible que como ocurría en Cataluña se incluyera a alguno por delitos comunes.

En Cataluña conocemos las causas de la detención de 23 personas en Barcelona. Únicamente en cuatro casos no se especificaba ser "revolucionario" o "demócrata". A pesar de ello, ser tildado de tener malos antecedentes o ser vago no excluye las connotaciones políticas, especialmente para aquellos que eran tildados de peligrosos en todos los sentidos. En cuanto a los represaliados por su ideología en las descripciones se incluía ser considerado peligroso, haber participado en actos revolucionarios y se asociaba a los detenidos con conductas inmorales, vagancia o actos delictivos. El día 12 de septiembre, el Gobierno determinó que 17 serían deportados a Fernando Poo y el

\footnotetext{
${ }^{108}$ Embarque de deportados, s/f. Oficios de subsecretaria de Hacienda a ministro de Ultramar, 24 de agosto y 3 de septiembre de 1866. Oficio de Gobierno superior civil de Filipinas a ministro de Ultramar, 17 de febrero de 1868. AGA, África-Guinea, Caja, 81/6941. Desconocemos el origen de estos soldados, pero llegaron a Cádiz procedentes de Barcelona y Sevilla; hubo más casos de militares llevados a Filipinas, como por ejemplo el sargento Joaquín Gracia. La Discusión, 4 de noviembre de 1868.

${ }^{109}$ Relaciones de individuos que a consecuencia de su participación en los sucesos políticos de 1866 y 1867 fueron destinados a presidio e indultados al batallón de Cazadores Isabel II números dos y tres, de Cuba, 5 y 16 de diciembre de 1868, AGMM, Capitanía General de Cuba, Caja 4422.

${ }^{110}$ Oficio de Ministerio de la Guerra al de Ultramar, 11 de septiembre de 1866, incluye relación. AGA, África-Guinea, Caja, 81/6941. Había 2 ciudadanos de Belver de Cinca, 1 de Alcalá de Cinca; 2 de Sarsamarcuello, 1 de Aniés, 2 de Torrente de Cinca, 1 de Ponzano, 1 de Fraga, 11 de Peralta de la Sal, 3 de Barbastro, 2 de Salas Altas, 1 de Salas Bajas, 5 de Alcampell, 1 de Tamarite de Litera, 1 de Altorricón, 12 de Monzón, 1 de Almunia de San Juan, 1 de Binaced, 2 de Castejón del Puente, 1 de Sariñena, 1 de Lanaja, 1 de Torres de Alcanadre, 1 de Alcalá del Obispo, 1 de Barbuñales y 1 de Huesca.
} 
resto a Marianas, ${ }^{111}$ a pesar de que las acusaciones que les imputaban eran cuanto menos dudosas. Su presencia en la provincia se consideraba perjudicial por miedo a que se sumasen a las revueltas, pero entre ellos había cuatro maestros de escuela y otro al que se acusaba de vagar por la provincia de Gerona con el pretexto de dar lecciones de primera enseñanza. Las autoridades estaban temerosas por la extensión de las ideas avanzadas mediante la palabra.

Todos los aragoneses, excepto uno, permanecieron presos en Cádiz y ya en febrero 1867 irían a las Canarias. Lo mismo sucedió con los catalanes destinados a Fernando Poo. En cambió los 6 catalanes que tenían que ir a las Marianas fueron embarcados hacia las Filipinas, donde permanecerían. Eran aquellos a los que se imputaban los hechos más graves: Silvestre Franch (a) Aresta, "Revolucionario designado como Jefe de Barricada en Barcelona”; Ramón Roig y Ramón Grifoll "Presos por la policía de Barcelona vagos, matuteros, malos antecedentes, escandalosa conducta y revolucionarios"; Ignacio Sigró y un individuo apodado Llar de Gracia, ambos por "Revolucionario jefe de Barricada, complicado en dos asesinatos y perversa conducta"; y Francisco Morera (a) Llar de las Borjas "Procedente de Marsella sospechoso como agente revolucionario, desertor del ejército de Cuba y encausado por robos de consideración". 112

Las detenciones continuaron. A instancias del gobernador civil de Lérida fue detenido José Ignacio Llorens, de la Seo de Urgel. Era abogado, registrador de hipotecas, "furibundo demócrata y director de los hombres de estas ideas, es de carácter activo y firme" y había sido preso en 1856 por creérsele confabulado con el Noi de la

\footnotetext{
${ }^{111}$ Oficio de Ministerio de la Guerra a Ministerio de Ultramar, en que le informa de lo ordenado al Capitán general de Cataluña, 12 de septiembre de 1866, incluye relación. AGA, ÁfricaGuinea, Caja, 81/6941.

112 "Relación de los individuos que según lo prevenido en real orden de esta fecha deberán ser conducidos a las islas Canarias, en vez de serlo a la colonia de Fernando Poo", 7 de febrero de 1867. Oficio de Ministerio de la Guerra a ministro de Ultramar, 30 de octubre de 1866, en que informa de que Francisco Dumas pasó deportado a Ceuta. Oficio de Gobierno superior civil de Filipinas a ministro de Ultramar, 17 de febrero de 1868. "Relación de los individuos que se hallan presos en las cárceles nacionales de esta capital a disposición de S.E. sin estar sujetos a causa y que como medida gubernativa pasan a Ultramar en calidad de confinados", 6 de septiembre de 1866. AGA, África-Guinea, Caja, 81/6941. Conocemos la ciudad de residencia de algunos de ellos. Había un individuo de cada una de las siguientes poblaciones: San Martin de Provençals, San Pere de Riudevitlles, Martorell, Barcelona y Tremps. De otros tenemos pistas, ya que uno vagaba por la zona de Figueras y otro en la provincia de Gerona. Cuatro fueron detenidos a instancia del gobernador militar y del teniente alcalde de Figueras, por lo que vivirían en esta población u otras cercanas. Otro participó en la sublevación de Tarragona, por lo que sería de esta ciudad o de alguna población próxima. De otros se indica que fueron presos por la policía, por lo que se entiende que serían de Barcelona.
} 
Barraqueta. A mediados de septiembre el duque de Valencia aprobaba su deportación a Canarias junto con los detenidos a instancias del gobernador militar de Figueras, Jaime Madreñas, propietario de Terradas "demócrata de los más exaltados, propagandista de sus ideas y revolucionario", y Martin Vilanova, maestro de escuela y detenido por "republicano y ser de los que apoyaron un movimiento revolucionario". 113

Las represalias contra demócratas y republicanos tanto aragoneses como catalanes tenían varios puntos en común que diferían de las experiencias anteriores. Eran castigos plenamente planificados que muestran la institucionalización de la represión política. En las etapas anteriores, los capitanes generales actuaban por su cuenta, al margen de las autoridades locales que incluso en ocasiones se posicionaban en contra. Ahora todo discurría sin estridencias, el Capitán general a instancias de sus subordinados y colaborando con los mandatarios civiles detenían a las personas que estos indicaban. Con posterioridad informaban al Gobierno central que autorizaba la punición solicitada. La acción de unos y otros se complementaba, puesto que las autoridades militares teóricamente eran subordinadas y las relegaciones se decretaban con el aval del Ejecutivo, incluso cuando lo hacían a Fernando Poo porque la idea de su utilización en la colonización había calado entre las élites.

La mayoría de los detenidos de los que conocemos su origen eran ciudadanos de poblaciones pequeñas, lo que mostraba como las ideas avanzadas habían rebasado su ámbito urbano tradicional. De ahí el miedo de las élites del Estado, que contemplaban cómo la composición social estaba cambiando y que las ideas favorables a la revolución se extendían. Frente a la expansión de las ideas democráticas, la elite trataba de mantener sus prebendas y se hizo más conservadora y autoritaria.

En Cataluña, el 1 de octubre el ministro de la Guerra informó al Capitán general de que aprobaban su decisión y le instaban a embarcar a los diez presos que tenía en la urca de vela Pinta, 7 con dirección a Ceuta, 2 a Marianas y uno a Fernando Poo. La acción gubernamental se extendió a otros puntos de la Península. A finales de septiembre, el mismo organismo mandaba conducir a Cádiz para ser remitido a Fernando Poo a Federico Garcés, residente en Salamanca, y a José Ortá Torras y José Ros Martínez, que se encontraban bajo la jurisdicción de la capitanía general de

${ }^{113}$ Oficio de Ministerio de la Guerra a Capitán general de Cataluña, 12 de septiembre de 1866. Relación de individuos que deben pasar a los puntos acordados, 17 de septiembre de 1866. África-Guinea, Caja, 81/6941. Madreñas fue llevado a Canarias en febrero de 1867. De los otros dos desconocemos su destino, aunque lo más probable es que sufrieran el mismo destino ya que no fueron deportados a Filipinas ni Fernando Poo. 
Granada. El 23 de octubre de 1866 se ordenaba que el ciudadano de Valencia preso en Cádiz, Francisco Benzala y Morant, fuera deportado a Canarias en lugar de Fernando Poo, a donde había sido destinado con anterioridad. ${ }^{114}$

En el grupo de los 10 de Cataluña, únicamente uno fue condenado mediante juicio, por lo que posiblemente habría algún tipo de prueba contra él. Se observa un cambio en el perfil, ya que únicamente a uno se le tildaba de republicano y el resto fueron catalogados como "vagos, jugadores y de malos antecedentes". En las zonas donde se había producido una represión política fue ampliándose hacia sujetos con un perfil cercano a la marginación. En los lugares que habían quedado al margen, alcanzó a la oposición política. Dejando al margen a los encarcelados en Barcelona y Valencia, tanto el detenido en Salamanca como los que se encontraban en la provincia militar de Granada tienen apellidos de origen o muy extendidos en Cataluña. No podemos afirmar fehacientemente que estos ciudadanos fueran oriundos de allí, pero lo cierto es que tras un fuerte castigo muchos individuos salieron de sus lugares de origen. En el caso catalán, la frontera más próxima y segura era la francesa, sin embargo, esto planteaba problemas entre los cuales cabría destacar la búsqueda de trabajo o manutención, por lo que algunos que dispondrían de contactos en otros lugares de la geografía española se refugiarían dentro de sus propias fronteras.

En Cataluña, el 26 de octubre, el ministro de la Guerra autorizó al Capitán general a deportar a Fernando Poo a 27 hombres. A cinco se les relacionaba con delitos políticos y en otro caso se especificaba que era sospechoso "bajo todos los conceptos", lo que podía extenderse al ámbito ideológico. El resto estaban relacionados con la vagancia y el juego, siendo algunos delincuentes con múltiples detenciones, dos estaban relacionados con la prostitución y uno con la corrupción de menores. El 2 de noviembre

\footnotetext{
${ }^{114}$ Oficio de Ministerio de la Guerra a ministro de Ultramar en que le informa de lo ordenado al Capitán general de Cataluña, 1 de octubre de 1866, incluye relación. Oficio de Gobierno superior civil de Filipinas a ministro de Ultramar, 17 de febrero de 1868. "Relación de los individuos que según lo prevenido en real orden de esta fecha deberán ser conducidos a las islas Canarias, en vez de serlo a la colonia de Fernando Poo", 7 de febrero de 1867. Oficio de Ministerio de la Guerra a ministro de Ultramar en que le informa de lo mandado al Capitán general de Castilla la Vieja, 20 de septiembre de 1866. Oficio de Ministerio de la Guerra a Ministerio de Ultramar, 29 de septiembre de 1866. Oficio de Ministerio de Ultramar a ministro de Marina, 4 de octubre de 1866. Oficio de Ministerio de la Guerra a ministro de Ultramar, 23 de octubre de 1866. África-Guinea, Caja, 81/6941. El único republicano era Ramón Grebot (a) Bisbe, propietario de un cafetín en Masamet de la Selva. Rubies pasó a Filipinas y Baldrich a Canarias.
} 
se aprobó una nueva expedición con diez sujetos entre los que había dos demócratas y un socialista. ${ }^{115}$

Fueron incluidos miembros del movimiento obrero, en lo que supuso el aprovechamiento de la situación para proceder a una limpieza de Cataluña no solo de revolucionarios, sino también de individuos cuyo comportamiento era tenido por poco apropiado: delincuentes habituales y gente de los bajos fondos que tenían un componente urbano más acusado. La represión puramente ideológica estaba llegando a su fin y partiendo de ella el Capitán general había aprovechado para reprimir a un sector social diferente transformándose desde una predominantemente política a otra social ejercida contra aquellos que no eran opositores, pero cuyas acciones suponían una transgresión de la ley. Las huidas, exilios y las numerosas detenciones habían hecho mella de manera importante en el número de demócratas y republicanos destacados. El paso del tiempo, desde los sucesos del 22 de junio tendía a enfriar las represalias, especialmente teniendo en cuenta que en ese momento el estado era de tranquilidad.

Esto se tradujo en una bajada de intensidad frente a la disidencia, que no una desaparición, ya que las actividades conspirativas continuaban. En Aragón, los agentes del Gobierno interceptaron una carta de Prim dirigida al director de la Caja de Descuentos de Zaragoza, Benito Beris. El sobre contenía otras dos dirigidas a Juan Antonio Pie y a Domingo Giménez. El 5 de noviembre a las cuatro de la mañana, ambos, Beris y Pie, fueron detenidos, y a raíz de los interrogatorios a que fueron sometidos se prendió a otros más y se llegó a la conclusión de que buena parte de los sargentos de artillería de la guarnición de la ciudad estaban involucrados en el movimiento. Once de ellos partieron ese mismo día con dirección a Cádiz, desde donde habían de ser trasladados a Filipinas. ${ }^{116}$

\footnotetext{
115 Oficio de Ministerio de la Guerra a ministro de Ultramar en que informa de lo ordenado al Capitán general de Cataluña, 26 de octubre de 1866, incluye relación. "Relación de los individuos que según lo prevenido en real orden de esta fecha deberán ser conducidos a las islas Canarias, en vez de serlo a la colonia de Fernando Poo", 7 de febrero de 1867. Oficio de Ministerio de la Guerra a ministro de Ultramar, 2 de noviembre de 1866. Caja 81/6941. Únicamente uno de los deportados por motivos políticos en 26 de octubre, Pedro Antonio Torres, había sido sentenciado por ello. Los demás lo fueron por expediente gubernativo. Todos fueron a Canarias excepto Francisco Llobet al que se liberó porque "no ha dado lugar a una sola queja, justificándose además que ha cambiado de vida de algún tiempo a esta parte".

${ }^{116}$ Manuel Salcedo Olid, Ramón María Narváez, pp. 766-767.
} 


\subsection{Las deportaciones. Fernando Poo y otros destinos}

La década de 1850 y 1860 se enmarcaba en un contexto de toma de posición en el continente de las grandes potencias europeas. ${ }^{117}$ En España, a pesar de los continuos fracasos, la inestabilidad política proporcionaba opositores con los que reanudar los intentos. En 1866, la opinión del gobernador era, de nuevo, contraria a que se convirtiera en un lugar de deportación masiva. Las argumentaciones que esgrimía eran la alarma entre los escasos colonos por miedo a que se reprodujera la epidemia que diezmó a los remitidos por los sucesos de Loja, a que se alterara la tranquilidad, a que aumentara la escasez de recursos y a que afectara negativamente al comercio de armas y municiones con los indígenas de la costa occidental africana. Para su alojamiento únicamente disponían de unos barracones que no eran saludables para los europeos. Según Gómez de Barreda, debido a su carácter incipiente y a su clima, no era posible que pudieran ganarse la vida y quedarían sujetos a la caridad del Gobierno, por lo que sugería que se les llevara a otro lugar donde su presencia pudiera ser provechosa. Exponía que los relegados no tardarían en caer enfermos y tener que ser ingresados en el hospital, carente de espacio y de recursos, lo que produciría un perjuicio para la atención de la guarnición. Abocados a unas pésimas condiciones de existencia y rencorosos por el castigo podrían provocar alteraciones del orden que le obligarían a utilizar la represión con el consiguiente menoscabo de la influencia moral de los blancos sobre la población negra. Tampoco creía que contaba con los medios suficientes para hacer frente a las posibles fugas, ya que aumentar la vigilancia no era factible disponiendo de una única goleta de guerra y un número tan limitado de soldados. ${ }^{118}$

La presencia de los deportados suponía un perjuicio para el normal funcionamiento de la colonia. Dados los recientes fracasos en las intentonas repobladoras, nada hacía presagiar que el destino de estos podía ser mejor. Las impresiones del gobernador general, si bien un tanto exageradas en algunos aspectos, eran en general ciertas. Obligados a ir por su carácter opositor, no dudarían en volver a sus lugares de residencia en cuanto les fuera posible. A las negativas perspectivas y opinión de la máxima autoridad de la isla habría que unir un motivo de no menor

117 Dolores García Cantús, Fernando Poo. Una aventura colonial española en el África occidental, p. 345.

${ }^{118}$ Oficio de gobernador general de Fernando Poo a ministro de Ultramar, 30 de septiembre de 1866. AGA, África-Guinea, Caja 81/6941. 
relevancia, la llegada en 3 de octubre de 166 cubanos en la Rosa del Turia. ${ }^{119}$ Remitidos por incorregibles, haber sufrido diversas condenas y ser considerados vagos, su presencia resultaba incluso más peligrosa que la de los opositores políticos peninsulares.

El 5 de octubre llegó la urca de la marina de guerra Marigalante, con el único envío de relegados a Fernando Poo como consecuencia de los sucesos de junio de 1866. De los 19, la mayoría "venían escasos de recursos y sin medios de subsistencia", por lo que el gobernador les conminó a procurarse alojamiento y manutención, aunque ubicándoles momentáneamente a bordo de la urca. A los dos días, siete le comunicaron que habían encontrado hospedaje y el resto la imposibilidad de lograrlo, por lo que fueron alojados en una cabaña que servía de almacén a la estación naval y ordenó al Comandante de Ingenieros que proporcionara trabajo a los que tuvieran oficio. A los pocos días, el comisario de policía le informó de que algunos no podían comer por carecer de todo recurso, de modo que se estableció una ayuda de ocho reales diarios. ${ }^{120}$ De este modo, los deportados que no disponían de recursos económicos, después de unas vacilaciones iniciales fueron ayudados por el Estado.

El resto lograron el alojamiento en las pocas casas particulares que había, cinco de ingleses y dos de españoles, según Juan Pablo Soler, que consiguió hospedaje en la de su paisano el aragonés Anselmo Garulla. A causa de la escasa población blanca, sus pasos eran conocidos por todos y el intendente de policía y los oficiales de la guarnición les vigilaban, pero disfrutaban de completa libertad de movimientos y un trato digno, relacionándose entre sí, con la población británica y con las autoridades españolas, con las que ocasionalmente compartían mesa y mantel. La fuga se antojaba complicada por cuanto los barcos que pasaban por el territorio eran escasos: uno ingles mensualmente, uno del Gobierno español cada cuatro meses y otro catalán una vez al año. ${ }^{121}$ Los de origen europeo, especialmente aquellos que consiguieron la hospitalidad de algunos de sus habitantes, disfrutaron de una posición material y social relativamente buena. La

\footnotetext{
${ }^{119}$ Oficios de gobernador de Fernando Poo a ministro de Ultramar, 3 y 31 de octubre de 1866. AHN, Ultramar, Leg. 4718, Exp. 5. Expediente sobre medidas contra individuos de mala conducta.

${ }^{120}$ Oficio de gobernador general de Fernando Poo a ministro de Ultramar, informando de la llegada de 19 deportados políticos en la urca Marigalante, 30 de octubre de 1866. AGA, ÁfricaGuinea, Caja 81/6941. De los 21 que había previsto deportar dos eludieron su destino. Se trataba de Ángel Gallifa a quien se autorizó a pasar al extranjero y Francisco Ruzafa quien quedó enfermo en Cádiz.

${ }^{121}$ Emilio Castelar et al., Biografías de los diputados a Cortes de la Asamblea Constituyente de 1869, tomo I, pp. 733-735. Corresponde a una carta de Juan Pablo Soler, en que explica su deportación.
} 
ayuda de la población europea pudo deberse a hechos puntuales como proceder de la misma región, pero la importancia o la consideración social y económica de los deportados tendrían un papel determinante. Los que dispusieran de dinero para costearse su estancia y sus alimentos tendrían mayores facilidades.

Las condiciones de los peninsulares no tuvieron nada que ver con las que tuvieron que soportar los cubanos que arribaron en el Rosa del Turia. A su llegada fueron colocados temporalmente en el pontón y poco después trasladados al cayo Enríquez, frente a Santa Isabel, por el miedo que habían despertado entre colonos y aborígenes. ${ }^{122}$ El cayo tenía unas dimensiones de “¡DOCE varas de largo por OCHO de ancho! (...). Aquel cayo se movía y estaba totalmente rodeado de tiburones cuyas espoletas múltiples contemplábamos horrorizados". ${ }^{123}$ Solo con el tiempo, a algunos privilegiados se les dejaba pasar a la isla principal para realizar algún tipo de trabajo, lo que constituyó un beneficio indudable mientras que el resto tuvieron que residir en el mencionado cayo "tan haraposos en su mayor parte, tan depauperados física y moralmente, que daba lastima verlos". 124

Las relaciones sociales permitieron la fuga de Soler y de su amigo, el valenciano Miguel Jordán. Para esto contó con la ayuda del inglés Mr. Hoglan, propietario de una factoría, con quien había desarrollado una estrecha relación y que había prometido ayudarle en su huida. El 13 de febrero Mr. Hoglan le explicó que había un barco ingles en el que nadie sabía hablar español que zarpaba a las diez de la noche. Le expuso que si lo alcanzaba con cualquier papel sellado, podía hacerles creer que se trataba de la orden para regresar a España, y le dio dos pasaportes que habían dejado unos misioneros que se habían alojado en su casa. Soler, determinado a la fuga, habló con aquellos compañeros que disponían de dinero para pagarse el billete y estos le indicaron que el plan era peligroso y que disponían de casa, compañía europea y médico. Temían las represalias en caso de que fracasara y le manifestaron que en el mejor de los casos acabarían en Corisco o Elobey. Únicamente Jordán se mostró dispuesto a intentarlo. ${ }^{125}$

\footnotetext{
122 Oficios de gobernador de Fernando Poo a ministro de Ultramar, 3 y 31 de octubre de 1866. AHN Ultramar, Leg. 4718, Exp. 5. Expediente sobre medidas contra individuos de mala conducta.

${ }^{123}$ Hipólito Sifredo y Llópiz, Los mártires cubanos en 1869, Imprenta La Prensa, La Habana, 1893 , p. 25.

${ }^{124}$ Francisco Javier Balmaseda, Los confinados a Fernando Poo e impresiones de un viaje a Guinea, Imprenta de la Revolución, Nueva York, 1869, p. 153.

${ }^{125}$ Emilio Castelar et al., Biografías de los diputados a Cortes de la Asamblea Constituyente de 1869, tomo I, pp. 733-734. Soler en su carta explica que el capitán inglés desconocía la
} 
Esa misma noche, los comerciantes, los empleados y algunos de los deportados entre los que se incluían Soler y Jordán, estaban invitados a cenar a casa del señor Reilen, jefe de la administración militar de la posesión. A las nueve de la noche, Soler manifestó estar indispuesto y a pesar de los numerosos ofrecimientos de ayuda y atenciones de los médicos y los amigos, pudo convencerles de que fuera Jordán el que le acompañara a casa a darle una refriega con un bálsamo. A continuación se dirigieron a la bahía donde estaba el vapor inglés Etíope, cuyo capitán únicamente les exigió las seis libras del pasaje hasta Cameron, donde contrataron un pasaje a Liverpool. La huida desconcertó a las autoridades españolas. En un primer momento creyeron que se habían fugado en un bergantín español que fue registrado en dos ocasiones. ${ }^{126}$

En octubre de 1867 una epidemia de fiebre amarilla atacó la isla. El origen se atribuyó al vapor número 3 de La Habana, denominado General Álava, que llegó el 24 de septiembre y zarpó el 9 de octubre para la Península. La propagación de la epidemia continuó a partir de esa fecha y provocó que se abandonara el pontón Perla, que se había convertido en el principal foco de infección. ${ }^{127}$

En 1867 se produjeron varios indultos parciales de los represaliados como consecuencia de los sucesos de enero y junio del año anterior. El 24 de abril se contemplaba para los cabos y soldados que cumplían condena. La medida tuvo un éxito notable ya que a fecha de 20 de mayo se habían presentado 883 individuos a las autoridades, principalmente en Francia y Portugal. La liberación afectó a muchos más, ya que esta se produciría de manera automática para los que estaban presos. Quedaron al margen los civiles y los de rango militar superior a cabo. También a raíz de la insurrección fracasada de agosto de 1867 se produjeron varios perdones. Un real decreto de 5 de septiembre conmutó de la pena de muerte a los condenados por los consejos de guerra. El 26 de septiembre se concedió una nueva amnistía para los carabineros de

prohibición de acoger a pasajeros sin el consentimiento del Gobierno por ser un transporte especial y que el cónsul y el vice-cónsul ingles se encontraba de excursión en el interior de la isla. El gobernador de la isla expone que el cónsul se encontraba fuera de la isla y que esta circunstancia había sido comunicada personalmente al capitán del barco por el comisario de policía; Oficio de gobernador de Fernando Poo y sus dependencias a ministro de Ultramar, 27 de febrero de 1867. AGA, África-Guinea, Caja 81/6941.

${ }^{126}$ Emilio Castelar et al., Biografías de los diputados a Cortes de la Asamblea Constituyente de 1869, tomo I, pp. 734-735; oficio de gobernador de Fernando Poo y sus dependencias a ministro de Ultramar, 27 de febrero de 1867. AGA, África-Guinea, Caja 81/6941.

127 Luis Iglesias Pardo, Observaciones teórico-prácticas sobre las fiebres africanas de Fernando Poo, p. 14. 
tropa y los paisanos que hubieran huido al extranjero. ${ }^{128}$ Estas medidas de carácter parcial dejaban momentáneamente al margen a los remitidos a Fernando Poo, pero dada su reiteración parecía factible que tarde o temprano alguna les incluyera.

La conjunción de un estado sanitario altamente peligroso, la posibilidad real de amnistía próxima y el tiempo de estancia superior a un año, llevaron a siete de ellos a pedir el indulto a la reina, entre el 28 y 29 de octubre. La petición remarcaba el tiempo de relegación y las cuestiones sanitarias. Únicamente en dos casos exponían que no habían encontrado trabajo y la situación de inasistencia que esto provocaba en sus familias, pidiendo que se les permitiera regresar. Todos pedían ser amnistiados y para conseguir sus reivindicaciones se aclamaban al buen corazón que se le suponía a la reina. El gobernador, José Gómez de Barreda, avalaba todas las peticiones, lo que no resulta de extrañar dada la presencia de un gran número de deportados cubanos y la poca fuerza armada disponible. ${ }^{129}$ Resultaba innegable que la epidemia provocó excitación y además daba argumentos a las peticiones de indulto.

La mala comunicación, la escasez perentoria de recursos en la colonia y la presencia de un número tan importante de cubanos tendrían un papel determinante en que la inmensa mayoría de los castigados a ser conducidos a Fernando Poo no sufrieran ese destino. El 21 de octubre, el ministro de la Guerra comunicó al de Ultramar que en tanto no se organizara una expedición permanecerían encarcelados. Dicha expedición no se produjo y a excepción de los del Marigalante, los 124 que debieron pasar a la posesión fueron a Canarias en la urca Pinta, según lo dispuesto en real orden de 7 de febrero de 1867. Esto incluiría a los nuevos represaliados que iban llegando y que en

${ }^{128}$ Gaceta de Madrid, 25 de abril y 7 y 27 de septiembre de 1867; Gaceta de Madrid, 19 de mayo de 1867. Se trataba de 547 individuos exiliados en Francia y 350 en Portugal; Gaceta de Madrid, 21 de mayo de 1867. Añade 2 más en Portugal y 8 en Francia; algunos exiliados tomaron este camino conociendo la pena que se les impondría de aprehenderlos. Este es el caso de Federico Gomis, progresista y amigo personal de Prim, que fue condenado a deportación a Fernando Poo por real orden de 2 de octubre de 1866. Miguel Uzuriaga, militar demócrata había sido condenado a confinamiento en Ceuta por real orden de 10 de noviembre de 1866. Los diputados pintados por sus hechos, tomo II, pp. 40 y 101.

${ }^{129}$ Cartas de petición de indulto de Pedro Bagán, cerrajero; Mariano Campo, secretario del ayuntamiento de Bolea, Manuel Gandio, o (Gandia), sastre; Antonio Sabater, albañil; Joaquín Bolsa, labrador; José Gonzalvo, alpargatero y Ruperto Lozano, carpintero. Oficio de Ministerio de la Guerra a ministro de Ultramar en que explica lo expuesto por Gómez de la Barreda, 28 de agosto de 1867. AGA, África-Guinea, Caja 81/6941. 
teoría deberían ir también a Fernando Poo y a los que fueron destinados allí desde el primer momento cuya traslación no se produjo. ${ }^{130}$

Ocho ciudadanos salieron hacia las Filipinas, teóricamente con destino final en las Marianas en la fragata mercante Echagüe que zarpó de Cádiz el 11 de febrero de 1867. Los militares sentenciados al archipiélago asiático fueron muchos más. En 6 de diciembre de 1866 se estipuló que todos los sargentos y cabos que por los sucesos de enero o junio de 1866 habían sido mandados a continuar sus servicios en el Regimiento fijo de Ceuta o condenados a presidio en esta ciudad o en Melilla, habían de ser conducidos a Cádiz donde esperarían los buques necesarios para su salida al ejército filipino. Se trataba de unos 800 hombres que saldrían inmediatamente, puesto que en 12 de diciembre ya había tres buques preparados: el M. López, el General Echague y el Esperanza, para poder cargar a 300 individuos: 200 en tercera clase, 50 en segunda y 50 en primera. ${ }^{131}$

En total se ordenó la relegación de 50 personas a Ceuta desde la capitanía general de Valencia, 29 desde la de Granada, 31 desde la de Castilla la Vieja, uno desde la de Andalucía y 27 desde las de Aragón y Cataluña respectivamente. Además, a un sujeto le señalaron las Chafarinas. ${ }^{132}$ La dificultad se plantea en saber si recabaron allí o en Canarias, ya que entre estos se encontraba el líder obrero barcelonés, Antonio Gusart que finalmente fue a Canarias. Seguramente habría otros en su situación, pero tal y como sucedió con los que debían ir a Fernando Poo y Filipinas algunos recabarían en el enclave. Lo mismo pudo pasar a 25 progresistas, que en agosto de 1867 fueron embarcados, teóricamente hacia las Filipinas. ${ }^{133}$

Gusart preconizaba la resolución pactada de conflictos y el cooperativismo. Fue el líder del periódico El Obrero, creado en Barcelona en 1867, y primer firmante de un escrito que elevó al presidente del Gobierno pidiendo la libertad de asociación, motivo que provocó su deportación. Permaneció en Canarias, donde subsistió ayudado por sus

\footnotetext{
${ }^{130}$ Oficio de Ministerio de la Guerra a ministro de Ultramar, en que le informa de lo ordenado al Capitán general de Andalucía, 7 de febrero de 1867, incluye relación. AGA, África-Guinea, Caja 81/6941.

${ }^{131}$ Oficio de Gobierno de la provincia de Cádiz al Ministerio de Ultramar, de 11 de febrero de 1867. Oficios del Ministerio de la Guerra al de Ultramar, 6 y 19 de diciembre de 1866 y 4 de enero de 1867 y telegrama del Ministerio de Marina al de Ultramar con los preparativos, s/f. AGA, África-Guinea, Caja 81/6941.

${ }^{132}$ Relación de paisanos deportados por medida gubernativa por capitanes generales, s/f. BRAH, Archivo de Narváez, 9/7821, I-F-c-10.

${ }^{133}$ Matthew Stewart, El somni de Monturiol. L'extraordinària historia de l'inventor que volia salvar el món, Graó, Barcelona, 2009, pp. 228-229.
} 
amigos desde Cataluña y el escaso trabajo que consiguió. A los de 1866 habría que añadir, los que fueron reconducidos desde otros destinos teóricos y los motivados por el intento de sublevación de agosto de 1867. En total, a principios de 1868 había en el archipiélago 813 personas remitidas por motivos políticos: dos mariscales de campo, siete brigadieres, cinco coroneles, tres tenientes coroneles, 12 comandantes, 16 capitanes, 22 tenientes, seis alféreces, 13 sargentos, 270 soldados y 457 paisanos. La presencia de un número tan elevado de opositores preocupaba al gobernador de las islas, que pidió un refuerzo de 150 guardias civiles. Según la información, algunos "de la clase obrera" se ocupaban en las faenas del campo y el resto de la misma clase lo harían si reuniesen buenas cualidades. ${ }^{134}$

Las Canarias se convirtieron en el lugar masivo de deportación, en el que confluyeron gentes de condiciones sociales y en regímenes de estancia muy diferenciados, síntoma de hasta qué punto convergían en la necesidad de derrocar al sistema sectores sociales muy diferentes. A los militares no se les exigió que trabajaran, ya que estaban allí de cuartel y a pesar de la distancia tendrían unas condiciones de acuerdo a su rango. Diferente era el tema de los paisanos, pertenecientes a las clases obreras a los que se les demandaba que encontraran empleo y en caso contrario se les tildaba de vagos. Aun así obtuvieron una ayuda de dos reales de vellón diarios, ${ }^{135}$ para que no quedaran absolutamente abandonados. Encontrar ocupación dependería no solo de la voluntad, tal y como desde una perspectiva despectiva y clasista induce el texto, sino también con la disponibilidad del mismo para una mano de obra que se había incrementado de manera importante. El hecho de que los paisanos pudieran laborar indica que dispondrían de libertad de movimientos cuanto menos limitada.

A pesar de ser el destino mayoritario, las Canarias no fueron el único punto tampoco en esta última etapa del Gobierno moderado. En agosto de 1867 el fotógrafo Rafael Guillen fue relegado a Ceuta, donde continuó su actividad conspiratoria. En 1866, Pedro Rubalcavar, acusado de estar comprometido en los movimientos de enero y junio de 1866 fue deportado a las Baleares y "separado del ejército". También fue conducido a la Ciudadela un eclesiástico. Después del fracaso de la intentona de agosto de 1867 fueron remitidos a Ibiza desde Valencia el teniente coronel Rivas y el teniente

\footnotetext{
${ }^{134}$ Josep Maria Poblet, Antoni Gusart, un pioner de l'obrerisme, Rafael Dalmau, Barcelona, 1971, pp. 15, 29, 31, 42 y 45-48; La Época, 11 de enero de 1868. Información de El País de Santa Cruz de Tenerife; La Época, 9 de septiembre de 1867. Información del rotativo sevillano El Independiente.

${ }^{135}$ El Lloyd Español, 27 de marzo de 1867. Información de El Guanche.
} 
Rubio, del segundo batallón de San Fernando. El mismo destino sufrieron el comandante Roquisqui, el capitán Ramos, los tenientes Alcalá y Domínguez, un veterinario, un brigada y un sargento primero, todos ellos del batallón de Sagunto. ${ }^{136}$ En Ibiza, había "un considerable número de jefes y oficiales del ejército", la mayoría de alta graduación, “pues, fuera de unos cuantos capitanes y tenientes, los demás la tenían todos de comandante por lo menos, contándose varios tenientes coroneles y coroneles y hasta alguno que otro brigadier". Los militares estaban en buenas relaciones con los oficiales de la guarnición e incluso con el gobernador de la plaza que los visitaba de vez en cuando. Se alojaron en casas particulares o en la fonda que había en la ciudad y a pesar de permanecer libres estaban sometidos a vigilancia, sin poder alejarse a una cierta distancia de la ciudad y habiendo de informar diariamente del punto donde iban a pasar la noche. ${ }^{137}$

Teniendo en cuenta que los de Ibiza eran militares de cierta graduación, la ausencia de referencias a carencias de productos básicos y el hecho de que ocuparan la tarde en distraerse, indica en nuestra opinión que contarían con ayuda, bien fuera por no ser expulsados del ejército o por proporciónasela el gobernador bajo su responsabilidad. Las deferencias respecto a los oficiales obligados a residir en Ibiza, que partían desde el propio gobernador y abarcaban a sus subordinados, muestran el corporativismo castrense, que el Gobierno quizá no se atreviera a subyugar. A medida que la represión subía hacia arriba en la escala social, se hacía más suave para estos individuos.

\section{$5.4 \mathrm{El}$ regreso}

Los indultos parciales continuaron. El 10 de octubre se concedió una rebaja de condena a algunos presos que cumplían penas en la Península e islas adyacentes. No se

\footnotetext{
${ }^{136}$ Rafael Pérez del Álamo, Apuntes sobre dos revoluciones andaluzas, p. 115; La Iberia, 13 de octubre de 1868; La Época, 12 de diciembre de 1868; La Ilustración Republicana Federal, 15 de octubre de 1871. El 9 de agosto de 1868, se levantó al frente de un grupo de partisanos en la provincia de Cádiz. Guillen murió el 15 de octubre de 1869 en un enfrentamiento entre las partidas de Salvoechea a las que acababa de unirse y las tropas del Gobierno; carta de Luis Alcalá Zamora a Prim, 26 de septiembre de 1867. V. Álvarez Villamil y Rodolfo Llopis, Cartas de conspiradores. La Revolución de Septiembre. De la emigración al poder, Espasa-Calpe, 1929, pp. 345-352. El Coronel Crespo, máxima autoridad del levantamiento de Valencia fue remitido a Canarias; El Imparcial, 30 de octubre de 1868.

${ }^{137}$ Lluís Salvador, arxiduc d'Àustria, Las Baleares. Obra escrita y publicada en alemán con el título de Die Balearen in wort und bild geschildert, Biblioteca Popular, Palma de Mallorca, 1890, tomo II, pp. 116-124.
} 
circunscribía a los delitos considerados políticos, pero parte de sus beneficiarios lo serían por estas causas. En 1 de noviembre de 1867 se concedió un indulto que se extendió a todos aquellos que se encontraban fuera de sus poblaciones por providencia gubernativa a raíz de los sucesos de enero y junio de 1866. A partir de esa fecha comenzó un lento regreso de los deportados. El 6 de noviembre, 140 represaliados que se encontraban en Cádiz fueron embarcados en la goleta Prosperidad rumbo a Barcelona, de los que tres de ellos desembarcaron en Cartagena y 136 en Barcelona. ${ }^{138}$ Por pura proximidad geográfica, los más cercanos a sus domicilios fueron los primeros que retornaron.

La mayoría se encontraba en el archipiélago canario, desde el que empezaría un retorno escalonado. El 29 de noviembre zarpaba de Santa Cruz de Tenerife el vapor de guerra General Álava con más de 80. El martes 17 de diciembre llegó a Cádiz el vaporcorreo América procedente de las Canarias, con 53 individuos más que regresaban a sus casas. El 28 de diciembre salió de las Palmas el vapor América, con 28. Pocos días antes había salido de Las Palmas la goleta Vicenta, portando a 102 que habían residido en dicha ciudad. ${ }^{139}$

El Ejecutivo no se comprometió en absoluto con la repatriación ya que muchos tuvieron que depender de las suscripciones para conseguir fondos para la compra del pasaje a la Península. En diciembre de 1867 se realizó una suscripción en la capital tinerfeña y en mayo de 1868 se realizó una nueva colecta en Santa Cruz de Tenerife, La Laguna y La Orotava, que recaudó 15.080 reales para el retorno de los más pobres. ${ }^{140}$ Parece ser que únicamente los de un estrato social más elevado pudieron hacer frente al pasaje o incluso en algunos casos se lo pudo abonar el Estado. La repatriación se producía de manera escalonada y abarcando a un número muy inferior al total.

\footnotetext{
${ }^{138}$ Real decreto de 10 de octubre y real orden de 26 de noviembre. CLE, Imprenta del Ministerio de Gracia y Justicia, Madrid, 1867, tomo XCVIII, pp. 532-534 y 703-706; Gaceta de Madrid, 3 de noviembre de 1867. Las causas alegadas eran que el indulto ya se había producido para los hechos de agosto de 1867, que las deportaciones fueron realizadas gubernativamente y los prejuicios que ocasionaban a los interesados y especialmente a las familias; La Correspondencia de España, 9 de noviembre de 1867; El Imparcial, 14 de noviembre de 1867; Uno de los indultados fue Agustín Albors que estaba esperando para ser embarcado a Marianas. posteriormente seria alcalde republicano-federal de Alcoy y que hizo frente a la huelga general que había proclamado la Internacional, siendo asesinado por ello. Javier Paniagua y José Antonio Piqueras (dirs.), Diccionario biográfico de políticos valencianos, p. 31.

${ }^{139}$ El Imparcial, 5 de diciembre de 1867 y 4 de enero de 1868; La Época, 21 de diciembre de 1867; La Nueva Iberia, 26 de enero de 1868. Remite a una información de El País de las Palmas.

${ }^{140}$ La Esperanza, 4 de enero de 1868; El Imparcial, 6 de mayo de 1868.
} 
Excluyendo motivaciones personales que pudieron darse en casos particulares, como haber encontrado trabajo o haber rehecho su vida, no cabe la menor duda de que fue el Ejecutivo el que ralentizó el regreso masivo de los deportados. Para lograrlo recurrió a una vieja táctica, la de otorgar el indulto y no proporcionarles los medios para el embarque, imposibilitando o escalonando el retorno de la mayoría. El resto tendrían que esperar a obtener ayuda de sus familiares o mediante las suscripciones principalmente de sus correligionarios políticos canarios, que en esta ocasión resultaban enormemente dificultosas a causa del gran número de relegados. Los de menor rango social no tenían nada que ver con el intento gubernamental de ampliar la base social del régimen. Sus vicisitudes pasaban inadvertidas para la mayoría de la prensa y su presencia en España no suponía ningún beneficio para los mandatarios.

El Gobierno superior civil en Manila, al no recibir comunicación respecto a la aplicación del indulto de 20 de octubre a los militares que había en presidio en el archipiélago, procedió a aplicarlo por iniciativa propia. El 17 de febrero los puso a todos en libertad y empezó el regreso. En Fernando Poo, 14 salieron de la isla el 24 de enero en el vapor San Quintín. Pancracio Calonge y Juan Bañón habían embarcado a finales de diciembre del año anterior en un paquete ingles costeándose el viaje y León Tolosana había fallecido. ${ }^{141}$ A pesar de tener la posibilidad de permanecer en sus lugares de deportación nadie lo hizo. Obligados a vivir en territorios coloniales, en los que apenas podían ejercer ninguna actividad profesional, especialmente en Fernando Poo, y con un clima con mayor peligrosidad para los europeos, ninguno optó por esta vía. El Estado, al menos se hizo cargo de su repatriación, aunque éste se produjo de manera muy lenta.

En las Azores, muchos se negaron a regresar para esperar los acontecimientos políticos en España. En la isla Terceira, embarcaron 182 de los casi 250 que había. ${ }^{142}$

\footnotetext{
${ }^{141}$ Oficio de Ministerio de la Guerra al de Ultramar, 1 de noviembre de 1867, adjunta relación de los 11 que había en Filipinas y los 16 en Fernando Poo. Oficio de Gobierno superior civil de Filipinas a ministro de Ultramar, 17 de febrero de 1868. Oficio de Gobierno de Fernando Poo a ministro de Ultramar, 29 de enero de 1868. AGA, África-Guinea, Caja 81/6941; respecto al indulto a militares, desconocemos el número de los militares que se encontrarían allí, pero en 12 de enero de 1869 decidió aplicarlo a Víctor García Segura, Pascual Gimeno, Francisco Giner, Manuel Guerra, Antonio Matén, José García, Manuel Valina y Jaime Fral, que se encontraban presos en Manila. Oficio de Ministerio de la Guerra a ministro de Ultramar, en que le indica lo ordenado al Capitán general de Filipinas, 19 de febrero de 1869. Relación de los confinados europeos procedentes del ejército de la Península a quienes comprende el decreto de indulto de 20 de octubre último, 12 de enero de 1869. AGA, África-Guinea, Caja 81/6941; Los diputados pintados por sus hechos, tomo II, p. 58. Afirma que Juan Bañón fue deportado exclusivamente por ser hermano del importante progresista Joaquín Bañón y Algarra.

${ }^{142}$ Carlos Cordeiro y Susana Serpa, "«Mártires da liberdade»”, p. 187.
} 
Del resto, algunos volverían tras el triunfo de la gloriosa, pero otros se establecerían definitivamente en la misma.

\section{EL OCASO DEL RÉGIMEN}

Los apoyos a la reina y a los moderados eran cada vez más escasos. Si en 1856 la Unión Liberal podía presentarse como una fuerza aglutinadora, ahora el apoyo se resquebrajaba. Los progresistas se negaron a colaborar con el sistema, tal y como les había demandado O'Donnell, ${ }^{143}$ y se situaron en la oposición armada. Posteriormente, la muerte del conde de Lucena, el 5 de noviembre de 1867, facilitó la aproximación a Prim de importantes militares unionistas. El sector integrista del Partido Moderado también abandonaba a la Reina, a la que la pérdida de Narváez y O’Donnell dejó sin sus máximos valedores. Incluso la élite económica se mostraban cada vez más beligerante con el Gobierno de Narváez, que a raíz de la crisis de 1866 aumento impuestos, restringió el gasto y retrasó las subvenciones a las compañías ferroviarias. ${ }^{144}$

Con unos apoyos cada vez más escasos se optó por una política de mano dura. El 3 de octubre de 1866 fueron clausuradas las Cortes y a finales de 1867 permanecían cerradas, lo que suponía el incumplimiento de la Constitución que mandaba que debía hacerse una legislatura por año. Esto, unido al autoritarismo y la sospecha de que el Ejecutivo pretendía dar un golpe de Estado, hizo reunir a un grupo de diputados y senadores a instancias de los presidentes de esas dos cámaras, Antonio Ríos Rosas y Francisco Serrano Domínguez. De la reunión salió una exposición firmada por más de cien diputados que se pretendía presentar a la reina. El presidente del Congreso intentó llevar la exposición a la Reina mediante una comisión formada por el propio Ríos Rosas, Fernández de la Hoz, Martí de Herrera, Pedro Salaverría y Mauricio López Roberts. Narváez respondió remitiéndolos a todos a Baleares, excepto a Ríos Rosas que debía pasar a Puerto Rico y que finalmente lo hizo a Canarias desde donde se exilió en Lisboa. Con los de Baleares partió Ramón Goicorrotea, quien formaba parte de la comisión y se entregó para ser castigado con sus compañeros. Serrano tras un breve

\footnotetext{
${ }^{143}$ Nelson Durán de la Rua, La Unión Liberal y la modernización de la España isabelina, Akal, Madrid, 1979, pp. 302-305.

${ }^{144}$ Alberto Olilet Palá, El conflicto social y la legitimidad de la monarquía ante la revolución de 1868, Ministerio de Trabajo y Seguridad Social, Madrid, 1989, pp. 47-48.
} 
paso por el Castillo de Santa Bárbara de Alicante fue impelido a fijar su residencia en Mahón y Cánovas del Castillo fue desterrado a Carrión de los Condes para después pasar a Palencia. Cuatro magistrados del tribunal supremo fueron cesados. ${ }^{145} \mathrm{La}$ extensión hacia arriba de la represión facilitaba el apoyo a la conspiración de Prim, especialmente cuando este tenía gran apoyo social pero escaso entre las altas esferas del ejército, lo contrario que ocurría a los generales unionistas.

El 10 de marzo de 1867 se celebraron las nuevas elecciones que resultaron en una aplastante mayoría de los moderados, siendo elegidos dos neocatólicos, dos o tres unionistas y unos pocos disidentes más. La intransigencia del partido no significó únicamente abstraerse del tejido social, algo por otra parte habitual, sino que excluyeron de todo el poder posible al otro sostén sobre el que se había asentado el sistema. En este sentido, ya en 21 de octubre de 1866 la nueva Ley de Ayuntamientos significó la exclusión de los unionistas del poder local. ${ }^{146}$ Los moderados, convertidos en el último bastión de la reina pretendieron capitalizar todos los beneficios del sistema y con su actitud no hacían sino debilitar la posición de aquella a la que se habían conjurado a defender por todos los medios.

Decididos a acaparar el poder, optaron por las represalias como método para afianzarse en el mismo. El 20 de marzo comenzó a regir la Ley de Orden Publico de 1867. En ella, se estipulaba como delito o falta contra el orden público: "toda manifestación pública que ofenda a la religión, a la moral, a la monarquía, a la Constitución, a la dinastía reinante, a los cuerpos legisladores y al debido respecto a las leyes". Contemplaba tres estados: el normal, el de alarma y el de guerra y regulaba las actuaciones represivas en cada caso. Incluso en el periodo normal, aquel en que no hubiera ni siquiera indicios de sublevación, se establecían restricciones a la circulación y hospedaje de personas e instaba a formar padrones especiales con carácter reservado de jugadores, vagos y demás sujetos de carácter sospechoso. La prevención se extendió a las capas populares empujadas a la proletarización y que sufría el desempleo y los

\footnotetext{
${ }^{145}$ Francisco Pi y Margall y Francisco Pi y Arsuaga, Historia de España en el siglo XIX, tomo IV, pp. 377-383; La Esperanza, 11 de mayo de 1867. La residencia de Salaverría se fijó en La Ciudadela; La Correspondencia de España, 25 de mayo de 1867. Noticia aparecida en el periódico canario $E l$ Guanche; a Serrano como presidente del Senado se le permitió volver al iniciarse las sesiones del mismo, ver DSC. Senado 8 de abril de 1867.

${ }^{146}$ Francisco Pi y Margall y Francisco Pi y Arsuaga, Historia de España en el siglo XIX, tomo IV, p. 382; José Antonio Piqueras y Enric Sebastià, Agiotistas, negreros y partisanos, pp. 184189.
} 
salarios miserables por la crisis económica. La nueva Ley de Vagos, cuyo proyecto fue debatido en el Parlamento a principios de febrero de 1868 iba en esta dirección. ${ }^{147}$

En enero, el último gabinete de Narváez comenzó la creación de la Guardia provincial, que en solo tres meses alcanzará los 13.962 hombres. El coste del cuerpo se cargó a los municipios y estuvo formado principalmente por soldados licenciados. Su instauración permitió aumentar los efectivos armados contrarrevolucionarios sin coste para las arcas del Estado. Fue un intento apresurado del Gobierno de blindarse, pero de dudosa eficacia. Por otro lado, el poder trató de distender ligeramente los ánimos mediante la magnanimidad. El 23 de enero promulgó un indulto que se extendió a todos los paisanos que habían sido condenados por los tribunales a causa de los sucesos de 1866 y $1867 .^{148}$

Dentro del armazón en el que el Estado pretendía parapetarse para conjurar la revolución también cabía la deportación. Por real orden de 17 de agosto de 1867 se creó una Junta con objeto de establecer las condiciones de estancia de los relegados a Fernando Poo. En ella se analizaron los mejores lugares para trasladar a los opositores cuyo número creían que podría aumentar considerablemente. Las conclusiones fueron que Fernando Poo no era un lugar adecuado y que lo mejor era dejarla para los deportados cubanos. En las Canarias había alimentos y guarnición, pero el empleo disponible no era suficiente ni para los naturales. Las Filipinas tenían el mismo problema que las Canarias, pero con el hándicap añadido del clima. El lugar preferido por la Junta fue las Marianas donde el "clima es templado y agradable y permite el trabajo en las faenas del campo de todas las razas, sin peligro de las enfermedades comunes en los países próximos al ecuador”. Según argumentaban, en el archipiélago había ocupación abundante, los naturales eran tranquilos y apacibles y había disponibilidad de terrenos. Por esto, en este archipiélago "concurren las circunstancias de economía, seguridad, higiene y facilidad de alimentación", que posibilitaban la repoblación. Las desventajas eran el precio del transporte y el posible menoscabo de la opinión de los indígenas respecto a la raza europea, por lo que las remisiones se

\footnotetext{
${ }^{147}$ La ley en $C L E$, Imprenta del Ministerio de Gracia y Justicia, Madrid, 1867, tomo XCVII, pp. 548-570; sobre la Ley de Vagos y la gravedad de la situación social en el Valencia, extensible a todo el Estado ver José Antonio Piqueras y Enric Sebastià, Agiotistas, negreros y partisanos, pp. 330-337; Francisco Pi y Margall y Francisco Pi y Arsuaga, Historia de España en el siglo $X I X$, tomo IV, pp. 395-396. La ley, según Pi se aprobó pero no se aplicó.

${ }^{148}$ Vicent Mir Montalt, Desposeer y custodiar, pp. 114-117; Gaceta de Madrid, 23 de enero de 1868.
} 
realizarían en números cortos, se aumentaría la guarnición, se dificultaría la relación con los nativos y para reducir el importe del viaje se efectuarían en buques del Estado. ${ }^{149}$ Los continuos fracasos en Fernando Poo no eliminaron la idea de la represión colonizadora, pero variaron el emplazamiento hacia el archipiélago de la Micronesia. Detrás de estas argumentaciones subyacía la idea de que remitirles a un punto más lejano facilitaba el ocultamiento de la represión y que su retorno sería más dificultoso.

En marzo de 1868 se retomaron las conversaciones entre Prim y los generales unionistas, que habían fracasado antes, que finalmente proporcionarían a la revolución la ayuda entre un grupo elitista dentro del ejército, lo que fue de gran relevancia ya que sin el apoyo de esta institución el triunfo se había constatado imposible En abril se produjo la muerte del duque de Valencia. Narváez, gozaba de un gran prestigio en un sector del ejército, algo que su sucesor González Bravo, civil, no pudo mantener. Los opositores tradicionales: republicanos, demócratas y progresistas se veían ampliados con elementos importantes del unionismo, de tendencia conservadora pero que habían optado por rechazar a la reina, circunscribiéndose el apoyo a Isabel II únicamente a los moderados. Las represalias sobre militares de gran relevancia planteaban problemas. Su pertenencia a un extracto social elevado y la imposibilidad de conocer si dichos generales se sumarían a una futura sublevación tuvieron como consecuencia una represión selectiva y no excesivamente dura. Reprimirlos severamente era contraproducente por cuanto laminaría incluso más el apoyo de la institución armada.

El 7 de julio de 1868 una real orden ordenaba el arresto de una serie de destacados militares unionistas. El mismo día fueron detenidos en Madrid los generales Francisco Serrano Domínguez, Domingo Dulce, Francisco Fernández de Córdova, Francisco Serrano Bedoya, Juan de Zabala y el brigadier Letona. En San Sebastián fue detenido el teniente general Rafael Echagüe y en Zamora el mariscal de Campo Caballero de Rodas. Serrano Bedoya, Dulce, Serrano Domínguez, el teniente coronel López Domínguez y Caballero de Rodas irían a Canarias. Córdova a Baleares o Soria, Echague a Baleares, Zabala a Galicia y Letona finalmente fue llevado a Oviedo. Otros de menor relevancia fueron destinados de cuartel a distintos lugares: el general Marchessi fuera de Madrid; el general Messina a Ateca; el general Ustariz a Teruel; el

${ }^{149}$ Actas de las sesiones de la Junta creada por real orden de 17 de agosto de 1867. AGA, África-Guinea, Caja 81/6946. La Junta fue presidida por el subsecretario de la Ministerio de Ultramar Salvador Albacete. Los vocales fueron: Juan Ignacio Berriz, director general de establecimientos penales; Salvador Moreno Miranda, director del depósito hidrográfico; y Alejandro Planell, oficial del Ministerio de la Guerra. 
general Cervino a Estella; el brigadier Alaminos a Ronda y el brigadier Sánchez Bregua a León. ${ }^{150}$ La importancia de los represaliados muestra la propia debilidad del sistema que había prescindido de uno de los dos baluartes que lo sostenían, jugándoselo todo a la baza moderada e incrementado su lado represivo. Tener en contra a personalidades de tanta relevancia y tan alto rango castrense constituía un grave peligro. Unas condiciones restrictivas incrementarían la oposición al trato dado, pero dejarles libres y proporcionarles capacidad de movimientos inutilizaba en gran medida la lejanía que el traslado a Canarias pretendía.

El envío a Canarias de los militares de mayor relevancia formaba parte de un plan estipulado de alejamiento de la capital de aquellos a los que se consideraba supuestamente sediciosos. Por la mayor importancia del duque de la Torre, Dulce y los demás, fueron remitidos a un punto más lejano. Sin embargo, esto habría que tenerse en cuenta, puesto que a pesar de que la mayor parte de la bibliografía los califica como desterrados o deportados realmente se trata de destinados de cuartel. ${ }^{151}$ Esta diferenciación es relevante por cuanto no perderían su empleo ni sus rangos en el ejército. Los de mayor relevancia, aun cuando conspiraban abiertamente contra el Ejecutivo y suponían un peligro mayor, no tuvieron que sufrir las condiciones que soportaron los relegados.

Las condiciones de detención y traslado diferían de las que soportaban los civiles, especialmente los de condición más humilde. Los detenidos en Madrid fueron a las prisiones castrenses de San Francisco donde pudieron ser visitados por sus respectivas familias. Por la noche fueron conducidos a la estación de ferrocarril y allí despedidos por sus amigos antes de salir en dirección a Cádiz. A su llegada fueron recluidos en el castillo de San Sebastián, pero pudieron dejar instrucciones para el desarrollo de la conspiración. El 12 de julio fueron embarcados en el Vulcano con destino a las Canarias, arribando el 16 por la mañana. Una vez allí se les separó. El general Serrano Domínguez a La Orotava, acompañándole su primo. Serrano Bedoya

\footnotetext{
${ }^{150}$ La Época, 8 de julio de 1868; Francisco Pi y Margall y Francisco Pi y Arsuaga, Historia de España en el siglo XIX, tomo IV, pp. 399; La Nueva Iberia, 14 de julio de 1868. Cita información recogida de El Independiente de Sevilla; Eugenio García Ruiz, Historias, tomo II, pp. 719. Córdova, para los dos periódicos fue a Soria y según Pi y Margall y García Ruiz a Baleares.

${ }^{151}$ La Nueva Iberia, 24 de julio de 1868. Cita información recogida en El Independiente de Sevilla; La Época, 27 de julio de 1868. Cita informaciones de diarios de Tenerife; La Época, 7 y 8 de julio de 1868; Eduardo de Palacio, España desde el primer Borbón hasta la revolución de septiembre, Manuel Rodríguez, Editor, Madrid, 1869, tomo V, p. 830.
} 
quedó en Santa Cruz y Dulce y Caballero de Rodas fueron llevados a Las Palmas. ${ }^{152} \mathrm{El}$ buen trato que recibieron contrastaba con las condiciones de buena parte de los deportados políticos anteriores, que sufrieron plagas y hambre, aun cuando en muchos casos sus actividades conspirativas no fueron probadas. Con los generales prestigiosos se repitió el castigo aplicado a principios de los años 50, que había resultado ineficaz para atajar el levantamiento. En esta ocasión el resultado fue el mismo, ya que embarcados en el Buenaventura buena parte de estos generales regresaron a Cádiz y participaron de manera importante en el pronunciamiento militar contra la reina.

${ }^{152}$ La Esperanza, 9 de julio de 1868; La España, 15 de julio de 1868; La Época, 27 de julio de 1868, Información de diarios de Santa Cruz de Tenerife; La Época, 7 de agosto de 1868, información de El Independiente de Sevilla. 


\section{CAPÍTULO 6. DEL SEXENIO DEMOCRÁTICO AL PRONUNCIAMIENTO DE VILLACAMPA}

\section{UN RÉGIMEN SUSTANCIALMENTE DIFERENTE. LAS PRIMERAS DEPORTACIONES}

El triunfo de la Revolución Gloriosa significó la conclusión del sistema político basado en un turnismo forzado y discontinuo entre moderados y unionistas. Se iniciaba una etapa política nueva, cuyas interpretaciones han variado desde considerarla como el último intento fracasado de realización de una revolución burguesa en España a entenderla como el traslado del sujeto revolucionario desde la burguesía al proletariado. El Sexenio significó la plasmación de una serie de cambios sociales producidos en los años anteriores a su eclosión, en los que la prensa, los cambios en la cultura política y el desarrollo del movimiento obrero tuvieron una importancia capital. También el colapso político de un sistema cada vez más restringido que ni siquiera supo mantener a una parte muy importante de las bases sociales elitistas que lo sustentaban. ${ }^{1}$

A las causas políticas había que añadir la fuerte crisis económica de 1866 y una crisis de subsistencia que se manifestó en 1867 y 1868 con consecuencias catastróficas. Las malas cosechas en el bienio incrementaron el precio del trigo y tuvieron un efecto devastador entre la población. Según un testimonio, 1868 "Fue el más terrible y miserable para la mayor parte de las provincias de España pero principalmente para las de La Mancha, Jaén y Castilla que recuerda la historia, sobre todo las de Palencia y Tierra de Campos". La sequía de 1867 había impedido que creciesen los pastos lo que provocó la muerte de más de la mitad del ganado lanar. Los campesinos abandonaban los arriendos y con ellos las mulas cuyos cadáveres servían de alimento para los desesperados braceros. La cosecha descendió brutalmente, en el coto de Villaverde desde las "4.000 fanegas de granos que es su habitual cosecha en las 250 obradas de sembradura y 400 carros de paja, solo arrancándose pudo cogerse entre todos 28 fanegas de trigo 16 de cebada y unos 20 carros de paja y 42 cantaros de vino". La prohibición a la exportación y la importación sin derechos redujeron el precio de los granos, pero aun así "No pudieron pagarse las contribuciones, y los infelices jornaleros ofrecían su

\footnotetext{
${ }^{1}$ Rafael Serrano García, "La historiografía en torno al sexenio 1868-1874. Entre el fulgor del centenario y el despliegue sobre lo local”, Ayer, núm. 44, 2001, pp. 11-17.
} 
trabajo, por la comida, o por un pan, o por lo que se les ofrecía". ${ }^{2}$ Para amplios sectores populares la Revolución no constituyó un hecho puramente político, sino que sirvió para canalizar su desesperación.

La Gloriosa significó un cambio importante con la proclamación de la soberanía nacional y del sufragio universal. La Constitución de 1869 reconocía de un buen número de derechos, libertades políticas y económicas y garantías jurídicas: inviolabilidad de la correspondencia, habeas corpus, derechos de asociación, petición y residencia, libertad de expresión, de ejercicio profesional y de empresa, entre otros. ${ }^{3} \mathrm{El}$ proceso tuvo su traslación en la creación de un nuevo Código Penal que humanizaba los castigos, eliminando algunos anacrónicos y limitando la utilización de los ajusticiamientos. $^{4}$

La mayor sensibilidad hacia los derechos de los ciudadanos se hizo extensible a la disidencia política. Marcar distancia y mostrarse como un régimen nuevo y garantista inhabilitaba la opción de los fusilamientos masivos contra los opositores. Aun cuando entre sus precursores hubo antiguos unionistas, que directa o indirectamente eran responsables de la feroz represión pasada. La extraordinaria dureza con que el régimen de Isabel II trató de frenar las tendencias revolucionarias, con numerosas ejecuciones, socavaron su apoyo social. Caracterizado el sistema político anterior por una violencia extrema, está claro que el Sexenio por principios y como modo de distanciarse de su predecesor trataría de llevar a cabo una política más contemporizadora.

Los sectores ideológicos que compartían la necesidad del derrumbamiento del sistema diferían en sus proyectos políticos. Para los partidarios del republicanismo y del incipiente internacionalismo, el triunfo de la Gloriosa debía ir acompañado de cambios de calado en la estructura política, económica y social del país. No se conformaban con una simple ampliación de derechos políticos, pedían medidas concretas como la

\footnotetext{
2 Joaquín del Moral Ruiz, "Capitalismo y capitalistas. Nuevas mentalidades, otros paisajes (1836-1882)", en Nicolás Ortega Cantero (ed.), Estudios sobre historia del paisaje español, Servicio de Publicaciones de la Universidad Autónoma de Madrid-Catarata, Madrid, 2002, p. 82; las medidas tomadas por el Gobierno frente a la crisis de subsistencia en Antón Costas Comesaña, Apogeo del liberalismo en "La Gloriosa". La reforma económica en el Sexenio Liberal (1868-1874), Siglo XXI, Madrid, 1988, pp. 17-20. Narváez trató de compaginar el abastecimiento con la protección de los productores, pero finalmente debido a las presiones, motines y extrema necesidad permitió la importación de productos alimenticios temporalmente en el verano de 1867 y suprimió los derechos de importación de trigos y harinas en 17 de marzo de 1868.

${ }^{3}$ Un estudio de los mismos en José Antonio Souto Paz, "Las libertades públicas en la Constitución de 1869”, Revista de Derecho Político, núm. 55-56, 2002, pp. 131-158.

${ }^{4}$ Antón Oneca, "El Código Penal de 1870", pp. 235-250.
} 
abolición de las quintas y del impuesto de consumos. El Sexenio supuso la llegada al Parlamento de nuevas opciones políticas que teóricamente representaban a las capas populares, que cada vez más se fueron desplazando hacia partidos y movimientos con una mayor radicalidad. Algo absolutamente intolerable para las élites. Desde la derecha, el carlismo se había fortalecido. Su visión conservadora de la sociedad chocaría con la expansión de derechos políticos, sociales y la laicidad del Estado. La inestabilidad reactivaría el miedo a los excesos de los revolucionarios. Desde una perspectiva más práctica, la vacante en el trono significaba una oportunidad para la entronización de la línea dinástica proscrita.

Las diferencias irreconciliables entre los distintos proyectos políticos tuvieron como consecuencia que comenzaran a producirse una serie de insurrecciones desde los inicios del Sexenio. El camino de la revolución no gustaba a los federales entre los cuales se iba instalando la idea de que debían luchar con las armas para conseguir avances significativos. En Barcelona, ante la negativa de algunos voluntarios de la libertad de entregar las armas, hubo enfrentamientos con 16 muertos y multitud de detenidos. Tras la victoria gubernamental fue destituido el ayuntamiento, así como prohibidos algunos periódicos, clubs y comités republicanos. ${ }^{5}$

En Valls, las noticias de Barcelona causaron una gran conmoción y tras la proclamación de la República federal en Reus, procedieron a hacer lo propio el 1 de octubre. La llegada de las tropas provocó la huida de los republicanos, decenas de los que fueron aprehendidos y terminarían en la Carraca. Dos hombres fueron ejecutados acusados de los altercados que hubo en la ciudad. Los máximos mandatarios políticos Francisco Puigjaner, Rafael Miracle y Bartolomé Pozas fueron condenados a muerte aunque no se haría efectiva. ${ }^{6}$ Las revueltas se reprodujeron en otros puntos del País Valenciano, Aragón, Castilla, Andalucía, Extremadura, Murcia, Asturias y Galicia. Fueron especialmente importantes las de la ciudad de Valencia, con unos 10.000 federales armados defendiendo la ciudad entre los cuales unos 2.000 campesinos, la de la provincia de Gerona con unos 8.000 y las partidas andaluzas. En total, 40.000 individuos se alzaron en armas. La estrategia del Gobierno de disolver de manera escalonada las milicias para delimitar las convulsiones tuvo éxito, y finalmente todas

\footnotetext{
${ }^{5}$ Conrad Roure, Memorias de Conrad Roure. Recuerdos de mi larga vida. El movimiento republicano de 1869 (tomo IV), Josep Pich i Mitjana (ed.), Institut Universitat d'Història Jaume Vicens i Vives-Eumo, Vic, 1994, pp. 74-81.

${ }^{6}$ Joan Papell i Tardiu i Julio Luis Quílez Mata, La Història de Valls, p. 151; La Discusión, 5 de diciembre de 1869.
} 
fueron aplastadas por el ejército. ${ }^{7}$ Teniendo en cuenta la magnitud de la insurrección la punición no fue especialmente virulenta. Tal y como sucedió en Valls, la mayoría de los prisioneros, solo en Valencia fueron más de 700, permanecería recluidos durante un breve tiempo y posteriormente serían liberados. Hubo algún fusilamiento aislado, como el de Froilán Carvajal, pero no constituyó una práctica generalizada. La represión en Valls tuvo que ver con los asesinatos acaecidos, lo que explica su mayor rigurosidad.

Entre los represaliados de Valls hubo distinción. A los causantes de los asesinatos esclarecidos se les ajustició sin implicar a un número exagerado. El propio Prim revisó los expedientes, alguien debía pagar por las muertes y la sublevación, pero en comparación con otros levantamientos se trató de medidas comedidas y estructuradas, ya que distinguía entre el levantamiento y los excesos producidos en el mismo. También distinguía entre los dirigentes, Pozas, antiguo capitoste carlista reconvertido en republicano exaltado y hombre de acción, y Miracle, comandante de los insurreccionados de Tarragona, llegaron a Filipinas. El cabecilla republicano andaluz Fernández de la Maza fue incluido por el grave temor de las élites regionales a causa de la miseria en que vivían los campesinos y peones agrícolas. No sucedió lo mismo con Puigjaner, que aunque se había unido y comandaba las fuerzas alzadas mostró una actitud sosegada durante el periodo de su alcaldía en la población. Las gestiones de su familia y personalidades de la ciudad consiguieron que quedara en Cádiz por enfermo y meses después fue puesto en libertad. ${ }^{8}$ Sus mayores influencias le sirvieron para evitar la deportación, pero políticamente la decisión implicaba el deseo de no sustraerse el apoyo de la izquierda radical. En el resto de alzamientos de menor importancia se siguió una política similar: a Pedro Caimó, jefe de los rebeldes de la Bisbal del Ampurdán, se le conmutó la pena de muerte por la de confinamiento en Filipinas, pero no fue embarcado por "falta de buque", y finalmente seria llevado a la frontera francesa. ${ }^{9} \mathrm{Su}$ carácter de diputado y colaborador del periódico demócrata y republicano La Discusión explican la medida.

\footnotetext{
${ }^{7}$ Román Miguel González, La Pasión Revolucionaria, pp. 302-313; Josep Termes, Anarquismo y sindicalismo en España. La Primera Internacional (1864-1881), Critica, Barcelona, 2000, pp. 58-59; José Antonio Piqueras, La Revolución Democrática, pp. 102-118.

${ }^{8}$ Joan Papell i Tardiu i Julio Luis Quílez Mata, La Història de Valls, pp. 29-30.

${ }^{9}$ AHN, Ultramar, Leg. 5210, Exp. 34. "Conmutación de la pena de muerte a Pedro Caimó Vascos"; La Época, 23 de diciembre de 1869; sobre la vida de Pedro Caimó ver Josep Clara y Ángel Jiménez, El federal Pere Caimó (1819-1878), Pòrtic, Barcelona, 1975.
} 
También serían enviados a islas Marianas los cabecillas de la insurrección ultramontana de agosto de ese mismo año. El brigadier Juan Polo, el canónigo Antonio Milla y el alférez Tomás Fidalgo habían sido sentenciados a muerte como cabecillas, y otros seis fueron castigados a la misma pena como implicados en la conspiración descubierta en Pamplona. ${ }^{10}$ Hubo una gran campaña que abarcaba desde sectores católicos hasta democráticos para evitar el fusilamiento de los cabecillas, en la que tuvo una influencia la pretensión de no proporcionar nuevos mártires a la causa del pretendiente. ${ }^{11}$ La maniobra, muestra del nuevo espíritu de concordia que se había instaurado con el advenimiento del Sexenio y de la existencia de un mayor humanitarismo que en las guerras legitimistas precedentes. Desde un punto de vista político significaba tratar de contemporizar con las dos facciones que se habían sentido perjudicadas con la elección de Amadeo de Saboya como monarca. Para los republicanos la oposición a la pena capital era ideológica, no sucedía lo mismo con otras facciones liberales que habían combatido sin cuartel a los ultramontanos con anterioridad.

En 15 de enero de 1870 se les conmutó la condena por la de relegación a las Marianas, siendo trasladados a Cádiz y embarcados en la fragata Reina de los Cielos con destino a Manila, a donde llegaron el 28 de julio. A pesar de sus peticiones para quedarse en la capital, el Capitán general de Filipinas no se vio autorizado para contradecir las órdenes recibidas y el 15 de agosto salieron en la fragata Shangai, asignándoles una ayuda para que procuraran su manutención con el "decoro indispensable a nuestra raza". La pensión fue de 30 pesos mensuales para Juan Polo y Bartolomé Pozas; 20 para Antonio Milla, Rafael Miracle, Daniel Fernández de la Maza y Mariano Larumbe; 15 para José Aparregui y Tomás Fidalgo; ocho para Simón Santamaría y seis para Nicasio Mateo y Raimundo Puello. ${ }^{12}$ La ayuda garantizaría una

\footnotetext{
${ }^{10}$ Relación de los individuos a los que se ha conmutado la pena de muerte por relegación a las islas Marianas, 15 de enero de 1870. AHN, Ultramar, Leg. 5211, Exp. 3. "Deportación a Marianas de insurrectos. Amnistía".

${ }^{11}$ AGA, Presidencia del Gobierno, 51/3489, Exp. 744. Peticiones para salvar la vida al jefe carlista; La Igualdad, 25 de agosto de 1869; Rafael Villena Espinosa, El Sexenio Democrático en la España rural. Ciudad Real (1868-1874), Instituto de Estudios Manchegos, 2005, p. 320.

${ }^{12}$ AHN, Ultramar, Leg. 5211, Exp. 3. "Deportación a Marianas de insurrectos. Amnistía". De la lista de doce indultados fueron excluidos de la deportación el paisano Francisco Puigjaner y Joaquín Elio (marqués de las Hormazas) y fue incluido Daniel Fernández de la Maza. Elio evitó su deportación al tener que prestar declaración por un proceso de lesiones contra su persona; AHN, Ultramar, Leg. 5210, Exp. 43. "Conmutada la pena de muerte por reclusión a D. Fernández de Maza"; los deportados fueron los republicanos Pozas y Miracle por la
} 
subsistencia mínima que evitaría que los indígenas tuvieran que ver el triste espectáculo de ver a algunos blancos haciendo pasar hambre a otros.

La ayuda pecuniaria fue establecida en base a la consideración social, por lo que en principio no se establecieron diferencias entre ambos grupos políticos. En la práctica, al arribo a Agaña, lugar donde residieron los meses que estuvieron deportados, Milla fue alojado en el convento de la población y el resto de ultrarrealistas importantes en las casas principales de la población mediante la mediación del gobernador. ${ }^{13}$ Las condiciones seguramente se extenderían también a los republicanos, ya que a pesar de ser considerados más sediciosos eran peninsulares, de un estrato social medio, y al fin y al cabo no representaban ningún peligro. Una mayor simpatía por los carlistas por parte de los clérigos no implica necesariamente un mal trato para los demás. Además, las medidas tomadas vendrían dispuestas por las autoridades.

La remisión a Ultramar significaba una magnifica sustitución de la sentencia de muerte. En principio se pensó en los presidios de Filipinas, ${ }^{14}$ pero trasladar a alguien a miles de millas de distancia en un viaje de varios meses para permanecer encerrados desvirtuaba la medida que podía ser empleada en la Península y plazas africanas. De nuevo, la relegación aparecía sin una organización clara ni una voluntad manifiesta y era la improvisación y la adaptación a unas circunstancias concretas la que llevó a un Gobierno de signo político muy diferente a emplearla, lo que da buena muestra de su utilidad para el poder. El alejamiento que representaba facilitaba su uso ya que no existía un punto bajo soberanía española más alejado de la metrópoli. En ausencia de muerte, el archipiélago micronesio cumplía con los requisitos necesarios para una desactivación de la disidencia. El mantenimiento de una estructura represiva eficaz en ningún momento se puso en duda, solo cambió el método. La condena impuesta, si bien no era tan dura como la de muerte, tenía una clara función ejemplarizante.

insurrección de Valls y Fernández de la Maza, cabecilla de una partida republicana andaluza; Milla, Polo y Fidalgo por la insurrección carlista; Larumbe, Aparregui, Santamaría, Mateo y Puello, por la conspiración descubierta en Pamplona; sobre Mariano Larumbe, ver Javier Larráyoz Zarranz, "El quijote navarro. Vida y aventuras del brigadier de los ejércitos carlistas, don Mariano Larumbe" (parte II), Príncipe de Viana, núm. 150-151, 1978, pp. 203-280.

${ }^{13}$ Francisco-Engracio Vergara, La masonería en Filipinas. Estudio de actualidad. Apuntes para la historia de la colonización española en el siglo XIX, París, s/f, p. 10.

${ }^{14}$ AHN, Ultramar, Leg. 5210, Exp. 33. "Conmutación de pena a varios sentenciados a muerte"; en 21 de octubre de 1869 se estableció que los condenados a relegación perpetua lo hicieran al Golfo de Guinea o en las Marianas. Este era el procedimiento legal mediante tribunales ordinarios que no se siguió en ningún caso, pero muestra cómo había alguna intención colonizadora inconexa. La relegación se establecía para algunos delitos políticos de poca relevancia, ver Gaceta de Madrid, 22 de octubre de 1869. 
En todo momento se pretendió dar una sensación de legalidad, ya que los castigos fueron impuestos por Consejo de guerra y el indulto fue obra del presidente del Consejo de Ministros. También los afectados se amparaban en el Código Penal para exponer que dado que la verdadera naturaleza de la pena era el alejamiento de la patria y que en las Marianas no podían dedicarse a su "profesión u oficio" y por tanto no podrían mantenerse. Este legalismo se extendió a las autoridades coloniales para corroborar lo expuesto por los deportados. ${ }^{15}$ El cambio que supuso el nuevo régimen en el que la concepción de derechos adquirió una consistencia mayor se observa en lo expuesto tanto por represaliados como por represores. El mayor interés por los derechos de los opositores no puede ocultar que fueron juzgados mediante tribunales especiales, al margen de la penalidad ordinaria.

Su estancia fue breve por cuanto en 9 de agosto de 1870 se decretó el indulto, bajo la condición de acatamiento de la Constitución. El perdón fue anterior a la propia traslación a las Marianas, pero la lejanía del archipiélago y las malas comunicaciones retrasaban su repatriación. La aplicación en puntos tan lejanos tenía irremediablemente estas consecuencias, por otro lado bien conocidas. Era una manera de ganar tiempo y de que mientras el Ejecutivo alardeaba de haberles indultado, los perdonados quedaban desactivados durante varios meses más, incluso cuando se procedía con premura. El Gobernador superior civil de Filipinas adelantó para diciembre el barco que debería haber salido para febrero de 1871. Bartolomé Pozas y Rafael Miracle embarcaron directamente en una fragata inglesa el 10 de febrero, retornando directamente a Europa vía Hong Kong. El resto lo hicieron a través de Manila después de jurar de la Constitución. ${ }^{16} \mathrm{Su}$ escaso número pudo favorecer la amistad, o al menos el respecto, independientemente de opciones políticas. Dos de los republicanos, Pozas y Miracle, viajaron juntos, pero Fernández de la Maza vino con todos los carlistas y ambos grupos de opositores se enfrentaron juntos a su traslado a Agaña. Compartir avatares y la lejanía crearían una sensación de solidaridad entre los mismos que pudo ser capaz de superar las enormes diferencias políticas entre ambos grupos.

\footnotetext{
${ }^{15}$ AHN, Ultramar, Leg. 5211, Exp. 3. "Deportación a Marianas de insurrectos. Amnistía". La instancia fue firmada por los 11 relegados.

${ }^{16}$ Ibídem.
} 


\section{LA TERCERA GUERRA CARLISTA}

El consensó que se dio entre todos los conspiradores para acabar con el reinado de Isabel II no se reprodujo en la elección del nuevo rey. Los republicanos eran por principios contrarios a la monarquía, los carlistas eran partidarios de su pretendiente e incluso entre los monárquicos había disparidad de opiniones. Finalmente hubo 191 votos para Amadeo, 60 para la república federal y otros 3 para otras modalidades de la misma, 27 para Montpensier, 8 para Espartero y 2 para el futuro Rey Alfonso de Borbón, 1 para la Duquesa de Montpentsier y 19 en blanco. La elección del nuevo monarca agitó enormemente el ambiente político. ${ }^{17}$ Fue un proyecto que salió adelante gracias al carisma de Prim. Los 120 diputados que no le votaron muestran la fragmentación, pero incluso existió poco convencimiento entre muchos de los que optaron por el rey de origen italiano. El asesinato de Prim, en 30 de diciembre de 1870, dejó al rey sin su máximo valedor.

El fracaso en los alzamientos legitimistas de verano de 1869 en ambas Castillas, Cataluña, Navarra y País Valenciano, estimuló temporalmente la vía política. ${ }^{18}$ En 1872 , la imposibilidad de acceder al poder por la vía electoral llevó de nuevo al movimiento a la vía armada. Políticamente, pese a la debilidad extrema del partido los factores exógenos eran los idóneos: la elección de un Rey extranjero, la muerte de Prim y las dificultades económicas de buena parte de la población hacían que el momento fuera el propicio, atrayéndose a grupos conservadores que temían a la revolución. Más importante todavía fueron las causas sociales que determinaron a unos individuos a jugarse la vida en los montes: el rechazo a las quintas y al servicio militar en Cuba, y, principalmente el hambre. Las clases populares habían sido objeto de un proceso de empobrecimiento que se acentuó entre 1868 y 1872 cuando la producción agraria no podía satisfacer la demanda de alimentos. La mala situación económica se extendió a pescadores, artesanos, ganaderos y mineros sometidos a empobrecimiento $\mathrm{y}$ proletarización. ${ }^{19} \mathrm{El}$ hambre y la miseria, que en entornos urbanos tendieron a favorecer la extensión de ideologías revolucionarias, en lugares con una estructura social más

\footnotetext{
${ }^{17}$ Pere Anguera, El general Prim, pp. 605-609.

${ }^{18}$ Jordi Canal, El carlismo, pp. 163-164.

${ }^{19}$ Enriqueta Sesmero Cutanda, Clases populares y carlismo en Bizkaia, 1850-1872, Universidad de Deusto, Bilbao, 2000.
} 
tradicional se expresaron en la adhesión al carlismo. En gran medida ambos extremos estaban formados por los excluidos.

Su caso fue atípico. Desde las deportaciones de realistas en el Trienio se habían utilizado en el ejército colonial. En el inicio de la Guerra de los Siete Años hubo una gran prevención hacia el empleo en los regimientos, pero posteriormente el propio Tacón reubicó a la mayoría en el instituto armado. A partir de este momento, este grupo ideológico y social fue el considerado idóneo para ser empleado como fuerza armada en las Antillas. Algunos elementos dificultaban retomar la práctica: habían pasado más de 20 años desde la anterior rebelión legitimista, un largo periodo de tiempo que había ido acompañado de la muerte de los líderes de los partidos tradicionales y la desaparición de sus agrupaciones políticas. Algunas de las personalidades que pasaron a ocupar las más altas cotas de poder del momento, como Prim y Serrano, tenían una larga trayectoria política, pero por el carácter liberal del primero y al menos tendente al mismo del segundo, tenían una mayor prevención hacia lo que el partido ultramontano representaba.

El embarque de prisioneros significó copiar la política empleada por los moderados para dar respuesta a la Guerra dels Matiners. Copiar una práctica alegal no parecía el mejor modo de iniciar la nueva etapa que pretendía el reconocimiento de los derechos de las personas, especialmente cuando en la contienda precedente las relegaciones se dispusieron por decisión unilateral del Capitán general de Cataluña. Otro factor que dificultaba su utilización era la situación de insurrección generalizada en Cuba. Con anterioridad, las remisiones se habían hecho en condiciones de paz en la colonia y si bien estaban situados ideológicamente en las antípodas del independentismo, ambos movimientos combatían desde sus posiciones diferentes al régimen. Abrir un nuevo frente en Cuba siempre había sido temido por las autoridades.

La posibilidad de utilización de los apresados carlistas y republicanos para combatir en la Antilla mayor se dio desde los inicios de la sublevación. Esta medida fue planteada únicamente para los aprehendidos con las armas en la mano, que fueran solteros y que resultaran peligrosos, ${ }^{20}$ pero finalmente no se aplicó y el Ministerio de la Guerra ordenaba que no se aplicara permitiendo solo el uso de voluntarios. ${ }^{21} \mathrm{La}$

\footnotetext{
${ }^{20}$ AGMM, Capitanía General de Vascongadas. Sig. 5994.43. "Clasificación de prisioneros carlistas y republicanos destinados al ejército de Cuba".

${ }^{21}$ AHN, Ultramar, Leg. 4723, Exp. 1. Telegrama sobre prisioneros carlistas y republicanos que prefieren cumplir sus condenas en la Península, 17 de noviembre de 1869.
} 
deportación se concibió como un alejamiento de los más amenazadores, mientras que el resto podían volver a sus casas. La expedición selectiva a un país lejano como soldados hubiera dificultado la reincorporación a las filas rebeldes. Aunque finalmente no se aplicó para tratar de contemporizar con el movimiento y debido a la debilidad de la insurrección puede considerarse un precedente y permitió la salida de algunos como voluntarios.

El 2 de enero de 1872 el nuevo rey entraba en España y el 15 de abril Carlos VII llamaba a la revuelta, siendo su grito acogido principalmente en Cataluña y el País Vasco. El intento de que la reacción permaneciera dentro del sistema político se disipaba. El 4 de mayo de ese mismo año las fuerzas liberales sorprendieron a las legitimistas en Oroquieta, infringiéndoles una severa derrota. En los campos quedaron los cadáveres de 38 combatientes y 749 fueron hechos prisioneros. ${ }^{22}$ El pretendiente huyó a Francia y el carlismo vasco-navarro quedo desmoralizado y vencido momentáneamente.

Para los liberales, la derrota ultramontana implicaba una magnífica oportunidad de desarticular al carlismo y para ello era necesaria una correcta gestión de la victoria, especialmente en lo referente a qué hacer con el elevado número de aprehendidos. Siendo los primeros que se habían levantado en armas, era probable que a la menor oportunidad lo hicieran de nuevo, por lo que se optó por enviarles a Canarias, en donde debían establecerse depósitos para unos $1.500 .^{23}$ Inmediatamente comenzaron los traslados de los apresados hacia los puertos costeros, el 17 de agosto llegaron a su destino 298 procedentes de Cataluña y Baleares, siendo ubicados 249 en el depósito de La Laguna y el resto en el castillo de Paso-Alto. El mayor despliegue se hizo desde el norte ya que la mayoría eran de Navarra, Vitoria y Vizcaya, el 30 de octubre embarcaron 533 desde Santander a Canarias. ${ }^{24}$ Con ellos debían remitirse las causas que se debían seguir instruyendo, lo que conllevó problemas con algunos jueces que se resistieron al castigo mientras no hubieran sido juzgados y que finalmente tuvieron que ceder.

\footnotetext{
${ }^{22}$ Josep Carles Clemente, Los carlistas, Istmo, Madrid, 1990, p. 80.

${ }^{23}$ Real orden de 15 de julio de 1872. AGMM, Ministerio de la Guerra, Sig. 5950.24. "Expediente general de traslados y destinos de prisioneros carlistas (1872-1880)"; además hubo al menos otro deposito en La Orotava. AGMM, Ministerio de la Guerra, 5948.21. "Solicitud de indulto para 61 presos en La Orotava (Santa Cruz) en 1873.

${ }^{24}$ AGMM, Ministerio de la Guerra, Sig. 5950.24. "Expediente general de traslados y destinos de prisioneros carlistas (1872-1880)"; AGMM. Capitanía General de Vascongadas. Sig. 5969.5. "Traslado de prisioneros carlistas a Canarias".
} 
La pretensión teórica de que continuaran los juicios era muy difícil de cumplir en un punto tan alejado del lugar de residencia y comisión del supuesto delito. Aun así, indicaba la voluntad gubernamental de aparentar legalidad. Los envíos continuaron, lo que obligó a habilitar los conventos de Santa Catalina y Santo Domingo. A 21 de diciembre ya había 1.100 represaliados, por lo que el Capitán general pedía que no se superara la cifra estipulada dadas las carencias en la infraestructura y la tropa disponible. La saturación provocó la salida hacia otros puntos, desde Cataluña partieron 142 en 12 de diciembre a Mahón. Las Baleares eran el punto más cercano que reproducía las condiciones deseadas, pero la mayoría continuaron remitiéndose a Cádiz para marchar hacia las Canarias. En enero se embarcaron 124 desde Cataluña para Cádiz y en 31 de marzo llegaron 217 a la ciudad andaluza procedentes de Madrid. Cuando se alcanzó el límite estipulado se encontraron con dificultades para proporcionarles ropa de cama, utensilios y vigilancia adecuada. Como modo de aligerar la presión se abrió la posibilidad de que se alistaran voluntariamente para Cuba y algunos con buena conducta fueron liberados. ${ }^{25} \mathrm{El}$ resto, es posible que fueran accediendo a pequeños espacios de libertad en el que algunos podrían salir de los depósitos.

Las remisiones de prisioneros a las Canarias no fueron planteadas como deportaciones en sentido estricto, sino como depósitos de detenidos a los que se dotaba de un gran alejamiento. En la primera de las guerras legitimistas hubo distintos depósitos en distintos puntos de la Península, en los que eran utilizados en obras públicas. En ese momento los trabajos forzados no se contemplaban, por lo que los beneficios de mantenerlos en el continente desaparecieron. Las Canarias ofrecían la ventaja de una mayor lejanía, dificultaban la fuga y reincorporación a las filas rebeldes y favorecía la ocultación de la situación bélica en la que se encontraba el país. No fue únicamente una manera de gestionar el desastre de Oroquieta, ya que también afectaron a los catalanes y de otros puntos, sino una medida que respondía a la generalización de la contienda.

En el frente del norte las huestes del pretendiente fueron ganando terreno durante el primer semestre de 1873, lo que provocó que desde enero hasta agosto

\footnotetext{
${ }^{25}$ AGMM, Ministerio de la Guerra, Sig. 5950.24. "Expediente general de traslados y destinos de prisioneros carlistas (1872-1880)".
} 
hubiera cuatro diferentes jefes en el ejército liberal allí destacado. ${ }^{26}$ La proclamación de la República supuso una reactivación del movimiento que organizaba una tropa regular en el País Vasco y Navarra y disponía de numerosas partidas en Cataluña, el Maestrazgo y otros lugares de España.

En Guipúzcoa, en febrero de 1873 la Diputación foral, parlamentarios y autoridades locales e incluso el Capitán general pedían la remisión a Ultramar de los combatientes carlistas desmovilizados. Previendo nuevos alzamientos, se mostraban contrarios a la política de magnanimidad e indultos que estaban minando la moral de las bases liberales. ${ }^{27}$ Ante su elevado número, las quejas constantes desde la jefatura militar canaria y la prolongación de la contienda en Cuba, la República llevó adelante sus pretensiones. Su utilización ofrecía un número limitado, pero significativo de soldados en un contexto de intensificación de la guerra en el interior que aconsejaba una política de mayor dureza que la empleada hasta el momento. Implicaba el embarque forzado desde los depósitos de unos individuos que probablemente se habían revelado por la miseria, pero que estaban en las antípodas ideológicas de los republicanos, por lo que su movilización no significaba pérdida de apoyo social, al contrario, les permitía presentarse como los que más enconadamente luchaban contra la reacción. (Tabla 6).

La medida significó sacar de Canarias a estos individuos para enviarles al frente, donde probablemente su neutralización seria definitiva. La animadversión republicana por los ultrarrealistas influyó en esta medida que pretendía minimizar el impacto de las remisiones de soldados a la colonia, con lo que se solucionaba el problema de la gran cantidad de presos a la vez que eran desviados a la Antilla mayor sin movilización de quintos, una de sus grandes promesas. La gran mayoría fueron incluidos, únicamente algunos quedarían en el norte para los habituales canjes de prisioneros, y otros permanecerían en las numerosas cárceles diseminadas por la geografía del país. Los más de 3.500 soldados representan respecto a los 11.995 remitidos durante ese año desde la Península, ${ }^{28}$ un porcentaje que rondaba el $30 \%$. Una cifra nada despreciable que pudo incluso causar incomodidad o alarmismo entre los propios mandos militares, y que de seguirse con ese ritmo podía incluso representar un peligro para la cohesión de los regimientos.

\footnotetext{
${ }^{26}$ Cesar Alcalá, La Tercera Guerra Carlista, 1872-1876, Medusa, Madrid, 2004, p. 103.

${ }^{27}$ Narración militar de la Guerra Carlista de 1872 a 1876 por el Cuerpo de Estado Mayor del Ejército, Imprenta y Litografía del Ministerio de la Guerra, Madrid, 1884, tomo II, pp. 280-286.

${ }^{28}$ Cesar R. Yáñez Gallardo, "La última invasión armada. Los contingentes militares españoles a las guerras de Cuba, Siglo XIX”, Revista de Indias, vol. 52, núm. 197, p. 110.
} 
Tabla 6. Deportaciones de prisioneros carlistas en 1873

\begin{tabular}{|c|c|c|c|c|}
\hline $\begin{array}{ll}\text { Lugar } & \text { de } \\
\text { Salida } & \\
\end{array}$ & $\begin{array}{ll}\begin{array}{l}\text { Nombre del } \\
\text { vapor }\end{array} & \text { del } \\
\end{array}$ & Fecha de salida & $\begin{array}{l}\text { Lugar de recogida } \\
\text { de los presos }\end{array}$ & $\begin{array}{l}\text { Presos que } \\
\text { transporta }\end{array}$ \\
\hline Cádiz & Madrid & $\begin{array}{l}10 \text { de abril de } \\
1873\end{array}$ & Cádiz & 400 \\
\hline Cádiz & Alicante & $\begin{array}{l}11 \text { de abril de } \\
1873\end{array}$ & $\begin{array}{l}\text { Santa Cruz de } \\
\text { Tenerife }\end{array}$ & 400 \\
\hline Cádiz & Isla de Cuba & $\begin{array}{l}20 \text { de abril de } \\
1873\end{array}$ & $\begin{array}{l}\text { Santa Cruz de } \\
\text { Tenerife }\end{array}$ & $770-970 *$ \\
\hline Cádiz & Antonio López & $\begin{array}{l}23 \text { de abril de } \\
1873\end{array}$ & Cadiz & 300 \\
\hline Cádiz & Puerto Rico & $\begin{array}{l}29 \text { de mayo de } \\
1873\end{array}$ & $\begin{array}{ll}\text { Cádiz (231) } & \text { y } \\
\text { Tenerife } & (230)\end{array}$ & 461 \\
\hline Santander & Comillas & $\begin{array}{l}15 \text { de junio de } \\
1873\end{array}$ & Santander & 94 \\
\hline Santander & España & $\begin{array}{l}4 \text { de septiembre } \\
\text { de } 1873\end{array}$ & Santander & 42 \\
\hline La Coruña & Guipúzcoa & $\begin{array}{l}17 \text { de octubre de } \\
1873\end{array}$ & La Coruña & 30 \\
\hline La Coruña & Méndez Núñez & $\begin{array}{l}17 \text { de noviembre } \\
\text { de } 1873\end{array}$ & La Coruña & 43 \\
\hline Cádiz & Comillas & $\begin{array}{l}28 \text { de noviembre } \\
\text { de } 1873\end{array}$ & Cádiz & 800 \\
\hline Santander & Pasajes & $\begin{array}{l}31 \text { de noviembre } \\
\text { de } 1873\end{array}$ & Santander & 222 \\
\hline Total & & & & $3.562-3.762$ \\
\hline
\end{tabular}

* Según órdenes del Ministerio de la Guerra al Capitán general de Canarias debía preparar a los entre 1.000 y 1.200 que restaban en los depósitos del archipiélago tras la salida del Alicante y llevarlos a Santa Cruz de Tenerife para que fueran embarcados en el vapor Isla de Cuba. De esta cantidad he descontado los 230 que quedaban en el archipiélago y que fueron embarcados en el Puerto Rico. Es posible que no todos salieran en el Isla de Cuba, ya que el Antonio López hizo escala en Santa Cruz de Tenerife, llevando a 300 por lo que pudieron ser embarcados algunos. En el Comillas iban además 127 reclutas, por lo que es probable que en los buques con menos carlistas fueran también quintos.

Fuente: Elaboración propia a partir de: AHN, Ultramar, Leg. 4776, Exp. 15. "Traslado de prisioneros carlistas destinados al ejército de Cuba"; AHN, Ultramar, Leg. 4776, Exp. 16. "Transporte de tropas a Cuba"; La América, 13 de abril de 1873; La Correspondencia de España, 15 de junio, 4 de septiembre y 28 de noviembre de 1873; Telegrama de capitanía general de Santander a ministro de la Guerra, 31 de noviembre de 1874. AGMM, Ministerio de la Guerra, Sig. 5949.12. "Embarque de prisioneros carlistas para Cuba entre 1873 y 1874"; Expediente general de deportados Prisioneros cantonales. AGMM, Ministerio de la Guerra Sig. 5949.11, "Destino y embarque de los prisioneros procedentes de la insurrección cantonal de Cartagena (Murcia) entre 1873 y 1875"; Boletín de Comercio, 29 de noviembre de 1873.

El 18 de febrero de 1874 se suspendió el traslado de legitimistas hacia el Caribe. $^{29}$ A partir de este momento, con un ejército ultramarino saturado de ultrarrealistas, se optó por esperar a digerir tan pesada carga con la inestimable ayuda de los insurrectos, las enfermedades y el hambre que diezmaban a la tropa: 5.902 soldados

${ }^{29}$ El Mundo, 19 de febrero de 1874. Información de El Tiempo del día anterior. 
fallecieron y 1.298 fueron enviados a la metrópoli por inútiles en $1873 .^{30} \mathrm{~A}$ principios de 1874, 200 carlistas fueron llevados a isla de Pinos para vigilar a los independentistas y marginados allí remitidos. ${ }^{31}$ Con los depósitos descongestionados, el Gobierno se centró en la represión de las pasadas insurrecciones federales a las que se dio un rumbo totalmente distinto: las Marianas. A pesar de que ambos grupos constituían la disidencia al régimen, solo el más desideologizado era susceptible de combatir en la guerra colonial. Una remisión demasiado elevada de elementos radicales era inadmisible para el Ejecutivo por el peligro que implicaban.

Los embarques a Cuba causaban autentico pavor entre los afectados, que iniciaron una serie de peticiones de indulto, especialmente entre aquellos en los se aplicó con excesiva severidad, con los que concurrían causas atenuantes o que creían que debían evitar la deportación. En 6 de junio de 1873 se ordenó que no se remitiera a los menores de 16 años y en 1 de diciembre la prohibición se extendió a los de más de 50. El 15 de diciembre se decretó la exclusión de aquellos que no eran combatientes y no se les aprehendiese con las armas en la mano. ${ }^{32}$ Estas aclaraciones indican que en ocasiones las autoridades se excedieron en la aplicación de la medida. A finales de año ya se decidió limitar la relegación masiva mediante clasificaciones. Se pretendía una mejor calidad entre los que eran remitidos. En teoría, las causas debían continuar tramitándose en la Antilla mayor.

La única intensificación legislativa fue la de 13 de noviembre de 1873 mediante orden del Ministerio de la Guerra, según la cual todos los apresados carlistas que fueran "mozos de la reserva" debían ir a ejército ultramarino, algo que se extendería con posterioridad a aquellos que tenían responsabilidad de quintas. ${ }^{33}$ Una medida lógica teniendo en cuenta que muchos de ellos se habían enrolado en las filas del pretendiente precisamente para evitar las levas. Con unas partidas que operaban cerca de su población, resultaba mejor combatir en las mismas que en el inhóspito clima caribeño. La ley, en la práctica significaba terminar castigando a los prófugos con la pena que les correspondía si no hubieran realizado el "delito" de deserción, lo que en la práctica

\footnotetext{
${ }^{30}$ Antonio Pirala, Anales de la Guerra de Cuba, tomo III, p. 920.

${ }^{31}$ La Época, 8 de febrero de 1874.

${ }^{32}$ AGMM, Ministerio de la Guerra, Sig. 5948.23. "Expediente general de indultos y destinos de prisioneros carlistas".

${ }^{33}$ AGMM, Ministerio de la Guerra, Sig. 5950.2. "Reales órdenes relativas a prisioneros carlistas (1875-1879)".
} 
avalaba que se continuara realizando y contribuía al enquistamiento de la situación bélica en la Península.

Durante la presidencia de Serrano se llevó a cabo una política de indultos con los combatientes legitimistas para tratar de desactivar la guerra. El 5 de junio de 1874 se ordenó el indulto de todos los presentados voluntariamente, acción que fue seguida por la liberación de los presos más antiguos de los depósitos. El Capitán general de Cataluña amplió la medida a todos los que se presentaran, incluyendo los desertores. ${ }^{34}$ Tras las remisiones masivas en principio parecía que la práctica se paralizaba, pero con un régimen más estable podía diseñarse una política para terminar con los problemas acuciantes del país que lo desangraban económica y humanamente. Terminar con los conflictos era una necesidad y se aprovecharon para ello los recursos humanos disponibles. El pronunciamiento de Pavía significó que las viejas élites recobraban su influjo. Las más involucradas con la cuestión colonial eran partidarias de ganar la contienda a toda costa, por lo que la suspensión del envío de soldados ultramontanos fue una mala noticia. Especialmente para los criollos propeninsulares, que durante los inicios de la contienda controlaban los centros de decisión política y económica fundamentales y al cuerpo de voluntarios, ${ }^{35}$ y que a partir de 1871 fomentaron la creación de centros Hispano Ultramarinos con el objetivo de defender sus intereses. ${ }^{36}$

El 7 de agosto de 1874, el centro Hispano Ultramarino de Madrid pedía al Gobierno que todos los soldados canjeados, tanto ultrarrealistas como gubernamentales, se enviaran a la Antilla mayor. La idea implicaba la colaboración de los comandantes rebeldes por lo que apelaba a su patriotismo. ${ }^{37}$ Difícilmente seria realizable ya que implicaba que los alzados debían renunciar a un número similar de soldados que sus oponentes cuando se encontraban en una situación de gran desventaja numérica. Además, la reciente prohibición de los embarques actuaba como elemento que dificultaba su reinicio inmediato. Para los ultraconservadores, el fin de la contienda en la metrópoli debía ir acompañado de la movilización de los recursos disponibles para acabar con la Guerra de los Diez Años.

\footnotetext{
${ }^{34}$ AGMM, Ministerio de la Guerra, Sig. 5948.23. "Expediente general de indultos y destinos de prisioneros carlistas".

${ }^{35}$ Ángel Bahamonde y José Cayuela, Hacer las Américas. Las élites coloniales españolas en el siglo XIX, Alianza, Madrid, 1992, p. 46.

${ }^{36}$ María del Carmen Barcia, Élites y grupos de presión. Cuba 1868-1898, Editorial de Ciencias Sociales, La Habana, 1998, p. 23.

${ }^{37}$ AHN, Ultramar, Leg. 4738, Exp. 61. "Propuesta de envío a Cuba de los prisioneros carlistas y republicanos".
} 
La colaboración del gran capital cubano con la causa española se había extendido desde los inicios de la guerra con contribuciones en metálico y apoyo logístico, destinadas al sostén de los voluntarios o al traslado de soldados. Parte del dinero se destinó a crear redes de influencia mediante la prensa y conexiones con altas esferas políticas. Esta política dio lugar a grandes negocios a través de empréstitos o mediante la movilización de soldados. ${ }^{38}$ En cuanto a la traslación de la tropa, fue Antonio López, propietario de la Trasatlántica, el que haría un pingüe negocio hasta el punto de que la propia subvención que recibía por cada porte superaba ampliamente al precio de los billetes de los pasajeros. Solo en 1876, los subsidios oficiales por los 12 vapores ordinarios y los 8 extraordinarios que salieron desde Santander ascendieron a 1.512.500 pesetas, a los que habría que sumar las 594.780 por el transporte de los viajeros y mercancías, entre los que se incluían los militares y los suministros. ${ }^{39}$

Las condiciones para la reanudación del procedimiento se darían pronto. El 7 de enero de 1875, un Cánovas recién estrenado en el poder emitía una real orden mediante la cual los cautivos carlistas que no estuviesen sujetos a causas por delitos comunes pudieran alistarse voluntariamente en el ejército ultramarino. ${ }^{40}$ No era leva masiva como la de 1873, pero constituía un precedente. Con el ultraconservadurismo presionando para una mayor atención a la colonia y debido a la escasez de recursos y hombres, reanudar la utilización de los legitimistas era una solución fácil de realizar y que suscitaría el apoyo de los grandes capitalistas con intereses en la Antilla mayor.

En 1875 el empuje de las huestes del pretendiente en el norte se estaba agotando. El 11 de marzo Cabrera reconocía a Alfonso XII. Las levas incrementaron las fuerzas gubernamentales desde los desde 32.000 efectivos en diciembre de 1873 a 91.000 en enero de $1875 .^{41}$ Un obstáculo demasiado elevado para unos destacamentos rebeldes que se mantuvieron constantes y que ejercían su soberanía sobre un pequeño pedazo de

\footnotetext{
${ }^{38}$ Eduardo Marrero Cruz, Julián de Zulueta y Amondo. Promotor del capitalismo en Cuba, Ediciones Unión, La Habana, 2006, pp. 124-146.

39 Martin Rodrigo Alharilla, Los Marqueses de Comillas, 1817-1925, LID Editorial Empresarial, Madrid, 2001, p. 33; el enorme negocio a pesar del retraso en los pagos gubernamentales provocaron que las casas extranjeras Robins y Wilford, Frederic Powell y Merchants Trading Company pretendieran entrar en el mismo. AHN, Ultramar, Leg. 4776, Exps. 7, 9 y 13. "Comunicaciones entre el Ministerio de la Guerra, el Ministerio de Ultramar y la empresa de Vapores Correos Trasatlánticos en relación con el transporte de tropas a Cuba".

${ }^{40}$ AGMM, Ministerio de la Guerra, Sig. 5948.23. "Expediente general de indultos y destinos de prisioneros carlistas".

${ }^{41}$ Juan Pardo San Gil, "La Segunda Guerra Carlista en «el norte» (1872-1876). Los ejércitos contendientes", Bilduma, núm. 14, 2000, p. 365.
} 
territorio en clara inferioridad económica y humana. La situación era incluso peor en Cataluña, donde la guerra terminó el 21 de noviembre. Con la rendición de los carlistas catalanes, que agotados decidieron acogerse al indulto, quedaba abierto un único frente. Un peligro que el pretendiente y sus asesores comprendieron tratando infructuosamente de levantar de nuevo a los combatientes del principado. ${ }^{42}$

En reales órdenes de 21 de julio y 19 de agosto de 1875 se dispuso que todos los ultrarrealistas presos en la Península fuesen llevados a Cádiz, desde donde marcharían a Cuba para ser enrolados en el ejército ultramarino, con las excepciones de los de Cantavieja, que habían sido indultados por Martínez Campos, los que probasen haber sido oficiales en la facción y los inútiles para el servicio. Aun así, de los 2.265 capitulados en la población aragonesa, que habían sido llevados principalmente a Baleares, 1.042 tenían responsabilidad por quintas y por tanto debían ser reclutados, 245 fueron a Cádiz bajo la calificación de voluntarios y otros 69 como prófugos. ${ }^{43} \mathrm{La}$ inaplicación del castigo a los oficiales pretendía desactivar su implicación en la causa y facilitar su presentación. Los soldados eran más incultos, más fácilmente maleables y permanecerían en una situación de mayor subordinación, por lo que su peligrosidad era mucho menor. Además, no podemos obviar un fuerte componente clasista mediante el cual las personas que estaban yendo a combatir y muriendo eran aquellos que no podían hacer frente a la redención en metálico.

La concentración de apresados en Cádiz se reanudó, en lo que significaba una ofensiva total contra el independentismo cubano. El cese de los embarques desde 1873 y las continuas acciones habrían incrementado el número de presos, hasta el punto de que fuera conveniente proceder a su disminución drástica. Si la República no había tenido problemas en conculcar los derechos de los legitimistas, menos todavía a un régimen con un sesgo claramente represivo siempre que fuera ejecutado con pobres. Se trataba de hacer limpieza en los depósitos en un momento en el que parecía que la guerra podía acercarse a su fin para dejar espacio a los próximos prisioneros y explotar al máximo una fuente de mano de obra que estaba pronta a extinguirse.

\footnotetext{
${ }^{42}$ Robert Vallverdú, El tercer carlisme a les comarques meridionals de Cataluña, 1872-1876, Publicacions de l'Abadia de Montserrat, Barcelona, 1997, pp. 187-190.

${ }^{43}$ AGMM, Ministerio de la Guerra, Sig. 5949.13. "Reunión en Cádiz de los prisioneros carlistas para su embarque a Cuba (1875-1877)"; telegrama de Capitán general de Baleares a Ministerio de la Guerra, 11 de agosto de 1875. Telegrama de Ministerio de la Guerra a director general de administración militar, 13 de julio de 1875. Estado de prisioneros de Cantavieja. AGMM, Ministerio de la Guerra, Sig. 5950.3. "Destino de los oficiales carlistas apresados en Cantavieja (Teruel) en 1875".
} 
En total fueron 1.870 los carlistas relegados desde septiembre de 1875 hasta fecha tan tardía como abril de 1877, de ellos, apenas 12 fueron a Puerto Rico y el resto a la Antilla mayor. En el primer envío que salió el 7 de septiembre de 1875 iban 800 en el vapor Puerto Rico. Una vez aligerados los distintos depósitos se pasó a un periodo con una incidencia menor, apenas 67 desde la salida del Puerto Rico hasta el 11 de febrero del año siguiente. ${ }^{44}$ Los desplazamientos fueron planteados para vaciar los depósitos en un momento en que fueron movilizados 19.401 soldados entre septiembre y diciembre de $1875 .{ }^{45}$ El 7 de enero se abrió una recluta para el ingreso voluntario en la tropa en las provincias en las que la insurrección había sido dominada, ofreciéndoseles la expiación de delitos comunes relacionados con la propia condición de facciosos a cambio de un tiempo de servicio de cuatro años: 204 se alistarían desde Baleares. ${ }^{46}$ La política de deportaciones se intensificó con el desmembramiento del frente del norte a inicios de 1876: 510 salieron de los depósitos entre el 10 de marzo y el 30 de junio y otros 344 en calidad de sorteados o sentenciados. A partir de ahí, las remisiones descendieron paulatinamente y apenas afectaron a algunos casos aislados en $1877,{ }^{47}$ con el objetivo de que no se reprodujera la sublevación.

El colapso de las huestes del pretendiente se solucionó con el embarque masivo de soldados para Cuba. En la Península resultaban un peligro para el Gobierno que quería cerrar a toda costa uno de los dos frentes que tenía abiertos. El envío masivo a la colonia ayudaba a desactivar la posibilidad de nuevas revueltas, especialmente cuando

\footnotetext{
44 "Noticia de prisioneros carlistas destinados a servir en el ejército de Ultramar". Relación de individuos que en concepto de prisioneros de guerra han sido embarcados con destino a los ejércitos de Cuba y Puerto Rico. AGMM, Ministerio de la Guerra, Sig. 5950.25. "Envío de prisioneros carlistas a Cuba y Puerto Rico como soldados (1876-1878)".

${ }^{45}$ Listados de embarques de soldados. AHN, Ultramar, Leg. 4776, Exp. 4. "Comunicaciones entre el Ministerio de la Guerra, el Ministerio de Ultramar y la empresa de Vapores Correos Trasatlánticos en relación al transporte de tropas a Cuba”.

${ }^{46}$ Circular de 7 enero de 1875. Resumen de carlistas alistados voluntariamente en el ejército. AGMM, Ministerio de la Guerra, Sig. 5950.2. "Reales órdenes relativas a prisioneros carlistas (1875-1879)".

47 "Noticia de prisioneros carlistas destinados a servir en el ejército de Ultramar". Relación de individuos que en concepto de prisioneros de guerra han sido embarcados con destino a los ejércitos de Cuba y Puerto Rico. AGMM, Ministerio de la Guerra, Sig. 5950.25. "Envío de prisioneros carlistas a Cuba y Puerto Rico como soldados (1876-1878)"; en 12 de octubre de 1876 se dictó la deportación a Cuba para alcaldes y paisanos colaboradores de las partidas residuales que quedaban. AGMM, Capitanía General de Vascongadas. Sig. 6029.34. "Bando de deportación a Cuba de los alcaldes y paisanos colaboradores con malhechores y cuadrillas"; sobre el proceso de ocupación del ejército liberal de las plazas en el norte ver José María Rodríguez Gómez, La Tercera Guerra Carlista, 1869-1876, Almena, Madrid, 2004, pp. 173178.
} 
muchos luchaban por sus malas condiciones económicas o por evitar las quintas, y ambos problemas persistían. El terrible castigo de obligarles a combatir bajo un clima tropical y en unas condiciones de extrema precariedad podía servir para intimidar posibles nuevas insurrecciones colectivas, derivando la salida hacia soluciones individuales, básicamente la emigración, cuya incidencia sobre el Estado era mucho menor. La medida fue tomada de manera consciente, de modo que el desmembramiento del frente del este a finales de 1875 no fue seguido de traslaciones masivas, en un intento de no endurecer la resistencia en el norte. Únicamente cuando se produjo el colapso del frente del norte se intensificaron las relegaciones desde los depósitos de prisioneros de Barcelona y Valencia.

Solamente al final del colapso carlista se contempló la amnistía para un sector determinado. A los "individuos de la clase de tropa" que habían pasado a Francia desde el $1^{\circ}$ de febrero de 1876 se les otorgaba un plazo de 40 días para regresar a España y reincorporarse a la vida civil. ${ }^{48} \mathrm{El}$ indulto no alcanzó a los oficiales, a los que por el momento se pretendía lejos del país. En cuanto a los combatientes, se trató de evitar sus entradas ocasionales. Las partidas dispersas y con pocos integrantes no representaban un peligro real para una fuerza regular, pero exigían mantener la movilización en un ejército que convenía utilizar en las Antillas. Eran más útiles en sus casas y trabajando que en cualquier otro lugar, algo que no sucedía con los que ya estaban combatiendo contra los independentistas.

Los carlistas eran soldados en teoría de buena aptitud, conocían el uso del armamento y estaban acostumbrados a la guerra y a las privaciones de la misma. Desde un punto de vista social, la mayoría eran pobres. El envío a los regimientos coloniales de las clases bajas era otro modo de limpieza social, similar al de la deportación a Marianas, ya que muchos de ellos iban a fallecer. En un momento en que las clases bajas se insurreccionaban, la contienda cubana, con todos los inconvenientes que generaba, ofrecía la ventaja de proporcionar un espacio al que desplazarles. El clasismo gubernamental se desplazó incluso a los cautivos que pudieron evitar el embarque mediante el pago de las 2.000 pesetas de la redención en metálico siempre que no fueran desertores o estuvieran sujetos a responsabilidad de quintas: 35 hombres lo evitaron mediante esta vía.

\footnotetext{
${ }^{48}$ Gaceta de Madrid, 8 de marzo de 1876.
} 
El elitismo se distingue en la forma de reprimir a los altos cargos del ejército. La circular de 28 de abril de 1876 englobaba a todos aquellos presos ultrarrealistas considerados aptos entre los 18 a 40 años, incluidos los jefes, oficiales y cadetes en la facción. Únicamente tres días más tarde se estipulaba que los mandos lo hicieran al de Puerto Rico. Al resto de oficiales se les eximió de la medida poniéndoseles incluso en libertad y facilitando su reincorporación a los escuadrones regulares. ${ }^{49}$ En la Guerra de los Siete Años se estipuló un mayor castigo para los oficiales que para los soldados. En aquel momento, bajo una mentalidad arcaica, se consideraba que la gente del pueblo no se movía por sí sola. Ahora ya se les consideraba sediciosos que representaban un peligro. La mayor conciencia de clase de los de abajo se reprodujo en los de arriba, que aunque fueran enemigos formaban un mismo estrato social. Ya no se trata de que la burguesía se apropiara de las tierras de la Iglesia y de hacer revolución liberal, ahora la transformación ya estaba hecha y se pretendía el orden social a toda costa.

Respecto a la repatriación, se plantea el mismo problema que en los conflictos anteriores. Los prisioneros fueron moneda de cambio, así por acuerdo con un cabecilla legitimista en febrero de 1875 se ordenó al Capitán general de Cuba el retorno de unos 300, de los que 189 atracaron en Santander y pudieron volver a sus casas. ${ }^{50}$ Sin embargo, este fue un hecho puntual. En 1873 se estipuló que se les conmutaran los años de las sentencias por rebelión y los delitos comunes asociados por años de servicio, ${ }^{51}$ lo que implicaba que sobre cada uno de ellos se hiciera el correspondiente juicio, algo que con toda seguridad no se produciría. Según lo dispuesto en 27 de julio de 1875, el tiempo de servicio para aquellos que tuvieran responsabilidad por quintas seria de ocho años y en tres los que no, tiempo que se rebajó en 28 de marzo de 1876 al tiempo de llamamiento de su quinta, establecido en aquel momento en seis años. ${ }^{52}$ En la práctica, estas medidas asimilaban a los carlistas a los quintos con los que compartían la estancia.

\footnotetext{
49 AHN, Ultramar, Leg. 4740, Exp. 24. "Circular general de 28 de abril de 1876 y otras disposiciones relativas a carlistas"; AHN, Ultramar, Leg. 4740, Exp. 69. "Sobre la puesta en libertad del carlista Ricardo Mondriá Coll”.

${ }^{50}$ AGMM, Ministerio de la Guerra, Sig. 5950.24. "Expediente general de traslados y destinos de prisioneros carlistas (1872-1880)".

${ }^{51}$ Informe sobre carlistas deportados, 25 de marzo de 1873, AGMM, Capitanía General de Cuba, Caja 4426, Exp. 23. "Expediente general de indultos y destinos de prisioneros carlistas".

${ }^{52}$ Reales órdenes circulares de 27 de julio de 1875 y 28 de marzo de 1876. AGMM, Ministerio de la Guerra, Sig. 5950.2. "Reales órdenes relativas a prisioneros carlistas (1875-1879)"; Esaú Rodríguez Delgado, "La sustitución o redención para el servicio militar a mediados del siglo XIX”, Iberian. Revista Digital de Historia, núm. 4. mayo-agosto 2012, p. 18.
} 
A los que no tenían responsabilidad de quintas se les indultó por real orden circular de 22 de febrero de 1879, permitiéndoseles la venida a la Península. ${ }^{53}$ Una vez finalizada la guerra no pretendieron mantener una fuerza armada tan importante. Con una emigración constante a la isla, su presencia no era necesaria ya que su misión no era de colonizadores sino la de soldados. Funcionarios, militares regulares y una emigración libre que se reactivó con fuerza después de la finalización del conflicto, ${ }^{54}$ hacían prescindible la presencia de legitimistas.

Como ha demostrado de Miguel para la Guerra de Independencia, los regimientos completos eran repatriados en la Guerra. Cuando todavía había combatientes dispersos, a mediados de 1878 , iban a ser retornados unos $17.000 .^{55}$ Los carlistas fueron una minoría dentro del ejército colonial en el que fueron enrolados en los regimientos como reclutas, tal y como lo habían sido los quintos. Por esto, tras años de soportar los mismos padecimientos que sus compañeros resulta muy difícil pensar en que tuvieran un trato diferente. El regreso fue escalonado, de manera que algunos quedaron momentáneamente en Cuba, en donde en 1880 todavía había 30.000 soldados, ${ }^{56}$ lo que se extendería a los carlistas, algunos de los cuales residirían temporalmente en la colonia como soldados de las fuerzas regulares. La mayoría, tal y como sucedía con resto de reclutas irían retornando.

Esto no es óbice para que algunos quedaran. Un tiempo largo de residencia facilitaba en algunos casos el desarrollo de relaciones necesarias para establecerse. Entre estos Patricio Delgado Luaces, quien después de la finalización de la contienda participaría en diversas actividades periodistas y publicaría en La Habana una novela titulada A Besta, bajo el seudónimo de Xan de Masma, en que contaba sus vivencias como guerrillero. Delgado fue deportado en 1873 y junto a otros huyó para reincorporarse al ejército del norte. ${ }^{57}$ Otro de los deportados fue el escritor Eugenio

${ }^{53}$ AGMM, Ministerio de la Guerra, Sig. 5950.25. "Envío de prisioneros carlistas a Cuba y Puerto Rico como soldados (1876-1878)".

${ }^{54}$ Jordi Maluquer de Motes, Nación e inmigración. Los españoles en Cuba (siglos XIX y XX), Ediciones Júcar, Colombres, 1992, p. 49. En el periodo de 1882 a 1994 arrojó un saldo positivo de 105.095.

${ }_{55}$ Enrique de Miguel Fernández, Azcárraga, Weyler y la conducción de la guerra de Cuba, Tesis doctoral de la Universitat Jaume I, Castellón de la plana, 2008, pp. 177-227, 279-286 y 505-560; Gaceta de Sanidad Militar, 10 de junio de 1878.

${ }^{56}$ Manuel R. Moreno Fraginals y José J. Moreno Masó, Guerra, migración y muerte, pp. 100101.

${ }^{57}$ Alfredo Comesaña Paz, Hijos del Trueno. La Tercera Guerra Carlista en Galicia y el norte de Portugal, Schedas, Madrid, 2016, pp. 175-176 y 505. 
Antonio Flores que arribó a Cuba el 23 de septiembre de 1873 y a principios de 1874 fue nombrado "Escribiente en la Sub Inspección y ordenanza en el Batallón de la capitanía general" hasta que el 15 de marzo regresó a España, para volver a Cuba poco después como empleado de la administración. Su caso constituiría una excepción a causa del formar parte de una familia acomodada y con mucha influencia social. ${ }^{58} \mathrm{El}$ perfil culto de ambos y su significancia, se diferencia del carlista medio cuyos avatares pasaban en gran medida inadvertidos.

La gran cantidad de soldados movilizados suponía una oportunidad que bien aprovechada podía fomentar el establecimiento ya que muchos de ellos cumplían el tiempo de servicio en un periodo que excedía al de la guerra. Junto al real decreto de 27 de octubre de 1877 de colonización de terrenos incultos, se planteó la instalación de colonias militares que ofrecían la posibilidad de asentar una ocupación que compensara al campesinado criollo oriental de tendencias separatistas. Durante el mandato de Camilo Polavieja como gobernador de Puerto Príncipe, creo cinco, pero tras su marcha a la provincia oriental en junio de 1879 fueron abandonados. Posteriormente crearía otro en Palma Soriano. Un nuevo intento, mediante la utilización de los soldados que desearan dejar el servicio para trabajar, fue vetado por el Ejecutivo por la condición abusiva de los contratistas y por afectar a la aptitud de la tropa. Los proyectos posteriores se desecharon. ${ }^{59}$

El poblamiento con soldados fue en gran medida un proyecto personal de Polavieja que con su habitual autoritarismo pretendía afianzar el dominio sobre la isla mediante la instalación de agricultores proespañoles con experiencia de combate. Más allá de la figura del general, no despertó un excesivo interés por la presencia de intereses contradictorios. Las pretensiones de Polavieja implicaban proporcionar tierras a los soldados, lo que contravenía los intereses de los que querían adquirirlas para sí mismos y de los plantacionistas que de ese modo no obtenían la mano de obra barata que pretendían. En aquel momento el flujo de inmigración peninsular que entraba en el mercado de trabajo era constante por lo que resultaba más provechosa. También la afluencia de soldados continuó, pero sin que ello significara que se les tuvieran que otorgar las tan codiciadas tierras.

\footnotetext{
${ }^{58}$ Luis Álvarez Castro, "Introducción", a Eugenio Antonio Flores, Trata de Blancas (novela social), Institución Fernando el Católico (CSIC), Zaragoza, 2014, pp.13-14.

59 Imilcy Balboa, Los brazos necesarios, Centro Tomás y Valiente UNED AlziraValencia/Fundación Instituto de Historia Social, Valencia, 2000, pp. 94-103.
} 


\section{LA REVUELTA CANTONAL}

\subsection{La gestación de los embarques}

La Revolución Gloriosa fue el resultado de la convergencia de unionistas con capas progresistas y demócratas mayoritariamente de carácter civil, que habían protagonizado los envites armados al sistema en los años precedentes. Los unionistas accedieron apoyar a los progresistas "a cambio de marginar a los demócratas", lo que supuso la continuación de parte de las antiguas élites. Sin embargo, al mismo tiempo accedieron al poder grupos que habían estado marginados como progresistas, demócratas y republicanos, con mayor conexión con las clases medias y las populares. La entrada de nuevos partidos políticos y nuevas clases sociales dieron al Sexenio una nueva configuración en lo que constituyó un régimen diferente con unas pretensiones que diferían de su predecesor. ${ }^{60}$

El carácter reformista del nuevo régimen sería insuficiente para muchos. A pesar de haberse reconocido el derecho de asociación, la Internacional fue perseguida a raíz de los hechos de octubre de 1869. El hostigamiento se reiniciaría a instancias de Sagasta entre mayo y julio de 1871, basándose en su supuesta inmoralidad, coincidiendo con la parte final y represión de la comuna de París. Entre enero y abril del año siguiente se instaba a los gobernadores a considerarla fuera de la Constitución y a perseguirla con el máximo rigor. ${ }^{61}$ Las promesas de revisión de la desamortización de 1855 , regulación del trabajo infantil, limitación de horas de trabajo y creación de jurados mixtos para conflictos laborales fueron obviados por un sector social radicalizado y harto de las promesas incumplidas. En cuanto a la abolición de las quintas, los federales asumieron la petición de eliminar un sistema muy impopular y criticado en el que en la práctica el enrolamiento se hacía únicamente para aquellos que no podían hacer frente a la redención en metálico o no disponían de otros mecanismos para evitarlas. Acuciados por una doble guerra, la colonial y la carlista que se reactivó con la vacante en el trono, en 17 marzo de 1873 los federales aprobaron la abolición de las quintas y la creación de un ejército voluntario, pero otorgándose la facultad de llamar a reservistas si fuera

\footnotetext{
${ }^{60}$ José Antonio Piqueras, "La cuestión cubana. De la Revolución Gloriosa a la Restauración", en Rafael Serrano García (dir.), España, 1868-1874. Nuevos enfoques sobre el Sexenio Democrático, Junta de Castilla y León, Valladolid, 2002, pp. 160-165.

${ }^{61}$ Rafael Serrano García, El sexenio revolucionario en Valladolid. Cuestiones sociales (18681874), Junta de Castilla y León, Valladolid, 1986, pp. 89-90 y 30-33.
} 
necesario. ${ }^{62}$ En agosto fueron llamados 80.000 , en lo que significaba un grave incumplimiento de su programa.

El 12 de febrero se produjeron disturbios aislados en Montilla como una acción espontanea popular contra los ricos. En Sanlucar de Barrameda, el 14 del mismo mes un comité revolucionario formado por los anarquistas locales tomó el control de la población, encerró a los miembros de la policía y quemó los archivos notariales. El 13 de abril grupos de campesinos de Pozoblanco y otras poblaciones de la comarca se reunieron reclamando tierras, lo que dio lugar a una protesta contra los autoridades que finalmente se disolvió pacíficamente. ${ }^{63}$ A finales de marzo, en distintos pueblos de las provincias de Cáceres, Badajoz y Cuenca se produjeron altercados y reparticiones de propiedades de los latifundistas locales. El malestar se reprodujo en los núcleos urbanos, el 16 de abril obreros vinícolas iniciaron una huelga exigiendo trabajo y jurados mixtos y el día 30, 2.000 obreros sevillanos cesaron sus trabajos pidiendo aumento de sueldo. En mayo los fundidores sevillanos iniciaron un paro demandando mejor retribución y disminución en las horas de trabajo. En el mismo mes diversos oficios de Cádiz y el Puerto de Santamaría hicieron lo propio y los mineros de Minas Tarsis dirigieron un manifiesto a sus compañeros de la región en que denunciaba sus condiciones. En junio, los carpinteros de Granada tomaron como rehén al exsenador radical Juan Ramón la Chica y no lo liberaron hasta que se reconocieron sus reivindicaciones. ${ }^{64}$ Muchos habían depositado en el federalismo sus ansias por mejorar su situación y con su advenimiento trataron de cobrarse su apoyo. En un contexto de desarrollo importante del anarquismo andaluz por las peculiaridades de la región, la situación era peligrosa y las insurrecciones una amenaza.

La Internacional contribuyó a expandir la conciencia de clase entre los trabajadores y la revolución de 1868 ayudó a que adquirieran concepto de su ciudadanía, ${ }^{65}$ lo que facilitó que ante la exclusión que sufrían se decidieran a hacer valer sus reivindicaciones. El 8 de julio comenzó en Alcoy una huelga revolucionaria. El 12 del mismo mes se proclamó el cantón de Cartagena, iniciativa que en los días siguientes

\footnotetext{
${ }^{62}$ Albino Feijoo Gómez, Quintas y protesta social en el siglo XIX, Ministerio de Defensa, Madrid, 1996, p. 163.

${ }^{63}$ Juan Díaz del Moral, Historia de las agitaciones campesinas andaluzas, Alianza, Madrid, 1984, pp. 86-91; Telma Kaplan, Orígenes sociales del anarquismo en Andalucía, Crítica, Barcelona, 1977, pp. 93-102.

${ }^{64}$ Clara E. Lida, Anarquismo y revolución en la España del siglo XIX, pp. 175-176.

${ }^{65}$ Jesús de Felipe Redondo, Trabajadores. Lenguaje y experiencia en la formación del movimiento obrero español, pp. 292-301.
} 
se trasladaría a un buen puñado de ciudades andaluzas y del País Valenciano, ${ }^{66}$ especialmente tras la caída del Gabinete de Pi y Margall, en 18 de julio. En la base de los pronunciamientos una lucha contra el centralismo y en defensa de la República. Junto a ello, los problemas latentes de la pérdida del acceso a las tierras tradicionales de los campesinos, unas malas condiciones higiénicas y de vida, un aumento en los precios de los bienes de primera necesidad y la difusión de ideas socialistas y anarquistas. ${ }^{67}$

La insurrección de Alcoy se explica por la fortaleza del movimiento obrero y el progresivo distanciamiento del federalismo. En la ciudad había habido una ruptura en el seno de la Internacional en la que un sector propugnaba la violencia como modo de adquirir mejoras laborales. Las cifras de afiliados a la AIT son estimadas, pero en aquel momento ya comenzaba a tener una fuerza considerable. Termes estima que en 1873 había unos 30.000 afiliados a la Internacional en España. ${ }^{68}$ El decantamiento de la AIT hispana hacia el anarquismo y el hartazgo por la reiteración en el incumplimiento de las promesas llevaron a los obreros a mantener una posición maximalista. La actuación de los federalistas intransigentes e internacionalistas proporcionó a los sectores más conservadores la excusa para propiciar gobiernos de acuerdo a sus intereses. Sus temores de alteraciones del orden social se habían cumplido.

Políticamente, las revuelta significaron la caída el 18 de julio del Gabinete de Pi y Margall, a quien los más liberales dentro de su partido atacaron a raíz de los

${ }^{66}$ El cantonalismo ha sido profusamente estudiado, por citar a algunos, en Alcoy Rafael Aracil y M. García Bonafé, "Clase obrera y revuelta social. La identidad del cantonalismo alcoyano". Estudios de Historia Social, núm. 7, 1978, pp. 163-183; en Alicante, Rosa Ana Gutiérrez Lloret, Republicanos y liberales. La Revolución de 1868 y la Primera República en Alicante, Instituto Juan Gil-Albert. Diputación Provincial de Alicante, Alicante, 1985 y "Republicanismo federal e insurrección cantonal en Alicante”, Anales de Historia Contemporánea, núm. 6, 1987, pp. 165182; Pedro Parrilla Ortiz, El cantonalismo gaditano, Caja de Ahorros de Cádiz, Cádiz, 1983; Juan Antonio Lacomba Abellán, "Cantonalismo y federalismo en Andalucía. El manifiesto de los federales de Andalucía", Revista de Estudios Regionales, núm. 59, 2001, pp. 267-276; María Victoria Goberna Valencia, "El cantonalismo en el País Valenciano", en Primer congreso de historia del País Valenciano, 1977, vol. IV, pp. 463-470; los hechos contados por un protagonista en Eduardo González Alcántara, Memorias de la revolución cantonal iniciada en Cartagena el 14 de julio de 1873, Imprenta el Argentino, Buenos Aires, 1875.

${ }^{67}$ Juan Bautista Vilar, El Sexenio Democrático y el Cantón Murciano (1868-1874), Academia Alfonso X el Sabio, Murcia, 1983.

${ }^{68}$ Josep Termes, Historia del anarquismo en España (1870-1980), RBA libros, Barcelona, 2011, p. 67. La mayoría de las federaciones locales eran catalanas, un $40 \%$, por un $22 \%$ andaluzas, un $10 \%$ valencianas y un $9 \%$ castellanas. Atendiendo a sociedades obreras agrupadas en las federaciones locales un $63 \%$ eran catalanas, un $17 \%$ andaluzas, un $8 \%$ del País Valenciano y un $6 \%$ de Castilla; esta gran expansión no se entiende sin la creación de una cultura obrera que daba gran importancia a la propaganda, ver Manuel Morales Muñoz, Cultura e ideología en el anarquismo español (1870-1910), Centro de Ediciones de la Diputación de Málaga, Málaga, 2002, pp. 41-56. 
acontecimientos de Alcoy y la expansión de la sublevación. Pi y Margall había adquirido un gran prestigio a raíz de su actuación al frente del Ministerio de la Gobernación, que hizo fracasar el intento de golpe de los radicales en 23 abril de 1873. Su figura se asociaba a la honradez y a la consecución de una administración para el pueblo. ${ }^{69}$ Muy en su línea, trató de articular un Ejecutivo de unidad entre todas las facciones republicanas en el Congreso, algo que no fue posible por lo que su breve presidencia se caracterizó por la oposición de aquellos para los que el federalismo representaba la revolución social de carácter municipal y los que se oponían al socavamiento del orden político y económico. ${ }^{70}$

Los sustitutos de Pi y Margall, Nicolás Salmerón y Emilio Castelar, iniciaron una política de asentamiento del orden público, con el empleo del ejército, la ampliación de la Guardia Civil y la proclamación del estado de sitio en todas las provincias. ${ }^{71} \mathrm{El}$ cantonalismo fue sofocado fácilmente, excepto en Cartagena, donde lo seria el 12 de enero de 1874. El 3 del mismo mes, el pronunciamiento de Pavía suponía el preludio de la Restauración. Teóricamente el sistema republicano se mantenía, pero las decisiones adquirían un perfil cada vez más conservador que se acrecentó tras el nuevo Gobierno emanado del golpe militar.

El nuevo Ejecutivo estaba presidido por el general Serrano y contaba con Sagasta en la cartera de Estado y con el republicano unitario García Ruiz en Gobernación. Sus acciones fueron encaminadas a imponer un mayor autoritarismo. El 10 de enero anunciaba la persecución de los "perturbadores de la tranquilidad pública y a toda sociedad, que como la llamada Internacional, atente contra la propiedad, contra la familia y demás bases sociales". Esto suponía prohibir todas las "reuniones y sociedades políticas en las que de obra o de palabras se conspire contra la seguridad pública, contra los altos y sagrados intereses de la patria, contra la integridad del territorio español y contra el poder constituido". ${ }^{72}$ De acuerdo al texto no solamente se

\footnotetext{
${ }^{69}$ Pere Gabriel "Pi y Margall y el federalismo popular y democrático del pueblo", Historia Social, núm. 48, 2004, p. 49.

${ }^{70}$ Román Miguel González, La Pasión Revolucionaria, pp. 358-366.

${ }^{71}$ AHN, Ultramar, Leg. 4738, Exp. 13. "Declaración del estado de sitio en todas las provincias de la Península e islas adyacentes".

${ }^{72}$ Gaceta de Madrid, 11 de enero de 1874. Decreto de 10 de enero de 1874. He respetado la cursiva del texto; la colaboración de Sagasta con Serrano le provocó numerosas críticas y desafecciones personales, muchas de ellas de antiguos amigos y correligionarios, ver José Luis Ollero Valles, Sagasta. De conspirador a gobernante, Marcial Pons-Fundación Práxedes Mateo Sagasta, Madrid, 2006, p. 405.
} 
excluía a la Internacional sino a los propios republicano-federales, aunque la proscripción no constituía una lista cerrada y podía extenderse a otros grupos. Resulta significativa la referencia a las transgresiones de palabra, lo que en la práctica resultaba acabar con los derechos de reunión y asociación pacifica reconocidos por la Constitución de 1869.

El decreto amparaba una gran discrecionalidad que fue incluso superada por los hechos. Después del pronunciamiento de Pavía hubo 120 detenidos en Madrid, de los que 47 serían deportados. Desconocemos el perfil de todos, pero en el caso de los embarcados encontramos que 41 hombres y cuatro mujeres estaban acusados de ser "timadores", "tomadores" y "rateros", acusaciones que en el caso de las féminas se extendían a la de prostitutas. Según García Ruiz únicamente a dos se les imputaban delitos políticos al estar acusados de pertenecer a la partida carlista que voló el puente de Vilches y de jactarse de su acción en Madrid, ${ }^{73}$ imputación basada en rumores con poca solidez. El ministro trataba de ocultar la presencia de federales intransigentes e internacionalistas, obviando que él mismo informaba al Gobierno que "están presos varios cantonales y que el Saladero y el Pardo está lleno de vagos". ${ }^{74}$ Se trataba de mostrar la represión ejercida contra los ultrarreaccionarios, mientras que la realidad era que se incluía la izquierda política y las capas socialmente populares.

A mediados de mayo había unos 500 dirigentes obreros encarcelados en las cárceles españolas. ${ }^{75}$ Resulta además significativa la deriva social que adquirió amparándose en el mantenimiento del orden público. La excitación política permitió al Gobierno extender la punición hacia individuos que no eran opositores. La capital incrementó en 100.000 personas su población entre 1869 a 1877, lo que dio lugar a una sensación de descontrol. ${ }^{76}$ En Madrid y Barcelona había una delincuencia importante y bien estructurada, que en un contexto de creciente urbanización disponía de mayor

\footnotetext{
${ }_{73}^{73}$ Eugenio García Ruiz, Historias, tomo II, p. 991.

${ }^{74}$ Actas del Consejo de Ministros, sesión del 21 de enero de 1874. Se han respetado las mayúsculas en el texto.

${ }^{75}$ Pere Gabriel, "Anarquismo y anarcosindicalismo en la España del siglo XIX", en Manuel Ortiz Heras, David Ruiz González e Isidro Sánchez Sánchez, (coords.), Movimientos sociales y Estado en la España contemporánea, Publicaciones de la Universidad de Castilla-La Mancha, Cuenca, 2001, p. 134.

${ }^{76}$ Vicente Pérez Moreda, "La población de la ciudad de Madrid, siglos XVIII al XX", en Visión histórica de Madrid (siglos XVI al XX), Real Sociedad Económica Matritense de Amigos del País, Madrid, 1991, p. 187.
} 
facilidad para ocultarse y escapaba a la acción de la policía. ${ }^{77} \mathrm{Al}$ represaliar a los pobres y vagos trataban de englobar a la delincuencia de poca monta que se nutría de estos grupos. Asimismo fueron incluidos, tenidos por delincuentes y exconvictos. Esto fue llevado a cabo por un régimen que aun deslizándose hacia el autoritarismo enarbolaba la bandera de los derechos jurídicos de los ciudadanos.

La aplicación de esta medida excepcional se hizo en un contexto en que los castigos de los pobres por el mero hecho de serlo eran posibles. Cuando esta vía quedara bloqueada por motivos humanitarios se produciría una permutación parcial en la forma de actuar del Estado, lo que sería una de las causas de su asunción por parte de la cuestión social, ${ }^{78}$ ya que ante la imposibilidad de eliminación física del "problema" había que lidiar con él. La expansión del ideologías revolucionarias entre los trabajadores y el crecimiento urbano frenético causado por las malas cosechas y el hambre que se daba a poca distancia de los centros de poder, atemorizaron a los gobernantes que impulsaron una política de mano dura mediante una represión con un contenido social tan acusado que puede compararse con la de 1848 realizada por los moderados. No hubo alteraciones del orden público en Madrid, sino que fue el temor el que modeló la acción gubernamental hasta el punto de pretender aterrorizar a los recién llegados con la idea de que el Estado seria implacable. La inclusión de este perfil social muestra el mayor temor que inspiraba el orden público en la propia capital. También debemos considerar la disposición como una búsqueda de apoyo entre las élites sociales del momento. En un contexto en que los partidarios del principie Alfonso se estaban organizando, la aplicación de una medida dura contra los supuestos alborotadores era una manera de contemporizar con la alta burguesía para que no se opusieran al proyecto que el Sexenio representaba, una pretensión de cuyo éxito dependía en buena medida su propia supervivencia política.

\subsection{Los embarques}

El primer embarque se produjo en Málaga, el 25 de julio. Dos días después de la proclamación del cantón fueron detenidos muchos federales intransigentes e

\footnotetext{
${ }^{77}$ Pedro Fraile, Un espacio para castigar. La cárcel y la ciencia penitenciaria en España (siglos XVIII-XIX), Ediciones del Serbal, Barcelona, 1987, pp. 85-86.

${ }^{78}$ Sobre la cuestión social ver Miguel Ángel Cabrera, El reformismo social en España (18701900). Los orígenes del estado del bienestar, Universitat de Valencia, Valencia, 2014.
} 
internacionalistas y 45 de ellos fueron deportados a Melilla. ${ }^{79}$ Esta acción ejecutada por las autoridades locales debe ser desligada de la práctica posterior, ya que fue un desembarazo tomado por una autoridad local espontáneamente por el beneficio que les reportaba. Un provecho que se mantenía en el caso de que una autoridad central lo dictara y que determinó el uso de otras formas de alejamiento: un número indeterminado de marineros continuaron su servicio en el apostadero de La Habana y 37 individuos, todos fugados, fueron condenados a muerte, como modo de garantizar un alejamiento hasta la proclamación de una posible amnistía. ${ }^{80}$

El movimiento en Cartagena fue político y estuvo formado por "republicanos federales, internacionalistas, miembros de la Commune francesa, militares, obreros y representantes de la burguesía". " La mayoría eran de la ciudad pero otros procedían de otros puntos de España. En consonancia con el movimiento, los represaliados lo fueron principalmente por causas políticas: 143 se encontraban presos en Cartagena. Un grupo de 88 de distintas procedencias fueron llevados a Ceuta, y posteriormente se incluyeron entre los remitidos a Filipinas por los gobiernos de Salmerón y Castelar por "ardientes cantonales e internacionalistas", ${ }^{82}$ por lo que probablemente participarían en los distintos movimientos o destacarían por su militancia política.

En Cartagena, para facilitar la rendición de los sublevados se les había indultado del delito de rebelión, quedando los militares a disposición del Ejecutivo, los presos sujetos a traslado a otra cárcel peninsular y a los civiles se les permitiría regresar a sus casas. Quedaban excluidos los delincuentes comunes y los miembros de las Juntas revolucionarias. ${ }^{83}$ Con la amnistía y la huida en la fragata Numancia de los generales Contreras y Ferrer, los diputados Gálvez y Araus, doce miembros de la Junta, diez jefes y oficiales, 480 marineros, 248 soldados, 356 milicianos, 492 presidiarios y 44 mujeres

\footnotetext{
${ }^{79}$ Josep Termes, Anarquismo y sindicalismo en España, pp. 226-227.

${ }^{80}$ Diego Victoria Moreno, "La represión política durante y después del cantón murciano. Estructura y connotaciones sociales", Anales de Historia Contemporánea, núm. 10, 1994, pp. 469-470.

${ }^{81}$ María-Alice Medioni, El cantón de Cartagena, Siglo XXI, Madrid, 1979, p. 108. En contraposición al de Alcoy con un carácter proletario.

${ }^{82}$ Eugenio García Ruiz, Historias, tomo II, pp. 991-992. De ellos, diez eran de Madrid, 17 de jerez, 32 de Sevilla, diez de Sanlúcar, ocho de Vejer, ocho de Cádiz y tres del Puerto de Santamaría.

${ }^{83}$ José López Domínguez, Cartagena. Memorias y comentarios sobre el sitio de Cartagena, J. Conde y Cía., Madrid, 1877, p. 204-206.
} 
y niños, ${ }^{84}$ las cosas podrían haberse tranquilizado. Pero en febrero comenzó una fuerte represión que terminó con más de 500 reclusos en Cartagena, mientras que a los cantonales de Murcia se les anularon los beneficios penitenciarios de que disfrutaban. Dos expediciones de exiliados a finales de marzo y principios de abril elevan la tensión, a pesar de que pudieron ser neutralizadas. ${ }^{85}$ Los tres meses de diferencia entre estas y el comienzo de los transportes muestran que no hubo una relación de causa-efecto. Aun así, las salidas permitían vaciar las cárceles y desactivarlos durante un buen tiempo. Fue la manera en que se solucionó su saturación.

Los cantonalistas sobre los que pesaba orden de deportación a las colonias lo fueron a Filipinas, ya que tanto por su potencial peligrosidad como por el hacinamiento que sufrían fueron embarcados con carácter de urgencia en el León. Sin embargo, no todos sufrían el mismo destino ya que en Santoña había detenidos otros 223, que salieron en 4 de septiembre de 1873 con 42 legitimistas y 72 presos comunes para el ejército de Cuba. En 31 de noviembre salieron en el vapor Pasajes " 2 jefes, 200 voluntarios, 210 cantonales y 222 carlistas". ${ }^{86}$ Desde el norte, donde la mayoría eran carlistas, fueron unidos al destino del grupo mayoritario. Al no haber insurrecciones en el área se trataría de republicano-federales o internacionalistas represaliados de manera preventiva para su utilización contra las partidas independentistas. Difuminados entre los soldados y los ultrarrealistas, su capacidad de acción política quedaba desactivada. Aun así, constituirían un peligro de seguir realizándose la práctica por lo que la peligrosidad que el radicalismo democrático podía tener en una colonia alzada en armas varió su destino.

El León zarpó el 10 de mayo de 1874 con 275 individuos y una escolta de 40 hombres y arribó a su destino el 16 de agosto. Posteriormente salió el Irurac-Bat desde el Puerto de Barcelona recogiendo presos en Cádiz y atracando en 25 de diciembre de 1874 con 463 relegados. El León realizó un nuevo recorrido mediante el que llegó a

\footnotetext{
${ }^{84}$ Antonio Puig Campillo, El cantón murciano, Consejería de Cultura y Educación de la Región de Murcia, Murcia, 1986, p. 364.

${ }^{85}$ Julián Navarro Melenchón, Organización social y sistemas políticos durante la I República, pp. 359-361.

${ }^{86}$ Oficio de Ministerio de la Guerra a capitanía general de Valencia, 9 de mayo de 1874. Expediente general de deportados prisioneros cantonales. AGMM, Ministerio de la Guerra, Sig. 5949.11. "Destino y embarque de los prisioneros procedentes de la insurrección cantonal de Cartagena (Murcia) entre 1873 y 1875"; telegrama de capitanía general de Santander a ministro de la Guerra, 31 de noviembre de 1874. AGMM, Ministerio de la Guerra, Sig. 5949.12. "Embarque de prisioneros carlistas para Cuba entre 1873 y $1874 "$.
} 
Manila el 8 de enero de 1875 portando a otros 338, totalizando $1.076{ }^{87}$ La deportación se extendió desde Cartagena a otros puntos de modo que en la primera remisión los de esta procedencia eran el $51 \%$, por un $32 \%$ en el segundo y un $16 \%$ en el tercero. ${ }^{88}$

Entre los llegados en el segundo viaje del León, había 95 calificados como "criminales de la peor conducta y antecedentes" de Córdoba y Sevilla. ${ }^{89}$ Lo que significaba extender el perfil de los castigados de Madrid a Andalucía. Era una represión que aun cuando incluía a disidentes políticos estaba principalmente motivada por un desprecio social que se extendía a los considerados de malos antecedentes e iba ligada a la extensión hacia debajo de la política. Con un perfil mayoritario de opositores cultos y ricos el procedimiento hubiera sido otro. La mayoría de los afectados correspondían a un mismo perfil social, republicanos-federales exaltados, internacionalistas y gente de los bajos fondos alejados de la política.

Lo primero que cabría destacar es el desconocimiento de las causas de muchos de ellos. En total, en las relaciones del Ministerio de Ultramar se estipulaban las causas en únicamente 623 individuos. Esto no quiere decir que no hubiera justificación, de hecho incluso en el caso de los que sí que conocemos puede ser muy laxa, pero habla de la gran discrecionalidad del proceso seguido en el que autoridades intermedias y locales, dotadas de facultades para ello actuaron a sus anchas. El mayor grupo de represaliados eran los cantonalistas, con 259. Por malos antecedentes, 227. Otros fueron los acusados de ejercer alguna actividad delictiva, 123, a los que no se acusaba de delitos concretos sino de actividades ilícitas pero que al menos se les atribuía algún motivo más que el tener simplemente malos antecedentes. De mucha menor importancia son el resto de grupos: cinco por carlistas, dos por prostitutas, un internacionalista y un líder obrero, tres acusados de ladrones y cantonalistas y otros dos acusados de ladrones y de estar implicados en el asesinato de Prim y en el atentado contra Amadeo de Saboya. En cuanto al perfil de los civiles, la mayoría correspondían a un perfil urbano de trabajadores siendo los campesinos una minoría. ${ }^{90}$

\footnotetext{
${ }^{87}$ Deportados a Filipinas, Marianas y Fernando Poo, 30 de enero de 1877, AHN, Ultramar, Leg. 5222, Exp. 3. "Expediente general de deportados a Marianas y Filipinas. Regreso".

${ }^{88}$ Julián Navarro Melenchón, Organización social y sistemas políticos durante la I República, p. 363.

${ }^{89}$ Relación de circunstancias de individuos embarcados en el vapor León en 23 de noviembre de 1874. AHN, Ultramar, Leg. 5222, Exp. 1. "Expediente general sobre deportados a las islas Marianas y Filipinas".

90 "Relación nominal de los deportados a las islas Filipinas según datos que obran en este Ministerio procedentes del Gobierno general de dichas islas y de los Ministerios de la
} 
Aprovechando las revueltas se llevó a cabo una política de deportaciones de delincuentes y marginados. Es digna de resaltar la figura de malos antecedentes, que estaría más ligada a la marginalidad que a la política. En esta línea incide que los pocos casos en que los malos antecedentes van unidos a otra penalidad lo están con la delincuencia, en cuyo caso los he catalogado como delincuentes ya que al menos se les atribuía alguna actividad delictiva. Es posible que en ocasiones se les pretendiera menospreciar pero está claro que valiéndose de las rebeliones se llevó a cabo una política de "limpieza social" que consideraba a desempleados y pobres como disidentes sociales potencialmente peligrosos incluso políticamente. Ante la crisis económica y la falta de expectativas, el Gobierno optó por emigrar forzosamente a un buen número de españoles, los más vulnerables en el escalafón social, en un momento de inestabilidad social en el que las salidas del país se incrementaron. ${ }^{91}$

La represión se focalizó en las zonas del país que habían tenido mayor significancia en las revueltas y la resistencia al poder central había sido más encarnizada. Incluso en el caso de la social se centró en los lugares políticamente más activos y que representaban un mayor peligro para el Gobierno: Murcia-Cartagena y Sevilla. La insurrección de Cartagena es sobradamente conocida, en Sevilla, la oposición armada a las tropas gubernamentales fue enconada y costó casi 300 bajas a los insurrectos entre muertos, heridos y perdidos. ${ }^{92}$ El carácter clave que Pavía otorgó a la ciudad andaluza para dominar el movimiento ampliamente extendido por Andalucía, $^{93}$ dio lugar a una punición ejemplarizante. Los castigos fueron complementados en el resto de Andalucía y con mucha menor importancia en Cataluña, Madrid y el País Valenciano. En las provincias interiores fueron de menor intensidad incluyendo a casos aislados, entendidos como un aprovechamiento de las autoridades para desactivar a elementos políticos perjudiciales o a gente tenida por indeseable socialmente: en las provincias de Zamora y Salamanca no hay constancia de que

Gobernación, de Guerra y de Marina y listado de deportados". Relación de los deportados embarcados en el Victoria con sus profesiones. AHN, Ultramar, Leg. 5222, Exp. 3. "Expediente general de deportados a Marianas y Filipinas. Regreso".

${ }_{91}$ Cesar Yánez, La emigración española a América (siglos XIX y XX), Archivo de Indianos, Colombres, 1993, p. 120.

${ }^{92}$ Manuel Pavía y Rodríguez de Alburquerque, Pacificación de Andalucía y expediente de la Cruz de Quinta Clase de San Fernando obtenida, Establecimiento Tipográfico de M. Minuesa de los Ríos, Madrid, 1878, p. 60.

${ }^{93}$ José Barón Fernández, El movimiento cantonal de 1873 (Primera República), Edicios do Castro, La Coruña, 1998, pp. 117-119. 
hubiera ningún deportado, mientras que en otros puntos donde no hubo alzamientos como en la cornisa cantábrica y en las castellanas de Valladolid y Logroño, sí que hubo algunos embarcados. Las 33 provincias en las que hubo represaliados, en la mayoría apenas unos pocos revelan una medida "presente" en la mayor parte del territorio nacional, una amenaza latente para la población políticamente activa o socialmente conflictiva. (Gráfico 2).

Gráfico 2. Origen de los deportados por provincia de procedencia

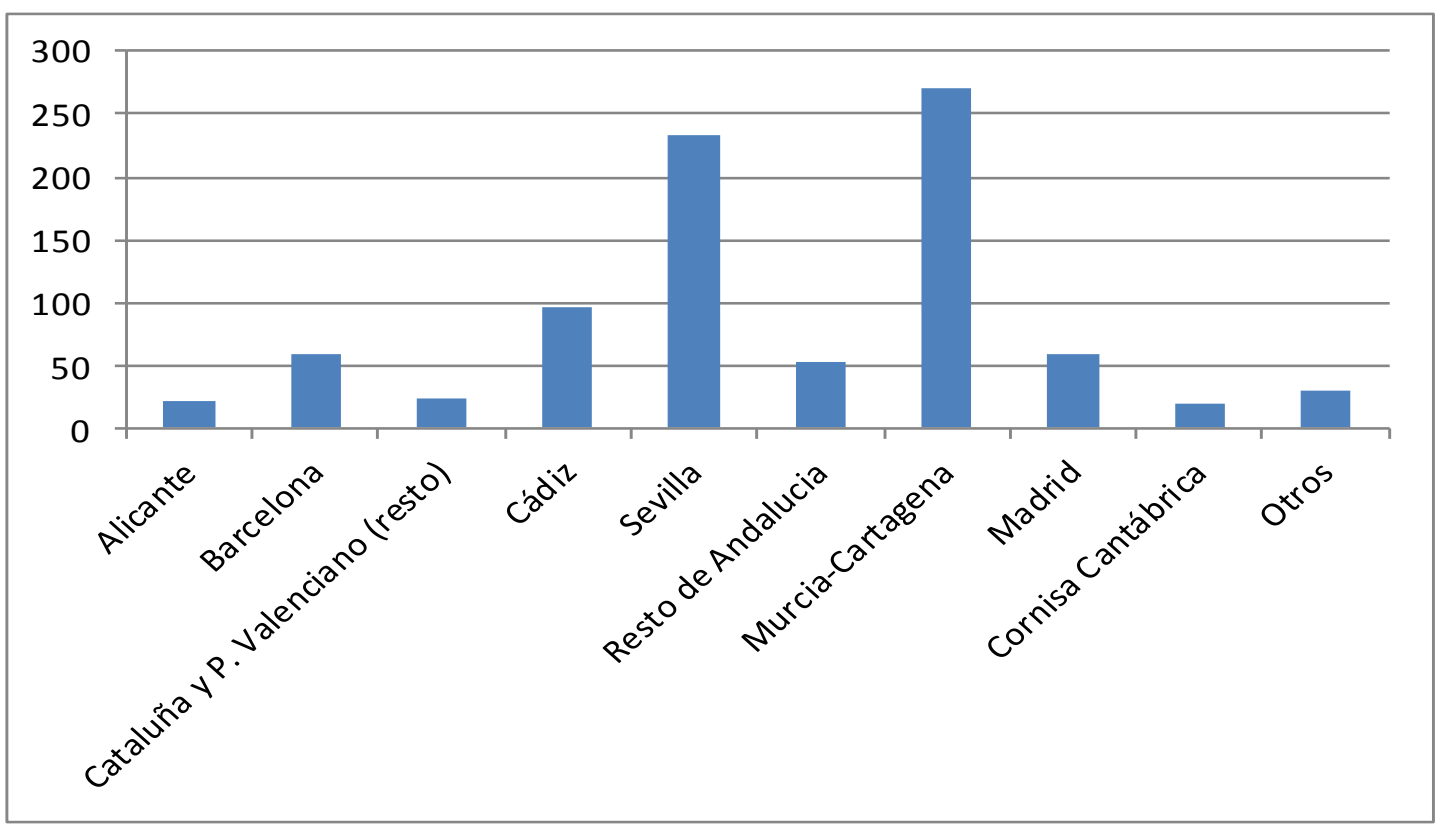

Fuente: Elaboración propia a partir de AHN, Ultramar, Leg. 5222, Exp. 2. Expediente general sobre deportados a Marianas y Filipinas (continuación). Realizada sobre los 867 casos en que se conoce la provincia de los deportados. En otros 81 las autoridades tienen dudas entre dos de ellas.

Los cuatro meses del nuevo desde la llegada del nuevo ministerio hasta la realización del primer viaje muestran que no fue una política ejecutada apresuradamente. Un Gobierno realmente atemorizado no hubiera esperado tanto, por lo que la represión política posteriormente extendida a la gente de los bajos fondos y tenidos por delincuentes, fue pensada y motivada. En el caso de los disidentes sirvió para neutralizarlos por un tiempo más prolongado, lo que suponía conculcar sus derechos de una forma más intensa de la que se había producido anteriormente. Sus predecesores no se atrevieron con una medida de tal magnitud, realizando las relegaciones a la cercana Ceuta. A medida que los gabinetes se iban haciendo más conservadores la severidad se incrementaba, incluso cuando las revueltas cada vez 
estaban más lejanas en el tiempo. La remodelación del Ejecutivo en 13 de mayo de 1874, en el que perdieron peso los radicales y se produjo la salida de García Ruiz, fue en esa dirección.

\subsection{La estancia en las Islas Marianas}

Las islas Marianas eran una posesión escasamente poblada, totalmente alejada de la metrópoli y con una economía incapaz de absorberlos. La agricultura se encontraba enormemente atrasada, con unas tierras de poca calidad y alejadas de los circuitos comerciales y una ganadería escasa y abocada a la subsistencia. Además "no había verdaderos comerciantes ni artesanos ni industriales que merecieran tal nombre, pues el chamorro, para atender a sus obligaciones familiares, había de dedicarse a varias ocupaciones y no solo a una". ${ }^{94}$ Era una economía de subsistencia y cuya agricultura proporcionaba pocos excedentes a los que acceder en el caso de que se extendiera a ellos el sistema de asignaciones diarias que cobraban los deportados cubanos coetáneos en la Península e islas y plazas adyacentes. El comercio era igualmente exiguo y se carecía de trabajos artesanales o industriales. En el archipiélago filipino la cercanía de Manila y las mejores comunicaciones facilitaban la ayuda del Estado y el asentamiento de los relegados, aun teniendo en cuenta el precario estado en su colonización. La elección de las Marianas estuvo motivada por el alejamiento, obviando la dificultad para ser atendidos.

El 6 de agosto llegaron a Agaña 237 en el Panay, entre ellos cuatro mujeres, con raciones de armada para 71 días. ${ }^{95}$ El envío comprendía al primer trayecto del León, con algunas excepciones: a 24 se les aceptó su solicitud de ingreso en el Regimiento de Artillería peninsular por el periodo de cuatro años; los muchachos fueron llevados al hospicio, donde los jesuitas les darían las primeras enseñanzas, para posteriormente pasar al arsenal de Cavite en el que ingresarían en la Maestranza de Artillería o de Ingenieros; seis quedaron enfermos y fueron ubicados en otro barco hasta su próximo

\footnotetext{
${ }^{94}$ Belén Pozuelo Mascaraque, Presencia y acción españolas en las islas Marianas, pp. 465-551.

${ }^{95}$ Sumaria instruida para conocer las medidas tomadas para el sostenimiento de los deportados. AHN, Ultramar, Leg. 5236, Exp. 14. "Concesión de la Cruz de Beneficencia, solicitada por el Gobierno político militar de islas Marianas, para varios individuos que se destacaron en la ayuda a deportados enfermos"; el carácter de peninsulares hizo que fueran transportados en mejores condiciones que los presos nativos. Oficio de director general de hacienda a contador general, 18 de octubre de 1875. PNA, Decretos, Leg. 13.
} 
regreso a España, entre los que se encontraba el intendente general del cantón Virgilio Llanos. Desconocemos quienes eran el resto pero dado que a algunos se les permitió evitar el traslado con el ingreso en el ejército y teniendo en cuenta el carácter militar de la autoridad probablemente se trataría de un trato de favor hacia miembros de este colectivo de mayor rango. Esto permitió aligerar levemente la presión sobre las Marianas y con una excusa razonable como la de maximizar el provecho a los desplazados. Al resto se les dieron víveres para dos meses, periodo en el que se esperaba que pudieran encontrar sus propios medios de subsistencia, ya que pensaban que en un mes ya podrían autoabastecerse y para ello se pidió al gobernador de la posesión que les facilitaran las herramientas para dedicarse a la agricultura. ${ }^{96}$

Después del desembarazo inicial se trató de conseguir el aprovechamiento de la fuerza de trabajo de los individuos. La idea de colonización del archipiélago seguía latente. En 3 de septiembre de 1857 con motivo de la orden de embarque de deportados políticos españoles se propuso la creación de un establecimiento para los transportados de esta clase. En real decreto de 20 de junio de 1861 se ordenó la creación de un penal, idea que se desechó por las facilidades que tendrían para la fuga y el clima. El gobernador aconsejaba a los reclusos filipinos de los que había un número que oscilaba entre 60 y 80 y que estableció en 100 en 1862. Con ellos era posible ejercer una mayor vigilancia y se les podía obligar a trabajar para el Estado en la construcción de obras públicas. $^{97}$ El precedente más inmediato con represaliados políticos fue el de 22 supuestos conspiradores de la insurrección de Cavite, que tal y como sucedió con los peninsulares anteriores fueron alojados en casas particulares. ${ }^{98}$

La llegada de los relegados supuso un problema para los dirigentes locales, que formaron una Junta de Autoridades que decidió pedir ayuda a la población chamorra y en especial a los vecinos más acomodados. Se estableció el reparto de las raciones diarias que no habían quedado inutilizas en el traslado y una ayuda monetaria para los

\footnotetext{
${ }^{96}$ Informe del Capitán general de Filipinas a ministro de Ultramar sobre los deportados, 16 de agosto de 1874. AHN, Leg. 5222, Exp. 1. Expediente general sobre deportados a las islas Marianas y Filipinas.

${ }^{97}$ Felipe de la Corte Ruano, Memoria descriptiva e histórica de las islas Marianas, pp. 188194; en 1851 hubo un intento de colonización penal con convictos filipinos condenados a muerte que resultó un fracaso, ya que únicamente un mes más tarde el gobernador tuvo noticias de que pretendían insurreccionarse y los hizo apresar y enviar de nuevo a Filipinas, Charles Beardsley, Guam Past and Present, Charles E. Tuttle Company, Tokyo, 1964, pp. 180-181.

${ }^{98}$ Carlos Madrid, Beyond Distances: Governance, Politics and Deportation in the Mariana Islands from 1870 to 1877, Northern Marianas Council for Humanities, Saipan, 2006, p. 71.
} 
enfermos e inútiles, y al resto hasta que encontraran trabajo. Los otros puntos acordados: traer ropas, materiales y más raciones así como mejorar las comunicaciones con Manila, se dejaban para más adelante. ${ }^{99}$ La ineficacia en el planteamiento impedía su éxito. Pretender que alguien pueda autoalimentarse en un mes dedicándose a la agricultura, muestra la ignorancia al respecto combinada con el desprecio hacia los represaliados. Todavía más cuando aun en el caso de aquellos que conocían el funcionamiento de las explotaciones agrarias el clima y los cultivos eran totalmente diferentes.

En Madrid, en mayo, el Gobierno autorizó al Capitán general de la posesión a pedir un crédito de 6.000 pesos para la compra de herramientas y aperos para los que había en Marianas, indicando que a los relegados gubernativos no se les podía obligar a trabajar por lo que debía ser un estímulo. ${ }^{100}$ El hecho de venir de Manila la propuesta y la respuesta gubernamental indica que no habían previsto esta posibilidad. Ahora bien, el fracaso en la puesta en marcha de las explotaciones agrícolas muestra como este no era el único modo mediante el cual podían obtener su propio sustento, y que la opción tuvo un componente ideológico muy claro. El Ejecutivo pretendió neutralizar a la disidencia y la supuesta colonización se planteó, y no por ellos, con posterioridad.

La desorganización derivó en que los transportados a la Micronesia se desenvolvieron en una enorme precariedad puesto que no se les proveyó de raciones hasta la llegada del vapor de guerra Patiño, en 1 de marzo de 1875. Con ellas, las herramientas necesarias para el inicio de las explotaciones agrícolas. El retraso tendría que ver con algún problema logístico ya que no tenía sentido infringir un castigo añadido a los relegados. La regularidad posterior en los suministros avala esta idea. Durante este intervalo fueron ayudados por los mandatarios locales, miembros de la guarnición, así como por parte de los notables y de la población nativa en general. Se estableció un hospital para los enfermos y algunos les acogieron en su casa o se comprometieron a alimentarlos. Muchos tuvieron que recurrir a comer raíces y como

\footnotetext{
${ }^{99}$ Belén Pozuelo Mascaraque, Presencia y acción españolas en las islas Marianas, pp. 690-692; Carlos Madrid, Beyond Distances, p. 118.

${ }^{100}$ Oficio de Ministerio de Ultramar a Gobernador general de Filipinas, 7 de mayo de 1874. AHN, Ultramar, Leg. 5225, Exp. 62. Crédito para la compra de herramientas y ganado para deportados.
} 
consecuencia de la mala alimentación a partir de los seis meses de su arribo se intensificaron las enfermedades. ${ }^{101}$

Junto con las provisiones iban otros 473 de los que recientemente habían atracado a Manila en el Irurac-Bat y en el segundo embarque del León. No fueron desembarcados y la Junta de Autoridades decidió que 451 de ellos salieran rumbo a Saipán, junto con 45 soldados y 15.730 raciones. ${ }^{102}$ La llegada causó una gran conmoción. Seguramente bajarían a tierra únicamente los considerados menos problemáticos y el resto llevados a la isla del norte, en una acción de desembarazo copiada a la que se había hecho desde Manila trasladándolos a Agaña.

Si Guam, con 8.140 habitantes en $1886,{ }^{103}$ apenas pudo hacer frente a un grupo de 237, resulta significativo que Saipán, mucho menos poblada, pudiera albergar adecuadamente y proporcionar alimentación a un grupo humano que significaba un $40 \%$ de su población. A causa del temor a los problemas que pudieran ocasionar simplemente trataron de ubicarlos en el lugar más lejano disponible, para que les afectaran lo menos posible. En Saipán se les proporcionaron herramientas, cuyo importe debían reingresar a las arcas públicas con las cosechas futuras. Con ellos fueron transportadas algunas tiendas como residencia provisional, pero había instrucciones de que se fabricaran sus propias casas con la colaboración de los nativos. Algunos construyeron sus propios hogares, otros se alojaron con chamorros y otros iniciaron nuevas explotaciones agrícolas en el interior. ${ }^{104}$

El 3 de junio de 1875 se aligeró la presión de Saipán embarcando a 150, de los que 100 fueron a Guam y 50 a Rota, que fue utilizada como punto para ubicar a los más problemáticos, como el francés Joseph Combatz, que lideró un intento de revuelta exigiendo mejoras en sus condiciones. Los problemas de orden público se sucedieron a causa del hacinamiento y el perfil social de muchos de ellos; según fray Aniceto Ibáñez nunca se habría producido tanta violencia desde la conquista de las islas. A las reyertas entre los deportados que produjeron al menos dos fallecidos, habría que unir peleas con tagalos y nativos, agresiones a nativos y un intento de tomar un barco ingles para

\footnotetext{
${ }^{101}$ Sumaria instruida para conocer las medidas tomadas para el sostenimiento de los deportados. AHN, Ultramar, Leg. 5236, Exp. 14. "Concesión de la Cruz de Beneficencia, solicitada por el Gobierno político militar de islas Marianas, para varios individuos que se destacaron en la ayuda a deportados enfermos".

${ }^{102}$ Carlos Madrid, Beyond Distances, pp. 128-129.

${ }^{103}$ Belén Pozuelo Mascaraque, Presencia y acción españolas en las islas Marianas, p. 157.

${ }^{104}$ Carlos Madrid, Beyond Distances, pp. 135-140.
} 
fugarse. ${ }^{105}$ Dados los antecedentes de muchos de ellos y las graves carencias que soportaron, las infracciones más habituales fueron los hurtos. Los delincuentes fueron expedidos a Manila donde fueron juzgados. Los chamorros, víctimas de los robos e incluso de algún caso de violación, dejaron los campos y fueron a la capital, lo que dejo las cosechas desguarnecidas. En Agaña, los vecinos hicieron incluso patrullas para asegurar el orden. ${ }^{106}$

Otros optaron por tener un buen comportamiento, lo que requería ganarse el favor de las autoridades y tratar de asegurarse los medios de subsistencia, por si se reproducía la carencia de suministros durante el primer periodo. Algunos participaron en la creación de obras públicas tras vencer en las correspondientes subastas. ${ }^{107} \mathrm{Al}$ margen de casos individuales, en general la colonización resultó un fracaso por la escasa implicación de los afectados y el clima que no permitía esfuerzos prolongados a los europeos, resultando en un gasto para la administración que no podía cesar en envío de raciones. La pobreza era tal, que incluso se les tuvieron que comprar ropas ya que algunos iban desnudos. ${ }^{108}$ En una situación de carencia, la absoluta mayoría de perfil urbano y sin conocimientos agrícolas en un clima muy diferente, y en espera del indulto, la puesta en marcha de explotaciones agrícolas resultaba muy complicada.

El desconocimiento del archipiélago por el Gobierno metropolitano supuso un lastre enorme para los propios mandatarios filipinos que tenían un mejor conocimiento del terreno y pudieron haberles ubicados en lugares donde su empleo al Estado hubiera sido más útil. Eso sí, atendiendo a su comodidad resultaba mejor enviarlos a la Micronesia donde los problemas que les podían causar estarían más alejados. La mala distribución se explica por las motivaciones de los embarques que obedecieron únicamente a un afán de neutralización de la disidencia política y social. En principio, ni siquiera se pararon a pensar donde podían ser más sutiles al Estado. Tal y como afirmaba el Capitán general de Filipinas, las Marianas no podían absorber a tanta gente y con un número más equilibrado de sexos podían haber sido remitidos a Palaos,

\footnotetext{
${ }^{105}$ Marjorie G. Driver y Omaira Brunal Perry, Chronicle of the Mariana Islands, pp. 181-188; Carlos Madrid, Beyond Distances, pp. 146 y 150-152.

${ }^{106}$ PNA, Real Audiencia, Leg. 268. Expediente sobre comunicaciones e instancias referente a deportados con delitos de 1874 a 1876; Carlos Madrid, Beyond Distances, pp. 120-121.

${ }^{107}$ Carlos Madrid, Beyond Distances, pp. 170-171.

${ }^{108}$ Oficios de Gobernador general de Filipinas a ministro de Ultramar, 15 de octubre de 1875 y 3 de febrero de 1876, AHN, Ultramar, Leg. 5222, Exp. 1. Expediente general sobre deportados a las islas Marianas y Filipinas.
} 
Carolinas, Paragua o Balabac. ${ }^{109}$ La ausencia de mujeres suficientes dificultaba la iniciación de posibles plantaciones y su continuidad. Siempre era más fácil de que se produjeran cuando se tenía apoyo y una familia que mantener.

En cuanto a las siete féminas, apenas tenemos unos pocos datos de ellas. Además de las dos consideradas prostitutas, María Escribano Salvador fue deportada por cantonalista y Juana Abuleco, de Córdoba, por “malísimos antecedentes". De las otras cinco, tres eran de Madrid y una de Cádiz. ${ }^{110}$ Por primera vez encontramos a mujeres, en una muestra de que su posición social estaba cambiando, y si bien continuaba siendo subordinada, el poder ya empezaba a tenerlas en consideración para reprimirlas. De Josefa Lara, una de las trasladadas a Marianas sin que se explicitara el motivo, se decía que estaba enferma y que su conducta era poco moral y que rebajaría el concepto de los españoles si se dedicara a la prostitución con los naturales, por lo que fue llevada a Manila para servir en algunas casas, pero su delicada salud no le permitía salir del hospicio. ${ }^{111}$

Del mismo modo que el desprecio social sobre los varones se manifestaba tildándoles de vagos o delincuentes, hacia las mujeres lo hizo asimilándolas con la prostitución. Las mujeres de las clases más bajas sufrían además la estigmatización de ser consideradas de poca moralidad. Estas acusaciones no probadas en el propio expediente, resultan maliciosas cuando fueron realizadas contra personas que estaban por las calles de Madrid y tras ser apresadas, transportadas a miles de millas de sus casas. Siendo pocas las mujeres entre tantos hombres era normal que se mezclaran y tuvieran trato con ellos y en el caso de ejercer la prostitución, cosa que no se constataba, lo haría empujada por la necesidad y el desamparo. En el caso de los varones sus familias quedaban desprovistas de ingresos proporcionados por su trabajo, en el de las mujeres no significaba únicamente la posible pérdida de su sueldo, sino la atención

\footnotetext{
${ }^{109}$ Oficio de Gobernador general de Filipinas a ministro de Ultramar, 25 de diciembre de 1874, AHN, Ultramar, Leg. 5222, Exp. 1. Expediente general sobre deportados a las islas Marianas y Filipinas.

110 "Relación nominal de los deportados a las islas Filipinas según datos que obran en este Ministerio procedentes del Gobierno general de dichas islas y de los Ministerios de la Gobernación, de Guerra y de Marina y listado de deportados". AHN, Ultramar, Leg. 5222, Exp. 3. "Expediente general de deportados a Marianas y Filipinas. Regreso"; concesión de indulto a Josefa Segarra, 1 de diciembre de 1876. AHN, Ultramar, Leg. 5222, Exp. 2. Expediente general sobre deportados a las islas Marianas y Filipinas (continuación).

${ }^{111}$ Oficio de Gobernador general de Filipinas a ministro de Ultramar, 20 de octubre de 1876. AHN, Ultramar, Leg. 5222, Exp. 2. Expediente general sobre deportados a las islas Marianas y Filipinas (continuación).
} 
social que garantizaban a sus familiares entre los que se encontraban padres e hijos. Resulta tremendamente contradictorio que atribuyéndoseles conductas inadecuadas y siendo represaliadas por ello, en el caso de Josefa Lara tenía un hijo menor en la Península. Curiosa manera de fomentar la defensa de la familia.

Al igual que con los hombres hemos de cuestionar lo expuesto por la autoridades, ya que si es cierto que fueron incluidos muchos delincuentes de muchos otros se desconocían los motivos. Por ejemplo, Catalina Fernández, de Madrid, obtuvo trabajo pidiéndolo casa por casa y después estuvo en el hogar del marmolista Rodoreda y en el hospicio donde decían de ella "la mejor de las de su clase que ha estado en esta casa, de una conducta ejemplar de buenas costumbres, muy trabajadora, y que no ha dado lugar a la menor reprensión". 112

La inclusión de féminas, aunque poco importante numéricamente iba en consonancia con su mayor incorporación social y nada tuvo que ver con intenciones colonizadoras. En el Sexenio hicieron patente su malestar en disturbios relacionados con fraudes o el precio de los alimentos, pero estos actos relacionados con las necesidades familiares se vieron superados con presencia en las manifestaciones en contra de las quintas y de la esclavitud, a favor de la libertad de cultos y de la República e incluso participando activamente en huelgas y en la insurrección cantonal. ${ }^{113}$ Además de su participación activa en actos políticos y sociales cotidianos desfiguradas entre la multitud, era muchísimo más importante la participación directa en la política a través de la prensa y el debate que se abrió en la sociedad respecto al papel de la mujer en la misma. Una discusión emanada de sectores avanzados de mujeres que pretendían la extensión a ellas mismas de los derechos liberales, y que incluso provocaría oposición a cambios inmediatos en amplios sectores del republicanismo, entre los cuales estaba Pi y Margall. ${ }^{114}$

\footnotetext{
112 Informe sobre la deportada Catalina Fernández. AHN, Ultramar, Leg. 5222, Exp. 2. Expediente general sobre deportados a las islas Marianas y Filipinas (continuación).

${ }^{113}$ Gloria Espigado Tocino, "Mujeres «radicales». Utópicas, republicanas e internacionalistas en España (1848-1874), Ayer, núm. 60, 2005, pp. 34-35.

${ }^{114}$ ver Gloria Espigado Tocino, "Las primeras republicanas en España. Prácticas y discursos identitarios (1868-1874), Historia Social, núm. 67, 2010, pp. 75-91 y "El discurso republicano sobre la mujer en el Sexenio Democrático, 1868-1874. Los límites de la modernidad", Ayer, núm. 78, 2010, pp. 143-168; María del Carmen Bolaños Mejías, "La imagen de la mujer española durante el Sexenio. Entre el cambio social y el reconocimiento jurídico", Feminismo/s, núm. 2, 2003, pp. 25-40; algunos textos referentes a la situación y proyección de la mujer se pueden consultar en Gregorio de la Fuente Monge y Rafael Serrano García, La Revolución
} 


\subsection{Otros lugares de deportación}

Como hemos visto, muchos de los que habían llegado en el Irurac-Bat y en el segundo embarque del León no fueron distribuidos hacia las Marianas. Al pequeño archipiélago micronesio fue desviado un número mucho mayor de los que podía albergar y alimentar. Para evitar un auténtico colapso se distribuyó a parte de ellos a otros lugares, una postura mucho más inteligente por cuanto en Filipinas había multitud de islas vagamente colonizadas. Puestos a sacar provecho de los relegados, es evidente que allí nada más se les podía sacar e incluso la aglomeración en la misma suponía un estorbo, mientras que la remisión a otros puntos aumentaba las posibilidades ampliándolas a otros lugares.

Entre los que llegaron en el Irurac-Bat quedaron en Manila los 12 menores y 11 "de oficio o profesión conocida que han sido distribuidos en los distritos de Mindanao, bajo la vigilancia de la autoridad". ${ }^{115}$ El Capitán general de Filipinas evitó asumir la responsabilidad de que causaran problemas habiendo desobedecido las órdenes, por lo que ordenó que quedaran en Luzón solo unos pocos, aquellos que tendrían mayor influencia o algún tipo de recomendación. Al resto los desvió hacia otros puntos.

Según cifras del Capitán general de Filipinas, al margen de los 710 llevados a las Marianas, hubo 40 en la isla de Balabac, 240 en la de Paragua y el resto fueron repartidos entre Manila y el Corregidor, escogiendo para estos dos últimos puntos a aquellos que habían tenido algún cargo en la administración o resultaban de confianza. ${ }^{116}$ Tanto la capital como la pequeña ínsula que daba acceso a la bahía de Manila, con una población de apenas 400 personas de las que la mayoría hablaba un perfecto castellano y con presencia de religiosos, ${ }^{117}$ eran lugares mejores para la estancia. Se produjo una criba entre distintos grupos de deportados de acuerdo a su condición social distribuyéndose los de mayor categoría e influencia hacia los mejores

Gloriosa. Un ensayo de regeneración nacional (1868-1874). Antología de textos, Biblioteca Nueva, Madrid, 2005, pp. 105-114.

${ }^{115}$ Oficio de Gobierno general de Filipinas a ministro de Ultramar. AHN, Ultramar, Leg. 5222, Exp. 1. Expediente general sobre deportados a las islas Marianas y Filipinas.

${ }^{116}$ Oficio de Gobierno general de Filipinas a ministro de Ultramar, 15 de octubre de 1875. AHN, Ultramar, Leg. 5222, Exp. 1. Expediente general sobre deportados a las islas Marianas y Filipinas.

117 José Montero y Vidal, El archipiélago filipino y las islas Marianas, Carolinas y Palaos. Su historia, geografía y estadística, Imprenta de Manuel Tello, Madrid, 1886, pp. 155 y 175; Adolfo Diez Muñiz, "Estudio sociológico-demográfico de isla de Corregidor y Llana (Filipinas, Siglo XIX)", Hispania Sacra, vol. 47, núm. 97, 1995, p. 750. 
lugares. Una vez producido el desembarazo se estaba implementando una política de maximizar el aprovechamiento de su fuerza de trabajo, la extensión espacial ofrecía teóricamente nuevas posibilidades. Además, la mayor cercanía respecto de Manila facilitaba la organización y la logística.

En su distribución también intervinieron las recomendaciones e influencias. Resulta lógico que en caso de tener familiares o amistades en Filipinas, los propios afectados o sus parientes acudieran a ellos tratando de mejorar su estancia. El propietario del almacén "La casualidad" de Manila solicitaba que se permitiera tener a su servicio a Alfonso Huertas Martínez, que se encontraba en las Marianas. ${ }^{118}$ Hechos como estos fueron aislados pero mostraban que pese a la rigidez en la norma había mecanismos para mejorar las condiciones de relegación. Obtener trabajo y salir de la esfera de control gubernamental era la mejor opción y ofrecía ventajas para las autoridades ultramarinas, para las que significaba eludir el tutelaje sobre determinados sujetos.

Otra cosa es que estas circunstancias fueran aprovechadas puesto que el asentamiento y colonización de europeos ofrecía dificultades y el objetivo principal fue aligerar la presión sobre el archipiélago micronesio. En Balabac e isla de Corregidor se les asignaron "víveres, medicinas y estancias", consistiendo la alimentación en ración de armada. A los enfermos en el hospital, además de las medicinas se les pagaban 23 céntimos de peso por día, ${ }^{119}$ suponemos que para la alimentación.

La manutención y la asistencia médica les garantizaban la supervivencia más básica, quedando excluida cualquier otra ayuda monetaria que quedaría a la voluntad de las autoridades filipinas. Resulta sintomático del carácter autoritario del Gobierno peninsular que no se les otorgara ninguna pensión más allá de la propia alimentación, inhibiéndose en este asunto y desplazando el problema a los mandatarios de la posesión, que habían tenido que recurrir a sucesivos créditos para hacer frente a los gastos que les ocasionaban los deportados. La despreocupación del Ejecutivo se debía a un fuerte componente clasista, ya que la mayoría de los relegados formaban parte de las capas más desfavorecidas de la sociedad o estaban relacionados con la pequeña delincuencia o la vagancia. Sin embargo, entre los represaliados políticos encontramos a militares

\footnotetext{
${ }^{118}$ Autorización para fiar al deportado Alfonso Huertas. PNA, Expedientes Gubernativos, Leg. 29.

${ }^{119}$ Oficio de Gobierno general de Filipinas a ministro de Ultramar, 21 de septiembre de 1876. AHN, Ultramar, Leg. 5222, Exp. 15. "Aprobados créditos para para gastos de hospital de deportados".
} 
retirados de alta graduación como capitanes con los que hubo trato de favor ya que algunos pudieron quedar en Manila o sus cercanías y en la que los oficiales retirados del ejército, pudieron cobrar la pensión que les correspondía como tal, y no únicamente una ayuda alimenticia. ${ }^{120} \mathrm{El}$ desprecio social y político no tenía por qué extenderse a las colonias, cuando había personas con cierta distinción social.

Al grupo de 11 trasladados a Marianas en los inicios del Sexenio se les asignaron ayudas públicas. También se les concedió pensión a los de 1848 a los que se estableció primero en Manila, facilitando su asentamiento y la obtención de trabajo. Es evidente que no pretendían que murieran, pero el nuevo régimen tenía un carácter de defensor del orden que encontraba en este aspecto un posible nuevo baluarte. Un Gobierno supuestamente regenerador y que abogaba por dejar atrás los conflictos políticos podía recurrir a una fuerte represión política avalada por sus adalides, que podía ser presentada como un intento de retornar a la grandeza de España al contribuir al poblamiento de territorios nominalmente patrios en los que la presencia real era muy escasa.

La situación de los relegados contrastaba con la ayuda que se daba a los cubanos en la Península, que continuaron recibiendo la correspondiente ayuda de un peso y medio por día para su manutención. Esto cuando el desafío independentistas, exteriorizado a través de una guerra abierta estaba costando al erario público una cantidad ingente en dinero y decenas de miles de vidas de jóvenes, eso sí mayoritariamente pobres. En cambio, las revueltas cantonales supusieron una insurrección extendida pero limitada y sin posibilidades de vencer. Que los peninsulares, cuyas faltas en teoría eran menores, tuvieran que soportar unos castigos más duros tiene que ver con el carácter de unos y otros, en el caso de los europeos mayoritariamente disidentes políticos y sociales y en el caso de los criollos elementos a los que se pretendía reincorporar al proyecto político de la metrópoli.

Los 240 deportados en la isla de Paragua fueron transportados por el Marques de la Victoria a principios de febrero y establecidos en Puerto Princesa, el único punto colonizado en la misma. Se les proporcionaron herramientas y semillas por valor de 4.000 pesos con el objeto de que iniciaran sus explotaciones agrarias y posteriormente

\footnotetext{
${ }^{120}$ Oficio de Gobierno general de Filipinas a ministro de Ultramar, 3 de febrero de 1876. Informe de Ministerio de la Guerra acerca de las pensiones de oficiales retirados del ejército, 8 de mayo de 1876. AHN, Ultramar, Leg. 5222, Exp. 13. "Militares deportados solicitan una pensión alimenticia". Por la fecha del informe, tardarían bastante en poder cobrarla.
} 
se enviaron 1.500 pesos adicionales para la compra de animales. ${ }^{121} \mathrm{El}$ hecho de que los animales se compraran meses más tarde nos hace dudar de si fracaso la agricultura o se trataba de complementar aquella actividad por la mayor inmediatez para la alimentación que proporcionaban los animales. En cualquier caso, la adaptación era más fácil en un lugar con mejores comunicaciones. El esfuerzo planteado en la colonización, mayor que en casos precedentes, muestra que a pesar de la desorganización acabó planeándose como una deportación de largo alcance.

En Paragua funcionaba la primera compañía disciplinaria formada por real decreto de 12 de septiembre de 1871. Estaba compuesta de presos por causas militares, a los que podrían unirse los sentenciados por causas civiles que lo solicitasen. Su fin era el de fomentar la expansión española en la misma, siendo destinados según la necesidad a trabajos de obras públicas o campañas armadas y recompensados por sus servicios en metálico o en la reducción del tiempo de sus condenas. Cultivaban huertos para autoabastecerse ellos y sus familias y vendían los excedentes. ${ }^{122}$ En la década de 1870 se intensificó una política de colonización penal de gente tenida por indeseable, con antecedentes penales y presos comunes. Su destino fue principalmente el sur del archipiélago, en donde se establecieron para afianzar el dominio sobre la posesión. ${ }^{123}$ Una vez que los relegados estuviesen en Filipinas la práctica facilitó su empleo, de la utilización de "indeseables" nativos a peninsulares había solo un paso.

La existencia de colonias penitenciarias con reclusos nativos, dotaba a estos intentos de una relativa organización. Este factor explica, en parte, que ante las llegadas continuas de deportados se les empleara en estos menesteres. Sin embargo, tampoco el intento en Paragua fructiferó dado que en 2 de junio de ese 1875 el Capitán general ordenaba el traslado de los peninsulares junto con las herramientas y utensilios que les pertenecían a isla de Corregidor. Las motivaciones aducidas fueron que de no hacerlo

\footnotetext{
${ }^{121}$ Protocolo de Hacienda de compra de herramientas, 22 de mayo de 1875. Informe de dirección general de la administración civil de Filipinas, 20 de noviembre de 1875. Informe a Capitán general de Filipinas sobre el estado de los deportados en Paragua, 17 de marzo de 1876. PNA, Obras Públicas, Leg. 456. De los 4.000 pesos de la compra de las herramientas 935,10 pesos todavía se adeudaban a los comerciantes.

${ }^{122}$ Alicia Castellanos Escudier, "Las compañías disciplinarias en la reducción y colonización de Mindanao", El lejano oriente español. Filipinas (siglo XIX), Actas VII jornadas nacionales de historia militar (Sevilla, 5-9 mayo de 1997), Catedra General Castaños, Sevilla, 1997, pp. 545547 y $551-553$.

${ }^{123}$ Greg Bankoff, "Deportation and the Prison Colony of San Ramón, 1870-1898", Philippine Studies, vol. 39, num. 4, 1991, pp. 443-457.
} 
los nativos se hubieran retirado a los bosques a causa del temor que les tenían. ${ }^{124}$ En Corregidor, donde en teoría habían sido llevados los menos peligrosos, en enero del 1875 de que había habido un intento de envenenar a la guarnición para fugarse. ${ }^{125}$ Las injusticias sufridas, las privaciones, las muertes, la aglomeración de individuos y la inclusión entre los relegados de procedentes del mundo de la delincuencia, llevaron a la realización de acciones poco decorosas.

Es posible que estos sucesos fueran exagerados por las autoridades puesto que pretendían la paralización y retorno de los confinados y la remisión a Corregidor puede entenderse como un intento de aplicación inmediata del indulto. Uno de los conceptos más repetidos era el de la supuesta superioridad moral de los españoles que podía menoscabarse si ejercían acciones poco decorosas, lo que tendía a magnificar las malas acciones de unos pocos. Por supuesto, esto implicaba solo a una parte, porque el envío por el Gobierno a miles de millas de distancia de individuos sin formación de causa y sin recursos, no consideraban que menoscababa la buena opinión de los habitantes de la madre patria.

Dado que la colonización agraria era un completo fracaso, la situación internacional ofreció una nueva posibilidad de utilización de los deportados en beneficio del Estado. Al tradicional contencioso hispano-británico acerca de la soberanía sobre el archipiélago joloano se había unido Alemania, molesta por el apresamiento de dos barcos que comerciaban con Joló y que fueron detenidos por la armada española por no realizarlo a través de los puertos habilitados para ello. A partir de aquí se inició una presión conjunta británico-germana a favor de la libertad de comercio, que incluso llevaron a que Londres dudara de los derechos de soberanía alegados por España. ${ }^{126} \mathrm{La}$ situación aconsejaba una demostración de fuerza que afianzara el dominio sobre el

\footnotetext{
${ }^{124}$ Expediente para la compra de aperos de labranza por valor de 918,10 pesos y 1.500 pesos para la compra de animales de labor. AHN, Ultramar, Leg. 5225, Exp. 62. Crédito para la compra de herramientas y ganado para deportados; oficio de Gobernador general a ministro de Ultramar, 15 de octubre de 1875. AHN, Ultramar, Leg. 5222, Exp. 1. Expediente general sobre deportados a las islas Marianas y Filipinas.

${ }^{125}$ Oficio de Gobernador general a ministro de Ultramar, 2 de enero de 1875. AHN, Ultramar, Leg. 5222, Exp. 1. Expediente general sobre deportados a las islas Marianas y Filipinas.

${ }^{126}$ Luis Álvarez Gutiérrez, "Divergencias y acuerdos entre España, Gran Bretaña y Alemania sobre las islas de Joló", en María Dolores Elizalde (ed.), Las relaciones internacionales en el Pacifico (siglos XVIII-XX). Colonización, descolonización y encuentro cultural, CSIC, Madrid, 1997, pp. 276-289; la campaña en Pio A. de Pazos y Vela-Hidalgo, Joló. Relato históricomilitar desde su descubrimiento por los españoles en 1578 hasta nuestros días, Imprenta y Estereotipia de Polo, Burgos, 1879, pp. 223-240.
} 
territorio, de modo que se organizó una expedición militar que partió desde Manila en 5 de febrero de 1876.

La campaña ofreció la posibilidad de emplear a los relegados combatiendo en el ejército contra los rebeldes y afianzar la soberanía sobre la isla. Dado que los de Marianas estaban muy alejados y los de Manila probablemente serían los de un estrato social más elevado y tenían mayores posibilidades de haberse integrado en la sociedad filipina, se optó por ofrecer la posibilidad de incorporarse a las filas a los que habían en Corregidor y Balabac. La recompensa fue el regreso a casa una vez terminada la campaña para los que observaran buena conducta. Unos 140 se alistaron de los que nueve fallecieron en combate o por las enfermedades. ${ }^{127}$ Finalmente fueron indultados seis oficiales, cuatro voluntarios de primera y entre 111 y 114 de segunda; en el Victoria salieron 107 inmediatamente y el resto debían hacerlo en breve. La mayoría eran represaliados por la sublevación de Cartagena, ${ }^{128}$ por lo que podemos hablar de un aprovechamiento de militares cantonalistas en la campaña que sirvió para consolidar la dominación efectiva sobre el territorio. La expedición consiguió tomar una porción de terreno entre la cual la capital, donde se levantó un fuerte y fue establecido un Gobierno político-militar dirigido por un coronel. También se estableció una compañía disciplinaria para desertores nativos del ejército. ${ }^{129}$ Hábilmente se iniciaron conversaciones con Gran Bretaña y Alemania que terminaron con la proclamación de la libertad de comercio en 11 de marzo de 1877. Sin ayuda internacional, el sultán de Joló reconocía la soberanía española en acuerdo ratificado por el Capitán general en 15 de agosto de 1878.

${ }^{127}$ Apertura de alistamiento voluntario para la campaña de Joló. AHN, Ultramar, Leg. 5222, Exp. 2. Expediente general sobre deportados a las islas Marianas y Filipinas (continuación); Julián Navarro Melenchón, Organización social y sistemas políticos durante la I República, p. 365.

${ }^{128}$ Lista de los voluntarios de Joló que han obtenido indulto por buena conducta. AHN, Ultramar, Leg. 5222, Exp. 2. Expediente general sobre deportados a las islas Marianas y Filipinas (continuación). Había algunos cubanos deportados por Lersundi en 1866, por considerarles "vagos o de mala nota" a los que no se permitió regresar a Cuba, aunque sí a la Península. Del indulto fueron excluidos los que se mostraron indisciplinados, entre los que hubo al menos cuatro. Los oficiales volvieron en pasaje de primera.

${ }^{129}$ Jesús Paniagua Pérez, Memoria reservada de don Domingo Moriones sobre el Gobierno de Filipinas (1877-1880), Universidad de León, León, 1988, pp. 129-133 y 62. 


\subsection{El cese de la situación de deportados: fugas, fallecimientos e indultos}

La deportación administrativa impedía que se les mantuviera recluidos, pero el carácter insular de los puntos de destino dificultaba enormemente la fuga y le confería unas características restrictivas. Mas cuando en el caso de Paragua y Balabac los puntos de residencia eran enclaves y la huida hacia el interior, poblado por nativos a veces hostiles a los españoles, era inviable. El aislamiento determinó que dado su elevado número las fugas fueran testimoniales. José Bonafont, y otros tres pudieron evadirse a principios de 1875 de las Marianas en un buque inglés que los dejó en las islas Palaos y después otro navío de la misma nacionalidad les apeó en Singapur. El 12 de agosto Bonafont solicitó ayuda al cónsul, pero ante su intención de devolverles a las Filipinas embarcó como polizonte en diversos barcos con los que se cree que consiguió llegar a Barcelona. Además de este grupo, se evadieron del mismo archipiélago otros ocho en un buque americano, de lo cual informaba el Capitán general en 28 de septiembre de 1875. ${ }^{130}$ A finales de noviembre de 1875 se fugaron de Manila Gerónimo del Corral García y otro, de apellido Muñoz, ambos trabajaban para Luis Céspedes, y José Bragulat, que trabajaba en Manila para Miguel Puig y Llagostera. ${ }^{131}$

El número de defunciones fue bastante elevado, un total de 82. La escasez de comida incidió también en los chamorros, cuyos casos de disentería se hicieron más frecuentes. ${ }^{132}$ Tal mortandad habla de la desidia del Gobierno con los relegados, no solo en el momento del embarque ni por las condiciones que sufrieron. La lentitud con que se produjo el retorno, una vez sabidas las muertes que se estaban ocasionando, muestra su menosprecio y su falta de humanitarismo. Si lo que se pretendía era la neutralización de la disidencia al final un buen número resultaron efectivamente desactivados mediante su muerte. Así la responsabilidad del Ejecutivo quedaba más difuminada, ya que no fueron ejecutados directamente sino que expiraron por el clima y la falta de condiciones.

\footnotetext{
${ }^{130}$ AHN, Ultramar, Leg. 5225, Exp. 36. Fuga del deportado José Bonafont. El segundo grupo estaba formado por Simón Barcelona, José García Cañavate, Felipe Lastra, Gaspar Martínez, José Pérez Vara, José Bueno Fuentes, Juan Greches y Manuel Toribio Delgado.

${ }^{131}$ Oficios de Gobernador general de Filipinas a ministro de Ultramar, 21 de enero y 17 de marzo de 1876. AHN, Ultramar, Leg. 5222, Exp. 1. Expediente general sobre deportados a las islas Marianas y Filipinas.

132 "Relación nominal de los deportados a las islas Filipinas según datos que obran en este Ministerio procedentes del Gobierno general de dichas islas y de los Ministerios de la Gobernación, de Guerra y de Marina y listado de deportados". AHN, Ultramar, Leg. 5222, Exp. 3. "Expediente general de deportados a Marianas y Filipinas. Regreso"; Carlos Madrid, Beyond Distances, p. 139.
} 
Los que habían fallecido no molestarían más y el resto habían sido testigos y padecido el severo correctivo. Transportados a miles de millas de distancia y "obligados a trabajar" en un clima al que no estaban acostumbrados era de prever que esto sucediera en cantidades importantes. Las muertes iban ligadas al propio traslado y al modo en que se ejecutó y si no fueron más numerosas fue por la labor de los médicos militares. ${ }^{133}$

La deportación de los seres queridos se vivió como un gran drama para sus parientes. Destaca el elevado número de las peticiones de indulto tanto de los propios relegados como de sus familias. ${ }^{134}$ Los intentos se multiplicaron tras la proclamación del real decreto de amnistía, el 13 de febrero de 1875, poco después de la llegada del último barco, en cuya aplicación quedaban exentos los que tenían responsabilidad por delitos comunes. Las solicitudes en caso de ser realizadas por la familia ofrecían la ventaja de que incluso en el caso de que fueran rechazados, podían ofrecer información sobre si su familiar estaba vivo y su paradero. Una vez pasado el peligro, la situación de privaciones, muerte y gasto que ocasionaban pesaban más en la balanza que su neutralización.

“castigados están con la prisión o la deportación sufridas, y los que sólo hayan sido envueltos en esas medidas generales por la triste necesidad de acudir a la salvación del orden público, antes que a las investigaciones minuciosas de la culpabilidad individual, acreedores son á que se les devuelva su pérdida libertad. ${ }^{135}$

El Ejecutivo reconoció que había procedido a realizar una represión indiscriminada que había terminado en encarcelamientos y embarques sin conocimiento de la verdadera culpabilidad y determinaba que se debía proceder a la liberación de los presos y retorno de los deportados. No tenía sentido proseguir con esta situación anómala en cuando ya se sentían plenamente afianzados. En el trasfondo el mensaje era el olvido del pasado, pero también el intento de constatación de que se había instaurado un tiempo nuevo caracterizado por la calma frente a las convulsiones del pasado.

${ }^{133}$ AHN, Ultramar, Leg. 5231. Exp. 24. "Concesión de la Cruz de la Orden de Isabel la Católica al médico del cuerpo de sanidad de la armada D. José da Hermenegildo Tomás del Valle y Ortega, por la asistencia a los deportados españoles en la isla de Corregidor"; AHN, Ultramar, Leg. 5231. Exp. 25. "Concesión de la Cruz de la Orden de Isabel la Católica al médico de Sanidad Militar D. José Franco y Manzano, por los Servicios prestados a los deportados peninsulares en la isla de Balabac"; AHN, Ultramar, Leg. 5239, Exp 37. "D. Rafael Calvo Ballester, médico de Sanidad Militar de la Armada, solicita recompensa por los servicios prestados a los deportados en Paragua".

${ }^{134}$ Para ver las peticiones de indulto: AHN, Ultramar, Leg. 5222, Exp. 1. Expediente general sobre deportados a las islas Marianas y Filipinas y también en AGA, Presidencia del Gobierno, $51 / 3486$.

${ }^{135}$ Gaceta de Madrid, 14 de febrero de 1875. 
Cánovas, se aprovechó de las decisiones tomadas por otros, prolongando su situación para mantener atemorizadas a las clases más bajas, pero finalmente era mejor terminar con esta situación anómala.

El procedimiento instaurado para el regreso no se caracterizó por su agilidad. Los capitanes generales de las colonias ultramarinas estaban obligados a hacer unas listas con los relegados por causas políticas y por delitos comunes. El propósito de que los reclusos por delitos comunes no se mezclaran con el resto y se evitara que quedaran impunes retrasó la repatriación de los represaliados políticos. La consecuencia fue que el proceso se desarrolló con gran lentitud violando una vez más sus derechos. Según el punto de vista gubernamental eran ellos los que otorgaban el indulto de propia voluntad, y el hecho de que estos sujetos habían sido detenidos y embarcados allende los mares era un hecho accesorio. Sus derechos quedaban en nada frente al Ejecutivo.

La capitanía general desconocía las motivaciones y por ello pidió dos veces estos datos, la primera el 8 de julio y la segunda el 18 de diciembre de 1875 . Relación que el Ministerio de Ultramar no le entregó porque la desconocía, ya que era competencia del Ministerio de la Gobernación. Esta manera, nada dinámica de proceder a la vuelta fue dando lugar a una serie de peticiones de indulto particulares que daban lugar a levantamientos del castigo de los peticionarios durante $1876 .{ }^{136} \mathrm{La}$ desorganización muestra cómo no se dio a este asunto un carácter prioritario. Dada la gran cantidad de peticiones de indulto el procedimiento se hizo muy tedioso y más aun teniendo en cuenta que el Estado había pasado más de un año sin realizar las listas. Los indultados tenían que costearse el pasaje por lo que fue el Capitán general de Filipinas el que bajo su responsabilidad ordenó su pago en algún caso. ${ }^{137}$ Desconocemos si esto se extendería a todos, pero supone la opción más factible en el caso de que no pudieran hacer frente a los gastos que generaba, como modo de desembarazarse de su presencia en Filipinas, lo que implicaría retrasos por la solicitud y aplicación de la medida.

El mantenimiento de la situación alegal se hacía insostenible durante más tiempo. La Ley de amnistía 10 de enero de 1877 establecía que tan pronto como el

\footnotetext{
${ }^{136}$ Oficio de Gobierno general de Filipinas a ministro de Ultramar, 20 de enero de 1876. AHN, Ultramar, Leg. 5222, Exp. 1. Expediente general sobre deportados a las islas Marianas y Filipinas; indultos individuales en AHN, Ultramar, Leg. 5222. Exp. 1. Expediente general sobre deportados a las islas Marianas y Filipinas y Leg. 5222, Exp. 2. Expediente general sobre deportados a las islas Marianas y Filipinas (continuación).

${ }^{137}$ Deportados españoles embarcados en el vapor Aurora. AHN, Ultramar, Leg. 5222, Exp. 2. Expediente general sobre deportados a las islas Marianas y Filipinas (continuación).
} 
Gobierno dispusiera del crédito para el pago de los billetes procedería a organizar la repatriación, que debería producirse antes de seis meses, toda vez que se estaba procediendo a la clasificación de los mismos. El dinero se consignó en 6 de febrero de ese mismo año y en 7 de febrero se hizo la relación, si bien reconociendo que contenía carencias en la información sobre algunos hombres, que se tenían que complementar. ${ }^{138}$

A partir de aquí, el regreso se aceleró. El 25 de mayo zarparon unos 360 pasajeros en el vapor Gloria, de los cuales 150 eran relegados. El naufragio del barco hizo que permanecieran diecinueve días en una isla hasta que fueron rescatados por el vapor ingles Bentham, que los transportó a Singapur donde atracaron en una situación “casi de desnudez". Allí se les compró una muda de ropa a cada uno y se les alquilaron cinco casas para que pudieran hospedarse. El 15 de julio llegó el Victoria a Singapur y debía salir al día siguiente de allí. Este buque llevaba a 692 pasajeros de los cuales 590 eran deportados. El itinerario del mismo transcurrió por las Marianas, donde recogió a los que allí quedaban y desprovisto de carga y con las bodegas preparadas recogió los que había en el enclave británico. ${ }^{139}$

Únicamente algunos rezagados embarcaron con posterioridad. El 18 de agosto el vapor mercante Cádiz recogió a algunos que no pudieron hacerlo en el Victoria por encontrarse enfermos. En el vapor León salieron dos individuos que estaban sujetos a responsabilidad criminal y habían sido absueltos y otros dos que se negaron a repatriase en Singapur en el Victoria y fueron remitidos a Filipinas de nuevo. En el enclave británico debían ingresar otros cinco que se habían negado a hacerlo en los barcos precedentes. ${ }^{140}$ La negativa a volver de algunos relegados puede explicarse por distintas razones. Tras un periodo de más de dos años de estancia algunos obtendrían trabajo o

\footnotetext{
${ }^{138}$ Oficio de presidente del Consejo de Ministros a ministro de Ultramar, 20 de enero de 1877. Real decreto de Ministerio de Hacienda de 6 de febrero de 1877. "Relación nominal de los deportados a las islas Filipinas según datos que obran en este Ministerio procedentes del Gobierno general de dichas islas y de los Ministerios de la Gobernación, de Guerra y de Marina y listado de deportados". AHN, Ultramar, Leg. 5222, Exp. 3. "Expediente general de deportados a Marianas y Filipinas. Regreso".

${ }^{139}$ Relación de deportados embarcados en el Gloria, finalmente tres o cuatro no lo hicieron por estar enfermos. Oficios de cónsul de Singapur a Ministerio de Ultramar, 23 de junio y 7 de julio de 1877. Oficio de cónsul de Singapur a ministro de Ultramar, 15 de julio de 1877. AHN, Ultramar, Leg. 5222, Exp. 3. "Expediente general de deportados a Marianas y Filipinas. Regreso".

${ }^{140}$ Oficios de Gobierno general de Filipinas a ministro de Ultramar, 26 y 27 de septiembre de 1877. AHN, Ultramar, Leg. 5222, Exp. 3. "Expediente general de deportados a Marianas y Filipinas. Regreso". En el hospital de Singapur quedaba el también relegado Salvador Tamayo, por encontrarse enfermo.
} 
conseguirían una integración social o afectiva por lo que decidieron establecerse. La opinión de los afectados importó al Gobierno absolutamente nada, mostrando su desprecio por ellos y su incompetencia. El hecho de que algunos individuos decidieran asentarse en el archipiélago suponía un avance, poco relevante quizás, pero positivo si lo que se pretendía era afianzar la soberanía basada en la afluencia de población de origen europeo. La poca aportación a la colonización se desechó.

La otra motivación que explica la negativa al retorno era que algunos posiblemente tuvieran causas pendientes en la Península, por lo que en teoría tendrían que hacer frente a la justicia. En Port Said se fugaron doce pero fueron apresados en Suez y puestos a disposición del cónsul de España en dicha ciudad, que afirmaba que en las ciudades por las que pasaban se producían robos y engaños, ${ }^{141}$ algo que por otra parte no puede sorprendernos dadas las características de algunos transportados y el gran número de pasajeros en el Victoria.

\title{
4. LOS DEPORTADOS EN FERNANDO POO
}

En 1876, según palabras del gobernador de Fernando Poo, el estado de los dominios en el golfo de Guinea era el siguiente:

\begin{abstract}
"No tenemos recursos ni para pagar a los trabajadores de color; a los empleados y marinos se les da un socorro; el hospital esta en ruinas, hay que hacer grandes gastos y España nos tiene olvidados por completo. En enero retiramos el destacamento de Elobey; Corisco casi se llama isla inglesa y en cuanto a Annobon, sus naturales se han debido olvidar del nombre de España y de los colores de su bandera". ${ }^{142}$
\end{abstract}

El pesimismo que destilaban las palabras del gobernador general, Diego Santisteban, no era sobrevenido o causado por una percepción individual de alguien que destinado a un lugar lejano y con un abrasivo clima tropical, sentía añoranza. Era la sensación general que no hacía sino reafirmar los vanos intentos que de manera esporádica y desorganizada se habían llevado a cabo para colonizar el territorio y que habían resultado infructuosos. En 1869 se intentó una vez más el establecimiento de

\footnotetext{
${ }^{141}$ Informe de consulado general de España en Egipto, 31 de agosto de 1877. AHN, Ultramar, Leg. 5222, Exp. 3. "Expediente general de deportados a Marianas y Filipinas. Regreso".

${ }^{142}$ Manuel Iradier, África, viajes y trabajos de la Asociación Euskara La Exploradora. Reconocimiento de la zona ecuatorial de África en las costas de occidente, Miraguano/Polifemo, Madrid, 1994, p. 72.
} 
pobladores, "los cuales fueron devueltos inmediatamente a España en el más deplorable estado y sin haber conseguido con su venida aquí otra cosa que adquirir el profundo convencimiento de que la colonización en esta forma era imposible y ruinosa". ${ }^{143}$ En 1872 se produjo una reforma en el reglamento de la posesión que redujo el personal al mínimo imprescindible. En 1870 hacía más de siete meses que no llegaba ningún barco de la metrópoli y los víveres eran suministrados por los buques ingleses, por lo que el gobernador proponía que fueran los mismos navíos los que trasladasen a la Península a los enfermos. ${ }^{144}$ Difícilmente se podía mostrar mayor incapacidad que depender de la marina de una potencia rival para las comunicaciones con un dominio. La situación era de total abandono, peor incluso cuando esta derivaba de los reiterados fracasos que hicieron dudar de la posibilidad de asentamiento efectivo en la misma más allá de la presencia testimonial de unas autoridades civiles y militares y de una escasa guarnición en condiciones de gran precariedad, que incluso se había tenido que replegar abandonando las dotaciones en las islas menores del Golfo.

La tranquilidad terminó con la salida el 8 de noviembre de 1874 de 30 deportados en la corbeta Trinidad. Entre ellos había 12 relacionados con la delincuencia común, diez internacionalistas y un carlista, mientras que en el resto de casos no se especifica. Todos ellos fueron remitidos por las autoridades civiles y militares de San Fernando, Madrid, Sevilla, Badajoz, Jerez y Cádiz. ${ }^{145}$ Tanto su perfil como su procedencia, similares a las de los transportados a las Filipinas nos remiten a un grupo que llegaría a Cádiz con posterioridad a la salida del León y con antelación al IruracBat. El elevado número de represaliados permitía desviar a unos pocos al golfo de Guinea, en un embarque a un destino diferente y con menor capacidad de absorción. Su escaso número muestra conocimiento sobre la situación de la posesión.

En octubre de 1875 arribaron otros 14 a Fernando Poo: 11 de ellos tenidos por secuestradores, cuatro de ellos de Alicante y el resto de diversas poblaciones andaluzas. Únicamente a uno se le calificaba como insurrecto carlo-federal, mientras que en los

\footnotetext{
${ }^{143}$ AGA, África-Guinea, Caja 81/6939. Estado de la colonización de Fernando Poo.

${ }^{144}$ Oficio de gobernador general de Fernando Poo a ministro de Ultramar, 15 de diciembre de 1870. AGA, África-Guinea, 81/6963, Exp. 7.

${ }^{145}$ Relación nominal por orden alfabético de los deportados a Fernando Poo. Relación de desterrados embarcados en la urca Trinidad, 16 de marzo de 1875. AGA, África-Guinea, Caja $81 / 6942$.
} 
otros dos casos no se especificaba. ${ }^{146}$ En Andalucía, a principios de la década de 1870 comenzaron a incrementarse los secuestros, lo que llevó al Gobierno a destinar a Julián Zugasti como gobernador de Córdoba. Zugasti tomó diversas medidas para acabar con el bandolerismo. En muchas ocasiones los bandoleros resultaban muertos al ser aprehendidos por la Guardia Civil. Los presos eran juzgados de acuerdo a las leyes, ${ }^{147}$ por lo que los traslados se aplicaron para unos pocos de aquellos contra los que no había pruebas o no se había podido conseguir testimonio. La represión contra la delincuencia urbana en Madrid se expandió al sur del país, aunque con diferencias ostensibles en cuanto a su alcance. En el sur se acotó contra aquellos que se creía eran delincuentes o colaboradores, mientras que en Madrid tuvo un carácter mucho más social y por tanto, más masivo.

La segunda remisión se produjo una vez aprobado el real decreto de indulto, por lo que la medida quebrantaba el espíritu del decreto ya que tanto los represaliados políticos como los comunes debían regresar, aunque estos últimos debían ser juzgados por los tribunales ordinarios. En un periodo de calma política, y con Cuba en guerra, Fernando Poo era un punto más adecuado. Así se estimaban las peticiones del Capitán general de Filipinas que protestaba por la presencia de deportados esgrimiendo el clásico argumento del menoscabo que producían en la idea de superioridad moral que los nativos tenían sobre los europeos. La prohibición de embarques al archipiélago asiático, ${ }^{148}$ requería de búsqueda de lugares alternativos. Toda la prensa informaba de sus avatares en las Marianas, por lo que llevarles a la isla africana suponía un mayor disimulo. Aunque era un peligro mayor por las características sanitarias del territorio se producía a un punto más cercano por lo que en cierto modo podía pasar como un castigo menor. Por el perfil de los afectados era difícil que levantara excesiva oposición.

Los envíos continuaron en febrero y marzo de 1876 cuando se produjeron diversos viajes que totalizaron a 31 personas. Pero en este momento el perfil de los

\footnotetext{
${ }^{146}$ Oficio de gobernador de Fernando Poo a ministro de Ultramar, 15 de marzo de 1877. Relación nominal por orden alfabético de los deportados a Fernando Poo. AGA, África-Guinea, Caja 81/6942. Los de Alicante estaban acusados de formar de la banda que se denominaba "los secuestradores de la Marina".

${ }^{147}$ Manuel Pérez Regordán, El bandolerismo andaluz, Quadix, Cádiz, 1990, vol. III, pp. 70-155. Las críticas a su actuación le llevaron a defenderse, ver Julián de Zugasti, El bandolerismo. Estudio social y memorias históricas (1876-1880), Imprenta de T. Fortanet, Madrid, 1876-1800, 10 vols.

${ }^{148}$ Oficio de Ministerio de Ultramar a Ministerio de la Guerra, 9 de febrero de 1876. AGA, África-Guinea, Caja 81/6942.
} 
relegados había cambiado ya que 19 de ellos eran conspiradores carlistas. ${ }^{149}$ Por la procedencia de los dos únicos en los que esta se cita, Badalona y San Celoni, y los apellidos del resto, lo que se pretendía era evitar que se reabriera de nuevo el frente catalán apaciguado a finales del año anterior con la toma de la Seo de Urgell. Aun así, se trató de un número muy reducido por lo fueron medidas selectivas sobre sujetos de significación o que efectivamente habría indicios de que estarían conspirando. En ocho casos eran secuestradores, siete de Alicante y uno de Murcia, por lo que parece la continuación de la lucha contra los bandoleros alicantinos, lo que suponía la extensión de la represión en Andalucía. Con las Marianas bloqueadas, Fernando Poo fue utilizado como destino para una práctica poco importante numéricamente que incluía a sujetos con un perfil muy diverso.

La llegada a Fernando Poo causó la usual consternación del gobernador de la posesión, ante la carencia de medios disponibles y de ni siquiera habérsele dado instrucciones. Como de costumbre tuvo que improvisar y los ubicó en la casa cuartel, socorriéndoles con la misma ración que la armada. Además avisaba de la escasez de la tropa y las medidas tomadas para evitar conflictos. Esta carta muestra los temores exacerbados respecto al arribo de los represaliados, que no se cumplieron ya que no se produjeron problemas de orden público y hubo una única fuga. ${ }^{150}$ En esta ocasión no hubo epidemias, por lo que únicamente se produjeron seis fallecimientos, ${ }^{151}$ lo que en comparación con ocasiones anteriores y con el estado de abandono no puede considerarse excesivo. Las atenciones de las autoridades influirían en este hecho, pero principalmente se trató de suerte, un factor que en otras ocasiones se les había negado.

El 2 de junio de 1876 se indultó a los que habían llegado en la Trinidad amparándose en el decreto de 13 de febrero de 1875, e irían saliendo en el segundo semestre de ese mismo año. Nueve no pudieron efectuarlo al no disponer de dinero para el pasaje, por lo que en 16 de marzo de 1877 el gobernador les pago el billete para

\footnotetext{
${ }^{149}$ Relación de desterrados embarcados en la urca Trinidad, 16 de marzo de 1875. AGA, ÁfricaGuinea, Caja 81/6942. En cuanto al número de deportados, entre los años 1874 y 1876 fueron 80. Los pocos casos en que no se detalla el año o existen fuentes contradictorias no se han especificado en el texto.

${ }^{150}$ Oficio de gobernador general de Fernando Poo a ministro de Ultramar, 3 de enero de 1875. Informe del Ministerio de Ultramar sobre los deportados en Fernando Poo, s/f. AGA, ÁfricaGuinea, Caja 81/6942. El fugado fue Antonio Gómez, del primer grupo de relegados.

${ }^{151}$ Deportados a Filipinas, Marianas y Fernando Poo, 30 de enero de 1877, AHN, Ultramar, Leg. 5222 Exp. 3. "Expediente general de deportados a Marianas y Filipinas. Regreso"; oficio de gobernador general de Fernando Poo a ministro de Ultramar, 15 de marzo de 1877, AGA, África-Guinea, Caja 81/6942.
} 
Tenerife, medida que se extendió a otros 15 con posterioridad. De este modo, el gobernador en Fernando Poo se los sacaba de encima con un costo económico más asequible. El envío a las Canarias no puede generalizase, ya que algunos regresaron a la Península donde fueron liberados y un otros siete a su llegada fueron juzgados por secuestradores. $^{152}$ Las Canarias ofrecían algunas ventajas, ya que aunque legislativamente formaba parte de España, estaba lo suficiente alejado para que una vez allí quedara neutralizado el temor que generaban. A los relegados les permitía establecerse en un lugar más saludable y plenamente poblado.

A dos catalogados como carlistas se les permitió volver durante 1876, probablemente por haber sido su traslado demasiado precipitado y a otros dos se les embarcó pagándoles incluso el billete por su mal estado de salud. ${ }^{153}$ Pero la mayoría tuvieron que esperar a 20 de enero de 1877, cuando se ordenaba que se sufragara el importe de los pasajes. A partir de aquí se aceleró la repatriación del resto que se produciría durante este año. ${ }^{154}$ Dieciséis restaban a 22 de junio de los que los cinco con antecedentes penales serían llevados al continente y el resto a Canarias. Mostrándose como la decisión de desviarles hacia el archipiélago fue una decisión plenamente consciente de sustituir un destino por otro en la cual persistía la neutralización. A un grupo de diez considerados conspiradores legitimistas se les permitió retornar a la Península en septiembre. ${ }^{155}$ Si bien el 18 de agosto de 1878 todavía seria deportado por motivaciones políticas el teniente de la Guardia Civil Prudencio Crespo Pastor. ${ }^{156}$

\section{LOS ÚLTIMOS USOS DE LA DEPORTACIÓN EN LA ESPAÑA PENINSULAR DEL SIGLO XIX}

En 1879 se celebró en Estocolmo el Congreso Penitenciario Internacional, en el que con la excepción de Francia se produjo una desaprobación unánime a la

\footnotetext{
${ }^{152}$ Oficios de gobernador general de Fernando Poo a ministro de Ultramar, 16 de marzo, 20 de julio y 6 de noviembre de 1877. AGA, África-Guinea, Caja 81/6942.

${ }_{153}$ Oficio de Ministerio de la Gobernación de Ministerio de Ultramar, 3 de mayo y 14 de septiembre de 1876. AGA, África-Guinea, Caja 81/6942.

${ }^{154}$ Oficio de presidente del Consejo de Ministros a ministro de Ultramar, 20 de enero de 1877. AGA, África-Guinea, Caja 81/6942. Nota a oficio de Ministerio de la Gobernación.

${ }^{155}$ Oficios de gobernador de Fernando Poo a ministro de Ultramar, 9 de abril y 7 de junio de 1877. Oficio de presidente del Consejo de Ministros a ministro de Ultramar, 27 de septiembre de 1877. AGA, África-Guinea, Caja 81/6942.

${ }^{156}$ Oficio de gobernador general de Fernando Poo a ministro de Ultramar, 19 de agosto de 1878. AGA, África-Guinea, Caja 81/6942. Lamentablemente no se especifican los motivos.
} 
deportación. ${ }^{157}$ Quedaba como una pena anacrónica en un mundo que cada vez más exigía derechos y garantías para los penados. En España, las remisiones no lo habían sido mediante condenas impuestas por la justicia ordinaria y su aplicación había sido impuesta desde una esfera gubernamental para neutralizar problemas políticos y sociales. Aun produciéndose al margen de las leyes en la práctica influyeron en el desarrollo de la misma, por lo que si no era justificable hacerlo mediante la normativa menos aún lo era impuesta administrativamente. A pesar de esto, varios elementos impedían una inmediata disipación de la penalidad en el territorio metropolitano. Existía una pesadez en la maquinaria estatal que no absorbía y plasmaba inmediatamente en la norma los últimos avances en materia penal, que no facilitaba su desaparición inmediata.

Durante la primera parte del mandato de Cánovas, de enero de 1875 a enero de 1877 estuvieron suspendidas las garantías constitucionales. El presidente del Gobierno se aprovechó de las medidas que habían tomado sus predecesores para reprimir al cantonalismo y al carlismo, ${ }^{158}$ por lo que en principio, en caso de considerarlo necesario podía recurrir a cualquier tipo de punición. Continuaba utilizándose contra los carlistas, por lo que podía haberse extendido hacia otros grupos opositores cuando las circunstancias lo recomendasen y no era posible castigarles legalmente.

Las únicas relegaciones se produjeron contraviniendo la condena de reclusión impuesta por los tribunales. Fermín Salvochea y Pablo Pérez Lazo fueron sentenciados por Consejo de Guerra a cadena perpetua y a veinte años respetivamente. Pero cuando llegaron al Peñón de Vélez de la Gomera en abril de 1874, el gobernador de la plaza, Tomás Urra, les alojó en dos habitaciones dándoles libertad absoluta para moverse por el territorio e incluso navegar en pequeñas embarcaciones. Tras un par de años se les llevó al Hacho y posteriormente, los dos y un preso cantonal sevillano, Carrero, fueron llevados a Chafarinas, donde también permanecieron libres y Salvochea organizó una escuela para los hijos de los relegados antillanos. En 1880 Salvochea retornó al Peñón de Alhucemas y residía en una casa en la playa. ${ }^{159}$

La conmutación informal del presidio por deportación constituía una excepción probablemente causada por el estrato social de Salvochea y por haber sido diputado a

${ }^{157}$ Fernando José Burillo Albacete, La Cuestión penitenciaria. Del Sexenio a la Restauración, Prensas Universitarias de Zaragoza, Zaragoza, 2011, pp. 66-67.

${ }^{158}$ Manuel Ballbé, Orden público y militarismo en la España constitucional, pp. 229-232.

${ }^{159}$ Fernando de Puelles, Fermín Salvochea. República y anarquismo, el autor, Sevilla, 1984, pp. 127-131; El País, 27 de octubre de 1902. 
Cortes y alcalde de Cádiz. También es posible que se ampliara a individuos influyentes, especialmente en lugares apartados y con menos presos. A otros no se les permitiría residir fuera de los penitenciarías, pero siendo sus causas políticas es posible que tampoco estuvieran recluidos en sentido estricto. El hecho de ser disidentes políticos en pequeñas islas cuyas fronteras restringían la libertad circulatoria, posiblemente mejoraría las condiciones de muchos. La utilización profusa de la relegación en años recientes expandió la idea de un sentido no carcelario de la punición que benefició a un número indeterminado de represaliados políticos. En estos años fueron transportados a Chafarinas, Ceuta y Melilla un buen número de cubanos por la Guerra Chiquita. La creación de una deportación ultrarrestringida provocó que en ocasiones, ambas penas se confundieran.

La represión de la oposición política discurrió por los cauces ordinarios porque pudo encauzarse dentro de la legalidad. La debilidad de los envites al sistema canovista supuso que no fueran necesarios los cauces extraordinarios de castigo. Esto cambiaria cuando se produjeran hechos con la suficiente relevancia. En 1878 se produjo una "huelga" de colonos en la huerta de Valencia por su oposición al pago de las cuotas a los propietarios, amparándose en la grave sequía que sufrieron los campos. La mayoría no sufragó las cuotas de junio y diciembre y los que lo hicieron se exponían a las venganzas de sus compañeros mediante incendios provocados, pasquines amenazadores y agresiones. El 31 de diciembre, la Liga de Propietarios de Valencia emitía una petición al Consejo de Ministros para que se aplicase la Ley de Secuestros porque permitía al Ejecutivo establecer el punto de residencia de los considerados "vagos y gentes de mal vivir", puntualizando que no se les tratase como a tal. El Gobierno asumió lo planteado por la alta burguesía alfonsina de la ciudad y entre el 10 de enero y el 10 de febrero comenzaron las detenciones de todos los agricultores sospechosos de intervenir en la agitación. El 12 de febrero, 78 eran embarcados en la goleta de guerra África y llevados a Menorca, donde todos aquellos que no podían mantenerse fueron empleados en los trabajos de fortificación de la Mola a cambio de un miserable sueldo para subsistir. $^{160}$

La relegación se prolongó durante apenas unos meses. El 22 de agosto regresaron los pocos que aún permanecían en la isla. ${ }^{161}$ Dado que la dureza había

\footnotetext{
${ }^{160}$ Alfons Cucó, Republicans i camperols revoltats, Eliseu Climent, Valencia, 1975, pp. 39-107. ${ }^{161}$ La Época, 24 de agosto de 1879.
} 
solucionado el conflicto se optó por el perdón de los colonos. Incluso para alguien tan preocupado por la propiedad y el mantenimiento del orden y la desigualdad como Cánovas, ${ }^{162}$ la prolongación de esta medida resultaba excesiva. El conflicto no pretendió subvertir el orden político establecido y tuvo una violencia limitada. Si bien estuvo organizado fue una cuestión local sin conexiones con la Internacional, de modo que el escarmiento se consideró suficiente.

La represión se realizó sin aducir los hechos que se imputaban a cada uno por lo que revistió un carácter colectivo en la que se incluiría a muchos inocentes, lo que en un conflicto de escasa peligrosidad favorecía el perdón. Resulta reveladora la remisión a la ley contra los secuestros a instancia de los propietarios, inaplicable en este caso, lo que indica que en caso de considerarse necesario se hubiera podido acudir a ella para cualquier embarque y que la violación de la norma no hubiera supuesto ningún impedimento. El carácter rural de los represaliados pudo significar un desprecio hacia los mismos, pero también pudo favorecer el perdón por la tradicional displicencia hacia los habitantes del campo que les consideraba incultos y, por tanto, poco peligrosos. Además, su trabajo redundaba en beneficio directo de los propietarios y estaba paralizado. En lo expeditivo del castigo pudo influir que se trataba de un conflicto que se arrastraba desde el Sexenio, ${ }^{163}$ en que el republicanismo federal se alzaba contra el Gobierno y la Internacional se expandía y hacia proselitismo entre los trabajadores. La deportación a Menorca fue un modo de cortar con los problemas que se arrastraban en un conflicto aislado en una ciudad importante, pero alejada de la capital.

En la Restauración, con el orden restablecido, la conflictividad social era suficientemente anacrónica para la magnanimidad. El decaimiento en el uso de la relegación tuvo que ver con un sistema que aun siendo fuertemente conservador, no significaba una vuelta al pasado. ${ }^{164}$ La tranquilidad política y el asentamiento del nuevo régimen facilitaban que no se empleara y fuera calando la inconveniencia de aplicación de esta punición en el caso de los peninsulares. Diferente era para las colonias, la inestabilidad política a la que estaban sujetas y su propia condición las excluían de las

${ }^{162}$ Carlos Dardé, La aceptación del adversario. Política y políticos de la Restauración, 1875 1900, Biblioteca Nueva, Madrid, 2003, pp. 62-63.

${ }^{163}$ José Antonio Piqueras, La Revolución democrática, p. 185.

${ }^{164}$ Fidel Gómez Ochoa, "El conservadurismo canovista y los orígenes de la Restauración. La formación de un conservadurismo moderno", en Manuel Suarez Cortina (ed.), La Restauración, entre el liberalismo y la democracia, Alianza, Madrid, pp. 129-130. 
corrientes de pensamiento humanitarias. El mantenimiento de la soberanía sobre las posesiones ultramarinas se haría a cualquier precio y por encima de todo.

En contraposición, entre 1875 y 1886 hubo una serie de intentonas revolucionarias republicanas que tuvieron un impacto limitado. ${ }^{165} \mathrm{El}$ entramado represivo urdido por Cánovas en la Restauración se manifestó muy eficaz para mantener el orden. Los pronunciamientos militares tuvieron un carácter aislado y las partidas que se le levantaban tenían pocos hombres y se veían acosados por sus perseguidores. Sin conexión con cualquier componente popular que las hiciera masivas y peligrosas para el orden y la propiedad, se solucionaron con fusilamientos, presidios en la Península y plazas africanas e indultos. Únicamente el brigadier Villacampa y otros cinco condenados a muerte fueron llevados a Fernando Poo, en donde atracaron en 4 de noviembre de 1886 a bordo del crucero Navarra, al conmutárseles la pena de muerte por la de reclusión perpetua. Finalmente los seis sentenciados no desembarcarían y serían transportados a Melilla en el mismo barco. ${ }^{166}$ En realidad no se trataba de una deportación, sino de una reclusión a un lugar que habitualmente había servido como punto de relegación. El caso de Villacampa ejemplifica el declive de su uso y la reformulación que sufriría el castigo.

\footnotetext{
${ }^{165}$ Eduardo González Calleja. La razón de la fuerza, pp. 32 y 76-144.

${ }^{166}$ AGA, África-Guinea, Caja 81/6941. Manuel Villacampa y otros, condenados a reclusión perpetua; Villacampa llegó a Melilla en 15 de febrero de 1887 donde permanecería presó hasta su fallecimiento en 12 de febrero de 1889; para que cumpliera la condena se acondicionó una pequeña casa en el pequeño islote Enríquez frente a Santa Isabel. Casita que posteriormente se dedicaría a Lazareto de infecciosos, Armando Ligero Morote, La sanidad en Guinea Ecuatorial, 1778-1968, el autor, Jaén, 1997, pp. 52-53.
} 


\section{TERCERA PARTE.}

\section{LA DEPORTACIÓN EN CUBA}




\section{CAPÍTULO 7. LA CAPITANÍA GENERAL DE TACÓN Y LOS AÑOS DEL"PELIGRO NEGRO"}

\section{EL MANDATO DEL CAPITÁN GENERAL MIGUEL TACÓN (1834-1838)}

\subsection{El número de deportados}

Existe una gran opacidad respecto a la represión en general, y sobre las deportaciones en particular, durante el periodo de Miguel Tacón como Capitán general, por lo que en primer lugar cabría delimitar su importancia. El propio Tacón afirmaba que el número de deportados era de 54, todos ellos en virtud de causa de acuerdo a las leyes. ${ }^{1}$ En línea opuesta iban los críticos con la actuación del Capitán general. Un anónimo de la época, escrito por un detractor suyo, afirmaba que estos fueron más de 200, de los que únicamente unos 30 lo fueron a raíz de un juicio manipulado. ${ }^{2}$ En la misma línea se manifiesta Francisco Calagno que establece que durante su mandato hubo 190 relegados y el número de presos era de $1.015 .^{3}$

Además de la documentación impresa podemos recurrir a fuentes oficiales. El Ministerio de Marina, de Comercio y de Gobernación de Ultramar hizo en 4 de marzo de 1839 una lista de los deportados políticos de Cuba que había en la Península con objeto de pasársela al nuevo Capitán general, Joaquín Ezpeleta, para que diera su opinión respecto al indulto de los mismos. La enumeración contenía un total de 71 nombres, e incluía a aquellos cuyas sumarias estaban en su posesión y a aquellos de los que se tenía conocimiento por haber interpuesto queja los afectados, es decir, que habían sido transportados sin comunicarlo a las autoridades peninsulares y sin el correspondiente expediente. La mayoría fueron acusados de tener relación con el levantamiento constitucional del general Manuel Lorenzo en Santiago de Cuba, un total de 24; por conato de insurrección, cinco; por vagos y de mala nota, 21, de los cuales a cuatro se les atribuían ideas perniciosas; por sus ideas políticas, tres; por participar en la

\footnotetext{
${ }^{1}$ Miguel Tacón, Relación del Gobierno y capitanía general de la isla de Cuba, p. 8.

${ }^{2}$ Bosquejo de la conducta del teniente general D. Miguel Tacón en la isla de Cuba, Imprimerie des Bouchez, Marsella, 1838, pp. 5-8.

${ }^{3}$ Francisco Calcagno, Diccionario biográfico cubano, Imprenta de N. Ponce de León, Nueva York, 1878, p. 611. Calagno no lo atribuye a razones políticas, lo que resta credibilidad a sus afirmaciones.
} 
edición del periódico Libre Imprenta, dos; por manifestaciones en favor de la Carta Magna de 1812 o en contra del Gobierno, tres; por ideas de independencia siete, de los cuales a dos se les atribuía alguna complicidad con los sucesos de Santiago. De los seis restantes, a uno se le atribuyeron papeles sospechosos, a otro se le catalogaba por sedicioso, a otro sospechoso sin más, a uno de ser escritor subversivo y revolucionario y respecto a los otros dos no se especifica el motivo. ${ }^{4}$

Justo de Latorre, doctor en Medicina y Cirugía por la Universidad de La Habana y en Jurisprudencia por la de Sevilla, nos aporta una lista numerosa con otros represaliados, que cotejándolos con la lista confeccionada por el Ministerio de Marina, nos añade a 12 relegados más a los conocidos por la lista confeccionada en Madrid. Entre los eclesiásticos, un grupo de cinco o seis fue llevado a Canarias y otros cuatro a Málaga tras ser encerrados en el castillo de la Punta. ${ }^{5}$ Además, el juez de letras Florencio Montoliu y el subteniente de milicias Vicente M. Moré fueron trasladados a la Península, a pesar de no aparecer en la relación de 1839 y lo mismo sucede con los capitanes de pardos Pedro González y José Rosario Tales. Loreto Espinal fue condenado a deportación en rebeldía por lo que en principio dicha pena no se cumpliría. Otros 25 individuos fueron juzgados por la Comisión Militar, y aunque la mayoría acabaron absueltos alguno pudo haber sido condenado a esta pena. Los castigos impuestos fueron variados, ya que otros siete civiles fueron llevados a los presidios africanos acusados de conato de subversión y expresiones contra el Ejecutivo y una decena de militares fueron condenados a presidios en Cuba. ${ }^{6}$

\footnotetext{
${ }^{4}$ ANC, Asuntos Políticos, Leg. 39, Sig. 69. "Real orden, fecha 4 marzo 1839 contentiva de la lista de los procesados y expulsados por delitos políticos de la isla de Cuba por el Gobernador y Capitán general D. Miguel Tacón"; José María Morote finalmente no fue deportado porque el Capitán general lo impidió, dándole un año para actuar contra sus acusadores. ANC, Comisión Militar, Leg. 22, Exp. 2. Causas del primer semestre de 1838 del fiscal José María Puente.

${ }^{5}$ Justo de Latorre, Una ojeada al manifiesto que publicó el Excmo. Sr. D. Miguel Tacón al dejar el mando de la isla de Cuba, pp. 15-16; Olga Portuondo, Cuba. Constitución y liberalismo (1808-1841), Editorial Oriente, Santiago de Cuba, 2008, tomo II, 155-156; Jesús Raúl Navarro, Entre esclavos y constituciones (el colonialismo liberal de 1837 en Cuba), CSIC, Sevilla, 1991, pp. 160-161 y 168-169; "Instancia de Justo de Latorre, solicitando el cargo de secretario en la Universidad de La Habana", AHN, Ultramar, Leg, 260, Exp. 1. "Notas y documentos sobre asuntos académicos"

${ }^{6}$ Jesús Raúl Navarro, "Militares y libertad, reflexiones en torno al papel desempeñado por el ejército peninsular en la política colonial (1835-1838)", Temas de Historia Militar, vol. III, 1988, pp. 419-420; AHN, Ultramar, Leg. 4613, Exp. 21. "El capitán de pardos don José Rosario Tales, desterrado de la isla por los sucesos de 1836 es declarado por Guerra comprendido en el indulto de 29 de Diciembre de 1840"; Joaquín Llaverías, La Comisión Militar Ejecutiva y Permanente de la isla de Cuba, El Siglo, La Habana, 1929, pp. 185-191; Manuel de Latorre
} 
Ángel Revuelta fue condenado a ser extrañado durante dos años y Francisco Almenares durante cuatro. Vicente Macías fue condenado a extrañamiento durante seis años, eligiendo como destino Nueva Orleans. ${ }^{7}$ Desconocemos el destino de los condenados a extrañamiento, pero tal y como sucedió con Macías no se trataba de deportados en sentido estricto, ya que se les había impelido a salir del país. Pero aun así, es necesario saber que hubo a otros a los que se obligó a establecerse en el exterior.

Entre los embarcados forzosamente en las fuentes descritas hemos localizado a muchos militares. Los miembros del ejército tampoco eran deportados, ya que al estar sujetos a disciplina y normativa castrense, sus libertades y entre ellas la de residencia estaban limitadas. No fueron apartados del ejército sino cambiados de destino y sometidos a condiciones menos favorables. Además, una vez en la Península su peligrosidad política desaparecía y con toda probabilidad seguirían cumpliendo sus funciones tal y como sucedió con Manuel Lorenzo y con Ignacio Herrera. ${ }^{8}$ De este modo evitaban las condiciones de vigilancia y precariedad que debían soportar los relegados en sus puntos de remisión. Aun así, los castigos que se les impusieron nos dan una idea de la extensión de la misma. Analizando los datos de los que disponemos, ${ }^{9}$ vemos que aproximadamente 130 miembros del ejército fueron represaliados por la Comisión Militar. Su destino principal fue el traslado a la metrópoli, donde algunos fueron utilizados en la guerra contra el carlismo, y los presidios a Ceuta. Más de 60 fueron juzgados por la misma sin que sepamos las penas que se les impusieron.

Que la punición fuera mayor hacia el ejército denota que el liberalismo se había extendido entre ellos, pero también que al permanecer a un instituto armado el miedo que se les tenía era mayor. Los recientes acontecimientos de La Granja atestiguaban la importancia que un grupo de militares de poca graduación podía adquirir. Por otro lado, la Península se encontraba en una situación de guerra civil contra el carlismo y algunos

Machado, El procónsul de La Habana y los deportados de la isla de Cuba. Manifiesto al magnánimo pueblo español, Imprenta del Comercio, Cádiz, 1836, pp. 10-11.

${ }^{7}$ ANC, Comisión Militar, Leg. 16, Exp. 3. Causa contra Ángel Revuelta y otros por habérsele encontrado impresos favorables a la Constitución de 1812; ANC, Comisión Militar, Leg. 18, Exp. 4. "Relación de causas del primer semestre del año 1837, fiscal José María Pierra"; ANC, Comisión Militar, Leg. 20, Exp. 6. "Causa contra Vicente Macías y otros acusados de conspiración para la independencia"; causas del fiscal Pedro María Cruces en julio de 1838. ANC, Comisión Militar, Leg. 131, Exp. 2. "Relaciones de las causas que ha sentenciado la Comisión Militar del año 1826 a 1839".

${ }^{8}$ José Antonio de Olañeta, Juicio de residencia del Excelentísimo señor don Miguel Tacón, Imprenta de A. Walker, Filadelfia, 1839, p. 169.

${ }^{9}$ Jesús Raúl Navarro, "Militares y libertad, reflexiones en torno al papel desempeñado por el ejército peninsular en la política colonial (1835-1838)", pp. 418-421. 
de estos hombres pudieron ser aprovechados en la misma. Sus dotes para el combate y su militancia política antiabsolutista les hacían recomendables para ello.

Resulta evidente la limitación de los datos que conocemos para establecer una cantidad exacta de deportados, ocultación que parte de la propia voluntad del Capitán general por minimizar los hechos. La información del Ministerio de Marina obedecía a una recopilación efectuada en fecha concreta de aquellos que se sabía que residían en la metrópoli, por tener el mismo las sumarias o por las reclamaciones interpuestas por estos. En cuanto a las cifras dadas por Justo de Latorre, su temprana relegación y el gran alejamiento que provocó, significarían necesariamente un conocimiento menor de lo que estaba sucediendo en la isla, aunque su información resulta de gran utilidad puesto que complementa a la anterior. Además, encontramos algunas limitaciones en la misma como que en ocasiones se incluía a alguien en las listas que no sufrió este castigo. Es este el caso de los nueve militares que incluye la lista oficial, o de José Antonio Saco, quien no fue embarcado forzosamente sino que se le señaló que debía abandonar el país y se le dejó un tiempo para que efectuara dicho viaje al punto que quisiera. Ello hace que su caso pueda considerarse como de expulsión o exilio forzoso. Lo mismo ocurre con otros individuos que están recogidos en la lista y que en realidad fueron expulsados del país, cuyas particularidades son descritas en el texto.

A pesar de ello, las cifras de que disponemos son bastante aproximadas. Podemos establecer una cifra de deportados de alrededor de $80 .{ }^{10} \mathrm{Si}$ a estos añadimos los miembros del ejército expulsados del país y enviados a presidio en Ceuta y a los civiles y miembros del ejército de los que en las fuentes no se especifica su condena, vemos como la represión sobrepasa ampliamente incluso la cifra dada por los detractores de Tacón. Respecto a los relegados, hemos de tener en cuenta que la mayoría lo fueron al margen de la Comisión Militar y si por cualquier causa, como ausentarse de la Península, no hubieran interpuesto reclamación y su causa no hubiera sido remitida, no estarían recogidos. A pesar de esto, en este caso aunque podría haber algún caso más las cifras son bastante fidedignas y muestran la trayectoria por la que transcurrió su utilización. En el caso de la tropa, la mayoría de los que hemos encontrado fueron juzgados por la Comisión Militar, pero no todos, por lo que es probable que de la punición sufrida por algunos de estos tampoco tengamos constancia.

${ }^{10}$ Sin contar a Félix Artires y José Eduardo Bulte que fueron expulsados a Francia, aunque posteriormente fueron voluntariamente a la Península, donde pasarían a estar bajo la tutela de las autoridades españolas. 
La diversidad de fuentes consultadas y su complementariedad nos permiten calificar las cifras como representativas del alcance de las represalias y evidencian que estas fueron muy importantes. Aun así, corresponden a cifras mínimas que pudieran ser incrementadas a medida que se conozca más del periodo.

\subsection{La Llegada de Tacón y la primera represión.}

Miguel Tacón y Rosique fue nombrado Capitán general de Cuba el 7 de marzo de 1834 y llegó a la misma en 31 de mayo de ese mismo año en sustitución de Mariano Ricafort Palacín y Abarca. Fue propuesto por el general Zarco del Valle, sin embargo, su nombramiento estuvo también ligado al de Martínez de la Rosa en la presidencia del Gobierno, en 15 de enero de 1834, a quien le unía una relación de amistad. Durante el Trienio había sido gobernador de Málaga y posteriormente de Sevilla. En 1823 fue enviado de cuartel a Málaga donde permaneció diez años, hasta que en 1833 fuera nombrado Capitán general de Andalucía, cargo en el que apenas estaría unos meses. ${ }^{11}$

A priori, su trayectoria podía hacer pensar en una mayor apertura en las posesiones antillanas, pero Tacón llegaba a La Habana con instrucciones precisas de Martínez de la Rosa de ser expeditivo en sus actuaciones. De hecho, poco después de su nombramiento ya se le concedió la facultad de suspender de sus destinos y hacer salir de la isla a quienes comprometiesen la tranquilidad de la misma. ${ }^{12}$ Para el presidente del Ejecutivo, de tendencia moderada, los cambios que debían producirse en la Península habían de ser limitados y pausados. Para la colonia, en cambio, pretendía imponer un orden rígido y esto fue bien interpretado por el recién llegado: "La primera medida de Tacón fue un bando sobre el porte de armas prohibidas, luego la creación del cuerpo de serenos, organizado militarmente, como policía nocturna. A esto añadió la creación del

\footnotetext{
${ }^{11}$ Juan Pérez de la Riva, "Introducción" a Correspondencia reservada del Capitán general don Miguel Tacón, 1834-1836, pp. 13-18; Nicomedes Pastor Díaz y Francisco de Cárdenas, Galería de españoles celebres contemporáneos, Imprenta de Vicente de Lalana, Madrid, 1842, tomo III, pp. 26-28.

${ }_{12}$ Leví Marrero, Cuba. Economía y Sociedad, vol. 15, p. 118; real orden de 21 de marzo de 1834. AHN, Ultramar, Leg. 4601, Exp. 53. "Facultades del Gobernador Capitán general de Cuba para realizar deportaciones".
} 
cuerpo de la capitanía general". Además desvió hacia la Comisión Militar los delitos de homicidios o desórdenes públicos que la Real Audiencia no convocaba ante sí. ${ }^{13}$

Al inicio de su mandato se produjo el retorno de algunos exiliados, entre ellos Tomás Gener y José María Heredia. Se hizo alguna ostentación pública como en el caso del entierro del primero y del desembarco del segundo, y no molestó a destacados liberales. Si bien les vigilaba, como a Gener y a sus seguidores. Eso que según Tacón, Gener había tratado de seducir al comandante del Castillo de San Severino y al $2^{\circ} \mathrm{Jefe}$ de regimiento de Galicia, a quienes cambió de destino, y actuaba defendiendo las ventajas de la unión con Estados Unidos. ${ }^{14}$ Sin embargo, el hecho de haber regresado recientemente de un exilio de 11 años probablemente actuaría como un elemento disuasorio. Durante esta época informaba al Gobierno de sus actuaciones y los controlaba, pero no actuó con contundencia a pesar de las acusaciones que les dispensaba.

$\mathrm{Su}$ actitud no fue moderada o contemporizadora. El hecho de vigilarlos ya demuestra que permanecía atento y que no confiaba en ellos, pero por el momento no se había producido ningún acto que pudiera suponer un desafío serio para las autoridades y por eso decidió mantener una actitud prudente, permitiendo cierto grado de discrepancia política. Esto no significaba que no hubiera represión, bajo su mandato se persiguió la vagancia asociándola a la delincuencia y se creó un sistema de trabajos forzados conformado por presos, pobres, emancipados y cimarrones. ${ }^{15}$ Lo que ocurría era que no era necesario extenderla a las clases medias, por mucho que algunos miembros de estas eran liberales. Actuar con demasiada contundencia en un momento de calma y de afianzamiento de la nueva política española en Ultramar, podía resultar contraproducente. Por esto, sobre estos ejerció un control que solo en algunos casos individuales terminó en salidas forzadas de opositores.

Entre los expulsados podemos mencionar a José Antonio Saco, a quien el Capitán general expidió una orden en 17 de junio de 1834 para que saliera rumbo a Trinidad en un plazo de quince días. Al recibirla, Saco solicitó audiencia con Tacón

\footnotetext{
${ }^{13}$ Juan Pérez de la Riva, "Introducción", a Correspondencia reservada del Capitán general don Miguel Tacón, 1834-1836, pp. 13-18; Nicomedes Pastor Díaz y Francisco de Cárdenas, Galería de españoles celebres contemporáneos, tomo III, pp. 26-27.

${ }^{14}$ José Ahumada y Centurión, Memoria histórico política de la isla de Cuba, redactada de orden del señor ministro de Ultramar, Imprenta de A. Pego, La Habana, 1874, pp. 64-65.

${ }^{15}$ Yolanda Díaz Martínez, "De marginados a trabajadores. Usos y destinos de la población penal en La Habana", Millars. Espai i Història, núm. 35, 2012, p. 141.
} 
quien le dijo que el destierro le había sido impuesto por ofender a Juan Bernando O'Gavan y por tener mucha influencia sobre la juventud de la isla. Además entraban enemistades personales, puesto que su expulsión se realizó a petición del conde de Villanueva. Algunos amigos de Saco recurrieron al general que se negó a mantenerlo en Cuba, pero dándole permiso para ir a donde quisiera. Mientras encontraba el barco que le acomodase a su destino permaneció libre. Finalmente, el 13 de septiembre salió destino a Falmouth. ${ }^{16}$

A principios de 1835 embarcó hacia la Península el editor y periodista Tiburcio Campe por orden de Tacón, argumentando que este era el líder en las reuniones y clubs secretos y que tendía a escribir en sentido peligroso. De su imprenta habían salido papeles considerados subversivos e injuriosos, en concreto uno firmado por Domingo del Monte contra la Real Sociedad Económica de La Habana. La revista quincenal que dirigía Campe, El Pasatiempo, había dejado de publicarse en septiembre de 1834 a causa de la aplicación del Reglamento de Imprenta. ${ }^{17} \mathrm{Al}$ margen de posibles enemistades, los represaliados tenían diversos puntos en común. Eran hombres que destacaban por sus ideas, pero por encima de ellas por su ascendencia sobre otras personas. La posibilidad de expansión de sus opiniones a través de sus escritos resulta una característica común a ambos casos. La ideología liberal podía tolerarse siempre que las personas que la mantuvieran permanecieran en un plano discreto o anónimo.

El mantenimiento de una represión individualizada se hizo sobre la base de que el orden político estaba plenamente garantizado. Pero aun así, la intención de mantener

\footnotetext{
${ }^{16}$ José Antonio Saco, Colección de papeles científicos, históricos, politicos y de otros ramos sobre la isla de Cuba ya publicados ya inéditos, Imprenta d'Abussons y Kugelmann, París, 1859, tomo III, pp. 45 y 62-84. O'Gavan era deán de la catedral de La Habana y presidente de la Real Sociedad Patriótica; Eusebio Valdés Domínguez, Los antiguos diputados de Cuba y apuntes para la historia constitucional de esta isla, El Telégrafo, Cuba, 1879, pp. 256-257. Durante su intercambio de palabras con Tacón, Saco le reprendió por el destierro de Telesforo Correa. O'Gavan era deán de la catedral de La Habana y presidente de la Real Sociedad Patriótica.

${ }^{17}$ Jesús Raúl Navarro, Entre esclavos y constituciones, pp. 175-181; Juan Pérez de la Riba, "Introducción", a Correspondencia reservada del general Tacón, 1834-1836, pp. 133-134. El general Tacón al hablar de la marcha a la Península de Campe no indica si esta había sido forzada o no. Pero es cierto que a continuación habla de Pedro Sirgado, amigo íntimo de Saco y de sus mismas ideas y dice que este pasó voluntariamente. La omisión respecto a Campe parece interesada y va en la línea de omitir que fue obligado a dejar la isla. También desconocemos si fue conminado a irse o embarcado forzosamente, aunque lo primero tal y como había sucedido con Saco parece la opción más factible; Juan José Sánchez Baena, El terror de los tiranos. La imprenta en la centuria que cambio Cuba (1763-1868), Universitat Jaume I, Castellón, 2009, pp. 139-140.
} 
las colonias al margen del sistema liberal y su autoritarismo, ${ }^{18}$ harían que actuara en este sentido en cuanto fuera necesario. El 29 de septiembre fondeó en Santiago de Cuba el bergantín Guadalupe con diarios de Cádiz y la Gaceta de Madrid, que recogían el real decreto de 13 de agosto de 1836 por el que se proclamaba la Constitución de 1812. Esa misma noche el mariscal Manuel Lorenzo, gobernador de la parte oriental, reunió al ayuntamiento perpetuo de la ciudad que decidió la proclamación de la Carta Magna, a imitación de lo que ya había sucedido en Puerto Rico. ${ }^{19}$ Estos hechos significaron una variación en la forma de reprimir para aquellos sobre los que ya estaba actuando sin que se hubiera adoptado sobre ellos una posición definitiva. Ante los cambios en la situación política, Tacón decidió actuar de manera más contundente.

En este caso se encuentra el abogado Juan Ramírez de Estenoz, que había sido preso en la isla y que logró escapar fugándose con los autos a Madrid para que el Tribunal Supremo de España e Indias viera la cuestión. En Madrid se le redujo a prisión durante seis meses y posteriormente fue llevado a La Coruña desde donde se le embarcó para La Habana, en cuyo puerto entró en febrero de 1836. Desde allí fue trasladado al castillo del Morro y finalmente castigado por el Capitán general a seis años de destierro del país. El 12 de octubre de 1836 fue deportado a Puerto Rico, pero permaneció poco tiempo allí puesto que el 17 de noviembre se le refrendó el pasaporte con la condición de que pasase a Málaga, por estimar su presencia perjudicial. Durante su breve estancia en la Antilla menor publicó un folleto titulado: A las islas de Cuba y Puerto Rico: estudio de derecho público, que fue censurado y que finalmente se editó con un pie de imprenta de Santo Tomás para eludir la prohibición. Desde Málaga fue remitido a Cádiz donde publicó un nuevo folleto denominado Manifiesto a la nación española y a su Gobierno constitucional, con el que según sus palabras pretendía difundir los errores absurdos que se cometen en la nación y por el que fue tildado de separatista. ${ }^{20}$

En la Península, su actuación fue la de intentar salir ya que no podía ejercer su profesión. Precisamente esta, además de su liberalismo exaltado, explica su deportación ya que en la etapa de represión arbitraria que se avecinaba no era conveniente la presencia de incomodos defensores de los apresados. El 30 de enero de 1838 pidió que se le dejara retornar a Santiago de Cuba y el 16 de julio de 1839, de nuevo, alegando

\footnotetext{
${ }^{18}$ Luis Navarro García, La Independencia de Cuba, Mapfre, Madrid, 1992, p. 118.

${ }^{19}$ Manuel Lorenzo, Manifiesto del general don Manuel Lorenzo a la nación española, Imprenta de Tiburcio Campe, Cádiz, 1837, pp. 9-11.

${ }^{20}$ AHN, Ultramar, Leg. 4612, Exp. 18. "Expulsión de la isla del abogado Juan Ramírez de Estenoz, acusado de excesos cometidos en el uso de la imprenta".
} 
que no había participado en los sucesos políticos de la ciudad y que había cumplido la mitad del tiempo de destierro. Ante la imposibilidad de volver pidió que se le dejara pasar a Estados Unidos, petición de la que posteriormente se retractó. Finalmente, cuando estaba tratando de incorporarse al colegio de abogados de Cádiz, fue incluido en la amnistía y el 27 de octubre de 1840 se le expidió pasaporte para regresar aunque permanecería vigilado por las autoridades. ${ }^{21}$

Un caso similar es el que le sucedió a otro grupo de individuos. Justo de Latorre fue denunciado el 2 de noviembre de 1835 por haber proferido unas supuestas palabras subversivas en el acto de elección de oficios en la Universidad. Poco después la causa se amplió a los doctores Blas de Wiarreta y Rubio, Antonio Font y José Antonio Aragón, quienes supuestamente habían mantenido con el primero la conversación sediciosa. Todos quedaron detenidos aunque solo conocemos la ubicación exacta de Latorre, en La Cabaña, y Wiarreta en el Morro. El fiscal militar les abrió sumaria, pero todos los testigos desmintieron al denunciante Antonio Pita, por lo que fueron abiertas nuevas diligencias en las que declararon otras 23 personas sin resultado positivo para la acusación. La causa a pesar de que formalmente continuaba y pasó al auditor de guerra en la práctica quedó detenida por la ausencia de elementos incriminatorios. A falta de ellos, el 17 de julio se produjo un registro de su celda en que se encontró una carta en donde se quejaba de la tiranía de su opresor. Como consecuencia de esto fue trasladado a una galera de la Nueva Cárcel y ubicado en una de las celdas recientemente construidas por indicación del propio Tacón. ${ }^{22}$

Ante el nulo avance del procedimiento y la ausencia de pruebas se puso al frente de la causa a José Ildefonso Suarez, asesor suyo y quien había apadrinado la denuncia de Pita. Este ordenó la prisión de Manuel de Latorre Machado, padre de Justo. La inculpación contra ambos de Latorre y Wiarreta continuó por “haber faltado en algunas frases de nuestros escritos a la delicadeza del señor presidente de la comisión y del fiscal del juzgado de guerra". Según de Manuel de Latorre, José Antonio Aragón había sido absuelto y liberado, sin embargo, su nombre está recogido en la recopilación del Ministerio de Marina, por lo que posiblemente seria relegado posteriormente. Ante la poca solidez de los cargos el fiscal pidió de nuevo el sobreseimiento y todos esperaban

\footnotetext{
${ }^{21}$ Ibídem.

${ }^{22}$ Manuel de Latorre Machado, El procónsul de La Habana y los deportados de la isla de Cuba, pp. 1-6. La carta iba supuesta dirigida al conde de las Navas; ANC, Asuntos Políticos, Leg. 39, Sig. 69. "Real orden, fecha 4 marzo 1839 contentiva de la lista de los procesados y expulsados por delitos políticos de la isla de Cuba por el Gobernador y Capitán general don Miguel Tacón".
} 
ser liberados, pero el 16 de octubre de 1836 se les avisó de que el 18 los cuatro saldrían hacia Barcelona con la prohibición perpetua de volver. Hasta entonces tan solo podrían comunicarse con su familia a través de los vigilantes, para que les facilitaran ropa y dinero. Con ellos saldría Agustín Delgado, antiguo empleado de hacienda, que oyendo que se iba a proclamar la Constitución en el Teatro el día 29 salió a celebrarlo y fue apresado al día siguiente. ${ }^{23}$

Con la proclamación de la Carta Magna el Capitán general se decidió a actuar contra aquellos con los que el proceso estaba detenido. Esto supuso instaurar un nuevo rasero para medir las conductas sediciosas, que serían menos toleradas y reprimidas de una forma más severa y discrecional. Con anterioridad les había retenido, pero con la excusa de continuar el proceso ya se atrevió a deportarles. Además, supuso que la reactivación de la represión sobre los civiles liberales fue tendente a la de expelerlos del país. En esta actuación encontramos un juicio de valor del propio Tacón, cuando actuó así fue porque consideró que esta era la mejor manera de atajar la posibilidad real de cambio que se entreabría. No olvidemos que la relegación estaba muy presente en esos momentos, ya que miles de prisioneros carlistas habían llegado desde la Península y estaban siendo empleados en el ejército y en la realización de obras públicas. Aplicar este castigo también para los disidentes políticos cubanos era una cuestión de que fuera más eficaz que otros en su caso concreto.

En la isla, además de los carlistas, centenares de hombres sin voz: emancipados, cimarrones y presos eran obligados a trabajar, bajo el mismo principio de utilidad. A la explotación que sufrieron se debe en buena medida el proceso de modernización llevado a cabo en las infraestructuras de La Habana. Sin embargo, la marginalidad, convertida en disidencia social por Tacón, constituía la menos peligrosa de las conductas inapropiadas para el Capitán general, puesto que era relativamente fácil de encauzar al llevarse a cabo por sujetos numerosos pero aislados, sin conexión, ni pretensiones de transformación social ni política. La otra, la perniciosa y percibida como realmente amenazadora era la compuesta por individuos con ideología que concebía a las personas, o a algunas de ellas, como poseedoras de derechos políticos. Todo lo opuesto al rígido orden colonial que se pretendía implantar. Poner a trabajar a una elite ilustrada

\footnotetext{
${ }^{23}$ Causas seguidas en el segundo semestre de 1836. ANC, Comisión Militar, Leg. 131, Exp. 2. "Relaciones de las causas que ha sentenciado la Comisión Militar del año 1826 a 1839"; Manuel de Latorre Machado, El procónsul de La Habana y los deportados de la isla de Cuba, pp. 3-4 y 6-10. La cita original en cursiva en el texto.
} 
era altamente contraproducente, por cuanto a pesar de cuestionar el orden poseían solvencia económica y posición social. Además, mezclados entre los marginados podían darles algún tipo de instrucción y, todavía peor, expandir entre ellos sus ideas. Este peligro se agudizaba incluso más si formaban parte de su mismo estrato social, como fue el caso de algunos de los confinados. Por esto, la mejor opción para el poder fue la de sacarles del país.

Del mismo modo se desató una oleada represiva contra aquellos tenidos por liberales en La Habana. Ocho soldados y un distinguido del regimiento de La Habana fueron sacados de sus cuerpos y llevados a Europa, por haber cantado canciones patrióticas. En la misma causa, José Guzmán, José de la Tejera, Juan Álvarez Carantoña y Juan Núñez de la Terga fueron condenados por providencia gubernativa a cadena perpetua en Melilla. El 17 de octubre habían sido embarcados con destino a Cádiz los capitanes Nicolás Canalejo, del regimiento fijo de La Habana y Pedro Menéndez Arango, ayudante del regimiento de Galicia, el primero por hacer un gesto con que descalificaba el ultraje que de Latorre estaba sufriendo y el segundo por haberse manifestado contra el sistema tiránico. Otros quedaron presos: Luis Ugarte, por haber preguntado si un buque que se acercaba era el Guadalete, del que se decía que traía noticias para reinstaurar la Carta Magna; José García Fernández, por manifestar que pronto cesarían las delaciones y falsos testimonios al pasar por delante de Antonio Platero, quien había denunciado a su hermano Antonio por vago; Francisco Castrillón, oficial tercero de la marina, por haber pedido una sopa constitucional en una fonda. Junto a ellos, Sebastián Ferragut, José Eligio, José María del Junco, José de Moya, Ramón Lorenzana, Manuel López, entre otros. Moya, García Fernández, Lorenzana y López serían finalmente deportados a la Península, donde también recabaría Castrillón. $^{24}$

\subsection{La represión tras la exclusión de Cuba del alcance de la Constitución}

La espera de Tacón finalizó el 21 de octubre, día en que le llegaron las órdenes. El nuevo Gobierno, presidido por el progresista José María Calatrava, se decantó a su favor. En las instrucciones se estipulaba que la aplicación de la Constitución se

\footnotetext{
${ }^{24}$ Manuel de Latorre Machado, El procónsul de La Habana y los deportados de la isla de Cuba, pp. 10-11; Justo de Latorre, Una ojeada al manifiesto que publicó el Excmo. Sr. D. Miguel Tacón al dejar el mando de la isla de Cuba, p. 15.
} 
circunscribía a la Península e islas adyacentes y le pedían que acomodase a ello sus disposiciones. En las reales órdenes se conminaba a realizar con prontitud las elecciones y no se decía nada acerca del modo de actuar contra los partidarios de la Carta Magna. ${ }^{25}$ A pesar de ello, en la práctica significó un aval a la política emprendida por la máxima autoridad colonial, que intensificó su política de castigo y la presión que ejercía sobre Lorenzo. A partir de ese momento se sintió fuerte para actuar según su propio criterio, dada la postura del Gobierno de mirar hacia otro lado sin involucrarse en las disposiciones que ejerciese para ello. La ausencia de indicaciones del Ejecutivo dejaba a voluntad del Capitán general las acciones que tomara contra los liberales, por tanto, la represión ejecutada está intrínsecamente ligada a su figura.

Extender la Constitución gaditana a Cuba significaba configurarla como un territorio español más. Suponía ampliar los derechos políticos que existían en la Península e incluirla en la nación española. Esto daba fuerzas a los partidarios de la abolición puesto que plantarse que pudiera haber esclavos en Europa e islas adyacentes era simplemente impensable y la extensión de los derechos políticos hubiera llevado a cuestionarse la pervivencia de la esclavitud que en 1833 había sido abolida en todos los territorios británicos.

Además, significaba conceder potestad política a los criollos. Es decir, otorgar poder a unas élites liberales e ilustradas que realizarían propuestas para defender sus intereses, que no tenían necesariamente que converger con los que desde Madrid se habían diseñado. La elección previa para el Estamento de Procuradores de José Antonio Saco por Santiago de Cuba, así como las de Juan Montalvo por La Habana y Francisco de Armas por Puerto Príncipe, en contra de la opinión de Tacón, mostraba que había entre los criollos un deseo de hacer valer sus intereses. Todo ello suponía un peligro económico para los intereses peninsulares, no solo porque significaba que podía acelerarse el fin del creciente y económicamente rentable esclavismo, sino que además quitaba a la mayor de las Antillas la consideración de colonia, y por tanto, de territorio destinado a la extracción de rentas por la metrópoli.

Por todo esto, aquellos que se atrevieron a proclamar la Constitución pagarían por ello, aunque no habían hecho sino secundar lo estipulado por el real decreto de 13 de agosto de 1836. A Cuba se le había otorgado representación en el Estamento de

\footnotetext{
${ }^{25}$ Jesús Raúl Navarro, Entre esclavos y constituciones, p. 110; Manuel Lorenzo, Manifiesto del general don Manuel Lorenzo a la nación española, p. 13. Según Lorenzo, las órdenes le llegaron el 21 o el 22 de octubre. Las reales órdenes de 19, 23 y 25 de agosto en pp. 66-68.
} 
Procuradores en 1834, a pesar de las continuas trabas para ello del Capitán general. Además, en la Península habían accedido al poder los partidarios de un liberalismo más extendido, por lo que los liberales más avanzados en las Antillas procedieran a proclamar el texto de 1812 era previsible, y no solo eso, sino consecuente con sus principios. El decreto de aprobación de la vigencia de la Carta Magna de 1812 no estipulaba excepción alguna y en la misma se establecía en su capítulo primero que "la nación es la reunión de todos los españoles de ambos hemisferios", incluyendo en el concepto a los habitantes de las posesiones ultramarinas y por consiguiente otorgándoles derechos políticos.

A pesar de lo expuesto, el intento de extender la promulgación de la Constitución no puede considerarse como ingenuo. Teniendo en cuenta que la situación política de Cuba estaba por determinar, las actuaciones de los liberales iban encaminadas a decantar la balanza hacia su lado. Intentaron de ese modo aprovechar la situación de incertidumbre que se produjo después de los sucesos de la Granja, tratando de llevar a cabo una política de hechos consumados que dificultara una vuelta atrás. Sobre todo con los antecedentes que supuso el Trienio, en el que el proyecto de conceder cierta autonomía política culminó en un fracaso estrepitoso.

Los liberales más exaltados en la Península se configuraron en la práctica como fervientes partidarios del mantenimiento de las últimas posesiones en América como colonias. Los argumentos que aportaban eran diversos pero abarcaban la distinta composición de la población, la lejanía, las diferencias entre ambas islas y la conveniencia de las leyes especiales para un mejor Gobierno y para el mantenimiento de las mismas. Durante el transcurso de los debates en el Congreso acerca de la situación de Cuba, surgieron dos ideas que capitalizaron el debate y pasaron a formar parte del discurso oficial: la concesión de derechos políticos llevaba irremediablemente a la independencia y a la dominación negra. Amparándose en estas argumentaciones tergiversadas, la Antilla mayor pasó "de colonia de Antiguo Régimen a colonia moderna" ${ }^{26}$ De este modo, cualquier persona que realizara la más mínima petición de derechos políticos podía ser acusada de independentismo. Esto suponía un burdo intento

\footnotetext{
${ }^{26}$ José Antonio Piqueras, Sociedad civil y poder en Cuba, pp. 80-86. El más enconado opositor a la extensión de los derechos políticos a Cuba fue Agustín Argüelles, aunque Vicente Sancho también tuvo un papel destacado. Tan solo unos pocos del ala más radical del progresismo se mostraron en contra de esta política. Ver la intervención de Diego González Alonso en 12 de abril y Fermín Caballero en 14 de abril de 1837. A pesar de sus intentos la isla seria excluida de representación en Cortes.
} 
de manipulación, mediante el cual, los liberales que tanto clamaban por los derechos en Europa trataban de esconder la contradicción que significaba condenar a los cubanos a vivir en un estadio de sitio permanente. Eso los libres, porque los esclavos no eran sino una mera posesión.

Si la actuación de Tacón había ido tendente a un aumento de la represión ya incluso antes de recibir el apoyo gubernamental, al contar con esta dio una nueva vuelta a la tuerca. En primer lugar actuó contra los liberales de La Habana. El 23 de octubre de 1836 detuvo al platero Casimiro Maurenti. Tras permanecer preso hasta el 6 de noviembre fue embarcado en el Vigilante junto con Claudio Valdés, Tiburcio Carrasco y Rafael Estrada, que resultaron como él condenados en un juicio caracterizado por la celeridad y la falta de rigor. Llegaron a La Coruña el 5 de diciembre de 1836, quedando libres pero bajo la vigilancia del gobernador militar de la provincia. Residieron en dicha ciudad hasta que el 22 de agosto de 1837 se les conminó a salir de la misma, puesto que a pesar de que podían vivir libres en la Península estaban exceptuados los sitios reales, corte y puertos de mar hasta la distancia de 20 leguas. ${ }^{27}$

Junto a ellos, en La Coruña residiría Ignacio Lafita, del que desconocemos la fecha y las condiciones de su deportación. Este fue catalogado como vago y de mala nota, aunque dentro de estos era un caso diferente. Había cumplido diez años de prisión en Puerto Rico por robo, y fue embarcado acusado de haber cometido dos nuevos robos. ${ }^{28}$ Las autoridades aprovecharon la confusión del momento para incluir en los embarques a gente sin vinculaciones políticas cuya conducta era tenida por poco apropiada y entre ellos es posible que encontremos a otros que habían delinquido. En el caso de Lafita, la relegación muestra la desidia respecto a estos individuos y la incongruencia de las autoridades. Para casos como el suyo existían los tribunales ordinarios y para ponerles fuera de circulación no era necesario recurrir a su traslado. Para Tacón y su mentalidad autoritaria cualquier tipo de disidencia constituía una transgresión.

\footnotetext{
${ }^{27}$ AHN, Ultramar, Leg. 4613, Exp. 6. "Casimiro Maurenti, natural de La Habana y confinado en La Coruña pide volver a su país". Maurenti pasó a un pueblo del interior de la misma provincia; AHN, Ultramar, Leg. 4613, Exp. 7. "Expediente promovido en 1837 por Tiburcio Carrasco solicitando se le levante el destierro que para La Coruña le impuso el Capitán general y que se le permita regresar a La Habana".

${ }^{28}$ AHN, Ultramar, Leg. 4613, Exp. 14. "Expediente sobre el regreso a la isla del expulsado y confinado a La Coruña don Ignacio Lafita".
} 
También encontramos entre los primeros represaliados a los militares Pedro Rojas, Felipe Farías, Julián Parreño, Agustín Sojo, y al civil Florentino Montolio. Acusados de haber "arrancado" a artesanos y campesinos de su trabajo y suprimir la obediencia de pardos y morenos. Fueron condenados por la Comisión Militar a ser enviados a La Coruña. ${ }^{29}$

La forma de actuación de Tacón suponía dominar la capital, enviando un mensaje claro de cuáles eran sus planteamientos y de que no permitiría ningún cuestionamiento de los mismos. Pero el siguiente paso consistía en someter al oriente. Algo que resultó satisfactorio para sus intereses puesto que los intentos de Lorenzo para que su acción tuviera repercusión más allá de la ciudad de Santiago fracasaron. Para reafirmar su autoridad, el Capitán general consideró que el mejor medio era extender la represión hacia otras poblaciones a fin de abortar cualquier replica o ayuda a la proclamación llevada a cabo en Santiago.

El presbítero Ramón Fernández, capellán del ejército de la isla y de la Milicia Nacional de Sevilla, había huido en 1823 a Cuba después de permanecer en el sitio de Cádiz. Allí, se estableció en Santa Clara como teniente cura de la villa. Durante la proclamación del texto de 1812 en Santiago de Cuba mostró una gran exaltación. Por esto fue detenido el 12 de diciembre de 1836 y encerrado en la cárcel. Al cabo de tres meses se le tomó declaración atribuyéndole la lectura de papeles inapropiados y la intención de jurar la Constitución en Santa Clara. El 21 de marzo de 1837 fue embarcado en el vapor Juliana con el administrador de correos de la misma localidad, Jesús María Ledón, que habría sufrido un periplo similar. Ambos desembarcaron en Santander. Durante su estancia en la ciudad, Fernández envió una carta solicitando indulto, reconociendo que aunque era liberal jamás se había opuesto a las disposiciones del Gobierno, mostrándose indignado porque el expediente le había calumniado. Sin embargo, poca fe tuvo en su éxito ya que durante el desplazamiento en una galera a Valladolid, lugar donde debían ubicar su residencia, ambos se fugaron. ${ }^{30}$

El caso de Fernández era especialmente destacado. De origen peninsular, capellán del ejército triunfante de la isla y de la Milicia Nacional de Sevilla. Estuvo en el sitio de Cádiz y se vio obligado a huir para eludir la represión que siguió a la caída del Trienio Liberal. Una vez allí, había mantenido sus principios y precisamente por

\footnotetext{
${ }^{29}$ Olga Portuondo, Cuba. Constitución y liberalismo (1808-1841), tomo II, pp. 167-168.

${ }^{30}$ AHN, Ultramar, Leg. 4608, Exp. 9. Expediente de deportación de Ramón Fernández y Jesús María Ledón.
} 
ellos fue acusado de separatista y deportado. Un cumulo de circunstancias demasiado importante para determinados liberales en el Ejecutivo.

Ramón Gil de la Cuadra, ministro de la Marina, manifestó a raíz de la petición de Fernández que se estaban revisando las solicitudes de indulto y que era conveniente el olvido de dichos sucesos excepto para los que habían cometido excesos, delitos comunes u ocasionado perjuicio a terceros. Esta medida contribuiría a evitar la ruina de muchos individuos y de sus familias. Pedía ser benevolente, puesto que la actuación de algunos no había tenido intenciones separatistas, sino de adhesión a la Constitución, creyendo que su publicación seria buena para aquel país. Los fiscales se mostraron de acuerdo con tal pretensión. No obstante, el Tribunal que revisaba sus causas no se mostró tan magnánimo, y ante los defectos sustanciales en los expedientes de relegación pidió al Capitán general que subsanara las deficiencias aportando mayor información sobre las motivaciones e indicara de manera precisa el tiempo que estos hombres debían permanecer en la Península. De este modo, con el sumario de Fernández y Ledón sucedía lo mismo que con las 32 peticiones anteriores, correspondiente a otras tantas solicitudes de indulto. ${ }^{31}$ Una actuación que prolongaba el tiempo de confinamiento y que no contribuía a la pronta resolución de sus expedientes. Quedaba claro que al tratarse de las colonias no se hacía distinción entre sujetos de una u otra clase, no importaba la amplia trayectoria liberal, puesto que en lo referente a estas la distinción era otra, cualquiera que se opusiera a la consideración colonial de Cuba era un enemigo. Esto incluía tanto a peninsulares como a criollos, estos últimos serían los más afectados por la buena relación y el apoyo que recibieron de Lorenzo, pero el origen no fue un elemento determinante de la represión, que se ejecutó sobre los liberales sin importar su procedencia.

El caso de Fernández resultaba contrapuesto al de Cirilo Alameda, quien había sido nombrado arzobispo de Santiago de Cuba en abril de 1831 como modo de alejarle de la Península, dadas sus simpatías carlistas. Al producirse los sucesos de la Granja en España se pronunció abiertamente contra el liberalismo, pero durante los sucesos de Santiago tuvo una actitud favorable a Tacón y a su política ultramarina, y utilizó su influencia contra Lorenzo. El 2 de enero de 1837 había llegado la goleta Isabel II con instrucciones para su apresamiento y posterior envío a la metrópoli. Pero alertado de la

\footnotetext{
${ }^{31}$ AHN, Ultramar, Leg. 4608, Exp. 9. Expediente de deportación de Ramón Fernández y Jesús María Ledón.
} 
orden se puso bajo el amparo de las autoridades británicas que le embarcaron rumbo a Jamaica, donde llegó el día 6. El motivo que dio el arzobispo fue que temía un atentado, pero lo cierto es que la situación en Santiago estaba bajo control de los enviados de Tacón y que en ese caso hubiera regresado poco después. En realidad fue una recompensa del Capitán general por actuar contra la implantación del liberalismo en la isla. $^{32}$

El apoyo dado desde el Gobierno central a la máxima autoridad colonial y la aproximación de las tropas enviadas desde el occidente provocaron que Lorenzo fuera perdiendo apoyos entre los jefes y oficiales del ejército de tierra y la marina, que el 18 de diciembre le mandaron dos exposiciones en que afirmaban que el mando de Tacón no había sido cuestionado en ningún momento, que acataban la suspensión de la aplicación de la Constitución y que no iban a luchar contra las tropas de la reina. Pedían al gobernador oriental que cediera para evitar una confrontación, por el bien de Cuba y de su permanencia en España. Lorenzo se sintió enormemente contrariado por estas manifestaciones, aunque el día anterior ya se había reunido el ayuntamiento que envió una comisión en la que aceptaba suspender la vigencia de la Carta Magna. A cambio, trataban de asegurar la inviolabilidad de los que habían participado en su proclamación y de las autoridades. El 21 de diciembre, las tropas enviadas desde occidente ya se encontraban en Bayamo y el 22 Lorenzo embarcó en la fragata inglesa Vestal, dos días más tarde pasó a la Ana María que le llevó a Cádiz. ${ }^{33}$

Las órdenes del ejército eran de castigar cualquier falta que se hubiera cometido durante los episodios políticos. ${ }^{34}$ Una vez afianzado el poder pronto comenzaría la represión. El día 7 de enero de madrugada se inició una redada en Santiago de Cuba que terminó con varios detenidos que fueron llevados el día 9 al Castillo del Morro. Allí se hallaban Vicente Moureau, panadero y contratista de los víveres de los buques de guerra de la estación de la ciudad; el relojero Pedro Jeunet; el agricultor Félix Artires; el escribano José Eduardo Bulte y Rafael Trujillo, campesino arrendatario mediante pago en especie en una propiedad de Pedro Arango. A continuación se les formó la correspondiente causa con objeto de determinar su culpabilidad. En ella, además de los citados estuvieron incluidos Joaquín de Faria, a quien se permitió residir en su casa

\footnotetext{
${ }^{32}$ Jesús Raúl Navarro, "El exilio carlista", pp. 173-182.

${ }^{33}$ Manuel Lorenzo, Manifiesto del general don Manuel Lorenzo a la nación española, pp. 19-21 у 125-133.

${ }^{34}$ Jesús Raúl Navarro, Entre esclavos y constituciones, p. 168.
} 
hasta que la sentencia del juicio, y el hacendado Daniel Termes, que también se encontraba preso. Además se incluyó en el procedimiento a algunos que no habían sido detenidos y se encontraban en busca y captura. Estos eran José María Otamendi, Ramón Cuervo, Esteban Griñán, Andrés Silva, Rafael Vega, Leopoldo del Castillo, Eduardo Azanza y Honori Castell. Desconocemos la profesión de la mayoría de ellos, a excepción del escribano de la aduana Rafael Vega y del comerciante y poseedor y arrendatario de seis esclavos Honori Castell. El resto estaban catalogados como vagos, acusación que en ciertos momentos se extiende a todos, pero respecto a estos comprende uno de los pilares fundamentales mostrando que su perfil social era diferente. ${ }^{35}$

La causa seguía unas pautas claramente abusivas. No se les hizo una imputación concreta formal y ni siquiera se les tomó declaración. Una sucesión de testigos declararon sobre la presunta vagancia de muchos de los incriminados, que tenían ideas exaltadas, de que habían oído rumores sobre ellos y de que les habían visto en algunas acciones "subversivas" concretas. La acusación incidía con insistencia sobre una supuesta reunión que se había realizado el 22 de diciembre en la que los participantes supuestamente acordaron continuar perturbando el orden. Ese día hubo incidentes en la ciudad, con miembros del Regimiento de Cataluña y de la Milicia Nacional apoyando a la Constitución, pero la situación fue finalmente reconducida. Cuando algunos de los acusados presentaron testigos que les exculpaban, estos simplemente se desecharon. Así ocurrió con José Eduardo Bulte, de quien varios vecinos declararon que se encontraba enfermo y no había salido de casa durante los días de la supuesta reunión. ${ }^{36}$

De este modo, se trataba de legitimar su actuación tratando de aparentar una supuesta trama conspirativa que no había realizado acción alguna. Por esto podemos considerarlo un pretexto con el que pretendía hacer ver que el peligro continuaba y justificar así su forma de proceder frente a otra posibilidad que se planteaba, la de la magnanimidad. Lo cierto es que la represión se hacía contra aquellos que habían tenido un papel destacado durante la proclamación de la Carta Magna y con aquellos que habían destacado por su liberalismo. Junto a ellos, otros considerados pobres o vagos, a

\footnotetext{
${ }^{35}$ AHN, Ultramar, Leg. 4613, Exp. 12. "Expediente sobre la expulsión de la isla de don Félix Artires en 1837 y sobre la vuelta a aquel país". Esta distinción se hizo en el propio juicio y dio como resultado que en los clasificados de vagos estaban incluidos Otamendi, Cuervo, Griñan, del Castillo, Azanza, Silva y Trujillo. En el grupo de los subversivos se incluyó a Vega, Moureau, Bulte y Artires.

${ }^{36}$ Ibídem.
} 
los que se temía por su posible incorporación a revueltas o desórdenes, a los que se desposeía de significancia política quizá únicamente por su perfil social. La mayoría de ellos habían participado en los sucesos aunque ello no quiere decir que su adscripción política en general fuera tan sólida como en el resto, integrantes de las clases medias. El cualquier caso, el temor de las élites de que una minoría ilustrada pudiera conducir al "populacho" hacia la militancia política o utilizarlos en casos de sublevaciones era recurrente y por eso, según la visión de Tacón, era necesario que miembros de ambos grupos fueran reprimidos. Teniendo en cuenta los modos de represaliar a las clases bajas, la deportación constituyó una pena utilizada únicamente en relación con los sucesos de Santiago. Con el resto se empleaban las penas habituales, que incluían los trabajos temporales en obras públicas. ${ }^{37}$

Que el juicio fuera una farsa no quiere decir que algunos no hubieran participado en los actos de proclamación de la Constitución. No fue este el caso de Bulte, que posteriormente fue absuelto manifestando las autoridades que "se le expulsó al calor de los acontecimientos". ${ }^{38}$ Sin embargo, resulta evidente que si se trataba de reprimir a los liberales más destacados, es lógico que algunos de ellos se hubieran dejado ver en apoyo al general Lorenzo. Los testigos, por favorables al Gobierno que fueran, también nos aportan información sobre estos hechos. Dos de ellos decían que habían visto personalmente a Moureau, natural de Verona (Italia), y a Jeunet, oriundo de Besamor (Francia), portando la bandera tricolor francesa acompañados por otros individuos. Uno de ellos afirmaba que además iban cantando la marsellesa. Otros dos afirmaban que varias personas les habían comentado lo propio acerca de ellos. Además, iban acompañados según algunos testigos de mujeres y gentes de color, como elemento que trataba de denigrar a los principales acusados, aunque ninguna mujer fue represaliada y únicamente encontramos dos capitanes de pardos entre los relegados. Si bien las acusaciones contra estos dos iban en esta dirección, no sucedía lo mismo con Termes, Artires, Bulte y Bravo, cuyas acusaciones iban en la línea de señalar que eran liberales destacados. Sin embargo, la sentencia declaró probado que eran extranjeros, como

\footnotetext{
${ }^{37}$ Causas seguidas del primer semestre de 1835 y 1836. ANC, Comisión Militar, Leg. 131, Exp. 2. "Relaciones de las causas que ha sentenciado la Comisión Militar del año 1826 a 1839"; ANC, Comisión Militar, Leg. 13, Exp. 5. Causa contra José Díaz y otros por tener este un periódico en que se difamaba al Capitán general y Clemente Ruiz por leerlo; ANC, Comisión Militar, Leg. 18, Exp. 11. Causa contra Lisandro Castellanos, acusado de seducir al cabo Blas Metia.

${ }^{38}$ ANC, Comisión Militar, Leg. 19, Exp. 4. Causa contra José Eduardo Bulte y otros por su conducta política en la proclamación de la Constitución en Santiago de Cuba.
} 
Moureau y Jeunet, y que habían defendido la actitud de Lorenzo y cantando la Marsellesa en su presencia. ${ }^{39}$

Desconocemos que paso con Jeunet, aunque probablemente sería expulsado del país. A los demás, sabemos que se les conminó a decir el lugar a donde querían pasar, exceptuado Puerto Rico. Sin embargo, finalmente tanto Bulte como Artires, que decidió pasar a Jamaica, fueron expulsados a Marsella en el bergantín Alfonso, probablemente con los demás encausados en este procedimiento. Desde allí, Artires pasó a Barcelona y trató de que se le indultara, contando con el aval del jefe político José María Cambronero que certificaba su buena conducta. Al analizar la situación de Artires, las autoridades se quejaban de que no tenían el expediente de deportación y criticaban la actitud no por haberle reprimido, sino por no haber seguido el procedimiento legal para ello, estipulado en las Leyes de Indias. Finalmente, esto resultó en su propio beneficio ya que al haberse producido sin dejar ningún tipo de constancia su expulsión a dicha ciudad francesa no estaba en la lista de aquellos a los que se prohibía retornar. ${ }^{40}$ Del grupo únicamente Artires y Bulte están recogidos en la lista del Ministerio de la Marina ya que posteriormente pasaron a la Península. Por ello, el hecho de que Termes, Bravo, Jeunet y Moureau no se encuentren en la misma indica que lo más probable es que no lo hicieran, o que de hacerlo no interpondrían ninguna queja. En el caso de los dos extranjeros es probable que volvieran a sus países.

Tener deportados bajo su tutela resultaba indeseado para las autoridades receptoras. José María Cambronero, jefe político de Cataluña, fue junto al Capitán general de Cataluña, el barón de Meer, la persona que encarnó la represión del liberalismo radical barcelonés a raíz de la toma del poder por los moderados en octubre de 1837 y a quien algunos de los acusados otorgaron la máxima responsabilidad. Que una persona del perfil de Cambronero pretendiera que uno de los desterrados residente en Barcelona obtuviera el permiso para volver a su país, parece ser más bien un intento por deshacerse de elementos cuya presencia en la ciudad aborrecía.

Del resto de procesados, sabemos que Joaquín de Faria fue conducido a la Península y que se le permitió retornar en 1838 o 1839. A Trujillo no sabemos que le ocurrió, pero en el juicio se consideró que su vagancia estaba plenamente acreditada,

\footnotetext{
${ }^{39}$ AHN, Ultramar, Leg. 4613, Exp. 12. "Expediente sobre la expulsión de la isla de don Félix Artires en 1837 y sobre la vuelta a aquel país".

${ }^{40}$ Ibídem; ANC, Comisión Militar, Leg. 19, Exp. 4. Causa contra José Eduardo Bulte y otros por su conducta política en la proclamación de la Constitución en Santiago de Cuba.
} 
igual que el resto a los que se aplicó este castigo. Castell fue detenido aunque seria finalmente liberado y quedó sujeto a vigilancia de la autoridad. Desconocemos que ocurrió con el resto de procesados que no habían sido arrestados, pero ninguno de ellos aparece entre los listados de deportados ni entre los que tenemos constancia que regresaron. Probablemente evitarían ser apresados y dejarían sus lugares de origen por otro lugar en el interior o el extranjero. En el caso de que hubieran permanecido en la isla, el transcurso del tiempo en un contexto de tranquilidad política haría que las ansias represivas se enfriaran, actuando a su favor.

La actuación de Tacón al margen de la ley y la ausencia de constancia escrita sobre ello, manifiesta la plena impunidad con la que su actitud se desenvolvía, especialmente teniendo en cuenta que había expulsado a Francia a unos sujetos a sabiendas de que su nacionalidad era española. La no utilización de las leyes no significó más que una queja individual en el Ministerio. Sin embargo, esta actitud, además debe explicarse en el carácter autocrático del Capitán general, que no solo se dedicó a reprimir duramente a opositores políticos, delincuentes y pobres, sino que además en este caso lo hizo mofándose de los propios represaliados. Remitir a Marsella a unos hombres acusados de cantar la marsellesa debe entenderse en este sentido, más aun cuando se les preguntó el punto a donde querían ir y esto no se consideró. Para Tacón, mantener principios liberales en la colonia era asimilable a mantener una actitud antiespañola.

Además de las ideas, podía haber una actitud interesada en la represión de algunos de estos. Por ejemplo, Moureau era contratista de los bienes de los buques de la armada en Santiago de Cuba y Jeunet era relojero. Los bienes de ambos fueron requisados, en el caso del segundo aduciendo que se hacía para evitar robos y que nadie los había reclamado, aunque Jeunet estaba casado y lo más lógico era que su esposa se hubiera hecho cargo de los mismos. ${ }^{41}$ Por esto, intervenirles los bienes era una medida innecesaria, a no ser que lo que se pretendiera precisamente fuera apropiarse de parte o de su totalidad desde una posición de fuerza. Lo mismo podría decirse de Moureau. Incautar sus bienes equivalía a tener suministros gratuitos para la armada. Enviarle lejos significaba seguramente que en el caso de que hubiera deudas con él, estas no fueran

\footnotetext{
${ }^{41}$ AHN, Ultramar, Leg. 4613, Exp. 12. "Expediente sobre la expulsión de la isla de don Félix Artires en 1837 y sobre la vuelta a aquel país".
} 
saldadas. Además, desposeerle de la venta de los bienes dejaba abierta la posibilidad de la entrada en este negocio.

La lejanía respecto a la metrópoli y el poder omnímodo otorgado a la máxima autoridad militar facilitaba que la represión tuviera un espectro tan amplio como la voluntad del Capitán general. Sin embargo, con ciertos individuos era mejor no extralimitarse, este es el caso de varios miembros del cabildo eclesiástico de Santiago de Cuba que fueron trasladados a Canarias. El Ministerio de Gracia y Justicia dispuso en real orden que les embarcara en el primer buque que zarpara hacia Canarias, probablemente a petición o consulta de Tacón, lo que muestra colaboración del Gobierno al menos en este caso. Se trataba de Bartolomé Mascareñas, Marcelino Quiroga, Miguel Hidalgo, José Antonio Odoardo y Miguel Ángel Pérez, que salieron en La Veloz entre el 5 y el 6 de diciembre de 1837. Sobre José Teodoro Martínez las fuentes son contradictorias y no sabemos si salió junto a ellos. Una vez en su destino, su importancia social les permitiría que tuvieran una estancia más cómoda y una rehabilitación más rápida. El propio Ministerio accedió en 11 de abril de 1838 a que Miguel Hidalgo pasara a Madrid. El deán Mascareñas, quien había recibido el juramento de la Constitución de Lorenzo, se encontraba en La Habana en 1839 y el 10 de octubre de ese mismo año ya obtuvo el permiso para regresar a Santiago. ${ }^{42}$ Miguel Ángel Pérez y Antonio Odoardo fallecieron en Santa Cruz entre 1838 y 1839.

Si los religiosos liberales fueron represaliados, lo mismo sucedería con los más estrechos colaboradores de Lorenzo, personajes importantes en la sociedad de Santiago. En el extremo oriental de la colonia la capacidad de limitar las acciones de las autoridades a causa de los contactos e influencias era más dificultosa. De este modo encontramos al coronel de milicias, Juan Kindelán, y el abogado y auditor de guerra honorario, Francisco Muñoz del Monte, quienes junto a otros fueron embarcados hacia la Península. El alcalde, Francisco Mozo de la Torre, fue encarcelado y sería liberado en 1838. ${ }^{43}$ Tal y como sucedió con los eclesiásticos, estos tendrían una vida más acomodada al pertenecer a un estrato social elevado y disponer tanto de caudales como de relaciones en la capital.

\footnotetext{
${ }^{42}$ Olga Portuondo, Cuba, Cuba. Constitución y liberalismo (1808-1841), tomo II, pp. 155-156. Según Portuondo, José Teodoro Martínez no fue embarcado quedando preso, mientras que para Navarro si lo fue; Jesús Raúl Navarro, Entre esclavos y constituciones, pp. 160-161 y 168-169.

${ }^{43}$ Justo Zaragoza, Las insurrecciones en Cuba. tomo I, p. 474. Jesús Raúl Navarro, "Militares y libertad, reflexiones en torno al papel desempeñado por el ejército peninsular en la política colonial (1835-1838)", p. 420.
} 
Las dificultades de la estancia no vendrían únicamente determinadas por la carencia de alimentos y ausencia de hogar. La presión política sobre ellos continuó en la metrópoli con objeto de que no difundieran el modo de proceder de la máxima autoridad en Cuba, lo que indirectamente suponía criticar al Ejecutivo que lo había avalado. La Antilla mayor había quedado al margen de la libertad de expresión y saltarse esta prohibición podía tener consecuencias para quienes lo hicieran. Justo de Latorre fue encarcelado en la Ciudadela por escribir contra Tacón, hecho que según reconoce el mismo tuvo sobre él un efecto disuasorio ya que no volvió a escribir hasta el fin de la legislatura de $1836-1837 .{ }^{44}$ La relegación supuso un castigo en sí mismo, pero la dureza de la estancia todavía podía aumentar en caso de no mantener una actitud prudente.

Entre los represaliados que había en Cádiz se encontraba Joaquín Valdés, nominalmente confinado pero que actuaba como espía de Tacón. Este delató una supuesta conspiración para subvertir el orden en la isla e iniciar la independencia, en la que implicaba a algunos de los transportados como Wiarreta, Manuel de Latorre, Justo de Latorre y Agustín Delgado. Junto a ellos, Ramón Zaldo, teniente coronel de caballería también expulsado de la Antilla mayor y algunos ciudadanos residentes en la Península y en Cádiz. La incoación del procedimiento causó grandes contratiempos al deportado Manuel Abreu, a quien Valdés presionó para que apoyara su denuncia, prometiéndole el regreso a Cuba y un buen empleo. La negativa del confinado hizo que Valdés huyera de la ciudad, pero aun así Abreu fue llevado a declarar en el juicio en el que desmintió las acusaciones del espía. ${ }^{45}$

Por todo lo expuesto, debemos clasificar la represión como muy importante. Unas 300 personas fueron afectadas, la mayoría miembros del ejército de quienes se desconfiaba por su componente liberal, exacerbado posiblemente por la guerra que se estaba librando en la metrópoli contra los absolutistas. Respecto a los civiles, se llevó a cabo contra aquellos más destacados abarcando aproximadamente 110, lo que serviría a modo de ejemplo a los demás de que la actividad política era peligrosa. En su caso puede considerarse de menor amplitud, en consonancia con la menor peligrosidad que implicaba la actuación de civiles no armados. De los miembros del ayuntamiento

\footnotetext{
${ }^{44}$ Justo de Latorre, Una ojeada al manifiesto que publicó el Excmo. Sr. D. Miguel Tacón al dejar el mando de la isla de Cuba, p. 3.

${ }^{45}$ Manuel Machuca, Continuación de las noticias preliminares, e indispensables para conocer la justicia e injusticia que halla en el resultado del juicio de residencia, intentado para examinar la conducta de Miguel Tacón y Rosique, Viuda e Hijo de Bosch, Cádiz, 1839, pp. 163.
} 
constitucional únicamente el alcalde Francisco Mozo de la Torre fue encarcelado y lo mismo podemos decir respecto a las clases sociales más bajas, ya que la proclamación de la Carta Magna llevaría acarreado festejos y actos en los que participaría un número elevado de ciudadanos. Esto no significa eximir a Tacón de su responsabilidad, puesto que pudiendo optar por el olvido de los actos eligió el camino de las deportaciones, lo que tuvo un efecto innegable de sufrimiento para los afectados y sus familias.

Sin embargo, existe una gran diferencia entre aquellos que fueron obligados a trabajar forzosamente y los castigados como consecuencia de estos sucesos. Los represaliados de carácter político sufrieron una punición diferente, que abarcó a un número importante de personas pero que se circunscribió principalmente a los implicados en los sucesos de Santiago y a liberales muy destacados en otras poblaciones. La pertenencia a sectores sociales diferentes determina la diferencia en el modo de proceder, una represión continuada de hacendados, artesanos y profesionales hubiera sido de más difícil asunción en la Península. Lo mismo podemos decir respecto a la remisión constante de individuos pobres pero blancos. La prolongación de esta práctica hubiera podido laminar la cohesión social basada en la composición racial que se daba en la isla, acentuada por el incremento en el número de esclavos.

\section{$1.4 \mathrm{El}$ regreso}

Desde el primer momento, los deportados, fuera de sus lugares de origen y lejos de sus familias, trataron de que se les concediera el indulto para volver a su vida cotidiana. El traslado significó además desposeerles de sus medios de subsistencia y tener que empezar sin nada en un lugar a miles de millas de distancia, con una idiosincrasia diferente y en muchos casos sin redes sociales de apoyo. Los primeros retornos se produjeron como casos excepcionales. Los bayameses extrañados Rafael Pérez, Jorge Tamayo y Francisco Javier Tamayo lo habían hecho sin permiso de las autoridades y obviando la imposibilidad de regresar hasta pasados seis años, por lo que 
se les abrió el consiguiente juicio por la Comisión Militar. ${ }^{46}$ Otros como Bulte, obtuvieron el permiso de las autoridades, ya en $1838 .{ }^{47}$

Desconocemos las condiciones de vida de todos, pero sí las de algunos. Maurenti y Carrasco estaban en la más absoluta miseria y vivían de la caridad. La avanzada edad, para la época, en el momento de su relegación, unos 60 años en el caso del primero y 57 en el del segundo, agravaron las condiciones y los problemas de salud que ello conllevaba dificultaban que pudieran encontrar un medio de subsistencia. ${ }^{48}$ En última instancia evidenciaba el nulo interés de las autoridades de Cuba por el destino de estas personas, ya que algunas con un perfil determinado era bastante previsible que tuvieran que vivir en condiciones de extrema precariedad. Esto no quiere decir que todos estuvieran en la indigencia, los de mayores posibilidades económicas podrían sostenerse y vivir dignamente, aunque en este caso también les afectaría en el ejercicio de sus profesiones y por tanto a sus ingresos y calidad de vida.

$\mathrm{Al}$ socavamiento de las condiciones de vida producidas para unos hombres que disponían en sus lugares de origen de medios de vida habría que unir la sensación de impotencia por haber sufrido un castigo mediante un juicio carente de garantías. Precisamente a ellos que consideraban los derechos individuales como uno de los pilares de su ideología y que habían visto como el triunfo de los progresistas en la Península no se había extendido a las colonias ultramarinas. Esto provocaría en muchos de ellos un sentimiento de incomprensión y la creencia de haber sido objetos de una injusticia que derivaba de la propia actitud de Tacón, cuando es evidente que su deportación formaba parte de una política que excedía de la exclusiva voluntad del Capitán general.

Por ejemplo, Carrasco en sus peticiones culpaba directamente a Tacón a quien calificaba como bárbaro y déspota. Acusaba a la policía de estar corrompida y ser depravada y a los testigos de estar amañados, puesto que habían sido los mismos para

\footnotetext{
${ }^{46}$ Causas seguidas por el Ministerio fiscal a 22 de diciembre de 1837. ANC, Comisión Militar, Leg. 131, Exp. 2. "Relaciones de las causas que ha sentenciado la Comisión Militar del año 1826 a 1839"; habían sido condenados a seis años de extrañamiento. Olga Portuondo, Cuba. Constitución y liberalismo (1808-1841), tomo II, p. 168.

${ }^{47}$ ANC, Comisión Militar, Leg. 19, Exp. 4. Causa contra José Eduardo Bulte y otros por su conducta política en la proclamación de la Constitución en Santiago de Cuba.

${ }^{48}$ AHN, Ultramar, Leg. 4613, Exp.6. "Casimiro Maurenti natural de La Habana y confinado en La Coruña pide volver a su país"; AHN, Ultramar, Leg. 4613, Exp. 7. "Expediente promovido en 1837 por Tiburcio Carrasco solicitando se le levante el destierro que para La Coruña le impuso el Capitán general y que se le permita regresar a La Habana".
} 
todos los condenados, y de haber cometido perjurio por las contradicciones en que incurrieron. Sus palabras denotaban un liberalismo apasionado, Tacón no se equivocaba con él y por eso manifestó que el extrañamiento debía ser perpetuo y que fuese exceptuado de cualquier indulto. A pesar de ello, el 4 de abril de 1841 fue comprendido en el indulto, dando permiso al jefe político de La Coruña para expedir el correspondiente pasaporte. ${ }^{49}$

La denuncia de un juicio lleno de irregularidades, de la actitud de la policía y de la arbitrariedad con que se actuó no era necesaria, puesto que eran perfectamente conocidas y compartidas por las autoridades españolas. Sin embargo, la insistencia en ello demuestra que no llegó a comprender o a asimilar el hecho de que los liberales de la Península habían dejado sin derechos a sus homólogos cubanos. Esto no afectó a todos, puesto que algunos avispadamente comprendieron que habían sido castigados por su ideología y no por una actitud unilateral de la máxima autoridad colonial desconocida por el Gobierno. Estenoz, tras ser remitido por las autoridades peninsulares de nuevo a la isla, fue condenado a seis años de destierro. Eso le haría abrir los ojos, puesto que ahora alegaba que el Capitán general había sido prevenido falsamente en contra suya, en un intento de eludir, o al menos mitigar, la responsabilidad de Tacón. A continuación afirmaba que:

"Esta grave injusticia exaltó mi espíritu, y con este móvil irresistible escribí después de mi destierro, dos folletos, uno en Puerto Rico que es casi insignificante, y otro en Cádiz, que debo confesar lo escribí con ánimo de instruir al Gobierno e ilustrar a los que no conociesen los atentados que se cometían en la isla de Cuba". ${ }^{0}$

Trataba de quitar hierro a su actuación, en un intento de hacer entender que había sido provocada por un momento de indignación y que ambos folletos fueron efectuados con un espíritu constructivo y no de crítica a Tacón o al Ejecutivo. Él había comprendido mejor lo que había sucedido, dándose cuenta de que lo más conveniente era responsabilizarse a sí mismo y no exigir unos derechos políticos que no le habían sido otorgados por nadie.

Las peticiones para conseguir el indulto se sucedieron, pero este era un proceso lento. Casimiro Maurenti lo pidió ya en julio de 1837 y a pesar de contar con el apoyo

\footnotetext{
${ }^{49}$ AHN, Ultramar, Leg. 4613, Exp. 7. "Expediente promovido en 1837 por Tiburcio Carrasco solicitando se le levante el destierro que para La Coruña le impuso el Capitán general y que se le permita regresar a La Habana".

${ }^{50}$ AHN, Ultramar, Leg. 4612, Exp. 18. "Expulsión de la isla del abogado Juan Ramírez de Estenoz, acusado de excesos cometidos en el uso de la imprenta".
} 
de las autoridades provinciales que certificaban su buena conducta y su carácter afable que le granjeó "la compasión y aprecio de todos los que le han tratado", no se le concedió hasta 1841. En agosto de dicho año, el Capitán general, Jerónimo Valdés, comunicó a las autoridades peninsulares que aceptaba que se le dejara volver. Lo mismo sucedió con el capitán de pardos, José Rosario Tales, deportado por los sucesos de 1836 y que solicitó el indulto el 18 de enero de 1841 mientras residía en Cataluña. ${ }^{51}$ Este y Pedro González son los únicos hombres de color que conocemos que fueron deportados. Es posible que hubiera alguno más pero en la mayor parte de los individuos no se expresa su apariencia racial, muestra de que esta cuestión no fue determinante en la represión. Se reprimió a los liberales, y la gran mayoría de ellos eran blancos.

La razón por la que se permitió el regreso fue la extensión a las provincias de Ultramar, en 29 de diciembre de 1840, del decreto de indulto de 30 de noviembre de ese mismo año. La amnistía fue realizada expresamente para los presos, desterrados o que sufriesen cualquier otra pena relacionada con la proclamación de la Carta Magna española en Cuba en 1836 y dejaba fuera a independentistas y carlistas. La aplicación fue inmediata para los exiliados. En cambio, los presos y deportados debían solicitar que se les aplicara, lo que retardó su retorno. En ambos casos el Capitán general quedaba facultado para hacerles residir fuera de su localidad una vez en la isla. ${ }^{52} \mathrm{El}$ cambio político en la Península, con el inicio de la Regencia de Espartero, propició el retorno de los represaliados políticos.

En el plano discursivo, el decreto desmontaba categóricamente la falsa asociación entre independentismo y liberalismo, al distinguir claramente entre ambos grupos. En la realización de las relegaciones se habían especificado dos grupos con perfiles muy diferentes: los políticos, castigados por su participación en los sucesos constitucionales o por su liberalismo radical, comprendidos en la amnistía y los tenidos por vagos o individuos de mala nota, cuyo traslado teóricamente no obedecía a su militancia política sino a su condición social. Sin embargo, a Carrasco y a Maurenti pese a que nominalmente se les negó el sentido político a su confinamiento en realidad fueron tratados como tales y se les permitió volver. Esto se extendería a los demás que se encontraran en su situación.

\footnotetext{
${ }^{51}$ AHN, Ultramar, Leg. 4613, Exp. 6. "Casimiro Maurenti natural de La Habana y confinado en La Coruña pide volver a su país"; AHN, Ultramar, Leg. 4613, Exp. 21. "El Capitán de pardos don José Rosario Tales, desterrado de la isla por los sucesos de 1836 es declarado por Guerra comprendido en el indulto de 29 de Diciembre de 1840".

${ }^{52}$ Gaceta de Madrid, 1 de enero de 1841 (Suplemento).
} 
No sucedió lo mismo con Ignacio Lafita. El 15 de enero de 1841 solicitaba poder regresar a La Habana. Argumentaba su petición en su avanzada edad, 62 años, y en su situación ya que según sus propias palabras estaba "padeciendo los horrores del hambre, desnudez y frio, andando errante por las calles, sufriendo las tormentas más indecibles”. La petición contaba con el aval del gobernador superior político de La Coruña, que certificaba su buena conducta. Aun así, el 30 de agosto de ese mismo año Valdés le declaró excluido de la medida de gracia ya que su embarque no obedeció a causas políticas. ${ }^{53}$ Es posible que esta situación se extendiera a alguno más, siempre que efectivamente su relegación no obedeciera realmente a motivaciones ideológicas, aunque en la práctica suponía avalar una situación injusta por no haber sido juzgado de acuerdo a las leyes ordinarias. Ni siquiera la avanzada edad de Lafita, la situación de precariedad en la que vivía y la buena conducta que había mostrado sirvieron para que pudiera retornar a su país.

Resulta digno de señalar, que a pesar de la política autoritaria efectuada por Tacón, su relevo vino determinado por las enemistades que contrajo con personas influyentes de Cuba y en especial del conde de Villanueva y de otros sectores importantes de criollos hartos de su autoritarismo. ${ }^{54}$ El 9 de diciembre, los diputados Antonio Benavides y Alejandro Olivan, ambos de perfil claramente conservador, criticaban las facultades de las que gozaba el Capitán general y abogaban por un régimen más tolerante. El día 11, el conde de las Navas, adscrito a la versión radical del progresismo, hizo un parlamento todavía más duro en que criticaba el autoritarismo y la represión efectuada en la isla. La polémica sobre la situación real de la colonia saltó a los periódicos y el 5 de enero Tacón fue relevado. ${ }^{55}$ Pero el modo de gobernar la posesión no varió en nada, evidenciando que las denuncias provenientes de sectores moderados únicamente trataron de debilitar su figura y no cambiar la política respecto a la colonia.

\footnotetext{
${ }^{53}$ AHN, Ultramar, Leg. 4613, Exp. 14 "Expediente sobre el regreso del expulsado y confinado a La Coruña don Ignacio Lafita".

${ }^{54}$ María José Vilar, "Un cartagenero para Ultramar. Miguel Tacón y el modelo autoritario de la transición del Antiguo Régimen al liberalismo en Cuba (1834-1838)", Anales de Historia Contemporánea, vol. 16, 2000, pp. 256-256 y 269.

${ }^{55}$ DSC, 9 y 11 de diciembre de 1837.
} 


\section{LOS AÑOS DEL "PELIGRO NEGRO” (1837-1845)}

\subsection{Los primeros años}

La conversión de Cuba en una economía basada en la plantación mediante la utilización de mano de obra esclava determinó un constante pánico a las revueltas de esclavos. Estas se reprodujeron ocasionalmente con unos objetivos alejados de la transformación política, generalmente se trataba de obtener la libertad y en no pocas ocasiones iban ligadas a una forma de venganza contra los blancos. La mayoría de veces, estas revueltas, a pesar del pánico que desataban, eran fácilmente sometidas por las autoridades. Los cabecillas eran castigados cruelmente y muchos insurreccionados se convertían en cimarrones, constituyendo una forma de disidencia de baja intensidad intrínseca al sistema. El mayor temor lo constituía la unión de esclavos y libres de color, o el apoyo que los segundos podían prestar a los primeros dotando a las conspiraciones de una organización más adecuada y de un contenido político.

A la lejana Conspiración de Aponte, habría que añadir la frecuencia en las sublevaciones y en los complots descubiertos entre 1837 y 1843, lo que contribuyó a incrementar el miedo a una revuelta de grandes dimensiones. A comienzo de 1838 hubo dos motines paralelos en Trinidad, uno de ellos formado por esclavos urbanos de algunas de las altas autoridades de la región. ${ }^{56}$ Estos complots acrecentaron el temor de las autoridades respecto a las rebeliones de esclavos y las consecuencias que podían tener sobre la vida y las pertenencias de los blancos, por lo que se incrementaron las medidas de presión sobre las reuniones de personas de color. El 12 de julio de 1839 se inició causa contra un grupo de ellos. El caso fue sobreseído, pero el 10 de diciembre pasó a la Comisión Militar que dictó sentencia el 25 de abril de 1840. Al capitán de pardos León Monzón le impuso la pena de cuatro años de presidio en la Península, con prohibición de volver a Cuba a su finalización, y a otros nueve individuos la de relegación perpetua en La Coruña. Eran José del Monte del Pino, Pilar Borrego, Margarito Blanco, José Andrade, Felipe Cabrera, Agustín Toledo, José Florencio Davan, Tomás Peñalver y Francisco Valdivia, que se encontraba en prófugo. Se les castigaba "por haber firmado, escrito o mantenido en su poder papeles subversivos y

\footnotetext{
${ }^{56}$ Gloria García, "Vertebrando la resistencia. La lucha de los negros contra el sistema esclavista, 1790-1845", en María Dolores González-Ripoll, et al., El rumor de Haití en Cuba. Temor, raza y rebeldía, 1789-1844, CSIC, Madrid, 2004, pp. 309-320.
} 
otros datos agravantes que hay contra ellos". A todos se les quitarían los empleos y distinciones que tuvieren. Otros siete fueron sentenciados a seis meses de trabajos forzados y dos fueron declarados inocentes. ${ }^{57}$

A Monzón se le encontraron en casa las dos proclamas de los batallones de morenos y pardos de 11 y 13 de abril de 1823 en apoyo del régimen liberal, dos folletos titulados Libertad y Tiranía y ¡Republicanos en Barcelona! y una Constitución de la Monarquía Española. ${ }^{58}$ Uno de los detenidos, el subteniente de bomberos Pilar Borrego, había sido condenado a cuatro años de prisión en Puerto Rico por participar en la conspiración de José Antonio Aponte en 1812. Otro era Margarito Blanco, Ocongo de Ultán. Los cabecillas de la conspiración de 1812 y aquellos que formaban parte de este grupo de aprehendidos constituían un mismo perfil. Cosa bien diferente es la supuesta peligrosidad de este grupo, detenido por considerarse sospechosas sus reuniones pero que en ningún momento se demostró que conspiraban. Según Margarito Blanco sus pretensiones eran las de constituir junto con sus homólogos de Efó, Ososo y Obane un "cabildo o corporación Arupapá". 59

Es cierto que a Monzón se le encontraron papeles políticos, pero su mera posesión no indica conspiración. Para la mayoría de libres de color con cierta cultura la permanencia de la esclavitud resultaba aborrecible. Su sensibilización respecto al problema era importante, especialmente cuando ellos a pesar de ser libres sufrían una fuerte discriminación. Sin embargo, lo realmente peligroso de este caso para las autoridades era la existencia de reuniones de negros bajo la apariencia de bailes o Constitución de cabildos.

El intento de desactivación de estas sociedades de personas de color motivó la prohibición de las abundantes academias de baile, aun reconociendo que hasta ese momento no habían tenido objetivo criminal. ${ }^{60}$ En 29 de noviembre y 4 de diciembre se ordenaba extremar la vigilancia sobre las agrupaciones de gente de color, especialmente

\footnotetext{
${ }^{57}$ AHN, Ultramar, Leg. 4638, Exp. 21. "Sobre los confinados José Montes del Pino, Jose Felipe Cabrera y Agustín Toledo".

${ }^{58}$ Gloria García, Conspiraciones y revueltas, pp. 107-109.

${ }^{59}$ Pedro Deschamps Chapeaux, "Margarito Blanco, «Ocongo de Ultán»”, Boletín del Instituto de Historia y del Archivo Nacional, tomo LXV, 1964, pp. 97-109. Según Deschamps en la trama confluían tres grupos diferentes, uno comandado por Monzón de carácter más político y profesional; uno liderado por Tomás Andrade formado por pertenecientes al servicio doméstico y otro dirigido por Blanco integrado principalmente por albañiles, canteros y trabajadores de los muelles.

${ }^{60}$ AHN, Ultramar, Leg. 4610, Exp. 11. "Medidas contra las reuniones clandestinas de gentes de color".
} 
sobre las milicias disciplinadas y urbanas. ${ }^{61}$ Todo esto a pesar del desconocimiento por parte de las autoridades del funcionamiento y finalidades de muchas de estas, lo que daba lugar principalmente a simples interacciones sociales, pero al mismo tiempo posibilitaba la aparición de un asociacionismo materializado en sociedades secretas y facilitaba la posibilidad de conspiraciones. Pero esto era extensible a las reuniones de blancos, que pudieran al mismo tiempo servir para conspirar y no se prohibieron. En última instancia la medida constataba tanto el miedo a un levantamiento de siervos, como la discriminación racial que estos sufrían.

Las recientes revueltas de esclavos constituyeron una preocupación para las autoridades. Tras la abolición de la esclavitud en los territorios británicos, Cuba había quedado como lugar con esclavitud rodeado de lugares en los que estaba prohibida. Sin embargo, el perfil de los acusados estaba lejos del de los siervos: incultos, pobres y carentes incluso de su propia libertad. Formaban, en cambio, una especie de elite de color, sabían leer y escribir, tenían ideología y cierta posición social que les haría probablemente objeto de admiración entre los de su procedencia e interactuar con cierto equilibrio social con los blancos. Una minoría culta que constituía un peligro puesto que incluso a los libres les estaba vedado cualquier tipo de participación política. En los años anteriores muchos blancos habían sido relegados a causa de la proclamación de la Constitución o su liberalismo exaltado. Estos individuos, por el contrario, fueron deportados únicamente por reunirse y tener documentación en casa que no trataban de difundir. Todo con la excusa de "proteger" a los blancos, aunque los papeles políticos que se les encontraron iban en la línea de adhesión al liberalismo, por la creencia de que la proclamación de la Carta Magna en la colonia significaría la concesión de derechos a todos los hombres de color.

El 23 de junio la sentencia fue ratificada por el Capitán general y el 24 fueron embarcados, saliendo rumbo a La Coruña en donde deberían permanecer. Esto muestra la escasa importancia de la supuesta sublevación, ya que en el caso de las conspiraciones de esclavos solía emplearse una gran severidad para ejemplificar. La utilización de este castigo indica que no se les quería allí, pero que al mismo tiempo no se llegaba a entender del todo la significación de esta asociación. En un principio la sociedad tenía el carácter de ñáñigo, es decir asociada al carácter religioso y a la ayuda mutua. Pero con posterioridad podía haber evolucionado hacia connotaciones políticas.

${ }^{61}$ Gloria García, Conspiraciones y revueltas, p. 108. 
Por tanto, las autoridades decidieron cortar de raíz con el problema. Allí coincidieron con los trasladados a causa de la proclamación de la Constitución en Santiago de Cuba en 1836. Con ellos compartieron las mismas condiciones de pobreza y exclusión: Agustín Toledo y Margarito Blanco declaraban estar en la miseria más absoluta. ${ }^{62}$ Las ayudas traducidas en limosnas o trabajos probablemente serían más dificultosas para las personas de color por su carácter racial.

Este grupo fue excluido de la amnistía, ya que esta fue realizada expresamente para los presos, desterrados o que sufriesen cualquier otra pena relacionados con la proclamación de la Carta Magna española en Cuba en 1836. La ley se aplicó en sentido estricto, por lo que estos individuos libres de color de carácter urbano quedaron al margen del indulto, incluso cuando el Capitán general afirmó en 27 de agosto de 1841 que no tenía inconveniente en su vuelta, puesto que en caso de reincidencia en sus faltas aplicaría la ley con todo rigor. De este modo, sus peticiones de 1841 fueron rechazadas desde España, lo mismo que sucedería en 1853, año en que José Montes del Pino tenía 56 años, Agustín Toledo 51 y José Felipe Cabrera $71 .^{63}$

Todo parece indicar que su relegación seria efectivamente perpetua, tal y como proclamaba la sentencia, evidenciando un trato diferente al del resto de deportaciones, en las que finalmente se permitía el retorno de los afectados. En su caso predominaría el pánico a una revuelta de esclavos y la decisión de excluirles del cuerpo social. Resulta destacable que no se les permitiera cuando Valdés había dado su asentimiento, es decir, desde la propia Península se pretendía un control todavía mayor. Esto determinó que los capitanes generales supieran que para contar con el beneplácito del Ejecutivo debían llevar a cabo una política más severa.

Varios elementos determinaban el cambio en los castigos respecto a la conspiración de Aponte, cuando a los libres de color condenados se les dejó regresar una vez cumplida la condena. A finales de la década de 1830, los libres de color comenzaban a adquirir para las autoridades un perfil peligroso por el incremento en su número y porque empezaban a ser conscientes de su discriminación y reclamaban derechos. Por tanto, incluso cuando Blanco y el resto en realidad no estaban involucrados en una conspiración de carácter político sino en la expansión del

\footnotetext{
${ }^{62}$ AHN, Ultramar, Leg. 4638, Exp. 21 "Sobre los confinados José Montes del Pino, José Felipe Cabrera y Agustín Toledo"; AHN, Ultramar, Leg. 4612, Exp. 39 "Expediente promovido por Margarito Blanco, individuo de color, expulsado de La Habana".

${ }^{63}$ Ibídem.
} 
ñañiguismo, se les deportó a perpetuidad. La expulsión de la sociedad se configuraba como un castigo para este sector social.

La constante introducción de bozales tenía que ver con los enormes beneficios que algunos obtenían con ello, pero al mismo tiempo representaba un riesgo potencial en el orden público de la isla. En 1841 la población negra ya superaba a la blanca, siendo esta ultima un $41,5 \%$ del total. Los esclavos suponían el 43,3\% y los libres de color el 15,1\%. ${ }^{64}$ El crecimiento provocó el pánico a la "africanización". Esto aumentaba la prevención de las autoridades, especialmente temiendo la conjunción de siervos y libres de color. Dado que la entrada de esclavos suponía un enorme negocio no se actuaba contra ella, lo que llevó a las autoridades a desviar la atención sobres los libres, aquellos que no eran directamente explotables y generaban una plusvalía mucho menor.

El pavor de que se reprodujeran revueltas de esclavos era tal que una simple quema de la casa de su ama por un esclavo en San Juan de los Remedios a finales de febrero de 1841, unida a un falso denunciador y al exceso de celo del comisario de policía, terminaron con treinta y dos detenidos, que posteriormente serían liberados a excepción del que provocó el incendio. ${ }^{65}$ En 1842 se produjo una huelga de los esclavos que construían el palacio de Aldama en La Habana. Además se sucedieron otros levantamientos en varios ingenios, el más importante de los cuales de 42 negros en el ingenio Arratia. ${ }^{66}$

En 16 de septiembre de 1841 ya se ordenaba al Capitán general que reprimiese cualquier desmán político mediante la aplicación de las Leyes de Indias. ${ }^{67}$ Legislación que le permitía actuar con una gran arbitrariedad, incluyendo la relegación de sujetos por vía administrativa siempre que se expusieran las causas. La inclusión de esta medida en un contexto de levantamientos de esclavos no es casual, puesto que para ellos cualquier insurrección de siervos tendría como finalidad acabar con los blancos. Además se temía una invasión armada desde el exterior, la cercanía de Jamaica y Haití

\footnotetext{
${ }^{64}$ Resumen del censo de población de la isla de Cuba a fin del año de 1841. Imprenta del Gobierno, La Habana, 1842, p. 19.

${ }^{65}$ AHN, Ultramar, Leg. 4613, Exp. 2. "Sobre el incendio ocurrido en San Juan de los Remedios".

${ }^{66}$ Aisha K. Finch, Insurgency at the Crossroad: Cuban Slaves and the Conspiracy of La Escalera, 1843-1844, Tesis doctoral de la Universidad de Nueva York, Nueva York, 2007, p. 190.

${ }^{67}$ AHN, Ultramar, Leg. 8, Exp. 6. "Expediente reservado recomendando aplicar con dureza la ley contra desmanes políticos".
} 
generaba un miedo constante. El Gobierno inglés presionaba a las autoridades españolas por considerar que ejercían una competencia desleal para sus plantacionistas y por humanitarismo. Las posiciones abolicionistas se reforzaban, algunas de ellas mantenidas por individuos de origen extranjero.

Este fue el caso del moreno libre José Mitchel, originario de un enclave inglés en África había residido en Jamaica desde donde pasó a la mayor de las Antillas, lugar en que vivía de su trabajo. Hasta que en noviembre de 1842 fue detenido "gravemente sospechoso de cooperar a las maquinaciones de Mr. Turnbull”, cónsul ingles en Cuba. Condenado a muerte, la pena le fue conmutada por diez años de presidio en Ceuta con prohibición perpetua de regresar a las posesiones españolas. ${ }^{68}$ En 1843 fue preso el pardo Felipe Valdés García y posteriormente enviado al presidio de Valladolid por un periodo de seis años por "conspiración fraguada por los de su clase para extermino de la raza blanca". 69

\subsection{La respuesta a la conspiración de la Escalera}

Con estos antecedentes, el nuevo Capitán general, Leopoldo O’Donnell, llegó con una idea muy clara de la que iba a ser su política. En 18 de febrero de 1844, la gente participante en un baile en el café de Escauriza se negó a abandonar el lugar a las once de la noche, hora estipulada para ello, desobedeciendo a las autoridades. Dos días más tarde, en un nuevo baile, el Capitán general apercibió a las autoridades de que hiciesen cumplir la ley, y en el desalojo de la gente en el mismo lugar se produjeron insultos, silbidos y abucheos al alcalde tercero Fernando O'Reilly e incluso alguien le lanzó un vaso de ponche de leche, acto que provocó risas entre la gente. Cinco de los que estaban más cercanos a él fueron prendidos, pero posteriormente al ver que sus antecedentes no eran malos fueron liberados y arrestados otros siete, que fueron deportados a la Península en la fragata Carmen. ${ }^{70}$

\footnotetext{
${ }^{68}$ AHN, Ultramar, Leg. 4638, Exp. 24. Expediente negando el indulto al moreno José Mitchel.

${ }^{69}$ AHN, Ultramar, Leg. 4641, Exp. 39. Petición de Felipe Valdés para regresar a Cuba.

${ }^{70}$ Justo Zaragoza, Las insurrecciones en Cuba, tomo I, pp. 538-543 y 778. Los deportados eran Andrés López de Consuegra, doctor en leyes; Francisco Javier Sánchez Pando (hijo), abogado; Ramón Charum, "vago" y abolicionista; Telesforo Forrea, militar expulsado del servicio; Antonio de los Olivos, Luis Velázquez de la Mar y Marcos Morejón, oficiales retirados; Charum estuvo relegado en Valladolid, Herminio Portell Vilá, Narciso López y su época, Cultural, La Habana, 1930, tomo I, p. 161.
} 
O’Donnell quiso castigar estos actos que suponían de algún modo un desafío, juvenil y apolítico, a la autoridad. En estos momentos no se pretendía tolerar el más mínimo acto de desacato, pero debido a que los arrestados no tenían antecedentes políticos fueron puestos en libertad y sustituidos por opositores. Relegar a cinco jóvenes sin motivo daba argumentos a los liberales, represaliar a estos últimos, en cambio, era más útil por cuanto servía para atemorizarlos. O’Donnell no podía permitir actos como estos en La Habana, de hecho se aprovechó de ellos para explicitar que mantendría la autoridad a toda costa, incluso actuando contra los ciudadanos blancos que tenían postulados considerados radicales en el tema de la esclavitud. La expulsión de liberales no podía entenderse sin el contexto político en que se encontraba la isla y significaba enviar un mensaje a los blancos, pero también a los libres de color y los esclavos, ya que significaba que la represión no se detendría ante nada.

Las sublevaciones de 1843 en los ingenios Alcancía y Triunvirato tuvieron la suficiente importancia para ocasionar el encrespamiento necesario para que cuando la esclava Polonia denunciara una nueva y vasta conspiración que se estaba fraguando cerca de Matanzas, se actuara con la máxima dureza con centenares de presos y torturados en aras de obtener confesiones y otros nombres de implicados. Es la conocida como la conspiración de la Escalera, cuya existencia real tradicionalmente fue puesta en duda por los historiadores, aunque ahora se da por cierta entendiéndola como varias redes conspirativas que coexistían y que pretendían coordinarse entre sí. ${ }^{71}$

Además, en la Cuba de la época la simple tenencia de papeles políticos era considerada sediciosa, en especial para los negros. En la punición de la Escalera confluirían todos los temores acumulados por las sucesivas revueltas de esclavos con el miedo a una intervención exterior, elementos que unidos al carácter fuertemente autoritario de la metrópoli desembocaría en una represión brutal y concienzuda que fue utilizada como modo de escarmentar a posibles futuros insurrectos. Las confesiones se arrancaron a base de torturas en las que decenas murieron recibiendo latigazos en busca de confesiones e inculpaciones. En la década de 1840, la afluencia de bozales continuaba, aunque se hizo más dificultosa. Elevar el temor de la población blanca podía frenar las liberaciones de esclavos. Algo que no funcionó ya que la coartación

\footnotetext{
${ }^{71}$ Robert L. Paquette, Sugar is made with blood: The conspiracy of La Escalera and the Conflict between Empires over Slavery in Cuba, pp. 248-249, Wesleyan University Press, Middleton, 1988, pp. 248-249; Aisha K. Finch, Insurgency at the Crossroads, 1841-1844, pp. 211-214.
} 
continuó empleándose, de manera que las autoridades maniobraron para convertirla en una vía que no llevara a la liberación, necesaria para mantener la economía de plantación. $^{72}$

Las condenas, según Vidal Morales consistieron en 78 ejecutados, 328 a presidio por diez años, 652 a presido entre uno y ocho años y 312 a la misma pena entre uno y seis meses, 435 desterrados, 27 consignados a establecimientos piadosos, 14 sentenciados a penas más leves y 1.230 absueltos. La mayoría de los sentenciados fueron negros libres, en total 1.232, frente a los 590 esclavos y los 14 blancos. En cuanto a la cifra de desterrados, estaba compuesta por 433 libres de color, 2 blancos y ningún esclavo. ${ }^{73}$

Las cifras de Vidal Morales no son las únicas de que disponemos, en una recopilación realizada por las autoridades de las sentencias ejecutadas se dan unos números aproximados a los anteriormente expuestos, si bien difieren en algunos aspectos. $^{74}$ La lista oficial comprende a 3.361 sentenciados por la Comisión Militar, mientras que la de Vidal Morales incluye a 3.076, que según el historiador eran "el número de prisioneros hechos entonces y como se dispuso de ellos". Esto es una posible explicación al desfase pero altamente improbable ya que en el momento de las sentencias había alrededor de 750 que se encontraban huidos y nos parece tremendamente difícil que la gran mayoría fueran aprehendidos, especialmente teniendo en cuenta que la mayoría eran libres de color a los que se quería fuera de la sociedad. Por tanto, lo más probable es que los datos del historiador cubano fueran incompletos y que el Estado, además de expulsar forzosamente a algunos de la colonia, facilitó la huida de otros mediante la acusación de determinados sujetos.

En cualquier caso, las cifras dadas por las autoridades son ligeramente superiores, estableciendo que 86 fueron sentenciados a muerte, 854 a presidio, 356 a ramal y grillete en las fincas de su amo realizando los trabajos más duros, 463 desterrados, 19 condenados a azotes y el resto absueltos: 439 de ellos de forma permanente y 1144 "por ahora", lo que significaba que debían ser vigilados. La forma

\footnotetext{
${ }^{72}$ Claudia Varella, Esclavos a sueldo. La coartación cubana en el siglo XIX, Tesis doctoral de la Universitat Jaume I, Castellón de la Plana, 2010, p. 82.

${ }^{73}$ Vidal Morales y Morales, Iniciadores y primeros mártires de la revolución cubana, Avisador Comercial, La Habana, 1901, p. 173. Según Morales no hubo esclavos desterrados, lo que contrasta con los datos de la lista oficial.

${ }^{74}$ Colección de fallos pronunciados por una sección de la Comisión Militar establecida en Matanzas para conocer de la causa de conspiración de la gente de color. Imprenta del Gobierno, Matanzas, 1844. Recopilación de las causas que contiene esta colección, (s/p).
} 
de reprimir, tan amplia, provocaba que en realidad muchos de ellos fueran inocentes, lo que explica la gran cantidad de sobreseimientos cuando se pretendía una represión de gran alcance. Pero por la forma de actuar, detenciones masivas y acusaciones mediante delaciones y torturas, se muestra como desde la capitanía se desconocía el alcance real de la conspiración. En la relación oficial, los datos más fiables y completos, se distingue entre presidios en África y presidios en Cuba. A los presidios ultramarinos fueron condenados 512 individuos, de los cuales únicamente había dos blancos y 28 esclavos. A los presidios en la isla fueron condenados 162 pardos libres, 5 blancos y 175 esclavos.

Resulta evidente que había una clara tendencia a que los esclavos cumplieran las condenas impuestas en la colonia, mientras que con los pardos libres se llevó a cabo una política de expulsión del país, un total de 917 salieron de ella en calidad de presos o desterrados, a los que habría que sumar los 37 o 38 que fueron ejecutados. Una autentica limpieza racial y social, ya que en la mayoría de las sentencias se estipulaba que tanto si se trataba de siervos o libres no podían regresar ni establecerse en Puerto Rico, siendo condenados a muerte, en caso de retornar, los que habían sido condenados a presidio y a reclusión perpetua los desterrados. A ellos habría que añadir los que salieron tras la proclamación en abril de 1844 que estipulaba que todos los libres de color nacidos en el extranjero debían abandonar Cuba, 739 lo hicieron hasta el 30 de junio. ${ }^{75}$ Parece claro que la conspiración de la Escalera se utilizó para sacar del país a libres de color, especialmente a aquellos que habían conseguido cierto tipo de representación social y cultura, por lo que se temía que podían influir negativamente sobre los esclavos y guiarlos hacia una insurrección de grandes dimensiones. Una salida forzada de un mínimo de 1.693 individuos de entre los 152.838 libres de color que había en la isla, ${ }^{76}$ representa poco más del $1 \%$. Una represión no masiva, pero si lo suficientemente intensa para mostrar su presencia la sociedad. A estos habría que añadir los que se encontraban prófugos y que habrían conseguido huir del país para escapar de la represión. Los esclavos, por el contrario, además de explotables eran menos peligrosos si se les aislaba de los alborotadores.

\footnotetext{
${ }^{75}$ María del Carmen Barcia y Eduardo Torres-Cuevas, "El debilitamiento de las relaciones sociales esclavistas. Del reformismo liberal a la revolución independentista", en María del Carmen Barcia, Gloria García y Eduardo Torres-Cuevas, La colonia. Evolución socioeconómica y formación nacional. De los orígenes hasta 1867, Editora Política, La Habana, 1994, p. 436.

${ }^{76}$ Resumen del censo de población de la isla de Cuba a fin del año de 1841, p. 8.
} 
Entre los siervos, la mayoría fueron condenados a ramal y grillete en las fincas de sus amos, lo que permitía incluso aumentar su explotación. Solo los considerados más culpables serían condenados a presidio, privando de esta manera a sus amos de su fuerza de su trabajo. Encontramos únicamente a 17 esclavos que salieron del país y 28 condenados a presidio en África, una parte mínima de la represión efectuada. La pena de "relegación" se impuso en bastantes casos a los prófugos por lo que en el caso de los esclavos no suponía un menoscabo directo de su fuerza de trabajo en la isla, ${ }^{77}$ ya que suponía la constatación jurídica de un hecho que ya se había realizado, el paso al cimarronaje e incluso la fuga del país de algunos de estos individuos. La prisión en África para los esclavos debe entenderse como sacar de la isla a los considerados más peligrosos. En este caso la permanencia en el territorio se consideraba menos recomendable que la pérdida de fuerza de trabajo o el perjuicio que la condena ocasionaba a sus amos. Lo mismo sucedía con los esclavos considerados cabecillas de la conspiración, 39 de ellos fueron ejecutados. La ejemplificación pretendida por las autoridades requería que algunos de ellos fueran ajusticiados.

En cuanto a los condenados a relegación perpetua de Cuba y Puerto Rico, se les permitió elegir a que punto querían pasar a residir y se les pagó el billete a sus destinos. Como consecuencia de ello, 30 decidieron pasar a Caracas, 35 a Campeche y uno a Jamaica. ${ }^{78}$ Además, respecto a los 739 obligados a abandonar el país, 416 fueron a México, 92 regresaron a África, 40 fueron a Estados Unidos y el resto a Jamaica, Brasil y Europa, ${ }^{79}$ por lo que es posible que también los expulsados pudieran pasar a estos lugares ya que en ambos casos hubo posibilidad de elección. La tendencia seria a ir a los países cercanos ya que hombres con sus profesiones y sus familias en la Antilla mayor es lógico que su intención fuera retornar en cuanto fuera posible.

La remisión a la metrópoli era un castigo añadido, de quien solo conocemos a un individuo condenado por las autoridades a ser desterrado a la Península. Se trataba del

\footnotetext{
${ }^{77}$ Ver sentencias $\mathrm{n}^{\circ} 3 \mathrm{y} \mathrm{n}^{\circ} 18$. Colección de fallos pronunciados por una sección de la Comisión Militar establecida en Matanzas para conocer de la causa de conspiración de la gente de color. 78 "Relación de individuos de color sentenciados a relegación perpetua de esta isla y la de Puerto Rico que han elegido para su residencia los puntos que al margen se expresan", 16 de febrero de 1845. "Liquidación que se forma de los gastos hechos por la hacienda por la causa de la conspiración de la gente de color ocurrida en el año de 1844 en varios puntos de la isla; y de los enteros que se han ingresado en cajas reales para reintegro de estos adelantos, con distinción de los puntos en que se han causado". ANC, Comisión Militar, Leg. 132, Exp. 1 "Relaciones de las causas que ha sentenciado la Comisión Militar del año 1840 a 1856".

${ }^{79}$ Pedro Deschamps Chapeaux, El negro en la economía habanera del siglo XIX, Unión de Escritores y Artistas de Cuba, La Habana, 1971, pp. 25-26.
} 
negro Julián González, quien permanecía allí hasta que en 1852 se le autorizó a volver. ${ }^{80}$ Sin embargo, esta pena fue muy rara ya que en la inmensa mayoría de las ocasiones, la condena era a expulsión de Cuba y Puerto Rico, de ahí que se les dejara elegir el punto de residencia.

Al margen de este caso aislado, estos sujetos fueron expulsados del país y no deportados, ya que el Estado no intervino en el traslado ni tampoco tuteló las condiciones en que se produjo el viaje ni la estancia en los lugares de residencia. Esto significaba su exclusión del cuerpo social, ya que se trataba de una proscripción definitiva en la que ni siquiera se les permitía residir en otro punto del Estado o de Cuba donde su peligrosidad quedara desactivada. Su carácter racial determinó que no se deseara su permanencia en Europa. En su caso no importaba el lugar de residencia, sino la salida del país, algo que sí que sucedía en otros casos donde a pesar de tratarse de díscolos no eran condenados al ostracismo total. En estos casos se dejaban abiertas las puertas al reingreso social y al mismo tiempo se consideraba la necesidad de vigilarles, algo que no se contemplaba ahora ya que a estos libres de color no se les consideraba ciudadanos.

La aglomeración de libres de color en México causó la alarma en las autoridades cubanas que se cuestionaban la conveniencia del elevado número de expulsados y exiliados en un lugar tan cercano a la costa occidental de la colonia. ${ }^{81}$ A pesar de ello, su regreso se consideraba aún más peligroso. La salida perpetua de la isla fue el objetivo y muestra hasta qué punto existía temor y se creía perentoria esta medida. Esto cuando existía un sistema de trabajos forzados de grandes dimensiones con los presos comunes y que podría haberse extendido a los represaliados por la Escalera. México se encontraba enormemente débil, con la independencia de Texas como problema candente y con las ansias expansionistas de su vecino del norte, por lo que las autoridades optarían por no enemistarse con las españolas.

Algunos de los condenados a presidio lo harían en la Península. En la mayoría de las sentencias se explicitaba presidio en Ceuta, pero en ocasiones se hablaba de presidios fuera de Cuba o en Ultramar, lo que entreabría la posibilidad de que algunos fueran desviados hacia la metrópoli. Por ejemplo, el pardo Ramón Medrano, platero de

\footnotetext{
${ }^{80}$ AHN, Ultramar, Leg. 4637, Exp. 8. "Sobre el permiso al negro Julián González para volver a la isla”.

${ }^{81}$ Michele Reid-Vazquez, The Year of the Lash: Free People of Color in Cuba and the Nineteenth-Century Atlantic World, University of Georgia Press, Athens (Georgia), 2011, p. 85.
} 
profesión, cumplía su condena de seis años de presidio en Cádiz de donde se fugó en diciembre de 1845 y se estableció en Oran. Al presidió de Sevilla fueron enviados cuatro sentenciados, y en el de Valladolid cumplió la condena de ocho años Juan Ramón Oliva. $^{82}$

Aunque teóricamente se trató de una conspiración de esclavos, la mayoría de los castigados fueron libres de color. Sobre este grupo se focalizó la represión ya en sus comienzos, a fecha de 9 de mayo de 1844 habían sido detenidas ocho personas blancas y más de 20 de color. Entre estas últimas había dos dentistas, un muñidor, un sastre, cuatro capataces de muelle y dos músicos. ${ }^{83}$ Entre los considerados cabecillas de la sublevación el poeta mulato Placido; el capitán del batallón de pardos, Ceballos; así como un albañil y un talabartero. ${ }^{84}$ Un perfil que se diferenciaba del de los esclavos, simbolizando a una población de color con mayor nivel cultural y económico que interactuaba con la blanca desde una posición diferente a la de amo a esclavo. Representaban un tipo de sociedad multicultural, más cooperativa, en la que la desigualdad racial existía pero que podía ir disminuyendo a medida que más personas de color fueran adquiriendo riqueza y estatus social. De ahí el peligro de estos individuos que mostraban a los esclavos que había gente como ellos que vivía dignamente y que podía establecer vínculos con ellos para tratar de ayudarles. Por esto, el proceso fue en realidad contra los opositores a la sociedad esclavista, incluyéndose en ellos a algunos blancos. Para estos interactuar con los esclavos desde una posición de mayor igualdad podía implicar la constatación de que los negros no eran inferiores e impulsar el abolicionismo entre los miembros del grupo racial dominante.

Con los blancos ejercer una represión severa era más dificultoso. Entre los detenidos encontramos a varios abogados: Félix Manuel Tanco, Manuel Martínez Serrano y Santiago Bombalier. ${ }^{85}$ Este último había sido el abogado de oficio de casi todos los presos políticos de la isla desde 1836. Lo mismo sucedió en 1844 cuando pasó a defender a algunos acusados en la pretendida conspiración, hasta que finalmente él mismo fue detenido y sometido a juicio, aunque como no se le pudo probar nada tuvo

\footnotetext{
${ }^{82}$ AHN, Ultramar, Leg. 4641, Exp. 41. "Ramón Medrano, desertor del presidio de Cádiz"; AHN, Ultramar, Leg, 4627, Exp. 7. "Los individuos José Gertrudis Ramos, José Carbó, Damián de Fleites y Dámaso Ramos, solicitan indulto". Petición de 1849 que les fue denegada; AHN, Ultramar, Leg. 4646, Exp. 12. Expediente de condena de Juan Ramón Oliva.

${ }^{83}$ La Posdata, 13 de junio de 1844.

${ }^{84}$ Vidal Morales Morales, Iniciadores y primeros mártires de la revolución cubana, pp. 153154.

${ }^{85}$ Vidal Morales Morales, Iniciadores y primeros mártires de la revolución cubana, p. 157.
} 
que ser absuelto. ${ }^{86}$ En el caso de la gente de color cualquier disidencia era política, pero tampoco a los blancos se les deja participar en política ni cuestionar el sistema colonial instaurado desde la metrópoli. A los abogados, además de por su ideología se le castigaría por involucrase en la defensa de los supuestos sediciosos.

De este modo, en la Escalera confluyeron tres tipos de punición, la mayoritaria fue la ejercida contra los libres de color que habían conseguido ascender socialmente, que cuestionaban abiertamente la esclavitud y profesaban ideas liberales. Su porcentaje había aumentado en la población y eran una competencia cada vez mayor para los blancos. Los esclavos, cuyas reiteradas revueltas en los años precedentes habían puesto en alerta a las autoridades y que fueron duramente escarmentados. Con los blancos la represión fue mucho menor: tres ejecutados, dos condenados a presidio en África, otros cinco en la Península y tres desterrados. Ciertamente, con ellos se tenía que ser mucho más comedido, aun así fueron afectados destacados liberales y abolicionistas, y otros tuvieron que esconderse. ${ }^{87}$ Pero era patente que formaban parte del grupo que conformaba el sector social del cual el Gobierno esperaba apoyo. Una fijación excesiva con ellos era contraproducente por cuanto produciría resquemor hacia las autoridades y porque dificultaría la pretendida cohesión de este grupo racial en torno al discurso oficial de que los negros representaban una amenaza contra los blancos.

La represión, convenientemente manipulada por O’Donnell para servir a sus intereses, fue un éxito en cuanto a su objetivo principal. El periodo de revueltas de esclavos terminó y estas tuvieron un carácter más esporádico y una importancia menor. El sector de los libres de color quedó neutralizado por el éxodo y el terror que provocó la actuación del Capitán general y tendría un papel subsidiario durante el anexionismo.

Sin embargo, la actitud gubernamental dejó entrever que existía una oposición política formada en la que tras la brutal represión tendría lugar un cambio significativo. Para la mayoría de la disidencia, la salvación de Cuba ya no pasaría por España dado que la metrópoli significaba la barbarie y el inmovilismo. De ahí que muchos prefirieran aliarse con los Estados Unidos, un país que en el plano político garantizaba altas cotas de libertad a los estados miembros, que posibilitaban la permanencia de la esclavitud, y en el económico garantizaría la libertad de comercio. Por esto, el periodo que

\footnotetext{
${ }^{86}$ AHN, Ultramar, Leg. 4645, Exp. 36. "Expediente reservado sobre el destierro de Santiago Bombalier por su conexión con Narciso López".

${ }^{87}$ Sobre el surgimiento del reformismo en Cuba, que cuestionaba la continua importación de esclavos y pretendía un blanqueamiento de la población de la misma ver Kharim Ghorbal, Réformisme et esclavage à Cuba, Publibook, París, 2009.
} 
comenzaría en 1848 y terminaría a mediados de la década de los 50 no se entiende sin los sucesos de 1844. En este caso, serían principalmente los blancos, el grupo del cual las autoridades coloniales esperaban apoyo, quienes liderarían la oposición al poder español.

La Escalera encarna la otra cara del progreso económico y el hiperesclavismo en Cuba. Los grandes damnificados podían sublevarse contra su situación y representaban un peligro. Por esto, Cuba se configuró como un sistema dictatorial con facultades omnímodas para el Capitán general que pretendió imponer un orden estricto a cualquier precio, centrándose en los considerados más peligrosos pero que en realidad lo abarcaba casi todo. En 20 de marzo de 1844 informaba al Ministerio de Ultramar de la existencia de individuos de mala conducta y vagos en La Habana y de la salida de 11 de ellos hacia Pinos. En abril de 1846 había unos 600 con estas características en Pinos. ${ }^{88}$ Cualquier tipo de disidencia era considerada una transgresión, aunque era evidente que la delincuencia de poca monta, vagancia, embriaguez y otras conductas similares no tenían connotaciones políticas.

A pesar de la explicitación de que los que salían del país no podían volver a él, el tiempo transcurrido facilitaba que algunos lo pudieran hacer. A los mulatos libres José Rosario Pineda, Bernabé Díaz, Genaro de León y Pedro Modesto Mondesín, condenados a relegación, se les extinguió la acción penal en abril de 1846 por los trabajos que habían hecho construyendo la iglesia parroquial de Bejucal. ${ }^{89}$ A finales de 1846 desembarcaron diez cumplidos en el bergantín Pelicano, por lo que ante las quejas de O’Donnell se recordó a todas las autoridades que no permitieran ningún retorno sin consultar al Gobierno. ${ }^{90}$ Nicolás Manresa pudo volver a Cuba en septiembre de 1852, al cumplir su condena de presidio en Ceuta, porque en su sentencia no se estipulaba la proscripción de la isla. ${ }^{91}$ A Julián González se le autorizó el regreso en febrero de 1852 atendiendo a su avanzada edad, 56 años. Los presos que cumplían condena quedaban en una situación extraña, quedando libres pero sin poder trasladarse a sus hogares. Juan Ramón Oliva, cumplió su condena en el presidio de Valladolid 6 de enero de 1852. Después se trasladó a Madrid, donde tenía trabajo y observaba buena conducta, y fue

\footnotetext{
${ }^{88}$ AHN, Ultramar, Leg. 4627, Exp. 9. Sobre recursos y apelaciones de individuos confinados en isla de Pinos por medida de policía.

${ }^{89}$ Herminio Portell Vilá, Narciso López y su época, Compañía Editora de Libros y Folletos, La Habana, 1952, tomo II (1848-1850), p. 327.

${ }^{90}$ ANC, Reales Órdenes y Cédulas, Leg. 175, Exp. 23.

${ }^{91}$ AHN, Ultramar, Leg. 4636, Exp. 43. Petición de regreso de Nicolás Manresa.
} 
autorizado a repatriarse en 6 de agosto de $1856 .{ }^{92}$ En cualquier caso la vuelta seria excepcional ya que la política oficial era que no pudieran retornar, y exceptuando el caso del Pelicano en el resto se pidió antes la aprobación del Capitán general, lo que determinaba que no se produciría más que en casos puntuales. Además el cumplimiento de las penas para la mayoría coincidiría con las insurrecciones y expediciones anexionistas.

${ }^{92}$ AHN, Ultramar, Leg. 4646, Exp. 12. Expediente de condena de Juan Ramón Oliva. 


\section{CAPÍTULO 8. EL MOVIMIENTO ANEXIONISTA Y LA GUERRA DE LOS DIEZ AÑOS.}

\section{LA REPRESIÓN DE ANEXIONISMO (1848-1855)}

\subsection{La política española y el auge del anexionismo}

La exclusión de Cuba de la nación española en 1837 significó quedar al margen de la aplicación de la Constitución y de los derechos políticos y ser regidos directamente por un gobernador militar enviado desde Madrid. Esto originó entre buena parte de la élite criolla una sensación de incomprensión. Para suavizar su enojo se les prometió la próxima promulgación de leyes especiales, una propuesta que en momentos puntuales se renovaba pero que en última instancia no era más que un intento de ocultar la situación de gobierno autoritario de los capitanes generales. ${ }^{1}$ En este contexto de búsqueda de derechos políticos fue desarrollándose el anexionismo, movimiento que tradicionalmente no ha sido fácil de ubicar en la supuesta línea recta por la que transcurre el proceso de independencia de la isla, aunque últimamente ha sido mejor definido, considerándose como una etapa en el camino hacia la misma. ${ }^{2}$

Al descontento entre los criollos habría que añadir otros elementos como las relaciones económicas con el vecino del norte, que en ese momento ya era el principal socio comercial, principalmente en la venta de maquinaria y en la adquisición de la mayor parte de las exportaciones de la Antilla mayor. ${ }^{3}$ La influencia del gigante americano no hacía sino crecer, muchos de los hijos de la élite criolla habían estudiado en Inglaterra o los Estados Unidos, la lamentable situación en el que se encontraban muchas de las antiguas colonias en América y la composición racial de la población cubana incrementaron el ascendiente de los Estados Unidos. El temor a la "africanización" a partir de 1841 hizo temer a muchos por los posibles costes de la independencia: desórdenes, guerras, levantamientos de esclavos o incapacidad para hacer frente a la presión abolicionista británica. La reciente incorporación de Texas y la

\footnotetext{
${ }^{1}$ Josep María Fradera, Gobernar colonias, Península, Barcelona, 1999, pp. 71-93.

2 Josef Opatrný, US Expansionism and Cuban Annexationism in the 1850s, Charles University, Prague, 1990, p. 253.

${ }^{3}$ Julio Le Riverend, Historia económica de Cuba, Instituto Cubano del Libro, La Habana, 1974, pp. 382-394.
} 
guerra contra México, que mostró el poderío norteamericano, reforzaron la percepción en muchos criollos de que su futuro pasaba por su incorporación al vecino del norte, que se veía no solo como el punto de destino sino también como un aliado que podía prestar ayuda directa para deshacerse del dominio colonial español.

El anexionismo se configuró como el modo que en la época tuvieron las élites criollas para conseguir derechos políticos, ya que habían quedado sujetas a un estado de sitio permanente y a una exclusión política, permitiéndoseles únicamente las libertades económicas, incluida la de posesión de esclavos. Habían sido desplazados de las carreras administrativas y políticas y de los beneficios económicos que ello conllevaba y la política gubernamental no era lo suficientemente flexible con sus demandas. España mantenía la afluencia de bozales pero a un precio cada vez más elevado y los intentos de introducción de colonos blancos llevados a cabo por personalidades como Domingo Goicouria y Gaspar Betancourt Cisneros no gozaron con el apoyo gubernamental, ${ }^{4}$ que creía que mantener un equilibro entre razas frenaba las tendencias emancipadoras. Para aquellos que pensaban que la introducción constante de esclavos era contraproducente y se mostraban partidarios del fomento de la inmigración blanca, España era una rémora por su política de paridad racial. Los contrarios a la emancipación temían la debilidad española frente a las presiones abolicionistas inglesas. Los independentistas creían que solos no podrían liberarse del dominio español. A ellos se sumaron liberales y conocidos independentistas como José Aniceto Iznaga.

Esto configuró tres grupos principales de conspiradores. El organizado en torno al Club de La Habana, formado por algunas de las personalidades más importantes de la isla y cuyo objetivo era el mantenimiento de la esclavitud; el de Las Villas, también conservador y con intereses negreros, y el de Puerto Príncipe, que tenía un carácter más avanzado al estar compuesto por liberales convencidos de que las reformas en España eran imposibles y que recelaban de las posibilidades de emancipación del pueblo cubano. ${ }^{5}$ Los grandes hacendados veían un país fuerte para la permanencia de la esclavitud, los partidarios del blanqueamiento que disponían de tiempo de adaptación y facilidad para introducción de colonos blancos, y los más liberales se sentían atraídos

\footnotetext{
${ }^{4}$ Manuel de Paz Sánchez, "Un reformador social cubano del XIX. Gaspar Betancourt Cisneros, El Lugareño", Anuario de Estudios Atlánticos, núm. 50, tomo II, 2004, p. 1057; Domingo de Goicouria, Memorial presentado a su majestad para el fomento de la población blanca y la producción del azúcar en la isla de Cuba, Imprenta de J. Martin Alegría, Madrid, 1846.

${ }_{5}^{5}$ María del Carmen Barcia y Eduardo Torres Cuevas, "El debilitamiento de las relaciones sociales esclavistas. Del reformismo liberal a la revolución independentista", pp. 438-439.
} 
por su sistema democrático. Los tres colectivos pretendían adquirir derechos políticos y capacidad de decisión sobre los asuntos que incumbían a sus intereses.

Un grupo en torno a Narciso López ya se encontraba conspirando desde 1847. El Club de La Habana se sumaría más tarde a la conspiración. Los sucesos de 1848 en Francia, con la proclamación de la República y la abolición de la esclavitud en las colonias actuaron como detonador. Ante el temor a que tal medida se extendiera a España, se decidieron a actuar tratando de obtener la ayuda del presidente Polk y del general Worth, uno de los principales jefes en la guerra contra México. La sublevación, que contaba con ramificaciones en otras ciudades, sufrió diversas demoras propiciadas por el grupo habanero, y posteriormente fue descubierta por una delación realizada desde el Gobierno norteamericano. ${ }^{6}$ Los retrasos deben ser entendidos como un intento de maduración de sus planes, que consistían en obtener la necesaria ayuda norteamericana. Por sus haberes y su importancia, su actuación era más cautelosa al tener mucho que perder. Los grandes propietarios no estaban dispuestos a arriesgar sin tener seguridad de que sus intereses serían respetados. Por eso se movieron en la ambivalencia, y su postura también debe ser entendida como un modo de presionar al Ejecutivo para que la política colonial no les perjudicara. En la posición contraria se situaba López, hombre de acción, dado su carácter de general del ejército español.

Tras instar procedimiento a los acusados, en abril de 1849 se dictó la sentencia definitiva de muerte contra Narciso López, y de seis años de prisión a Aniceto Sánchez Iznaga, ambos en rebeldía. En octubre se abrió un nuevo proceso en el cual Miguel Teurbe Tolón y Cirilo Villaverde, ya fugados, fueron condenados a ser ejecutados. Sebastián Alfredo de Morales lo fue a seis años de confinamiento y los hermanos Gaspar y Francisco Mateo de Acosta a dos años de la misma pena. A seis individuos se les sobreseyeron las causas. En 1848, en relación con estos acontecimientos había sido deportado a Pinos Ramón Ignacio Arnao. ${ }^{7}$

\footnotetext{
${ }^{6}$ Herminio Portell Vilá, Narciso López y su época, tomo I, p. 219 y 235-238; Candelaria Saiz Pastor, "Narciso López y el anexionismo en Cuba. En torno a la ideología de los propietarios de esclavos", Anuario de Estudios Americanos, núm. 43, 1994, pp. 453-454; Herminio Portell Vilá, Narciso López y su época, tomo II (1848-1850), pp. 22-28 y 99.

${ }^{7}$ Vidal Morales y Morales, Iniciadores y primeros mártires de la revolución cubana, pp. 196 y 210; Herminio Portell Vilá, Narciso López y su época, tomo I, pp. 290-292; en 21 de marzo de 1850 Emilia Teurbe Tolón, mujer y prima de Miguel, fue obligada a embarcarse para Nueva York" donde estaba su marido, acusada de conspirar. Biblioteca Nacional de Cuba José Martí (en adelante BNCJM), Manuscritos, Treserra, núm. 1.
} 
Las autoridades se inclinaron por una represión severa en apariencia, pero en la que la punición efectivamente aplicada no fuera excesivamente dura y que no alcanzara a un número excesivo de acusados. Por el hecho de que no estallara, por desconocimiento de su verdadero alcance, o por temor a que las pesquisas llegaran a personalidades de las altas esferas, se optó por restar importancia a esta primera intentona de sublevación. Algo muy diferente a lo que había sucedido pocos años antes con la conspiración de la Escalera. Poco después, Narciso López y algunos de los emigrados formarían la Junta cubana, en una prueba de que el fracaso no iba a poder con la determinación de los conspiradores.

Ignoramos si el confinamiento de los hermanos de Acosta fue dentro de Cuba o en el exterior, pero Gaspar se encontraba en el país en $1851,{ }^{8}$ por lo que es probable que su hermano también estuviera allí. El botánico, poeta y médico, Sebastián Alfredo de Morales iba a ser llevado a Filipinas. El 9 de abril de 1850 se encontraba en la cárcel pública de Cádiz aquejado de una enfermedad que paralizó momentáneamente su embarque. En 20 de junio, ya restablecido, estaba presto a embarcar en la primera ocasión. ${ }^{9}$ La relegación se contempló desde el primer momento como una pena útil para hacer frente a las intentonas insurreccionales. Las realizadas a Filipinas por las revueltas de 1848 en la Península pudieron haber influido en esta medida, sin embargo, dado el carácter colonial del archipiélago no parece muy adecuado enviar a separatistas antillanos. De hecho este punto de destino no se repitió con posterioridad, ya que en Europa su peligrosidad era mucho menor.

En 1849, la extensión del descontento contra la metrópoli entre la juventud se manifestó con pequeños actos de rebeldía. El joven poeta José Ricardo Fresneda fue sentenciado por la Comisión Militar a relegación a Santiago de Compostela, en cuya universidad continuaría sus estudios de Derecho, por un poema publicado en marzo de 1849 en La Aurora de Matanzas en el que las iniciales de cada verso componían la frase "Libertad vuestra patria, hijos de Cuba". ${ }^{10}$ En octubre de ese mismo año, otros cuatro jóvenes fueron trasladados a Cádiz por boicotear un baile en el que participaban militares españoles, lo que contrasta con el destierro a la parte occidental de cuatro

\footnotetext{
${ }^{8}$ Causas del fiscal Juan Larrazábal a 25 de julio de 1851. ANC, Comisión Militar, Leg. 132, Exp. 1. "Relaciones de las causas que ha sentenciado la Comisión Militar del año 1840 a 1856". ${ }^{9}$ AHN, Ultramar, Leg. 4651, Exp. 41. "Sobre el deportado don Sebastián Morales".

${ }^{10}$ ANC, Asuntos Políticos, Leg. 216, Sig. 3. "Publicación de un acróstico en La Aurora de Matanzas, por don José Ricardo Fresneda, que fue enviado a la Península".
} 
individuos de Pinar del Rio acusados de conspiración, ${ }^{11}$ y con la represión no excesivamente dura por el intento de insurrección del año anterior. En un momento en que las conspiraciones no eran visibles se trató de ocultarlas. Justamente lo contrario que ocurría con los actos públicos de desacato, que a pesar de ser triviales fueron reprimidos proporcionalmente de una manera más dura precisamente por su explicitación. La distancia entre criollos y peninsulares aumentaba pero las autoridades trataron de esconderla, unos castigos excesivamente numerosos y rigurosos de los complots hubiera supuesto un reconocimiento implícito de su importancia.

La táctica del Capitán general se vio ayudada por la política norteamericana, que deseaba la anexión mediante compra. Funcionarios de la alta administración de los Estados Unidos habían delatado la intriga de 1848. La conspiración que se estaba llevado a cabo en Round Island al año siguiente fue neutralizada por la acción gubernamental. No en vano, en aquel momento el país estaba inmerso en una acalorada disputa acerca de la esclavitud en California y Nuevo México. El Gobierno federal pensaba que el apoyo de Mississippi a la expedición había ido demasiado lejos y pronunció que su país cumpliría su compromiso de neutralidad adquirido con España, prometiendo penas duras para los filibusteros y no protegerles en caso de que su situación pudiera demandarlo. ${ }^{12}$

Mientras tanto, las maquinaciones de los separatistas continuaban y desde Madrid eran plenamente conscientes de ello. En abril de 1850, el Ejecutivo daba instrucciones precisas a la máxima autoridad colonial acerca del procedimiento a seguir contra las personas que habían participado en planes sediciosos. En estas se establecían medidas como los destierros a Ultramar y las prisiones, que deberían ser hechos con la mayor confidencialidad posible, para evitar en la medida de lo posible escritos, quejas y murmuraciones contra el domino español, así como recriminaciones en la prensa. También ordenaba a la máxima autoridad cubana a asumir la jefatura de la represión

\footnotetext{
${ }^{11}$ AHN, Ultramar, Leg. 4633 Exp. 6. "Acusación contra varios vecinos de Matanzas por comportamiento subversivo". Plutarco González pudo huir a Estados Unidos. Los deportados fueron Joaquín Delgado, Joaquín Álvarez y los hermanos Francisco y Calixto Sorondo. González, el más implicado políticamente, pudo huir. El 20 de octubre de 1850 les fue otorgado permiso para volver a Cuba, donde permanecerían vigilados por las autoridades; Delgado estaba acusado de haber robado 25.000 pesos a la Real Hacienda. AHN, Ultramar, Leg. 4645, Exp. 16. "Expediente reservado sobre la aplicación del indulto concedido por el nacimiento de la princesa de Asturias".

${ }^{12}$ Rafael de la Cova, "The Taylor administration versus Mississippi Sovereignty: The Round Island expedition of 1849", The Journal of Mississippi, vol. LXII, núm. 4, 2000, pp. 295, 304 y 325 .
} 
para evitar extender el coste político de la misma a las autoridades locales. ${ }^{13}$ Es decir, se trataba de que esta fuera percibida como actos arbitrarios emanados de la voluntad de una autoridad despótica y no como una actuación estatal plenamente estructurada.

Los trabajos de López se materializaron en el desembarco de Cárdenas de 19 de mayo de 1850, protagonizado por unos quinientos individuos entre los cuales había únicamente siete cubanos. ${ }^{14}$ El Capitán general aprovechó la nacionalidad de los expedicionarios, incluida la del cabecilla venezolano, para calificarles de extranjeros depravados y tratar de fomentar el espíritu patriótico, consiguiendo que varios miles se presentaran voluntarios para combatirles. ${ }^{15}$ Por el contrario, a López solamente se le unieron algunos soldados y sus proclamas tuvieron muy poca acogida entre los oriundos. Las barreras idiomáticas entre la mayoría de los expedicionarios y el pueblo, la desmoralización de los expedicionarios y el temor a la llegada de refuerzos, forzaron al general a huir y dejar a la población a merced de las autoridades.

La materialización de la insurrección suponía un incremento indudable en la escala del desafío anexionista. Cinco rezagados fueron apresados, de los que uno evitó el fusilamiento al haber salvado la vida a un militar español herido. ${ }^{16} \mathrm{Al}$ margen de los combatientes, las represalias no se caracterizarían por ser brutales, aunque sí bastante arbitrarias. Hubo 30 detenidos, entre los que había algunos militares, ${ }^{17}$ que fueron castigados por la Comisión Militar al regimiento fijo de Ceuta de carácter disciplinario. El canario Bernardino Hernández fue agarrotado, por haber requisado caballos para López. El negro José Rosario Pinedo que había ayudado a López en la extinción del incendio de la casa capitular y en el transporte de provisiones fue sentenciado a tres años de destierro en Santiago de Cuba. Otros ocho vecinos fueron llevados presos a La Habana. Únicamente el carpintero mestizo Pedro Ordaz fue castigado con dos años de extrañamiento en la Península. ${ }^{18}$ En noviembre de 1851, a Silvestre Pérez de la Hera se le impusieron 10 años de presidio ultramarino, por haber tratado de unirse a los

\footnotetext{
${ }^{13}$ AHN, Ultramar, Leg. 4645, Exp. 9 "Noticias de la situación política de la isla de Cuba, temores de insurrección y medios empleados para contenerla".

${ }^{14}$ Leví Marrero, Cuba. Economía y sociedad, vol. 15, pp. 176-177.

${ }^{15}$ Apuntes históricos acerca de la expedición pirática que invadió la isla de Cuba en mayo de 1850, y detalles de la causa seguida contra el ex-general Narciso López y sus cómplices, Imprenta de Alemán y Gómez, Nueva Orleans, 1850, pp. 5-8.

${ }^{16}$ Joaquín Llaverías, Comisión Militar Ejecutiva y Permanente de la isla de Cuba, p. 99. La pena le fue conmutada por diez años de presidio en Ceuta.

${ }^{17}$ Herminio Portell Vilá, Historia de Cárdenas, Cuba Intelectual, La Habana, 1928, pp. 123126.

${ }^{18}$ Herminio Portell Vilá, Narciso López y su época, tomo II (1848-1850), pp. 328-331.
} 
insurrectos. Manuel Galeano y Juan Arenas fueron sentenciados a relegación indefinida en la metrópoli por tratar de insurreccionar a la tropa. ${ }^{19}$

El motivo aducido para imponer la muerte a Hernández fue que en el momento de su aprehensión llevaba un sable al cinto que se negó a entregar. Sin restar importancia a este hecho, parece que se buscó un chivo expiatorio más con carácter ejemplificador que de castigo. Su carácter de no cubano sirvió de advertencia, tratando de no levantar excesivamente el resentimiento criollo contra la metrópoli. Así, la primera expedición de López terminó con cinco ejecutados, ninguno de ellos criollo, resulta evidente que el Gobierno trataba de evitar enemistarse con ellos.

A raíz de esta intentona, se utilizaron algunos destierros dentro de la Antilla mayor. $^{20}$ Esto significaba una manera menos dura de apartar a los supuestos conspiradores de su medio, pero dado que aunque en diferente escala el anexionismo estaba disperso por todo el territorio, su eficacia era menor. Por el contrario, con algunos extranjeros se optó por sacarles del país, ${ }^{21}$ esta era la opción más fácil con los naturales de otro estado y que no necesitaba ningún tipo de planificación especial. Este tipo de medidas consistentes en sacar a los individuos de su medio conspirativo se reforzaron con el nuevo Capitán general.

\subsection{El mandato de José Gutiérrez de la Concha}

Las presiones inglesas por la tolerancia de Roncali al tráfico ilegal de esclavos y la aparente incapacidad de la máxima autoridad colonial en lo político llevaron al Ejecutivo español a destituirle, para reemplazarle por José Gutiérrez de la Concha. Desde su llegada, el 10 de noviembre de 1850, llevó a cabo medidas como la introducción de la Guardia Civil en la isla, reforma de la policía, reglamentación y mejora de las prisiones, modernización administrativa, mayor vigilancia sobre la figura de los emancipados y cambios en la regulación de los ayuntamientos. El carácter de sus

\footnotetext{
${ }^{19}$ ANC, Comisión Militar, Leg. 100, Exp. 7. Causa contra los acusados de haber intentado ayudar a Narciso López; relación de las causas a cargo del fiscal Luis de la Guardia, 1 de octubre de 1851. ANC, Comisión Militar, Leg. 132, Exp. 1. "Relaciones de las causas que ha sentenciado la Comisión Militar del año 1840 a 1856".

${ }^{20}$ ANC, Comisión Militar, Leg. 92, Exp. 7. Causa contra Cayetano Fortún; causas a cargo del fiscal Luis de la Guardia a 1 de junio de 1851. ANC, Comisión Militar, Leg. 132, Exp. 1. "Relaciones de las causas que ha sentenciado la Comisión Militar del año 1840 a 1856".

${ }^{21}$ ANC, Comisión Militar, Leg. 91, Exp. 8. Causa contra los italianos Juan Bautista y Santiago Sturlas.
} 
disposiciones tendentes a la racionalización de la estructura administrativa levantó ciertas expectativas entre los reformistas como José Antonio Saco y Domingo del Monte, si bien sus deseos no se materializaron. En cuanto al orden público, incrementó la centralización en torno a su figura, mejorando la eficacia de la administración que encabezaba. $^{22}$

Utilizó sus poderes para mejorar la estructura opresiva, en la que destaca la reorganización del ejército llevada a cabo con la colaboración del Gobierno en Madrid. Aumentó las fuerzas operativas desde los 14.498 disponibles en 1 de septiembre de 1850 a 19.577 en 1 de abril de 1851. Perfeccionó la distribución y el entrenamiento de las tropas, optimizó el material y los suministros del ejército, mejorando la alimentación y la sanidad, e inició una política de obras públicas con objeto de facilitar el transporte y la comunicación de las tropas con la creación de ferrocarriles, caminos y líneas telegráficas. Asimismo se proyectó la edificación de nuevas fortificaciones, algunas de las cuales comenzaron a construirse. ${ }^{23}$

Resultaba evidente la preparación para hacer frente a nuevas insurrecciones. La racionalización en el ejército fue acompañada de otras medidas y de aquí el salto cualitativo que se produjo con la adaptación del uso de la deportación que hasta el momento había sido utilizada en actos de disidencia concretos. Gutiérrez de la Concha la concibió como una modalidad de neutralización preventiva, incorporando la política moderada ejecutada contra opositores políticos y pobres tras la réplica española de las revueltas de 1848, aunque con muchísimo más tacto respecto a los cubanos al afectar a un número muy reducido. En este caso, el castigo se centró sobre aquellos de los que se tenía la idea que conspiraban, contrariamente a lo que sucedió en la Península, donde las relegaciones alcanzaron a progresistas únicamente por su militancia política y fue complementada por la ejecutada contra desempleados y marginados.

Nada más llegar se encontró con un juicio por introducción de armas en el país, que terminó con cuatro condenados a cinco años de presidio ultramarino, dos a cuatro y otros dos a deportación en la Península. ${ }^{24}$ El alejamiento adquirió importancia en esta

\footnotetext{
${ }^{22}$ Josep María Fradera, Colonias para después de un imperio, Bellaterra, Barcelona, 2005, pp. 299-322.

${ }^{23}$ José G, Cayuela Fernández, Bahía de Ultramar. España y Cuba en el siglo XIX. El control de las relaciones coloniales, Siglo XXI, Madrid, 1993, pp. 136-162.

${ }^{24}$ ANC, Comisión Militar, Leg. 89, Exp. 1. Causa por introducción clandestina de fusiles. Los condenados a relegación eran Felipe Hernández, que eligió Sevilla como destino y Carlos Collins, que se encontraba prófugo.
} 
primera sentencia, incluso en lo referente a los presidios, que también se manifestó en el traslado a Europa para los que creía menos implicados. Poco después solicitó al Ejecutivo que le otorgara la potestad para embarcar rumbo a la metrópoli a los independentistas contrarios a la tranquilidad pública. ${ }^{25}$ Creía que amputando de la sociedad a líderes políticos separatistas podía mantener el orden público con más facilidad.

El primer detenido fue el abogado Santiago Bombalier, quien había ejercido como defensor de la mayoría de los presos políticos de Cuba desde 1836 y había sido procesado en 1836 y 1845, siendo absuelto en ambas ocasiones. Las acusaciones contra Bombalier eran muy graves, ser el máximo representantes del movimiento anexionista en La Habana, haber ayudado económicamente a la insurrección y mantener correspondencia con Narciso López. A pesar de no encontrársele ninguna prueba incriminatoria, el 10 de mayo de 1851 salió en el bergantín Joven Enrique en dirección a Cádiz, desde donde pasaría a las Baleares. ${ }^{26}$ El caso del letrado es muy significativo, la causa real seria la inconveniencia de su presencia en la colonia dado el periodo de vulneración de derechos que se avecinaba. Por su importancia, fue el primero sobre el que recaería esta punición administrativa.

La neutralización del abogado facilitaba la aplicación de la medida a otros, a la par que las conspiraciones tanto dentro de la isla como desde los Estados Unidos crecían en intensidad y trataban de crear una acción coordinada con una sublevación interior que apoyara al desembarco de las expediciones. En Puerto Príncipe fueron detenidas once personas, en base al seguimiento que se les estaba realizando y en las opiniones de delatores. Uno quedó en la ciudad para procedimientos posteriores y los otros diez fueron enviados a La Habana con objeto de ser deportados. De estos, ocho eran de Puerto Príncipe y dos de Nuevitas. Desconocemos la profesión de algunos, aunque había cuatro abogados y dos escribanos. Finalmente, los nueve partieron en las fragatas Paquete Habanero y Venus con rumbo a Cádiz, desde donde fueron distribuidos a Sevilla, Córdoba, Málaga y Madrid. De la primera sabemos que salió en mayo y la segunda que llegó a su destino en 31 de julio de $1851 .^{27}$

\footnotetext{
${ }^{25}$ AHN, Ultramar, Leg. 4634, Exp. 52. "El Gobernador general pide facultades para expulsar de Cuba a quien altere el orden".

${ }^{26}$ AHN, Ultramar, Leg. 4645, Exp. 36. "Expediente reservado sobre el destierro de Santiago Bombalier por su conexión con Narciso López".

${ }^{27}$ AHN, Ultramar, Leg. 4645, Exp. 17. "Expedientes reservados de varios cubanos deportados a la Península". Los deportados fueron José Joaquín Rivera, Manuel de Jesús Arango, Agustín
} 
Al margen de los directamente implicados, las intentonas anexionistas derivaron en un incremento en la presión política, haciendo todavía más estrecha la posibilidad de discrepancia. Se trata de juicios por hechos aislados, generalmente haber proferido unas simples palabras subversivas, que fueron una constante pero adquirieron mayor vigencia en los tiempos de mayor convulsión. En ocasiones se utilizaban para "extraer" de un punto o de la isla a determinados ciudadanos. Con de la Concha, la deportación a la Península se utilizó para reprimir estos actos, sustituyendo a isla de Pinos que se había utilizado en anterioridad. ${ }^{28}$ Por palabras subversivas fue remitido a Europa en diciembre de 1850 durante dos años el mulato Pedro Ordaz. En febrero de 1851 Juan Hernández (a) Pelado, vecino de San Luis de la Ceiba, fue condenado a ser relegado durante seis años a Sevilla. Antonio Fleury fue remitido a Vigo y posteriormente llevado al Hacho, por temor a que regresara. ${ }^{29}$

En ocasiones, estos juicios individualizados tenían un trasfondo político más amplio, o al menos así se les otorgaba por las autoridades. En este caso, los apresados eran acusados de alguna acción concreta que excedía las simples palabras, o eran acusados bajo el concepto amplio de infidencia. A Juan Francisco Asensio se le impuso la relegación definitiva en la Península en noviembre de 1851 por intento de sedición a la tropa. Francisco Martínez Muñoz fue deportado en 1850 a la metrópoli por pretender repartir proclamas de Narciso López y José D. Trigo y Felipe González a La Coruña por “infidencia”. Manuel Higinio Ramírez fue relegado a fines de 1851 por portar armas prohibidas. En 1853 sufrieron el mismo castigo Lorenzo Baseiro, perpetuamente, y Tomás Santa Cruz durante cuatro años. ${ }^{30}$

Miranda, José Ramón Betancourt, Salvador Cisneros, Fernando Betancourt, Melchor Silva, José María Valdés y Francisco Quesada y Guerra. Finalmente a Serapio Recio no se le aplicó este castigo.

${ }^{28}$ ANC, Comisión Militar, Leg. 83, Exp. 18. Causa contra Matías Arango. Fue deportado a isla de Pinos en 1848 por palabras subversivas.

${ }_{29}$ ANC, Comisión Militar, Leg. 90, Exp. 3. Causa contra el mulato Pedro Ordaz; ANC, Comisión Militar, Leg. 90, Exp. 2. Causa contra Juan Hernández (a) Pelado; ANC, Comisión Militar, Leg. 102, Exp. 8. Causa contra varios acusados de infidencia. Resulta curioso el destino seguido por Fleury, ya que en realidad no podría estar preso en el Hacho, por lo que es probable que fuera llevado a Ceuta, o que aun estando en el Hacho no estuviera preso. Collins fue puesto en libertad por esta causa en pago a los servicios prestados.

${ }^{30}$ ANC, Comisión Militar, Leg. 99, Exp. 2. Causa contra Juan Francisco Asensio; ANC, Comisión Militar, Leg. 95, Exp. 4. Causa contra acusados de ser agentes de Narciso López; ANC, Comisión Militar, Leg. 93, Exp. 1. Causa contra acusados por infidencia; relación de causas del fiscal Pedro Cruces en segundo semestre de 1851. ANC, Comisión Militar, Leg. 132, Exp. 1. "Relaciones de las causas que ha sentenciado la Comisión Militar del año 1840 a 1856"; 
La mera existencia de estos juicios era una prueba del rigor y la arbitrariedad del sistema colonial español, especialmente en lo que se refiere a haber proferido palabras consideradas sediciosas. Pero, al mismo tiempo servían para que el estricto sistema estuviera presente al margen de las conspiraciones más serias, manteniendo un temor constante entre la población. El mero apresamiento y desarrollo del proceso era una advertencia velada. En muchas ocasiones estos encausamientos venían por denuncias de anónimos.

Las relegaciones administrativas utilizadas contra las conspiraciones no consiguieron paralizar los alzamientos. El 4 de julio se alzó en Puerto Príncipe un grupo de unos 40 individuos comandando por Joaquín de Agüero. Tras un intento frustrado de proveerse de material en Las Tunas, donde dos grupos de rebeldes acabaron enfrentándose en la oscuridad de la noche, se produjo una desbandada. Agüero y su grupo fueron apresados el 23 de julio tras un combate con los soldados españoles en que murieron varios de estos y cinco insurrectos. ${ }^{31}$ El desafío contra la autoridad española fue todavía mayor, atendiendo a que la sublevación de Puerto Príncipe estaba en connivencia con otras en Trinidad y Santa Cruz, que debían producirse al unísono, abriendo varios frentes interiores a los que se uniría la expedición de López. Diversas causas retrasaron el alzamiento en Trinidad, que se materializó el día 23 de julio, agrupando a unos sesenta o setenta hombres que contaron con la ayuda de algunos de los hacendados más importantes de la ciudad. ${ }^{32}$ Atacados por las tropas españolas, la mayoría no tardaron en dispersarse y en ser capturados o presentarse.

De entre los revolucionarios de Puerto Príncipe, cuatro sujetos fueron sentenciados a ser ejecutados; 18 a diez años de presidio, siete de las cuales con carácter ultramarino; 11 a ocho años de presidio; uno a reclusión en un seminario; tres fueron compurgados con la prisión sufrida y uno a seis años de presidio en La Coruña. Trece penas de muerte fueron dictadas en rebeldía, pero a otros cinco penados a expiración les fue conmutada por diez años de presidio en Ceuta. Finalmente los únicos ajusticiados

ANC, Comisión Militar, Leg. 911, Exp. 2. Causa contra Tomás Santa Cruz y Lorenzo Baseiro por infidencia.

${ }^{31}$ Fernando Portuondo, "Joaquín Agüero y sus compañeros de Camagüey", Cuadernos de Historia Habanera, núm. 51 (Homenaje a los mártires de 1851), 1951, p. 22; Francisco Agüero Estrada (El Solitario), Biografía de Joaquín Agüero, Molina y Cía., Impresores, La Habana, 1935 , p. 39.

${ }^{32}$ Hernán M. Venegas, Trinidad de Cuba. Corsarios, azúcar y revolución en el Caribe, Centro de Investigación y Desarrollo de la Cultura Cubana Juan Marinello, La Habana, 2005, pp. 7374. 
fueron Joaquín Agüero y tres de los cinco que le acompañaban en el momento de su detención, ejecución que tuvo lugar el 12 de agosto. Tres fugitivos fueron castigados con la expulsión de Cuba y Puerto Rico. ${ }^{33}$

Lo mismo sucedió en Trinidad respecto a los cabecillas. El 18 de agosto fueron fusilados los cabecillas José Isidoro Armenteros, Fernando Hernández y Rafael Arcis; diez fueron condenados a entre ocho y diez años de presidio en África (tres de los cuales en rebeldía); 15 a entre dos y seis años de presidio en la Península, y cuatro a dos años de presidio. A un grupo se le impuso la deportación perpetua en la metrópoli, en donde debían elegir el punto de residencia. Entre ellos había 16 blancos, de los cuales dos se encontraban prófugos, siete pardos y un chino. ${ }^{34}$ La relegación se empleó para extender la represión a los que se creía menos implicados cuando la situación estaba bajo control de las autoridades. Con la insurrección de Agüero se siguió una política de mayor dureza, basada en los presidios.

Acerca del carácter de la sublevación de Agüero, en sus manifiestos revolucionarios se excluía a los negros y se garantizaba el derecho de propiedad. ${ }^{35}$ Elda Cento ha dudado de que dicho comunicado, aun estando firmado por Joaquín de Agüero, fuera redactado por él y que incluso ni siquiera hubiera dado su consentimiento, constatando su carácter abolicionista. ${ }^{36}$ Las proclamas no implican

33 ANC, Comisión Militar, Leg. 105, Exp. 2. Causa contra Joaquín Agüero y otros; ANC, Comisión Militar. Leg. 105, Exp. 1. Causa contra Manuel Facundo Agüero y otros acusados de auxiliadores de don Joaquín de Agüero y Agüero; ANC, Comisión Militar, Leg. 104, Exp. 4. Causa contra Melchor María de Agüero y Castillo, acusado de pertenecer a la partida insurrecta; ANC, Comisión Militar, Leg. 104, Exp. 3. Causa contra los quince reos prófugos que pertenecieron a la partida de insurrectos de Puerto Príncipe; ANC, Comisión Militar, Leg. 100, Exp. 1. Causa contra José Agustín Agüero y Arteaga y otros, acusados de rebelión al Gobierno; ANC, Comisión Militar, Leg. 105, Exp. 3. Expediente contra Joaquín de Agüero y Sánchez; ANC, Comisión Militar, Leg. 109, Exp. 6. "Causa contra Juan y Ubaldo Arteaga y otros, acusados de tomar parte en la insurrección de Joaquín Agüero"; ANC, Comisión Militar, Leg. 104, Exp. 1. Causa contra varios individuos acusados de complicidad con la partida de Joaquín de Agüero y Agüero. Los expulsados de la isla eran Carlos Varona Mola, Vicente Quiñones y Santiago de Zayas.

${ }^{34}$ ANC, Comisión Militar, Leg. 101, Exp. 1. Segunda sentencia por la causa de la insurrección de Trinidad. Insurrectos de Trinidad; AHN. Ultramar, Leg. 4638, Exp. 18. "Expediente de deportación de Cuba de José Antonio González". A González, uno de los condenados a relegación, la pena le fue conmutada por destierro a la parte occidental de la isla, castigo que vulneró, por lo que finalmente también fue deportado a la Península.

${ }^{35}$ Raúl Cepero Bonilla, Obras históricas, Instituto de Historia, La Habana, 1963, pp. 64-65; a pesar de ello los alzados contaban entre sus filas con dos pardos, un mulato y un negro. BNCJM, Manuscritos, Arredondo, 1851. Primera jornada de la libertad en Camagüey. Joaquín de Agüero y Agüero y la legión libertadora, p. 37.

${ }^{36}$ Elda E. Cento, El camino de la independencia. Joaquín de Agüero y el alzamiento de San Francisco de Jucaral, Ácana, Camagüey, 2003, pp. 92-94. 
necesariamente que los alzamientos tenían un carácter esclavista, sino que los revolucionarios no querían sustraerse del apoyo de los hacendados, conocedores de su importancia para el éxito de la revolución. Las posibles diferencias acerca de este tema se apartaron para conseguir el objetivo fundamental de la separación de la metrópoli. La adquisición de derechos políticos podía tener un papel secundario para algunos, pero otros lo considerarían capital ya que si el anexionismo era la derivación ideológica de los plantacionistas, también lo era del independentismo de los años 20 y del liberalismo que se pronunció a favor de la Constitución en 1836. La exclusión de una parte de los habitantes del país, aquellos que eran propiedad, no era diametralmente opuesta al pensamiento liberal, ahí estaba el vecino del norte como ejemplo, considerado para muchos el paradigma de la libertad y la democracia y que contaban con una nutrida población subyugada. Para el liberalismo del siglo XIX, la limitación de derechos políticos no era una contradicción, así le sucedía a la inmensa parte de la población europea, blanca y libre, por cuestiones de renta.

La salvedad aplicada a Cuba en el alcance de la Constitución fue una decisión puramente política cuya causa fundamental fue el beneficio económico que desde la Península obtenían la reina, las arcas públicas y poderosos banqueros, para los que la configuración de la Antilla mayor como colonia significaba instaurar una sumisión económica inquebrantable. ${ }^{37} \mathrm{Y}$ como tal fue percibida por todos los criollos. Porque incluso para los hacendados más recalcitrantes la defensa de sus intereses pasaba por la obtención de derechos políticos. Cuando no disponían de ellos las medidas abolicionistas podían ser tomadas por las autoridades a miles de millas de distancia. En Norteamérica, la connivencia entre los esclavistas y las autoridades del sur eran evidentes. Y el poder del que gozaban los Estados garantizaba un contrapeso muy importante a la autoridad de Washington.

La revolución de 1848 en Europa había puesto sobre aviso a los esclavistas, pero al mismo tiempo había tenido influjo sobre los sectores más avanzados políticamente de la población de Cuba. ${ }^{38}$ La movilización de estos sectores por los referentes democráticos y populares de la revolución fue un hecho, y dentro de estos podemos englobar a Joaquín Agüero y a algunos de sus seguidores. Agüero no aceptó ser elegido jefe de la insurrección sin someterse a votación y cooperó en la formación de escuelas,

\footnotetext{
${ }^{37}$ José Antonio Piqueras, Sociedad civil y poder en Cuba, p. 83.

${ }^{38}$ José Luciano Franco, Revoluciones y conflictos internacionales en el Caribe, 1789-1854, Academia de Ciencias de Cuba, La Habana, 1965, pp. 295-296.
} 
labor por la que fue reconocido. Años antes había liberado a sus esclavos por una motivación ideológica. Todas sus acciones se corresponden con las de un liberal progresista.

La intentona de Puerto Príncipe supuso una ruptura muy importante, porque era la primera vez que se había producido una sublevación armada desde el interior con objeto de sustraer la isla al dominio de España. Cuatro fusilamientos y una treintena de condenas a presidio son sin duda alguna atroces. Pero hay que tener en cuenta que únicamente tres años antes en la metrópoli habían sido fusiladas 14 personas y cerca de 900 habían sido deportadas a causa de la réplica hispánica de las revueltas de 1848. Es decir, los propios peninsulares sufrieron unos castigos mayores. El Partido Moderado, en el poder, temía sobremanera la extensión de derechos políticos y sociales, pero también la humillación y el fin de las rentas que significaría la pérdida de la colonia. Por tanto, la diferencia no estribó en las peticiones sino en quienes las ejercieron: en Europa, excluidos políticos y sociales, y en Cuba, miembros del cuerpo social a los que no cabía reprimir salvajemente ya que lo que se pretendía en última instancia era que estos retornaran a la lealtad al Estado, con los que ejercer una punición brutal era contraproducente.

La distinción derivaba de la jerarquización de la propia sociedad esclavista, dividida en estamentos, en la cúspide la población blanca, en medió los libres de color y los siervos en la parte más baja del escalafón social. ${ }^{39}$ El Gobierno había decidido que los primeros estaban destinados a apoyarle, mientras que el resto, con sus diferencias, permanecerían en una posición subordinada. En 1846 la conjunción de peninsulares y canarios representaba únicamente el $11 \%$ de la población blanca de la isla y el 5,23\% de la total. ${ }^{40}$ La debilidad de la presencia española determinaba que había que contar con los criollos, lo que suponía aumentar la masa social "progubernamental" hasta aproximadamente un $40 \%$ del total. La población de peninsulares y canarios suponía una masa social muy exigua, a pesar de que era evidente que la unión de criollos, libres de color y esclavos era en estos momentos imposible. La propia supervivencia a largo plazo de la dominación española determinaba la necesidad del apoyo de los isleños de ascendencia europea.

\footnotetext{
${ }^{39}$ Eduardo Torres Cuevas, "La sociedad esclavista y sus contradicciones", en María del Carmen Barcia, Gloria García y Eduardo Torres-Cuevas, La colonia. Evolución socioeconómica y formación nacional, pp. 282-283.

${ }^{40}$ Consuelo Naranjo, "Evolución de la población desde 1760 a la actualidad", en Consuelo Naranjo (coord.), Historia de Cuba, CSIC-Doce Calles, Madrid-Aranjuez, 2009, p. 43.
} 
De este modo, los levantamientos armados quedaron finiquitados con el fusilamiento de los cabecillas y otras penas para los demás condenados. Esta estructura represiva ejecutada por la Comisión Militar emanaba directamente de la voluntad del Capitán general. Las ejecuciones, hechas con celeridad, pretendían atemorizar y demostrar que el Ejecutivo actuaría con presteza. Una vez controlada la situación, Gutiérrez de la Concha afirmaba que vencidas las partidas interiores y destrozada la invasión de López, "cabe ahora la clemencia y la compasión". ${ }^{41}$

La deportación a la Península no significaba una exclusión social absoluta y permanente, sino que debe ser entendida como una exención temporal. Este castigo servía para que los afectados recapacitaran fuera del área donde se les consideraba peligrosos. Para las clases medias la residencia en un punto muy alejado del Estado era perjudicial, pero podrían sobrellevarlo sin penurias excesivas. Esto puede extenderse incluso a aquellos relegados perpetuamente, ya que a los represaliados de su clase social se les indultaba al finalizar los periodos convulsos. Sus haberes no fueron confiscados en ningún caso. Únicamente se les impuso el pago de las costas procesales, que en el caso de algunos de los fugitivos se amplió al pago de los gastos que las expediciones habían causado al Estado. ${ }^{42}$ Esto suponía que los exiliados y prófugos sufrirían mayor corrección, en lo que constituyó la plasmación de un hecho consumado. A pesar de esto, en su caso tampoco significó excluirles de manera definitiva.

La actitud de Gutiérrez de la Concha contra las insurrecciones interiores contrastó con las medidas tomadas contra los expedicionarios en el intento de invasión de López, que según ordenó debían ser tratados como "piratas sin bandera ni nacionalidad", lo que implicaba que no se harían prisioneros y que todos serían

\footnotetext{
${ }^{41}$ Carlos Sedano Cruzat, Cuba desde 1850 a 1873. Colección de informes, memorias, proyectos y antecedentes sobre el gobierno de la isla de Cuba, relativos al citado periodo, Imprenta Nacional, Madrid, 1873, pp. 135-136. Oficio de 31 de agosto dirigido al ministro de la Guerra.

${ }^{42}$ En el caso del desembarco de Cárdenas se condenó a los miembros de la Junta cubana residente en Nueva York a las costas y a indemnizar al Estado y a los particulares por los perjuicios que causó la insurrección. ANC, Comisión Militar, Leg. 86, Exp. 1. Causa contra los miembros de la Junta Promovedora de los Intereses Políticos de Cuba de Nueva York; también a Francisco de Armas, tras fugarse de Vigo en dirección a Nueva York se le condenó al pago de costas y al resarcimiento de bienes que ocasionaron al erario las expediciones. ANC, Comisión Militar, Leg. 110, Exp. 2. Causa contra Francisco de Armas por infidencia; ANC, Comisión Militar, Leg. 104, Exp. 3. Causa contra los 15 reos prófugos que pertenecieron a la partida de insurrectos de Puerto Príncipe; ANC, Comisión Militar, Leg. 109, Exp. 13. Causa contra reos acusados acusados de complicidad con la insurrección de Joaquín de Agüero; ANC, Comisión Militar, Leg. 110, Exp. 9. Causa contra el licenciado José Elías Hernández; ANC, Comisión Militar, Leg. 110, Exp. 11. Causa contra Domingo Goicouria.
} 
ejecutados inmediatamente. ${ }^{43}$ Pretensión favorecida por la proclama del presidente americano Fillmore, que excluía a los expedicionarios de la protección de su país. ${ }^{44} \mathrm{La}$ incursión de alrededor de 500 hombres desembarcó en la playa de Morillo en Las Pozas el 12 de agosto. Enfrentándose a unas fuerzas españolas muy superiores, pronto comenzaron a verse acosados y perseguidos. Un grupo comandado por el coronel Crittenden quedó atrás con la intención de unirse con posterioridad a López y los suyos, pero hostigados decidieron volver a Morillo y huir en los barcos en los que habían atracado. Hechos prisioneros por la marina española, fueron llevados a La Habana donde fueron fusilados el día 16 de agosto. Entre ellos había 40 estadounidenses, cuatro irlandeses, dos cubanos, dos húngaros, un italiano, un escocés y un filipino. ${ }^{45}$

El suceso causó una gran conmoción en el vecino del norte, donde se informó que los cuerpos de sus compatriotas habían sido profanados y se produjeron disturbios y destrucciones de propiedades de españoles. El Capitán general ordenó que se respetase la vida de los prisioneros cuando la sublevación ya estaba prácticamente finalizada. De resultas de esta política, de los 484 que desembarcaron en las playas solo habían salvado la vida 147, falleciendo el resto en los combates, la represión o mientras intentaban escapar. Este grupo saldría hacia los presidios africanos. También fue detenido el periodista Juan S. Trasher, corresponsal de diarios norteamericanos, condenado a ocho años de presidio a Ceuta. ${ }^{46}$ En La Habana quedaron 24 enfermos o heridos y el resto, 123, fueron embarcados rumbo a la Península en el vapor Isabel la Católica y en la fragata Primera de Guatemala, escoltada por la corbeta Venus. Los barcos llegaron a Cádiz durante el mes de diciembre, tras 65 días de viaje. ${ }^{47}$

Según Gutiérrez de la Concha, por la cercanía entre el bando y la remisión de los expedicionarios a La Habana, de haber procedido con magnanimidad hubiera llevado a

${ }^{43}$ Carlos Sedano y Cruzat, Cuba desde 1850 a 1873, p. 129. Oficio del Capitán general al ministro de la Guerra, 2 de agosto de 1851.

${ }^{44}$ Proclama de 25 de abril de 1851. José Antonio Rodríguez, Estudio histórico sobre el origen, desenvolvimiento y manifestaciones prácticas de la anexión de la isla de Cuba a los Estados Unidos de América, La Propaganda Literaria, La Habana, 1900, pp. 155-157.

${ }^{45}$ Anderson C. Quisenberry, Lopez's expeditions to Cuba, 1850-1851, John Morton and Company, Louisville, 1906, pp. 87-88.

${ }^{46}$ Oficio del Capitán general a presidente del Consejo de Ministros de 31 de agosto de 1851. AHN, Ultramar, 4645, Exp. 6. "Comunicaciones traídas por el brigadier Fulgencio Salas"; José Gutiérrez de la Concha, Memorias sobre el estado político, gobierno y administración de la isla de Cuba, Establecimiento Tipográfico de José Trujillo, Madrid, 1853, pp. 226-227. Trasher, fue indultado al poco tiempo.

${ }^{47}$ El Católico, 14 de octubre de 1851; AHN, Ultramar, Leg. 4635, Exp. 72. Pago de gastos de la corbeta Venus. 
enviar una señal de debilidad. Así, se enviaba a los Estados Unidos una señal inequívoca de fortaleza y de que consideraba una intromisión que algunos de sus ciudadanos se lanzaran a invadir a un país amigo. Esto suponía, según su opinión, que una guerra sería inevitable si ganaba las elecciones el Partido Demócrata. ${ }^{48}$ Las ventajas de jugar diplomáticamente al límite eran enviar un mensaje claro al presidente norteamericano y a los posibles nuevos invasores, pero especialmente tratar de cohesionar a la sociedad cubana mostrando el conflicto como una lucha entre patriotas e invasores extranjeros. Contra estos últimos podían llevarse a cabo unos castigos despiadados, aunque hubiese entre ellos algunos criollos emigrados o exiliados, porque no formaban parte del cuerpo social de la isla. La brutalidad con los conspiradores desde el exterior muestra como la política española en el interior fue más calculada, más meditada, más razonada y menos salvaje con los cubanos de lo que suele creerse. Con estos, mantener unas represalias atroces ofrecía más inconvenientes que ventajas. A los expedicionarios americanos de 1851 se les atribuyó el mismo papel cohesionador que a los hombres de color en la conspiración de la Escalera de 1844. Los ataques a españoles en Estados Unidos reforzaron el éxito de las pretensiones del Capitán general.

La relegación cumplió un papel importante en la represión, aunque estaba predestinada para otro grupo, constituido por quienes no habían participado directamente en los combates. Dice Justo Zaragoza que los deportados fueron treinta y tantos, "individuos de las Juntas de conspiración o propagandistas y agentes de los mismos". ${ }^{49}$ Resulta sintomático de los temores del Gobierno que utilizara los recientes acontecimientos para reprimir a sujetos sobre los que no había pruebas. Un grupo salió en el vapor Isabel la Católica el 8 de septiembre y llegó a la Península a mediados de octubre. Entre ellos se encontraban Ramón y Esteban Rodríguez y Benigno Valdés Redonet, que debían permanecer en Santiago; Francisco de Agüero y Varona en Pontevedra, Francisco de Armas y Esteban Díaz en Lugo, y Domingo Goicouria en Cádiz, aunque desde allí deberían ser trasladados a algún lugar en el interior. A Francisco de Armas, periodista y asesor propietario del Tribunal de Comercio de

\footnotetext{
${ }^{48}$ Oficio del Capitán general a presidente del Consejo de Ministros de 31 de agosto de 1851. AHN, Ultramar, 4645, Exp. 6. "Comunicaciones traídas por el brigadier Fulgencio Salas". Por eso inmediatamente se buscó el apoyo de Francia e Inglaterra para garantizar la posesión española de Cuba. Estos dos países ya habían dado orden a su marina a apresar barcos de filibusteros que se dispusiesen a invadir Cuba. Basil Rauch, American interests in Cuba: 18481855, Octagon Books, Nueva York, 1974, pp. 167-168.

${ }^{49}$ Justo Zaragoza, Las insurrecciones en Cuba, tomo I, pp. 636 y 782.
} 
Matanzas, se le acusaba de "Hombre de acción, de malos antecedentes políticos, emprendedor y revoltoso hasta ser tildado por toda la opinión pública no solo como amante de la revolución en sentido anexionista, sino como díscolo y marcadamente desafecto a las instituciones españolas". ${ }^{50}$ Es decir, se le represaliaba por su ideología.

La deportación se utilizó de manera preventiva, para gente de la que se sospechaba que estaba intrigando o por sus opiniones o porque se creía que podrían participar en la conspiración en el futuro. Sin embargo, el hecho de no haber pruebas contra ellos no quiere decir que fueran inocentes. Esteban Díaz era, en realidad, el jefe de los revolucionarios en el distrito de Colón, de La Habana, y Domingo Goicouria había tratado de levantar al pueblo de La Habana. ${ }^{51}$ Algo conocido por las autoridades que calificaban a este ultimo como intelectual brillante destinado a ocupar cargos importantes en caso de triunfar los planes anexionistas. El Capitán general le calificaba como uno de los más activos promovedores de la invasión, a la que según la declaración de dos detenidos había contribuido con fondos. ${ }^{52}$ La utilización del castigo como modo para evitar posibles futuras revueltas o extirpar de la sociedad de la isla a anexionistas importantes implicaría que entre ellos habría algunos que no habían participado en las conspiraciones. Sin embargo, aun así, por su número constituye una represión selectiva. Las dificultades probatorias no se solucionaron con confinamientos masivos, con los criollos cubanos esto no hubiera sido aceptable, como tampoco lo era haber obtenido pruebas de manera poco ortodoxa, tal y como sucedió en la Escalera.

La adaptabilidad de esta figura hizo que se empleara en otros casos, sirviendo para dar salida a la partida que se levantó en Santa Cruz y que se entregó sin disparar un solo tiro, siendo finalmente indultada por el comandante general del departamento del centro. Todos pudieron irse a sus casas, excepto los cabecillas, Manuel Núñez y Miguel Barroso, que fueron relegados administrativamente a la Península. ${ }^{53}$

Con motivo del boicot de la juventud a un baile de la Sociedad Filarmónica previsto para el 10 de octubre de 1851, Gutiérrez de la Concha se propuso castigar a los clubes anexionistas. Aprovechando la disputa entre "jóvenes y hombres de respeto" por

\footnotetext{
${ }^{50}$ AHN, Ultramar, Leg., 4645, Exp. 4. "Expediente reservado sobre deportación a la Península de varios cubanos por motivos políticos"; El Genio de la Libertad, 9 de septiembre de 1851.

${ }^{51}$ Juan Arnao, Paginas para la historia de Cuba, Imprenta La Nueva, La Habana, 1900, pp. 132 y $144-145$.

${ }_{52}$ AHN, Ultramar, Leg. 4645, Exp. 4. "Expediente reservado sobre deportación a la Península de varios cubanos por motivos políticos".

${ }^{53}$ Carlos Sedano y Cruzat, Cuba desde 1850 a 1873, pp. 127-129. Oficio del Capitán general al ministro de la Guerra, 2 de agosto de 1851.
} 
el baile programado para el cumpleaños de la reina, creyó conveniente la remisión a la Península de cuatro individuos por acreditarse que habían esparcido proclamas. En relación a la misma causa fueron relegados a la misma plaza, el 25 de enero, Pedro Santacilia y los hermanos Bienvenido y Luis Hernández "por ser inconveniente su presencia en la isla". ${ }^{54}$

\subsection{La etapa final de las conspiraciones}

Valentín Cañedo Miranda fue nombrado Capitán general en 16 de abril de 1852. Las dificultades con las que se encontró desde el primer momento fueron importantes. Internacionalmente hubo una gran tensión con Estados Unidos. En noviembre de 1852 los demócratas habían ganado las elecciones con el apoyo de la anexionista Joven América. El nuevo gabinete presidido por Franklin Pierce tuvo una actitud más favorable a los anexionistas, aunque esperaba que cubanos y norteamericanos se insurreccionaran a semejanza de Tejas y posteriormente pidieran la anexión. ${ }^{55} \mathrm{La}$ incorporación de la Antilla mayor fue objeto de rivalidad entre los Estados de la Unión, no solo por la cuestión esclavista sino también en las relaciones de poder con el Ejecutivo central. En este contexto, el Gobierno, si bien en ocasiones dejó hacer a los anexionistas e incluso tuvo vínculos con ellos, en ningún momento pretendió una adquisición militar de la plaza. El equilibro entre Estados Unidos y las potencias europeas, Francia e Inglaterra, dificultaba enormemente la intervención norteamericana. ${ }^{56}$

En el plano interno, el Capitán general trató de diseccionar a la sociedad cubana. Circunscribía el partido español a los peninsulares, a la nobleza, a los habitantes del campo y a los ricos propietarios. Al Partido de la anexión pertenecía la mayor parte de la juventud criolla educada en los Estados Unidos y entre los partidarios de la independencia situaba a un grupo similar en número al de los anexionistas. Definía a otro grupo como "expectantes", aquellos que a pesar de que podía simpatizar con los

\footnotetext{
${ }^{54}$ ANC, Comisión Militar, Leg. 110, Exp. 8. Causa contra Cayetano Hechavarria, Juan de Mata Tejada, Tomás Asencio y Joaquín Portuondo por esparcir banderas subversivas; Boris Rosen Jelomer, Pedro Santacilia, el hombre y su obra, Centro de Investigación Científica Jorge L. Tamayo, 1983, vol. I, pp. 3-50.

${ }^{55}$ Charles H. Brown, Agents of Manifest Destiny. The Lives and Times of the Filibusteros, University of North Carolinas Press, Chapel Hill, 1980, pp. 105 y 117-118.

${ }^{56}$ Tom Chaffin, Fatal Glory. Narciso López and the First Clandestine U.S. War against Cuba, University Press of Virginia, Charlottesville, 1996, pp. 58, 97, 166 y 172.
} 
opositores al dominio español apoyaría al Ejecutivo siempre y cuando se mostrara fuerte. A los esclavos los excluía como factor político, pero advirtiendo que podían aprovechar cualquier inestabilidad para tratar de lograr su emancipación. ${ }^{57}$ Consideraba suficientes los apoyos a España, pero las clases medias e ilustradas se estaban perdiendo para la causa española, además de muchos de los propietarios de ingenios. Los apoyos a la metrópoli se centraban en los peninsulares, la mayor parte de la alta sociedad, los temerosos de que los cambios supusieran alguna revuelta o que no confiaban en las posibilidades reales y el pueblo iletrado del interior.

Estos datos son muy relevantes a la hora de establecer la importancia de los partidos independentista y anexionista, a los que otorga un número similar de partidarios. Sin embargo, su perfil era diferente, los independentistas no formaban parte de la élite económica y social de la isla. Además, habría que tener en cuenta a los libres de color, a los que la represión brutal de 1844 había dejado desarticulados. Este grupo no encontraría ventaja alguna en la anexión, por lo que estuvieron mayoritariamente en un segundo plano. Sin embargo, habrían evolucionado políticamente y su derivación natural, dada la discriminación que sufrían en España y la que sufrirían en los Estados Unidos, era el independentismo.

A pesar de que los partidos no eran bloques ideológicos compactos, en general, los anexionistas formaban parte de un estrato social más elevado, tenían mayores posibilidades económicas y contaban con la ayuda de numerosos ciudadanos norteamericanos, motivo por el que las intentonas armadas fueron promovidas por ellos. Esto no quería decir que su fortaleza en las conspiraciones se tradujera en un mayor apoyo social. Las inquietudes de Saco acerca de la pérdida de la nacionalidad cubana que implicaría la incorporación a los Estados Unidos, y sobre ser gobernados por un país extranjero, ${ }^{58}$ eran compartidas por muchos. La independencia es el camino habitual de los países que pretenden emanciparse, también en el caso de Cuba, que poco tenía que ver con el coloso del norte. Únicamente la esclavitud, unida a la importancia de sus partidarios, y la posible ayuda que podían prestar los norteamericanos llevó a parte de la isla a querer unirse a un país cultural, político y socialmente extranjero.

\footnotetext{
${ }^{57}$ Oficio de Capitán general a presidente del Consejo de Ministros, 24 de agosto de 1852. AHN, Ultramar, Leg. 4645, Exp. 12. "Expediente reservado sobre lo que pudiera alterar la tranquilidad en Cuba".

${ }^{58}$ Josef Opatrný, José Antonio Saco y la búsqueda de la identidad cubana, Karolinum, Praga, 2010, pp. 184-215.
} 
Las continuas insurrecciones y actos de propaganda política probablemente habían hecho acrecentar el número de los que se sumaran a este partido, incluyendo a independentistas dispuestos a sumar su apoyo a la facción más importante dentro del separatismo. Sin embargo habría que distinguir entre ideología y acción ya que por mucho que el separatismo, aunque circunscrito a unas élites se iba expandiendo, otra cosa era estar dispuestos a alzarse contra el dominio español, lo que implicaba exponerse a las represalias precisamente en un sector social que solía mantenerse cauteloso. De hecho, las sublevaciones y desembarcos no lograron adhesiones significativas numéricamente desde el interior.

Con una estructura represiva asentada y eficaz, en la conspiración de Vuelta Abajo la respuesta gubernamental siguió las pautas marcadas. Los primeros hechos en ser juzgados fueron los referentes al periódico La Voz del Pueblo Cubano, cuya difusión desde el 13 de junio de 1852 puso en jaque a las autoridades. El 23 de agosto una redada descubrió la imprenta en Regla, siendo detenidos once individuos. En 13 de septiembre la Comisión ya dictó la sentencia en relación con la causa seguida contra el periódico: los dos prófugos y Eduardo Facciolo fueron condenados a muerte, ejecución que en el caso del aprehendido tuvo lugar el día 28 de ese mismo mes. Se condenó a relegación perpetua de Cuba, a cumplir en Palma Mallorca, a Juan Atanasio Romero y Antonio Bellido de Luna; a tres la pena se les compurgó por la prisión sufrida y serían vigilados por tres años; otros seis fueron absueltos. Posteriormente Ramón Fonseca seria confinado en Arévalo (Ávila) y en mayo de 1853 se ordenaría su traslado a Ceuta. ${ }^{59}$ En 13 de noviembre se impuso a José Agustín Quintero la pena de cuatro años de presidio en la Península. A Carlos Collins, José Varona, Manuel Santa Cruz y Eduardo E. Pronty se les condenó a relegación en la misma, los dos primeros de manera indefinida y el resto por cuatro años. ${ }^{60}$

La causa por la conspiración no se falló hasta 23 de febrero de 1853. Dieciséis fueron condenados a muerte, aunque finalmente se les conmutaría por entre ocho y diez años de presidio en Ceuta. Además hubo otros penados con presidio ultramarino, tres durante diez años y cinco por ocho años, aunque cuatro de ellos se encontraban

\footnotetext{
${ }^{59}$ AHN, Ultramar, Leg. 4645, Exp. 37. "Expediente reservado sobre el proceso al periódico clandestino de Nueva York La Voz del Pueblo"; AHN, Ultramar, Leg. 4645, Exp. 31. "Expediente reservado sobre orden de traslado a Ceuta del relegado cubano Ramón Nonato Fonseca".

${ }^{60}$ ANC, Comisión Militar, Leg. 112, Exp. 2. Causa para la averiguación de los autores del periodo subversivo La Voz del Pueblo Cubano.
} 
prófugos. Francisco Frías, conde de Pozos Dulces, fue confinado en Osuna durante dos años y Ramón María Pinto a Cáceres, con carácter perpetuo. El resto terminarían compurgados o absueltos. ${ }^{61}$ En una nueva causa por la misma hubo un castigado a ocho años de presidio ultramarino, uno a dos años y tres desterrados en el punto que eligiera la máxima autoridad colonial. ${ }^{62}$ Entre los recién llegados a la metrópoli una personalidad como Francisco Frías.

El número de deportados comenzaba a ser considerable por lo que mediante real orden de 23 de abril de 1853, el Gobierno pidió al Capitán general que cesaran o que en caso de hacerse lo fueran mediante juicio. Además advertía que era mejor la expulsión a territorio extranjero. ${ }^{63}$ Las pretensiones del Ejecutivo fueron fáciles de ser llevadas a cabo, ya que durante 1853 no se produjo ninguna conspiración de importancia y no se tuvo que recurrir a medidas especiales. Aun así, los procesos en marcha continuaron, en agosto de 1853 Juan Francisco Cárdenas fue sentenciado a dos años de relegación en Puente del Arzobispo (Toledo), por la portación de unos versos subversivos escritos de su misma letra y haber hecho uso de ellos. ${ }^{64}$ Por una causa de introducción de papeles subversivos desde el extranjero se produjeron diversas condenas, entre ellas la de deportación a la Península durante cuatro años de José de Silva. ${ }^{65}$

La presión inglesa y la tranquilidad relativa hicieron que el Ejecutivo nombrara Capitán general a Manuel de la Pezuela, el 23 de septiembre de 1853. El 4 de diciembre de 1853 varias de las más importantes personalidades de la sociedad cubana pedían indulto para los relegados. ${ }^{66}$ Atendiendo a sus peticiones, mediante real decreto de 22 de marzo de 1854 se dictó una amnistía para todos lo que habían conspirado. En el perdón

\footnotetext{
${ }^{61}$ ANC, Asuntos Políticos, Leg. 48, Sig. 18. "Sentencia de la causa de conspiración conocida por la de Vuelta de Abajo"; ANC, Comisión Militar, Leg. 117, Exp. 3. Cuaderno de costas por causa contra Francisco Valdés y otros.

${ }^{62}$ ANC, Comisión Militar, Leg. 109, Exp. 1. Causa contra Francisco Valdés y otros, segundo término. Se trataba de José Feria, Pedro García y Simancas y Francisco Baeza, seguramente serían desterrados dentro de Cuba ya que no hay constancia de que recabaran en la Península; según Justo Zaragoza, la represión consistió en diez condenados a muerte, dos relegados y veintitantos deportados, pero creemos que se equivoca ya que cita a Bombalier y a Francisco Quesada y Guerra que había sido deportado con anterioridad. Además, al no hablar de condenados a presidio, lo más probable es que los veintitantos sean realmente los condenados a presidio. Justo Zaragoza, Las insurrecciones en Cuba, tomo I, p. 650

${ }^{63}$ Carlos Sedano Cruzat, Cuba desde 1850 a 1873, pp. 69-70.

${ }^{64}$ AHN, Ultramar, Leg. 4638, Exp. 17. "Expedientes reservados de varios cubanos deportados a la Península.

${ }^{65}$ ANC, Comisión Militar, Leg. 115, Exp. 1. Causa para la averiguación de remisión desde el extranjero de papeles subversivos.

${ }^{66}$ AHN, Ultramar, Leg. 4641, Exp. 42. "Varios individuos de posición en la isla de Cuba piden se amnistíe a los confinados políticos".
} 
primó la voluntad general de reincorporar a la población criolla a su proyecto político, lo que unido a una política de ciertos cambios pretendía congratularse con sectores reformistas y hasta liberales, para que viendo la imposibilidad de vencer se adhirieran a posiciones más posibilistas. Pero la intención del Capitán general de acabar con la trata y la toma de ciertas medidas de control sobre los esclavos, así como la formación de compañías de pardos y morenos, le llevó a granjearse la feroz oposición de los grandes propietarios, lo que contribuyó a encender de nuevo los ánimos. El intento tímido de congraciarse con reformistas de perfil urbano no sirvió para terminar con las insurrecciones.

En julio de 1854, en medio de la inestabilidad política española, Pezuela fue sustituido por Gutiérrez de la Concha, que tenía prestigio entre los peninsulares y representaba la certeza de que no acabaría con la esclavitud. Bajo su mandato fue descubierta la conspiración encabezada por Ramón Pintó. Esta intentona, según el Capitán general, tenía unas dimensiones excepcionales y las características de ser dirigida por un español y aceptada por otros. ${ }^{67}$ La acusación se basó en las delaciones de un tal Antonio Rodríguez, preso común en Ceuta que escapó con alguno de los confinados políticos de allí. Sus declaraciones eran muy graves, intentar asesinar a la máxima autoridad colonial y llevar a cabo un alzamiento de grandes dimensiones con apoyo de un desembarco de 4.000 combatientes. ${ }^{68}$ Aunque no se aportaron pruebas concluyentes la confabulación llegaba en un mal momento, después de la amnistía y cuando la situación estaba más calmada, por lo que se procedió a dar una salida rápida y ejemplar.

Pintó y Francisco Estrampes fueron ajusticiados, y cuatro más fueron condenados a presidio. ${ }^{69}$ En esta ocasión, el general optó por llevar a cabo principalmente deportaciones administrativas individuales. La ventaja de hacerlo al margen de los tribunales era evidente, ya que no era necesaria la aportación de pruebas. Tampoco había que perder tiempo en los procesos, aunque para los capitanes generales era mejor hacerlo mediante juicio ya que así evitaban los incomodos reproches del

\footnotetext{
${ }^{67}$ José de Ahumada y Centurión, Memoria histórico política de la isla de Cuba, pp. 347-348.

${ }^{68}$ BNCJM, Manuscritos, Bachiller, núm. 10. Apuntes para la defensa de Ramón Pintó; Carlos Sedano y Cruzat, Cuba desde 1850 a 1873, p. 207.

${ }^{69}$ ANC, Comisión Militar, Leg. 117, Exp. 9. Causa contra Francisco Estrampes y otros; ANC, Comisión Militar, Leg. 123, Exp. 1. Causa contra Ramón Pintó y otros; AHN, Ultramar, Leg. 4645, Exp. 42. "Sobre los condenados por conspiración Juan Cadalso y Nicolás Pinelo de Rojas, confinados al castillo del Hacho".
} 
Gobierno. Sin embargo, Gutiérrez de la Concha, tras ser llamado de nuevo a la capitanía se encontraría lo suficientemente fuerte para actuar de este modo.

En junio llegaron a Cádiz ocho hombres en los vapores Fernando el Católico y Pinta y otros tres se encontraban listos para embarcar. ${ }^{70}$ En julio fueron embarcados otros tres sujetos y otros dos expelidos hacia París. En agosto se dictó el castigo para otros cuatro, de los que tres lo fueron a la Península y el otro a isla de Pinos, y en septiembre otros dos. A estos habría que sumar otros seis deportados a causa de la misma conspiración. Del total, ocho ya habían sido trasladados a la metrópoli en 1851, lo que unido a la ausencia de pruebas indica que habían quedado marcados políticamente. ${ }^{71}$ De hecho, era habitual que tras alguna conspiración fueran detenidos una serie de destacados liberales que en la mayoría de los casos resultaban absueltos. Con ellos podía emplearse esta corrección como modo de neutralización, pero el propio encausamiento suponía una desarticulación temporal, ya que garantizaba que durante la incoación del proceso los acusados estaban en prisión. Además servía para recordarles que estaban en la diana de las fuerzas represivas y que debían permanecer alejados de las conspiraciones.

A los únicos a los que se impuso la relegación por Consejo de Guerra fueron Benigno Gener, a cuatro años en Sevilla, y Alejo Iznaga y Francisco Pérez Zúñiga, a dos años en la metrópoli. ${ }^{72}$ Los tres habían sido condenados ya en 1851. Esto demuestra que algunos conspiraban a su regreso, ya que de no haber habido pruebas hubieran podido ser remitidos administrativamente. La inclusión de personalidades de importancia y prestigio como Pintó, los administradores de la empresa de ferrocarriles

\footnotetext{
${ }^{70}$ AHN, Ultramar, Leg. 4646, Exp. 58. "Expediente sobre el confinamiento de varios sujetos de la isla a la Península". Las causas eran hallarse más o menos complicados en la causa de Pintó. Aunque el Capitán general en 15 de julio ya dictaminó que los que habían llegado en estos dos vapores pudieran regresar. A los tres que embarcarían con posterioridad, José Joaquín Arce, Pedro Pablo Arei y Miguel Cantos, no se les permitió regresar.

${ }^{71}$ AHN, Ultramar, Leg. 4646, Exp. 57. Expediente de deportación por conspiración Pintó. José Antonio Echevarria y Carlos Rusca fueron acusados de transportar armas en el ferrocarril, empresa de la cual eran los administradores; Carlos del Castillo, director de la Caja de Ahorros de La Habana, de supuestamente enviar fondos; Francisco Pérez Angueria, abogado, por obstaculizar la justicia con sus manejos. A Carlos Collins, Agustín Montoro, Francisco Candelario y Silvestre Pérez de las Heras se les acusaba de haber participado en el asesinato del capitán Castañeda. A José Francisco Balbín, se le dejó pasar a París para continuar sus estudios; AHN, Ultramar, Leg. 4650, Exp. 12. "Expediente de deportación de varios cubanos acusados de conspiración"; AHN, Ultramar, Leg. 4646, Exp. 73. "Benigno Gener, confinado por la conspiración Pintó".

${ }^{72}$ AHN, Ultramar, Leg. 4646, Exp. 73. "Benigno Gener, confinado por la conspiración Pintó"; solicitud de pase a París de Alejo Iznaga y Francisco Pérez Zúñiga. AHN, Ultramar, Leg. 4646, Exp. 57. Expediente de deportación por conspiración Pinto.
} 
José Antonio Echevarría y Carlos Rusca, y el director de la Caja de Ahorros de La Habana, Carlos del Castillo, supuso que las deportaciones alcanzaran a un sector social alto. Fue un toque de atención a la élite de la sociedad criolla para que pararan las conspiraciones o las represalias ascenderían hacia arriba.

\subsection{Condiciones de la estancia de los deportados}

Como hemos dejado claro durante todo el texto, la represión tanto la ejecutada por la Comisión Militar como la realizada administrativamente por el Capitán general, fueron selectivas. El objetivo era castigar a un número reducido pero tratando de que sirviera de escarmiento. En la mayoría de los deportados confluían las circunstancias de criollo blanco y con posición, precisamente aquel sector social del cual el Gobierno esperaba apoyo. Siendo magnánimos en Cuba, allá donde podían ser más peligrosos, era de esperar que las condiciones de estancia en Europa fuera benignas.

La dicotomía entre lo que representaban los relegados para el Ejecutivo, hombres blancos y con posición económica, y lo que encarnaban para la máxima autoridad en la isla, subversivos, se observa en el tratamiento que recibieron en la metrópoli. Allí era más fácil distinguir la otra cara de los conspiradores, señores ricos y en su mayoría cultos, que formaban parte del mismo estrato social que la clase dirigente española. El carácter militar de la máxima autoridad colonial en la Antilla mayor y la residencia en el núcleo conspirador provocaban una mayor prevención frente a las actividades de estos en la Península. A petición del Capitán general, el 2 de febrero de 1852, el Gobierno de Madrid manifestaba que se dejaba a juicio de la máxima autoridad cubana la aplicación e indulto para los relegados o huidos. ${ }^{73}$

Sin embargo, la lejanía difuminaba la autoridad de los capitanes generales. A su llegada, a algunos de los relegados se les dejó establecer el lugar a donde debían fijar su residencia, ${ }^{74}$ aunque este no fue el caso más habitual. De todos modos, una vez en la metrópoli, la mayoría de los que lo pidieron pudieron reubicarse según su conveniencia.

\footnotetext{
${ }^{73}$ AHN, Ultramar, Leg. 4645, Exp. 16. "Expediente reservado sobre aplicación del indulto concedido por el nacimiento de la princesa de Asturias.

${ }^{74}$ AHN, Ultramar, Leg. 4638, Exp. 18. "José Antonio González es relegado a la Península por haber tomado parte en la insurrección de Trinidad"; al canario residente en Cuba Francisco Montes de Oca, deportado por portar unos versos subversivos estuvo dos años en Santander y posteriormente se le permitió volver a su casa. Su hermano Graciliano fue ajusticiado en 29 de abril de 1851. AHN, Ultramar, Leg. 4641, Exp. 59. "Concesión de permiso para volver a Canarias a Francisco Montes de Oca".
} 
Únicamente a aquellos considerados más peligrosos se les prohibió establecerse en Madrid. Así, la gran mayoría de los cubanos se concentraron en la capital, punto desde el que según Gutiérrez de la Concha seguían conspirando. Por esto, en comunicación reservada de 12 de marzo de 1852 pedía que se les diseminase por provincias. ${ }^{75}$

Las continuas peticiones de la máxima autoridad colonial general fueron recogidas por el Ejecutivo, que en octubre de ese mismo año ordenó que se les vigilara mejor y que se les distribuyese por diferentes puntos de la geografía peninsular, ${ }^{76}$ con objeto de aislarles de sus compañeros. Sin embargo, no parece que las condiciones se endurecieran inmediatamente, ya que al temer este empeoramiento varios de ellos se fugaron. Entre ellos Francisco de Armas, Domingo Goicouria, Santiago Bombalier, Manuel Higinio Ramírez, Fernando Betancourt, Salvador Cisneros, Luis y Bienvenido Hernández, Agustín Miranda, Melchor Silva y Santiago Bombalier. En marzo de 1853 huyó Pedro Santacilia. ${ }^{77}$ Parece claro que el control que se ejercía sobre ellos no se incrementaría excesivamente. Su carácter de criollos les privó de ciertos privilegios, pero no olvidemos que también actuaban los típicos factores de clase donde las diferencias entre unos y otros eran determinadas por sus bienes o por las profesiones que ejercían. De este modo, dentro de cada estamento la riqueza y el prestigio actuaban como impulsores hacia arriba o hacia abajo, y la mayoría de estos individuos gozaban de riqueza y posición.

Las características de las remisiones hacían dificultoso el control de los confinados, pero aun así las circunstancias de los condenados a presidio también son dignas de mención. Según el testimonio de los integrantes del primer grupo de cubanos presos en Ceuta, tras una primera etapa de unas dos semanas en que fueron tratados como el resto de presos, fueron llevados al castillo del Hacho donde tenían que llevar un grillete, pero pudieron deambular por el mismo. Tenían permiso para bajar a la ciudad por turnos, en horarios y zonas acotadas, donde una mujer incluso hizo una fonda para

\footnotetext{
${ }^{75}$ AHN. Ultramar, Leg. 4645 Exp. 17. "Expedientes reservados de varios cubanos deportados a la Península"; AHN, Ultramar, Leg. 4645, Exp. 16. "Expediente reservado sobre aplicación del indulto concedido por el nacimiento de la princesa de Asturias".

${ }^{76}$ AHN, Ultramar, Leg. 4645, Exp. 4. "Expediente reservado sobre deportación a la Península de varios cubanos por motivos políticos".

${ }^{77}$ Pablo Prida Santacilia, Apuntes biográficos de Pedro Santacilia, Cuadernos de Lectura Popular, México D.F., 1966, pp. 23 y 24. A los fugados en 1852 se les abrió causa, que pedía entra otras penas la de confiscación de bienes. Desconocemos como terminó la misma; AHN, Ultramar, Leg. 4645, Exp. 36. "Expediente reservado sobre el destierro de Santiago Bombalier por su conexión con Narciso López".
} 
ellos. ${ }^{78}$ Estas condiciones se extendieron a los que llegaron nuevamente. Se trataba de órdenes emanadas desde el Gobierno, ya que no tenía sentido infringir un castigo añadido al de estar lejos de su patria y privarles de participación en actividades subversivas. Por tanto, su estancia en Ceuta, si bien no podía considerarse de relegación pura tampoco era de presidiarios en sentido estricto. Era una figura a medio camino, que podía ser incluida en una noción amplia de la palabra deportación.

Los fugados iban a Estados Unidos donde continuaban con sus actividades políticas, entre las cuales la prensa ejercía un papel fundamental. ${ }^{79}$ La mayoría regresarían a casa por el indulto de 1854. Sin embargo, restarían excluidos los de la conspiración de Pintó, para los que se legisló la real orden de 26 de mayo de 1856 por la que se mandaba expedir pasaporte para Cuba a todos los deportados por providencia gubernativa. Aun así, Juan Cadalso y Nicolás Pinelo obtuvieron permiso para retornar en febrero de 1858 y Francisco Pérez Angueira, que estaba en Ibiza, todavía estaba reclamando poder volver en marzo de $1858 .{ }^{80}$

La conspiración de Pintó marcó un punto de inflexión en esta etapa. Tras la muerte de López no hubo nadie con su determinación. La incapacidad militar de los anexionistas era manifiesta y la situación volvió a la exigencia de reformas. El Ejecutivo español, por su parte, se convenció de que era necesario hacer cambios con el objeto de que su proyecto tuviera un mayor apoyo social. El separatismo se fue alejando del anexionismo y de la élite criolla y trató de expandir sus ideas entre las capas menos favorecidas, incluyendo a los esclavos. ${ }^{81}$ Tras la constatación de que Estados Unidos había intentado comprar la isla a espaldas de los cubanos y de que no se involucraría ayudando directamente a los separatistas, la permanencia de la postura anexionista se hacía más dificultosa.

\footnotetext{
${ }^{78}$ BNCJM, Manuscritos, Morales, tomo 37, núm. 7. Juan O’Bourke, Relación de la fuga del presidio de Ceuta de varios confinados políticos cubanos en 1852. Los cinco primeros presos eran Ignacio de Belén Pérez, Alejo Iznaga Miranda, Néstor Cadalso, José María Rodríguez y Juan O'Bourke; AHN, Ultramar, Leg. 4637, Exp. 22. Fuga de Schlessinger y otros del presidio de Ceuta. Los fugados fueron Alejo Iznaga, Juan O'Bourke, Ignacio B. Pérez, Luis Schlessinger, Domingo Machado, José Machado y Donoso Maestro.

${ }^{79}$ Las tendencias de la prensa cubana en: Roberto Lazo, Filibustering and Cuban Exiles in the United States, University of North Carolina Press, Chapel Hill, 2005, pp. 30-85.

${ }^{80}$ AHN, Ultramar, Leg. 4645, Exp. 42. "Sobre los condenados por conspiración Juan Cadalso y Nicolás Pinelo de Rojas, confinados al castillo del Hacho"; AHN, Ultramar, Leg. 4646, Exp. 57. "Expediente de deportación de Cuba de varios conspiradores, asesinos y sediciosos".

${ }^{81}$ Gerald E. Poyo, With All, and for the Good of All: The Emergence of Popular Nationalism in the Cuban Communities of the United States, 1848-1898, Duke University Press, Durham, 1989, pp. 15-16.
} 
En cuanto a los relegados y exiliados, la amnistía les permitió volver y algunos como Cirilo Villaverde así lo hicieron, siendo redactor del periódico literario La Habana. En la capital de la Antilla mayor se creó el Círculo Reformista, frecuentado por algunos antiguos anexionistas. Otros, por un mayor compromiso con el separatismo o por haberse establecido, ya no lo harían, lo que significó una pérdida muy importante de personalidades con talento. Bombalier paso a Nueva Orleans, Pedro Santacilia se quedó en Estados Unidos y Domingo Goicouria vivió en ese mismo país, Europa y Brasil. El conde de Pozos Dulces tras un paso por París se instalaría en La Habana, donde dirigiría entre 1863 y 1866 el periódico portavoz del reformismo, El Siglo. Fue concejal de la ciudad y en 1866 fue elegido comisionado para la Junta de Información y Reformas por Villaclara, al igual que el también deportado José Antonio Echevarria por Colón. ${ }^{82}$ Económicamente, el traslado les causaría perjuicios, pero la mayoría podrían sobrellevarlos teniendo en cuenta sus bienes y su posición social. En la decisión de no retornar pesaría mucho la intención de no aceptar la situación de falta de libertades que se daba en la colonia, pero aun así el Estado mantuvo la posibilidad de reingreso en la sociedad, siempre que ello significara aceptar el estatus político impuesto por España y la limitación de derechos. La mayoría de ellos fueron derivando su posición hacia al independentismo. Goicouria, por ejemplo, murió agarrotado tras ser capturando luchando en la Guerra de los Diez Años. Francisco Quesada y Guerra combatió en las filas de Céspedes. ${ }^{83}$

\section{LA GUERRA DE LOS DIEZ AÑOS}

\subsection{El inicio de la Guerra}

Después del ocaso del movimiento anexionista, las conspiraciones, como la del Ave María, fueron de escasa importancia. Hasta el inicio de la Guerra Grande se vivieron unos años de relativa tranquilidad, en los cuales larvadamente se fueron dando unos cambios que explican la posterior insurrección. Demográficamente se incrementó la población blanca, que en 1862 constituía el 56,3\% de la población, y la libre de color

\footnotetext{
${ }^{82}$ Levi Marrero, Cuba. Economía y sociedad, vol. 15, p. 231.

${ }^{83}$ Justo Zaragoza, Las insurrecciones en Cuba, tomo I, p. 650.
} 
que se multiplicó por dos desde el anterior censo de 1846, mientras la esclava apenas sufrió un leve incremento a la par que un envejecimiento. En 1862, la población de color representaba un $43,7 \%$ del total, pero dentro de ellos el 37,2\% eran libres. ${ }^{84}$ En Santo Domingo, el ejército español había dejado muestra de su debilidad y la sensación de injusticia tanto por el tratamiento fiscal como por el político se incrementó.

La crisis económica mundial hacía notar sus efectos, que se acentuaban en el caso de los ganaderos y campesinos de la parte centro-oriental de la isla por la importación de tasajo para la alimentación de los esclavos y la sequía. Los arrendatarios no lograban prosperar, muchos campesinos no podían acceder a la tierra y las clases populares urbanas soportaban la escasez y el alto precio de los alimentos. Con estas premisas, el nuevo impuesto del $10 \%$ promulgado tras el fracaso de la Junta de Información fue considerado abusivo. Pero para que todo este descontento terminara en una guerra independentista era necesario un sustrato político consistente. Los criollos habían desarrollado una identidad propia frente a la exclusión política y la divergencia de intereses con la metrópoli. Los libres de color aspiraban a que terminara la segregación a que eran sometidos por el Gobierno central y a ser tratados como ciudadanos. Para los esclavos, aunque fueron el grupo menos activo políticamente, la abolición no llegaba, lo que les había predispuesto contra las autoridades coloniales. ${ }^{85}$

La guerra significa la constatación del fracaso de las reformas. La esclavitud continuaba vigente, los criollos habían sido ninguneados, el poder autoritario del Capitán general seguía y se había implementado un nuevo impuesto que grababa todos los negocios que se efectuaban en la isla. Tras estos hechos, la obtención de derechos parecía que iba irremediablemente unida al independentismo. En estos momentos ya no se daba la confluencia de intereses en torno al anexionismo que se dio en los años 50. Para los plantacionistas, tras la abolición de la esclavitud posterior a la Guerra de Secesión, esta no tenía sentido, alineándose con el Ejecutivo español. Para los más liberales, que se habían unido al mismo por ser mayor su posibilidad de triunfo, esta era una opción pasada, anacrónica. El independentismo garantizaba la plena soberanía sin intermediarios, por esto, en esta ocasión sucedió lo contrario que en los años 50, siendo

\footnotetext{
${ }^{84}$ Conde Armíldez de Toledo, Noticias estadísticas de la isla de Cuba, en 1862, Imprenta del Gobierno y Capitanía General, La Habana, 1864, pp. 2 y 8.

${ }^{85}$ Jorge Ibarra Cuesta, Patria, etnia y nación, Editorial de Ciencias Sociales, La Habana, 2009, pp. 3-82.
} 
el independentismo la opción con mayor fuerza los anexionistas se unieron a la corriente mayoritaria para poder conseguir la separación de la metrópoli.

Los Estados Unidos tenían sus propias intenciones respecto a la Antilla mayor. Ejercieron cierta presión sobre España e incluso intentaron su compra. Pero preferían que esta permaneciera bajo el dominio de una potencia débil hasta que finalmente pudieran absorberla. El secretario de Estado, Hamilton Fish, eludió todas las presiones y ni siquiera se planteó reconocer la beligerancia de los insurgentes, lo que les condenaba a un embargo de armas. ${ }^{86}$ La carencia de suministros, la escasa financiación y la disparidad de fuerzas, obligaron a los rebeldes a llevar a cabo una guerra de guerrillas en la que las enfermedades mataban a tantos o más soldados españoles que los mal armados partisanos cubanos. En la lucha tuvo una gran importancia la situación económica, la inestabilidad social y las características de la sociedad criolla. Combatiendo en las filas rebeldes encontramos a independentistas convencidos, a esclavos fugados que luchaban contra el poder que les había oprimido o como modo de asegurarse la subsistencia, a marginados que anteriormente acababan en las filas del bandolerismo y a muchos otros reclutados forzosamente. ${ }^{87}$

El inicio de la guerra lo marcó el grito de Yara, producido en la finca La Demajagua en la noche del 9 al 10 de octubre de 1868, siendo Capitán general Francisco Lersundi, de tendencia política moderada. Contaba con unas fuerzas militares escasas, e incapaz de advertir la sublevación, armó batallones de voluntarios que resultaron enormemente eficaces para limitar el alcance de la insurrección y que a finales de diciembre estaban compuestos por unos 35.000 hombres. Las tropas regulares se dedicaron principalmente a combatir contra los alzados mientras que los voluntarios quedaron para proteger los núcleos urbanos y las haciendas. Destituido Lersundi a finales de ese mismo año por su oposición a introducir cambios políticos, fue sustituido por Domingo Dulce. El nuevo Capitán general introdujo algunas reformas, promulgando varios decretos sobre libertad de imprenta y una amnistía para los presos políticos y los combatientes que entregaran las armas. El aperturismo llegaba tarde, no

\footnotetext{
${ }^{86}$ Philip S. Foner, Historia de Cuba y de sus relaciones con Estados Unidos, Instituto Cubano del Libro-Editorial de Ciencias Sociales, La Habana, 1973, vol. II, pp. 217-245 y 265-278.

${ }^{87}$ Hugh Thomas, Cuba. La lucha por la libertad, Debate, Barcelona, 2004, pp. 200-201.
} 
satisfacía a los cubanos y se encontró con la oposición de los españoles intransigentes que finalmente le destituyeron. ${ }^{88}$

Durante su mandato creó las bases que constituirían la política represiva española durante la guerra. Por decreto de 15 de abril de 1869 se ordenaba embargar los bienes a las personalidades más importantes de la sublevación, por el de 20 de abril la medida se hacía extensiva a todos los que hubieran tomado parte en la misma o la hubiesen auxiliado. El precepto tuvo una connotación fiscal, puesto que los bienes pasarían a ser gestionados por el Estado, ${ }^{89}$ pero también dos importantes aspectos en cuanto al orden público, el primero fue que la movilización de recursos hacia la infidencia se hacía más dificultosa y el segundo, que hacía patente el coste económico que el apoyo a la rebelión conllevaba. Se trataba de evitar que determinados individuos con riqueza aun simpatizando con los independentistas, se les unieran o les apoyasen. En el mismo sentido pueden considerarse las confiscaciones que se realizaron en algunos casos para los bienes de los infidentes. Realizados por los tribunales, suponían la privación definitiva de los bienes de los condenados.

En el mismo sentido planteó desde los inicios la utilización de la relegación, "tengo trescientos cincuenta presos fuerte Cabaña. Seria de grande efecto deportarlos pronto Fernando Poo o Ceuta", decía Dulce en telegrama de 27 de febrero al ministro de Ultramar, quien al día siguiente contestaba: "A Fernando Poo". 90 De este modo, el Gobierno avalaba la decisión del Capitán general y optaba por la opción más dura de las dos planteadas. Los motivos fueron varios, el impacto pretendido seria mayor, pero tras las fracasadas intentonas colonizadoras de la isla por peninsulares a causa de su falta de adaptación al clima tropical, una Junta formada en agosto de 1867 había decidido que la colonia africana quedaría como punto de destino para los cubanos. ${ }^{91}$ Durante su anterior mandato, Dulce había iniciado una política de deportaciones de antiguos delincuentes y gentes catalogadas como de "mal vivir", que sin duda influenciarían su actuación una vez iniciada la contienda.

\footnotetext{
${ }^{88}$ María Dolores Domingo Acebrón, Los voluntarios y su papel contrarrevolucionario en la Guerra de los Diez Años en Cuba, 1868-1878. L'Harmattan, París, 1996, p. 41 y 83-89.

${ }^{89}$ Inés Roldán de Montaud, La hacienda en Cuba durante la Guerra de los Diez Años (18681880), Instituto de Estudios Fiscales, Madrid, 1990, pp. 69-70.

90 AHN, Ultramar, Leg. 4777, Exp. 2. "Antecedentes y disposiciones de carácter general relativas a los deportados políticos".

${ }^{91}$ Actas de las sesiones de la Junta creada por real orden de 17 de agosto de 1867. AGA, ÁfricaGuinea, Caja 81/6946.
} 
Finalmente, los relegados fueron 250 que embarcarían el 21 de marzo de 1869. Atados en grupos de cuatro fueron llevados al muelle custodiados por voluntarios, que les separaban de la multitud que profería gritos a favor y en contra de los detenidos. ${ }^{92}$ La tensión durante el embarque fue muy grande, de modo que dos individuos fueron apresados acusados de haber proferidos mueras a los españoles y a España, y juzgados de forma sumaria serían fusilados esa misma tarde. ${ }^{93}$ La represión planteada por Dulce, de carácter ejemplificador e intimidatorio, denota cómo el independentismo se había extendido por buena parte de la sociedad criolla. No se trataba de acciones concretas frente a hechos puntuales, sino de limitar el apoyo a una insurrección que había adquirido los visos de guerra abierta.

Del total, 227 eran cubanos, nueve peninsulares, ocho canarios y el resto extranjeros. Todos blancos, a excepción de tres pardos y un moreno esclavo. En cuanto a los oficios, había 33 empleados de comercio, 32 hacendados, 20 labradores, 18 propietarios, 11 empleados en el foro, diez carpinteros, ocho escribanos públicos, siete profesores, siete administradores de fincas, seis médicos cirujanos, seis empleados de ferrocarriles, cinco tabaqueros, cinco sacerdotes y cinco maestros de azúcar. El resto tenia distintas profesiones u oficios, ${ }^{94}$ mostrando como el perfil social del independentismo se había extendido entre la población, abarcando incluso a sectores considerados conservadores como los labradores y los propietarios. La raza y el carácter profesional de los relegados, muestra que no se trataba de marginados sino de gente profesional y en muchos casos con posición social. En este sentido recuerda a la ejecutada contra los anexionistas, ya que se centró contra un grupo social del que el Ejecutivo esperaba apoyo y no lo tenía. Actuar contra ellos significaba enviar un mensaje a la sociedad en su conjunto, ya que si la represión no se detenía ante sujetos de riqueza y posición, no lo haría ante nada. En cuanto a la residencia de los deportados, la mayoría eran de La Habana y de Remedios, pero afectaron a un buen número de ciudades, especialmente de las provincias de La Habana y Las Villas. (Gráficos 3 y 4).

\footnotetext{
${ }^{22}$ Miguel Bravo Senties, Deportación a Fernando Poo. Relación que hace uno de los deportados, Hallet \& Breen, Nueva York, 1869, pp. 47-49; Juan B. Saluvet, Los deportados a Fernando Poo en 1869, Aurora del Yomuri, Matanzas, 1892, pp. 6-7.

${ }^{93}$ Oficio de Capitán general a ministro de Ultramar, 30 de marzo de 1869, AHN, Ultramar, Leg. 4777, Exp. 2. "Antecedentes y disposiciones de carácter general relativas a los deportados políticos".

${ }^{94}$ Miguel Bravo Senties, Deportación a Fernando Poo, p. 107.
} 
Gráfico 3. Núcleos urbanos con mayor presencia de residentes deportados en el San Francisco de Borja

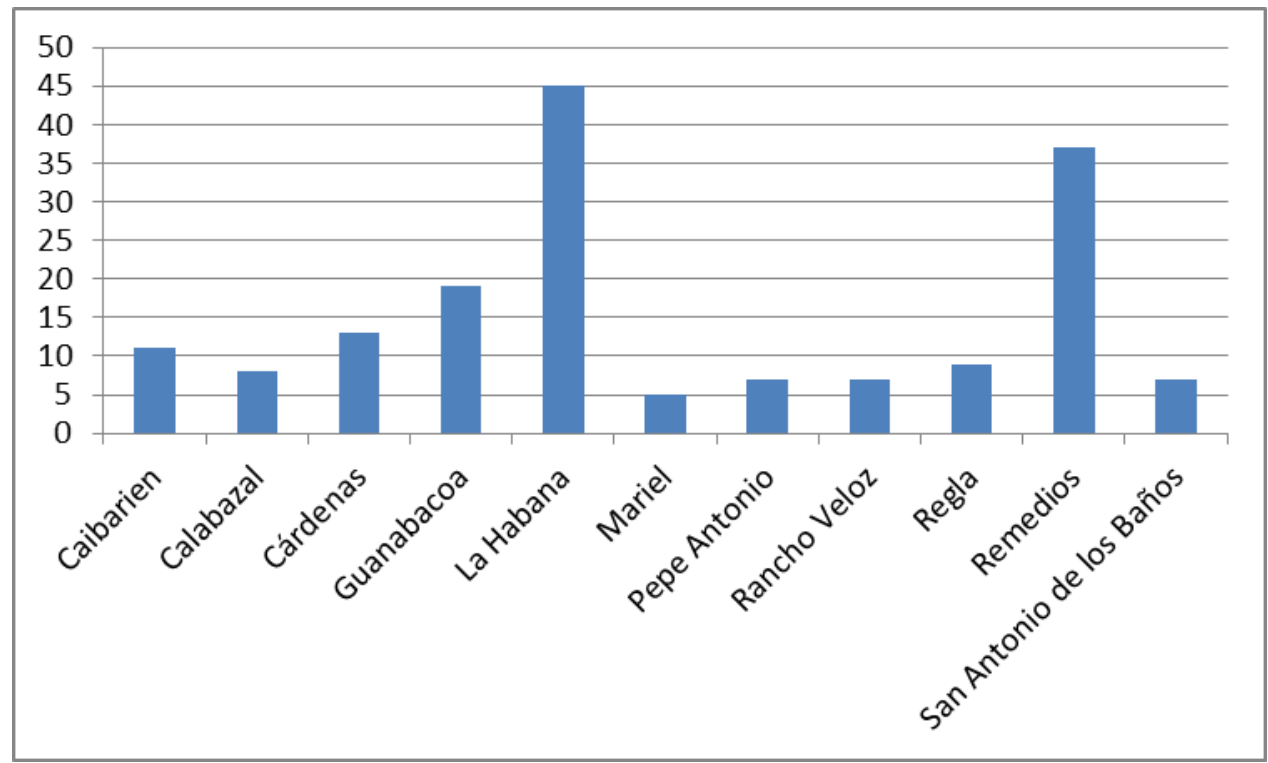

Fuente: Elaboración propia a partir de: Miguel Bravo Senties, Deportación a Fernando Poo. Relación que hace uno de los deportados, pp. 99-106. Existen otros listados con algunos pequeños cambios. Un anónimo en la Biblioteca de la Universidad de La Habana. Sección de libros raros, Relación nominal de deportados políticos con expresión de profesiones, edad, naturalidad, y fecha de prisión. Fuga y fallecimientos Nueva York, 1869. Otro con algunas omisiones en ANC, Donativos y Remisiones, Caja 695, Sig. 48. "Deportados a Fernando Poo durante el Gobierno del Capitán general Domingo Dulce". Un análisis estadístico más profundo de este grupo en María del Carmen Barcia, "Desterrados de la patria", pp. 31-35.

Gráfico 4. Distribución de los deportados del San Francisco de Borja por provincia de residencia

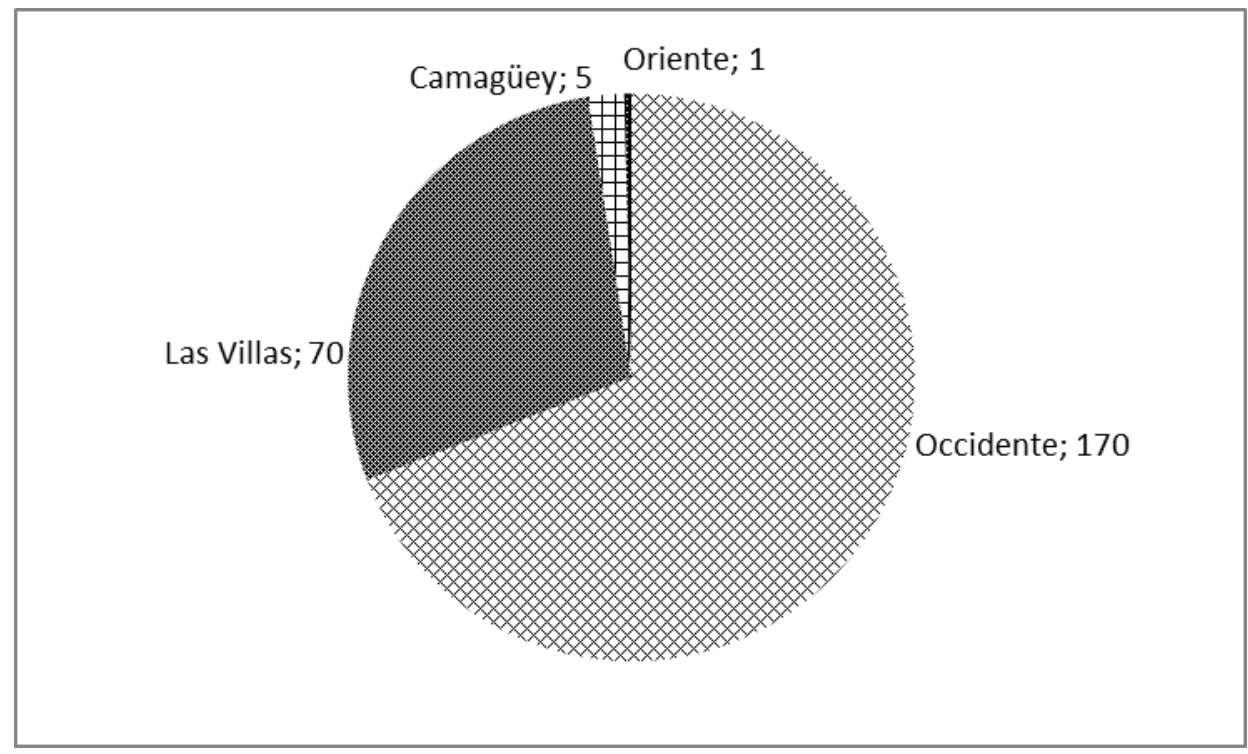

Fuente: Elaboración propia a partir de Miguel Bravo Senties, Deportación a Fernando Poo. Relación que hace uno de los deportados, pp. 99-106. Se ha utilizado la división provincial de 1869. 
La represión estuvo localizada geográficamente en grupos sociales y zonas determinadas, lo que no fue casualidad. Según el estudio de Quiroz, los embargos se centraron entre blancos propietarios medios y pequeños de las áreas central y oriental. ${ }^{95}$ Precisamente aquellos entre los que se temía que se podía expandir la insurrección, lo que significaba un intento de imposibilitar la incorporación al frente de estos hombres en puntos donde la guerra estaba activa.

El caso del San Francisco de Borja fue diferente porque lo que pretendía era limitar el alcance geográfico del alzamiento. Las prisiones de estos sujetos empezaron a finales de enero y continuaron hasta poco antes del embarque, un momento en que la guerra ya había comenzado y en el que estaba localizada en la parte oriental de la isla. Se trató de una relegación preventiva que pretendía atajar la expansión de la guerra y que esta no se reprodujera en las provincias occidentales. Por otro lado, 82 de ellos residían en lugares en los que el número de deportados fue menor de cinco, lo que muestra la amplia dispersión geográfica. Se trató de una represión selectiva, bien estructurada y ejecutada, que fue planificada para incluir a individuos con simpatías independentistas o de los que se creía que estaban auxiliando o podían auxiliar a la rebelión. Pero esto no se extendió a propósito al oriente, donde a pesar de haberse expandido la rebelión el ejército español controlaba las principales ciudades. El objetivo fue que cerca del teatro de operaciones el apoyo a los rebeldes no se incrementara. Al ser ejecutada por vía administrativa y sin pruebas, que afectase a un número excesivo de sujetos hubiera sido contraproducente.

La deportación se institucionalizó y quedó configurada como uno de los medios represivos que se iban a emplear durante la contienda. Que fuera por vía administrativa no determina su ilegalidad, el Gobierno superior de Cuba justificaba esta práctica legislativamente que procedía desde la Recopilación de Indias, la real cedula de 28 de mayo de 1825, la real orden de 25 de mayo de 1847 y el real decreto de 16 de noviembre de 1867 , que permitían realizarlas adjuntando las motivaciones, para que desde Madrid se resolviera lo que correspondía. ${ }^{96}$ Una serie de leyes que simplemente justificaban la transgresión de otras, al castigar a individuos sin ningún tipo de juicio. El

\footnotetext{
${ }^{95}$ Alfonso W. Quiroz, "Costos socioeconómicos de la Guerra de los Diez Años. Insurrección cubana”, en José G. Cayuela (coord.), Un siglo de España. Centenario 1898-1998, Universidad de Castilla-La Mancha, Cuenca, 1998, pp. 256 y 272-274.

${ }^{96}$ AHN, Ultramar, Leg. 4770, Exp. 46. Deportación de José María Gally.
} 
Ejecutivo no denunció esta práctica, aunque es evidente que le incomodaba su utilización al margen de los tribunales, por mucho que fuera "legal" atendiendo a estas disposiciones especiales.

Antonio Caballero y Fernández de Rodas, nuevo Capitán general, llegó a la Antilla mayor el 28 de junio 1869. Se propuso vaciar las prisiones del fuerte de la Cabaña, donde a su llegada había 300 presos. Contra los que tenía pruebas serían juzgados por consejo de guerra, en cuanto a los que sin tener pruebas había indicios, serían remitidos a la Península desde donde serían distribuidos hacia África o poblaciones seguras, ya que en su mayoría se trataba de hombres ricos acaudalados e influyentes. Los que no cumplían estas premisas pero se sospechaba que habían conspirado, serían desterrados dentro de Cuba. A un cuarto grupo, formado por presos cuya delación estuviera probado que era falsa se les debería poner en libertad. ${ }^{97}$ Así, al menos teóricamente, se produjo una categorización de los puntos de destino atendiendo al perfil de los represaliados.

Esto significaba revertir la presunción de inocencia, ya que solo aquellos de los que se demostrara su inocencia serían puestos en libertad, quedando un grupo muy amplio de personas a las que no se podía demostrar su culpabilidad, pero que puestos en la cárcel por alguna delación tampoco podían demostrar su inocencia. De estos, los más peligrosos, por tener influencia o dinero, serían relegados a la metrópoli. Así encontramos entre ellos a individuos con un perfil muy diferenciado entre sí, catalogados por el Gobierno como independentistas, desafectos, conspiradores, auxiliadores, agentes y reclutadores de la insurrección, cabecillas presentados, masones, periodistas y abolicionistas. ${ }^{98}$ Esto sería incluso más arbitrario por cuanto obedecían al temor y a la justificación de las autoridades de la colonia. También se observa un miedo a la extensión de la sublevación entre los campesinos y los miembros de las clases más

${ }^{97}$ Oficio de Capitán general a ministro de Ultramar, 30 de julio de 1869, AHN, Ultramar, Leg. 4777, Exp. 2. "Antecedentes y disposiciones de carácter general relativas a los deportados políticos".

${ }_{98}$ Relación motivada de diecisiete deportados políticos. Relación de individuos que salen para la Península en vapor de 30 de agosto de 1869. Relación de individuos que conduce para la Península el vapor Canarias. AHN, Ultramar, Leg. 4777, Exp. 1 "Expediente general de deportados políticos en la Guerra de los Diez Años"; AHN Ultramar, Leg. 4771, Exp. 13. Expediente de deportación de Alejandro Muxo y Pablos; también encontramos algún caso anecdótico como el de dos voluntarios que se habían excedido en sus funciones por registrar con gran escándalo la casa del director del Banco Español en Cuba buscando a un sospechoso. AHN, Ultramar, Leg. 4771, Exp. 4. Expediente de deportación de Juan Lleonies y José Alejardo; María Dolores Domingo Acebrón, "Los deportados de la Guerra de los Diez Años. Cuba (1868-1878)", pp. 154-155. 
populares y los esclavos. El carácter despótico de los capitanes generales se incrementaría al tener que hacer frente a una contienda militar, pero su autoritarismo era superado incluso por otros sectores integristas ya fueran civiles o militares. En este sentido, en cuanto a los embargos, el propio Dulce se quejaba de los excesos que se producían en los mismos. ${ }^{99}$ En realidad, la propia ley predisponía para ello, ya que según ella podían alcanzar a aquellos contra los que existían "presunciones fundadas" de complicidad con los insurgentes. ${ }^{100}$ Puesta la represión en manos de los integristas, que se excedieran resultaba previsible.

Tras el caso del San Francisco de Borja se produjo un cambio en la manera de proceder a las deportaciones. Las condiciones que soportaron en Fernando Poo fueron pésimas, por lo que se decidió cambiar el destino y no infringirles un castigo añadido. A partir de entonces fueron enviados a la Península, desde donde eran distribuidos hacia las plazas africanas o al interior. Esto era mucho más sencillo desde el punto de vista logístico y mucho más económico, puesto que se aprovechaban los vapores correo que unían periódicamente a la metrópoli con la colonia. Los mismos barcos que transportaban soldados para la guerra en una dirección, y entre ellos a algunos prisioneros carlistas enrolados forzosamente en el ejército, servían en el trayecto opuesto para trasladar a los cubanos represaliados por vía administrativa. Este servicio, era desempeñado por la naviera Antonio López, que consiguió unos beneficios grandes y seguros. En total se embarcó a 228 sujetos, en una práctica que decreció a medida que avanzaba la guerra. (Tabla 7).

Los vínculos entre Caballero de Rodas y la naviera son manifiestos, ya que incluso recibió una parte del capital de la misma. ${ }^{101}$ Esto pudo estimularle a realizar deportaciones, aunque lo cierto es que los relegados supusieron un negocio de poca envergadura comparándolo con las remisiones de soldados peninsulares. Como se aprecia en la tabla, Caballero de Rodas fue un gran defensor de este castigo, pero una vez aligeradas las cárceles implicaron a unos pocos hombres. Cuando el Capitán general fue sustituido por Blas de Villate, en noviembre de 1871, apenas fueron algunos casos

\footnotetext{
99 Carlos Sedano y Cruzat, Cuba. Estudios políticos, Imprenta de Manuel G. Hernández, Madrid, 1872, pp. 402 439-440 y 496.

100 "Resumen de las instrucciones referidas a embargo de bienes por infidencia". AHN, Ultramar, Leg. 3655.

101 Javier Paniagua y José Antonio Piqueras, Poder económico y poder político, Centro Francisco Tomás y Valiente UNED Alzira-Valencia/Fundación Instituto de Historia Social, Valencia, 1998, pp. 101-102.
} 
individuales. El hecho de estar centrada sobre gente con recursos e influencia, y estos serían los que mayores facilidades tendrían para exiliarse. Entre 30.000 y 100.000, según las fuentes, embarcaron hacia el extranjero. ${ }^{102}$

Tabla 7. Deportados a la Península desde agosto de 1869 hasta 10 de octubre de 1877.

\begin{tabular}{|c|c|c|c|}
\hline Fecha de salida & Nombre del vapor & $\mathrm{N}^{0}$ de deportados & Lugar de destino \\
\hline $15-8-1869$ & España & 45 & Santander y Cádiz \\
\hline $30-8-1869$ & Guipúzcoa & 75 & Santander y Cádiz \\
\hline $15-9-1869$ & Puerto Rico & 7 & Santander y Cádiz \\
\hline $18-9-1869$ & Canarias & 8 & Santander y Cádiz \\
\hline $25-9-1869$ & Antonio López. & 11 & Cádiz \\
\hline $9-10-1869$ & Comillas & 6 & Cádiz \\
\hline $30-10-1869$ & España & 5 & Cádiz \\
\hline $30-11-1869$ & Antonio López & 6 & Cádiz \\
\hline $15-12-1869$ & Isla de Cuba & 3 & Cádiz \\
\hline $15-1-1870$ & Guipúzcoa & 2 & Cádiz \\
\hline $30-1-1870$ & Puerto Rico & 4 & Cádiz \\
\hline $15-2-1870$ & Antonio López & 7 & Cádiz \\
\hline $15-3-1870$ & Isla de Cuba & 3 & Cádiz \\
\hline $30-3-1870$ & Comillas & 2 & Cádiz \\
\hline $15-4-1870$ & Guipúzcoa & 2 & Cádiz \\
\hline $30-5-1870$ & Isla de Cuba & 2 & Santander \\
\hline $30-6-1870$ & Canarias & 1 & Santander \\
\hline $30-8-1870$ & Antonio López & 6 & Santander \\
\hline $15-9-1870$ & Comillas & 1 & Santander \\
\hline $15-3-1871$ & Antonio López & 1 & Cádiz \\
\hline $15-6-1871$ & Antonio López & 1 & Santander \\
\hline $15-4-1872$ & Guipúzcoa & 1 & Cádiz \\
\hline $15-6-1872$ & Guipúzcoa & 1 & Santander \\
\hline $30-12-1872$ & Puerto Rico & 1 & Cádiz \\
\hline $30-3-1873$ & Isla de Cuba & 2 & Cádiz \\
\hline $30-8-1874$ & Antonio López & 5 & Santander \\
\hline $15-10-1874$ & Puerto Rico & 14 & Santander \\
\hline $15-2-1875$ & Méndez Núñez & 2 & Santander \\
\hline $15-11-1876$ & España & 4 & Santander \\
\hline \multicolumn{2}{|c|}{ Total de deportados } & 228 & \\
\hline
\end{tabular}

Fuente: Elaboración propia a partir de "Relación de los individuos que en calidad de deportados políticos han sido embarcados en los vapores de la empresa por disposición del Gobierno superior desde 10 de octubre de 1868 hasta la fecha" (10 de marzo de 1877). AHN, Ultramar, Leg. 3655.

\footnotetext{
102 Justo Zaragoza, Las insurrecciones en Cuba, tomo II, p. 374; Herminio Portell Vilá, Historia de Cuba en sus relaciones con los Estados Unidos y España, J. Montero-Minemosyne Publising, Miami, 1969, vol. II, p. 227. Portell Vila, estableció la cifra de 30.000, rebajando ostensiblemente la de Zaragoza.
} 
La elección del perfil social de deportados, además de otras ventajas, ofrecía la de proporcionar mayores recursos para la guerra contra la insurrección. Esta política de criminalización de personalidades influyentes, radicadas en la capital y con recursos no parece muy inteligente a largo plazo, ya que eran precisamente los sectores cuyo apoyo era más perentorio para el Gobierno. Sin embargo, lo que constataba era que en buena medida ya se habían perdido para la causa, y que el objetivo fundamental era ganar la guerra, lo que exigía medidas inmediatas. Especialmente en los primeros momentos de tensión en que los excesos eran más fáciles y la voz de los que pedían mayor dureza terminaba en muchas ocasiones imponiéndose. El poder, al sentir que las bases sociales sobre las que se sustentaban eran más débiles de lo que pensaba, optó por una represión amplia en la creencia de que la mano dura enderezaría la situación, lo que a largo plazo contribuyó a hacerla incluso más frágil.

\subsection{Isla de Pinos como lugar de deportación.}

El otro motivo que explica el decrecimiento en el número de remitidos a Europa fue el empleo de isla de Pinos como nuevo destino. El 3 de junio de 1869 comenzaron los traslados a este territorio, que en 31 de julio de 1870 ya albergaba a 191 relegados por delito de infidencia, 43 de ellos de color. ${ }^{103}$ Para proceder al embarque, los apresados eran sacados de su prisión y escoltados por la Guardia Civil, llevados por cordillera a Batabanó desde donde eran embarcados. En su destino, había tanto deportados por vía administrativa como sentenciados por los tribunales. A su llegada permanecían libres aunque vigilados por la autoridad. ${ }^{104}$ En la isla había escasez de recursos para el sostenimiento de un número tan elevado de represaliados. Precisamente, las malas condiciones fueron un elemento importante ya que las autoridades coloniales pensaban que el temor que generaba entre los independentistas la estancia en la metrópoli era menor, por lo que el efecto disuasorio de este castigo quedaba muy atenuado. Según ellas, la libertad de la que disfrutaban en la Península

\footnotetext{
${ }^{103}$ Relación nominal de los individuos extrañados en isla de Pinos a 31 de julio de 1870 . AHN, Ultramar, Leg. 3648.

${ }^{104}$ Oficio de teniente gobernador de isla de Pinos a Ministerio de Ultramar, 1 de febrero de 1870. Oficio de negociado de orden público a Gobernador Superior Civil de Cuba, 3 de marzo de 1870. AHN, Ultramar, Leg. 3648.
} 
facilitaba que siguieran colaborando con los insurgentes. ${ }^{105}$ Allí la vigilancia era mucho más fácil y estando a cargo de una autoridad militar y más cercana al teatro de operaciones, mucho más diligente.

En la Península, la presencia de los revolucionarios incordiaba a las autoridades, y la cuestión cubana generaba una gran incomodidad. Los gobiernos centrales lamentaban la falta de libertades, sin embargo, no se decidieron a hacer reformas en la misma amparándose en la propia insurrección. ${ }^{106}$ Aun así, la situación política condicionaba su actuación estando resueltos a actuar dentro de la legalidad. Se mostraban contrarios a las deportaciones gubernativas y recordaban la inconstitucionalidad de aprobar medidas administrativas al margen de los tribunales, lo que implicaba a su vez que al menos teóricamente no podían ser sujetos a la vigilancia de la autoridad. ${ }^{107}$ Las remisiones a Europa suponían un inconveniente para los capitanes generales de Cuba, puesto que sus pretensiones sobre los relegados chocaban con la actitud del Ejecutivo.

De entre las ciudades destacan por número de embarques Sancti Spíritus con 72 y Holguín con 28, conteniendo el resto apenas unos pocos. Vemos como su lugar de residencia había cambiado respecto al San Francisco de Borja. Una vez que era patente que la rebelión no se extendería al occidente, se focalizaron en Las Villas tratando de contener la expansión de la guerra en la provincia continua la capital. (Gráfico 5).

La escasez de recursos determinó que algunos de ellos, aquellos que habían obtenido mejor comportamiento, pasaran a residir a la Antilla mayor. Treinta y nueve salieron en 4 de septiembre de 1870 y otros 20 estaban esperando para hacerlo en octubre de ese mismo año. ${ }^{108}$ La salida de deportados a isla de Pinos hacia otros puntos

\footnotetext{
${ }^{105}$ Informe de Gobernador político de La Habana, 25 de octubre de 1871, AHN, Ultramar, Leg. 4777, Exp. 5. "Deportados cubanos a isla de Pinos".

${ }^{106}$ Isaías Táboas Suárez, El republicanismo federal y la primera guerra de Cuba (1868-1878), el autor, Barcelona, 2004, p. 62.

${ }^{107}$ Oficio de ministro de Ultramar a Gobernador Superior Civil de la isla de Cuba, 28 de agosto de 1869. AHN, Ultramar, Leg. 4777. Exp. 2. "Antecedentes y disposiciones de carácter general relativas a los deportados políticos". Oficio de Ministerio de Ultramar a gobernadores provinciales, 29 de julio de 1870. Ministerio de la Gobernación. AHN, Ultramar, Leg. 4777, Exp. 1. "Expediente general de deportados políticos en la Guerra de los Diez Años".

108 "Relación nominal de cincuenta individuos de los extrañados por infidencia en la misma y jurisdicciones de donde proceden". "Relación nominal de treinta y nueve extrañados en esta isla por delito de infidencia, que en ese día salen a fijar su residencia forzosa de orden superior a las jurisdicciones que a continuación se expresan". "Relación nominal de los veinte individuos extrañados en esta isla por infidencia que optan por pasar a las jurisdicciones que a continuación se expresan". AHN, Ultramar, Leg. 3648.
} 
se planteaba como cambiar la residencia de los que habían sido relegados administrativamente y su presencia en la isla principal no suponía inconveniente. ${ }^{109} \mathrm{El}$ objetivo era aprovechar el espacio y los recursos limitados de la pequeña ínsula para establecer a otros sujetos. Isla de Pinos no fue considerada como un punto intermedio para el que realizar remisiones a la Península, sino que ambos destinos fueron independientes. Respecto de los 39 a los que se reubicó en la Antilla mayor, había entre ellos ocho pardos y tres negros, por lo que no se aprecia ninguna diferencia racial considerable. Cuatro pudieron residir en Trinidad y otro en Guantánamo, pero el resto residirían en poblaciones de la provincia de occidente. El proceso de extracción de gente considerada peligrosa de la zona de riesgo para reubicarlos en el oeste era patente.

Gráfico 5. Provincia de procedencia de los deportados a Pinos en 31 de julio de 1870

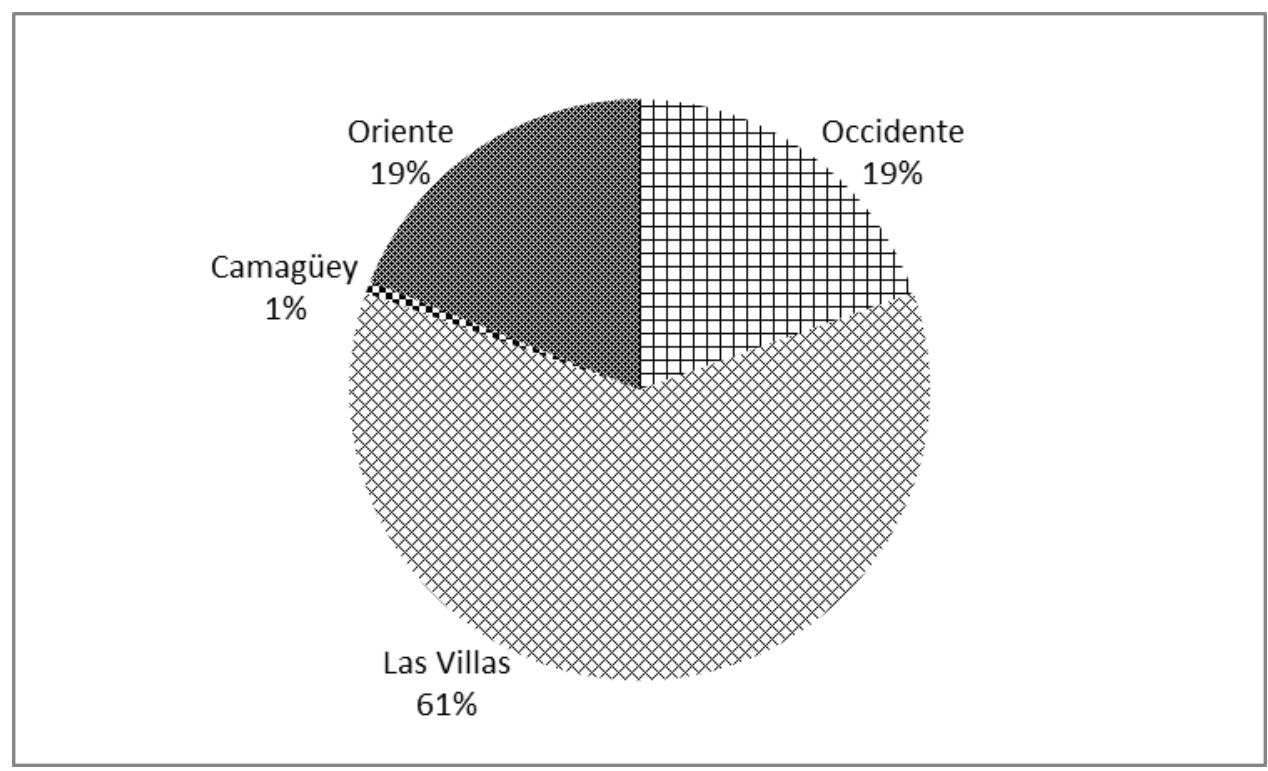

Fuente: Elaboración propia a partir de AHN, Ultramar, Leg. 3648. Relación nominal de los individuos extrañados en la Pinos a 31 de julio de 1870.

El número de deportados en Pinos crecía pero se mantenía estable. El 19 de noviembre de 1871 fueron llevados a esta 55 individuos entre los cuales siete abogados, seis propietarios, cuatro escribanos, tres hacendados, tres médicos, tres comerciantes, dos procuradores y un notario. ${ }^{110}$ La mayor oposición a su permanencia en la Península

\footnotetext{
${ }^{109}$ Notas a oficio de teniente gobernador de isla de Pinos a capitanía general de La Habana, 19 julio de 1870. AHN, Ultramar, Leg. 3648.

${ }^{110}$ Gil Gelpi Ferro, Historia de la revolución y guerra de Cuba, Gaceta Oficial, La Habana, 1889, vol. II, pp. 96-97. Había además 5 empleados en el foro, 2 empleados y un agrimensor. Del resto no conocemos su profesión.
} 
determinó que personas con estatus pasaran al territorio contiguo, haciendo inviables las pretensiones de Caballero de Rodas. En diciembre de 1873 había 176 relegados por causas políticas, entre los cuales 11 mujeres. ${ }^{111}$ De los 191 que había en la isla en 1870 por causas políticas, únicamente 45 de ellos (incluyendo a diez negros) continuaban tres años más tarde. Para la mayoría de ellos, exceptuando a los más peligrosos, constituyó un lugar de residencia temporal. Las remisiones continuaron, mostrando un gran dinamismo, lo que eleva el número de los que pasaron por la ínsula y dificulta establecer una cifra exacta, aunque superaría holgadamente los 1.000 y pudo llegar a los varios miles.

Junto a los relegados políticos había otros catalogados como vagos, rateros, delincuentes habituales y gentes de mal vivir. De esta manera, el número total era ligeramente mayor, 295 en octubre de 1870 y 301 en agosto de $1874 .{ }^{112}$ El grupo de trasladados por su conducta social se mantuvo constante en su número, siendo algo más de cien individuos durante estos años. Isla de Pinos quedaría principalmente como lugar de deportación para gente con pocos recursos, ya que los proindependentistas con mayores haberes fueron objeto de los primeros embarques y se exiliaron con mayor facilidad. Además, de quedarse en la Antilla mayor podían ser intimidados mediante el miedo al embargo, algo que no funcionaba de igual modo contra aquellos que estaban en la pobreza.

En 1870, el número de los represaliados de color era manifiestamente menor al de los blancos. Esto pudo deberse a una tendencia mayor hacia otro tipo de penas para los negros, aunque en ese periodo la insurrección estaba comandada principalmente por blancos, y que en general, entre los rebeldes se temía la incorporación masiva de negros e incluso hubo desmovilizaciones por ese motivo. ${ }^{113}$ Entre la tropa mambí, los esclavos ocuparon un papel subsidiario y los jefes rebeldes en ningún momento se propusieron la abolición inmediata de la esclavitud, en un intento por extender su apoyo social al occidente cubano. Solo la constatación de que los hacendados no iban a apoyar a la

\footnotetext{
111 AHN, Ultramar, Leg. 3617. Relación nominal de los individuos deportados políticos en Pinos en 1 de diciembre de 1873. Las mujeres eran Ramona y Luisa Tamayo, Matilde Rosanes, María Rojas, Concepción Calderón, Victoria Pérez, Amalia de la Cruz y Manuela Risco. Candelaria Rodríguez y Paula García salieron para Puerto Príncipe el 2 de diciembre.

${ }^{112}$ ANC, Asuntos Políticos Leg. 62, Sig. 17. Estados de deportados en isla de Pinos en octubre de 1870; ANC, Asuntos Políticos, Leg. 69, Sig. 42. Estados de deportados en isla de Pinos en agosto de 1874.

${ }^{113}$ Ada Ferrer, Insurgent Cuba. Race, Nation, and Revolution, 1868-1898, University of North Carolina Press, Chapel Hill, 1999, pp. 47-54.
} 
revolución produjo una dura pugna entre las tendencias abolicionista y la que pretendía la abolición gradual. Pero en cualquier caso, los esclavos mantuvieron una posición subordinada tanto en el territorio controlado por los rebeldes como en sus propias filas. ${ }^{114}$ Carentes en su mayoría de instrucción, educación y ubicados mayoritariamente en la parte occidental de la Antilla mayor, resulta lógico que su contribución fuera menor proporcionalmente a la población y por tanto la represión que sufrieran también lo seria.

La deportación a Pinos, realizada en su mayoría preventivamente y por vía administrativa podía abarcar a muchos inocentes. El temor de las autoridades coloniales y de sus subalternos, justificaba que en determinados momentos algunos de los tenidos por sospechosos fueran apresados y llevados a la pequeña ínsula. Cuando el pánico se incrementó, los castigos gubernamentales lo hicieron a la par. La guerra carlista y la inestabilidad política en la Península provocaron una situación de equilibrio que fue derivando en un mayor asentamiento y victorias de los mambises en 1873 y 1874. Esto llevó a que los insurrectos quisieran aprovecharse de sus pequeñas pero continuar victorias para extender la guerra al oeste. ${ }^{115}$

En la noche del 6 al 7 de enero de 1875 las fuerzas rebeldes cruzaron la trocha y se internaron hacia el occidente de la provincia de Las Villas con el objetivo de extender la guerra al occidente, en lo que supuso el esfuerzo máximo de los rebeldes. Esto atemorizó a las autoridades españolas, que temían la llegada de refuerzos a los pocos que combatían en la parte occidental. ${ }^{116}$ Por esto, amparándose en que en octubre de 1875 las actuaciones del grupo de Carlos García alcanzaron a la provincia occidental y a las proximidades de La Habana, se ordenó la deportación inmediata a isla de Pinos de 395 individuos, blancos y de color, "gente de justificado mal vivir, varios cumplidos de presidio que no hubo posibilidad de conseguir se dedicasen al trabajo y algunos otros

\footnotetext{
${ }^{114}$ Raúl Cepero Bonilla, Azúcar y abolición, Crítica, Barcelona, 1976, pp. 112-140.

115 Para más información de la marcha de la guerra, además de los ya citados me gustaría mencionar: Vanessa Michelle Ziegler, The Revolt of "the Ever-faithful Isle": The Ten Years War in Cuba, 1868-1878, Tesis doctoral de la Universidad de California, Santa Bárbara, 2007; Miguel del Rey, La Guerra de los Diez Años (1868-1878), Ristre, Madrid, 2003; Oscar Loyola y Diana Abad, La Guerra de los Diez Años. Primera guerra de liberación nacional, Universidad de La Habana, La Habana, 1987; sobre los primera etapa de la insurrección, ver Agustín Martínez de las Heras, La crisis cubana en el arranque el Sexenio Democrático, Tesis doctoral de la Universidad Complutense de Madrid, Madrid, 1984; acerca de las expediciones navales en la guerra: Milagros Gálvez Aguilera, Expediciones navales en la Guerra de los Diez Años, Ediciones Verde Olivo, La Habana, 2000.

${ }^{116}$ Ramiro Guerra, La Guerra de los Diez Años, Pueblo y Educación, La Habana, 1986, tomo II, pp. 268-272.
} 
todos auxiliadores reconocidos de su partida". ${ }^{117}$ Esto constituyó una llamada a una represión de amplio alcance que determinaría el cenit en cuanto al número de los que había en aquel territorio, que alcanzaría la cifra de 884 en ese año. A ellos habría que añadir los 358 que había en el correccional, en un momento que la población civil de la isla estaba conformada por únicamente 1.757 personas. ${ }^{118}$

El pánico a la extensión de la guerra determinó la extensión de las represalias que alcanzarían al sector más débil de la sociedad, precisamente el primer damnificado por la misma. Durante la guerra se llevó a cabo un proceso de reconcentración de población rural en las ciudades, lo que unido a un aumento de la presión impositiva con el fin de atender a los gastos de la guerra, hizo necesaria la ayuda pública para garantizar la subsistencia de esta población. ${ }^{119}$ Sin embargo, tras la no extensión de la guerra al occidente había una serie de causas que venían determinadas por las peculiaridades sociales y económicas de la región central y oriental. Esto es, la poca importancia de la esclavitud, el trato diferente a los esclavos, la menor presencia de ingenios y la escasa presencia de peninsulares habían determinado una estructura social diferente que difuminaba en muchos aspectos la estructura del Estado. ${ }^{120}$

\subsection{Las deportaciones como condena y como alzamiento de pena para infidentes}

Junto a los deportados por vía administrativa a isla de Pinos hubo otros a los que las penas les fueron impuestas mediante juicio. La relegación por sentencia se diferenciaba de la realizada por vía administrativa ya que fue impuesta por los tribunales, lo que incluso cuando estos carecían de algunas garantías legales y eran parciales, implicaba la aportación de pruebas en juicio. Difería por tanto de la planteada anteriormente realizada con finalidad preventiva y de atemorización. En este caso se planteaba como una corrección por hechos efectuados con el añadido de que el cambio forzoso de residencia determinaba la lejanía del teatro de operaciones.

\footnotetext{
117 "Noticia de las medidas adoptadas para indultar a los deportados de la isla de Pinos". AHN, Ultramar, Leg. 3655.

${ }^{118}$ Julián Ajo Jacques, "Memoria histórica, geográfica y política agrícola e industrial de la isla de Pinos desde su descrubrimiento hasta el tiempo presente", BANC, núm. 12, 1912, p. 295.

${ }^{119}$ Julio Le Riverend, Historia económica de Cuba, pp. 462-464.

${ }^{120}$ José Abreu Cardet, Introducción a las armas. La guerra de 1868 en Cuba, Editorial de Ciencias Sociales, La Habana, 2005, pp. 43-61.
} 
Las penas de deportación impuestas por delitos de infidencia no representan un número muy elevado, únicamente 46, la mayoría de ellas en la Península aunque encontramos casos aislados en Ceuta y Melilla. Los castigos más impuestos en los juicios fueron presidio con retención de diez años que era el que correspondía a los delitos por infidencia, que generalmente se cumplía en Ceuta. Sin embargo, el número de relegados por vía judicial se incrementó con aquellos a los que la condena a presidio les fue conmutada por esta. En este sentido, se produjo un cambio ya que al principio las permutas eran puntuales y eran los propios individuos los que elegían su lugar de residencia. A partir de marzo de 1873, todos aquellos a los que se permutaba la de prisión por confinamiento fueron reubicados hacia Mahón. Este año se produjeron la mayor parte de conmutaciones, que no continuaron con posterioridad. ${ }^{121}$ El golpe de Pavía, de 4 de enero de 1874, supuso el fin de la política más contemporizadora respecto a Cuba, cuya causa contaba con parte de la opinión pública a su favor, especialmente entre internacionalistas y republicanos partidarios de la abolición de las quintas. $^{122}$

El bloqueo en la cesación de permutas determinó la prolongación de la estancia en las cárceles. A primero de octubre de 1875 había 133 presos en Ceuta, 11 en Cartagena y dos en Sevilla, y en noviembre de 1877 todavía restaban 52 en Ceuta. ${ }^{123}$ Según los juicios, la pena de muerte no fue excesivamente empleada, e incluso en muchas ocasiones los encausados fueron absueltos o se les imponían sanciones menores. ${ }^{124}$ Sin embargo, esta apariencia de cobertura legal no daba una imagen real de la dureza del conflicto, en el que la política oficial era la de fusilar a todos los rebeldes cogidos con las armas en la mano. A ello habría que añadir los excesos que en toda guerra ocurrirían cometidos por los voluntarios y las fuerzas regulares del ejército por

121 "Sentenciados por los tribunales de la isla de Cuba por delitos de infidencia y destinados a la Península y sus posesiones de África". AHN, Ultramar, Leg. 4775, Exp. 2. "Expediente general de confinados políticos de la isla de Cuba entre los años 1869 y 1878"; un total de 76 cubanos murieron en Ceuta hasta la fecha del indulto total, aunque no se distingue entre presos comunes y políticos.

${ }_{122}$ Clara E. Lida, “Cuba. Un desastre anunciado, 1868-1898”, Illes i Imperis, núm. 8, 2006, pp. 74-77.

123 "Relación de los penados que sufren condena por sentencia de los tribunales de guerra". AGMM, Capitanía General de Cuba, Caja 4419; relación de individuos que piden indulto de acuerdo al real decreto de 27 de octubre de 1877. AHN, Ultramar, Leg. 4775. Exp. 9. "Expediente general de deportados políticos de la isla de Cuba. Solicitud de indulto de Manuel Gómez Montoya".

${ }^{124}$ AHN, Ultramar, Leg. 4368, 4371, 4765 y 4767. Expedientes individuales de represaliados por la Guerra de los Diez Años. 
un lado y las fuerzas independentistas por el otro. A falta de un estudio sistemático que comprenda toda la guerra las únicas cifras de que disponemos son las recogidas por un anónimo que a través de la recopilación de noticias sobre la guerra establecía que desde octubre de 1868 hasta 10 de noviembre de 1873 fueron ejecutadas un total de 2.927 personas por las fuerzas españolas. El folleto da además una lista de 4.672 prisioneros de los cuales dice que se desconoce su paradero y muchos de los cuales pudieron haber sido ajusticiados y de 191 condenados a muerte en garrote vil. ${ }^{125}$ Respecto a la represión efectuada por los independentistas carecemos de cifras, pero carentes de recursos y estructura para el sostenimiento de los presos, las opciones se limitaban a dejarles marchar o ejecutarles.

\subsection{La estancia de los deportados}

Fernando Poo

En 1869 el estado de Fernando Poo era ruinoso, puesto que ninguna de las intentonas realizadas durante la década había conseguido establecer una colonización efectiva del territorio. Esto supuso un retraimiento del Estado con la convicción de que era la iniciativa privada la que debía fomentar el progreso económico de la misma. ${ }^{126} \mathrm{El}$ precario avance de la colonización determinaría que la presencia de 250 nuevos residentes supusiera un gran problema para las autoridades de la misma. No ocurrió así con buena parte de la población cuya economía se vio dinamizada por el alquiler de habitaciones, la venta de víveres o de cualquier otro bien y servicio. ${ }^{127}$

El barco con los relegados llegó el 22 de mayo de 1869. ${ }^{128} \mathrm{Al}$ desembarcar fueron objeto de una alocución del gobernador de la colonia, Joaquín de Sousa, quien les explicó que su permanencia en la isla seria corta a causa de la escasez de recursos de la misma. Les permitió que se fueran en libertad y que se alojaran donde buenamente

\footnotetext{
${ }^{125}$ The book of blood. An authentic record of policy adopted by modern Spain to put an end to the war for the Independence of Cuba, N. Ponce de Leon, Broadway, 1873, pp. III-IV y 1-58.

${ }^{126}$ Mariano L. De Castro y María Luisa de la Calle, La colonización española en Guinea Ecuatorial (1858-1900), Ceiba, Vic, 2007, pp. 85-86.

${ }^{127}$ John Holt, The Diary of John Holt (Peter N. Davies, ed.), International Maritime Economic History Association, St. John's (Newfoundland), 1993, pp. 97-98.

${ }^{128}$ AGMM, Ministerio de la Guerra, Sig. 5602.14 "Traslado de deportados políticos desde Cuba a Fernando Poo, con escala en Puerto Rico"; Francisco Javier Balmaseda, Los confinados a Fernando Poo, e impresiones de un viaje a Guinea, pp. 5-7.
} 
pudieran, a la vez que les amenazaba en caso de tener un mal comportamiento y prometía benignidad con todos los que se portaran bien. De este modo, la fonda existente en Santa Isabel se llenó y algunos particulares alojaron a su vez a algunos de los deportados. ${ }^{129}$ Se les permitió la libertad en la ciudad y sus alrededores, por donde podían deambular con plena libertad.

El Estado no les abandonó totalmente. Los que no obtuvieron hospedaje fueron alojados en el edificio del mercado y se les otorgó una ración de comida a cargo del Gobierno. Además, frenó la especulación interviniendo el precio de los alimentos. Esto, unido a las frutas tropicales les permitió subsistir, aunque no en las mejores condiciones. El gobernador general mandó una expedición a la costa a por víveres, temiendo que la exigua caja de la colonia no pudiera costear la comida de los relegados. Pero, en general, dado el carácter de interinidad del castigo y de su elevado número, Souza no intervino apenas en su vida. La única atrocidad fue la muerte a consecuencia de los palos recibidos a un deportado de origen canario que había robado a otro durante el traslado. ${ }^{130}$ Con este hecho, el mensaje que había pretendido dar se confirmaba, no entrometerse mientras nada hicieran y corrección brutal en caso de cualquier desacato.

Resuelta la subsistencia inmediata de los represaliados, aparecieron las temidas fiebres que reiteradamente afectaban a los europeos residentes en la isla y que habían dejado sin efecto cualquier intento de colonización. ${ }^{131}$ Las enfermedades comenzaron a hacer estragos, en 16 de junio había nada menos que 62 enfermos: 36 por fiebre intermitente, nueve por disentería, cuatro por fiebre perniciosa y tres por fiebre cerebral. El 19 de junio se produjo el primer fallecimiento y a partir de ahí se fueron sucediendo hasta alcanzar a otros 14 durante su estancia. ${ }^{132}$

El estado de Fernando Poo imposibilitaba enormemente la posibilidad de obtención de empleo. Las carencias, la añoranza, la sensación de injustica y el gran número de aquellos, custodiados por una guarnición escasa determinaron a muchos

\footnotetext{
${ }^{129}$ Francisco Javier Balmaseda, Los confinados a Fernando Poo, pp. 12-26.

${ }^{130}$ AGMM, Ministerio de la Guerra, Sig. 5602.14. "Traslado de deportados políticos desde cuba a Fernando Poo, con escala en Puerto Rico"; Hipólito Sifredo y Llopiz, Los mártires cubanos en 1869, p. 23; Francisco Javier Balmaseda, Los confinados a Fernando Poo, pp. 10, 13 y 16. Otro individuo había fallecido anteriormente durante el viaje.

131 José Ignacio de Granda Orive, "Sanidad militar y aspectos sanitarios en Fernando Poo durante el Gobierno de los brigadieres (1859-1869)", Sanidad militar, vol. 67, núm. 1, 2011, pp. $55-57$.

132 "Relación nominal de deportados políticos que se hallan enfermos". AHN, Ultramar, Leg. 4718, Exp. 5. Expediente de deportados cubanos del San Francisco de Borja; Hipólito Sifredo y Llopiz, Los mártires cubanos en 1869, p. 24.
} 
individuos a tratar de fugarse de la misma. Pretensión que se incrementaría a medida que algunos de sus compañeros iban enfermando. Los primeros en fugarse fueron Francisco Javier Balmaseda y otros dos que huyeron el 19 de junio con la ayuda de un ciudadano español, yendo a parar a Aqua y desde ahí a Liverpool. Otro grupo de 17 lo conseguiría en 21 del mismo mes y otros 13 en 3 de agosto, en los vapores Biafra y Scotia en dirección a Liverpool. ${ }^{133}$ La gran cantidad de bahías en la isla y la escasa dotación hacían la vigilancia ineficaz, pero también hay que tener en cuenta que para el sector social al que pertenecían los relegados era fácil comprar la ayuda de barcos extranjeros, además de tener la posible simpatía de los ingleses. ${ }^{134}$

La ansiada evacuación no tardo en suceder, el 19 de agosto, 168 fueron embarcados en el vapor San Antonio con dirección a Santa Cruz de Tenerife, estando unos 90 enfermos en el momento de su embarque. Las pésimas condiciones en que se realizó el viaje, la ausencia de medicamentos y alimentos, el mal trato de los guardianes y del equipo médico determinaron que, cuando el 19 de octubre el barco llegó a su destino 16 habían fallecido durante el viaje. A su arribo a Mahón se les emplazó en el lazareto para la consiguiente cuarentena, en donde fueron bien tratados y asistidos, proveyéndoseles de los utensilios necesarios para hacer leña, guisar y una ayuda de dos reales diarios para manutención. Posteriormente pasarían a la fortaleza de la Mola. ${ }^{135}$

El resto salieron en la urca Pinta con dirección hacia Santa Cruz de Tenerife, aunque en realidad se dirigieron hacia Puerto Rico por disposición del capitán del barco. Las autoridades de la colonia se mostraron indignadas por este de hecho y por el mal

133 "Relación de deportados fugados desde el 28 de mayo hasta 19 de agosto". Subsecretario de Estado informa a ministro de Ultramar de comunicación del cónsul de España en Liverpool de 11 de agosto de 1869. AHN, Ultramar, Leg. 4718, Exp. 5. Expediente de deportados cubanos del San Francisco de Borja; Francisco Javier Balmaseda, Los confinados a Fernando Poo, pp. $159-176$ y 209.

${ }^{134}$ Hipólito Sifredo y Llopiz, Los mártires cubanos en 1869, p. 25. Oficios de gobernador de Fernando Poo a ministro de Ultramar, 8 y 13 de julio de 1869. AHN, Ultramar, Leg. 4718, Exp. 5. Expediente de deportados cubanos del San Francisco de Borja; ante las continuas fugas el gobernador se decidió a actuar de manera preventivamente, llevando a un grupo de ellos a un cayo frente a la capital de la colonia, aunque solo dos días. En el caso de intento de fuga la causa se sobreseyó y en otro protagonizado por un grupo de 16 fueron únicamente encerrados en la cárcel.

${ }^{135}$ BNCJM, Manuscritos, Ponce, núm. 663. Deportados cubanos. Viaje de la isla de Fernando Poo a la ensenada del lazareto de Mahón. Vapor San Antonio. 1869, (por un deportado cubano), passim, ver pp. 5 y 34 de la versión mecanografiada; BNCJM, Manuscritos, Pino, núm. 1, Este testigo presencial afirma que eran 92 los enfermos; relación de deportados de la isla de Cuba embarcados en el San Antonio. Oficio de Capitán general de Baleares a ministro de la Guerra, 26 de octubre de 1869. AHN, Ultramar, Leg. 4718, Exp. 5. Expediente de deportados cubanos del San Francisco de Borja. Según la documentación oficial los enfermos eran 88. 
trato recibido de manera que sustituyeron al oficial. Finalmente, llegaron a Mahón el 16 de julio habiendo fallecido durante el traslado 21 hombres de los 48 que transportaba. ${ }^{136}$ Allí se les ubicó en el lazareto, en las condiciones antes mencionadas de semilibertad. En 23 de noviembre todos fueron puestos en libertad con la condición de no volver a Cuba mientras durara la guerra, siendo diseminados a petición de los mismos. La ciudad menorquina fue el punto neurálgico de la deportación en España, hacia allí fueron reubicados también los presos de Ceuta a los que se les imponía como conmutación por la pena de presidio, además de al menos otros 18 de los relegados administrativamente. ${ }^{137}$

\section{Las llegadas a la Península}

La Península se encontraba en una situación política compleja. En septiembre de 1868, la Revolución Gloriosa enviaba al exilio a Isabel II y su agotado sistema moderado-unionista. Sin embargo, las contradicciones, patentes desde el inicio mismo de una revolución realizada por un amplio abanico social que iba desde las clases populares hasta a importantes generales unionistas, dotaron al sistema de una gran inestabilidad. Este sistema dual, en el que unos querían una revolución conservadora y otros cambios radicales y profundos generó graves conflictos dentro de la revolución. ${ }^{138}$ La elevada inestabilidad social y política en España y los intereses de la sacarocracia cubana no permitieron una política de reformas en Cuba. Si bien es cierto que el trato dado a los deportados en la metrópoli fue bueno.

En cuanto los barcos llegaban a Santander y Cádiz se producía la primera criba. Aquellos que habían sido relegados mediante sentencia irían a los puntos estipulados para ello y el resto quedaba a disposición del Ministerio de Ultramar. Esto en la práctica se manifestaba mediante la aprobación del Ministerio, en la mayoría de los casos, a la

${ }^{136}$ Juan B. Saluvet, Los deportados a Fernando Poo en 1869, pp. 63-132; Hipólito Sifredo y Llopiz, Los mártires cubanos en 1869, p. 45.

${ }^{137}$ Deportados políticos de la isla de Cuba que han residido en Mahón. AHN, Ultramar, 4775, Exp. 1. "Expediente general de confinados políticos de la isla de Cuba entre los años de 1869 y 1878"; allí pidieron quedarse 42, en Madrid fueron ubicados 28, en Barcelona y Cádiz 13 respectivamente, 19 en las islas Canarias y uno en Santander. Relación de los confinados liberados bajo palabra de no regresar a Cuba, 23 de noviembre de 1869. AHN, Ultramar, Leg. 4777, Exp. 1. "Expediente general de deportados políticos en la Guerra de los Diez Años".

${ }^{138}$ Antoni Jutglar i Bernaus, "La revolución de septiembre. El Gobierno provisional y el reinado de Amadeo I", en José María Jover Zamora (dir.) La era isabelina y el Sexenio Democrático (1834-1874), Historia de España de Menéndez-Pidal, Espasa-Calpe, Madrid, 1988, tomo XXXIV, pp. 645-648. 
petición formulada por los propios interesados a través de los gobernadores de los puntos donde desembarcaban, con la condición de presentarse a los gobernadores de la provincia donde pasaban. ${ }^{139}$ Dado que no eran represaliados mediante juicio, el Gobierno pretendió hacer menos dificultosa su estancia en la Península, facilitando su establecimiento en los puntos de su elección en los que podían tener familia, amigos o conocidos. Esto mejoraba su estancia y aumentaba las posibilidades de encontrar trabajo y de integrarse. Pero también servía para camuflar su condición de deportados. Poco a poco se fueron creando colonias de cubanos en distintas ciudades, que actuarían como redes sociales de apoyo.

A los que no disponían de trabajo o de relaciones sociales que facilitaran su manutención se estipuló el abono de una ayuda estatal de 1,50 pesetas para hacer frente a su subsistencia. A pesar de esto, el auxilio no se estableció hasta el 17 de mayo de 1871 cuando se concedió mediante orden del regente a aquellos que estaban en Cádiz. El 17 de julio, a instancias de los residentes en Barcelona, la medida se adoptó con carácter general. ${ }^{140}$ Una vez fuera de la isla y en aras de una posible futura pacificación, no tenía sentido crear un sufrimiento innecesario que provocaría mayor resquemor entre los criollos.

La colonia más importante de deportados estuvo en Madrid, con 89 individuos, pero la mayoría pudieron distribuirse por las provincias costeras sin ningún problema: 70 en Barcelona, 63 en Cádiz, 61 en Canarias, 43 en Mahón y Santander respectivamente y 39 en otras provincias costeras, ${ }^{141}$ desde las que la fuga era más fácil. Se observa una diferencia sustancial respecto a los deportados políticos anexionistas a los que se trató de alejar de la capital y de la costa. En este caso se concentraron en unas pocas ciudades, ya que la mayoría se establecieron en la capital, sede del Ejecutivo y donde tendrían mayor facilidad para establecer grupos de presión. También muchos otros en Barcelona en donde solían instalarse los que habían sido trasladados a Mahón. En la Península, la percepción de peligro que representaban difería ostensiblemente a la

\footnotetext{
${ }^{139}$ Telegrama de Ministerio de Ultramar a gobernador de Santander, 28 de septiembre de 1869. Oficios de gobernador de Santander a ministro de Ultramar, 22 y 29 de septiembre de 1870. AHN, Ultramar, Leg. 4777, Exp. 1. "Expediente general de deportados políticos en la Guerra de los Diez Años".

${ }^{140}$ Nota a oficio de subgobernador de Menorca a Ministerio de Ultramar, 12 de octubre de 1871. AHN, Ultramar, 4770. Exp. 7. "Socorro a deportados".

${ }^{141}$ AHN, Ultramar, 4777, Exp. 7. Expedientes individuales de deportados cubanos por medida gubernativa. Realizada sobre los 431 expedientes en los que se explicita este dato. Además había 23 en otras provincias del interior.
} 
que se tenía desde Cuba, donde se conjugaban el carácter autoritario de la máxima autoridad colonial con la guerra en la que la isla estaba inmersa. Influiría en esta postura del Gobierno español la pretensión de recuperar la lealtad de estos individuos y posiblemente la percepción de que la medida tomada contra ellos, aunque tolerada, no era compartida. Recordemos que por el modo empleado de represión, habría entre ellos muchos inocentes o cuyo delito era puramente ideológico.

Esta deferencia no se extendió a aquellos remitidos mediante sentencia de los tribunales militares, ya que a mediados de 1878 todavía había algunos de ellos en Ceuta. ${ }^{142}$ Permitirles elegir el lugar de su domicilio en la metrópoli tuvo que ver con su propia condición de represaliados por vía administrativa. Únicamente a una minoría de estos relegados extrajudiciales se les estipuló su punto de residencia, por querer imponérseles unas condiciones más estrictas. Esto no significó que se les limitase su libertad, sino que permanecieron libres en un recinto más acotado en el que la posibilidad de vigilancia era mayor: Ceuta y Melilla. ${ }^{143}$ A estos se les concedió una mayor peligrosidad por considerárseles implicados en las insurrecciones en grado de dirigentes o por ser gente de color a la que consideraban que ejercían mala influencia entre los esclavos.

La gran cantidad de deportados y la dispersión en los destinos provocó un caos. Para organizarlo se estipularon unas cédulas en las que se autorizaba a los individuos a residir en un punto determinado ya que no podían salir de la población en la que vivían. En caso de cambio de domicilio debían solicitar autorización y presentarse a la autoridad del lugar en donde estipulaban su nuevo alojamiento. ${ }^{144}$ Las cédulas se utilizaban también para pedir los socorros de modo que eran los propios interesados los que las solicitaban, pero el descontrol era grande y en ocasiones cuando estas llegaban

\footnotetext{
${ }^{142}$ Telegrama de gobernador de Cádiz a ministro de Ultramar, s/f. AHN, Ultramar. Leg. 4775, Exp. 1. "Expediente general de confinados políticos de la isla de Cuba entre los años de 1869 y 1878 ".

${ }^{143}$ El 30 de julio de 1869, 18 salieron para Ceuta y uno a Melilla y poco después otros tres en dirección a Melilla; relación de individuos que salen para la Península en vapor de 30 de agosto de 1869. "Relación conceptuada de individuos que por delito de infidencia se extrañan a los puntos que se expresa", 25 de septiembre de 1869. AHN, Ultramar, Leg. 4777, Exp. 1 "Expediente general de deportados políticos en la Guerra de los Diez Años"; AHN, Ultramar, 4777, Exp. 7. Expedientes individuales de deportados cubanos por medida gubernativa.

${ }^{144}$ Cedula expedida a Domingo Bloto. AHN, Ultramar, Leg. 4777, Exp. 1. "Expediente general de deportados políticos de la isla de Cuba".
} 
los relegados no las recogían, por desconocimiento o por haber cambiado de residencia, ya que los cambios de ciudad fueron muy habituales. ${ }^{145}$

A partir de marzo de 1870 comenzaron a concederse los primeros permisos para instalarse en lugares fuera del territorio nacional. Se trataba de una política escalonada en el tiempo que se mantuvo hasta 1873, con la excepción de un único caso en 1874. En total, fueron 25 los que recibieron permiso para instalarse en el extranjero principalmente en Francia, México y Puerto Rico. Mayor incluso fue el número de los que fueron autorizados a regresar a Cuba antes de la finalización de la contienda, 128 en total. En este caso no encontramos un límite temporal, si bien es cierto que la mayoría se produjeron en $1873 .{ }^{146}$ Con la Primera República y específicamente en la etapa federal de Pi y Margall, se intentaron tomar medidas de reforma en las colonias que incluían la inclusión de Cuba y Puerto Rico en la nación Española. ${ }^{147}$ Para este grupo, que representa aproximadamente un tercio del total de los represaliados por vía administrativa, la estancia en la Península fue temporal. Una política más madurada y más inteligente, trataba de buscar la reconciliación con los relegados, pero en ello no estaba exento el propio devenir de la insurrección. Teniendo en cuenta que las deportaciones se realizaron para prevenir la expansión de la guerra al occidente, una vez constatado que la guerra no se había generalizado y que su alcance geográfico era limitado, podían implementarse medidas como estas.

La remisión a Fernando Poo tuvo que ver con un intento del Capitán general para causar un golpe de efecto. La elección de la colonia africana resultó contraproducente para las autoridades españolas al dar razones a los independentistas para magnificar el alcance de la represión. Esto fue así por la gran voluntad de los cubanos de dejar testimonio de sus vivencias con un fin político muy determinado, por lo que a pesar del posible efecto temporal de atemorización fue un error político muy grave. Las muertes en la isla africana y las condiciones del trayecto en la Pinta y San Antonio dieron argumentos a los independentistas y les permitieron "demostrar" la

\footnotetext{
${ }^{145}$ Relación nominal de deportados de la isla de Cuba, para los que el ministro de Ultramar remitió cédulas en comunicación de 29 de julio. Relación nominal de los deportados políticos y sujetos a la vigilancia que procedentes de la Isla de Cuba se encuentran domiciliados en esta Capital y desean se les libre la oportuna cedula de seguridad". AHN, Ultramar, Leg. 4777, Exp. 1. "Expediente general de deportados políticos de la isla de Cuba".

${ }^{146}$ AHN, Ultramar, 4777, Exp. 7. Expedientes individuales de deportados cubanos por medida gubernativa.

147 Javier Echenagusia, La Primera República. Reformismo y revolución social, RBA, Barcelona, 2012, pp. 35-36.
} 
tiranía de España. Por eso tuvo el efecto contrario y supuso una victoria de los independentistas en la guerra propagandística contra el Ejecutivo, esto cuando es evidente que el objetivo de las autoridades eran alejarles del país y no el de provocar fallecimientos entre ellos. ${ }^{148}$ De este modo, las condiciones relativamente buenas de la mayoría, los que había en la Península, quedaron sin visibilidad y ocultas.

La generosidad en los cambios de residencia y la permisividad en salir del país y en la posibilidad de retornar a la isla, determinaron que las fugas no fueran muy numerosas. Según los registros de las autoridades, únicamente cinco se fugaron, a los que podría añadirse otros cuatro de los que se desconocía su paradero. La mayoría se produjeron en 1869 antes de la implementación de la posibilidad de salida de la isla. Otros preferirían permanecer en la metrópoli "voluntariamente", prefiriendo esperar al fin de la guerra para regresar a Cuba. No olvidemos que muchos otros habían salido voluntariamente con destino a Europa y Estados Unidos para escapar de la sangrienta guerra.

En un primer momento la vigilancia que se ejercía sobre ellos era muy tenue, aunque poco a poco fue incrementándose. En diciembre de 1871 ya se ordenaba espiarles tanto en España como en otras ciudades del extranjero, ${ }^{149}$ con objeto de acabar con la colaboración que algunos prestaban a la insurrección y con la recaudación de fondos para la misma. En junio de 1872 se ordenaba disolver una Junta creada en Sevilla y que recibía fondos de 34 relegados. ${ }^{150}$ Compaginar el control sobre ellos sin conculcar más sus derechos fue una constante preocupación para las autoridades españolas, ya que en realidad muchos de los deportados y exiliados eran colaboradores de la sublevación.

\footnotetext{
${ }^{148}$ De hecho solo nueve fallecieron durante su estancia en la Península. AHN, Ultramar, 4777, Exp. 7. Expedientes individuales de deportados cubanos por medida gubernativa. El expediente contiene por error el deceso de algunos individuos deportados a las Filipinas. Pero no se trata de deportados políticos, sino de relegados por Lersundi en 1866. Eran delincuentes habituales, vagos y demás marginados sin ningún tipo de vinculaciones políticas.

${ }^{149}$ Oficio reservado de subsecretario de Ministerio de Ultramar a contabilidad, 24 de diciembre de 1881. Oficio reservado de Ministerio de Estado a Ministerio de Ultramar, 12 de enero de 1872. AHN, Ultramar, Leg. 4777, Exp. 2. "Antecedentes y disposiciones de carácter general relativas a los deportados políticos"; oficio de Ministerio de Ultramar a gobernadores de Cádiz y Santander, 7 de julio 1870. AHN, Ultramar, Leg. 4777, Exp. 1. "Expediente general de deportados políticos de la isla de Cuba".

${ }^{150}$ Oficio de Capitán general a ministro de Ultramar, 14 de junio de 1872. AHN, Ultramar, Leg. 4777, Exp. 2. "Antecedentes y disposiciones de carácter general relativas a los deportados políticos".
} 
Isla de Pinos concentraba en un único punto a extrañados y a destinados al correccional. Los deportados permanecían libres, pero aquellos que no observaban una buena conducta eran ingresados en el presidio, lo que actuaba como elemento atemorizador. ${ }^{151}$ Las condiciones materiales de la estancia determinarían diferencias entre los relegados. Por ejemplo, José Martí se alojó en la hacienda de José María Sarda, amigo personal de su padre. ${ }^{152}$ Sin embargo, este caso constituía un hecho puntual, dado que al ser planteados como una forma de represión ejecutada principalmente por vía administrativa, tuvieron que soportar unas condiciones más duras que en la Península, ya que la vigilancia era más estrecha.

Según el testimonio de Raimundo Cabrera, uno de los condenados a destierro en isla de Pinos por tratar de unirse a los insurrectos, el proceso fue el siguiente: residente en Güines escapó tratándose de unirse a los rebeldes, pero fue apresado en 21 de agosto de 1869 y juzgado por una Comisión Militar que el Capitán general Francisco Lersundi había reinstaurado, por la que tras un juicio de 40 días lo condenó a dicha pena. Después del falló los familiares acudieron a despedirse en las horas de visita del presidio de La Habana. Posteriormente fueron trasladados a la estación de ferrocarril donde una multitud acudió a despedirlos y fueron llevados a Bejucal, donde un familiar les prestó camas, sabanas y almohadas para que no durmieran en el suelo. A continuación embarcaron rumbo a isla de Pinos desde Batabanó. ${ }^{153}$ A su llegada a Nueva Gerona, el jefe de la plaza les hizo una alocución:

"Deportados: tenéis la ciudad por cárcel; ninguno podrá alejarse medio kilómetro de ella sin mi permiso escrito. Debéis dar parte dentro de veinticuatro horas de vuestro alojamiento. Los domingos tenéis la obligación de presentaros aquí a las nueve de la mañana a pasar la lista. La isla es pequeña y solo tiene ochocientos habitantes; pero la guarnición a mis órdenes es sobrada para mantener el orden: no hay que soñar con revueltas. Si os conducís bien, el Gobierno será vuestro padre; para que los que cometan faltas seré inexorable! ¡Podéis marcharos!”154

\footnotetext{
${ }^{151}$ Antonio Núñez Jiménez, Isla de Pinos. pp. 466-467.

${ }^{152}$ Luis Toledo Sande, Cesto de llamas. Biografia de José Marti, Alfar, Sevilla, 1998, pp. 3946. Martí fue condenado a seis años de presidio en 4 de marzo de 1870, y tras estar realizando trabajos forzados, se le conmutó por confinamiento en isla de Pinos. Estuvo allí desde 13 de octubre de 1870 hasta 12 de diciembre de ese mismo año, en que a petición de su madre se le concedió pasar a realizar sus estudios en España.

${ }^{153}$ Raimundo Cabrera, Mis Buenos tiempos (memorias de un estudiante), Sociedad de Ediciones Literarias y Artísticas. Librería Paul Ollendorff, París, 1891, pp. 73-76, 78 y 99-108.

${ }^{154}$ Ibídem, p. 108. He respetado las cursivas en el texto y los signos de puntuación.
} 
El texto recoge con claridad las condiciones en que se desenvolvía su vida. El carácter militar de la autoridad y las condiciones de la colonia hicieron más difíciles las condiciones del confinamiento. Una vez en el territorio cada uno debía procurarse su subsistencia lo que planteaba la dificultad de conseguir trabajo o alimentos en un lugar con una escasez perentoria de recursos. Ante estos hechos y a petición del propio teniente gobernador, en mayo de 1870 la ayuda para los pobres de que gozaban los trasladados en la Península se extendió a esta ínsula. Sin embargo, solo alcanzaba a los relegados por motivos políticos y no a los castigados por vagancia. ${ }^{155}$

\subsection{El fin de la guerra y el retorno de los relegados}

En 1875 la situación de equilibrio entre los dos bandos se había roto. El Gobierno revolucionario pasaba por una grave crisis y desde la Península se enviaron nuevos efectivos. De este modo, en 1876, el Capitán general Joaquín Jovellar disponía de 72.000 hombres, a los que pronto se unirían otros por el fin de la guerra carlista. ${ }^{156}$ Ante la imposibilidad de vencer los insurrectos se desmoronaron pidiendo en su mayor parte el armisticio. Únicamente Antonio Maceo continuaría la guerra, pero falto de las fuerzas necesarias tuvo que exiliarse.

El periplo de la mayoría de los deportados terminaría con las sucesivas amnistías. En febrero, se indultó a todos los de la jurisdicción de las Villas deportados a isla de Pinos o desterrados a otras partes de la Antilla mayor. ${ }^{157}$ El 5 de mayo de 1877 , el Ejecutivo aprobó una disposición del Capitán general de Cuba mediante la cual se alzaban todos los destierros gubernativos impuestos. La vuelta seria a cargo del crédito concedido al Estado para ello. Aun así, los relegados debieron hacer momentáneamente frente al importe del pasaje ya que tras el indulto únicamente se les concedió un $25 \%$ de descuento con el objetivo de retardar el retorno. Desconocemos a partir de qué momento se les pagaría el importe del pasaje de regreso y si esto se produjo efectivamente, pero teniendo en cuenta los precedentes se produciría con toda seguridad. Además implicaba comenzar un proceso de desembargo de los bienes requisados gubernativamente de los

\footnotetext{
${ }^{155}$ Nota a oficio de teniente gobernador de isla de Pinos, 19 de julio de 1870. AHN, Ultramar, Leg. 3648.

${ }^{156}$ Luis Navarro García, Las guerras de España en Cuba, Encuentro, Madrid, 1998, pp. 89-93.

${ }^{157}$ AHN, Ultramar, Leg. 4775, Exp. 12. "Indulto concedido por el Gobernador general a los confinados políticos en isla de Pinos y otros puntos de la isla".
} 
acogidos a indulto, de los que quedarían excluidos los jefes y los reincidentes. ${ }^{158}$ Un real decreto de 22 de octubre de 1877 ampliaba a la real orden anterior comprendiendo a todos los condenados a presidio y a los que se hallaban en rebeldía y a los bienes que se les había embargado. Para todo ello, era necesario solicitar el perdón y el informe favorable de la máxima autoridad colonial. ${ }^{159}$

Con la constatación del abandono de la guerra por la mayoría de los combatientes, Martínez Campos dictó un bando en 28 de marzo de 1878 que implicaba el sobreseimiento de las causas en curso y el indulto total de todos los represaliados mediante sentencia o providencia gubernativa, exiliados e incluso de los desertores del ejército que solo tendrían que finalizar el tiempo que les quedaba de servicio. ${ }^{160}$ Con ello, una vez finalizada la guerra, el Gobierno pretendió realizar una política de reconciliación, que implicaba que la inmensa mayoría de los relegados regresaran, especialmente en los lugares donde eran un estorbo. La única excepción la constituía la isla de Pinos, donde en mayo todavía llegaron 21. La posesión se utilizó como punto de relegación de los últimos represaliados, pero también es cierto que su número se había reducido considerablemente, ya que a esa fecha albergaba únicamente a un total de 56. ${ }^{161}$ Desconocemos las causas pero probablemente se trataría de sujetos con el mismo perfil social que los anteriores.

\footnotetext{
${ }^{158}$ Real orden de 25 de mayo de 1877. Informe a Ministerio de Ultramar del regreso de varios deportados, 6 de junio de 1877. AHN. Ultramar, Leg. 4777, Exp. 1. "Expediente general de deportados políticos de la isla de Cuba"; medidas parciales para el desembargo de bienes se habían producido con anterioridad. Especialmente para no privar de subsistencia a la familia de los infidentes, siempre que se hubieran mantenido fieles al Gobierno. "Resumen de las órdenes referentes a embargos por infidencia”. AHN, Ultramar, Leg. 3655.

${ }^{159}$ Gaceta de Madrid, 22 de octubre de 1877.

${ }^{160}$ AHN, Ultramar, Leg. 3655.

${ }^{161}$ ANC, Asuntos Políticos, Leg. 62, Sig. 17. Estados de deportados en isla de Pinos.
} 


\section{CAPÍTULO 9. UNA DEPORTACIÓN CADA VEZ MÁS RESTRICTIVA. LA GUERRA CHIQUITA Y LA GUERRA DE INDEPENDENCIA CUBANAS}

\section{LA GUERRA CHIQUITA}

\subsection{Los inicios de la guerra}

La paz de Zanjón había supuesto el reconocimiento del agotamiento de las dos partes, pero sobre todo de la incapacidad del independentismo para vencer al poder colonial. La ayuda financiera menguaba y el fin de la Tercera Guerra Carlista significó la llegada de refuerzos militares. Tras el armisticio se realizaron una serie de reformas limitadas que ofrecían la posibilidad de representación política y de defensa de sus intereses. La nueva vía era incluso más apetecible cuando el independentismo había sido bloqueado por los hechos, con un coste descomunal de trescientos millones de dólares y 258.000 vidas. ${ }^{1}$ Dados los antecedentes, muchos desconfiaron de España y no se conformarían con nada que no fuera la emancipación y el fin de la esclavitud. Aun así, la desmovilización era inevitable, las deserciones y el exilio se sucedieron en el campo rebelde que desmoralizado abandonó momentáneamente la contienda.

Al iniciarse la Guerra Chiquita había en España un régimen consolidado que nada tenía que ver con la sucesión de gobiernos e incluso de regímenes en los inicios de la guerra anterior. El Sexenio, por principios y como modo de diferenciarse del autoritarismo de moderados y unionistas, enarboló la bandera de los derechos que chocaba con las represalias extrajudiciales. Por esto, una vez en la metrópoli se ejerció una política menos opresiva contra los deportados que mayoritariamente residieron en la Península y más de un tercio regresaron antes de la finalización de la contienda. La Restauración, por el contrario, pretendía manifestarse como un sistema nuevo, garante del orden frente a los "desmanes" de la etapa pasada. Los ejecutivos más estables y homogéneos desde su inicio derivaron hacia una estructura represiva sin vaivenes y menos timorata, que mantuvo una mayor coherencia a pesar de los cambios en la presidencia del Gobierno. El nuevo sistema no pretendía basar su actuación en el

\footnotetext{
${ }^{1}$ Hugh Thomas, Cuba. La lucha por la libertad, p. 209.
} 
respeto a los derechos políticos y sociales, facilitándose la aplicación de unas políticas de castigo de mayor dureza.

En la Guerra Chiquita encontramos un precedente inmediato de deportaciones, lo que facilitaba su aplicación puesto que las medidas y el resultado eran conocidos. En la Guerra Grande el antecedente fueron las realizadas contra los anexionistas, pero tuvieron un carácter más individualizado, en consonancia con la extensión de las ideas separatistas principalmente entre unas élites cultas. También diferían las características de los principales instigadores de las insurrecciones del periodo 1848-1855, que formaron parte de un estrato social más elevado, por lo que la práctica tuvo que cambiar ante una guerra de grandes proporciones con presencia de todos los estratos sociales y razas. Las relegaciones efectuadas durante la Guerra de los Diez Años fueron actualizadas por el nuevo régimen, con la pretensión fundamental de mejorar su eficacia. Era un sistema liberal y no democrático, aunque con aspiraciones a evolucionar hacia la democracia.

El retorno de los represaliados de la Guerra Grande no supuso la conclusión de los embarques, Miguel Porta Santa María lo fue en agosto de 1878. Tras el fin de la guerra y en relación a nuevas conspiraciones fueron confinados en la Península Segundo Pereda y Víctor Duran, en 5 de marzo de 1879, y en 25 de ese mismo mes Pablo Beola, Flor Crombet y José María Rodríguez. ${ }^{2}$ El carácter de continuación de la Guerra Chiquita respecto de su predecesora se aprecia en las remisiones a la metrópoli, que se utilizaron sobre sujetos con un determinado perfil social y con carácter selectivo, reproduciendo lo acontecido en la contienda precedente. En los meses siguientes continuaron, aunque sin afectar a un número importante. La realización de los traslados mediante los vapores correo implicaban un menor coste económico y una mayor confidencialidad, evitando partidas masivas que otorgaran publicidad a la causa independentista, levantaban rumores y "constataban” la tiranía que oprimía a los cubanos. Muchos de ellos eran trasladados a Puerto Rico, en donde se organizaban los envíos dado su carácter de base segura desde la que organizar la práctica con mayor tranquilidad y sigilo.

\footnotetext{
${ }^{2}$ AHN, Ultramar, Leg 4793, Exp. 17. Expediente de deportación de Miguel Porta Santa María; AHN, Ultramar, Leg. 4803, Exp. 43. Expediente de deportación de Segundo Pereda; AHN, Ultramar, Leg. 4762, Exp. 20. Expediente de deportación de Pablo Beola, Flor Crombet y José María Rodríguez.
} 
Las conspiraciones eran conocidas por las autoridades coloniales, ${ }^{3}$ que utilizaron las deportaciones para neutralizarlas sin pretender atemorizar a la sociedad en general. La cercanía con el fin de la guerra anterior y la política de reformas no hacía recomendable una política de mayor dureza, aunque fueran destacados independentistas y conspiradores. Únicamente el inicio de la guerra, en 24 de agosto en San Lorenzo, provocaría un aumento a final de año. El 10 de noviembre salió el vapor Congo con 41 sujetos y un mes después el Méndez Núñez con 23. A partir de aquí se compaginarían las salidas individuales con algunas más numerosas, intensificándose estas últimas a mediados del año siguiente con el desmembramiento militar del independentismo. En julio y agosto de 1880 salieron de la isla un mínimo de $242 .{ }^{4}$ Posteriormente los envíos continuaron, pero con la excepción del Josefita llevaron un número menor.

A noviembre de 1881 había 604 cubanos que habían sido remitidos a la Península y a Fernando Poo, y 128 en isla de Pinos, además de otros cuatro expulsados del país. Los datos pueden considerarse fidedignos, ya que fueron recopilados por el Capitán general cuando la guerra había sido finiquitada desde hacía tiempo, y atendiendo a los expedientes personales no hubo deportados con posterioridad a la metrópoli, aunque sí a isla de Pinos, donde a 15 de noviembre de 1882 había $168 .^{5}$ Las relegaciones se emplearon como un modo de castigar a hombres a los que la justicia no llegaba, por lo que se planteó una punición al margen de esta. La sangrienta guerra que acababa de finalizar y el hecho de que las autoridades españolas consideraran que los insurrectos habían faltado al compromiso que el Pacto de Zanjón representaba, explican esta represión.

\footnotetext{
${ }^{3}$ Francisco Pérez Guzmán y Rodolfo Sarracino, La Guerra Chiquita. Una experiencia necesaria, Letras Cubanas, La Habana, 1982, pp. 100-103.

${ }^{4}$ AHN, Ultramar, Leg. 4673 Exp. 50. Expediente de deportación de Bartolomé Maso; AHN, Ultramar, Leg. 4673 Exp. 49. Expediente de deportación de Francisco Marrón; AHN, Ultramar, Leg. 4793, Exp. 11. Expediente de deportación de José Molinero; AHN, Ultramar, Leg. 4763, Exp. 7. Expediente de deportación de José de la Cruz Fuentes; AHN, Ultramar, Leg. 4762, Exp. 60. Expediente de deportación de D. Miguel de Enbil y el pardo Victoriano Fernández; AHN, Ultramar, Leg. 4763, Exp. 47. Expediente de deportación de Teófila Lezcay; AHN, Ultramar, Leg. 4763, Exp. 11. Expediente de deportación de Pablo Fuentes; AHN, Ultramar, Leg. 4763, Exp. 23. Expediente de deportación de José Guerra; AHN, Ultramar, Leg. 4764, Exp. 32. Expediente de deportación de Juan Soto; AHN, Ultramar, Leg. 4763, Exp. 43. Expediente de deportación de Cipriano Eduardo Lores.

${ }^{5}$ Relación numérica de los deportados durante la Guerra Chiquita realizada por el Capitán general, 3 de noviembre de 1881. AGMM, Capitanía General de Cuba. Caja 4418; ANC, Asuntos Políticos, Leg. 77, Sig. 25. "Estado del número de los políticos extrañados a isla de Pinos por orden superior".
} 
El mayor autoritarismo del nuevo régimen determinó que para una guerra como la de los Diez Años, mucho más importante, con muchos más movilizados y con una periodicidad mucho más extensa, los trasladados a la Península fueran menos que en la Guerra Chiquita. No sucede así con los llevados a isla de Pinos, cuya cuantía fue mucho más reducida en la nueva contienda. Aun así, podría hablarse de una mayor dureza ya que proporcionalmente afectó a un número más elevado de personas que fueron remitidas a un lugar más lejano y con unas condiciones mucho más restrictivas.

Todas las relegaciones fueron realizadas administrativamente, prescindiendo de juicios que requerían de tiempo y de la aportación de algún tipo de prueba con lo que los pocos vestigios de justicia en estos procesos desaparecieron. La potestad para su realización correspondía al Capitán general, ${ }^{6}$ que en muchas ocasiones ni siquiera motivaba su decisión o lo hacía de manera genérica con acusaciones de ser infidentes o de que su permanencia en la isla era inconveniente. El Estado asumió las disposiciones emanadas desde La Habana, que encontraron un Gobierno plenamente receptivo a las políticas ejecutadas y a sus reivindicaciones.

La deportación se utilizó principalmente contra los presentados a indulto, gente relevante en la insurrección y los sospechosos. Esto abarcó a cualquier tipo de participación en la insurrección, desde reclutador o conspirador hasta a aquellos que tomaron las armas y también a otros por tener opiniones separatistas, periodistas, guerrilleros españolistas que se excedieron en los atropellos, e incluso a delincuentes de los que se pensaba que podían unirse a la insurrección como un modo de amparar su forma de vida. ${ }^{7}$ Estos grupos que no participaron directamente en la rebelión no constituyeron el principal objetivo de las medidas de alejamiento, especialmente aquellos que no obedecían a causas políticas, pero empezada la guerra esta medida podía ampliarse sobre cualquiera. En cuanto a los individuos hemos de distinguir los del este, vinculados directamente con la misma y los de la región occidental cuyas actuaciones iban en la línea de apoyar, reclutar, financiar y tratar de expandir la rebelión.

\footnotetext{
${ }^{6}$ Los expedientes individuales de los relegados en AHN, Ultramar, Legs. 4762, 4763, 4764, 4792,4793 y 4795 .

${ }^{7}$ AHN, Ultramar, Leg. 4940. Relaciones de deportados de La Habana, Matanzas y Santa Clara, Santiago de Cuba y provincia de Santiago de Cuba, 5 de agosto de 1882; AHN, Ultramar, Leg. 4795, Exp. 1. Deportación de tres periodistas a la Península; AHN, Ultramar, Leg. 4793, Exp. 1. Deportación de cuatro individuos por excederse en los atropellos; AHN, Ultramar, Leg. 4761, Exp. 5. Deportación de individuos de antecedentes criminales.
} 


\subsection{De la Península a las plazas africanas}

El traslado se llevaba a cabo hacia Santander y Cádiz, a cuya llegada se les recluía en el presidio. Eran relegados y debían permanecer como tal, pero no se les llevó directamente hacia su destino para ser liberados inmediatamente sino que el proceso fue mucho más rígido y permanecieron encerrados hasta que se aclaraba su destino definitivo. La severidad en los viajes fue objeto de quejas por parte de los represaliados, Domingo Adell afirmaba que fueron desde Puerto Rico a Santander en la bodega en unas condiciones lamentables y que una vez allí fueron "atados de dos en dos y llevados a la cárcel”, procedimiento que se repitió en los envíos posteriores hacia Cádiz y Chafarinas. ${ }^{8}$ Había una mayor seguridad, más temor y un desinterés total por aparentar legalidad. Desde las cárceles se vería que hacer con ellos, pero con la tranquilidad de saber que no escaparían.

La política de rigidez fue impuesta por los hechos. En un principio, tal y como ocurrió con anterioridad, fueron puestos en libertad en distintos puntos de la Península con la posibilidad de elección del punto de residencia. Esto acarreó los consabidos problemas de fugas y cambios de residencia. De los 113 deportados con anterioridad a 19 de marzo de 1880, 28 se habían fugado o se encontraban en paradero desconocido. ${ }^{9}$ Un porcentaje demasiado elevado para un Gobierno muy preocupado en mantener el orden, que en 1 de mayo decretó la detención de todos y la salida inmediata hacia los nuevos puntos asignados. ${ }^{10}$ Apenas unas decenas quedaron en el continente bajo la promesa estricta de no fugarse. Con el resto empezó el proceso de traslación principalmente hacia Chafarinas, Ceuta, Mahón, y en mucha menor medida, Melilla. A partir de entonces las nuevas remesas fueron distribuidas rápidamente hacia estos lugares, donde la vigilancia se facilitaba y era llevada a cabo por las autoridades militares.

\footnotetext{
${ }^{8}$ ANC, Asuntos Políticos, Leg. 79, Sig. 29. "Relación de deportados políticos que piden regresar a la isla de Cuba, 1 noviembre de 1880".

9 "Deportados políticos de la isla de Cuba", s/f. AHN, Ultramar, Leg. 4940.

${ }^{10}$ AHN, Ultramar, Leg. 4762, Exp. 32, Expediente de deportación de Manuel Castillo; AHN, Ultramar, Leg. 4762, Exp. 38. Expediente del fallecimiento del deportado en Chafarinas Juan Mata Cintra, AHN, Ultramar, Leg. 4764, Exp. 6, Expediente de deportación de Ramón Rodríguez; el 26 de mayo llegaron los primeros a Chafarinas y Melilla, en Ceuta ya habían llegado algunos desde 1879, en el momento en que había libertad de elección. En 13 de mayo llegaron cuatro a Ceuta y otros cuatro el día 28. Estadísticas de los deportados en Chafarinas (30 de octubre de 1880), Ceuta (25 de noviembre de 1880) y Melilla (30 de noviembre). AHN, Ultramar, Leg. 4764, Exp. 58. Comisión de visita a los deportados de la isla de Cuba en las posesiones de África.
} 
La adaptación a los problemas que surgían aumentaba la eficacia del castigo. Esto se vio favorecido por la mejora en las comunicaciones y la dinamicidad en las consultas entre las distintas autoridades. Sin estar estructurada desde el principio, se fue imponiendo una represión que le daba un sentido carcelario. En la sociedad liberal, la pena de prisión se había impuesto como punición por excelencia por ser "la forma más inmediata y civilizada de todas las penas". ${ }^{11}$ Lo que se pretendió fue conseguir los beneficios del sistema carcelario para el poder, pero con la limitación de que no se trataba de presos ni se había seguido ningún proceso judicial contra ellos.

Las condiciones en que se mantuvieron no fueron equiparables a la de los presidiarios. Fue una readaptación del castigo que adquirió tintes carcelarios y que puede considerarse como una deportación muy restrictiva o incluso como un presidio con beneficios, lo que suponía una grave conculcación del estado de derecho. Un paso más en la dureza impuesta a la oposición política y que chocaba con los principios básicos del liberalismo, pero que encajaba con el sentido de la Restauración como reacción contrarrevolucionaria contra el intento de apertura política realizada durante los años del Sexenio. ${ }^{12}$ Con esta actuación se les enviaba el mensaje de que del mismo modo que se habían endurecido las condiciones, era posible que estas empeoraran hasta el punto de que se restringiera más su libertad en caso de no comportarse adecuadamente.

En 8 de diciembre de 1880 había 102 relegados en Mahón, 117 en Chafarinas, 63 en Ceuta y siete en Melilla. Además de uno en Barcelona y 31 distribuidos por distintas parte de la geografía peninsular, vigilados por la autoridad y con la promesa explicita de no evadirse. Junto a ellos 35 mujeres y 22 niños. Los muchachos eran familiares excepto uno de doce años que era criado de dos presentados, y otro, de catorce, que estaba en la insurrección y se entregó. Las seis féminas se presentaron con sus familiares o maridos, ${ }^{13}$ lo que deja la incógnita de si estuvieron en la rebelión o se entregaron junto a ellos para no separarse, pero en todos los casos las autoridades las consideraban como acompañantes y no como potencialmente peligrosas. La presencia

\footnotetext{
${ }^{11}$ Michele Foucault, Vigilar y castigar. Nacimiento de la prisión, Siglo XIX, Buenos Aires, 2002 , p. 213.

${ }^{12}$ Eduardo González Calleja, La razón de la fuerza, p. 30.

13 "Deportados políticos de la isla de Cuba", s/f. AHN, Ultramar, Leg. 4940; "Antecedentes relativos a mujeres y niños que llegaron a la Península con los deportados cubanos". AHN, Ultramar, Leg. 4764, Exp. 58. Comisión de visita a los deportados de la isla de Cuba en las posesiones de África.
} 
de sus mujeres e hijos, un hecho novedoso en estos avatares, muestra las características de esta deportación, muy estricta, pero con el objetivo de neutralización de la revuelta. Se trató de evitar causar sufrimiento añadido al estrictamente necesario para mantenerles absolutamente controlados y vigilados y evitar fugas que derivasen en conspiraciones o entrada en el país de nuevos combatientes. Una vez verificado este aspecto se pretendió que su estancia fuera cómoda, tanto para ellos como para sus familias a las que se evitaba que quedaran desvalidas.

Además, había 37 condenados a presidio en Ceuta sometidos a las mismas condiciones que los presos comunes, esto es, portaban cadenas y participaban en la realización de obras públicas. Algunos cumplían condena en la Península donde gozarían de mejores condiciones. ${ }^{14}$ Los encarcelados habían sido condenados por los tribunales a cadena perpetua, reemplazando esta pena a la de diez años por delito de infidencia de la guerra anterior. Así se neutralizaba definitivamente a los combatientes sin recurrir a los fusilamientos, nada aptos para el nuevo tiempo político en Cuba ni para el intento de forzar la finalización del conflicto mediante el acoso y aislamiento de los insurrectos para forzar su presentación, lo que junto con el hambre y el pago a algunos jefes rebeldes logró desactivarlo. ${ }^{15}$ Los condenados a presidio en Ceuta eran todos campesinos excepto dos, lo que muestra que el independentismo ya se había expandido a todas las capas sociales e indica los desajustes sociales que tuvieron que soportar los campesinos del área oriental. Tras la finalización de la guerra, los campos de las provincias orientales estaban devastados y la ganadería se había reducido sobremanera. El hambre, la agitación revolucionaria y el sentimiento anticolonial propiciaron esta nueva insurrección. ${ }^{16}$

\footnotetext{
${ }^{14}$ Estadística de presos en Ceuta, 27 de noviembre de 1880. AHN, Ultramar, Leg. 4764, Exp. 58. Comisión de visita a los deportados de la isla de Cuba en las posesiones de África. A finales de este año, las deportaciones disminuyeron de forma muy importante de manera que las realizadas en 1881 y 1882 fueron testimoniales; AGMM, Documentación de Puerto rico, Sig. 5161.27; telegrama de Ministerio de la Guerra a Ministerio de Ultramar, 7 julio 1880. AHN, Ultramar, Leg. 4940, Exp. 1. Expediente general de deportados cubanos de la Guerra Chiquita.

${ }^{15}$ Alfredo López Serrano, El general Polavieja y su actividad política y militar, Tesis doctoral de la Universidad Complutense de Madrid, Centro de Publicaciones del Ministerio de Defensa, Madrid, 2001, tomo I, pp. 122-128; Luis Navarro García, Las guerra de España en Cuba, p. 126.

${ }^{16}$ Imilcy Balboa, La protesta rural en Cuba. Resistencia cotidiana, bandolerismo y revolución (1878-1902), CSIC, Madrid, 2003, pp. 64-70; un análisis sobre las consecuencias de la Guerra de los Diez Años, en Fe Iglesias, "El desarrollo capitalista de Cuba en los albores de la época imperialista", en María del Carmen Barcia, Gloria García y Eduardo Torres-Cuevas, Las luchas
} 
Dado que la guerra estuvo concentrada en el oriente, la mayoría de los deportados provenían de dicha región. ${ }^{17}$ La insurrección quedó arrinconada en el este de la isla y el número de los que procedentes de otros puntos acudieron a sumarse a los insurrectos fue muy limitado. La mayoría de los relegados eran trabajadores del campo o se dedicaban a cualquier otro oficio, siendo en la práctica casos puntuales aquellos que eran propietarios, tenían negocios o se dedicaban a trabajos que requerían estudios o proporcionaban ingresos elevados. En consonancia con lo expuesto, el porcentaje de los que ni siquiera sabían leer ni escribir ascendía al 62\%. En apariencia racial, la composición estuvo muy compensada, aunque con leve predominancia de blancos y negros. (Gráfico 6).

Gráfico 6. Apariencia racial de los deportados políticos en la Península y territorios adyacentes durante la Guerra Chiquita.

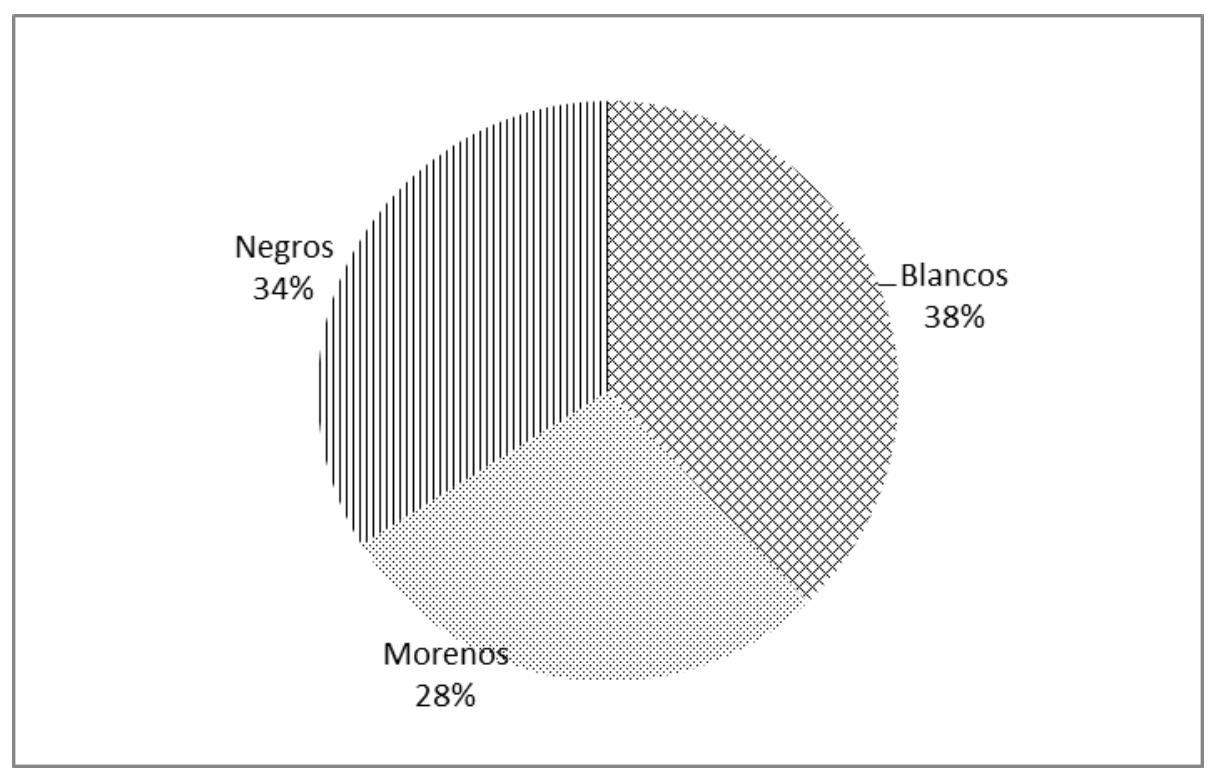

Fuente: Elaboración propia a partir de "Deportados políticos que procedentes de la isla de Cuba se encuentran en las posesiones de África y en la Península", s/f. AHN, Ultramar, Leg. 4940.

Un 53\% de ellos había participado en la insurrección y el resto fueron embarcados por medida gubernativa. Se pretendió sacar del país a muchos de los antiguos combatientes temiendo su reincorporación a la lucha. Junto a ellos, aquellos que ya se habían unido a la misma ya que fue concebida como un medio muy eficaz

por la independencia nacional y las transformaciones estructurales. 1868-1898, Editora Política, La Habana, 1996, pp. 159-164.

${ }^{17}$ Relaciones de deportados en Chafarinas (30 de octubre de 1880), Ceuta (25 de noviembre de 1880) y Melilla (30 de noviembre de 1880). AHN, Ultramar, 4764, Exp. 58. Comisión de visita a los deportados de la isla de Cuba en las posesiones de África. 
para dar salida a la gran cantidad de presentados, sirviendo como una forma de gestionar el fracaso de la insurrección. No solo como un modo de deshacerse de los capitulados, sino a la vez como incentivo a la entrega de los combatientes que agotados, perseguidos y hambrientos, se desmoralizaban al ver que el levantamiento no se generalizaba. Ante la perspectiva de una constante huida y de ser continuamente hostigados, la desmovilización y la salida de Cuba era una opción que podía ser considerada, máxime cuando desde las autoridades hubo engaños prometiendo a muchos que irían a la cercana Jamaica. ${ }^{18}$ Incluso en el caso de conocer su destino era mejor que terminar en prisión o muerto, y al menos tendrían su subsistencia asegurada y gozarían de libertad limitada. La vía administrativa facilitaría el retorno una vez finalizadas las hostilidades, especialmente teniendo en cuenta que así había sido en la guerra precedente.

La experiencia reciente también determinaba el comportamiento de las autoridades, por lo que se estipuló desde el primer momento un socorro de 1,50 pesetas, incrementándose en 50 céntimos la ayuda que se les otorgó en la Guerra Grande. Los auxilios se daban a petición de los interesados, pero se estipularon con prontitud, anticipándose a las carencias y a los problemas para subsistir y agilizando su concesión. Se trataba de evitarles sufrimientos añadidos tanto a ellos como a sus familias, a las que también se extendieron las ayudas. ${ }^{19}$ La medida fue concebida como una cuestión práctica: había que mantenerles y esto suponía un gasto que había que asumir, un precio ínfimo en comparación con los beneficios de mantenerlos alejados de la isla.

La concentración de cubanos en puntos determinados facilitó su control y vigilancia. Al mismo tiempo tuvo un efecto positivo para los mismos ya que el Gobierno estuvo más involucrado y garantizaba que dispusieran de unas condiciones mínimas, tratando de evitar que se repitiera el nefasto efecto propagandístico que supuso el San Francisco de Borja en 1869. Dentro de estos parámetros se escogió la opción más económica y eficaz, es decir, en vez de optar por aumentar los efectivos

\footnotetext{
${ }^{18}$ Oficio de comisionado de visita de los deportados a Ministerio de Ultramar, 31 de octubre de 1880. AHN, Ultramar, Leg. 4764, Exp. 58. Comisión de visita a los deportados de la isla de Cuba en las posesiones de África.

${ }^{19}$ Telegrama de Ministerio de Ultramar a gobernador de Cádiz, 13 de noviembre de 1879. Telegrama de Ministerio de Ultramar a gobernadores de provincias, 27 de diciembre de 1879; AHN, Ultramar, Leg. 4940, Exp. 1. Expediente general de deportados políticos de la isla de Cuba en la Guerra Chiquita; "Antecedentes relativos a mujeres y niños que llegaron a la Península con los deportados cubanos”. AHN, Ultramar, Leg. 4764, Exp. 58. Comisión de visita a los deportados de la isla de Cuba en las posesiones de África.
} 
policiales se decidió variar las condiciones de los relegados y que pasaran a ser más restrictivas. Esta elección aseguraba una mayor eficacia puesto que las propias características físicas de los lugares de residencia dificultaban las fugas.

Una vez conseguida su neutralización, las autoridades querían proporcionarles todas las "comodidades y auxilios que sean compatibles con el régimen de custodia y vigilancia al que se hallan sometidos". ${ }^{20}$ Su estancia transcurría con plena libertad de movimientos durante el día, en que podían pasear y ocuparse en distracciones licitas. Solo permanecían encerrados en sus pabellones de noche o cuando atracaba algún barco. La autoridad exigía que se les vigilara y que hubiera separación entre guardianes y cubanos, pero al mismo tiempo que se les dispensara un buen trato y desautorizaba los castigos físicos, avalando únicamente, en caso de faltas, la privación de salida de los barracones. $^{21}$

El archipiélago de las Chafarinas había sido ocupado en 1848, tras lo cual comenzaron en la isla de Isabel II los trabajos de edificación de varios aljibes, allanamiento de terrenos, edificaciones civiles y militares y del puerto. Las características de la misma, la única que estuvo habitada, de únicamente 2.000 metros de perímetro, ${ }^{22}$ la configuraban como una especie de prisión al aire libre. Un lugar muy indicado para tener libres y a la vez controlados a los opositores políticos. La vigilancia era sencilla y la posibilidad de continuar intrigando o estar en contacto con otros núcleos conspiradores y las fugas se dificultaba. Sus características la configuraron como el lugar preferido para ubicar a los represaliados. Chafarinas condensaba en una plaza el sentido "carcelario" que el Gobierno pretendía para los deportados y de ahí el ubicar allí el mayor número posible.

Las condiciones de vida no fueron idílicas, aunque otros la habitaban voluntariamente. La escasez de viviendas determinaba que apenas 17 residían en casas particulares y el resto en los barracones establecidos para ello. Tenían asegurada la subsistencia con la ayuda monetaria y la "ración de agua que a cada uno se le pasa, igual a la del soldado, y consistente en 2 litros 500 mililitros diaria y 16 litros al mes para

\footnotetext{
${ }^{20}$ Oficio de Ministerio de Ultramar a Ministerio de Hacienda, 7 de octubre de 1880. Oficio de comisión de visita de los deportados a Ministerio de Ultramar, 6 de diciembre de 1880. AHN, Ultramar, Leg. 4764, Exp. 58. Comisión de visita a los deportados de la isla de Cuba en las posesiones de África.

${ }^{21}$ Oficio de Ministerio de la Guerra a ministro de Ultramar, 9 de julio de 1880. AHN, Ultramar, Leg. 4940.

${ }^{22}$ Jacinto López Tirada, Islas Chafarinas. Un paseo por su historia, Consejería de Cultura de la Ciudad Autónoma de Melilla, Melilla, 2010, pp. 19 y 35-40.
} 
lavar, además de aceite para alumbrado, leña para guisar, habitación y cama". ${ }^{23}$ Garantizando las condiciones de vida y vigilando su salud para que no se produjeran epidemias, se desarticulaba la batalla propagandística a la que también contribuía la opacidad que el aislamiento garantizaba. Además, dado que muchos vivirían en la pobreza en Cuba, alimentarles adecuadamente tendría un efecto positivo puesto que de este modo no se alimentaba el rencor hacia la metrópoli. Con un buen trato, se pretendía que la imagen de España saliera reforzada, especialmente cuando lo que se esperaba a medio y largo plazo era su reincorporación al proyecto español.

Las continuas remisiones a Chafarinas provocaron la saturación del alojamiento disponible, lo que llevó a las autoridades a ordenar que se llevaran a cabo las obras pertinentes con objeto de ampliar el espacio y a sacar del lugar a los presidiarios españoles que no fueran necesarios para las obras con destino al presidio de Ceuta. ${ }^{24}$ En la ciudad africana se había creado un sistema de trabajos forzados para los presos peninsulares con condenas superiores a ocho años. Muchos de los cuales al final de sus condenas o habiéndose extinguido estas se quedaban a residir en la ciudad. ${ }^{25}$

Hasta el 15 de octubre de 1880 habían fallecido cinco relegados en Chafarinas. La aglomeración en un espacio tan reducido facilitaba la propagación de enfermedades. Las autoridades trataron de acotar su expansión, por haber 14 hospitalizados se decidió llevarles a unas habitaciones habilitadas en otra zona para proceder a la limpieza y desinfección de las suyas. ${ }^{26} \mathrm{Su}$ carácter de no condenados hizo que recayera sobre ellos una vigilancia especial en este sentido, que posteriormente se trasladaría a los presos con la creación en 1885 del Negociado de Higiene y Antropología, la Ley de Prisiones de 1888, el Anuario Penitenciario y Administrativo de 1889 y las reformas en las

${ }^{23}$ Estadística de deportados cubanos en Chafarinas en 30 de octubre de 1880. Oficio de Comisión de visita de los deportados a Ministerio de Ultramar, 31 de octubre de 1880. AHN, Ultramar, Leg. 4764, Exp. 58. Comisión de visita a los deportados de la isla de Cuba en las posesiones de África.

${ }^{24}$ AHN, Ultramar, Leg 4764, Exp. 59. "Sobre las obras que han de llevarse a cabo en Chafarinas para alojar a los deportados de la isla de Cuba".

${ }^{25}$ José Luis Gómez Barceló, "El siglo XIX", en Fernando Villada Pareces (ed.), Historia de Ceuta. De los Austrias al siglo XX, Instituto de Estudios Ceutíes, Ceuta, 2009, pp. 191-192.

${ }^{26}$ Oficio de comisión de visita de los deportados a Ministerio de Ultramar, 15 de octubre de 1880. AHN, Ultramar, Leg. 4764, Exp. 58. Comisión de visita a los deportados de la isla de Cuba en las posesiones de África; oficio de Ministerio de la Guerra a Ministerio de Ultramar, 7 de diciembre de 1881, AHN, Ultramar, Leg. 4940. Exp. 1. Expediente general de deportados políticos de la isla de Cuba en la Guerra Chiquita. 
cárceles en los primeros años del siglo $X X{ }^{27}$ El modo en que la práctica de la deportación influiría en la reforma penitenciaria que se estaba llevando a cabo en esos años pudo extenderse a la importancia de las Chafarinas, dada la gran cantidad de deportados y los pocos problemas que ocasionaron, en 1888 se decidió que los presidios menores de África fueron los puntos en los que se ubicara a los presidiarios más peligrosos de Ceuta y Melilla. ${ }^{28}$

En Melilla y Ceuta, los relegados también residían libremente en la ciudad, y debían retirarse a sus hogares a las diez de la noche. ${ }^{29}$ Ceuta ocupaba 18,5 kilómetros cuadrados y tenía una población de 9.694 personas en $1877 .{ }^{30}$ Por ser una plaza mayor y con una población más numerosa la sensación de libertad seria mayor y tendrían más posibilidades de ocio. Con la subsistencia asegurada no era necesario trabajar y los días se emplearían de manera inactiva. Esto dio lugar a que un grupo de diez se emborrachara frecuentemente y diera lugares a escándalos. Los excesos eran castigados con la reclusión en el Hacho. José Martínez estuvo detenido ocho días en dicha fortaleza por hallarse en estado de embriaguez y Martin Solenzal fue arrestado por haberse retrasado en la hora de ir a su casa. ${ }^{31}$ Encontrarse totalmente lejos de su hogar y sin nada que hacer, facilitaba que algunos cayeran en la bebida.

\subsection{Las Baleares y la Península}

El plan gubernamental de ubicar a los deportados principalmente en Chafarinas $\mathrm{y}$ en su defecto en el resto de plazas africanas se vio pronto superado por los acontecimientos. Su elevado número colapsó los puntos de destino, en agosto de 1880

\footnotetext{
${ }^{27}$ Ver Luis Gargallo Vaamonde, Desarrollo y destrucción del sistema liberal de prisiones en España. De la Restauración a la Guerra Civil, Tesis doctoral de la Universidad de Castilla-La Mancha, 2015, pp. 89-93. Sobre el higienismo ver Rafael Alcaide, "La introducción y el desarrollo del higienismo en España durante el siglo XIX", Scripta Nova. Revista Electrónica de Geografía y Ciencias Sociales, núm. 3, 1999, pp. 32-54.

${ }^{28}$ Fernando José Burillo Albacete, La cuestión penitenciaria, p. 147.

${ }^{29}$ Oficio de comisión de visita de los deportados a Ministerio de Ultramar, 25 de noviembre de 1880. AHN, Ultramar, Leg. 4764, Exp. 58. Comisión de visita a los deportados de la isla de Cuba en las posesiones de África.

${ }^{30}$ Manuel Gordillo Osuna, Geografía urbana de Ceuta, Artes Gráficas Clavileño, Madrid, 1972, pp. 44 y 331.

${ }^{31}$ AHN, Ultramar, Leg. 4762, Exp. 53. "Petición para 1levar a Chafarinas a deportados de mala conducta en Ceuta"; AHN, Ultramar, Leg. 4763, Exp. 66. Expediente del deportado político José Martínez Santos; AHN, Ultramar, Leg. 4764, Exp. 37. Expediente del deportado Martin Solenzal Lema.
} 
las Chafarinas estaban llenas y en Ceuta y Melilla no podía garantizarse una vigilancia adecuada. $^{32}$ A partir de ese momento se desviaron varias remisiones para Mahón. La condición insular de Menorca y las malas comunicaciones existentes en la época dificultaban la fuga y la configuraban como el punto más adecuado, de entre los disponibles, para las pretensiones del Gobierno. Las características de la Mola diferían de las de los otros puntos. Se trataba de una plaza militar fortificada que se había estado reforzando en los años precedentes en que se habían invertido ingentes cantidades de dinero y estaba acondicionada para una guarnición de unos 4.000 soldados. $^{33}$

El 21 de enero de 1881, se dispuso que 86 de ellos "que se hallan custodiados en la fortaleza de Mahón sean puestos en libertad, autorizándoles para fijar su residencia en dicha plaza o en otro punto cualquiera de la isla de Menorca", siempre que dieran palabra de honor de no fugarse. Los liberados se establecieron en Mahón y Villa Carlos. ${ }^{34}$ Esto deja abierta la posibilidad de interpretación de la palabra custodiados, lo que teniendo en cuenta lo que sucedía en otros lugares a nuestro parecer no significaría estar encerrados todo el día en sus celdas. Seguramente podrían deambular por la fortaleza o lugares acotados de esta y probablemente salir de manera muy limitada de la misma. Es posible que teniendo en cuenta a los antecedentes del Gobierno, el carácter "menos presidiario" de la ínsula se supliera con un mayor control de los confinados que iría disminuyendo a medida que su comportamiento fuera el correcto y que paralelamente se produciría un proceso progresivo de libertad que comenzaría con aquellos considerados menos peligrosos. De no hacerlo así estarían incumpliendo sus propias leyes, ya que no era posible retener a nadie bajo custodia sin condena judicial.

En este sentido, se plantea una incógnita respecto a la utilización de los castillos como lugar de residencia. En Cádiz, algunos residían en los penales percibiendo socorro antes de la reubicación, ${ }^{35}$ por lo que se entiende que estaban libres y residiendo en los penales, probablemente por falta de espacio en la ciudad o por resultarles más

\footnotetext{
${ }^{32}$ Oficios de Ministerio de la Guerra a Ministerio de Ultramar, 27 y 30 de agosto de 1880. AHN, Ultramar, Leg. 4940, Exp. 1. Expediente general de deportados políticos de la isla de Cuba en la Guerra Chiquita.

${ }^{33}$ Francisco Fornals, Fortaleza de Isabel II en la Mola de Puerto de Mahón, Museo Histórico Militar de Menorca, Mahón, 2000, pp. 22-33.

${ }^{34}$ Real orden de 21 de enero de 1881. AHN, Ultramar, Leg. 4940; oficio de subgobernador de Mahón a Ministerio de Ultramar, 19 de febrero de 1881. AHN, Ultramar, Leg. 4940, Exp. 1. Expediente general de deportados políticos de la isla de Cuba en la Guerra Chiquita.

35 Oficio de gobernador de Cádiz a Ministerio de Ultramar, 31 de marzo de 1880. AHN, Ultramar, Leg. 4940, Exp. 1. Expediente general de deportados políticos de la isla de Cuba en la Guerra Chiquita.
} 
económico, ya que así no debían hacer frente al pago del alquiler. Esto se produjo antes de la constricción en las condiciones, pero es posible que se extendiera con posterioridad a otros lugares una vez establecidos allí de manera definitiva. A pesar de que se trató de evitar su permanencia en la Península, la continuación de las remisiones provocó la ampliación de los lugares de destino. En octubre de 1880 había un número indeterminado de "residentes" en el Castillo de Figueras en calidad de deportados y percibiendo socorro. ${ }^{36}$ Esto significaría que su traslado fuera de un espacio ultramarino probablemente iría acompañado de unas condiciones más restrictivas.

Resulta digno de resaltar el conflicto sucedido entre los confinados y los naturales en Menorca, por cuanto no tenemos constancia de sucesos así con anterioridad. En el caso de los relegados a Fernando Poo en la Guerra de los Diez Años, al ser enviados a Mahón todos coinciden en el buen trato que se les dispensó. Ahora en cambio, los cubanos aseguraban en una instancia anónima que eran maltratados por la población y las autoridades de Mahón. Algo que las autoridades negaban, diciendo que había sido su conducta y los insultos a España los que habían generado conflictos que fueron controlados por la fuerza pública. ${ }^{37}$

El elevado número de bajas y la prolongación de la guerra crearían un gran resquemor de la sociedad respecto a los insurrectos. Esto supuso la reactivación de un nacionalismo español, que existía de manera latente y se difundía con la ayuda de ciertos historiadores y novelistas y que encontró en los sublevados en este periodo el equivalente a los franceses de principios de siglo. Si bien la oposición máxima entre España y Cuba se dio en la Guerra de Independencia, no pueden desdeñarse la importancia de las guerras anteriores como elemento que creo las condiciones necesarias para que esto se produjera, dada la exaltación que desde la historiografía americanista se hacía sobre el pasado colonial español y la necesidad de conservar los restos del antaño glorioso imperio. ${ }^{38}$ La distancia entre estos grupos se había

\footnotetext{
${ }^{36}$ Oficio de gobernador de Gerona a Ministerio de Ultramar, 14 de octubre de 1880. AHN, Ultramar, Leg. 4940, Exp. 1. Expediente general de deportados políticos de la isla de Cuba en la Guerra Chiquita.

${ }^{37}$ Instancia de los deportados a Ministerio de Ultramar. Oficio del subgobernador de Menorca a Ministerio de Ultramar, 14 de junio de 1882. AHN, Ultramar, Leg. 4940, Exp. 1. Expediente general de deportados políticos de la isla de Cuba en la Guerra Chiquita.

${ }^{38}$ Juan Sisinio Pérez Garzón, "El nacionalismo español, de las Cortes de Cádiz al 98”, en Los 98 ibéricos y el mar, Sociedad Estatal Lisboa 98, 1998, Madrid, Tomo III (El Estado y la política), pp. 228-232. Sobre el nacionalismo español en el XIX ver Antonio Morales Moya, Juan Pablo Fusi y Andrés de Blas Guerrero, (dirs.), Historia de la nación y del nacionalismo español, Galaxia Gutembert, 2013; Carlos Taibo, "Sobre el nacionalismo español” y Juan Sisinio Pérez
} 
incrementado y en ambos bandos, el nacionalismo actuaba como factor disgregador que configuraba al otro como enemigo dejando de lado el componente humano.

\subsection{Isla de Pinos}

Isla de Pinos también fue empleada como punto de remisión. En la guerra anterior había servido para ubicar a un perfil de individuo con menor status social y cuya participación en la insurrección, en general, estuvo menos probada. En esta guerra, la actuación sobre este perfil de sujeto se acentuó, en consonancia con la estructura económica de oriente que desde el fin de la Guerra de los Diez Años había acentuado su retraso. ${ }^{39}$ Así se decretó el pase a la misma de "todos los vagos de la isla", ${ }^{40}$ donde compartirían espacio con relegados políticos pertenecientes a las clases más populares. Dado que las causas materiales que explicaban la anterior guerra no se habían eliminado, desde las altas instancias gubernativas se trataría que la represión también alcanzase a los miembros de este grupo social de manera preventiva.

A mediados de 1880 habían sido detenidos unos cincuenta sujetos de la parte oriental de Cuba, casi todos negros o pardos. Después de un mes y medio presos, dos terceras partes fueron liberados y del resto quince pasaron a isla de Pinos y los demás a Puerto Rico. ${ }^{41}$ La mayoría de los represaliados continuaban su destino hacia Europa, pero algunos quedaban momentáneamente en Puerto Rico, mientras se arreglaba lo referente al embarque o esperaban para ser incorporados a otros envíos. También es posible que algunos quedaran allí definitivamente.

En los últimos meses de 1880, el eficaz servicio de espionaje montado por Polavieja desarticuló una conspiración promovida por la Liga Antillana y encabezada

Garzón, "De nacionalismo de Estado a esencia cultural", en Carlos Taibo (dir.), Nacionalismo español. Esencias, memorias e instituciones, Catarata, Madrid, 2007, pp. 11-48 y 49-73; Juan Sisinio Pérez Garzón, "Los mitos fundacionales y el tiempo de la unidad imaginada del nacionalismo español", Historia Social, núm. 40, 2001, pp. 7-28; que el nacionalismo español ya se expresaba con profusión antes de la crisis de 1898 da buena muestra lo sucedido en la crisis de las Carolinas de 1885, que superó con creces al patriotismo expresado en la guerra de Marruecos de 1859-1860, Elena Hernández Sandoica, Pensamiento burgués y problemas coloniales en la España de la Restauración, Tesis doctoral de la Universidad Complutense de Madrid, Madrid, 1982, pp. 616-617 y 643.

39 Antonio Santamaría y Alejandro García, Economía y colonia. La economía cubana y la relación con España, 1765-1902, CSIC, Madrid, 2004, p. 185.

${ }^{40}$ AHN, Ultramar, Leg. 4762, Exp. 54. "Deportados a la isla de Pinos en la Guerra Chiquita".

${ }^{41}$ Petición de indulto de Domingo Adell, ANC, Asuntos Políticos, Leg. 76, Sig. 29. "Relación de deportados políticos que piden regresar a la isla de Cuba, 1 noviembre de 1880". 
por Antonio Maceo. El complot contaba con apoyos en distintas localidades de oriente y entre ellos había algunos blancos. ${ }^{42}$ A pesar de su carácter interracial, fue aprovechado por las autoridades para resaltar el peligro negro como modo de atraerse a la población blanca. La mayoría de los detenidos fueron transportados a Fernando Poo en el Josefita, pero 66 capturados con posterioridad lo fueron a isla de Pinos en 14 de febrero de 1881. En 24 de marzo de 1881 embarcaron siete procedentes de Guantánamo y que estaban retenidos en Batabanó. Otros 27 hicieron lo propio el 3 de abril acusados de querer levantar la jurisdicción de Guantánamo. ${ }^{43}$ A excepción de dos de El Caney, el resto eran de la parte oriental.

El número teórico de los relegados políticos en isla de Pinos no fue muy elevado, 168 a 15 de noviembre de 1882, de los que 49 eran blancos, todos varones, y 119 de color, entre los cuales dos mujeres. Su distribución racial desmonta las falsedades gubernamental de presentar la guerra como una cuestión de los negros contra los blancos. En este caso se dio una inversión en la cuantía total respecto de la guerra anterior, cuando la mayoría lo fueron a esta posesión y la minoría a la Península. Un mayor alejamiento dificultaba que pasaran a Cuba y tomaran las armas. Con un Gobierno que comulgaba plenamente con los castigos contra el independentismo, la remisión a la metrópoli ofrecía la ventaja de la mayor lejanía y ocultaba en mayor grado la realidad de lo acontecido, facilitando la creencia de la versión oficial.

En realidad los deportados no fueron tan pocos, ya que el sistema de contabilización distinguía entre los remitidos por causas políticas y los delincuentes comunes y considerados "vagos". Gente de los bajos fondos y pobres, fueron llevados a la pequeña ínsula para neutralizar su hipotética incorporación a la rebelión a causa de su situación desesperada o por encontrar mayor cobertura a su modo de vida en el caso de los delincuentes habituales. Esta forma de desactivación y control a una población no sediciosa políticamente, pero si despreciada socialmente ya se dio en la guerra precedente pero ahora se les contabilizó aparte para enmascaras el alcance de la represión. El sistema consistía en sacarles de las poblaciones en las que residían habitualmente, llevarles a isla de Pinos por un tiempo determinado donde se les tenía controlados y vigilados, y tras un tiempo prudencial obtenían la baja y se les permitía el

\footnotetext{
${ }^{42}$ Alfredo López Serrano, El general Polavieja y su actividad política y militar, tomo I, pp. 128145; Antonio Pirala, Anales de la Guerra de Cuba, tomo III, pp. 876-877.

${ }^{43}$ AHN, Ultramar, Leg. 4762, Exp. 54. "Deportados a la isla de Pinos en la Guerra Chiquita"; AGMM. Gobiernos Militares, Sig. 3228.
} 
regreso. ${ }^{44}$ Tal y como sucedió en la Guerra de los Diez Años, isla de Pinos fue adquiriendo importancia como punto de confinamiento conforme más avanzaba la guerra, cuando se decidió ampliar la punición para que excediera de la disidencia puramente política. De nuevo, la dinamicidad imposibilita conocer el número exacto de los que pasaron por allí, pero serían varios cientos.

Aproximadamente la mitad de los que había estaban relacionados con la conspiración de Maceo recabaron allí, pero teniendo en cuenta el perfil social de los otros relegados es posible que en esta conspiración hubiera mucho de exageración y se hicieran unos castigos indiscriminados que incluyera a sujetos únicamente por su condición de marginado, en cuya consideración la raza era un factor importante. El tradicional temor hacia los pobres se incrementaría ya que en ciertos conflictos armados, incorporarse a la lucha como combatiente proporcionaba un modus vivendi a aquellos que carecían de él. Muchos de los combatientes en la guerra anterior provenían de este sector social y en el caso de inexistencia de una guerra, probablemente hubieran ido a parar al bandolerismo.

\subsection{Fernando Poo}

Según el gobernador general del territorio, "En 1880, Fernando Poo seguía siendo una colonia pobre, improductiva y costosa; la actividad comercial con la metrópoli era prácticamente inexistente; los cultivos agrícolas se desarrollaban con excesiva lentitud", lo que provocaría que no fuesen colonos a la misma durante mucho tiempo. ${ }^{45}$ Una nueva remisión, tras los numerosos fallecimientos acaecidos pocos años antes, indica la poca estima que las autoridades les tenían.

A pesar de que la situación de la posesión no había cambiado sustancialmente y habían fracasado todos los intentos de poblarla, el interés por la conquista de África se estaba desatando entre las potencias europeas. En España se tradujo en la creación de la sociedad africanista en 1877, impulsada por Joaquín Costa para influir en la colonización de África y en el Congreso Africanista de 1883. La exploración y conquista del continente no gozaba de amplio respaldo popular ni gubernamental, pero

\footnotetext{
${ }^{44}$ ANC, Asuntos Políticos, Leg. 77, Sig. 25. "Altas al protectorado del trabajo según lo dispuesto en el art. $6^{\circ}$ de la ley de 17 de octubre de 1879".

${ }^{45}$ Gonzalo Sanz Casas, Política colonial y organización del trabajo en la isla de Fernando Poo, 1880-1930, Tesis doctoral de la Universidad de Barcelona, Barcelona, 1983, p. 49.
} 
gracias a un activo grupo de propagandistas comenzó a despertar interés. ${ }^{46}$ El 26 de noviembre de 1880 se había promulgado un nuevo estatuto para la isla que aconsejaba realizar algunas reformas e introducir dos escuelas, una para los niños de cada sexo; una pequeña ampliación de la administración civil y la creación de un consejo de vecinos. ${ }^{47}$ Los africanistas trataban de influir en la política para que España no quedara al margen del reparto del continente. El Ejecutivo, aletargado e incapaz, no acometía con ímpetu la empresa, pero ante la ausencia de colonos la presencia de los cubanos era una buena opción ya que su fuerza de trabajo podía ser utilizada en beneficio del Estado.

La caracterización mayoritaria de los represaliados como combatientes o sospechosos incluía a sujetos de elevada condición social. Las personas influyentes eran temidas por tener una mayor formación, cultura y ascendencia sobre sus conciudadanos. En la Guerra Chiquita encontramos a gente con este perfil entre los primeros envíos a Cádiz. El vapor Correo Antonio López, que atracó el 26 de noviembre de 1879 llevaba a 53 individuos, todos blancos excepto uno de color, entre los que había algunos de consideración social. ${ }^{48}$ Todos fueron liberados, lo que no denota un trato de favor ya que era la política en los primeros momentos de la guerra. En este caso no fueron diferenciados del resto con la intención de ejemplificar, tal y como había ocurrido en la Guerra Grande, sino que se evitó que fueran destinados a Fernando Poo por el nefasto efecto propagandístico que tuvo en la guerra anterior para la causa española. Los libros de testimonios hablando sobre las terribles desgracias que les sucedieron, en algunos casos con evidentes exageraciones como el caso de Balmaseda, sirvieron al independentismo para "demostrar" el carácter despótico del Gobierno español y constituyeron un factor propagandístico muy importante para su causa.

El principal problema para España en el San Francisco de Borja no fue el lugar de destino, sino el perfil social de los relegados, gente importante y con recursos monetarios que tenían la cultura y los medios para contar sus vivencias. Con la medida, las autoridades españoles pretendieron manifestar que no se detendrían frente a nada en la represión, pero la intención de amedrentar se volvió en su contra. El Ejecutivo no fue

\footnotetext{
${ }^{46}$ Azucena Pedraz Marcos, Quimeras de África. La Sociedad española de Africanistas y Colonistas. El colonialismo español a finales del siglo XIX, Polifemo, Madrid, 2000, p. 330.

47 Dolores García Cantús, Fernando Poo. Una aventura colonial española en el África occidental, pp. 539-541.

${ }^{48}$ Telegramas de gobernador de Cádiz a Ministerio de Ultramar, 16 de noviembre y 1 y 2 de diciembre de 1879. AHN, Ultramar, Leg. 4940, Exp. 1. Expediente general de deportados políticos de la isla de Cuba en la Guerra Chiquita.
} 
inteligente, deportó a la isla africana por el efecto que produciría sin pensar en las consecuencias negativas que podía acarrear por la muerte de los cubanos. El trato en la Pinta fue inhumano, pero no fue exclusivamente su culpa. En cuanto a las defunciones en el San Antonio, no hubo especificaciones para que fueran mal tratados, y aunque tampoco las hubo en sentido contrario lo cierto es que muchos embarcaron enfermos. No hubo humanidad ni inhumanidad expresa por parte del Ejecutivo, para ellos era solo una medida de desembarazo y ejemplificación, aunque mal diseñada y planificada para sus intereses.

La intención inicial de dejar al margen al territorio africano finalmente se reconsideró, aunque con unos sujetos con un perfil social y racial totalmente opuesto al de sus predecesores. Los involucrados en la conspiración de la Liga Antillana cuyo posible fallecimiento no supondría un costo político elevado. Incluso, dado que el Gobierno pretendía hacer pasar esta intentona por una conspiración de negros contra los blancos, ${ }^{49}$ que se hablara de ellos y de su condición racial determinaba la asunción inconsciente de esta versión tergiversada. El racismo determinó el punto de destierro, pero no pueden excluirse otras causas, como el hecho de que los lugares acotados para ello en las inmediaciones de la Península estaban llenos. Entre ellos había 24 blancos, ${ }^{50}$ lo que demuestra la falsedad de la versión gubernamental. Los relegados a los puntos peninsulares e isla de Pinos también eran mayoritariamente pardos y morenos.

El odio "racial" hacia estos individuos, la especificidad del envío alejado de las rutas normales de vapores correo que llevaban al resto de deportados hacia Europa y la lejanía de Fernando Poo respecto de las autoridades metropolitanas configuraron una traslación con características propias donde el autoritarismo y el fanatismo emergieron con mayor facilidad. El viaje se hizo en un barco velero para ahorrar, lo que determinó que durante la remisión de los 267 hombres en la barca Josefita murieran 35, desembarcando únicamente 232. A su llegada el gobernador dio a cada uno de ellos

\footnotetext{
${ }^{49}$ La propaganda oficial influenció a los separatistas, que apartaron a Antonio Maceo del mando supremo del ejército cubano precisamente para neutralizar esos temores, lo que desilusionaría a muchos otros, Philip S. Foner, Antonio Maceo, The "bronze titan" of Cuba's Struggle for Independence, Monthly Review Press, 1977, pp. 96-97; otra biografía muy completa de Maceo en José Luciano Franco, Antonio Maceo, Apuntes para una historia de su vida, Editorial de Ciencias Sociales, La Habana, 1989, 3 tomos.

${ }^{50}$ Relación de presos en la fragata Almansa comprendidos en la conspiración que iba a estallar, AGA, África-Guinea, Caja 81/6942.
} 
2,75 pesetas por una sola vez y se comprometió a alimentarlos con carne salada y arroz, hasta que pudieran procurarse su propia subsistencia. ${ }^{51}$

Los trasladados arribaban a una colonia en estado de precariedad, aunque su destino teórico era Corisco y Annobon, orden que el gobernador no cumplió por carecer de barcos para ello, lo que teniendo en cuenta el total abandono de las mismas les salvaría la vida. En la posesión no había ningún lugar apropiado para ubicarles, por lo que fueron alojados en el edificio del cuartel, en estado de ruina y que tuvo que ser apuntalado y el suelo forrado con las cajas de tocino ya vacías. La tropa se limitaba a 40 hombres de la infantería de marina, por lo que ante el temor a un levantamiento y el revuelo que se había formado entre los isleños por su llegada, el gobernador prohibió el comercio de armas de fuego y hacer ruidos por la noche, reservándose la potestad de imponer penas gubernativas y otorgando a los miembros de la marina facultades de orden público. ${ }^{52}$ La venida de los relegados supuso elevar el temor de las autoridades.

Las posibilidades de encontrar ocupación eran muy escasas, aunque algunos lo consiguieron: Benito Caro trabajó como panadero y Pedro Mancebo como maestro albañil. Nueve deportados cubanos acompañaron al gobernador de Fernando Poo, José Montes de Oca, en una expedición sobre el Rio Muni que declaró el área bajo soberanía española. ${ }^{53}$ Dada la carencia de recursos cualquier ocupación era buena, incluso el ayudar al Estado contra el que teóricamente luchaban y que violaba reiteradamente sus derechos a expandir sus dominios sobre otros pueblos. La idea era que se proporcionaran el sustento ellos mismos.

"1. Que a los deportados que no hayan podido hallar colocación se les señalen terrenos en los sitios que se juzgue más conveniente y se les proporcionen los útiles más indispensables para su cultivo. 2. Que en los mismos terrenos que se demarque a dichos deportados construyan ahora para su albergue, con el fin de procurar su separación y evitar que puedan ponerse de acuerdo entre sí para producir alteraciones en el orden público u otra clase de asechanzas. 3. Los gastos que produzcan dichos deportados sean con cargo al presupuesto de la isla de Cuba, que es la que los ocasiona". ${ }^{54}$

\footnotetext{
${ }^{51}$ Oficio de gobernador de Fernando Poo a ministro de Ultramar, 8 de marzo de 1881. AGA, África-Guinea, Caja 81/6942.

${ }^{52}$ Oficio de gobernador de Fernando Poo a ministro de Ultramar, 28 de febrero de 1881. AGA, África-Guinea, Caja 81/6942.

${ }^{53}$ Oficio de gobernador de Fernando Poo a ministro de Ultramar, 4 de agosto de 1881. AGA, África-Guinea, Caja 81/6942; La Ilustración Española y Americana, 30 de junio de 1886.

54 "Sobre distribución de los deportados cubanos allí residentes, medios de su subsistencia y trabajos a que se les destina, así como de los gastos de útiles y herramientas que al efecto les son necesarias". AGA, África-Guinea, Caja 81/6942.
} 
Para esto se les proporcionaron cien machetes, cien hachas y cien azadas. En una política muy repetida cuando tras el simple desembarazo que las determinaba comenzaban las ansias colonizadoras. Así, el Estado se aprovechaba de su condición, pero al mismo tiempo servía para desfigurar su carácter de represaliados políticos. Convertirles en colonos contribuía a deshacer la cohesión que tenían como grupo, tratando de transformarlos en sujetos que lucharan de manera individual para progresar en esas tierras lejanas.

La mayoría vivía en la más absoluta indigencia, por lo que las remesas de carne salada y arroz se mantuvieron. El gobernador calificaba el resultado de "exiguo", produciendo un tabaco de poca calidad que los bubis se negaban a consumir argumentando que tenía poca fuerza. La mayoría abandonaron las tierras con el objeto de dedicarse a la cría de gallinas para poder comer. A pesar de que se les había prometido que podían traer a su familia por cuenta del Estado, ninguno lo había solicitado y la mayoría se encontraban en la más absoluta indigencia. ${ }^{55}$ Las enfermedades y la mala alimentación hacían fracasar los intentos, según el propio gobernador, era inútil todo lo que no pasara por el trabajo de los krumanes.

La escasez de recursos, la mala comunicación y el abandono hacían que fuera Montes de Oca quien tenía que solucionar el problema de los deportados. Los datos explicitaban el alto precio que se estaba pagando por el mantenimiento de esta intentona colonizadora, 62 más fallecieron desde su llegada hasta mayo de 1884. La penuria y las malas condiciones determinaran a algunos a fugarse. Hasta el 6 de noviembre de 1884 lo habían conseguido 16, lo que contrasta con los 31 en el caso del San Francisco de Borja. Casi el doble consiguió huir en la Guerra de los Diez Años, en apenas tres meses, que los que lo hicieron en cuatro años en la guerra Chiquita. Una cifra que en este último caso no puede considerarse excesiva teniendo en cuenta su número y las necesidades que padecían. Para hombres blancos y con cierto nivel de riqueza obtener ayuda era más sencillo, mientras que los segundos apenas podrían pagarse el billete en

\footnotetext{
55 "Resultado obtenido en la isla de Fernando Poo, en el cultivo por los deportados cubanos y solicitud de indulto de varios de estos". AGA, África-Guinea, Caja 81/6942; AGA, ÁfricaGuinea, Caja 81/6970. Exp. 14. "Sobre pago a los Sres. Zulueta y Cía. de Londres de los suministros de arroz y carne a los deportados cubanos allí residentes"; la casa se quejaba de los impagos, por lo que incluso se negó a continuar las remisiones sin cobrar al contado. AGA, África-Guinea, Caja 81/6971, Exp. 4. "Nota justificativa de las cantidades que deben reintegrarse por el presupuesto de la isla de Cuba por gastos causados en esta colonia por los deportados cubanos". En 7 de julio la subasta para llevar los víveres quedó desierta, nadie pudo hacer frente a las barreres de entrada.
} 
los vapores ingleses, por lo que el auxilio sería mucho más complicado y tuvieron que recibirlo por compasión o introduciéndose escondidamente en los mismos. ${ }^{56}$ La carencia de recursos hacia la salida mucho más complicada y no por falta de voluntad, puesto que la mayoría intentaron repetidamente conseguir el indulto.

\subsection{El regreso desde la Península e islas y territorios adyacentes}

El regreso anticipado fue excepcional y tuvo que ver con casos individuales. ${ }^{57}$ En el retorno se trató de retardar al máximo su reincorporación a la sociedad cubana. Esto se observa en el tiempo transcurrido entre el fin de la guerra y el comienzo de la repatriación y se explica por el despotismo de las autoridades y la manifestación del propio cambio en las circunstancias políticas. El independentismo se había expandido hasta el punto de desafiar a la metrópoli mediante una guerra abierta que había durado trece años prácticamente ininterrumpidos. El resultado fue el refuerzo del mando militar sobre el terreno. La época en que las autoridades peninsulares toleraban a disgusto las deportaciones, e incluso a veces regañaban por ello a los capitanes generales, había pasado dando lugar a una colaboración entre ambas, aunque en la práctica existió una preponderancia del Capitán general que dotado del mando sobre el terreno decidía las políticas a efectuarse. En abril de 1882, el Capitán general, Luis Prendergast, aun se oponía a su vuelta argumentando que tenían una instrucción regular, suficiente para

\footnotetext{
${ }^{56}$ Lista de cubanos fallecidos desde 1881 hasta 31 de mayo de 1884. Deportados llegados a Fernando Poo en la barca Josefita, según relación que remite el gobernador de aquella colonia, en 6 de noviembre de 1884. AGA, África-Guinea, Caja 81/6942; Leonardo Mesa y José Burgos se fugaron en un vapor cuyo nombre no conocemos a Liverpool a finales de 1882, tras numerosas instancias que les fueron denegadas. Declaraban no haber sido insurrectos y en cambio haber servido durante doce años como voluntarios en el escuadrón de Santiago de Cuba. Oficio de Ministerio de Estado a Ministerio de Ultramar, 14 de noviembre de 1882; Marcos Medrano y Juan Bandera en el vapor ingles Loanda, uno de los que traía suministros a la isla. Las autoridades acusaban al capitán del barco de encubrirlos. Oficio de gobernador de Fernando Poo a Ministerio de Ultramar, 10 de junio de 1883; Justo Specht e Hipólito Flandrin en un vapor inglés, en 1 de septiembre de 1885. AGA, África-Guinea, Caja 81/6942; Néstor Mirabre, Fernando González e Hipólito Ferrándiz tuvieron menos suerte, ya que tras haberse introducido en el vapor ingles Kinsembo, el barco regresó a los tres días para entregarlos a las autoridades. AGA, África-Guinea, Caja 81/7060, Exp. 21. Fuga de tres deportados de Fernando Poo.

${ }^{57}$ AHN, Ultramar, Leg. 4763, Exp. 62. Expediente de deportación de Joaquín Milanés. Se le permitió regresar porque se ofreció a luchar por España.
} 
tener ascendencia sobre el pueblo, fomentaban el odio a España y trabajarían para una nueva guerra, siendo como eran en su mayoría gente acostumbrada a las privaciones. ${ }^{58}$

En cuanto al nivel de instrucción, vemos que el 38\% sabía leer y escribir. En 1899, en la provincia de Santiago de Cuba, solo un 26,8\% de la población sabía leer, ${ }^{59}$ por lo que ciertamente el nivel de instrucción era superior a la media aunque tampoco demasiado elevado. En realidad, Prendergast pretendía ralentizar el proceso con argumentaciones tergiversadas por el inconveniente que le representaban. El nivel de instrucción muestra cómo el independentismo se había expandido entre las capas bajas de la sociedad, que incluso pudieron "aprovecharse" de la guerra para dar expresión a su desesperación. El nivel de alfabetización cuestiona que fueran únicamente los necesitados los adheridos a la insurrección, correspondiéndose los alzados como los de mayor cultura dentro del sector más popular. El miedo a que tuvieran prestigio y ascendencia entre ciertas personas, lo era en cierto modo, a que la difícil situación económica incitara a algunos a lanzarse a la insurrección por la influencia por los mejor preparados de entre sus círculos de relaciones afectivas. La agrupación de individuos con un perfil similar facilitaba la aparición de partidas dispersas, aunque constaran de pocos hombres. Especialmente teniendo en cuenta la nefasta situación económica en la que se encontraba la posesión por el impacto de la guerra, agravada por la gran presión fiscal impuesta desde España, ${ }^{60}$ A esto habría que añadir la fuerte caída en los precios del azúcar en 1883 y 1884 que prolongaban esta situación.

Aun así, el Capitán general no gozaba de autonomía total y en un contexto de fin de la guerra su bloqueo no podía continuar indefinidamente. Los deportados fueron divididos en tres grupos: el primero era el que su regreso no constituía inconveniente; el segundo, el más importante numéricamente, lo conformaban aquellos que serían trasladados a la Península donde podrían residir libremente con la vigilancia de la autoridad y con prohibición expresa de retornar a la isla de Cuba y Puerto Rico; y el tercero estaba constituido por los que debían permanecer en los lugares de

\footnotetext{
${ }^{58}$ Oficio reservado de Capitán general a ministro de Ultramar, 24 de abril de 1882, AHN, Ultramar, Leg. 4940, Exp. 1. Expediente general de deportados políticos de la isla de Cuba en la Guerra Chiquita.

${ }^{59}$ Informe sobre el censo de Cuba, 1899 (Teniente coronel J. P. Sanger, dir.), Imprenta del Gobierno, Washington, 1900, p. 157.

${ }^{60}$ Oscar Zanetti, "En camino al 98. Cánovas y el problema económico de Cuba (1878-1881)", Revista de Indias, vol. 58, núm. 212, 1998, pp. 198 y ss.
} 
confinamiento. ${ }^{61}$ El proceso se estructuró en torno a los habituales parámetros de orden, priorizando el de aquellos cuya aprehensión se sustentaba sobre unas bases más endebles por ser su grado de implicación menor o por no estar suficientemente probado. La ralentización debe interpretarse como un intento de conseguir un proceso gradual y con una mayor sistematización, en el que la ansiada vuelta a casa se conseguía por etapas, dejando entrever que la autoridad del Estado estaba siempre presente.

Mediante real orden de 7 de junio 120 sujetos fueron autorizados a repatriarse. De ellos, 33 estaba en Chafarinas, 31 en Ceuta, 32 en Mahón, uno en Melilla, Barcelona y Rio-Tinto respectivamente, nueve en Cádiz, nueve en Madrid y tres en Sevilla. Todos fueron llevados a Cádiz desde donde se produjeron los embarques en los meses de junio, julio y agosto, junto a sus mujeres y sus hijos. Mientras se aprobaban las salidas, se iban llevando a la Península a aquellos que en un primer momento debieron permanecer en sus lugares de confinamiento. Mediante real orden de 8 de junio fueron autorizados a residir en la Península, cuatro desde Melilla, 28 desde Chafarinas, 52 desde Menorca y 38 desde Ceuta. A mediados de julio se hicieron los desplazamientos. ${ }^{62}$ Una vez en el continente podían elegir el punto en el que residir.

Después de las primeras salidas transitorias debían ir zarpando el resto en grupos reducidos. La residencia en la metrópoli debe ser entendida como un estadio medio entre la relegación y la libertad, que teóricamente no debería prolongarse demasiado en el tiempo, pero que en la práctica transcurría con una gran lentitud. Durante todo 1883 volvieron a Cuba 118 y todavía quedaban 180 en la Península y 274 en las ínsulas y territorios adyacentes. El Capitán general insistía en no apresurar el proceso y en enero de 1886 todavía había unos 400 fuera de la Antilla mayor y 146 en isla de Pinos. ${ }^{63}$ Es indiscutible que el regreso se interrumpió hasta el punto de que cinco años después de la finalización de la guerra quedaba un número muy elevado de ellos.

${ }^{61}$ Relaciones de estos tres grupos a 25 de abril de 1883. AHN, Ultramar, Leg. 4940; esta clasificación difería de la pretendida por Polavieja, cuya intención fue hacer una con los que podían volver, otra de los que podrían volver al cabo de unos años y el tercer grupo formado por aquellos que no debían regresar nunca. Camilo García de Polavieja, Relación documentada de mi política en Cuba; lo que vi, lo que hice, lo que anuncie, Imprenta de Emilio Minuesa, Madrid, 1898, pp. 53-54.

62 "Relación de deportados políticos de la isla de Cuba, a quienes por reales órdenes de esta fecha se autoriza para regresar a dicha isla". Relaciones de los embarcados en el Méndez Núñez (30 de junio), Coruña (10 de julio), Habana, (30 de agosto). Seis niños habían nacido en Chafarinas. Relaciones de los que podían pasar a la Península desde Melilla y Chafarinas, Menorca y Ceuta, fechas 10, 17 y 18 de julio de 1883. AHN, Ultramar, Leg. 4940.

${ }^{63}$ Oficios de Capitán general de Cuba a Ministerio de Ultramar, 2 de enero de 1884 y 5 de enero de 1886. AHN, Ultramar, Leg. 4940. 
Llegó un momento en que esta situación era insostenible y no se les podía retener por más tiempo. El arribo al poder de Práxedes Mateo Sagasta con un programa reformista y aperturista para la colonia, ${ }^{64}$ hacia recomendable pruebas de buena voluntad. La prolongación de su permanencia suponía un daño añadido para ellos y sus familias. La dureza no podía determinar todas las actuaciones del Ejecutivo cuando se pretendía conseguir apoyo social de la sociedad criolla. Así, apenas un mes después de la nueva presidencia de Sagasta, el Gobierno decidió "no sostener la situación ilegal de los deportados de esa isla" y acelerar el retorno que sería pagado por el Estado y en base a expedientes individuales, en los que se reservaba al Capitán general la potestad de paralizar los embarques mediante causa justificada. ${ }^{65}$

Los liberales, que se manejaban con mayor incomodidad entre la violación reiterada de derechos que los conservadores, decidieron acabar con una situación anómala que se prolongaba excesivamente. En un contexto de alzamientos, que fueran neutralizados los que se presentaron o incluso los que sin haberse sublevado lo hubieran hecho en épocas precedentes, podía ser tolerable. Pero que después de cinco años de la finalización de la guerra la situación de retención ilegal continuara, empezaba a ser inadmisible. La vuelta de los sujetos muy implicados con la insurrección podría resultar contraproducente, pero llegó un momento en que todavía lo era más la prolongación de la situación en la que se encontraban.

A partir de ese momento se reactivó el traslado de los que quedaban en los territorios adyacentes hacia la metrópoli, con el objeto de remitirles a Cuba. Los lugares destinados para zarpar fueron Santander, La Coruña y principalmente Cádiz, de donde salieron 116 entre el 1 de marzo y el 3 de mayo. ${ }^{66}$ Según el real decreto de indulto de 2 de enero de 1886, el regreso debía producirse con celeridad ya que aquellos que en dos meses no lo hubieran solicitado cesarían en el percibo de la ayuda que recibían. ${ }^{67} \mathrm{El}$ deseo de terminar con esta situación ilegal determinó que no se les obligaba a repatriarse, pero en caso de quedarse lo harían teniendo que procurarse su sostenimiento

\footnotetext{
${ }^{64}$ José Cepeda Adán, Sagasta. El político de las horas difíciles, Fundación Universitaria Española, Madrid, 1995, p. 131.

${ }^{65}$ Telegrama de ministro de Ultramar a Capitán general de Cuba, 23 de diciembre de 1885. Oficio de Ministerio de Ultramar a los gobernadores de Cádiz, Santander y La Coruña, 22 de febrero de 1886. Oficios de gobernador de Cádiz a Ministerio de Ultramar, 3 y 11 de marzo, 1 y 12 de abril y 3 de mayo de 1886. AHN, Ultramar, Leg. 4940. Exp. 1. Expediente general de deportados políticos de la isla de Cuba en la Guerra Chiquita.

${ }^{66}$ Relaciones de deportados regresados en los distintos envíos, AHN, Ultramar, Leg. 4940.

${ }^{67}$ Real decreto de 2 de enero de 1886. En Gaceta de Madrid, 9 de enero de 1886.
} 
y pasando a residir voluntariamente en el país. Para aquellos que vivían en la pobreza, la deportación había supuesto una modesta ayuda que permitía su subsistencia.

El proceso se reprodujo en isla de Pinos. Entre 1886 embarcaron la mayoría de los 134 relegados allí. Al año siguiente hicieron lo propio siete, y en 1888 los cinco restantes. ${ }^{68}$ El hecho de que se prolongara durante tres años y que unos pocos vinieran tan tarde estuvo motivado porque no hicieron sus solicitudes antes, probablemente lo pedirían después de perder su modo de subsistencia. Pero aun así resulta sintomático del estado del territorio que ni uno solo de ellos decidiera instalarse. La certeza en el retorno de la totalidad de los remitidos a la ínsula muestra que el indulto fue concebido para englobar a todos. Al margen de alguna posible excepción individual entre los remitidos a la Península y lugares adyacentes, la permanencia fue exclusivamente voluntaria.

\subsection{El retorno desde Fernando Poo}

Fernando Poo constituía un caso especial por el perfil de los trasladados, por la lejanía de la metrópoli y por ser un país apenas colonizado. De ahí el gran empeño que se puso en que se procurasen su manutención para estimular el asentamiento e incentivar el progreso económico de la posesión. Como en el resto de lugares, las autorizaciones para retornar dependían de la voluntad del Capitán general, por lo que fueron puntuales: a Benito Caro se le permitió en 25 de diciembre de 1882 y a Benigno López Osorio, en 4 de febrero de 1883. Isidro Coba zarpó para Santiago de Cuba el 15 de septiembre de $1833 .{ }^{69}$ La utilidad que aportaban al Estado determinó que su vuelta fuera incluso más lenta que el del resto.

En 17 de junio de 1886 llegó a Las Palmas el vapor ingles Benguela con 95 deportados en Fernando Poo y el 13 de julio embarcaron en el Ciudad de Cádiz para La Habana. ${ }^{70}$ Los pocos que permanecieron enfermos saldrían con posterioridad sino

\footnotetext{
${ }^{68}$ AHN, Ultramar, Leg. 4805, Exp. 1. Solicitudes de regreso de deportados en Pinos; AHN, Ultramar, Leg. 4804, Exp. 37. "Elías Navarro y seis más, deportados en isla de Pinos, solicitan permiso para regresar a sus domicilios".

${ }^{69}$ Oficio de Capitán general de Cuba a Ministerio de Ultramar, 25 de diciembre de 1882. Oficio de Gobierno general de la isla de cuba a Ministerio de Ultramar, 4 de febrero 1883. Oficio de Gobierno de Fernando Poo a Ministerio de Ultramar, 13 de julio de 1883. AGA, África-Guinea, Caja 81/6942.

${ }^{70}$ La Unión, 19 de junio de 1886; El Correo Militar, 31 de julio de 1886; únicamente cinco pudieron hacer frente al pago del pasaje, el resto retornaron por cuenta del Estado. AGA, África-Guinea, Caja 81/7077, Exp. 16. Expediente de los gastos ocasionados por los pasajes de los deportados de Cuba en Fernando Poo.
} 
fallecieron en la misma. Contrariamente a lo que sucedió con los relegados en la Península y territorios adyacentes, el regreso se retrasó hasta mediados de 1886. La lejanía lo dificultaba pero podía haberse previsto con antelación. Lo gradual del proceso supone un intento de compaginar la legalidad con la utilidad. Retardarlo una vez impuesto facilitaba tratar de fomentar su asentamiento. Una población reducida podía ser absorbida con mucha mayor facilidad.

Al promulgarse el indulto se sucedieron las instancias con el objeto de obtenerlo. ${ }^{71}$ Las ansias por salir de la mayoría contrastan con la prácticamente nula acomodación que en términos generales se había conseguido. Los que se establecieron lo hicieron en unas condiciones muy ventajosas, Miguel Duverger lo solicitó ya en mayo 1885 , pero pidiendo que trajeran a la misma a su mujer y sus dos hijos y recursos para mantener a tres o cuatro krumanes con el objeto de poner en explotación las tierras que se les daban en propiedad, comprometiéndose a devolver el dinero cuando la finca empezara a producir. El Estado accedió a ambas peticiones con la pretensión de que sirviera de ejemplo a los demás. Posteriormente, otros 23 expresaron su deseo de permanecer si se les extendían las condiciones otorgadas a Duverger, petición que les fue concedida. ${ }^{72}$

Algunas de estas plantaciones prosperarían y saldrían adelante, lo que de algún modo reactivó los planes colonizadores sobre el territorio, ya que a finales de las décadas de 1880 y 1890 se produjo la llegada de varios contingentes. ${ }^{73}$ El interés del Estado en fomentar la población les llevó a tener un trato correcto con los deportados, con el objetivo de neutralizar las enfermedades y las defunciones provocadas por el clima tropical para que decidieran establecerse. Pagar el traslado de su familia y además el capital necesario para retribuir a los trabajadores eran condiciones muy ventajosas. Algunas de estas plantaciones prosperarían y saldrían adelante, lo que incentivó los planes de explotación de la isla y la emigración libre.

Teniendo en cuenta como habían sido embarcados, los fallecimientos causados por el clima, las carencias que soportaron y las condiciones en las que residían, el hecho

${ }^{71}$ AGA, África-Guinea, Caja 81/7068, Exp. 12. Instancias de 123 deportados cubanos en Fernando Poo, manifestándose que se acogen al real decreto de 2 de enero de 1886.

${ }^{72}$ AGA, África-Guinea, Caja 81/7060, Exp. 23. "Sobre conveniencia de transportar por cuenta del Gobierno a la colonia de Fernando Poo a la familia de deportado cubano Miguel Duverger; oficio de Ministerio de Ultramar, a gobernador general de Fernando Poo, 30 de julio de 1886. AGA, África-Guinea, Caja 81/6942.

${ }^{73}$ Mariano L. De Castro Antolín, La población de Santa Isabel en la segunda mitad del siglo XIX, AEA, Madrid, 1996, pp. 53-57. 
de decidir quedarse indica cual sería su situación en su país. Además pone en duda su verdadero compromiso revolucionario, lo que parece indicar que una vez más las autoridades cubanas llevaron a cabo una represión amplia que excedió de los represaliados políticos.

En cualquier caso, si de los errores se aprende, el Gobierno español fue buena muestra de ello en este aspecto. Por una vez lo pasado con anterioridad sirvió de ejemplo para plantear unas modificaciones en la práctica de acuerdo a sus intereses. El caso de los del San Francisco de Borja resultó un fracaso estrepitoso. En la Guerra Chiquita se llevó a unos ciudadanos vulnerando todos sus derechos con el objetivo de aprovecharse de su fuerza de trabajo. Pero el cambio en el perfil social de los relegados tuvo como consecuencia que ni uno solo de ellos dejara testimonios de sus desventuras.

\section{LA GUERRA DE INDEPENDENCIA}

\subsection{Los inicios de la guerra}

Después de la finalización de la Guerra Chiquita, Cuba entró en una nueva dinámica. La última insurrección armada había mostrado la dificultad de derrotar a la metrópoli. Por su parte, también desde esta se había reflexionado y se pretendió emplear una política reformista en aras de atraerse de nuevo el apoyo de los criollos. Para esto se otorgó a la colonia la facultad de enviar representantes a Cortes, así como diversas disposiciones relativas a su organización política y administrativa, mediante las cuales se fijaron las funciones del gobernador general. Se crearon seis diputaciones provinciales y se reguló la administración local. Las reformas, aunque fueron muy limitadas, constituyeron una indudable mejora respecto a la situación anterior. ${ }^{74}$

La dificultad del Estado para controlar las elecciones y la diferente estructura política, económica y social de la posesión, dio como resultado la configuración de unos partidos diferenciados. La Unión Constitucional fue el gran partido de la alta burguesía, empleados públicos españoles y sectores populares de procedencia peninsular, y el Partido Liberal Autonomista se configuró como un partido pragmático, reformista y que pretendía la consecución paulatina de pequeñas cuotas de autogobierno. Una agrupación

\footnotetext{
${ }^{74}$ Inés Roldán de Montaud, La Restauración en Cuba, pp. 121-125.
} 
que encauzaba dentro del sistema a buena parte del "nacionalismo moderado", ${ }^{75}$ y que sociológicamente, representaba a las clases medias constituyéndose principalmente por "abogados notables, médicos, profesores, hacendados medios, salvo alguna excepción". 76

La configuración de una agrupación autonomista fuerte y con posibilidades reales de ejercer reformas graduales se topaba con la realidad. Desde Madrid se tenía miedo a ceder demasiado poder a una colonia que en muchos aspectos la desbordaba. Las relaciones económicas entre la colonia y la Península eran ínfimas en comparación con las que la isla tenía con Estados Unidos. La política española estuvo nuevamente basada en sus propios intereses, esto es, el mantenimiento de Cuba como posesión y asegurarse los beneficios económicos que esta le acarreaba. Una administración destinada a compensar los perjuicios que a España le causaban las cesiones comerciales a los norteamericanos con el incremento de impuestos y la ausencia de reformas que beneficiaran los intereses económicos cubanos. ${ }^{77}$

Para el mantenimiento de la predominancia de los intereses de la metrópoli se impuso un sistema electoral que beneficiaba a la Unión Constitucional, con el que se aseguraron su supremacía en el panorama político interno. El cambio de la ley electoral fue una petición de los autonomistas, especialmente durante el periodo de 1885-1890 en que Sagasta ocupó la presidencia del Gobierno. La no aprobación de la medida provocó la abstención de estos en las elecciones de 1891. Volvieron a participar en las elecciones de 1894 a causa de haberse producido algunos cambios electorales introducidos por Maura, que ampliaron el censo electoral dejándolo en un 3,09\%. ${ }^{78}$

La exclusión política de la mayor parte de la sociedad y los escasos avances del autonomismo se producían en un contexto en el que ya se había desarrollado el sentimiento de pertenencia a una nación. En el imaginario colectivo, por oposición a lo

${ }^{75}$ Luis Miguel García Mora, "La fuerza de la palabra. El autonomismo en Cuba en el último tercio del siglo XIX", Revista de Indias, vol. 61, núm. 223, 2001, pp. 724-726 y 742.

${ }^{76}$ Marta Bizcarrondo, "El autonomismo Cubano 1878-1898. Las ideas y los hechos", Historia Contemporánea, núm. 19, 1999, p. 71.

${ }_{77}$ Oscar Zanetti, Comercio y poder. Relaciones cubano-hispano-norteamericanas en torno a 1898, Casa de las Américas, 1998, pp. 157-208; el estudio de la progresiva penetración de Estados Unidos en el mercado cubano en José Antonio Piqueras, Cuba, emporio y colonia. La disputa de un mercado interferido (1878-1895), Fondo de Cultura Económica de España, Madrid, 2003; un análisis económico del periodo en Antonio Santamaría y Consuelo Naranjo (eds.), Más allá del azúcar. Política, diversificación y prácticas económicas en Cuba, 18781930, Doce Calles, Aranjuez, 2009.

${ }^{78}$ Inés Roldán de Montaud, "Política y elecciones en Cuba durante la Restauración", Revista de Estudios Políticos, núm. 104, 1999, pp. 245-287. 
que representaba España, atraso y autoritarismo, Cuba significaba progreso, justicia social y democracia. ${ }^{79}$ El proceso de consolidación de la conciencia nacional pudo ser soliviantado temporalmente por el autonomismo. Sin embargo, el dominio electoral de los ultraconservadores y los escasísimos avances impedían la consolidación de un proyecto político con posibilidades de triunfo. La feroz oposición de conservadores y el temor de los liberales de Sagasta a reformas de calado, estrechaban cada vez más el margen de acción de los autonomistas. El alto número de excluidos de la participación política y exiliados hacia previsible que se reorganizara una nueva insurrección. En 10 de abril de 1892 se creó en Key West el Partido Revolucionario Cubano, en lo que suponía la plasmación de un proyecto político moderno y libre de prejuicios raciales con el fin de preparar la guerra que les liberase del domino español. ${ }^{80}$

El Partido Revolucionario organizó la guerra, que empezó en 24 de febrero de 1895 con el levantamiento simultáneo en 35 poblaciones de oriente. Las autoridades lograron amputar la insurrección en el occidente, por lo que en un principio la guerra volvía a quedar circunscrita al oriente. Con el inicio de la guerra se nombró Capitán general a Arsenio Martínez Campos, por el prestigio que tenía tras la finalización de la Guerra Grande y la consecución del tratado de paz con el sultán marroquí. Martínez Campos llegó a la isla el 16 de abril de 1895, pero las deportaciones empezaron incluso antes. El 25 de marzo arribaron dos hombres a Cádiz acusados de tener ideas separatistas. El 2 de abril, ambos y un tercero entraban en Madrid. ${ }^{81}$ La decisión fue improvisada y de carácter puntual, basada en su utilidad para deshacerse de unos individuos molestos y sobre los que no había pruebas. Con Martínez Campos, la represión transcurría principalmente por otros parámetros: los insurrectos cogidos con las armas en la mano eran juzgados sumariamente por Consejo de Guerra y fusilados,

${ }^{79}$ Louis A. Pérez, The Structure of Cuban History: Meanings and Purpose of the Past, University of North Carolina Press, Chapel Hill, 2013, pp. 32-62.

${ }^{80}$ Sobre la creación el Partido Revolucionario Cubano, ver Diana Abad, De la Guerra Grande al Partido Revolucionario Cubano, Editorial de Ciencias Sociales, La Habana, 2005, pp. 194209; sobre Martí y sus ideas véase, Paul Estrade, José Martí. Los fundamentos de la democracia en Latinoamérica, Doce Calles, Aranjuez, 2002; el programa del PRC en José Martí, El Partido revolucionario Cubano, Universidad de Oviedo, Oviedo, 1998; sobre el transcurso de la guerra Antonio Elorza y Elena Hernández Sandoica, La Guerra de Cuba (1895-1898), Alianza, Madrid, 1998 y Francisco Pérez Guzmán, "La Revolución del 95. De los alzamientos a la Campaña de Invasión" y "La Revolución del 95. Desde la conclusión de la Camapa de Invasión hasta el fin de la dominación española", en María del Carmen Barcia, Gloria García y Eduardo Torres-Cuevas, Las luchas por la independencia nacional y las transformaciones estructurales. 1868-1898, pp. 430-546.

${ }^{81}$ La Correspondencia de España, 25 y 27 de marzo de 1895; La Época, 3 de abril de 1895. 
los conspiradores serían llevados a los presidios de Ceuta u otros de África, a los entregados se les dejaría libres y podrían salir hacia el extranjero. ${ }^{82}$

Esta organización dejaba a la deportación con un carácter preventivo y un papel en teoría residual. En abril de 1895 una comisión presidida por el ministro de Ultramar había decidido castigar la "propaganda separatista" con la relegación. ${ }^{83}$ Esta definición podía tener una interpretación amplia, pero lo cierto es que las remisiones a la Península en los vapores correo junto a los presos abarcaron por el momento a unos pocos sujetos de carácter culto y urbano: periodistas, comerciantes, propietarios y abogados. A finales de año había únicamente 14 en Ceuta y algunos más que se encontraban en otros puntos. $^{84}$

Entre los represaliados encontramos a algunos autonomistas, ${ }^{85}$ a los que no se perdonó que no apoyaran incondicionalmente a España. Entre ellos muchos que se lanzaron a combatir con los independentistas, si bien el partido hizo un llamamiento a confiar en las reformas, incluso posponiendo la petición de la autonomía. ${ }^{86} \mathrm{El}$ bloqueo a su proyecto y la constatación de la imposibilidad de materialización del mismo dentro de España hacia más que probable su incorporación al independentismo. La poca importancia de la relegación no tiene que ver con una política de tibieza, sino que quedó en un segundo plano destinada para casos excepcionales ante la priorización de las prisiones. Su perfil era el de gente que no había tenido participación en la insurrección o esta no se conocía. A pesar de esto, las autoridades se justificaban calificándolos como infidentes, favorables a la independencia, considerados revolucionarios, recaudadores de fondos, cuatreros o ñáñigos.

\footnotetext{
${ }^{82}$ La Época, 9 de julio de 1895. Recoge este bando de un diario y se refiere a los enviados a Ceuta como deportados, aunque en realidad se trataba de presos. Valga como ejemplo La Correspondencia de España, 21 de agosto de 1895; La Unión Católica, 19 de septiembre de 1895.

${ }^{83}$ La Correspondencia de España, 4 de abril de 1895.

${ }^{84}$ El Imparcial, 30 de diciembre de 1895; La Iberia, 20 de septiembre de 1895. Se trataba de Elpidio Marín, Miguel Valdés, Pedro Saavedra y José Yáñez; Diario Oficial de Avisos de Madrid, 27 de octubre de 1895. Doce más, que fueron llevados a Ceuta, llegaron a finales de octubre; La Dinastía, 27 de septiembre de 1896; a principios de 1896 llegaron el comerciante Rafael Silveira y el abogado de La Habana Enrique Brian, también destinados a Ceuta. El Liberal, 8 de enero de 1896; La Época, 23 de enero de 1896.

${ }^{85}$ La Época, 17 de octubre de 1895. Se trataba de Eudaldo Tamayo, Abogado; Antonio Bravo; Alfredo Betancourt, vicepresidente de la diputación provincial de Santiago de Cuba; Ricardo Landa, diputado; Antonio Monferrer; y otro apellidado Fajardo.

86 Delphine Sappez, Ciudadanía y autonomismo en Cuba. Antonio Govín (1847-1914), Publicacions de la Universitat Jaume I, Castellón de la Plana, 2016, pp. 317-319.
} 
Para el traslado se recurrió al procedimiento habitual. Una vez detenidos por la policía permanecían encarcelados, sin que ni siquiera se les tomara declaración. El día estipulado eran sacados de las prisiones para proceder a su embarque en medio de un alboroto en el que se mezclaban insultos por parte de los integristas y apoyo por parte de sus familiares que acudían a despedirse ${ }^{87} \mathrm{El}$ destino principal para los embarcados fue Cádiz. El carácter de nudo de comunicaciones que hacía de enlace con los vapores procedentes de Ultramar y sus presidios la hacían una ciudad adecuada para distribuirles hacia los espacios coloniales al sur de la ciudad andaluza. Solo en los primeros envíos algunos iban a La Coruña y Santander desde donde se les distribuía a otros puntos de la Península.

En la ciudad gaditana eran encerrados en la cárcel, en donde había tanto deportados filipinos y cubanos como presos comunes españoles y prisioneros de guerra. La distribución de cada grupo estaba organizada del siguiente modo:

"Los prisioneros de raza negra fueron encerrados en un calabozo en el patio número dos, los blancos en las galeras y calabozos junto con los presos españoles, y a los deportados los alojaron en las galeras de distinción que estaban en la parte alta del edificio, también separados por razas". ${ }^{88}$

La clasificación entre clases análogas se complementaba posteriormente con otra racial y otra determinada por el dinero y la importancia social. Entre los calabozos más acomodados se encontraban el exredactor de La Discusión, Antonio Escobar, y el doctor José María Montalvo. Este grupo podía además tener una mejor alimentación ya que mediante pago podían adquirir comida por su cuenta y evitar el rancho de la cárcel. ${ }^{89}$ Así, malviviendo en los calabozos esperaban su traslado hacia Chafarinas, Ceuta o Fernando Poo. En esta ocasión, Mahón, que en la Guerra Chiquita fue habilitada por carecer de espacio en Chafarinas, quedó al margen. De todos los destinos se optó por mantener aquellos que tenían un ámbito espacial más reducido, dificultando de este modo las posibilidades de fuga o de comunicación con otros conspiradores. En los puntos de destino, los relegados recibieron la ayuda de peseta y media que se había estipulado en la guerra anterior. ${ }^{90}$

\footnotetext{
${ }^{87}$ Manuel Miranda, Memorias de un deportado, Imprenta la Luz, Habana, 1903, pp. 11-12.

${ }^{88}$ Pablo de la Concepción, Prisioneros y deportados cubanos en la Guerra de Independencia, 1895-1898, Imprenta de P. Fernández y Cía., La Habana, 1932, p. 156.

${ }^{89}$ Manuel Miranda, Memorias de un deportado, pp. 19-20.

${ }^{90}$ Real orden de 13 de noviembre de 1895 . Oficio de Gobierno civil de Málaga a ministro de Ultramar, 15 de septiembre de 1897. AHN, Gobernación, Leg. 238. Reintegrable como fue habitual al presupuesto de Cuba.
} 
Un total de 430 individuos fueron condenados a presidio en el castillo del Hacho en Ceuta. La mayoría eran prisioneros de guerra, es decir, gente que había combatido con las armas contra el dominio español, pero también encontramos a participantes y auxiliadores de la misma en distintos grados. La ciudad africana fue el lugar principal de presidio para los cubanos. Como plaza militar fuertemente custodiada por militares ofrecía las condiciones idóneas para una vigilancia efectiva. Pero aun así hubo prisioneros de guerra en otros lugares como Madrid, Chafarinas, Cartagena e incluso en Canarias. ${ }^{91}$ Los condenados a presidio habían cometido delitos relacionados directamente con la rebelión y resultaban condenados por juicio. La deportación se utilizó para complementar esta represión.

Este no fue el único medio de salida forzada establecido por las autoridades del país, aunque sí el más importante. A algunas personas una vez presas se les permitió que eligieran su punto de destino. Este es el caso de Joaquín Forns, a quien se le dejó ir a Barcelona, y a Rodrigo Ponce de León, a quien se le permitió pasar a Veracruz. Al turco Rechid Aon se le expulso a Tampica y al vecino de Güira de Melena de 75 años de edad José Eusebio González Blanco se le desterró a Santiago de Cuba. ${ }^{92}$ Estas otras formas de expedición constituyeron casos excepcionales por la edad, nacionalidad u condicionantes sociales que influirían en la obtención de este trato de favor. Sin embargo, la salida hacia el extranjero planteaba problemas a las autoridades ya que en ese caso era imposible mantenerles vigilados y evitar que ayudaran a los alzados. Las comunidades de exiliados ayudaron en la medida de lo posible a la insurrección. Entre ellas destacó Key West, desde donde salieron numerosas expediciones con combatientes y armas, que contribuyeron de una manera muy relevante al triunfo de la insurrección. ${ }^{93}$

\footnotetext{
${ }^{91}$ ANC, Donativos y Remisiones, Leg. 695, Sig. 49. Presos en Ceuta durante los mandatos de Emilio Calleja a Valeriano Weyler; "Confinados políticos cubanos cuyo indulto ha comunicado por cable el Gobernador general para que fuesen puestos en libertad". AHN, Ultramar, Leg. 5007, Exp. 25; Javier Márquez Quevedo, "Convictos cubanos deportados a Canarias y África durante la represión del independentismo", Boletín Millares Carlo, núm. 17, 1998, p. 13.

${ }^{92}$ Expedientes individuales de deportación de Joaquín Forns y Rivera y Rodrigo Ponce de León y de expulsión de Rechid Aon. AHN, Ultramar, Leg. 5915. Expedientes individuales de deportados en la Guerra de Independencia cubana.

${ }^{93}$ Gerald E. Poyo, Exile and Revolution: José D. Poyo, Key West, and the Cuban Independence, University Press of Florida, Gainesville, 2014, pp. 192-215.
} 


\subsection{La sustitución de Martínez Campos por Weyler}

El 10 de febrero de 1896, con un panorama desastroso para las tropas españolas, Weyler fue nombrado Capitán general. La política de defensa de Martínez Campos había sido calamitosa y había facilitado la invasión del occidente por parte de los rebeldes. Weyler, carente de escrúpulos, pudo pacificar la zona cercana a La Habana y limitar la insurrección a las zonas más oriental y occidental. ${ }^{94}$ La severidad se acentuó incrementándose el número de presos y deportados. A finales de mayo el número de relegados en Ceuta ya se consideraba excesivo y se decidió que los nuevos que fueran llegando recabaran en Chafarinas. ${ }^{95} \mathrm{El}$ incremento indica que se fue menos escrupuloso en la aplicación del castigo, aunque momentáneamente no se modificara el perfil de los represaliados.

Desde los inicios de la guerra se había instalado en La Habana gente procedente del campo cubano, lo que incrementó la población en situación de necesidad. En 21 de octubre de 1896, Weyler decretaba la política de reconcentración que incrementó de manera exponencial la gente sin trabajo y sin posibilidades de adquirir productos básicos. Así, se diseñó una represión que excedería del ámbito puramente político y englobaría al social, con objetivo de controlar a la población que residía en las ciudades. El aumento en su número planteaba problemas de alojamiento, enfermedades y malnutrición, acentuadas por el hecho de que las zonas de cultivo previstas solo se habían implementado parcialmente por lo que únicamente un $20 \%$ de los reconcentrados pudieron encontrar trabajo. ${ }^{96}$ La situación de carestía contrasta con la disminución en el nivel de delincuencia durante $1897,{ }^{97}$ por lo que probablemente algunos delincuentes no fueran sancionados de acuerdo a las leyes ordinarias y serían englobados entre los deportados. Aun así, la situación social estuvo controlada por lo que la punición preventiva de unos para aterrorizar a otros funcionó.

\footnotetext{
94 John Lawrence Tone, Guerra y genocidio en Cuba, 1895-1898, Turner Publicaciones, Madrid, 2008, p. 229; sobre el mandato de Weyler en la guerra, ver Enrique de Miguel Fernández, Azcárraga, Weyler y la conducción de la Guerra de Cuba.

${ }^{95}$ El Correo Militar, 27 de mayo de 1896.

${ }^{96}$ Andreas Stucki, Las guerras de Cuba. Violencia y campos de concentración (1868-1898), La Esfera de los Libros, Madrid, 2017, pp. 280-281.

${ }^{97}$ Yolanda Díaz Martínez, La peligrosa Habana. Violencia y criminalidad a finales del siglo XIX, Editorial de Ciencias Sociales, La Habana, 2005, pp. 129-133. También se implementaron otras medidas como una mayor vigilancia policial.
} 
El 29 de octubre de 1896 apareció un artículo titulado "Los Neutros" en el Diario de La Habana y otro "Sobre los Neutros" en El Comercio de la misma ciudad, en los que se criticaba a los que permanecían al margen de la política. En un momento de guerra total cualquiera que no tuviera una posición proactiva españolista podía ser señalado como colaboracionista y castigado, incluyendo a los de procedencia peninsular. Esto no significó una generalización de la represión contra aquellos considerados indiferentes, pero esta se acentuó incluyendo a algunos de estos. En realidad de lo que se trataba era de dar cobertura a la política de castigo preventivo que se iba a utilizar contra un colectivo diferente.

La relegación de baja intensidad continuó pero fue complementada por otra realizada en grupo. En su utilización no podía estar exento el ejemplo de Filipinas, donde los traslados entre islas fueron utilizados en la guerra y donde a principios de octubre 151 filipinos fueron embarcados hacia a la Península. ${ }^{98}$ En La Habana, los confidentes de la policía hicieron listas de todos los sospechosos, entre los que fueron incluidos los ñáñigos, grupo en el que según López Hidalgo se incluyeron a los de color, mientras que los blancos fueron catalogados como cuatreros. ${ }^{99}$ Dado que la consideración de infidente podía extenderse hacia otros como simpatizantes de la rebelión, parece claro que la consideración de abakuá o cuatrero podía del mismo modo ampliarse a individuos con un perfil social similar. Algunos de ellos pudieron haber participado en la rebelión, pero de este modo se les despojaba de su condición de represaliados políticos.

Esta catalogación, cuyo objetivo era denigrar a las víctimas, era falsa y pretendía ocultar el verdadero carácter de estos. Entre los ñáñigos de Figueras había 89 tabaqueros, 35 cocineros, 32 jornaleros, 18 carpinteros y 15 zapateros, mientras que el resto tenían diferentes oficios. Un 40,6\% sabía leer, lo que superaba la media cubana, aunque este dato debe ser matizado, ya que el $82 \%$ procedían de La Habana, la zona con mayor alfabetización, en la que en 1899 un $34 \%$ sabían leer. ${ }^{100}$ Es irrefutable su componente popular, pero también que en general no eran marginados ni delincuentes.

\footnotetext{
${ }^{98}$ La Correspondencia de España, 13 y 21 de octubre de 1896.

${ }^{99}$ Ambrosio Valentín López Hidalgo, De La Habana a Chafarinas, Galería Literaria, Matanzas, 1900, pp. XI-XVI.

${ }^{100}$ David García Algilaga, "Presidi colonial a Figueras. Els ñáñigos", en Joan Ramón Inglada (coord.), Presons i Castell. Figueres, Associació d'amics del Castell de San Ferran-GORBS, Figueres, 2012, p. 111 y 121; Informe sobre el censo de Cuba, 1899 (Teniente coronel J. P. Sanger, dir.), p. 159.
} 
Su clasificación como abakuás se hizo para denigrarles, lo que permitió a las autoridades actuar con mayor libertad. Aunque se trató de una represión amplia, entre los afectados seguramente se encontrarían algunos de los más radicales de entre los pertenecientes a los sectores populares.

La inclusión de estos grupos permitió englobar a un sector que siendo de perfil urbano, no comulgaba exactamente con aquellos que tenían ideas políticas definidas a favor de la independencia. Tuvo un contenido social muy acusado, comprendiendo a un colectivo que contrariamente a lo que había sucedido en las guerras anteriores ahora se sacó del Caribe. También fueron incluidos miembros del movimiento obrero, que ante la discriminación y el despotismo que sufrían por parte de España, una vez comenzada la guerra adoptaron mayoritariamente una actitud que iba desde el apoyo al independentismo hasta la indiferencia, posición que beneficiaba al separatismo cuando se transformaba en un llamamiento a los voluntarios para no combatir a los hermanos cubanos o trataban de aprovecharse de la guerra para hacer la revolución. ${ }^{101}$ Esto significaba el fracaso de la política de favorecimiento de la inmigración blanca peninsular. $^{102}$

El 8 de diciembre llegó a la metrópoli un grupo de 32 deportados con destino a las Chafarinas y Fernando Poo. Desde esta fecha hasta el 2 de mayo arribaron a la Península aproximadamente 1.000 individuos entre relegados y catalogados como ñánigos. ${ }^{103}$ Tras el atentado que sufrió, Weyler prohibió las lecturas en los talleres tabaqueros y clausuró la SGT, algunos ácratas sufrieron deportación por lo que serían

\footnotetext{
101 Joan Casanovas Codina, ¡O pan, o plomo! Los trabajadores urbanos y el colonialismo español en Cuba, 1850-1898, Siglo XXI, Madrid, 2000, pp. 265-266. El proceso mediante el cual el movimiento obrero va separándose de la causa española por el autoritarismo y la exclusión que sufría es anterior, pp. 239-259.

${ }^{102}$ Sobre la inmigración en Cuba en este periodo me gustaría destacar, Consuelo Naranjo y Armando García, Racismo e inmigración en Cuba en el siglo XIX, Doce Calles, Aranjuez, 1996 y "Los trabajos y los días. Colonos gallegos en Cuba en el siglo XIX, Semata, Ciencias Sociais e Humanidades, vol. 11, 1999, pp. 191-215; Jordi Maluquer de Motes, Nación e inmigración; Antonio Santamaría y Luis Miguel García Mora, "Colonos. Agricultores cañeros, ¿Clase media rural en Cuba? 1880-1898”, Revista de Indias, vol. 58, núm. 212, 1998, pp. 131-161; un estudio regional en Maritza Pérez Dionisio, "La inmigración hispana en Santiago de Cuba (18681898)", Estudios de Historia Social y Económica de América, núm. 13, 1996, pp. 427-443.

${ }^{103}$ La Dinastía, 8 de noviembre de 1896; La Época, 15 de noviembre de 1896; La Iberia, 14 de diciembre de 1896; La Unión Católica, 14 de diciembre de 1896; El Globo, 23 de enero de 1897; Diario Oficial de Avisos de Madrid, 29 de enero de 1897; El Correo Español, 27 de febrero de 1897; La Iberia, 27 de marzo de 1897; El Día, 2 de mayo de 1897. El número aunque aproximado puede considerarse fidedigno. La dificultad para establecer el alcance exacto se debe a la diferencia de datos entre periódicos sobre el mismo envío y a la existencia de una confusión terminología, en ocasiones, entre presos y deportados.
} 
incluidos entre los abakuás. ${ }^{104}$ La distinción entre estos y cuatreros pudo tener que ver también con la procedencia de los represaliados del campo o la ciudad. Esta medida sirvió para lidiar con la fuerte crisis a raíz de la imposición de aranceles en los Estados Unidos a los productos cubanos en 1894 y la consiguiente respuesta española en la misma dirección, que provocaron escasez de productos, incremento en los precios y aumento del desempleo. ${ }^{105}$ La nefasta situación económica y el hambre se incrementaron con la política de reconcentración en las urbes, por lo que los embarques fueron una manera de actuar limitadamente sobre un grupo determinado dentro del exceso de población y las carencias que se vivían en las ciudades.

Los envíos provocaron que los lugares habilitados en Cádiz se saturaran, teniendo que ampliarse. Posteriormente se volvió a una menor intensidad, tal y como sucedía antes del mandato de Weyler, aunque sin un carácter tan personalizado. Esto significa que la "limpieza especial" que se había diseñado para que afectara a estos hombres de las capas populares de la sociedad urbana se había cumplido en buena medida. Ahora, sin desaparecer afectaban a un número mucho menor.

Una vez ejecutado lo más duro de la represión, con motivo del cumpleaños del rey, el 17 de mayo, a Weyler se le concedió aprobar una lista con indultados, que expidió a principios de julio, comprendiendo a 13 sujetos a los que se les dejaba pasar desde Ceuta y Chafarinas a la Península y a 93 a los que se les permitía retornar a Cuba. A finales de julio lo ampliaba a otros 45, entre los que se encontraba el doctor Montalvo, vocal de la Junta directiva de los autonomistas y otros 79 del mismo perfil ideológico. Era el inicio de una nueva política mediante la cual el propio Cánovas pidió al Capitán general que fuera prudente por las críticas a la dureza de sus políticas, especialmente desde los Estados Unidos, lo que llevó a Weyler a conceder un indulto en 3 de julio para los presentados. ${ }^{106}$

\footnotetext{
${ }^{104}$ Carlos Serrano, "La colonie pénitentiaire: rebelles, anarchistes, ñáñigos dans les pénitenciers espagnols", en Mélanges américanistes en hommage à Paul Verdevoye, Éditions Hispaniques, París, 1985, pp. 85-89.

${ }^{105}$ Louis A, Pérez, Cuba Between Empires, 1878-1902, University of Pittsburgh Press, Pittsburgh, 1983, p. 33.

${ }^{106}$ La Iberia, 8 de julio de 1897. Contiene la lista de los indultados; El Imparcial, 31 de julio de 1897; La lista en La Época, 25 de agosto de 1897. No especifica donde estaban deportados los indultados, pero tratando de congraciarse con el autonomismo es evidente que su objetivo era los que estaban en Chafarinas y Ceuta; La Época, 5 de agosto de 1897; Gabriel Cardona y Juan Carlos Losada, Weyler, nuestro hombre en La Habana, Planeta, Barcelona, 1997, p. 227.
} 
Las amnistías muestran los excesos de la represión, ya que si hubiera el convencimiento de que representaban un peligro no les hubieran permitido regresar. Exceptuando a unos pocos pardos y morenos el resto eran blancos, lo que muestra el perfil social de aquellos con los que querían congraciarse para aumentar su apoyo social: blancos y autonomistas. Esta política empezó con Weyler, apenas meses después de haber incrementado sustancialmente la punición, y todavía con Cánovas en la presidencia del Gobierno. En febrero de 1897, el Senado norteamericano había autorizado al presidente a reconocer la beligerancia de Cuba, lo que hacía aconsejable una política de contemporización para la colonia.

Otra cosa es la intención real de muchos de ellos de volver a un país inmerso en una guerra total por parte de los dos bandos, por lo que muchos aprovecharon para pasar al extranjero. ${ }^{107}$ En cualquier caso el indulto fue escalonado, alcanzando a la mayoría de los que había en Chafarinas y Ceuta. En septiembre de 1897 restaban 43 en Chafarinas y 37 en Ceuta mientras que de Fernando Poo apenas habían salido unos pocos casos aislados. ${ }^{108}$ A mediados de octubre habían sido indultados 291 relegados políticos de los 445 que habían sufrido este castigo. Para acelerar el proceso se promulgó la real orden de 15 de octubre alzaba la deportación gubernativa por motivaciones políticas, exceptuando a aquellos considerados cuatreros y ñáñigos y al anarquista Manuel Miranda. ${ }^{109}$ Es decir, únicamente aquellos considerados más peligrosos y cuyo indulto no ofrecía ventajas políticas permanecieron en la misma. Para las autoridades españolas esta era una guerra social en la que las élites debían actuar en favor de España mientras desechaban el apoyo del "populacho". Además, indultarles significaba reconocer que la represión había sido arbitraria también con ellos.

\subsection{Las islas Chafarinas}

El traslado a las Chafarinas se efectuaba desde Málaga. El viaje a dicha ciudad era en tren en caso de abonarlo los propios deportados, o a pie en caso contrario. En este segundo caso se les dispensó una pequeña ayuda para los gastos del viaje y se

\footnotetext{
${ }^{107}$ La Época, 18 de agosto de 1897.

${ }^{108}$ El Liberal, 28 de septiembre de 1897; El Día, 2 de septiembre de 1897.

${ }^{109}$ El Imparcial, 15 de octubre de 1897. Reales órdenes sobre deportados. AHN, Ultramar, Leg. 5007, Exp. 25.
} 
habilitaron carromatos para ayudarles en el transporte de los equipajes y llevar a los enfermos. ${ }^{110}$ Una vez allí eran embarcados con dirección a la isla de Isabel II.

Las mejoras efectuadas en la plaza en la Guerra Chiquita facilitaban que pudiera acoger sin problemas a un número similar de deportados. A fecha de 15 de abril de 1897 había 135, de los cuales 36 eran filipinos y el resto cubanos. Además había una población penal de 180 presos por causas comunes y una guarnición de 165 militares. Los presos comunes realizaban trabajos de fortificación o ayudaban en tareas como el almacén y el hospital a cambio de un pequeño jornal. ${ }^{111}$ Los civiles residentes eran 172 , de ellos 25 hombres y 67 mujeres, esposas de los primeros y de los miembros de la guarnición y la nada despreciable cifra de 80 niños. ${ }^{112}$ Se daba en la colonia una curiosa convivencia entre penados, confinados, militares y civiles y las mujeres y niños de estos. Todos, incluyendo a los penados, formaban una población de 652 individuos en un territorio en el que incluso había que traer el agua potable. Una población del todo artificial que afianzaba el dominio español sobre la posesión.

Entre los cubanos, 79 eran blancos, tres pardos y seis morenos. A ellos habría que sumar un portorriqueño blanco y diez peninsulares. ${ }^{113}$ La proporción entre las diferentes razas está demasiado descompensada para ser casual. En la desorganización del momento las cribas que se producían nunca eran perfectas, en el sentido que grupos catalogados como de un tipo determinado acababan mezclándose con otros por hallarse presos en las mismas fechas o en los mismos lugares. Pero en este caso es evidente que se produjo una selección de aquellos con mayor perfil social. La escasa guarnición y sobre todo la presencia de un número tan elevado de mujeres y niños españoles hacia recomendable el desvío hacia Chafarinas de aquellos de los que se pensaba que podían tener un mejor comportamiento.

Esto tendía a una mayor implicación en la insurrección o un mayor activismo político. Pero una vez fuera de Cuba las consideraciones políticas perdían su

\footnotetext{
${ }^{110}$ Emilio Valdés Infante, Cubanos en Fernando Poo. Horrores de la dominación española, Imprenta "El Figaro", La Habana, 1898, pp. 19-20; Pablo de la Concepción, Prisioneros y deportados cubanos en la Guerra de Independencia, pp. 169-190.

${ }^{111}$ Carlos Esquembri Hinojo, "Las islas Chafarinas, desde 1848 hasta finales del siglo XIX", Aldaba, núm. 37, 2013, pp. 213-124.

112 "Estadística de Chafarinas" y "Estadística de la deportación", en el periódico manuscrito editado en Chafarinas por los propios relegados El Deportado. ANC, Donativos y Remisiones, Leg. 525, Sig. 1.

113 "Estadística de la deportación", en El Deportado. ANC, Donativos y Remisiones, Leg. 525, Sig. 1.
} 
importancia y quedaban las características personales de poseer mayor cultura y riqueza. En este sentido, 80 tenían instrucción y solo 19 carecían de ella. En la isla realizaban obras de teatro y editaron un periódico manuscrito cuyo consejo de redacción estaba compuesto de 13 sujetos, mostrando claramente que fue un empeño colectivo. Chafarinas y Ceuta, se configuraron como lugares destinados para una población más elitista. Allí no había nada que colonizar y no se pretendía poner en marcha ningún tipo de explotación agrícola. El trabajo era escaso, puesto que la presencia de civiles era mínima y obedecía a negocios relacionados con la presencia militar. A pesar de ello, tenían cubiertas sus necesidades básicas y se entretenían como buenamente podían.

\subsection{Ceuta}

La plaza, de nuevo, se configuró como un lugar central en la estrategia represiva. Por sus características orográficas, poco más que una ciudad enclavada en África, y su dotación militar, el control de los relegados se hacía más fácil para el Estado. A partir de la Ordenanza General de Presidios de 1834, los condenados con penas superiores a ocho años se reasignaron hacia los presidios Africanos, donde quedaban a disposición de las autoridades para realizar los trabajos necesarios en perjuicio de las empresas de Caminos de Andalucía y Canal de Castilla. ${ }^{114}$

Ceuta fue el lugar principal de remisión de los presos de guerra y además hubo 102 deportados en la plaza entre 1895 a $1898 .{ }^{115}$ Entre los relegados había 17 de la provincia de Pinar del Rio; 30 de La Habana, de los cuales siete eran de la capital; cuatro de Matanzas; 12 de Santa Clara; cinco de Camagüey; 29 de Oriente; cuatro españoles; y uno de América del sur. Una distribución que alcanzaba a toda la isla, como corresponde a una guerra expandida por todo el territorio de la misma. Sin embargo, el mayor número correspondía a Oriente, el lugar con más partidarios de la independencia, así como de La Habana y Pinar del Rio, allá donde se estaba dirimiendo la guerra.

Ambos grupos compartieron espacio, aunque con condiciones diferentes. Los cubanos y los tres filipinos fueron ubicados en los denominados pabellones militares, en

\footnotetext{
${ }^{114}$ Fernando J. Burillo Albacete, El nacimiento de la pena privativa de libertad, Edersa, Madrid, 1999, pp. 108-109.

${ }^{115}$ Pablo de la Concepción, Prisioneros y deportados cubanos en la Guerra de Independencia, pp. 509-512.
} 
"salones higiénicos y ventilados". Podían bajar libremente a la ciudad siempre que volvieran al castillo antes del recuento de las cinco de la tarde. Tras pernoctar en el Hacho y después del recuento matutino podían salir del recinto y algunos incluso consiguieron permiso para alojarse en la ciudad. Los prisioneros de guerra fueron alojados en las galeras y obligados a trabajar en las fortificaciones militares en las mismas condiciones que los presos comunes peninsulares, aunque obteniendo el doble de jornal que estos, seis centavos al día por tres los penados europeos, lo que suponía el reconocimiento de la condición de combatientes. La alimentación fue pésima y los abusos por parte de los guardianes constantes. ${ }^{116}$

Desde el punto de vista de alguien obligado a realizar trabajos forzados, las condiciones de los otros eran relativamente buenas, "Los deportados por medida gubernativa, justo es confesarlo, recibían buen trato de parte de sus guardianes; tenían como hemos dicho, la ciudad por cárcel durante el día y recibían nueve pesos mensuales para su alimentación". ${ }^{117}$ Las diferencias fundamentales entre ambos grupos explicaban este trato diferenciado. En primer lugar, unos se habían insurreccionado en armas contra España lo que suponía un ataque contra la integridad de la nación, pero también implicaba que se les responsabilizara de los aproximadamente 44.000 soldados españoles muertos en Campaña. ${ }^{118}$ Sobre los otros caían sospechas de colaboración, pero no en grado de combatientes. Además, muchos fueron trasladados únicamente por sus opiniones políticas lo que no suponía directamente una agresión contra España.

En cuanto al perfil social fue un destino similar a Chafarinas, en oposición a Fernando Poo que quedaba configurado como el lugar de envío para los considerados cuatreros o anarquistas. Algunas personalidades que en principio iban a ser llevadas al territorio africano usaron sus influencias para poder recabar en Ceuta, allí estaban el Hacendado Manuel Regueira, los doctores José Antonio González Lanuza, Alfredo

\footnotetext{
${ }^{116}$ Deportados existentes en 5 de octubre de 1898. AHN, Ultramar, Leg. 5007, Exp. 25; Pablo de la Concepción, Prisioneros y deportados cubanos en la Guerra de Independencia, pp. 221224 y 476.

${ }^{117}$ Pablo de la Concepción, Prisioneros y deportados cubanos en la Guerra de Independencia, p. 253.

${ }^{118}$ Bonifacio de Esteban y Marfil, La sanidad militar española en la Guerra de Cuba (18951898), Tesis doctoral de la Universidad Autónoma de Madrid, Madrid, 2000, pp. 124-125; Silvia Sánchez Abadía, "Olvidos de una guerra. El coste humano y económico de la independencia (Cuba-España, 1895-1898)”, Revista de Indias, 2001, vol. 61, núm. 221, 2001, p. 122.
} 
Zayas y el médico José Rafael Montalvo, entre otros. ${ }^{119}$ Algunos de ellos ocuparían cargos importantes durante la República, e incluso Zayas fue presidente del Gobierno. Las condiciones relativamente buenas se mantuvieron hasta la fuga de dos relegados en Chafarinas. En este momento se terminaron las pernoctaciones fuera del castillo y se decidió que únicamente pudieran bajar ocho cada día a Ceuta, además de los 12 o 13 que lo hacían diariamente para realizar las compras necesarias. ${ }^{120}$ La vigilancia se incrementó. Aun así podían moverse por el Castillo y cuando podían bajar a la ciudad disponían de un buen número de comodidades y servicios en caso de disponer de algún capital.

Esto no se extendió a todos los deportados, ya que entre ellos había 23 considerados como ñáñigos que tuvieron unas condiciones muy diferentes. El ñañiguismo fue prohibido por las autoridades españolas en 1876, a lo que siguió la aprehensión de 217 miembros de la sociedad que fueron utilizados en la realización de fortificaciones militares en Santiago de Cuba. ${ }^{121} \mathrm{La}$ disminución en los esclavos determinó su sustitución mediante la utilización de una mano de obra libre. En los albores del fin de la esclavitud, la emergencia de sectores subalternos era tan importante que unida al temor hacia ellos de las autoridades podía terminar con su utilización en trabajos forzados.

En 1896, la presión sobre los mismos se incrementó con numerosas aprehensiones. Su asociación a la delincuencia y su carácter eminentemente popular determinó la represión sobre el movimiento. ${ }^{122} \mathrm{El}$ fomento del miedo hacia un colectivo formado primordialmente por negros y mulatos de baja condición social, contribuía a expandir la idea de que en una Cuba independiente reinarían las luchas raciales y los desórdenes públicos. La actuación hacia los ñáñigos tuvo un efecto propagandístico, pero al mismo tiempo indica el temor hacia una sociedad secreta de la que se conocía muy poco y que estaba formada principalmente por individuos sometidos a una fuerte discriminación. Mediante su configuración como enemigos y posterior aprehensión, aun

\footnotetext{
${ }^{119}$ María del Carmen Barcia, "Los deportados de la Guerra. Cuba 1895-1898", en Consuelo Naranjo, Miguel Ángel Puig-Samper y Luis Miguel García Mora (eds.), La nación soñada. Cuba, Puerto Rico y Filipinas ante el 98, Doce Calles, Aranjuez, 1996, p. 642; Pablo de la Concepción, Prisioneros y deportados cubanos en la Guerra de Independencia, pp. 223-224.

${ }^{120}$ Oficio de comandante de Ceuta a Ministerio de Ultramar, 7 de septiembre de 1897. AHN, Gobernación, Leg. 238.

${ }^{121}$ Oficio de Estado Mayor de Cuba a gobernador de Santiago de Cuba, 2 de junio de 1876. AGMM, Gobiernos Militares, Sig. 3228.

${ }^{122}$ Enrique Sosa Rodríguez, Los ñáñigos, Casa de las Américas, La Habana, 1982, pp. 307-313.
} 
en el caso de no tratarse de iniciados, las autoridades pretendían mostrar que actuaban para proteger a la población de los excluidos.

El grupo de abakuás llegó a Ceuta a finales de 1896. Catalogados como hombres peligrosos y de conducta depravada, las órdenes eran que permanecieran en las mismas condiciones que los presos. El comandante general de Ceuta los encerró en el departamento para presidiarios de El Hacho, poniéndoles cadena y ordenando "que no salieran a más trabajos que los puramente mecánicos dentro de la fortaleza". Sin embargo, a causa de su buena conducta decidió sacarles de la fortaleza a disposición de los ingenieros pero sin retribución. Finalmente, como no dieron queja continuaron ejerciendo los mismos trabajos sin la cadena y con retribución. ${ }^{123}$ De este modo, hubo presos sin juicio a los que por el desprecio social y el temor que inspiraban fueron obligados a trabajar, estando recluidos en condiciones similares a las de los sentenciados por participar en la insurrección y a las de los presos comunes españoles. Un nuevo paso en el incremento del despotismo gubernamental.

\subsection{Otros lugares de deportación}

A causa de la diferencia respecto a la guerra anterior no fueron habilitados otros lugares que contuvieran contingentes importantes. Dado que los tres puntos elegidos fueron suficientes para alojarles, los destinados a otros territorios fueron excepcionales. Ceuta y Chafarinas, ambas plazas fortificadas, facilitaban la concentración de relegados y su vigilancia, estableciéndose preferentemente para aquellos con cierta consideración social. En la ínsula africana simplemente se expelió a personas cuya vida nada importaba al Estado, siendo utilizados como carne de cañón supuestamente para tratar de fomentar la colonización.

Existieron casos diferenciados que posibilitaban que algunos pasaran a otros puntos. A Manuel Cabrera Espinosa se le fijó por residencia la ciudad de Las Palmas de Gran Canaria. El hacendado Manuel Regueiro, deportado en Ceuta, consiguió pasar a Madrid, José A. González Molina, residió en La Coruña. Además hubo 43 que residieron en Cádiz, ${ }^{124}$ y otros en Madrid u otros lugares de la Península. Su

\footnotetext{
${ }^{123}$ Oficio de comandante general de Ceuta a Ministerio de Ultramar, 17 de enero de 1898. AHN, Gobernación, Leg. 238.

${ }^{124}$ Oficio de Capitán general de Canarias a Ministerio de Ultramar, 19 de noviembre de 1897, Oficio de Ministerio de Ultramar a gobernador civil de La Coruña, 30 de noviembre de 1897.
} 
procedencia es difícil de precisar, aunque posiblemente una vez en la ciudad andaluza evitaran ser llevados a los puntos de destino. Otros se encontrarían en el presidio a la espera de su traslado y se les aplicarían los distintos indultos. En cualquier caso, por ser una ciudad peninsular la estancia sería más favorable reservándose para aquellos con influencia o cuya peligrosidad se considerarse escasa.

Hemos encontrado distintas órdenes de embarque a Filipinas, aunque finalmente a última hora todos estos fueron ubicados hacia las Chafarinas. Este es el caso de 24 individuos, ${ }^{125}$ a los que el gobernador de la región occidental ordenaba destinar al archipiélago asiático, probablemente pensando en la mayor lejanía y proscripción que ello significaba. Sin embargo, estas acciones fueron neutralizadas por la autoridad superior a causa de la poca conveniencia de enviar a supuestos sediciosos a un territorio que igualmente estaba en guerra por la independencia. Aun así, no puede descartarse totalmente que se produjera algún caso específico, que sería anecdótico. ${ }^{126}$

El proceso de represalias iniciado en la Guerra Chiquita, mediante el cual también aquellos de los que se sospechaba que podían colaborar con los infidentes o directamente eran conceptuados como vagos y de mala conducta eran llevados preferentemente a destinos que no fueran isla de Pinos continuó, ahora elevado por la mayor represión sobre este grupo en consonancia con el alcance de la guerra. En mayo de 1896 había en la misma 139, a los que habría que añadir otros 211 presos. ${ }^{127}$ Entre los relegados seguramente, tal y como había sucedido con anterioridad, había tanto por motivaciones políticas como sociales. El motivo de esta variación fue que los considerados vagos y de mala conducta constituían un peligro en la posesión por su cercanía al teatro de operaciones. No desapareció del todo, algunos elementos como la costumbre influían en ello, pero en líneas generales se abrieron nuevos puntos de destino para la gente englobada en este perfil. La rigidez y el autoritarismo gubernamental iban en aumento, lo que explica la variación en los puntos de destino.

AHN, Gobernación, Leg. 238; ANC, Donativos y Remisiones, Leg. 84, Exp. 123. Recopilación de confinados y deportados del doctor Alfredo de Zayas; Pablo de la Concepción, Prisioneros y deportados cubanos en la Guerra de Independencia, p. 224.

${ }^{125}$ Oficios de Gobierno general de Cuba a gobernador de la región occidental y de esta provincia, 5 de noviembre y 26, 27 y 29 de diciembre de 1896. AHN, Ultramar, Leg. 5914. Deportados, años 1896 y 1897.

${ }^{126}$ Solo conocemos un caso al que se le expidió orden para pasar a Filipinas, se trataba de Julio Mora. AHN, Ultramar, Leg. 4763, Exp. 59. "Julio Mora, deportado político de la isla de Cuba".

${ }^{127}$ Jane Mcmanus, La isla cubana de ensueño. Voces de la isla de Pinos y de la Juventud, La Memoria, La Habana, 2005, p. 4. 
Las circunstancias bélicas marcaron la conveniencia de desviarlos hacia otros puntos, pero puesta la elección en manos de un Ejecutivo autoritario en grado sumo el resultado fue la remisión a presidios en la Península y Ceuta. Tras la aplicación del indulto quedaban en los presidios los distintos ñáñigos: 23 en Ceuta, 69 en Santoña, 335 en Figueras, 121 en Cádiz cuyo destino final era Santoña y uno en Chafarinas, totalizando 549. A estos había que añadir los 32 que habían fallecido hasta ese momento en Figueras en la más absoluta pobreza. La estancia de los abakuás se caracterizó por unas graves carencias ya que fue el ayuntamiento de Figueras el que debía anticipar los gastos, resultando en una mala alimentación y en una falta de ropas de abrigo adecuadas para el invierno peninsular y mantas. ${ }^{128}$ Esto suponía contravenir cualquier principio de legalidad, ya que se les encerró en las prisiones sin que recayera ninguna sentencia, lo que suponía incumplir flagrantemente su propia legislación.

Los ñáñigos constituyeron el grupo peor tratado, ya que según real orden de 9 de noviembre de 1896 se ordenó que se extremaran con ellos las medidas de vigilancia y que no se les aplicara el socorro y trato que se daba al resto de relegados, incluyendo a los cuatreros. Dado que el Capitán general los consideraba "individuos de carácter depravado y avezados al crimen" se decidió que debían recibir la misma ayuda y trato "que a los corrigiendos o presos gubernativos". ${ }^{129}$ Esta distinción entre cuatreros y abakuás no deja de resultar sorprendente, ya que se otorgaban peores condiciones a aquellos que se creía que eran tendentes al crimen que a otros, los cuatreros, represaliados supuestamente por criminales, lo que demuestra que en realidad la calificación de ladrones era falsa. Contrariamente a lo que sucedía en Ceuta, en la Península su salida aun cuando fuera a realizar trabajos era más dificultosa.

Entre las llevadas a isla de Pinos diez mujeres acusadas de ñáñigas. ${ }^{130}$ La noticia no especifica si en calidad de presas o deportadas. En el trasfondo de esta medida

\footnotetext{
${ }^{128}$ Sitios donde residen los deportados ñáñigos no indultados. AHN, Ultramar, Leg. 5007, Exp. 25; oficio de Ministerio de Ultramar a subsecretaria de este Ministerio aprobando la compra de vestidos y mantas para los ñáñigos en Cádiz, 3 de febrero de 1898. Oficios de Capitán general de Cataluña a Ministerio de la guerra en que informa de los fallecimientos de ñáñigos, fechas 21 de enero, 25 de enero, 4 de febrero, 6 de febrero, 24 de febrero, 18 de junio, 19 de junio, 13 de diciembre de 1898 y 28 de febrero de 1899. Ninguno dejó absolutamente nada de su propiedad a excepción de Andrés Álvarez que lego "un corto número de prendas en mal estado y catorce cartas de familia que han sido entregadas a su compañero, José Manuel del Valle". AHN, Gobernación, Leg. 238.

${ }^{129}$ Informe sobre deportados por motivos políticos y ñáñigos. AHN, Ultramar, Leg. 5007, Exp. 25.

${ }^{130}$ La Unión Constitucional, 3 de abril de 1897.
} 
encontramos la intención de separarlas de sus compañeros varones, lo que indica que se trataba de un destino accesorio. El desprecio hacia este grupo derivó en este traslado colectivo de mujeres, algo que no solía suceder. Por su condición, su destino fue peor que el de la otra extrañada por la guerra, Matilde Ferrer y Farriol, a la que por su mala conducta moral y política fue impelida a dejar Cuba en 15 días y el 25 de enero de 1897 partió hacia Barcelona. ${ }^{131}$

La libertad relativa de que gozaban dio lugar a intentos de fuga. En enero de 1896 lo consiguieron diez, tras obligar al patrón de un barco a sacarles de allí y posteriormente se incorporaron a las filas de Maceo. En 26 de julio de ese mismo año hubo un intento de sublevación en el territorio. Unos 250 hombres intentaron apoderarse de Nueva Gerona, a la vez que otra facción tomaba como rehén al coronel de caballería José Berriz. Finalmente, Berriz fue liberado y los insurrectos apresados quedando en la plaza excepto 21 que fueron remitidos a La Habana. ${ }^{132}$ La cercanía a la guerra y la expansión del independentismo entre amplias capas de la sociedad provocaron que la posesión dejara de ser un lugar seguro para depositar a los independentistas.

\subsection{Fernando Poo}

Los destinados a Fernando Poo eran sacados del presidio de Cádiz atados de dos en dos y custodiados por la Guardia Civil hasta el embarcadero. Allí podían comprar alimentos para el viaje de 17 o 18 días con escala en Canarias, Rio de Oro y Sierra Leona. ${ }^{133}$ A finales de la década de 1880 se había producido un tímido avance en la colonización. Esto estaba motivado por la llegada de cultivadores a los que se otorgaron concesiones de tierras. Entre 1884 y 1890 se realizaron un total de 93 para otras tantas nuevas explotaciones. ${ }^{134}$ Como hemos visto, algunas de ellas corresponderían a los

\footnotetext{
${ }^{131}$ Oficios de alcalde de Guanabacoa a gobernador de la región y provincia de La Habana, 19 y 25 de enero de 1897. AHN, Ultramar, Leg. 5914. Deportados, años 1896 y 1897.

${ }^{132}$ La Unión Católica, 23 de enero de 1896; Jane Mcmanus, La isla cubana de ensueño, p. 4; Fernando Soldevilla, "Conspiración en la isla de Pinos", en El Año Político (1896), Imprenta de Enrique Fernández de Rojas, Madrid, 1897, pp. 309-310.

${ }^{133}$ Emilio Valdés Infante, Cubanos en Fernando Poo, pp. 20-21 y 22-28; Manuel Miranda, Memorias de un deportado, pp. 20-25.

${ }^{134}$ Mariano L. De Castro y María Luisa De La Calle, La colonización española en Guinea Ecuatorial, pp. 216-223; El avance colonizador vino acompañado por una frenética actividad misional de los padres claretianos a partir de noviembre de 1883, Jacint Creus, "Cuando las almas no pueden ser custodiadas. El fundamento identitario en la colonización española de Guinea Ecuatorial”, Hispania. Revista Española de Historia, vol. 67, núm. 226, pp. 526-533.
} 
deportados cubanos que decidieron quedarse, pero paralelamente se produjo una afluencia de pobladores blancos y el acceso a las tierras de los fernandinos.

Por primera vez, a los confinados se les llevaba a un lugar que estaba despertando cierto interés y en donde se estaba implementando una política de desarrollo de las plantaciones. Dentro de las carencias, las comunicaciones había mejorado y la posesión se encontraba más conectada con la metrópoli, una vez cada tres meses el vapor Larache unía Cádiz con Santa Isabel. Esto evitó que se fletaran barcos exclusivamente para transportarles allí, por lo que hasta Cádiz su periplo era igual al del resto de relegados. La remisión en que llegó Miranda estaba compuesta de 18 infidentes, dos que se habían opuesto a la suscripción a favor de España en un taller de tabaco y 74 que fueron catalogados como cuatreros. ${ }^{135}$ Se observa como su perfil era bien diferente del de los remitidos a Chafarinas, puesto que la mayoría estaba constituida teóricamente por delincuentes, a los que se daba esta consideración por su condición social.

Fernando Poo se incorporó como destino a mediados de 1896. En 20 de mayo Weyler pidió al Gobierno autorización para ello y el 19 de junio el Ejecutivo se la concedió, por el bien para el orden público que ello representaría y por los beneficios que supondría para la agricultura en la misma ya que "los deportados con ocasión de la insurrección pasada introdujeron cultivos tan valiosos como los del tabaco y el café, para la producción de los cuales es muy apropiado aquel territorio". Para ello le recomendaban que destinase allí preferentemente "a los que se hallen prácticos en los mencionados cultivos o hubiesen sido agricultores o jornaleros del campo, los cuales estarían en condiciones de hacer allí vida apropiada, con ventaja para ellos y beneficio para la isla". ${ }^{136}$

Así, la inclusión del dominio fue a petición del Capitán general. No debemos de desdeñar el apoyo de la prensa más conservadora, que incidía en los beneficios que esta práctica había supuesto. En 1887 la colonia progresaba moderadamente y había en

\footnotetext{
${ }^{135}$ Manuel Miranda, Memorias de un deportado, pp. 5, 11 y 12. Afirma que fue relegado por no querer participar en una suscripción para ampliar la marina de guerra; hubo bandoleros que para obtener cobertura a sus actuaciones, por identificación con la causa o por vengarse de las fuerzas de orden público se unieron a la insurrección, pero resulta evidente que nada tenían que ver con los calificados como "cuatreros", ver Manuel de Paz Sánchez et al. El bandolerismo en Cuba. Presencia canaria y protesta rural, Centro de Cultura Popular Canaria, 1994, pp. 125193; Imilcy Balboa, La protesta rural en Cuba, pp. 149-173.

${ }^{136}$ Oficio de ministro de Ultramar a Capitán general de Cuba, 19 de junio de 1896, AGA, África-Guinea, Caja 81/7057, Exp. 17.
} 
Santa Isabel 415 españoles y 778 extranjeros, de los que 108 eran blancos. La preponderancia masculina era evidente, 961 varones por 232 mujeres. ${ }^{137}$ La importancia de los represaliados cubanos de la Guerra Chiquita para la colonización está fuera de toda duda. Ahora bien, en estos momentos en que esta se estaba afianzando la afluencia no era necesaria. Es cierto que pudo suponer un cierto empuje, pero a nuestro juicio, tiene que ver más con una política de castigo contra los insurreccionados. Teniendo en cuenta que la petición fue a instancias de Weyler, hemos de preguntarnos qué beneficios ofrecía para él. Probablemente, pensando en que de este modo le era más fácil justificar la extensión hacia debajo de la práctica y la inclusión en ella de individuos que excedían la pura oposición política, y aun la de delincuentes, siempre que se pensara que con ello se desarrollaría la agricultura en la misma. Del mismo modo, le servía como excusa al Gobierno para no inmiscuirse en las condiciones de los relegados, puesto que pretendidamente el Estado iba a salir beneficiado. La idea de la ayuda de los transportados a consecuencia de la Guerra Chiquita había reforzado la colonización había calado, aunque olvidando el alto costo humano que se había tenido que pagar.

De este modo, fueron 119 los cubanos deportados a Fernando Poo en los diferentes envíos que desde Cádiz llegaron en el Larache. Junto a ellos una cantidad incluso mayor de Filipinos, 211 en total según la documentación oficial y 211 varones y seis mujeres según Valdés. ${ }^{138}$ Los traslados empezaron el 31 de diciembre de 1896 y finalizaron en marzo 30 de marzo de 1897. Una operación puntual que no se prolongó en el tiempo y que tuvo como objeto proporcionar ubicación a la multitud de detenidos.

Resulta digna de señalar la mayor presencia de asiáticos que constituían casi dos tercios del total. Además, los de esta procedencia fueron remitidos principalmente a esa posesión ya que únicamente otros 36 fueron llevados a Chafarinas y tres a Ceuta. Lo que configura la represión contra estos como más dura. En cuanto a su número, esto no indica necesariamente que fuera menor, ya que también se utilizaron para ello otras

\footnotetext{
${ }^{137}$ Abelardo de Unzueta y Yuste, Geografía histórica de la isla de Fernando Poo, Instituto de Estudios Africanos, Madrid, 1947, p. 289. Datos del censo de 1887; la descompensación entre sexos se compensaba para los varones con las mujeres negras, favorecidos por la mayor permisividad sexual de las sociedades africanas y su posición de superioridad, ver Gustau Nerín, Guinea Ecuatorial, historia en blanco y negro, Península, Barcelona, 1997, pp. 104-113.

${ }^{138}$ Deportados existentes en octubre de 1898. AHN, Ultramar, Leg. 5007, Exp. 25; Emilio Valdés Infante, Cubanos en Fernando Poo, pp. 71-72. La lista de deportados cubanos en pp. 8486; la cantidad de relegados no fue casual, ya que previamente el gobernador de la isla había estipulado que podía albergar a unos 300 siempre que le avisaran con un mes de antelación para la construcción de los barracones. Telegrama de gobernador de Fernando Poo a ministro de Ultramar, 22 de junio de 18996. AGA, África-Guinea, Caja 81/7057, Exp. 17.
} 
ínsulas del archipiélago. A falta de una aclaración explicita en la documentación sobre un trato diferenciado, es posible que tan solo se trate de una casualidad, ya que el destino de los cubanos era determinado desde la capitanía general algo que no sucedió en el caso de los filipinos en que fueron las autoridades peninsulares las que lo establecieron.

El número de antillanos fue complementado con la disponibilidad de asiáticos, lo que manifiesta un mayor desprecio hacia estos últimos con una base racial. Entre los cubanos buena parte de ellos eran blancos, lo que dificultaba su explotación en Fernando Poo. Por el contrario, teniendo en cuenta la composición racial de la población el porcentaje de relegados blancos entre los filipinos seria ínfimo o inexistente, lo que determinaba que prácticamente todos podían ser explotados. Además hemos de tener en cuenta la gran mortalidad que se había dado en los sucesivos intentos pobladores. La extensión de la insurrección a la colonia asiática ofrecía la posibilidad de probar con los procedentes de este archipiélago.

Por las fuentes no nos es posible afirmar categóricamente si realmente se trataba en su mayor parte de agricultores o si constituía únicamente una excusa. La información de que disponemos no va precisamente en este sentido. Entre los filipinos remitidos a Fernando Poo había toda clase de oficios y algunos con mayor importancia social que fueron destinados a Chafarinas. La distinción no fue entre campo y ciudad sino entre clases sociales. ${ }^{139}$ Miranda era tabaquero en La Habana, donde se produjeron redadas contra ñáñigos y cuatreros, por lo que incluso los catalogados bajo este último concepto pudieron no tener un perfil rural. Del resto, considerados traidores desconocemos la mayoría de los datos puesto que las autoridades coloniales en la mayoría de los casos ni siquiera se preocupaban de justificar la causa en los expedientes. Aun así, en ciertos casos se proporcionan algunos datos al respecto, por ejemplo Emilio Valdés Infante y otros siete residían en La Habana. Otros dos vecinos de la capital fueron llevados allí, uno por haber gritado "Muera España", el otro simplemente por considerarle infidente y otro por ser considerado como tal y haberse presentado. ${ }^{140}$ Por tanto, nada parece

\footnotetext{
139 "Distribución de los deportados procedentes de Filipinas que se encuentran en Barcelona en Espera de punto de destino", 24 de noviembre de 1896, AGMM, Ministerio de la Guerra, Ultramar, Filipinas, Caja 5439.

${ }^{140}$ Gobierno general de isla de Cuba a gobernador de la región occidental, 26 de febrero de 1897. Expediente de Tranquilino de Córdova y Veraza. Expediente de José de la Merced Capdevila. AHN, Ultramar, Leg. 5915. Expedientes individuales de deportados en la Guerra de Independencia cubana; Oficio de Gobierno general de la isla de Cuba a gobernador de la región
} 
indicar que se utilizara como un lugar específico concreto para esta profesión y más bien se trata de un destino considerado peor por las autoridades y que fue concebido como un castigo más severo. La remisión de los tenidos por traidores se correspondía con pertenecer a un estrato social más popular y por tanto, ser mayor la aversión de las autoridades hacia ellos.

Respecto de los miembros de la sociedad secreta de raíz africana, la prensa informaba en ocasiones que iban a Fernando Poo. Aunque también de que a partir de noviembre de 1896 los cubanos deportados iban a Figueras y a otros castillos de la Península, ${ }^{141}$ algo que tampoco es cierto. El número de antillanos en el territorio, como hemos comentado, fue bastante acotado de manera que estas informaciones en la prensa no se cumplieron. Los traslados a la isla africana de cuatreros e infidentes ha sido explicado y ninguno de los libros de testimonios ni de las fuentes de archivo habla de abakuás en isla africana. Miranda informaba de su embarque en el Ciudad de Cádiz y también como bailaban y cantaban durante el trayecto, mostrando bien poca simpatía por ellos, pero esto fue en el viaje a Cádiz y después ya nada dice de ellos. El propio Miranda dice que el Diario de la Marina de 28 de noviembre de 1896 informaba de que los ñánigos iban a Chafarinas, cuando en realidad la noticia decía que iban a Fernando Poo. ${ }^{142}$ ¿Qué podía provocar esta variación en un hecho del que como testigo era conocedor? Sin duda el conocimiento de que finalmente no fueron llevados allí. Todos estos serios indicios se ven corroborados por la documentación oficial que tras el decreto de indulto, del que fueron excluidos los abakuás, numera en 40 los que continuaban relegados allí: 39 cuatreros y el anarquista Manuel Miranda. Esto cuando los ñáñigos estaban en la documentación también perfectamente contabilizados en sus respectivos destinos. ${ }^{143}$

Esta aclaración se hace necesaria cuando en este caso concreto la información dada en la prensa puede llevar a confusiones, pero la documentación es clara, no hubo deportados clasificados como pertenecientes a la sociedad secreta en Fernando Poo en la Guerra de Independencia de Cuba. Es posible que alguno de los calificados en los otros

occidental de esta provincia, 19 de diciembre de 1896. AHN, Ultramar, Leg. 5914. Deportados, años 1896 y 1897.

${ }^{141}$ La Vanguardia, 5 de mayo de 1897; La Unión Constitucional, 13 de noviembre de 1896.

${ }^{142}$ Manuel Miranda, Memorias de un deportado, p. 11-12 y 15-16; Diario de la Marina, 28 de noviembre de 1896.

143 "Sitios donde residen los deportados no indultados". "Deportados existentes en 6 de octubre de 1898". AHN, Ultramar, Leg. 5007. Exp. 25; relación de los deportados que en 3 de febrero de 1898 residen en Fernando Poo. AHN, Gobernación, Leg. 238. 
grupos perteneciera a esta asociación, pero de producirse algún caso anecdótico seria puramente casual precisamente porque no se conocía su condición, ya que a los abakuás se les quería presos. ${ }^{144}$

Una vez en el territorio, el gobernador les hacía una alocución en la que les amenazaba con ejecutarles si intentaban escapar y con castigarles severamente en caso de molestar a algún español. Posteriormente les enviaba al barracón donde se agolpaban todos los que no habían podido obtener la libertad inmediata a su llegada, mediante la presentación de recomendaciones o el dinero. Así se producía una distinción inmediata, los que podían mantenerse por su cuenta que previa solicitud podían pasar a residir libremente. El resto tenían garantizada la alimentación básica con ración diaria y una pequeña ayuda mensual, pero algunos eran utilizados para arreglo de caminos, apertura de hoyos en el cementerio o cualquier otra ocupación que pudiera salir. Se les remuneraba con el sueldo establecido para los krumanes, o sea tres duros al mes. De estos trabajos forzados estuvieron exentos los blancos. ${ }^{145}$

La diferencia de trato es evidente, pero ello no quiere decir que este grupo resultara excluido del fomento de la colonización. No eran obligados a laborar directamente y teóricamente con el rancho, la asignación y la recolección de frutas tropicales hubieran podido ir subsistiendo. Sin embargo, según Miranda el cabo Fernández había aumentado el rigor y la vigilancia con aquellos que habían quedado en el barracón por no encontrar trabajo o no estar dispuestos a hacerlo por ese sueldo. De este modo se les incentivó a salir de allí como fuera, ya fuera buscando un empleo o dedicándose al cultivo de tabaco, café y cacao o como braceros en dichas plantaciones. Esto cuando existía la creencia de que los blancos no eran adecuados para esfuerzos prolongados en la isla, por lo que obligarles a laborar en tareas agrícolas era una falta muy grave de conmiseración respecto a ellos. Así se privaba al Estado de hacerse cargo de su manutención, además, explotarles a la vista de todos era contraproducente, pero que sus muertes se produjeran ocultas no suponía ningún problema para las autoridades.

\footnotetext{
${ }^{144}$ Esto invalidada las afirmaciones de Isabela de Aranzadi sobre las deportaciones e influencia ñáñiga en Fernando Poo, que no se debió a la Guerra de Independencia. Isabela de Aranzadi, "El legado cubano en África. Ñáñigos deportados en Fernando Poo. Memoria viva y archivo escrito", Afro-Hispanic Review, vol. 31, núm. 1, 2012, pp. 29-60.

${ }^{145}$ Emilio Valdés Infante, Cubanos en Fernando Poo, pp. 34-38; Manuel Miranda, Memorias de un deportado, pp. 26-27, 36 y 54. Únicamente a dos de ellos se les hizo trabajar con los negros, uno por haber robado un poquito de arroz y otro por negarse a continuar trabajando de cocinero para un practicante de la armada.
} 
El cometido que se les designó fue diferente. Muchos de los deportados convertidos en jornaleros agrícolas y colonos fallecieron, lo que hablaba plenamente de la inhumanidad de las autoridades que sabían que para que se produjeran algunos avances los decesos múltiples eran inevitables. ${ }^{146}$ No puede considerarse tan riguroso como la realización de trabajos para la autoridad, pero aun así fue letal en muchos casos. En cuanto a los peones agrícolas, los malos tratos y los abusos por parte de las autoridades facilitaban la extensión de estos a aquellos que habían encontrado colocación.

La mayoría no consiguieron progresar, de hecho lo más habitual era que los fallecidos no dejaran ninguna pertenencia, ${ }^{147}$ lo que indica que su prosperidad pese al esfuerzo fue muy limitada. Además, respecto a los que tenían algún bien es posible que lo hubieran traído consigo. La distinción en las ocupaciones basada en la raza no debe ser entendida únicamente como un desprecio hacia los cubanos de raza negra, ya que se hizo teniendo en cuenta a los fernandinos, a los que había que enseñar quien estaba encima de quien: los españoles de los antillanos por supuesto, pero también los blancos de los negros. Que capataces negros explotaran a los blancos era enviar un mensaje equivocado a los habitantes de la posesión. Por eso, la distinción que se hizo reforzaba la posición de superioridad de los colonizadores respecto de los nativos.

Las palizas y los malos tratos fueron habituales. Cualquier mínima falta era castigada con la "barra", en la que los deportados eran atados y golpeados y en la que permanecían varios días bajo el sol tropical. Una mujer filipina fue violada por el cabo. El trato no era mejor en el hospital, en el que los enfermos recibían una atención lamentable y padecían una carencia muy importante de alimentos. Prueba de la denuncia de las condiciones el número de fallecidos: desde el 17 de enero de 1897 hasta 3 de febrero de 1898 habían fallecido 139 relegados, de los cuales 99 eran filipinos y 40 cubanos. Entre los asiáticos, cuatro mujeres de las seis que habían sido trasladadas y un hombre y dos niños nacidos allí que fallecieron con posterioridad al recuento. ${ }^{148} \mathrm{De}$

\footnotetext{
${ }^{146}$ La experiencia así lo demostraba. Además, en aquel momento todavía existían prejuicios raciales pseudocientíficos que consideraban a la raza negra menos evolucionada y por tanto inferior intelectualmente, ver Consuelo Naranjo y Armando García, Racismo e inmigración en Cuba en el siglo XIX, pp. 152-164.

${ }^{147}$ Relación de los deportados cubanos y filipinos fallecidos desde 17 de enero a 29 de mayo de 1897. AGA, África-Guinea, Caja 81/8201. Únicamente 7 entre los 59 fallecidos entre el 17 de enero y 31 de mayo de 1897.

${ }^{148}$ Manuel Miranda, Memorias de un deportado, pp. 28-33, 39-40 y 71. Las cifras que da son muy aproximadas, pero difieren en unos pocos individuos de las oficiales; Emilio Valdés
} 
estos datos se observa una diferencia entre los fallecimientos de filipinos y cubanos a 3 de febrero de 1898 de cerca de un $47 \%$ en el primer caso y casi un $35 \%$ en el segundo. Esto no tiene que ver con un mayor desprecio hacia los procedentes del archipiélago asiático, sino que es la manifestación de las diferencias raciales. Dado que los blancos fueron exceptuados de los trabajos forzados, su mortalidad sería inferior a la del resto de grupos descompensando por tanto las cifras de antillanos y filipinos. Lo cierto es que las condiciones de los hombres de color fueron las mismas que las de los indígenas filipinos.

En las muertes hubo una responsabilidad del Estado que no puede ser disimulada. Esta siempre existió, incluso en el caso de los primeros transportes. En el caso del San Francisco de Borja, ante los continuos decesos enseguida se optó por sacarles de allí inmediatamente. En 1897, conociendo los precedentes nada puede servir de excusa. Menos todavía cuando no fue únicamente el clima el que produjo los fallecimientos. Los malos tratos y la obligación de trabajar en un clima inhóspito resultaron un escollo insuperable para muchos. Las supuestas intenciones colonizadoras no se cumplieron por cuanto primó la punición sobre los considerados traidores a la patria a una explotación efectiva y racional. Esto no quiere decir que no se pretendiera, sino que se hizo sin un plan claro y racional y con una gran ausencia de humanitarismo.

\subsection{El Gobierno de Sagasta y el regreso de los deportados}

La política de Cánovas de no escatimar medios ni hacer concesiones a los cubanos, había generado un costo económico y humano de grandes proporciones que

había agotado al país. ${ }^{149}$ Esto, unido a la creciente presión del coloso norteamericano y al temor que despertaba aconsejaba llevar a cabo una política más prudente. El asesinato de Cánovas y la llamada de Sagasta a la presidencia del Ejecutivo activaron una política que buscaba una respuesta militar menos cruenta combinada con la reactivación del

Infante, Cubanos en Fernando Poo, pp. 38-51; estado de deportados fallecidos en Fernando Poo desde 17 de enero de 1897 a 3 de febrero de 1898. AHN, Gobernación, Leg. 238; el ultimo deportado filipino falleció en julio de 1898. Relaciones de deportados fallecidos por mes. AGA, África-Guinea, Caja 81/6963; este ultimo fallecido era filipino. Deportados existentes a 6 de octubre de 1898. AHN, Ultramar, Leg. 5007, Exp. 25.

${ }^{149}$ José Antonio Piqueras, Cánovas y la derecha española. Del magnicidio a los neocon, Península, Barcelona, 2008, p. 56. 
autonomismo y un intento a toda costa de evitar la guerra con los Estados Unidos buscando incluso la mediación, infructuosa, de las potencias europeas. ${ }^{150}$

La permanencia en los castigos arbitrarios de buena cantidad de sujetos resultaba contraproducente con la nueva política de impulso del autonomismo y de consecución del apoyo de parte de la sociedad criolla. Las relegaciones administrativas por mucho que fueran un hecho público y notorio y que se había reproducido en todas y cada una de las guerras anteriores, suponían una actuación al margen de la ley. Por tanto, su reversión significaba una demostración de buena voluntad y la manifestación de que a partir de ese momento se iniciaba una nueva etapa de reconocimiento de derechos individuales que se extendería a los políticos. El intento de congraciarse con la opinión pública y enviar el mensaje de que la nueva política iba en serio, requirió la cesación de la situación en la que se encontraban los deportados políticos.

En 6 de diciembre de 1897 el Capitán general Ramón Blanco liberaba a 41 presos, comprometiéndose en breve en expedir indulto para los domiciliados forzosos en isla de Pinos. ${ }^{151}$ Esto significaba abrir la puerta a un autonomismo que hasta el momento había sido silenciado y presionarlo para posicionarse a favor del Gobierno. Tras el asesinato de Cánovas, Sagasta procedería al último intento por mantener la soberanía de Cuba, la autonomía. La tentativa animó a los autonomistas y supuso un inconveniente para los jefes rebeldes, que decretaron el ajusticiamiento de cualquier que llegara con ofertas de paz, y para los norteamericanos, cuya política de inmiscuirse progresivamente en la guerra por razones humanitarias resultaba mucho más fácil con la intransigencia de Cánovas y Weyler. Aun así, arribó en un momento en que el independentismo había ganado el espacio político. ${ }^{152}$

Esto suponía un último intento, a la desesperada, de mantener el dominio sobre la posesión, en el que no estaba ajena la tentativa de contemporizar con los Estados Unidos. Aunque tampoco en el plano internacional las cosas irían bien para España, ya que poco después, a principios de 1898, los norteamericanos declararon la guerra a España convencidos de que la contienda terminaría con la independencia, algo que no estaban dispuestos a permitir. Esto en un momento en que la causa cubana incrementaba su apoyo entre la sociedad norteamericana.

\footnotetext{
${ }^{150}$ José Ramón Milán García, Sagasta o el arte de hacer política, Biblioteca Nueva, 2001, pp. 405-407.

${ }^{151}$ Gaceta de La Habana, 6 de diciembre de 1897. Extraído de AHN, Gobernación, Leg. 238.

${ }_{152}$ Marta Bizcarrondo y Antonio Elorza, Cuba/España. El dilema autonomista, 1878-1898, Colibrí, Madrid, 2001, pp. 385-390.
} 
La real orden de indulto 15 de octubre de 1897 fue la que representó el cambio político, aunque fueron exceptuados los represaliados no políticos y Manuel Miranda. Los cuatreros y ñáñigos en teoría no ejercían actividades políticas, pero su traslado obedecía a razonamientos políticos de las autoridades por miedo a que se unieran a la rebelión o a que pudieran ser manipulados por el independentismo o por los insurrectos. En su caso se pensó que los inconvenientes de su retorno superaban a las ventajas, y por ello se decidió su permanencia en los puntos de destino. Al formar parte de sectores populares de la sociedad la prolongación de la situación anómala en que se encontraban suponía un costo político aceptable. El hecho de que permanecían en las peores condiciones no importó al Gobierno, al fin y al cabo esto era una decisión política y nada tuvieron que ver en la misma cuestiones humanitarias o legales.

Al estar exceptuados algunos grupos de la amnistía, las remisiones a la Península no se paralizaron de manera completa. Los 11 catalogados como cuatreros o abakuás que llegaron en mayo no pueden compararse con los centenares que lo habían sido con anterioridad. En 25 de octubre, apenas unos días después de la amnistía, fue llevado a isla de Pinos otro grupo formado por 15 blancos, un pardo y dos morenos. ${ }^{153}$ Lamentablemente desconocemos nada más acerca de estos, cuya represión se encontraba ya en marcha al decretarse el indulto, por lo que es posible que su destino sufriera una variación de última hora y fuesen embarcados hacia la pequeña isla, como un modo de que pasara desapercibida. Únicamente en el caso de Ceuta, ya a mediados de febrero, los ñáñigos pasaron a la condición de deportados, no permitiéndoles salir de la plaza, pero dejándoles dedicarse a su profesión u oficio. ${ }^{154}$ Pero esto constituiría un caso especial, por una cierta preocupación hacia ellos y por ser su presencia menor. La propia configuración de la ciudad, como una especie de recinto cerrado grande, facilitaba la aplicación de esta medida.

A pesar de la negativa al indulto colectivo algunos irían obteniendo la libertad de manera personal durante 1898. En 5 de octubre de 1898 restaban 506 individuos entre relegados y abakuás, lo que indica que 113 de los que había tras la real orden de indulto ya no estaban presos. Algunos habrían fallecido, pero la inmensa mayoría habían sido liberados. Esto no quiere decir que todos hubieran regresado a Cuba, ya que tenemos

\footnotetext{
${ }^{153}$ Puntualización a la relación de ñáñigos y cuatreros, 29 de mayo de 1898. AHN, Ultramar, Leg. 5007, Exp. 25; La Unión Constitucional, 25 de octubre de 1897.

${ }^{154}$ Oficio de Ministerio de Ultramar a Ministerio de la Guerra, 12 de febrero de 1898. AHN, Gobernación, Leg. 238.
} 
constancia de que a algunos se les dejó en libertad con la condición de que pasaran a isla de Pinos. ${ }^{155}$ El resto deberían esperar hasta su traslado, pero probablemente quedarían libres muchos lo que suponía una mejora en sus condiciones. El mismo proceso de salida paulatina se extendió a los presos, ya que en 16 de febrero de 1898 se dictó un indulto para los mismos que no afectó a todos, en Ceuta quedaban 309 en prisión. ${ }^{156}$

La mayoría de los que no fueron liberados permanecían en los presidios y en Fernando Poo, pero el cambio en las circunstancias políticas determinó que la prolongación de su situación resultaba insostenible. Perdida la guerra, lo más conveniente era la vuelta inmediata de los mismos. A partir del 6 de octubre de 1898 comenzó la repatriación generalizada tanto de los ñáñigos como de los prisioneros de guerra. El tratado de París, firmado en 10 de diciembre, obligaba al indulto de todos los represaliados como consecuencia de las insurrecciones separatistas antillana y filipina. En cuanto a los relegados, los que más dificultades tuvieron fueron los de Fernando Poo ya que las difíciles comunicaciones de la isla lo retrasaban. Para los rezagados, el Gobierno informaba en 15 de diciembre de 1898 a la Trasatlántica que embarcara a todos los deportados, incluyendo a los que había en la ínsula africana, en pasajes de tercera clase por cuenta del Estado. ${ }^{157}$ A partir de este momento se intensificó el retorno de los que quedaban, lo que suponía el fin de su periplo. El regreso junto a los penados, que al menos habían sido castigados tras ser juzgados, supuso el último de los abusos que estos últimos grupos soportaron del Gobierno español.

${ }^{155}$ Oficio de Ministerio de Ultramar a gobernador civil de Santander, 21 de enero de 1898. AHN, Gobernación, Leg. 238.

156 “Confinados" s/f, AHN, Ultramar, Leg. 5007, Exp. 25.

${ }^{157}$ Oficio de Ministerio de Ultramar a gobernador general de Fernando Poo y al representante de la Compañía Trasatlántica, 15 de diciembre de 1898, AHN, Gobernación, Leg. 238. 


\section{EPÍLOGO. HACIA UNA REFORMULACIÓN DE LA DEPORTACIÓN}

Un castigo legalmente cada vez más cuestionado

A finales del siglo XIX la deportación sufrió una reformulación en su aplicación. A nivel teórico, su utilización se planteaba cada vez más complicada puesto que rompía con uno de los principios penales más básicos, el de la proporcionalidad de los castigos. Fue tratada por primera vez en el congreso de la Unión Internacional de Derecho penal de Londres, en 1872, con una desaprobación generalizada. La hostilidad hacia la misma se hizo más manifiesta en los siguientes congresos celebrados en Estocolmo, en 1878, y San Petersburgo, en 1890. No obstante, en el de París, en 1895, la mayoría de los participantes se mostraron favorables y a principios del siglo $\mathrm{XX}$, todavía se discutía su adecuación. ${ }^{1}$ Al margen de lo decidido en el congreso de París, probablemente influenciado por la reanudación de la práctica en Francia, en el ámbito del derecho iba configurándose cada vez más como una figura extemporánea e inaplicable desde un punto de vista de la justicia con los reos. Tal y como estaba planteada en el Código Penal no era igual para todos los seres humanos, puesto que el rico podía sobrevivir sin problemas en el lugar de destierro y para la gente con pocos recursos podía poner en riesgo incluso su propia existencia. Esto desde un punto de vista legal, aquel que tenían en cuenta los juristas, aunque la praxis era bien diferente y transcurría por otros derroteros, ya que los trasladados fueron principalmente humildes y como hemos visto no fueron completamente abandonos por el Estado. Según las teorías jurídicas, la igualdad en la aplicación del derecho quedaba seriamente trastocada, y esto en un sistema cada vez más garantista suponía una contradicción imposible de resolver.

En Inglaterra, las relegaciones cesaron a partir de 1868 por diversas motivaciones. Las causas de su aplicación fueron diversas: controlar la delincuencia, atemorizar a ciertas capas sociales, reformar al convicto y colonización de la colosal isla de Australia. A nuestro juicio, la ultima es con diferencia la más importante sirviendo las otras como mera excusa su aplicación. Con la parte oriental del territorio repoblado, los últimos transportes se dirigieron hacia occidente: en junio de 1850 salió el primer

\footnotetext{
${ }^{1}$ Pedro Dorado Montero, “Deportación”, p. 757.
} 
embarque hacia el oeste y en enero de 1868, una vez asentada una población en la misma, la práctica desaparecía. Su finalidad no se explica únicamente por el cumplimiento de su principal objetivo, ya que la oposición social en el interior era cada vez mayor. De hecho, la finalización de la medida causó un estancamiento de la población y un desastre económico en la parte oriental. La de esta parte del territorio fue una colonización incompleta, dejada a medio hacer, pero en cualquier casó los envíos habían permitido repoblar un vasto continente en un tiempo mucho menor del que se hubiera conseguido con una emigración libre. ${ }^{2}$

El caso británico no es el único. En Francia, la ley de relegación de los reincidentes data de 27 de mayo de 1885, lo que produjo una reactivación en los embarques hacia Nueva Caledonia y, principalmente, hacia Guyana, donde las tasas de fallecimiento eran muy elevadas por el duro régimen disciplinario y la mala alimentación. ${ }^{3}$ Si bien las causas que la justificaban iban entrelazadas entre sí, esta claro que en el caso británico a Australia premiaba el fomento de su incorporación a la Corona, mientras que en el francés reinaugurado a finales del siglo iba dirigido a la eliminación de los delincuentes, al menos de la metrópoli. A finales del siglo XIX tenía más detractores que defensores, aunque también estos últimos tenían influencia y sus propuestas asomaban de vez en cuando en forma de debate y proposiciones. Algunos países, cuya influencia era menor, como Rusia y Portugal, mantenían el traslado de delincuentes a territorios inhóspitos o plazas ultramarinas.

A pesar de su inaplicación por vía judicial, el Código Penal de 1870 mantenía la figura para delitos contra los diputados y el Gobierno cuya totalidad de supuestos se dirimían con de deportación, confinamiento y destierro. ${ }^{4}$ Esto ampliaba lo dispuesto por su predecesor que la contemplaba en diversos delitos atenuados de rebelión. ${ }^{5}$ El mantenimiento en el Código Penal y la ampliación de los delitos comprendidos en el castigo, muestra que existía una voluntad de mantenerla vigente, posiblemente sin intención de utilizarla pero tampoco de denostarla definitivamente, porque podía ser

\footnotetext{
${ }^{2}$ Robert Hughes, The Fatal Shore: A History of Transportation Convicts to Australia, 17871868 , pp. 580 y 588. Según el autor se hubiera necesitado medio siglo más.

${ }^{3}$ Jean-Lucien Sánchez, La relégation des récidivistes en Guyane française, p. 14. La esperanza de vida de un trasladado entre 1887 a 1918 no llegaba a los seis años.

${ }^{4}$ Arts. 165-180. Código Penal de 1870. También se contemplaba para funcionarios públicos que disolviesen violentamente una reunión sin haber avisado dos veces con resultado de muerte. art. 234.

${ }^{5}$ Arts. 167-173. Código Penal de 1848.
} 
utilizada en sustitución de las ejecuciones en tiempos de revuelta políticas, aun cuando en estos supuestos no había sido aplicada.

En 1875, la Real Academia de Ciencias Morales y Políticas convocó un concurso titulado "¿Convendría establecer en las islas del golfo de Guinea o en las Marianas unas colonias penitenciarias como las inglesas de Botany-Bay?". La convocatoria, realizada dos años después de las masivas deportaciones que siguieron a las revueltas cantonales de 1873, muestra la relación entre ambos hechos. Los puntos de destino fueron precisamente los nombrados en el concurso, por lo que de algún modo se pensaba que eran los lugares más adecuados, aunque existían otros dominios: la mayoría del Archipiélago filipino estaba en la misma situación que estos emplazamientos y además habría que tener en cuenta a Puerto Rico y Cuba, con una idiosincrasia muy diferente. Precisamente a la Antilla mayor eran enviados la mayoría de los relegados en el periodo, pero el carácter de los mismos: pobres y de carácter rural, les hacía pasar inadvertidos. Al fin y al cabo, la cuestión era un problema de utilidad y los carlistas lo eran combatiendo en la Guerra de los Diez Años. El planteamiento era como cumplir el mismo objetivo con los de perfil urbano de 1873 , lo que implicaba también a parte de los represaliados que lo fueron por considerárseles delincuentes o por estar al borde de la misma.

Sometida la pregunta desde un punto de vista jurídico, la respuesta de los participantes fue en la misma dirección. La ganadora fue la intelectual Concepción Arenal, que abjuraba de esta figura al negar su justicia. Según ella, su aplicación podía ser cruel para hombres enfermos o mayores y no era proporcional al delito al aplicarse tanto a grandes criminales como a disidentes políticos. El trato en la posesión británica fue muy dispar y arbitrario y no llevaba en si los medios para corregir la conducta del sentenciado. Los condenados eran utilizados en beneficio del Estado y dejó de ser ejemplar con la prosperidad del país. Criticaba que hubiera sido utilizada como modo de desembarazarse de los delincuentes a un menor coste. ${ }^{6}$ Otros penalistas añadían defectos como su inmoralidad al corromper las costumbres de un determinado territorio, ${ }^{7} \mathrm{y}$ Groizard, desde un punto de vista técnico consideraba inviable que la relegación se

\footnotetext{
${ }^{6}$ Concepción Arenal, Las colonias penales de la Australia y la pena de deportación, Imprenta de Eduardo Martínez, Madrid, 1877, pp. 30, y 71-75.

${ }^{7}$ Florencio García Goyena y Joaquín Aguirre, Febrero o librería de jueces abogados y escribanos, Imprenta de Gaspar y Roig, Madrid, 1852, tomo V, pp. 147-148.
} 
ejecutara en África y Ultramar cuando castigos más graves no debían cumplirse en dichos espacios. ${ }^{8}$

A pesar de mostrarse en contra, según Arenal, el carácter inglés posibilitó el triunfo de la misma, algo que según su opinión no sucedería en España ya que no disponía de los recursos necesarios para llevar a cabo una colonización penitenciaria exitosa y no disponía de personal adecuado para realizar una buena administración penitenciaria. "El tesoro no se halla en estado de sufragar los muchos gastos que exige el enviar a países remotos, con seguridad, buenas condiciones higiénicas e instrumentos de trabajo, gran número de criminales". 9

Aun en el caso de que se pudiera llevar a cabo, explicaba que la cuestión sanitaria determinaría su fracaso. Caracterizaba a Fernando Poo, teniendo en cuenta los intentos de repoblación y las deportaciones efectuadas, como un lugar insalubre para los europeos. Consideraba que las Marianas no eran tan perjudiciales pero tampoco posibilitaban la prolongación de la residencia y trabajo de europeos sin que su salud resultase afectada. Los sucesos recientes avalaban esta opinión. Para ella, "El suelo no es tan fértil como el de Filipinas; el país está casi despoblado; no hay medios de subsistencia, y hasta que se crearan, todo habría de ser llevado de Manila, capital de un país semisalvaje". Aun así, la lejanía del archipiélago micronesio era demasiado grande para que el influjo de esta pudiera ayudarles de una manera definitiva. Siendo Filipinas un territorio pendiente de desarrollar, más cercano a un punto con población española y con una mayor presencia del Estado, la propuesta de las islas Marianas se desvirtuaba. ${ }^{10}$

La idea de Arenal era perfectamente clara, se trataba de una empresa incompatible con la moralidad, la justicia y la humanidad. Y si esto no importara lo suficiente, también con la economía. En la obra de Arenal se encuentran muy presente los derechos de los afectados, lo que es una muestra de su condición como pensadora, pero también de que los tiempos estaban cambiando y en 1875 los embarques forzados eran cada vez menos tolerables. Además, las remisiones debían hacerse con unas mínimas condiciones que garantizaran su supervivencia, algo que en el caso ingles con el que se muestra muy beligerante en el aspecto teórico pero alabando su éxito, tampoco se dio.

\footnotetext{
${ }^{8}$ Alejandro Groizard y Gómez de la Serna, El Código Penal de 1870 concordado y comentado, Imprenta de D. Timoteo Arnaiz, Burgos, 1872, tomo II, p. 491.

${ }^{9}$ Concepción Arenal, Las colonias penales de la Australia y la pena de deportación, pp. 43-45 y 83-84.

${ }^{10}$ Ibídem, pp. 85-93.
} 
En la misma línea iba la memoria de Pedro Armengol, ganadora del primer accésit, que resultaba ser una sucesión de argumentos contrarios al empleo de la colonización con penados. Desde cuestiones médicas a causa de la insalubridad de las Marianas y Fernando Poo, cosa que provocaría muerte o enfermedades y la censura a España del resto de naciones civilizadas. Consideraba su uso tal y como se había realizado hasta el momento como ilegal, puesto que había sido empleado para eliminar a la disidencia política por los gobiernos de turno al margen de la vía judicial. ${ }^{11}$ La consideraba antieconómica e inhumana, puesto que había costado la vida a miles de personas y la asimilaba a una especie de esclavitud blanca. Inglaterra, el país que mejor había empleado esta práctica la había suspendido y muchos otros estados habían renunciado a ella. ${ }^{12}$

El único que en la memoria estuvo de acuerdo con el sistema era Francisco Lastres, obra que obtuvo el segundo accésit. Lastres partía de una concepción patriótica de la posesión de estos archipiélagos, a los que presentaba como dotados de unas grandes posibilidades económicas y perfectamente habitables para los blancos. Según el autor, Fernando Poo era perfectamente saludable, el clima era bueno y no incidían las enfermedades que diezmaban la población en Europa y América. Las únicas dolencias eran las causadas por las fiebres típicas de la isla, que se combatían perfectamente con granos de quinina. También las Marianas gozaban de una posición ventajosa y de grandes posibilidades económicas. Proponía una colonización compuesta por europeos a ambos territorios y en el caso de que fuera cierto que los rumores de que las mujeres se volvían estériles en Fernando Poo, llevar a antillanos de raza negra. ${ }^{13}$ Establecía las causas del fracaso en la mala planificación.

"Más a pesar de las prescripciones legislativas, no se ha organizado nunca de un modo serio la colonización penitenciaria, sólo en momentos dados, y por medida gubernativa, se han enviado a Fernando Poo y a las Marianas a los conspiradores vencidos y algunas veces a los vagos y hombres de mala conducta; pero se ha procedido siempre sin método, sin preparación ninguna, y no es de extrañar por tanto, que los resultados hayan sido negativos". ${ }^{14}$

\footnotetext{
${ }^{11}$ Pedro Armengol y Cornet, ¿A las islas Marianas o al golfo de Guinea?, Imprenta y librería de Eduardo Martínez, Madrid, 1878, pp. 51-60 y 101.

${ }^{12}$ Ibídem, pp. 44, 60-63, 83, 90-104.

${ }^{13}$ Francisco Lastres, La colonización penitenciaria de las Marianas y Fernando Poo, pp. 37-38, $44-46$ y 60.

${ }^{14}$ Ibídem, pp. 30-31.
} 
Definía a la deportación como una pena que ha sido siempre utilizada por casi todas las naciones, a la que auguraba un gran porvenir y entronizada con la tradición española ya que estaba incluida en las Partidas. Proponía aprovechar la experiencia inglesa y la francesa, según él la mejor, para poder perfeccionarla. Se trata de instaurar un sistema de etapas en el que tras un primer periodo de aislamiento, se pasase a uno en que los presos realizasen tareas agrícolas o industriales y durmieran en la penitenciaria por la noche. En el caso de superar satisfactoriamente este periodo se les daría la completa libertad, dándoles tierras para que las cultivasen por su cuenta. ${ }^{15} \mathrm{El}$ autor partía de unas argumentaciones sesgadas que provenían de unas ideas preconcebidas, más que del verdadero conocimiento de las ínsulas y de lo que había acaecido en los sucesivos intentos de establecer población tanto por la vía de la inmigración como por la de las relegaciones. Posteriormente fue nombrado representante de España en el Congreso Penal de 1879, a raíz de lo que abjuró de su posición, "habiendo estudiado más a fondo el asunto, y después de los debates que presencie en el Congreso de Estocolmo, he cambiado radicalmente de opinión", escribió. ${ }^{16}$

En principio, dados los intentos precedentes en la isla de Fernando Poo con gente de todo tipo, desde presidiarios y opositores políticos peninsulares a emancipados y delincuentes cubanos y las enfermedades y muertes en que ellos derivaron, parecía poco recomendable organizar un sistema que contaba con el clima y las enfermedades tropicales como factor insuperable. Aun así, resulta digna de resaltar que ninguno de los tres hiciera referencia al sistema existente en Ceuta y que había demostrado que podía organizar un sistema exitoso de aprovechamiento de la población carcelaria. El desvío hacia Ceuta de los delincuentes con delitos más graves fue probablemente el motivo para que la deportación vía legal no terminara utilizándose, tal y como se hizo en los países del entorno. El enclave, por otra parte, formaba parte del territorio metropolitano a efectos jurídicos.

Queda claro que la mayoría de los juristas de la época no la consideraban adecuada como forma de lucha contra la delincuencia y mucho menos cuando la disidencia era por motivaciones políticas. Arenal había manifestado la iniquidad que

\footnotetext{
${ }^{15}$ Ibídem, pp. 23-28, 30 y 64-67.

${ }^{16}$ Francisco Lastres, Estudios Penitenciarios, Establecimiento Tipográfico de Pedro Núñez, Madrid, 1887, pp. 51-52 y 111.
} 
significaba mezclarlos con los reclusos por causas comunes. ${ }^{17}$ Lastres reiteraba esta injusticia y diseñaba un sistema en el solo hacía referencia a delincuentes, aunque especifica que todos los que fueran condenados a más de ocho años de cárcel debían ser llevados a las colonias penales, lo que pudiera dejar abierta la puerta a los opositores. ${ }^{18}$ Aun así, hemos de tener en cuenta que en caso de ser incluidos no eran el objetivo de la propuesta. Armengol era el más duro en este sentido, puesto que desaprobaba tajantemente los traslados de detractores y recomendaba para ellos la creación de un presidio específico en la Península. ${ }^{19}$

A finales de siglo únicamente algunos juristas conservadores pretendían mantener su vigencia. En 1895 Fernando Cadalso trataba de refutar los argumentos de Arenal y abogaba por un sistema al estilo francés, en la que los reos pasasen por diferentes etapas y se primase su rehabilitación y su utilidad al Estado. Esto significaría la extensión a otros lugares del sistema utilizado en Ceuta, con el objetivo de conseguir la regeneración del reo y defender a la sociedad. Para esto defendía aplicarla a gente con un perfil determinado: jóvenes, robustos y que hubieran sido castigados a cadena o reclusión perpetua o temporal. ${ }^{20}$

A pesar de que sus defensores eran minoritarios y de su inaplicación real, la plasmación de intentos vagos y dispersos en la legislación continuaron. Mediante real decreto de 26 de enero de 1889 se estableció una colonia penal con convictos peninsulares en la isla de Mindoro. Debería estar compuesto por 500 pesos y contemplaba la presencia de mujeres sentenciadas a reclusión temporal o perpetua y otras si lo hiciesen voluntariamente y a hombres punidos con cadena o reclusión perpetua o temporal. El proyecto finalmente no se llevó a cabo al igual que había ocurrido con las leyes anteriores, si bien es cierto que en esta ocasión se contemplaba con condenados a cárcel por delitos comunes.

Pronto se reformuló la situación de Ceuta que quedó como el punto designado para aquellos a los que se imponían ambas penas de presidio tanto temporal como perpetuo. Suponía la instauración de un sistema progresivo, aunque en la práctica la ley

\footnotetext{
${ }^{17}$ Concepción Arenal, Las colonias penales de la Australia y la pena de deportación, pp. 72-73 y 81.

${ }^{18}$ Ibídem, pp. 47 y 59-68.

${ }^{19}$ Pedro Armengol y Cornet, ¿A las islas Marianas o al golfo de Guinea?, pp. 107-109.

${ }^{20}$ Fernando Cadalso, La pena de deportación y la colonización por penados, pp. 11-13, 18, 31 y 46-48; sin embargo, el sistema establecido en Ceuta también tendría los días contados. Isabel Ramos La reforma penitenciaria en la historia contemporánea de España, Dykinson, Madrid, 2013, pp. 405-406.
} 
lo único que hacía era reformular lo establecido en la ordenanza general de presidios de 1834, que establecía que las condenas de más de ocho años debían cumplirse en las penitenciarías africanas. $^{21}$

Legalmente, tanto la teoría como la aplicación iban en contra de la realización de deportaciones. Existiendo un aprovechamiento del trabajo de los penados comunes por vía reglamentaria se entorpecía el desarrollo de un sistema de utilización de los disidentes, cuando su cuantía era mucho menor y su existencia inconstante. Ya hemos visto como las relegaciones se ejecutaban al margen de las leyes, pero la punición al margen de la legislación era cada vez menos tolerable. Al fin y al cabo, tampoco terminaba de tener sentido, ya que si eran los gobernantes los que implementaban las leyes, podían dictar las disposiciones que quisieran para reprimir a su gusto. Por los cambios que se estaban produciendo en la situación política y social, la represión favorable para el poder iba a producirse por otros derroteros.

\section{El cambio en las circunstancias políticas y sociales}

El Sexenio Democrático constituyó una ruptura de grandes dimensiones. A partir de 1848 y la creación al año siguiente del Partido Demócrata, el republicanismo pasó a conformar la oposición más radical, que armada había participado ocasionalmente en distintas insurrecciones que se habían producido como la Guerra dels Matiners o en los levantamientos producidos contra el Bienio Progresista. A partir de los años 60 adquirieron mayor importancia grupos de partisanos republicanos que combatían a las fuerzas gubernamentales y fueron uno de los factores desestabilizadores del sistema. La proclamación de la República supuso un duro golpe para las élites más conservadoras que vieron como un sistema al que aparejaban con la inestabilidad social podía llegar al poder. $^{22}$

Sin embargo, las ideas de emancipación social de los republicanos eran limitadas. Hacia mediados de la década de 1860 los socialistas fueron excluidos del

\footnotetext{
${ }^{21}$ Real decreto de 23 de diciembre de 1889. CLE, Imprenta del Ministerio de Gracia y Justicia, Madrid, 1890, tomo CXLIII, pp. 1435-1447; Ordenanza general de los presidios del reino, 14 de abril de 1834; en el Código Penal de 1870, la cadena y reclusión temporal mínima eran de 12 años y un día.

${ }^{22}$ ver José Antonio Piqueras, "Detrás de la política. República y federación en el proceso revolucionario español”, en José Antonio Piqueras y Manuel Chust (comps.), Republicanos y republicas en España, Siglo XXI, Madrid, 1996, pp. 1-43.
} 
partido y se aprobó una línea de colaboración con los progresistas para terminar con la monarquía de Isabel II. $^{23}$ Incluso en el caso de los republicano-federales estaban relacionadas con la coexistencia junto con el capitalismo de otras formas que permitieran la emancipación de colectivos de trabajadores agrupados mediante cooperativas. La creación de cooperativas de producción se intensificó en el Sexenio con el resultado de un sonoro fracaso. ${ }^{24}$ Esta doctrina, por muy escandalosa y perjudicial para sus intereses que pudieran parecer a las élites, no planteaba una reformulación total del sistema ni una desposesión de la riqueza que habían acumulado. De hecho, junto con ciertas medidas sociales, su programa iba más en la línea de extensión de los derechos políticos y este era el gran peligro que constituían para el poder, que mediante la consecución de estos las clases bajas consiguieran mejoras sociales.

El fracaso del cooperativismo y la disolución de la confianza del movimiento obrero frente a los republicanos tras la experiencia del Sexenio conllevaron la creación de organizaciones de clase autónomas. ${ }^{25}$ El peligro del republicanismo, formado en su base por un extracto popular pero cuya aportación estaba mediatizada por unas capas pequeño-burguesas o formadas por profesionales liberales, ${ }^{26}$ no era nada en comparación con el que representaban otras acciones políticas y sociales. Por su carácter que excedía de la simple oposición, la represión contra movimientos obreros como las huelgas de Barcelona en el Bienio Progresista, o agrarios como las sublevaciones de El Arahal de 1857 o de Loja en 1861, se habían caracterizado por su extraordinaria dureza. Las huelgas obreras y la petición de tierras entre los campesinos constituían una amenaza en sí, pero estos movimientos espontáneos, desorganizados y carentes de una estructura de carácter estatal o regional que los apoyara eran fáciles de dominar por las fuerzas de orden público. De ahí los intentos de limitación del asociacionismo obrero.

\footnotetext{
23 Demetrio Castro Alfin, "Unidos en la adversidad, unidos en la discordia. El partido demócrata, 1849-1868", en Nigel Townson (ed.), El republicanismo en España, p. 82.

${ }^{24}$ Francesc-Andreu Martínez Gallego, Esperit d'associació. Cooperativisme i mutualisme laics al País Valencià, Universitat de Valencia, Valencia, 2010, p. 80.

${ }^{25}$ Josep Termes, Anarquismo y sindicalismo en España, pp. 218-231, Manuel Morales Muñoz, El republicanismo malagueño en el siglo XIX, Asukaría Mediterránea, Málaga, 1999, pp. 95108.

${ }^{26}$ Pere Gabriel, "Insurrección y política. El republicanismo ochocentista en Cataluña”, en Nigel Townson (ed.), El republicanismo en España, pp. 351-352.
} 
La petición de inclusión en la vida pública del país y las reivindicaciones sociales como mejoras laborales o acceso a la propiedad de la tierra eran temidas por las clases altas por cuanto significaban que sus beneficios serían menores. Pero todavía lo eran más cuando iban acompañadas de doctrinas revolucionarias que preconizaban el reparto de la riqueza y las propiedades, lo que para los acaudalados significaba simplemente la desposesión. La expansión de las doctrinas socialistas y libertarias entre obreros y campesinos, supuso un cambio considerable. Los progresistas y los republicanos pretendían la extensión hacia abajo de los derechos de participación y la construcción de un verdadero liberalismo, pero al fin y al cabo representaban a la baja y media burguesía. Un grupo diferenciado de la élite social, pero cuyo proyecto no planteaban en esencia cambiar el modo de producción capitalista.

La aparición en escena de las clases bajas con un programa diferenciado, suponía un cambio sustancial en el perfil de la oposición, que pasó a estar constituida por los sectores más populares de la sociedad. El desprecio puramente social hacia estas se incrementaba por las doctrinas que profesaban de socializar los medios de producción y distribuir la riqueza, lo que significaba acabar con el capitalismo y la destrucción de la sociedad tal y como estaba establecida. Las deportaciones de las clases populares desde la Península fueron habituales en un Estado que no dudó en sacar provecho de las mismas. Realizadas principalmente sobre el carlismo, un grupo con un perfil ideológico muy bajo, el riesgo que implicaban también era muy bajo. Sin embargo, el caso de los izquierdistas, en los dominios siempre había sido más problemático. Desde los primeros liberales transportados a Cuba que fueron llevados a Pinos, a los relegados de 1848, que según la cultura política conservadora había significado el inicio del fin de la dominación del archipiélago, ya que se perdió el buen concepto que los nativos tenían de los españoles. ${ }^{27}$ Estas opiniones planteaban la dificultad de buscar una ubicación adecuada a los más izquierdistas, a los que se desvió hacia los espacios coloniales más alejados donde se les consideraba menos peligrosos.

La expansión del movimiento ácrata entre los trabajadores fue vista como una amenaza de grandes dimensiones por las élites. Esto, a pesar de que el anarquismo entre 1869 a 1874 tenía un programa basado en la acción pacifica, la asociación legal, el proselitismo y la huelga como instrumento de presión. La punición gubernamental fue

\footnotetext{
${ }^{27}$ Oficio de Consejo de Estado a ministro de Ultramar, 14 de octubre de 1885. AHN, Ultramar, Leg. 5221, Exp. 22. Aprobación de la orden dispuesta por el Gobernador general de Filipinas sobre los presos españoles en el archipiélago.
} 
cimentando una respuesta violenta, que en un principio fue principalmente teórica, pero que la persistencia en las represalias gubernamentales orientó hacia el terrorismo, practicado por pocos pero con amplia justificación entre la prensa libertaria, en una espiral que se retroalimentaba. ${ }^{28}$

La represión del anarquismo significó continuar de algún modo con la versión más social de la misma. Las malas cosechas en Andalucía en los años 1881 y 1882 provocaron un malestar social muy fuerte con robos, incendios, invasiones de fincas, tumultos, peticiones de trabajo a los ayuntamientos y quejas por los bajos sueldos y por la falta de trabajo. ${ }^{29}$ En este contexto de carencias y temor por las consecuencia sociales que estas podían acarrear se produjeron tres crímenes en la provincia de Cádiz, que ante la presión sensacionalista de los medios se atribuyeron a una organización revolucionaria denominada la "Mano Negra". Las detenciones ascendieron a más de $1.000 .^{30}$ Siete personas fueron ejecutadas y el resto, alrededor de una docena, condenadas a penas de prisión. ${ }^{31}$ El número de detenidos y ejecutados y el desvío de la atención hacia la Federación de Trabajadores de la Región Española, hace que la mayoría de historiadores la consideren un montaje. Pero que unos hechos aislados derivasen en una punición de tal calado hacia los ácratas muestra claramente el temor que se le tenía a lo que significaba la organización de los jornaleros en un contexto de malas cosechas. La respuesta a la "Mano Negra", auguraba un incremento en el despotismo del Estado.

Las diversas acciones terroristas que derivaban en castigos brutales y masivos, generaban mayor radicalidad e incrementaban el apoyo social entre los partidarios de la acción directa. En este contexto, la actuación gubernativa derivó hacia acciones diferentes a la deportación. El 8 de febrero de 1892 cuatro obreros jerezanos fueron ejecutados por la sublevación en esa ciudad. El 5 de abril del mismo muchos anarquistas extranjeros fueron expulsados tras un supuesto complot para poner una bomba en el

\footnotetext{
${ }^{28}$ José Álvarez Junco, La ideología política del anarquismo español (1868-1900), Siglo XXI, Madrid, 1991, pp. 483-510.

${ }^{29}$ Antonio López Estudillo, Republicanismo y anarquismo en Andalucía. Conflictividad social agraria y crisis finisecular (1868-1900), La Posada, Córdoba, 2001, pp. 333-352.

${ }^{30}$ Demetrio Castro Alfin, Hambre en Andalucía, antecedentes y circunstancias de la mano negra, Ayuntamiento de Córdoba, Córdoba, 1986, pp. 169-171.

31 Juan Avilés Farré, La Daga y la dinamita. Los anarquistas y el nacimiento del terrorismo, Tusquets, Barcelona, 2013, pp. 156-158; los atentados terroristas entre 1888 a 1909 en Rafael Núñez Florencia, El terrorismo anarquista (1888-1909), Siglo XXI, Madrid, 1983, pp. 43-83; ver Clara E. Lida, La Mano Negra. Anarquismo agrario en Andalucía, Zero, Madrid, 1972.
} 
Congreso de los diputados. El 24 de septiembre de 1893, el intento de asesinato de Martínez Campos se saldó con la ejecución del perpetrador. A raíz del atentado del Liceo se decretó la expatriación de todos los ácratas forasteros y la vigilancia sobre los nacionales. Al menos en Barcelona la expulsión con destino al territorio francés se produjo en un número indeterminado y seis fueron ajusticiados en relación con el ataque el día 21 de mayo de 1894 y otro el 21 de noviembre. La bomba en el día del Corpus dio lugar a entre 359 a 424 detenciones, abarcando no solo a vinculados a grupos relacionados con la violencia sino también a republicanos y otros ácratas pacíficos o anticlericales. Ocho personas fueron condenadas a muerte, de las que fueron ajusticiadas cinco, y 68 a distintas penas de prisión. ${ }^{32}$

Únicamente en los procesos de Montjuic se planteó la utilización de la deportación para los anarquistas, pero para los 63 que habían sido absueltos ${ }^{33}$. Por la saturación de Fernando Poo en ese momento por la presencia de los relegados cubanos y filipinos se pensó en embárcales hacia Rio de Oro en el General Valdés, pero poco después se suspendió la medida y se dio prioridad al envío al extranjero, ${ }^{34}$ llegando a 27 a la Liverpool en el Isla de Luzón el 28 de julio. ${ }^{35}$ El 12 de junio previo, otro grupo de 52 había sido abandonado en el municipio francés de Cerbère, fronterizo con Portbou y otro contingente lo seria con posterioridad. El Ejecutivo español pidió permiso a Londres para trasladar a una cuadrilla de libertarios, pero sin especificar que eran los de Montjuic, por lo que el Gobierno británico se negó a aceptar a ninguno más. Respecto a Francia, tras la primera expulsión hubo un acuerdo sobre el procedimiento. ${ }^{36}$

El objetivo planteado, los inocentes, muestra cómo se consideraba como una corrección demasiado trivial para lo que el anarquismo, tanto el violento como el pacifico, representaba. Fue planteada para gente contra la que no se sabía que hacer por ser inocentes del atentado pero concienciados con “el ideal”. Con los inculpados se tenía claro como reprimirles y también como obtener confesiones y delaciones. Las quejas de

\footnotetext{
${ }^{32}$ Eduardo González Calleja, La razón de la fuerza, pp. 267-286; también en el caso de Jerez, el dirigente sindical José Sánchez Rosa y otros fueron condenados a prisión en el Hacho. AGA, África-Guinea, Caja 51/3486, Exp. 139. José Sánchez Rosa y otros solicitan indulto de 26 de enero de 1900

${ }^{33}$ La Unión Católica, 1 de mayo de 1897. Según el periódico 5 fueron ejecutados y 20 a penas de prisión de entre ocho y veinte años, por lo que es posible que a algunos de los condenados con anterioridad a prisión se les absolviera finalmente en la revisión efectuado por el Consejo Supremo de Guerra y Marina.

${ }^{34}$ La Época, 8 de junio de 1897.

${ }^{35}$ La Época, 29 de julio de 1897.

${ }^{36}$ Eduardo González Calleja, La razón de la fuerza, pp. 287-288.
} 
los remitidos en los distintos viajes del siglo hacían referencia a las malas condiciones de estancia, la vigilancia, las carencias, la rigurosidad en el embarque e incluso en alguna ocasión a castigos físicos y malos tratos durante el viaje. Pero aun en el caso de la violencia física no formaba parte intrínseca de la acción estatal y no se hablaba de torturas, algo que ahora se producía con profusión, en una muestra del desmesurado desprecio y temor que se les profesaba. Indudablemente estamos hablando de un desafío nuevo que requería para el poder una postura incluso más autoritaria, elemento que no solo tiene que ver con este movimiento pero se manifestó en su mayor grado contra él. La mayor rigurosidad manifiesta la tendencia hacia un progresivo endurecimiento de la represión política que por ejemplo en el caso del independentismo cubano pasaría desde la simple deportación en la Península al confinamiento en plazas cada vez más reducidas y a prisiones administrativas en el caso de los ñáñigos.

Para hacer frente a los actos terroristas que grupos minoritarios ejercían, como influencia de la acción gubernamental y el contexto internacional, ${ }^{37}$ el Estado entre 1880 y 1887 promulgó una serie de leyes para impedir la difusión de las ideas y simbología ácrata, así como controlar el asociacionismo obrero y sus manifestaciones de carácter anarquista. En 10 de julio 1894 se promulgó la ley contra los atentados mediante explosivos, que trataba de cubrir el vacío existente en el Código Penal de $1870 .^{38}$ En la misma se contemplaba la pena de muerte para casos en que resultaren heridas o muertas personas o hubiere riesgo de ello, y distintos grados de presidio en función de la gravedad de los hechos, pero no se incluía la relegación. La disposición fue modificada por la de 2 de septiembre de 1896 que colocaba bajo la jurisdicción de guerra a los implicados en estos actos, endurecía la punición e intensificaba las represalias contra los centros de reunión y propaganda. La ley contemplaba en su artículo cuarto la salida del país de los que formasen parte de asociaciones libertarias o difundiesen estas ideas y en caso de regresar se les condenaría a "relegación a una colonia lejana". Lo prioritario era la muerte o la cárcel, según la gravedad y solo para casos de proselitismo preconizaba la expulsión del territorio nacional. A causa de que no se les podía impedir el regreso desde el extranjero, era tenida en cuenta solo como último caso frente a la inevitabilidad de tenerlos en la metrópoli.

\footnotetext{
${ }^{37}$ Ángel Herrerín López, Anarquía, dinamita y revolución social, pp. 86-92.

${ }^{38}$ Eduardo González Calleja, La razón de la fuerza, pp. 270 y 274.
} 
La única voz que pretendía su aprovechamiento en beneficio del Estado era la de Cadalso, que en 1896 proponía la muerte y la deportación como los mejores métodos represivos contra los ácratas. Se mostraba contrario al extrañamiento porque significaba endosarle el problema a otra nación por lo que proponía la colonización penitenciaria que implicaba el aprovechamiento de su trabajo pero permaneciendo sin contacto con la sociedad. Como lugar de destino proponía las Filipinas donde creía que tanto los anarquistas como los presos comunes podían ser el germen de una inmigración libre que creara riqueza y que sirviera para asegurar la posesión en la isla. ${ }^{39}$ Las ideas de Cadalso, ya bastante extemporáneas para su tiempo no fueron aplicadas más que en el caso de la muerte, pero no se debió a su influencia ya que el poder tenía sus propias pretensiones en la punición sobre este movimiento.

La pérdida de las colonias.

Al llamado "desastre del 98" no siguió una conmoción política en España de grandes dimensiones. La Corona y los partidos dinásticos siguieron ejerciendo el control del país y las agrupaciones rivales: carlistas y republicanos se mostraron impotentes en aprovechar la debacle. Dos caminos surgieron a raíz del impactó que el 98 tuvo en las conciencias, uno de carácter democrático y social y otro de carácter antiliberal, militarista y autoritario. ${ }^{40}$ Este último evolucionaria hacia un desprecio total de adversario político que en general dejó poco margen para la relegación, pero en lo inmediato el castigo tal y como se entendía en el siglo XIX iba íntimamente ligado a la condición de colonia. Las ventajas eran evidentes, la lejanía implicaba necesariamente su prolongación. Además existía un componente de establecimiento de una población europea que en el caso español apenas tuvo resultados tangibles, pero que se aprecia en las sucesivas leyes, inconexas e incumplidas a partes iguales, que fueron apareciendo. La experiencia inglesa exitosa en Australia y la práctica en otros estados, con resultados dispares, no permanecieron al margen.

En los inicios de la Restauración, España cada vez tenía menos colonias en las que efectuar el traslado. Físicamente eran las mismas, pero el espació que la nación

\footnotetext{
${ }^{39}$ Fernando Cadalso, El anarquismo y los medios de represión, Romero, Impresor, Madrid, 1896, pp. 10-41, 46, 49-50 y 87-88.

${ }^{40}$ Juan Pro Ruiz, "La política española en tiempos del desastre”, en Juan Pan-Montojo (coord.), Mas se perdió en Cuba. España, 1898 y la crisis de fin de siglo, Alianza, Madrid, pp. 250-253.
} 
ocupaba en ellas era cada vez menor, especialmente en ciertos lugares. En Cuba, el independentismo había sido capaz de retar al Gobierno mediante una guerra abierta durante trece años casi ininterrumpidos. Tras el fin de la Guerra de los Diez Años, es innegable que algo había cambiado y que el proceso de pérdida de apoyo social estaba avanzado. El autonomismo constituyó el último intento de conciliar la permanencia en el Estado con la obtención de reformas y autogobierno, pero su fracaso daría lugar posteriormente a una nueva guerra. Teniendo la opinión que se tenía del anarquismo, el envió a la Antilla mayor de los ácratas más comprometidos, donde podían participar en huelgas, hacer proselitismo, o incluso colaborar en actos terroristas no era factible. Las posesiones eran lugares cada vez más hostiles en los que depositar a los opositores era una opción cada vez menos viable.

En cuanto a las relegaciones con origen en las colonias, la extensión de las ideas separatistas en las mismas constituyó la otra cara del mismo proceso. El intento de mantenerlas aisladas del mundo tan solo pudo retrasar la extensión del antagonismo político. Pero una vez este se había formado, la rigidez de la posición española y su reticencia a cualquier cambio determinaron el decantamiento por la independencia, fomentada por la ausencia de derechos, la rigidez del sistema y el destino de las mismas para beneficio económico de la metrópoli. Una vez que el separatismo se hizo hegemónico, una forma de lidiar con él fue la utilización de las deportaciones. De ahí las realizadas en las guerras de independencia cubanas y en las Filipinas a partir del crecimiento de los partidarios de la autodeterminación. Al producirse el fin de la dominación española, su utilización necesariamente iba a circunscribirse al restringirse la población bajo soberanía del Estado.

Esto teniendo en cuenta que España siempre había tratado de que la Antilla mayor permaneciera incomunicada por sus especificidades. Incluso en el archipiélago asiático, territorio con una población europea ínfima y en el que la presencia de transportados podía aportar ventajas en cuanto a la extensión de su población, existía la idea de que la presencia de disidentes era perjudicial. De ahí que los remitidos en 1848 a Manila se transformaron en los de 1873 a Marianas, en un intento de que sus doctrinas no entraran en contacto con la población nativa, o visto de otro modo, en un intento de ocultar como parte de la "bondadosa" población blanca oprimía a otra gente de su misma raza. 
Fernando Poo era diferente al no existir un movimiento independentista. Pero el hecho de que tanto en la Guerra Chiquita como en la Guerra de Independencia fuera el destino de grupos de cubanos la hacían inconveniente para ubicar a los represaliados peninsulares en esos periodos. Además, como hemos comentado, el perfil de los oponentes en la metrópoli estaba cambiando. Desde el poder se consideró que el anarquismo constituía en ese contexto determinado una ideología prácticamente vedada en las colonias. O al menos los más peligrosos de ellos, aunque es cierto que la emigración libre ya había comenzado a expandir las ideas ácratas en la isla en las últimas dos décadas de la centuria. ${ }^{41} \mathrm{El}$ temor a la militancia de los represaliados en las posesiones, que de una manera más limitada ya sucedía con el liberalismo se incrementó de manera exponencial con el movimiento libertario. Paralelamente al crecimiento de su peligrosidad en el exterior, se produjo una disminución en el interior, porque si el liberalismo era una ideología que se había expandido, con sus diferencias, por todo el territorio nacional, las reivindicaciones obreras y campesinas necesitaban de unas ciertas condiciones: industria y explotación, o desempleo obrero en un caso, y malas condiciones en el trabajo campesino y mala, o nula, distribución de la tierra en el otro.

El movimiento obrero estuvo focalizado principalmente en ciertas zonas del País Valenciano como Alcoy, País Vasco o Cataluña, y a la circunscripción de las reivindicaciones agrarias en los lugares en los que existían grandes latifundios agrarios, principalmente Andalucía. Fuera de esos lugares las ideas que preconizaban el reparto de la propiedad eran de difícil aceptación, lo que dejaba abierta la posibilidad del empleo de destierros a otros puntos de la Península. Las expulsiones a Francia fueron muy usadas en tiempos de la dictadura de Primo de Rivera. Ello no implica que no se utilizara la deportación contra anarquistas en casos puntuales, pero el temor que se les profesaba era tanto que en ocasiones se trataba de expulsarles de España tratando de trasladar el problema a otros lugares. Esto supone la aparición de una concepción más moderna de la relegación, que en el siglo XIX iba irremediablemente unida al espacio ultramarino. Únicamente con ciertos gobiernos más tolerantes como en la II República, esta concepción reapareció precisamente porque suponía un castigo menor al de los

\footnotetext{
${ }^{41}$ Amparo Sánchez Cobos, Sembrando ideales, Anarquistas españoles en Cuba (1902-1925), CSIC, Madrid, 2008, pp. 104-115.
} 
fusilamientos que consideraban injustificables. También El Sahara se utilizó en los primeros momentos de la guerra como depósito de prisioneros antifascistas. ${ }^{42}$

Sin embargo, el movimiento obrero y campesino no constituía la única disidencia. Desde sectores liberales y republicanos burgueses, se alzaron voces contra los tintes cada vez más autoritarios de los ejecutivos. Estas voces, sin duda aisladas, eran molestas e incomodas por ser ejercidas por personalidades con gran prestigio a las que se trató de silenciar. De nuevo su ambigüedad facilitaba que se adaptara a ciertos casos y este fue uno de ellos. Encerrar a personalidades relevantes por sus opiniones podía suponer un desgaste para el Gobierno por la injusticia que suponía y porque la repercusión podía ser mayor. Por el contrario, los envíos a ciertos lugares suponían limitar de manera significativa las posibilidades de propagación de las críticas al Ejecutivo, sin tener que recurrir a los encarcelamientos. El caso de Miguel de Unamuno y del diputado por Valencia Rodrigo Soriano, llevados en Fuerteventura en 1924 por criticar a la dictadura de Primo de Rivera, puede englobarse en esta categoría. Ambos se fugaron apenas unos meses después de su llegada. ${ }^{43}$ A Chafarinas fueron llevados algunos, como Jiménez de Asua, transportados en 1925 y que estuvo únicamente quince días. $^{44}$

De este modo, la relegación no desapareció, pero cambió para centrarse sobre un número más limitado de individuos y más localizado y solo en épocas de mayores convulsiones se empleó de manera más profusa rescatándose en estos casos el espacio ultramarino. O más bien dicho, derivándose en parte hacia otros territorios como el Ifni o el Sahara occidental, auténticos enclaves españoles en un área efectiva de control muy reducida, y en el caso del Sahara con un espacio circundante prácticamente letal, lo que le confería un amplio sentido carcelario y una disposición colonizadora nula. El castigo adquirió tintes cada vez más restrictivos en consonancia con la significancia del

\footnotetext{
${ }^{42}$ Ver Guadalupe Pérez García, "La colonia penitenciaria de Villa Cisneros. Deportaciones y fugas durante la Segunda República", Historia y Comunicación Social, vol. 7, 2000, pp. 169186; José Rial, Villa Cisneros. Deportación y fuga de un grupo de antifascistas, Ediciones Españolas, Valencia, 1937; José Ramón Diego Aguirre, Historia del Sahara Español, Kaydeda, Madrid, 1998; Jesús Giráldez Macía, Creyeron que eramos rebaño. La insurrección del Alto Llobregat y la deportación de anarquistas a Canarias y África durante la II República, Zambra Iniciativas Sociales, Málaga, 2009.

43 Sebastián de la Nuez Caballero, "Unamuno en Fuerteventura", Anuario de Estudios Atlánticos, núm. 5, 1959, pp. 133-236. El 28 de febrero ambos fueron embarcados en el Atlante, llegaron el 4 de marzo a Fuerteventura. El 9 de julio se fugaron a Las Palmas, donde llegaron el 11, el mismo día que se decretó una amnistía para delitos políticos.

${ }^{44}$ Juan Pedro Yañiz, La crisis del pequeño imperio español, Dirosa, Barcelona, 1974, p. 121.
} 
anarquismo y la evolución de la condena, imponiéndose en algunos casos aislados, como el traslado al castillo de la Mola del Noi del Sucre y otros 35 sujetos, en un contexto de pistolerismo que acabó con la vida de 22 personas en Barcelona entre el 9 y el 30 de noviembre de $1921 .^{45}$

En este sentido, la deportación en el siglo XIX conjugaba la neutralización del adversario político con el aprovechamiento de su trabajo o de su simple estancia en un lugar determinado. Con la pérdida de la utilidad para el Estado de los opositores, estos pasaban a ser además de peligrosos, disidentes y cuantos adjetivos negativos eran capaces de colocarles. La desestimación de su capacidad de trabajo y la presentación como individuos cada vez más deleznables influyeron de una manera importante en los cambios en la práctica en los años 30 y 40 del siglo XX. El proceso culminó con el nazismo, donde a falta de colonias y conmiseración con las víctimas, el enemigo ni siquiera merecía vivir. De este modo, la gente ya no era alguien a quien se expulsaba a Ultramar, ya que eso era demasiado "humano" para ellos. Debían ser eliminados mediante el asesinato en cadena o por no ser capaz de soportar los trabajos inhumanos a que eran sometidos.

La versión española del fascismo, el régimen franquista, se apropió de esta máxima ejerciendo una represión brutal. La cárcel y el presidio fueron los ejes fundamentales en su acción gubernamental porque la deportación permitía seguir libre y vivo a aquellos que eran considerados enemigos acérrimos. Según su concepción la medida no tenía sentido, puesto que les permitiría ejercer de antiespañoles en los lugares donde residieran. Únicamente en casos puntuales se utilizaría con gente como el carlista Fal Conde, que aunque discrepante formaba parte del mismo bando en la guerra y con el que no era recomendable extralimitarse. El carlista estuvo apenas desde octubre a diciembre de 1941 en Ferrerías (Menorca), tras lo cual se le permitió pasar a Sevilla. ${ }^{46}$ En una modalidad más cercana al confinamiento que a la relegación del siglo XIX.

Sabiendo que les esperaban la muerte y la cárcel, muchos optaron por el exilio, de manera que las salidas del país no fueron impuestas directamente por el Estado, sino

\footnotetext{
${ }^{45}$ Manuel Cruells, Salvador Seguí. El Noi del Sucre, Ariel, Esplugues de Llobregat, 1974, pp. 136-146. Desconocemos las condiciones en que estuvieron en el Castillo, pero dado que no había sentencia probablemente no estarían recluidos en sentido estricto y podrían deambular aunque fuera por dentro del castillo.

${ }^{46}$ Stanley G. Payne, Identidad y nacionalismo en la España Contemporánea El carlismo, 18331975, Actas, Madrid, 1996, p. 161; con anterioridad Fal Conde había estado desterrado en Portugal tres el decreto de unificación política de 1937, donde permaneció hasta su regreso en 1941.
} 
que fueron los propios perseguidos los que "optaron" por ella porque no tenían otra posibilidad. La neutralización franquista del oponente pasaba por su neutralización expeditiva, el exilio junto con un férreo control ideológico, político y policial y el agotamiento de la oposición le permitieron mantener la estabilidad en el interior. En este proyecto, la disposición no desapareció, pero si su esencia colonial. El proyecto de asesinato eficiente y de trabajos forzados más allá de los límites de la capacidad humana, permitió la inclusión de españoles en esta maquinaria desarrollada para el asesinato masivo, con el consentimiento el propio régimen franquista. De este modo, el cambió de la deportación del siglo XIX a la nueva sin vinculación con Ultramar también ocurrió en España, suponiendo el fin definitivo de la vieja práctica, ya que para el régimen no era adecuado enviar a las escasas posesiones que mantenía el país a los considerados traidores. 


\section{CONCLUSIONES}

Las carencias en el conocimiento de la represión política en general y de la deportación en particular, requerían de un minucioso trabajo de investigación. A raíz de la averiguación de los embarques efectuados gracias a pequeñas referencias dispersas en el tiempo parecía lógico pensar que esta práctica no hubiera surgido de la nada, que hundía sus raíces en los tiempos precedentes y que había sido empleada con profusión como elemento punitivo por parte del Gobierno. Daba la impresión de que algo se escapaba, por ejemplo, los 66 fusilados y unos 600 presos en la revuelta de San Gil pueden expresar una explicación convincente de las represalias, pero implicaba que el Ejecutivo hubiera renunciado a un blindaje preventivo mediante la relegación y el traslado de militares liberales. Lo mismo ocurre con el carlismo, en el que la explicación oficial era que todos los prisioneros eran fusilados y precisamente para evitarlo se firmó el Convenio Eliot. Aunque en la realidad la deportación se utilizaba con anterioridad al mismo, si atendemos a la explicación oficial tendríamos que preguntarnos qué se haría con los presos carlistas tras la firma del mismo. Dejarles a todos en prisiones y depósitos significaba una infraestructura ingente y un riesgo de huida o rescate que había que tener presente. Hechos de la guerra como las expediciones hacían pensar sobre ello.

Atendiendo a lo acontecido en los estados de nuestro entorno, especialmente en Francia, que tantas veces ha servido de inspiración para nuestro país, donde se llevaron a cabo remisiones a las colonias tanto de reincidentes como de oponentes políticos parecía que posiblemente en España la relegación hubiera sido un castigo ampliamente impuesto. Al menos en el caso de los delincuentes comunes puede considerarse que se cumplían a grandes rasgos los parámetros en los países del entorno. El Gobierno inglés sacaba a los pequeños delincuentes de su tierra natal y los embarcaba hacia Australia porque allí eran más útiles al Estado. El Ejecutivo español utilizaba a los presos comunes con mayores condenas en la construcción de instalaciones militares en Ceuta porque era allá donde mejor servían a sus intereses. El hecho de que los territorios de destino fueran posesiones o no, tenía una importancia menor, lo que realmente fue trascendente era la utilidad. 
¿Podía este mismo provecho alcanzar a la disidencia política? En los países del entorno la respuesta era sí, y en el nuestro también. Sin embargo se aprecian diferencias, en España la medida sirvió para desembarazarse de los detractores sin un plan para un mejor aprovechamiento de los mismos que se fue improvisando, algo que no sucedió del mismo modo en los otros países, donde había unas reglas perfectamente estructuradas, tal y como sucedía en Ceuta con los presidiarios españoles. La espontaneidad privó al Estado de una mejor explotación de la fuerza de trabajo de estos individuos y a ellos de una correcta tutela gubernamental. La falta de una estrategia establecida a largo plazo y coherente sobre la aplicación de los traslados nos hace pensar en su utilización por gobiernos de signos diferentes en periodos diferentes. La vaga referencia a lo sucedido con anterioridad puede ser una explicación, pero el elemento central que determinó su uso fueron los beneficios que acarreaba.

La deportación permitía realizar una represión de gran alcance numérico sin recurrir a los fusilamientos que no hubieran podido ser empleados en un grado tan elevado. Si el fusilamiento de 66 personas es considerado un hecho atroz, y sin duda lo era, la remisión forzada de varios cientos podía pasar mucho más desapercibida, y de hecho lo hizo. También estaban las prisiones, en ocasiones se mantuvieron presos a muchos opositores durante un tiempo largo, pero esta opción era más visible puesto que la prisión estaba cerca del lugar donde vivían los detenidos. Además, a pesar de que hubo excepciones se tendía a que los presos tuvieran que ser condenados mediante juicio que requería la aportación de algún tipo de prueba. La relegación, por el contrario, permitía el embarque inmediato sin tener que demostrar la culpabilidad de nadie y precisamente por esto facilitaba el cometido del poder en tiempos en que se sentía débil o quería demostrar fortaleza. Adquirió entidad propia como una forma correctiva del Estado que complementaba a las otras, mejor conocidas. En tiempos de convulsiones y revueltas se optó por el desembarazo apresurado.

Acudir a la legislación ha sido el error tantas veces repetido, de ahí que entenderla como un hecho administrativo ha sido lo que ha permitido desenmascarar la práctica. Recurrir a la regulación legal de la misma, tanto en el Código Penal como en las distintas leyes que establecieron los lugares preferentes de destino o dictaban la creación de presidios, ha provocado que permaneciera oculta. A priori, desde el desconocimiento, parecía que debería transcurrir por los cauces normativos y que en términos generales se cumpliría lo estipulado en ellas referente a que los deportados 
debían estar libres en el punto de destino. En realidad, esto no derivaba únicamente de los artículos del Código Penal, ya que desde el poder se conocía perfectamente la ilegalidad de las medidas represivas ejecutadas y como modo de "resquicio legal" se estipulaba su libertad en los puntos de remisión. De este modo, la relegación no se aplicó por esta vía, pero en general se tuvo en consideración lo que la normativa imponía y de ahí la evolución en los diferentes códigos penales. Este no fue el único elemento, porque una vez neutralizada su presencia allá donde eran peligrosos, sin sentencia condenatoria no se requería de su prisión. Fue visto como una transgresión temporal de la norma por parte de las autoridades, en los lugares de destino la tutela se siguió dando en formas diversas, pero no en forma de encarcelamiento. La ventaja más importante de la misma era el alejamiento durante varios meses al margen de lo legislado.

Otro de los problemas con que partíamos a priori, era la vaguedad del término y la confusión terminológica. Deportación, destierro, confinamiento, extrañamiento, exilio son términos que aparecen en ocasiones confundidos en algunas fuentes. A pesar de esto, en general existía ya en la época la idea de un traslado a un lugar remoto y ultramarino definido preferentemente como deportación. Esta inexactitud en la definición que se que se daba en algunas fuentes, especialmente en la prensa, pudo derivar en parte del sistema inglés, el más conocido de la época que establecía inserción social por etapas y un riguroso control a priori, en los puntos de destino. Línea en la que iban las normativas legales españolas, a pesar de que no se cumplieron. También en el caso francés se diferenciaba entre deportación, relegación y transportación.

En la utilización de la deportación observamos distintas etapas. Tras un primer momento de imposición individual, desorganizada y confusa, se institucionalizó en el Trienio. En este periodo, las primeras actuaciones fueron pedidas desde abajo como modo de represaliar a los ultrarrealistas en Barcelona. Posteriormente, el poder las asumió como propias como un modo de desembarazo que complementaba a los otros establecidos, persistiendo su uso incluso tras la caída del Trienio. Esta primera fase, de instauración, caracterizado por una gran confusión que abarca tanto a España como a Cuba, en el sentido de que en ambos territorios se estaba configurando la forma que iba adoptar el Estado.

Una vez asumida la práctica, nos adentramos en una nueva etapa de consolidación del liberalismo. En ella, es el Estado el que pasa a reprimir a aquellos que 
el mismo había excluido política y socialmente. En la Península, carlistas y liberales, y en Cuba los partidarios de la extensión del liberalismo a la misma. A partir de aquí se configuró como una práctica habitual para el trato de la disidencia. Gobiernos diferentes la utilizaban en periodos dispares, habitualmente tras varios años sin emplearse y recurriendo a embarques efectuados con celeridad. Se estructuraba generalmente mediante la remisión a Cádiz desde donde los represaliados embarcaban a su destino ultramarino. Destino que cambiaba en el caso de los miembros de la izquierda mostrando que el elemento determinante era el desembarazo a donde se creía que no generarían problemas. A los carlistas se les enviaba preferentemente a las colonias antillanas donde su utilidad como elemento cohesionador y refuerzo del dominio metropolitano quedó establecida desde el principio. En el dominio, en términos generales, los envíos eran realizados a Cádiz y derivaban en estancias en la Península en el caso de aquellos de estrato social superior y Fernando Poo sobre el resto. Paralelamente, hubo una deportación a isla de Pinos de sujetos tenidos por delincuentes y "vagos".

Una tercera etapa tiene que ver con el otorgamiento a los enemigos de un papel incluso más pernicioso. En ese momento el opositor ya no era alguien que pedía una extensión de los derechos para sí mismo u otros grupos similares, sino que era alguien que pretendía disolver el orden social en el caso de la metrópoli y obtener la independencia en Cuba. Además, estas ideas eran sostenidas por elementos cada vez más populares lo que añadía mayor desprecio si cabe por el poder. Este elemento se superpone con la segunda etapa en el caso de los internacionalistas, que fueron transportados a la antigua usanza, pero al emplazamiento más lejano posible. En Cuba se les remitía a lugares donde sus condiciones eran cada vez más restrictivas y ya en la Guerra de Independencia a algunos se les puso directamente en la prisión. Ciertamente, este castigo no se aplicaba a todos, a partir de 1879 decenas de criollos deportados lograron permanecer en la Península, pero eran casos excepcionales puesto que muchos incluso de alta consideración social recabaron en Ceuta y en Chafarinas. En la consideración al disidente de "enemigo", además del carácter cada vez más despótico del Estado, y por eso afecta a elementos de la burguesía, en última instancia se debía a la eclosión en la política de las clases populares, que planteaban alternativas a la concentración del poder y riqueza de unos pocos y la exclusión de la mayoría. Esta lucha contra el de arriba en España, la representa a partir de la década de 1870 el 
anarquismo, dotado de un pensamiento que atacaba a la propiedad y pretendía sustituir la sociedad existente por otra. En Cuba, las tensiones separatistas y la vinculación de la disidencia política hacia la pequeña delincuencia o el miedo a esta, configuraron al enemigo sobre el que cayó la mayor represión.

Es importante subrayar que a causa de ser ejecutada de manera recurrente y en casi todas las conspiraciones e insurrecciones de cierta relevancia, el hecho de adolecer de una estructuración legal hizo que no se mantuviera estática. En cierto modo, cada Gobierno aportó su impronta y de ahí la variación ocasional en los puntos de destino y en las condiciones de estancia, que fueron similares pero no uniformes. En algunos aspectos la propia práctica tendía a la uniformidad porque no se iba a dejar a los sujetos sin subsistencia, pero las acciones fueron inconexas y tomadas improvisadamente. No permaneció inamovible ni estuvo perfectamente reglada, pero se pueden establecer generalizaciones en su uso.

La pérdida de las colonias tanto como lugar emisor como receptor de deportados tuvo un papel determinante en la menor aplicación de la medida. Es posible que hubiera continuado aplicándose a los criollos, pero en la Península cesó su uso por la extensión del anarquismo entre la clase obrera, que era temido por sus planteamientos y por la violencia que algunos sectores minoritarios profesaban. Con ellos, se consideró que relegarlos no era adecuado, se pensaba que merecían un castigo más severo y se temía que pudieran extender sus doctrinas en los dominios. Además las posesiones eran cada vez más escasas y en el caso de Fernando Poo estaba comenzando a desarrollarse. El Sahara era un desierto y el norte de Marruecos y África estaban desprovistos de la insularidad que reforzaba la punición. Distinto fue allí donde el jaque lo realizaba el independentismo, lo que supondría privar a la metrópoli de prestigio y valiosas rentas, aun así el tratamiento con la élite y la clase media criolla fue mucho mejor que con los peninsulares. Únicamente en el caso de la Guerra Chiquita y de Independencia, cuando el independentismo se había expandido entre las capas populares hubo sobre estos sectores una deportación en condiciones muy penosas.

Hemos documentado la magnitud de los traslados en la España del siglo XIX. Nuestra intención de realizar un estudio sistemático que nos permitiera su conocimiento creemos que ha sido cumplido. Probablemente habría otros embarques que no hemos sido capaces de documentar, pero con características más individualizadas. La envergadura del método de reprensión ha sido demostrada y la mayoría de las 
relegaciones han salido a la luz, especialmente en lo referente a los periodos de mayor inestabilidad política. Lamentablemente, en algunos casos las fuentes no nos proporcionan el número exacto, pero la significación de la práctica es patente y se ha explicado su aplicación en cada caso concreto teniendo en cuenta las particularidades del momento histórico.

Aun así pueden hacerse estimaciones bastante aproximadas. Unos 1.800 cubanos fueron deportados a la metrópoli y Fernando Poo en las diferentes sediciones. Corresponden la mayoría de ellos a gente con cierta consideración social, especialmente en el caso de los que residieron en el continente. En la ínsula africana, si bien en la Guerra Grande se llevó a 250, algunos de ellos ricos, inmediatamente se les trasladó quedando a partir de entonces la plaza como lugar para aquellos tenidos por indeseables por ser de menor consideración social. Sujetos de la misma clase fueron llevados a isla de Pinos en cantidad de varios miles. En condiciones de represión más severa o intensificación de la guerra se incrementaba su número, de modo que constituyeron el grupo principal de los cubanos relegados y al mismo tiempo los que fueron peor tratados, ya que se les utilizó para fomentar la colonización en ambas plazas, con efectos dramáticos en el caso de Fernando Poo.

En cuanto a los españoles peninsulares, tuvo una mayor importancia en un tiempo más temprano, a causa de la considerable conflictividad política en la Península. Se inició con embarques esporádicos al Ultramar cercano, principalmente las Baleares para paulatinamente incrementarse y derivar hacia la utilización del lejano como punto de remisión. Los peninsulares fueron unos 14.800, de los cuales la mayoría fueron carlistas o ultrarrealistas, unos 11.300 combatientes, enrolados principalmente en los regimientos del ejército en el Caribe. Teniendo en cuenta que a los carlistas de rango social superior se les llevó principalmente hacia Baleares, o se les fusiló en tiempos de la Guerra de los Siete Años, y del perfil de los soldados carlistas, resulta que los afectados principalmente fueron gente que había perdido su modo de vida, un resultado que no difiere mucho de la realizada en Reino Unido ya que ambas fueron utilizadas como una válvula de escape para aquellos a los que el sistema era incapaz de absorber. Esto demuestra como la mayor parte de los miembros de este grupo luchaban puramente por su supervivencia y que una vez que se les alimentaba convenientemente y pasaban a ocupar una posición en la que estaban por encima de otros grupos, podían servir para realizar correctamente cualquier tarea que se les asignara. El paso de una sociedad 
agraria feudal a una capitalista y la redistribución de la tierra que se le asociaba, acabó con muchos de los excluidos de la desamortización preferentemente en las Antillas para servir en el ejército colonial, allá donde eran útiles al Estado. Esto no sucedió únicamente con los provenientes del medio rural, en el Bienio Progresista el mismo destino se aplicó a decenas de trabajadores industriales en el área de Barcelona y a los paisanos implicados en la revuelta gallega de 1846, aunque su importancia fue mucho menor. Las cifras totales de deportados, corresponde a un mínimo que pudiera ser incrementado, aunque no en demasía.

El segundo grupo más numeroso fue el de la izquierda a los diferentes gobiernos, conglomerado ligado a la inestabilidad y cuya relevancia fue extendiéndose a sectores cada vez más populares. En el Trienio y durante la instauración del liberalismo afectó a un número reducido, que fue incrementándose a raíz de la oposición al moderantismo. En la rebelión de Galicia, entre los 1.150 llevados a los regimientos ultramarinos, hubo un grupo minoritario de paisanos y especialmente en las revueltas de 1848 que afectaron a entre 850 y 900 individuos y que combinaban motivaciones políticas y sociales, suponiendo la entrada en escena de las clases más populares. A raíz de aquí, se mantuvo en niveles no demasiado considerables con la excepción de momentos muy convulsos. Unas 500 personas fueron deportadas en el periodo que va desde San Gil hasta la Gloriosa y 1.076 en las revueltas cantonales.

La calificación de izquierda no refleja la complejidad de un conjunto de grupos muy diferentes y por tanto debe ser aclarada. En el Trienio y en la década de 1830 afectó a liberales que en su mayor parte integraban a clases medias. En 1848 la represión alcanzó a progresistas, pero principalmente afectó a sujetos de condición social baja. En el periodo inmediatamente anterior a la Gloriosa también se incluyeron integrantes de las clases medias y altas, pero conformaban un grupo minoritario. Ya en la revuelta de 1848, la gran importancia numérica de las clases populares se tradujo en que fueron la mayoría de los relegados. Esto continuó en otros sucesos que no constituyeron un desafío con posibilidades de éxito pero tuvieron una gran carga simbólica como las revueltas agrarias del Bienio Moderado o la de Loja. La llegada de la Internacional a España derivó en la traslación más numerosa de izquierdistas españoles, la llevada a cabo a raíz del cantonalismo. Las Marianas como lugar más alejado bajo soberanía española simbolizan la proscripción máxima con los más 
indeseables. A pesar de no ser una regla estricta, desde la Península hubo una tendencia de imponer a los de menor consideración social lugares más lejanos.

El liberalismo español pretendió extender la revolución durante el Sexenio, pero fue superado por los acontecimientos: la industrialización, la urbanización, la experiencia sindical y la difusión de nuevas ideas elevaron el recelo del Gobierno que decidió hacer unos castigos ejemplarizantes y de amplio espectro en los que fueron incluidos muchos por considerarles vagos o asociarles al mundo de la delincuencia. La extensión hacia las capas más populares de la política hizo que el poder con su tradicional clasismo lo asimilara con la vagancia y la delincuencia. Se trataba de un hecho deleznable en sí mismo, por cuanto se atribuían que iban a otorgar derechos a las personas, pero al mismo tiempo significó una llamada desesperada a las élites para que no se atemorizaran y decidieran no terminar con el Sexenio. La disidencia comenzó siendo liberal de clases medias y acabó siendo republicano-federal o anarquista, con un fuerte contenido social.

También hemos conseguido hacer un seguimiento de las condiciones en que se produjeron los embarques y en la mayoría de los casos conocer como transcurrió su estancia. En ocasiones se desconoce el alcance del regreso, pero dadas las carencias únicamente en el caso de los carlistas, hemos aventurado nuestra opinión de acuerdo a los datos disponibles. Como fueron tratados y que hicieron en las colonias ha quedado acreditado, exponiendo su relevancia en los puntos de destino, que fue limitada pero importante. El análisis de la deportación como modo masivo de represión implica conocer cómo se extendió la "tutela" del Estado sobre estos individuos en los puntos de remisión. Ya que tanto por su condición de peligrosos como por la utilidad de los mismos, en algunos casos sobrevenida, esta era necesaria. La vigilancia a la que eran sometidos tuvo una implicación positiva humanamente hablando, ya que no quedaron totalmente abandonados y en mayor o menor medida fueron "ayudados" por el Estado. Un socorro que fue superior en el caso de los pertenecientes a las clases más elevadas, a lo que uniendo las condiciones climáticas y de poblamiento resulta en que los criollos en la Península fueron los que tuvieron una mejor estancia.

En el caso de los cubanos la libertad se fue restringiendo, pero aun así sus condiciones de garantía de alimentos, ausencia de trabajo forzado y libertad puede considerarse relativamente buena en comparación con otros. Los caribeños de las clases más populares, que en la Guerra de Independencia incluso acabaron presos, fueron los 
peor tratados en Fernando Poo y sufrieron muchos estragos. Con los peninsulares humildes las condiciones variaron, pero su propia destinación en lugares con climas tropicales era un castigo en sí, además en principio se les ayudaba pero la intención era que se ganaran su sustento, tanto si fueron incluidos en el ejército ultramarino como en la colonia africana y en las Marianas cuando se les exigió contribución en la colonización.

Las preguntas que nos planteábamos en el inicio de la investigación han sido resueltas. Ha quedado demostrado que la relegación fue concebida como una forma de punición beneficiosa para el poder. Que como modo de represalia política iba íntimamente ligada a ciertos periodos de inestabilidad y que su empleo llegó a adquirir caracteres "masivos" al afectar a las clases más populares. De ahí se explica la elevada significación en el Sexenio, un periodo teóricamente de mayores libertades y que significó la primera vez en que se instauró el sufragio universal masculino, proceso que fue acompañado de una mayor limpieza en las elecciones de 1869 y 1872 y en las realizadas bajo el periodo de la República Federal de Pi y Margall. ${ }^{1}$

La participación aumentó, pero en el fondo las clases pudientes temían la intervención de las más populares. Esto provocó que paralelamente a la extensión de la política hacia abajo fuera produciéndose una expansión de la represión, de la que no están exentos algunos elementos característicos del siglo. En el caso del carlismo por su carácter ultrarreaccionario y un cierto desprecio hacia estos elementos ignorantes, de carácter rural y fuertemente influenciados por la Iglesia. Con ellos, se siguió una línea más o menos recta entre los primeros ultrarrealistas embarcados en el Trienio al ejército de Ultramar hasta aquellos enrolados en el ejército al que combatían en la Península para combatir al independentismo. En el caso de los sectores urbanos más populares porque se les asociaba a la delincuencia y a la vagancia, el temido "populacho", que igual era capaz de asesinar a algún agente de la autoridad que de insurreccionarse pidiendo una república que los incluyera. Las revueltas de 1848 como primera vez en que las clases bajas se alzaron contra la exclusión política y el acaparamiento en la rentas que algunos estaban haciendo para sí, marcan la profundización de este temor que acaba en cuanto a las remisiones de los ñáñigos a finales del siglo.

\footnotetext{
${ }^{1}$ Sobre las elecciones ver Miguel M. Cuadrado, Elecciones y partidos políticos en España (1868-1931), 2 vols., Taurus, 1969, vol. 1, pp. 49-208.
} 
Sectores más elitistas también hicieron política fuera de los límites del sistema, por lo que el clasismo únicamente no explica el castigo. La diferencia en el perfil de los opositores, sí explica por el contrario la diferencia en el trato. Desde los liberales peninsulares en los años 30, a los que se eximió de trabajar en un momento en que en la isla había un sistema de trabajos forzados de grandes dimensiones, a los deportados por Tacón en el mismo periodo. La diferencia en el tratamiento se observa perfectamente entre los cubanos y se expresa con toda claridad en las condiciones en que estuvieron los anexionistas en la Península, incluso aquellos condenados a presidio en Ceuta. Con la extensión del independentismo hacia abajo y su masificación la represión se hizo más extensa y más severa, aun así, los criollos de alta alcurnia social tuvieron un trato más favorable. A los independentistas más pobres incluso se les metió en prisión sin ninguna sentencia condenatoria.

Los beneficios para el poder están bien claros, era un castigo que permitía una neutralización inmediata $\sin$ necesidad de ningún tipo de juicio. Permitía una desactivación prácticamente total de la peligrosidad en el país de salida sin necesidad de recurrir a fusilamientos masivos. La ambigüedad hacía que pudiera verse tanto como de una gran severidad por la traslación a lugares tan lejanos, como suave en el sentido de que se les dejaba libres en los puntos de destino. Iba ligada al aprovechamiento de la fuerza de trabajo de los mismos, lo que a medida que fue avanzando el siglo, especialmente a partir de la etapa de la Unión Liberal, fue visto como un progreso en la colonización de los territorios en aras de retornar la grandeza al país. A pesar de que era una grave manipulación, utilizar a los excluidos en bien del Estado era fácilmente dirigible para la mayoría de la prensa creadora de opinión por cuanto sus perfiles sociales diferían sobremanera del de los represaliados.

La deportación estuvo íntimamente ligada a la inestabilidad del convulso siglo XIX, pero esta no fue la única causa que la explicaba. La falta de un sistema estructurado como el inglés le confirió un carácter político muy acusado. En realidad, ambos factores no se excluyen mutuamente. El siglo XIX en Inglaterra fue más sosegado. Esto derivaba de una tradición diferente que se enmarca desde Cromwell y la supresión del absolutismo, pero también tiene relación con que durante todo el siglo se llevó a cabo una "limpieza social" constante. La gente a la que el sistema no podía absorber era sacada del Reino Unido para aprovecharla en un vasto continente apenas colonizado. En España, las tensiones y la miseria acumulada explotaban en momentos 
de crisis económica donde la pobreza de las clases más populares se incrementaba y unida a la exclusión provocaba hombres "echados al monte" y conflictos sociales urbanos. En este momento comenzaba la represión que en ocasiones adquiría un fuerte componente social.

También ha quedado acreditada la vinculación inexorable del precepto con el liberalismo. Difiere en este caso de la experiencia portuguesa de aprovechamiento de los penados en África, precursora a otros países. En España, la afluencia libre a América hizo innecesarias las relegaciones a las colonias en la Edad Moderna. La deportación evolucionó desde la pena de destierro aplicada en el Antiguo Régimen, castigo que se extendió a la disidencia política en el momento de aparición de la misma, pero estaba realizada desde la visión de un mundo antiguo, con un carácter individualizado y sobre individuos con un carácter elitista. El liberalismo, como ideología en la que términos como la practicidad o la utilidad adquirían una gran relevancia, supo aprovecharse de una forma de punición antigua para adecuarla a los nuevos tiempos, dotándolas de unas características masivas y haciendo que pudiera ser aplicada a cualquiera.

La práctica, que durante el Trienio comenzó a imponerse pedida desde sectores liberales populares, fue institucionalizándose como elemento de represión contra el ultrarrealismo en la Península, especialmente a partir del Gobierno avanzado de San Miguel. Con el avance del tiempo, paralelamente al establecimiento en el poder de un sector del liberalismo muy conservador enraizado ideológicamente con el doctrinarismo francés, adquirió unos tintes conservadores y fue utilizada entre otros contra aquellos mismos que la habían instaurado para luchar contra la reacción. La división entre el liberalismo se plasmó también en su aplicación, creándose dos grupos, el de aquellos que la imponían y el de los que eran víctimas.

En cuanto a la estancia en los puntos de remisión no podemos hablar de unas condiciones homogéneas. En cierto modo lo fueron para los carlistas remitidos a las Antillas que fueron empleados en el ejército, aunque en periodos con circunstancias diferentes. En otras ocasiones, los carlistas fueron remitidos junto a otros grupos y las condiciones tendieron a ser similares a las de los mismos. En general, en todos los casos se trató de establecer algún tipo de ayuda para los relegados, que a medida que se iba repitiendo y adquiriendo cierto proceso de estandarización tendió a ser más garantista. Sin embargo, otros individuos cuya incorporación al proyecto que representaban las élites no era necesaria, como el caso de los procedentes de la Península de menor rango 
social, tuvieron que soportar otras circunstancias. En general dado el carácter de blancos peninsulares en un territorio colonial, las autoridades trataron de ayudarles, el problema era que a falta de una planificación gubernamental en la mayoría de los casos tuvieron que hacerlo con sus propios y escasos recursos. Esto suponía un problema que se incrementaba a la par que lo hacía el número de hombres deportados y los recursos del lugar receptor eran menores. En cuanto a los criollos, la tendencia hacia una mejor estancia en los puntos de destino sucedió de una manera clara con los remitidos a la metrópoli o plazas adyacentes. Con aquellos que se pretendía reincorporar al proyecto español una punición excesivamente dura era contraproducente y se intentó que tuvieran un buen trato y una buen alimentación, incluso en los momentos de mayor restricción de movimientos. En cambio, con los que fueron remitidos hacia otros espacios coloniales entraban las consideraciones raciales, culturales y nacionales. Para los cubanos a los que el proyecto español no quería seducir, las condiciones fueron bien distintas hasta el punto de considerarse las peores.

Hemos visto como en el fin del siglo la pena se hacía cada vez menos justificable hasta que teóricamente se desaprobaba. El anarquismo se planteaba como un enemigo todavía más peligroso, ya que no pretendía adquirir derechos políticos, sino que atacaba directamente a la propiedad. En este momento comenzó una etapa de represión del mismo en el que las relegaciones fueron mucho más complementarias del resto. El precepto se utilizó, pero a la par que cárceles, destierros y la ley de fugas, y cuando el encontronazo entre patronos y obreros se hizo más acusado directamente se recurrió al asesinato, perdiendo en gran medida el carácter propio diferenciador que tuvo con anterioridad. También perdió utilidad, ahora sacar a un anarquista de Barcelona y llevarle al interior rural tenía un efecto neutralizador muy relevante por cuanto no se daban las condiciones necesarias para la expansión de su ideología. En muchas ocasiones, se les expelía hacia el extranjero, preferentemente a territorio francés, en lo que suponía una eliminación de la totalidad el problema, ya que con la expulsión no residían en territorio nacional y no requerían de ninguna otra acción de tutela o vigilancia.

Una vez explicada y puesto el foco tanto en la deportación y su utilidad como en los individuos que la sufrieron creo que es interesante mencionar los puntos de destino, por cuanto a pesar de la desorganización de la misma hay una clara tendencia entre perfiles de sujetos y lugares de remisión. Esto se ve muy claramente en el caso de los 
cubanos, isla de Pinos o Fernando Poo habilitados para hombres con bajo perfil político o pertenecientes a las clases más populares; la Península o lugares adyacentes para los más importantes. En cuanto a los peninsulares, los ultrarrealistas son los que mantienen una mayor coherencia, aunque no hemos de olvidar que algunos de estos fueron relegados tanto a Fernando Poo como a Filipinas. Con los peninsulares liberales, demócratas, republicanos e internacionalistas hubo mayor versatilidad ya que el Estado no terminaba de tener claro dónde podrían serle más útiles y las decisiones de remitirles a uno u otro punto dependieron de las circunstancias de cada caso concreto. El proceso que va desde un alejamiento cercano: Baleares y Canarias, se completa en su caso con la lejanía colosal que simbolizan las Marianas. Dado que según las autoridades las deportaciones de 1848 habían empezado a socavar el buen nombre de los españoles en Filipinas, es lógico que se emplearan lugares cada vez más lejanos y perdidos.

Con el objeto de dar a conocer las vicisitudes que sufrieron por su condición de disidentes políticos algunos de los embarcados, escribieron libros u opúsculos en que nos contaban sus avatares. Lamentablemente, su caso fue aislado y en general correspondía a un perfil de represaliado culto que no fue el mayoritario. Aquellos que pertenecían a las clases más bajas, los más afectados, no pudieron dejar testimonio de sus vivencias, por lo que la tesis además de sacar a la luz, explicar y analizar una práctica represiva habitual en la época, también debe ser entendida como un intento de dar la voz a los que no pudieron expresarla y un homenaje a todos los que la sufrieron. 


\section{CONCLUSIONS}

The dearth of knowledge about political repression in general and deportation in particular meant that painstaking research work was required. The minor references scattered over time which brought to light the embarkations carried out made it seem reasonable to think that this practice had not simply emerged unprecedentedly, but that it dated back to earlier times and had been widely applied by the government as a punitive procedure. Something seemed to be missing: for example, the 66 shot and roughly 600 prisoners taken in the San Gil uprising might represent a convincing explanation of the reprisals, but implied that the authorities had relinquished any preventive reinforcement of their position by deporting and resettling military Liberals. The same thing occurs with Carlism, in which the official explanation was that all the prisoners were shot, and that the Eliot Convention was signed precisely to prevent this. Although deportation was used earlier, if the official explanation is accepted one cannot help wondering what would have been done with the Carlist prisoners after signing this treaty. Leaving them all in prisons and depots implied a huge infrastructure and a risk of escaping or being rescued that had to be taken into account. Circumstances of war such as expeditions meant that such possibilities had to be borne in mind.

In view of what took place in the countries around us, especially France, which has so often been an inspiration for this country, and where both repeat offenders and political opponents were shipped off to the colonies, deportation would seem to have been an extensively imposed punishment. At least in the case of common criminals the parameters may be considered to have been complied with in our neighbouring countries. The English government took minor offenders from their native land and transported them to Australia because they were more useful to the State there. Spanish authorities used common prisoners with the longest sentences to build military installations in Ceuta because it was there that they served its interests best. Whether the destination countries were possessions or not is of less importance, since what was really significant was the utility.

Could the same use have been made of political dissidents? In our neighbouring countries the answer was affirmative, and here in Spain too. There were differences 
however, as in Spain the measure was used to get rid of detractors with no plan for making any better use of them, left to gradual improvisation. This did not happen in the same way in the other countries, where there were properly structured rules, as occurred in Ceuta with Spanish convicts. Spontaneity deprived the State of better exploitation of the labour force meant by these individuals and left them without any proper government tutelage. The lack of any long-term consistent strategy as regards the application of displacements makes one wonder why this was used by governments of different tendencies at different times. The vague reference to what had happened before may be an explanation, but the central feature determining its use was the profit meant by it.

Deportation allowed repression to be exploited on a large numerical scale without resorting to firing squads, which could not have been used to such a great extent. If shooting 66 persons is considered an awful matter, as it doubtlessly was, the forced displacement of several hundred could go much more unnoticed, as it in fact did. There were also prisons, which sometimes held large numbers of opponents for long periods of time, but this option was more perceptible since the prison was close to where the detainees lived. In spite of the exceptions to this, there was also a tendency to require that prisoners should be convicted by trial, which entailed providing some kind of evidence. Deportation, on the other hand, enabled their immediately embarkation without having to prove anyone's guilt and precisely for this reason facilitated the implementation of authority at times when it felt weak or wished to make a display of strength. This took on its own importance as a corrective form of the State used as a complement to the other better-known ones. Hurried eradication was opted for at times of unrest and revolt.

Resorting to legislation has been an oft-repeated mistake, which is why understanding this as an administrative matter was what enabled unmasking the practice. Having recourse to its legal regulation, in both the Criminal Code and in the different laws that established the preferred destinations or dictated the creation of prisons, has meant that this remained concealed. A priori, lack of knowledge led to the practice seeming to have to be processed by regulatory channels and that in general terms what was stipulated in these should be complied with as regards the deportees having to be free at the destination. In fact, this did not only stem from the articles in the Criminal Code, as the authorities were perfectly aware of the illegality of the repressive 
measures carried out and established their freedom at their places of exile as a form of "legal loophole". This meant that deportation was not applied by this channel, but in general what was laid down by regulations was taken into consideration, which was the reason for the evolution in different criminal codes. This was not the only aspect involved, because after neutralising their presence where they were dangerous, their imprisonment without a conviction was not required. This was seen as a temporary transgression of the rule by the authorities and at the destinations tutelage continued to be practised in different ways, but not in the form of jailing. Its most important advantage was keeping them well away for several months outside the law.

Another of the problems from which we started a priori was the vagueness of the term and terminological confusion. Deportation, banishment, confinement, expulsion or exile are terms which are on occasions mixed up in some sources. Nonetheless, in general the idea of a transfer to a remote and overseas destination preferably defined as deportation already existed at the time. This inaccuracy in the definition which was found in some sources, especially in the press, could partly stem from the English system, the one best known of the time, which established social insertion by stages and a strict control a priori, at the points of destination. The Spanish legal norms took this approach, in spite of not complying with it. In the French case too they differentiated between deportation, relegation and transportation.

Several different stages in the use of deportation can be seen. After an initial period of individual, disorganised and confused imposition, this was institutionalised in the Triennium. In this period the first measures were requested from below as a form of reprisals against the ultra-royalists in Barcelona. Later on, the authorities assumed these as a complementary way of getting rid of people to the other ones established, its use persisting even after the fall of the Triennium. This first stage of establishment, characterised by major confusion, extended to both Spain and Cuba, since in both territories the form that was to be adopted by the State was being shaped.

After the practice had been assumed, a further stage of consolidation of Liberalism ensued. It was now the State which went on to repress the people that it had excluded politically and socially: on the Spanish mainland, Carlists and Liberals, and in Cuba the advocates of extending Liberalism to this island. From here on it became regular practice for dealing with dissidence. Different governments used this in different periods, usually after not having been implemented for several years and resorting to 
hastily carried out embarkations. It generally took the form of sending the victims to Cadiz, from where they embarked on their overseas voyage. The destination changed in the case of members of the left, showing that the determining factor was to send people away to where it was thought that they would not make trouble. Carlists were preferably sent to the Antilles colonies, where their utility as a cohesive element reinforcing metropolitan dominion was established right from the start. From the dominion, as a general rule they were sent to Cadiz and resulted in stays on the Peninsula for the higher classes and Fernando Poo for the rest. In parallel, those considered to be delinquents and "vagrants" were deported to the Isle of Pines.

In a third stage these enemies were considered to have an even more pernicious role. At this time the opponent was no longer someone demanding an extension of rights for himself or other similar groups, but an adversary intending to dissolve the social order, in the case of the metropolis, and to gain independence, in Cuba. These ideas were furthermore upheld by increasingly popular elements, which resulted in even greater contempt by the authorities. This aspect overlaps with the second stage in the case of the Internationalists, who were transported as in earlier times, but to the furthest possible location. In Cuba they were sent to places where their conditions were increasingly restrictive and by the time of the War of Independence some were put straight into prison. This punishment was indeed not applied to all of them and from 1879 dozens of banished Creoles managed to stay on the Peninsula, but these were exceptional cases, since many of them, even of higher social standing, ended up in Ceuta and the Chafarinas. Seeing the dissident as an "enemy", apart from the State's increasingly despotic nature, which is why this affected parts of the bourgeoisie, was ultimately due to the emergence in politics of the popular classes, putting forward alternatives to the concentration of power and wealth of a few and the exclusion of the majority. This struggle against those at the top in Spain was from the 1870s represented by anarchism, with its line of thought against ownership and its aspiration to replace existing society with another one. In Cuba, the separatist tensions and the association of political dissidence with minor delinquency or with fear of this formed the enemy on whom repression fell with greatest force.

It is important to stress that because of being carried out repeatedly and in almost all conspiracies and uprisings of any importance, the fact of lacking any legal structure meant that this did not remain static. To some extent, each government made 
its own mark on the practice, which was the reason for the occasional changes in destinations and the conditions of the stay there, which were similar but not uniform. In some aspects the practice itself tended towards uniformity because the subjects could not be left without any subsistence, but the measures were disconnected and taken haphazardly. It was not stable or properly organised, but some generalisations in its use can be established.

The loss of the colonies as both point of departure and receiver of deportees played a determining role in the lesser application of the measure. It might have gone on been applied to the Creoles, but on the Peninsula its use died out through the spread of anarchism among the working classes, feared for its ideas and for the violence that some minority sectors professed. For them, it was considered that deportation was not appropriate, as they were thought to deserve a more severe punishment and it was feared that they might extend their doctrine to the dominions. The possessions were furthermore increasingly small and in the case of Fernando Poo this was starting to be developed. The Sahara was a desert and the north of Morocco and Africa did not offer the insularity which bolstered the punishment. It was a different matter in the places where the check was imposed by secessionism, which meant depriving the metropolis of prestige and valuable income, but even so the treatment of the elite and Creole middle class was much better than that of Peninsular deportees. Only in the case of the Little War and War of Independence, when secessionism had spread among the popular classes, was there any deportation for these sectors, in very pitiful conditions.

The magnitude of the displacements in $19^{\text {th }}$ century Spain has been documented. Our intention to carry out a systematic study providing knowledge of these may be considered to have been fulfilled. There may probably have been other embarkations which we have not been able to authenticate, although these would have been on a more individual basis. The extent of the repression method has been proven and most of the deportations have come to light, especially as regards the periods of greatest political instability. Unfortunately, the sources do not provide the exact number in some cases, but the significance of the practice is clear and its application has been explained in each specific case taking into account the particular aspects of the historical time.

Even so, some fairly approximate estimations can be made. About 1800 Cubans were deported to the metropolis and Fernando Poo in the different seditions. Most of these were people of some social status, especially in the case of those who lived on the 
continent. Although 250, some of them rich, were taken to the African island in the Ten Years' War, they were immediately transferred, the place becoming from then a destination for those who were considered undesirable through being members of lower social classes. Several thousands of people of the same class were taken to the Isle of Pines. Their number increased in more severe surges of repression or as the war heightened, until they formed the main group of banished Cubans and at the same time those who were treated worst of all, as they were used for promoting colonisation in both places, with dramatic effects in the case of Fernando Poo.

The practice was of greater importance for the Peninsular Spanish, at an earlier time, because of the considerable political conflict on the Peninsula. It started with irregular embarkations to nearby overseas destinations, mainly the Balearic Islands, but gradually increased and led to the use of more distant places for their exile. There were around 14,800 deportees from the Peninsula, most of whom were Carlists or ultraroyalists, around 11,300 fighting men, mainly enrolled in the army's regiments in the Caribbean. Taking into account the fact that the higher social class Carlists were mainly sent to the Balearic Islands, or shot in the times of the Seven Years' War, and considering the profile of the Carlist soldiers, the people involved prove mainly to have been those who had lost their way of living. This does not differ much from the practice in the United Kingdom, as both systems were used as an outlet for those whom the system was unable to absorb. This shows that most of the members of this group were fighting purely and simply for their survival and that after they had been properly fed and had taken on a position in which they were set over other groups, they could be used to properly carry out any task assigned to them. The change from a feudal agricultural society to capitalism and the redistribution of land that went along with this ended up with many of those excluded by disentailment preferably being sent to Antilles to serve in the colonial army, where they were useful to the State. This did not happen only with people from the rural setting, as in the Progressive Biennium the same destination was used for dozens of industrial workers in the Barcelona area and for the civilians involved in the Galician revolt of 1846, though of much lesser importance. The total numbers of deportees represent a minimum figure which could be higher, but not much.

The second most numerous group was that of the left of different governments, associated with instability, and whose relevance gradually extended to more popular 
sectors. In the Triennium and during the establishment of Liberalism this affected a small number, which gradually rose through opposition to Moderantism. In the Galician rebellion, there was a minority group of civilians among the 1150 taken to the overseas regiments, and especially in the 1848 uprisings, which affected from 850 to 900 individuals and combined political and social motivations, representing the emergence of the most popular classes. From then on the practice was kept on fairly insignificant levels, with the exception of extremely tumultuous times. Around 500 were deported in the period from San Gil to the "Gloriosa" revolution and 1076 in the Cantonal Rebellion.

The term 'left-wing' does not reflect the complexity of a set of highly different groups and must for this reason be cleared up. In the Triennium and in the 1830s this affected Liberals who were mostly from the middle classes. In 1848 the repression extended to progressives, but mainly those of low social class. In the period just before the Glorious Revolution members of the middle and upper classes were also included, but these formed a minority group. By the 1848 insurrection, the great numerical importance of the popular classes meant that they formed the majority of the deportees. This situation continued in other events which did not constitute a challenge with any chance of success, but had major symbolical value, such as the agricultural uprisings of the Moderate Biennium or the Loja revolt. The International's arrival in Spain led to the most numerous transportation of Spanish left-wingers, as a result of Cantonalism. The Mariana Islands, as most remote destination under Spanish rule, symbolised the utmost proscription for the most undesirable. In spite of not being a strict rule, there was a tendency on the Peninsula to impose the most distant destinations on those of lowest social class.

Spanish Liberalism sought to extend the revolution during the Sexennium, but events proved too much for this: industrialisation, urbanisation, the trade union experience and the dissemination of new ideas accentuated the government's apprehension, leading it to decide to impose a wide range of exemplary punishments in which many were included through being considered idlers or associated with the world of crime. The extension of politics to the more popular classes meant that the authorities, with their traditional classism, assimilated this with vagrancy and delinquency. This was despicable in its own right, as they were said to be going to give rights to the people, but at the same time represented a desperate call to the elites for 
them not to be afraid and put an end to the Sexennium. Dissidence began as a liberal movement of the middle classes and ended up being republican-federal or anarchist, with a major social aspect.

We have also managed to follow up the conditions in which the embarkations took place and in most cases find out what their stay abroad was like. In some cases it is not known how many came back, but we have given our opinion in accordance with the information available in view of the lack of data, only in the case of the Carlists. It has been accredited how they were treated and what they did on the colonies, explaining their relevance at the destinations, which was limited but important. The analysis of deportation as a form of mass repression involves finding out how the "tutelage" of the State extended over these individuals at their places of exile. Such supervision was necessary due both to their consideration as dangerous and for their utility, in some cases unforeseen. The surveillance to which they were subjected had positive implications in human terms, as they were not utterly abandoned and to a greater or lesser extent were "aided" by the State. This aid was greater in the case of members of the upper classes, which along with the weather and settlement conditions means that the Creoles on the Peninsula had the best stays.

In the Cubans' case freedom was gradually limited, but even so their conditions as regards guaranteed food, no forced labour and freedom may be considered relatively good in comparison with others. The Caribbean deportees from the most popular classes, who had even ended up as prisoners in the War of Independence, were the ones treated worst on Fernando Poo and underwent great suffering. The conditions varied for the lowlier Peninsular deportees but their very destination in places with tropical climates was a punishment in its own right. Furthermore, at first they were assisted but the intention was for them to obtain their own subsistence, whether they were enlisted in the overseas army and in the African colony or sent to the Mariana Islands, when they were required to make a contribution to colonisation.

The questions brought up at the start of the research have been answered. Deportation has been proven to be conceived as a form of punishment that was beneficial for the authorities; that as a form of reprisal it was closely linked to certain periods of instability and that its use reached a "massive" scale when it affected the most popular classes. This is the reason for the high incidence in the Sexennium, a period theoretically involving greater freedoms and which brought universal male 
suffrage for the first time, a process that went along with greater fairness in the elections of 1869 and 1872 and in the ones held in the period of Pi y Margall's Federal Republic. ${ }^{1}$

Participation rose, but behind it all, the better-off classes were afraid of the common people's intervention. This meant that in parallel to the downward extension of politics there was also an expansion of repression, which was not absent from certain characteristic elements of that century: in the case of Carlism, due to its ultrareactionary nature and a certain contempt for these ignorant rural elements, highly influenced by the Church. In their case there was a more or less straight line between the first ultra-royalists sent to join the overseas army during the Triennium and the ones enrolled to combat secessionism in the army that they fought against on the Peninsula. In the case of the urban working class, this was because they were associated with delinquency and vagrancy, the much-feared "rabble", which was just as capable of murdering an agent of authority as it was of rising up to demand a republic to include them. The 1848 revolts, as the first time the lower classes rebelled against political exclusion and the monopolising of revenue hoarded by some, mark the heightening of this fear, which ended up in the expatriations of the Náñigos at the end of the century.

More elitist sectors were also involved in politics beyond the limits of the system, so classism alone cannot explain the punishment. The difference in the opponents' profile does indeed explain the difference in treatment, on the other hand: from the Peninsular Liberals of the $30 \mathrm{~s}$, who were released from working at a time when there was a large-scale system of forced labour on the island, to those deported by Tacón in the same period. The difference in treatment between the Cubans can clearly be seen and is expressed with absolute clarity in the conditions in which the annexationists were kept on the Peninsula, even those sentenced to prison in Ceuta. With the downward spread of secessionism and its widespread growth, repression became more extensive and more severe, and even so the higher-class Creoles were treated more favourably. The poorer secessionists were even jailed without any conviction.

The benefits for the authorities were very clear: this was a punishment which enabled immediate neutralisation with no need for any kind of trial. It allowed an almost total deactivation of the danger in the country of origin with no need to resort to mass

\footnotetext{
${ }^{1}$ On these elections see Miguel M. Cuadrado, Elecciones y partidos políticos en España (18681931), 2 vols., Taurus, 1969, vol. 1, pp. 49-208.
} 
executions. Its ambiguity meant that this could be seen as both extremely severe, through deportees being sent to such far-off places, and lenient in the sense of their being left free at their destinations. This was linked with taking advantage of them as a labour force, which as the century drew on, especially from the Liberal Union stage, was seen as progress in colonisation of territories with a view to making the country great again. In spite of this being serious manipulation, using deportees in the State's benefit was something easy to handle for most of the opinion-leading press insofar as their social profiles were utterly unlike those of the reprisal victims.

Deportation was closely linked to the instability of the turbulent $19^{\text {th }}$ century, but this was not the only cause explaining this. The lack of a structured system like the English one gave it a more marked political character. In fact, both factors are not mutually exclusive. The $19^{\text {th }}$ century was more peaceful in England, as a result of a different tradition established since Cromwell and the suppression of absolutism, but also connected with the fact that a constant "social cleansing" was carried out throughout the century. The people whom the system could not absorb were removed from the United Kingdom to take advantage of them in a vast, hardly colonised continent. In Spain the tensions and accumulated misery blew up at times of economic crises when the poverty of the popular classes increased and along with exclusion led to men "taking to the hills" and urban social conflicts, and this was the point where the repression, which sometimes involved a major social component, really began.

The inescapable association of the precept with Liberalism has also been accredited. It differs in this case from the Portuguese experience of making use of the deportees in Africa, as a precursor of other countries. In Spain, the free flood of people to America made deportation to the colonies unnecessary in the Modern Age. Deportation evolved from the sentence of banishment applied in the Old Order, a punishment which extended to political dissidence when this appeared, but which was applied from the viewpoint of the old world, on an individualised basis and to individuals with an elitist nature. Liberalism, as an ideology in which terms such as practicality or utility took on great relevance, managed to take advantage of an ancient form of punishment by adapting this to new times, giving this massive scope and making it applicable to anyone.

The practice, which started to be imposed during the Triennium at the request of certain popular Liberal sectors, was gradually institutionalised as an element of 
repression against ultra-royalism on the Peninsula, especially from San Miguel's advanced government. As time went by, and as a highly conservative sector of Liberalism ideologically linked with French doctrinaire thought became established in power, this took a conservative turn and was used against the same people who had introduced it to fight against reaction. The division between Liberalism was materialised in its application too, with two groups being created: those who imposed this and those who were its victims.

As regards the stay at their destinations, no uniform conditions can be established. To some extent these were fairly constant for the Carlists sent to the Antilles who were used in the army, though in periods with differing circumstances. At other times Carlists were deported along with different groups and their conditions tended to be similar to the others'. In general an attempt was made in all cases to set up some type of aid for the deportees, which, as this was repeated and underwent some kind of standardisation process, tended to offer guaranteed rights. Conversely, other individuals who were not needed in the project represented by the elites, such as those from the Peninsula with lowlier social backgrounds, had to suffer other situations. In general the authorities attempted to help them, due to their nature as Peninsular whites in a colonial territory, but the problem was that they had to do this with their own scant resources, lacking any governmental planning in most cases. This meant a problem which heightened as the number of exiles rose and the destination's resources dwindled. As regards Creoles, those sent to the metropolis or nearby places clearly benefitted from the tendency to enjoy a better stay. Any excessively harsh punishment of those who were intended to be reincorporated in the Spanish project was counterproductive and an attempt was made to treat and feed them well, even at the times when their movements were most restricted. On the other hand, racial, cultural and national aspects came into the matter with those who were sent to other colonial areas. Conditions were very different for the Cubans whom the Spanish project did not wish to seduce, to the extent of being considered the worst of all.

It has been shown that at the end of the century the punishment became less and less justifiable, to the extent of theoretically being disapproved. Anarchism was considered to be an even more dangerous enemy, as it did not seek to acquire political rights, but directly attacked ownership. A stage of repressing this started at this time, when deportations were much more complementary to the rest. The measure was used, 
but at the same time as prison, banishment and the law allowing escaping prisoners to be shot. And when the conflict between owners and workers became more acute they resorted directly to murder, deportation losing to a large extent its own previous differentiating quality. It also lost its utility, for now, taking anarchists out of Barcelona to the rural interior had a very relevant neutralising effect insofar as the conditions required for expansion of their ideology were not present. On many occasions they were expatriated, preferably to French territory, in what was considered to be an elimination of the whole problem, as expulsion meant they no longer lived in national territory and did not require any other tutelage or supervision work.

After explaining and focussing on both deportation and its utility and the individuals who suffered this I consider it interesting to mention the destinations, insofar as there is a clear association between subjects' profiles and the destinations to which they were sent, in spite of the disorganisation involved. This is very clearly seen in the case of the Cubans: the Island of Pines or Fernando Poo prepared for men with a low political profile or from the lower classes; the Spanish mainland or nearby areas for the most important ones. As regards deportees from the Peninsula, the ultra-royalists are the most consistent ones, though we should not forget that some of them were shipped to both Fernando Poo and to the Philippines. There was greater flexibility with the liberal, democratic, republican and internationalist Peninsular victims, as the State did not clearly understand where they could be most useful and the decisions to send them to one place or another depended on the circumstances involved in each specific case. The process starting from a nearby destination - Balearic Islands and the Canary Islands - was as the case may be completed with the enormous remoteness of the Marianas Islands. Since the 1848 deportations had according to the authorities started to undermine the good name of the Spanish in the Philippines, it is understandable that increasingly distant and remote locations should be used.

In order to make known the vicissitudes undergone through their status as political dissidents, some of the deportees wrote books or articles in which they recounted their experiences. Unfortunately this was only in isolated cases and in general done by an educated deportee not representing the majority. Members of the lowest classes, the ones most affected, could not bear witness to their experiences, which is why, as well as attempting to disclose, explain and analyse a repressive practice regularly used at the time, the thesis must also be understood as an attempt to speak out 
for those who could not express this and a tribute to all those who underwent this punishment. 


\section{APÉNDICE DOCUMENTAL}

Documento 1. Decreto de 11 de noviembre de 1822 sobre las deportaciones de realistas.
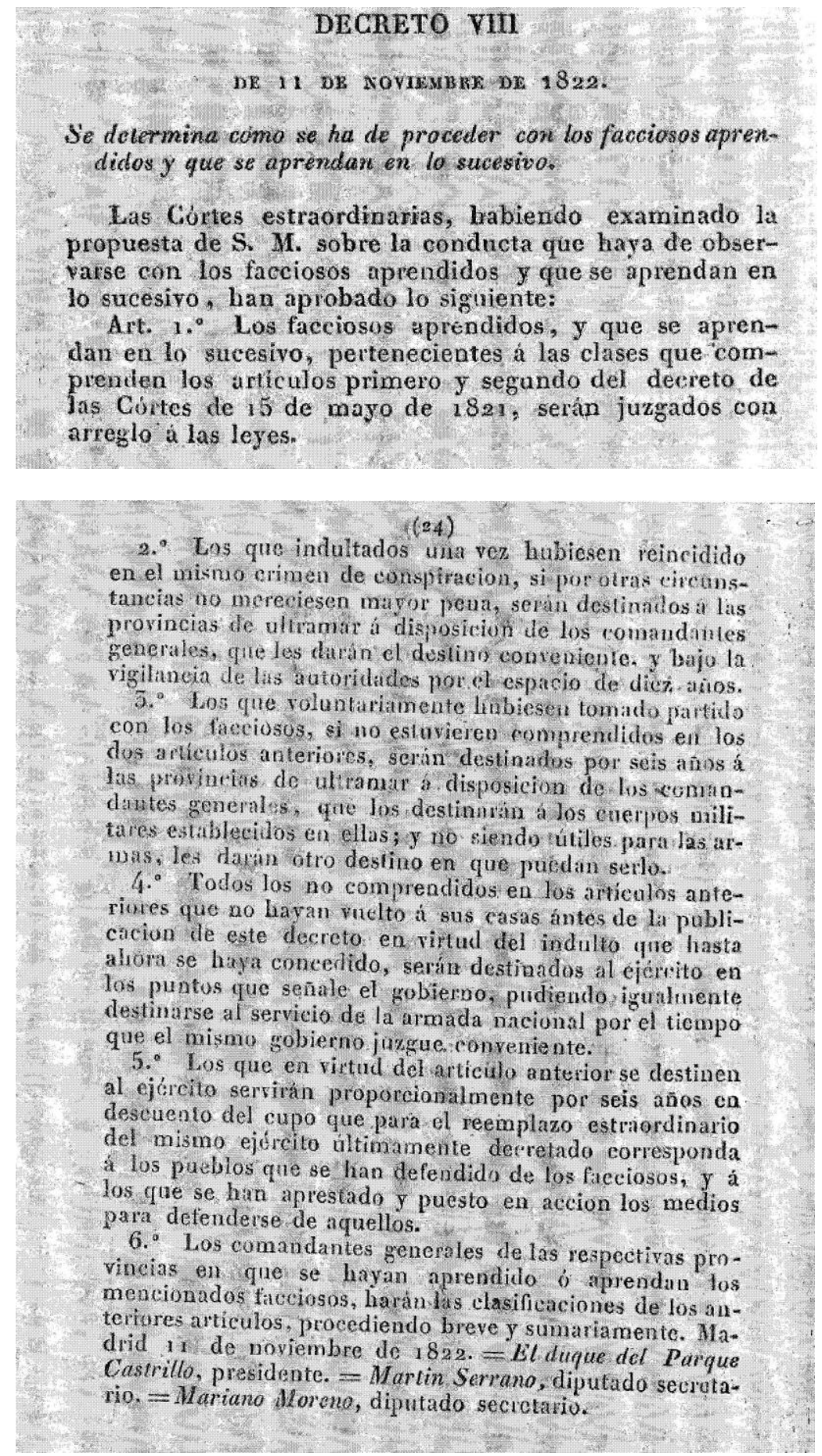
Documento 2. Petición de indulto de Hipólito Flandrin, deportado a Fernando Poo en la Guerra Chiquita.
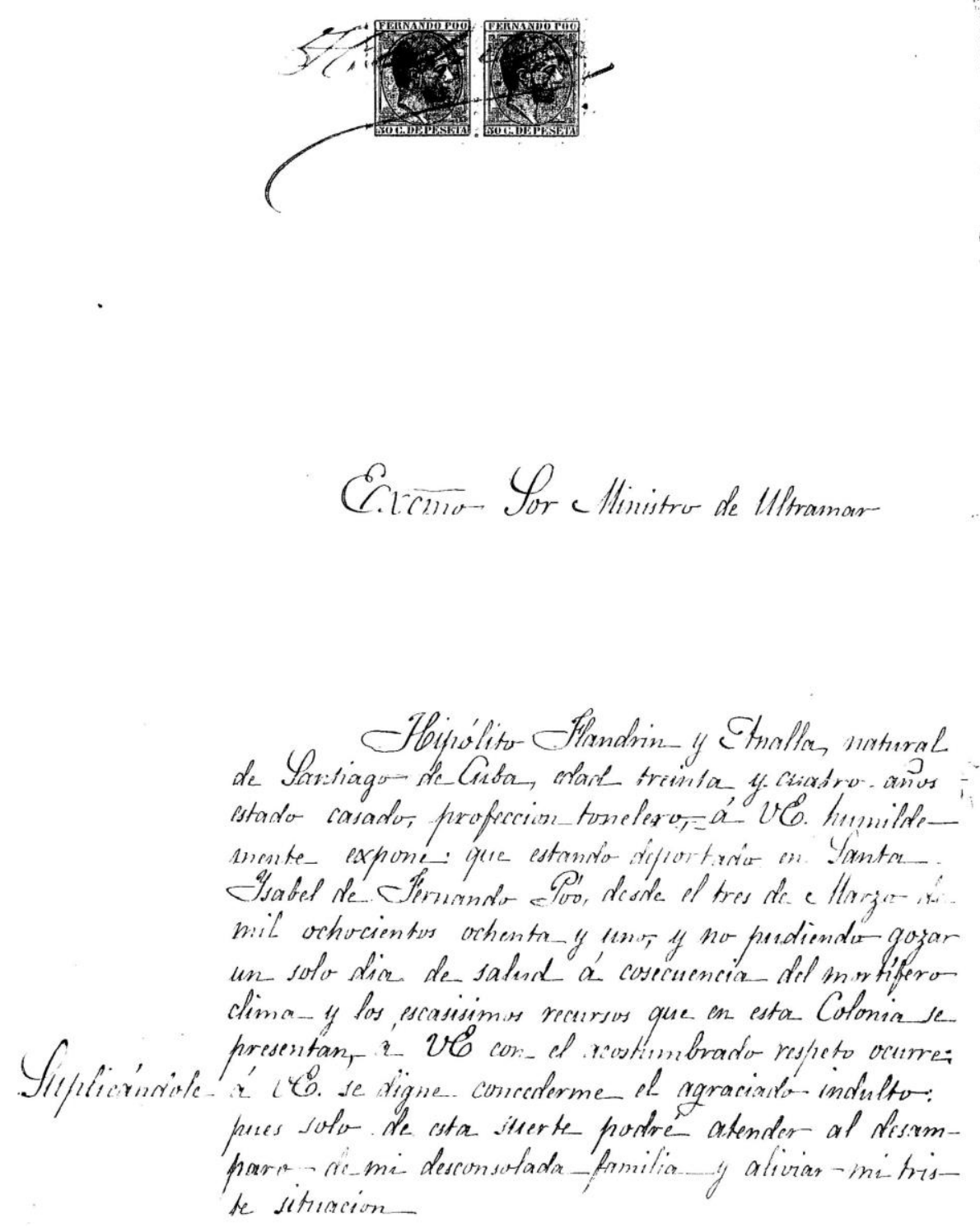

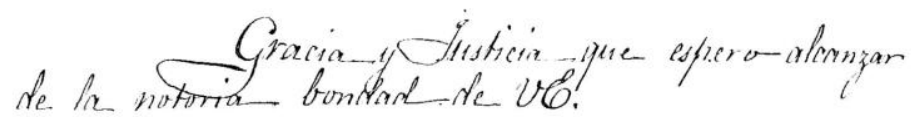

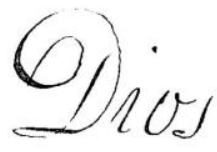




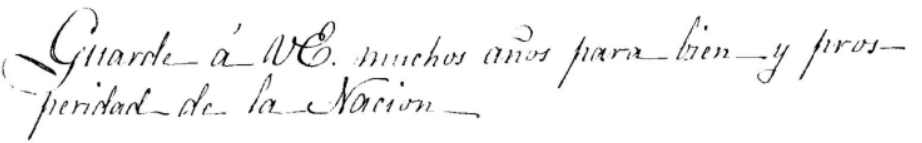

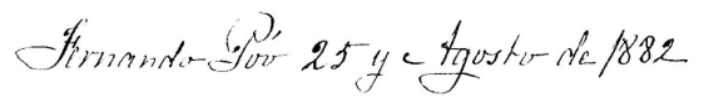
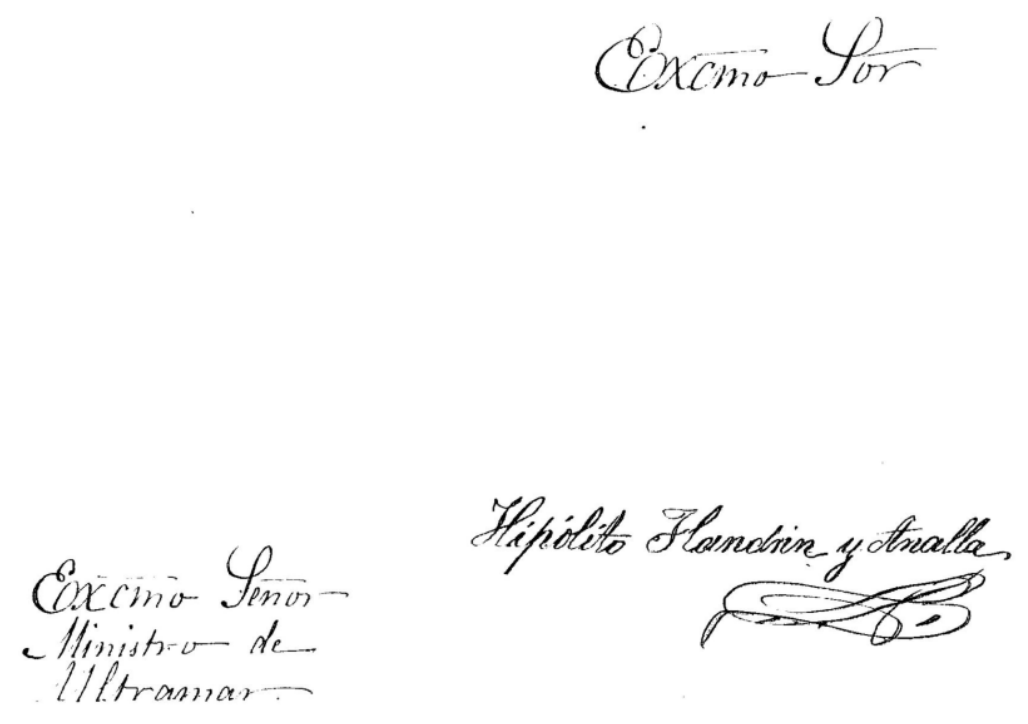

Fuente: AGA, África-Guinea, 81/6942.

Documento 3. Suscripción realizada en varias ciudades canarias para el regreso de los deportados que no podían hacer frente al regreso.

A 15,080 reales ascendió la contidad recaudada $\in n$ Santa Cruz de Tenerife, la ciudad de Laguna y la villa de la Orotava, con el objetu de atender al embarque de los peninsulares pobres que, en clase de deportados politicos, fueron destinades á aquellas islas.

Fuente: El Imparcial, 6 de mayo de 1868. 
Documento 4. Deportados en Fernando Poo fallecidos desde 17 de enero de 1897 a 3 de febrero de 1898, con la causa de deceso.

$$
\text { Del } u^{0} / 1
$$

Estacho demostrativo de hos deportados bubanos y Gitipinos que han fallecido en esta botonia desde tu llegacha a ha misma en IF de Enero deb año anterior, hasta el dia de ha fecha.

\begin{tabular}{|c|c|c|c|c|c|}
\hline cleombres. & Enfermedad. & Eecha & a deb falte & gimients & Crocedencia. \\
\hline & & Dia. & doés. & año. & \\
\hline Cuan Gemander Grorest & & 17 & Enero & 1897 & otitipino \\
\hline S'eliciano de hos cantos * & Gubérentotis. & 24 & & " & क्o \\
\hline Jose Esteban bata * & çol. & 26 & & " & $y d$ \\
\hline Dieqo J'anstino + & ơielve palúdica. & 25 & J'elvero & $"$ & Id \\
\hline Gimoteo abancarpiot & Guberenhatis. & 26 & $"$ & " & Id \\
\hline Sedro Pasenal y & ơielne patiolica. & 27 & " & " & Id \\
\hline Cisto efarcia $x$ & Sol. & 28 & & & yd \\
\hline Gristobal Stbontano & कीd. & $f_{\pi}^{0}$ & Moartso & " & Cubans \\
\hline Escofástieo ö'rancox & Id. & 3 & 1 & $"$ & Gritipino \\
\hline Dionieio Suatonk & Idd. & 5 & " & " & Id \\
\hline cabino seres. & कैd. & 5 & " & " & bubano \\
\hline Sedno Gapuno $x$ & Euberenhosis. & 7 & " & " & ofitipino \\
\hline Evaristo Branco & Entericolitis aguida. & 12 & & ". & Cubano \\
\hline Augusto babeda & Stielre palídica. & 20 & " & " & Id \\
\hline Leoncio Enviqub x & Iol. & 22 & , & " & ớitipino \\
\hline Aloiqueb Atbenchizabab & Fol. & 23 & " & " & Gubano \\
\hline clberto simenets & yd. & 3o & " & " & Id \\
\hline Bonifacis MillareabX & Id. & 3 & abrib & " & Gitipino \\
\hline batimiro Pacaghinananx & chd. & 3 & 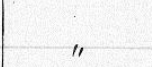 & " & Gol \\
\hline Santiago sar $x$ & cod. & 8 & " & " & Iol \\
\hline Cuan Bautista Hoauroner & 70. perniciosta cerelral. & 8 & " & " & Gubano \\
\hline Bonifacio Yatdés & Sielre palídica. & So & " & , & gdo \\
\hline Inintion Noetinax & Enteritis aguida. & 12 & " & " & ơétipino \\
\hline Balistro de la Teruze & otielne palindica. & 13 & " & " & Id \\
\hline Mariano Arana & ydd & JH & , & " & Id \\
\hline Bemaidino salvadorx & Eubereutosis. & Jh & " & , & yd \\
\hline Eregorio Eachees x & Fielre palindica & 16 & " & , & éd \\
\hline Abiquel abman & ofd & 16 & , & , & Gubano \\
\hline Santiago Sarmientor & yd & 17 & , & " & Eitipino \\
\hline Joté Houtio Farcia & bonsuncion & 18 & " & " & Gubano \\
\hline Osidoro de la Gruk $x$ & Idd & 18 & & 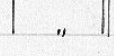 & Gitifoino \\
\hline
\end{tabular}




\begin{tabular}{|c|c|c|c|c|c|}
\hline \multirow{2}{*}{ crombres. } & \multirow{2}{*}{ Enfermedad. } & \multicolumn{3}{|c|}{ fecha pel fallecimpiento } & \multirow{2}{*}{ Srocechencia. } \\
\hline & & Dia. & Shès. & año. & \\
\hline Agustin Canton $x$ & sielve polindica. & 23 & abil. & 1897 & otilipins \\
\hline Sedro Egfavinox & Idd comotota. & fi: & Hhape & 4 & Ido \\
\hline Tatricio de ha Rosa & Enteritis ubeeroso. & 5 & 1 & " & Gubano \\
\hline Andres Reyest: & ataques comoulsivos & 5 & " & , & Clitifino \\
\hline Eugenia Zagamanx & bonsuncion & 6 & " & " & bol. \\
\hline Leon Abendiofax $x$ & bólicomicerere & 6 & " & & ydd \\
\hline Adolfo Eontales & Disenteria & 6 & $"$ & " & bubano \\
\hline Sivan Lopes Sortuna & prélere premicionsta. & $\tau$ & " & " & edd \\
\hline Hoanuel cardrinanox & Gaquevia foalídica & 8 & " & " & óilipino \\
\hline Jranciseo Mbadro & Saludismo cerchrab & 9 & " & $"$ & Caubano \\
\hline Lorentho berwh $x$ & & So & " & " & Jitipino \\
\hline Sirutrot Alocrobefar x & " & If & & " & Ido \\
\hline Niranciseo Bernardo- & " & $1 \%$ & $"$ & " & fod \\
\hline Rafact Ramos & 1. & 52 & " & " & bubans \\
\hline öelipe buetro & , & 13 & & , & Id \\
\hline Lorentso Mbayared $x$ & Arongintis & 13 & & " & dotipino \\
\hline Cimon Gurena & Sielre fremieiosa & 15 & 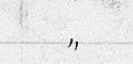 & , & Id \\
\hline Homingo alerliofar & bontuncion & 18 & " & " & ydo \\
\hline Bernardino brute $x$ & Jielnt cerelrab & 18 & " & " & Id \\
\hline Pio Juriel & Enolocanditis agúda & 18 & " & " & bubano \\
\hline Aquilino salvo $<$ & trielne cerelrab & 19 & " & , & otitipino \\
\hline Anachetro Mbingas $x$ & Ido perniciosa & 22 & " & " & âd. \\
\hline duan Siña - & Id foalúdica & 22 & " & " & Ido \\
\hline Abiquel Sobapusx & Id eerelrab & 23 & " & " & $y$ \\
\hline Gorge Raimundox & Euberentosis & 23 & " & " & Id \\
\hline fiforencio del Talle & atagub de dimea cardfe & 28 & " & ", & bubano \\
\hline Eruchencio de ha terwtox & Enteritis aguda & 29 & " & , & J'itipino \\
\hline Mbartin Fognacio Gruzx & " & 30 & " & $"$ & वै० \\
\hline Serónimo Sarcia Serpa & Sielve permiciosa & 30 & , & " & bubano \\
\hline Obilario Babita X & Hhasteria fisiológica & 5 & Sunio & " & filipino \\
\hline Abefandro Stoartin x & Fielne pernieiota & 6 & "1 & " & ôd \\
\hline dicotás barrion $x$ & Raquitismo & 8 & " & " & Idd \\
\hline Aquitina Zamurio x & Disenteria & If & 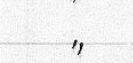 & " & İd \\
\hline Abanueb Tartés & $\|$ Enterettis agícha & 18 & $"$ & " & Gubano \\
\hline
\end{tabular}




\begin{tabular}{|c|c|c|c|c|c|}
\hline \multirow{2}{*}{ cpombres. } & \multirow[t]{2}{*}{ Enfermectad. } & \multicolumn{3}{|c|}{ otecha del fallecimiento. } & \multirow{2}{*}{ Procedencia. } \\
\hline & & Dia. & stoés. & año. & \\
\hline Antonio Farcia Borget & Gielre palidica. & 21 & Dunio & 1897 & bubanso \\
\hline Anachetro avibésx & Hbiseria fistoróogica & 23 & " & " & Sitipino \\
\hline Santiago Santonx & " & 24 & " & " & abdo \\
\hline Guiltermo bastañox & " & 24 & " & " & $y d$ \\
\hline Sablo Sahavaria & asistolia & 25 & " & " & bubano \\
\hline Wonato Manesel $x$ & Eubereuhosis & 26 & " & " & F'́lipino \\
\hline Lueas sanetrageox & Hbiseria fisiofógica & 26 & " & " & Ifdo \\
\hline Santiago boronado x & dielns perniciosa & 30 & " & " & Fd \\
\hline d'forentino sanchete - & , " & 5 & dulio & " & yod \\
\hline Calviel bandretariar & Enteritis & 9 & " & " & yd \\
\hline Leandro Aeal < & Fastro enteritis & 11 & " & " & $y d$ \\
\hline coose de fa cth. Arazes & " " & 12 & " & " & bubano \\
\hline Geodoro Rodriquet. & Jielre cerclral. & 13 & "I & , & cூd \\
\hline Gecilia Loureto $/$ & Abiseria fisionórgica & 13 & , & " & Ëitipino \\
\hline Abetardo Diaz & Gieloce cerelrab & 14 & & , & bubano \\
\hline Albacario Sanchicor & Euberenlosis & 15 & & " & J'itipino \\
\hline Echuards Protrocarrero & " & 15 & ", & " & bubano \\
\hline Jrancises Tampanax & ofiehre cerelrab. & 17 & " & " & Ctitipino \\
\hline Naniel de Entmanx & |Hoiseria fistoróagica & 18 & & " & $\begin{array}{l}y \\
d\end{array}$ \\
\hline Albariano Nominguetax & " , " & 19 & & " & âd \\
\hline Leoncio cricofás & Enteritis agiuda & $2 \%$ & " & " & sob \\
\hline Cbitaris brus Atbemaracionx & Hbiseria fisionogica & 27 & " & ". & Ido \\
\hline Pabention Abanabaysay & Enchearditis & 27 & 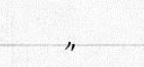 & " & bde \\
\hline Rotendo de ha Rota. & Mhiseria fistiológica & 29 & " & " & Ido \\
\hline Emilio Mbirandra Lutax & Jielne cerelrab & 3f & 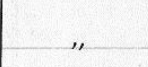 & " & add \\
\hline Inivieo borderoy & " & 3 & agost to & , & rdo \\
\hline Célipe thacario, & " & 4 & ( & " & Jol? \\
\hline Coaquin Shartineto & oftheseria fistiologica & 4 & "1 & " & bubano \\
\hline Bartotomé Anghayo $x$ & Angina de pecho & So & "I & " & C’ilipino \\
\hline Sedro Gucenax & Alisteria fisiologica & 19 & $"$ & " & chdo \\
\hline Atbanueb dofacs thenendes & fielve cerelral & 25 & " & " & bubans \\
\hline Emilio Abartine\% & Id comotosa & 28 & " & " & $\hat{s}_{d}$ \\
\hline Ehadio Chupangox & " & 30 & & & Jilipino \\
\hline & ILbiseria fisionógica & 3 & aeptiemen & ” & Id \\
\hline
\end{tabular}




\begin{tabular}{|c|c|c|c|c|c|}
\hline cpombres. & Enfermechad. & Jécha & Let faltecin & mento & Srocectencia. \\
\hline & & Dia. & etoes. & año. & \\
\hline basimiro Misedro X & Ensuficencia mitral & 4 & Septiemlor & 1897. & Jítipino \\
\hline Yicente Diego ofuemero & Gubereubrosis intertina af & Jo & 4 & ," & butano \\
\hline abelino Wiar & Fielre cerelrab & 9 & " & & Ido \\
\hline Dionieis Rabellax & Itd palindica & $15^{\circ}$ & " & " & Fitipino \\
\hline Arigicho Alboracha x & Endobarditis rewmatic & 16 & " & , & fod \\
\hline Tatentin Moartino $x$ & $\|$ & 19 & " & " & İd \\
\hline batimiro famboa * & Eublerentosis intrestinall & 23 & 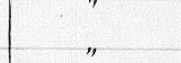 & " & Ido \\
\hline Antonia Sarvitto - & Hisiseria fisiologica & 23 & " & " & Fol. \\
\hline Simon de ta brutax & Beumatismo candiaes & 27 & " & " & $y_{d}$ \\
\hline Chocencio Ferodia X & otielre permiciosa. & 30 & & " & $I_{d}$ \\
\hline Simon Maralit & Enolvearditis aquidro & 2 & oetulve & " & Sol \\
\hline Rafal Dutamay & Asma cardiaca & 3 & 1 & 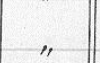 & ydo \\
\hline S'ranciseo Bhaneo & Gubereubosis & 2 & & & $2 d$ \\
\hline Agapito Corut $x$ & Reumatismo visceral & 8 & & , & Yol \\
\hline Angeb de fa Hoon Eandarilla & Ěisis & 9 & & " & bubano \\
\hline Antonio Angeles Atbangon, & Anemia cerelrab & 14 & ", & , & Silipino \\
\hline Ganuto abistado $x$ & Endweanditistreumatica. & JH & " & " & colo \\
\hline Échardso de fa tie & Anemia cerelrab & 20 & & " & bubano \\
\hline Romuatcho Areltaño \& & Embolia cerehrab & 28 & ", & " & F'ilipino \\
\hline d'emands Galkeltat & Tieht foahíchica & 28 & 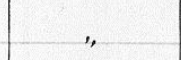 & " & bubans \\
\hline Bonifacio Tidha X & Uleera gástrica & 5 & Aoviembre & " & S'ilipino \\
\hline Unbano acosta. & Fielre cerelrab & 6 & 年 & " & bubano \\
\hline dose de ha brutex & Rematiomo viseerab & 7 & " & " & stilipino \\
\hline Serafin Euerrero Gutman & Fastroventeritiss a gindal & 9 & , & " & bubano \\
\hline Abipólito Belitan X & indreanditis reumatica & So & 1. & " & Atilipino \\
\hline OAnacio alganas & " & 14 & $\therefore$ & " & Add \\
\hline Sedro Ramos & ofielve eerehrab & 15 & " & " & bubano \\
\hline Albanuel de bastro gahomino & touberentotis & 21 & & " & Id \\
\hline águedo Samaniego & Reumatismo & $2 \%$ & " & " & Stidipino \\
\hline Leon bormb < & j̆d & 23 & & ", & colo \\
\hline Atejandro Mbendiahax & Pielne foalindiea & $25^{\circ}$ & & & Ido \\
\hline Agapito Bantistax & Ido cerelrab & 28 & & " & Ido \\
\hline Abateo Hemande\% & Id polidica & 3 & Diciemblre & ; & bubano \\
\hline Homingo Mbartinet & Ide comotota & H & & 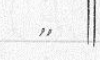 & Silipino \\
\hline
\end{tabular}




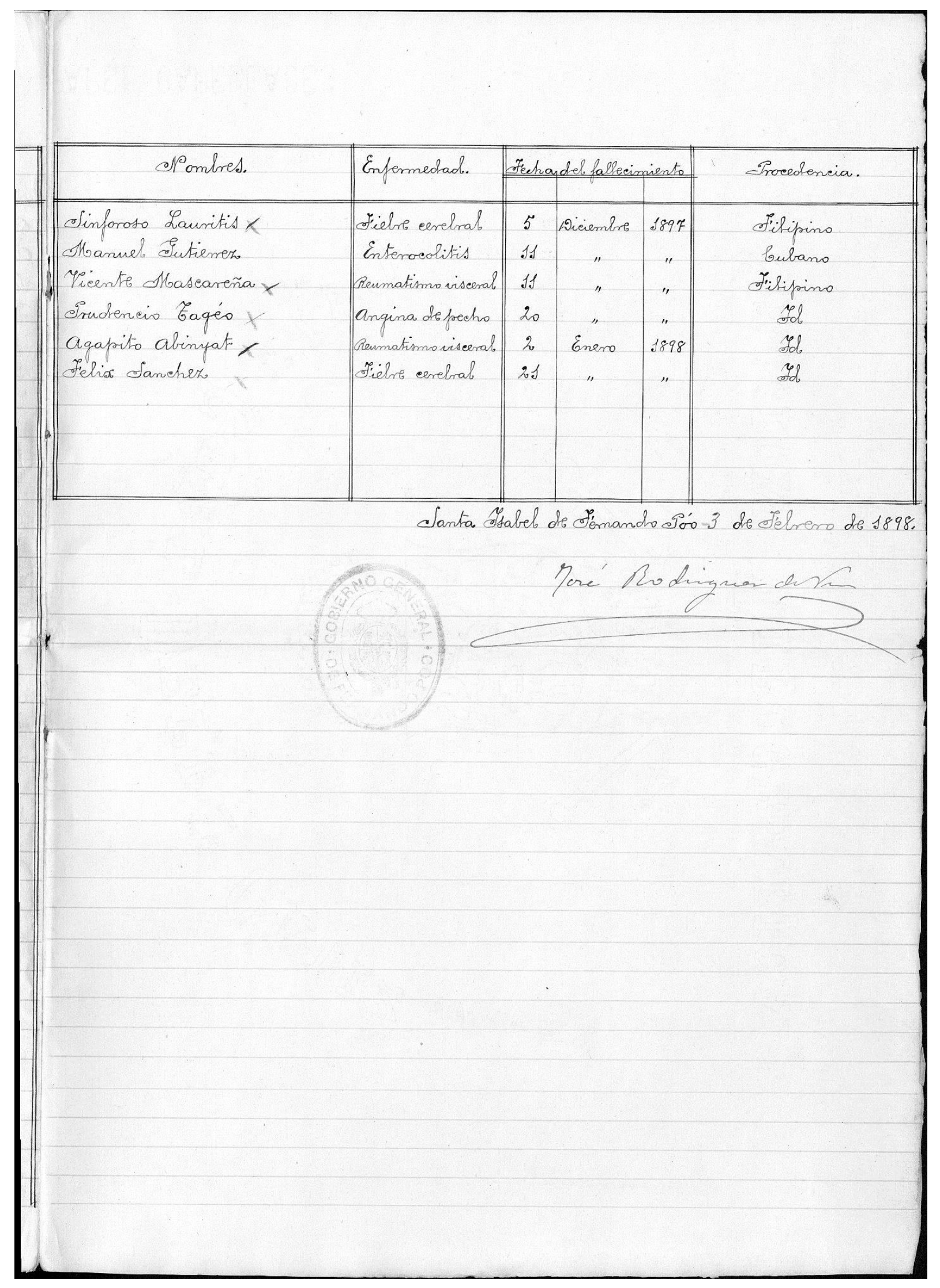

Fuente: AHN, Gobernación, Leg. 238. 
Documento 5. Cesación en el percibo de la ayuda para el deportado en las revueltas de 1848, Antonio Canals, que recibió permiso para establecerse en Filipinas.

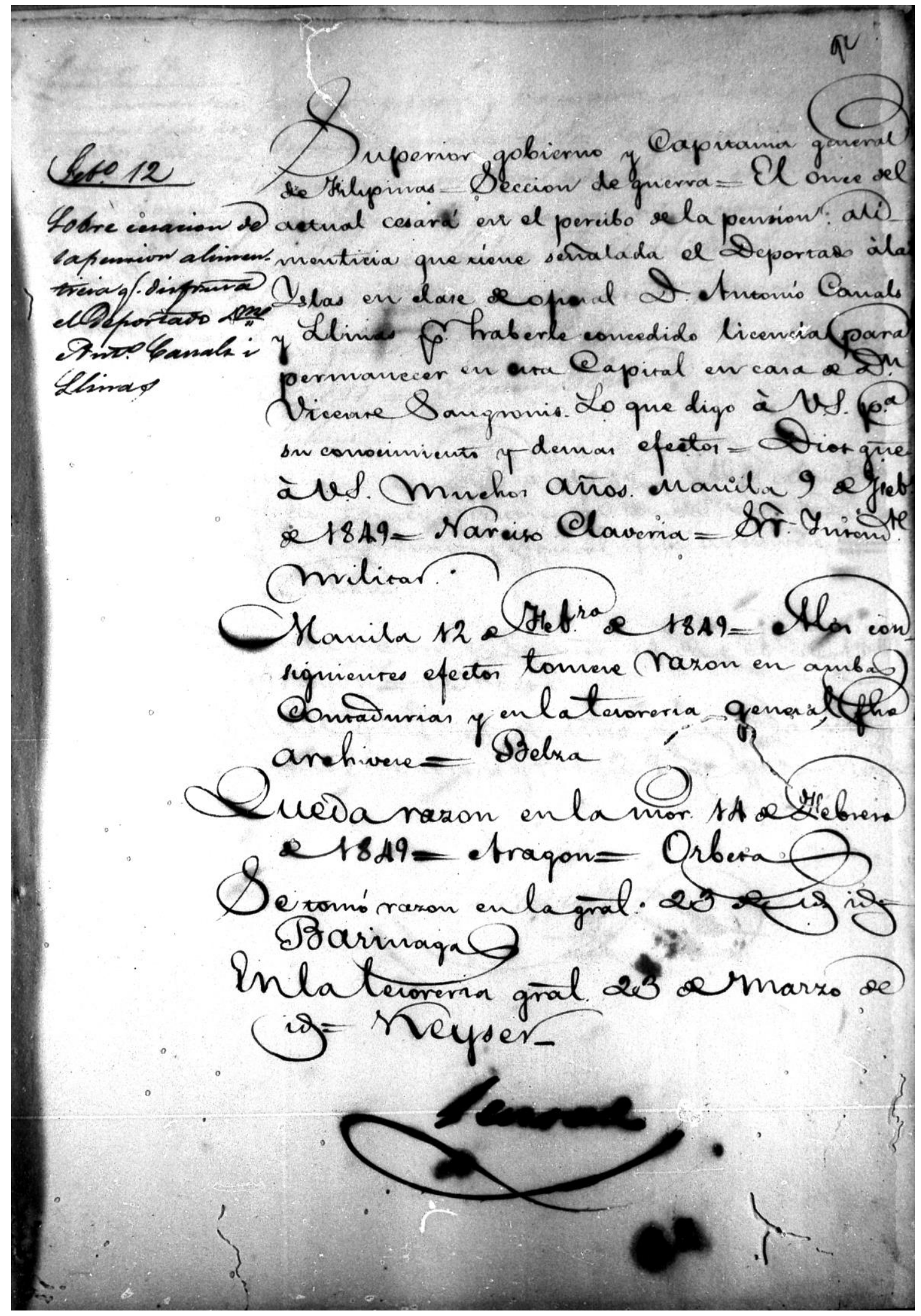

Fuente: PNA, Guerra, Leg. 136. 
Documento 6. Presupuesto para la compra de herramientas y otros menesteres necesarios para la agricultura para los deportados cantonalistas en las islas Marianas.

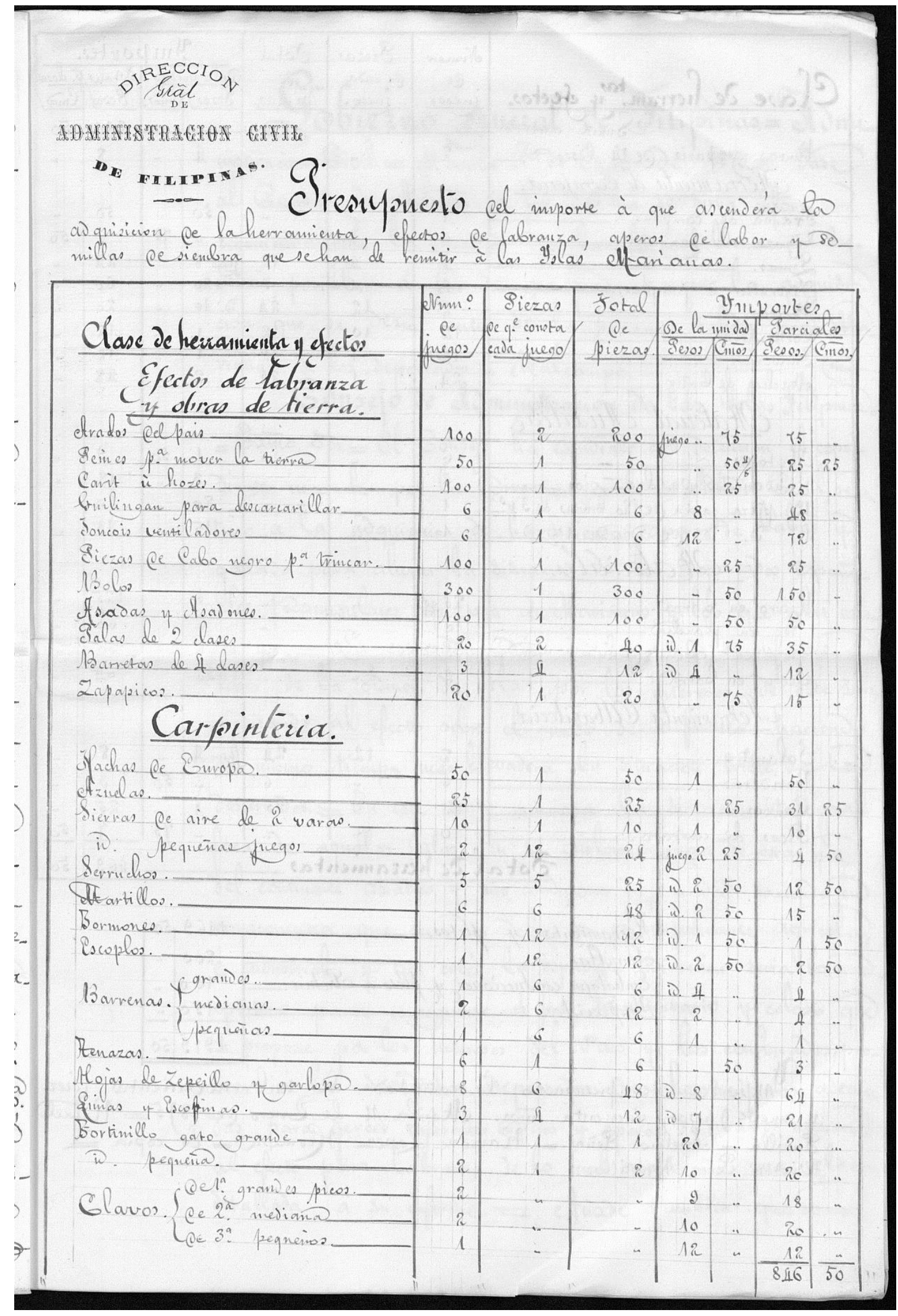



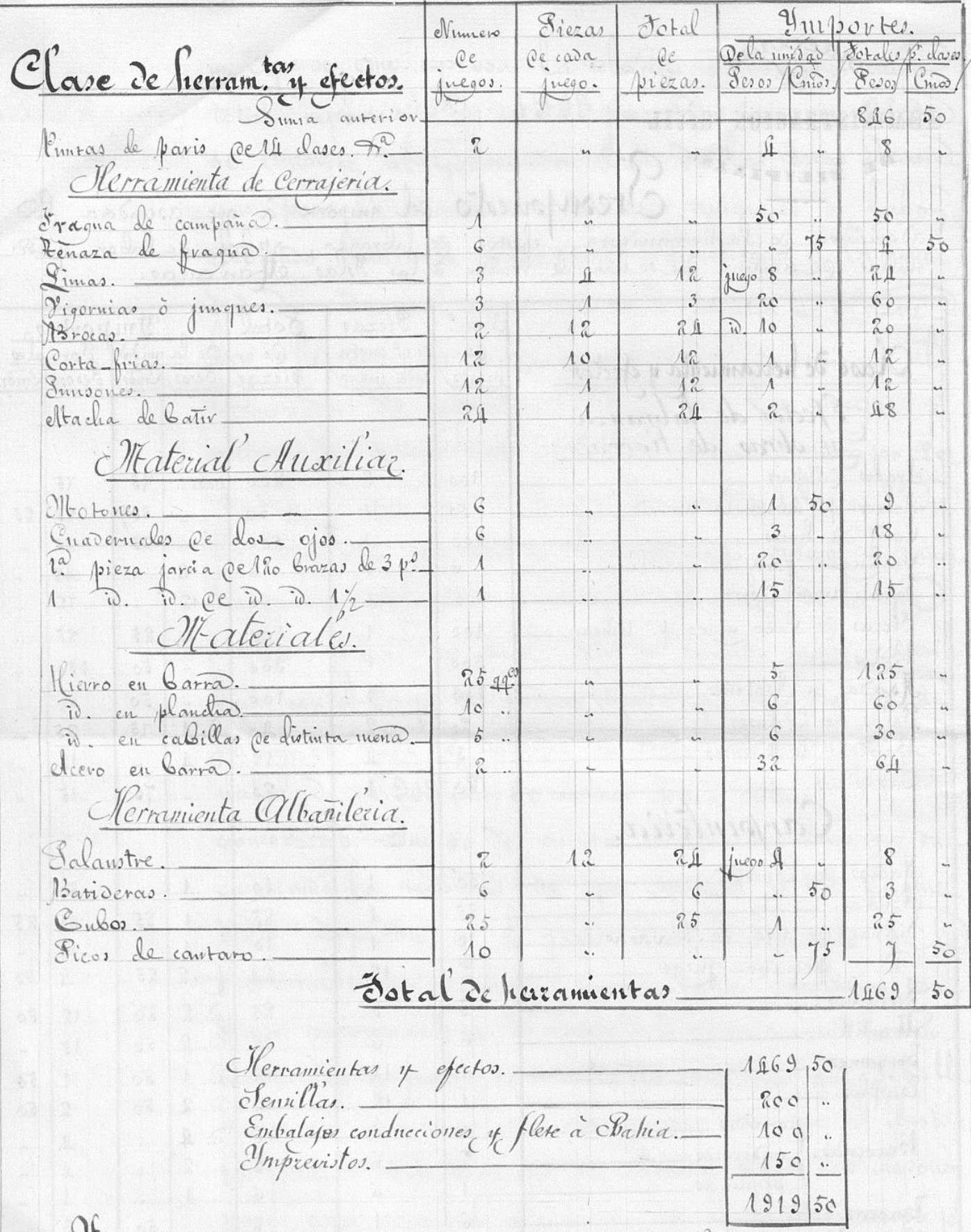

If 111 orta este preampress la eanitidad de nil noverientos dier

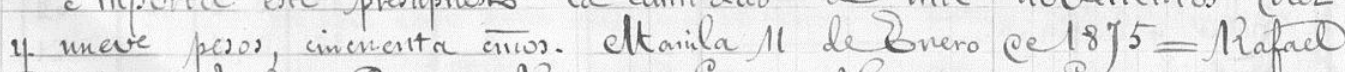

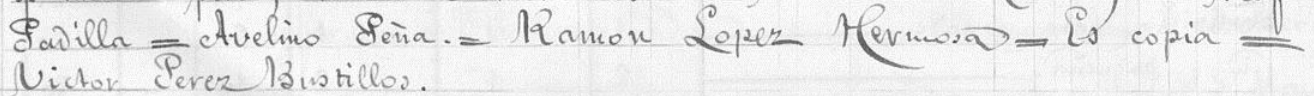

Fuente: AHN, Ultramar, Leg. 5225, Exp. 62. 
Documento 7. Fuga de varios deportados cantonales de las islas Marianas.

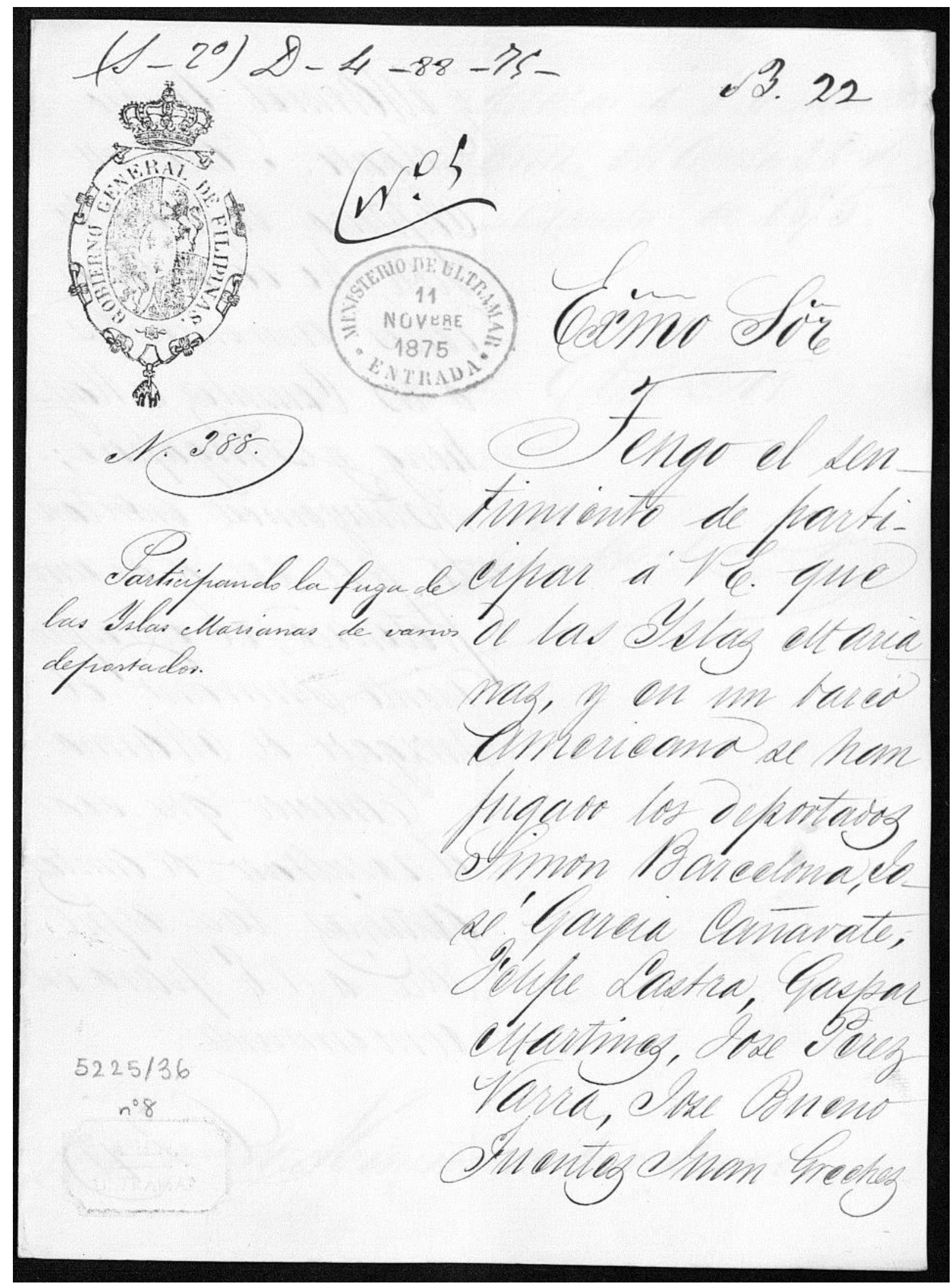




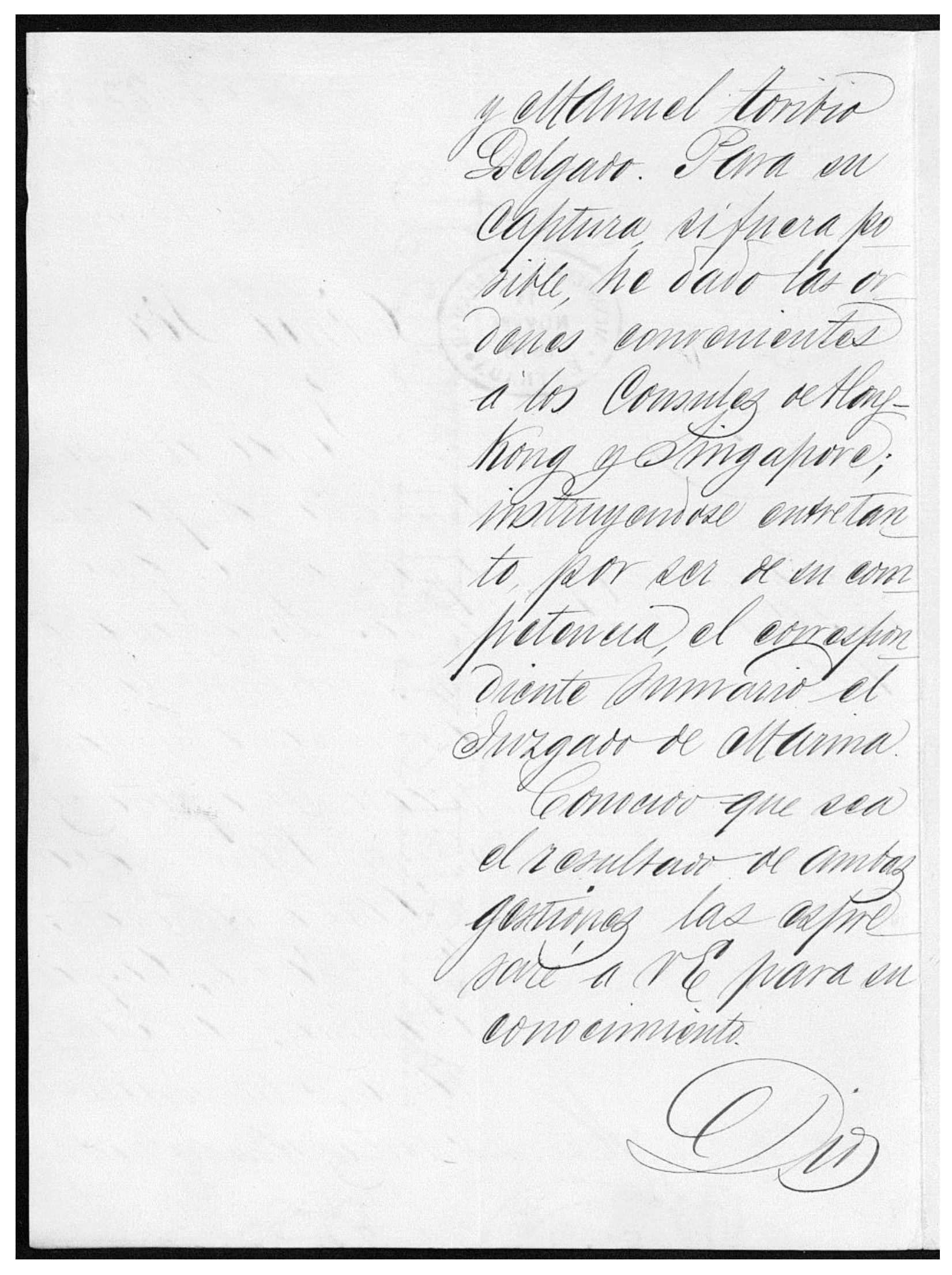




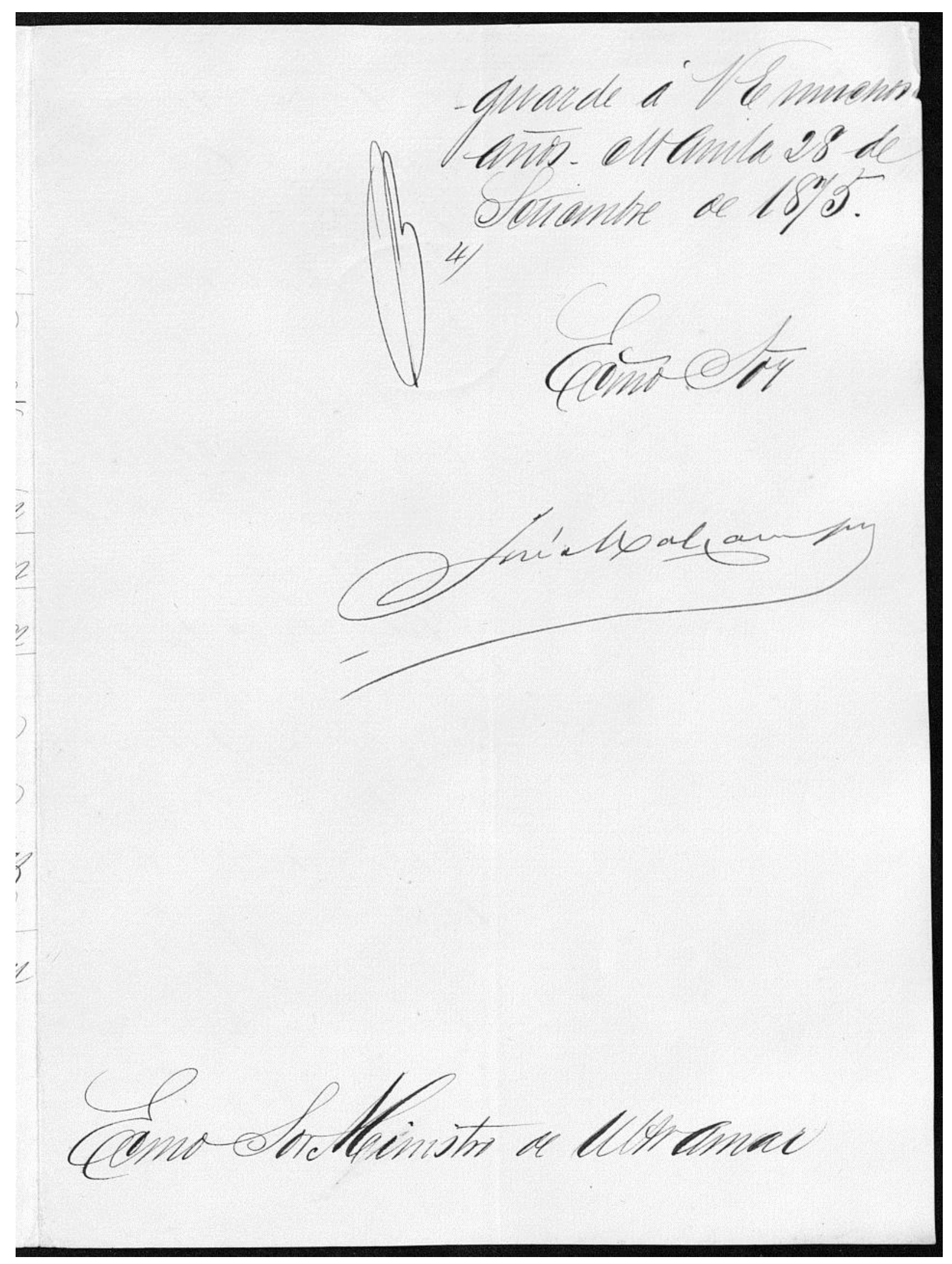

Fuente: AHN, Ultramar, Leg. 5225, Exp. 36. 


\section{FUENTES Y BIBLIOGRAFÍA}

\section{FUENTES}

\section{ARCHIVOS}

Arxiu Històric de la Ciutat de Barcelona (AHCB)

- $\quad$ Fons Antoni Giberga

Arxiu Municipal Contemporani de Barcelona (AMCB)

- $\quad$ Comissió de governació

Archivo General de la Administración (AGA)

- África-Guinea

- $\quad$ Presidencia del Gobierno

$\underline{\text { Archivo General de Indias (AGI) }}$

- Ultramar

Archivo General Militar de Madrid (AGMM)

- Capitanía General de Cuba

- Capitanía General de Vascongadas

- Documentación de Puerto Rico

- Gobiernos Militares

- Guerras Carlistas

- $\quad$ Ministerio de la Guerra

Archivo Histórico Nacional (AHN)

- Gobernación

- Ultramar

$\underline{\text { Archivo Intermedio Militar Sur (AIMS) }}$

- $\quad 2^{\mathrm{a}}$ División Orgánica

Archivo Nacional de Cuba (ANC)

- Asuntos Políticos

- Comisión Militar

- Donativos y Remisiones

- Junta de Fomento

- $\quad$ Reales Órdenes y Cédulas

Philippines National Archives (PNA)

- Consultas

- Decretos

- $\quad$ Expedientes Gubernativos

- Guerra

- $\quad$ Obras Públicas

- Oficios

- $\quad$ Real Audiencia 
Biblioteca Nacional de Cuba José Martí, Manuscritos (BNCJM)

\begin{tabular}{ll} 
- & Arredondo \\
- & Bachiller \\
- & Pintó \\
- & Ponce \\
\hline
\end{tabular}

Biblioteca de la Real Academia de Historia (BRAH)

- $\quad$ Archivo de Narváez

\section{PRENSA}

Boletín de Comercio, 1873.

Diario Constitucional de Barcelona, 1823.

Diario Constitucional de Palma, 1848, 1849.

Diario Constitucional, Político y Mercantil de Barcelona, 1823.

Diario de la Marina, 1896.

Diario Oficial de Avisos de Madrid, 1895, 1897.

El Áncora, 1854, 1855.

El Año Político, 1897.

El Balear, 1854-1856.

El Boletín del Ejército, 1844.

El Católico, 1844, 1847, 1849, 1851.

El Clamor Público, 1844, 1846-1850, 1854-1856, 1862, 1864.

El Comercio, 1848.

El Contemporáneo, 1861, 1863.

El Correo Español, 1897.

El Correo Militar, 1886, 1896.

El Día, 1897.

El Eco del Comercio, 1835-1840, 1844-1846.

El Español, 1835, 1836, 1848.

El Espectador, 1848.

El Genio de la Libertad, 1840, 1844, 1851, 1854.

El Globo, 1897.

El Heraldo, 1844, 1849.

El Imparcial, 1867, 1868, 1895, 1897.

El Liberal, 1896, 1897.

El Lloyd Español, 1867.

El Mundo, 1874.

El Nacional, 1848-1850.

El Observador, 1849.

El País, 1902.

El Popular, 1848, 1849.

El Universal, 1821.

Gaceta de Sanidad Militar, 1878.

La América, 1873.

La Corona de Aragón, 1855.

La Correspondencia de España, 1861, 1867, 1873, 1895, 1896.

La Dinastía, 1896.

La Discusión, 1856-1858, 1861, 1862, 1866, 1868, 1869.

La Época, 1850, 1854-1858, 1861, 1862, 1864, 1867-1869, 1874, 1879, 1895-1897.

La España, 1848, 1849, 1855, 1856, 1861, 1868.

La Esperanza, 1845-1847, 1849, 1850, 1854-1856, 1861, 1862, 1867, 1868. 
La Iberia (1854), 1854-1856, 1858, 1864, 1866.

La Iberia (1868), 1868, 1895-1897.

La Ilustración, 1854.

La Ilustración Española y Americana, 1886.

La Ilustración Republicana Federal, 1871.

La Libertad, 1855.

La Nación, 1849.

La Nueva Iberia, 1868.

La Posdata, 1844.

La Revista Española, 1833-1835.

La Unión, 1886.

La Unión Católica, 1895-1897.

La Unión Constitucional, 1896, 1897.

La Vanguardia, 1897.

Miscelánea de Comercio, Política y Literatura, 1821.

The Newspaper, 1848.

\section{FUENTES LEGISLATIVAS}

Boletín de Jurisprudencia y Legislación (Nueva Serie), Imprenta de la Viuda de Jordán e hijos, Madrid, 1842, 3 tomos.

Código Penal francés de 1810.

Código Penal español de 1822.

Código Penal español de 1848.

Código Penal español de 1870.

Código Penal de Cuba y Puerto Rico de 1879.

Código Penal de Filipinas de 1884,

Colección de los decretos y órdenes generales expedidos por las Cortes extraordinarias, de los años de 1820 y 1821, en el segundo periodo de su diputación, que comprende desde el 25 de febrero hasta el 30 de junio del último año. Impresa de orden de las mismas, (tomo VII), Imprenta Nacional, Madrid, 1821.

Colección de los decretos y órdenes generales expedidos por las Cortes extraordinarias, que comprende desde el 3 de octubre de 1822 hasta 19 de febrero de 1823. Impresa de orden de las mismas, (tomo X), Imprenta de don Tomás Albán y Cía., Madrid, 1823.

Colección general de las providencias hasta aquí tomadas por el Gobierno sobre el extrañamiento y ocupación de temporalidades de los regulares de la compañía que existían en los dominios de S.M. de España, Indias e Islas Filipinas. A consecuencia del real decreto de 27 de febrero, y pragmática sanción de 2 de abril de este año, Imprenta Real de la Gaceta, Madrid, 1767.

Colección Legislativa de España. (Continuación de la Colección de Decretos), Imprenta Nacional/Imprenta del Ministerio de Gracia y Justicia, Madrid, 1849-1889. 
Colección legislativa de presidios y casas de corrección de mujeres. Comprensiva de la ordenanza general de presidios de 14 de abril de 1834, y de todas las disposiciones legales y reglamentarias referidas al ramo, expedidas posteriormente hasta $1^{\circ}$ de noviembre de 1861. Formada de orden de la dirección general de establecimientos penales, Imprenta Nacional, Madrid, 1861, 2 tomos.

Constitucions, capítols, $i$ actes de cort. Fetes i atorgades, per la S.C.R. majestat del rei nostre senyor don Carlos III. Rei de Castella, de Aragó, Comte de Barcelona \&. En la Cort celebrà als catalans en la ciutat de Barcelona, en la casa de la Diputació del General de Catalunya, en lo any de 1706, Estampa de Rafel Figuerò, Barcelona, 1706.

Decretos del rey nuestro señor don Fernando VII, y reales órdenes, resoluciones y reglamentos generales expedidos por las secretarias del despacho universal y consejos de S.M. desde $1^{o}$ de enero hasta fin de diciembre de 1830. Por don Josef María de Nieva, (Tomo XV), Imprenta Real, Madrid, 1831.

Decretos de S.M. la reina doña Isabel II, dados en su real nombre por su augusta madre la reina gobernadora, y reales órdenes, resoluciones de reglamentos generales expedidos por las secretarias del despacho universal desde $1^{\circ}$ de enero hasta fin de diciembre de 1836. Incluye en el apéndice las leyes y decretos de las Cortes que por las actuales y por S.M. han sido restablecidos en el mismo año. Por Josef María de Nieva, (tomo XXI), Imprenta Nacional, Madrid, 1837.

Fuero Juzgo en latín y en castellano, cotejado con los más antiguos y preciosos códices, Real Academia Española, Madrid, 1815.

Fuero Real (citado de Opúsculos Legales del rey don Alfonso el Sabio, publicados y cotejados con varios códices antiguos, Imprenta Real, Madrid, tomo II, 1836).

Fueros y observancias del Reino de Aragón, Diputación de Aragón, 1667, 2 tomos.

Furs de Valencia, (edición de Germà Colon i Arcadi García), Barcino, Barcelona, 1970-2008, 11 vols

Gaceta de Madrid, 1823, 1834, 1840, 1841, 1848, 1849, 1856, 1862, 1867-1869, 1874-1877, 1886.

Gaceta de La Habana, 1897.

Miranda Junco, Agustín: Leyes Coloniales. Legislación de los territorios españoles del golfo de Guinea, Sucesores de Rivadeneyra, Madrid, 1945.

Las siete Partidas del rey don Alfonso el Sabio, cotejadas con varios códices antiguos por la Real Academia de la Historia, Imprenta Real, Madrid, 1807, 3 tomos.

Novísima Recopilación de las leyes de España. Dividida en XII libros. En que se reforma la Recopilación promulgada por el señor don Felipe II en el año de 1567, reimpresa últimamente en el de 1775: Y se reincorporan las pragmáticas, cédulas, decretos, órdenes y resoluciones reales, y otras providencias no recopiladas y expedidas hasta el de 1804, Madrid, 1805, 5 tomos.

Recopilación de las leyes de estos reinos hecha por mandato de la majestad católica del rey don Felipe II nuestro señor; que se han mandado imprimir con las leyes que después de la 
última impresión se han publicado por la majestad católica del rey don Felipe IV el grande nuestro señor, Catalina de Barrio y Angulo y Diego Díaz de la Carrera, Madrid, 1640, 3 vols.

Recopilación de las Leyes de Indias de los reinos de las Indias. Mandadas imprimir y publicar por la majestad católica del rey don Carlos II, nuestro señor, Boix Editor, Madrid, 1841, 4 tomos.

Recopilación compendiada de las Leyes de Indias, aumentada con algunas notas que no se hallan en la edición de 1841 y con todas las disposiciones dictadas posteriormente para los dominios de Ultramar, por los doctores don Joaquín Aguirre y don Juan Manuel Montalbán, catedráticos de jurisprudencia en la Universidad de Madrid, Adición al febrero, Imprenta de D. Ignacio Boix, Madrid, 1846.

\section{FUENTES IMPRESAS}

Aguirre, Ramón: Relación de los sucesos de Barcelona en julio de 1856, Imprenta de M. Rivadeneyra, Madrid, 1856.

Ahumada y Centurión, José: Memoria histórico política de la isla de Cuba, redactada de orden del señor ministro de Ultramar, Imprenta de A. Pego, La Habana, 1874.

Ajo Jacques, Julián: "Memoria histórica, geográfica y política agrícola e industrial de la isla de Pinos desde su descubrimiento hasta el tiempo presente, situación actual de su municipio y diversos ramos de su administración y gobierno, escrita en el año de 1875 por el coronel de infantería D. Julián Ajo Jacques y de orden el Excmo. señor Gobernador general de la isla de Cuba", BANC, núm. 12, 1912.

Alba Salcedo, Leopoldo de: La revolución española en el siglo XIX, Biblioteca Universal Económica, Madrid, 1869.

Apuntes históricos acerca de la expedición pirática que invadió la isla de Cuba en mayo de 1850, y detalles de la causa seguida contra el ex-general Narciso López y sus cómplices, Imprenta de Alemán y Gómez, Nueva Orleans, 1850.

Arango y Parreño, Francisco: "Representación hecha a S.M. con motivo de la sublevación de esclavos en los dominios franceses de la isla de Santo Domingo", en Obras, Imprenta de Howson y Heinen, La Habana, 1888, tomo I, pp. 47-52.

Arenal, Concepción Arenal: Las colonias penales de la Australia y la pena de deportación, Imprenta de Eduardo Martínez, Madrid, 1877.

Armíldez de Toledo (conde de): Noticias estadísticas de la isla de Cuba, en 1862, Imprenta del Gobierno y Capitanía General, La Habana, 1864.

Arnao, Juan: Paginas para la historia de Cuba, Imprenta La Nueva, La Habana, 1900.

Artagán, (barón de) (seudónimo de Reynaldo Brea): Cruzados modernos, Imprenta y Litografía Fiol, Barcelona, 1910.

Aviraneta e Ibargoyen, Eugenio de: Mis memorias intimas o apuntes para la historia de los últimos sucesos ocurridos en la emancipación de la Nueva España, 1825-1829, Moderna Librería Religiosa de J. L. Vallejo, México, 1906. 
y Bertrán Soler, Tomás: Mina y los proscriptos, Imprenta de la Colonia, Argel, 1836.

Ayguals de Izco, Wenceslao: El palacio de los crímenes o el pueblo y sus opresores, Imprenta de Ayguals de Izco hermanos, Madrid, 1855, 2 tomos.

Balmaseda, Francisco Javier: Los confinados a Fernando Poo e impresiones de un viaje a Guinea, Imprenta de la Revolución, Nueva York, 1869.

Barraquer y Roviralta: Cayetano: Los religiosos en Cataluña durante la primera mitad del siglo XIX, Francisco J. Altés y Alabart, Barcelona, 1915-1917, 4 tomos.

Beccaria, Cesare: De los delitos y las penas, (traducido por Juan Antonio de las Casas), Joaquín Ibarra, Impresor, Madrid, 1774.

Bentham, Jeremías: Teoría de las penas y de las recompensas, Masson e hijo, París, 1826.

Bermejo, Ildefonso: Alzamiento popular de 1854, que comprende desde la cuestión de ferrocarriles hasta la entrada del duque de la Victoria en Madrid y disposiciones posteriores. Establecimiento tipográfico de Mellado, Madrid, 1854.

Bertrán de Lis, Vicente: Apuntes biográficos de don Vicente Bertrán de Lis o sea apéndice a los folletos titulados los gobiernos y los intereses materiales, Establecimiento Tipográfico Militar de Mateo y Torrubia, Madrid, 1852.

Biografía del Excmo. Señor Manuel Pavía y Lacy, marqués de Novaliches, Imprenta de Manuel Minuesa, Madrid, 1861.

Boix, Vicente: Historia de la ciudad y reino de Valencia, Imprenta de D. Benito Montfort, Valencia, 1845-1847, 3 tomos.

Bosquejo de la conducta del teniente general D. Miguel Tacón en la isla de Cuba, Imprimerie des Bouchez, Marsella, 1838.

Bravo Senties, Miguel: Deportación a Fernando Poo. Relación que hace uno de los deportados, Hallet \& Breen, Nueva York, 1869.

Burgos, Francisco Javier de: Anales del reinado de doña Isabel II, Establecimiento Tipográfico de Mellado, Madrid, 1850-1851, 6 tomos.

Buxéres, Antonio: Elogio del difunto coronel don Antonio Puig y Luca, Imprenta de José Tauló, Barcelona, 1849.

Buzeta, Manuel y Bravo, Felipe: Diccionario geográfico-estadístico-histórico de las islas Filipinas, Imprenta de D. José C. de la Peña, Madrid, 1851, 2 tomos.

Cabrera, Raimundo: Mis Buenos tiempos (memorias de un estudiante), Sociedad de Ediciones Literarias y Artísticas. Librería Paul Ollendorff, Paris, 1891.

Cabrerizo, Mario: Historia de mis vicisitudes políticas desde 1820 a 1836, Imprenta de Mario Cabrerizo, Valencia, 1854.

Cadalso, Fernando: La pena de deportación y la colonización por penados, Imprenta de José Góngora, Madrid, 1896. 
Calcagno, Francisco: Diccionario biográfico cubano, Imprenta de N. Ponce de León, Nueva York, 1878.

Calbo y Rochina de Castro, Dámaso y Cabrera y Griñó, Ramón: Historia de Cabrera y de la Guerra Civil en Aragón, Valencia y Murcia, Establecimiento Tipográfico de D. Vicente Castelló, Madrid, 1843.

Campe, Tiburcio: Al público. Acusación contra el conde de Clonard cometida en la persona de Tiburcio Campe, Imprenta de F. Orza, La Coruña, 1838.

Canalejas, José María: Breve reseña de los sucesos de abril y mayo de 1837 en Reus y Barcelona, con relación al juicio y sentencia de don Ramón Xaudaró, Imprenta de Julio Barile, Marsella, 1839.

El ciudadano José María Canalejas, uno de los deportados a Pinos, conjura y provoca a sus perseguidores y detractores a que denuncien los delitos y faltas que hubiese cometido como particular y como empleado, Imprenta del Constitucional, Barcelona, 1839.

, et al.: Justificación de los deportados de Barcelona a Canarias y Pinos, y relación de las vicisitudes de los fugados hasta su arribo a Barcelona, Imprenta del Constitucional, Barcelona, 1839.

Cartas de Jeremías Bentham, al señor conde de Toreno, sobre el proyecto del Código Penal presentado a las Cortes, Imprenta de don Diego García y Campoy, Madrid, 1821.

Castelar, Emilio, et al., Anuario republicano federal, compendio de lo más útil e indispensable del saber humano en filosofía, ciencias, literatura, arte y política. Con el calendario republicano para 1871, J. Castro y Cía., Editores, Madrid, 1870.

: Biografías de los diputados a Cortes de la Asamblea Constituyente de 1869, con los retratos de los mismos perfectamente litografiados por los principales artistas de esta capital, Imprenta de Tomás Alonso, Madrid, 1869, 2 tomos.

Castillo y Mayoné, Joaquín del: Las bullangas de Barcelona o sacudimientos de un pueblo oprimido por el despotismo ilustrado, Imprenta de A. Gaspar y Cía., Barcelona, 1837.

: La ciudadela inquisitorial o las victimas inmoladas en aras del atroz despotismo del conde de España, Imprenta de Manuel Saurí, Barcelona, 1835.

Causas sentenciadas por la Comisión nombrada por S.M., Imprenta Real, Madrid, s/a.

Colección Eclesiástica Española, Imprenta de E. Aguado, Madrid, 1823-1824, 14 tomos.

Colección de fallos pronunciados por una sección de la Comisión Militar establecida en Matanzas para conocer de la causa de conspiración de la gente de color, Imprenta del Gobierno, Matanzas, 1844.

Columbrí, Alberto: Memorias de un presidiario político (1857), I. López, Editor, Barcelona, 1864.

Corte Ruano, Felipe de la: Memoria descriptiva e histórica de las islas Marianas y otras que las rodean en relación con ellas y su organización actual, con estudio analítico de todos sus 
elementos físicos, morales y políticos y propuesta de su reforma en todos los ramos para elevarlas al grado de prosperidad que les corresponde. Escrita por el teniente Ceronsi, Imprenta Nacional, Madrid, 1875.

Degollada, Rafael: Memoria del abogado don Rafael Degollada, en defensa de su honor ultrajado. Con las cuatro persecuciones sufridas por sus opiniones políticas desde el mes de enero de 1836 hasta el de octubre de 1837, en que fue deportado a La Habana y de allí a Pinos, Imprenta Senés, Marsella, 1839.

Diario de Sesiones de las Cortes, 1820-1823 (incluye actas secretas de 1822), 1836-1840, 1848, 1849, 1854-1856, 1858, 1862, 1867.

Do-Porto, Juan: Reseña histórica de los últimos acontecimientos políticos de Galicia, Imprenta de la viuda de Burgos, Madrid, 1846.

Dorado Montero, Pedro: “Deportación”, en Luis Moutón Ocampo et. al., Enciclopedia jurídica española, Francisco Seix, Editor, Barcelona, 1911, tomo, X, pp. 757-794.

: "Colonias penitenciarias" en Luis Moutón Ocampo et al., Enciclopedia jurídica española, Francisco Seix, Editor, Barcelona, 1910, tomo VII, pp. 164-180.

Dufort, Armand: Révélations d'un militaire français sur les agraviados d'Espagne ou sont dévoilées les véritables causes de l'insurrection de la Catalogne en 1827, Levavaseur, París, 1829.

Espoz y Mina, Francisco: Memorias del general don Francisco Espoz y Mina, escritas por el mismo. Publícalas su viuda doña Juan María de Vega, condesa de Espoz y Mina, Imprenta de M. Rivadeneyra, Madrid, 1851-1852, 5 tomos.

Fastos españoles o efemérides de la Guerra Civil desde octubre de 1832, Imprenta de D. Ignacio Boix, Madrid, 1839-1840, 2 tomos.

Fernández de Córdova, Fernando: Mis memorias intimas, Sucesores de Rivadeneyra, Madrid, 1886-1889, 4 tomos.

Fernández Cuesta, Nemesio, et al.: Causas formadas a consecuencia de la sedición militar que tuvo lugar en la noche del 7 de octubre de 1841, Compañía General de Impresores y Libreros, Madrid, 1841.

Fernández de los Ríos, Ángel: Estudio histórico de las luchas políticas en la España del siglo XIX, English y Gras, Madrid, 1879-1880, 2 tomos.

García Goyena, Florencio, y Aguirre, Joaquín: Febrero o librería de jueces abogados y escribanos, comprensiva de los códigos civil, criminal y administrativo, tanto en la parte teórica como en la práctica, con arreglo en un todo a la legislación vigente. Imprenta de Gaspar y Roig, Madrid, 1852, 6 tomos.

Groizard y Gómez de la Serna, Alejandro: El Código Penal de 1870 concordado y comentado, Imprenta de D. Timoteo Arnaiz, Burgos, 1870-1899, 8 tomos.

Guichot, Joaquín: Historia general de Andalucía desde los tiempos más remotos hasta 1870, Eduardo Perié, Sevilla, 1869-1871, 8 tomos. 
Gutiérrez de la Concha, José: Memorias sobre el estado político, gobierno y administración de la isla de Cuba, Establecimiento Tipográfico de José Trujillo, Madrid, 1853.

Flávio, E.: Historia de don Ramón Cabrera, Establecimiento Tipográfico de G. Estrada, Madrid, 1870, 2 tomos.

Fuente, Vicente de la: Historia eclesiástica de España, Impresores y Libreros del Reino, Madrid, 1873-1875, 6 tomos.

: Historia de las sociedades secretas antiguas y modernas en España, y especialmente de la francmasonería, Imprenta de Soto Freire, Lugo, 1870-1871, 3 tomos.

Galería militar contemporánea, colección de biografías y retratos de los generales que más han conseguido en los ejércitos liberal y carlista, durante la última guerra civil, con una descripción particular y detallada de las campañas del norte y Cataluña, obra original, redactada con presencia de diarios originales de operaciones y otros documentos inéditos proporcionados por los diferentes caudillos que han de figurar en la historia, Sociedad Tipográfica de Hortelano y Cía., Madrid, 1846, 2 tomos.

García Camba, Andrés: Los diez y seis meses de mando superior de Filipinas, Imprenta de D. Domingo Feros, Cádiz, 1839.

García de Polavieja, Camilo: Relación documentada de mí política en Cuba; lo que vi, lo que hice, lo que anuncie, Imprenta de Emilio Minuesa, Madrid, 1898.

García Ruiz, Eugenio: Historias, Imprenta del Pueblo Español/A. Bacaycoa, Madrid, 18761878,2 tomos.

Garrido, Fernando: Historia del último Borbón de España. De los crímenes, apostasías, opresión, corrupción, inmoralidad, despilfarros, hipocresía, crueldad y fanatismo de los gobiernos que han regido España durante el reinado de Isabel de Borbón, Salvador Manero, Editor, Barcelona, 1868-1869, 3 tomos.

Garrido, Roque E.: Historia documentada de la Conspiración de los Soles y Rayos de Bolívar, Imprenta El Siglo, La Habana, 1929, 2 tomos.

Gebhart, Víctor: Historia general de España y de sus Indias, desde los tiempos más remotos hasta nuestros días. Tomada de las principales historias, crónicas y anales que acerca de los sucesos ocurridos en nuestra patria se han escrito, Imprenta de Luis Tasso, Barcelona, 1863, 7 tomos.

Gelpi Ferro, Gil: Historia de la revolución y guerra de Cuba, Gaceta Oficial, La Habana, 18871889,3 vols.

Gonzaga Oronoz, Luis: Manifiesto que Fr. Luis Gonzaga Oronoz hace a la España entera sobre la sonada conspiración para destituir las autoridades legítimamente constituidas, levantar nuestras fuerzas militares, remover los empleados en el ramo de hacienda, jueces de las Audiencias, y cometer otros excesos, substituyendo al Gobierno monárquico moderado hereditario el demócrata, o republicano, de que se acusó a dicho Oronoz, a D. Jorge Besieres, y al Ayudante supernumerario de la ciudadela de esta plaza D. Francisco Brotons; cuyas causas tuvieron origen de la prisión del primero en la noche del 20 de mayo último. En refutación a la conclusión, o manifiesto, fiscal por el Coronel don Manuel Fernández, Imprenta Constitucional de Joaquín Jordi, Barcelona, 1821. 
González Alcántara, Eduardo: Memorias de la revolución cantonal iniciada en Cartagena el 14 de julio de 1873, Imprenta el Argentino, Buenos Aires, 1875.

Gorostiza, Manuel: Cataluña a fines de 1822, o sea rápida ojeada sobre el origen, progreso, proyectos y recursos de la facción liberticida en las cuatro provincias, Imprenta de Eusebio Álvarez, Madrid, 1822.

Guillemard, Adolfo de: Opúsculo sobre la colonización de Fernando Poo y revista de los principales establecimientos de la costa occidental de África, Imprenta Nacional, Madrid, 1852.

Hallam, George: Narrative of the voyage from Montego Bay in the island of Jamaica to England; by a route never gone before or since, across the island of Cuba to Havana: from thence to Charles Town, South Carolina, Newcastle on the Delaware, and Baltimore, Maryland, and by land to Washington and back; thence to Philadelphia, and through the Jerseys, to New York. Performed in the autumn, 1809. Also of a voyage from England to Barbados by Cadiz, Tenerife, and Guadeloupe, in 1810, C.J.G. \& F. Rivington, London, 1831.

Iglesias Pardo, Luis: Observaciones teórico-prácticas sobre las fiebres africanas de Fernando Poo, precedida de una reseña histórico-geográfica de la isla, Taxonera, Ferrol, 1874.

Informe sobre el censo de Cuba, 1899 (Teniente coronel J. P. Sanger, dir.), Imprenta del Gobierno, Washington, 1900.

Informe de la comisión nombrada por el gobernador de Fernando Poo en 5 de mayo de 1860, Imprenta Nacional, Madrid, 1861.

Jaumar, Joaquín: Manifiesto del ciudadano don Joaquín Jaumar, en vindicación de las calumnias que se le han prodigado, durante su deportación a la isla de Pinos, Imprenta de Julio Barile, Marsella, 1839.

Kostka Vayo, Estanislao de: Historia de la vida y reinado de Fernando VII de España, Repullés, Madrid, 1842, 3 tomos.

Lastres, Francisco: Estudios Penitenciarios, Establecimiento Tipográfico de Pedro Núñez, Madrid, 1887.

: La colonización penitenciaria de las Marianas y Fernando Poo, Imprenta de Eduardo Martínez, Madrid, 1878.

La Revolución y bombardeo de Barcelona en 1842. Escrita por un sargento primero, que era en aquella época, del batallón de artillería de la Milicia Nacional de esta ciudad, Imprenta de A. Albert, Barcelona, 1843.

Latorre, Justo de: Una ojeada al manifiesto que publicó el Excmo. Sr. D. Miguel Tacón al dejar el mando de la isla de Cuba, Domingo Feros, Cádiz, 1838.

Latorre Machado, Manuel de: El procónsul de La Habana y los deportados de la isla de Cuba. Manifiesto al magnánimo pueblo español, Imprenta del Comercio, Cádiz, 1836.

López Domínguez, José: Cartagena. Memorias y comentarios sobre el sitio de Cartagena, J. Conde y Cía., Madrid, 1877.

López Hidalgo, Ambrosio Valentín: De La Habana a Chafarinas (los cubanos deportados en el vapor Santiago), Galería Literaria, Matanzas, 1900. 
Los diputados pintados por sus hechos. Colección de estudios biográficos sobre los elegidos por el sufragio universal en las constituyentes de 1869. Recopilados por distinguidos literatos y seguido de un exacto e imparcial resumen de las causas y efectos de la revolución española hasta el día en que las Cortes decidan la forma definitiva de gobierno que ha de regir la nación. Ilustrada con magníficos retratos en litografía, por el acreditado artista Santiago Llanta, R. Labajos y Cía., Editores, Madrid, 1869-1870, 3 tomos.

Lorenzo, Manuel: Manifiesto del general don Manuel Lorenzo a la nación española, Imprenta de Tiburcio Campe, Cádiz, 1837.

Machuca, Manuel: Continuación de las noticias preliminares, e indispensables para conocer la justicia e injusticia que halla en el resultado del juicio de residencia, intentado para examinar la conducta de Miguel Tacón y Rosique, Viuda e Hijo de Bosch, Cádiz, 1839.

Manifiesto de don Antonio de Gironella, primer comandante del $6^{\circ}$ batallón de línea de la Guardia Nacional de Barcelona, Imprenta de Vicente Bonet, Santa Cruz de Tenerife, 1836.

Marliani, Manuel de: La regencia de D. Baldomero Espartero, conde de Luchana, duque de la Victoria y de Morella, y sucesos que la prepararon, Imprenta de Manuel Galiano, Madrid, 1870.

Marquet y Roca, José: Memorias para la historia de la última guerra civil de España. Contiene los principales sucesos de Cataluña, desde que se levantaron los primeros realistas hasta el fin de dicha guerra, Imprenta de Brusi, Barcelona, 1826, 2 tomos.

Martos, Cristino: La revolución de julio de 1854, Colegio de Sordomudos y Ciegos, Madrid, 1854.

Martínez Villergas, Juan y Fontseré, José Ribot, Los políticos en camisa, historia de muchas historias, escrita por J. M. V. y un Jesuita, confesor cesante de los farsantes de alto copete, que sabe todas sus marrullerías porque ellos se las han dicho en secreto de confesión y él nos las ha revelado, también en secreto, así como nosotros en secreto las confesamos a todo el público español recomendándole el secreto, Imprenta del Siglo, Madrid, 1845-1847, 3 tomos.

Mas, Sinibaldo de: Informe sobre el estado de las islas Filipinas en 1842. Escrita por el autor del Aristodemo, del sistema musical de la lengua castellana, Imprenta de I. Sancha, Madrid, 1843,2 tomos.

Miranda, Manuel: Memorias de un deportado, Imprenta la Luz, Habana, 1903.

Montero y Vidal, José: Historia general de Filipinas desde el descubrimiento de dichas islas hasta nuestros días, Imprenta de M. Tello/Viuda e Hijos de Tello, Madrid, 1887-1895, 3 tomos.

Montero y Vidal, José: El archipiélago filipino y las islas Marianas, Carolinas y Palaos. Su historia, geografía y estadística, Imprenta de Manuel Tello, Madrid, 1886.

Montes, Pedro Domingo: Historia de la gloriosa revolución española en septiembre de 1868. Con las biografías y retratos de los libertadores de la patria, Elizalde y Cía., Editores, Madrid, 1868.

Morales y Morales, Vidal: Iniciadores y primeros mártires de la revolución cubana, Avisador Comercial, La Habana, 1901. 
Móros y Morellón, José de y Ríos, Juan Miguel de los: Memorias sobre las islas africanas de Fernando Poo y Annobón, Compañía Tipográfica, Madrid, 1844.

Muñoz y Gaviria, José (Vizconde de San Javier): Tres años en Fernando Poo. Viaje a África, Urbano Manini, Editor, Madrid, 1871.

Narración militar de la Guerra Carlista de 1872 a 1876 por el Cuerpo de Estado Mayor del Ejército, Imprenta y Litografía del Ministerio de la Guerra, Madrid, 1883-1889, 14 tomos.

Navarro, Joaquín J.: Apuntes sobre el estado de la costa occidental de África y principalmente de las posesiones en el golfo de Guinea, Imprenta Nacional, Madrid, 1859.

Olañeta, José Antonio de: Juicio de residencia del Excelentísimo señor don Miguel Tacón, vizconde del Bayamo, marqués de la Unión de Cuba, caballero de la insigne orden del Toisón de Oro, teniente general de los ejércitos nacionales, Gobernador y Capitán general que fue de la isla de Cuba: o sea colección de varios escritos presentados por su apoderado y defensor el señor don José Antonio de Olañeta, fiscal electo de la audiencia pretorial mandada establecer en la ciudad de La Habana, y dados a luz por el comercio, con un apéndice que contiene las respectivas sentencias, Imprenta de A. Walker, Filadelfia, 1839.

Opisso, Alfredo, Oliver, Miguel de los Santos, Rahola, Federico: Historia de España y de las repúblicas latino-americanas por Alfredo Opisso; con un prólogo de Miguel S. Oliver; y otro prólogo referente a la parte de América de Federico Rahola, Gallach, Barcelona, 1847-1919, 25 tomos.

Opúsculo que contiene el discurso que pronunció el Sr. Alejandro Oliván diputado de la provincia de Huesca en la sesión del 9 de diciembre y diferentes documentos concernientes al relevo y partida del Excelentísimo señor don Miguel Tacón, Imprenta del Gobierno y Capitanía General, La Habana, 1838.

Ovilo y Otero, Manuel: Historia de las Cortes de España y biografías de todos los diputados y senadores más notables contemporáneos, Imprenta de D. Baltasar González, Madrid, 18471854,11 tomos.

Palacio, Eduardo de: España desde el primer Borbón hasta la revolución de septiembre, Manuel Rodríguez, Editor, Madrid, 1868-1869, 5 tomos.

Panorama español, crónica contemporánea. Obra pintoresca. Con 30 láminas en acero y 75 grabados en madera de cada tomo; destinada a exponer todos los acontecimientos políticos desde octubre de 1832 hasta nuestros días; con los retratos de los personajes que han figurado durante la revolución en uno y otro partido, y las principales acciones y escaramuzas de la guerra civil de los últimos siete años. Por una reunión de amigos colaboradores, Imprenta del Panorama Español, Madrid, 1842-1845, 4 tomos.

Pastor Díaz, Nicomedes y Cárdenas, Francisco de: Galería de españoles celebres contemporáneos o biografías y retrasos de todos los personajes distinguidos de nuestros días en las ciencias, en la política, en las armas, en las letras y en las artes. Imprenta de Sanchiz/Imprenta de Vicente de Lalana/Imprenta de D. Ignacio Boix, Madrid, 1842-1846, 9 tomos.

Pavía y Lacy, Manuel: Memorias sobre la guerra de Cataluña, desde marzo de 1847 hasta septiembre del mismo año y desde noviembre de 1847 a septiembre de 1848, D. B. González, Madrid, 1851. 
Pavía y Rodríguez de Alburquerque, Manuel: Pacificación de Andalucía y expediente de la Cruz de Quinta Clase de San Fernando obtenida, Establecimiento Tipográfico de M. Minuesa de los Ríos, Madrid, 1878.

Pazos y Vela-Hidalgo, Pio A. de: Joló. Relato histórico-militar desde su descubrimiento por los españoles en 1578 hasta nuestros días, Imprenta y Estereotipia de Polo, Burgos, 1879.

Pezuela, Jacobo de la: Historia de la isla de Cuba, Carlos Bailly-Bailliere, Madrid, 1868-1895, 4 tomos.

Pi y Margall, Francisco y Pi y Arsuaga, Francisco: Historia de España en el siglo XIX. Sucesos políticos, económicos, sociales y artísticos acaecidos durante el mismo. Detallada narración de sus acontecimientos y extenso juicio crítico de sus hombres. Miguel Seguí, Editor, Barcelona, 1902, 8 tomos.

Pirala, Antonio: Anales de la Guerra de Cuba, Felipe González Rojas, Editor, Madrid, 18951898, 3 tomos.

: Historia contemporánea. Segunda parte de la guerra civil. Anales de la guerra civil hasta el fallecimiento de Alfonso XII, Felipe González Rojas, Editor, Madrid, 1893-1895, 6 tomos.

: Historia de la guerra civil, y de los partidos liberal y carlista, segunda edición, refundida y aumentada con la historia de la Regencia de Espartero, Imprenta de F. de P. Mellado y Cía./Imprenta del Crédito Comercial/Imprenta de Dionisio Chaulié/Imprenta y Librería Universal, Madrid, 1868-1869, 5 tomos.

Pruneda, Víctor: Un viaje a las islas Canarias, Imprenta de Anselmo Zarzosa y Cía., Teruel, 1848.

Puente, José María: Manifiesto que hace a la nación don José María Puente, jefe superior político que fue en la provincia de Galicia con motivo de su exoneración del mando por las prisiones que decretó en 30 de mayo de este año de varias personas indicadas de conspiración, Imprenta del Imparcial, Madrid, 1821.

Puig Pujadas, Ignacio: Vida d'heroi. Narcís Monturiol, inventor de la navegació submarina, L’Avenç, Barcelona, 1918.

Quisenberry, Anderson C.: Lopez's expeditions to Cuba, 1850 and 1851, John Morton and Company, Louisville, 1906.

Relación nominal de deportados políticos con expresión de profesiones, edad, naturalidad, y fecha de prisión. Fuga y fallecimientos, Nueva York, 1869.

Resumen del censo de población de la isla de Cuba a fin del año de 1841. Formado de orden del Excmo. Sr. Capitán general de la misma por una comisión de jefes y oficiales nombrada especialmente para verificarlo. Precedido de una advertencia preliminar y notas justificativas del director de la comisión. Imprenta del Gobierno, La Habana, 1842.

Reverter, Agustín: Carta que ha dirigido a sus amigos y enemigos el ciudadano Agustín Reverter, en la que se refiere en bosquejo de padecimientos de su deportación a Filipinas, con otras cosas curiosas, Imprenta de Antonio Puigrubí y Canals, Tarragona, 1855. 
Ribot y Fontseré, Antonio: La revolución de julio en Madrid. Reseña de los hechos que constituyen este glorioso alzamiento, precedida del examen razonado de las causas que lo han producido, y seguida de la exposición de los principales sucesos que se han desenvuelto simultáneamente en el resto de España. Obra adornada con multitud de preciosos grabados, que representan los personajes que han figurado en primer término, los hechos más importantes de la revolución, y las escenas más notables de que ha sido teatro Madrid, Imprenta de Gaspar y Roig, Madrid, 1854.

Barcelona, 1839.

: Mi deportación. Trovas marítimas y americanas, Imprenta de Gaspar y Cía.,

Rodríguez, José Antonio: Estudio histórico sobre el origen, desenvolvimiento y manifestaciones prácticas de la anexión de la isla de Cuba a los Estados Unidos de América, La Propaganda Literaria, La Habana, 1900.

Rotalde, Santiago de: La España vindicada o baraja de fulleros en la época de la revolución española. Obra formada con presencia de los diseños y apuntes sacados del archivo de Plutón por un radical español, que en desagravio de la buena causa la publica en Londres, patria de los libres, J. Ridway and E. Wilson, Londres, 1825.

Saco, José Antonio: Colección de papeles científicos, históricos, políticos y de otros ramos sobre la isla de Cuba ya publicados ya inéditos, Imprenta d'Abussons y Kugelmann, París, 1858-1859, 3 tomos.

Salvador, Lluís (arxiduc d'Àustria), Las Baleares. Obra escrita y publicada en alemán con el título de Die Balearen in wort und bild geschildert, versión castellana de Santiago Palacio, corregida y considerablemente aumentada con anuencia y conforme a las indicaciones del autor, por Francisco Manuel de los Herreros y Schwager, Biblioteca Popular, Palma de Mallorca, 1886-1890. 2 tomos.

Saluvet, Juan B.: Los deportados a Fernando Poo en 1869, Aurora del Yomuri, Matanzas, 1892.

Sánchez, Rafael: Historia de don Carlos y de los principales sucesos de la guerra civil de España, Imprenta de Tomás Aguado y Cía., Madrid, 1844, 2 tomos.

Sedano Cruzat, Carlos: Cuba desde 1850 a 1873. Colección de informes, memorias, proyectos y antecedentes sobre el gobierno de la isla de Cuba, relativos al citado periodo, Imprenta Nacional, Madrid, 1873.

: Cuba. Estudios políticos, Imprenta de Manuel G. Hernández, Madrid, 1872.

Sidro y Surga, José y de Quevedo Donis Antonio: La Guardia Civil. Historia de esta institución y de todas las que se han conocido en España con destino a la persecución de malhechores, Atlas, Madrid, 1858.

Sifredo y Llópiz, Hipólito: Los mártires cubanos en 1869. La más exacta narración de las penalidades y martirios de los 250 deportados políticos a Fernando Poo. Primeras víctimas propiciatorias de la insurrección en La Habana, Imprenta La Prensa, La Habana, 1893.

Soldevilla, Fernando: "Conspiración en la isla de Pinos", en El Año Político (1896), Imprenta de Enrique Fernández de Rojas, Madrid, 1897, pp. 309-310. 
Sotorra, Juan: Historia del ilustre español don Guillermo Oliver, alcalde primero constitucional de la muy ilustre ciudad de Barcelona, diputado a Cortes por la misma, y por la provincia de Tarragona en el año 1837, Imprenta de Francisco Sánchez de los Baños, Barcelona, 1841.

Tacón, Miguel: Relación del Gobierno superior y capitanía general de la isla de Cuba, Imprenta del Gobierno y Capitanía General, La Habana, 1838.

Teatro de la guerra. Cabrera, los montemolinistas y republicanos en Cataluña. Crónica de nuestros días. Redactada por un testigo ocular de los acontecimientos, Imprenta de D. R. González, Madrid, 1849.

Tettamancu, Francisco: La Revolución gallega de 1846, Librería Regional de E. Carré, La Coruña, 1908.

The book of blood. An authentic record of policy adopted by modern Spain to put an end to the war for the Independence of Cuba (October 1868 to November 10, 1872, N. Ponce de Leon, Broadway, 1873.

Torres de Castilla, Alfonso: Historia de las persecuciones políticas y religiosas, ocurridas en Europa desde la Edad Media hasta nuestros días, Imprenta de Salvador Manero, Barcelona, 1863-1866, 6 tomos.

Tresserra, Ceferino: Carta de un demócrata confinado, dirigida al Excmo. Sr. D. Juan Zapatero, Capitán general del ejército y principado de Cataluña, Benavides, Granada, 1856.

Usera, J.: Memoria de la isla de Fernando Poo, Imprenta de Tomás Aguado, Madrid, 1848.

Valdés, Ramón Francisco: Diccionario de Legislación y jurisprudencia criminal, en que se comprenden todas las disposiciones que rigen en la isla de Cuba, según las leyes especiales orgánicas de su administración de justicia y autos acordados vigentes, Imprenta Militar de D. Manuel Soler, La Habana, 1859.

Valdés Domínguez, Eusebio: Los antiguos diputados de Cuba y apuntes para la historia constitucional de esta isla, El Telégrafo, Cuba, 1879.

Valdés Infante, Emilio: Cubanos en Fernando Poo. Horrores de la dominación española, Imprenta "E1 Figaro", La Habana, 1898.

Vergara, Francisco-Engracio: La masonería en Filipinas. Estudio de actualidad. Apuntes para la historia de la colonización española en el siglo XIX, París, s/f.

Viladarga y Cañellas, Jacinto: Efemérides berguedanas. Colección de todos los hechos acaecidos en Berga que han llegado a nuestra noticia desde los primitivos tiempos hasta nuestros días, Imprenta San José, Manresa, 1919.

Xaudaró, Ramón: Manifiesto de las injustas vejaciones sufridas por D. Ramón Xaudaró, redactor del periódico El Catalán que se publicaba en Barcelona, Imprenta de M. Calero, Madrid, 1836.

Zaragoza, Justo: Las insurrecciones en Cuba. Apuntes para la historia política de esta isla en el presente siglo, Imprenta de Manuel G. Hernández, Madrid, 1872-1873, 2 tomos.

Zugasti, Julián de: El bandolerismo. Estudio social y memorias históricas (1876-1880), Imprenta de T. Fortanet, Madrid, 1876-1800, 10 vols. 


\section{BIBLIOGRAFÍA}

Abad, Diana: De la Guerra Grande al Partido Revolucionario Cubano, Editorial de Ciencias Sociales, La Habana, 2005.

Abreu Cardet, José: Introducción a las armas. La guerra de 1868 en Cuba, Editorial de Ciencias Sociales, La Habana, 2005.

Actas del Consejo de Ministros, Javier García Fernández (ed.), Ministerio de Relaciones con las Cortes y de la Secretaria del Gobierno/Ministerio de la Presidencia, Madrid, 1989-1996, 10 tomos.

Agüero Estrada (El Solitario), Francisco: Biografía de Joaquín Agüero, Molina y Cía., Impresores, La Habana, 1935.

Alarcón Caracuel, Manuel R.: El derecho de asociación obrera en España (1839-1900), Ediciones de la Revista de Trabajo, Madrid, 1975.

Alcaide, Rafael: "La introducción y el desarrollo del higienismo en España durante el siglo XIX”, Scripta Nova. Revista Electrónica de Geografía y Ciencias Sociales, núm. 3, 1999, pp. $32-54$

Alcalá, Cesar: La Tercera Guerra Carlista, 1872-1876, Medusa, Madrid, 2004.

Alcoberro, Agustí: L'exili austriacista (1713-1747), Fundació Noguera, Barcelona, 2002, 2 vols.

Alemany, Vicente: Andanzas del buscón don pablos por México y Filipinas, (Celsa Carmen García Valdés ed.,) Universidad de Navarra, Pamplona, 1998. (Primera edición de 1767)

Alexander, Alison: Tasmania's Convicts: How Felons built a Free Society, Allen and Unwin, Crows Nest, 2010.

Alonso Romero, María Paz: Cuba en la España liberal (1837-1898), Centro de Estudios Políticos y Constitucionales, Madrid, 2002.

Alonso Tejada, Luis: Ocaso de la inquisición en los últimos años del reinado de Fernando VII. Juntas de Fe, Juntas Apostólicas, conspiraciones realistas, Zero, Vizcaya, 1969.

Álvarez Gutiérrez, Luis: "Divergencias y acuerdos entre España, Gran Bretaña y Alemania sobre las islas de Joló", en María Dolores Elizalde (ed.), Las relaciones internacionales en el Pacifico (siglos XVIII-XX). Colonización, descolonización y encuentro cultural, CSIC, Madrid, 1997, pp. 269-290.

Álvarez Junco, José: La ideología política del anarquismo español (1868-1900), Siglo XXI, Madrid, 1991.

Álvarez Villamil, V. y Llopis, Rodolfo: Cartas de conspiradores. La Revolución de Septiembre. De la emigración al poder, Espasa-Calpe, 1929.

Anca Alamillo, Alejandro: La armada en la Primera Guerra Carlista, Fundación Alvargonzález, Gijón, 2011. 
Anguera, Pere: El general Prim. Biografía de un conspirador, Edhasa, Barcelona, 2003.

: “Por qué eran combatientes carlistas?”, Vasconia. Cuadernos de HistoriaGeografía, núm. 26, 1998, pp. 111-124.

: Déu, rei i fam. El primer carlisme a Catalunya, Publicacions de l'Abadia de Montserrat, Barcelona, 1995.

Aranzadi, Isabela de: "El legado cubano en África. Náñigos deportados en Fernando Poo. Memoria viva y archivo escrito", Afro-Hispanic Review, vol. 31, núm. 1, 2012, pp. 29-60.

Aracil, Rafael y García Bonafé, M.: "Clase obrera y revuelta social. La identidad del cantonalismo alcoyano”. Estudios de Historia Social, núm. 7, 1978, pp. 163-183.

Arbeloa, Víctor Manuel: Clericalismo y anticlericalismo en España, (1767-1930), Encuentro, Madrid, 2009.

Arnabat Mata, Ramón: La revolució de 1820 i el Trienni Liberal a Catalunya, Eumo, Barcelona, 2001.

: "Violencia política y guerra civil durante el Trienio Liberal en Cataluña (18201823), Vasconia. Cuadernos de Historia-Geografía, núm. 26, 1998, pp. 49-62.

88, 1993, pp. 391-429.

: "Els matiners al Penedès, una hipòtesi de treball", Miscel-lània Penedesenca, núm.

Aroca Lara, Ángel: "Iznajar en el levantamiento de Pérez del Álamo", en Juan Alonso Sánchez Martínez (coord.), Rafael Pérez del Álamo, 150 aniversario de la Revolución de Loja, Loja, 2011, pp. 11-30.

Aróstegui, Julio: "Introducción” a dossier Violencia y Política en España, Ayer, núm. 13, 1994, pp. 11-16.

Artola, Miguel: Los afrancesados, Alianza, Madrid, 2008.

: Antiguo Régimen y revolución liberal, Ariel, Barcelona, 1978.

Avilés Farré, Juan: La Daga y la dinamita. Los anarquistas y el nacimiento del terrorismo, Tusquets, Barcelona, 2013.

Aymes, Jean-René: Los españoles en Francia (1808-1814). La deportación bajo el primer imperio, Siglo XXI, Madrid, 1987.

Azagra Ros, Joaquín: El Bienio Progresista en Valencia. Análisis de una situación revolucionaria a mediados del siglo XIX, Publicaciones de la Universidad de Valencia, Valencia, 1978.

Bachero Bachero, Juan Luis: "La represión en el absolutismo. Entre la ley y la arbitrariedad", en Marieta Cantos y Alberto Ramos (coords.), La represión absolutista y el exilio, Servicio de Publicaciones de la Universidad de Cádiz, Cádiz, 2014, pp. 71-82.

Bahamonde Ángel y Cayuela José: Hacer las Américas. Las élites coloniales españolas en el siglo XIX, Alianza, Madrid, 1992. 
Balboa, Imilcy: La protesta rural en Cuba. Resistencia cotidiana, bandolerismo y revolución (1878-1902), CSIC, Madrid, 2003.

: Los brazos necesarios, Centro Tomás y Valiente UNED Alzira-Valencia/Fundación Instituto de Historia Social, Valencia, 2000.

Ballbé, Manuel: Orden público y militarismo en la España constitucional (1812-1983), Alianza, Madrid, 1983.

Bankoff, Greg: "Deportation and the Prison Colony of San Ramón, 1870-1898", Philippine Studies, vol. 39, num. 4, 1991, pp. 443-457.

Barbançon, Louis-José : L'Archipel des forçats: Histoire du bagne de Nouvelle-Calédonie, 1863-1931.

: "Les transportés de 1848 (statistiques, analyse, commentaires)", Criminocorpus. Revue hypermédia. Historie de la justice, des crimes et des peines, 2008, [en Línea], https://criminocorpus.revues.org/148\#text.

: Entre les chaînes et la terre. L'évolution de l'idée de déportation au XIX siècle en France, aux origines de la colonisation en Nouvelle-Calédonie. Thèse de doctorat d'histoire, Université de Versailles Saint-Quentin-en-Yvelines, 2000.

: Les Origines de la colonisation pénale en Nouvelle-Calédonie (1810-1863). Mémoire de D.E.A. d'histoire, Université française du Pacifique, 1992.

: Déportation et colonisation pénale en France (1789-1847). Introduction à la colonisation pénale en Nouvelle-Calédonie. Mémoire de maîtrise d'histoire, Université de Provence, 1991.

Barbastro Gil, Luis: Revolución liberal y reacción (1808-1833). Protagonismo ideológico del clero en la sociedad valenciana, Caja de Ahorros Provincial de Alicante, Alicante, 1987.

: El clero valenciano en el Trienio Liberal (1820-1823). Esplendor y ocaso del estamento eclesiástico, Instituto de Estudios Juan Gil-Albert, Alicante, 1985.

Barcia, María del Carmen: Cuba. Acciones populares en tiempos de la independencia americana, Ediciones Matanzas, Matanzas, 2011.

: "Desterrados de la patria. Cuba 1869-1898", Revista de la Universidad de La Habana, núm. 258, 2003, pp. 31-56.

: Élites y grupos de presión. Cuba 1868-1898, Editorial de Ciencias Sociales, La Habana, 1998.

: "Los deportados de la Guerra. Cuba 1895-1898", en Consuelo Naranjo, Miguel Ángel Puig-Samper y Luis Miguel García Mora (eds.), La nación soñada. Cuba, Puerto Rico y Filipinas ante el 98, Doce Calles, Aranjuez, 1996, pp. 635-646.

: y Torres-Cuevas, Eduardo: "El debilitamiento de las relaciones sociales esclavistas. Del reformismo liberal a la revolución independentista", en María del Carmen Barcia, Gloria García y Eduardo Torres-Cuevas, La colonia. Evolución socioeconómica y formación nacional. De los orígenes hasta 1867, Editora Política, La Habana, 1994, pp. 401-463. 
Barnosell Jordà, Genís: "«Libertad, igualdad humanidad». La construcción de la democràcia en Cataluña (1839-1843)", ambos en Manuel Suarez Cortina (ed.), La redención del pueblo. La cultura progresista en la España liberal. Universidad de Cantabria, Santander, 2006, pp. 145182.

Barón Fernández, José: El movimiento cantonal de 1873 (Primera República), Edicios do Castro, La Coruña, 1998.

Barreiro Fernández, Xosé R.: El levantamiento de 1846 y el nacimiento del galleguismo, Pico Sacro, Santiago de Compostela, 1977.

Bazán Díaz, Iñaki: "La pena de muerte en la Corona de Castilla en la Edad Media", Clío \& Crimen. Revista del Centro de Historia del Crimen de Durango, núm. 4, 2007, pp. 306-352.

: "El destierro en el País Vasco (siglos XIV-XVI)" en Cesar González Mínguez, Iñaki Bazán Díaz e Iñaki Reguera (eds.), Marginación y exclusión social en el País Vasco, Servicio Editorial de la Universidad del País Vasco, Bilbao, 1999, pp. 25-54.

: Delincuencia y criminalidad en el País Vasco en la transición de la Edad Media a la Moderna, Servicio de Publicaciones del Gobierno Vasco, Vitoria-Gasteiz, 1995.

Beardsley, Charles: Guam Past and Present, Charles E. Tuttle Company, Tokyo, 1964.

Belmonte, José y Leseduarte Gil, Pilar: El auge y expulsión de los judíos. Auge y ocaso del judaísmo en Sefarad, Beta III Milenio, Bilbao, 2007.

Benet, Josep i Martí, Casimir: Barcelona a mitjan del segle XIX, Curial, Barcelona, 1976, 2 vols.

Benito Fraile, Emilio de: "Nuevas aportaciones al estudio sobre la aplicación práctica del Código Penal de 1822”, Foro, Nueva Época, núm. 8, 2008, pp. 41-68.

Bermejo Cabrero, José Luis: "Sobre la entrada en vigor del Código Penal de 1822", Anuario de Historia del Derecho Penal, núm. 66, 1996, pp. 967-972.

Bernabé Pons, Luis F.: Los moriscos. Conflicto, expulsión y diáspora, Catarata, Madrid, 2009.

Bernal Serna, Luis María: Sociedad y violencia en Portugalete (1550-1833), Ayuntamiento de Portugalete, Portugalete, 2007.

Berraondo, Mikel: "Maneras de matar. Violencia y envenenamiento en la Navarra de los siglos XVI y XVII", en Carlos Mata Induráin y Adrián J. Sáez (eds.), «Scripta manent». Actas del I congreso internacional jóvenes investigadores Siglo de Oro (JISO 2011), Servicio de Publicaciones de la Universidad de Navarra, Pamplona, 2012, pp. 47-49.

Bizcarrondo, Marta: "El autonomismo Cubano 1878-1898. Las ideas y los hechos", Historia Contemporánea, núm. 19, 1999, pp. 69-94.

Madrid, 2001.

y Elorza, Antonio: Cuba/España. El dilema autonomista, 1878-1898, Colibrí,

Bleiberg, Germán: El «informe secreto» de Mateo Alemán sobre el trabajo forzoso en las Minas de Almadén, Támesis Books Limited, London, 1985. 
Bolaños Mejías, María del Carmen: "La imagen de la mujer española durante el Sexenio. Entre el cambio social y el reconocimiento jurídico”, Feminismo/s, núm. 2, 2003, pp. 25-40.

Bravo Lira, Bernardino: "La Fortuna del Código Penal español de 1848", Anuario de Historia del Derecho Español, núm. 74, 2004, pp. 23-58.

Brooke Alan and Brandon, David: Bound for Botany Bay: British Convict Workers to Australia, The National Archives, Kew, 2005.

Brown, Charles H.: Agents of Manifest Destiny. The Lives and Times of the Filibusteros, University of North Carolinas Press, Chapel Hill, 1980.

Bullón de Mendoza, Alfonso: "La nobleza carlista", en María del Carmen Iglesias et al., Nobleza y sociedad en la España moderna, Fundación Cultural de la Nobleza Española-NobelFundación Central Hispano, 1996, 1997, 2 vols.

: La Primera Guerra Carlista, Actas, Madrid, 1992.

Burillo Albacete, Fernando José: La Cuestión penitenciaria. Del Sexenio a la Restauración, Prensas Universitarias de Zaragoza, Zaragoza, 2011.

: El nacimiento de la pena privativa de libertad, Edersa, Madrid, 1999.

Cabeza Sánchez-Albornoz, Sonsoles: Los sucesos de 1848 en España, Fundación Universitaria Española, Madrid, 1981.

Cabrera, Emilio: "Crimen y castigo en Andalucía durante el siglo XV", Meridies. Revista de Historia Medieval, núm. 1, 1994, pp. 9-38.

Cabrera, Miguel Ángel: El reformismo social en España (1870-1900). Los orígenes del estado del bienestar, Universitat de Valencia, Valencia, 2014.

Calero, Antonio María: “Introducción”, en Rafael Pérez del Álamo, Apuntes sobre dos revoluciones andaluzas, Zero, Algorta, 1971, pp. 5-41.

Camps i Giró, Joan: La Guerra dels Matiners y el catalanisme polític (1846-1849), Curial, Barcelona, 1978.

Canal, Jordi: El carlismo, Alianza, Madrid, 2000.

Candel Crespo, Francisco: La azarosa vida del Deán Ostolaza, Academia Alfonso X el Sabio, Murcia, 1981.

Cánovas Sánchez, Francisco: "El Partido Moderado", en José María Jover Zamora (dir.), La era isabelina y el Sexenio Democrático (1834-1874), Historia de España de Menéndez Pidal, Espasa-Calpe, Madrid, 1988, tomo XXXIV, pp. 373-410.

: El Partido Moderado, Centro de Estudios Constitucionales, Madrid, 1982.

Cardona, Gabriel y Losada, Juan Carlos: Weyler, nuestro hombre en La Habana, Planeta, Barcelona, 1997.

Caridad Salvador, Antonio: "El carlismo aragonés en armas. La revuelta de 1855", Cuadernos de Historia Contemporánea, vol. 36, 2014, pp. 165-188. 
Carrera Pujal, Jaime: Historia política de Cataluña en el siglo XIX, Bosch, Barcelona, 19571958,6 vols.

Carrete Parrondo, Carlos: "Comunidades judías castellano-leonesas", en Ana María López Álvarez y Ricardo Izquierdo Benito (coords.), Juderías y sinagogas de la Sefarad medieval, Universidad de Castilla-La Mancha, Cuenca, 2003, pp. 365-382.

Casado Ruiz, José Ramón: "La aplicación del Código Penal de 1822", Anuario de Derecho Penal, núm. 32, 1979, pp. 333-344.

Casals Bergés, Quintí: La representación parlamentaria en España durante el Primer Liberalismo (1810-1836), Edicions de la Universitat de Lleida-Servicio de Publicaciones de la Universidad de Cádiz, Lleida-Cádiz, 2014.

Casanovas Codina, Joan: ;O pan, o plomo! Los trabajadores urbanos y el colonialismo español en Cuba, 1850-1898, Siglo XXI, Madrid, 2000.

Castellano Gil, José Manuel: La Masonería española en Cuba, Centro de la Cultura Popular Canaria, Santa Cruz de Tenerife, 1996.

Castellanos Escudier, Alicia: "Las compañías disciplinarias en la reducción y colonización de Mindanao", El lejano oriente español. Filipinas (siglo XIX), Actas VII jornadas nacionales de historia militar (Sevilla, 5-9 mayo de 1997), Catedra General Castaños, Sevilla, 1997, pp. 541554.

Castells, Irene: La utopía insurreccional del liberalismo. Torrijos y las conspiraciones liberales de la Década Ominosa, Crítica, Barcelona, 1989.

Castro Antolín, Mariano L. de: La población de Santa Isabel en la segunda mitad del siglo XIX, AEA, Madrid, 1996.

y María Luisa de la Calle: La colonización española en Guinea Ecuatorial (18581900), Ceiba, Vic, 2007.

: Origen de la colonización española en Guinea Ecuatorial (1877-1860), Universidad de Valladolid, Valladolid, 1992.

Castro Alfin, Demetrio: “Orígenes y primeras etapas del republicanismo en España”, en Nigel Townson (ed.), El republicanismo en España (1830-1977), Alianza, Madrid, 1994, pp. 33-58.

: "Unidos en la adversidad, unidos en la discordia. El partido demócrata, 1849-1868", en Nigel Townson (ed.), El republicanismo en España, (1830-1977), Alianza, Madrid, 1994, pp. 59-86.

: “Agitación y orden en la Restauración. ¿Fin del ciclo revolucionario?”, Historia Social, núm. 5, 1989, pp. 37-49.

: Hambre en Andalucía, antecedentes y circunstancias de la mano negra, Ayuntamiento de Córdoba, Córdoba, 1986.

Cayuela Fernández, José G.: Bahía de Ultramar. España y Cuba en el siglo XIX. El control de las relaciones coloniales, Siglo XXI, Madrid, 1993. 
Cento, Elda E.: El camino de la independencia. Joaquín de Agüero y el alzamiento de San Francisco de Jucaral, Ácana, Camagüey, 2003.

Cepeda Adán, José: Sagasta. El político de las horas difíciles, Fundación Universitaria Española, Madrid, 1995.

Cepero Bonilla, Raúl: Azúcar y abolición, Crítica, Barcelona, 1976.

: Obras históricas, Instituto de Historia, La Habana, 1963.

Chaffin, Tom: Fatal Glory. Narciso López and the First Clandestine U.S. War against Cuba, University Press of Virginia, Charlottesville, 1996.

Childs, Matt D.: The 1812 Aponte Rebellion in Cuba and the Struggle against Atlantic Slavery, University of North Carolina Press, Chapel Hill, 2006.

Cifre de Loubriel, Estela: La formación del pueblo puertorriqueño. La contribución de los catalanes, baleáricos y valencianos. Instituto de Cultura Puertorriqueña, San Juan, 1975.

Clara, Josep: "Sobre la identitat dels matiners de les comarques del N.E. de Catalunya", Estudi General, núm. 1, vol. 1, 1981, pp. 179-185.

y Ángel Jiménez, El federal Pere Caimó (1819-1878), Pòrtic, Barcelona, 1975.

Clemente, Josep Carles: Los carlistas, Istmo, Madrid, 1990.

Clopas i Batlle, Isidre: "Els germans Martí, «El Noi» i «El Xic» de la Barraqueta, guerrillers del Baix Llobregat" en Ferran Balanza et al., Guerrilles al Baix Llobregat. Els "carrasquets" del segle XVIII, $i$ els carlins i els republicans del segle XIX, Abadia de Montserrat, Barcelona, 1986, pp. 709-752.

Coates, Timothy J.: Convict Labour in the Portuguese Empire, Brill, Leiden, 2014.

Codina i Vilà, Jaume: "Guerrilles i guerrillers a Sant Boi”, en Ferran Balanza i González et al., Guerrilles al Baix Llobregat. Els "carrasquets" del segle XVIII, i els carlins $i$ els republicans del segle XIX, Abadia de Montserrat, Barcelona, 1986, pp. 131-236.

Comellas, José Luis: Isabel II. Una reina y un reinado, Ariel, Barcelona, 1999.

Comesaña Paz, Alfredo: Hijos del Trueno. La Tercera Guerra Carlista en Galicia y el norte de Portugal, Schedas, Madrid, 2016.

Concepción, Pablo de la: Prisioneros y deportados cubanos en la Guerra de Independencia, 1895-1898, Imprenta de P. Fernández y Cía., La Habana, 1932.

Cordeiro, Carlos y Serpa, Susana: "«Mártires da liberdade». O exílio de revolucionários espanhóis nos Açores (1866-1868) na perspectiva da impresa local”, Pasado y Memoria. Revista de Historia Contemporánea, núm. 9, 2010, pp. 177-188.

Costas Comesaña, Antón: Apogeo del liberalismo en "La Gloriosa". La reforma económica en el Sexenio Liberal (1868-1874), Siglo XXI, Madrid, 1988.

Cova, Rafael de la: "The Taylor administration versus Mississippi Sovereignty: The Round Island expedition of 1849”, The Journal of Mississippi, vol. LXII, núm. 4, 2000, pp. 295-327. 
Cucó, Alfons: Republicans i camperols revoltats, Eliseu Climent, Valencia, 1975.

Cuenca Toribio, José Manuel: "La Iglesia española en el Trienio Constitucional", Hispania Sacra, vol. 18, núm. 36, 1965, pp. 333-362.

Creus, Jacint: "Cuando las almas no pueden ser custodiadas. El fundamento identitario en la colonización española de Guinea Ecuatorial”, Hispania. Revista Española de Historia, vol. 67, núm. 226, pp. 517-540.

Cruells, Manuel: Salvador Seguí. El Noi del Sucre, Ariel, Esplugues de Llobregat, 1974.

Cruz Villalón, Pedro: El estado de sitio y la Constitución, Centro de Estudios Constitucionales, Madrid, 1980.

Cuadrado, Miguel M.: Elecciones y partidos políticos en España (1868-1931), Taurus, 1969, 2 vols.

Delnore, Allyson Jaye: Political Convictions: French Deportation Projects in the Age of the Revolutions, 1791-1854, PhD Dissertation, University of Virginia, 2004.

Dardé, Carlos: La aceptación del adversario. Política y políticos de la Restauración, 18751900, Biblioteca Nueva, Madrid, 2003.

Deschamps Chapeaux, Pedro: El negro en la economía habanera del siglo XIX, Unión de Escritores y Artistas de Cuba, La Habana, 1971.

: "Margarito Blanco, «Ocongo de Ultán»", Boletín del Instituto de Historia y del Archivo Nacional, tomo LXV, 1964, pp. 97-109.

Díaz Marín, Pedro, "Espartero. El regente plebeyo", en Emilio La Parra López (coord.), La imagen del poder. Reyes y regentes en la España del siglo XIX, Síntesis, Madrid, 1998. pp. 177219.

Díaz Martínez, Yolanda, "Delincuencia, represión y castigo en La Habana bajo el Gobierno de Miguel Tacón”, Cuadernos de Historia, núm. 40, 2014, pp. 7-29.

: "De marginados a trabajadores. Usos y destinos de la población penal en La Habana", Millars. Espai i Història, núm. 35, 2012, pp. 129-149.

: La peligrosa Habana. Violencia y criminalidad a finales del siglo XIX, Editorial de Ciencias Sociales, La Habana, 2005.

Díaz del Moral, Juan: Historia de las agitaciones campesinas andaluzas, Alianza, Madrid, 1984.

Diego Aguirre, José Ramón: Historia del Sahara Español, Kaydeda, Madrid, 1998.

Diez Muñiz, Adolfo: "Estudio sociológico-demográfico de isla de Corregidor y Llana (Filipinas, Siglo XIX)”, Hispania Sacra, vol. 47, núm. 97, 1995, 750-775.

Domingo Acebrón, María Dolores: Los voluntarios y su papel contrarrevolucionario en la Guerra de los Diez Años en Cuba, 1868-1878. L'Harmattan, Paris, 1996. 
: "Los deportados de la Guerra de los Diez Años. Cuba (1868-1878)", Revista de Indias, vol. 51, núm. 191, 1991, pp. 143-168.

Domínguez, Antonio Ortiz y Vincent, Bernard: Historia de los moriscos. Vida y tragedia de una minoría, Revista de Occidente, Madrid, 1978.

Driver, Marjorie G. y Brunal Perry, Omaira: Chronicle of the Mariana Islands by Aniceto Ibáñez del Carmen, Francisco Resano del Corazón de Jesús et al., University of Guam, Mangilao, 1998.

Durán de la Rua, Nelson: La Unión Liberal y la modernización de la España isabelina, Akal, Madrid, 1979.

Echenagusia, Javier: La Primera República. Reformismo y revolución social, RBA, Barcelona, 2012.

Egido, Teófanes y Pinedo, Isidoro: Las causas "gravísimas y secretas de la expulsión de los jesuitas por Carlos III, Fundación Universitaria Española, Madrid, 1994.

Elizalde María Dolores y Huetz de Lemps, Xavier: "Un singular modelo colonizador. El papel de las órdenes religiosas en la administración española de Filipinas, siglos XVI al XIX", Illes $i$ Imperis, núm. 17, 2015, pp. 185-220.

Elorza, Antonio: La modernización política de España, Endymion, Madrid, 1990.

$69-74$.

: El Fourierismo en España, Ediciones de la Revista de Trabajo, Madrid, 1975, pp. : La ideología liberal en la Ilustración española, Tecnos, Madrid, 1970.

$\overline{1998 .}$

y Elena Hernández Sandoica, La Guerra de Cuba (1895-1898), Alianza, Madrid,

Epalza, Mikel de: Los moriscos antes y después de la expulsión, Mapfre, Madrid, 1992.

Esquembri Hinojo, Carlos: "Las islas Chafarinas, desde 1848 hasta finales del siglo XIX", Aldaba, núm. 37, 2013, pp. 191-219.

Espigado Tocino, Gloria: "El discurso republicano sobre la mujer en el Sexenio Democrático, 1868-1874. Los límites de la modernidad”, Ayer, núm. 78, 2010, pp. 143-168.

: "Las primeras republicanas en España. Prácticas y discursos identitarios (18681874), Historia Social, núm. 67, 2010, pp. 75-91.

: "Mujeres «radicales». Utópicas, republicanas e internacionalistas en España (18481874), Ayer, núm. 60, 2005, pp. 15-43.

Esteban y Marfil, Bonifacio de: La sanidad militar española en la Guerra de Cuba (18951898), Tesis doctoral de la Universidad Autónoma de Madrid, Madrid, 2000.

Estrade, Paul: José Martí. Los fundamentos de la democracia en Latinoamérica, Doce Calles, Aranjuez, 2002. 
Feijoo Gómez, Albino: Quintas y protesta social en el siglo XIX, Ministerio de Defensa, Madrid, 1996.

Feliu i Montfort, Gaspar: La clerencia catalana durant el Trienni, IEC, Barcelona, 1972.

Felipe Redondo, Jesús de: Trabajadores. Lenguaje y experiencia en la formación del movimiento obrero español, Genueve, Oviedo, 2012.

Fernández Cortizo, Camilo: "Las «ocurrencias revolucionarias» de 1846 en Galicia. Exilio en Portugal y relaciones hispano-lusas", População e sociedade: relações Externas de Portugal, vol. 21, 2013, pp. 11-27.

Fernández García, Antonio: "Madrid en el tiempo de las revoluciones burguesas", en Alfredo Alvar Ezquerra (coord.), Visión histórica de Madrid (siglos XVI al XX), Real Sociedad Matritense de Amigos del País, Madrid, 1991, pp. 217-251.

Fernández Prieto, Leida: "Una mirada sobre las independencias americanas. El ideario político de Joaquín Infante, de lo local a lo continental”. Revista de Indias, vol. 75, núm. 264, 2015, pp. 555-570.

Ferrer, Ada: Insurgent Cuba. Race, Nation, and Revolution, 1868-1898, University of North Carolina Press, Chapel Hill, 1999.

Ferrer, Melchor, Tejeda, Domingo y Acedo, José F.: Historia del tradicionalismo español, Editorial Católica Española/Editorial Tradicionalista/Editorial Trajano, Sevilla, 1941-1979, 30 tomos.

Ferrer Flórez, Miguel: "La regencia de Urgell y las Baleares", Bolletí de la Societat Arqueològica Lul·liana. Revista d'Estudis Històrics, núm. 59, 2003, pp. 133-156.

Fiestas Loza, Alicia: Los delitos políticos, (1808-1936), Librería Cervantes, Salamanca, 1994.

: "Algo más sobre la vigencia del Código Penal de 1822", Revista de Historia del Derecho, núm. II-I, 1977, pp. 55-77.

Finch, Aisha K.: Insurgency at the Crossroad: Cuban Slaves and the Conspiracy of La Escalera, 1843-1844, Tesis doctoral de la Universidad de Nueva York, Nueva York, 2007.

Flores, Eugenio Antonio: Trata de Blancas (novela social), (Edición de Luis Álvarez Castro) Institución Fernando el Católico (CSIC), Zaragoza, 2014.

Fontana, Josep: De en medio del tiempo. La segunda restauración española, 1823-1834. Crítica, Barcelona, 2006. Madrid, 2001.

Revolución liberal. Política y hacienda, 1833-1845, Instituto de Estudios Fiscales, : La quiebra de la monarquía absoluta. 1814-1820, Ariel, Barcelona, 1987.

: "Represión política y violencia civil en 1823-1833. Propuestas para una interpretación" en Manuel González Portilla et al. Industrialización y nacionalismo. Análisis comparativos. Actas del I coloquio vasco-catalán de historia celebrado en Sitges: 20-22 de diciembre de 1822, Servicio de Publicaciones de la Universidad Autónoma de BarcelonaBellaterra, 1985, pp. 313-327. 

10, 1980, pp. 7-16.

Michele Foucault, Vigilar y castigar. Nacimiento de la prisión, Siglo XIX, Buenos Aires, 2002. Fougere, Éric: Île-prison, bagne et déportation: les murs de la mer, éloigner et punir, L’Harmattan, París, 2002.

Foner, Philip S.: Antonio Maceo, The "bronze titan" of Cuba's Struggle for Independence, Monthly Review Press, 1977.

: Historia de Cuba y de sus relaciones con Estados Unidos, Instituto Cubano del Libro-Editorial de Ciencias Sociales, La Habana, 1973, 2 tomos.

Fornals, Francisco: Fortaleza de Isabel II en la Mola de Puerto de Mahón, Museo Histórico Militar de Menorca, Mahón, 2000.

Fraile, Pedro: Un espacio para castigar. La cárcel y la ciencia penitenciaria en España (siglos XVIII-XIX), Ediciones del Serbal, Barcelona, 1987.

Fradera, Josep María: Colonias para después de un imperio, Bellaterra, Barcelona, 2005.

: Gobernar colonias, Península, Barcelona, 1999.

Frost, Alan: Botany Bay, Black Inc., Collingwood, 2012.

Fuente Monge, Gregorio de la y Serrano García, Rafael: La Revolución Gloriosa. Un ensayo de regeneración nacional (1868-1874). Antología de textos, Biblioteca Nueva, Madrid, 2005.

Gabriel, Pere: "Más allá de los exilios políticos. Proscritos y deportados en el siglo XIX", en Santiago Castillo y Pedro Oliver (coords.), Las figuras del desorden. Heterodoxos, proscritos y marginados. Actas del V congreso de historia social de España (Ciudad Real, 10 y 11 de noviembre de 2005), Siglo XXI, Madrid, 2006, pp. 197-222.

: "Pi y Margall y el federalismo popular y democrático del pueblo", Historia Social, núm. 48, 2004, pp. 49-68.

: "Anarquismo y anarcosindicalismo en la España del siglo XIX", en Manuel Ortiz Heras, David Ruiz González e Isidro Sánchez Sánchez, (coords.), Movimientos sociales y Estado en la España contemporánea, Publicaciones de la Universidad de Castilla-La Mancha, Cuenca, 2001, pp. 127-151.

: "Insurrección y política. El republicanismo ochocentista en Cataluña", en Nigel Townson (ed.), El republicanismo en España (1830-1977), Alianza, Madrid, 1994, pp. 341-371.

Gallardo, Alexander: Britain and the First Carlist War, Norwood Editions, Norwood, 1978.

Gálvez Aguilera, Milagros: Expediciones navales en la Guerra de los Diez Años, Ediciones Verde Olivo, La Habana, 2000.

García, Gloria: "Vertebrando la resistencia. La lucha de los negros contra el sistema esclavista, 1790-1845", en María Dolores González-Ripoll, et al., El rumor de Haití en Cuba. Temor, raza y rebeldía, 1789-1844, CSIC, Madrid, 2004, pp. 233-320. 
: Conspiraciones y revueltas. La actividad política de los negros en Cuba (17901845), Editorial Oriente, Santiago de Cuba, 2003.

García Algilaga, David: "Presidi colonial a Figueras. Els ñáñigos", en Joan Ramón Inglada (coord.), Presons i Castell. Figueres, Associació d'amics del Castell de San Ferran-GORBS, Figueres, 2012, pp. 75-122.

García Cantús, Dolores: Fernando Poo. Una aventura colonial española en el África occidental (1778-1900), Tesis doctoral de la Universidad de Valencia, Valencia, 2004.

García de León y Pizarro, José: Memorias, (1770-1835), Edición de Álvaro Alonso-Castrillo, Centro de Estudios Políticos y Constitucionales, Madrid, 1998.

García Monerris, Carmen y Pérez Garzón, Juan Sisinio, "Las barricadas de 1854. Análisis sociológico", Anales del Instituto de Estudios Madrileños, núm. 12, 1976, pp. 213-237.

García Mora, Luis Miguel: "La fuerza de la palabra. El autonomismo en Cuba en el último tercio del siglo XIX”, Revista de Indias, vol. 61, núm. 223, 2001, pp. 715-748.

Garcia Rovira, Anna Maria: "Ramón Xaudaró, el «Marat barcelonés»", en Manuel Pérez Ledesma e Isabel Burdiel (eds.) Liberales eminentes, Marcial Pons, Madrid, 2008, pp. 125-156.

: "Republicanos en Cataluña. El nacimiento de la democracia (1832-1837)" en Manuel Suarez Cortina (ed.), La redención del pueblo. La cultura progresista en la España liberal. Universidad de Cantabria, Santander, 2006, pp. 115-144.

1998, pp. 63-90.

: "Radicalismo liberal, republicanismo y revolución (1835-1837)", Ayer, núm. 29,

: "Sociedades secretas, facciones y partidos políticos durante la revolución liberal. La Barcelona revolucionaria (1835-1837)”, Trienio. Ilustración y Liberalismo, núm. 32, 1998.

: La revolució liberal a Espanya i les classes populars, Eumo, Vic, 1989.

: "Liberalisme «no respectable» i poble menut urbà. Bullangues i revolució liberal (1832-1835)", Recerques. Història, Economia i Cultura, núm. 22, 1989, pp. 45-62.

García Trobat, Pilar: La expulsión de los Jesuitas. Una legislación urgente y su aplicación en el Reino de Valencia, Consell Valencià de Cultura, Valencia, 1992.

García Villarrubia, Fernando: Aproximación al carlismo andaluz en la guerra de los siete años, EASA, Madrid, 1979.

Gargallo Vaamonde, Luis: Desarrollo y destrucción del sistema liberal de prisiones en España. De la Restauración a la Guerra Civil, Tesis doctoral de la Universidad de Castilla-La Mancha, 2015.

Gesteiro Araujo, Manuel: "Desamortización y devolución de bienes durante el Trienio Liberal. Cuenca", Espacio, Tiempo y Forma, Serie V, Historia Contemporánea, número 15, 2002, pp. $97-121$.

Ghorbal, Kharim: Réformisme et esclavage à Cuba, Publibook, París, 2009. 
Gil, Juan: "El rol del tercer viaje colombino", Historiografía y Biblioteca Americanista, vol. XXIX, núm.1, Sevilla, 1985, pp. 83-110.

Gil Novales, Alberto: Diccionario biográfico de España (1808-1833), Mapfre, Madrid, 2010, 3 vols.

: "Las clases populares en la Revolución liberal española", en Manuel Ortiz Heras, David Ruiz González e Isidro Sánchez Sánchez (coords.), Movimientos sociales y Estado en la España contemporánea, Publicaciones de la Universidad de Castilla-La Mancha, Cuenca, 2001, pp. 25-44.

: El Trienio liberal, Siglo XXI, Madrid, 1989.

: Las Sociedades Patrióticas (1820-1823), Tecnos, Madrid, 1975, 2 vols.

Giráldez Macía, Jesús: Creyeron que éramos rebaño. La insurrección del Alto Llobregat y la deportación de anarquistas a Canarias y África durante la II República, Zambra Iniciativas Sociales, Málaga, 2009.

Goberna Valencia, María Victoria: "El cantonalismo en el País Valenciano", en Primer congreso de historia del País Valenciano, 1977, vol. IV, pp. 463-470.

Gómez Alfaro, Antonio: "La polémica sobre la deportación de los gitanos a las colonias de América", Cuadernos Hispanoamericanos, núm. 386, 1982, pp. 308-336.

Gómez Barceló, José Luis: "El siglo XIX", en Fernando Villada Pareces (ed.), Historia de Ceuta. De los Austrias al siglo XX, Instituto de Estudios Ceutíes, Ceuta, 2009, pp. 118-207.

Gómez Bravo, Gutmaro: Crimen y castigo. Cárceles justicia y violencia en la España del siglo XIX; Pedro Oliver, La pena de muerte en España, Síntesis, Madrid, 2008.

Gómez Ochoa, Fidel: "El conservadurismo canovista y los orígenes de la Restauración. La formación de un conservadurismo moderno", en Manuel Suarez Cortina (ed.), La Restauración, entre el liberalismo y la democracia, Alianza, Madrid, pp. 109-155.

González Calleja, Eduardo: “La política de orden público en la Restauración”; Espacio, Tiempo y Forma, Serie V, Historia Contemporánea, tomo 20, 2008, pp. 93-217.

: La violencia en la política. Perspectivas teóricas sobre el empleo deliberado de la fuerza en los conflictos de poder, CSIC, Madrid, 2002.

: La razón de la fuerza. Orden público, subversión y violencia política en la España de la Restauración, CSIC, Madrid, 1998.

González de Maya, Julián: Las penas restrictivas de la libertad ambulatoria en la codificación española, Tesis doctoral de la Universidad de Murcia, Murcia, 2011.

González-Ripoll, María Dolores: Cuba, la isla de los ensayos. Cultura y sociedad (1790-1815), CSIC, Madrid.

Gordillo Osuna, Manuel: Geografía urbana de Ceuta, Artes Gráficas Clavileño, Madrid, 1972.

Gordon Kiernan, Víctor: La revolución de 1854 en España, Aguilar, Madrid, 1970. 
Granda Orive, José Ignacio de: "Sanidad militar y aspectos sanitarios en Fernando Poo durante el Gobierno de los brigadieres (1859-1869)", Sanidad militar, vol. 67, núm. 1, 2011, pp. 53-59.

Guerola, Antonio: Memoria de mi administración en la provincia de Málaga, Fundación Sevillana de Electricidad, Sevilla, 1995. 4 vols.

Guerra, Ramiro: La Guerra de los Diez Años, Pueblo y Educación, La Habana, 1986. 2 vols.

Guerrero Latorre, Ana: "El reinado de Fernando VII, 1808-1814", en Alfredo Alvar Ezquerra, (dir.) Historia política, 1808-1874, Istmo, Madrid, 2004, pp. 15-150.

Guillamet, Jaume: Abdón Terradas. Primer dirigent republicà, periodista i alcalde de Figueres, Institut d'Estudis Empordanesos, Figueres, 2000.

Guiteras, Pedro José: Historia de la isla de Cuba, Cultural, Habana, 1927-1928, 3 tomos.

Gutiérrez Lloret, Rosa Ana: "Republicanismo federal e insurrección cantonal en Alicante", Anales de Historia Contemporánea, núm. 6, 1987, pp. 165-182.

: Republicanos y liberales. La Revolución de 1868 y la Primera República en Alicante, Instituto Juan Gil-Albert. Diputación Provincial de Alicante, Alicante, 1985.

Headrick, Daniel R.: Ejército y política en España (1866-1898), Tecnos, Madrid, 1981.

Hernández González, Manuel: Liberalismo, masonería y cuestión nacional en Cuba, 18081823, Idea, Santa Cruz de Tenerife, 2012.

Hernández Sandoica, Elena: Pensamiento burgués y problemas coloniales en la España de la Restauración, Tesis doctoral de la Universidad Complutense de Madrid, Madrid, 1982.

Herrerín López, Ángel: Anarquía, dinamita y revolución social. Violencia y represión en la España de entre siglo (1868-1909), Catarata, Madrid, 2011.

Herrero Herrero, Cesar: La Justicia Penal Española en la crisis del Poder Absoluto, Ministerio de Justicia, Madrid, 1989.

Hugues, Robert: The Fatal Shore: A History of Transportation of Convicts to Australia, 17871868, Vintage Books, London, 2003.

Ibarra Cuesta, Jorge: Patria, etnia y nación, Editorial de Ciencias Sociales, La Habana, 2009.

Iglesias, Fe: "El desarrollo capitalista de Cuba en los albores de la época imperialista", en María del Carmen Barcia, Gloria García y Eduardo Torres-Cuevas, Las luchas por la independencia nacional y las transformaciones estructurales. 1868-1898, Editora Política, La Habana, 1996, pp. 156-208.

Inarejos, Juan Antonio: Intervenciones coloniales y nacionalismo español. La política exterior de la Unión Liberal y sus vínculos con la Francia de Napoleon III (1856-1868), Silex, Madrid, 2010.

: La Revolución de 1854 en la España rural. El Bienio Progresista en Ciudad Real (1854-1856), Instituto de Estudios Manchegos, Ciudad Real, 2010. 
Iradier, Manuel: África, viajes y trabajos de la Asociación Euskara La Exploradora. Reconocimiento de la zona ecuatorial de África en las costas de occidente. Sus montañas, sus ríos, sus habitantes, clima, producciones y porvenir de estos países tropicales, posesiones españolas del golfo de Guinea; adquisición para España de la nueva provincia del Muni, Miraguano/Polifemo, Madrid, 1994. (Primera edición de 1901)

Jutglar i Bernaus, Antoni: "La revolución de septiembre. El Gobierno provisional y el reinado de Amadeo I", en José María Jover Zamora (dir.) La era isabelina y el Sexenio Democrático (1834-1874), Historia de España de Menéndez-Pidal, Espasa-Calpe, Madrid, 1988, tomo XXXIV, pp. 644-699.

Kaplan, Telma: Orígenes sociales del anarquismo en Andalucía, Crítica, Barcelona, 1977.

Kingsley, Mary: Cautiva en África, Mondadori, Barcelona, 2001.

Kahan, Alan S.: Liberalism in the Nineteenth Century Europe: The Political Culture of Limited Suffrage, Palgrave Macmillan, Basingtoke and New York, 2003.

Lacomba Abellán, Juan Antonio: "Cantonalismo y federalismo en Andalucía. El manifiesto de los federales de Andalucía”, Revista de Estudios Regionales, núm. 59, 2001, pp. 267-276.

Ladero Quesada, Miguel Ángel: "El número de judíos en la España de 1492. Los que se fueron", en Sefarditas. Conversos. La expulsión de 1492 y sus consecuencias, Ámbito, Valladolid, 1995.

Lara López, Luis: "La represión de los Afrancesados. Condenas sociales, jurídicas y políticas. El caso de Jaén (1812-1820)." Hispania Nova. Revista de Historia Contemporánea, núm. 3, 2003, pp. 39-50.

Larráyoz Zarranz, Javier: "El quijote navarro. Vida y aventuras del brigadier de los ejércitos carlistas, don Mariano Larumbe" (parte II), Príncipe de Viana, núm. 150-151, 1978, pp. 203280 .

: "La Segunda Guerra Carlista en Navarra. 1848-1849”, Príncipe de Viana, núm. 52, 1956, pp. $167-197$.

Lasa Iraola, Ignacio: "El primer proceso de los liberales (1814-1815)", Hispania. Revista Española de Historia, núm. 115, 1970, pp. 327-383.

Lasso Gaite, Juan Francisco: Crónica de la codificación española, Ministerio de JusticiaComisión General de Codificaciones, Madrid, 1970, Tomo 5 (Codificación penal).

Lazo, Roberto: Filibustering and Cuban Exiles in the United States, University of North Carolina Press, Chapel Hill, 2005.

Leblon, Bernard: Los gitanos de España. El precio y el valor de la diferencia, Gedisa, Barcelona, 1993.

León Sanz, Virginia: “«Abandono de patria y hacienda». El exilio austracista valenciano", Revista de Historia Moderna, núm. 25, 2007, pp. 235-256.

Le Riverend, Julio: Historia económica de Cuba, Instituto Cubano del Libro, La Habana, 1974, pp. 382-394. 
Lida, Clara E.: “Cuba. Un desastre anunciado, 1868-1898”, Illes i Imperis, núm. 8, 2006, pp. 69-82.

: "Los ecos de la república democrática y social en España. Trabajo y ciudadanía en 1848”, Semata. Ciencias Sociais e Humanidades, vol. 12, 2000, pp. 323-338.

: “¿Qué son las clases populares? Los modelos europeos frente al español en el siglo XIX”, Historia Social, núm. 27, 1997, pp. 3-23.

: La Mano Negra. Anarquismo agrario en Andalucía, Zero, Madrid, 1972.

Ligero Morote, Armando: La sanidad en Guinea Ecuatorial, 1778-1968, el autor, Jaén, 1997.

Llaverías, Joaquín: La Comisión Militar Ejecutiva y Permanente de la isla de Cuba, El Siglo, La Habana, 1929.

Llorens, Vicente: Liberales y románticos, Castalia, Madrid, 2006.

López Estudillo, Antonio: Republicanismo y anarquismo en Andalucía. Conflictividad social agraria y crisis finisecular (1868-1900), La Posada, Córdoba, 2001.

López Tirada, Jacinto: Islas Chafarinas. Un paseo por su historia, Consejería de Cultura de la Ciudad Autónoma de Melilla, Melilla, 2010.

López Serrano, Alfredo: El general Polavieja y su actividad política y militar, Tesis doctoral de la Universidad Complutense de Madrid, Centro de Publicaciones del Ministerio de Defensa, Madrid, 2001, 2 tomos.

Loyola, Oscar y Abad, Diana: La Guerra de los Diez Años. Primera guerra de liberación nacional, Universidad de La Habana, La Habana, 1987.

Luciano Franco, José: "Las conspiraciones de 1810 y 1812", en José Luciano Franco (comp.), Las conspiraciones en Cuba de 1810 y 1812, Red Ediciones, Barcelona, 2016.

: Antonio Maceo, Apuntes para una historia de su vida, Editorial de Ciencias Sociales, La Habana, 1989, 3 tomos.

: Ensayos históricos, Editorial de Ciencias Sociales, La Habana, 1974.

: Revoluciones y conflictos internacionales en el Caribe, 1789-1854, Academia de Ciencias de Cuba, La Habana, 1965.

: La conspiración de Aponte, Consejo Nacional de Cultura-Publicaciones del Archivo Nacional, La Habana, 1963.

Holt, John: The Diary of John Holt (Peter N. Davies, ed.), International Maritime Economic History Association, St. John's (Newfoundland), 1993.

Luis, Jean-Philippe: L'utopie réactionnaire. Épuration et modernisation de l'Etat dans l'Espagne de la fin de l'Ancient Régime. (1823-1834), Casa de Velázquez, Madrid, 2002.

Macabich, Isidoro: Historia de Ibiza, Daedalus, Palma de Mallorca, 1966, 2 vols. 
Madrid, Carlos: Beyond Distances: Governance, Politics and Deportation in the Mariana Islands from 1870 to 1877, Northern Marianas Council for Humanities, Saipan, 2006.

Maluquer de Motes, Jordi: Nación e inmigración. Los españoles en Cuba (siglos XIX y XX), Ediciones Júcar, Colombres, 1992.

: El socialismo en España. 1833-1868. Crítica, Barcelona, 1977.

Marichal, Carlos: La revolución liberal y los primeros partidos políticos en España, 1834-1844, Cátedra, Madrid, 1980.

Márquez Quevedo, Javier: "Convictos cubanos deportados a Canarias y África durante la represión del independentismo”, Boletín Millares Carlo, núm. 17, 1998, pp. 103-120.

Martí, José: El Partido revolucionario Cubano, Universidad de Oviedo, Oviedo, 1998.

Martin Rebollo, Juan Francisco: "El aporte gallego al ejército antillano en el siglo XVIII", en I Jornadas presencia de España en América. Aportación gallega, Deimos, Madrid, 1989, pp. 153-176.

Martínez Gallego, Francesc-Andreu: Esperit d'associació. Cooperativisme i mutualisme laics al País Valencià, Universitat de Valencia, Valencia, 2010.

.: Conservar progresando. La Unión Liberal (1856-1868), Centro Francisco Tomás y Valiente UNED Alzira-Valencia/Fundación Instituto de Historia Social, Valencia, 2001.

Martínez de las Heras, Agustín: La crisis cubana en el arranque el Sexenio Democrático, Tesis doctoral de la Universidad Complutense de Madrid, Madrid, 1984.

Martínez Martínez, Manuel: "Los gitanos en el reinado de Felipe II (1556-1598). El fracaso de una integración", Chronica Nova. Revista de Historia Moderna de la Universidad de Granada, núm. 30, 2003-2004, pp. 401-430.

Martínez Ruiz, Enrique: La delincuencia contemporánea. Introducción a la delincuencia isabelina, Universidad de Granada, Granada.

Marrero, Levi: Cuba. Economía y sociedad, Playor, Madrid, 1972-1992, 15 vols.

Marrero Cruz, Eduardo: Julián de Zulueta y Amondo. Promotor del capitalismo en Cuba, Ediciones Unión, La Habana, 2006.

Masons, Timothy: Distant revolutions, 1848 and the Challenge to American Exceptionalism, University of Virginia Press, Charlottesville, 2009.

Mcmanus, Jane: La isla cubana de ensueño. Voces de la isla de Pinos y de la Juventud, La Memoria, La Habana, 2005.

Medioni, María-Alice: El cantón de Cartagena, Siglo XXI, Madrid, 1979.

Mendoza Garrido, Juan Miguel, et al.: "Delincuencia y justicia en la Chancillería de Ciudad Real y Granada (1495-1510)." Primera Parte. Estudio, Clío \& Crimen. Revista del Centro de Historia del Crimen de Durango, núm. 4, 2007, pp. 353-488. 
Miguel Fernández, Enrique de: Azcárraga, Weyler y la conducción de la guerra de Cuba, Tesis doctoral de la Universitat Jaume I, Castellón de la plana, 2008.

Miguel González, Román: La Pasión Revolucionaria. Culturas políticas republicanas en la España del siglo XIX, Centro de Estudios Constitucionales, Madrid, 2007.

Milán García, José Ramón: Sagasta o el arte de hacer política, Biblioteca Nueva, 2001.

Mir Montalt, Vicent: Desposeer y custodiar. Transformación agraria y guardería rural en la provincia de Valencia, 1844-1874, Edicions Alfons el Magnànim, Valencia, 1997.

Moral Ruiz, Joaquín del: "Capitalismo y capitalistas. Nuevas mentalidades, otros paisajes (1836-1882)", en Nicolás Ortega Cantero (ed.), Estudios sobre historia del paisaje español, Servicio de Publicaciones de la Universidad Autónoma de Madrid-Catarata, Madrid, 2002.

Morales Moya, Antonio, Fusi, Juan Pablo y Blas Guerrero, Andrés de (dirs.): Historia de la nación y del nacionalismo español, Galaxia Gutembert, 2013.

Morales Muñoz, Manuel: “¡La burguesía al poder! De la quiebra del Antiguo Régimen «la Gloriosa»", en Diego Caro Cancela (ed.), El primer liberalismo en Andalucía (1808-1868). Política, economía y sociabilidad, Universidad de Cádiz, Cádiz, 2005, pp. 157-206.

: Cultura e ideología en el anarquismo español (1870-1910), Centro de Ediciones de la Diputación de Málaga, Málaga, 2002.

1999.

: El republicanismo malagueño en el siglo XIX, Asukaría Mediterránea, Málaga,

Morales Padrón, Francisco: Conspiraciones y masonería en Cuba (1810-1826), Anuario de Estudios Americanos, tomo 29, 1972.

Moreno Fraginals, Manuel: El ingenio. Complejo económico social cubano del azúcar, Critica, Barcelona, 2001.

y Moreno Masó, José J.: Guerra, migración y muerte (El ejército español en Cuba como vía migratoria), Ediciones Júcar, Colombres, 1993.

Moreno Lázaro, Javier: Los hermanos de Rebeca. Motines y amotinados a mediados del siglo XIX en Castilla la Vieja y León, Región Editorial, Palencia, 2009.

Moreu-Rey, Enric: Els immigrants francesos a Barcelona, IEC, Barcelona, 1959.

Moyano Bazzani, Eduardo L.: La nueva frontera del azúcar. El ferrocarril y la economía cubana del siglo XIX, CSIC, Madrid, 1991.

Murillo, Andreu: "La revolta menorquina de 1810. Aproximació al primer intent autonòmic de la Menorca contemporània”, Randa, núm. 2, 1976, pp. 57-100.

Naranjo, Consuelo: "Evolución de la población desde 1760 a la actualidad", en Consuelo Naranjo (coord.), Historia de Cuba, CSIC-Doce Calles, Madrid-Aranjuez, 2009, pp. 29-56.

: "Los trabajos y los días. Colonos gallegos en Cuba en el siglo XIX, Semata, Ciencias Sociais e Humanidades, vol. 11, 1999, pp. 191-215. 

Aranjuez, 1996.

y García, Armando: Racismo e inmigración en Cuba en el siglo XIX, Doce Calles,

Navarro García, Luis: Las guerras de España en Cuba, Encuentro, Madrid, 1998.

: La Independencia de Cuba, Mapfre, Madrid, 1992.

Navarro, Jesús Raúl: "El exilio carlista" en Daniel Rivadulla, Jesús Raúl Navarro y María Teresa Berruezo, El exilio español en América en el siglo XIX, Mapfre, Madrid, 1992, pp. 137302.

Sevilla, 1991

: Entre esclavos y constituciones (el colonialismo liberal de 1837 en Cuba), CSIC,

: "Carlistas castellano-manchegos sentenciados a Cuba durante la Primera Guerra Carlista”, en Campesinos y señores en los siglos XIV y XV. Castilla-La Mancha y América. Actas del I congreso de historia de Castilla-La Mancha, Talavera, 1988, tomo VI, pp. 67-76.

: "Militares y libertad, reflexiones en torno al papel desempeñado por el ejército

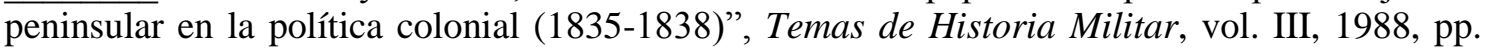
413-422.

: "Ejercito y Constitución en Cuba. Actitudes políticas en torno al año 1836" en Alberto Gil Novales (ed.), Ejercito, pueblo y Constitución. Homenaje al general Rafael del Riego. Actas del coloquio internacional celebrado en la Facultad de Ciencias de la Información, Universidad Complutense de Madrid, los días 9, 10 y 11 de abril de 1984. Anejos de la Revista Trienio. Madrid, 1984, pp. 516-531.

Navarro Melenchón, Julián: Organización social y sistemas políticos durante la I República, Universidad de Murcia, Murcia, 2004.

Nuez Caballero, Sebastián de la: "Unamuno en Fuerteventura", Anuario de Estudios Atlánticos, núm. 5, 1959, pp. 133-236.

Núñez Florencia, Rafael: El terrorismo anarquista (1888-1909), Siglo XXI, Madrid, 1983.

Núñez Jiménez, Antonio: Isla de Pinos. Piratas, colonizadores, rebeldes, Arte y Literatura, La Habana, 1976.

Núñez Muñoz, María Fe y Díaz de Cerio, Franco: El Bienio Progresista (1854-1856) y la ruptura de relaciones de Roma con España según los documentos vaticanos, Universidad de La Laguna, La Laguna, 1993.

Olilet Palá, Alberto: El conflicto social y la legitimidad de la monarquía ante la revolución de 1868, Ministerio de Trabajo y Seguridad Social, Madrid, 1989.

Oliver, Pedro: La pena de muerte en España, Síntesis, Madrid, 2008.

: Cárcel y Sociedad represora. La criminalización del desorden en Navarra (siglos XVII-XIX), Tesis doctoral de la Universidad del País Vasco, Bilbao, 2001.

: y Jesús Carlos Urda, La prisión y las instituciones punitivas en la investigación histórica, Ediciones de la Universidad de Castilla-La Mancha, Cuenca, 2014. 
Ollé Romeu, Josep María: Matiners, febrer, 1847 - 1848, febrer, PPU, Barcelona, 2007.

: Les bullangues de Barcelona durant la Primera Guerra Carlina (1835-1837), El Mèdol, Tarragona, 1993-1994, 2 vols.

Ollero Valles, José Luis: "De la liberación del presó encadenado al salto a las tinieblas: sobre representación y autenticidad en la cultura política del progresismo", Ayer, núm. 61, 2006, pp. $105-137$.

: Sagasta. De conspirador a gobernante, Marcial Pons-Fundación Práxedes Mateo Sagasta, Madrid, 2006.

Oneca, Antón: Derecho penal, Akal, Los Berrocales del Jarama, 1986.

: "El Código Penal de 1870", Anuario de Derecho Penal y Ciencias Penales, tomo 23, fasc./mes 2, 1970, pp. 229-251.

: "Historia del Código Penal de 1822", Anuario de Derecho Penal y Ciencias Penales, Tomo 18. fasc./mes 2, 1965, pp. 263-278.

Opatrný, Josef: José Antonio Saco y la búsqueda de la identidad cubana, Karolinum, Praga, 2010.

Prague, 1990.

: US Expansionism and Cuban Annexationism in the 1850s, Charles University,

Ortego Gil, Pedro: "Los ámbitos temporal y de exclusión territorial del destierro en los siglos XVI-XVIII. La práctica judicial gallega”, Boletín da Facultade de Direito de Coimbra, núm. 77, 2001, pp. 117-162.

Ortiz-Armengol, Pedro: Aviraneta o la intriga, Espasa-Calpe, Madrid, 1994.

Ortuño Martínez, Manuel: Servando Teresa de Mier, Memorias de un fraile mexicano desterrado a Europa, Trama, Madrid, 2006.

Pacheco, José Francisco: El Código Penal concordado y comentado, Imprenta de D. Santiago Saunaque, Madrid, 1848, 3 tomos.

Palop Ramos, José Miguel: “Delitos y penas en la España del Siglo XVIII”, en Estudis. Revista de Historia Moderna. Monográfico dedicado a conflictividad y represión en la sociedad moderna, núm. 22, 1996, pp. 65-103.

Paquette, Robert L.: Sugar is made with blood: The conspiracy of La Escalera and the Conflict between Empires over Slavery in Cuba, Wesleyan University Press, Middleton, 1988.

Paniagua Javier y Piqueras, José Antonio (dirs.): Diccionario biográfico de políticos valencianos, 1810-2006, Diputación de Valencia-Institució Alfons el Magnànim-Centro Francisco Tomás y Valiente. UNED Alzira-Valencia/Fundación de Instituto de Historia Social, Valencia, 2006.

: Poder económico y poder político, Centro Francisco Tomás y Valiente UNED Alzira-Valencia/Fundación Instituto de Historia Social, Valencia, 1998. 
Paniagua Pérez, Jesús: Memoria reservada de don Domingo Moriones sobre el Gobierno de Filipinas (1877-1880), Universidad de León, León, 1988.

Papel i Tardía, Joan i Quilez Mata, Julio Luis: La Història de Valls. Extractes de les "Anotaciones de la Historia de Valles por un vallense, anno MDCCCLXXXIV", Cossetania, Valls, 1999.

Pardo San Gil, Juan: "La Segunda Guerra Carlista en «el norte» (1872-1876). Los ejércitos contendientes", Bilduma, núm. 14, 2000, pp. 359-395.

Parra Pérez, Caracciolo: Historia de la Primera República de Venezuela, Biblioteca Ayacucho, Caracas, 1992.

Parrilla Ortiz, Pedro: El cantonalismo gaditano, Caja de Ahorros de Cádiz, Cádiz, 1983.

Pasqual i Domènech, Pere: "Carlisme i societat rural, la Guerra dels Set Anys a la conca d’Òdena", Recerques. Història, Economia i Cultura, núm. 10, 1980, pp. 51-91.

Payne, Stanley G.: Identidad y nacionalismo en la España Contemporánea. El carlismo, 18331975, Actas, Madrid, 1996.

Paz Sánchez, Manuel de: "Un reformador social cubano del XIX. Gaspar Betancourt Cisneros, El Lugareño", Anuario de Estudios Atlánticos, núm. 50, tomo II, 2004, pp. 1035-1067.

: et al. El bandolerismo en Cuba. Presencia canaria y protesta rural, Centro de Cultura Popular Canaria, 1994.

Pedraz Marcos, Azucena: Quimeras de África. La Sociedad española de Africanistas y Colonistas. El colonialismo español a finales del siglo XIX, Polifemo, Madrid, 2000.

Pérez, Joseph: Historia de una tragedia. La expulsión de los judíos de España, Crítica, Barcelona, 2004.

Pérez, Louis A.: The Structure of Cuban History: Meanings and Purpose of the Past, University of North Carolina Press, Chapel Hill, 2013.

: Cuba between Empires, 1878-1902, University of Pittsburgh Press, Pittsburgh, 1983.

Pérez del Álamo, Rafael: Apuntes sobre dos revoluciones Andaluzas, Zero, Madrid, 1971.

Pérez de la Blanca Sales, Pedro: Martínez de la Rosa y sus tiempos, Ariel, Barcelona, 2005.

Pérez Dionisio, Maritza: "La inmigración hispana en Santiago de Cuba (1868-1898)", Estudios de Historia Social y Económica de América, núm. 13, 1996, pp. 427-443.

Pérez García, Guadalupe: "La colonia penitenciaria de Villa Cisneros. Deportaciones y fugas durante la Segunda República”, Historia y Comunicación Social, vol. 7, 2000, pp. 169-186.

Pérez Garzón, Juan Sisinio: "De nacionalismo de Estado a esencia cultural", en Carlos Taibo (dir.), Nacionalismo español. Esencias, memorias e instituciones, Catarata, Madrid, 2007, pp. 49-73.

: "Los mitos fundacionales y el tiempo de la unidad imaginada del nacionalismo español”, Historia Social, núm. 40, 2001, pp. 7-28. 
: "El nacionalismo español, de las Cortes de Cádiz al 98", en Los 98 ibéricos y el mar, Sociedad Estatal Lisboa 98, 1998, Madrid, Tomo III (El Estado y la política), pp. 217-234.

: Milicia Nacional y revolución burguesa, CSIC-Instituto «Jerónimo Zurita», Madrid, 1978.

Pérez Guzmán, Francisco: "La Revolución del 95. De los alzamientos a la Campaña de Invasión", en María del Carmen Barcia, Gloria García y Eduardo Torres-Cuevas, Las luchas por la independencia nacional y las transformaciones estructurales. 1868-1898, pp. 430-480.

: "La Revolución del 95. Desde la conclusión de la Camapa de Invasión hasta el fin de la dominación española", en María del Carmen Barcia, Gloria García y Eduardo Torres-Cuevas, Las luchas por la independencia nacional y las transformaciones estructurales. 1868-1898, pp. 481-546.

y Sarracino, Rodolfo, La Guerra Chiquita. Una experiencia necesaria, Letras Cubanas, La Habana, 1982.

Pérez Moreda, Vicente: "La población de la ciudad de Madrid, siglos XVIII al XX", en Visión histórica de Madrid (siglos XVI al XX), Real Sociedad Económica Matritense de Amigos del País, Madrid, 1991, pp. 185-216.

Pérez Murillo, María Dolores: Aspectos demográficos y sociales de la isla de Cuba en la primera mitad del siglo XIX, Servicio de Publicaciones de la Universidad de Cádiz, Cádiz, 1988.

Pérez-Prendes Muñoz-Arraco, José Manuel: Historia del derecho español, Servicio de Publicaciones. Facultad de Derecho. Universidad Complutense, Madrid, 2004, 2 vols.

Pérez Regordán, Manuel: El bandolerismo andaluz, Quadix, Cádiz, 1990. 4 vols.

Pérez de la Riva, Juan: "Introducción" a Correspondencia reservada del Capitán general don Miguel Tacón, 1834-1836, Biblioteca Nacional José Martí, La Habana, 1963, pp. 13-96.

Peset Reig, Mariano y Peset Reig, José Luis: "Legislación contra liberales en los comienzos de la Década Absolutista (1823/1825)", Anuario de Historia del Derecho Español, núm. 37, 1967, pp. 437-485.

Peyrou, Florencia: "1848 et le Parti démocratique espagnol”, Mouvement Social, núm. 234, 2011, pp. 17-32.

: El republicanismo popular en España 1840-1843, Servicio de Publicaciones de la Universidad de Cádiz, Cádiz, 2002.

Pike, Ruth: Penal Servitude in early modern Spain, University of Wisconsin Press, Madison, 1983.

Pinilla Navarro, Vicente: Conflictividad social y revuelta política en Zaragoza (1854-1856), Diputación General de Aragón, Zaragoza, 1985.

: "La conflictividad social en Zaragoza durante el Bienio Progresista", Hispania. Revista Española de Historia, vol. 44, núm. 158, 1984, pp. 583-598. 
Piqueras, José Antonio: Bicentenarios de libertad. La fragua de la política en España y las Américas, Península, Barcelona, 2010.

: "Los amigos de Arango en la Corte de Carlos IV", en María Dolores González Ripoll e Izaskun Álvarez Artero (eds.), Francisco Arango y la invención de la Cuba azucarera, Ediciones Universidad, Salamanca, 2009, pp. 151-166.

: Cánovas y la derecha española. Del magnicidio a los neocon, Península, Barcelona, 2008.

: "El mundo reducido a una isla. La unión cubana a la metrópoli en tiempos de tribulaciones", en José Antonio Piqueras (ed.), Las Antillas en la era de las luces y la revolución, Siglo XXI, Madrid, 2005, pp. 319-342.

: Cuba, emporio y colonia. La disputa de un mercado interferido (1878-1895), Fondo de Cultura Económica de España, Madrid, 2003.

: "Leales en época de insurrección. La élite criolla cubana entre 1810 y 1814 ", en Izaskun Álvarez y Julio Sánchez (coord.), Visiones y revisiones de la independencia americana. III Coloquio de historia de América, "La independencia de América", Ediciones Universidad, Salamanca, 2003, pp. 183-206.

: "La cuestión cubana. De la Revolución Gloriosa a la Restauración", en Rafael Serrano García (dir.), España, 1868-1874. Nuevos enfoques sobre el Sexenio Democrático, Junta de Castilla y León, Valladolid, 2002, pp. 159-180.

: "Detrás de la política. República y federación en el proceso revolucionario español", en José Antonio Piqueras y Manuel Chust (comps.), Republicanos y republicas en España, Siglo XXI, Madrid, 1996, pp. 1-43.

: "El carlismo latente. Desposesión agraria y protesta campesina en Castellón (18431868)”, Saitabi, núm. 44, 1994, pp. 155-172.

: La Revolución Democrática (1868-1874). Cuestión social, colonialismo y grupos de presión, Ministerio de Trabajo y Seguridad Social, Madrid, 1992.

: y Enric Sebatià, Agiotistas, negreros y partisanos. Dialéctica social en vísperas de la Revolución Gloriosa, Alfons el Magnànim, Valencia, 1991.

Piretti, María Serena: “¿A quién representar, qué representar? Una mirada a través de la Europa del siglo XX”. Ayer, núm. 61, 2006, pp. 189-211.

Poblet, Josep Maria: Antoni Gusart, un pioner de l'obrerisme, Rafael Dalmau, Barcelona, 1971.

Portell Vilá, Herminio: Narciso López y su época, Cultural/Cía. Editora de Libros y Folletos, La Habana, 1930-1958, 3 tomos.

: Historia de Cárdenas, Cuba Intelectual, La Habana, 1928.

: Historia de Cuba en sus relaciones con los Estados Unidos y España, Minemosyne Publising, 1938-1969, La Habana-Miami, 4 vols.

Pons Anguera, Antoni: Libro de varias cosas sucedidas en esta villa y algunos parajes de Cataluña, Virgili \& Pagès, Lleida, 1988. 
Ponte Domínguez, Francisco J.: La masonería en la Independencia de Cuba, Editorial Modas Magazine, La Habana, 1954.

Portuondo, Fernando: "Joaquín Agüero y sus compañeros de Camagüey", Cuadernos de Historia Habanera, núm. 51 (Homenaje a los mártires de 1851), 1951, pp. 13-24.

Portuondo, Olga: Cuba. Constitución y liberalismo (1808-1841), Editorial Oriente, Santiago de Cuba, 2008, 2 tomos.

: "La inmigración negra en Saint Domingue en la Jurisdicción de Cuba (1798-1809), en Juan Manuel de la Serna (coord.), El Caribe en la encrucijada de su historia, 1780-1840, Universidad Nacional Autónoma de México, México, 1993, pp. 47-74.

Poblet, Josep Maria: Josep Anselm i Clavé i la seva època (1824-1874), Dopesa, Barcelona, 1973.

Poyo, Gerald E.: Exile and Revolution: José D. Poyo, Key West, and the Cuban Independence, University Press of Florida, Gainesville, 2014.

: With All, and for the Good of All: The Emergence of Popular Nationalism in the Cuban Communities of the United States, 1848-1898, Duke University Press, Durham, 1989.

Pozuelo Mascaraque, Belén: Presencia y acción españolas en las islas Marianas (1828-1899), Tesis doctoral de la Universidad Complutense de Madrid, Madrid, 1997.

Prida Santacilia, Pablo: Apuntes biográficos de Pedro Santacilia, Cuadernos de Lectura Popular, México D.F., 1966.

Prior Cabanillas, Julián Antonio: La pena de minas. Los forzados de Almadén, 1649-1699, Universidad de Castilla-La Mancha. Gabinete del Rector, Ciudad Real, 2003.

Pro Ruiz, Juan: "La política española en tiempos del desastre", en Juan Pan-Montojo (coord.), Mas se perdió en Cuba. España, 1898 y la crisis de fin de siglo, Alianza, Madrid, pp. 151-260.

Puelles, Fernando de: Fermín Salvochea. República y anarquismo, el autor, Sevilla, 1984.

Puig Campillo, Antonio: El cantón murciano, Consejería de Cultura y Educación de la Región de Murcia, Murcia, 1986.

Quirós Rosado, Roberto: "El mariscal Jorge Bessières (1780-1825). Vida de un aventurero en la España de Fernando VII”, Revista de Historia Militar, núm. 102, 2007, pp. 97-138.

Quiroz, Alfonso W.: "Costos socioeconómicos de la Guerra de los Diez Años. Insurrección cubana”, en José G. Cayuela (coord.), Un siglo de España. Centenario 1898-1998, Universidad de Castilla-La Mancha, Cuenca, 1998, pp. 245-282.

Ramos Vázquez, Isabel y Cañizares-Navarro, Juan B.: "La influencia francesa en la primera codificación española. El Código Penal francés de 1810 y el Código Penal español de 1822", en Aniceto Masferrer (ed.), La Codificación española. Una aproximación doctrinal $e$ historiográfica a sus influencias extranjeras, y a la francesa en particular, Thomson ReutersAranzadi, Cizur Menor (Navarra), 2014, pp. 193-270.

Rapport, Mike: 1848: Year of Revolution, Basic Books, New York, 2009. 
Rauch, Basil: American interests in Cuba: 1848-1855, Octagon Books, Nueva York, 1974.

Reid-Vazquez, Michele: The Year of the Lash: Free People of Color in Cuba and the Nineteenth-Century Atlantic World, University of Georgia Press, Athens (Georgia), 2011.

Renom Mercè: "Introducció" en Ferran Balanza i González et al., Guerrilles al Baix Llobregat. Els "carrasquets" del segle XVIII, $i$ els carlins $i$ els republicans del segle XIX, Abadia de Montserrat, Barcelona, 1986, pp. 7-130.

Revuelta, Manuel: Política religiosa de los liberales en el siglo XIX. Trienio Constitucional, CSIC, Madrid, 1973.

Rey, Miguel del: La Guerra de los Diez Años (1868-1878), Ristre, Madrid, 2003.

Rial, José: Villa Cisneros. Deportación y fuga de un grupo de antifascistas, Ediciones Españolas, Valencia, 1937.

Rio Aldaz, Ramón del: Orígenes de la guerra carlista en Navarra (1820-1824), Gobierno de Navarra-Institución Príncipe de Viana, Pamplona, 1987.

Rodrigo Alharilla, Martin: Los Marqueses de Comillas, 1817-1925, LID Editorial Empresarial, Madrid, 2001.

Rodríguez Delgado, Esaú: "La sustitución o redención para el servicio militar a mediados del siglo XIX”, Iberian. Revista Digital de Historia, núm. 4. mayo-agosto 2012, pp. 16-24.

Rodríguez Gómez, José María: La Tercera Guerra Carlista, 1869-1876, Almena, Madrid, 2004.

Roger Ekirch, A.: Bound for America: The Transportation of British Convicts to the Colonies, 1718-1775, Oxford University Press, Nueva York, 1987.

Roldán de Montaud, Inés: La Restauración en Cuba. El fracaso de un proceso reformista, CSIC, Madrid, 2001.

: "Política y elecciones en Cuba durante la Restauración", Revista de Estudios Políticos, núm. 104, 1999, pp. 245-287.

: La hacienda en Cuba durante la Guerra de los Diez Años (1868-1880), Instituto de Estudios Fiscales, Madrid, 1990.

Romeo Mateo, María Cruz: "Los mundos posibles del liberalismo progresista", en E. Laparra y G. Ramírez (eds.), El primer liberalismo. España y Europa desde una perspectiva comparada, Biblioteca Valenciana, Valencia, 2003, pp. 287-314.

: "La cultura política del progresismo. Las utopías liberales, una herencia en discusión”, Berceo, núm. 129, 2000, pp.9-30.

Rosen Jelomer, Boris: Pedro Santacilia, el hombre y su obra, Centro de Investigación Científica Jorge L. Tamayo, 1983, 2 vols.

Roure, Conrad: Memorias de Conrad Roure. Recuerdos de mi larga vida. El movimiento republicano de 1869 (tomo IV), Josep Pich i Mitjana (ed.), Institut Universitat d'Història Jaume Vicens i Vives-Eumo, Vic, 1994. 
Rueda, German: "El proceso de la desamortización de bienes de origen eclesiástico (1769-1964) en España. Cuantificación y consecuencias socioeconómicas", en Bernard Boidinier, Rosa Congost y Pablo F. Luna (eds.), De la Iglesia al Estado. Las desamortizaciones de bienes eclesiásticos en Francia, España y América Latina, Prensas Universitarias de Zaragoza, Zaragoza, 2009, pp. 177-204.

: La desamortización de Mendizábal y Espartero en España, Cátedra, Madrid, 1986.

Ruiz Astiz, Javier: "Castigos impuestos a los causantes de desórdenes. La actitud de los tribunales reales de Navarra durante la Edad Moderna", Sancho el Sabio, núm. 34, 2011, pp. 23 54.

Ruiz Jiménez, Marta: El liberalismo exaltado. La confederación de comuneros españoles durante el Trienio Liberal. Fundamentos, Madrid, 2007.

Ruiz Torres, Pedro: "Modelos sociales del liberalismo español”, en Ricardo Robledo, Irene Castells y María Cruz Romeo (eds.), Orígenes del liberalismo. Universidad, política, economía, Ediciones Universidad de Salamanca, Salamanca, 2003, pp. 173-203.

Rújula, Pedro: Contrarrevolución. Realismo y carlismo en Aragón y el Maestrazgo, Prensas Universitarias de Zaragoza, Zaragoza, 1998.

Saiz Pastor, Candelaria: "Narciso López y el anexionismo en Cuba. En torno a la ideología de los propietarios de esclavos", Anuario de Estudios Americanos, núm. 43, 1994, pp. 441-468.

Salcedo Olid, Manuel: Ramón María Narváez (1799-1868), Homo Legens, Madrid, 2012.

Salillas, Rafael: Evolución penitenciaria de España, Analecta, Pamplona, 1999, 2 tomos. (Edición facsímil de la primera, 1918).

Sánchez, Jean-Lucien : La relégation des récidivistes en Guyane française. Les relégués au bagne colonial de Saint-Jean-du-Maroni, 1887-1953, Thèse de doctorat d'histoire, Ecole des Hautes Etudes en Sciences Sociales (EHESS), 2009.

Sánchez González, María Dolores del Mar: La codificación penal en España. Los códigos de 1848 y 1850, Boletín Oficial del Estado-Centro de Estudios Políticos y Constitucionales, Madrid, 2004.

Sánchez Abadía, Silvia: "Olvidos de una guerra. El coste humano y económico de la independencia (Cuba-España, 1895-1898)”, Revista de Indias, 2001, vol. 61, núm. 221, 2001, pp. 113-140.

Sánchez i Agustí, Ferran: Carlins amb armes en temps de pau. Altres efemèrides d'interès (1840-1842), Pagès, Lleida, 1996.

Sánchez Baena, Juan José: El terror de los tiranos. La imprenta en la centuria que cambio Cuba (1763-1868), Universitat Jaume I, Castellón de la Plana, 2009.

Sánchez Carcelén, Antonio: "La repercusión del régimen constitucional en la Iglesia de Lleida durante el Trienio Liberal”, Hispania Sacra, vol. 59, núm. 119, 2007, pp. 323-336.

: La revolució liberal a Lleida (1820-1823), Universitat de Lleida, Lleida, 2006. 
Sánchez Cobos, Amparo: Sembrando ideales. Anarquistas españoles en Cuba (1902-1925), CSIC, Madrid, 2008.

Sánchez García, Raquel: "Reflexiones sobre la Revolución de 1848”, en Ayeres en discusión. Temas claves de historia contemporánea hoy, IX congreso de la Asociación de Historia Contemporánea, Murcia, 17-19 de septiembre de 2008, s/p.

: Alcalá Galiano y el liberalismo español, Centro de Estudios Políticos y Constitucionales, Madrid, 2005.

Sánchez Mantero, Rafael: Liberales en el exilio. (La emigración política en Francia en la crisis de Antiguo Régimen), Rialp, Madrid, 1975.

Sánchez Ortega, María Helena: "Los gitanos condenados como galeotes en la España de los Austrias" Espacio, Tiempo y Forma, Serie IV, Historia Moderna, tomo 18-19, 2005-2006, pp. 87-104.

: Documentación selecta sobre la situación de los gitanos españoles en el siglo XVIII, Editora Nacional, Madrid, 1977.

Sánchez Pardo, Salvador: La revolución de 1848 en España, Tesis doctoral de la Universidad Complutense de Madrid, Madrid, 1985, 2 tomos.

Santamaría García, Antonio y García, Alejandro: Economía y colonia. La economía cubana y la relación con España, 1765-1902, CSIC, Madrid, 2004.

Santamaría, Antonio y García Mora, Luis Miguel: "Colonos. Agricultores cañeros, ¿Clase media rural en Cuba? 1880-1898”, Revista de Indias, vol. 58, núm. 212, 1998, pp. 131-161.

Santamaría, Antonio y Naranjo, Consuelo (eds.), Más allá del azúcar. Política, diversificación y prácticas económicas en Cuba, 1878-1930, Doce Calles, Aranjuez, 2009.

Santillán, Ramón de: Memorias (1815-1856), Studium Generale, Pamplona, 1960, 2 vols.

Santirso, Manuel: Progreso y libertad, España en la Europa liberal (1830-1870), Ariel, Barcelona, 2008.

: Revolución liberal y guerra civil en Cataluña (1833-1840). Tesis doctoral de la Universitat Autònoma de Barcelona, Barcelona, 1994.

Santos Oliver, Miguel de los: Mallorca durante la primera revolución (1808-1814), Luis Ripoll, Palma, 1982, 3 tomos (primera edición de 1901).

Sanz Casas, Gonzalo: Política colonial y organización del trabajo en la isla de Fernando Poo, 1880-1930, Tesis doctoral de la Universidad de Barcelona, Barcelona, 1983.

Sappez, Delphine: Ciudadanía y autonomismo en Cuba. Antonio Govín (1847-1914), Publicacions de la Universitat Jaume I, Castellón de la Plana, 2016.

Sebastià, Enric: La revolución burguesa, la transición de la cuestión señorial a la cuestión social en el País Valenciano, Centro Tomás y Valiente UNED Alzira-Valencia/Fundación Instituto de Historia Social, Valencia, 2001, 2 vols.

y Piqueras, José Antonio: Pervivencias feudales y revolución democrática, Alfons el Magnànim, Valencia, 1987. 
Seco Serrano, Carlos: Historia del conservadurismo español. Una línea política integradora en el siglo XIX, Temas de Hoy, Madrid, 2000.

Secondat, Charles-Louis de (barón de la Brède y de Montesquieu), Del espíritu de las leyes, Tecnos, Madrid, 2007. (Primera edición de 1847).

Serna, Justo: Presos y pobres en España. La determinación social de la marginación, PPU, Barcelona, 1988.

Serrano, Carlos: "La colonie pénitentiaire: rebelles, anarchistes, ñáñigos dans les pénitenciers espagnols", en Mélanges américanistes en hommage à Paul Verdevoye, Éditions Hispaniques, Paris, 1985, pp. 79-92.

Serrano García, Rafael: "La historiografía en torno al sexenio 1868-1874. Entre el fulgor del centenario y el despliegue sobre lo local”, Ayer, núm. 44, 2001, pp. 11-32.

: El sexenio revolucionario en Valladolid. Cuestiones sociales (1868-1874), Junta de Castilla y León, Valladolid, 1986.

Sesmero Cutanda, Enriqueta: Clases populares y carlismo en Bizkaia, 1850-1872, Universidad de Deusto, Bilbao, 2000.

Sigüenza y Gondora, Carlos de: Infortunios de Alonso Ramírez, Maxtor, Valladolid, 2012, (Edición facsímil del original de 1690).

Solà i Montserrat, Roser: Joan Vilaregut i Albafull, industrial i progressista (Barcelona 18001854), Publicacions de l’Abadia de Montserrat, Barcelona, 2001.

Sosa Rodríguez, Enrique: Los ñánigos, Casa de las Américas, La Habana, 1982.

Souto Paz, José Antonio: "Las libertades públicas en la Constitución de 1869", Revista de Derecho Político, núm. 55-56, 2002, pp. 131-158.

Stephen Nicolas (ed.), Convict Workers: Reinterpreting the Australian Past, Cambridge University Press, Parramatta, 1988.

Stewart, Matthew: El somni de Monturiol. L'extraordinària historia de l'inventor que volia salvar el món, Graó, Barcelona, 2009.

Stucki, Andreas: Las guerras de Cuba. Violencia y campos de concentración (1868-1898), La Esfera de los Libros, Madrid, 2017.

Suárez, Federico: Documentos del reinado de Fernando VII. Tomo VIII. Los agraviados de Cataluña, EUNSA, Pamplona, 1972, 4 vols.

Successos de Barcelona. 1822-1835, Josep María Ollé Romeu (ed.), Universitat de BarcelonaCurial, Barcelona, 1981 (de un anónimo de la época).

Táboas Suárez, Isaías: El republicanismo federal y la primera guerra de Cuba (1868-1878), el autor, Barcelona, 2004.

Taibo, Carlos: "Sobre el nacionalismo español", en Carlos Taibo (dir.), Nacionalismo español. Esencias, memorias e instituciones, Catarata, Madrid, 2007, pp. 11-48. 
Termes, Josep: Historia del anarquismo en España (1870-1980), RBA libros, Barcelona, 2011.

: Anarquismo y sindicalismo en España. La Primera Internacional (1864-1881), Critica, Barcelona, 2000.

Thomas, Hugh: Cuba. La lucha por la libertad, Debate, Barcelona, 2004.

Thomson, Guy: El nacimiento de la política moderna en España. Democracia, asociación y revolución, 1854-1857, Comares, Albolote (Granada), 2014.

: "La revolución de Loja en julio de 1861. La conspiración de los carbonarios y la democracia en la España moderna", en Alda Blanco y Guy Thomson (eds.), Visiones del liberalismo. Política identidad y cultura en la España del siglo XIX, Publicacions de la Universitat de Valencia, Valencia, 2008, pp. 159-193.

(ed.): The European Revolutions of 1848 and the Americas, Institute for the Study of the Americas, London, 2002.

Thompson, I.A.A.: “A Map of Crime in Sixteenth Century Spain”, Economic History Review, núm. 21, 1976, pp. 244-267.

Tocqueville, Alexis: Recuerdos de la Revolución de 1848, Trotta, Madrid, 1994. (Original de 1850-1851).

Togores, Luis E.: "La última frontera. El establecimiento de la soberanía española en el país moro", en María Dolores Elizalde, Josep M. Fradera y Luis Alonso Álvarez (eds.), Imperios y naciones en el pacifico, CSIC, Madrid, 2001, vol. 1, pp. 675-698.

Toledano González, Lluís Ferran: “A Dios rogando y con el mazo dando. Monopolio de la violencia y conflicto político en la última guerra civil en Cataluña (1872-1876), Vasconia. Cuadernos de Historia-Geografía, núm. 26, 1998, pp. 191-208.

Toledo Sande, Luis: Cesto de llamas. Biografía de José Martí, Alfar, Sevilla, 1998.

Tomás y Valiente, Francisco: El derecho penal de la monarquía absoluta, (Siglos XVI-XVIIXVIII), Tecnos, Madrid, 1969.

Tone, John Lawrence: Guerra y genocidio en Cuba, 1895-1898, Turner Publicaciones, Madrid, 2008.

Torras Elías, Jaime: Liberalismo y rebeldía campesina, 1820-1823, Ariel, Barcelona, 1976.

: La guerra de los agraviados, Publicaciones de la Cátedra de Historia General de España, Barcelona, 1967.

Torre, Joseba de la y Lana Berasain, José Miguel: "El asalto a los bienes comunales. Cambió económico y conflictos sociales en Navarra, 1808-1836", Historia Social, núm. 37, 2002, pp. 75-95.

Torres Aguilar, Manuel: Génesis parlamentaria del Código Penal de 1822, Sicania University Press, Messina, 2008. 
Torres-Cuevas, Eduardo: Historia de la masonería cubana, seis ensayos, Imagen contemporánea, La Habana, 2004.

: "La sociedad esclavista y sus contradicciones", en María del Carmen Barcia, Gloria García y Eduardo Torres-Cuevas, La colonia. Evolución socioeconómica y formación nacional. De los orígenes hasta 1867, Editora Política, La Habana, 1994, pp. 225-313.

Tuñón de Lara, Manuel: El movimiento obrero en la historia de España, SARPE, Madrid, 1985, 2 vols.

Unzueta y Yuste, Abelardo de: Geografía histórica de la isla de Fernando Poo, Instituto de Estudios Africanos, Madrid, 1947.

Urigüen, Begoña: Orígenes y evolución de la derecha española. El neo-catolicismo, CSIC, Madrid, 1986.

Urquijo y Goitia, José Ramón de: "Las contradicciones políticas del Bienio Progresista", Hispania. Revista Española de Historia, vol. 57, núm. 198, 1997, pp. 267-302.

: La revolución de 1854 en Madrid, CSIC, Madrid, 1984.

Valle Calzado, Ángel Ramón del: Desamortización eclesiástica en la provincia de Ciudad Real, 1836-1854, Universidad de Castilla-La Mancha, Cuenca, 1995.

Vallverdú, Robert: La Guerra dels Matiners a Catalunya (1846-1849). Una crisi econòmica $i$ una revolta popular, Publicacions de l'Abadia de Montserrat, Barcelona, 2002.

: El tercer carlisme a les comarques meridionals de Cataluña, 1872-1876, Publicacions de l'Abadia de Montserrat, Barcelona, 1997.

Varella, Claudia: Esclavos a sueldo. La coartación cubana en el siglo XIX, Tesis doctoral de la Universitat Jaume I, Castellón de la Plana, 2010.

Venegas, Hernán M.: Trinidad de Cuba. Corsarios, azúcar y revolución en el Caribe, Centro de Investigación y Desarrollo de la Cultura Cubana Juan Marinello, La Habana, 2005.

Victoria Moreno, Diego: "La represión política durante y después del cantón murciano. Estructura y connotaciones sociales", Anales de Historia Contemporánea, núm. 10, 1994, pp. 463-476.

Vilar, Juan Bautista: El Sexenio Democrático y el Cantón Murciano (1868-1874), Academia Alfonso X el Sabio, Murcia, 1983.

Vilar, María José: Ceuta en el siglo XIX. A través de su cartografía histórica y fuentes inéditas. (1800-1912), Universidad de Murcia, Murcia, 2002.

: "Un cartagenero para Ultramar. Miguel Tacón y el modelo autoritario de la

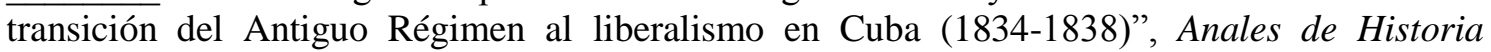
Contemporánea, vol. 16, 2000, pp. 239-278.

Vilches, Jorge: El Partido Progresista y la consolidación del régimen liberal, Alianza, Madrid, 2001. 
Villena Espinosa, Rafael: El Sexenio Democrático en la España rural. Ciudad Real (18681874), Instituto de Estudios Manchegos, Ciudad Real, 2005.

Wright, Jonathan: Los jesuitas. Una historia de los «soldados de Dios», Debate, Barcelona, 2005.

Yáñez Gallardo, Cesar: Saltar con red. La temprana emigración catalana a América, ca. 18301870, Alianza, Madrid, 1996.

Colombres, 1993.

: La emigración española a América (siglos XIX y XX), Archivo de Indianos,

Yañiz, Juan Pedro: La crisis del pequeño imperio español, Dirosa, Barcelona, 1974.

Zanetti, Oscar: "En camino al 98. Cánovas y el problema económico de Cuba (18781881),"Revista de Indias, vol. 58, núm. 212, 1998, pp. 195-213.

: Comercio y poder. Relaciones cubano-hispano-norteamericanas en torno a 1898, Casa de las Américas, 1998.

Zanetti, Oscar y García, Alejandro: Caminos para el azúcar, Editorial de Ciencias Sociales, La Habana, 1987.

Ziegler, Vanessa Michelle: The Revolt of "the Ever-faithful Isle": The Ten Years War in Cuba, 1868-1878, Tesis doctoral de la Universidad de California, Santa Bárbara, 2007.

Zurita, Rafael y Peña, María Antonia: "La representación política en el discurso del liberalismo español (1845-1874). Ayer, núm. 61, 2006, pp. 15-45. 


\section{RESUMEN}

La presente tesis doctoral ha examinado la práctica de la deportación como modo de represión política en España y Cuba a lo largo del siglo XIX. Los cambios producidos en España a raíz de 1808 que condujeron al nacimiento de la política contemporánea tuvieron como consecuencia el nacimiento de la oposición y la disidencia política, a la que el poder hizo frente por la vía de la represión. Nuestro análisis ha ido encaminado a descubrir y analizar uno estos métodos de castigo, la deportación, es decir, el traslado de los opositores a Ultramar, llenando un vacío historiográfico tanto en España como en Cuba. La práctica a comenzó como actos dispersos encaminados a desactivar la disidencia dirigidos a puntos cercanos como las Baleares y fue derivando en embarques cada vez más lejanos en los que no desapareció el elemento central que los motivaba, el desembarazo. Una vez en su destino, en la mayoría de ocasiones se trató de que los sujetos proporcionaran utilidad al Estado. La investigación ha expuesto su profusa utilización de las relegaciones por gobiernos de cariz muy diferente en periodos muy distintos, a menudo tras años sin usarse, lo que manifiesta la utilidad que tuvo para el Estado en ciertos momentos de debilidad o en periodos de crecimiento de la inestabilidad. En España, las deportaciones se realizaron al margen de las leyes, contrariamente a lo que sucedió en los países de nuestro entorno, lo que ha facilitado su ocultamiento. Aun así, el efecto de las mismas fue muy importante, especialmente en los lugares emisores, la España peninsular y Cuba, lo que se extendió a los puntos de destino donde en mayor o menor medida dejaron su impronta. 


\section{SUMMARY}

The present doctoral thesis has examined the practice of the deportation as a way of political repression in Spain and Cuba in the 19th century. The changes produced in Spain immediately after 1808 that led to the appearance of the contemporary politics resulted in the birth of the opposition and the political dissent, to which the power faced taking the path of the repression. Our analysis has gone directed to discover and to analyse one of these methods of punishment, the deportation, that is to say, the movement of the opponents to Overseas, filling a historiographical void in Spain and in Cuba. The practice began as dispersed acts directed to deactivating the dissent, sending them to nearby points as the Balearics islands, and was deriving in embark increasingly distant, in which the central element that was motivating them, the disembarrassment, did not disappear. Most of the times, it was intended to provide usefulness to the State through the work of the subjects in the points of destination. The investigation has exposed the profuse utilization of the deportations by governments of very different appearance in very different periods, often after years not being used, which demonstrates the usefulness that had for the State in certain moments of weakness or in periods of growth of the instability. In Spain, the deportations were realized outside of the laws contrary to what happened in the countries of our environment, which has facilitated his concealment. Even this way, the effect of the transportations were very important, especially in the issuing places, the peninsular Spain and Cuba, that spread to the points of destination where in major or minor measure the deportees left their mark. 